


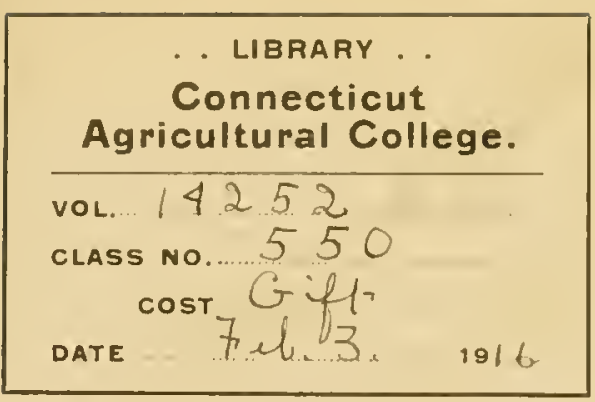


Digitized by the Internet Archive in 2009 with funding from . Boston Library Consortium Member Libraries 

UNITED STATES GEOLOGICAL SURVEY

GEORGE OTIS SMITH, DHEETOR

\title{
THE GEOLOGY OF \\ THE LAKE SUPERIOR REGION
}

\author{
BY \\ CHARLES RICHARD VAN HISE \\ AND \\ CHARLES KENNETH LEITH
}

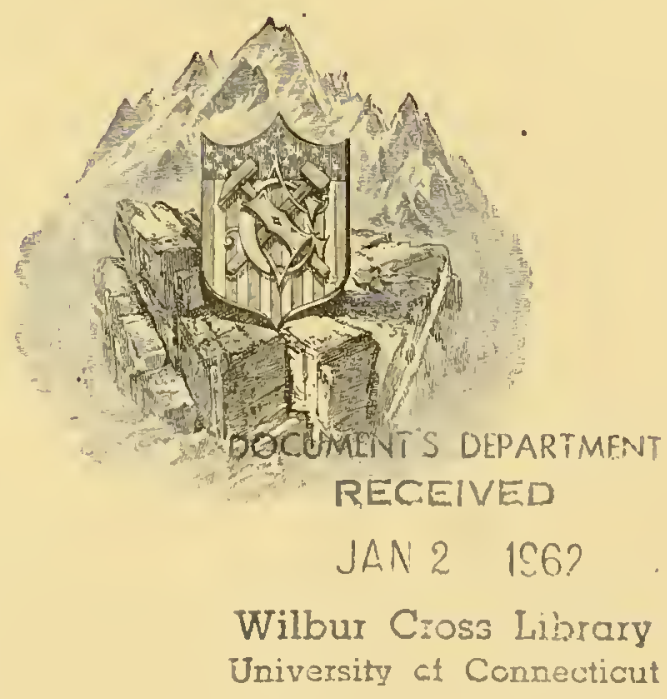

WASHI Y GTON

GOVERNMENT PIR INING OFFICE 1911 


$$
1.4252
$$




\section{CONTENTS.}

CHAPTER L Introduetiono

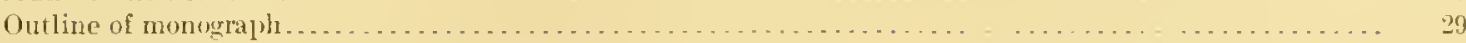

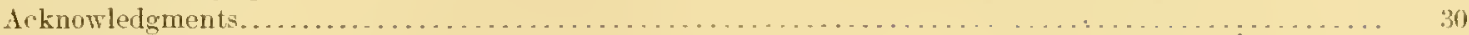

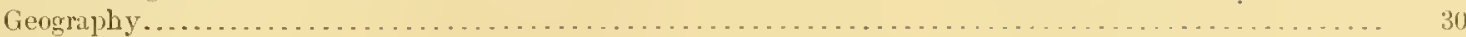

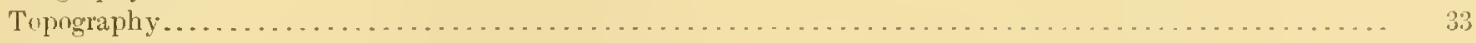

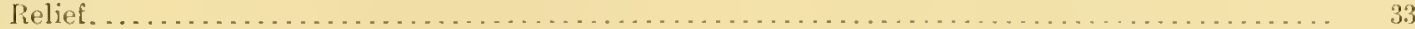

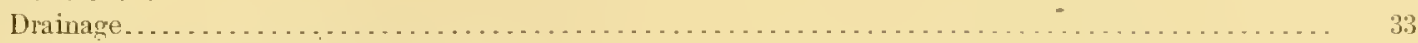

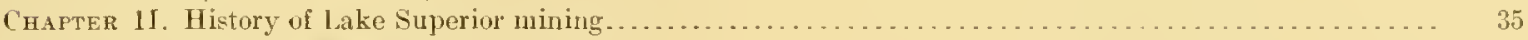

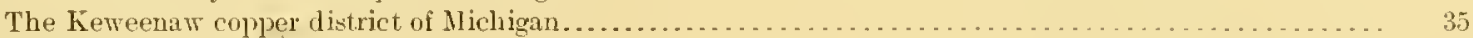

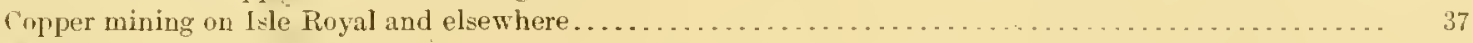

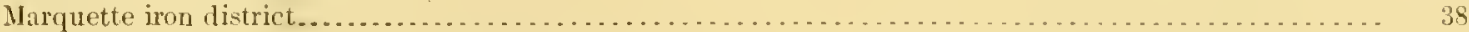

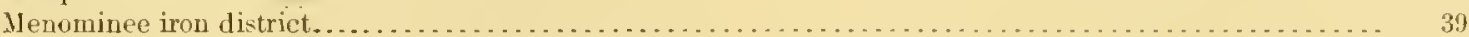

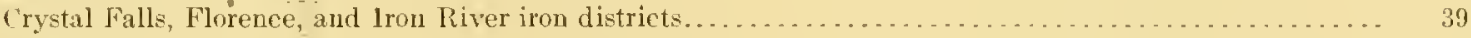

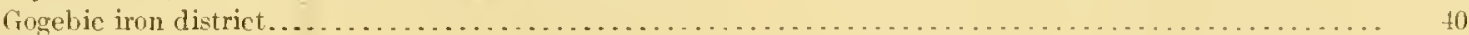

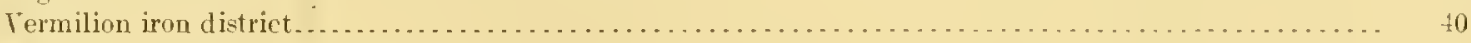

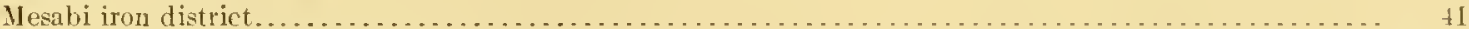

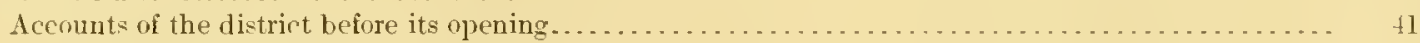

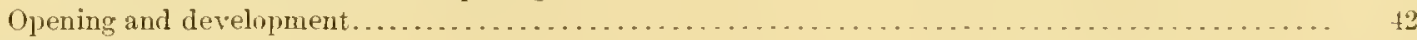

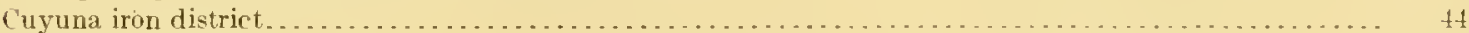

Baraboo iron district . . . . . . . . . . . . . . . . . . . . . . . . . . . . .

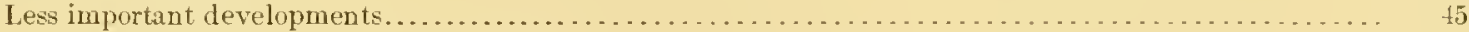

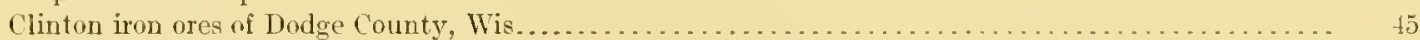

Pileozoic iron ores in western Wisconsin . . . . . . . . . . . . . . . . . . . . . . . . . 45

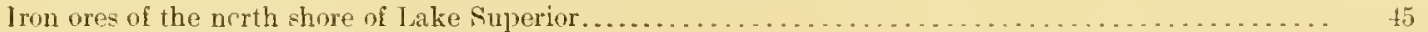

Silver mining on the north shore of Lake Superior . . . . . . . . . . . . . . . . . . . . . . . . 46

Lake Superior gold mining. . . . . . . . . . . . . . . . . . . . . . . . . . . . . . . . . . . . . . 46

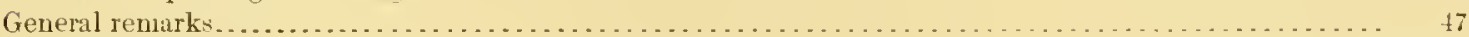

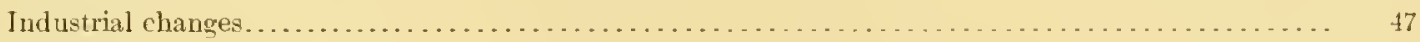

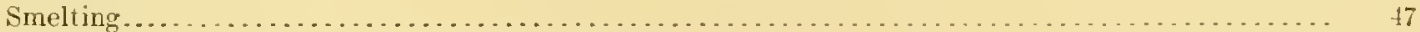

Influence of physiography on industrial development................................ 45

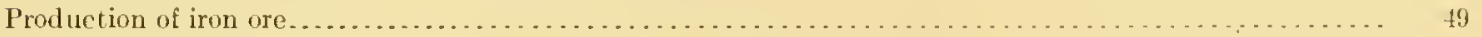

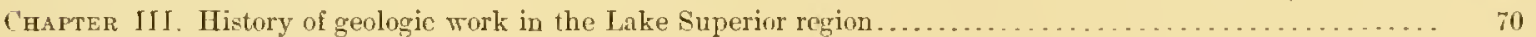

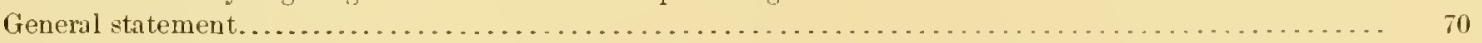

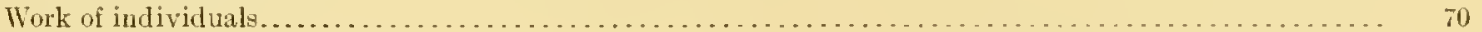

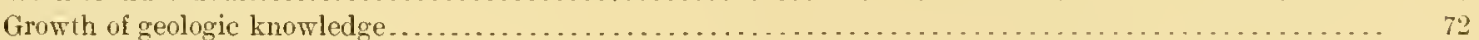

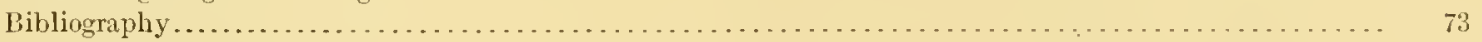

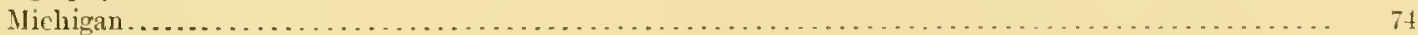

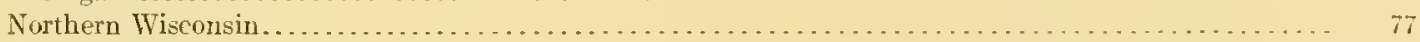

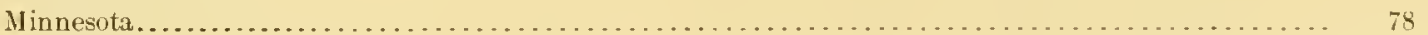

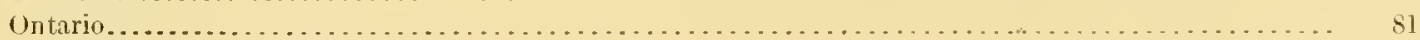

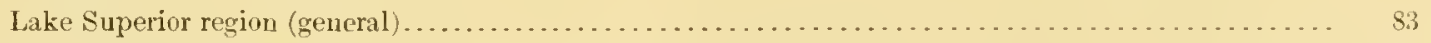

Chapter IV. Physical geograplyy of the Lake Superior region, by Lawrence Martin .................. 85

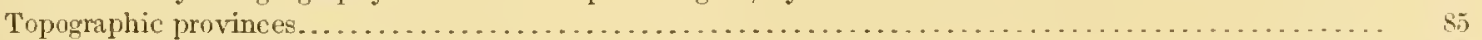

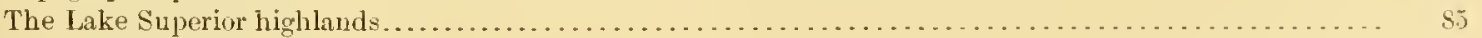

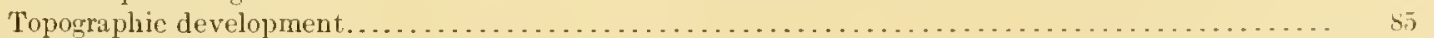

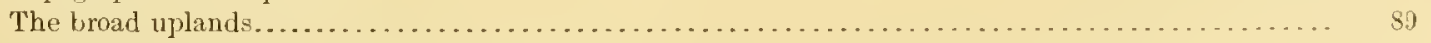

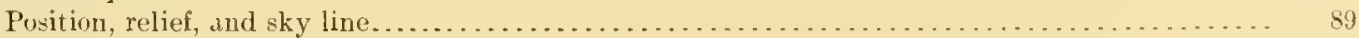

Relation of original and present topography . . . . . . . . . . . . . . . . . . . . . 89

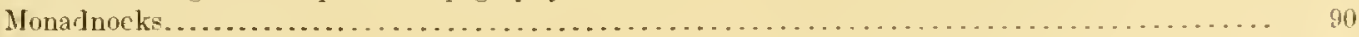

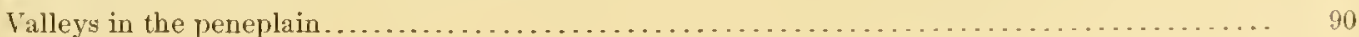


ChatTER IV. Plyyical gengra]hy of the lake superiur region, ly lawrence Martin-comlinued.

The Lake Superior highlands- ('ntinued.

The broad uplands-Continued.

Sull and glacial topogral

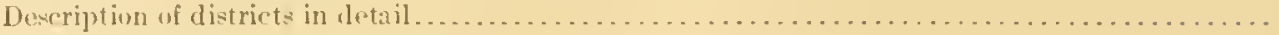

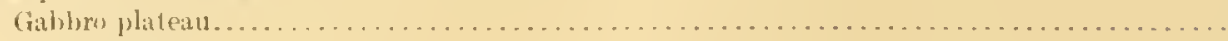

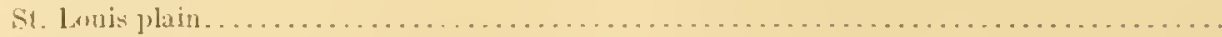

Vermilion district.

Rainy Lake and Lake of the Winds district

IIunters Island and Thunder liay region.

Region north of Lake Superior..

Region northeast of Lake Superior.

Michipicoten district..............

Region north of Sault Ste. Mlarie.

Marquette district.

Menominee district.

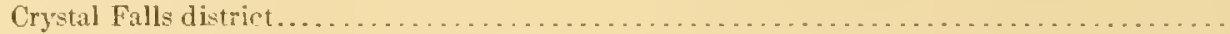

Kerreenaw Point.

Northern Wisconsin

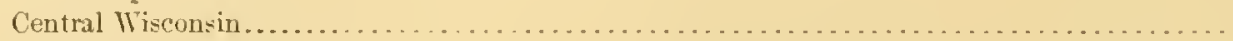

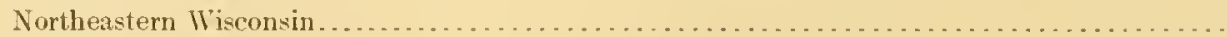

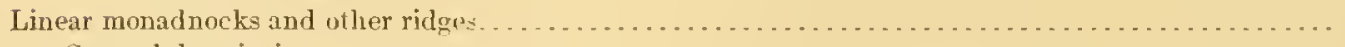

General description

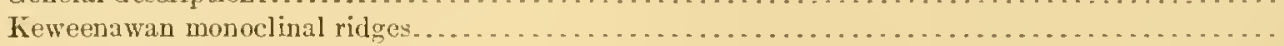

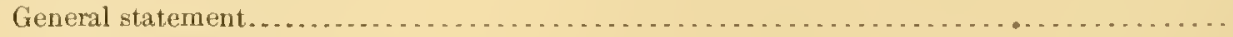

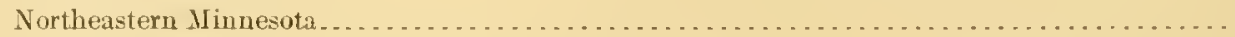

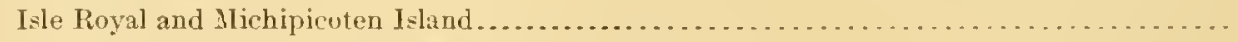

Keweenaw Point and northern Michigan and Wisconsin............................

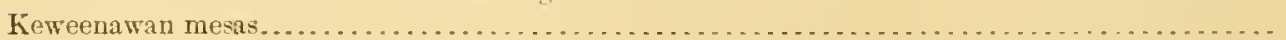

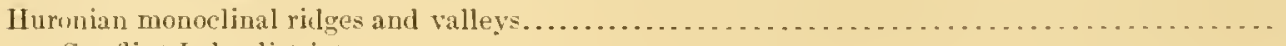

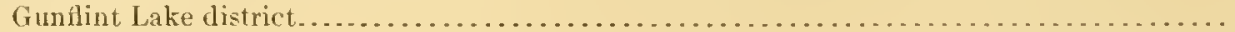

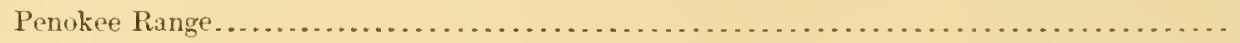

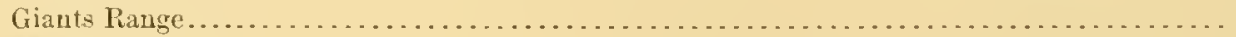

Marquette district. . . . . . . . . . . . . . . . . . . . . . . . . . . . . . . . . . . . .

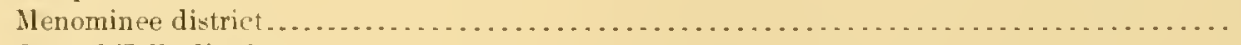

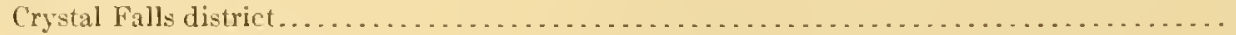

North-central Wisconsin . . . . . . . . . . . . . . . . . . . . . . . . . . . . . . .

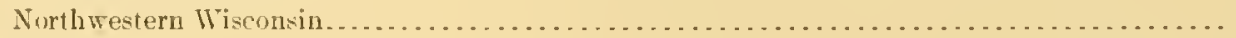

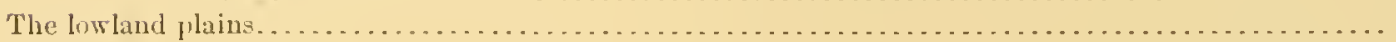

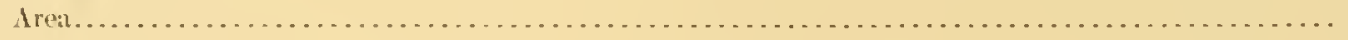

Character and structure.

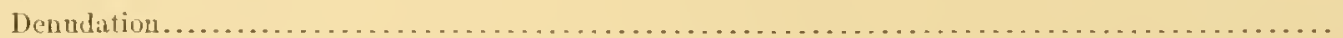

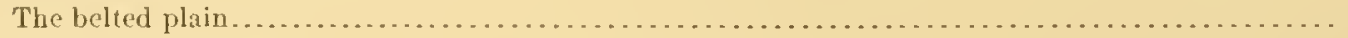

The Minnesota lowlands . . . . . . . . . . . . . . . . . . . . . . . . . . . . . . . . . . . . .

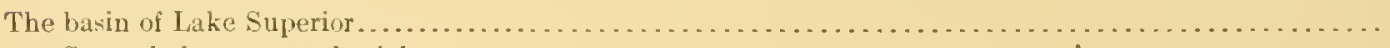

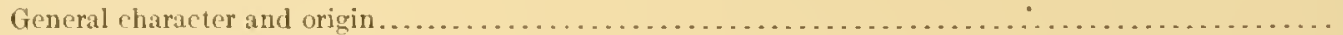

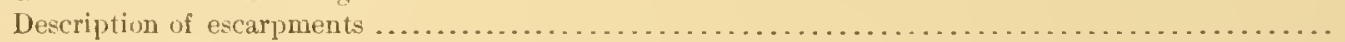

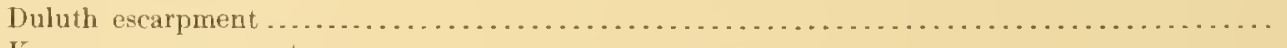

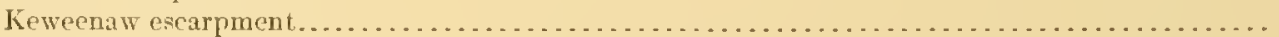

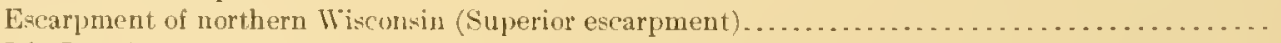

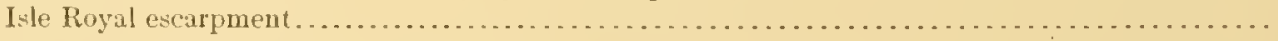

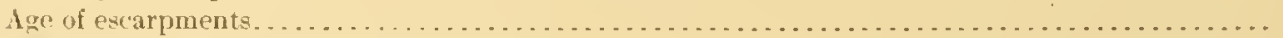

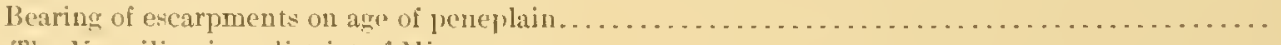

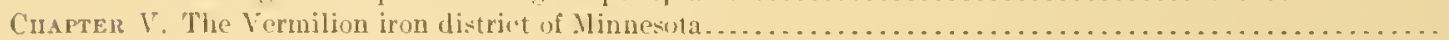

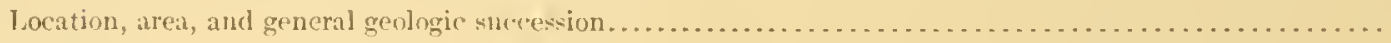

Topngraphy . .

Archean systcm.

Keewatin sries.

Ely greerenstone.

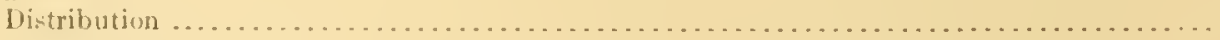

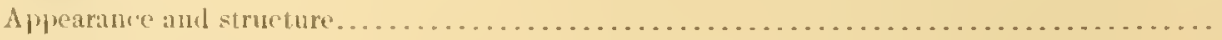

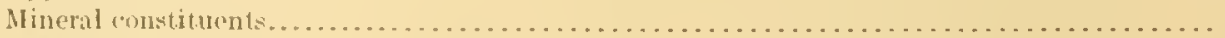

Clastic rucks. ... 
Chapter V.-The Vermilion iron district of Minnesota-Continued.

Page.

Archean system-Continued.

Keewatin series-Continued.

Ely greenstone-Continued.

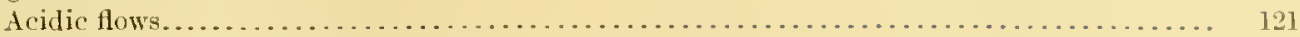

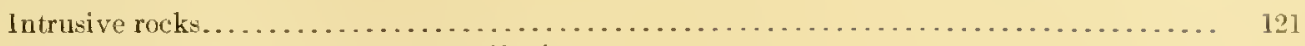

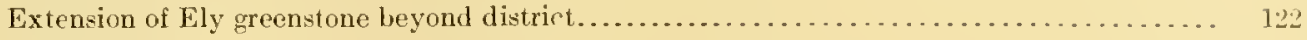

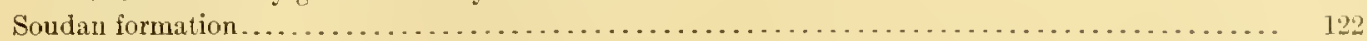

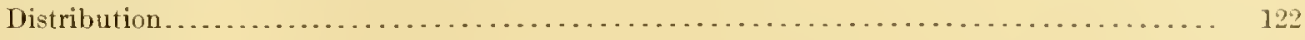

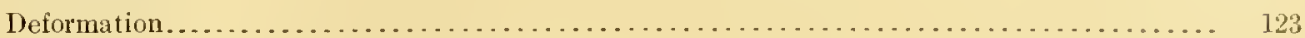

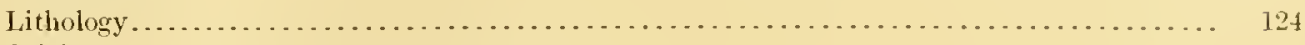

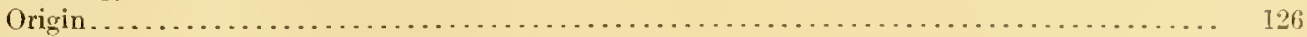

Relations of Ely greenstone and Soudan formation................................. 126

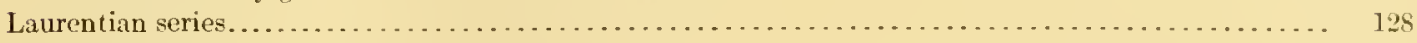

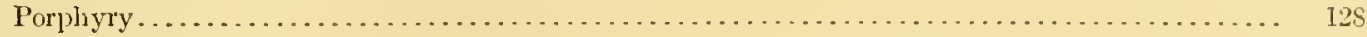

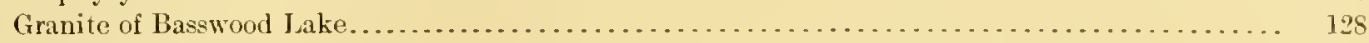

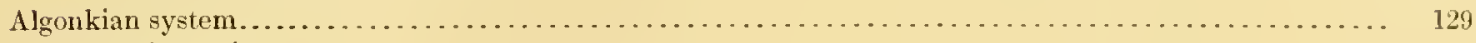

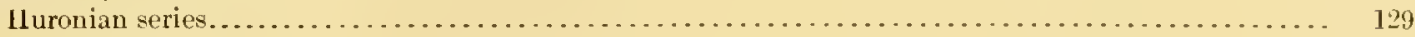

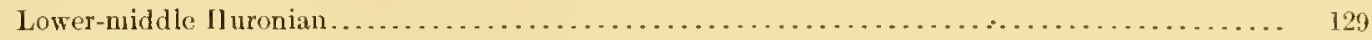

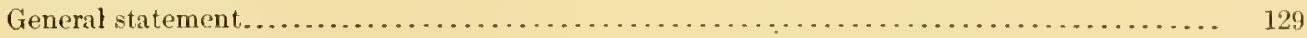

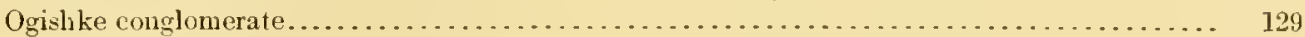

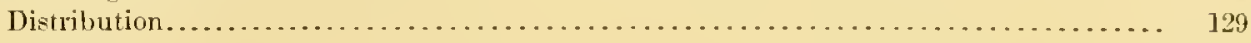

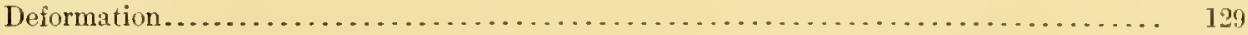

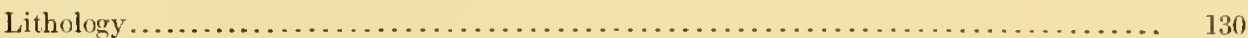

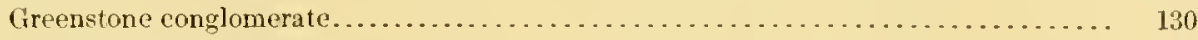

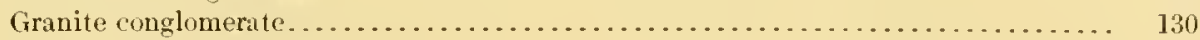

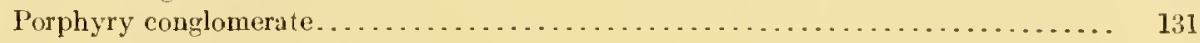

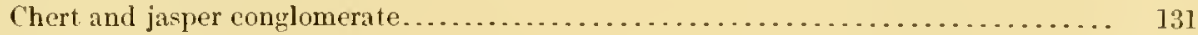

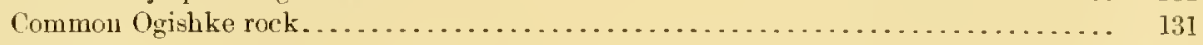

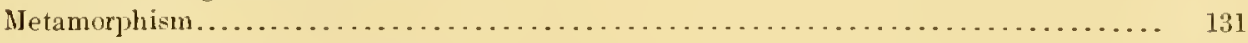

Relations to aljacent formations...................................... 132

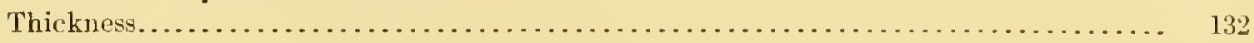

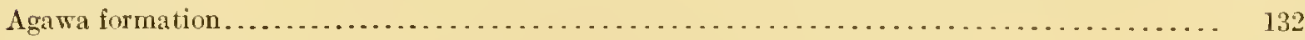

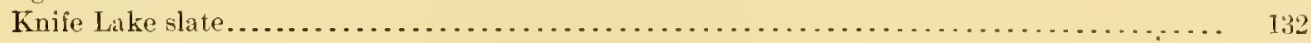

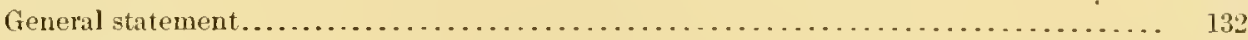

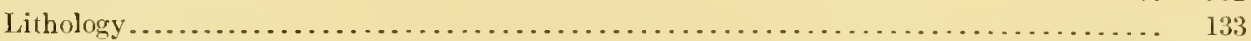

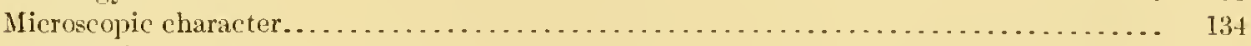

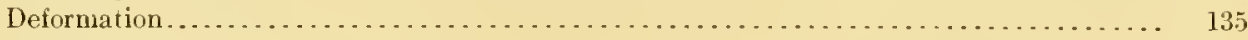

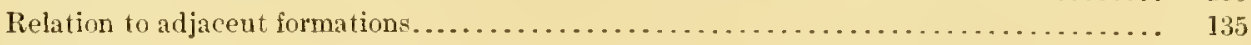

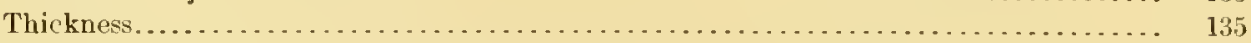

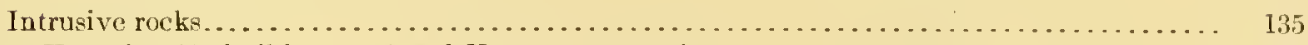

Upper Huronian (Animikie group) and Keweenawan series....................... 136

The iron ores of the Vernilion district, Minnesota, by the authors and W. J. Mead ................ 137

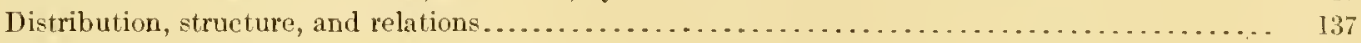

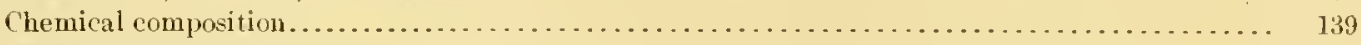

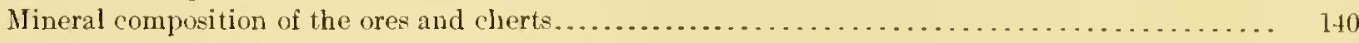

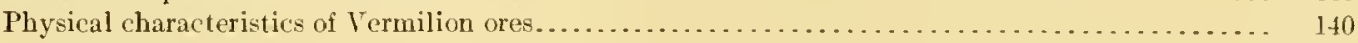

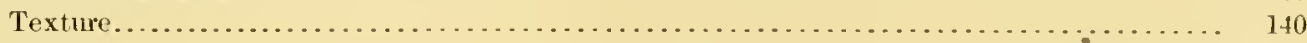

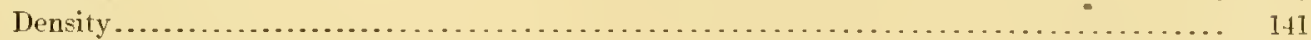

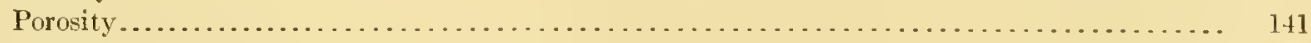

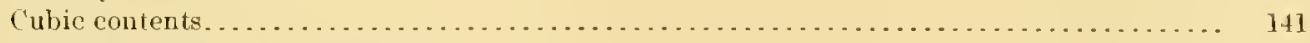

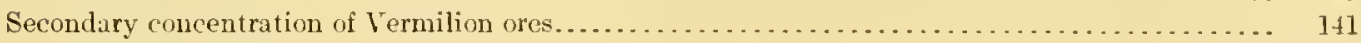

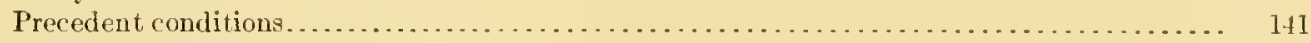

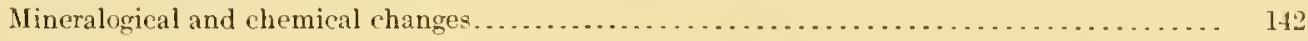

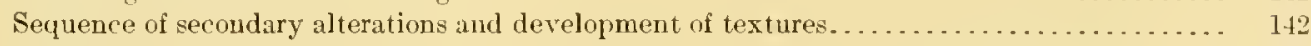

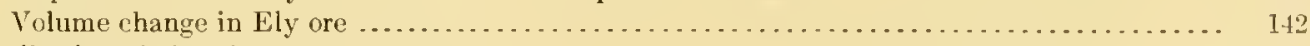

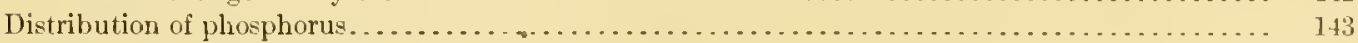

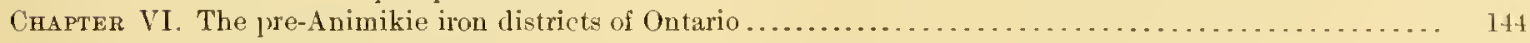

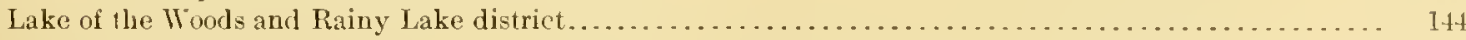

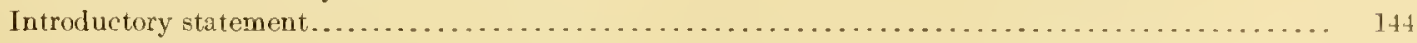

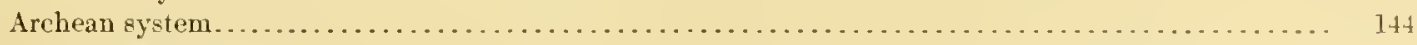

Keewatin series. . . . . . . . . . . . . . . . . . . . . . . . . . . . . . . . . . . . 144

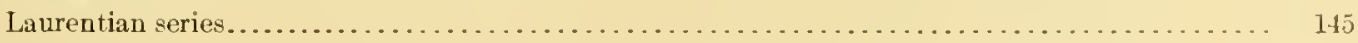


Chaptell V1. The pre-Animikie iron districts of Ontario fontinued. Page.

lake of the Ilouds and Rainy lake district-Continued.

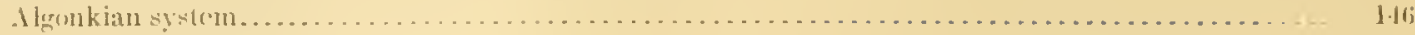

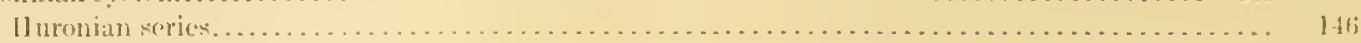

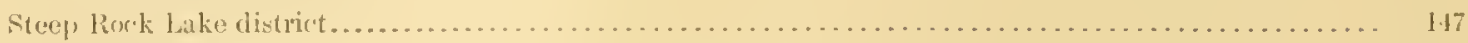

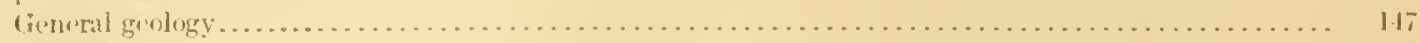

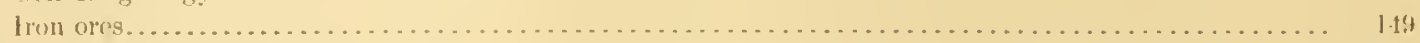

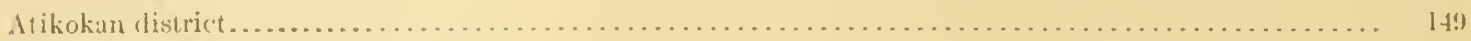

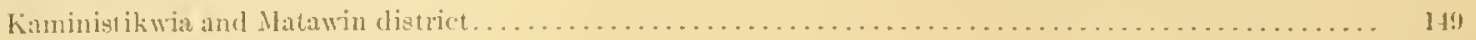

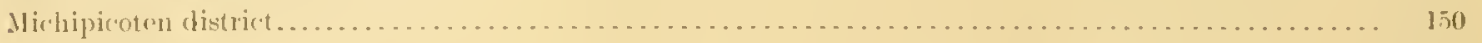

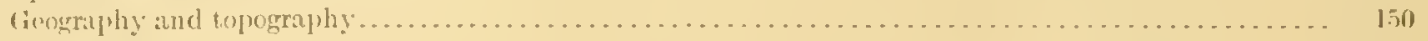

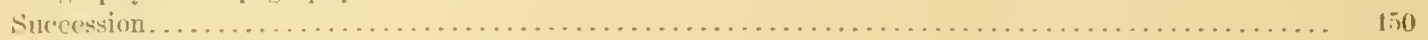

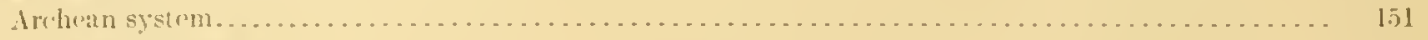

Kiewatin series. . . . . . . . . . . .

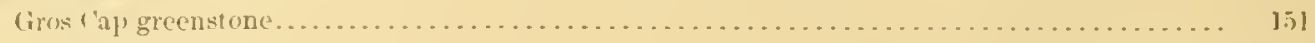

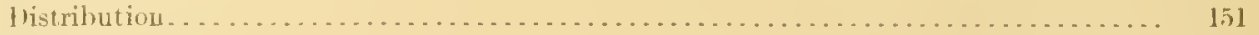

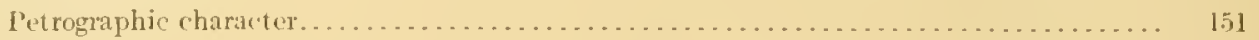

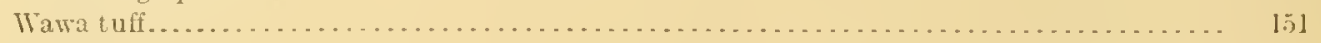

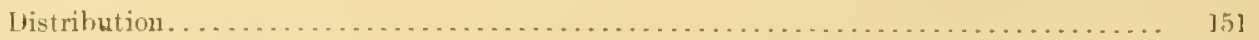

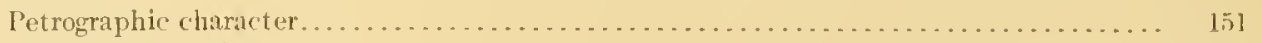

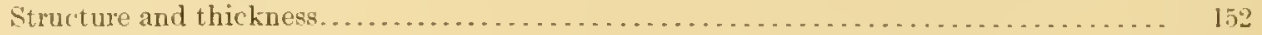

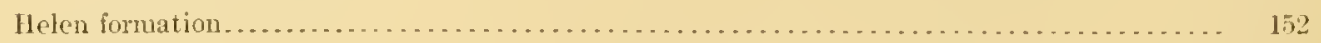

Distribution. . . . . . . . . . . . . . .

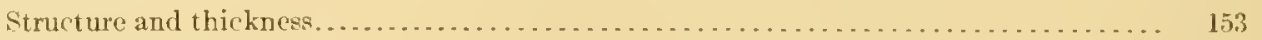

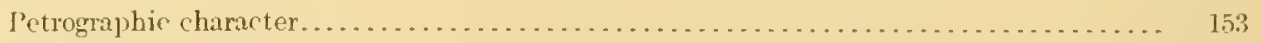

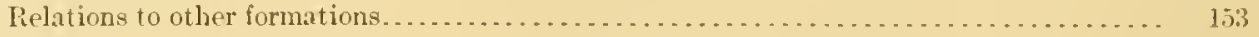

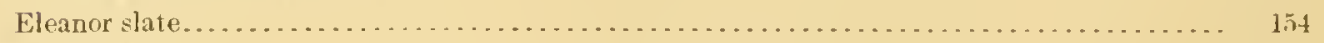

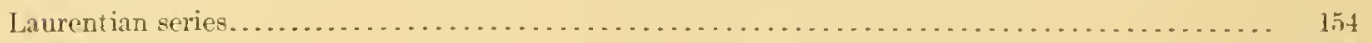

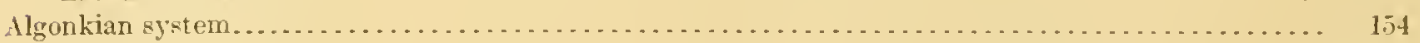

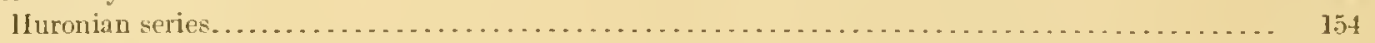

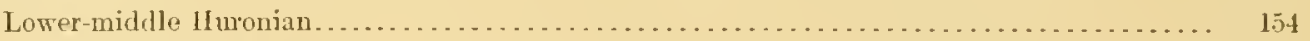

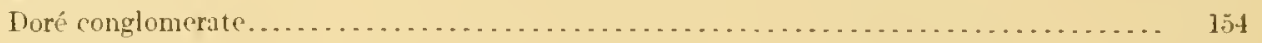

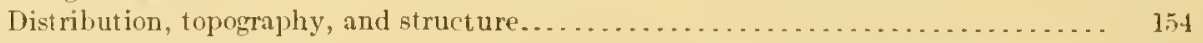

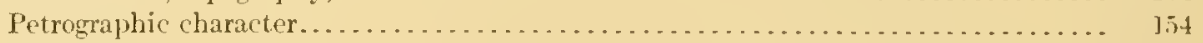

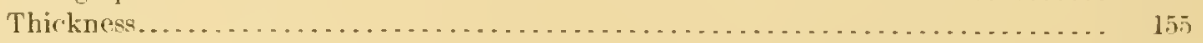

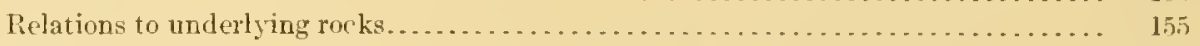

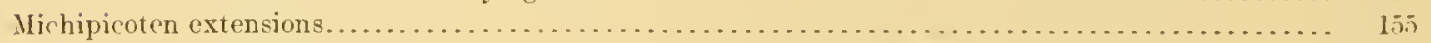

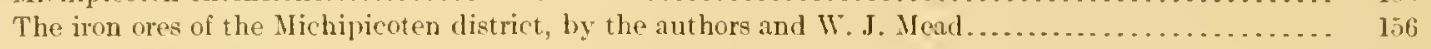

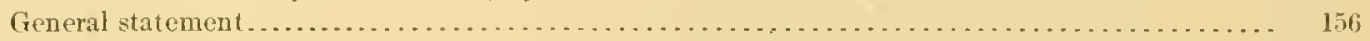

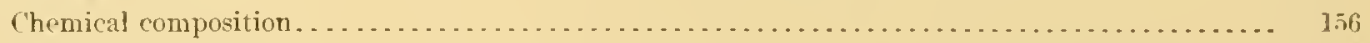

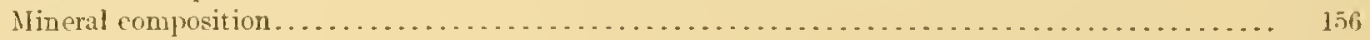

Physical charanteristics. . . . . . . . . . . . . . . . . . . . . . . . . . . . . . . . . 15.

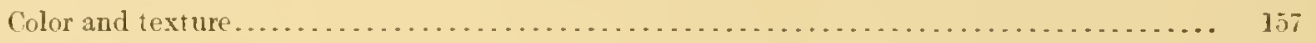

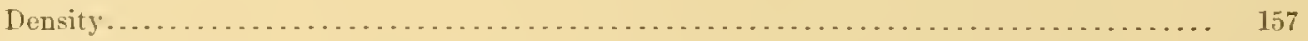

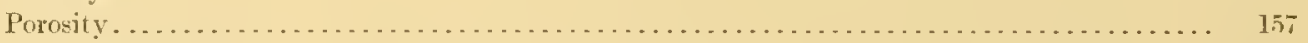

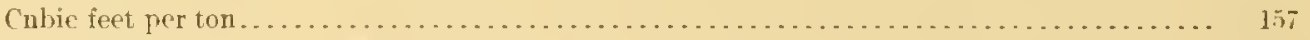

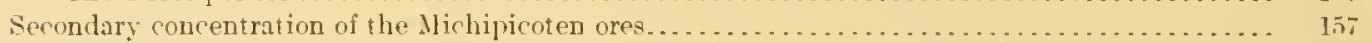

Chapter 111. The Mesabi iron district of Minnesota . . . . . . . . . . . . . . . . . . . . . . . 159

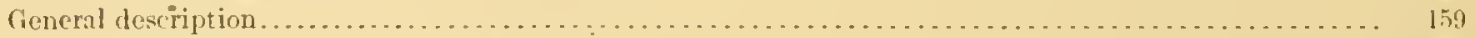

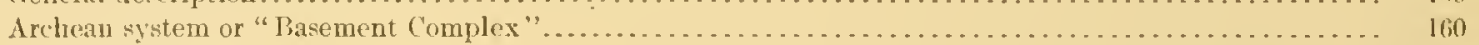

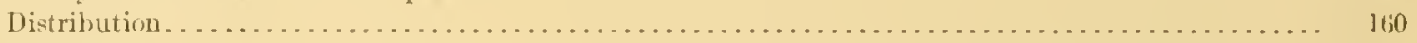

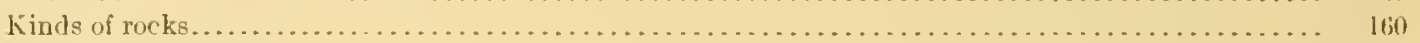

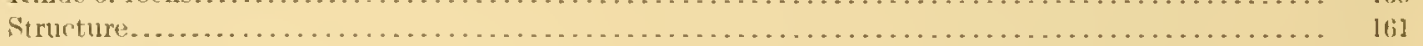

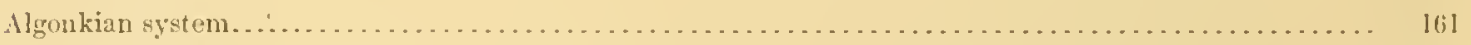

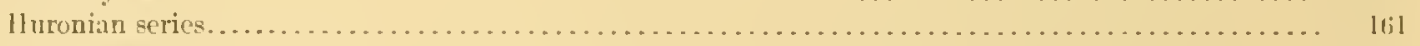

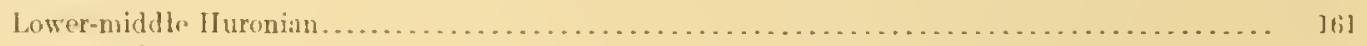

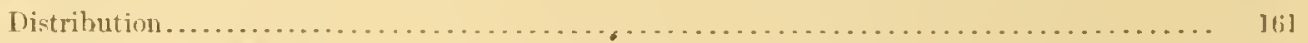

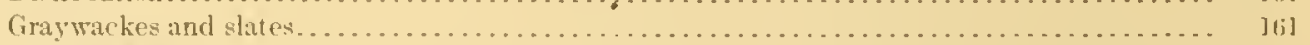

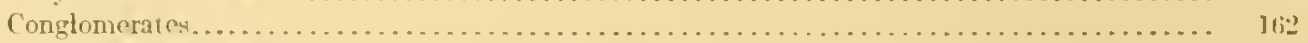

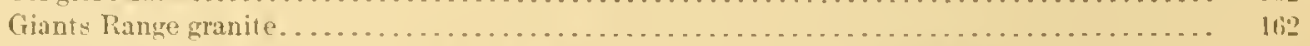

Relations of friants lange granite to the lower-niddle If uronian sedinents and of hoth to other

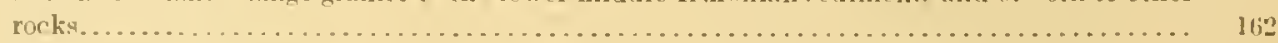

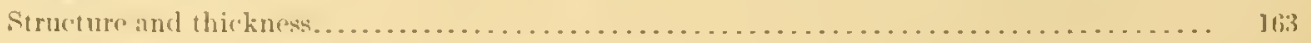

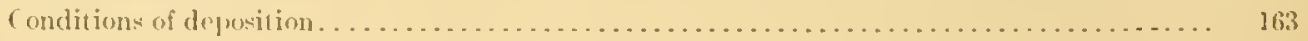


Chapter VII. The Mesahi iron district of Minnesota-Continued.

Algonkian system-Continued.

Hurnian series-Continued.

Upper lluronian (Animikie group)

Generil character and extent

Pokegama quartzite

Distribution. . .

Kinds of rocks. . . . . . . . . . . . . . . . . . . . . . .

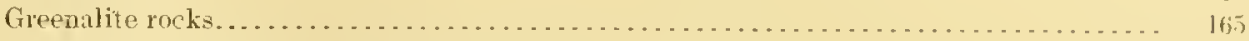

Ferruginous, amphibolitic, sideritic, and calcareons cherts.................. I6i8

Silireous, ferruginous, and amphibolitir slates......................... 170

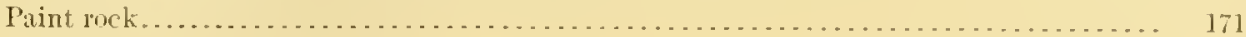

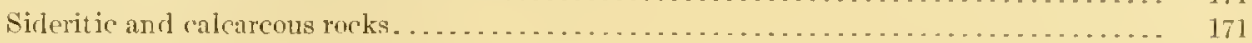

Conglomerates aud quartzitex................................... 171

Thickness........................................... 171

Alteration by the intrusion of Reweenawan granite and gabbro............. 171

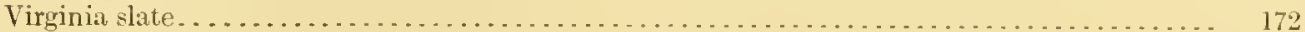

Distrilution. . . . . . . . . . . . . . . . . . . . .

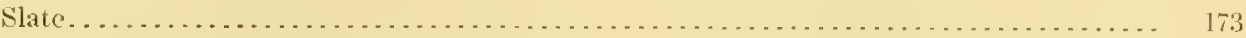

Cordierite hornstone resulting from the alteration of the Virginia slate by the Dubuth gabbro. 173

Relations to the Biwabik formation.................................. 174

Structure.......................................................... $17 t$

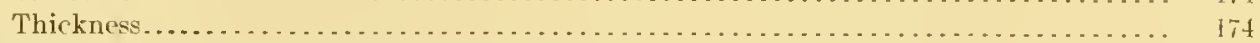

Structure of the upper lluronian (Animikie group) $\ldots \ldots \ldots \ldots \ldots \ldots \ldots \ldots \ldots \ldots \ldots \ldots \ldots \ldots$

Relations of the upper Iluronian (Animikie group) to ot her series. . . . . . . . . . . . . . . . . 176

Conditions of deposition of the upper lluronian (Animikie group) .................... 176

Keweenawan scries........................... 177

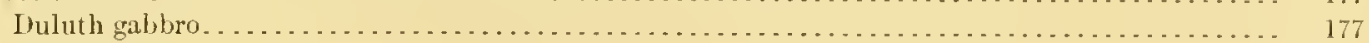

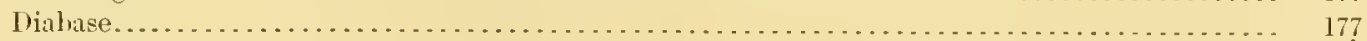

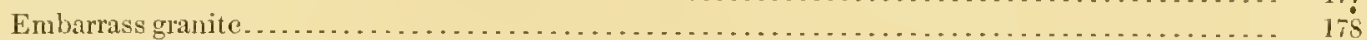

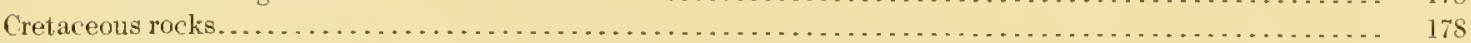

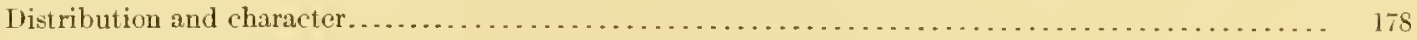

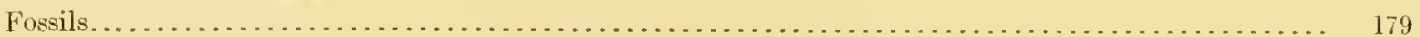

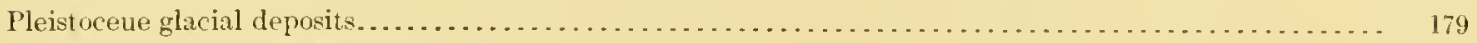

The iron ores of the Ilesabi district, by the authors and IV. J. Ilead . . . . . . . . . . . . . . . . . . 179

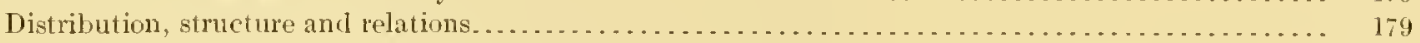

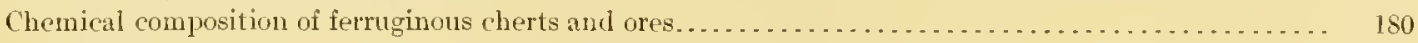

Analyses. . . . . . . . . . . . . . . . . . . . . . . . . . . . . . . . . . . . . . . . . . . 180

Representatiou by means of triangular diagram . . . . . . . . . . . . . . . . . . . . . . . . 182

Mineralogical compusition of ferruginous cherts and ores. . . . . . . . . . . . . . . . . . . . . . . . . 183

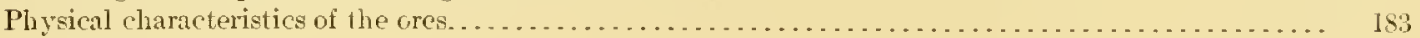

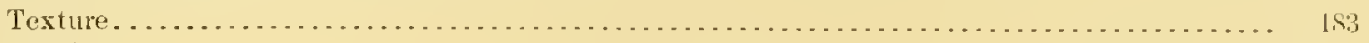

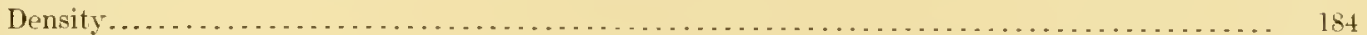

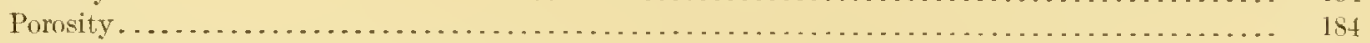

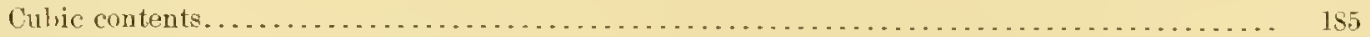

Magnetic phases of the iron-bearing formation. . . . . . . . . . . . . . . . . . . . . . . . 185

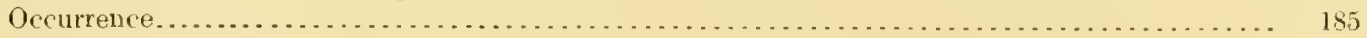

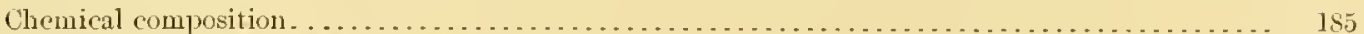

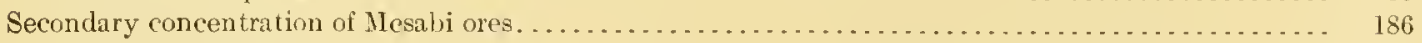

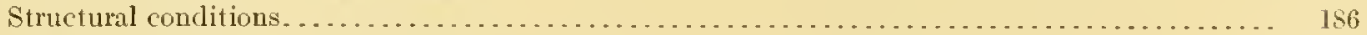

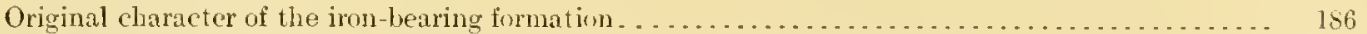

Alteration of sideritic or greenalitic chert to fermginous chert (taconite) $\ldots \ldots \ldots \ldots \ldots \ldots \ldots . .6187$

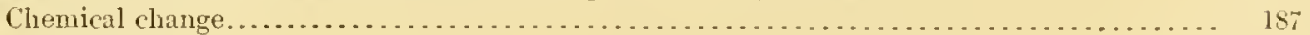

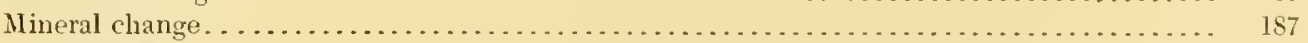

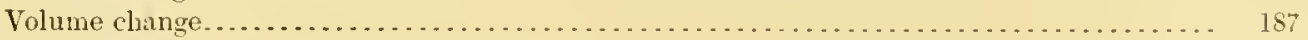

Development of porosity.......................................... 187

Alteration of ferruginous cherts (taconite) to ore.................................. 1 .

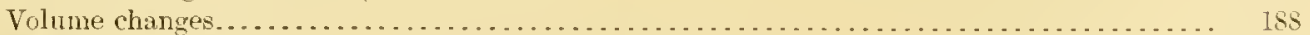

Hethod of expressing volume changes by triangular diagram....................... 189

Data used in triangle . . . . . . . . . . . . . . . . . . . . . . . . . . . . . . . . . 189

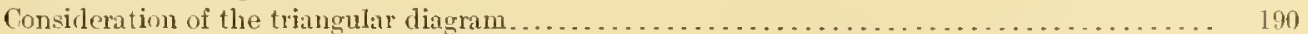

Alterations of associated rocks contemporaneous with secondary alteration of the iron-liearing formatiou. 
Cinptia V"11. The Mesalhi iron district of Minnesola- Continumbl.

The iron ores of the Mesabi district, lyy the atuthors and IV. J. Mead Continued.

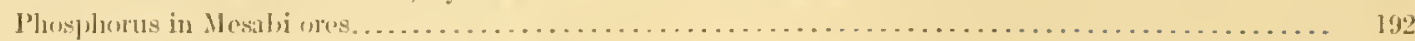

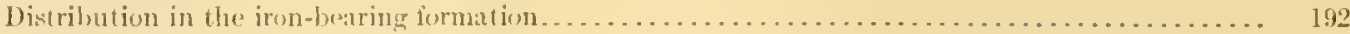

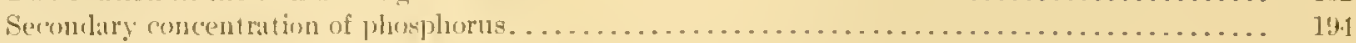

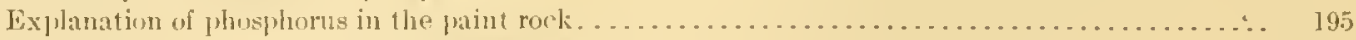

Phosphorus in the amphible-magnetite phases of the iron-bearing formation.............. 195

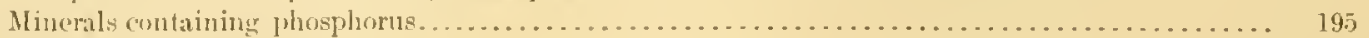

Detrital ores in the Cretacents rucks. . . . . . . . . . . . . .

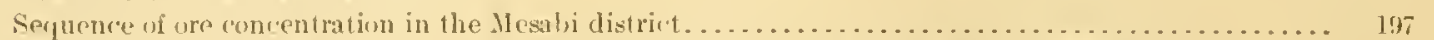

Сиapter VIII. The Gunflint Lake, Pigeon Point, and Animikie iron districts of Minnesota and Ontario..... 198

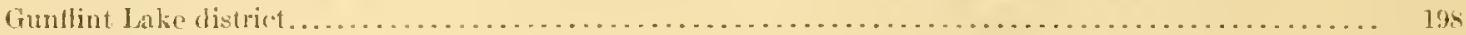

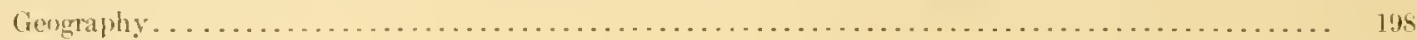

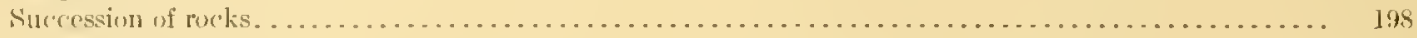

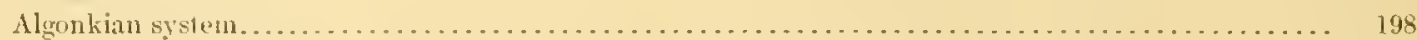

II

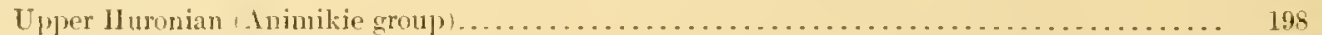

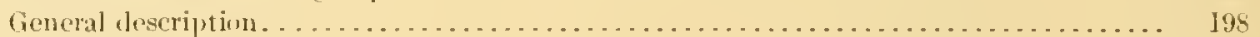

Gunflint formatimn............................................ 199

Distrilution. . . . . . . . . . . . . . . . . . . . . . . . . . . . . . . . 199

Structure ................................................... 199

Petrographic character........................................... 200

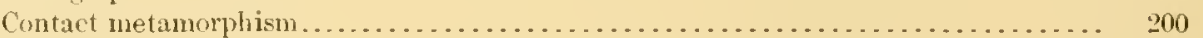

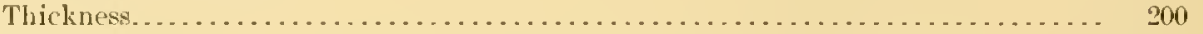

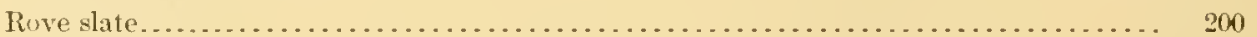

Distribution. . . . . . . . . . . . . .

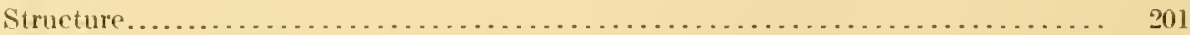

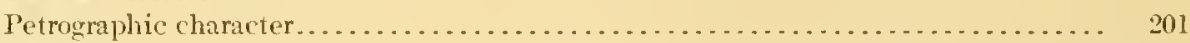

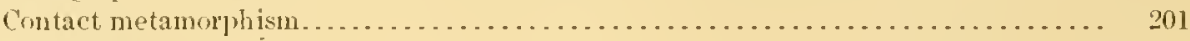

Thickness.................................................... 201

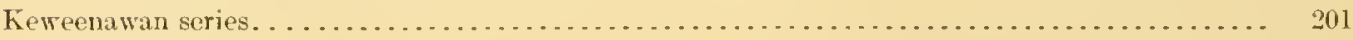

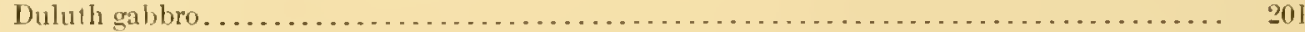

Logan sills. . . . . . . . . . . . . . . . . . . . . . . . . . . . .

Relations of the Keweenawan rocks to one another and to adjacent formations........ 202

Geolngic relations. . . . . . . . . . . . . . . . . . . . . . . . . . . . . . . . 202

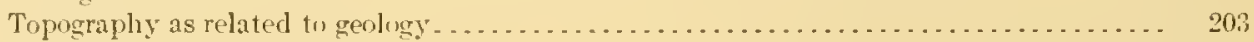

The iron ores of the Gunflint Lake district. . . . . . . . . . . . . . . . . . . . . . . . . . . 20.2

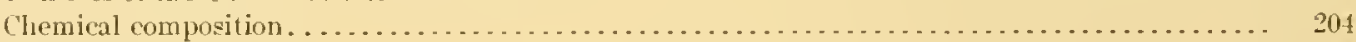

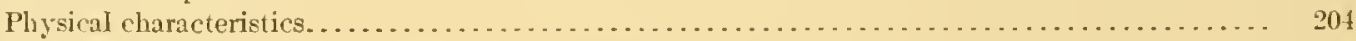

Pigenn Point district. . . . . . . . . . . . . . . . . . . . . . . . . . . . . . . . . . . . . . . . . . . . 204

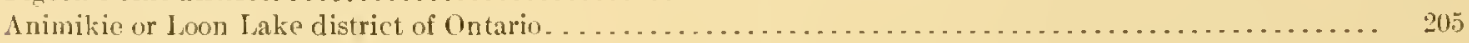

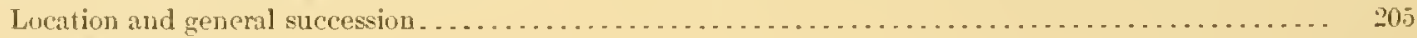

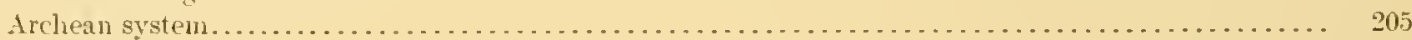

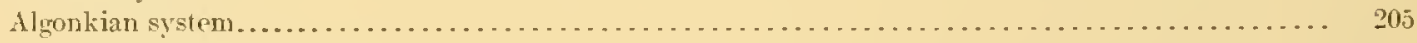

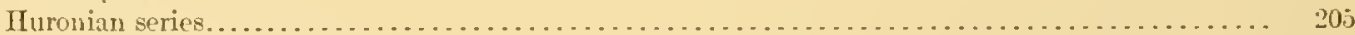

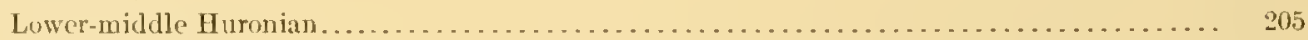

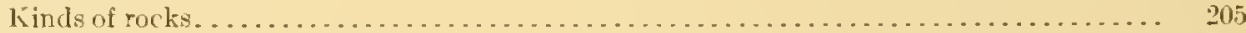

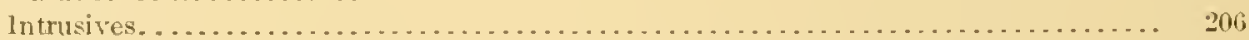

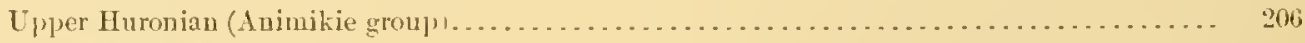
General description . . . . . . . . . . . . . . . . . . . . . . . . . . . . . . . . . .

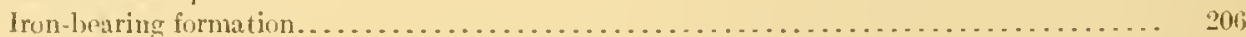

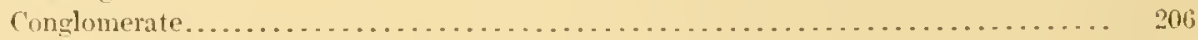

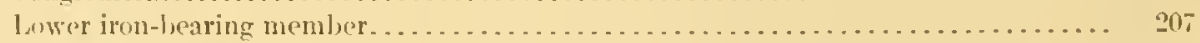

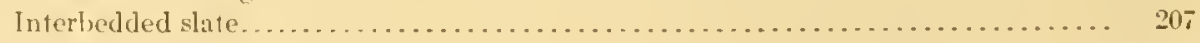

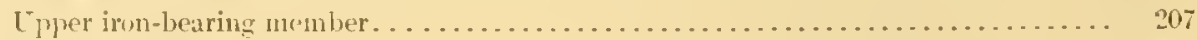

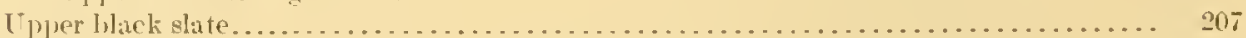

lieweenawan series. . . . . . . . . . .

(ineral destription . . . . . . . . . .

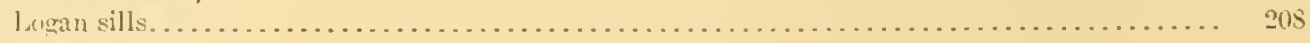

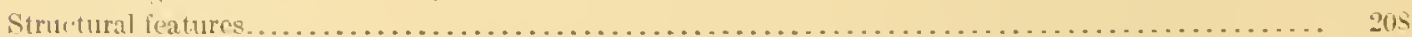

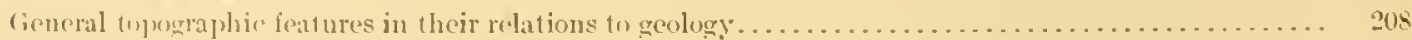

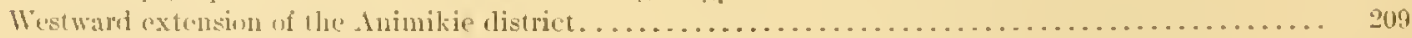


Chapter VIll. The Gunflint Lake, Pigeon Point, and Animikie iron districts of Minnesota and ()ntario-C'on. Page. Animikie or Loon Lake district of ontario-Continued.

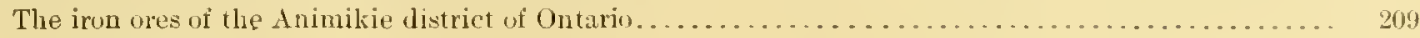

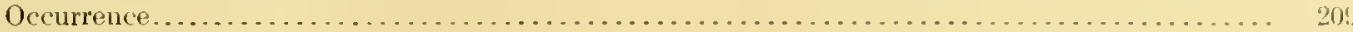

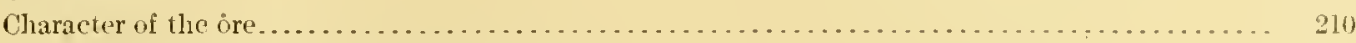

Secondary concentration of the Animikie rires. . . . . . . .

Structural conditions. . . . . . . . . . . . . . . . . . . . . . . . . . . . . . . . . . . 210

Original character of the iron-bearing formation . . . . . . . . . . . . . . . . . . 210

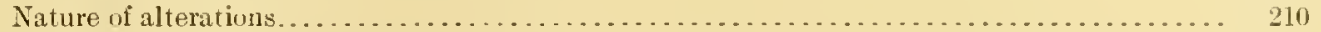

Sequence of ore concentration . . . . . . . . . . . . . . . . . . . .

Chapter IX. The Cuyuna iron distriet of Minnesota and its extensions to Carlton and Cloquet, and the Minne-

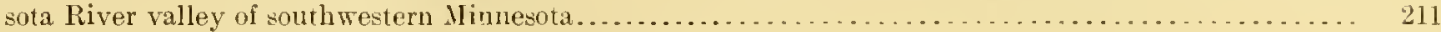

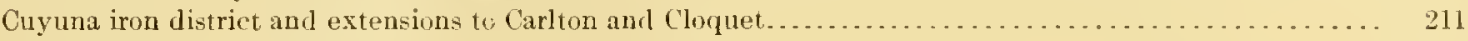

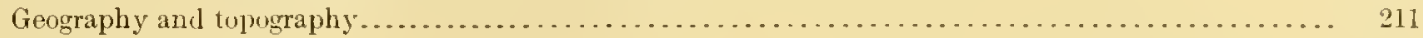

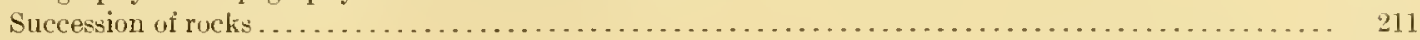

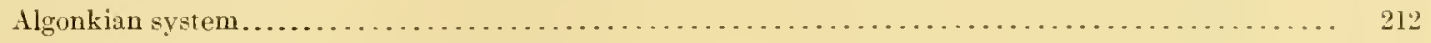

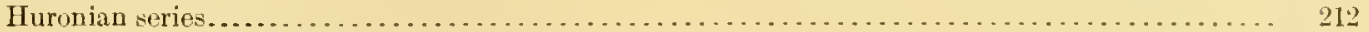

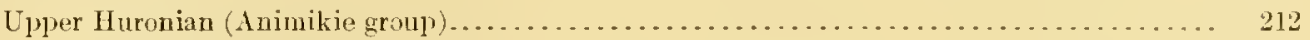

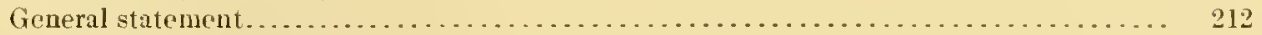

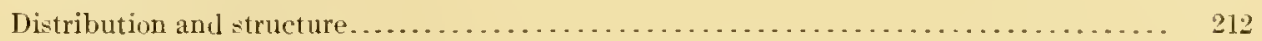

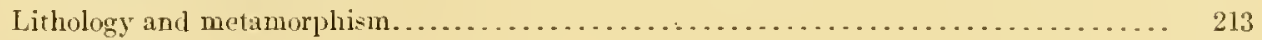

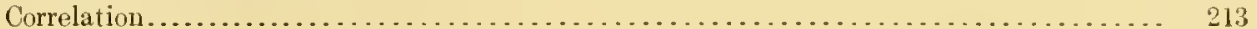

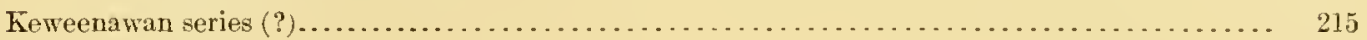

Cretaceous rocks............................................................. 215

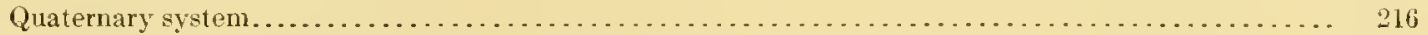

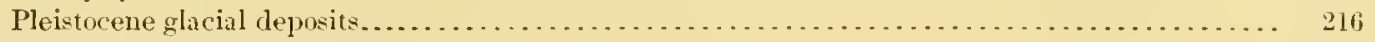

The iron ores of the Cuyuna district, by the authors and Carl Zapffe ..................... 216

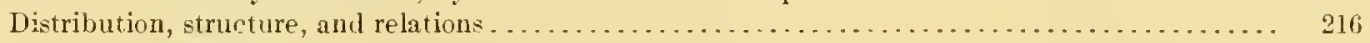

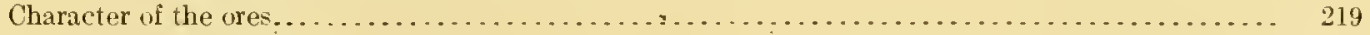

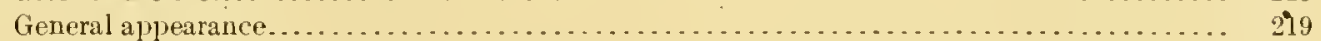

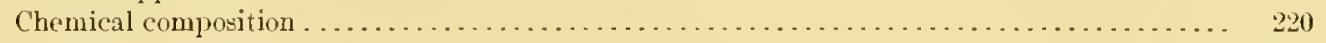

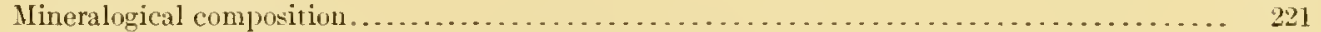

Texture . . . . . . . . . . . . . . . . . . . . . . . . . . . . . . . . . 223

Secondary concentration of cuyuna wres . . . . . . . . . . . . . 223

Structural couditions............................................. 223

Original character of the Deerwool iron-bearing member..................... 223

Mineralogical and chemical changes.................................... 223

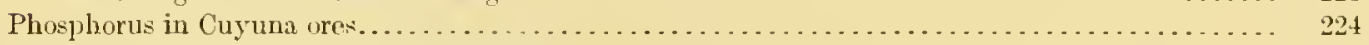

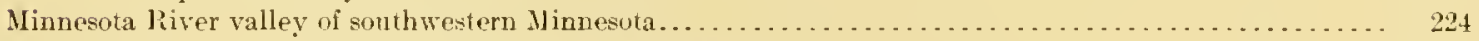

Chapter X. The Penokee-Gogebic iron district of Michigan and Wisconsin . . . . . . . . . . . . . . . . 225

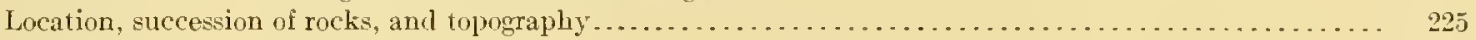

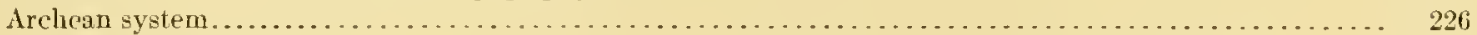

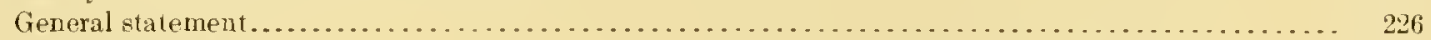

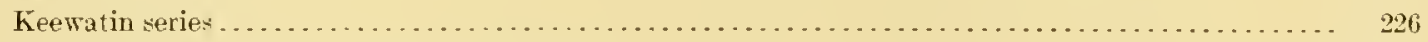

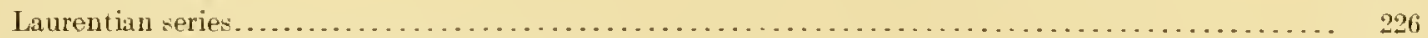

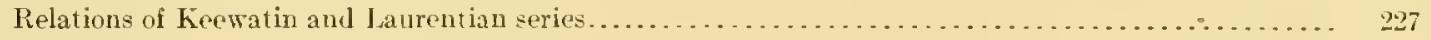

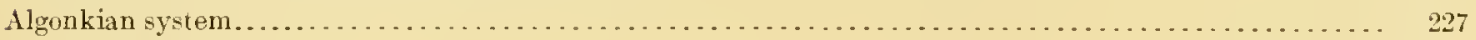

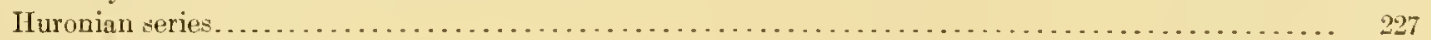

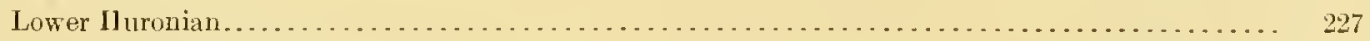

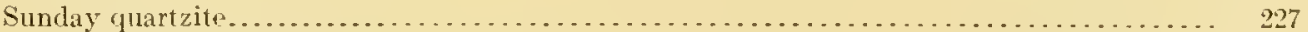

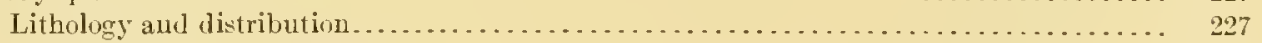

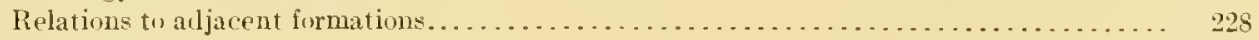

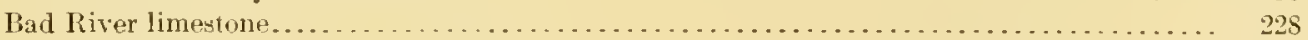

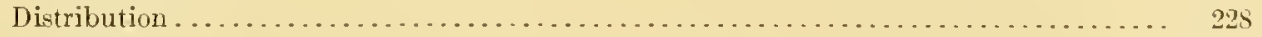

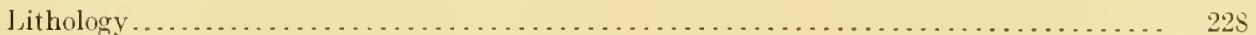

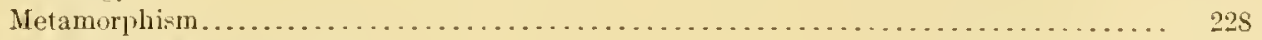

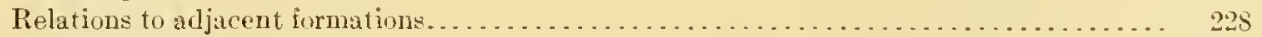

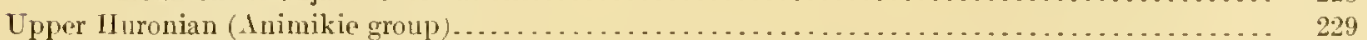

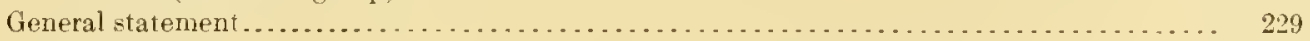

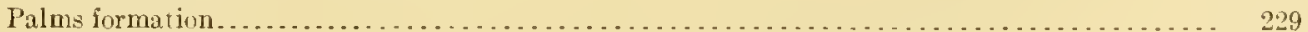

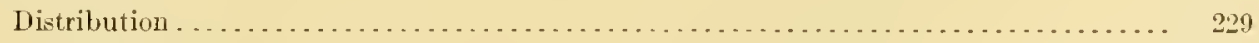

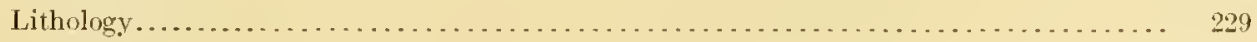

Relations to adjacent formations.................................... 230 


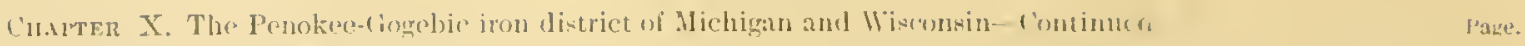

Algonkian system-continuted.

Iluronian series íntmed.

L'puer Il uronian (. Animikie group)-Continued.

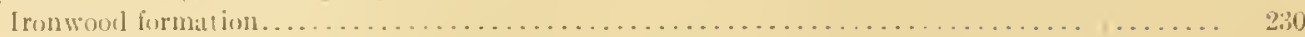

Distribuin

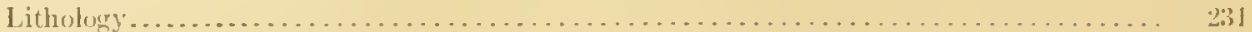

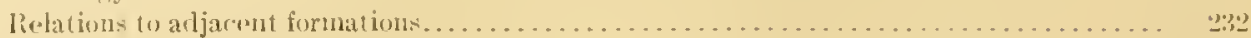

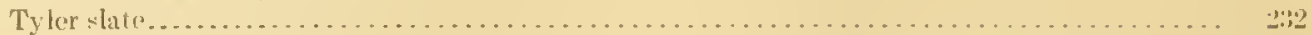

Distrilution . . . . . . . . . . .

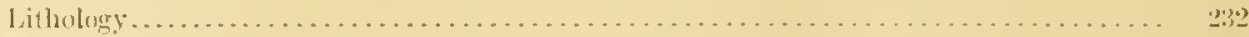

Vetamorphism.................

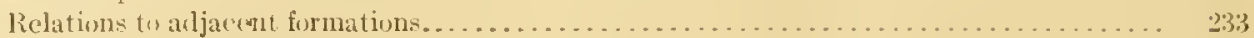

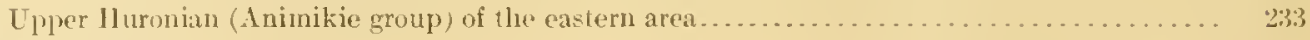

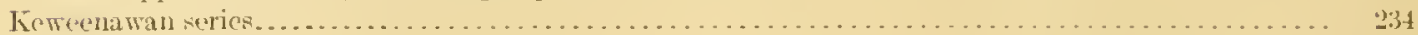

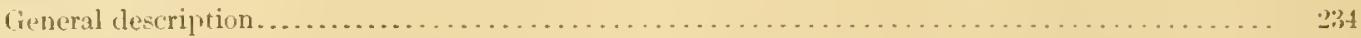

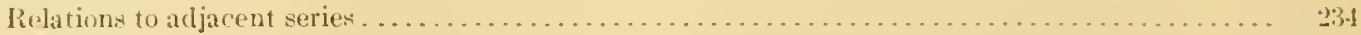

Cambrian sand

The iron ores of the Penokec-Gogebic district, by the atuthors and IT. J. Mead................... $2: 35$

Distri]ution, structure, and relations . . . . . . . . . . . . . . .

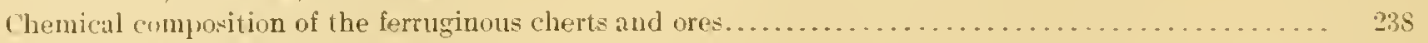

Imeralogiral composition of the ferruginous cherts and ures . . . . . . . . . . . . . . . . . . 240

Physical characteristics. . . . . . . . . . . . . . . . . . . . . . . . . . . . . .

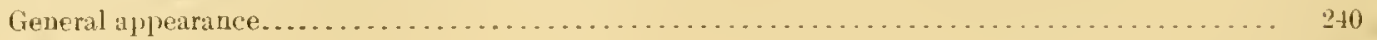

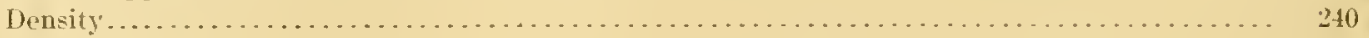

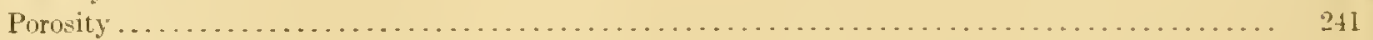

Cubic contents...........................................

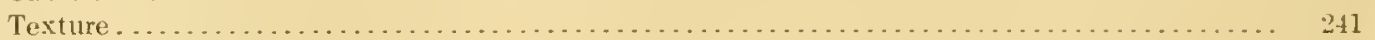

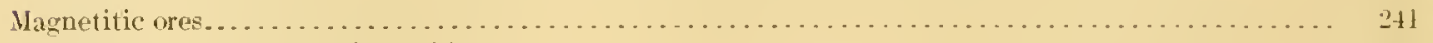

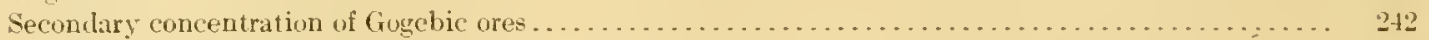

Structural conditions . . . . . . . . . . . . .

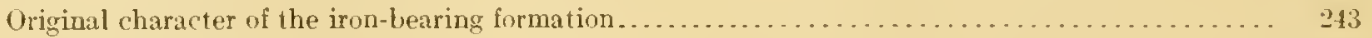

Alteration of cherty iron carbonate to ferruginous chert........................... 243

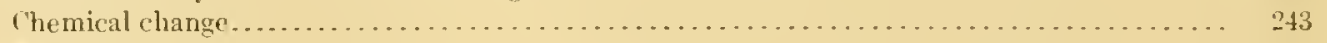

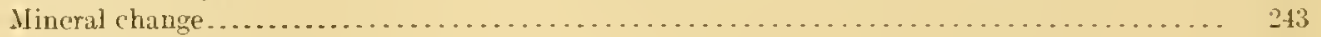

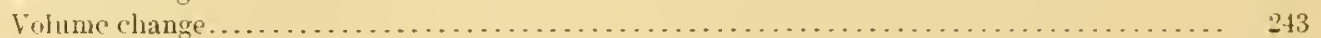

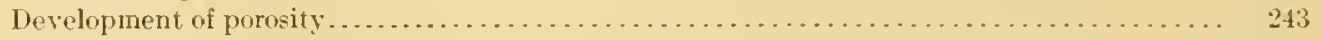

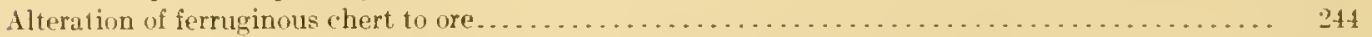

Triangular diagram illustrating sccondary concentration of Gogebic ores................ 240

Alteration of rocks associated with ores during their secondary concentration .............. $24{ }^{2}$

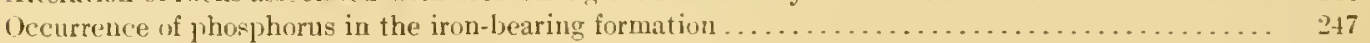

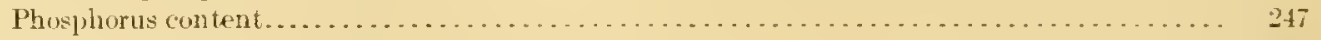

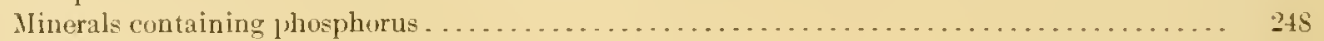

Behavior of phosphorus during secondary concentration.......................... 249

Sequence of ore concentration iu the Gogebic district . . . . . . . . . . . . . . . . . . . . . . 250

('hapter XI. The Marquette iron district of Michigan, including the. Swanzy, Dead River, and Perch Lake

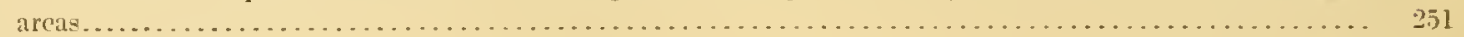

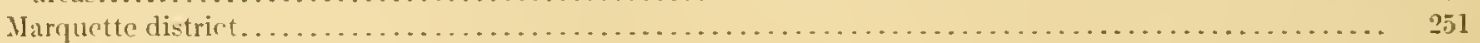

Introduction . . . . . . . . . . . . . . . . .

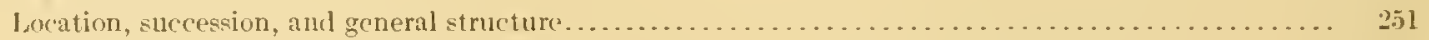

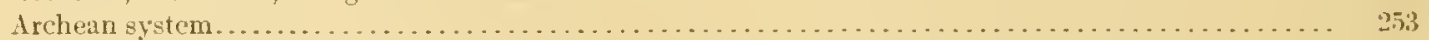

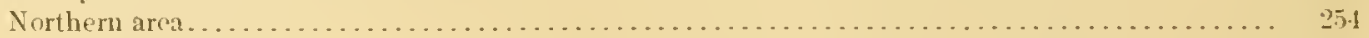

Kecwatin series . . . . . . . . .

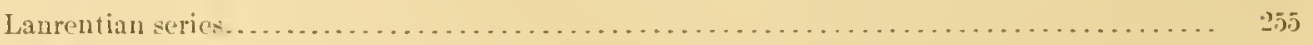

Southern area. . . . . . . . . . . . . .

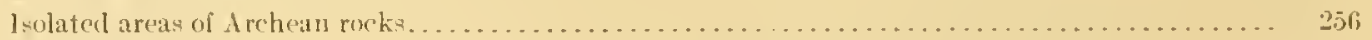

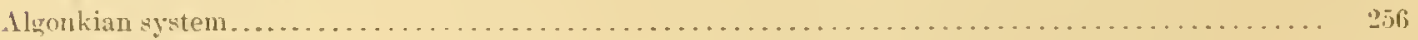

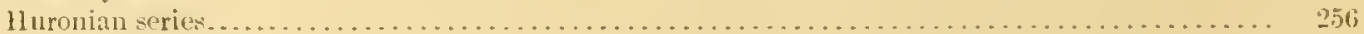

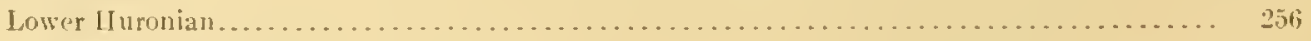

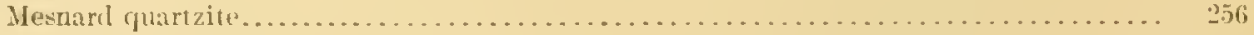

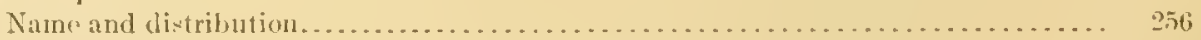

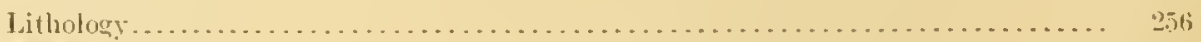

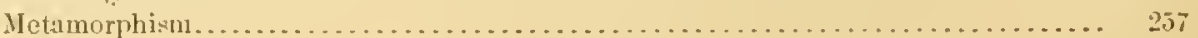


Chapter XI. The Jarquette iron district of Michigan, etc.-Continued.

Marquette district-continued.

Algonkian system-Continued.

Huroniau scries-Continued.

Lower Il urouian-Continucd.

Mesuard quartzite-continned.

Relations to aljacent formations.............................

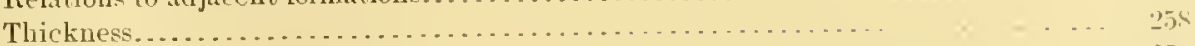

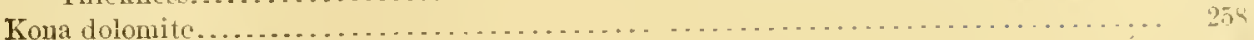

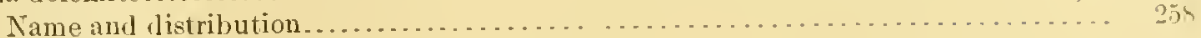

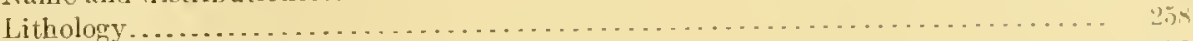

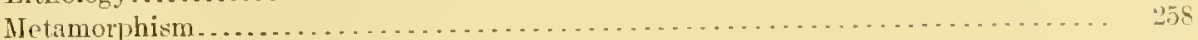

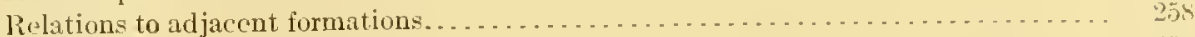

Thickness

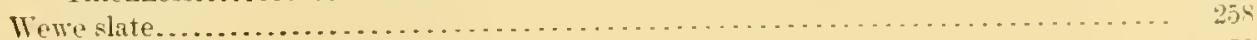

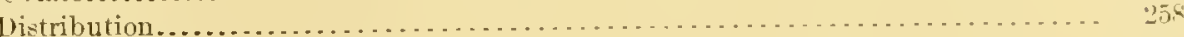

I

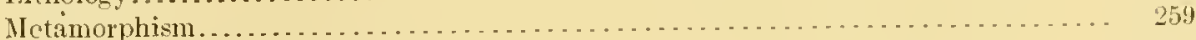

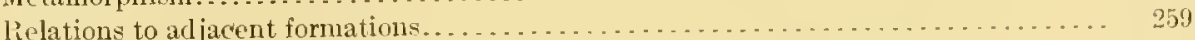

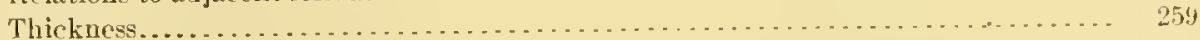

Viddle II uronian ........

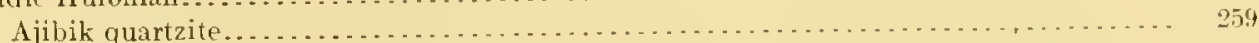

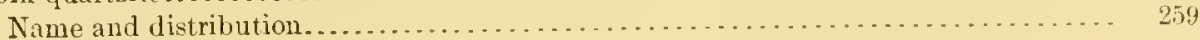

Deformation

Lithology

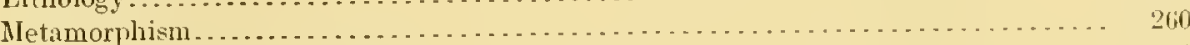

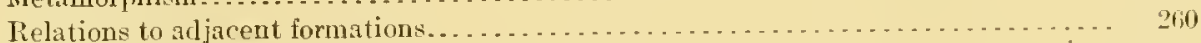

Thickness

Siamo slate

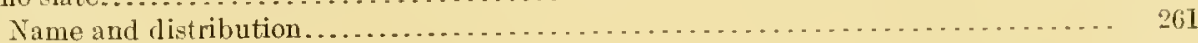

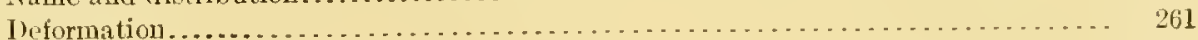

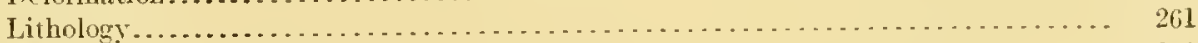

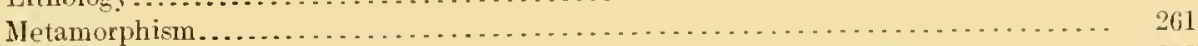

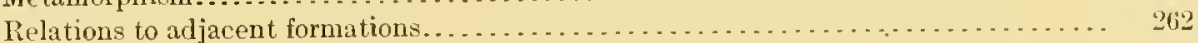

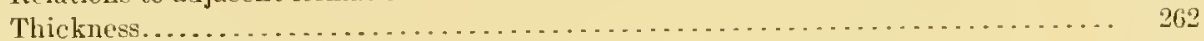

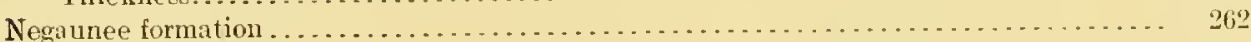

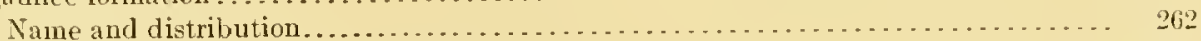

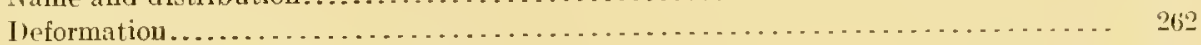

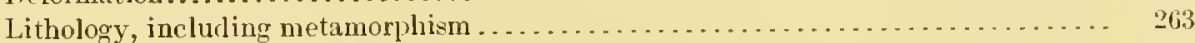

Relations to adjacent formations. . . . . . . . . . . . . . . . . . . . . . . . . . . 264

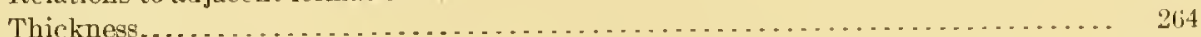

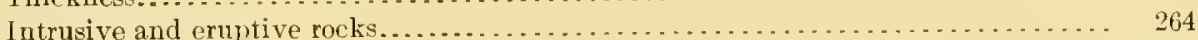

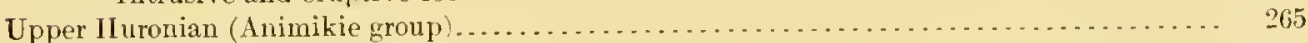

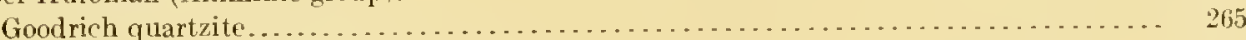

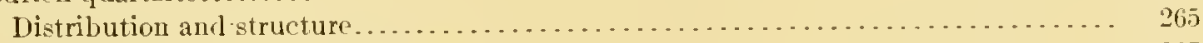

Lithology, inclurling metamorphism . . . . . . . . . . . . . . . . . . . . 265

Relations to adjacent formations. . . . . . . . . . . . . . . . . . . . . . . . . 265

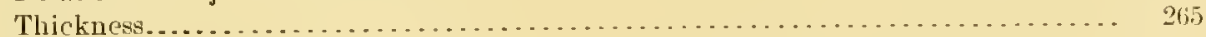

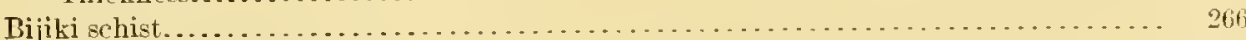

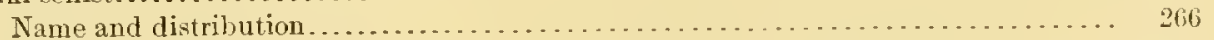

Lithology, including metamoryhism . . . . . . . . . . . . . . . . . . . . . 266

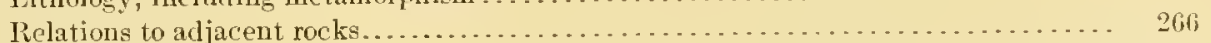

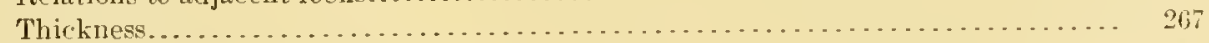

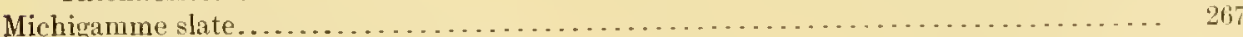

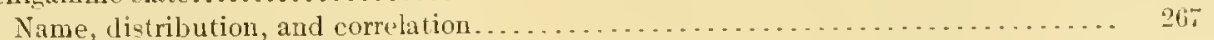

Deformation

Lithology

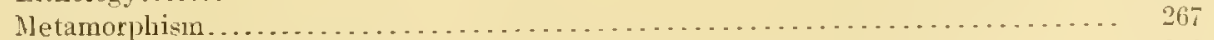

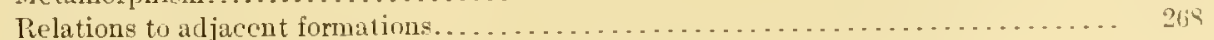

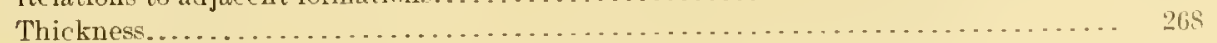

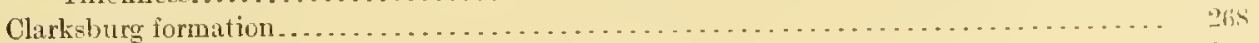

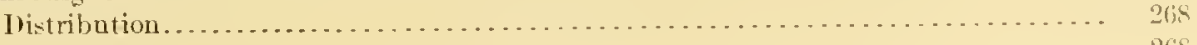

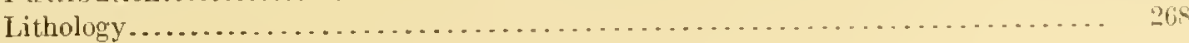


Chater Xi. The Marquetre inon districh of Mielnigan, ele-Continued.

Irarguete distriet-Continued.

Algonkian system-Cintinued.

Huronian series - continued.

Upper Hurunian (Animikie group)-('ontinuerl.

Clarksburg formation-C'ontinued.

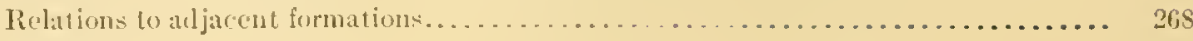

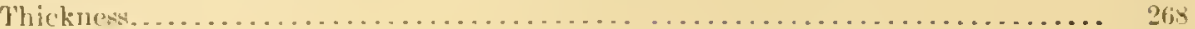

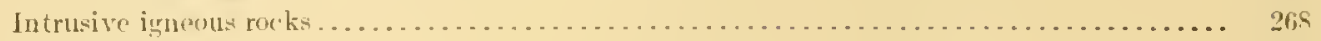

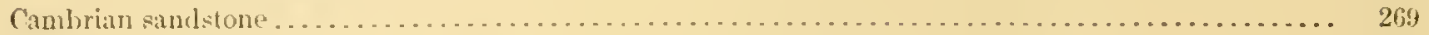

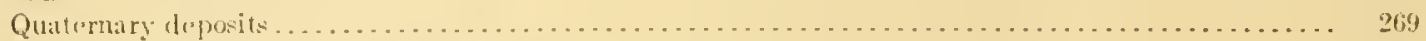

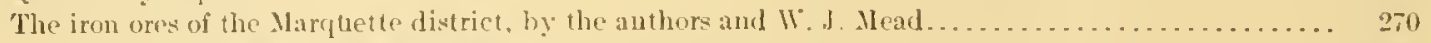

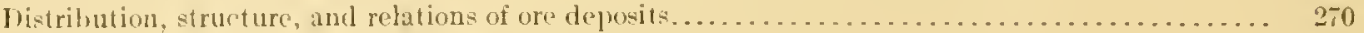

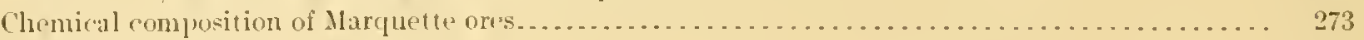

(hemiral compoution of iron-bearing Negaunee formation ......................... 273

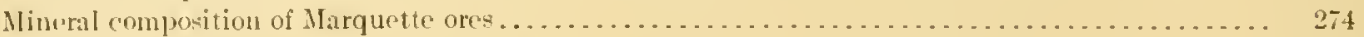

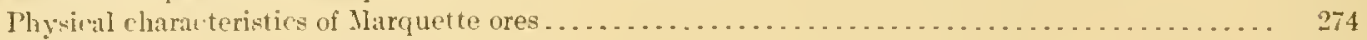

Secondary concentration of Ilarquette ores..................................... 27

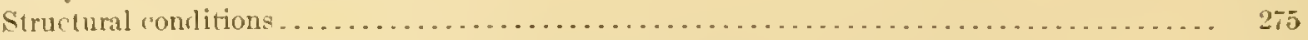

Chemical and mineralogical changes in secondary concentration of Ilarquette ores......... 270

Volume changes in secondary concentration of dlarquette ores ................... 276

Representation of ores and jaspers on triangular diagram........................ $27 \mathrm{~s}$

Sequence of ore concentration in the Harquette district.............................

Occurrence of phosphorus in the llarquette ores............................ 279

Distribution of phosphorus......................................... 279

Vineralogical oecurrence of phosphorus................................... 981

Phosphorus in relation to secondary concentration ........................... 281

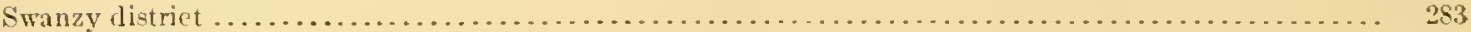

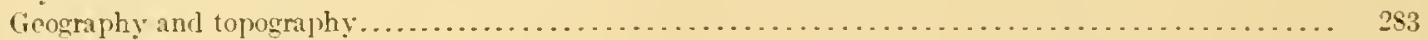

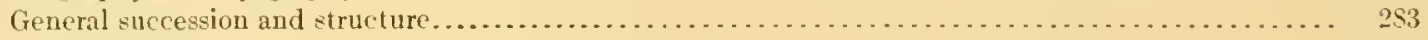

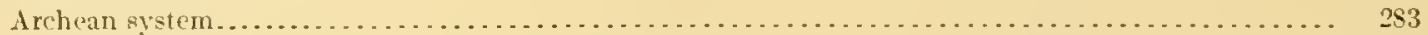

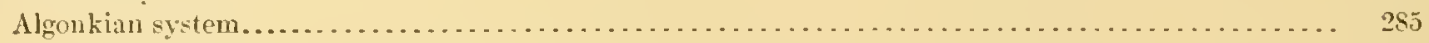

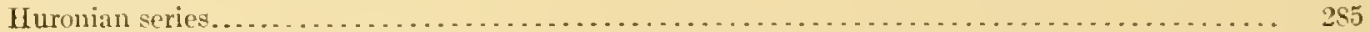

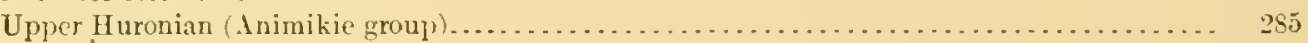

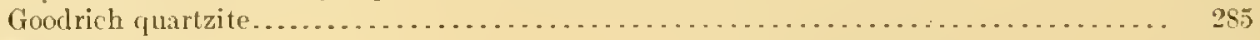

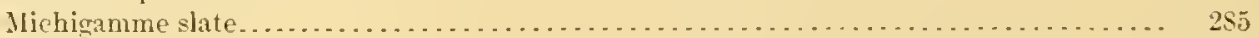

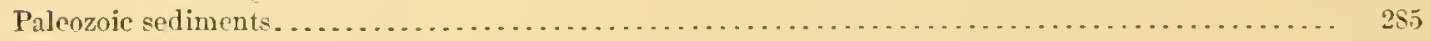

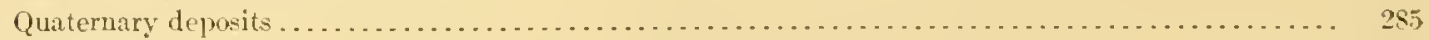

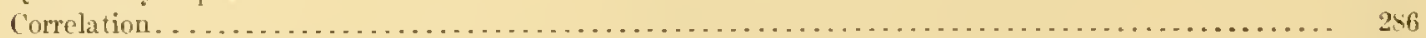

The iron ores of the Swanzy distriet, by the authors and II. J. Mearl . . . . . . . . . . . . . . . 286

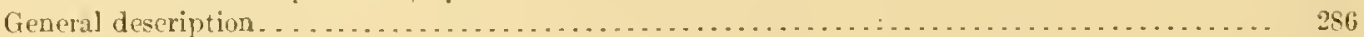

Secondary concentration of Swanzy ores . . . . . . . . . . . . . .

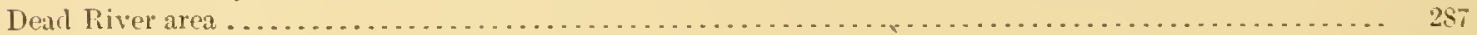

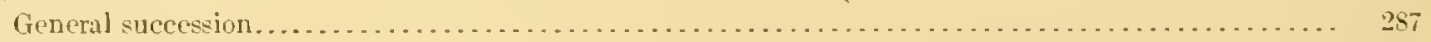

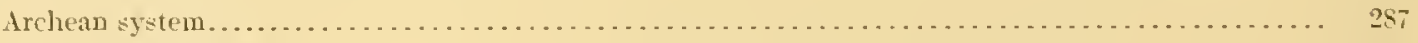

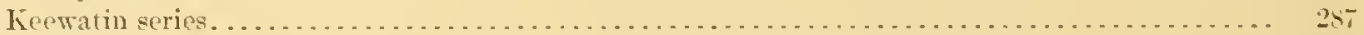

Laurentian series. . . . . . . . . . . . . . . . . . . . . . . . .

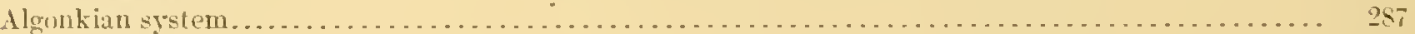

Huronian series.....................

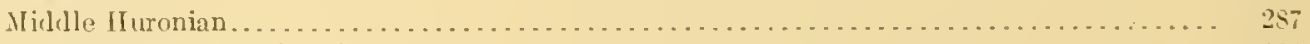

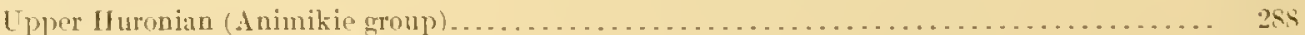

Perch lake distriet (inclulling western Jarquette) . . . . . . . . . . . . . . . . . . . . . . . . . .

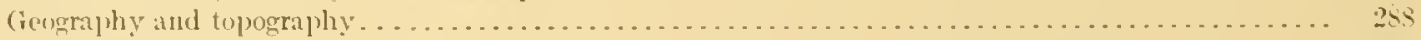

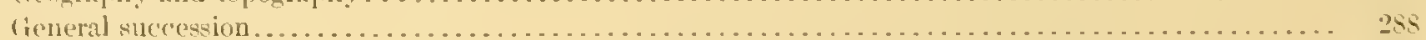

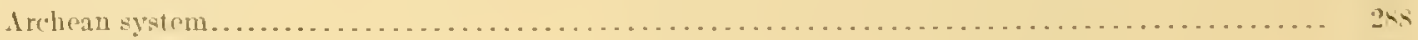

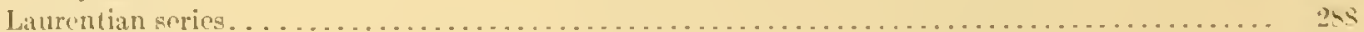

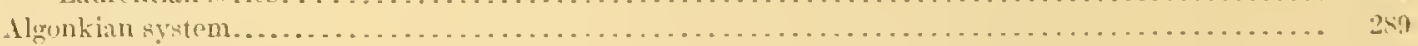

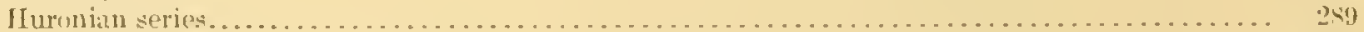

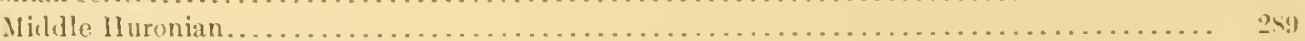

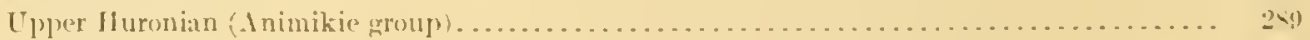

Quaternary deposits. . . . . . . . . . . . . . . . . . . . . . . . . . . . 
Chapter III. The Crystal Falls, Sturgeon, Feleh Mountain, Calumet, and Tron River iron districts of Michi- Page.

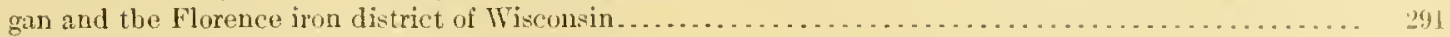

Crystal Falts iron district . . . . . . . . . . . . . . . . . . . . . . . . . . . . . . . . . . . . .

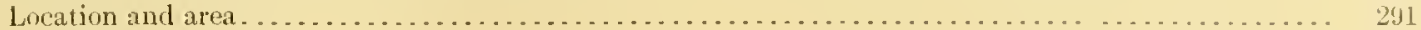

General succession and structure. . . . . . . . . . . . . . . . . . . . . .

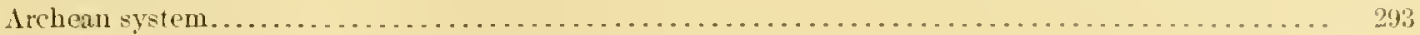

Laurentian series. . . . . . . . . . . . . . . . . . . . . . . . . . . . . . . . . . . . . . . . . 293

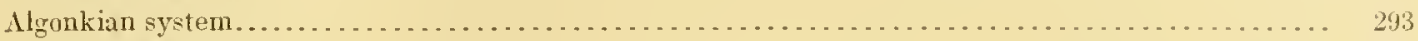

Hurunian series....... .

Lower Huronian . . . . . . . . . . . . . . . . . . . . . . . . . . . . . . . . . . . 293

Sturgeon quartzite.................................................. 293

Randville dolomite............................................... 293

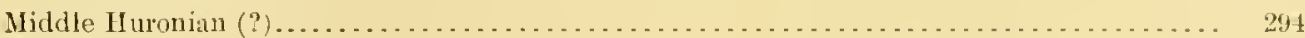

Hemlock formation............................................... 294

Distribution and general character................................. 294

Area south and west of the westemost Arehean wal..................... 294

Fence River area.............................................. 295

Other areas of the Hemlock formation. . . . . . . . . . . . . . . . . . . . . . . . . . . 295

Iron-bearing slate member ("Mansfield slate") of the llemlick formation . . . . . . . 295

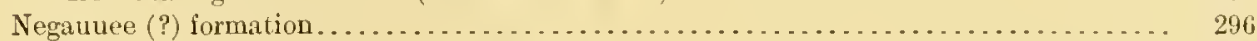

Magnetic belts northeast of Fence River . . . . . . . . . . . . . . . . . . . . . . . . 296

Negaunee (?) formation at Hichigamme Ilountain and in the Fence Piver area..... 296

Ferruginous quartzite associated with iron-bearing formation north of Michigamme

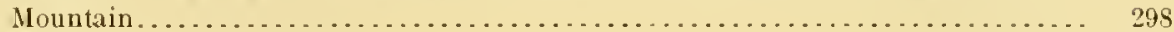

Upper Iuronian (Animikie group) .................................... 298

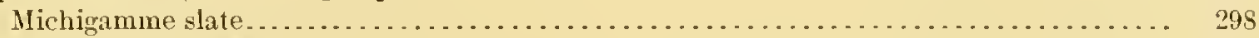

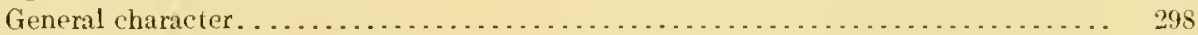

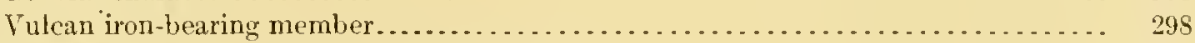

Intrusive and extrusive rocks in upper Huronian ........................... 299

Relations of the upper Huronian to underlying rocks . . . . . . . . . . . . . . . . . . 300

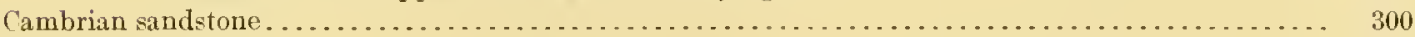

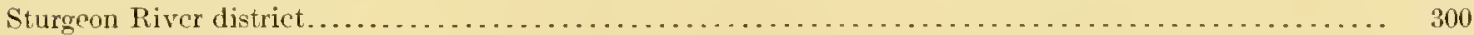

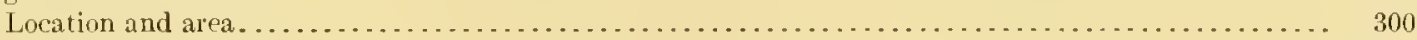

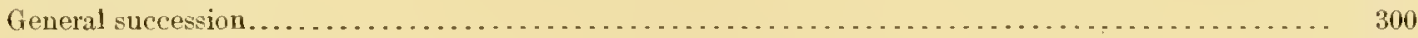

Archean system......... . . . . . . . . . . . . . . . . . . . . . . . . . . . . . . . . . . . 301

Laurentian series. . . . . . . . . . . . . . . . . . . . . . . . . . . . . . . . . . . . . . 301

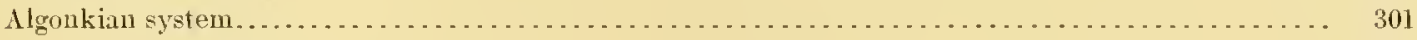

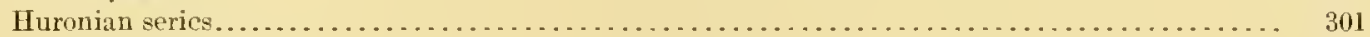

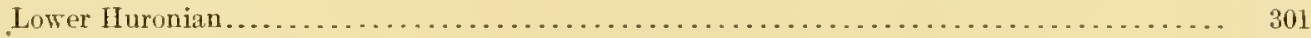

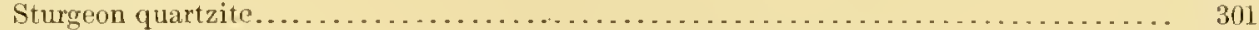

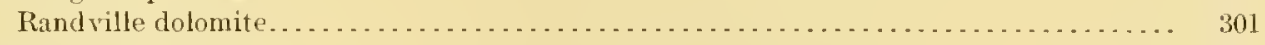

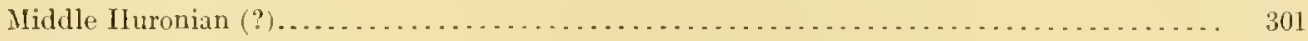

Negaunee (?) formation . . . . . . . . . . . . . . . . . . . . . . . . . . . . . . . 301

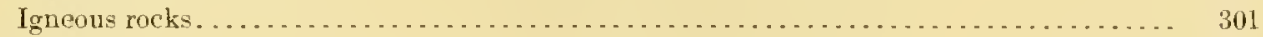

Keweenawan series (?) . . . . . . . . . . . . . . . . . . . . . . . . . . . . . . . . . 301

Felch Iountain district. . . . . . . . . . . . . . . . . . . . . . . . . . . . . . . . . . . . . . 302

Locătion, structure, and general succession . . . . . . . . . . . . . . . . . . . . . . . . . . 302

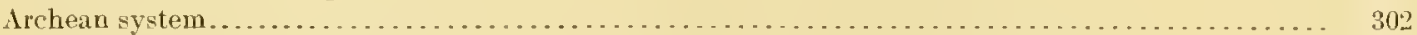

Laurentian scrics. . . . . . . . . . . . . . . . . . . . . . . . . . . . . . . . .

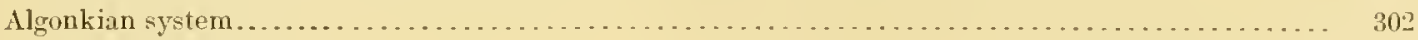

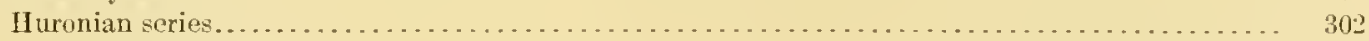

Lower Huronian..... . . . . . . . . . . . . . . . . . . . . . . . . . . . . . . . . . . . . . . 303

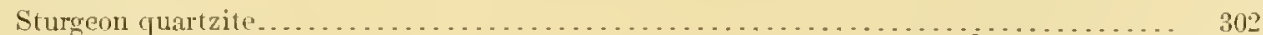

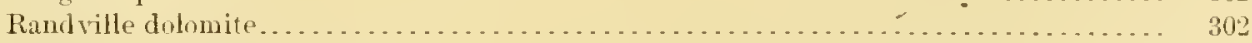

Upper IIuronian (Aninikie group) .... . . . . . . . . . . . . . . . . . . . . . . . . 303

Felch schist. . . . . . . . . . . . . . . . . . . . . . . . . . . . . . . .

Vulcan formation. . . . . . . . . . . . . . . . . . . . . . . . . . . . . . 303

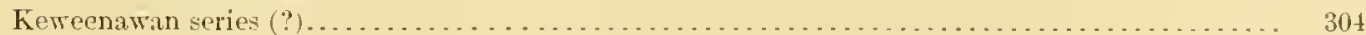

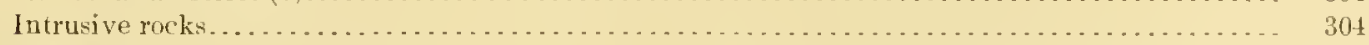

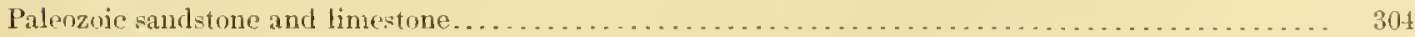

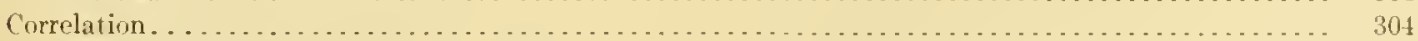

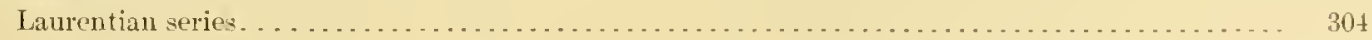

Lower Huronian . . . . . . . . . . . . . . . . . . . . . . . . . . . . . . . . . . . . . . . $300^{\circ}$ 


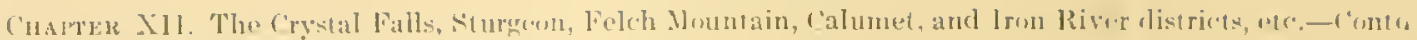

bloh Jountain distret-intinuml.

Correlation fontinued.

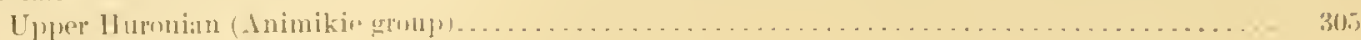

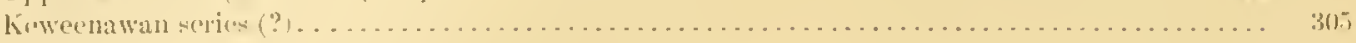

lalumet district...

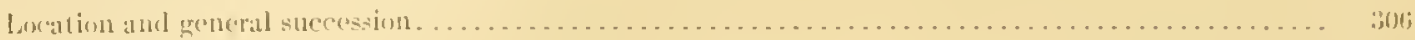

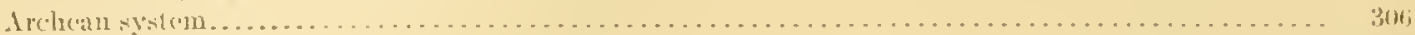

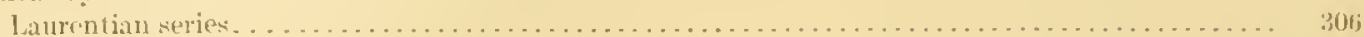

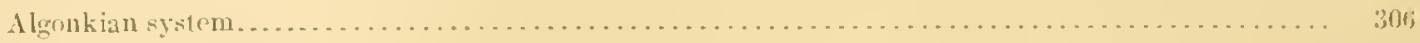

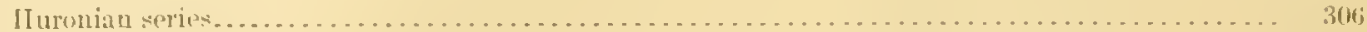

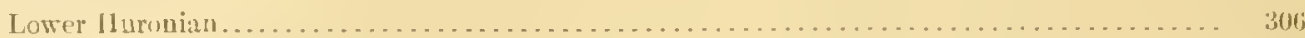

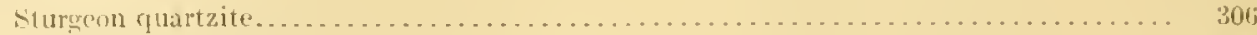

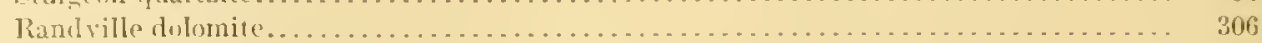

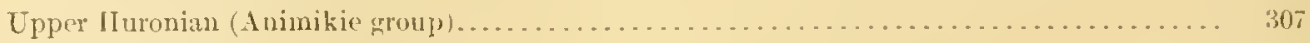

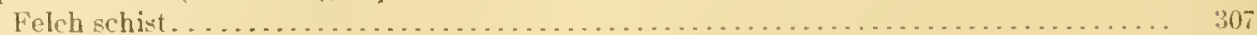

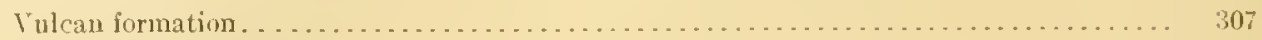

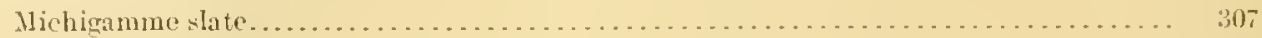

Paleozoic limestone and sandstone. . . . . . . . . . . . . . . . . . . . . . . . . . . . . . . .

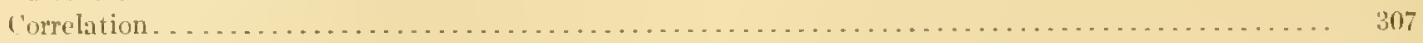

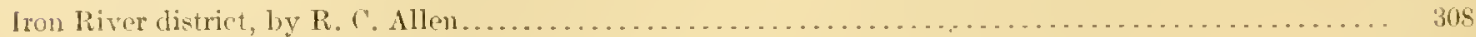

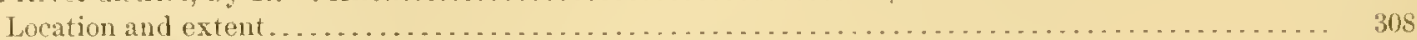

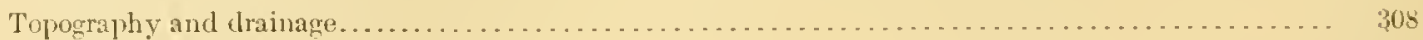

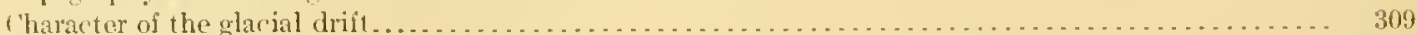

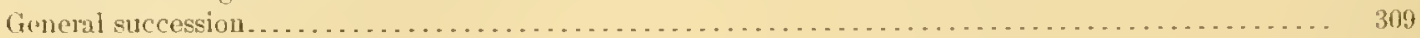

Archean $(?)$ system . . . . . . . . . . . . . . . . . . . . . . . . . . . . . . . . . . . . . . . . .

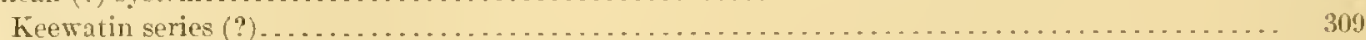

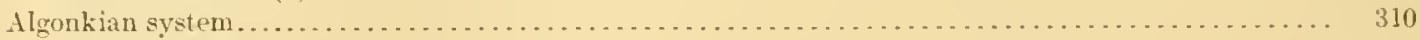

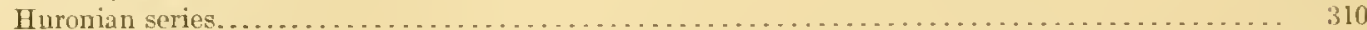

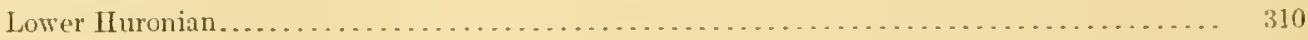

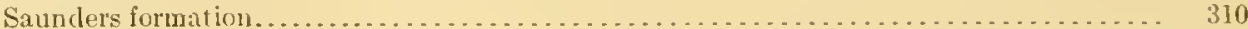

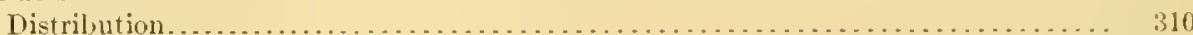

Lithologic characters . . . . . . . . . . . . . . . . . . . . . . . . . . . . . . 310

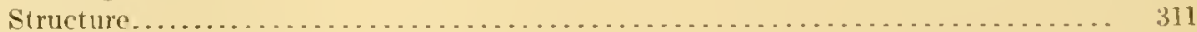

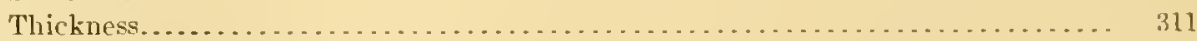

Relations to adjacent formations. . . . . . . . . . . . . . . . . . . . . . . . 311

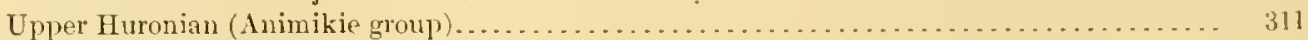

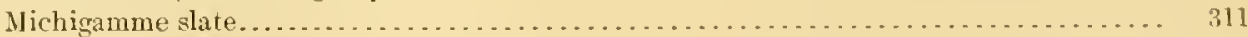

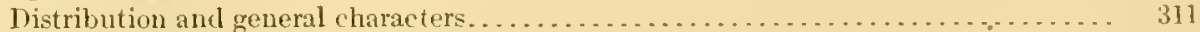

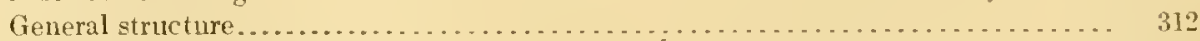

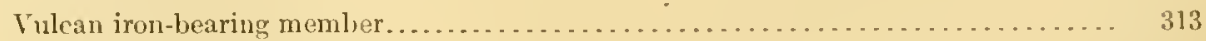

Distribution and exposures. . . . . . . . . . . . . . . . . . . . . . . . . . . 313

Relations to Michigamme slate. .............................. 313

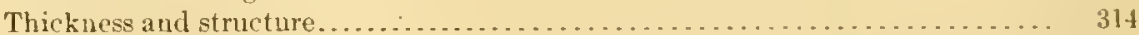

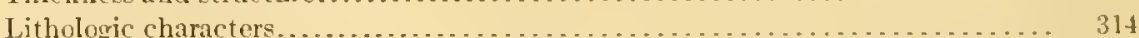

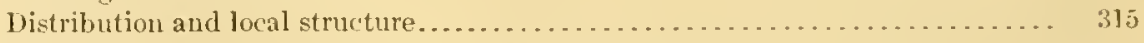

local magnetism in the Vulcan iron-hearing nember. .................. 31 i

Intrusive and extrusive rocks in the upper Huronian (Animikie group)............ 318

Relations of upper Huronian (Animikie group) to underlying rocks............... 31 s

Ordovician rocks.

Florence (Commonwealth) iron district of Wisconsin . . . . . . . . . . . . . . . . . . . . . . . . . .

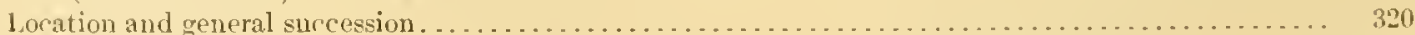

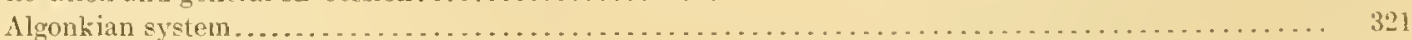

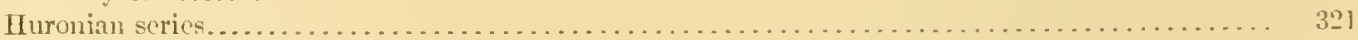

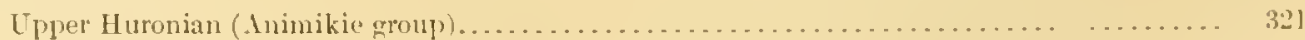

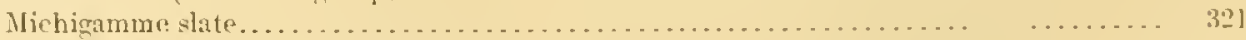

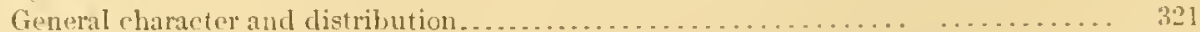

Vulcan iron-bearing member......................................... 321

Intrusive and extrusive grengtones and green schists. . . . . . . . . . . . . . . 32.2

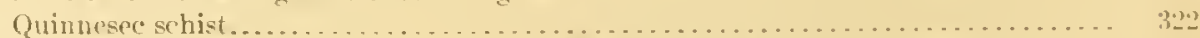

Intrusive and extrusive groenstones and green schists other than (juinuse('e....... 32.?

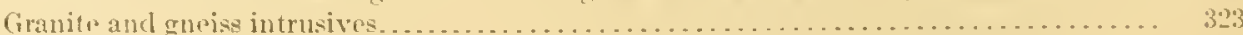

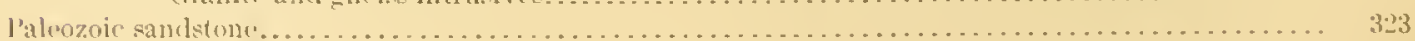

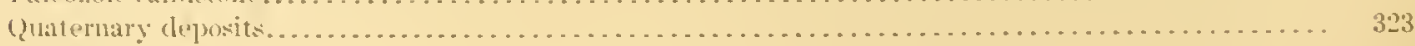


Cnapter XI1. The Crystal Fałls, Sturgeon, Felch Mlountain, Calumet, and Iron River rlistricts, etc. Contrl. Page.

The iron ores of the Crystal Falls, lron River, and Florence districts, by the authors and IT. J. Mearl........ 323

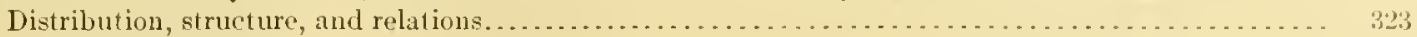

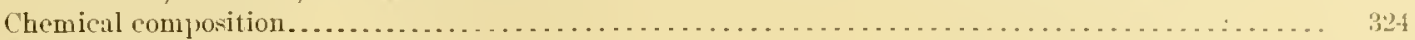

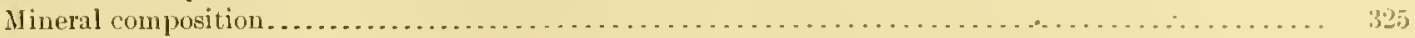

Physical characteristics. . . . . . . . . . . . . . . . . . . . . .

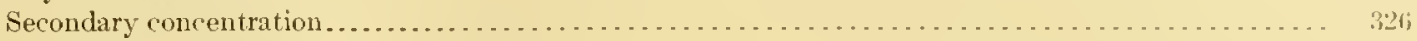

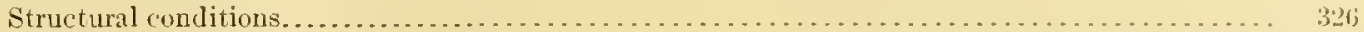

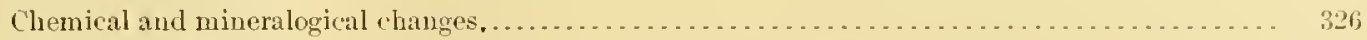

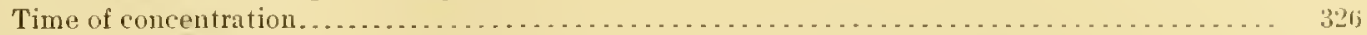

The iron ores of the Felch Mountain and Calumet districts, by the autloors and IV. J. Mearl. . . . . . . . . . . 326

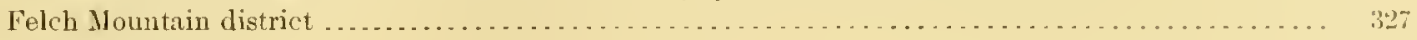

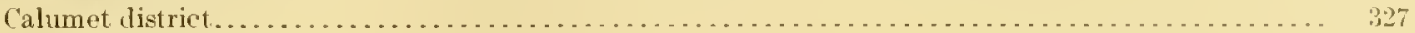

Secondary concentration of the Felch Hontain and calumet ores........................ 328

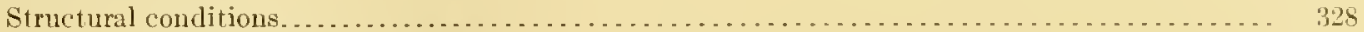

Chemical and mineralogical changes...............................................

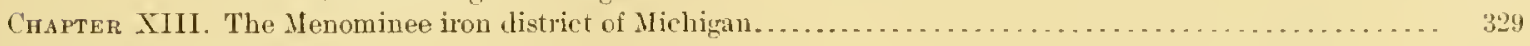

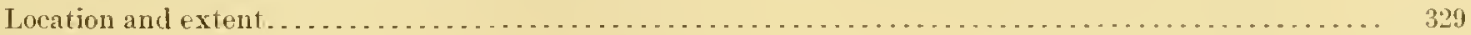

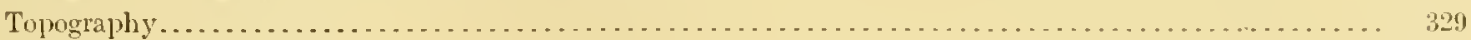

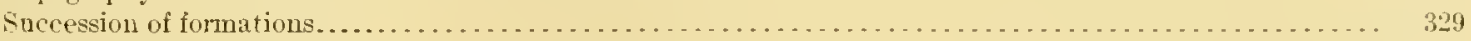

Arehean system ......... . . . . . . . . . . . . . . . . . . . . . . . . . . . . . . . . . . . . . . . . . . . 330

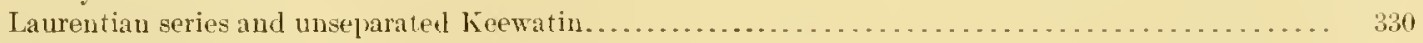

Algonkian system.......... . . . . . . . . . . . . . . . . . . . . . . . . . . . . . . . . . . . . . . . . 331

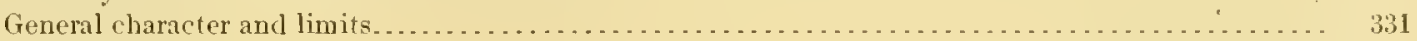

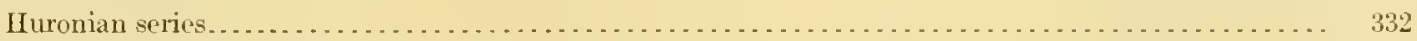

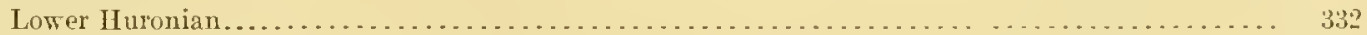

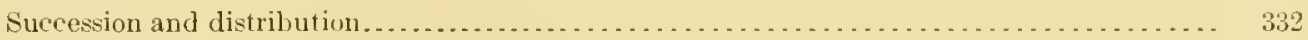

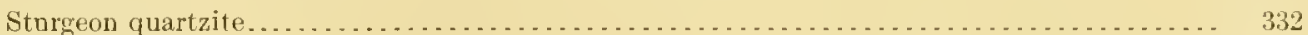

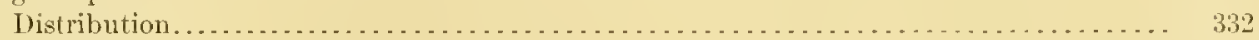

Lithology . . . . . . . . . . . . . .

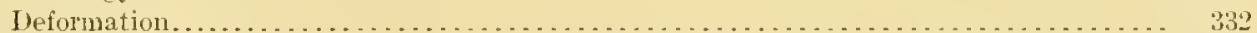

Relations to adjacent formations.................................... 332

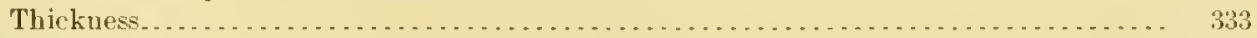

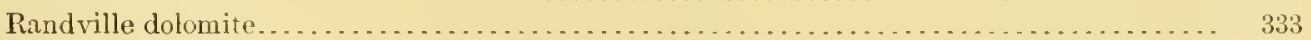

Distribution . . . . . . . . . . . . . . . . . . 333

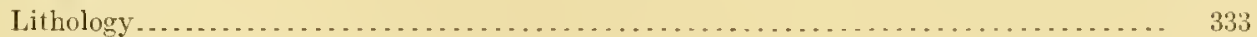

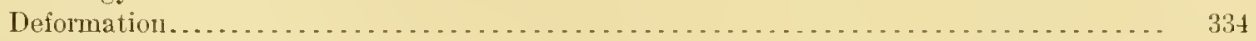

Relations to adjacent formations..................................... 334

Thickness.... . . . . . . . . . . . . .

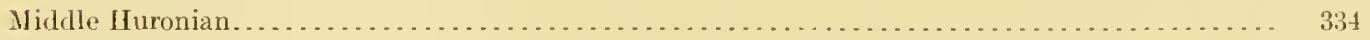

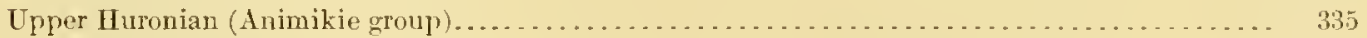

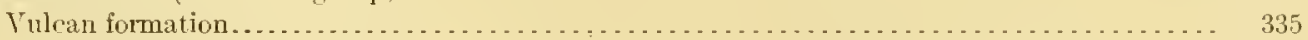

Subdivision into members . . . . . . . . . . . . . . .

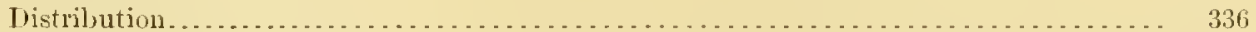

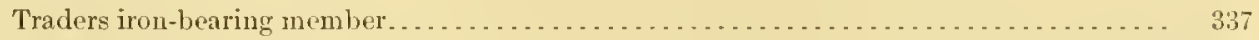

Brier slate member................................................ 337

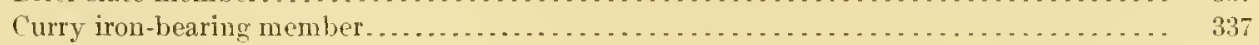

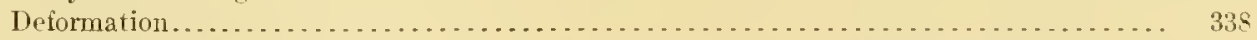

Relations between the member's of the Vnlean formation and the Mirhigamme slate..... 338

Thickness ............... . . . . . . . . . . . . . . . . . . . . . . . . . . 339

Michigamme ("Hanbury") slate . . . . . . . . . . . . . . . . . . . . . . . . . 340

Distribution. . . . . . . . . . . . . . . . . . . . . . . . . . . . . . . . 340

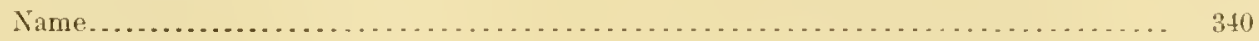

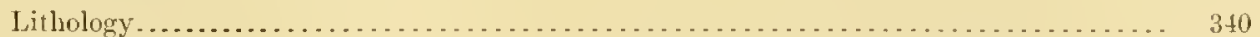

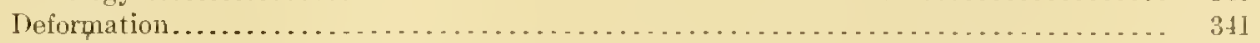

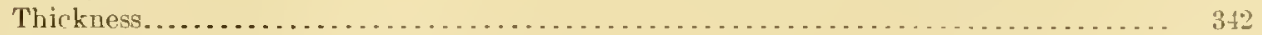

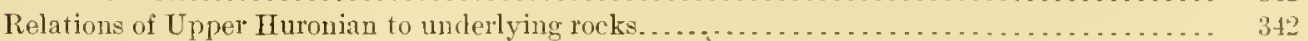

Relations between Vułcan formation and the lower Huronian .................. 342

Relations between Michigamme ("Hanbury") slate and the middle or lnwer Innronian... 343

Igneous rocks in the Algonkian... . . . . . . . . . . . . . . . . . . . . . . . . . . . . . . . . 34

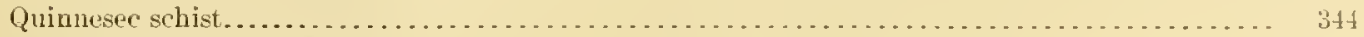

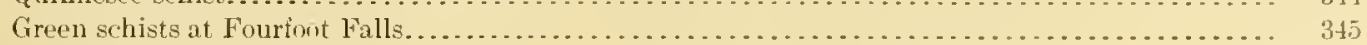

$47517^{\circ}-$ VOL $52-11-2$ 
Cuarter XIl1. The Menominee iron district of Michigan-Continued. Iage.

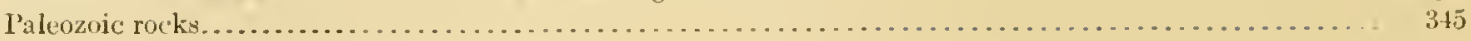

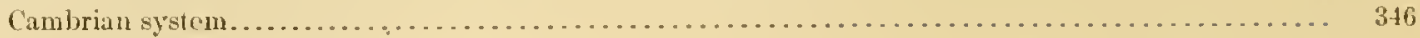

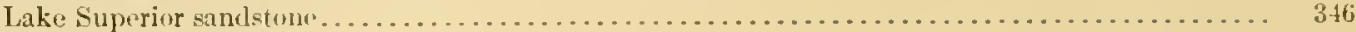

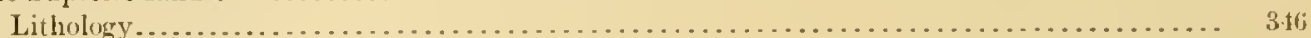

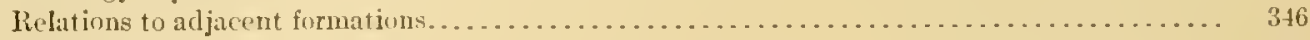

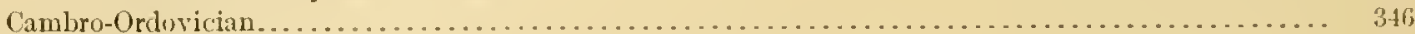

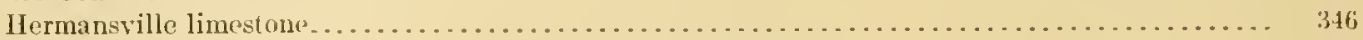

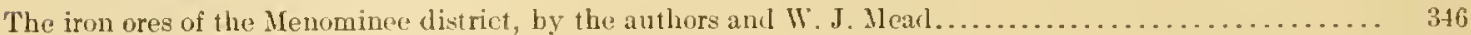

Distribution, structure, and relations. . . . . . . . . . . . . . . . . . . . . . . . . . . . . . 346

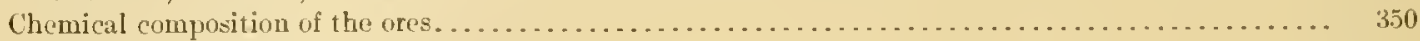

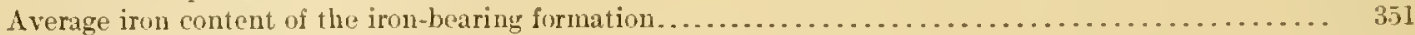

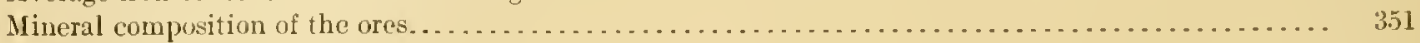

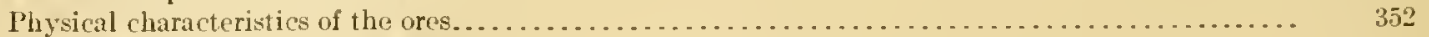

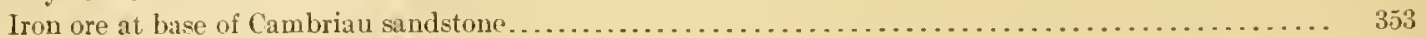

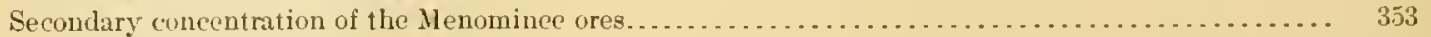

Structural conditions. ..................................................... 353

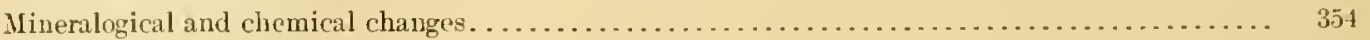

Sequence of ore concentration in the Mlenominee district ................................ 354

Chapter XIY. North-central Wiscousin and ontlying pre-Cambrian areas of rentral Wisconsin. ........... 355

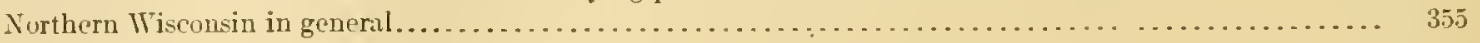

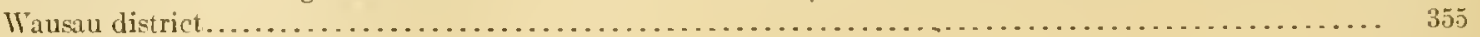

Location, area, and general geologic succession . . . . . . . . . . . . . . . . . . . . . . . .

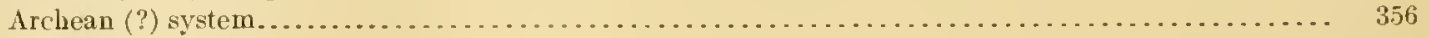

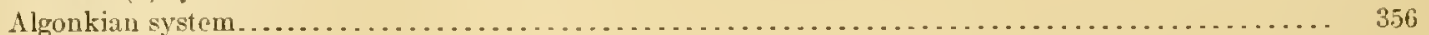

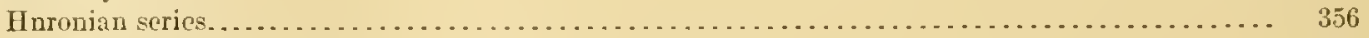

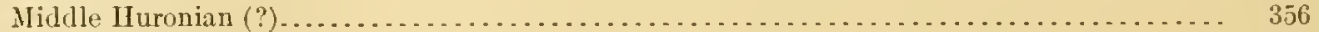

Rocks intrusive in middle Huronian (?) and Archean (?)...................... 357

Upper Huronian (?) . . . . . . . . . . . . . . . . . . . . . . . . . . . . . . 357

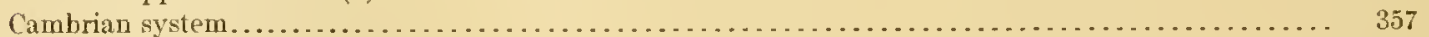

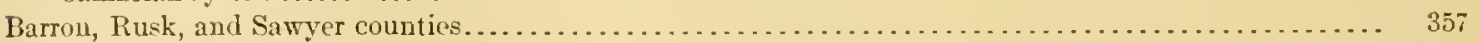

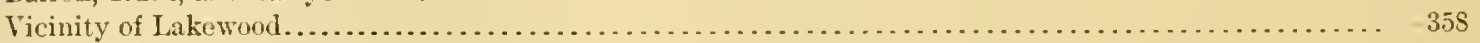

Necedah, North Bluff, and Black River areas. . . . . . . . . . . . . . . . . . . . . . . . . . . . . . 358

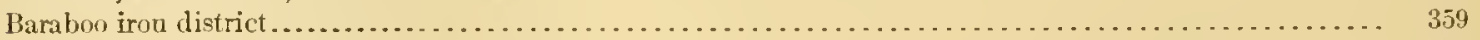

Location and general geologic succession . . . . . . . . . . . . . . . . . . . . . . . . . . . . . . . . 359

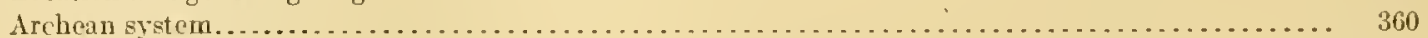

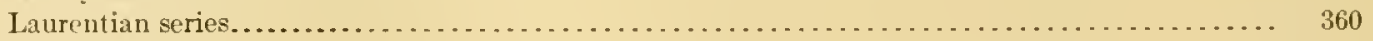

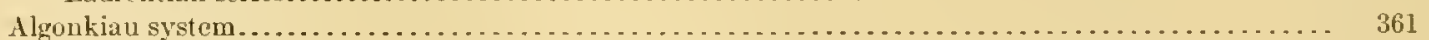

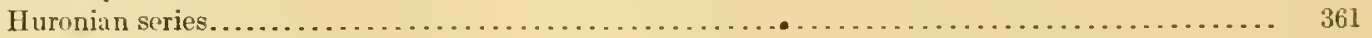

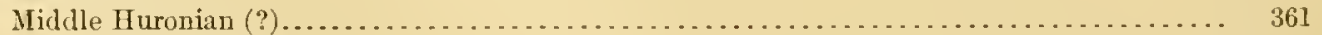

Baraboo quartzite. . . . . . . . . . . . . . . . . . . . . . . . . . . . . . . . . . 361

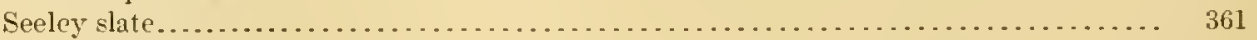

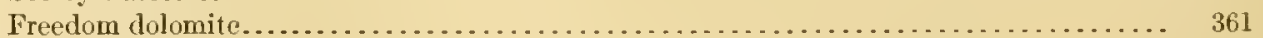

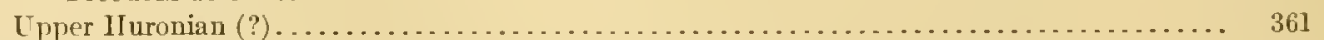

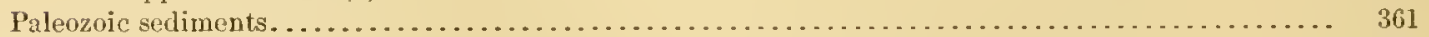

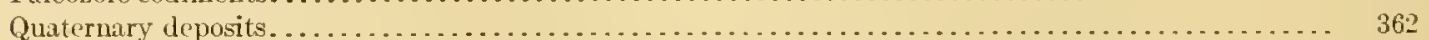

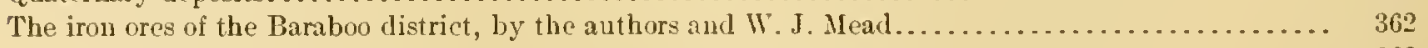

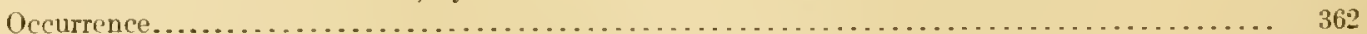

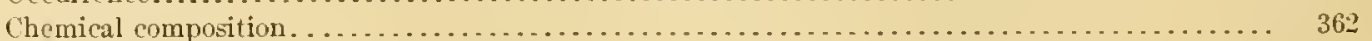

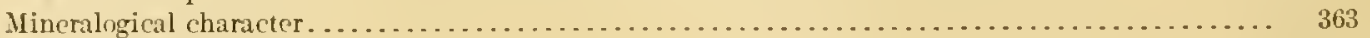

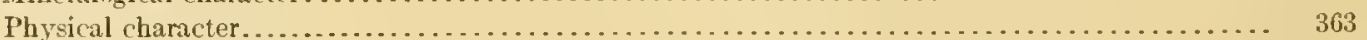

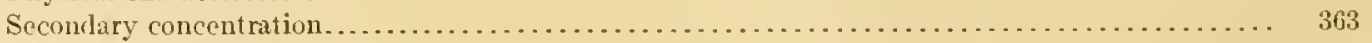

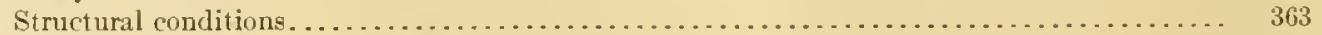

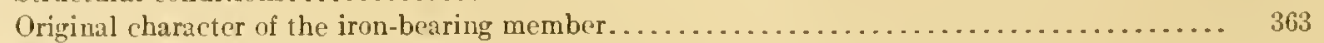

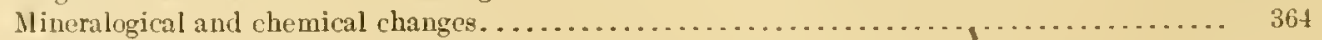

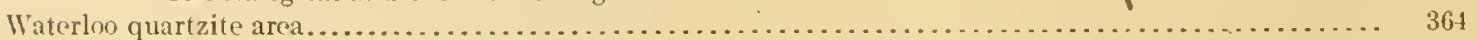

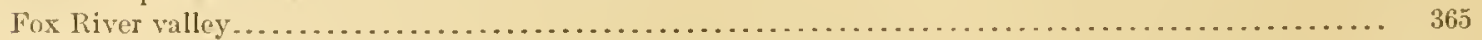

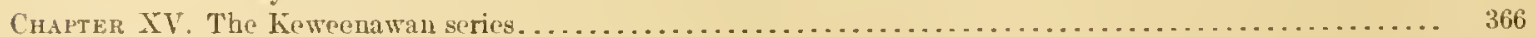

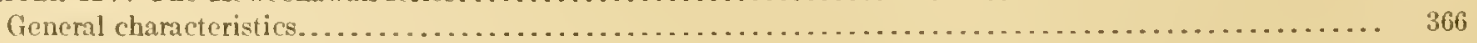

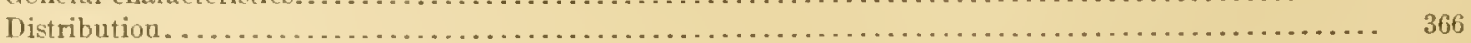

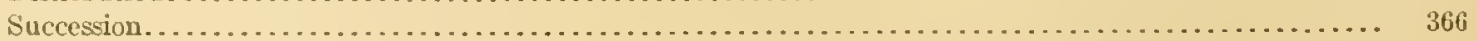


Chapter XV. The Keweenawan series-Continued.

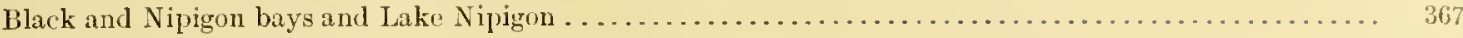

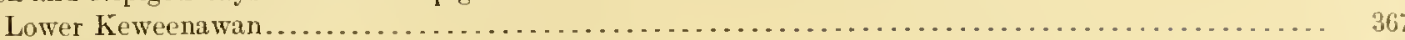

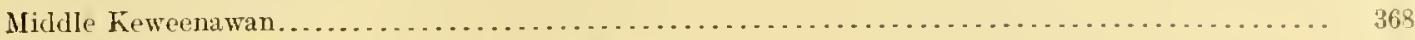

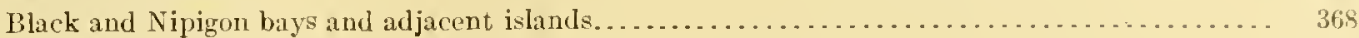

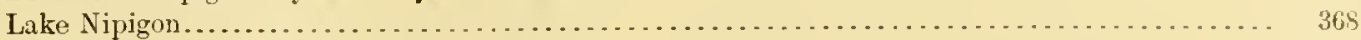

Relations of the Keweenawan of Black and Nipigon bays to other rocks................... 369

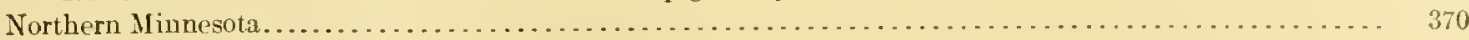

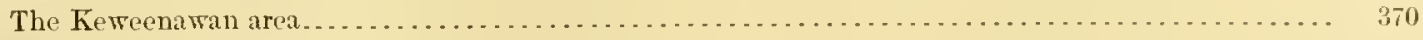

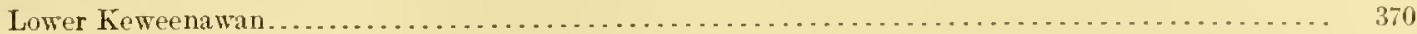

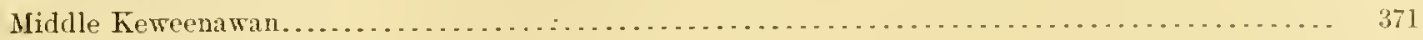

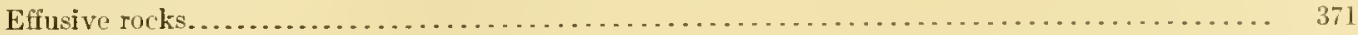

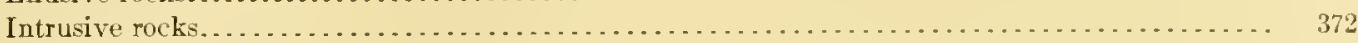

Basic rocks. . . . . . . . . . . . . . . . . . . . . . . . . . . . . . . . . . . 372

Duluth laccolith........................................................ 372

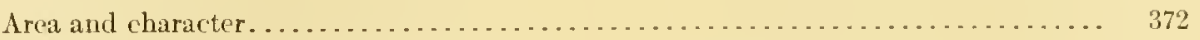

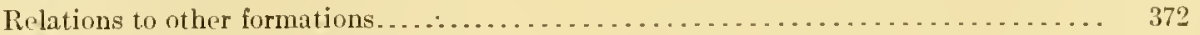

The Beaver Bay and other laccoliths and sills . . . . . . . . . . . . . . . . 373

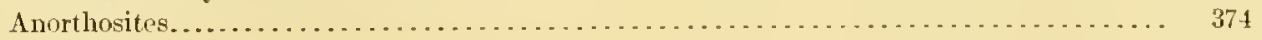

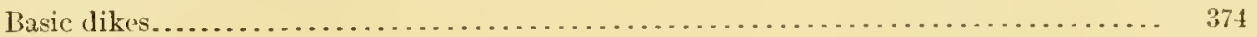

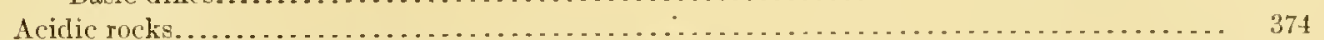

Kerreenawan rocks in the Cuyuna district of north-central Minnesota. . . . . . . . . . . . . . . . . 375

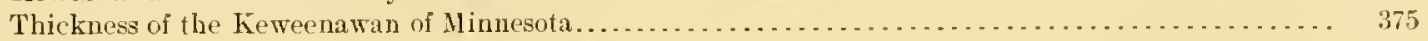

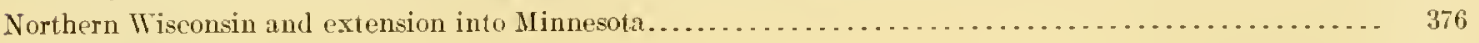

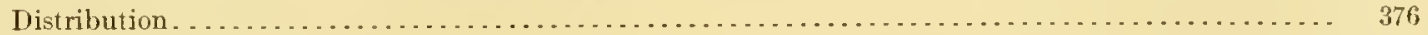

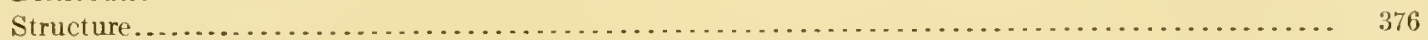

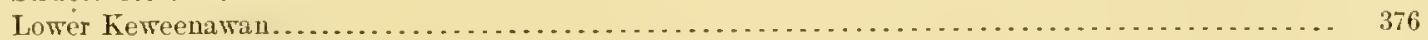

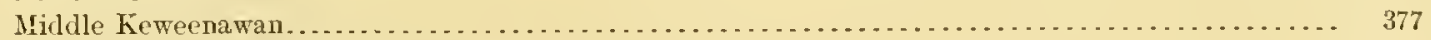

Upper Keweenawan . . . . . . . . . . . . . . . . . . . . . . . . . . . . . . . . . . . . . 378

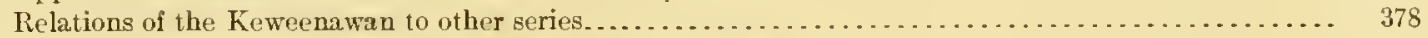

Keweenawan granites of Florence County, northeastern Wisconsin . . . . . . . . . . . . . . . . . . . . 379

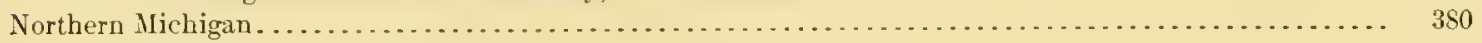

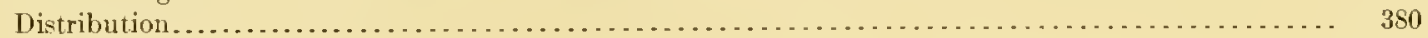

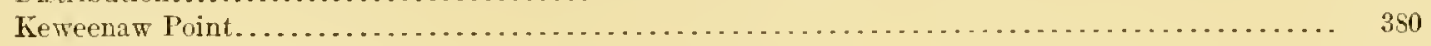

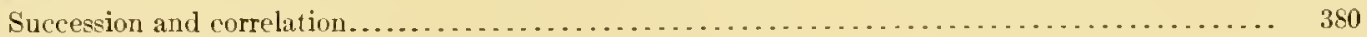

Lower and middle Keweenawan of Keweenaw Point............................. 381

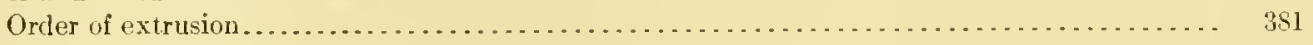

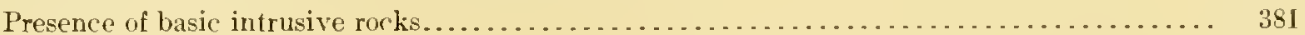

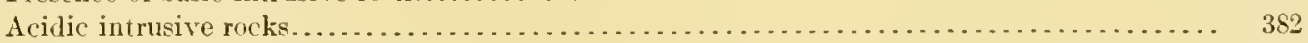

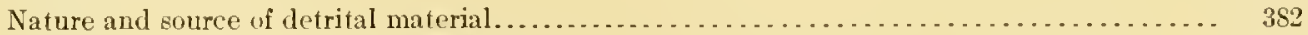

Variations in thickness of sedimentary beds ................................. 382

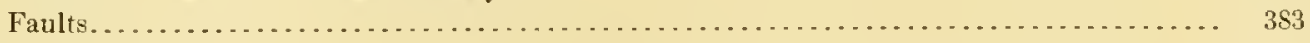

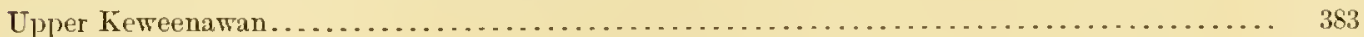

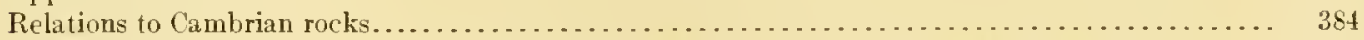

Hain area west of Keweenaw Point, inclucling Black River and the Porrupine Mlountains........... 384

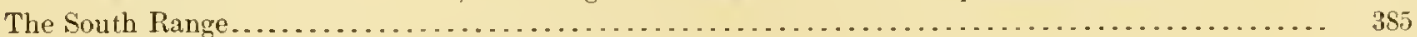

Rocks of possible Keweenawan age in outlying areas . . . . . . . . . . . . . . . . . . . . . . 356

Thickness of the Keweenawan of Michigan . . . . . . . . . . . . . . . . . . . . . . . . . . . . . 386

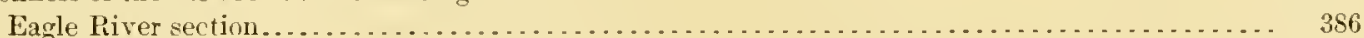

Portage Lake section. . . . . . . . . . . . . . . . . . . . . .

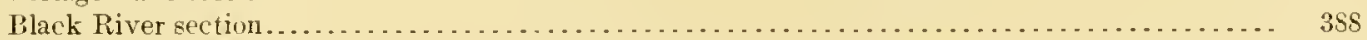

Relations of the Keweenawan of Mlichigan to underlying and overlying formations............... 358

Isle Royal. . . . . . . . . . . . . . . . . . . . . . . . . . . . . . . . . . . . . . . . . . . . 389

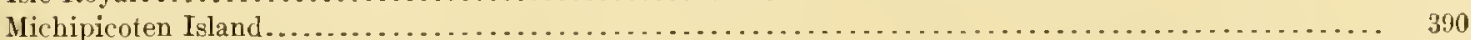

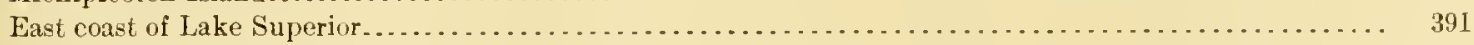

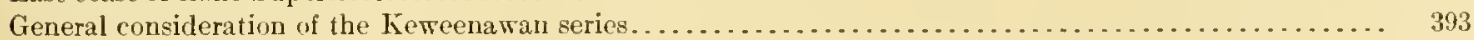

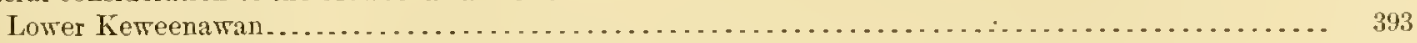

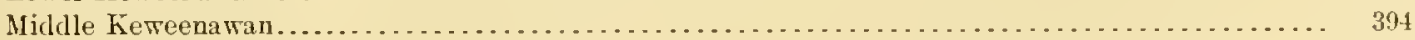

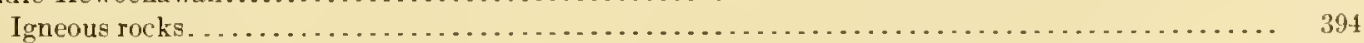

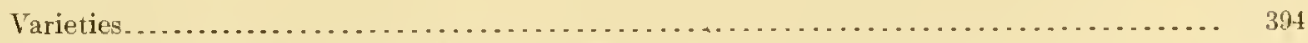

Review of nomenclature of Keweenawan igneous rocks, by 1 . . . Winchell. . . . . . . . . . . 395

The grain of Keweenawan igneous rocks - the practical use of observations............... 407

The extrusive masses. 
CHAPTER XV. The Keweenawan series-Continued.

General (4)nideration of the Keweenawan series-Continued.

Michlle Keweenawan-Continued.

lgneous rocks-Cont inued.

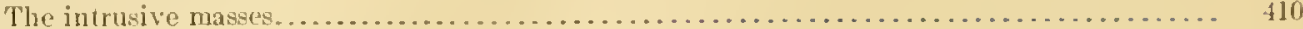

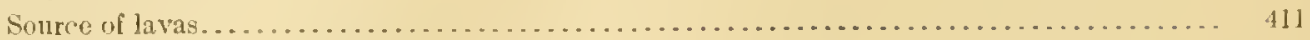

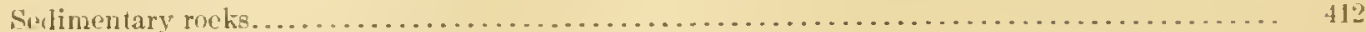

Source and nature of material . . . . . . . . . . .

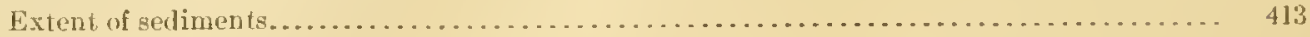

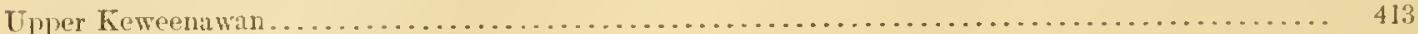

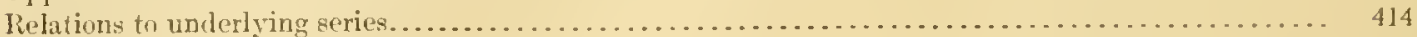

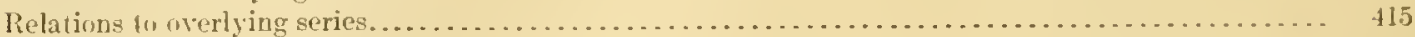

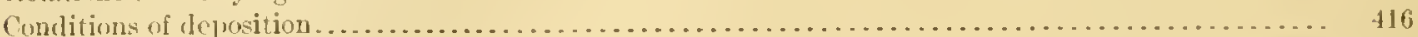

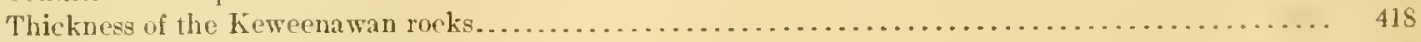

Areas of Keweenawan rocks..................................................... 419

Volune of Keweenawan rocks..................................................... 419

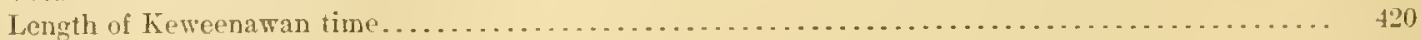

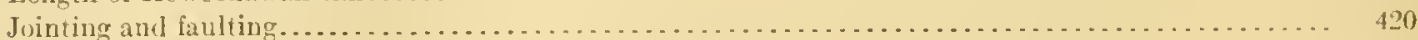

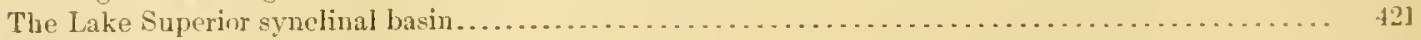

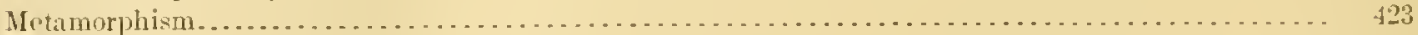

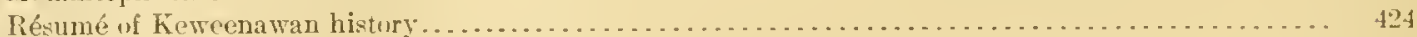

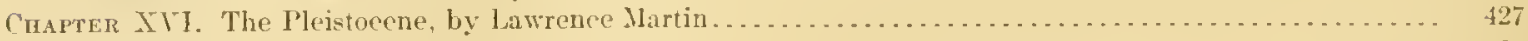

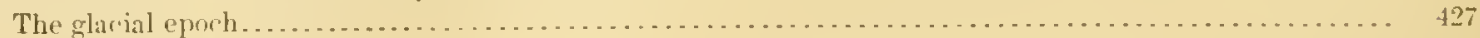

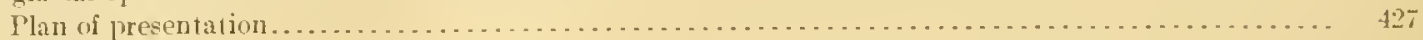

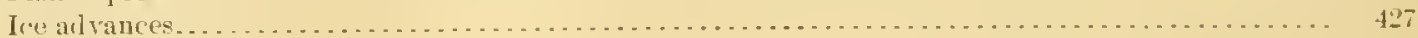

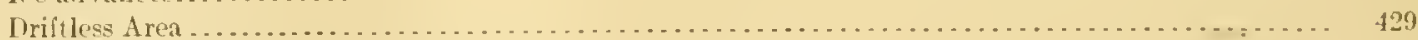

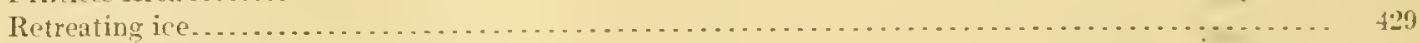

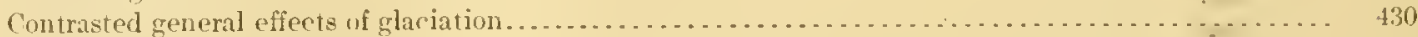

Destructive work of the glariers. . . . . . . . . . . . . . . . . . . . . . . . . . . . . . . . . . . 430

Removal of weathered rock............................................ 430

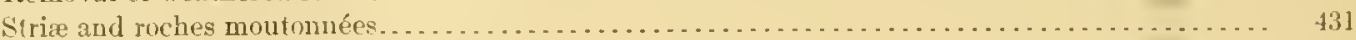

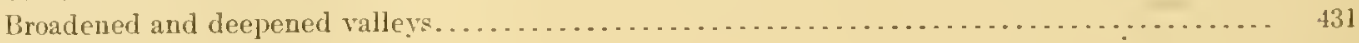

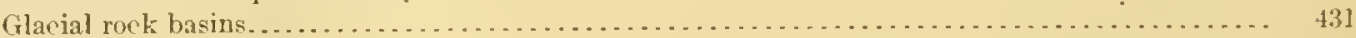

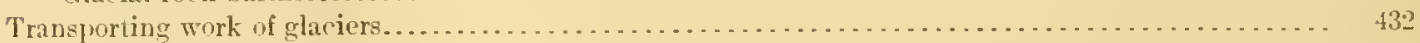

Constructive work of glaciers. . . . . . . . . . . . . . . . . . . . . . . . . . . . . . . . . . . . 433

Ground moraine

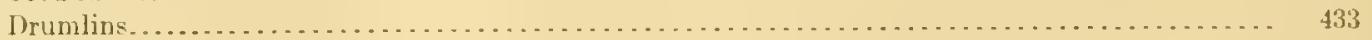

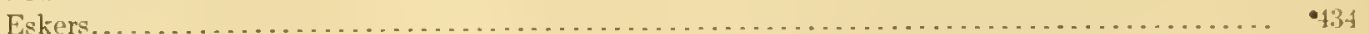

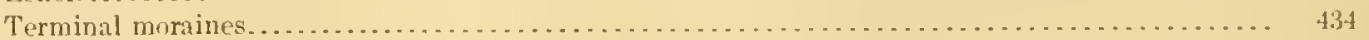

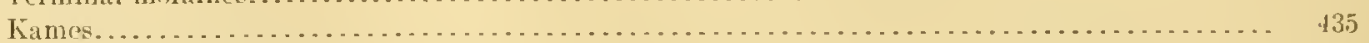

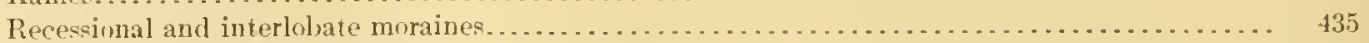

Drainage of drift-eovered areas............................................. 435

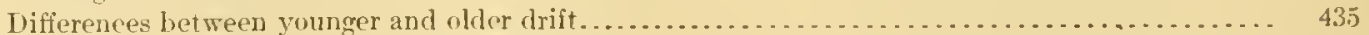

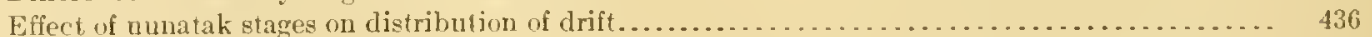

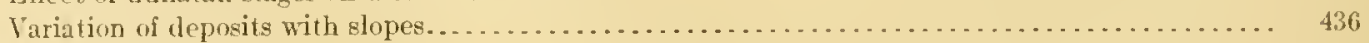

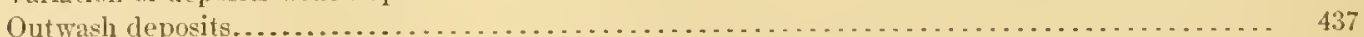

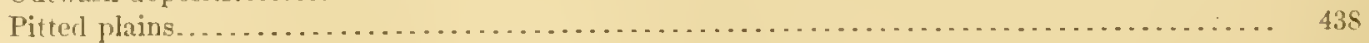

Loess

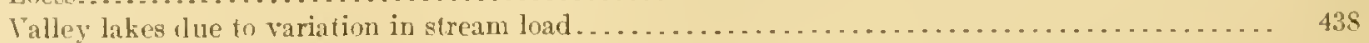

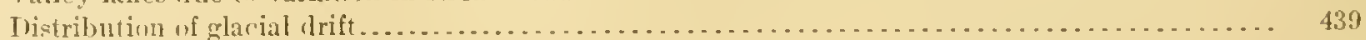

Yarqinal lakes.

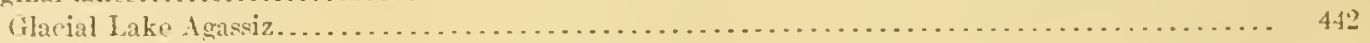

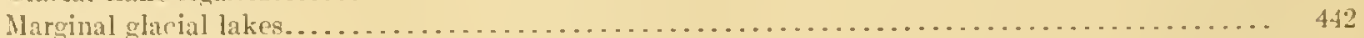

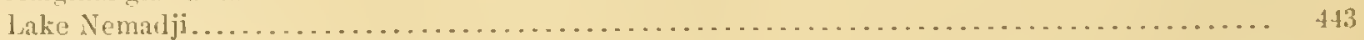

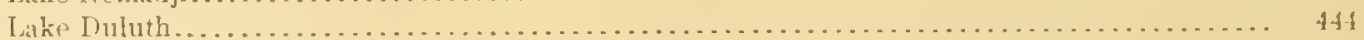

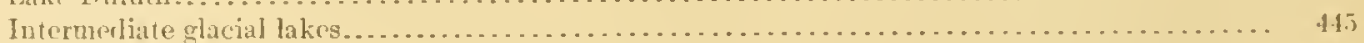

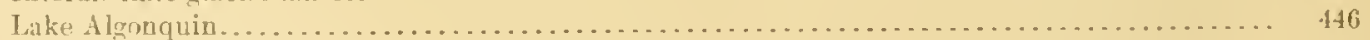

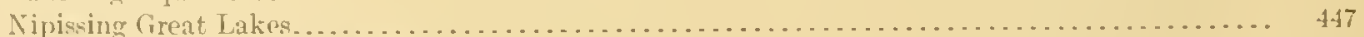

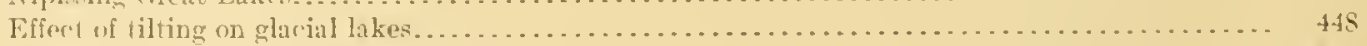

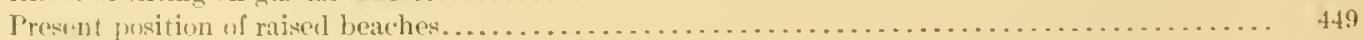

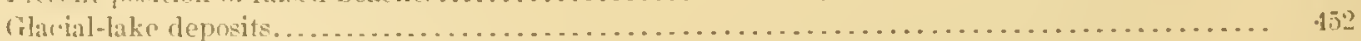

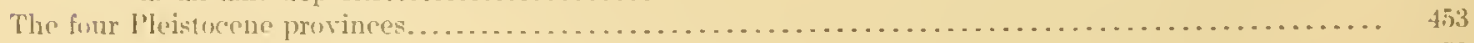

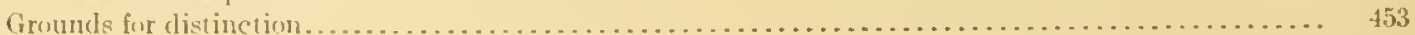


Charter XV1. The Pleistocene, by Lawrence Mart in-Continued.

The four Pleistocene provinces-Continued.

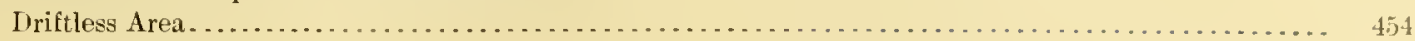

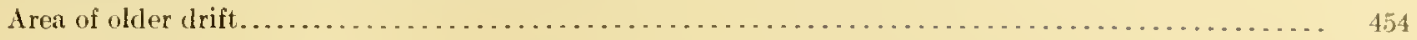

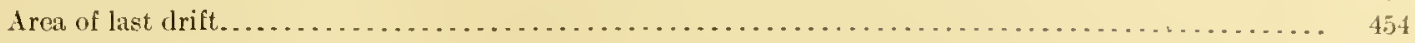

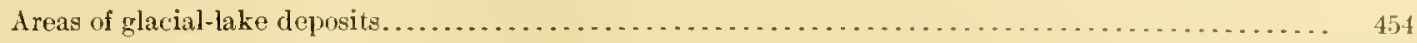

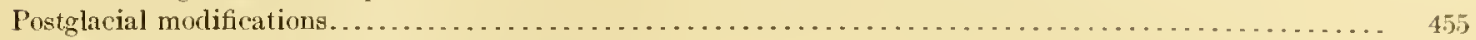

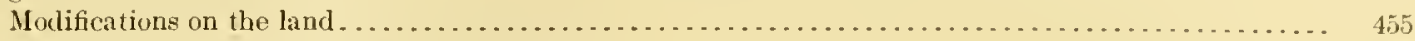

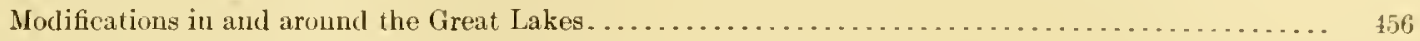

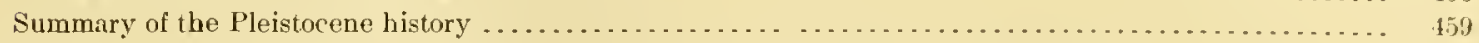

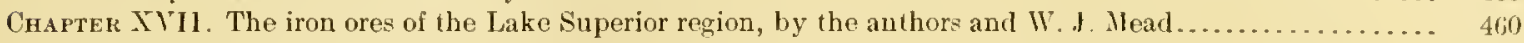

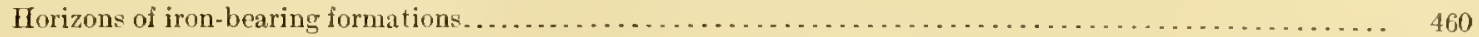

General description of ores of the Lake Superior pre-Cambrian sedimentary iron-bearing formations ..... 461 ,

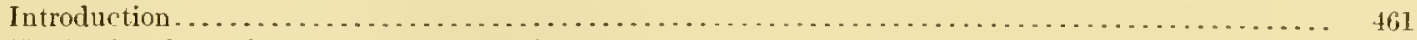

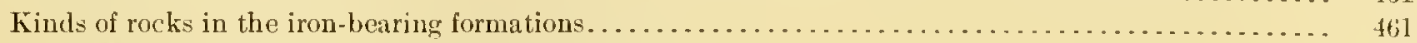

Chemical composition of the iron-bearing formations . . . . . . . . . . . . . . . . . . . . . . . 462

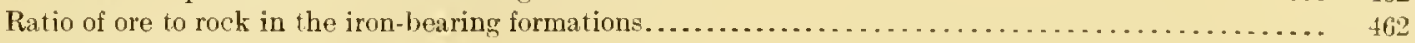

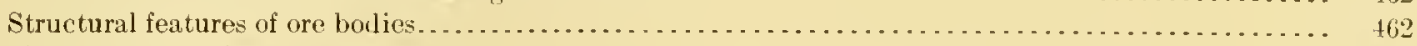

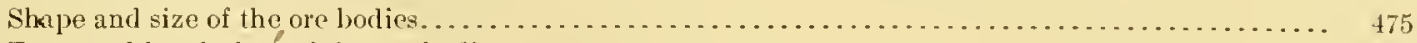

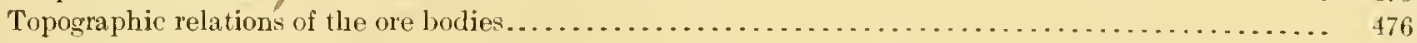

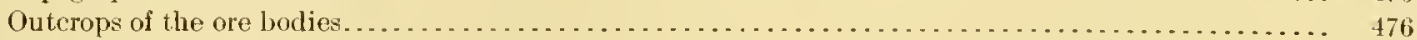

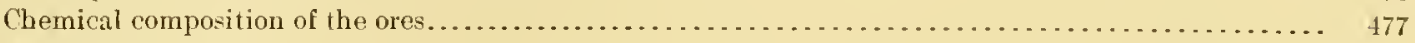

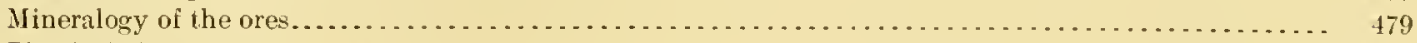

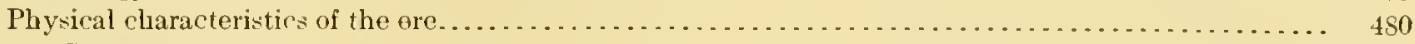

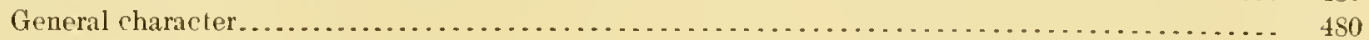

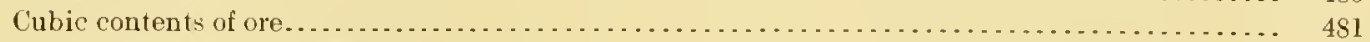

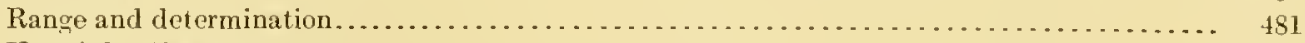

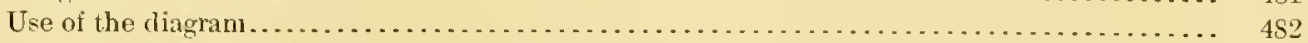

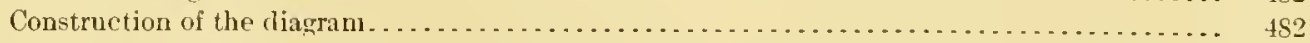

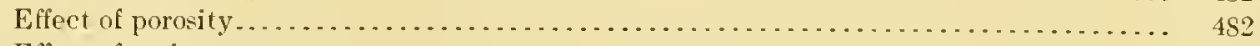

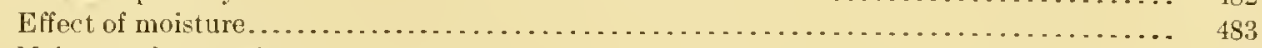

Moisture of saturation............................................ 483

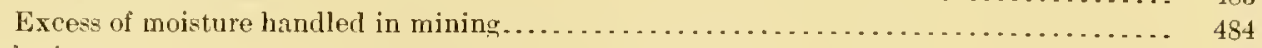

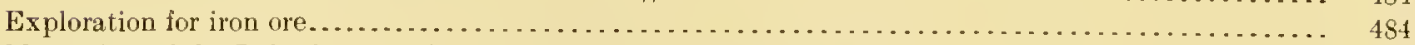

Magnetism of the Lake Superior iron ores and iron-bearing formations . . . . . . . . . . . . . . . . . . .

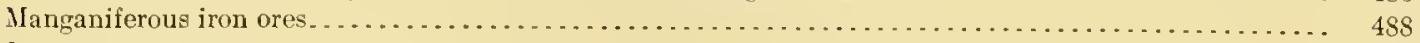

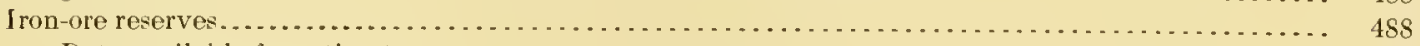

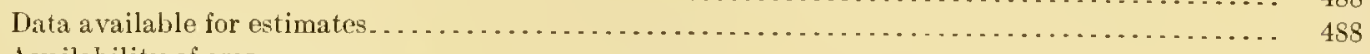

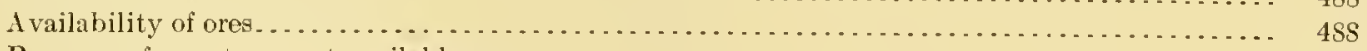

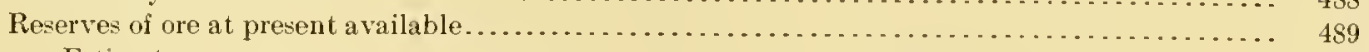

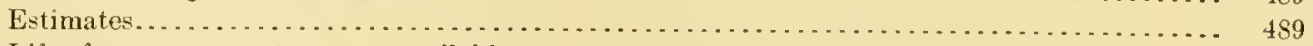

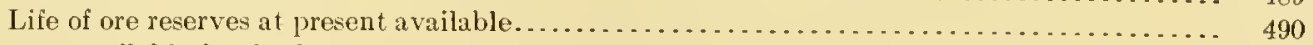

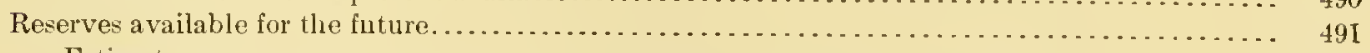

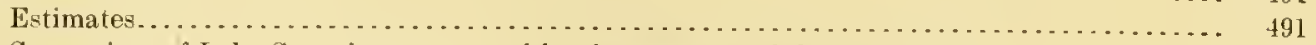

Comparison of Lake Superior reserves with otler reserves of the United States............ 492

Lowering of grade now discernible..................................... 493

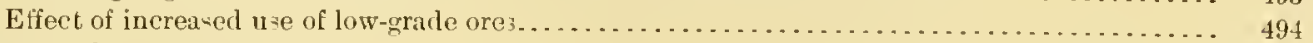

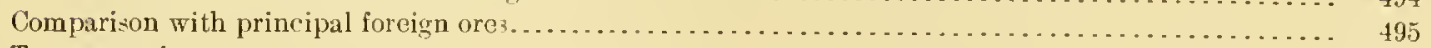

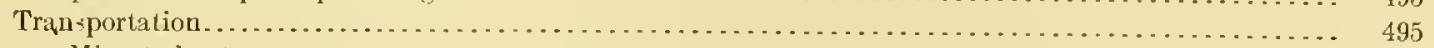

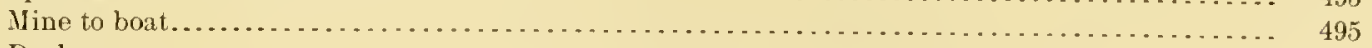

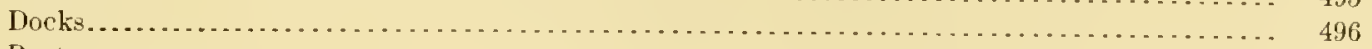

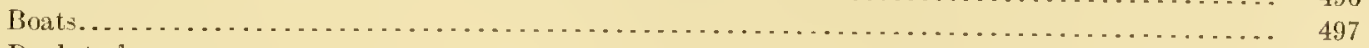

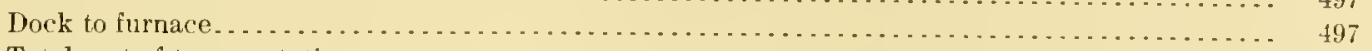

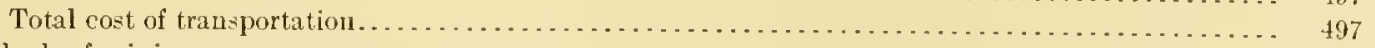

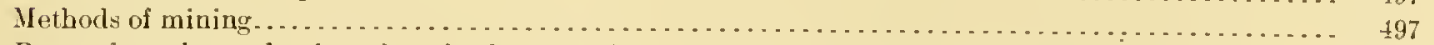

Rates of royalty and value of ore in the ground . . . . . . . . . . . . . . . . . . . . . . . . . . . . . 499

Origin of the ores of the Lake Superior pre-Cambrian sedimentary iron-bearing formations................. 499

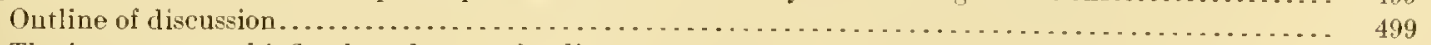

The iron ores are chiefly altered parts of sedimentary rocks. . . . . . . . . . . . . . . . . . . . . 500

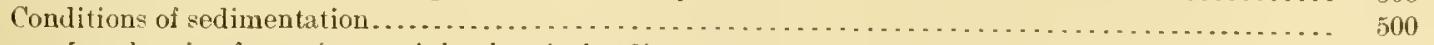

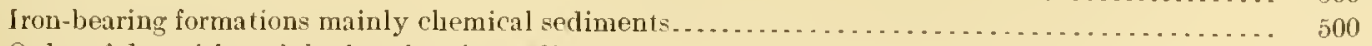

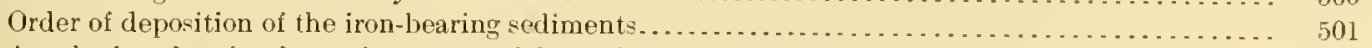

Are the iron-bearing formations terrestrial or subaqueous sediments? .................... 50 I 
Cirapter XVII. The iron ores of the lake Superior region, by the authors and W. J. IIead - Continued.

Origin of the ores of the Lake Superior pre-Canbrian sedimentary iron-bearing formations-continued.

Conditions of sedimentation- i'ontinued.

P'og and lagoon origin of part of the iron-bearing rocks. .

HJpothesis of bogand lagoon origin not applicable to the man mases of the iroub-bearing sodiments.

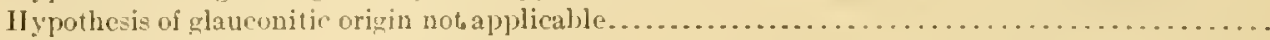

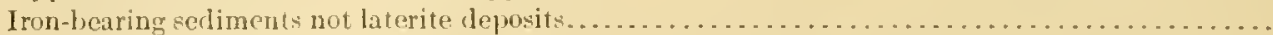
Iron-bearing mediments not chararteristic transported deponits of ordinary crosion eyeles........

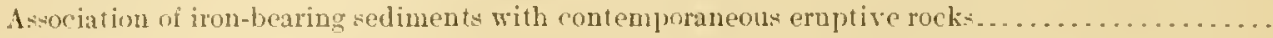
Association of iron-bearing sediments and eruptive rocks outuile of the lake superior ruxion..... Significaure of ellipsoidal structure of eruptive rocks in relation to origin of the ores........... Eruptive rocks associated with iron-bearing sediments of Lake Superior region carly abundant iron.

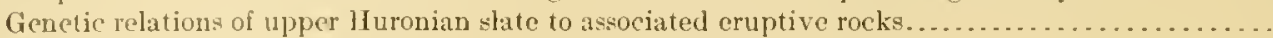
Hain mass of iron-bearing sedinents probably derived from associated eruptive rocks............

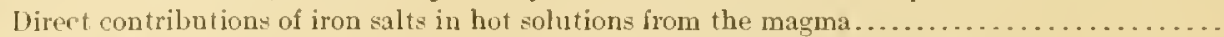

contribution of iron salts from crystallized igneous rocks in meteoric waters..............

C'ontribution of iron salts by reaction of hot igneous rocks with sea water................

Conclusion as to derivation of materials for the iron-bearing formations . . . . . . . . . . . . . . . . .

Variations of iron-bearing formations with different eruptive rocks and different conditions of

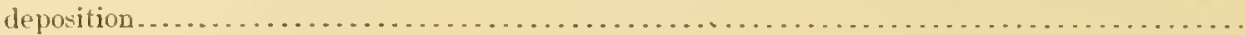

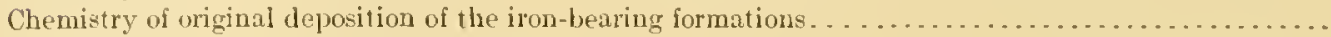

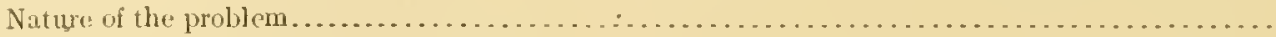

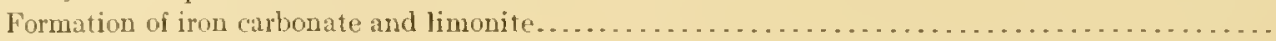

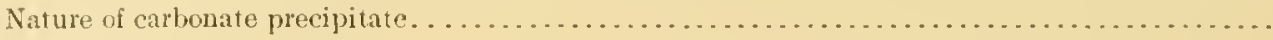

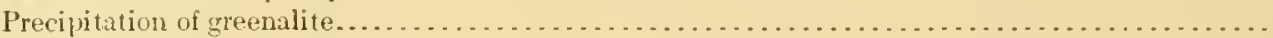

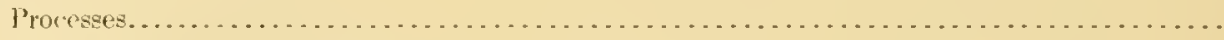

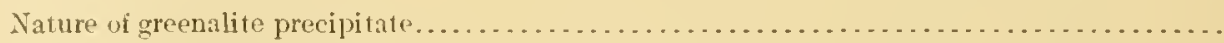

Source of alkaline silicates necessary to produce greenalite. . . . . . . . . . . . . . . . . .

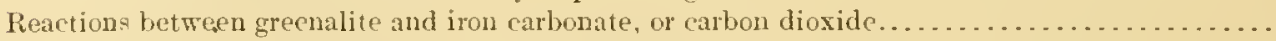

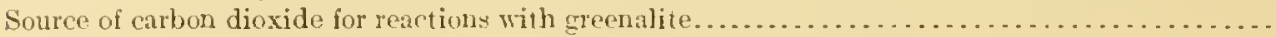

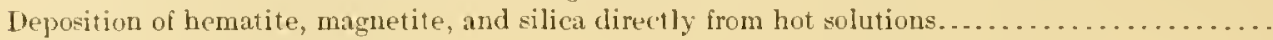

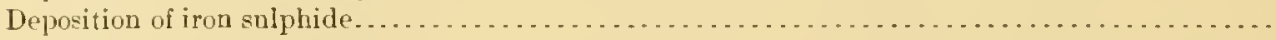

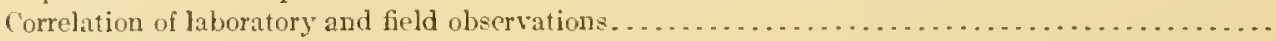

Secondary concentration of the ores. . . . . . . . . . . . . . . . . . . . . . . . . . . . . . . .

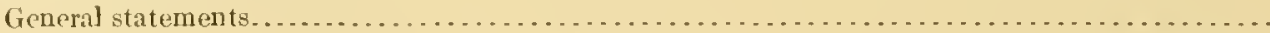
Chemical and mineralogical changes involved in concentration of the ore under surface conditions.

Outline of alterations

Oxidation and hydration of the greenalite and siderite producing ferruginous chert..........

AIteration of ferruginous chert to ore by the leaching of silica, with or without secondary intro-

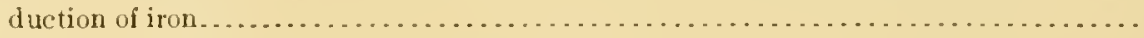

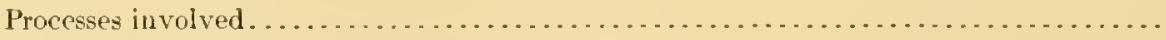

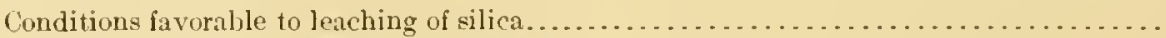

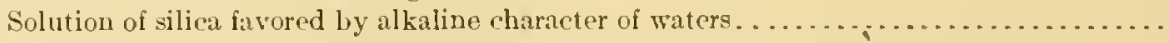

Transfer of iron in solution . . . . . . . . . . . . . . . . . . . . . . . . . . . . . . . . .

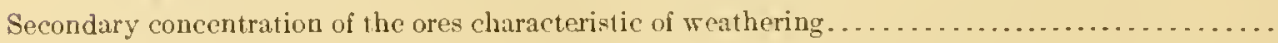
Mechanical concentration and erosion of iron ores. . . . . . . . . . . . . . . . . . . . . . . .

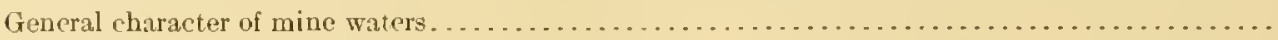
Localization of the ores controlled by special structural and topographic features............

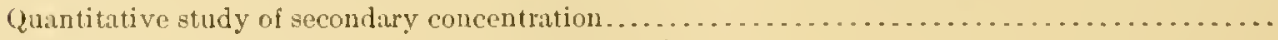
Alterations of iron-bearing formations by igneous intrusions. . . . . . . . . . . . . . . . . . .

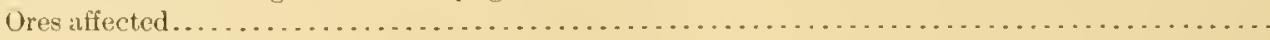
Possible contributions from igncous rocks. . . . . . . . . . . . . . . . . . . . . . . . . . .

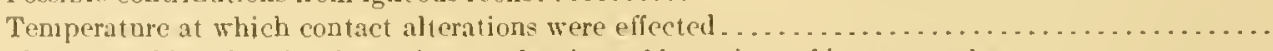

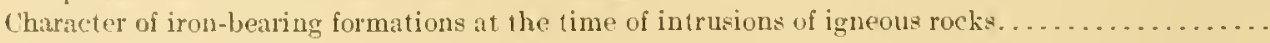
Chemistry of alterations.

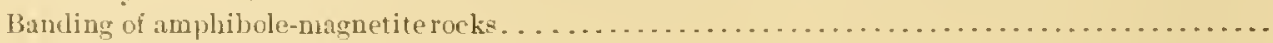

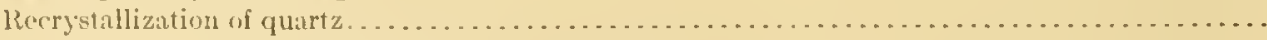
Iligh sulphur content of amphibole-magnetite rocks . . . . . . . . . . . . . . . . . . . . Secondary iron carbonate locally developed at igneous contacts. . . . . . . . . . . . . . . . . . Contact alterations not firorable to concentration of ore deposits. . . . . . . . . . . . . . . .

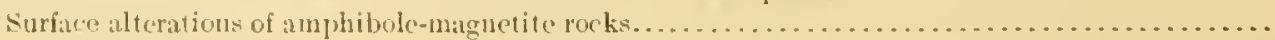
Summary of alterations of iron-bearing formations by igucous intrusions. . . . . . . . . . . . . . .

Page. 
Chapter XYII. The iron ores of the Lake Superior region, by the authors and W. J. Mead-Continued Origin of the ores of the Lake Superior pre-Cambrian sedimentary iron-bearing formatinns-Continued

Alteration of iron-bearing formations by rock flowage . . . . . . . . . . . . . . . . . . . . . 5 .

Cause of varying degree of hydration of the Lake Superior ores... . . . . . . . . . . . . . . . . .

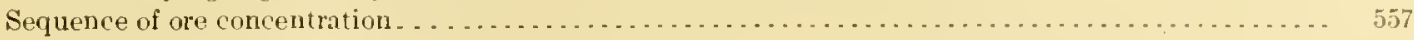

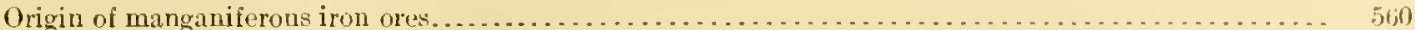

Part of the metamorphic cycle illustrated by the Lake Superior iron ores of sedimentary type........ 560 )

Titaniferous magnetites of northern dlinnesota. . . . . . . . . . . . . . . . . . . . . . . . . . 5 .

Magnetites of possible pegmatitic origin. . . . . . . . . . . . . . . . . . . . . . . . . . . . 562

Brown ores and hematites associated with Paleozoic and Pleistocene deposits in Wisconsin........... 562

Ores in the Potsdam. . . . . . . . . . . . . . . . . . . . . . . . . . . .

Brown ores in "Lower Hagnesian " limestone... . . . . . . . . . . . . . . . . . . . . . . . . . . 562

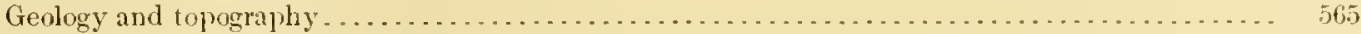

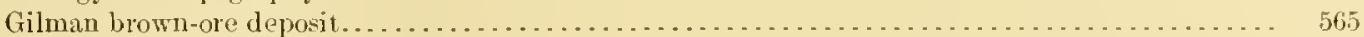

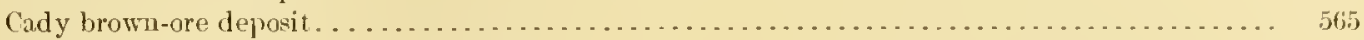

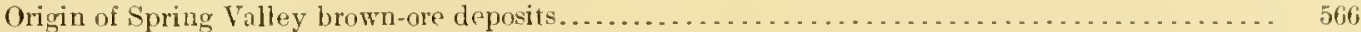

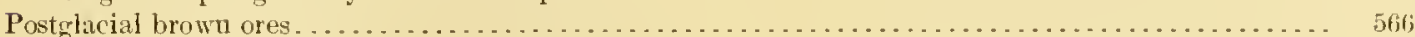

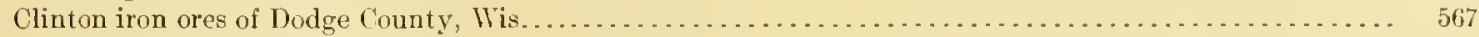

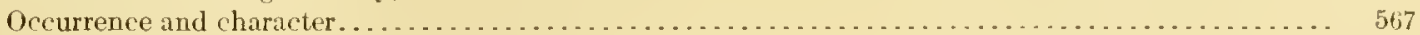

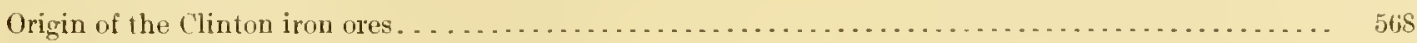

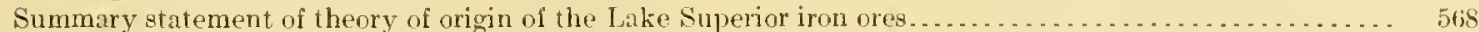

Other theories of the origin of the Lake Superior pre-cambrian iron ores. . . . . . . . . . . . . . . 569

Genetic classification of the principal iron ores of the world . . . . . . . . . . . . . . . . . . . . . . 571

Chapter XVIII. The copper mes of the Lake Superior region, by the authors, assisted by Edward Steidtmann. 573

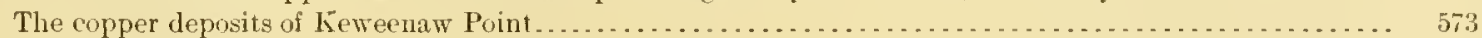

General account . . . . . . . . . . . . . . . . . . . . . . . . . . . . . . . . . . . . . . . 573

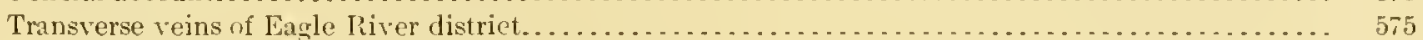

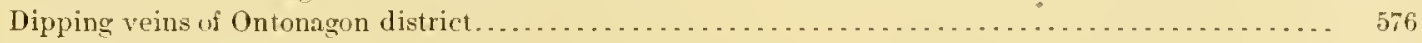

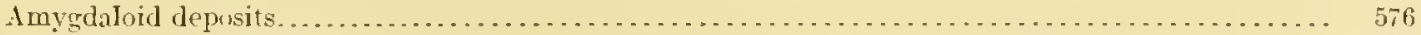

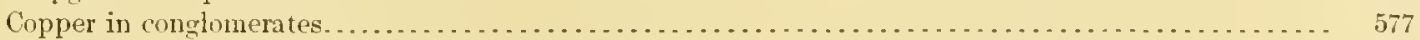

Composition of copper-mine waters................................................... 579

Copper in Keweenawan rocks in parts of the Lake Superior region other than Keweenaw I'oint . . . . . . . . . 580

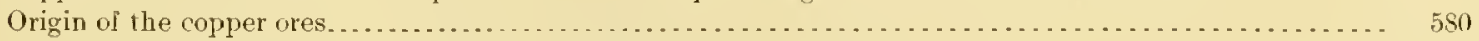

Comnon origin of the several types of deposits . . . . . . . . . . . . . . . . . . . . . . . . . . . . . 580

Previous views of nature of copper-depositing solutions and source of copler. . . . . . . . . . . . 580

Outline of hypothesis of origin of copper ores presented in the following pages . . . . . . . . . . . 581

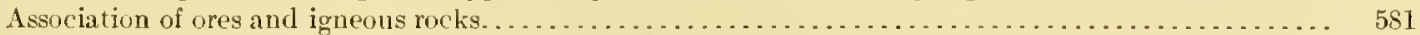

Ore deposition limited mainly to middle Keweenawan time........................... 581

Deposition of the copper accomplished by hot solutions............................. 582

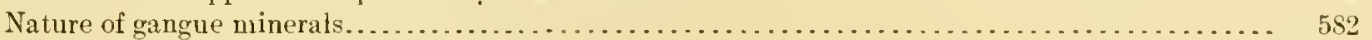

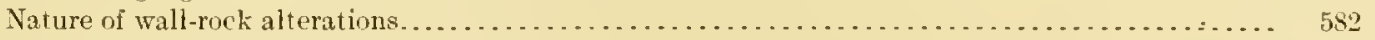

Paragenesis of copper and gangue minerals. .................................... 585

Contrast with present work of meteoric solutions............................... 555

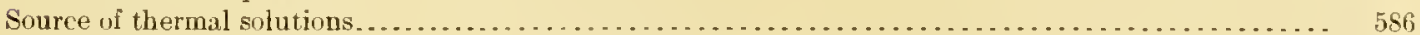

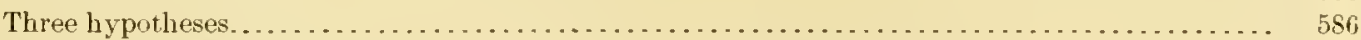

Were the thermal solutions derived from extrusive or from intrusive rocks? . . . . . . . . . . . 587

Significance of sulphides of copper in the intrusives and lower effusives . . . . . . . . . . . . . . . . 588

Conclusions as to source of copper-hearing solutious. . . . . . . . . . . . . . . . . . . . . 588

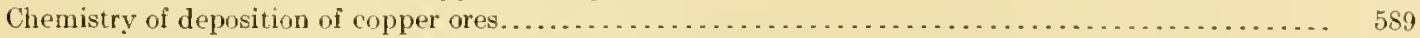

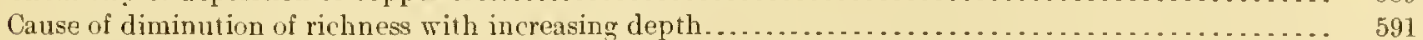

Relation of copper ores to other ores of the Keweenawan .............................. 591

Chapter XIX. The silver and gold ores of the lake Superior region. . . . . . . . . . . . . . . . . . . . . 593

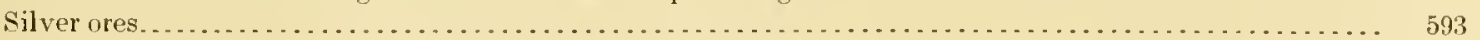

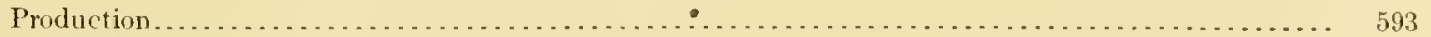

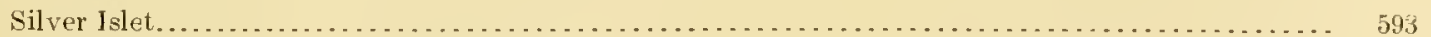

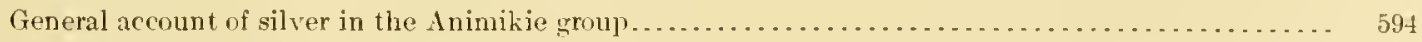

Origin of silver ores in the Animikie group . . . . . . . . . . . . . . . . . . . . . . . . . . . . . . 595

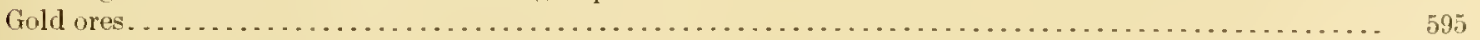

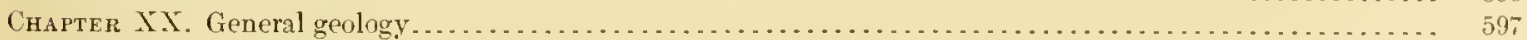

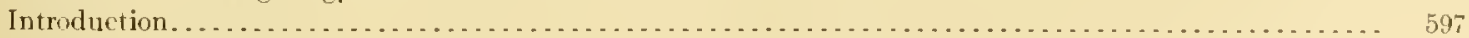

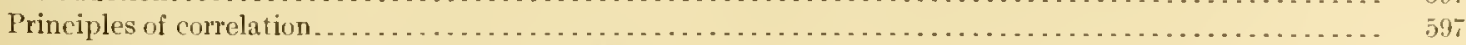

General character and correlation of the Archean . . . . . . . . . . . . . . . . . . . . . . . . . . . . . . 599

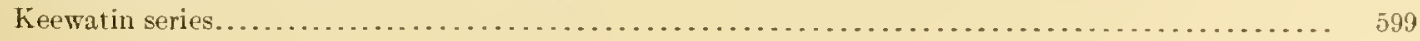


Chapter XX. General geology-iontinued.

General character and correlation of the Archean-Continued.

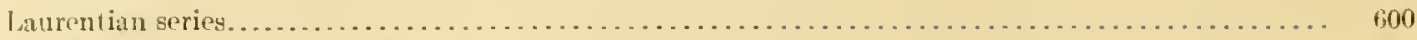

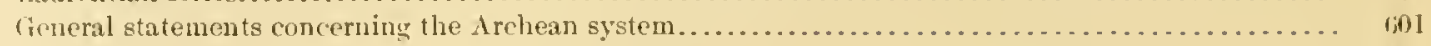

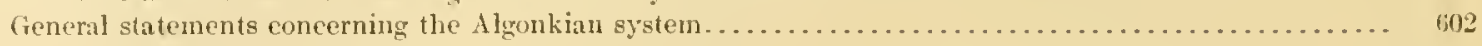

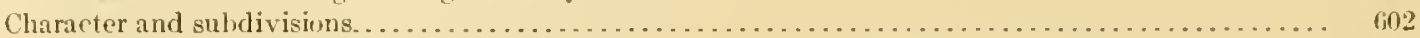

Northern II

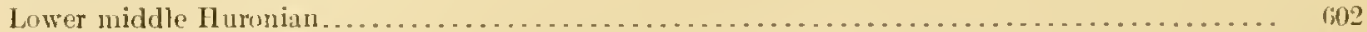

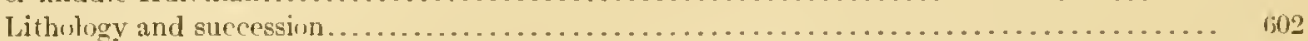

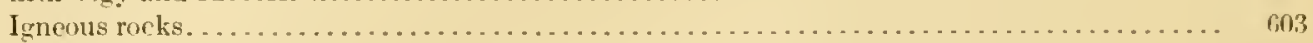

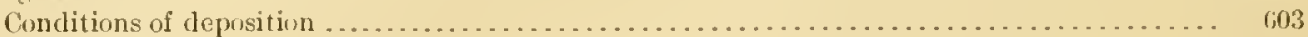

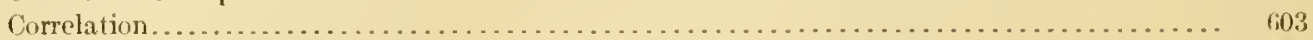

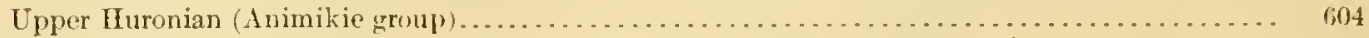

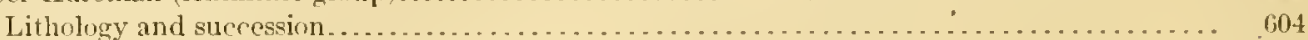

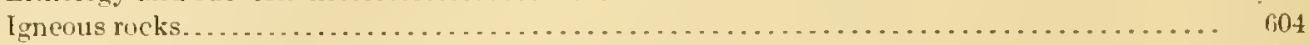

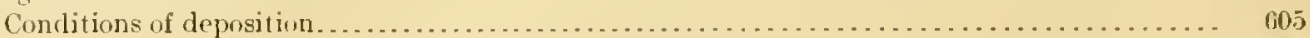

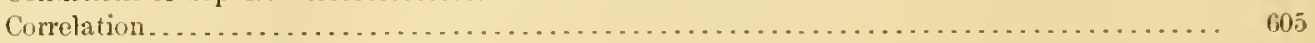

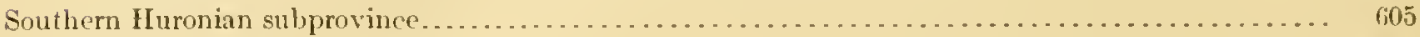

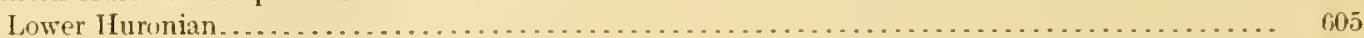

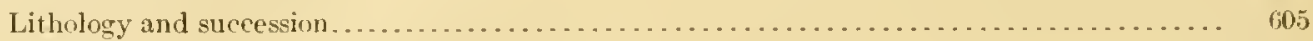

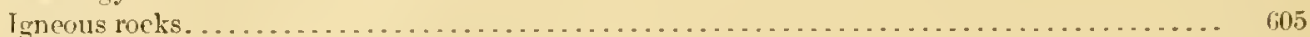

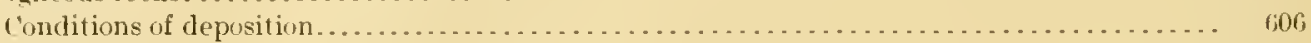

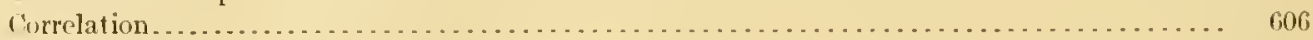

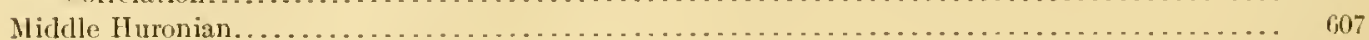

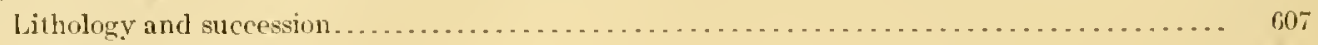

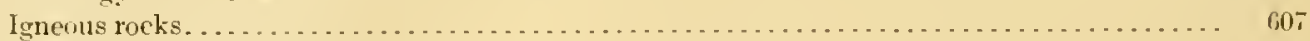

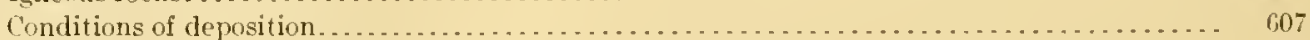

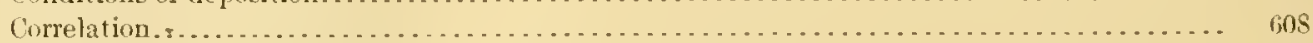

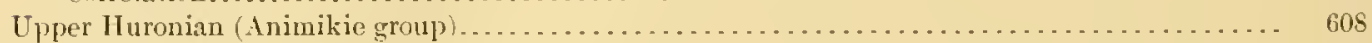

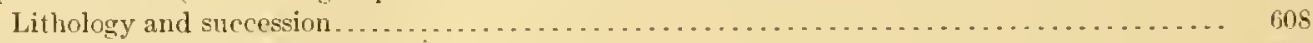

Igneous rocks . . . . . . . . . . . . . . . . . . . . . . . . . . . . . . . . . . . . . . .

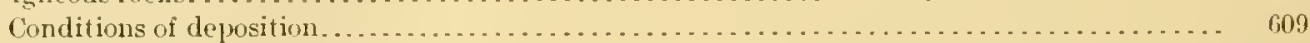

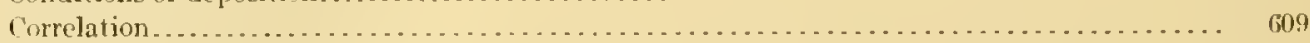

General remarks conceming the upper Huronian (Animikie group) of the Lake Superior region........ 010

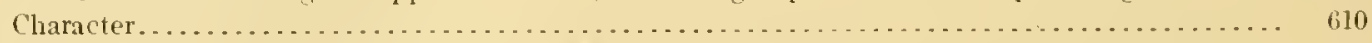

Conditions of deposition of the upper IIurnian (Animikie group) . . . . . . . . . . . . . 61 ?

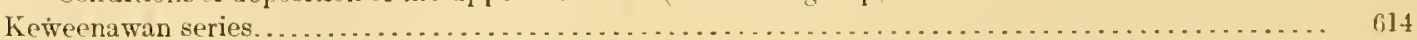

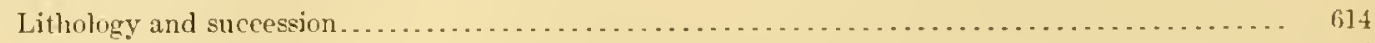

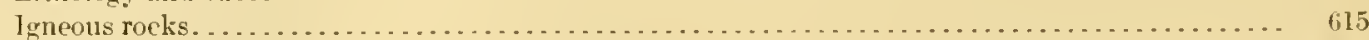

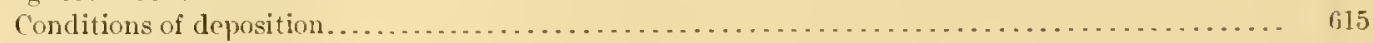

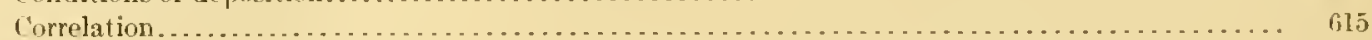

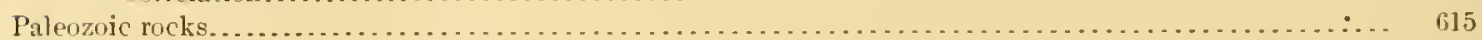

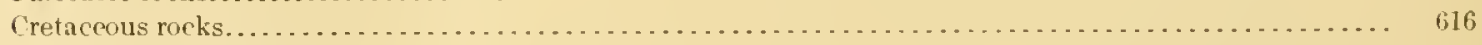

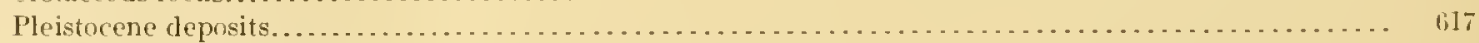

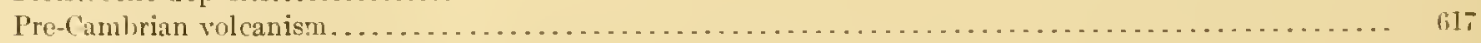

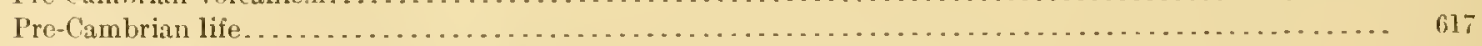

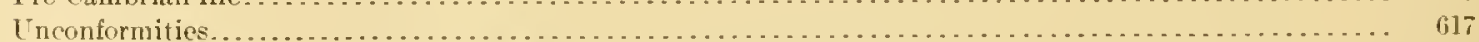

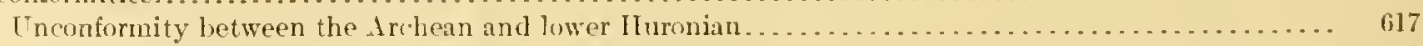

Unconformity between the lower and middle Huronian. . . . . . . . . . . . . . . . . . . . . . .

Unconformity at the base of the upper Huronian (Aninikie group) ... . . . . . . . . . . . . . .

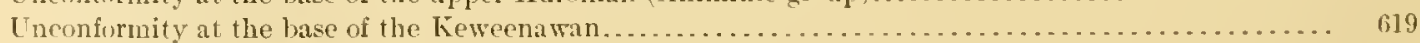

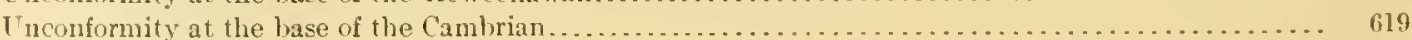

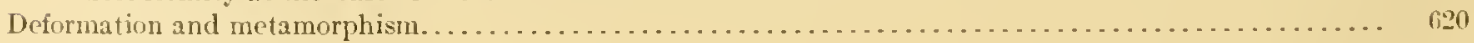

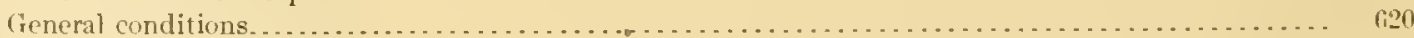

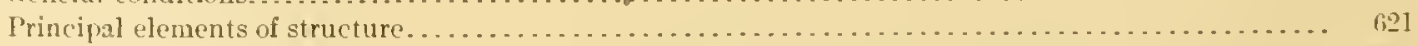

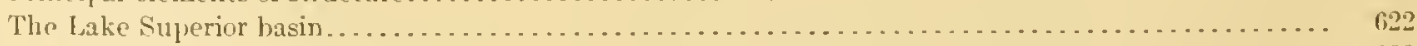

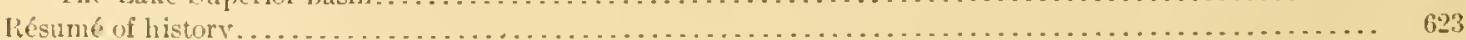

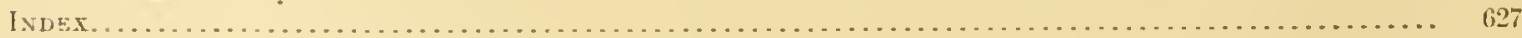




\section{ILLUSTRATIONS.}

PLATE 1. Geologic map of the Lake Superior region, with section $\ldots \ldots \ldots \ldots \ldots \ldots \ldots \ldots \ldots \ldots \ldots$ in pocket.

11. Relief map of the Lake Superior region, showing the larger topographic features............. 86

III. A, Pre-Cambrian peneplain in Ontario, near Michipicoten; $B$, Jasper Peak, near Tower, Jinn.... 88

IV. A, Topographic map of Rib Ilill, Wis.; B, Typical monoclinal ridge topography, lsle Royal, Mich. . 90

V. A, The Duluth escarpment and even upland of peneplain on Duluth gabbro in Ninnesota; $B$, Lake shore escarpment of Archean schists and Huronian quartzite near Harquette, Mich . . . . . . . . . 112

VI. Geologic map of the Vermilion iron-bearing district, Minn ......................... 118

VII. A, Ellipsoidal parting in Ely greenstone; $B$, Ellipsoidally parted Ely greenstone, showing spheru-

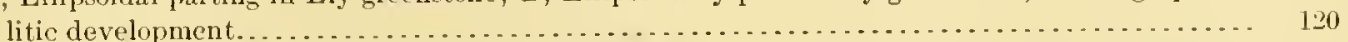

VIII. Geologic map of the Mesabi iron-bearing district, Minn....................... In pocket.

IX. Sharp folding of beds of iron-bearing Biwabik formation in Mesabi district, Minn.; 1 , IIawkins

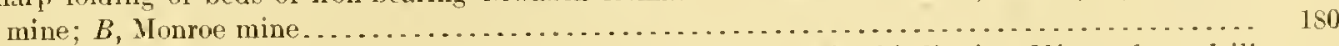

X. Typical cross section through iron-bearing Biwabik formation, Mesabi district, Minn., from dril!

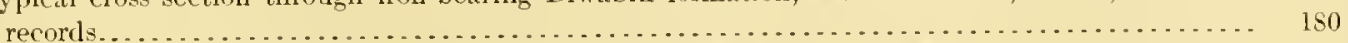

X1. A, Panoramic view of the Mountain Iron open-pit mine, Mlesabi district, Mlinn.; $B$, Panoramic view of the Shenango iron mine, Mesabi district, Minn . . . . . . . . . . . . . . . . . . . . . 180

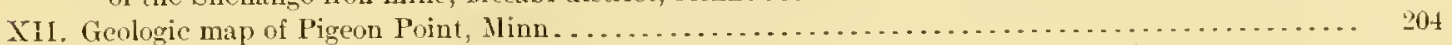

XIII. Geologic map of the Animikie iron-bearing district, north of Thunder Bay, Ontario............ 206

XIV. Map of central Minnesota, including Cuyuna district............................. 212

IV. Map of part of the Cuyuna iron district of Minnesota, showing magnetic belts................ . 212

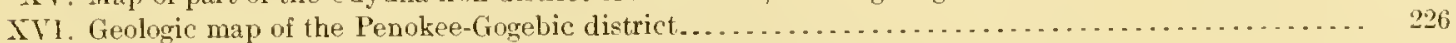

XVII. Geologic map of the Marquette iron-bearing district, Mich ..................... In pocket.

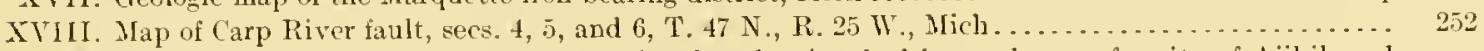

XIX. Detailed map of quartzite ridges of Teal Lake, showing faulting and unconformity of Ajibik and

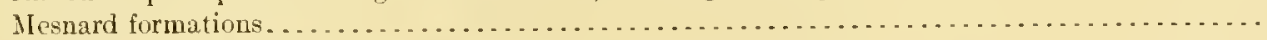

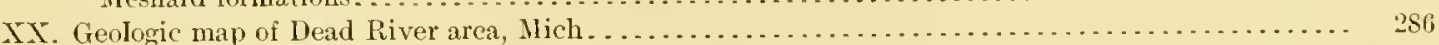

XXI. Map of Perch Lake district, Mich., showing distribution of onterops . . . . . . . . . . . . . . In pocket.

XXI1. Geologic map of the Crystal Falls district, Mich., including a portion of the Marquette district. In porket.

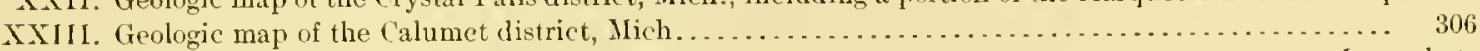

XXIV, Geologic maj of the Iron River distriet, llich............................... In pocket.

XXV. Geologic map of the Florence iron district, Wis................................. In procket.

XXVI. Geologic map of the llenominee iron district, Mich........................... In pocket.

XXYII. Vertical north-south cross sections through the Norway-Aragon area, Menominee district, Mich.,

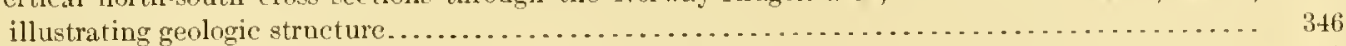

XXVIII. Geologic map of the Keweenaw Point copper district, Nich . . . . . . . . . . . . . . . . . . . 380

XXIX. A, Ilanging valley near Helen mine, Jichipicoten; $B$, Lake clay overlying stony glacial till in

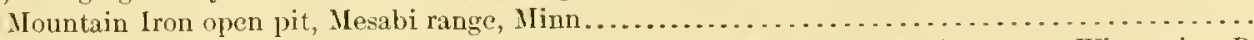

XYX. I, Terminal-moraine and outwash-plain topography in glaciated area of western Wisconsin; $B$, Glaciated valley of Portage Lake on Keweenaw Point, Mich., with hanging valley of Iluron Creek.

XXXI. A, Characteristic Driftless Area topography in northern Wisconsin; $B$, Characteristic muskeg and

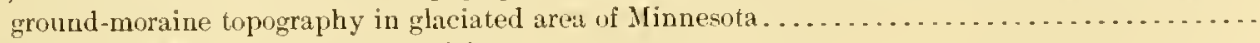

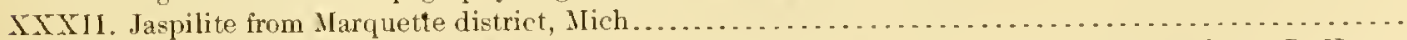

xXIIII. A, Folded and brecciated jaspilite of the Soudan formation, Termilion district, Minn.; $B$, Hematitic chert frum Negaunee, Narquette district, Mich................ . . . . . . . . . . 466

XXXIT. Ferruginous chert and slate of iron-bearing Biwabik formation, Mesabi district, Minn......... 468

XXXT. A, Amphibole-magnetite chert from Republic, Mich.; $B$, Sideritic magnetite-grünerite schist from

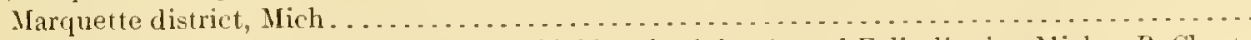

IXXV1. A, Jaspery filling in amygdules from ellipsoidal basalt of the ('rystal Falls district, Mich.; $B$, Cherty siderite from Marquette district, Mich.; C, Cherty siclerite from Penokee district, Mich. 


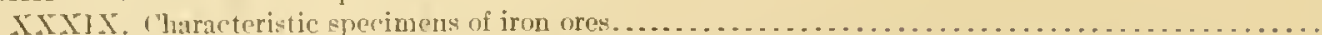

X1. Hiagram showing relation of density, porosity, and moisture to cubic feet per ton.........

XI.I. A, Ore dorks at Two llarbors, Minn.; $B$, Excavations at Stevenson, Minn...............

$\left.X_{3}\right]$. Plotomicrographs of matural and artificial grecnalite granules, cherty siclerite, and concre-

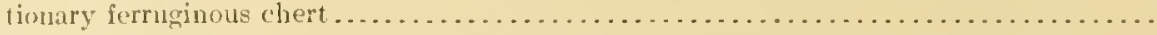

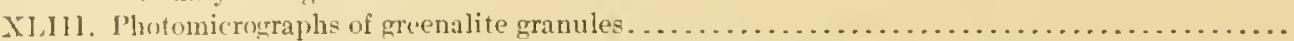

XI.] Y. Photomicrngraphe of ferruginous chert showing later stages of the alteration of greenalite granules

XLY. Photomicrographs of granules and concretionary structures jn t'linton iron ores............

$X L Y I$. A, Ore and jasper conglomerate from Marquette district, Mich.; B, Ferruginous chert from

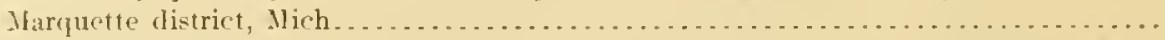

XIVIl. Photonicrograplss of ferruginous and amphibolitic chert of iron-bearing Biwabik formation

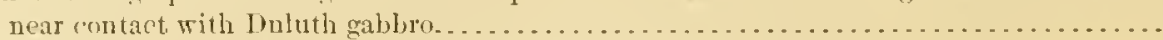

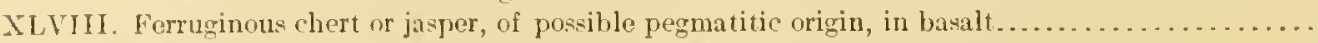

XLIX. Map showing location of copper-bearing lodes and mines on keweenaw Point ...........

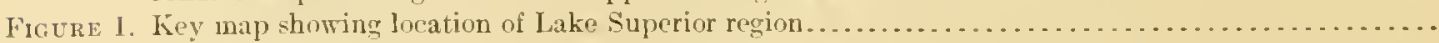

2. Sketch maj of the Lake Superior region, showing iron districts, shipping ports, and transportation

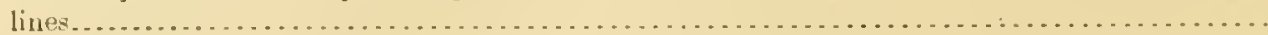

3. I) iagram showing annual production of iron ore in Lake Superior region since the opening of the region.

4. Generalized topographic map of the Lake Superior region . . . . . . . . . . . . . . . . . . . . . .

5. The topographic provinces of the Lake Superior region, with some subdivisions of the peneplain....

6. True-scale cross section of Keweenawan monoclinal ridges near the end of Keweenaw Point.....

7. If ypothetical cross section showing relation of secondary bowlands, mesas, monoclinal ridges, etc., to peneplain

8. Gralen or rift valley of western Lake Superior, showing escarpments on either ride and peneplain

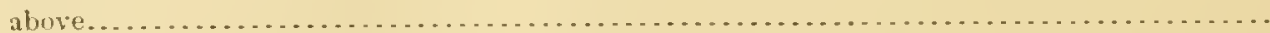

9. The drainage of the $\mathrm{St}$. Louis and $\mathrm{M}$ ississippi headwaters before the stream capt ures along the Duluth

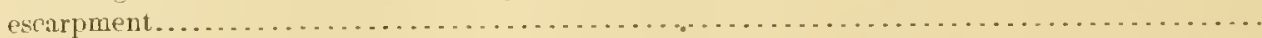

10. The drainage of the St. Louis aud Mississippi headwaters at present, after stream captures and

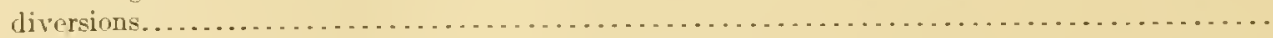

11. Structure profile in northern Wisconsin, showing the south erige of the peneplain on the preCambrian rocks and the northern part of the belted plain of the Paleozoic..................

12. Diagram to illustrate folding of "drag" typo, common in the Vermilion and other ranges..........

13. Section across jasper belt in secs. 13 and 14, T. 62 N., R. 13 IT., Vermilion iron range, Minn......

14. Transverse sections of Chandler, Pinneer, Zenith, Sibley, and Savoy mines, Vermilion district, $\|$

15. Diagram illustrating volume changes involved in the alteration of jasper to ore at Ely, Minn.......

I6. North-south cross section of an ore deposit on the Mesabi range near IJibbing, Minn.............

17. Triangular diagram showing composition of various phases of Mesabi ores and ferruginous cherts....

18. Section through iron-bearing Biwabik formation transverse to the range, showing nature of circula-

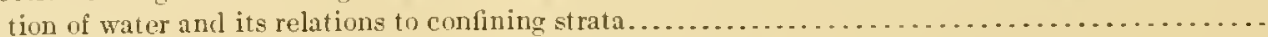

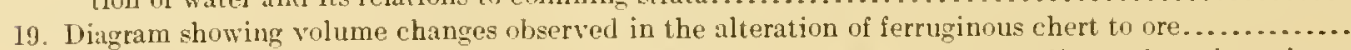

20. Graphic representation of the changes involved in the alteration of greenalite rock to ferruginous

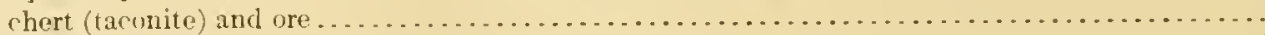

21. Triangular diagram representing volume composition of the various phases of ferruginous cherts and

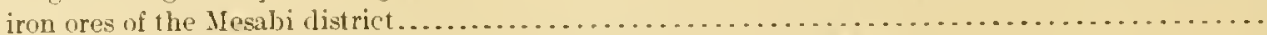

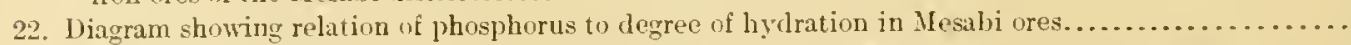

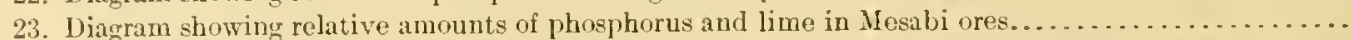

24. Cross section of iron-bearing Gunflint formation east of Paulson mine, Guuflint district, Minn.......

25. Plan and cross section of the iron-ore deposit in sec. 12. T. 43 N., R. 32 W., Crow Wing County, Minn.

26. Triangular diagram showing mineralogical composition of various phases of iron ores and ferruginous

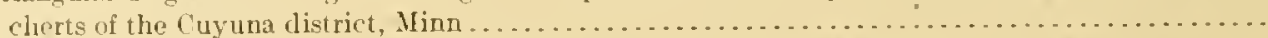

27. Triangular diagram showing volume composition of various phases of iron ores and ferruginous

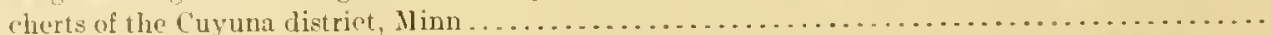

28. ('ross section showing the oreurrence of ore in pitching troughs formed by dikes and quartzite font-

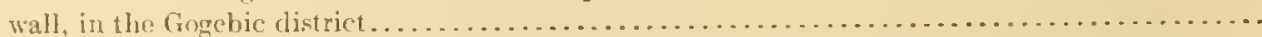

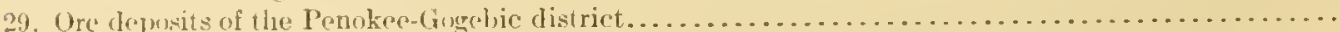

30. Triangular (fiagram showing (hemical composition of various plases of Gogebic ores and ferruginous

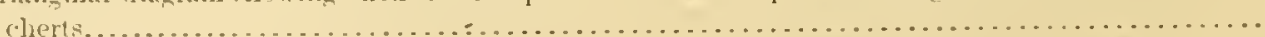

3I. Diagramatic representation of the changes involved in the alteration of cherty iron carbonate to firruginous chert and ore, Gogebic district 
Figure 32. Triangular diagram showing volume composition of the ferruginous cherts and iron ores of the Gogebic

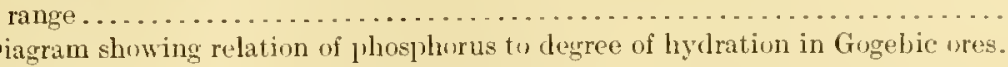

34. Diagram showing relative amounts of phosphorus and lime in Gogebic ores.

35. Idealized north-suth seetion through the Marquette district, showing abnormal type of synelinorium.

36. Ore cleposits of the Marquette district ..

37. Graphie representation of the volume composition of the principal phases of the iron-bearing Negaunee formation...

35. Triangular diagram showing the volume composition of the several grades of ore miner in the $M a r-$ quette district in 1906.

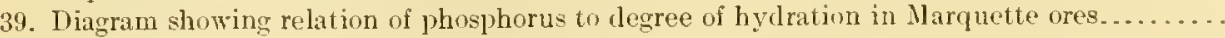

40. Diagram showing relative amounts of phosphorus and lime in Marquette wres....

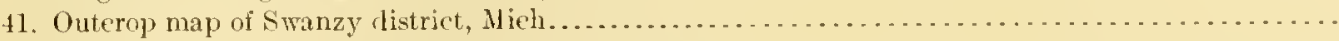

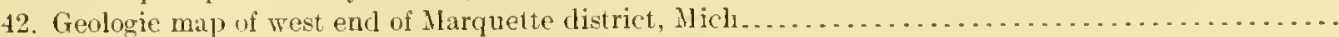

43. Sketch map to show general relations of iron-bearing rocks, principally upper Ifuronian, in Crystal Falls, Iron River, Florence, and Menominee districts.

44. Section showing roughly the succession of beds in the Vulcan iron-hearing member near $A$ tkinson, in the Iron River district, Nich. . . . . . . . . . . . . . . . . . . . . . . . . . . . . .

45. Geologir map and cross section of Iron Hill, Menomince district, showing relations of lower and niddle II ronian. . . . . . . . . . . . . . . . . . . . . . . . . . . . . . . . . . . . . .

46. Ilorizontal section of the Iragon mine at the first level, Menominee district, Mich.............

47. IIorizontal section of the Aragon mine at the eighth level, Menominee district, Mich..........

48. Vertieal north-south cross section through Burnt shaft, West Vulcan mine, Menominee district, Mich.

49. Sketch to show pitch of a drag fold in a monochinal succession . . . . . . . . . . . . . . . . . . . . .

50. Triangular diagram representing the volume composition of the various grades of ore mined in the

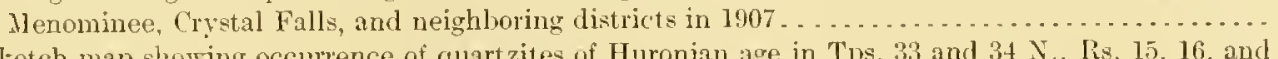

51. Sketch map showing occurrence of quartzites of Huronian age in Tps. 33 and 34 N., Ris. 15,16, and 17 E., ITis.

52. Sketch maly showing occurrence of Huronian quartzite near Necedah, Wis...................

53. Sketch map showing Baraboo, Fox River ralley, Necedal, Waushara, and Waterloo pre-Cambrian areas of south-central Wisconsin. . . . . . . . . . . . . . . . . . . . . . . . . . . . .

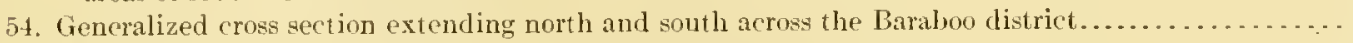

55. Vertical section of 11 linois mine. . . . . . . . . . . . . . . . . . . . . . . . . . . . . . .

56. Section on south eliff of Great Palisades, Minnesota coast . . . . . . . . . . . . . . . . . . . . . .

57. Sketch showing unconformable contaet between Keweenawan diabase porphyry and Cambrian sandstone at Taylors Falls, Mlinn.

58. Diagrammatic section illustrating the assigned change of attitude of a series of beds, like the Keweenawan, from an original depositional inclination to a more highly inclined attitude..........

59. Map of the Lake Superior basin, designed to show the structure and extent of the Keweenawan trough.

60. Sketch maj showing the glaciation of the Lake Snperior region, giving names of lobes and probable general directions of ire flow . . . . . . . . . . . . . . . . . . . . . . . . . . . . . .

61. Sketch showing the glacial cirque, the rork basins, and the hanging valley near the llelen nine,

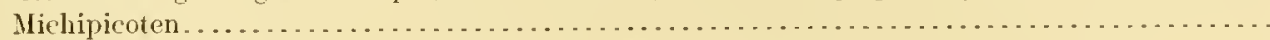

62. Sketch showing the origin of the drift deposits overlying the ore in the Mesabi iron range..........

63. Glacial Lake Nemadji. . . . . . . . . . . . . . . . . . . . . . . . . . . . . . . . . .

64. Glaeial Lake Duluth. . . . . . . . . . . . . . . . . . . . . . . . . . . . . . . . . . . .

65. 1lypothetical intermediate stage with the expansion of glacial Lake Chicago and the later stage of glacial Lake Duluth . . . . . . . . . . . . . . . . . . . . . . . . . . . . . . . . . .

66. Glacial Lake Algonquin. . . . . . . . . . . . . . . . . . . . . . . . . . . . . . . . . .

67. Part of Nipissing Great Lakes. . . . . . . . . . . . . . . . . . . . . . . . . . . . . . .

65. Sketeh maj showing Driftless Area and regions of older drift, last drift, and lake deposits.........

69. St. Louis River at the stage when it cut its valley and emptied directly into Lake Nipissing.......

70. The present St. Lonis River, which has been converted into an estuary lyy post-Nipissing tilting-

71. Triangular diagram showing chemical composition of all grades of iron ore mined in the Lake Superior region in 1906 .

72. Textures of lake Superior iron ores as shewn by screening tests.

73. Diagram showing relation between estimated ore reserves of the Lake Superior region and rate of produetion.

74. Diagram representing decline in grade of Lake Superior iron ore since 1589.

75. Cross section of Keweenaw Point near Calumet, showing copper lodes in ronglomerates and amy-

76. Triangular diagram comparing the amounts of undecomposed silicates, quartz, and residual weathered products in different kinds of muds, shales, and weathered rocks.

245

248

249

253

270 



\title{
THE GEOLOGY OF THE LAKE SUPERIOR REGION.
}

\author{
By C. R. Vax IIse and C. K. Leith.
}

\section{CHAPTER I. INTRODUCTION.}

\section{OUTLINE OF MONOGRAPII.}

The I ake Superior region is a part of the southern margin of the great pre-Cambrian shield of northern North America. It is hordered and overlapped on the south by Paleozoic rocks of the Mississippi Villey and on the southwest by Cretaceous deposits. The pre-Cambrian rocks . of the area, which nuy be divided into a considerable number of lithologic and time units, contain the great iron and copper deposits by which the region is most willely known. The great development of the mineral industry in this region has afforded the geologist unusual opportumity for study, as it has not only made the region more accessible but has justified larger expenditures for geologic study than would otherwise have been made. 'This fortunate combination of a field containing an exceptionally full record of a little-known part of the geologic column with the means of studying it has warranted the study of the pre-Cambrian with a degree of detail that has been practicable in but few other significant pre-Cambrian regions.

Geologic surveys of rarious parts of the Lake Superior region have been conducted under national, state, and private supervision almost without interruption since the early part of the nineteenth centurr, especially since the opening of the mining industry in the middle of the century. The later reports have naturally been more adequate than the earlier ones, becuuse they hare included the results of the earlier work and have gained the advantage derived from the creater accessibility of the district. The reports thus far issued have dealt with small parts of the region or with certain phases of its general geology. State and private surveys hare necessarily worked within prescribed areas, so that notwithstanding the multiplicity of reports certain parts of the region liave not yet been adequately corered. It has lieen the proper function of the United States Geological Survey to make detailed survers designed to accomplish the uniform treatment and corrclation of the several ore-bearing districts, and finally to publish a monographic report on the region as a whole. Work under a general plan for these surreys was begun in the early eighties under the direction of Prof. R. D. Frving, whose monograph on the copper-bearing rocks of Lake Superior a appenred in 1853 , though it was partly prepared at an earlier date, while he was connected with the Wisconsin Geological survey. The derelopment of this plan has since been continuous. Until 1SSS the work was in charge of Professor Irving: since that time it has been under the direction of Dr. Chanles R. Tan Hise, the senior anthor of this monograph. Detailed monographs on the tive leating iron ranges have been published and also papers covering diflerent phases of the general geologr of the region.

This monograph represents the first attempt to give a connected account of the geology of the Lake Superior region as a whole, with special reference to the iron and copper bearing formations. Attention is directad primarily to general features of correlation of the formations, 
to the geologic history of the region, and to the origin of the iron and copper ores. In addition, bricf chapters are presented on several parts of the district which harl not yet been rejorted on by the United States Creological Survey. No attenpt is made to give details. For these the reader is reforred to the publications of the Cnited States Cieological surrey and of state geologieal survey's and to other sources specified in appropriate places in this rolume.

Thougl this monogriph may be regarded as completing a stage in the progress of the geologic survey of the region, and hence may be considered final in one sense, it may also properly be regilded as only the first of a series of general studies of the clistrict. The area is so large and the record is so complex that this monograph will aceomplish its purpose if it discloses the elements of some of the major problems of the region and affords a basis for a better-directed attack on them than has heretofore been possible. Future monographs will undoubtedly be written on each of the many phases of subjects that are barely touched upon in this monograph, such, for instance, as the petrography and consanguinity of the igneous roeks of different periods, the conditions of sedimentation of various series, the relations of voleanism to ore deposition, and the correlation of major and minor structural features of the Lake Superior region with one another and with the various structural features of North America. Besides, certain areas not yet fully reported on will require detailed monographic description. It is hoped that the work of the United States Geological Survey in the Lake Superior region may be continued along the lines indicated.

Parts of the region have been studied at different times by men occupying different riewpoints. Some areas which have recently become commercially prominent hare not ret been adequately studied in detail. Finally, mining, drilling, and rarious pullic and private surreys are so rapidly extending the knowledge of the geology of the region that it is practically impossible at the present time to write a monograph that will not repuire modification in some particulars almost before it comes from the press. Because of these facts this work shows inequalities and inalequacies of treatment for different parts of the region and for different phases of the subject. It is hoped, howerer, that the monograph will be measured by the adrance it represents over previous available knowledge and especially by its attempt to loring out significant general features of the geology not heretofore discussed, and not by its deficiencies, of which the writers have a lively appreciation.

The parts of the report written partly or wholly by others than the authors bear the names of the writers. It will be understood that any chapter or section for which no names are given has been written by C. R. Van Hise and C. K. Leith.

\section{ACKNOWLEDGMENTS.}

The completion of this monograph and the detailed studies leading up to it hare leen facilitated by the cordial cooperation of the mining men of the region. To attempt to mention the names of all who have gone out of their way to render aid in these studies would involve the publication of a list including the greater number of local mining men, and even from such a list some names would probably be inadvertently omitted. Especially raluahle has been the information furnished by the Oliver Iron Mining Company (United States Steel Corporation), which has a most highly developed and efficient engineering and geologic staff. Valuable aid has been given by state and provineial surveys and by the Minnesota tax commission. To all these men and organizations we express our indebteilness and thanks.

We are indebted to Messrs. W. J. Mead, Lawrence Martin, Alexander N. Winchell, A. C. Lane, R. C. Allen, and Edward Stcidtmann for sections of this report hearing their numes, and to numerous other men mentioned in the report who have contributed in different ways. Not the least of our indebtedness is to Mr. A. C. Deming for ellicient clerical service.

\section{GEOGRAPIIY.}

The Lake Superior region comprises parts of Michigan, Wisconsin, Minnesota, and Ontario. adjacent to Lake Superior. (See figs. 1 and 2.) The acompanying general geologic map. 
(Pl. I, in pocket) covers the area between parallels $44^{\circ}$ and $49^{\circ}$ north and meridians $84^{\circ}$ and 95 west, comprising approximately 181,000 square miles-an area almost equal to that of the six New England States and New York, New Jersey, Pennsylvania, and Maryland, or that of Sweden and Belgium.

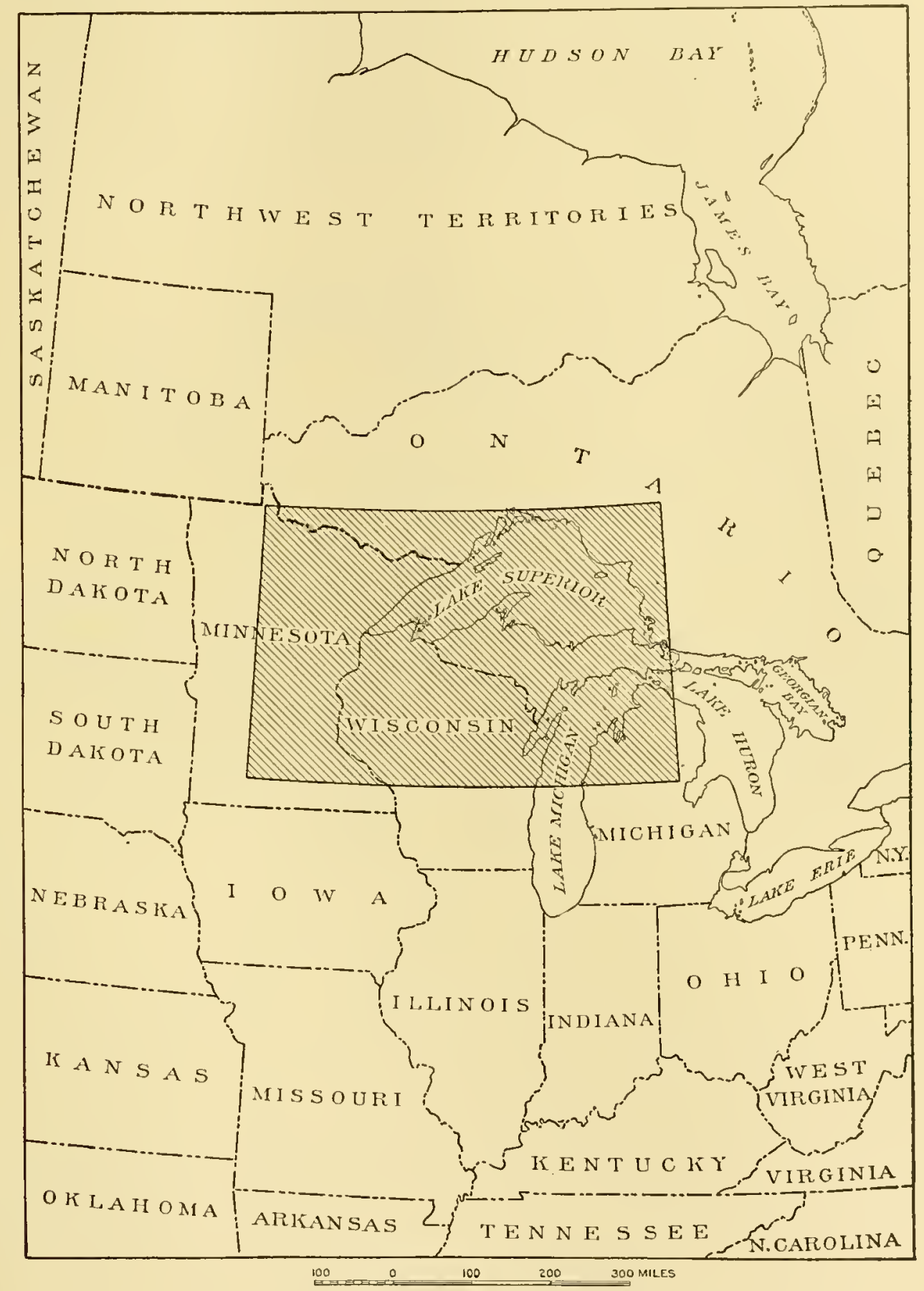

FigURE 1.- Key map showing location of Lako Superior region.

The region includes sereral ore-bearing districts of comparatively small area-the Keweenaw copper-bearing district of Keweenaw Point, Miehigan, about 1,350 squiare miles; the Marquette iron-bearing district of Michigan, extending westward from the city of Marquette 
on the lake shore, about 330 square miles: the Ifemominee iron-bearinger distriet, extending from tron Mountain in Jiehigan castwall along Menominee River, aggregating 12 square miles: the Crystal falls iron-beaning distriet in dliedigan, in the rieinity of the town of Crystal Falls, if 40 square miles: the hon River district, west of the Crystal Falls district, in the vieinity of the town of Iron Kiver, 210 square miles: the Florence iron-bearing distriet, in Wisconsin, west of the Henomine distriet. 75 square miles; the Calumet and felch Alountain iron-bearing districts of Michigan, in Dickinson County, aggregating 200 square miles: the Penokec-Gogebic iron-bearing distriet, in Michigan and Wisconsin, about 450 square miles: the Vermilion and Mesabi iron-bearing distriets of Minnesota, trending east-northeast in parallel areus along the northern boundary of the State, 1,400 square miles: the Cuyuna iron district of Minnesota, in

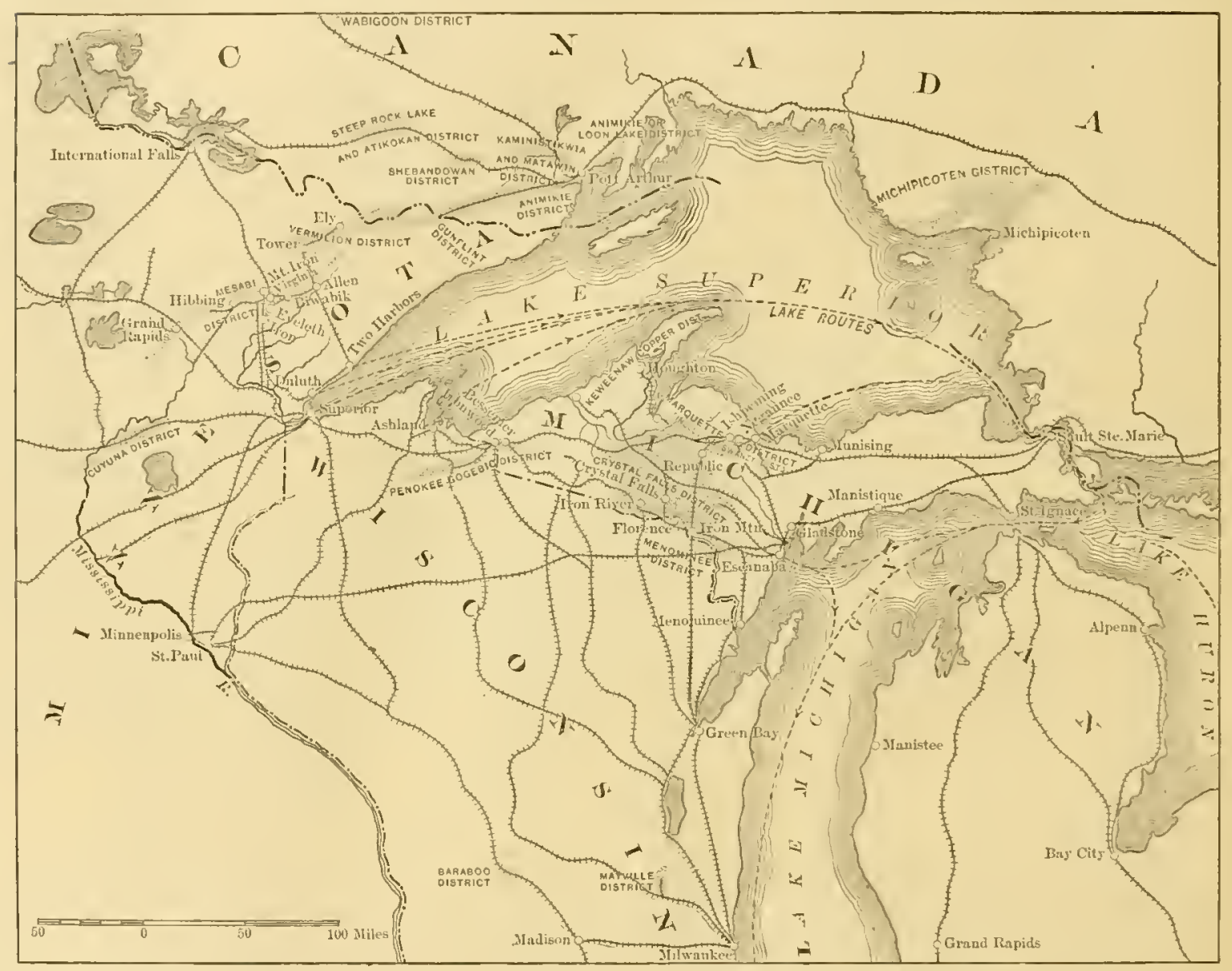

FIGURE 2.-Sketch map of Lake Superior region, showing iron districts, shipping ports, and transportation lines.

the vicinity of Brainerd, about 300 square miles; the Michipicoten distriet of the northeast shore of Lake Superior, aggregating 140 sfuare miles, and others of less importance. The total area of these principal ore-bearing areas is thus less than 3 per cent of that of the entire Lake superior region, but these districts are commercially important and the remaining portions are not; for the most part also they include a fuller succession of pre-Cambrian rocks than the intervening areas, and the detailed geologic mapping has been largely confined to them. For these reasons the term "hake superior region" is commonly usal an al collective designation of the ore-bearing district.s, notwithstanding the fact that they comprise only a small pereentage of the entire lanke Sujerior region. 


\section{TOPOGRAPIIY ${ }^{a}$}

\section{IRELIEF.}

The principal topographic feature of the Lake Superior region is the Lake Superior basin, which has a general easterly and westerly trend. Most of the ridges and valleys in the arljacent areas lie parallel to the axis of the Lake Superior syncline, and are due to the erosion of paralleltrending folds, fauts, and cleavage produced during deformations parallel to the axis of the Lake Superior basin.

The topograply has been modified by glacial action. Rirlges have been smootled and rounded and some of the valleys deepened, and the features have been then masked under a varying thickness of glacial irift.

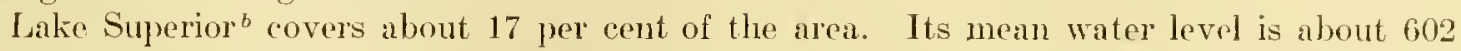
feet, about 21 feet higher than Lakes Michigan and Huron, whose mean level is 581 feet. The basin of Lake Superior descends 978 feet below lake level, nearly 400 feet bolow sea level. The greatest depth in upper Lake Michigan is 870 fect, or about 289 feet below sea level.

On the several sides of Lake Superior the land rises abruptly, reaching elevations of 1,400 to 1,700 feet (locally 1,900 feet) in northern Michigan and Wisconsin on the south; 1,300 to 1,700 feet (locally 1,900 to 2,200 feet) in nortlern Minnesota on the northwest; and 1,100 to 1,300 feet (locally 1,700 to 2,100 feet) in Ontario on the north and northeast. The range of clevation (from a maximum of 2,230 feet in the Cook County region of Mimnesota to 376 feet below sea level northenst of Keweenaw Point in Lake Superior) is 2,606 feet, but the actual observable relief is about 1,625 feet, from the level of Lake Superior to the high point in Cook County northwest of Grand Marais, Minn.

As the topographic map) (fig. 4, p. 87) shows, the Lake Superior region falls into thee natural divisions - the uplands, the lowlands, and the lake basins. All of the Upper Peninsula of Michigan from Marquette eastward to Sault Ste. Marie is lowland, nowhere rising more than 900 feet above sea level or 300 feet above Lake Superior. A similar very narow lowland belt skirts the south sliore of Lake Superior, with many interruptions, from Marquette westward to the head of the Lakes at Duluth and Superior. Elsewhere, except at some less important points, the upland borders the lake closely, and it ineludes the remainder of the Lake Superior region, lying between 1,000 and 1,700 feet (except locally) abore sea level, 400 feet higher than the lake. In this upland division are situated nearly all the mining districts. Parts of Lakes Superior, Michigan, and Huron occupy the depressions.

\section{DRAINAGE.C}

Lake Superior is situated south of the Ileight of Land, near the intersection of three major drainage systems. It is near the watersheds of the Hudson Bay, the St. Lawrence River, and the Mississippi River drainage.

A large part of the Lake Superior region is tributary to Lake Superior and Lake Michigan, and hence to the St. Lawrence River drainage system. The prineipal streams flowing into Lake Superior are Carp, Ontonagon, Black, Brule, Bad, Nemadji, and Montreal rivers in Michigan and Wiseonsin, on the south side of the lake, St. Louis River of Minnesota on the west sicle of the lake, and Kaministikwia and Nipigon rivers on the nortlo side of the lake. St. Marrs River, discharging from Lake Superior into Lake Huron, carries a kirger volume than any other stream in the area. It has been estimated ${ }^{d}$ to carry $\$ 6,000$ cubic feet of water a sccond past Sault Ste. Marie.

\footnotetext{
a For detalled account of topography and drainage, see Chapter IV.

b The general topography of this lake has been reviewed by M. W. Harrington (Nat. Geog. Mag. rol. 7, 1896, pp. 111-120), who has also studied the currents in the Great Lakes in detail (Bulletin B, Weather Bur., U. S. Dept. Agr., 1895).

c The physical geography of a part of this regiou was described in its larger aspects in 1550 by Foster and Whitney, Report on the geology and topography of a portion of the Lake Superior land district in Michigan, vol. 1, pp. 1S-83.

d Sehermerhorn, L. Y., Am. Jour. Sei., 3d ser., vol. 33, 1s\$7, p. 282. 
A number of short streans, such as Manistique, White, and Escanaba rivers, flow southward into Lake Michigan and Greon Bay. Menominee River, which forms the MichiganWisconsin boundary, Hows southeastwarl into Green Bay, receiving as tributaries the Paint and the Nichiganme. Peshtigo and Woll rivers drain northeastern Wisconsin. A number of small streans irain the northeastern part of the Lower Peninsula of Michigan.

Another large part of the Lake Superior region in Wisconsin and Minnesota is tributary to the Mississippi and so to the Gulf of Mexico. The principal tributaries in this area are Wrisconsin, St. Croix, Black, Chippewa, Swan, and Prairie rivers.

A thild large part of the Lake Superior region, in northern Minnesota and western Ontario, is tributary to Lake Winnipeg, and hence to Nelson River and I Iudson Bay. This system comprises the numerous large lakes occupying a large portion of the area of northern Minnesota and western Ontario, incluling Lakes Rainy and Vermition and Lake of the Woods.

The divide between the St. Lawrence and the Mississippi drainage systems extends from Portage in central Wisconsin, between Wisconsin and Fox rivers, north to the WisconsinMichigan boundary (fig. 4, p. 87) thence northwest and west into Minnesota, and thence north between upper Mississippi River and St. Louis River to the Giants Range. The Giants Range, extendling east-northeast across the northern part of Minnesota, separates the Mississippi and the St. Lawrence systems on the soutluwest and southeast, respectively, from the Nelson River and Hudson Bay system on the north. The areas of these three large drainage systems within the Lake. Superior region are as follows: St. Lawrence, 107,000 square miles; Mississippi, 52,000; Hudson Bay, 22,000.

As a whole the drainage of the Lake Superior region is very imperfect. The numerous lakes, swamps, waterfalls, and rapids are features of an immature drainage. 


\section{CHAPTER II. HISTORY OF LAKE SUPERIOR MINING.}

\section{THE KEIVEENAW COPPER DISTRICT OF MICHIGAN (1S4t). ${ }^{a}$}

The existence of copper was known to the Chippewa Indians net in the Lake Superior region by the earliest explorers. They exhibited crude ornaments of native eopper but seemed to make no further use of their knowledge. There is evidence that mining was carried on at a far earlier period.

Whether the mining was done by ancestors of the aboriginal tribes discnveren in possession of the Lake district by the earliest white explorers, or by some antecedent people of higher civilization, is a point that archaologists and ethnologists are still arguing. Whatever may have been the derivation or fate of that prehistoric race of copper miners vaguely termed "mound builders," it is certain that they enjoyed at least a rudimentary civilization and were successinl metallurgists, for they possessed the art of tempering copper. Weapons for the cluase and war and domestic ntensils of good finish and style and highly tempered are dug from mounds and found in sand dunes along the southern shore of Lake Superior from time to time. ${ }^{b}$

The existence of native copper on Keweenaw Point was reported by La Garde in 1636, hy the Jesuit missionaries in the "Relations," extending from 1632 to 1672 , by Baron Le Houtan in 1659 , by $P$. de Charlevoix in 1721 , and by Jonathan Carver in 1765 . The report of Captain Carver led to the formation of a mining company which actually mined copper ore in 1761 and 1762, but without commercial suceess. In 1771 Alexander Henry, an Englishman, began mining operations, but he desisted in 1774. The copper ores were noted in 1819 by H. L. Schoolcraft and in 1823 by Major Long, both of them conducting explorations for the Government. The first systematic survey and study of the copper ores was made by Douglass Houghton for the first Michigan Geological Survey. In 1S30, in company with Gen. Lewis Cass, he first visited the copper region, and some years later began combined geologic and topographic surveying, for which, by considerable effort, he had procured support from the Ifichigan legislature. His first report was published in 1841 .

Previous stories of mineral wealth on the southern shore of Lake Snperior had been too vague and confuscd to interest capitalists sufficiently to venture their money in attempts at mining in a country which was then much farther from the centers of wealth and population than is Cape Nome to-day, measured by time and transportation facilities. This apathy was dispelled by Dr. Ionghton's first report, which was chear and concise and bore upon its face the stamp of truth. IIe told the world that vast stores of copper existed upon the southern shore of Lake Superior. Pressure was brought to bear upon the Federal Government, and in 1843 an arrangement was concluded with Dr. IIoughton by which he was to combine a linear survey for the United States with a topographical and geographical survey he was then making for the State of Michigan. It was necessary that the linear survey be made before mining locations could be granted by the federal authorities, as there were no boundaries other than those of nature before that time. The work was begun in 1844, and during that and the following year rapid progress was macle. Dr. Houghton's career was brought to an untimely end by his acciclental drowning in Keweenaw Bay in the late fall of 1845 , but his work was then so far advanced that it was taken up and pushed to early completion by competent successors. ${ }^{c}$

The first actual copper mining at Lake Superior was done in $\mathbf{1 8 4 4}$, and the first product secured was a few tons of oxide ore-not native copper-taken from a fissure vein near Copper IIarbor, Keweenaw County, by the Pittsburg and Lake Superior Mining Company, which later developed the Cliff mine, nearly 20 miles to the southwest. The Minnesota mine, in Ontonagon County, was opened shortly after.d

The subsequent history of the copper district is one of continuous rapid growth with only minor fluctuations.

a In the following history of the Keweenaw copper district the authors have drawn Ireely on the excellent briel account ol early conditions in the Copper handbook, by Iloraee J. Stevens.

o Stevens, II. J., Copper handbook, vol, 6, 1906, p. 14.

cldem, vol. 2, 1902, pp. 16-17

¿Idem, vol. $u, 1906$, p. 17. 
The following table of annul production shows, in amount and in perecutage, the relation of Lake Suprerior shipments to those of the Tnited States:

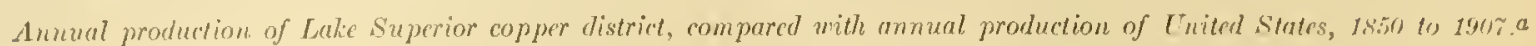

\begin{tabular}{|c|c|c|c|c|c|c|c|c|c|c|c|}
\hline \multirow{2}{*}{ Year. } & \multirow{2}{*}{$\begin{array}{l}\text { linited } \\
\text { States. }\end{array}$} & \multicolumn{2}{|c|}{$\begin{array}{l}\text { 1ake Superior } \\
\text { or Mlichigan dis- } \\
\text { trict. }\end{array}$} & \multirow{2}{*}{ Year. } & \multirow{2}{*}{$\begin{array}{l}\text { United } \\
\text { States. }\end{array}$} & \multicolumn{2}{|c|}{$\begin{array}{c}\text { Lake Superior } \\
\text { or Mlichigan dis- } \\
\text { trict. }\end{array}$} & \multirow{2}{*}{ Year. } & \multirow{2}{*}{$\begin{array}{l}\text { United } \\
\text { Stitites. }\end{array}$} & \multicolumn{2}{|c|}{$\begin{array}{l}\text { Lake Sujperlor } \\
\text { or Michigan dis- } \\
\text { trict. }\end{array}$} \\
\hline & & Amount. & $\begin{array}{c}\text { Per- } \\
\text { cent- } \\
\text { age. }\end{array}$ & & & Imount. & $\begin{array}{l}\text { l'er- } \\
\text { cent- } \\
\text { age. }\end{array}$ & & & Amount. & $\begin{array}{l}\text { l'er- } \\
\text { ('wint- } \\
\text { age. }\end{array}$ \\
\hline 1450 & Langtons. $^{\prime 250}$ & $\begin{array}{c}\text { Longtons. } \\
5722\end{array}$ & se & 15 & $\begin{array}{c}\text { Long tons. } \\
13,000\end{array}$ & $\begin{array}{c}\text { Long tons. } \\
11,422\end{array}$ & 91 & $189 z$ & $\begin{array}{c}\text { Long fons. } \\
15 \mathrm{t} \text {. } 01 \mathrm{~s}\end{array}$ & $\begin{array}{c}\text { Long tons. } \\
54.949\end{array}$ & 34 \\
\hline $1 \times 51$ & 900 & 779 & 86 & $1 \times 72$ & 12,500 & 10,961 & 87 & 1893 & 147,033 & 50,270 & 34 \\
\hline $1 \times 52$ & 1,100 & 792 & 72 & 1 s73 & 15,5 & 13,433 & 86 & $1 \times 94$ & 154,120 & 51,031 & 32 \\
\hline $1 \times 533$ & 2,000 & 1,297 & 65 & $1 \times 7$ & 17.5 & 15,327 & 87 & $1 \times ! 5$ & 169.917 & 57.737 & 34 \\
\hline ins & 2.250 & 1,819 & 81 & 187 & 14. & Ifi, 089 & 89 & 1 KOF & 205.384 & (ii3. $41 \mathrm{~K}$ & 31 \\
\hline 1455 & 3,000 & 2,593 & 86 & $15 \%$ & 11., 0 Ono & 17.085 & 89 & $18: 17$ & 220,571 & (ii) 70 & 29 \\
\hline $1 \times, j$ & 4,000 & 3. 6666 & 91 & 1877 & 21,000 & $17,4 \geq 2$ & 83 & $1 \times 98$ & 335,050 & (fi) $05 \%$ & 25 \\
\hline 18. & & 4.255 & 88 & 18 ? & $2 \mathrm{l}$, & 17,719 & $\$ 2$ & 1593 & $253, \leqslant 70$ & $(5),(6) 3$ & $2 t i$ \\
\hline 1458 & 5,500 & 4,058 & 74 & $1 \times 79$ & 23,0100 & 19. 129 & 83 & 1900 & 269,111 & (6i), $44 i 1$ & 24 \\
\hline 145 & (i. 300 & 3,95 & 63 & Is. & 27.0100 & 22,204 & 82 & 1901 & 268,522 & 69,501 & $24 i$ \\
\hline lsin & 7,20 & 5.3 & 74 & 1s: & 32, & 24,363 & 76 & 1902 & 291.297 & 76,050 & 26 \\
\hline 1661 & 7.500 & 6,713 & 89 & $1 \times x^{2} 2$ & 40, 467 & 25,439 & 62 & 1903 & 311.582 & 85.846 & 27 \\
\hline 1soi & 9.000 & 6,065 & 6 & 180 & 51,574 & $2 f, 653$ & 51 & 1904 & $3 i 2,739$ & 93,001 & $26 \mathrm{i}$ \\
\hline 1403 & 8.500 & 5.7 & 68 & $1 \mathrm{~s}$. & (it. 708 & 30,961 & 47 & 1905 & 402,704 & 100,874 & 25 \\
\hline 1664 & 8.000 & 5,576 & 69 & $18 \times 5$ & 74.052 & 32,209 & 43 & 1906 & $409,-114$ & 102.514 & 25 \\
\hline $15 f_{i}$ & 8,500 & 6,410 & 7 & $18 \mathrm{~s}$ & 70,430 & 36,124 & 51 & 1907 & 346,655 & $91.1 \times 0$ & 25 \\
\hline 1606 & 8.900 & 6,138 & 69 & $1 \times 57$ & 81,017 & 33,941 & 42 & $190 x$ & 420,953 & 99,409 & 23 \\
\hline $1 \times 67$ & 10,000 & 7,824 & 78 & 1sass & 101,054 & 38,604 & 38 & 1909 & 502,425 & 103.290 & 20.5 \\
\hline 1868 & 11,600 & $9,3 \pm 6$ & 80 & $18 \times 9$ & 101,239 & 39,364 & 35 & 1910 & 493,705 & 99,545 & 20 \\
\hline 1869 & 12.500 & 11,886 & 95 & 1890 & 115,966 & 45,273 & 39 & & & & \\
\hline 1570 & 12,400 & 10,992 & 87 & 1891 & $120 . \$ 39$ & 50.992 & 40 & & & & \\
\hline
\end{tabular}

a Stevens, II. J., op. cit., vol. 9, 1909, p. 1594. Production for 1909 and 1910 from Engineering and Mining Journal.

For many years the district held first place as a producer of copper ore in the United States, and in total production it is still first; but in 1887 and later years, except 1891, its annual shipments have been surpassed by those of the Butte district of Mlontana and since 1904 by the copper listricts of Arizona.

The deposits first to be developed were the transverse fissure veins, rich in mass copper, cutting across the strike of the beds in the Eagle IIarbor region, at the northeast end of the district. The Cliff mine was discovered by Charles T. Jackson in 1845. Production continued in this district until 1895. It is now inactive but has been newly explored with a view to a reopening.

Next to be developed were the rein or mass-copper deposits following the trend of the Keweenaw beds in Ontonagon County, at the southwestern end of the district. The presence of copprer in this district was known for many years, but systematic mining was not started until a few years after the Eagle River district was opened. The principal mines were the Ifinnesota (now the Michigan), the National, and the Mass. The Minnesota was discovered in 1847 by S. O. Knapp, through surface indentations of ancient workings. In one of these was found a mass of copper weighing 6 tons, together with rotted timbers on which it had been supported. The first shipment from this mine was made in 1848 , and for fourteen years 70 per eent of the ore was "mass." The opening of the Minnesota mine was followed by that of the National, Mlass, and other mines. The district is still actirely producing, lut principally from the anygdaloiclal beds, mass copper at present (1905) constituting only about "25 per cent of the ore producesl.

The anygdaloid deposits of the central part of the district were the next to receire attention. The first of these deposits was discovered, in 154.S, on the present Pewabic location, and the second on the Isle Royal location. The Quincy had been opened in 1847 on a transwerse vein, but the Quiney anygdaloid was not found until 1s56, the same year that the main "Pewabic" bell was found. During 1856 the Quincy produced 13.46.2 pounts of copper, but it did not becone profitable until 1S60. In 1576 the Oseeolal anygdaloid was discovered, and that year the ()scerla mine produced 2,744,7 Tr pounds of copper. The Wolverine was opened before 1890 but was not profitable until 1597. The Atlantic mine was opened in 1872. The 
richest anygdaloid bed in the district is the "Baltie," which was first proved valualule by the Baltic mine in 1597 , and a few years later was discovered on the (hampion location.

The amygdaloid deposits are now the most numerous, and in 1907 produced 73.1 per cent of the total copper ore of the district, of which about 75.5 per cent came from Houghton (ounty. A larger proportion of the production will come liom the amygdaloids in the future.

The last of the principal types of deposits to be discovered were those in the Allonez conglomerate and the Calumet am Ilecla conglomerate. Both conglomerates were discovered by E. J. Hullsert and associates. 'The Alloucz conglomerate was foumd, in 1859, at the site of the Allouez nine, and was worked for a short time, but soon proved to be unproductive, in this locality at least. Jater it was found to be productive farther south, on the Buston and Albany location, later the Peninsula and now the Franklin Junior. The Allouez conglomerate has yielded but little profit.

The site of the Calumet and Hecla was bought by IIulbert in 1860 , the evidence being a number of copper-bearing conglomerate bowlders and a few clepressions, such as in other parts of the district were found to indicate ancient workings. In 1869 IJulbert and his associates returned to the spot and dug through an amygdaloil into the conglonelate bed. The Calumet and Hecla paid their first dividends in 1869 and 1870. Up to January, 1910, the dividends of the Calumet and Hecla have aggregated $\$ 110,550,000$ on a capital of $\$ 2,500,000$.

The table below shows the relation in percentage of the ammal production of the Calumet and Ilecla mine, from 1867 to 1908, to the annual production of the Michigan district for the salme period.

Percentage of total Michigan copper production produced by the Calumet and IIecla mine, 1867 to $1908 .{ }^{a}$

\begin{tabular}{|c|c|c|c|}
\hline 1867. & 7.5 & 1881. & $1895 \ldots$. \\
\hline 1568. & 24.4 & $1882 \ldots$ & $1896 \ldots \ldots \ldots$ \\
\hline 1869. & 46.0 & $1883 \ldots$ & $1897 \ldots$ \\
\hline 1570. & 57.0 & $1854 .$. & $1898 \ldots$ \\
\hline $1871 \ldots$ & 61.0 & $1885 .$. & $1899 \ldots$ \\
\hline 1872. & 66.0 & $1886 \ldots \ldots \ldots \ldots$ & $1900 \ldots \ldots \ldots$ \\
\hline 873. & 62.5 & $1887 \ldots \ldots$ & $1901 \ldots \ldots \ldots$ \\
\hline $874 \ldots$ & 58.5 & $1858 \ldots .$. & $1902 \ldots \ldots \ldots$ \\
\hline $1875 \ldots$ & 59.5 & 1.889. & 1903. \\
\hline 1876. & 56.5 & 1890. & $1904 \ldots$ \\
\hline 1877. & 60.0 & 1891. & 1905. \\
\hline 1878. & 63.5 & $1892 \ldots \ldots$ & $1906 \ldots$ \\
\hline 1879. & 61.0 & $\ldots \ldots \ldots 53.5$ & 1907. \\
\hline $1 S 80$. & 63.5 & $1894 \ldots \ldots \ldots \ldots \ldots \ldots \ldots \ldots . \ldots \ldots . \ldots \ldots$ & $1908 \ldots \ldots \ldots$ \\
\hline
\end{tabular}

The only other mine now operating on the conglomerates is the Tamarack, opened in 1881.

\section{(OPPER MINING ON ISLE ROYAL AND ELSEWHERE.}

Isle Royal is unusually rich in interesting evidences of prehistoric copper mining. The first mining of historical record was begun soon al'ter the opening of Keweenaw Point, in 1S44, culminating in 1847 and $1 S 48$ and waning in 1855 , when the island was again withont permanent inhabitants. Another brief period of development, from 1871 to 1883 , resulted in the opening on the island of the Saginaw and Minong nines, with a combined production of less than 10,000 tons of copper. Since the nineties exploration has been going on intermittently, but without suceess. No mines are operating at the present time. The ores are essentially the same as those of Keweenaw Point. As mined they were low grade, probably less than 1 per cent. They occur principally in fissure reins in the traps.

The copper-bearing formation has been found elsewhere in the I alse Superior region, but the copper-mining industry has practically not extended beyond Koweenaw Point and Isle Royal. The southwestern extension of the Keweenaw district in Wisconsin and Minnesota is 
being extensirely explored and opened for mining, but thus far the prorluction has not been important. As the copper-prolucing area has been restricted to that of the early discoveries and as the copper-mining industry has developed evenly, it is mnecessary for our purposes to follow its listory in greater cletail.

\section{MARQUETTE IRON DISTRICT (1S4S).}

Iron was first discovered in 1844 near the site of Negaunee by the Govermment linear surveying party in charge of William $\mathrm{A}$. Burt, himself under the direction of Douglass Iloughton. The Michigan legishature having failed in 1543 to renew appropriations for the Michigan Survey, Dr. Houghton had turned to the Federal Government and hand succeeded in procuring an achlitional allowance per mile for geologic work in connection with the linear survey of the Upper Peninsula, which had alrealy been begun, and he limself took the eontract for the linear survey in order to have the clirection of the work.

In 1848 iron ore was mined by the Jackson Association (subsequently the Jackson Iron Company) and carried by team to a Catalan forge which they had constructed near Carp River. The project was not commercially successful and was closed in 1850. The Marquette Iron Company opened the Cleveland mine near the present town of Ishpeming in 1849 and carted its ore to a forge at Marquette. This also was a financial failure and was discontinued in 1854. In 1850 and again in 1852 a few tons of ore were shipped from the district to Pennsylwania for trial in Pennsylyania furnaces. The opening in 1855 of the ship canal along St. Marys River, connecting Lake IHuron and Lake Superior, was followed in 1856 by the first regular shipments of iron ore from the Harquette district to the lower lakes, amounting to 6,343 tons. Up to that time the local forges had consumed about 25,000 tons of ore. The completion in 1857 of the Iron Mountain Railway (later the Houghton, Marquette and Ontonagon Railway and ultimately the Duluth, South Shore and Atlantic Railway) between Marquette and the mines gave easy transit to the lake, and 22,576 tons were shipped in 1858 and five times that amount in 1860 .

From 1855 to 1862 transportation facilities rere so far improved as to make it possible to get ore out, but the mines had not yet been really brought into relation with the iron market. Therefore the companies met with no real success whether they tried to make iron themselves or to send their ore down to the furnaces of Ohio and Pennsylvania. The Lehigh Valley, and not Pittsburg, was still the iron center of the United States. The war suddenly changed the whole ontlook. A great demand spraug up for all kinds of iron goods, and both mining and iron making on the Upper Peninsula received a strong impetus. Shipments increased from 49,000 tons in 1861 to five times that amount in 1864, while the companies made fabulous profits. * * The year 1865 marked a slight retrogression, but the eight years following saw a wonderful growth, the boom in iron and steel reflecting the rapid industrial development of the country, and from 1870 to 1873 registering its speculative excitement. * * * In 1863 but three mines shipped ore; in 1864, five; in 1865, seven; in 1866, nine; 1868 added four more mines, 1870 three more, while in 1872 the table of shipments increases the total number of mines by 11 to 29, and in 1873 no less than 40 are representer. The total shipments of 1866 were just below 300,000 tons; those of 1873 almost exactly four times that amount. ${ }^{a}$

The opening of the Republic, Michigamme, and Spurr mines in 1872 practically completed the area of the Harquette district as known at present; though a few discoveries of importance lave been made within the area since that time. Exploration is still vigorous. The field for deep exploration opened by recent discoveries is a large one.

The necessary increase in means of shipment was made by the building of the Chicago and Northwestern Railway from Negaunee to Escanaba and by increase in the capacity of the docks already built at Mirquette. As a result of the panie of $1873-$

development work ceased, production fell off almost 25 per cent in 1874 and yet further in 1875 , and the number of mines reporting shipments declined from 40 in 1873 to 33 in 1874 and to 29 in 1875 . The working force of those that continued operations was largely reduced, and only five mines showed a larger ontput in 18.4 than in 1873.0

a Musspy, 11. R., Combination In the mining industry: Studies in history, economics, and public law, Columbla Unir., rol. 23, No. 3,1905 , pp. $55,57,59$.

6 Idern, p. 73. 
Returning prosperity brought an increase in shipments of 80 per cent between 1878 and 1882, and the number of producing mines increased from $29 \mathrm{in} 1875$ and 1877 to 48 in 1882 . The following year saw a considerable depression because of overproduction, but thenceforth the production showed a general increase until 1891, witl a minor depression in 1885 . The years 1891 and 1893 saw another falling off in production, the latter contemporaneous with the general panic of 1893 . From that time to the present there has been a general increase in production, with slight recessions in 1904 and 1906. The Lake Superior and Islppeming Railway was constructed in 1896 to carry the ores of the Cleveland-Cliffs Iron Company from the Ishpeming district to Lake Superior.

The table of production of iron ore from the Narquette range (pp. 51-60) summarizes the development of the district.

The Swanzy district, southeast of the Marquette district proper, is reached by the Chicago and Northwestern Railway; its production is usually credited to the Marquette district. The district was first explored in 1869, and the Smith (later the Cheshire and Princeton) mine was opened in 1871. Systematic exploration by drilling, begun in 1902 by the Cleveland-Clifts Company, greatly extended the ore reserves and determined the probable limits of the district. A largely increased production may be looked for.

\section{MENOMINEE IRON DISTRICT (1872).}

The Harquette district had been the sole producer of iron ore in the Lake Superior region for nearly thirty years when its first competitor, the Menominee district, entered the field.

The first practical discovery of iron ore in Menominee County was made by the brothers Thomas and Bartley Breen some time previons to 1867 , though the veteran explorer S. C. Smith claims to have been and probalsly was aware of its existence in that section as early as 1555, in which year le traversed what he called a new range, south and east from Lake Michigamme to Escanaba, locating what is now the estate of the Republic Iron Company on the way. The first practical work in the way of development was done by N. P. Hulst for the llilwaukee Iron Company at the Breen and Vulcan mines in 1572, and by John 1. Buell at the Quinnesee the following year. ${ }^{a}$

The existence of ore in shipping quantity had been demonstrated in 1874, but the distance of the district from the Grent Lakes and the lack of facilities for shipment prevented its further development until the extension of the Menominee branch of the Chicago and Northwestern Railroad from Escanaba to Quinnesec. This was carried through to Iron Mountain in 1880, and thence northwest to Iron River and the Gogebic range. The Chicago, Miwwaukee and St. Paul Railway entered the district in 1886 and the Wisconsin and Michigan Railway in 1903 . When shipment had once started it increased much more rapidly than that of the Marquette district. The first year's output of 10,405 tons jumped to 95,221 tons the following year, to 269,609 tons the third year, and to 592,086 tons the fourth year, and reached the million mark in 1882 . In 1901, 1902, and 1903 the Nenommee surpassed the Marquette range in shipment, but for the most part in later years it has been producing about the same amount yearly as the Marquette district. Its total shipment to the end of 1909 is $71,212,121$ tons as compared with a total of $91,838,558$ tons from the Marquette district. The table (pp. 61-65) includes shipments from the outlying Florence, Iron River, and Crystal Falls districts to the northwest.

\section{CRISTAL FALLS, FLORENCE, AND IRON RIVER IRON DISTRICTS (1880).}

The Crystal Falls, Florence, and Iron River districts may be regarded as northwesterly outliers of the Nenominee range, and they are included in it in tables of production.

For a number of years after the opening of the Menominee range prospectors worked in various places, among others in the vicinity of Crystal Falls, seeking to follow the iron range west of the Menominee River. As a result of this endeavor, the deposits at Florence, Wis., and then those farther north and west at Crystal Falls, Mich., were in turn located. It was not until 1881 that sufficient exploratory work had been done at Crystal Falls to warrant a belief in the future of this iron-bearing area. In April, 1882, the Chicago and Northwestern Railway completed

a Swineford, A. P., Annual review of the iron mining and other ind ustries of the Upper Peninsula for the sear ending December 31, 1881; Marquette, 1882, p. 119. 
its branch to 'rystal Falls, and the shipment of ore hegan. The Amasa deposits were not exploited to any great exient until the year $18 s$, when the chicago and Northwestern Railway luilt a branch from crystal l'alls to Amasa. The ('hicago, Mihwaukee and St. Paul lailway in 1893 completed a line from Channing to Sidnaw, which runs through A masa.$^{a}$

These distriets have as a whole developed slowly as compared with the other principal iron districts of the Lake Superior country, partly because of the slightly lower grade of many of the ore bodies and partly beeause of the lack of exposure, making exploration diflicult and costly. Consequently large areas remain to be tested underground. The increasing demand for iron ore of the lower grades las brought about a revival of exploration in this area during the last lew years. This is one of the most promising felds of exploration yet remaining in the Lake Superior region, and the next few years are likely to see Iarge developments.

\section{GOGEBIC' IRON DISTRICT (18S4).}

The Gogebic range of Michigan and its extension, the Penokee range of Wisconsin, sometimes referred to together as the Penokee-Gogebic district, were long known to explorers and had been mapped by the geologists of the Michigan and Wisconsin surveys priol to their opening in 18st. The first reeorded notice of their disenvery appears on the plats of the township surveys. It is remarkable that subsequent discoveries have been restricted to the areas first determined by the geologic mapping. Early exploration was largely confined to the wellexposed magnetic portions of the formation at the west end of the range, which have been less productive than the central, less well exposed portions of the iron-bearing formation. In $188+$ the first shipment of 1,022 tons was made from the Colby mine to Marquette. In the following year the shipment reached 119,860 tons, owing to good transportation facilities and to the remarkable speculation which in $18 S 6$ and 1857 led to the formation of mining companies in this district with a nominal capital exceeting $\$ 1,000,000,000$. The ineritable collapse in the fall of 1857 took the savings of smaller investors and many mines were closed down, but the stronger companies weathered the storm and in spite of the speculative failure the production of ore steadily increased until 1890, when for a period of several years the shipments reflected the depressol and unstable conditions which aflected the Lake Superior region as a whole. In the autumn of 1855 the Milwaukee, Lake Shore and Western Railway (subsequently part of the Chicago and Northwestern) was finished from the mines to Ashiland.

The Wisconsin Central Railway crossed the range at Penokee Gap in 1S73, conneeting with Asliland, and in $18 S 7$ extended a branch to the center of the district. 'The Duluth, Soutl Shore and Atlantic Railway alreaty paralleled the range on the north at the time of its discovery and afforded easy connection with the lake.

\section{YERMILION IRON DISTRICT (1885).}

J. M. Clements describes the opening of the Vermilion district, in Mimesota, as follows: ${ }^{b}$

The first mention of the occurrence of iron ore in the Yermilion district was made ly. J. G. Norwood, who observed it during his explorations in 1850 and published a statement concerning it in the report accompanying that of 1 ). $D$. Owen.c The iron he olserved is that which occurs near Gunfint Lake, at the extreme east end of Ihe distric1, and whirh geologically belongs with the ores of the Mesabi range. In this part of the Vermilion clistrict the ores have never been exploited to any extent and are at present of fittle commercial importance.

Interest in what is now known as the Termilion iron-bearing district was aroused in the sixties by the reported occurrence of gold in the vicinity of Vermilion Jake. There was considerable excitement for several years and a small rush to the district. Shafts were sunk and stamp mills were ereeted, the machinery having been packed in fron Duluth over the Vermilion trail. A town site was laid out near Pike River, at the southwest extremity of lermilion lake, and some buildings were ererted. In all a good deal of money was fruitlessly expended, as nuguld deposits of any importance were found.

a Clements, J. M., and Smyth, 11. 1., The Crystal Falls iron-bearing district of Michigan: Mon. [Z. \&. Geol. survey, vol. 36, 1s99, p. 175.

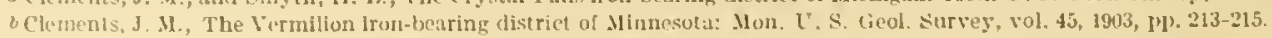

c.t report of the geological survey of $w^{2}$ isconsin, lowa, and Minnesota, 1.52, p. 417. 
Some time after this, in 1875 , the first exploration for iron ore in this district was taken mp by Mr. George R. Stuntz, accompanied by Mr. John Mallman, who began to prospect the iron furmation and iron ore exposed on Lee Hill, sonthwest of the Bay of Vermilion lake, which is now known as Stuntz Bay, named after Mr. Stuntz. The ore deposits on Soudan Hill were then discovered. In 1880 Prof. A. Il. Chester examined the Vermilion Lake iron formation for private parties and Mr. bialey Willis studied it for the Census Office. Systematic and extensive efforts were made in the late seventies and the early eighties to develop the iron ores. By this time the Minnesota lron Company had leen organized and all of the properties which at that time were known to contain ore and great stretries of country which were in the continuation of the ore range had been purchased, the company owning over 20 , acres of land on the Vermilion range proper and in the vicinity of the good harbor on Lake Superior known now as Two Harbors. On August 1, 1884, the Duluth and 1ron Range Railroad was completed from Two Harbors to Tower, near Vermilion Lake. This road was 72 miles long. At a later date it was connecterl with Duluth, 25 miles away. Wuring the first year (1884) 62,124 tons of ore were shipped, some of this haring come from the stock piles which had been growing during the years of development preceding the opening of the railroad.

Prospectors were busy in the years prior to the opening of the railroad in prospecting the district to the east of Tower, and in 1883 outerops of ore were found by Mr. II. R. Ilarvey in ser. 27, T. 63 N., R. 12 IT., near the present town of Ely. The body of iron ore indicated by these outcrops was further tested in 1885-6 and led to the opening up of the great deposits at Ely on which are now working the Chandler, Pioneer, Zenith, Sibley, and Savoy mines. During 1885 there were shipped from the Chandler mine 54,612 tons of high-grade ore.

. From this time on the development of the range was rapid and steady, as is shown by the annual increase in the shipments of ore.

The Vermilion range was thus opened at about the same time as the Gogebic range, but its mines, in contrast to those of the Gogebic, were from the start in the hands of a strong company, which controlled the railroad and prevented active competition. To quote from Mussey:

A comparison of the output of the two ranges by years discloses an interesting contrast between centralized control backed by adequate capital in the Termilion district and competitive exploitation based on small nndertakings and insufficient funds in the Gogelic district. The Gogebic district, which was not really opened up till 18s5, in the second year following produced more than a million tons; the Termilion, though opened a year earlier, did not reach the million mark till 1892, when the Gogebic protuced almost three millions, only to fall off to less than half that amount the next year. Prodnction on the Gogebie moves upward by leaps and starts, one season rising to excess, the next sinking back to defieieney; the output of the Vermilion, on the other hand, climhs with a regularity that is surprising, when one considers the variable conditions of the market in which it liad to be sold. ${ }^{a}$

\section{MESABI IRON DISTRICT (1S91).}

\section{ACCOUN'TS OF' TIIE DISTRICT BEFORE I'TS OPENING.}

In penetrating the vast wilderness north and west of the Great Lakes country, the early explorers were compelled for the most part to stick close to the waterways, for the nature of the country made travel for long distances exceedingly arduous by any other method than eanoeing. Three of the canoe routes to the country northwest of Lake Superior cross the Giants or Mesabi Range ${ }^{b}$ and its eastward continuation. Mississippi River and its tributaries, Prairie and Swan rivers, touch the western portion of the district. Embarrass Lake, tributary to St. Louis River, and thence to Lake Superior and the St. Lawrence, crosses the Giants Range near its east-central portion. Gunflint Lake, one of a chain of lakes tributary to Rainy River and Nelson River and thence to Hudson Bay, lies far to the east, on a continuation of what is now known as the Mesabi district. Hence the first published references to the Mesabi district concern the parts of the district immediately adjacent to these eanoe routes. Brief deseriptions of Pokegama Falls on Mississippi River and of adjacent areas were made by Z. M. Pike in 1810 , by James Allen and IIenry R. Schoolcraft in 1S32, and by J. N. Nicollet in 1841 . In 1841 also Nicollet published his nup of the hydrographic basin of the upper Mississippi, on which the Giants or Mesabi Range, called "Missabay Heights," was for the first time delinented,

a Mussey, H. R., Combination in the mining industry: Studies in history, economics, and public law, Columbia Unir., vol. 23, No. 3 , pp. 30-91.

o The name "Mesahi" has heen variously spelled and applied with various limits to the ridges of this district, and the usc of the same term to denote the iron-lyearing district as such has added to the confusion. The spelling "Mesahi" has heen aclopted by the Lnited States feographic Board. It has hecome usual, for the sake of clearness, to speak of the main topographic feature as the Giants Range. In this report the terms are definitely distinguished, Mesabi range being applied only' to the iron-bearing district that ocetupies a linear lielt of low sloping land at the base of the Giants Range. 
by hachures, although very imperfectly. In $1852 \mathrm{~J}$. G. Norwood reported the occurrence of iron-bearing rocks at Gunflint Lake and mentioned granite and gneiss seen in crossing the range at Embarrass Lake. In 1866 Charles Whittlesey reported on explorations macte in northern Minnesota during the years 1848, 1859, and 1864. He mentioned Pokegama Falls and made vague roference to the granitic rocks of the range. "Mesabi Range" was used in an indefinite way to cover what are now known as the Giants and Vermilion ranges. In 1866, also, Honry H. Eames, the first state geologist of Ninnesota, reported granite and gneiss seen on a trip across the range at Embirrass Lake. In describing the ranges of the northern part of thes State, inchuding the "Missabi Wasju," he stated that they appear to be traversed by metalbearing veins. Presumably, however, this statement refers mainly to the Vermilion range. In a second report, published the same year, Mr. Eames is more explicit, and, referring to the general elevated area of the northern part of the State, including the Giants Range, states: "In this region are found also immense borlies of the ores of iron, both magnetic and hematitic, occurring in dikes and associated with the rock in which it is found; in some of these formations iron enters so largely into its composition as to affect the magnetic needle." Pokegama Falls and Prairie River Falls were visited, and at the lat ter place the presence of "iron ore "was noted. These reports of Eames contain the first references to iron ore in the Mesabi district proper, although iron-bearing rocks had been noted by Norwood in 1852 at Gunflint Lake.

From this time on desultory exploration work was done in certain portions of the district. It was confined for the most part to the area west of Birch Lake, in Rs. 12, 13, and $14 \mathrm{~W}$., and to the vieinity of Prairie River. No published accounts of the earlier portion of this exploratory work are to be found.

The first examination of the Giants Range by a mining expert with particular reference to the occurrence of iron ore in workable deposits, noted in print, was made in 1875 by A. II. Chester, of Hamilton College, New York. Reaching the Giants Range at Embarrass Lake, he worked eastward toward Birch Lake. In his report (published in 18st) he ealled at tention to the magnetic character of the iron in this area and to the fact that the alternating iron layers are not thick or continuous. The percentage 44.68 was given as a fair average of iron in the rocks of this part of the district. In general, one gathers the impression that he was not favorably impressed with the economic prospects of this area. Between the time of Chester's examination of the range, in 1875 , and the publication of his report, in $1884, \mathrm{~N}$. H. Winchell, state geologist of Minnesota, briefly noticed the Mesabi district in two of his reports. In 1879 he told of the occurrence of iron ore in R. 14 W. and published analyses. In 1851 he told of a trip from Embarrass Lake east to range 14 and noted the magnetic character of the iron-bearing formation in range 14, as well as its similarity to the formation at Gunflint Lake. Indeed, the iron-bearing formation in range 14 was called the "Gunflint beds." In 1883 Irring called the iron-bearing roek series in the Mesabi district Animikie, a term which had been applied to similar rocks at Thunder Bay and westward to Gunflint Lake, and correlated the Animikie rocks with the original Huronian rocks of the north shore of Lake Huron and with the iron-bearing formation and associated rocks of the Penokee-Gogebic iron range of Michigan and Wisconsin. From this time on the term Animikie is much used in the literature on the Mesabi range to designate the iron-bearing formation and associated rocks. In 1SS4, in the same volume in which Chester's report was published, $\mathrm{N}$. H. Winchell discussed the age of the Mesabi rocks, assigning them to the "Taconic," then regarded as Lower Cambrian, and, following Irving, correlated them with the iron-bearing rocks of the Penokee-Gogebic district. In the late eighties a number of other reports on the district were issued by the Minnesota Survey, but they contain no important points not noted in reports above cited. This brings us to the opening of the district for mining.

\section{OPENING AND DEVELOPMENT.}

Since the late sixties there had been more or less exploration, particularly along the eastern portion of the district, from Embarriss Lake to Birch Lake, and the presence of iron-bearing rocks had been recognized and discussed in the reports mentioned above. However, not a single 
deposit of iron ore of such size and character as to warrant mining harl been revealed. In fact, the range had been "turnerl down" by many mining men who harl examined it. This was largely because of the fact that they confined their attention principally to the eastern, nagnetic end of the range, where exposures of the iron-bearing formation are numerous. Even up to the present time no ore has been found there in quantity. Yet the impression was gradually developing that iron ore in large quantity was to be found in this district, and a few prospectors were working diligently.

Among the more persistent of the Mesabi range explorers were the Merritts-Lon Merritt, Alfred Merritt, L. J. Merritt, C. C. Merritt, T. B. Merritt, A. R. Merritt, J. E. Merritt, and W. J. Merritt — of Duluth, Minn. 'Their faith in the range was the first to be rewarded. On November 16,1590 , one of their test-pit crews, in charge of J. A. Nichols, of Duluth, struck iron ore in the NW. ${ }_{4}^{1}$ sec. 3, T. 58 N., R. 18 W., just north of what is now known as the Mountain Iron mine. This was followed in 1891 by the cliseovery of ore in the area now covered by the Biwabik and Cincinnati mines. John MIcCaskill, an explorer, observed iron ore clinging to the roots of an upturned tree on what is now the Biwabik property. Test pitting by the Merritts, in charge of W. J. Merritt, led to the discovery of the Biwabik in August, 1S91. The Cincinnati mine was opened the same fall. The Hale, Kanawha, and Canton mines were opened in the spring of 1892 .

The discovery of ore near the sites of the present towns of Virginia, Eveleth, McKinley, and Hibbing followed in rapid succession. The excitement following the first discovery of ore at Mountain Iron was greatly angmented by each succeding find, and in 1891 and 1892 there was the inevitable rush of explorer's.

Up to October, 1892, there were two railways touching the range-the Duluth and Iron Range, crossing the range at Mlesaba station on its way to the Vermilion range, and the old Duluth and Winnipeg (now the Great Northern), reaching the range at Grand Rapids. Both these places were far removed from the exploring centers. Most of the explorers went through Mesaba station. Reaching this place by rail, they were compelled to truvel 12 to 50 miles to the west along "tote roads" which were all but impassable. The time, money, and energy needed to conduct even modest explorations at this time can be appreciated only by those who have experienced the difficulties of inland travel in the Lake Superior region away from railways. The stories of this "toting" period contain the usual records of misfortunes, lucky strikes, and enterprise incidental to a mining boom.

The railways were not long in getting into the field. In October, 1592, two lines were put in operation. The Duluth, Missabe and Northern Railway was built to comect the Mountain Iron mine with the old Duluth and Winnipeg Railway (now the Eastern Railway of Minnesota, a part of the Great Northern system) at Stony Brook Junction, and later was extended to Duhuth. Alnost immediately after the connection with Mountain Iron a branch was sent out to Biwabik. About the same tine the Duluth and Iron Range Railroad sent out a branch from its main line to the group of mines at Biwabik. Very soon thereafter both railways got into Virginia. Hibbing was reacherl by the Duhth, Missabe and Northern in 1893 . Eveleth was reached by the Duluth and Iron Range in 1894 and by the Duhuth, Missabe and Northern very soon thereafter. The Mississippi and Northern (Eastern Railway of Minnesota) about the same time projected a spur from Swan River to the Ilibbing district.

With the advent of railways the development of the range went on by leaps and bounds. This marvelous development has continued to the present time. The only considerable check oceurred during the period of general financial depression which the country underwent in 1894, 1895, and 1896. Almost an untouched wildemess in 1890, the distriet is to-day the greatest producer of iron ore in the world. The rapidity of the development of the mining industry of the district, carrying with it all the prosperity of the range, can not be better told than by the table of shipments from the district (pp. 65-68).

The development of the Mesabi range eastward toward the magnetic portions of the ironbearing formation has been less satisfactory than that to the west. A small amount of ore 
was opened up at the Suring mine, formerly the site of the Mallman mine, leading to the construction of a spur raitway, and minor discoveries not yet exploited liave been reportenl foum places fartler east. Atso certain ore deposits have been developed in the vicinity of the town of Mesaba, near the Jron Range Railway track. The last-1named deposits mark about the eastem linit of the principal mining operntions.

The most notewortly developments of the district in late years have been the exploration and cxploitation of the ores in the western part of the district, which, because of their content of hosc quartz grains, giving then the name "sandy taconite," were long regarelel as worthless. As a result of claborate experinents in washing tests it was found possible to utilize these ores. and mining operations are now being conclucted and planned on an enormous scale. Since 1900 sereral towns have spung up in what was before a wiklerness. The town of Coleraine, built by fiat of the Oliver Iron Mining ('ompany, is an example of what may be aceomplished in a short time by large capital intelligently expended by a single group of individuals working on a uniform plan. The railways have followed up and made possible much of the development of the western Mlesabi district. It is reached by spurs from both the Duluth, Missabe and Northern and the Creat Northern raitways, leaving the main lines soutl of Ilibbing.

Still more recent has been the extension of the district by exploration for 12 miles or more west of Pokegama Iake, near Mississippi River. The ores have been found to be lean but probably merchantable. The iron-bearing formation pinches out at the southwest end of the clistrict, the overlying slate coming into contact with the underlying quartzite. This part of the district, together with magnetic belts farther west, particularly the one ruming through Leech Lake, the east end of which comes within 12 miles of the Mesabi distriet, affords interesting possibilities for exploration, which will be adequately undertaken.

\section{CUYUNA IRON DISTRICT (1903).}

The development of the Cuyuna, the newest of the Lake Superior iron districts, in the same geologic group as the Mesali district, is unique in a way. The other iron ranges of the Lake Superior region were all diseovered though more or less conspicuous surface indications of ore bodies. Outcrops of the ore or of iron-bearing rocks existed. There are no rock outcrops in the Cuyma district, the drift mant le being 80 to 350 feet thick, and the first discovery of magnetic iron-bearing rocks in this region was made with the dip needle by Cuyler Adams. about 1895 .

The dip needle was the sole factor used in the subsequent tracing of the ore formations by Cuyler Adams and afterward ly others, preparatory to drilling, from the time of the first discovery of magnetic iron-bearing formations until 1907 , when more or less indiseriminate drilling hegan.

The first drilling was done in 1903 at a point just south of Deerwood, Minn., hy Cuyler Arlams, and has continued in greatly increasing amount to the present time, some 2,000 drill holes and two shafts having been put down, resulting in the discovery of a number of ore deposits. (See Pp. 216-219.) The distribution of the ore bodies and the linits of the district are yet very imperfectly known.

Extension of magnetic surveys to the west and north have shown isolated magnetic belts at several places, some of them beyond the westem boundary of Minnesota. The distribution of some of these belts is shown on the general map. Underground exploration of these helts has just begun. The nexf few years will see rapic exploration of the Cuyuma range and the country to the north and west.

For some time before the drilling began, geologists had suspected the existence of ironbearing formation in the Cuyma clistrict. The general geologic map of Mimesota, published by the Minnesota Geological and Natural History survey in 1901, showed this area as occupied by a southwestern extension of the slites and quart zites of the Mesalbi distriet. In 1903 C. K. Leith published a sketch showing the hypothetical extension to the southwest of the iron- 
bearing formation of the Mesabi listrict through the since discovered cuyuna district. I similar view of the geologie possibilities was held by W. N. Merrim, geologist for the United States Steel Corporation.

The Northern Pacific Railway extends throughout the length of the Cuyuna district and affords easy access to the ores. It also rums near some of the magnetic belts west and northwest of the Cuyuna district. The Minneapolis, St. Paul and Sault Ste. Marie Railway passes the district on the southeast and in 1910 completel a spur into the district. For both railways the lake port will be Superior.

\section{BARABOO IRON DISTRICT (1903).}

The liscovery of ore in the outlying and relatively small Baraboo district, in Wiseonsin, was not made until 1903. The quartzite ranges here conspicuously exposed had long been recognized as Huronian, and suggestion had been made that iron-bearing rocks might be assoeiated with them. In fact, for several years the Chicago and Northwestern Railway lad quarried small amounts of paint rock within a few feet of what is now known as the llinois mine. Because of the covering of Cambrian sandstone and glacial deposits the ore deposits themsclves escaped detection until drilling was, in 1900, begun by W. G. La Rue in the vicinity of the Illinois mine near North Freedom. Since that time, as a result of almost uninterrupted exploration, ore deposits have been found at various places in the Baraboo syncline. Only three shafts have been sunk and ore has been shipped from only one, the Illinois mine. The derelopment of the district has not been rapid because of the relatively low grade of ore, the considerable cost of mining, and the great expense of deep drilling, although these factors have been partly of'set by lower freight rates to Chicago. Both mining and exploration in the Baraboo distriet are in their infancy.

\section{LESS IMPORTANT DENELOPMIENTS.}

\section{CLINTON IRON ORES OF DODGE COUNTY, WIS. (I849).}

There is no record of the first liscovery of the Clinton iron ores in Dodge County, Wis., for they are exposed at the surfare in accessible country. Ore was first mined from them in 1849. The ores have been partly used in local charcoal furnaces at Inyville and Iron Ridge and partly shipped to Milwaukee, Chicago, and adjacent points. Because of their low percentage of iron, ligh phosphorus, and moderate quantity, they have not figured largely in Lake Superior production.

\section{PALEOZOIC IRON ORES IN WESTERN WISCONSIN (185T).}

Small hematite deposits seattered through the driftless portion of the Cambrian sandstone area north of Wisconsin River, in Wisconsin, were opened up about the time of the discovery of the Marquette district. In 1857 a charcoal furnace was built at Ironton, in Sauk County, to use these ores. Another was built at C'azenovia, in Richland County, in 1876, and torn down in 1879. None of these ores has been mined since 1850. Records of production are not arailable, but before 1873 alyout 25,000 tons of ore was mined from these deposits.

Farther north, at Spring Valley, in Pierce County, Wis, brown-ore deposits associated with Orlovician limestone were opened about 1890, and a chareoal furnace was built to use these ores in 1893. At a later period coke supplanted charcoal as a fuel.

\section{IRON ORES OF TIIE NORTII SHORE OF LAKE SUPERIOR (1900).}

Since the opening of the Lake Superior region for mining the nerth shore has been more or less explored and a considerable number of iron-bearing belts have been located in the territory extending from the Lake of the Woods beyond Michipicoten. Only three ore bodies have been found. The best known of these is the Helen ore body, which was discovered in 1897 in the 
Michipicoten district, on the northeast side of Lake Superior. This district was connected with Lake Superior by the builling ol the Algoma Central and IIudson Bay Railway (12 miles) in 1899 and beenan shipment, in 1900 .

Discovery of the Ifelen mine led to rather vigorous exploration in the many known ironbearing belts in the immelintely adjacent territory, in some places by drilling, but without conspicuous success. A small body of ore was found at the Josephine mine, a few miles northeast of the Holen mine.

The Atikokan ore deposit was discovered in 1859 , was explored by tumel and drilling in 1 S!S and 1s99, and became acessible for mining when the Canadian Forthern Railway passed it in 1901. Utilization ol' the ore has been restricted by its high sulphur content. A furnace has been constructod at Port Arthur on Lake Superior for the purpose of utilizing this ore, but thus far lithe has been actually mined and smelted.

At Steep Rock Lake a small body of ore was discovered in 1901 by the Oliver Iron Mining Company. To ore has yet been mined.

The presence of an iron-bearing formation in the Animikie group in the ricinity of Port Arthur and at points lying east and west of that place for several miles was noted by the earliest visitors to this region. I considerable amount of more or less desultory exploration has shown that the formation as a whole is lean and unmarketable. At Loon Lake, about 25 miles cast of Port Arthur, vigorous explorations begun in 1901-2 disclosed a few thin lajers of lean ore of considerable horizontal extent, which may be mined in the future.

In general the results of exploration for iron ore on the north shore of Lake Superior have been disappointing. The returns have not been proportionatcly so large for money expended as they have been on the south shore, partly owing to the fact that the iron-bearing formations are mainly of the lieewatin series, which on the south shore are found to have smaller quantities of iron ore than those of the upper Huronian (Animikic group). On the other hand, exploration has been slight refative to the extent of the known iron-bearing formation and the larre and not easily accessible areas open for exploration; moreover, the exploration has been largely confmed to the surfare. Future exploration and mining in this territory will be greater than that which has already been done.

\section{SILVER MINING ON THE NORTII SHORE OF LAKE SUPERIOR (1868).}

One of the interesting incilents in the development of the Lake Superior region was the discovery in 1868 of silver ore on Silver Islet, near Thunder Cape, on the northwest "oast of Lake Superior. Before the miue closed in 1884 it had yielded about $\$ 3,250,000$ worth of silver. The island is so small that it was necessary to inclose parts of the rein by a coflertam to prevent the inflow of the lake.

This development was lollowed by active exploration of a number of silver reins in the Animikie group to the west. The principal mines were the Shumiah, Rabbit Mountain, and Silver Mountain groups, which have yielded approximately $\$ 1, \$ 85,000$ worth of silver, but which are not now active.

\section{LAKE SUPERIOR GOLD MINING (1882).}

Still another less important phase of mining development in the Lake Superior region has been the production of small quantities of gold. Between 1852 and 1897 the Ropes gold mine in the Marquette district of Michigan produced about $\$ 650,000$ worth of gold. On the Ontario side of the lake approximately $\$ 2,250,000$ worth of gold has been mined, principally in the Rainy Lake district, which was opened in the early nineties and reached its greatest development in 1899. At present the production of gold in the Lake Superior region is practically nil, but exploration continues active, and from time to time considerable sums are spent in opening up mines and building mills on low-grade gold deposits. 


\section{GENERAI, REMARKS.}

\section{INDUSTRIAL, CHANGES.}

The foregoing chronologic account of the opening of the Lake Superior mining inclustry gives no adequate idea of the magnitule and diffieulty of the work and the forces involved. The bare statement that a listrict "lad been known to explorers for many years prior to its opening" but poorly expresses the persistent liunt of many explorers for many years at the expense of money and bodily fatigne through a wilderness diflicult to reach and superlatively difficult to penetrate and explore. Since the opening of the first mine in the region there has been no time in which such men have not been vigorously prosecuting the search. Surface exploration has been followed in favorable localities by test pitting and drilling at enormous expense. In the Vermilion district $\$ 2,000,000$ is probahly a conservative estimate of the amount spent in exploration with the drill, much the largest proportion of it entirely without success. In the Mesahi district 30,000 test pits and drill holes have been sunk in exploration of the range. The total expenditure on preliminary underground exploration in the Lake Superior region is probably not less than $\$ 22,000,000$. (See p. 485.)

Since the advent of large capital into the region exploration has been systematized and now often includes, as a preliminary or accompanying step, the complete geologic, topographic, and magnetic mapping of the areas to be explored.

The early development of the Lake Suparior iron mining district, from the opening of the Marquette range to 1873 , wis for the most part accomplished by small companies and small capital. The period from 1573 to 1592 was marked by the presence of larger companies with moderate capital; and since 1892 mines have been operated by strong companies with large capital. This increase in capital has been accompanied by combination of the mining companies.

At present cousiderably more than half of the Lake Superior iron-ore reserve is controlled by the Oliver Iron Mining Company, the mining branch of the United States Steel Corporation. The Minnesota tax commission's report for 1908 redits the Oliver Company with 76.6 per cent of the reserve of iron ore for Minnesota ${ }^{a}$ It is not clear that the company's dominance in Michigan is so great as this, but in view of the fact that the Minnesota reserve is so far in excess of that in Michigan it is not likely that the Olirer Company's perentage of the Lake Superior reserve is far short of that given for Mimnesota.

\section{SMELTING.}

The Lake Superior iron mines were opened at the time when anthracite and coke first began to be largely used in the smelting of iron. Before that time the fuel used in local furnaces was largely charcoal. Charcoal was surpassed in amount by anthracite in 1855 and by coke in 1869. More anthracite than coke was used until 1875 , but since then coke has gradually but almost completely replaced anthracite for smelting. The use of antiracite and coke made possible both a large increase and a centralization in pig-iron production, and the growth of the Lake Superior iron-mining industry is practically concurrent with the increased use of these substances instead of charcoal. Since the opening of the Lake Superior region much the larger part of its output has been used in coke and anthracite furnaces of the lower lake region.

The smelting of iron ore within the Lake Superior region itself has been thus far on a relatively small but still considerable seale. Detailed figures are not arailable, but it is roughly estimated that about 3 per cent of the total production has been locally smelted. Several small forges were built in the Marquette clistrict of Mlichigan in the decade before the first shipment was marle to the lower Lakes. Since then about 25 charcoal furnaces, most of them now abanloned, have been built in the Upper Peninsula of Michigan, also one at Ashland, Wis., and several in the northern part of the Lower Peninsula of Michigan, using almost entirely Lake Superior ores.

a First biennial report of the Minnesota tax commission to the governor and legislature of the State of Minnesota, St. Paul, 1908 , p. 122. 
In addition several small furnaces in Wisconsin, built principally for the use of local ores, have used small anounts of Lake Superior ores. Coke furnaces have been established at Duluth, Minn., and at Sault ste. Maric, ()ntario, and several of the eharcoal furmaces, on areount of the dephtion of the chareal supply and the increase in the arailibility of cokc, have substituted coke as luel. Milwatuke, (hingo, Detroit, and adjacent points have of course becu lange users of imu wre in coke furnares, lut these lake ports are outsite of the region. In 190 a $^{2}$ there were in ojeration a coke lurnace at Duluth, Minn., three in Wisconsin outside of Milwauker, five challcoal furnaces in the Upper Peninsula of Mirhigan, there furnaces in the northern part of the lower Poninsula of Michigan, and the steel plant at Sault Ste. Marie, Ontario. The largest plant yet projected for the local use of iron is to be built for steel making in West Duluth by the Cnited States Steel Corporation; it may be in operation in 1912.

In recent youss there has been an attempt to reeover ly-products from the charcoal burned, the first notable project being the Clereland-Cliffs furnace at Presque Isle, in the Marquette district. This plant is most elalorately equipped for the recovery, as by-products, of woor! alcohol and creosote. The Lake Superior Iron and Chenical Company, at Ashland, Wis., also has a well-equipped by-product plant. The Zenith furnace at Duluth has been rebuitt on a large scale to recover by-products from coke. At present it is supplying gas to the city of Duluth. The steel plant now planned at Duluth by the United States Steel Corporation will utilize the gases as fuel.

With increase of population directly tributary to the Great Lakes it is very likely that the local smelting of the ores will increase. The depletion of the timber will probably compel increased use of coke instead of charcoal. Peat, which is found locally in large quantities, may be considered as a possible fuel for the future.

\section{INFLUENCE OF PIYSIOGRAPHY ON INDUSTRIAL DEVELOPMENT.}

One of the prineipal relations between the physiography and history of the industrial Lake Superior region seems sufficientiy distinet to be summarized in a few words. The early stages of development were closely controlled by conditions of accessibility. The early explorers, traders, and prospectors were confined to the lake and river shores and to country easily accessible from them. When mining and lumbering began there was also a distinet localization of these industries in accessible places. With the growth of the industry and the introduction of railways the influence of plysiograply on the local distribution of activity gradually became less markerl, until at present this distribution is but little alfeeted by the configuration of the surface and drainage. The situation of ore deposits has of course localized the mining development. Favorable conditions of access, though arlvantage has been taken of them, have been subordinate factors. An iron deposit would be utilized whether it was in a swanp or on a mountain, whether easily accessible or not. In other words, increased demand for the raw materials of the Lake Superior region, due to general commercial conditions and the westward movement and increase of population, has gradually overridlen and more or less obliterated the natural plysiugraphic channels of development.

The relation of the Great Lakes to cheapness of water transportation and of the simple topography of the region to ease of railway construction to any mincral-producing district continues to be an important physiographic influence and one that is unusual in a mining district.

a Map of thy [ nitod States showing location of hlast furnaces in 1905, compiled by W. T. Thom from swank's Iron and sted works allnetory for

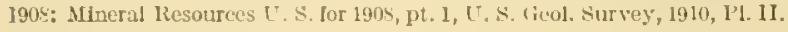




\section{PRODUCTION OF IRON ORE.}

The production of iron ore from the several producing ranges of the Take Superior region since their opening is given in the following table, compiled principally from the Iron Trade Review. The figures refer mainly to shipments rather than to production. The figures of the United States Geological Survey do not go back far enough for the purposes of this table. The facts of the table are graphically expressed in figure 3 .

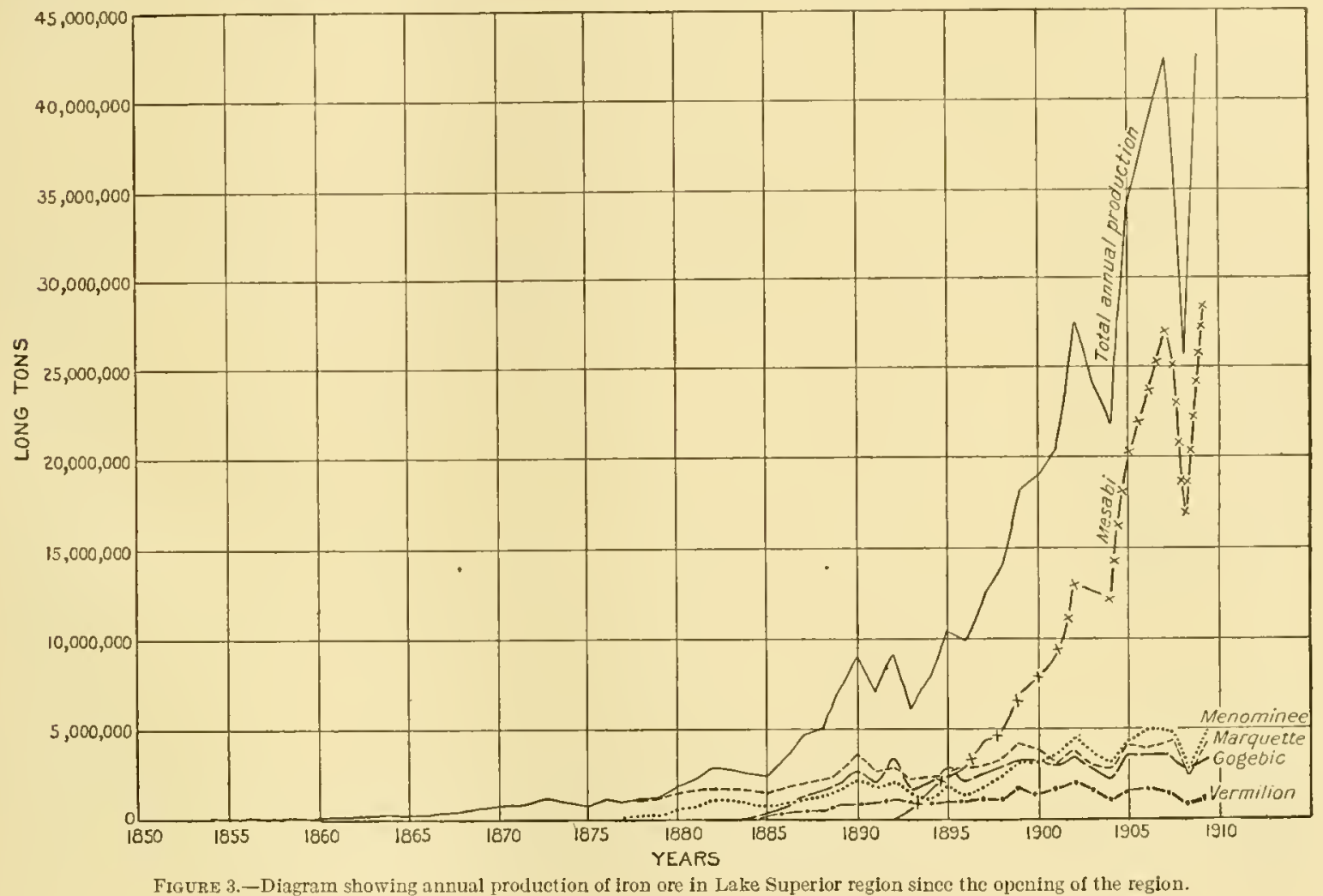

Table of Lake Superior iron-ore shipments from the earliest shipment to date.a

Gogeble Range.

[Gross tons.]

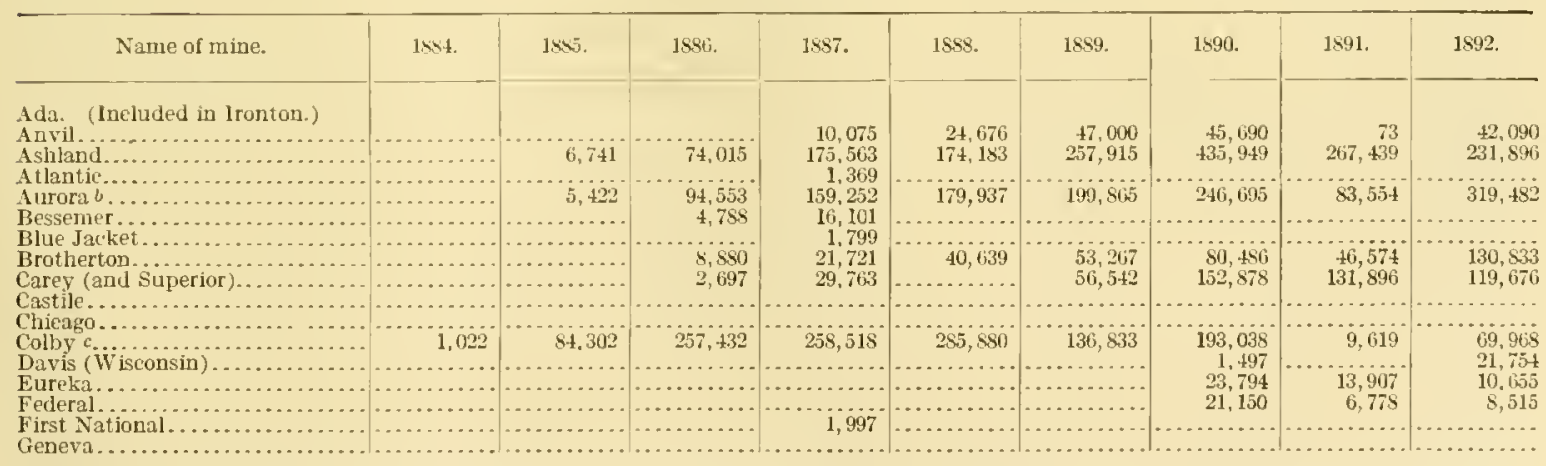

a Figures for 1593-1009, inclusive, from Supplement to the Iron Trade Review, vol, 46 , No. 9 , Mlarch 3, 1910. Figures for previous years compiled from the annual tables published by the Iron Trade Review and from "Annual review of the iron mining and other industries of the Upper Peninsula for the year ending December, 1850 ," by A. P. Swineford.

$b$ Under Norrie group after 1904

c Includes Tilden prior to 1591

$$
47517^{\circ}-\text { VOL } 52-11-4
$$


Table of Lake Superior iron-ore shipments from the carliest shipment to date-Continued.

Gogeble Range-Continued.

[Gross tons.]

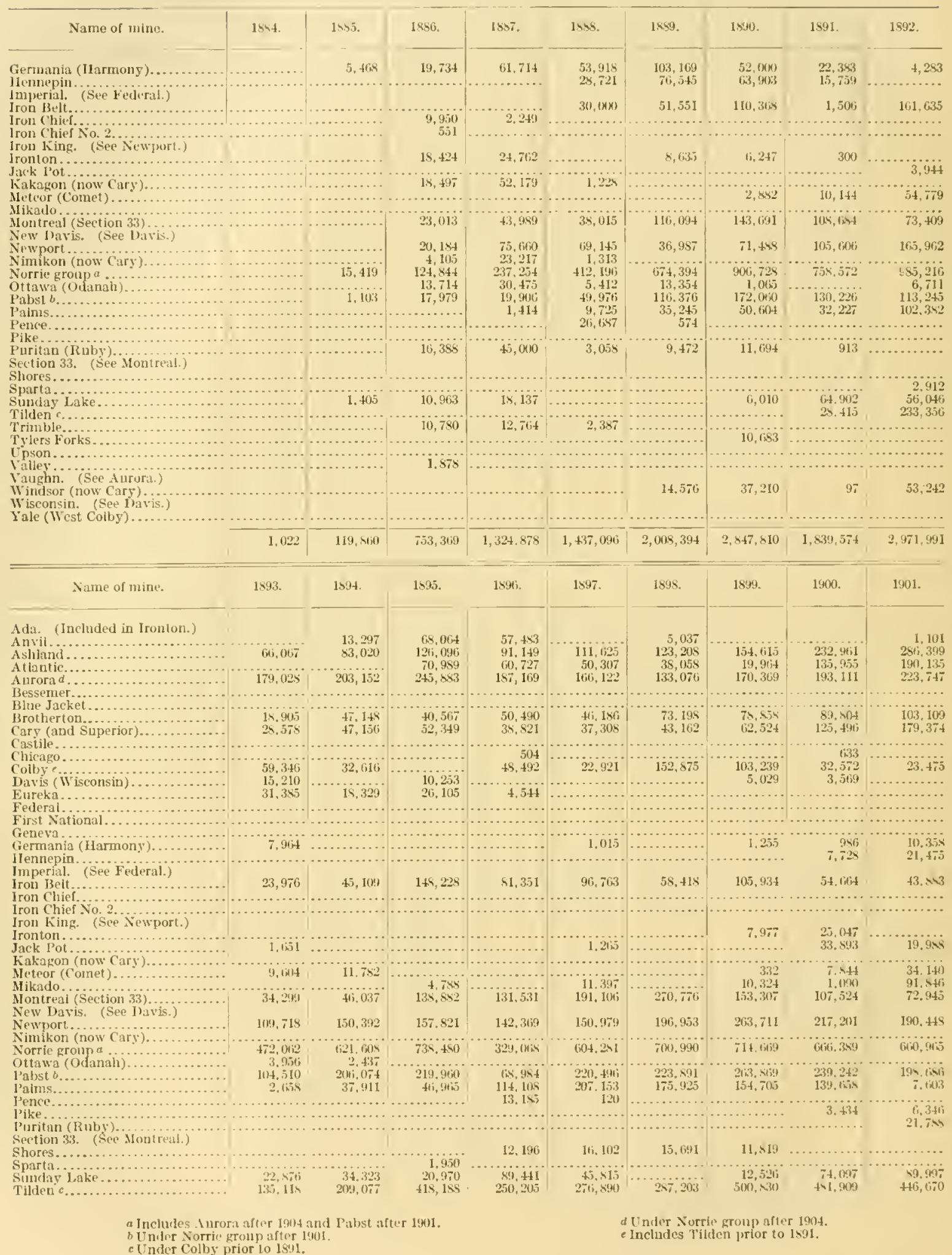


HISTORY OF LAKE SUPERIOR MINING.

Table of Lake Superior iron-ore shipments from the erarliest shipment to dute-continued.

Gogeble Range-Continued.

[Gross tons.]

\begin{tabular}{|c|c|c|c|c|c|c|c|c|c|}
\hline Name of mine. & 1593. & 1894. & 1895. & 1896. & 1897. & 1898. & 1899. & 1900. & 1901. \\
\hline \multirow{2}{*}{\multicolumn{10}{|c|}{ 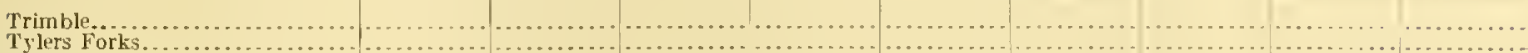 }} \\
\hline \multirow{2}{*}{\multicolumn{10}{|c|}{$\begin{array}{l}\text { Tyylers Forks. } \\
\text { Upson } \ldots \ldots \ldots \\
\text { Valley } . \ldots \ldots\end{array}$}} \\
\hline & & & & & & & & & \\
\hline \multirow{4}{*}{ 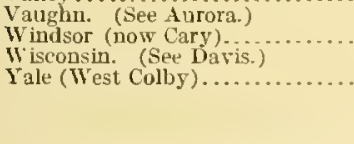 } & 2,474 & & 11,438 & 28,154 & 385 & & & ts & at1 \\
\hline & & & & & 3003 & & & & \\
\hline & & & & & & & & & $12,85(1)$ \\
\hline & $1,329,355$ & $1,809,468$ & $2,547,976$ & $1,799,971$ & 2.258 .230 & $2,49 x .41 i \mathrm{I}$ & $2,795,850$ & $2,875,293$ & $2,93 \times, 155$ \\
\hline Name of mine. & 1902. & 1903. & 1904. & 1905. & 19001. & 1907. & 1908. & 1909. & Total. \\
\hline \multicolumn{10}{|l|}{ Ada. (Included in 1ronton.) } \\
\hline 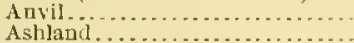 & 135,502 & $\begin{array}{r}11,309 \\
275\end{array}$ & $\begin{array}{r}45,595 \\
340^{\circ 2}\end{array}$ & 82,118 & 79,493 & $\begin{array}{r}39,495 \\
998,056\end{array}$ & 35,937 & 22,927 & $71 \mathrm{f}_{1}, 962$ \\
\hline Atlantic............. & 190,213 & 148,385 & 77,224 & 208,039 & $\begin{array}{r}3+1,841 \\
97,689\end{array}$ & $\begin{array}{r}295,0003 \\
91,759\end{array}$ & $\begin{array}{r}209,411 \\
41,4165\end{array}$ & 845 & $\begin{array}{l}5,38,156 \\
1,547,123\end{array}$ \\
\hline Aurora $a$. & 402,981 & 355,365 & 212,920 & & & & & & $3,961,0 \times 3$ \\
\hline \multicolumn{10}{|l|}{ l3esserner. } \\
\hline $\begin{array}{l}\text { Blue Jacket } \\
\text { Brotherton. }\end{array}$ & 53,255 & 94,986 & 8450 & 137.351 & (47 2s! & & $46-70$ & 103000 & $\begin{array}{r}1,799 \\
-7,409\end{array}$ \\
\hline 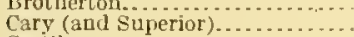 & 136.595 & & 61,860 & 146,414 & $\begin{array}{l}176,281 \\
216,992\end{array}$ & $200,4,407$ & $\begin{array}{l}96,110 \\
91 i, 358\end{array}$ & $\begin{array}{l}105,090 \\
224,251\end{array}$ & $\begin{array}{l}1,652,498 \\
2,289,615\end{array}$ \\
\hline \multicolumn{10}{|l|}{ 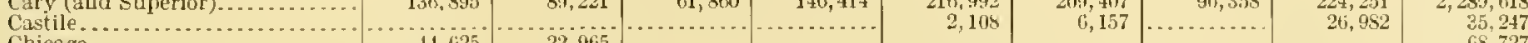 } \\
\hline $\begin{array}{l}\text { Chicago .............. } \\
\text { Colbre } b \text {. }\end{array}$ & $\begin{array}{l}+4,4 i 25 \\
22,52 t ;\end{array}$ & $\begin{array}{l}22,965 \\
54,915\end{array}$ & & & & & & & 68,727 \\
\hline Davis (Visconsin) & $31, .530$ & $\begin{array}{r}54,915 \\
734\end{array}$ & $\begin{array}{l}81,1+1 \\
11,225\end{array}$ & $\begin{array}{r}83,736 \\
3,1 \in 0\end{array}$ & $\begin{array}{l}113,001 \\
\ldots . . \ldots . .\end{array}$ & 94,450 & 58,305 & 170,095 & $\begin{array}{r}2,450,347 \\
103,961\end{array}$ \\
\hline \multicolumn{10}{|l|}{ 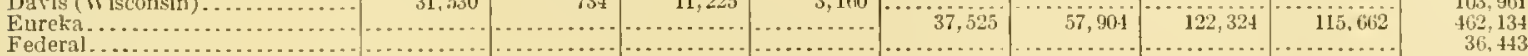 } \\
\hline \multirow{2}{*}{\multicolumn{10}{|c|}{ First National . . }} \\
\hline & & & & & & & & & \\
\hline \multicolumn{10}{|l|}{ 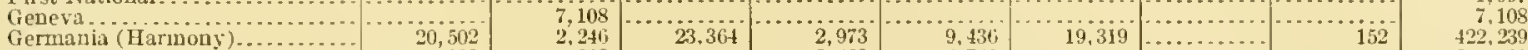 } \\
\hline \multicolumn{10}{|l|}{$\begin{array}{l}\text { Hennepin. } \\
\text { Imperial. (See Federal.) }\end{array}$} \\
\hline \multirow{2}{*}{\multicolumn{10}{|c|}{ 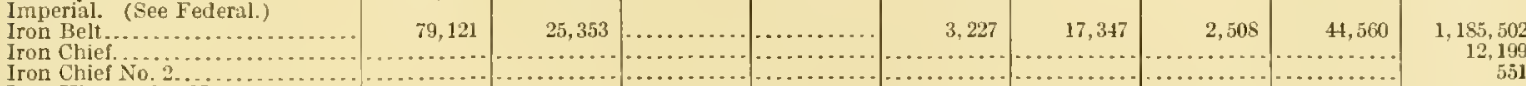 }} \\
\hline & & & & & & & & & 12,199 \\
\hline \\
\hline 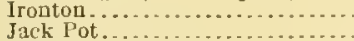 & 8, 555 & 16,875 & 23,197 & 41,314 & 106,158 & 190,968 & 32,932 & 277,594 & 848,985 \\
\hline \multicolumn{10}{|l|}{ Jack Pot. } \\
\hline Meteor (Comet)............... & 19,117 & 6,150 & 59,587 & & & & & & 216,367 \\
\hline Mikado $\ldots$ Montreal (Section 33 \}....... & 98.834 & 105,709 & 25,611 & 140,740 & 154,043 & 163,591 & 86.617 & 99,195 & 997,085 \\
\hline \multicolumn{10}{|l|}{$\begin{array}{l}\text { Montreal (Section } 33 \text { )................. } \\
\text { New Davis. (See Davis.) }\end{array}$} \\
\hline \multicolumn{10}{|l|}{$\begin{array}{l}\text { Newport. } \\
\text { Nimikon (now Cary)............... }\end{array}$} \\
\hline \multirow{2}{*}{\multicolumn{10}{|c|}{ 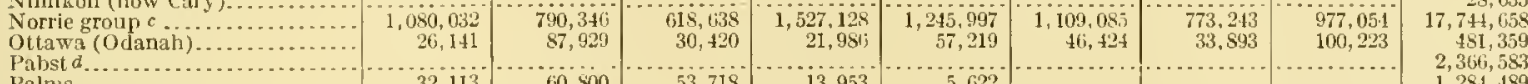 }} \\
\hline & & & & & $3 i,-19$ & & 35,093 & 223 & $2,366,583$ \\
\hline \multicolumn{10}{|l|}{ 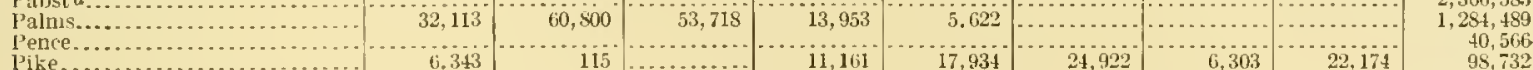 } \\
\hline 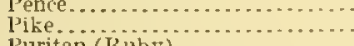 & 6.343 & 115 & & $i 1,16 i$ & 17,934 & 24,922 & 6,303 & 22,174 & $\begin{array}{l}40,566 \\
98,732\end{array}$ \\
\hline $\begin{array}{l}\text { Puritan (Ruby) } \\
\text { Section } 33 \text {. See Montreal.) }\end{array}$ & & & 1,259 & & & & & & 572 \\
\hline \multirow{2}{*}{\multicolumn{10}{|c|}{ 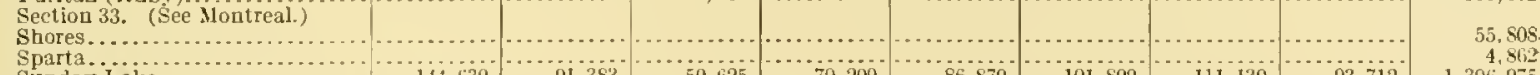 }} \\
\hline & & & & & & & \multirow{2}{*}{\multicolumn{3}{|c|}{ 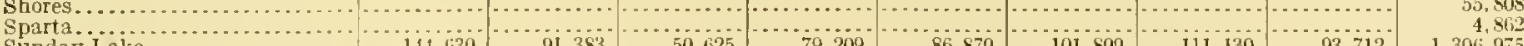 }} \\
\hline 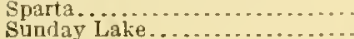 & $144, \operatorname{li} 30$ & 91,383 & & 79.209 & & $10 \mathrm{I}, 899$ & & & \\
\hline $\begin{array}{l}\text { Sunday Lake. } \\
\text { Tilden e....... }\end{array}$ & 465,$1 ; 2$ & 211,534 & 204,581 & 188,104 & 169,697 & 312,496 & 111,184 & 154,500 & $\begin{array}{l}1,3016,910 \\
5,088,735\end{array}$ \\
\hline ble..... & & …...... & & 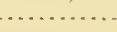 & .......... & & & & 25,931 \\
\hline $\begin{array}{l}\text { Tylers Forks... } \\
\text { Upson }\end{array}$ & & $\cdots \cdots$ & 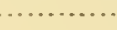 & 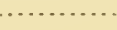 & & & 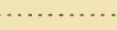 & & 10,683 \\
\hline 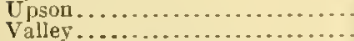 & 11,0 tis & 310 & & & & & & & 11,375 \\
\hline Vaughi. (See Aurora.) & & & & & & & & & 1. \\
\hline - & & & & & & & & & $14 \$, 905$ \\
\hline $\begin{array}{l}\text { Wisconsin. (See Daris.) } \\
\text { Yale (West Colby)....... }\end{array}$ & 26,043 & 40,211 & $46, \$ 60$ & 00,224 & 56,057 & 38,010 & 14,874 & $71,4.58$ & 373,173 \\
\hline & $3,654,929$ & $2.912,708$ & $2,398,287$ & $3,705,207$ & 3.643 .514 & $3 . \cos 7.102$ & 2.1999 .850 & 4. 088.057 & $60,896,457$ \\
\hline
\end{tabular}

Marquette Range.

\begin{tabular}{|c|c|c|c|c|c|c|c|c|c|c|}
\hline Name of mine. & $\begin{array}{l}\text { Years un- } \\
\text { knows. }\end{array}$ & 1854. & 1855. & 1856. & 1857. & $18 \mathrm{~s}$. & 1859 & 1510. & 1861. & $1 S 62$. \\
\hline American (Sterling). & & & & & & & & & & \\
\hline Ames.............. & & & & & & & & & & \\
\hline $\begin{array}{l}\text { Austin........ } \\
\text { Barnum } f . . .\end{array}$ & & & & & & & & & & \\
\hline Bay State............. & & & & & & & & & & \\
\hline 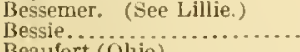 & & & & & & & & & & \\
\hline
\end{tabular}

a Under Norrie group after 1904 .

$b$ Includes Tilden prior to 1891

d Under Norrie group after 1901.

c Includes Aurora aIter 1904 and Pabst after 1901

e Under Colby prior to 1891 . 
Table of Lake Superior iron-ore shipments from the earliest shipmut to dute continued.

Marquette Range-Coutinued.

[Gross tons.]

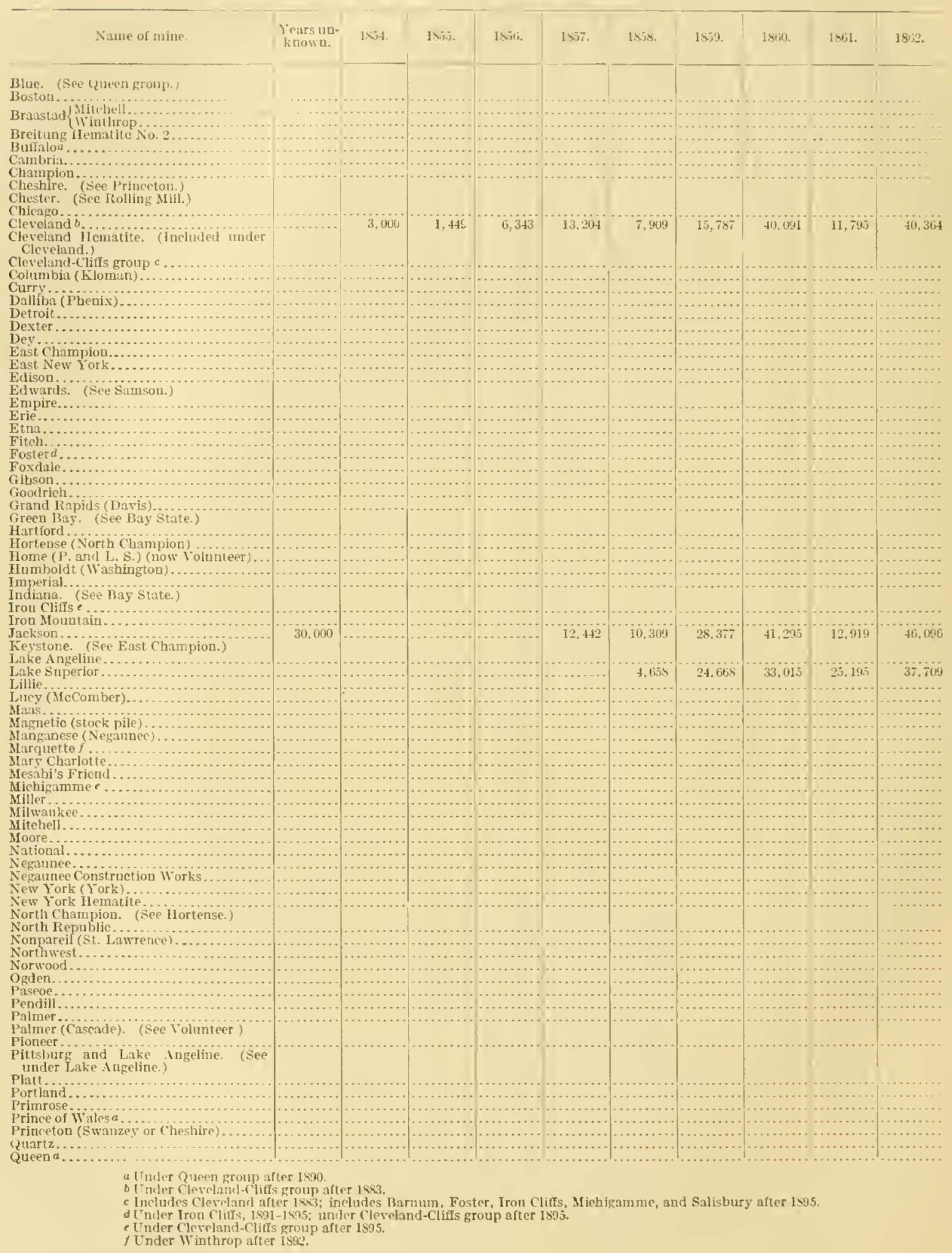


IISTORY OF LAKE SUPERIOR MINING.

Table of Lake Superior iron-ore shipments from the earliest shipment to date-Continued.

Marquette Range-Continued.

[Gross tons.]

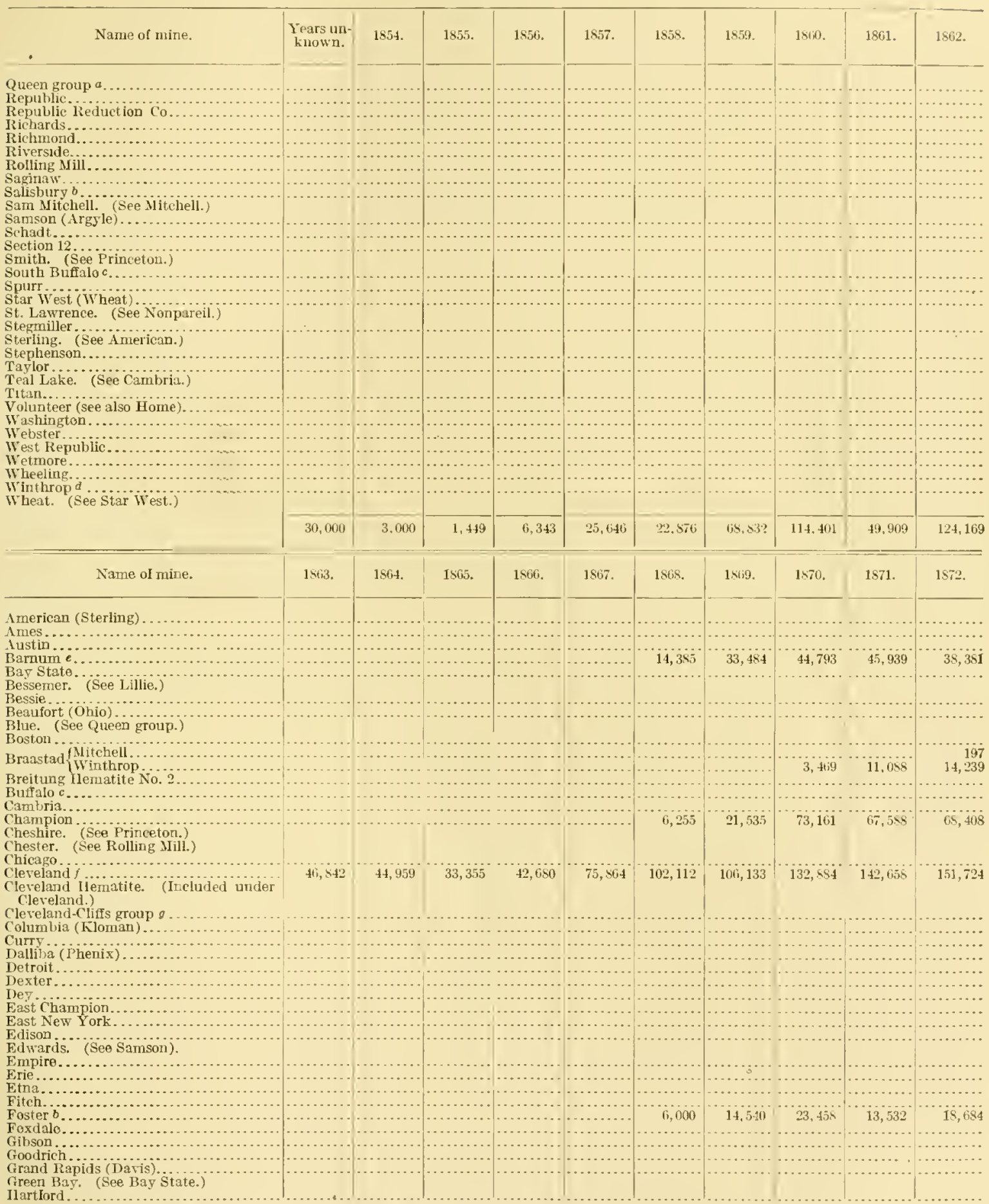

a Includes Buffalo, Prince of Wales, Queen, and South Buffalo after 1590

b Under Iron Cliffs, 1891-1895; under Cleveland-Cliffs group after 1895.

c Under Queen group after 1890.

d Priar to 1890. see Braastar: includes Narquette after 1892.

$e$ Under Iron Cliffs, 1R90-1895; under Cleveland-Cliffs group aiter 1895.

o Includes Cleveland after 15\$3; includes Barnum, Foster, Iron Cliffs, Michigamme, and Salislury after 1895. 
Table of Lake Supcrior iron-ore shipments from the carlicst shipment to date-Continued.

Marquette Range-Continued.

[Ciross tons.]

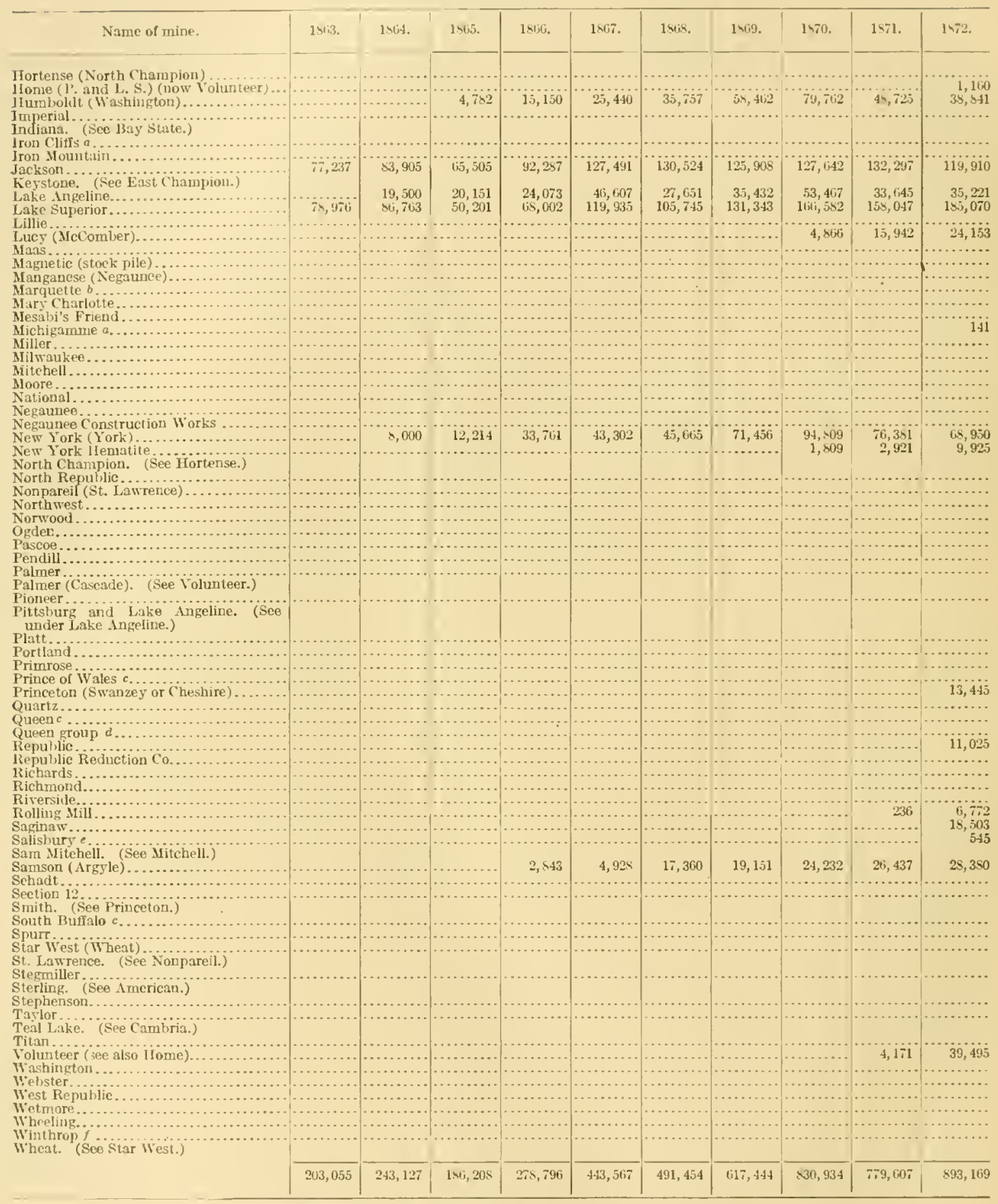

a Under Cleveland-Clifts gromp after 1 \$\$95.

b Under Winthrop after 1wa?.

c Under Quecn group after 1890.

dInclides Buffalo, I'rince of Wales, Queen, and South Buffalo after Is90.

Ender Iron Cliffs, 1891-1895; under Cleveland-Clifs group after 1895.

$f$ l'rior to 1590 , see Braastad; includes Marquette after 1592. 
HISTORY OF LAKE SUPERTOR MINING.

Table of Lake Superior iron-ore shipments from the carliest shipment to dute-Continued.

Marquette Range-Continued.

[Gross tons.]

\begin{tabular}{|c|c|c|c|c|c|c|c|c|c|c|}
\hline Name of mine. & 1873. & 1874. & 1875. & 1876. & & 1878. & 1579. & 1830. & 18.51 . & 1882. \\
\hline $\begin{array}{l}\text { Imeriean (Sterling). } \\
\text { Imes.................. }\end{array}$ & & & & & & & & $\begin{array}{l}797 \\
\cdots\end{array}$ & 4,702 & $\begin{array}{l}8,006 \\
\ldots\end{array}$ \\
\hline ustin............ & & & & & & & & & & \\
\hline 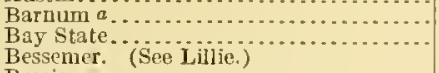 & 45,076 & 41,403 & 43,209 & $\begin{array}{r}37,632 \\
8,583\end{array}$ & & 26,680 & $\begin{array}{r}24,015 \\
3,336\end{array}$ & $\begin{array}{r}24,522 \\
2,268\end{array}$ & $27,8 \times 3$ & $\begin{array}{r}41,778 \\
1,236\end{array}$ \\
\hline $\begin{array}{l}\text { Bessie... } \\
\text { Beaufort (Ohio)................ } \\
\text { Blue. (See Queen group.) }\end{array}$ & & & & & & & & & & 5,532 \\
\hline Boston . quitehell............ & & & & & & & & $\begin{array}{r}6,478 \\
13,279\end{array}$ & 14,824 & $\begin{array}{l}18,245 \\
33,394 ;\end{array}$ \\
\hline Braastad $\{$ Witehell...... & $\begin{array}{r}8,658 \\
33,456 \\
-\ldots\end{array}$ & $\begin{array}{r}7,549 \\
7,549 \\
\cdots\end{array}$ & 7,502 & $\begin{array}{r}57,296 \\
27,236\end{array}$ & $\begin{array}{r}32,898 \\
12,549\end{array}$ & $\begin{array}{r}4,259 \\
23,740\end{array}$ & $\begin{array}{l}11,131 \\
26,595\end{array}$ & $\begin{array}{l}13,279 \\
45,247\end{array}$ & $\begin{array}{l}21,146 \\
43,630\end{array}$ & $\begin{array}{l}33,3965 \\
23,005\end{array}$ \\
\hline Builalo b................. & & & & & & & & & & \\
\hline $\begin{array}{l}\text { Cambria............ } \\
\text { Champion...... } \\
\text { Cheshire. (See Pr }\end{array}$ & 72,782 & $\begin{array}{r}2,610 \\
47,097\end{array}$ & 56,877 & $\begin{array}{r}6,329 \\
66,002\end{array}$ & $\begin{array}{r}10,083 \\
70,883\end{array}$ & $\begin{array}{r}3,754 \\
73,464\end{array}$ & $\begin{array}{r}6,724 \\
94,027\end{array}$ & $\begin{array}{r}6,958 \\
112,401\end{array}$ & $\begin{array}{r}19,246 \\
145,427\end{array}$ & $\begin{array}{r}64,545 \\
159,009\end{array}$ \\
\hline 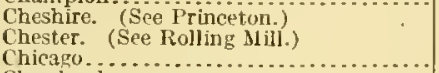 & & & & & & & 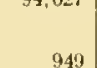 & 2,415 & $140,12=1$ & \\
\hline $\begin{array}{l}\text { develand } \text { coland IIematite. (Included under } \\
\text { Cleveland.) }\end{array}$ & $133,265^{\circ}$ & 105,858 & 129,851 & 146,393 & 152,188 & 152,737 & 131,167 & $\begin{array}{r}2,415 \\
212,748\end{array}$ & $\begin{array}{r}5,531 \\
198,569\end{array}$ & 206,120 \\
\hline bia (kloman). & 21,065 & 35,058 & 8,059 & & & & & 6,663 & 11,158 & 12,060 \\
\hline (Phenix).... & & & & & & & & & $10,95 i$ & 44,836 \\
\hline $\begin{array}{l}\text { Detro } \\
\text { Dext }\end{array}$ & & & & & & & & $\cdots$ & ......... & 5,402 \\
\hline Der & & & & & & & & & & \\
\hline mpion.......... & 10,426 & 5,227 & 3,346 & 7,715 & 14,495 & 5,401 & 4,029 & 10,217 & 3,408 & 4,002 \\
\hline Edison.......... & & & & & & & & & & \\
\hline $\begin{array}{l}\text { Edwards. (See } \\
\text { Empire........ }\end{array}$ & & & & & & & & & & \\
\hline Etna... & & & & & & & & & & $2,73 i$ \\
\hline H. & & & & & & & & & & . \\
\hline e............. & 18,107 & $4,719^{\circ}$ & 847 & 125 & & ... & 4,804 & 1,122 & 3,011 & 11,648 \\
\hline ............ & & & & & & & & & & \\
\hline radrich Rapids (Davis)............ & & & & $f 6,33 \mathrm{~s}$ & 503 & 7,547 & 3,992 & 11,131 & 10,245 & 9,998 \\
\hline ay. (se & & & & & & & & & & \\
\hline or & 21,498 & & & & & & & & & \\
\hline Aumboldt (Washington)..... & $\begin{array}{l}21,498 \\
38,014\end{array}$ & $\begin{array}{r}1,302 \\
27,890\end{array}$ & & & & 1.225 & 492 & 285 & & \\
\hline $\begin{array}{l}\text { Imperial } \\
\text { Indiana. (See Bay state.) }\end{array}$ & & & 9,642 & 3,333 & 16,545 & 23,921 & 18,204 & 14,726 & 26,302 & 43,463 \\
\hline Iron & & & & & & & & & & \\
\hline & 130,131 & 105,600 & 90,568 & 98,480 & 80,340 & 83,121 & 103219 & 120,620 & 118,939 & 96,830 \\
\hline 1.) & 933 & 31,526 & 06.370 & & & & & & & \\
\hline at & 155,078 & $\begin{array}{r}31,526 \\
114,074\end{array}$ & $\begin{array}{r}26,370 \\
129,339\end{array}$ & $\begin{array}{r}22.539 \\
111.766\end{array}$ & $\begin{array}{r}19,112 \\
127,349\end{array}$ & $\begin{array}{r}28,161 \\
109,674\end{array}$ & $\begin{array}{r}25,321 \\
173,938\end{array}$ & $\begin{array}{r}14,928 \\
204,004\end{array}$ & & $\begin{array}{r}14,326 \\
296,509\end{array}$ \\
\hline & & & & & & & & & $\begin{array}{l}262.235 \\
16,748\end{array}$ & $\begin{array}{r}296,509 \\
27,494\end{array}$ \\
\hline $\begin{array}{c}\text { ey }(\text { MeComber }) \\
\text { as }\end{array}$ & 38,969 & 2,642 & 10,407 & 17,276 & 19,691 & 30,180 & 28,962 & 31,206 & 28,051 & 40,406 \\
\hline & & & & & & & & ........ & & ....... \\
\hline ... & & & & $\cdots$ & & & . & & & ….. \\
\hline & & & & & & & 0. & 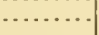 & . & $\ldots .$. \\
\hline & & & & & & & & & & \\
\hline ch & 29,107 & 45,294 & 44,763 & 70,074 & 28,238 & 58,622 & 56,970 & 52,766 & 57,272 & 43,71 \\
\hline & & & & & & & 941 & 13,142 & 31,635 & 40,591 \\
\hline (n..... & & & & & & & & & ......... & $\cdots . .$. \\
\hline & & & & & ... & $4,19 i$ & 33,310 & 29,351 & 24,833 & 23,360 \\
\hline & & & & & & & & & & \\
\hline & 70,882 & $77,017^{\circ}$ & $70,103^{\circ}$ & 58,563 & $55,581^{\circ}$ & 21,903 & 37.328 & 58,512 & 50,074 & 56,8 \\
\hline & 6,629 & $\cdots$ & 987 & 556 & 3,307 & 4,547 & 2,609 & 2,192 & & 30, \\
\hline . (See Ilortense.) & & & & & & & & & & \\
\hline & & & & & & & & & & 9,99 \\
\hline 7. & & & & & & & & & & , \\
\hline "1 & & & & & & & & & & -... \\
\hline & & & & & & & & & & is, ss \\
\hline 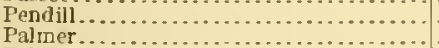 & & & & & $\ldots$ & 4,000 & 12,549 & 3,959 & 13,586 & 9,95 \\
\hline er (Cascade). (See Volunteer.) & & & & & & & & & & \\
\hline $\begin{array}{l}\text { ittsburg and Lake Angeline. (See } \\
\text { under Lake Angeline.) }\end{array}$ & & & & & & & & & & \\
\hline
\end{tabular}

a Under Iron Cliffs, 1890-1895; under Cleveland-Cliffs group after 1895 . $b$ Under Queen group after 1890 .

c Under Cleveland-Cliffs group after 1883 .

d Includes Cleveland after 18.53; includes Barnum, Foster, Iron Cliffs,

e Under Iron Cliffs, 1891-1895; under

$f$ Ineludes shipments for prior years.

$h$ Under Winthrop after 1892 . 
Table of Lake Superior iron-ore shipments from the carlirst shipment to date-Continued.

Marquette Range-Continued.

[Gross tons.]

\begin{tabular}{|c|c|c|c|c|c|c|c|c|c|c|}
\hline Name of mine. & 1573. & 1874 & 1875. & 1870. & $157 \%$ & 1875. & $1 \$ 79$. & 1440. & $1 \leqslant \$ 1$. & $13 \times 2$. \\
\hline \multicolumn{11}{|l|}{ Platt. } \\
\hline \multicolumn{11}{|l|}{$\begin{array}{l}\text { Portland. } \\
\text { Primrose. }\end{array}$} \\
\hline \multicolumn{11}{|l|}{ 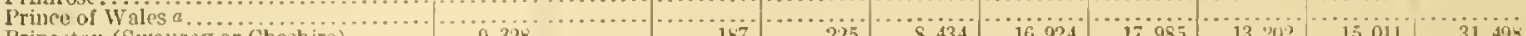 } \\
\hline 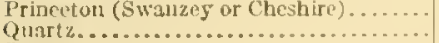 & $\begin{array}{r}9,325 \\
\ldots \ldots\end{array}$ & & 157 & $\begin{aligned} 225 \\
\ldots \ldots\end{aligned}$ & $\begin{array}{r}8,434 \\
\ldots .\end{array}$ & $\begin{array}{r}16,924 \\
\ldots\end{array}$ & $\begin{array}{r}17,985 \\
\ldots .\end{array}$ & 13,202 & 15,011 & $\begin{array}{l}31,498 \\
\ldots \ldots\end{array}$ \\
\hline \multicolumn{11}{|l|}{ 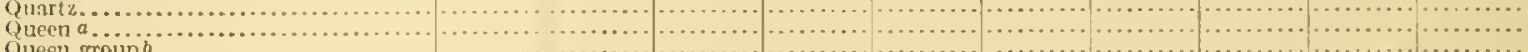 } \\
\hline $\begin{array}{l}\text { Queen group } 6 . \ldots \ldots \ldots \ldots \ldots \ldots \ldots \\
\text { Repubtic..................... }\end{array}$ & 105,453 & 122,639 & 119,726 & 120.095 & 165,536 & 170,221 & 135.231 & $23.5,347$ & $233,7 \mathrm{di}$ & 235,103 \\
\hline Republic Reduction Co... & & & & …...... & & & & ........ & (......... & ......... \\
\hline \multirow{2}{*}{\multicolumn{11}{|c|}{ 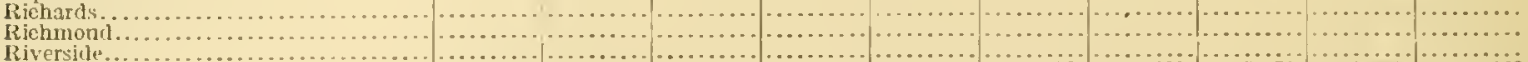 }} \\
\hline & & & & & & & \\
\hline Rolling Mill... & 11,319 & 16.643 & 37.806 & 53,265 & 38,121 & 30.773 & 10,039 & 15,172 & 1, tiris & 16,3 \\
\hline 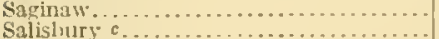 & 37,138 & $45.496 j$ & 55.318 & 56.979 & 44. 005 & 54,097 & 43.396 & 35,054 & 30.793 & $\begin{array}{l}16,276 \\
42,243\end{array}$ \\
\hline \multirow{2}{*}{\multicolumn{10}{|c|}{ 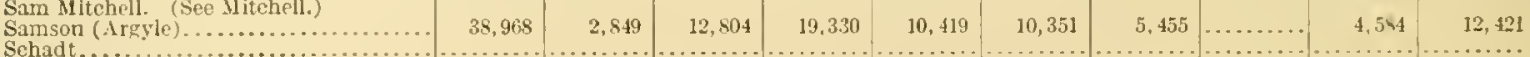 }} & 42.243 \\
\hline & & 2,849 & 12,804 & 19.3 .30 & 10,419 & 10,351 & 5,455 & & 4,544 & 12,421 \\
\hline \multicolumn{11}{|l|}{$\begin{array}{l}\text { Smith (See liniceton.) } \\
\text { South Btufialo } a . . . . . . .\end{array}$} \\
\hline Spurs & 31,933 & 42,068 & 23,094 & 20,276 & 22,801 & 2,225 & 1,409 & & 2,746 & 8.573 \\
\hline \multirow{2}{*}{\multicolumn{11}{|c|}{$\begin{array}{l}\text { Star West (Wheat) .......... } \\
\text { St. Lawrence. (See Nonpar } \\
\text { Stegmitler ............. } \\
\text { Sterling. (See Smerican.) } \\
\text { Stephenson.................... }\end{array}$}} \\
\hline & & & & & & & & & & \\
\hline \multicolumn{6}{|l|}{ 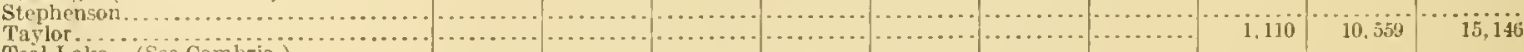 } & & & 1.110 & 10.559 & 13,196 \\
\hline \multicolumn{11}{|l|}{ 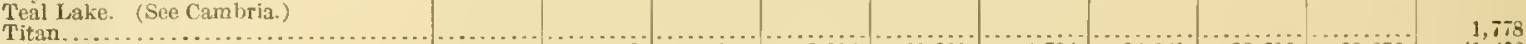 } \\
\hline Vohunteer (see also Home). & 28,920 & 18,198 & 4,071 & 15,324 & 20,211 & 4.704 & 24,141 & 38,596 & 39,276 & 41,456 \\
\hline \multirow{6}{*}{ 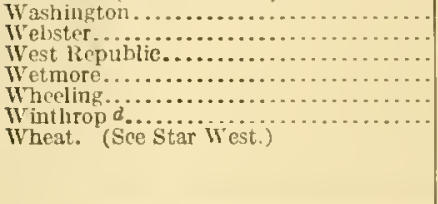 } & & & & & & & & & & 4,443 \\
\hline & & & & & & & $\ldots .$. & & 7,354 & $2 \pi, 86 \mathrm{~s}$ \\
\hline & & & & & & 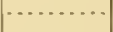 & $\cdots \cdots$ & & & \\
\hline & & & & & ...... & $\cdots$ & $\cdots \cdots$ & .. & & ........ \\
\hline & & & & & & & & & & \\
\hline & $1,158,249$ & 919,257 & 689,477 & $1,006,785$ & $1,010,404$ & $1,023.083$ & $1,130,019$ & 1.384 .010 & $1.579,834$ & $1,829,394$ \\
\hline Name of mine. & 1883. & 1884. & 1855. & 1856. & 1897. & 1888. & $18 \$ 9$. & $1 \leqslant 90$. & 1591. & $1 \$ 92$. \\
\hline \multirow{2}{*}{ 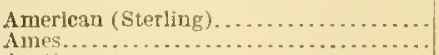 } & 3,618 & 2,916 & & & 1,483 & 13.699 & 20,032 & 21,000 & 21,1004 & 15,076 \\
\hline \multirow{2}{*}{\multicolumn{11}{|c|}{ 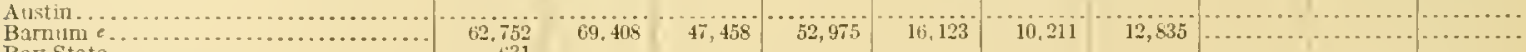 }} \\
\hline & 62,752 & 69.408 & & & & & & & & \\
\hline \multirow{2}{*}{\multicolumn{11}{|c|}{$\begin{array}{l}\text { Bessemer. (See Lillie.) } \\
\text { Bessio }\end{array}$}} \\
\hline & & & & & & & & & & \\
\hline & 18,976 & 18,360 & 17,166 & 17,354 & 12,829 & & & & & \\
\hline Blue. (See Queen group.) & & & & & & & & & & \\
\hline Boston . Mitcheli & 20,190 & (210 & & 7.017 & 16,419 & 4.091 & & & & \\
\hline Braastad W inthrop & $50,143^{\circ}$ & 73,144 & 53,913 & 58,743 & 74,067 & 86.789 & 155,341 & & & \\
\hline $\begin{array}{l}\text { Breilung Ilematite No. } 2 \\
\text { Butlaloa............... }\end{array}$ & 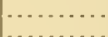 & 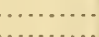 & & & & & & & & \\
\hline 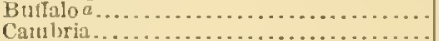 & 47.508 & 59.742 & 50.796 & $\begin{array}{l}10,560 \\
58,784\end{array}$ & $\begin{array}{l}24,686 \\
41,130\end{array}$ & 30.801 & 50,919 & $\begin{array}{r}100.464 \\
80.359\end{array}$ & & \\
\hline $\begin{array}{l}\text { Caubria........... } \\
\text { Champion. . . . . }\end{array}$ & 104.960 & 210,180 & 173,915 & 137,593 & $\begin{array}{r}41,130 \\
146,330\end{array}$ & 57.861 & 72,780 & $\begin{array}{r}80.359 \\
223,442\end{array}$ & $\begin{array}{r}34,612 \\
133,413\end{array}$ & $\begin{array}{r}41,54 ? 9 \\
109\end{array}$ \\
\hline Cheshire. (See Princeton.) & & & & & 146,330 & 174.650 & 215,098 & & 133,413 & $109.97 \mathrm{C}$ \\
\hline 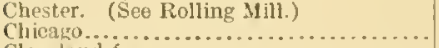 & & & & & & & & & & \\
\hline 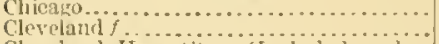 & $\begin{array}{r}117 \\
218,219\end{array}$ & & & $\ldots \ldots$ & & & & …', & n... & .. \\
\hline $\begin{array}{l}\text { Cleveland Ilematite. (Included under } \\
\text { (leveland.) }\end{array}$ & & & & & & & & & & \\
\hline Clevilaud-Clins group $g . .$. & & 225,474 & $218,75 \overrightarrow{7}$ & 203.664 & 207.441 & 184,316 & 274,048 & 331.713 & $221,7 \times 8$ & 310,907 \\
\hline Columbia (Kloman)...... & 714 & & & & & & & & & \\
\hline $\begin{array}{l}\text { Curry ..... } \\
\text { Dallibi }\end{array}$ & $10687^{\circ}$ & . & & 0 & & & 16,671 & 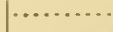 & & .. \\
\hline $\begin{array}{l}\text { Danina ( } \\
\text { Detroit... }\end{array}$ & 12.314 & 3,800 & 19,125 & 39,400 & $\begin{array}{r}1,005 \\
26,099\end{array}$ & 18,300 & io.jiz & $0.0 \times 0$ & & \\
\hline Dexter... & 4.878 & 1 ti, 202 & 750 & & & 1,821 & 3,895 & $9.13 i$ & 5. 445 & 13,000 \\
\hline 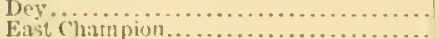 & & 2,709 & & & & & 697 & & & ... \\
\hline Fant New Xork........ & 5,039 & & & & & 13,1394 & 29,739 & 36,131 & 50,293 & 33,175 \\
\hline 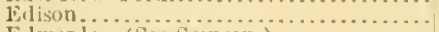 & & & & & & & 893 & & & \\
\hline $\begin{array}{l}\text { Fol wiards. (See Sitmson.) } \\
\text { Binpire. }\end{array}$ & & & & & & & & & & \\
\hline Eimp. & 5. 405 & & & & & & & & & \\
\hline & 1,001 & & & & & & & $\ldots$ & & \\
\hline & & & & & & & & $16,5,10$ & 15,0413 & \\
\hline 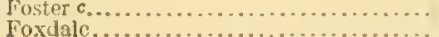 & $10.02 ! 3$ & 9,675 & 9,643 & (......... & & 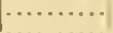 & ....... & 21,949 & & … \\
\hline
\end{tabular}

a Under Qusen group after I\$90.

Ineludes Buffato, l'riner of Wales, Qupen, and South Buffalo after 1 s9o.

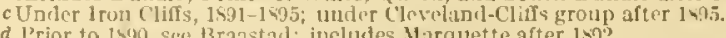

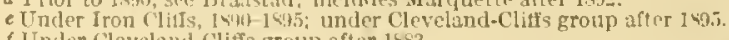

Includes Cleveland after 1553; includes Barnum, Foster, Iron Clills, I ichigamme, and Salishury after I4:5. 
HISTORY OF LAKE SUPERIOR MINING.

Table of Lake Superior iron-ore shipments from the carliest shipment to date-Continued.

Marquette Range-Contiuued.

[Gross tons.]

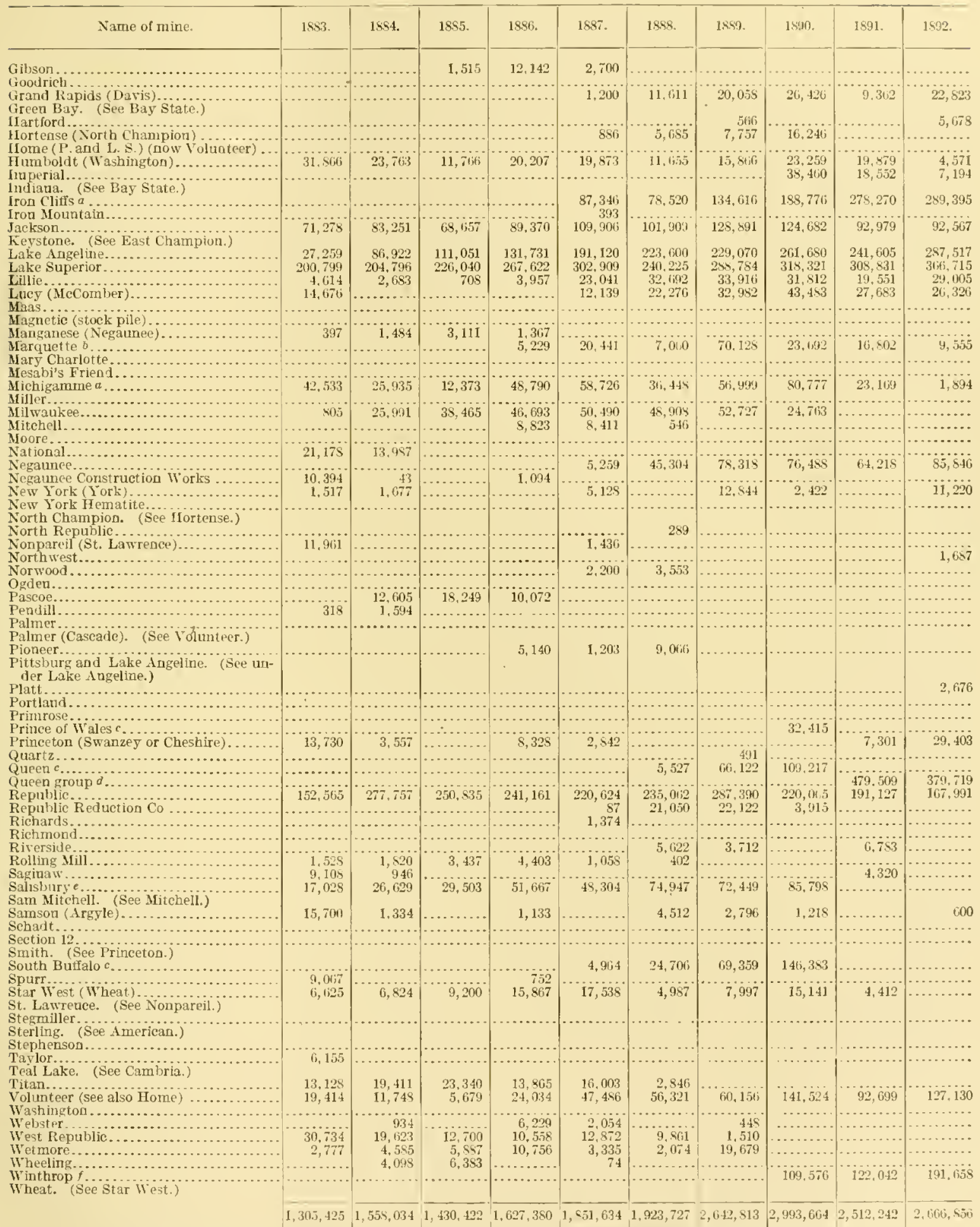

a Under Cleveland-Cliffs group after 1595. $b$ Uuder Winthrop after 1892 . $c$ Under Queen group after 1890 d Includes Buffalo, Prince of Wales, Queen. and South Buffalo after 1890. e Under Iron Cliffs, 1591-1895: under Clevela ad-Cliffs group after 1895. f Prior to 1890, see Braastad; includes Marquette after 189 ? 
Table of Jake Suprrior iron-ore shipments from the eurlicst shipment to date-Continued.

Marquette Range -. Continued.

[Gross tons.]

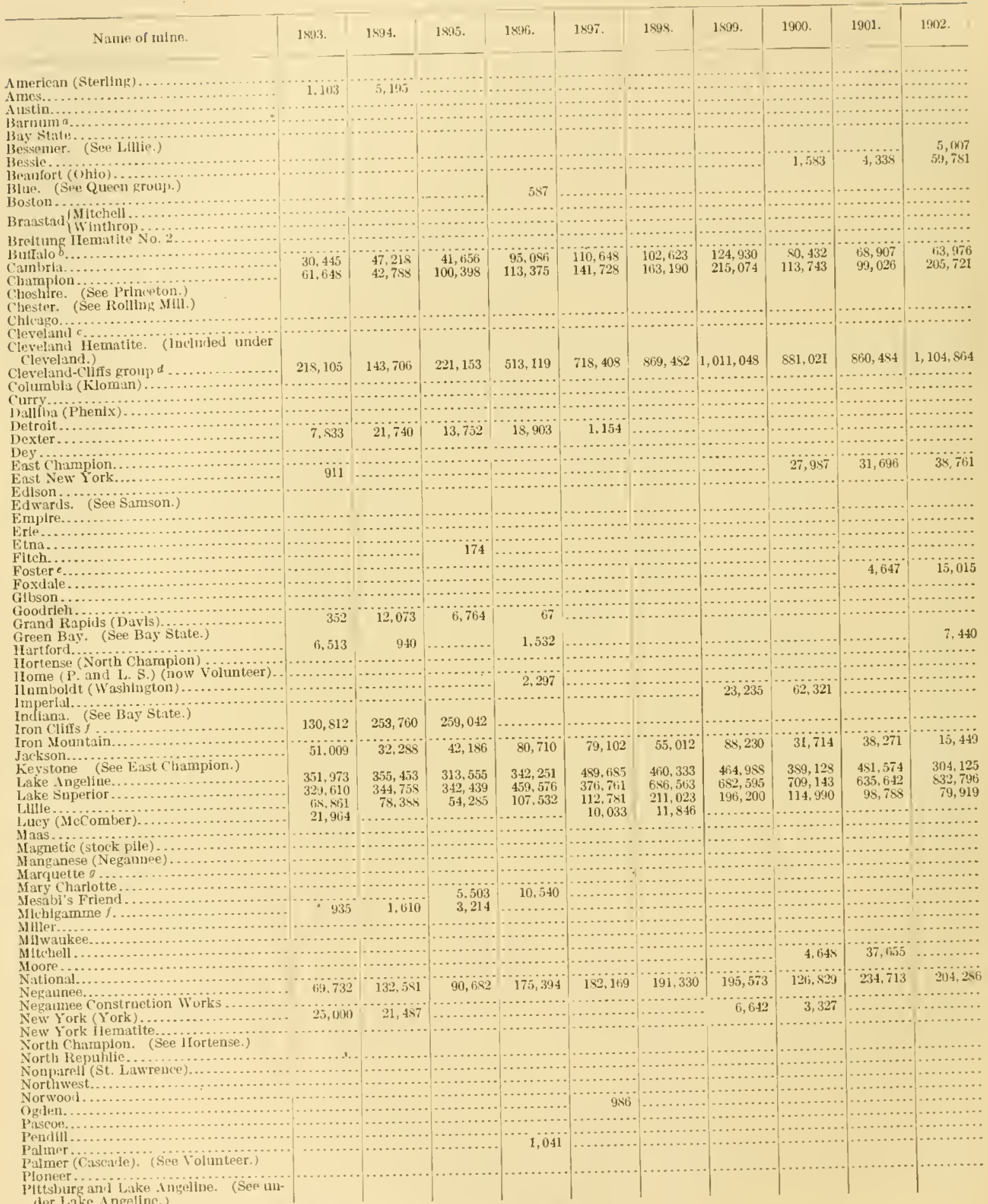
der bake Angeline.)

a Under lron Cliffs, 15.n-1\$9.5; under Cleveland-Cliffs group after 1595.

$b$ Under Queca graizp after 1 s.10.

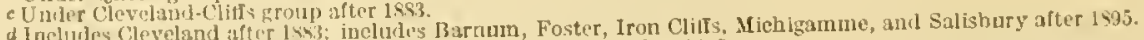

e Under l ron Clifis, 1\$.1 1\$93; under Cleveland-Cliffs group after 1895 .

$f$ Under Cleveland-Clifis group after 1895 .

Under Winthrop after 1492. 
Table of Lake Supcrior iron-ore shipments from the earliest shipment to date-Continued.

Marquette Range-Continued.

[Gross tons.]

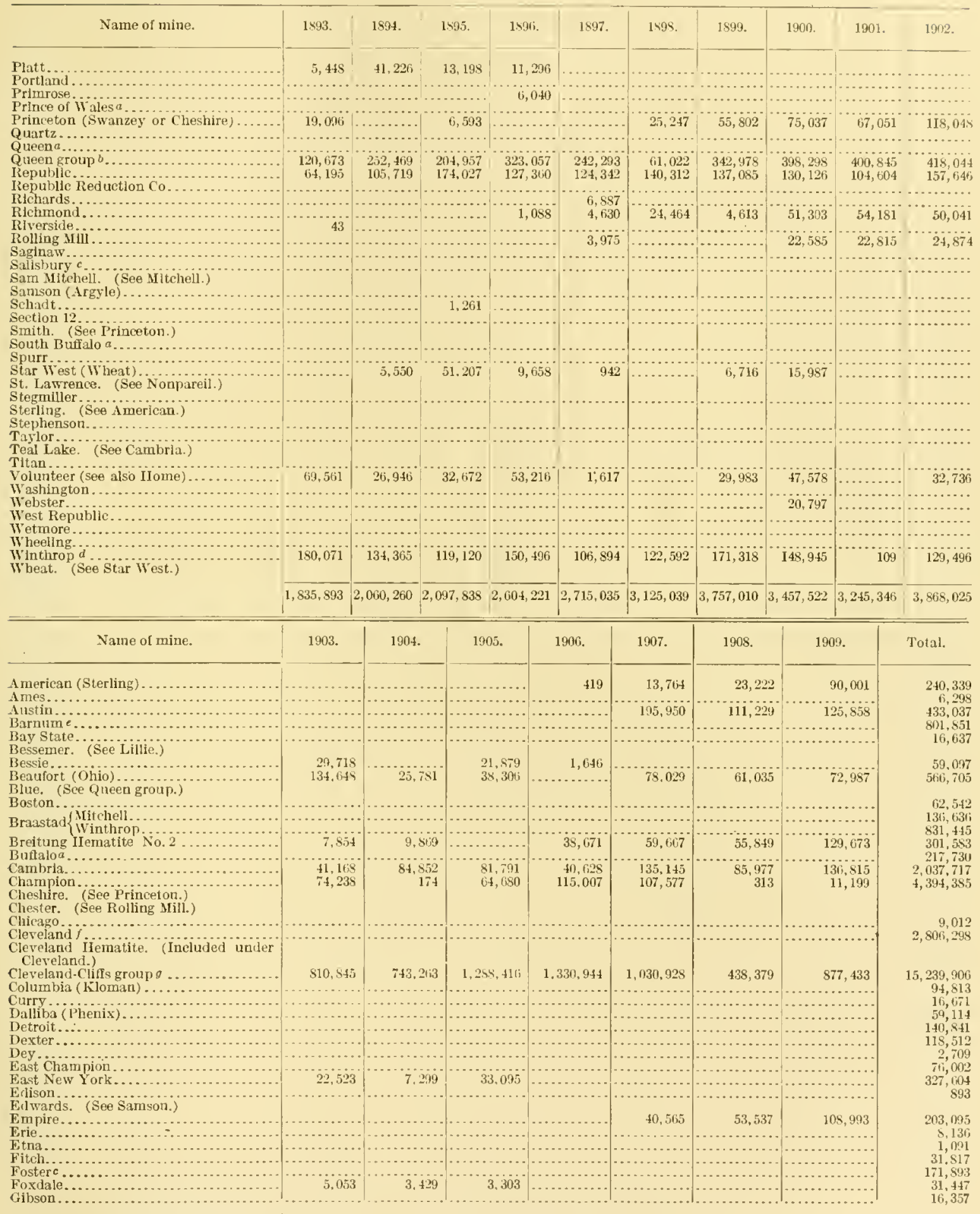

a Under Queen group after 1890.

$b$ Includes Butfato, Prince of Wales, Queen, and South Buffalo after 1890.

$c$ Under Iron Cliffs, 1991-1895; under Cleveland-Cliffs gronp after 189.5 .

d Prior to 1890 , see Braastad: inclitles Marquette after 1592.

e Under Iron ClitIs, 1890-159; under Cleveland-Cliffs group after 189.5

$f$ Under Cleveland-Cliffs group after 1883 .

$g$ Includes Cleveland after 1883; includes Barnum, Foster, Iron Cliffs, Michigamme, and Salisbury after 1805. 
Table of Lake Superior iron-ore shipments from the carlicst shipment 10 date-1'ontinued.

Marquette Range-Continus.

[Gross tons.]

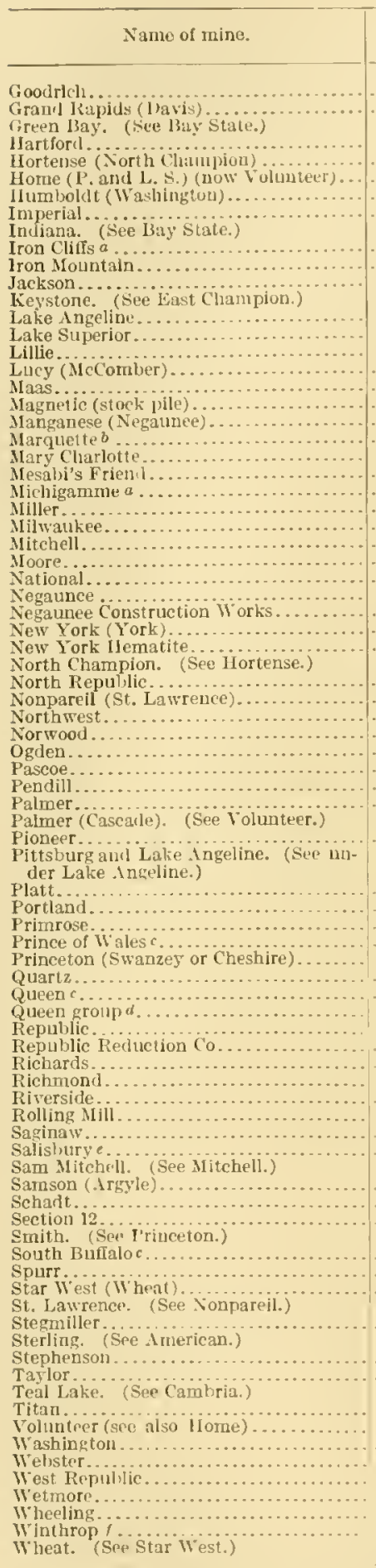

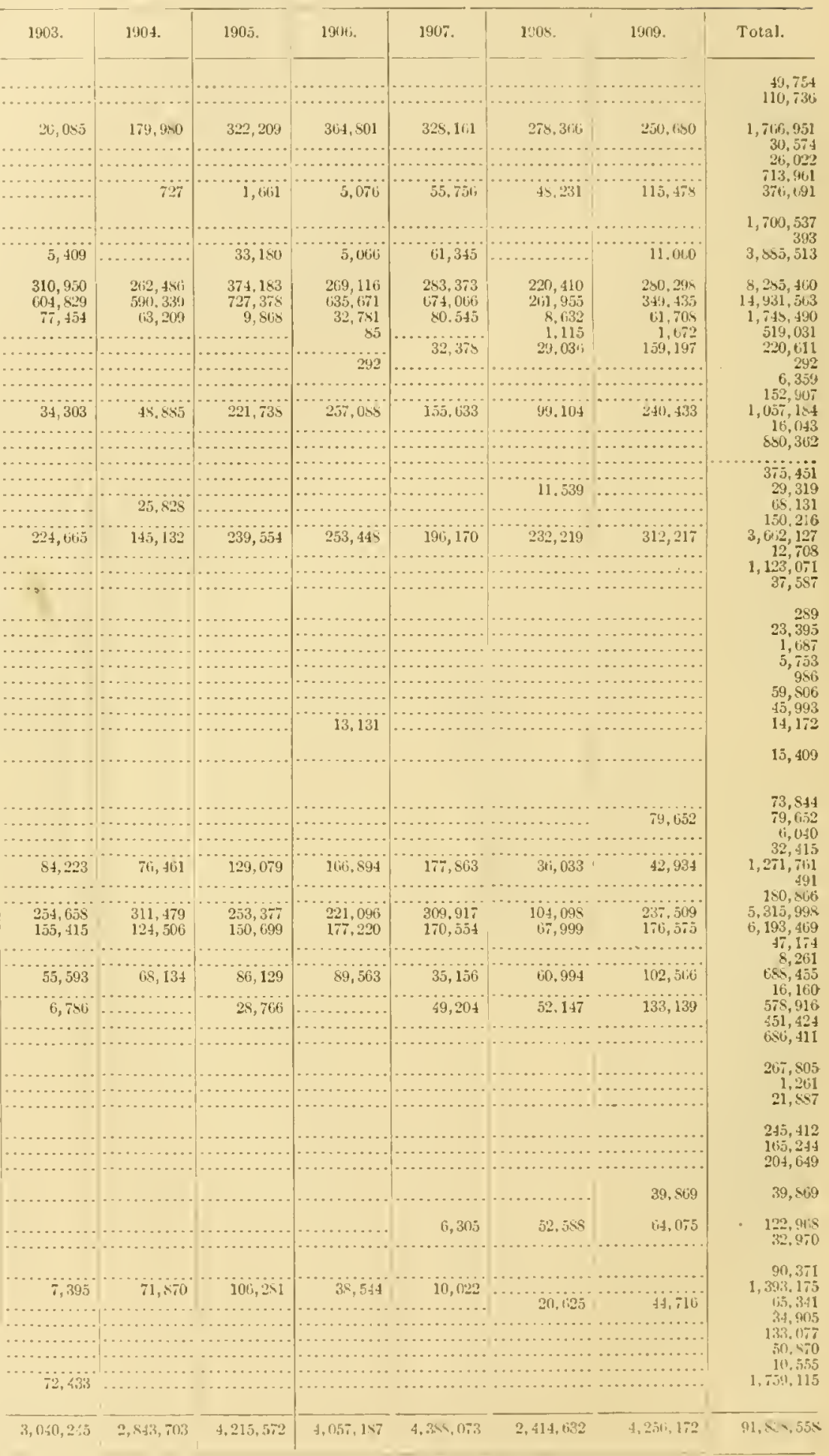


Table of Lake Superior iron-ore shipments from the earliest shipment to dute-Continued.

Menomlnee Range.

[Gross tons.]

\begin{tabular}{|c|c|c|c|c|c|c|c|c|c|}
\hline Name of mine. & 147. & $150 \mathrm{~s}$. & 15.9. & $1581 \%$ & 1Akl. & Ins?. & $14+3.3$. & $1.4 \times 1$. & 1As. \\
\hline \\
\hline \multicolumn{10}{|l|}{ 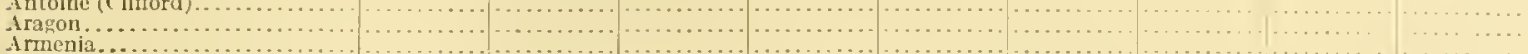 } \\
\hline \multicolumn{10}{|l|}{ Brmenla. } \\
\hline \multirow{2}{*}{\multicolumn{10}{|c|}{ Baltic..... }} \\
\hline & & & & & & & & & $\cdots$ \\
\hline & 5,812 & $4,796^{\circ}$ & 1,463 & 5,359 & & \multicolumn{4}{|c|}{ Beta... } \\
\hline \multirow{2}{*}{\multicolumn{10}{|c|}{ Bristol (Claire). }} \\
\hline & & & & & & & & & \\
\hline \multicolumn{10}{|l|}{$\begin{array}{l}\text { Calumiet..... } \\
\text { Caspian.... }\end{array}$} \\
\hline \multirow{2}{*}{\multicolumn{10}{|c|}{$\begin{array}{l}\text { Chapin (see also Ludington) } \\
\text { Cbatham ..................... } \\
\text { Clifford ................. }\end{array}$}} \\
\hline & & & & & & & & & $\cdots$ \\
\hline \multicolumn{10}{|l|}{ Columbia........ } \\
\hline \multirow{2}{*}{\multicolumn{10}{|c|}{ Commonwealt] }} \\
\hline \multirow{2}{*}{\multicolumn{10}{|c|}{$\begin{array}{l}\text { Cristal Falls.. } \\
\text { Ciff ......... }\end{array}$}} \\
\hline & & & & & & & & & \\
\hline \multicolumn{10}{|l|}{$\begin{array}{l}\text { Cundy. } \\
\text { Carry } a .\end{array}$} \\
\hline 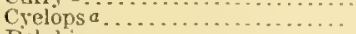 & & 6,028 & 46,158 & 14,$31 ; 8$ & $\begin{array}{l}17,534 \\
12,644\end{array}$ & $\begin{array}{l}13,374 \\
18,287\end{array}$ & $\begin{array}{r}3,67 i \\
2 ?\end{array}$ & 10,079 & 4.897 \\
\hline & & का & & ….... & & & $3,+10$ & $\begin{array}{r}2 \pm, 099 \\
505\end{array}$ & $\begin{array}{r}43,597 \\
9,850\end{array}$ \\
\hline $\begin{array}{l}\text { Dober } b \ldots \ldots \ldots \\
\text { Dunn .............. }\end{array}$ & & & & & & & & & ........ \\
\hline Eleanor (ippleton) & & & & & & & & & ... \\
\hline $\begin{array}{l}\text { Emmett } \ldots \ldots \ldots \ldots \\
\text { Fairbanks } c . \ldots \ldots\end{array}$ & & 12,397 & 22,474 & $31,13 i$ & 648 & & & & \\
\hline $\begin{array}{l}\text { Fairbanks } c . . . \\
\text { Florence..... }\end{array}$ & & & & & & 8,045 & 15.5 & & \\
\hline Fogarty ......... & & & & $14,1+3$ & 100,501 & 160,155 & 40,232 & & \\
\hline Forest......... & & & & & & & & & $\cdots$ \\
\hline $\begin{array}{l}\text { Genesce (Ethel)... } \\
\text { Gibson }\end{array}$ & & & & & & & & & $\cdots$ \\
\hline $\begin{array}{l}\text { Gibson } \\
\text { Great Western..... }\end{array}$ & & & & & & & & & \\
\hline & & & & & & 587 & $22, \times 25$ & 20,710 & ... \\
\hline Half and lials & & & & & & & & & $\cdots$ \\
\hline Hamilton....... & & & & & $\cdots$ & & & & $\cdots$ \\
\hline $\begin{array}{l}\text { Hemloch........... } \\
\text { Hersel............ }\end{array}$ & $\cdots$ & & & - & $\cdots$ & $\cdots$ & $\cdots$ & $\cdots$ & $\cdots$ \\
\hline $\begin{array}{l}\text { Hersel............ } \\
\text { II iawatha....... }\end{array}$ & & & & & & & & & \\
\hline $\begin{array}{l}\text { IIilltop............. } \\
\text { IJollister........ }\end{array}$ & & & & & & & & & . \\
\hline $\begin{array}{l}\text { IJollister . . . . . . } \\
\text { Hope........... }\end{array}$ & & & & & & & $\ldots . . .$. & & \\
\hline $\begin{array}{l}\text { Hope } \ldots . . . \ldots \ldots \ldots \\
\text { Indiana............ }\end{array}$ & & & & 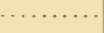 & & & & & \\
\hline Iron Riverd. & & & & ......... & $\cdots$ & 4,280 & $4,3 t i 2$ & 136 & 2,739 \\
\hline $\begin{array}{l}\text { James............ } \\
\text { Ireel Ridge..... }\end{array}$ & & & & & & 29,115 & 100,369 & 52,584 & 55,693 \\
\hline $\begin{array}{l}\text { Tieel Ridge........ } \\
\text { Kimball......... }\end{array}$ & & & & $11,+96$ & 19,511 & 23,425 & 5,033 & & $\cdots$ \\
\hline Lamont (ifonitor). & & & & & & & & & $\cdots$ \\
\hline 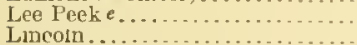 & & & & & & 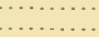 & . & & $\cdots$ \\
\hline $\begin{array}{l}\text { Luncoln............. } \\
\text { Loretta.......... }\end{array}$ & & & & & & & . & & ... \\
\hline Ludington $f$..... & & & & $\$, 516$ & $3,37-1$ & 52,152 & 102,632 & & \\
\hline $\begin{array}{l}\text { Manganate.... } \\
\text { Mansfield.... }\end{array}$ & & & & & & & & 101,165 & 124,194 \\
\hline $\begin{array}{l}\text { Mansfield........ } \\
\text { Mrastodon...... }\end{array}$ & & & & & & & & & \\
\hline $\begin{array}{l}\text { Mastodon .......... } \\
\text { MeDonald....... }\end{array}$ & $\cdots$ & & & & & 3,477 & 18,577 & 15,157 & 11,737 \\
\hline Metropolitan.............. & & & & & & 23,854 & 36,643 & 27,577 & .... \\
\hline 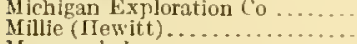 & & & & & 4,352 & 9,500 & 7516 & $\cdots 927$ & 4.627 \\
\hline Monongahela............. & & & & & & & & & $\begin{array}{l}4,021 \\
\ldots \ldots\end{array}$ \\
\hline 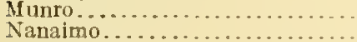 & & & & $\cdots$ & $\cdots$ & $\because$ & & & ....... \\
\hline 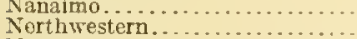 & & & & & & 2,450 & $\begin{aligned} 29,221 \\
7,202\end{aligned}$ & $\begin{array}{l}37,620 \\
11,004\end{array}$ & ....... \\
\hline Norway a.... & & 7,276 & 73,519 & 198,165 & $137,0 \div 7$ & 165,547 & 114,836 & 71,710 & 67,741 \\
\hline $\begin{array}{l}\text { Paint River (see also Fairbanks). . } \\
\text { Penn Iron Mining Co. }\end{array}$ & & $\ldots \ldots \ldots \ldots$ & 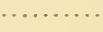 & $\cdots \cdots \cdots$ & …..... & 6,515 & 5,973 & 11,652 & 2,373 \\
\hline $\begin{array}{l}\text { Penn Iron Mining Co. } g \ldots \ldots \ldots \\
\text { Perry } \ldots \ldots \ldots \ldots \ldots\end{array}$ & & & & & & 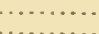 & 3.135 & & - \\
\hline Pewahie (see also walpole)....... & & & & & & & 3,135 & & \\
\hline 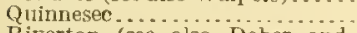 & & 25,925 & 11,954 & 52,436 & 43,711 & $+\$, 240$ & 21,676 & $16,995^{\circ}$ & 14,110 \\
\hline $\begin{array}{l}\text { Riverton (see also Deber and } \\
\text { Iron River) } h . . . . . . . . . . . . .\end{array}$ & & & & & & & & & \\
\hline Saginaw (Perkins)........... & & & 13,465 & 49,196 & 60,406 & $73,6+8$ & 76,514 & 38,120 & 18,020 \\
\hline 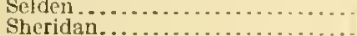 & & & $\cdots$ & ........ & & & & & $\cdots \cdots$ \\
\hline $\begin{array}{l}\text { Shelden \& Shafer (Union). (See } \\
\text { Columhia.) }\end{array}$ & & & & & & & & & \\
\hline 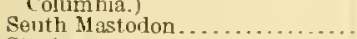 & & & & & & & & & \\
\hline Stephenson......... & & & 798 & 23.083 & 10,556 & & & & .... \\
\hline Sturgeon River.................. & & & $\cdots \cdots$ & ......... & & & & & …... \\
\hline $\begin{array}{l}\text { Tobin } \\
\text { Verona........... }\end{array}$ & & ....... & & & & & & & $\cdots \cdot$ \\
\hline $\begin{array}{l}a \text { Under Penn Iron } \\
b \text { Under Riverton aft } \\
c \text { lneluded in Paint } \\
d \text { Under Riverton aft }\end{array}$ & $\begin{array}{l}\text { Co. a } \\
00 \text {. } \\
\text { after } \\
92 .\end{array}$ & & & $\begin{array}{l}\text { rry Valle } \\
\text { luded in } \\
\text { ludes Cu } \\
\text { ludes Iro }\end{array}$ & $\begin{array}{l}\text { re. } \\
\text { Cyelop afte } \\
\text { iver aft }\end{array}$ & $\begin{array}{l}\text { rway, a } \\
\text { ra; inclu }\end{array}$ & $\begin{array}{l}\text { " } \\
\text { Dober } \\
\text { Dober }\end{array}$ & $\begin{array}{l}\text { to } 1893 . \\
1900 .\end{array}$ & \\
\hline
\end{tabular}


Table of Lake Superior iron-ore shipments from the carlirst shipment to date-Continued.

Menominee Range-Continued.

[Gross tons.]

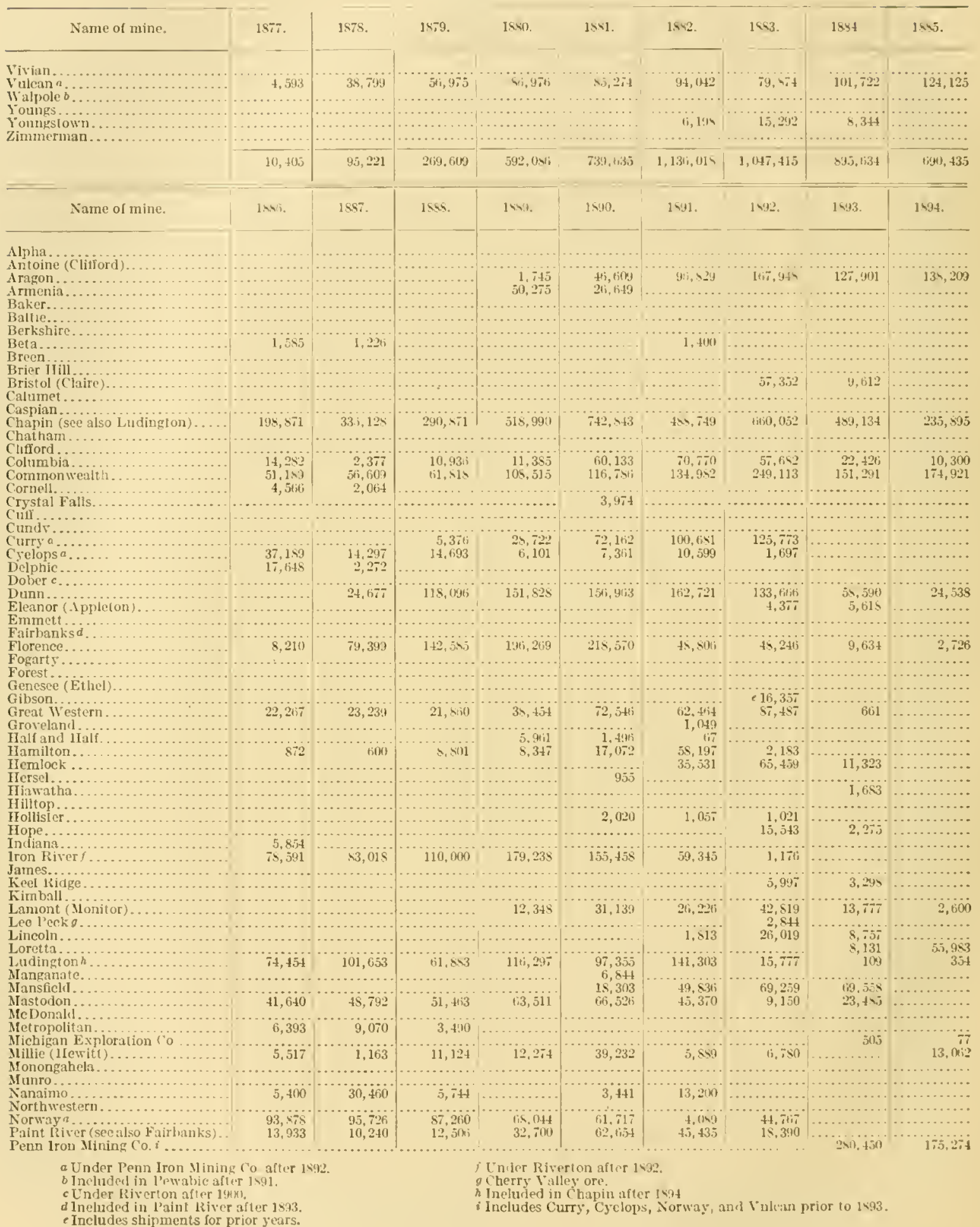


HISTORY OF LAKE SUPERIOR MINING.

Table of Lake Superior iron-ore shipments from the carlirst shipment to date-Continued.

Menominee Range-Continued.

[Gross tons.]

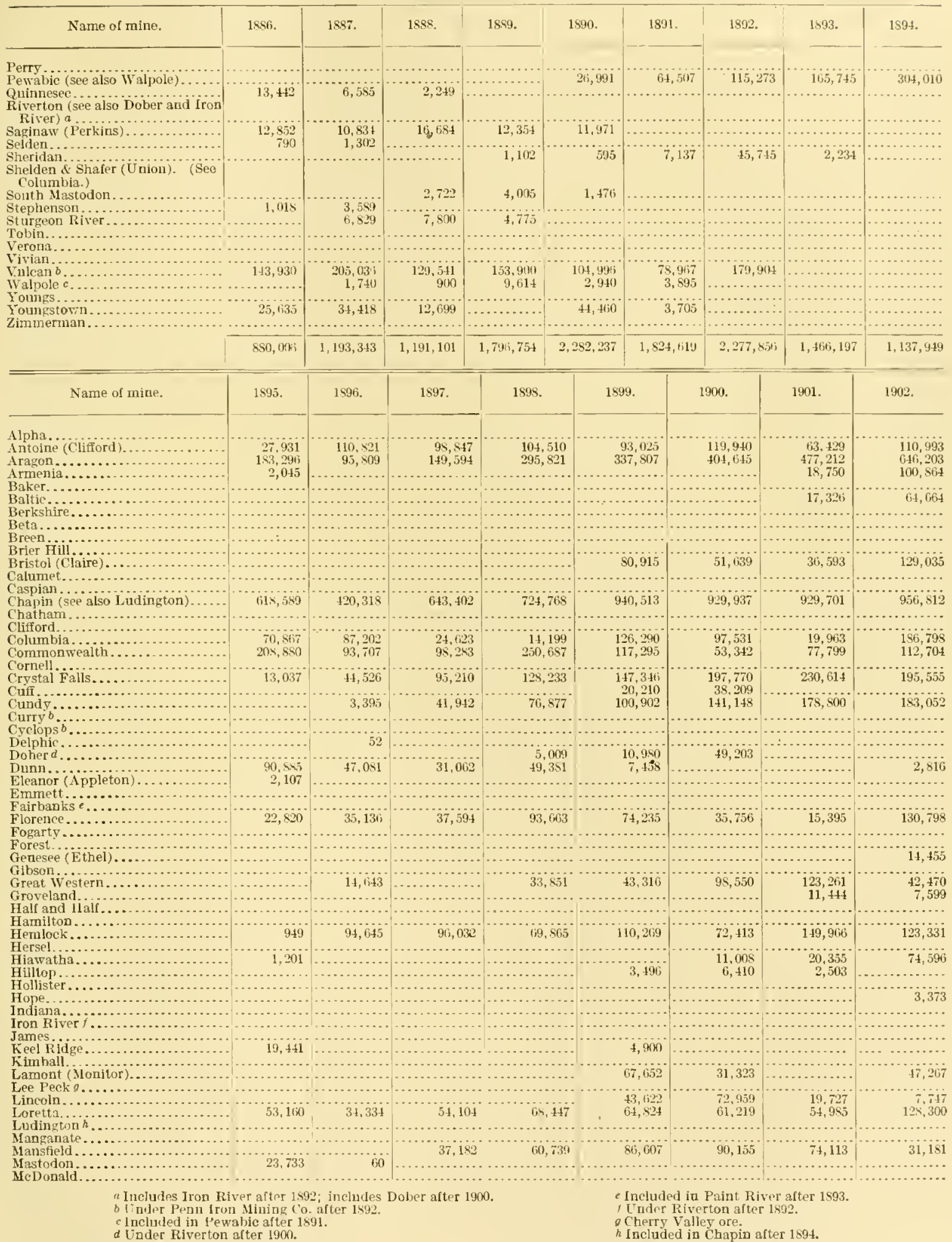


Table of Lake Supcrior iron-ore shipments from the carlirst shipment to date-Cuntinued.

Menominee Range Continized.

[Gross tons.]

\begin{tabular}{|c|c|c|c|c|c|c|c|c|}
\hline Name of mine. & $16,15$. & 1536. & $154 \pi$. & lings. & 1493. & 1900. & 1901. & 1942. \\
\hline \multicolumn{9}{|l|}{ letropolitan } \\
\hline $\begin{array}{l}\text { ichigan lixpl } \\
\text { illie (liewitt) }\end{array}$ & 1,071 & & $10 \begin{array}{r}216 \\
3 \pi 4\end{array}$ & & & & & $\begin{array}{l}53,272 \\
25,935\end{array}$ \\
\hline $\begin{array}{l}\text { Millie (liewitt).. } \\
\text { Monongahelit.... }\end{array}$ & $\begin{array}{ll}10,4124 \\
\ldots \ldots \ldots\end{array}$ & $\begin{array}{ll}21,415 \\
\cdots\end{array}$ & $\begin{array}{l}10,371 \\
\ldots \ldots \ldots\end{array}$ & $\begin{array}{l}17,130 \\
\ldots \ldots\end{array}$ & $15,19 \cdot 1$ & $\begin{aligned} 11,922 \\
\ldots \ldots \ldots\end{aligned}$ & $\begin{aligned} 12,133 \\
2,397\end{aligned}$ & 25,935 \\
\hline 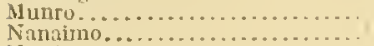 & & & & & & & & n.... \\
\hline orthweslern....... & & & & $\because$ & & & & $i, 32 i$ \\
\hline $\begin{array}{l}\text { Norwity a.......... } \\
\text { Paint River (see als }\end{array}$ & & & & & & $1,31 i$ & & $10,3 \times 3$ \\
\hline $\begin{array}{l}\text { Penn lron Minim } \\
\text { Perry ............ }\end{array}$ & 290,622 & 173,917 & $237,4 \times j$ & 223,713 & 209,161 & 197,600 & $354,121 j$ & 273,443 \\
\hline $\begin{array}{l}\text { Pewabic (sec also } \\
\text { Quinnesec........ }\end{array}$ & 212,551 & $273,5 \times 7$ & $279, \times 53$ & $305,0 \div 2$ & 530,129 & 374,013 & $507,7 \times 1$ & 530,291 \\
\hline $\begin{array}{l}\text { Quirnesect } \\
\text { Riverton (see also Dober and } 1 \text { ron } \\
\text { River) }\end{array}$ & & & & & 11,050 & 25,967 & $(i t), 383$ & $(12,531$ \\
\hline $\begin{array}{l}\text { River) c........ } \\
\text { Saginaw (l'erkins) }\end{array}$ & 2,101 & & & & 2,262 & 71,004 & 119,40 & $215, \$ 50$ \\
\hline 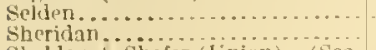 & & & & & & & & $\cdots$ \\
\hline $\begin{array}{l}\text { Shelden it shafer (Unjon). (See } \\
\text { Columbia.) }\end{array}$ & $10 i, 754$ & 3,119 & 146 & & 31,104 & $s, 063$ & & \\
\hline \\
\hline \multirow{2}{*}{\multicolumn{9}{|c|}{ 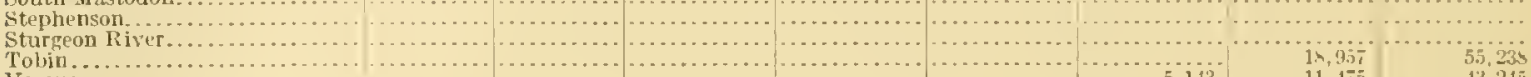 }} \\
\hline & & & & & & & $1 \rightarrow, 9 . \bar{z}$ & $5.5,235$ \\
\hline \multirow{2}{*}{\multicolumn{9}{|c|}{ 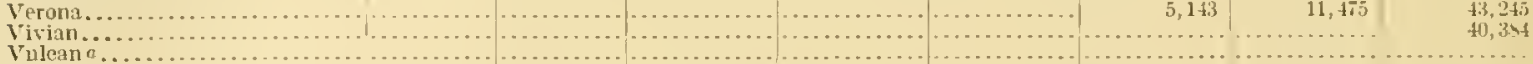 }} \\
\hline & & & & & & & & \\
\hline \multirow{2}{*}{\multicolumn{9}{|c|}{ 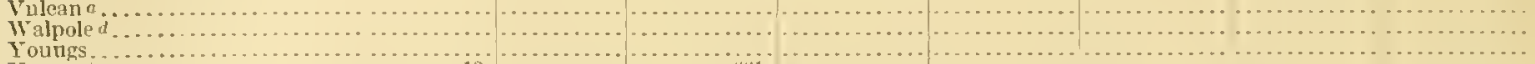 }} \\
\hline & & & & & & & & \\
\hline \multicolumn{9}{|l|}{ 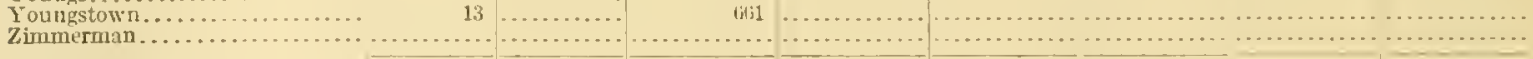 } \\
\hline & $1,923,795$ & $1,560,467$ & $1,937,013$ & $2,522,265$ & $3,301,052$ & $3,2 t i 1,221$ & $3,619,053$ & $4,-112,509$ \\
\hline Name & 1903. & 1904. & 1905. & 1900. & $190 \bar{i}$. & $190 \mathrm{~s}$. & 1909. & Total. \\
\hline pha..... & 1,370 & & & & & & & 1,370 \\
\hline (c) & 107,$481 ;$ & 91,164 & 138,395 & 195, $\$ 55$ & 100,996 & & & $1,3,3,792$ \\
\hline $\begin{array}{l}\text { Aragon ........ } \\
\text { Arumeniर .... }\end{array}$ & $\begin{array}{r}522,035 \\
31,901\end{array}$ & $\begin{array}{r}374,944 \\
16,577\end{array}$ & $\begin{array}{l}423,698 \\
.\end{array}$ & $\begin{array}{r}431,000 \\
2,, 552\end{array}$ & $\begin{array}{r} \pm 11,6.36) \\
36,665\end{array}$ & 226,354 & $24 t i, 954$ & $\begin{array}{r}5, \times 36,279 \\
311,605\end{array}$ \\
\hline aker......... & & & & & & & $\$ 5,003$ & $\begin{array}{r}311,005 \\
45,003\end{array}$ \\
\hline $\begin{array}{l}\text { Baltic } \\
\text { Berkshire...... }\end{array}$ & 123,236 & 151,114 & 133,246 & $186,+493$ & 159,119 & $129,03: 37$ & 174.426 & $1,165,6013$ \\
\hline $\begin{array}{l}\text { Berkshire..... } \\
\text { Beta........ }\end{array}$ & & & & & & 3,170 & 34,295 & $\begin{array}{r}37,735 \\
4,211\end{array}$ \\
\hline $\begin{array}{l}\text { Breen } \\
\text { Brier tilil......... }\end{array}$ & & & 11,625 & $21.00 s$ & 20,360 & & & 73,425 \\
\hline Bristol (Claire). & $24 i, 581$ & 132,420 & 210,388 & $29 \times .031$ & 345,670 & 190,300 & 390,525 & $\begin{array}{r}14,9 \times 1 \\
2,145,3677\end{array}$ \\
\hline $\begin{array}{l}\text { alumaet................. } \\
\text { aspian...... }\end{array}$ & & & & $15,7.3$ & 51,646 & 15,222 & & $\begin{array}{l}2,1,3,3 t i \\
121,35 t\end{array}$ \\
\hline $\begin{array}{l}\text { Caspian ........... } \\
\text { Chapin (see also I }\end{array}$ & $\begin{array}{r}2,0 \mathrm{NS} \\
70+, 051\end{array}$ & $\begin{array}{r}1,242 \\
541,324\end{array}$ & $\begin{array}{r}10,244 \\
902,625\end{array}$ & $80+\$ 75$ & 135 & $102,62 x$ & 149,023 & 527,971 \\
\hline Chatham.......... & . & 541,324 & $\begin{array}{l}902,628 \\
\ldots \ldots \ldots\end{array}$ & $\begin{array}{l}9 \$ 3,425 \\
\ldots \ldots \ldots\end{array}$ & $\begin{array}{r}855,305 \\
11,593\end{array}$ & $\begin{array}{r}391,6320 \\
45,926\end{array}$ & $\begin{aligned} 5 \times 5,64 i \\
6 \times, 730\end{aligned}$ & $16,152,416$ \\
\hline rd............ & & & $27 \mathrm{ss} 3$ & , n & …...... & ......... & $103,62 t$ & 103,626 \\
\hline $\begin{array}{l}\text { Columbia........ } \\
\text { Commonwealth. }\end{array}$ & 5,051 & $i, 617$ & 8,085 & 6,346 & & & & 942,703 \\
\hline Cornell ............. & & & & $(0,0)+0$ & & & $50,78 i$ & $\begin{array}{r}2,511,744 \\
49,302\end{array}$ \\
\hline $\begin{array}{l}\text { Crystal Falls... } \\
\text { Cuif............ }\end{array}$ & 117,096 & $1>0,983$ & 152,255 & 111,$8 ; 1$ & 114,159 & 296 & 986 & $1,735,251$ \\
\hline Cundy.... & iii, sui & & $\cdots \cdot$ & ....... & ….... & 1,410 & 5,512 & $\begin{array}{r}55,419 \\
844,659\end{array}$ \\
\hline a....... & & & & & & & ......... & 416,924 \\
\hline $\begin{array}{l}\text { Cyclopsa........ } \\
\text { Delphic........ }\end{array}$ & $\cdots \cdots$ & & $\cdots$ & $\cdots$. & & ....... & & 266,093 \\
\hline $\begin{array}{l}\text { Delphic......... } \\
\text { Dober }{ }^{2} . . . . .\end{array}$ & & & $\cdots \cdot$ & & & & & $\begin{array}{l}33,770 \\
65,192\end{array}$ \\
\hline Dunn ................ & 5,365 & $\cdots$ & $21,05 i$ & 91,476 & 141,992 & $8, \$ 29$ & 193,396 & $1,521,5-1$ \\
\hline Eleanor (Applet & ....... & & 1,819 & 3,121 & $1,67 T$ & ….... & $=0$ & 14,719 \\
\hline monetl........ & $\cdots$ & & , & & . & & & $\begin{array}{r}\text { Gi, } 655 \\
5,500\end{array}$ \\
\hline ..... & 95,577 & 153,452 & 233,858 & $169,+59$ & $17,9.955$ & 140,354 & 231,191 & \\
\hline$\cdots \cdots$ & $\ldots \ldots$ & ii. $9 \times$ & …...... & & 7,949 & 32,560 & 77.3513 & $117, x+5$ \\
\hline $\begin{array}{l}\text { Forest ... (E) } \\
\text { Genesee }) . .\end{array}$ & 61,694 & $\begin{array}{r}11.964 \\
132,3 \times 0\end{array}$ & & 80.071 & 36.981 & . . . . & 3 & $\begin{array}{l}11,+2 \times 1 \\
471,+39\end{array}$ \\
\hline ….. & & & 7,370 & 80,97 & $34,9,1$ & $\$ .540^{\circ}$ & $\begin{array}{l}(6,1,363 \\
36,24 i\end{array}$ & $\begin{array}{r}471,439 \\
57,151\end{array}$ \\
\hline $\begin{array}{l}\text { Great Western.... } \\
\text { Groveland....... }\end{array}$ & 100,751 & 68,315 & 191,265 & $311,21 \mathrm{~s}$ & 234,492 & 124,241 & 112,747 & $1,5=2,225$ \\
\hline $\begin{array}{l}\text { roveland. } \\
\text { alf and Hia }\end{array}$ & 1,294 & 4,737 & ......... & ........ & 13,913 & 9,123 & $24,9: 3$ & $7 \pm, 0 \%$ \\
\hline Half 5 & $\cdots$ & ( & & & & & & $\begin{aligned} 7,534 \\
9 ; 0 ; 2\end{aligned}$ \\
\hline ... & 79,420 & $13 t i, 232$ & 124,450 & 106,437 & iii,isi & 83,34 & ii2, 4 i & $1,5 \times 9,>14$ \\
\hline & & & & & & & & $1,3.0,4105$ \\
\hline atha... & $53, \times 25$ & $35,2 \times 4$ & $\begin{array}{r}9,704 \\
\ldots, \ldots \ldots\end{array}$ & $\begin{array}{r}20 \\
7,50\end{array}$ & & 139,160 & 131,739 & 45,612 \\
\hline$\cdots .$. & & & $\cdots$ & & 6,371 & $10,13,1$ & $25,8+2$ & 20,2392 \\
\hline & 7,339 & ….... & & $\cdots$ & & & & 2,530 \\
\hline rero & …... & $\cdots \cdots \cdots$ & $\ldots \ldots$ & & $\cdots \cdots$ & ....... & ....... & 17,71 \\
\hline ver $p .$. & & & & & 3.30 & 50,700 & (i) $\ddot{i}$ & 904,547 \\
\hline iidge.. & & & & & 2,300 & & (k),, (1) & $\begin{aligned} 152,971 \\
93,101\end{aligned}$ \\
\hline 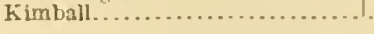 & . & & & & 11,224 & …. & ......... & 16,221 \\
\hline $\begin{array}{l}\text { a I'nder l'enn Iron Min } \\
\text { o Includes Curry, Cyclo } \\
\text { e Includes Iron River a } \\
\text { d Ineluded in l'ewable }\end{array}$ & $\begin{array}{l}\text { Ro. afle } \\
\text { I ixaz: in }\end{array}$ & $\begin{array}{l}1502 . \\
\text { and Vule: } \\
\text { cludes Dot }\end{array}$ & $\begin{array}{l}\text { to } 1893 . \\
1900 .\end{array}$ & & $\begin{array}{l}\text { E'nuler } \\
\text { f Inclui, } \\
0 \text { Under }\end{array}$ & $\begin{array}{l}\text { Riverton after } \\
\text { ed in Paint lit } \\
\text { Riverton aftes }\end{array}$ & $\begin{array}{l}1000 . \\
\text { ter after } 1893 . \\
1392 .\end{array}$ & \\
\hline
\end{tabular}


HISTORY OF LAKE SUPERIOR MINING.

Table of Lake Supcrior iron-ore shipments from the earliest shipment to date-Continued.

Menominee Range-Continued

[Gross tons.]

\begin{tabular}{|c|c|c|c|c|c|c|c|c|}
\hline Name of mine. & 1913. & 1904. & 1905. & $19,76$. & 1907. & 1908. & 1909. & Total. \\
\hline $\begin{array}{l}\text { Lamont (Monjtor).. } \\
\text { Lee l'eck } a . . . . . . .\end{array}$ & 43,736 & 29,393 & 74,991 & 89,950 & 42,090 & & & 555,341 \\
\hline Lineoln ............... & $15,100 i$ & 17,577 & 19,539 & 5.890 & $7 \mathrm{iji}$ & & 1,057 & $\begin{array}{r}2,841 \\
241,627\end{array}$ \\
\hline 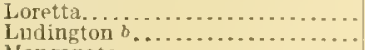 & 87,939 & 54,720 & $11 s, 738$ & 140,390 & 99,779 & $13,3.54$ & 96,613 & $1,190,020$ \\
\hline Manganate................ & & & & & & & & 6,444 \\
\hline $\begin{array}{l}\text { Mansfield....... } \\
\text { Mlastodon...... }\end{array}$ & 51,440 & 79,1103 & $38,5,54$ & & $1 \$ 3,532$ & 41,1333 & 115,713 & $1,102,998$ \\
\hline 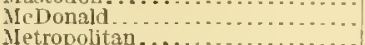 & & & & & & & $1,1 i i$ & $\begin{array}{r}425,103 \\
1,141\end{array}$ \\
\hline Michigan Exploration Co. . & & & 58,0 ss" & 146 & $39, \times 19$ & 603 & & 107,027 \\
\hline $\begin{array}{l}\text { Mfillie (Hewitt) } \ldots \ldots \ldots \ldots . . . \\
\text { Mlonongahela............ }\end{array}$ & $\begin{array}{r}40, \times 60 \\
6,913\end{array}$ & & & 36,815 & 18,691 & 3,322 & $10,387^{\circ}$ & 368,265 \\
\hline Munro.............. & 8,739 & 32,332 & 92,183 & 47,454 & 40,834 & 27,773 & 23,241 & $\begin{array}{r}9,310 \\
275,556\end{array}$ \\
\hline $\begin{array}{l}\text { Nanaimo........ } \\
\text { Northwestern. }\end{array}$ & izisgi & $0,0 \times 6$ & 91,238 & 91,792 & 53,778 & 305 & & 373,765 \\
\hline 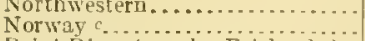 & & (a) & & & & & & 35,810 \\
\hline Paint River (see also Fairbanks).. & 9,863 & $11,257^{\circ}$ & 11,973 & 24,321 & 75,805 & & & $\begin{array}{r}1,291,352 \\
371,2 \times 9\end{array}$ \\
\hline $\begin{array}{l}\text { Penn Iron Mining Co. }{ }^{d} \ldots \ldots \ldots \\
\text { Perry } \ldots \ldots\end{array}$ & 343,543 & 141,918 & 423,244 & $496,5 \times 2$ & 351,128 & 176,211 & $42 x, 004$ & $\begin{array}{r}4,537,348 \\
3,138\end{array}$ \\
\hline 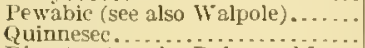 & $\begin{array}{r}489,175 \\
49,705\end{array}$ & 372,791 & 533,413 & $493, \$ 91$ & 457,796 & $3+5,341$ & 405,453 & $6,91 \%, 700$ \\
\hline Riverton (see also Dober and Iron & & & & & & & 3,147 & 502,903 \\
\hline $\begin{array}{l}\text { River) } \\
\text { Saginaw (Perkins) }\end{array}$ & $\begin{array}{c}97,633 \\
\ldots . . . .\end{array}$ & 81,543 & 82,611 & $\begin{array}{r}161,70-4 \\
21,017\end{array}$ & $\begin{array}{l}90,355 \\
26,0 \times 0\end{array}$ & $\begin{array}{l}47,073 \\
3 \times,(169)\end{array}$ & $\begin{array}{r}171.200 \\
19.994\end{array}$ & $1,141,098$ \\
\hline $\begin{array}{l}\text { Selden } \\
\text { Sheridan............................ }\end{array}$ & & & $\cdots$ & $-1,018$ & & & 19,997 & $\begin{array}{r}501,980 \\
2,092\end{array}$ \\
\hline $\begin{array}{l}\text { Shelden \& Shaler (Ünjon). (See } \\
\text { Columbia.) }\end{array}$ & & & & & & & & 116. 299 \\
\hline 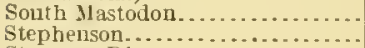 & & & & & & & & 5,203 \\
\hline $\begin{array}{l}\text { Stephenison } \\
\text { Sturgeon River............................ }\end{array}$ & & & & & & & & $\begin{array}{l}39,350 \\
19,404\end{array}$ \\
\hline Tobin $\ldots \ldots \ldots \ldots \ldots \ldots \ldots \ldots$ & $\begin{array}{l}45,396 \\
50,910\end{array}$ & I1.3, 669 & 166,529 & $235, \times 67$ & 237,781 & 161,612 & 359,668 & $1,394,737$ \\
\hline Vivian & 12,122 & 81,354 & 90,426 & 122,577 & 48,493 & 10,056 & & $\begin{array}{l}130,975 \\
405,412\end{array}$ \\
\hline 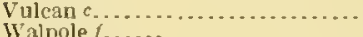 & & & & & & & & $1,665,6054$ \\
\hline Wralpole $1, \ldots \ldots \ldots$ & ...... & . & 10,926 & $47,5 \times 3$ & 92,632 & 70,094 & 154,150 & $\begin{array}{r}19,089 \\
375,355\end{array}$ \\
\hline \multirow{3}{*}{ Zimmerman......................... } & & & & & & 1..... & . & 151,425 \\
\hline & & & & & & 1,032 & 10 & 12,135 \\
\hline & $3,749,567$ & $3,074,845$ & $4,495,451$ & $5,109,058$ & $4,964,728$ & $2,679,156$ & $4,875,385$ & $71,212,121$ \\
\hline
\end{tabular}

Mesabl Range.

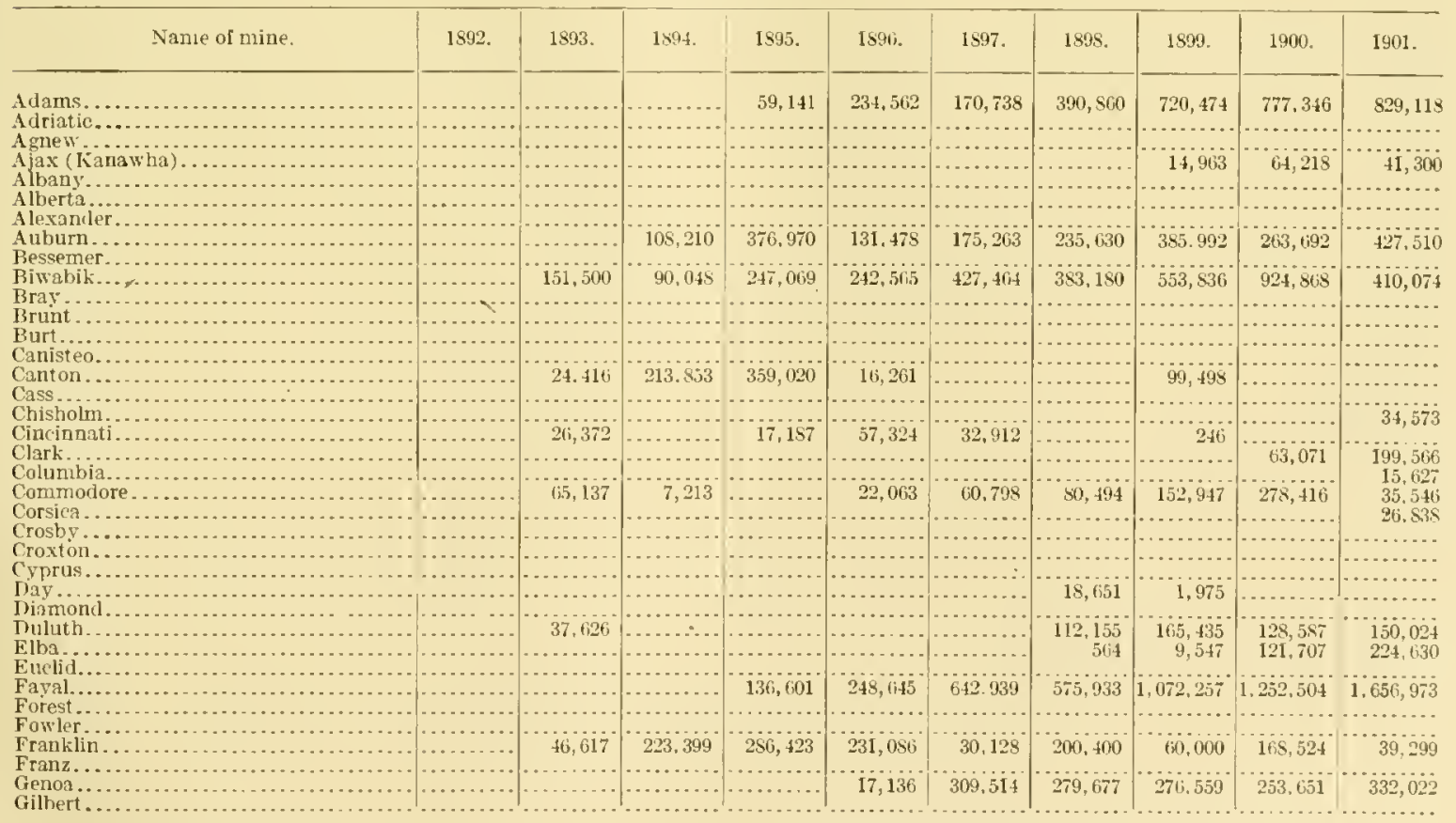

a Cherry Valley ore.

Included in Chapin after 1894.

c Under Penn Iron Mining Co. after 1992

d Includes Curry, Cvclops, Norway, and Vulcan prior to 1893.

e Includes Iron River after 1892: includes Dober alter 1900.

$47517^{\circ}$ - voL $52-11-5$ 
Table of Lake siuprior iron-ore shipments from the carlirst shipment to dute-Continued.

Mesabl Range - continued.

[Gross toris.]

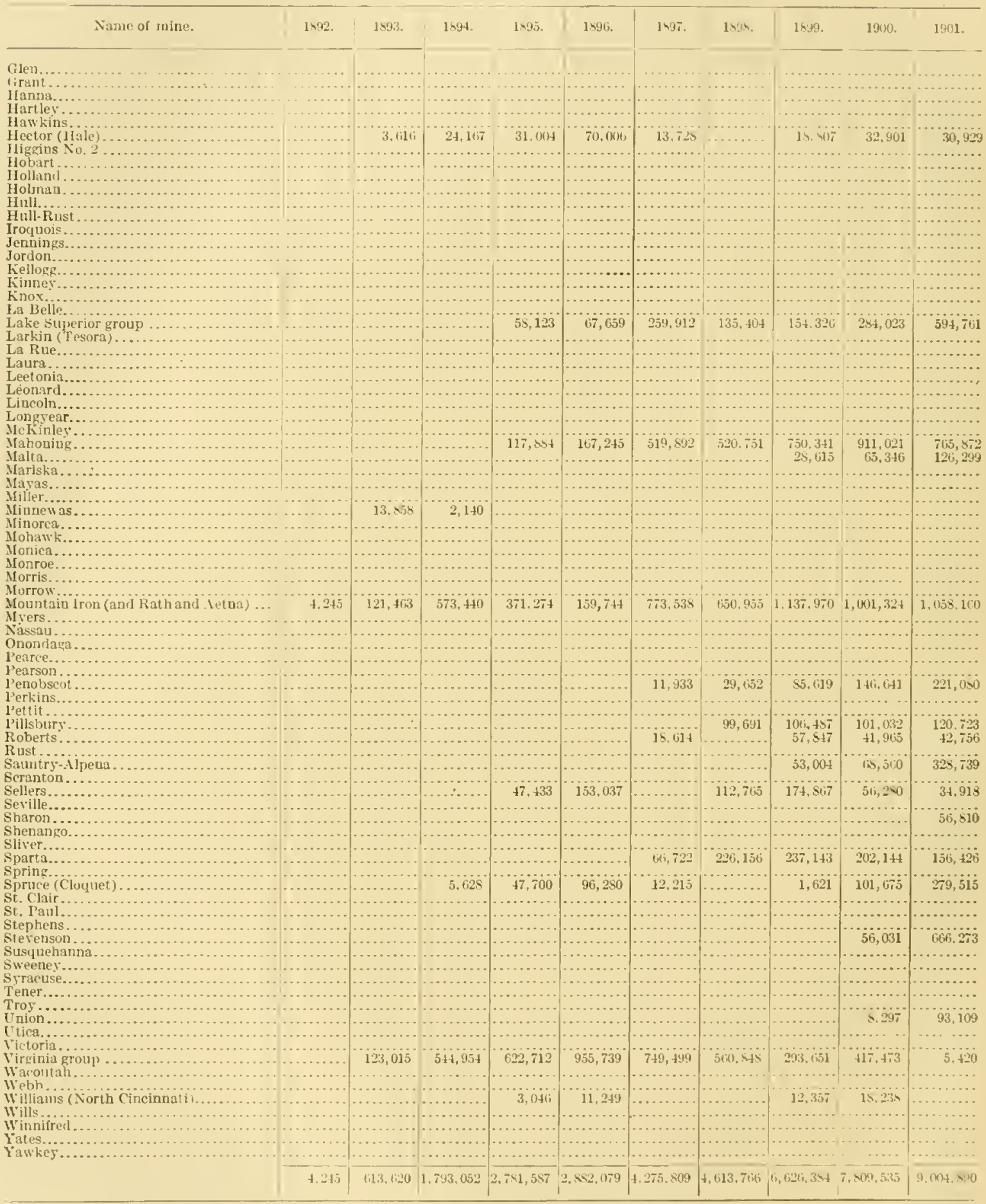


HISTORY OF IAAKE SUPERIOR MINING.

Table of Lake Superior iron-ore shipments from the carliest shipment to date-Continued.

Mesabi Range-Continued.

[Gross tons.]

\begin{tabular}{|c|c|c|c|c|c|c|c|c|c|}
\hline Name & 1902. & 1903. & 1904. & 1905. & 1906. & 1907. & 1908. & 1909. & Total. \\
\hline $\mathrm{da}$ & $1,242,923$ & $1,109,750$ & 940,105 & $1,140,981$ & $1,23 \%, 350$ & $1,136.513$ & 765,592 & $1,8: 9,372$ & $12,555^{\circ}$, \\
\hline $\begin{array}{l}\text { driati } \\
\text { gnew. }\end{array}$ & 40,552 & $10 \mathrm{~m}, 5 \pm 7$ & 96,405 & 44,651 & $\begin{array}{r}3,294 \\
1(3,3,260)\end{array}$ & $\begin{array}{r}70,157 \\
149,034\end{array}$ & & 317 & $92-2+3$ \\
\hline jax (lian & 24,529 & 23,932 & 912 & 25,439 & $9,0,57$ & & & & $\begin{array}{l}923, \\
207, \mathrm{c}\end{array}$ \\
\hline & & $109,60 \mathrm{~s}$ & 153,433 & $241,1 \bigcirc 6$ & 350,371 & 437,521 & $64,500^{\circ}$ & 368,057 & $1,731,0$ \\
\hline exar & & & & 073 & & & & $\cdots$ & \\
\hline abur & $3 s, 283$ & & & & 60,547 & & & & $\begin{array}{l}1,0 \\
3,0\end{array}$ \\
\hline $\begin{array}{l}\text { essem } \\
\text { iwabi }\end{array}$ & & & 80,303 & 112,630 & 131,791 & 78,012 & 120,350 & 227,767 & 6,8 \\
\hline $\begin{array}{l}\text { wabi } \\
\text { ay... }\end{array}$ & $\begin{array}{c}623,127 \\
\ldots \ldots \ldots\end{array}$ & 807,511 & 647,614 & 1,09 & 74 & 50 & 781 & $5+2,821$ & $9,121,5$ \\
\hline unt. & & & & & 75,401 & $17 \times, 935$ & $630^{\circ}$ & $\begin{array}{c}65,511 \\
14,212\end{array}$ & $\begin{array}{r}65,5 \\
269,1 \\
\end{array}$ \\
\hline urt... & & & & $1,860,452$ & $1,37 t, 875$ & 1,50 & $1,460,998$ & $1,660,101$ & $7,859,6$ \\
\hline & & & & & & $45 \pm$ & 2,760 & 505 & 3,7 \\
\hline LSS & & 50,155 & 29,554 & 59,552 & $\ddot{6} \overline{5}, 961$ & 34,121 & & & 241,3 \\
\hline ishol & 200,629 & 168,531 & 130,732 & 231,296 & & & 228,356 & 314,597 & $1,946,9$ \\
\hline $\begin{array}{l}\text { Cinciy } \\
\text { Clark }\end{array}$ & 350,799 & 300,492 & & & & & & & 0 \\
\hline Clark & & & 250 & $\begin{array}{r}358,091 \\
1,360\end{array}$ & 94 & 83 & 334 & 12 & 2 , \\
\hline . & 65,433 & $20,+36$ & $249^{\circ}$ & 146,901 & 203,401 & 477,203 & jiti, 0o9 & 409,148 & $2,201,8$ \\
\hline & 59,292 & 34,043 & 30,131 & & & & & & 636,1 \\
\hline & 18,594 & 100,297 & & & & 55 & & & 1 , \\
\hline . & & 815 & 244,343 & 235,351 & $192,1.14$ & 200,949 & 115 & 685 & $\begin{array}{l}1,0,2,0 \\
1,28,0\end{array}$ \\
\hline as & 106,516 & 107,751 & 8 & & & & & & \\
\hline uluth & 150,220 & $150,0,3$ & 149, & 142,172 & 36 & 93,120 & 149.135 & 601 & 1,7 \\
\hline & 207,454 & 93,616 & 123 & 125,724 & 25 & 134,438 & 147,916 & & 1,1 \\
\hline 3 & $1,919,172$ & $1,460,601$ & 975,102 & $1,35 \$, 922$ & $1,634,4,53$ & $1,578,512$ & $1,434,879$ & $\begin{array}{r}82,627 \\
1,879,357\end{array}$ & $8,132,55$ \\
\hline & & (n............ & 85,280 & 99,785 & 41,647 & $\begin{array}{r}1,0.40 \\
+.40\end{array}$ & $\begin{array}{r}1,420 \\
2,40\end{array}$ & 6, 304 & 240,2 \\
\hline $\ln$ & iii,0s5 & 92,019 & 65. & & & & 21.511 & 99,892 & 1 \\
\hline & & & 4 & 70,210 & $\begin{array}{l}66,935 \\
11,0 \text { is }\end{array}$ & $\begin{array}{r}30.926 \\
907\end{array}$ & 46 & 93 & 1,7 \\
\hline $\begin{array}{l}\text { enoa.. } \\
\text { ilbert. }\end{array}$ & 399,719 & 303,700 & 244,150 & $281,0 \leqslant 1$ & 179,468 & $10 x, 610$ & & & 2, \\
\hline ath & 23,875 & 171,705 & 280. & 257.835 & $279,42-1$ & & 331.927 & 3 & 1, \\
\hline rant. & $51,9+6$ & 15,928 & 41,413 & $\begin{array}{r}28 ., 830 \\
49,227\end{array}$ & $279,42-1$ & $205,+26$ & 272 & & 1,9 \\
\hline an & & & & & & & & 238,873 & \\
\hline $\begin{array}{l}\text { lart } \\
\text { Iaw }\end{array}$ & 5.592 & 107,905 & $99,0.55$ & 202 & & & & & \\
\hline $\mathrm{Her}$ & 54.289 & & & 30 & 21 & 4 & $\begin{array}{l}245 \\
\ldots\end{array}$ & $\begin{array}{r}316,783 \\
30,726\end{array}$ & $\mathbf{1 , 5}$ \\
\hline & & & 35,256 & 236,598 & 341,319 & 173 & & 322,504 & $\begin{array}{r}418,3 \\
1,111,1\end{array}$ \\
\hline Ho & & & & & 975 & & “. & 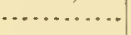 & \\
\hline & & & & $158,4 \$ 4$ & $95,4 \pi 2$ & & 1,682 & & 27 \\
\hline & & & & 233,065 & 592 & & 163 & 57 & 11 \\
\hline & & 17,562 & & & 1,0 & 2,0 & 2,92 & 3,03 & 10,5 \\
\hline $\begin{array}{l}\text { Iroqu } \\
\text { Jenn }\end{array}$ & & 17,562 & 50,215 & 61,109 & 190 & & 151 & & 87 \\
\hline & 147,931 & 190,024 & 97,474 & 185,854 & $\begin{array}{r}84,715 \\
110.765\end{array}$ & 2 & 13 & & 92 \\
\hline & & 3235 & & & 110,765 & 96 & 31 & & $\begin{array}{l}925,33 \\
196,7\end{array}$ \\
\hline $\begin{array}{l}\text { Finney. } \\
\text { Knox... }\end{array}$ & & 32,352 & 6,225 & 89,161 & 57,691 & 145,959 & 176,510 & 21 & 795,3 \\
\hline & 70,753 & 45,298 & 89,554 & 78,597 & $50,+66$ & $56,1 \pm 6$ & 51,638 & 27,216 & \\
\hline $\begin{array}{l}\mathrm{La} \\
\mathrm{La}\end{array}$ & 766,311 & $1,226,066$ & $1,415,884$ & & & & & & \\
\hline $\begin{array}{l}\text { Lar } \\
\text { La }\end{array}$ & $\ldots$. & 53 & 105 & 197 & & 22,040 & 14,030 & 1 & $1 ?$ \\
\hline $\mathrm{La}$ & 16,153 & & $\begin{array}{r}10,7,10 \\
3,778\end{array}$ & 27. & & & & & $1, \frac{2}{7}$ \\
\hline & 28,784 & & 228,5 & 352 & & & 289,490 & 553 & 2, \\
\hline & & & 151, & 297 & & & & & 2, \\
\hline $\begin{array}{l}\text { Line } \\
\text { Lon }\end{array}$ & 87,908 & 279,399 & 153,822 & 275,777 & 367,192 & 297,870 & 379,219 & 303,066 & \\
\hline$\cdots$ & 22,788 & 81,604 & 221 & 16,778 & & & & & \\
\hline & 1,038 & $1,009.466$ & 701,325 & $1,011,661$ & 1,27 & 1,5 & & & 12,5 \\
\hline & $222,6-10$ & 11,675 & 66,641 & 139,853 & 763 & & & & $1,044,32$ \\
\hline ? & & & & & & & 30 & 77,690 & $\begin{array}{l}108,05 \\
220,70\end{array}$ \\
\hline & & & & 118,520 & 234,071 & 279,453 & 224,321 & 277,119 & $1,133,1$ \\
\hline & & & & & & & & & $1,150,10$ \\
\hline & 35,499 & 115,880 & 121.739 & 117,653 & & & & & $\begin{array}{l}90 \\
55\end{array}$ \\
\hline Mon & & & & & & & 119 & & 55 \\
\hline & & & ... & 0 & $39^{\circ}$ & & & & \\
\hline .... & 35,571 & 19 & $\cdots$ & 1,07 & & 2,1 & 52 & $1,831,187$ & 7,3 \\
\hline n (and Rath and Aetna)... & $1,617,772$ & $\begin{array}{r}4,9 . \\
1,34 \%,\end{array}$ & $\begin{array}{r}33.01 \\
\end{array}$ & & & & & & \\
\hline & & $1,3+5,714$ & 1. I (kik, 850 & $\begin{array}{r}2,495,059 \\
158,568\end{array}$ & $2,563,111$ & $\begin{array}{l}1,97 \\
1,5\end{array}$ & $\begin{array}{l}206,198 \\
150,249\end{array}$ & & $\begin{array}{l}98,87 \\
14,73\end{array}$ \\
\hline & & & & 183,068 & 228, †1 & $\begin{array}{r}15 \\
1 !\end{array}$ & 150,249 & & 11 \\
\hline & & & & & & & 30,887 & & 80. \\
\hline & 54,854 & 50.204 & 235 & & 65,862 & 71,645 & & & \\
\hline$c^{2}+2$ & 209.531 & $1,(115$ & & & & & & $68,6 \$ 3$ & \\
\hline & & & & & & & & & 5 \\
\hline tit & 17,278 & 52. & $27,05 \mathrm{~s}$ & 140,239 & 57 & 74 & 57. & 83,548 & \\
\hline & $\begin{array}{r}23 \times, 122 \\
2 \times, 972\end{array}$ & 229,133 & ... & 161 & & 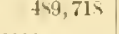 & & & $\begin{array}{r}1,64 \\
19\end{array}$ \\
\hline & & & & 272,114 & 281.517 & 213.355 & $22 \%, 079$ & & \\
\hline 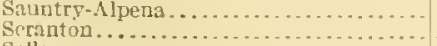 & 249,537 & & & & & . & & & \\
\hline ... & $193, \pm 29$ & 251,031 & & 261,501 & $2+1,031$ & 155,060 & & & \\
\hline & 10.0, & & $-20 i$ & & & & $35+.750$ & $\begin{array}{r}626,109 \\
23,585\end{array}$ & $\begin{aligned} 2,560,85 \\
23,54\end{aligned}$ \\
\hline
\end{tabular}


Table of Lake Superior iron-ore slipments from the earliest shipment to date-Continued.

Mesabl Range-Continued

[Gross Ions.]

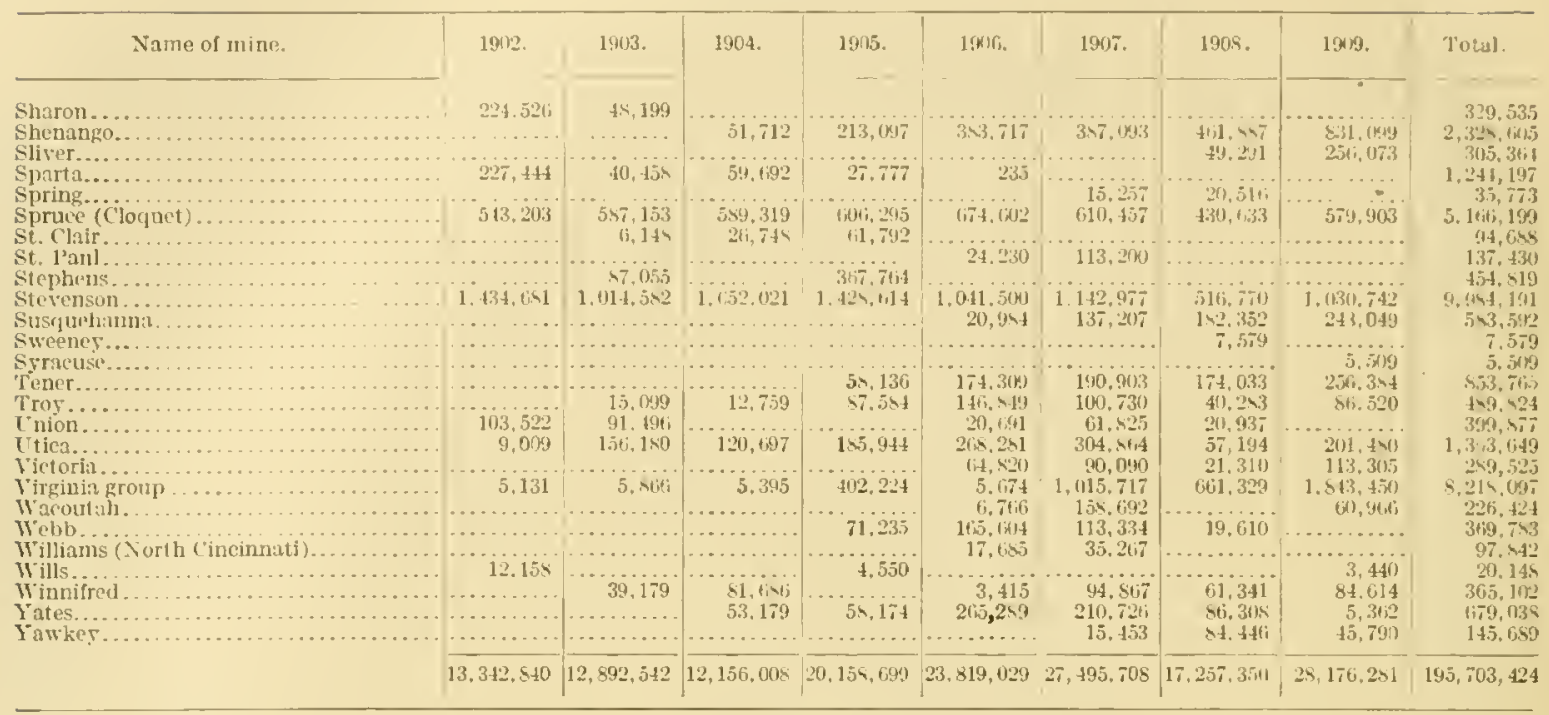

Vermilion Range.

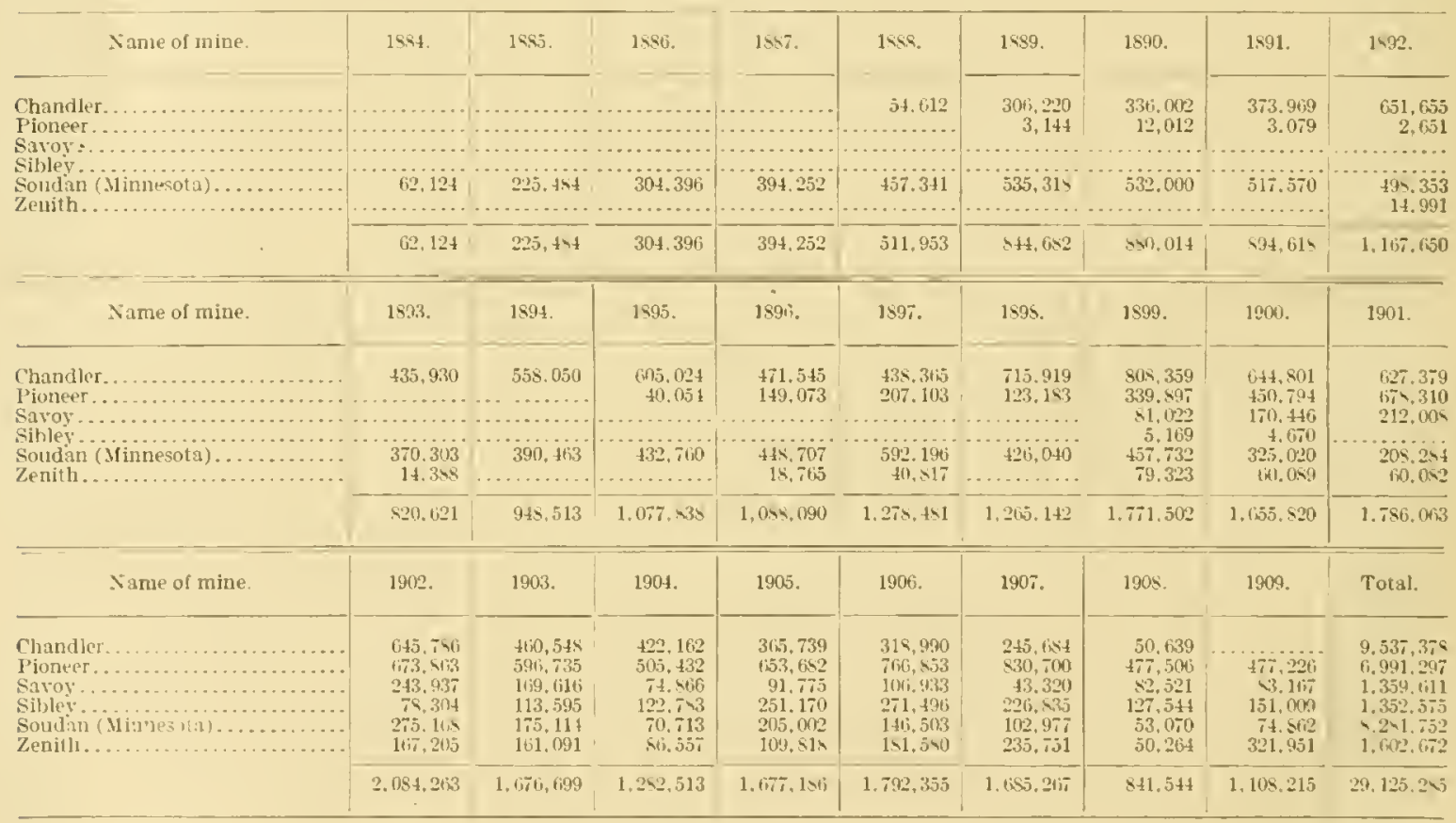

Miscellaneous (In Wisconsin).

\begin{tabular}{|c|c|c|c|c|c|c|c|c|c|c|}
\hline Name of mine. & $1 \times 92$. & 1593. & $1 \times 94$. & 189.5. & 189 f. & $189 \pi$. & $180 x$. & 1899 & 1900. & $19 n 1$. \\
\hline \multicolumn{11}{|l|}{$\begin{array}{l}\text { Illinois } \\
\text { lron Rivige. } \\
\text { Ifarvillo }\end{array}$} \\
\hline Mayville... & 9,044 & 7.923 & 10,311 & $1 i, 4 i 2$ & 13,141 & $10,54 \pi^{\circ}$ & is, 1.51 & 19.731 & 20.6vi & 22.410 \\
\hline & 9,044 & 7,925 & 10,511 & $1+i, 4 i 2$ & 13,144 & $10,5 * j$ & 18,151 & 19,731 & 20,94 & $\because 40$ \\
\hline
\end{tabular}


IIISTORY OF LAKE SUPERIOR MINING.

Table of Lake Supcrior iron-ore shipments from the carliest shipment to date-i"ontinned.

Miscellaneous (in Wisconsin)-Continised.

[Cross tons.]

\begin{tabular}{|c|c|c|c|c|c|c|c|c|c|}
\hline Name of mine. & 1902. & 1903. & 1904 & 1905. & 1906. & 1907. & $190 \mathrm{~s}$ & 1909. & Total. \\
\hline $\begin{array}{l}\text { Mllinois. ..... } \\
\text { Iron lidge.... } \\
\text { Mayville..... }\end{array}$ & 23,338 & $\begin{array}{l}17,913 \\
18, \$ 3 t\end{array}$ & $\begin{array}{l}47,922 \\
19,558 \\
26,562\end{array}$ & $\begin{array}{l}71,413 \\
39,978 \\
20,610\end{array}$ & $\begin{array}{l}67,118 \\
61,624 \\
15,847\end{array}$ & $\begin{array}{r}72,180 \\
3,1966 \\
19,1,44\end{array}$ & $\begin{array}{l}51,108 \\
71,341\end{array}$ & $\begin{array}{l}15,9.51 \\
\text { titi, So4 }\end{array}$ & $\begin{array}{l}309,741 \\
158,99 . \\
411,892\end{array}$ \\
\hline & 23,338 & 36,719 & 94,042 & 132,001 & $144,5 \$ 9$ & 95,790 & 122,449 & $82,75 y$ & $8 \$ 0,627$ \\
\hline
\end{tabular}

Summary.

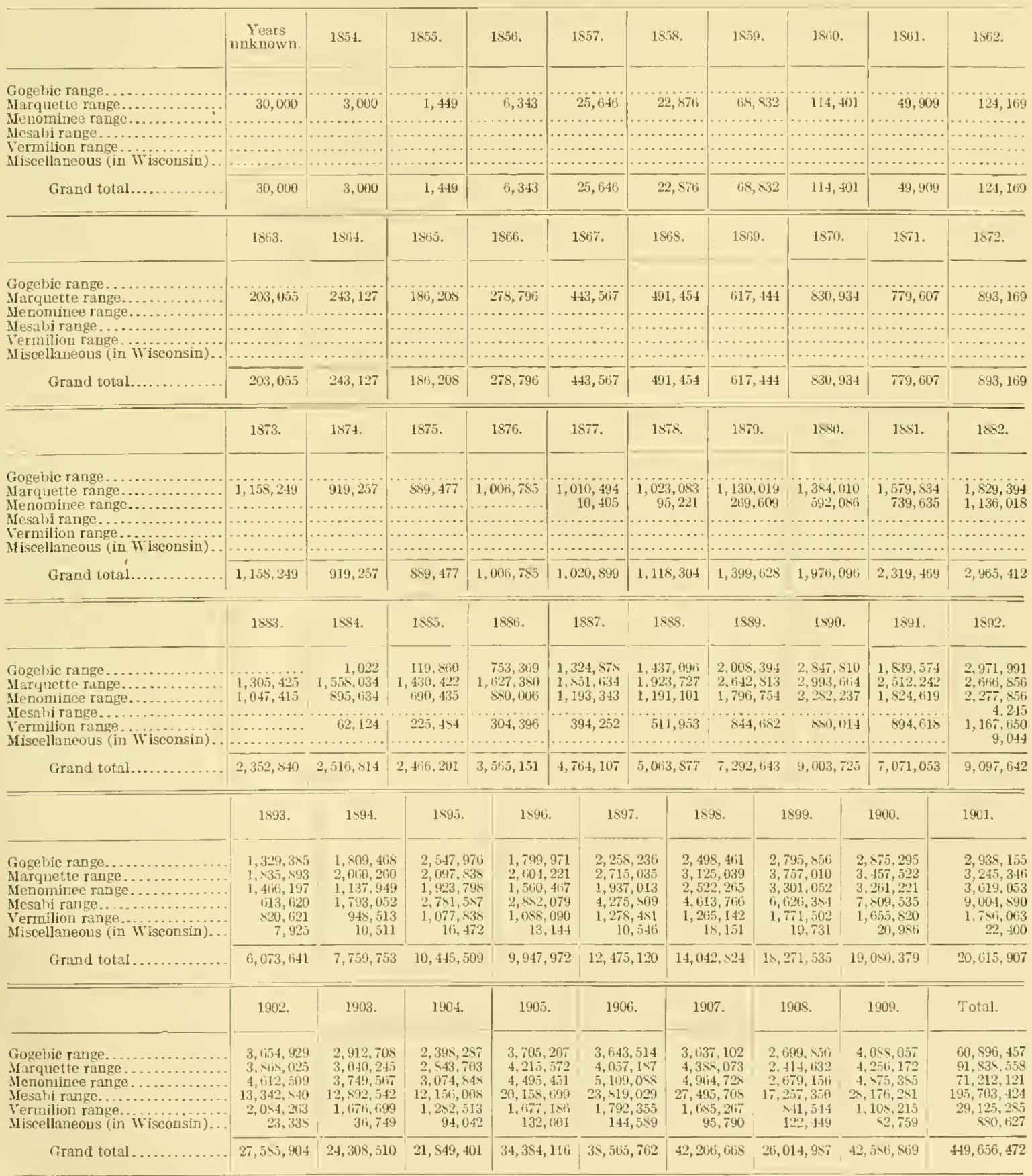




\title{
CHAPTER III. HISTORY OF GEOLOGIC WORK IN THE LAKE SUPERIOR REGION.
}

\author{
GENERAL S'TATEMEN'T.
}

The Lake Superior region is among the first in which detailed study and mapping of the ancient erystulline complex have been extended over large areas; it has had special attention because of the magnitude of the mining industry and the commereial importance in mining of a correct understanling of geologic strueture. Without the mines, expenditure for geolugic work upon so large a scale woukd scareely have been undertaken in a district so inaccessible. The inerease of knowledge eoncerning the geology of the region has elosely followed the development of mining.

The enrlier geologic work in the Lake Superior region was of a most general nature and was necessarily confined to the shores of Lake Superior and to parts immediately accessible from canoe routes tributary to Lake Superior. The great distances and the diffieulties of trarel made detailed mapping impracticable over large areas in the interior. Numerous important observations were made which have subsequently been found to be of value, but these were in the main fragmentary. Detailed geologic work has been lor the most part confined to the ore-bearing areas and wis not hegun until these areas had been located or opened for mining.

\section{WORK OF INDIVIDUALS.}

On the Canadian shore of Lake Superinr and in adjacent territory the geologic work has been of a somewhat general nature except in one or two localities. This is so largely because no ore-bearing districts lave been cliscovered in this part of the region of sufficient commercial importance to warrant large expenditures for geologic work. The geologists who have contribut ed most to the knowledge of this portion of the district are Bigsby $(1825,1552,1854)$, Barfield (1S29, 1S45), Logan (1S47, 1S52, 1S63), Murray (1S47, 1S63), Macfarlane (1S66, 1S6S, 1S69. 1S79), Robert Bell (1870, 1872-1S75, 1S\$3, 1890), Selwyn (1873, 1S83, 1855, 1S90), G. M. Dawson (1S75), Lawson (1886, 1858, 1890, 1891, 1893, 1896), II. L. Smyth (1891), Pumpelly (1891), IT. II. C. Smith (1S92, 1893), Coleman (1S95-1902, 1906, 1907, 1909), Willmott (1S9S, 1901, 1902), Vin IIise (1S9S, 1900), IIcInnes (1S99, 1902, 1903), Parks (1S9S, 1902, 1903), Clements (1900), Miller (1903), W. N. Suith (1905), Burwash (1905), J. M. Bell (1905), and Mloore (1907, 1909). All were in the service of the Canadian gorernment or of the Canadian Geological Surver except Coleman, Willmott, J.M. Bell, Burwash, and Moore, who represent ed the Ontario Bureau of Mines, and Pumpelly, II. L. Smyth, Van Hise, Clements, and W. N. Smith, Ameriean geologists. The principal detailed mapping has been that in the Lake of the Woods and Rainy Lake listrict by Lawson (18\$6-1S\$S), that in the Steep Rock Lake region by Pumpelly and Smyth (1S91). and that in the Miehipicoten iron district by Colcman, Willmott (1S9S), Burwash (1905), and J. II. Bell (1905). C'losely related is the extremely important work of Logan and Murray (1S63) in the original Iuronian clistrict east of Lake Superior and north of Lake IFuron.

In the United states portion of the lake Superior region early general observations were made by explorers sent ont hy the United States Crovernment. Schooleralt risited the south shore of Lake Superior and ascended St. Louis River (1S21, 1S54). Owen (1S.7, 1S51, 1S52) visited particularly the west end of Lake Superior and the upper Misciscippi and its tribu-

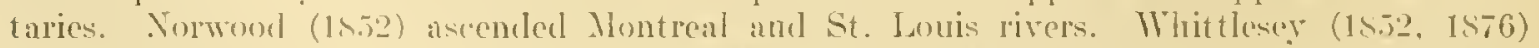
explored northern Wisconsin and northem Minnesota. Whitney (1S5t, 1S56, 185i) risited 
nearly all parts of the Lake Superior shore. tions on the Lake Superior region as a whole.

Houghton (1S40-1S41) made general olsserva-

However, much the larger part of the carly geologic exploration was confinat to the regions now known as the Marquette iron and Keweenaw copper districts, the extension of the Keweenaw district into the Gogebic district, and adjacent parts of the Upper I'eninsula. The first important detailed report on the Keweenaw copper distriet was that of Douglass Houghton, of the Michigan Geologieal Survey, in 1841, based on work done several years belore. This report led directly to the opening of the Keweenaw copper district. He was followed by Whitney (1847-1850), Foster (1848, 1850), Jackson (1849, 1850), and Agassiz $(1550,1867)$. Sulsequent geologic work on Keweenaw Point of great importunce was that of Brooks and Pumpelly (1S72, 1S73), Marvine (1873), Rominger (1873), and others, for the Michigan Geological Survey. Field study leading to the preparation of a monograph on the copper-bearing rocks of Lake Superior was begun by Irving prior to 1880 for the Wisconsin Geological Survey and completed in 1S82 for the United States Geological Survey. This volume ${ }^{a}$ has remained the standard reference book on the district to the present time, though contributions of much value have been made by Hubbard, Lane, Seaman, and others.

The extension of Houghton's work in the copper distriet and that of Burt, his assistant, led directly to the discovery and opening of the Marquette iron-bearing district in 1848 . The important early geologic work in this district was done by Burt (1850), Foster and Whitney (1851), Kimball (1865), and Credner (1869), all in the service of the United States Government. Later followed the important contributions of the geologists of the Michigan Geological SurveyBrooks (1S73, 1876), Wright (1S79, 1S80), Rominger (1S73, 1S81), and others. Wadswortli's contributions to the geology of the Marquette and Keweenaw districts (1Ss0, 18\$1, 18\$4, 1890, 1891) have been the subjeet of much controversy.

After the opening of the Keweenaw and Marquette districts geologic mapping began to be extended to the south and west through the Upper Peninsula of Michigan and northern Wisconsin. Particularly noteworthy are the reports of the Michigan Genlogical Survey on the general geology of the Upper Peninsula of Michigan, but particularly of the Marquette, Nenomince, and Gogebic districts, by Brooks (1S73, 1876), Wright (1879, 1850), Rominger (1881, 1895), and Alexander Winchell (1S88). The Menominee range in its Wisconsin extension was reported on by Wright (1880) and Brooks (1880) for the Wisconsin Survey, and Fulton (18s5). The Penokee district and adjacent territory in northern Wisconsin was described by the geologists of the Wisconsin Survey - Laphom (1860), Whittlesey (1863), Irving (187t, 1877, 1880), Sweet (1876), Chamberlin (1875), and Wright (1880). Early general observations in northern Wisconsin were contributer by Pereival (1S56), Daniels (1S58), Lapham (1860), Hall (1861-62), Irving (1872-1874, 1877, 1878, 1850, 1852, 1853), Murrish (1873), Eaton (1873), Wright (1873), Chamberlin $(1877,1878,1880,1882,1883)$, Strung (1880), Sweet (1880, 1882), and Van Hise (1884).

The aletailed geologic work by the United States Geological Survey leading up to the preparation of the series of monographs on the iron-bearing districts of Michigan and Wisconsin was begun in the Gogebic district by R. D. Irving and C. R. Yan Itise in 18s4. On the completion of work there detailed work was taken up in the Marquette district, 1858 to 1895, by Van Hise, Bayler, Merriam, Smyth, and others, and a monographic report ${ }^{b}$ was issued in 1895 ; similar work was done in the Crystal Falls district from 1893 to 1898 by Van Hise, Bayley, Clements, Smyth, Merriam, and others, and a monograph ${ }^{c}$ was issued in 1899; and the Menominee district was examined by I in ITise, Bayley, Clements, Weidman, and others, and a monograph $^{d}$ was issued in 190t. Since the completion of the work in the Henominee district in 1900 the Uniter States Geological Survey has been deroting its attention to Mimnesota, although a small amount of general work has been done in Michigan and Wisconsin. White the United States Geologrical Survey has been mapping the districts of the Upper Peninsuli, the Michigan Geological Surrey has given relatively less attention to this area than it had previously,

a Mon. I. S. Geol. Survey, vol. 5, 1s\%3.

b ldem, vol. $2 s, 1835,60 \mathrm{sp} ., 35$ pls., and atlas. c ldem, vol. 3f, 1*99, $512 \mathrm{pp} ., 53 \mathrm{pls}$.

c Idem, vul. 4 i, 1544,513 pp., 43 pls. 
but during this period it has issued inportant reports on the districts of Keweenaw Point, Poreupino Momntains, and Isle Royal by IJbbard, Lane, Wright, and others. Lane and Seaman in 1909 and 1910 published an interesting summary of their views on Michigun greology. In 1909 and 1910 R. ( . Allen, sucressor to Mr. Lane as state geologist, mapped and reported on the Bron River district of Alichigan and then took up the mappingr of the regron between the Jron River listrict and Lake Gorrebic.

The Wisconsin Geological Survey, after the completion of the work of Irring, Chamberlin, Wright, and others, was discontinued in 1883. The new Wisconsin Geological and Natural History Surver, established in 1597 , has been engaged continuously through Weidman in mapping the crystalline rocks of north-central Wisconsin and the outlying areas, ineluding the Baraboo iron district. Hobles and Leith (1907) mapped the voleanic rocks of Fox liver in central Wisconsin. In $1910 \mathrm{IV}$. O. Hotchkiss, for the Wisconsin Geological and Naturnl History Survey, took up the detailed mapping of the Florence iron-bearing district of northeastern Wisconsiu, and F. T. Thwaites, for the same organization, examined in detail the Kewcenawan and Cambrian sundstones on the southwestern shore of Lake Superior, with a riew of ascertaining their relations.

In Minnesota carly work of a most general nature was done by Owen (1S51, 1852), Schooleraft (1S21, 1S54), Norwood (1S47, 1S52), Eames (1S66), and Whittlesey (1866, 1S76). The Minnesota shore and the Gunflint Lake areas were examined in detail by Irving and assistants in 18S0. The Mimnesota Survey began its study of the crystalline rocks of northern Minnesota in 1872 and continued it until 1901. The men engaged in this work were N. H. Winchell, Alexander N. Winchell, II. T. Winchell, U. S. Grant, J. E. Spurr, and others. A number of speeial reports were issued, but the final general account appeared in volumes 4,5 , and 6 of the Mimmesota Surrey, published, respectively, in 1S99, 1900, and 1901. The Minnesota Survey was then discontinued. The work of the United States Geologieal Survey in IInnesota was begun in the Vermilion district in 1596 by Tan ILise, Clements, Bayley, and Leith, and a monographie report ${ }^{a}$ was issued in 1903. Upon the completion of this work in 1899 work was taken up in the Nesabi district by Leith under direction of C. R. Van Hise, and the monograph ${ }^{b}$ on this distriet was issued in 1903. Since that time no detailed mapping has been done in the Minnesota region by the United States Geological Survey, but many general observations have been made. Geologic work in Minnesota for commercial purposes hias been done by Merriam and Sebenius in the Termilion and Mesabi distriets and by Leith, Zapfe, and Adams in the Curuna district.

Detailed summaries of the work of all the men above mentioned and others will be found in the [nited States Geological Survey monographs on the sereral Lake Superior districts, and in Bulletin 360 of the United States Geologieal Survey, on the pre-Cambrian geology of North Ameriea. Only such names and reports have been mentioned here as seem necessary to a general sketch of the history of geologic knowledge in the region. I number of the men named have contributed, in addition to the reports speeifically mentioned, valnable information on the geologry of the Lake Superior region in gencral.

\section{GROWTII OF GEOLOGIC KNOWLEDGE.}

Ain attempt has been made in Bulletin 360 (cited abore) to sum up the salient features of the history of the development of geologic knowledge eonceming the Lake Superior region. This summary will not be repeated here. It shows how the present knowledge of the district has resulted from a long series of approximations, in general suecessively more adequate owing to gradual accumulation of facts, improvement of means ol studying them, and general advanco in knowledge of geologic principles. Necdless but perlapss incvitable confusion has resulted locally lrom duplication of geologic terms by different geologie observers and from varying inferences drawn by different men from the same set of facts. It is indeed curious to noto low differently truth is revealed to dillerent observers. A elironologic series of geologic majs of the Harquette distriet shows low it is possible in the development of geologic linowledge gradually 
to make closer approximations to actual conditions. It also illustrates well the fact, sometimes lost sight of, that a geologic map represents an approximation to the truth, limiterl in its accuracy and adequacy by the general stage of alvancement of the science, and pertaps falling shert of this limit if the map maker does not fairly represent that alvance. 'The Laps publisherl with this monograph are closer approximations to the truth than the maps previoushy pulylished. These maps in tum will be superseded by better approximations as facts acrumulate and geologic knowledge adrances. It is hoped that the user of these maps will measure them by their advance over preexisting maps rather than hy the distance they fall short of the ideally perfect inap.

In the geologic literature on the Lake Superior region a progressive change may be noted from the fragmentary descriptions of earlier writers to more elaborate lescriptions accompanied by attempts at stratigraphic and structural classification and the development of better principles for that purpose, and in tum a change to better understanding of the principles of correlation of the rocks, based on better knowledge of these rocks and of the conditions of the formation of rocks of this kind. The work on ore deposits similarly began with fragmentary descriptions, followed by fuller descriptions and attempts at lithologic and structural classification, then by hypotheses on the origin of the ore, which gradually gave way to accepted theories based on qualitative evilence. The present monograph is helieved to mark a further development in the same direction by transferring the theories of origin of the ore more largely from a qualitative to a quantitative basis.

Mention of names in connection with the general tendencies outlined above would lead to endless letail, but the tendencies may be noted in terms of years and organizations. Belore 1870 the geologie work was fragmentary, descriptive, and as a whole unorganized, though work of exceptional merit was done by indiviluals. The periorl f'rom 1570 to 1580 was marked by the better organized efforts of the Michigan and Wisconsin geological surveys, with correspontling improvements in the organization of geologic knowledge of the parts of the Lake Superior region studied, affording the first real contribution to the stratigraphie and structural geology of the region. Then the kinds of geologic work really began which are nuw followed in the Lake Superior region. In the early eighties the United States Geological Survey took up the study of the district, its first reports being based largely on information previously gathered by Irving and other member's of the Wisconsin and other State geological surveys. Since its entrance into the region the United States Geological Survey has studied the problem more continuously than the state surveys, over a larger area, and with a uniform plan, with the result that its publications since the early eighties mark the principal steps in the advancement of knowledge of the region. This is said without disparagement of contemporaneous work by the Michigan, Wisconsin, Mimesota, Ontario, and Canadian surveys, which have issued reports on different phases of the problem, but for reasons mentioned above these reports for the most part have been more limited in their scope than those of the United States Geological Survey. In recent years the Wisconsin Geological Survey has again taken up the mapping of the erystalline rocks of northern Wisconsin with thoroughness and with good results. The Michigan Geological Survey also has now taken up work in the Upper Peninsula of Michigan, on the iron-bearing distriet of Iron River and on the copper-bearing series, which is rapidly advancing our knowledge. It is to be hoped that all local organizations will continue to derelop. Even though they do, howerer, there will still be need for attention to the region by the United States Geological Survey, because its fiekl of work is broaler and it is in better position to take up general correlation and structural problems common to the distriet.

\section{BIBLIOGRAPHY.}

The following bibliography comprises references to literature on the geology of the region arranged first by districts and then by date. Reports on districts and mines that do not reler primarily to the geology are not here included. Also no relerence is made in the following list to literature dealing with the physical geography or with the Pleistocene geology of this region. All references to these subjects will be found as footnotes in Chapters IV and XVI. 


\section{MICHIGIN.}

Third annual report of the Cieological Survey of Michigan, l,y louglass Iloughton. State of Jichigan, Ilouse of Representatives, Xo. 8, ]p. 1-33.

Fourth annual report of the state geologist, Houglass lloughton. Hem, Lo, 27, list pp. See aloo Mletalliferous

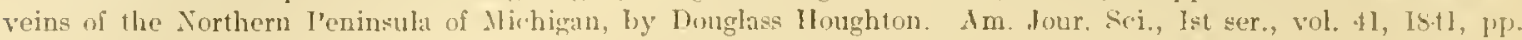
183-186.

Genlugy of l'orters Istand and Copper llarbur, hy Iohn Locke. Trans. Am. Phil. Sore, vol. 9, 1844, pp. 311-312, with maps.

Mineralogy and geology of Lake Superior, ly 11. 1). Rogers. Proe. Boston Soc. Nat. Hist., vol. 2, 1s4f, pp. $12 \cdot 1-125$.

Report of observations made in the survey of the Upper Peninsula of Michigan, by John Lacke. Senate burs, 1st sess. 30th Cong., 1847, vol. 2, No. 2, pp. 183-199.

Report of J. I). Whitney. Klem, pp. 221-230.

Report of J. D. Whitney. Senate Docs, 24 sess. 30th Cong., 1848-49, vol. 2, No. 2, pp. 154-159.

Report of J. W. Foster. Idem, pp. 159-163.

The Lake Superior copper and iron district, by J. I. Whitney. Jror. Boston Soe. Xat. Ilist., vol. 3, 1S49, pp. $210-212$.

On the geolugical strneture of Keweenaw Point, by Charles T. Jackson. Proc. Am. Assoc. Adr. Sri.. 1849, 2c] meeting, pp. 2ss-30l.

Report on the geological and mineralogical survey of the mineral lands of the United States in the State of Mirhigan, by Charles T. Jackson. Senate Docs., 1st sess. 31st Cong., 1549-50, vol. 3, No. 1, pp. 371-935, with 14 maps. Contains reports by Messrs. Jackson, Dickenson, McIntyre, Barnes, Locke, Foster and Whitney, Whitney, Gibbs, Whituey, jr., Irill and Foster, Foster, Burt, Hubbard.

United States geological survey of public lands in Xlichigan; field notes, by Jobn Locke. Idem, pp. 572-557.

Synopsis of the explorations of the geological corps in the Lake Superior land district in the Nortbern Peninsula of Jichigan, by J. IT. Foster and J. W. Whitney. Idem, pp. 605-626, with 4 maps.

Notes on the topography, soil, geology, ete., of the district between Fortage lake and the Ontonagon, by J. D. Whitney, Irem, pp. 649-666.

Report of J. 1). Whitney. Iden1, pp. 705-711.

Report of J. IT. Foster. Idem, pp. 766-772.

Notes on the geology and topography of the country adjacent to Lakes Superior and Michigan, in the Chippewa land district, by J. W. Foster. Idem, jp. 773-786.

Topography and geology of the survey with reference to mines and minerals of a district of township lines south of Lake Superior, by William 1. Burt. Idem, pp. 81I-832, with a geologic map opjusite p. 850.

General observations upon the geology and topography of the district south of Lake Superior, subdivided in 1845 under clirection of Douglass Houghton; deputy surveyor, Bela Hublard. Idem, pp. 833-842.

Geological report of the survey "with reference to mines and minerals" of a district of township lines in the State of Michigan, in the year 1846 , and tabnlar statement of specimens collected. Idem, pp. 842-882, with a geoloric map.

Report on the geology and topography of the Lake Superior land district; part 1, eopper lands, by J. IT. Fuster and J. D. Whitney. Executive Docs, 1st sess. 3Ist Cong., 1S49-50, vol. 9, No. 69, 224 pp., with map.

Report on the geology and topography of the Lake Superior land district; part 2, The iron region, by J. II. Foster and J. D. Thitney. Senate Docs, special sess. 32 l Cong., 1551, vol. 3, No. 4, to6 pp. with maps. See also A perçu de l'enzemble des terrains Siluriens du Lac: Supérieur, hy J. WF. Foster and J. D. Whitney. Bull. Soc. géol. France, vol. 2. $1850, \mathrm{pp} .89-100$.

Un the Azoic system as dereloped in the lake Superior land district, by J. W. Foster and J. D. Whitney. Proc. Ain. Assoc. Arly. Sci., 1851, 5th meeting, pp. 4- $i$.

(In the age of the sandstone of Lake Superior, with a description of the phenomena of the assuriation of igneous rocks, by J. II. Foster and J. D. Whitney. Idem, pp. 22-3S.

Geology, mineralogy, and topography of the lands around Lake Superion', lyy ('harles T. Jarkson. Senale Dhes., Ist sess. 321 Cong., 1851-52, rol. 11, yp. 232-244.

Age of the Lake Superior sandstone, by Charles T. Jackson. Proc. Joston Sox. Nat. Ihist., Vol. 7. 18tio, pp. 396-398. Ige of thrs sandstone, by William 13. Rogers. Idem, pl, 39.t-395.

First hiennial report of the progress of the geologisal survey of Hichigan, ly Alexander Winchell. Lansing. Is61. $339 \mathrm{pl}$.

Some contributions to a knowledge of the constitution of the eopere ranges of lake superior, hy C. P. Williams and J. li. IBlandy. Am. Jour. Sci., 2d ser., vol, 34, 1862. Jp. 112-120.

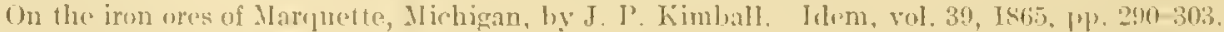

On the position of the sandstone of the sutherm slope of a portion of Kewernaw Foint, l.nke supurior, by Nlexander Agassiz. I'roc. Huston Soc. Xat. Ilist., vol. 11, 1867, 11. 2-14 246.

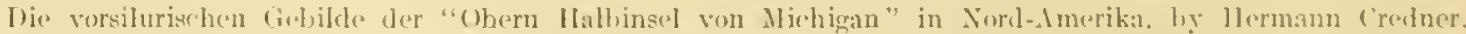

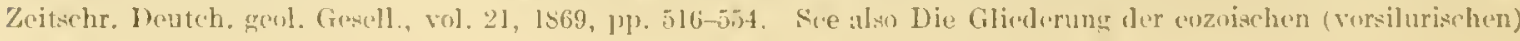


Formationsgruppe Nord-Amerikas, by IJermann Credner. Zeitschr. gesammtrn Naturwinscnschaften, wol. 32, (iiehel, 1868, pp. 353-105.

On the age of the copper-bearing rocks of Lake Superior, by T. B. Browks and R. Pumpelly. Am. Jour. Sci.,

$3 d$ ser., vol. 3,1872, pp. 428-132.

Iron-bearing rocks, by 'T. B. Bronks. Geol. Survey Michigan, vol. 1, pt. 1, 1869-1873, 319 pp, with maps.

Copper-bearing rocks, by R. Pumpelly. Idem, pt. 2, pp. 1-46,62-94, with maps.

Copper-bearing rocks, by A. R. Marvine. Idem, pt. 2, pp. 47-61, 95-140.

Paleozoic rocks, by C. Rominger. Iden, pt. 3, $102 \mathrm{pp}$.

Observations on the Ontonagon silver-mining district and the slate quarries of Ifuron Bay, by C. Rominger.

Geol. Survey Jichigan, vol. 3, pt. 1, 1876, pp. 151-166.

On the youngest In monian rocks sonth of Lake Superior and the age of the copper-bearing series, by T. B. Ironks.

Am. Jour. Sci., 3d ser., vol. 11, 1876, pp. 206-211.

Classified list of rocks observed in the IItronian series south of Lake Superior, lyy T. B. Lrooks. Idem, rol. 12,

p). 194-204.

Metasomatic development of the copper-bearing rocks of Lake Superior, ly Raphael Pumpelly. Proc. Am.

Acad. Arts Sci., vol. 13, 1878, pp. 253-309.

First annual report of the commissioner of mineral statistics of the State of Michigan for 1877-1878, by Charles E.

Wright. Narquette, $1579,229 \mathrm{pp}$.

Notes on the iron and copper districts of Lake Superior, by M. E. Wadsworth. Bull. Mus. ('omp. Zool. Harvard

Coll., whote ser., vol. 7; geol. ser., vol. 1, No. 1, 157 pp. See also On the origin of the iron ores of the Marquette dis-

trict, lake Superior. Proc. Boston Soc. Nat. Hist, vol. 20, 1878-1880, pp. 470-479. On the age of the copper-bearing

rocks of Lake Snperior (abstract). Proc. An. Assoc. Adv. Sci, 29th meeting, pp. 429-430. On the relation of the

"Keweenawan series" to the Eastern sandstone in the vicinity of Torch Lake, Michigan. Proc. Boston Soc. Nat.

Hist., vol. 23, 1884-1888, pp. 172-180; Science, vol. 1, 1883, pp. 248-249, 307.

Upper Peninsula, by C. Rominger. Geol. Survey Michigan, vol. 4, 1881, pp. 1-248, with a geologic map.

Geological report on the Upper Peninsula of Michigan, exhibiting the progress of work from 1881 to 1884, by

C. Rominger. Geol. Survey Michigan, vol. 5, pt. 1, 1895, 179 pp.

On a supposed fossil from the copper-hearing rocks of Lake Superior, by M. E. Walsworth. Proc. Boston Soc.

Nat. IIist., vol. 23, 1884-1888, pp. 208-212.

Observations on the junction letween the Eastern sandstone and the Keweenaw series on Kewrenaw Point, Lake

Superior, by R. D. Irving and T. C. Chamberlin. Bull. U. S. Geol. Survey No. 23, 1885, 124 pp., 17 pl.

Mode of deposition of the iron ares of the Menomince range, Michigan, by John Fulton. Trans. Am. Inst. Min.

Eng., vol. 16, 1887, pp. 525-536.

Report of N. H. Tinchell. Sixteenth Ann. Rept. Geol. and Nat. Hist. Survey Minnesota, for 1887, P13. 13-129.

Report of Alexander Winchell. Iden, pp. 133-391.

Unpublished field notes made by IV. N. Nerriam in the summers of 1888 and 1889.

Unpublished field notes made liy C. R. Van Il ise in the sumner of 1890.

The greenstone schist areas of the Menominee and Marquette regions of $\mathrm{W}$ ichigan, by Genrge Il untington IVilliams.

Bnll. U. S. Geol. Survey No. 62, 1890, pp. 31-238, with 16 pls. and maps. See also Some examples of dynamic meta-

morphism of the ancient ermptive rocks on the south shore of Lake Superior. Pror. Am. Assoc. Adv. Sri., 36th meeting,

1888, p1. $225-226$.

A sketch of the geology of the Harquette and Keweenawan district, by M. E. Madsworth. Along the sonth shore

of Lake Superior, by Julian Ralph. Ist ed., 1590, pp. 63-82.

Explanatory and historical note, by R. D. Irving. Bull. U. S. Geol. Survey No. 62, 1890, PP. 1-30.

The Penokee iron-bearing series of Michigan and Wisconsin, by R. D. Irving and C. R. Van IIise. Mon. U. S.

Geol. Survey, vol. 19, 1892, 534 pp., with plates and maps. See also Tenth Ann. Rept. U. S. Geol. Survey, for 1888-89,

1890, 1p. 341-507, with 23 pls. and maps.

A sketch of the geology of the Marquette and Keweenawan district, by M. E. Madsworth. Along the south shore

of Lake Superior, by Julian Ralph. 2d ed., 1891, pp. 75-99.

On the relations of the Eastern sundstone of Keweenaw Point to the Lower Silurian limestone, by M. E. Wadsworth.

Am. Jonr. Sci., 3d ser., vol. 42, 1891, pp. 170-171 (communicated).

The Sonth Trap range of the Keweenawan series, by M. E. Wadsworth. Idem, pp. 417-419.

Unpublished field notes made by Raphael Pumpelly and C. R. Tan Hise in the summers of 1891 and 1892.

The IInronian volcanirs south of Lake Superior, by C. R. Van Ilise. Bull. Geol. Soc. America, vol. 4, 1892,

pp. $435-436$

Wicroscopic characters of rocks and minerals, by A. C. Lane. Rept. State Board Geol. Survey llichigan for

1891-92, Lansing, 1893, pl. 176-183

A sketch of the geolugy of the iron, gold, and copper districts of Michigan, by M. E. Wadstorth. Idem, pp. 75-17t.

See alsn Ann. Repts. 1885-1892, pp. 38-73.

Subdivisions of the Azoic or Archean in northem Michigan, by 11. E. Nadsworth. Am. Jour. Sci., vol, 45, 1893,

pp. $72-73$.

The succession in the Marquette iron district of Jichigan, by C. R. Ian Ilse. Bull. Geol. Soc. America, vol. 5, 1893, pp. 5-6. 


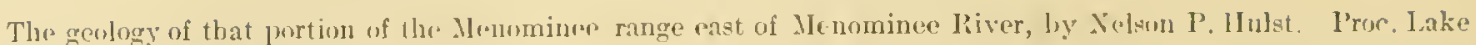

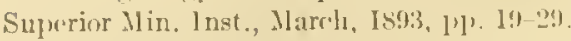

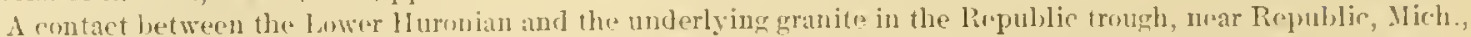

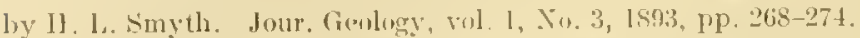

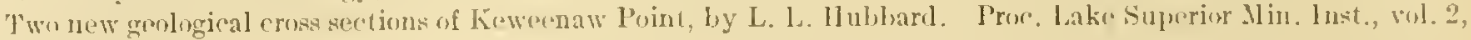
189.4, 1'1, 79-96.

Chararter of folds in the liarquette iron district, hy C. R. Fan llise. I'roc. Am. Assoc. Adv. Scri., $12 \mathrm{~d}$ meeting, 189) D, I7I (abstract).

Ralations of the Lower Mlenominee aud Lower Marquette series of Michigan (prelininary), by II. L. Smyth. Am. Jour. Sci., 31 ser., vol. 47, 1894, pp. 216-223.

The quartzite tongue at liepublic, Nich., by II. L. Smyth. Jour. Geolngy, vol. 2, 1894, pp. 680-69I.

The relation of the vein at the Central mine, Keweenar Point, to the Kearsarge conglomerate, lyy L. L. Hulbaril.

Pror. Lake Superior Min. Inst., wol. 3, 1895, yp. 74-83.

The IIarquette iron range of Michigas, hy G. A. Newett. Idem, pu, si 108. With genlugic map.

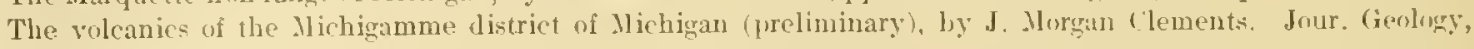
vol. $3,1895, \mathrm{pl}, 802-522$.

A rentral Wiscunsin trase-level, by C. R. Van Hise. Science, new ser., vol. 4, 1896, pp. 57-59. See also $A$ nmtherm Nichigan base-level. Idcm, Pl. 217-220.

Organic markings in Lake Superior iron ores, by W. S. Gresley. Science, new ser., vol. 3, 1836, 1r]? 6222-623; Trans. Am. Inst. Min. Eng., vel. 26, 1897, pp. 527-534.

The Mlarquette iron-bearing district of Alichigan, by C. R. Van Itise and W. S. Bayley; with a chapter on the Republic trough, by II. L. Sinyth. Non. U. S. Geol. Survey, vol. 28, 1897, 608 pp. With atlas of 39 plates. Preiminary report on same district publisher in Fifteenth $\mathrm{Ann}$. Rept. U. S. Geol. Survey, 1895, pp. 477-650.

The origin and mode of occurrence of the Lake Superior copper leposits, by $\lambda 1$. E. Wadsworth. Trans. Am. Inst. Min. Eng., vol. 27, 1898, 1'1. 669-696.

Some dike features of the Gogebic iron range, by C. M. Foss. Idem, DP. 556-563.

Genlogical report on Isle Royale, Jichigan, by A. C. Lane. Geol. Survey Michigan, vol. 6, pt. 1, 1895, 251 pp. Witl geologic map.

Keweenaw Point, with particular referenee to the felsites and their assoriated rucks, by L. L. IIubbard. Geol. Survey Michigan, vol. 6, pt. 2, 1898, 155 pp. With plates.

Unpublished notes by Prof. A. E. Seaman and thesis on the Gogebic district, by II". J. Sutton, Michigan College of Mines.

The Crystal Falls iron-bearing district of Michignn, by J. Morgan 'lements and II. L. Smyth, with a chapter on the Sturgeon River tongue, by W. S. Bayley, and an introduction by C. R. Van Hise. Mlon. C. S. Geol. Survey, vol. 36, 1899. Witb geologic maps.

Geology of the Mineral range, by A. E. Seaman. First Ann. Rept. Copper-Mining Industry of Lake Superior, IS99, pp. $49-60$.

Note sur la région euprifère de l'extremité nordest de la péninsula de Keweenaw (Lae Supérieur), par Louis Dupare. Archives sci. phys. et nat., vol. 10, 1900, p. 21.

The Ienominee special folio, by Charles R. Van Hise and IT. S. Bayley. Geologic Atlas U. S., folio 62, U. S. Geol. Survey, 1900.

Unpublished notes by Prof. A. E. Seaman made for Mlichigan Geological Survey, Michigan College of Mines, and United states Geological Survey. See also unpublished maps prepared for llichigan exhibit at st. Louis exposition, 1904.

Unpublished thesis by IV. O. Hotchkiss, Geol. Dept. Univ. Wisconsin, 1903.

Report of special conmittee on the Lake Superior region to Frank D. Adams, Robert Bell, C. Willard Hayes, and Charles R. Tin IIise, general committee on the relations of the Canarlian and the Lnited States geologifal surveys, 1904. Jour. Geology, rol. 13, 1905, pp. 89-I04. The special committee consisted of Frank D. Adams, Rol,ert Bell, C. K. Leith, C. R. Van Hise. There were present by invitation IT. G. Jliller, A. C. Lane, and for parts of the trip A. E. Seaman, W. N. Merriam, J. U. Sebenius, and W. N. Smith.

Mapo of the Harquette, Menominee, and Gogebic districts, Michigan, prepared by $\mathrm{A}$. E. Seanian for the St. Louis exposition, 1904. Unpublislied.

The Aenominee iron-bearing district of Michigan, by IT. S. Bayley. Mon. U. S. Gool. Survey. vol. 46, 1904, 5 I3 P1'.

The geology of some of the lands in the Upper Peninsula, by R. S. Rose. Proe. Lake Superior lim. Inst., I90.t, PI. SS-102.

Tnpublished notes of field work done in 1905 , by G. IV. Corey and C. F. Bowen.

black River work, by A. ('. Lane. Ann. Rejt. Genl. Survey Michigan for 1901, 1905, 11). 15\&-162.

licport of progrese in the lor(upines, by F. E. Wright. Ann. Rept. Geol. surveg IIiehigan for 1903, 190.5, pp. 33-14. Also Preliwinary greolorical map of the Pormpine Mountaius and vicinity, by f. E. Wright and A. C. Lane. .Anil. Repht. Geol, Survey .Hichigran for I90s, 1909, pl. 1.

The geology of Keweenaw Point a brief description, by A. C. Lame. Iroc. Lake Superiur llin. Inst., vol. 12, 1907, PI. 8I-104. 
Notes on the geological section of Michigan; part 1, the pre-Ordorician, by A. C. Lane and A. E. Seaman. Jour. Geology, vol. 15, 1907, pp. 680-695. Also notes on the geologiral section of Michigan, part 2, from the St. Peter sandstone up, by A. C. Lane. Jour. Geology, vol. 18, 1910, pp. 393-129.

A geological section from Bessemer down Black River, by W. C. Gorelon and Alfrel C. Iane. Ann. Rept. Geol. Survey Michigan for 1906, 1907, 11). 396-507.

Unpulblished geologic maps of Menoninee and Florence tistricts, Michigan and Wisconsin, prepalred for Oliver Iron Mliniug Company by W. N. Merriam.

Unpublished maps and report on geology of Crystal Falls, Menominee, and Iron River districts, Micligan, prepared during commercial surveys, by ' $\mathrm{K}$. Leith, R. C. Allen, and others.

Report on geology of Iron River district of Michigan, by R. C. Alfen. Michigan Geol. and Biol. Survey, pub. 3 , $1910,151 \mathrm{pp}$. , with geologic map.

The intrusive rocks of Mount. Bohemia, Michigan, by F. E. Wright. Ann. Rept. Michigan Geol. Survey for 1908, 1909, pp. 361-397.

\section{NORTHERN WISCONSIN.}

Report of a geological reconnaissance of the Chippewa land district of Tiseonsin, ete, by David $\mathrm{D}$. Owen. Senate Docs., lst sess. 30tlu Cong., 1848, vol. 7, No, 57, 72 pp.

Prelininary report containing outlines of the progress of the geological survey of Wiseonsin and Iowa up to ()ctoher 11, 1847, by David Dale Gwen. Senate Does., 1st sess, 30th Cong., 1847, vol, 2, No. 2, pp. 160-173.

Description of part of Wisconsin south of Lake Superior, by (harles Whittlesey. Report of a geological survey of Wisconsin, lowa, and Minnesota, 1852, pp. 419-470.

The Penokee iron range, by Increase A. Lapham. Trans. Wisconsin State Agr. Soc, vol. 5, 1858-59, pp. 391-400, with map. See also Report to the directors of the Wisconsin and Lake Superior Mining and Snelting Company, in the Penokee uron range of Lake Superior, with reports and statisties showing its mineral wealth and prospects, rharter and organization of the Wisconsin and Lake Superior Mining and Smelting Company, Milwanke, 1860, pp. 22-37.

Geological report of the State of Wisconsin, by James Hall. Report of the Superintendent of the Geological Survey (1861), exhibiting the progress of the work, $52 \mathrm{pp}$.

Physical geography and general geology, hy James Hall. Report on the geological survey of the State of Wisconsin, vol. 1,1862, pp. 1-72.

The Penokee mineral range, Wisconsin, by Charles Whittlesey. Proc. Boston Soe. Nat. Hist., vol, 9, 1863, pp. $235-244$

On some points in the geology of northern Tisconsin, by R. D. Irving. Trans. Wisconsin Acad. Sci., rol. 2, 1873-74, pp. 107-119. See also On the age of the copper-bearing rocks of Lake Superior, and on the westward continuation of the Lake Superior synclinal. Am. Jour. Sci., 3d ser., vol. 8, 1874, pp. 46-56. Ann. Rejt. Progress and Results of Trisconsin Geol. Survey for 1876, pp. 17-25. Report of progress and results for 1874. Geology of Wisconsin, vol. 2, pp. $46-49$.

Notes on the geology of northern Wisconsin, by E. T. Sweet. Trans. Wisconsin Aead. Sci., 1875-76, vol. 3, pp. $40-55$.

Note on the age of the crystalline rocks of Wisconsin, by R. D. Irving. An. Jour. Sci., 3cl ser., vol. 13, 1877, pp. 307-309. $67-89$.

Report of progress and results for the year 1875 , by $\mathrm{O}$. W. Wight. Geology of Wisconsin, vol. 2, 1873-1877, pp.

Geology of central Wisconsin, by R. D. Irving. Idem, pp. 409-636, with 2 athas maps.

On the geology of northern Wisconsin, by R. D. Irving. Ann. Rept. Wiseonsin Geol. Survey for 1877, Pp. $17-25$. Report on the eastern part of the Penokee range, by T. C. Chamberlin. Idem, pp, 25-29.

General geology of the Lake Superior region, by R. D. 1rving. Geology of Wisconsin, val. 3, 1880, pp. 1-24. Geology of the eastern Lake Superior district. Idem, Pp. 51-238, with 6 atlas maps. Nineral resources of Tiseonsin. Trans. Am. Inst. Min. Eng., vol. 8, 1880, pp. 478-50s, with map. Note on the stratigraphy of the Huronian aeries of northern Wisconsin, and on the equivalency of the Huronian of the Harquette and Penokee districts. Am. Jour. Sci., 3 d ser., vol. 17, 1879, pp. 393-398.

Huronian series west of Penokee Gap, by C. E. Wright. Geology of Wiseonsin, vol, 3, 18s0, pp. 241-301, with an atlas map.

Geology of the western Lake Superior district, by E. T. Sweet. Idem, pp. 303-362, with an atlas map.

Geology of the upper St. Croix district, hy T. C. Chamberlin and Moses Strong. Idem, pl). 363-428, with 2 atlas maps.

Geology of the Menomiuee region, by T. B. Prooks. Idlem, pp. 430-599, with 3 at las maps.

Geology of the Menominee iron region (economic resources, lithology, and westerly and sontherly extension), by Charles E. Wright. Iden, pp. 66it-734.

The quartzites of Barron and chippewa counties, by Mloses Strong, E. T. Sweet, F. H. Brotherton, and T. C

Chamberlin. Geology of Tisconsin, vol. 4, 1873-1879, pp. 573-581.

Geology of the upper Flambeau Valley, by F. I. King. Idem, pp. 583-615.

Crystalline rocks of the Wisconsin Valley, by R. D. Irving and C. R. Van Hise. Idem, pp. 623-714. 
General geology (of IVisconsin), by 'T. C. Chamberlin. Girology of Wisconsin, vol. 1, 1483, p'. 3-300, with an atlas map.

Lithology of lliscomsin, by R. W. Irvine. Idrm, lpp. 340-361.

Transition from the copper-bearing series to the J'otsdam, l)y 1. C. Ilooster. Am. Jour. Sroi., 34 ser., vol. 27, IxG1, pp. $463-465$.

Geology of the St. (roix Dalles, by ('. P. lierkey. Am. (reologist, vol. 20, 1897, 11). 345-383; vol. 21, 1894, 1'1", $139-155,270-294$.

Preliminary report on copper-bearing rocks in Douglas lounty, Wis., by L. S. Grant. liull. IIisconsin ficol. and Nat. Hist. Survey Xo, $6,1901$.

The pre-I'otsdam l'oncplain of the gre-canbrian of north-entral Wisconsin, by F. Weidnan. Jonr. Fieology, vol. 11, 1903, р1. 289-313.

Unpublished thesis Univ. Wisconsin, 1905.

The geology of north-central Wisconsin, by S. Neidman. Bull. Wisconsin Geol. and Nat. II Ist. Survey No. li, 1907. summary furnished by author in 1905 .

\section{MINNESOTA.}

Lecount of a journey to the Coteau des Prairies, with a description of the red pipestone quarry and granite bowlders found there, by Cieorge ('atlin. Im. Jour. Sci., lst ser., vol. 3s, pp. 13S-146.

Report of J. G. Norwood. Semate Docs, 1st sess. 30th Cong., 1S47, vol. 2, No. 2, P1. 73-134.

Description of the geology of middle and western Minnesota, including the country adjacent to the northwost and part of the southwest shore of Lake Superior; ilustrated by umerous general and local sections, woodcuts, and an nal', by J. G. Norwood. Report of a geological survey of Wisconsin, lowa, and Minnesota, 1852, pp. 209-11S.

Report of the State geologist on the metalliferons regioubordering on Lake Superior, Iy Henry II. Lamas. it. raul, $1866,23 \mathrm{pp}$.

Geological reconnassance of the northern, middle, and other counties of Mlinnesota, by Ilenry 11 . Eames. St. Paul, $1866,58 \mathrm{pp}$.

Notes upon the geology of some portions of Minnesota, from St. Paul to the western part of the State, by ames ITall. Trans, An. Philos. Soc., new ser., vol. 13, 1S69, pp. 329-340.

Report on the geological survey of the State of Iowa, containing results of examinations and observations macle within the years 1866, 1867, 1868, and 1869, by Charles A. White. Des Moines, 1870, vol. 1, 391 19p.; vol, 2, 443 pp.

First Anu. Rept. Geol. and Nat. Hist. Survey of Minnesota, by N. H. Winchell, 1873,129 pp.

The geology of the Minnesota. Valley, by X. II. Winchell. Second Ann. Rept. Geol. and Nat. Ilist. Survey Minnesota, 1874, pp. 127-212.

Ueber die krystallinischen gesteine von Minnesota in Nord-Amerika, by A. Streng and J. II. Iloos. Leonharl's Jahrbuch, 1877, pl. 31, 113, 225. Translated by N. I1. Winchell in Eleventh Ann. Rept. Geol. and Xat. Ilist. Survey Ninnesota, 1883, pp. 30-85.

Sixth Aun. Rept. Geol. and Nat. Hist. Survey Minnesota, for 1S77, by N. H. Winchell, 226 pp.

Sketch of the work of the season of 1878 , by N. H. Wincliell. Seventh Ann. Rept. Geol. and Nat. Iist. Survey Minnesota, for 1878 , pp. 9-25.

The cupriferons series at Dulnth, by X. H. Winchell. Eighth Ann. Rept. Geol. and Nat. IIist. Survey Mlinnesota, for 1879 , P]. 22-26.

Preliminary report on the geology of central and western Minuesota, by 1 arren Lpham. Idem, pp. 70-125.

Report of Prof. C. II. IIall. ldem, pp. 126-13S.

Preliminary list of rocks, by X. 11. Winchell. Winth Ann. Rept. Geol. and Nat. Mist. Survey Minnesota, [or 18s0, pp. 10-114.

The cupriferous series in Minnesnta, by X. II. Winclell. Proc. An. Assoc. Adv. Sci., 29th meeting, 1ssl, pp.

422-125. See also Ninth Ann. Rept. Geol. and Nat. IIist. Survey Minnesota, for 1880, pp. 385-387.

Preliminary list of rocks, by N. II. Winchell. Tenth Mnn. Rept. Geol. and Yat. Ilist. Survey Minnesota, for 18sI, p). $9-122$.

Notes on rock muterops in central Minnesota, by llarren Lpham. Wleventh Anu. Rept. Geol. and Iat. Ilist. Survey Minnesota, for 1582, pp. 86-136.

The iron region of northern Minnesota, by Albert H. Clester. Inem, MP. 15t-167.

Note on the age of the rocks of the Jesabi and Vermilion iron district, ly $\mathrm{N}$. H. Winchell. Irlen. Pr. 165-170. See also I'rux. Am. Assoc. Adv. Sci., 1s8.1, 33k meeting, pp. 363-379.

The geology of Minnesota, by N. II. Winchell and Warren Upham. Final Rept. Geol. and Xat. Hisl. Survey Mimesota, vol. 1, 1884, 695 pp.; vol. 2, 1858, $697 \mathrm{pp}$.

Jotes of a trip across lle Mesali range to Vermilion Lake, by N. Il. Wincliell. Thirteenth Ann. Rept. Creol. ank]

Nat. Hist. Survey Minnt'sotia, for 188.1, pp. 20-24.

The crystalline rorks of Minnesota, by X. H. Winchell. Inem, pp. 36-38.

The crystalline rucks of the Vurluwest, by X. II. Minchell. Irem, pl' 124-140.

Report of a trip on the upper Mississippi and to Vermilion Lake, by Bailey IVillis. Tenth ('ensus, vol. 15, 18s6, i) $457-167$ 
Report of geological observations male in northeastern Ninnesota during the seasun of 1886, by 1 lexander

Winchell. Fifteenth Ann. Rept. Ciesl. and Nat. Ilist. Survey Minnesota, for 1886, 1'p. 5-207.

Geological report of N. 11. Winchell. Idem, Pl). 209-399, with a map.

Report of N. H. Winchell, Sixteenth Ann. Rept. Geol. and Nat. Hist. Survey Minnesnta, for 1887, pp. 13-129.

Report of Alexander Winchell. Idem, PI. 133-391. See also The unconformities of the Animikie in Minnesota.

Am. Geologist, vol. 1, 1858, pp. 14-24. Two systems confounded in the Iluronian. Idem, vol. 3, 1859, pp. 212-214,

330-340. Systematic results of a field study of the Archean rocks of the Northwest. Proc. Am. Assoc. Arlv. Sci., 3ith meeting, 1859, p. 205. The genlogical position of the Ugishke conglomerate. Idem, 38th meeting, 1890, pp. 234-235.

Report of H. V. Winchell. Sixteenth Ann. Rept. Geol. and Nat. IIist. Survey Minnesuta, for 1887, pp. 39.5 16:2, with map.

The distribution of the granites of the Northwestern States and their general litholngic chararters, by C. II. HaII.

Proc. Am. Assoc. Adv. Sci., 37th meeting, 1859, pp. 189-190.

Report of N. H. Winchell. Seventeenth Anm. Rept. Geol. and Nat. IIist. Survey Minnesota, for 1888, pp. 5-74.

See also The Animikie black slates and quartzites and the Ogishke congkmerate of Minnesota, the equivalent of the

"Original Huronian." Am. Geologist, val. 1, 1888, pp. 11-14. Methods of stratigraphy in studying the 1 luronian. Idem, vol. $4,1889,342-357$.

Report of field abservations made during the season of 1858 in the iron regions of Minnesota, by II. T. Winchell. Seventeenth Ann. Rept. Geol. and Nat. 11 ist. Survey Minnesota, for 1S88, pp. 77-145. See also The diabasie schists containing the jaspilite heds of northeastern Minnesota. Am. Geologist, vol. 3, 1859, pp. 18-22.

Report of geological observations made in northeastern Minnesota during the summer of 1S8s, by U. S. Grant. Seventeenth Ann. Rept. Geol. and Nat. Hist. Survey Minnesota, for 1888, Pl. 149-215.

Conglomerates inclosed in gneissic terranes, by Alexander Winchell. Am. (ieologist, vol. 3, 18s9, pp. 153-105, $256-262$.

Some thoughts on eruptive rocks, with special reference to those of Minnesota, by N. II. Winchell. Proc. Am. Assoc. Adv. Sci., 37th meeting, 1885, 10, 212-221.

The Stillwater, IIinn, deep well, by A. D. Meads. Am. Geologist, vol, 3, 1859, pp. 341-342.

On a possible chenical arigin of the iron ores of the Jeewatin in Minnesota, hy N. II. and II. Y. Winchell. Idem, vol. 4, 1859, pp. 291-300, 382-386. Also l'roc. Am. Assoe. Adv. Siri., 38th meeting, pp. 235-242.

Some results of Archean studies, by Alexander Winchell. Bull. Geol. Soc. America, vol. 1, 1890, pp. 357-394.

The Taconic iron ores of Minnesota and of western New England, by N. II. and 11. V. Winchell. Am. Geologist, vol. $6,1890, \mathrm{pp} .263-274$.

Record of field observations in 1888 and 1859, by N. I. Winchell. Eighteenth Am. Rept. Geol. and Nat. IIist. Survey Minnesota, for $1889, \mathrm{PP} .7-47$.

The iron ores of Minnesota, by N. II. and H. V. Winchell. Bull. Geol. and Nat. 11 ist. Survey Minnesota No, 6, 1891, pp. 430, with a geologic map.

Geological age of the Saganaga syenite, by JIorace V. Winchell. Am. Jour. Sci., 3it ser., vol. 41, 1891, pp. 386-390.

Notes on the petrography and geology of the Akeley Lake region, in northeastern Minnesota, by W. S. Bayley.

Nineteenth Ann. Rept. Geol. and Nat. 1 ist. Survey Minnesota, for 1890, pp. 193-210.

The stratigraphic position of the Ogishke couglomerate of northeastern Minnesota, by U. S. Grant. Am. Geologist, vol. $10,1892, \mathrm{pp} .4-10$

Paleozoic formations of southeastern Minnesota, by C. W. Hall and F. W. Sardeson. Bull. Geol. Soc. America, vol. 3,1892 , pp. 331-368.

The basic massive rocks of the Jake Superior region, by W. S. Bayley. Jour. Geology, vil. 1, 1893, pp. 133-156, $587-596,688-716$; vol. 2,1891 , pp. \$14-825; vol. 3,1895 , pp. 1-20.

The crystalline rocks, hy N. II. Winchell. Twentieth Ann. Rept. Geol. and Nat. IIist. Survey Miunesota, for 1891, 1893, pp. 1-28.

Anorthnsites of the Minnesota shore of Lake Superior, by A. C. Lawson. Bull. Geol. and Nat. Ilist. Survey Minnesota No. 8, 1893, pp. 1-23.

The geology of Kekequabic Lake, in northeastern Minnesota, with special reference to an augite-soda granite, hy U. S. Grant; thesis accepted for degree of Ph. D. in Johns IIopkins University, 1893. Twenty-first Anu. Rept. Geol. and Nat. 11 ist. Survey Ninnesota, for 1892, 1893, W1.5-58. With geologic map and plates.

The eruptive and sedimentary rocks on Pigeon Point, Minnesota, and their contact phenomena, by IV. S. Bayley.

Bull. U. S. Geol. Survey No. 109, 1893, with maps and plates.

Field observations on certain granitic areas in northeastern Minnesota, by U. S. Grant. Twentieth Ann, Rept. Geol. and Nat. IIist. Survey Minnesota, 1893, Pp. 35-110.

Sketch of the coastal topography of the north side of Lake Superior, with special reference to the abandoned strands of Lake Warren, by A. C. Iawson. 1dem, pp. 181-289.

Actinolite-magnetite schists from the Mesabi iron range, in northeastern Minnessta, by W. S. Bayley. Am. Jour. Sci., 3d ser., vol. 46, 1893, pp. 176-180.

The Mesabi iron range, by I1. 1 . Winchell. Twentieth Ann. Rept. Geol. and Nat. Hist. Survey llinnesota, for 1891, 1893, Pl. 111-180.

Preliminary report of field work during 1893 in northeastern Minnesota, by U. S. Grant. Twenty-second Ann. Rept. Geol. and Nat. Hist. Survey Minnesota, pt. 4, 1894, pp. 67-78. 


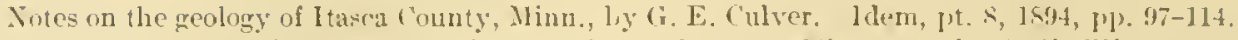

Prelininary report of ficld work during 1893 in northeastern Jlinnesota, by A. H. Elftman. ldem, 1t. 12, 1894,

(1p. $141-1 s 0$.

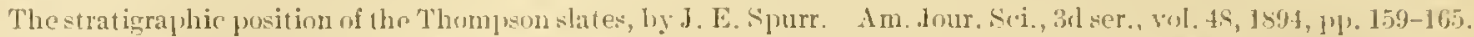

The iron-bearing rocku of the dlesalsi range in Minnesuta, by J. Edward Spurr. Bull. (ieol. and Xitt. Hirt. Surrry Minnesuta No. 10, 189., 268 pp., with geologic maps.

The origin of the Archean greenstones, by $\mathcal{X}$. 11. Winchell. Twenty-third Ann. Rept. Geol. and Nat. Hist. Survey Minnesota, for Is:94, pt. 2, 1895, pp. 435.

Preliminary regort on the liainy lake gold region, ly II. T. Winchell and IT. S. Grant. Idem, pp. 3fj-10is.

The iron ranges of Minnesol:1, by HI. V. Winchell. Proc. Lake Superior Nining Inst., vol. 3, IS95, pp. 11-32.

Notes upon the bediled and banted structures of the gabibre and upon an areit of troctolyte, by A. I1. Elftman. Twenty-third Inn. Rept. (reol. and Nat. IIst. Survey Xinnesota, for 1894, 1895, pt. 12, 1'1). 224-230.

The geological structure of the western part of the Vermilion range, Minnesota, by $\mathbf{H}$. L. Smyth and J. Ralyh Finlay. Trans. Im. Inst. Mlin. Engineers, vol. 25, 1595, 11p. 595-605.

The Kowchiching granite, Jy Alexander Irinchell. Am. Geologist, rol. 20, 1897, pp. 293-299.

Some new features in the geology of northeastern Ilinnesota, by X. H. Winchell. Idem, pl). $41-51$.

The origin of the Archean igneous rocks, by X. H. Winchell. Proe. An. Assoc. Adv. Sci., vol. 47, 1895, 1’p. 303304 (alstratct); Am. Geologist, vol. 22, 1898, pp. 299-310.

Some resemblanees between the Archean of Minnesota and of Finland, by X. H. Minchell. Am. Geologist, vol. 21,1898, pp. 222-2299.

The significance of the fragmental eruptive débris at Taylors Falls, Minn., by L. II.Tinchell. Am. Geologist, rol. $22,1898, p], 72-78$.

The oldest known rock, by N. II. Winchell. Proc. Am. Assoc. Adv. Sci., vol. 47, 1S9S, pu). 302-303 (abstract).

Sketch of the geology of the eastern end of the Mesabi iron range in Minnesota, ly. L. S. Grant. Engineers' Year Book Cuniv. Minnesota, 1898, pl. 49-62. With sketch wap.

The geolugy of Minnesnta, by X. II. Winchell, U. S. Grant, James E. Todd, Warren Tpham, and II. V. Winchell. Final Rept. Geol. and Nat. IIist. Survey Minnesota, vol. 4, 1s99, pp. 630. With 31 geologic plates. Structural geology of Minnesota, by X. 11. Winchell, assisted by LT. S. Grant. ldem, vol. 5, 1900, pp. 1-80, 972-1000. Vol. 4 contains an account of detailed field work in northeastern Minnesota, with incidental discussion of general problems. The area is treated by counties and smaller arbitrary geographic divisions, in the description of which several men have taken part. This manner of treatment leads to repetition in the discussion of the general geologic features, and in many cases it is extremely difficult to correlate the facts recorded in the different sections. Vol. 5 contains an acconnt of the general structural geology of the State based on the detailed work described in vol. 4. Grant's riews, as indicated in the detailed descriptions of special areas, in some cases differ somewhat widely from those of Winchell.

The gneisses, gabbro schists, and associated rocks of sonthwestern Minnesota, by C. W. Hall. Bull. U. S. Geol. Survey $\mathrm{N} \cap .15 \%, 1899,160 \mathrm{pp}$. With geologic maps.

Mineralogical and petrographic study of the gabbroid rocks of Minnesota, and more particularly of the plaginclastites, by Alexander Winchell. Am. Geologist, vol. 26, 1900, pp. 153-162. With geologic sketch map of northeastern Minnesota.

Unpublished field notes, summer of 1900, by C. R. Yan Hise and J. Morgan Clements.

Final Rept. Geol. and Nat. Hist. Survey Minnesota, vol. 6, 1900-1901. (N. H. Winchell.)

Keewatin area of eastern and central Minnesota, by C. IT. Hall. Bull. Geol. Soc. America, vol. 12, 1901, pp. $343-376$, pls. 29-32.

Keweenawan area of eastern Minnesota, by C. W. IIall. Idem, pl) 313-342, pls. 27-28.

Sketch of the iron ores of Minnesota, by N. I1. Winchell. Am. Geologist, vol. 29, 1902, pp. 154-16?.

The Mesabi iron-bearing distriet of Minnesota, by C. K. Leith. Mon. U. S. Geol. Survey, vol. 43, 1903, $316 \mathrm{pp}$.

The Vermilion iron-bearing district of Minnesota, by J. Morgan Clements. Idem, vol. 45, 1903, 463 pl.

Some results of the late Minnesota Geological Survey, by N. II. Winchell. Am. Geologist, vol. 32, 1903, pp. $246-253$.

The geology of the Cuyuna iron range, llinnesnta, by C. K. Leith. Econ. Geology, vol. 2, 1907, pp. 145-15:2.

The Cuyuna iron district of Minnesota. by Carl Zapffe. Unpublished bachelor's thesis Tniv. Wisconsin, 1907. See also The Cuyuna iron-ore district of Minnesota, by Carl Zapffe. Supplement to the Brainerd (Minn.) Tribune, Sept. 2, 1910, pl?. 32-3i), with map.

The iron-ore deposits of the Ely trough, Vermilion range, Minnesota, lỵ C. E. Abbott. Proc. Lake Snperior Min. Inst. (for 1906), vol. 12, 1907, 1pl). 116-142.

Geological history of the Redstone quartzite, hy lrederick II. Sarteson. Bull. Geol. Soc. America, fol. 19, 190s, pp. $221-242$.

Contribution to the petrography of the Keweenawan (with geologic map), ly l'rank F. Cirout. Jour. (Fenlogy, vol. 18,1910 , pp. 633-65\%

The iron formation of the Cuy"una range, by F. s. Adams. Econ. Geology, rol. 5, 1910, 11), 729-740: rol. 6, 1911, Pp. 60-70, 156-150. 


\section{ONTARIO.}

Notes on the geography and geology of Lake Superior, by John J. Iigstyy. Quart. Jour. Sci., Lit. and Arts, vol. 18,1825 , pp. 1-34, 222-269, with map.

Outlines of the geology of Lake Superior, by II. W. Bayfield. Trans. Lit. and Ilist. Soc. Quehec, vol. 1, 1829, PI. $1-43$.

On the junetion of the Transition and Primary rocks of Canada and Labrador, by Captain Layfield. Quart. Jour. Geol. Soc. London, vol. 1, 1S45, P1. 450-459.

On the geology and economic minerals of Lake Superior, by W. E. Logan. IRept. Prog. Geol. Survey of Canada for $1546-47$, pp. $8-34$.

Ou the geology of the Kaministiquia and Michipicoten rivers, by Alexander Murray. Idem, pp. 47-57.

On the age of the copper-bearing rocks of Lakes Superior and 11 uron, and various facts relating to the physical structure of Canada, by W. E. Logan. Rept. Brit. Assoc. Adv. Sci., 21st meeting, 1551, pp. 59-62, Trans.; Am. Jour. Sci., 2 d ser., val. 14, 1852, pp. 224-229.

On the geology of the Lake of the Woods, south Hudson Bay, by Dr. J. J. Migsby. Quart. Jour. Geol. Soc. London, vol. s, 1852, pp. $400-106$. With a geolugic nap of the Lake of the Woods.

On the physical geography, geology, and commercial resources of Lake Superior, by John $\mathbf{J}$. Bigsby. Edinburgh New Phil. Jour., vol. 53, 1852, pp. 55-62.

On the geology of Ramy Lake, south IIudson Pay, by Dr. J. I. Bigsby. Quart. Jour. Geol. Soc. London, vol. 10, 1554, pp. 215-222. With a geologic map of Rainy Iake.

On the geological structure and mineral deposits of the promon tory of Mamainse, Lake Superior, lyy John W. Dawson. Canadian Naturalist and Geologist, vol. 2, 1857, pp. 1-12, with a section.

Report of progress of the Geological Survey of Canada from its commencement to 1863, by W'. E. Logan, I863, $983 \mathrm{pp}$., with an atlas.

On the Laurentian, Huronian, and upper copper-bearing rocks of Lake Superior, by Thomas Macfarlane. Rept. Prog. Geol. Survey Canada, 1S63-1566, pp. 115-164.

On the geological formations of Lake Superior, by Thomas Macfarlane. Canadian Naturalist, 2d ser., vol. 3, $1866-186 s$, pp. 177-202, 241-256.

On the geology and silver ore of Woods Location, Thunder Cape, Lake Superior, by Thomas Macfarlane. Canadian Naturalist, 2 d ser., vol. 4, pp. $37-48,459+463$, with a map.

On the geology of the nortliwest coast of Lake Superior and the Nipigon district, by Robert Bell. Rept. Prog. Geol. Survey Canada, 1866-1569, pp. 313-364, with a topographic sketch map.

Report on the country north of lake Superior, between the Nipigon and Nichipicoten rivers, by Robert Bell. Idem, 1870-71, pp. 322-351.

Report on the country between Lake Superior and the Albany River, by Robert Bell. Idem, 1871-72, pp. 101-114.

Notes of a geological reconnaissance from Lake Superior to Fort Garry, by A. R. C. Selwyn. Idem, 1872-73, pp. 8-18.

On the country between Lake Superior and Winnipeg, by Robert Bell. Idem, pp. 87-111.

The geognostical history of the metals, by T. Sterry IJunt. Trans. Am. Inst. Min. Eng., vol. 1, 1873, pp. 331-345; vol. 2, 1874, pp. 58-59.

On the country between Red River and the South Saskatchewan, with notes on the geology of the region between

Lake Superior and Red River, by Robert Bell. Rept. Prog. Geol. Survey ('anada, 1873-74, pp. 66-90.

Report on the geology and resources of the region in the vicinity of the Forty-ninth parallel, from the Lake of the

Woods to the Rocky Mountains, lyy George Nercer Dawson, $357 \mathrm{pl}$., with a geologic map.

The mineral region of Lake Superior, by Robert Bell. Canadian Naturalist and Geologist, 2d ser., vol. 7, 1875, pp. 49-51.

On the country west of Lakes Manitoba and Winnipegosis, with notes on the geology of Lake Trinnipeg, by Robert

Bell. Rept. Prog. Geol. Survey Canada, 1874-75, pp. $24-56$.

lieport on an exploration in 1875 letween James Bay and Lakes Superior and Furon, by Robert Bell. Idem.

1875-76, pp. 291-342.

Report on geologieal researches north of Lake IJuron and east of Lake Sugerior, by Robert Bell. Idem,

1876-77, pp. 213-2:0

Remarks on Canadian stratigraphy, hy Thomas Macfarlaue. Canadian Naturalist, 21 ser., vol. 9, 1879, pp. 91-102.

Report on the geology of the lake of the Woods and adjaceut country, by Robert Pell. IRept. Prog. Geol. and

Nat. Hist. Survey Canarda, 1850-1852, pp. 11-15 c, with a map.

On the geology of Lake Superior, by A. R. C. Selwyn. Trans. Roy. Soc. Canada, vol. 1, sec. 4, 1883, pp. $11 \overline{7}-122$.

Age of the rocks of the northern shore of Lake Superior, ly A. R. C. Selwyn. Srience, vol. 1, 1883. p. 11. See

also The copper-bearing rocks of Lake Superior. Idem, p. 221.

Notes on observations, 1Ss3, on the geology of the north shore of Lake Superior, by A. R. C. Selwyn. Trans. Roy.

Soc. Canada, vol. 2, sec. 4, 1885, 13. 245.

$47517^{\circ}-\operatorname{vot} 52-11-6$ 


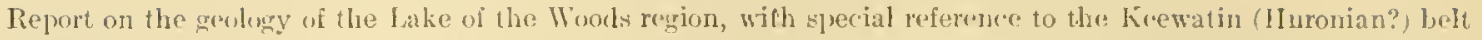

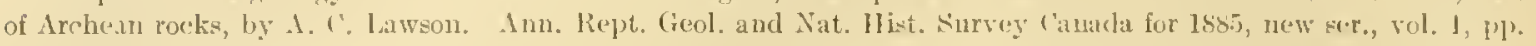
5-151 ce, with a map).

Geology and lithology of Michipicoten Lay, by C'. L. Herrick, W. G. Tight, and Il. L. Jones. Lull. llenison L'niv., vol. 2 , 1sist, p). 1:20-1.14, with 3 plates.

The rorrelation of the Animikie and Iluronian rocks of Lake Superior, by Poter Mckellar. Proc. and Trans. Rug. Sor. C'anarla, vol. 5, sec. 4, 1587, pr. 633-73.

Report of the geology of the Rainy Lake region, by A. ' '. Lawson. Ann. Rrept. Geol, and Nat. Hist. Survey ('anada for $1 S 87$ SS, new ser.. vol. 3, pp. 1-196 F, with 2 maps and 8 plates. See also The Archean geology of the region northwest of Lake Superior. Etules sur les schistes cristallins. Internat. Geol. ('ong., London, 1888, ply. 66j-88. Ginology of the Rainy lake region, with remarks on the classification of the crystalline rocks west of Lake Superior; preliniinary note. $\Lambda \mathrm{m}$. dour. Sci., 3il ser., vol. 33, 1S77, pp. $473-180$.

Report on mines and mining on Lake Superior, by l. 1). Ingall. Ann. Rept. Geol. and Lat. Hist. Surrey Canarla for 1887-88, new ser., vol. 3, pp. 1-131 11, with 2 maps and 13 plates.

Tracks of organic corigin in rocks of the Animikie group, by A. R. '. Selwyn. Am. Jour. Sici., 3il ser., wol. 39, 1890, 11. $145-147$.

The internal relations and taxonomy of the Archean of central Canada, by Andrew C. Lawsols. Bull. Geol. Soe. America, vol. 1, 1890, pp. 175-194.

Geology of Ontario, with special reference to economic minerals, by Rolert Bell. Rept. Roy. Comm. on Xin. Res. Ontario, Toronto, 1890, pp. 1-70.

Lake Superior stratigraphy, by Andrew C. Lawson. Am. Geologist, vol. 7, 1891, pp. 320-327.

The structural geology of Steep Rock Lake, Ontario, hy Henry Lloyd Snyth. Am. Jour. Sci., 3rl ser., vol. 42, 1891 , pp. 317-331.

Report on the geology of Hunters Island and acljacent country, by I. H. C. Smitb. Ann. Rept. Geol. Survey Canacla for 1890-91, vol. 5, pt. 1, G, 1892, pp. 5-76.

The Archean rocks west of Lake Superior, by W. H. C. Smith. Bull. Geol. Soc. America, vol. 4, 1S93, pp. 333-34S.

The laccolitic sills of the northwest coast of Lake Superior, by A. C. Lawson, Bull. Geol. and Nat. Hist. Surrey Minnesota No. 8, 1893, pp. 24-48.

Multiple diabase dike, by A. C. Lawson. Am. Geologist, vol. 13, 1894, pp. 293-296.

Note on the Keweenawan rocks of Grand Portage Island, north coast of Lake Superior, by U. S. Grant. Idem, pp. $437-135$.

Gold in Ontario; its associated rocks and minerals, by A. P. Coleman. Fourth Rept. Bur. Mines Ontario, for 1894, sec. 2, Toronto, 1895, pp. 35-100, with 2 geologic maps of parts of the Rainy River district.

The hinterland of Ontario, by T. $\Pi$. Gibson. Idem, sec. 3, pp. 124-125.

The new Ontario, by Archibald Bhue. Fifth Rept. Bur. Vines Ontario, for 1895-96, pp. 193-196.

A second report on the gold fields of western Ontario, by A. P. Coleman. Idem, see. 2, 1p. $47-106$.

The anorthosites of the Rainy lake region, by A. P. Coleman. Jour. Geology, vol. 4, 1896, III.907-911; Canadian Ree. Sci, vol. 7, 1897, 1p. 230-235.

Malignite, a family of basic plutonie ortboclase rocks rich in alkalies and lime, by Andrew C. Lawson. Rull. Dept. Geology L̈niv. California, vol. 1, 1896, pp. 337-362, pl. 18. $71-121$

Third report on the west Ontario gold region, by A. P. Coleman. Rept. Bur. IIines Ontario, vol. 6, 1897, pp.

The Alichipicoten mining division, by A. B. Millmott. Idem, vol. 7, 189s, pp. 184-206.

Geology of hase and meridian lines in the Rainy River district, by W. A. Parks. Iden, pP. 161-183, with geologic map.

Clastic Huronian rocks of western (Intario, by A. P. Coleman. Idem, pp. 151-160; Bull. Geol. Soc. America, vol. $9,1595,1)$ 1. 223-238.

Unpublished field notes hy C. R. Tan Hise, 18ns.

The geology of the area covered hy the Seine River and Lake Shebandowan map sheets, comprising portions of Rainy River and Thunder Bay districts, Ontario, by W'm. Alelnnes. Am. Rept. Grol. Surrey t'anarla, vol. 10. pt. H, 1899, pp. 13-5I, with geologic map.

Copper regions of the upper lakes, by $\perp$. P. Coleman. Rept. Bur. Mines (ontario, vol. 8, pt. 22, 1s99. [1], 1221-174.

Copper and iron region of Ontario, by A. P. Coleman. Idem, val. ?, 1900, pp. 143-191.

Upper and lower Huronian in Outario, hy A. P. Coleman. Bull. Geol. Soc. Amerixa, vol, 11, 1900, pl, 107-114.

Unpublished field notes loy $r^{3}$. R. Tan Ilise and J. Morgan Clements, summer of l!lo0.

The iron belt on Lake Nipigon, by I. W. Bain. Rept. Bur. Mines Ontario, vol. 10, 1901, PI. 212-214.

Iron ranges of the lower liuronian, by A. P. Coleman. Idem, l']. 181-21'.

The Nirhipicoten lluronian area, by A. B. Wiltmott. Am. Grulogist, vol. 29, 1901, Pr. 14-19.

The Michipicoten iron range, by $\mathrm{A}$. P. Coleman and $A$. B. Willmott. Vuir. Turonto studies, geol. ser., No. 2, 1902, 47 pp. See also Rept. Bur. Mines Ontario, 1902, 1'1\%. 152-155. 293-304.

Rock basins of Ilelen mine, Michipicoten, Canada, by A. ''. Colemau. Bull. Geol. Sorc. America, vol. 13, 1902, pp. 
Nepheline and other syenites near Port Coldwell, Ontario, by A. P. Coleman. Am. Jour. Sri., 4th ser., vol. I4, 1902, pp. 147-155. See also Rept. Bur. Mines Ontario, 1902, pp. 208-213.

liegion southeast of Lac Seul, by William Mclnnes. Summary lept. Cieol. Survey ('anarla for 1901-2, 11).87-93.

The country west of Nipigon I ake and River, by Alfred IT. G. Wilson. Idem, Jp. 94-103.

The country east of Nipigun Lake and Iiver, by W. A. Parks. Idem, Ip. 103-107.

Iron ranges of northwestem Ontario, by A. I'. ('oleman. Rept. J'ur. Mines Ontario, 1902, 1rp. 128-151.

Iron ranges of northern Ontario, hy W. G. Millex. Idem, 1903, pP. 304-317.

Region Jying nortleast of Lake Nipigon, by IT. A. Parks. Summary Rept. (ieol. Survey Canada for 1902-3, pp. $21 \mathrm{I}-20$.

Region on the northwest side of Lake Nipigon, by William MeInnes. Idem, pp. 206-211.

Nepheline syenite in westrm Ontario, by T. G. Miller. An. Geologist, vol. 32, 1903, pp. 182-185.

Genesis of the Animikie iron range, Outario, by F. Hille. Jour. Canalian Min. Inst, vol, 6, 1904, pp. 245-287.

The Animikie or Loon Lake iron-bearing disict, liy W. N. Smith (in charge of a party consisting of 1 . W. Lewis,

J. H. Warner, G. W. Craue, and R. C. Allen). Min. World, vol. 22, 1905, pp. 206-208, with geologie map.

Iron ranges of Mlichipicoten West, by J. M. Pell. Rept. Bur, Mines Ontario, vol. 14, I905, pt. 1, pp. 278-355, with geologic map. See also The possible granitization of acidic lower IIuronian sehists on the north shore of Lake Superior. Jour. Geology, vol. 14, 1906, pp. 233-242.

The genlogy of Michipicoten Island, by E. N. Burwash. Univ. Toronto studies, geol. ser., No. 3, Tornto, 1905, with map.

Pre-Cambrian nomenclature, by A. P. Coleman. Jour. Geology, vol. 14, 1906, pp. 60-61.

The Animikie iron range, by L. P. Silver. Rept. Bur. Mines Ontaria, vol. 15, 1906, pt. 1, pp. 156-173.

Iron ranges east of Lake Nipigon, by A. P. Coleman. Sixteenth Ann. Rept. Bur. Nines Ontario, 1907, pt. 1, pp. 105-135.

Iron ranges east of Lake Nipigon, the ranges around Lake Windebegokan, by E. S. Moore. Idem, pp. 136-14S.

Iron ranges of Nipigon district, by A. P. Coleman. Eighteenth Ann. Rept. Bur. Nines Ontario, 1909, pt. 1, pp. 141-153.

Iron range north of Rouud Lake, by E. S. Moore. Idem, pp. I54-162.

Geology of Unaman iron range area, by E. S. Noore. Idem, pP. 196-253.

The quartz diabases of the Nipissing district, Ontario, by W. H. Collins. Econ. Geology, vol 5, 1910, pp. $538-550$.

Diabase and granophyre of the Gowganda Lake distriet, Ontario, by Norman L. Bowen. Jour. Geology, vol. 18, 1910, pp. 65s-674.

\section{LAKE SUPERIOR REGION (GENERAL).}

Narrative journal of travels through the northwestern regions of the United States, extending from Detroit through the great elrain of American lakes to the sources of the Hississippi River, by IJenry R. Schoolcraft. Albany, 1821, 419 pp., with map.

Report of Walter Cunningham, late mineral agent on Lake Superior, Jannary 8, 1845. Senate Docs., 2d sess. 28th Cong., 1844-45, vol. 7, No.98, 5 pp.

Nineral report, by George N. Sanders. Idem, No. II7, pp. 3-9.

Report of J. B. Campbell. Idem, vol. 11, No. 175, pp. 4-8.

Report of George N. Sanders. Idem, Pp. 8-14.

Report of A. B. Gray. Idem, pp. 15-22.

Report of A. 13. Gray on mineral lands of Lake Superior. Executive Docs., Ist sess. 29th Cong., 1845-46, vol. 7, No. 211,23 pl., with map.

On the origin of the actual outlines of Lake Superior (diseussion), by William B. Rogers. Proc. Am. Assoc. Adv. Sci., Ist meeting, I848, pp. 79-80.

The outlines of Lake Superior, by Louis Agassiz. Lake Superior; its ploysieal chararter, vegetation, and aninals compared with those of other and similar regions, by Louis Agassiz and J. Elliot Cabot, pp. 417-426. See also Proc. Am. Assoc. Adv. Sei., 1st meeting, 1815, p. 79.

Abstract of an introduction to the fnal report of the geological surveys made in Wisconsin, Iowa, and Minnesota, in the years 1847,1818 , I8t9, and 1850, containing at synopsis of the geological features of the country, by Davicl D. Uwen. Proc. Am. Assoc. Adv. Sci., vol. 5, I851, pp. 119-131.

On the age, character, and true geological position of the Lake Superior red sandstone formation, by David D. Owen. Report of a geological survey of Wisconsin, lowa, and llinnesota, 1852, pp. 187-193.

Report of a geological survey of Wisconsin, Iowa, and Ninnesota, and, incidentally, of a portion of Nebraska Territory, made under instructions from the United States Treasury Department, by David D. (3wen. IS52, 638 pp.

A geolugical map of the United States and the British Provinces of North America, with an explanatory text, geolngical eections, ete., by Jules Ilareon, Boston, 1853, $92 \mathrm{pp}$. See also Réponse à la lettre de MII. Foster et Whitney sur le Lae Supérieur. Bull. Soc. géol. France, 2d ser., vol. 8, 1851, pp. 101105.-

The metallic wealth of the United States, by J. D. Whitney. Philadelphia, 1854, $510 \mathrm{pp}$.

Observations on the geology and mineralogy of the region embracing the soures of the Mississippi River, and the Great Lake basins, during the expeditiou of 1820 , by Henry R. Schoolcraft. Summary narrative of an exploratory 


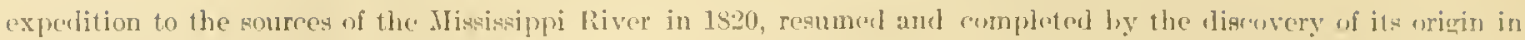
Itasca Lake in 1832. Philadelyhia, 1854, lpe. 303-362.

Remarks on some points connected with the geology of the north shore of lake Suproior, hy J. D. Whitney. Py, Am. Assoe. Altr. Sei., vol. ?, [8.56, p!). 204209

On the oceurence of the ores of iron in the Azoic system, by J. W. Wlituney. Idem, pp. 209-216;

Remarks on the Iluronian and haurentian systems of the fanatia Geological Survey, by J. D. Whitney. Am. Jour., Sri., 24 ser., vol. 23, 18.17, pp. 305-314

Physical geology of lake Superior, by ('harles Whittlesey. Proe. Am. Assor. Adv. Sri., vol. 24, 1876, pt. 2, jp. $60-72$, with map.

The copper-hearing rocks of lake Superior, by R. D. Irving. Ion. U. S. Geol. Survey, vol. 5, 1853, 464 pl]. 15 1., 29 pls and maps. See also Third Ann. Rept. U. S. Geol. Survey, 18s3, pp. 89-ISs, 15 flls. and maps; Srience, vol. 1, 1S83, pp. 140, 359, 122; Am. Jour. Sci., 3d ser., vol. 28, 1884, p. 462; vol. 29, 1885, pl). 67-68, 258-259, 339-340.

The enpler-bearing series of lake Superior, by T. C. Chamberin. Science, vol. 1, 1SS3, pp. 453-45.5.

On secondary enlargrments of mineral fragments in rertain rocks, by L. D. Irving and ('. R. Van Hise. Bull.

U. S. Geol. Survey No. \&, $1894,56 \mathrm{pp} ., 6 \mathrm{pls}$.

Divisibility of the Archean in the Northwest, by R. D. Irving. Am. Jour. Sci., 3d ser., vol. 29, 1885, pp. $237-249$.

Preliminary paper on an investigation of the Archean formations of the Northwestern States, hy R. D. lrving.

Fifth Ann. Rejt. U. S. Geol. Survey, 1885, pp. 175-242, 10 pls.

Orimin of the fermgimous schists and iron ores of the Lake Superior region, by P. D. Irving. Am. Jour. Sci., 3d sor., vol. 32,1886, pp. 255-272.

Is there a lluronian group? by R. D. Irving. Am. Jour. Sei., 3d ser., vol. 34, 1887, pp. 204-216, 249-263, 365-374.

A great Primordial quartzite, by X. H. Winchełl. Am. Geologist, vol. 1, 1888, pp. 173-178. See also Serenteenth Ann. Rept. Geol, and Nat. Hist. Survey Minnesota, for 1888, pp. 25-56.

On the classification of the early Cambrian and pre-Cambrian formations, by R. D. Irving. Serenth Ann. Rept.

U. S. Geol. Survey, 1888, pp. $365-454$, with 22 pla. and maps.

The iron ores of the Penokec-Gogel)ic series of Michigan and ITisconsin, hy 1 . R. Tan Ilise. Am. Jour. Sri., $3 d$ ser., vol. 37,1889, pp. 32- -18 , with plate.

An attempt to harmonize some apparently conflicting views of Lake Superior atratigraphy, by $C$. R. Tan Ilise. Idem, vol. 4 1, 1891, pp. 117-137.

The Norian rocks of Canada, by A. C. Lawson. Science, vol. 21, 1893, pp. 281-282.

The Norian of the Northwest, by X. II. Winchell. Bull. Geol. and Nat. Ilist. Survey Ninnesota, No. 8, 1893, plr. iii-xxii.

An historical sketch of the Lake Superior region to Cambrian time, by ' '. R. Tan Ilise. Jour. Geology, vol. 1, 1893,

pp. 113-128, with geologic map.

Crucial points in the geology of the Lake Superior region, by N. H. Winchell. $\lambda \mathrm{m}$. Geologist, vol. 15, 1S95, pp. 153-162, 229-234, 295-304, 356-363; vol. 16, 1895, pp. 12-20, 75-86, 150-162, 269-274, 331-337. See also Compt. Rend. Congrès géol. internat., 6th вess. (1894), 1897, pp. 273-308.

Pre-l'ambrian fossiliferous formations, by' ('harles D. Walcott. Bulł. Geol. Soc. America, vol. 10, 1899, pp. 199-244.

The iron-ore deposits of the Lake Superior region, by C. R. Van Hise, assisted in Ilesabi and Vermilion sections by

C. K. Leith and J. AIorgan (lements, respectively. Twenty-first Ann. Rept. U. S. Geol. Survey, pt. 3, 1901, pp. 305434 , with geologic maps.

Genlogical work in the lake Superior region, by C. R. Tan Hise. Proe. Lake Superior Min. Inst., Vol. 7, 1902, p]. 62-69.

The original souree of the Lake Superior iron ores, by J. E. Spurt. An. Geology, vol. 19, 1902, pl], $335-349$.

A romparison of the origin and development of the iron ores of the Mesabi and Gogebic iron ranges, by $C . K$. Leith.

Proc. Lake Superior Min. Inst., vol. 7, 1902, pp. 7j-81.

The Eparchenn interval; a eriticism of the use of the term Algonkian, by Andrew C. Lawson. Bull. Dept. Geolngy:

Univ. Caliiomia, vol. 3, 1902, pp. 5I-62.

The Ilurnian question, by A. P. Coleman. Am. Geology, vol. 29, 1902, pp. 325-334.

The nomenelature of the Lake Superior formations, by A. 13. Willmot1. Jour. Geology, vol. 10, 1902, pp. 6i-5ti.

Repurt of the special committee for the Lake Superior region, by C. R. Fan Hise and others. Jour. Genlngy. vol. 13, 1905, pp. S9-104; Rept. Ontario Bur. Nines, vol. 14. pt. 1, 1905, pp. 269-277; liept. Geol. Survey Jichican for 1904,1905 , pp. 133-143.

Report of the special committee for the Lake Superior region, personal comments, Jy $A$. C. Lanu. Ann. Rept. Geol. Survey Hichigan for 1904, 1905, pr. 143-153. See also Comment on the report of the special coumitter on the Lake Supurior rogion, Jour. (ieology, vol. 13, 190.). pp. 457-46t.

A sumnary of Lake Superior geology with special reference to recent studies of the iron-loaring series, Wy C. L. Leith. Trans. Am. Inst. Min. Eng., vol. 36, 1906, pl). 101-153, with geolugie maj'.

The movement of lake sujerior iron ores in I?09, with a map showing distribution of ures, by dohn liskinbine. Advance chapter from Alineral Resourees U. S. for 1909, U. S. lien\}. Survey, 1961. 7 [1".

In Algonkian basin in Ilulson lay-a comparison with the lake superior basin, hy C. K. Leith. Eom. Geology, vol. 5, 1910, ]'s. 227:-16. 


\title{
CHAPTER IV. PHYSICAL GEOGRAPHY OF THE LAKE SUPERIOR REGION.
}

\author{
By LAwrexce Malitix.
}

\section{TOPOGRAPIIIC PROVTACES.}

The Lake Superior region as deseribed in this report inchudes three topographic provinces (fig. 5) - (1) the Lake Superior highlands, a peneplain with hilly upland and lowland subdivisions; (2) a series of lowland plains surrounding the peneplain on the east, south, and west; and (3) the deep basin of Lake Superior embraced between parts of the highland and the lowland. These three topographie provinees are in various stages of development and preservation, depending on the underlying rock structure, the process by which they are being modifier, and the length of their period of development. The first consists essentially of Arehean and Algonkian rocks; the seeond of Cambrian and other early Paleozoic rocks and of Cretaceons rocks; the third is a present seat of roek deposition, and probably includes roeks of all ages represented in the other provinces, in addition to the glacial drift of the Quaternary, which also partly manthes the rocks in the first province and almost completely buries those of the second.

The peneplain highland was worn down from former lofty mountains. ${ }^{a}$ Diastrophism (warping, folding, and faulting) has notably modified the peneplain, tilting its borders and introducing the deep basin of Lake Superior. (See Pl. II.) Subsequent deposition of early Paleozoic and Cretaceous rocks in the Lake Superior basin and abont the margin of the peneplain (see fig. 5) has been followed by the exhuming of fossil topography and the produetion of a belted plain with alternate uplands and lowlands in the region of horizontal and gently tilted post-Algonkian rocks. Continental glaeiation has slightly modified the relief and completely altered the soil and drainage of the region (Chapter XVI, pp. 427-459).

\section{THE LAKE SUPERIOR HIGHLANDS.}

\section{- TOPOGRAPIIC IDEVLOPMENT.}

The highlands about Lake Superior fall into two elasses--(1) those underlain by coarsegrained homogeneous rocks, chicfly igneous, of both Arehean and Algonkinn age, and (2) those underlain by banded (both areally and structurally) alternating weak and resistant tilted rocks, chiefly sediments and lavas of Algonkian age. The areas of homogeneous jgneous rocks still preserve plateaus or high plains of slight relief, diversified only by monadnocks and by some valleys of greater than normal depth; the areas including belts of sediments have narrow plateaus, monoelinal ridges, and mesas isolated among broaler intermediate lowlands.

It is possible that the whole highland area was reduced to a peneplain, now represented by the plateau surfaces, the crests of some of the higher monoclinal ridges, and the tabular surfaces of the higher mesas, none of the arljacent lowland areas having been down-warped or downfaulted or excarated when the peneplain was most nearly perfeeted.

a Van 11 ise, C. R., Science, new ser..vol. 4, 1896, pp. 3i-59 and 217-220; Weidman, Samuel, Jour. Geology, vol. 11, 1903, np. 289-313; Wilson, A. W. G., Jour. Geology, vol. 11, 1903, pp. 615-667; Weidman, Samuel, Bull. Wisconsin Geol. and Nat. Hist. Survey No. 16, 1907, pp. 592-603 and 385-395. 
Diastrophism during post-Algonkian time, ly ehanging the altitude of the peneplain with reference to base-level, enablerl denudation to reattark tlis peneplain. Stream erosion was renewed actively along the fant escarpments, possibly being delayed in areas that hand been submerged and huried by Paleozoir sediments (p. 116). This renewal of eut ting was weak or not yet active at all in regions remote from the escarjements (liere also possilbly being delayed in the buried and protected parts), but was strongest in the areas of bunded Algonkian rocks, especially those near the steeper slopes. In these areas of banded rocks the remnants of the orjginal peneplain surfire are sullall and scattered, being largest where the vertical heds resisted erosion best, smaller where gentle tilting mule tevelopment of monoclinal ridges and intermediate valleys possible, and of least extent where horizontal beds allowed the opening of broar lowlands with only isolated unesas, as in the Thunder Bay region, or with protruding reexposed knobs, like the Baraboo range of Wisconsin and knobs north and east of it (figs. 53, 54, pp. 359, 360). The lowlands developel at several points may be incipient stages of a pene]lin of a later generation, developed with respect to a much lower base-level.

The older peneplain surface is found at various altitules, some of which are shown in the following table:

Altilude of different parts of the Lake superior highlands.

\begin{tabular}{|c|c|c|c|}
\hline Locality. & $\begin{array}{l}\text { Average } \\
\text { height } \\
\text { above sea } \\
\text { level.a }\end{array}$ & $\begin{array}{l}\text { Jighest } \\
\text { hill. }\end{array}$ & $\begin{array}{l}\text { Lowest } \\
\text { valley. }\end{array}$ \\
\hline Sontheast of Michipicoten. & $\begin{array}{c}\text { Fct. } \\
1,500-1,800\end{array}$ & Fret. & Feet. \\
\hline Near Michipicoten........ & $* 1,200-1,400$ & 1,700 & $\pm 1,100$ \\
\hline Northwest of Michipicoten. & $* 1,200-1,400$ & 2,120 & .......... \\
\hline Near Heron Bay......... & $* 1,100-1,300$ & & (a) \\
\hline North of Lake Superior. & $* 900-1,050$ & & - \\
\hline West of Lake Nipigon....... & $* 1.250-1,500$ & . & .... \\
\hline Thunder Bay and Hunters Island region... & $* 1,400-1,700$ & & \\
\hline Rainy Lake and Lake of the Woods region. & $* 1,200-1,400$ & 1,700 & 1,072 \\
\hline 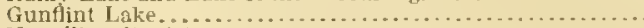 & $1,, 00-2,000$ & 2,232 & 1,547 \\
\hline Vermilion distriet. & $1,600-1,700$ & 1.910 & 1,300 \\
\hline Mesabi district.... & $1,400-1.500$ & 1,920 & 1,400 \\
\hline Gabbro plateau. & $1,400-1,700$ & 2,320 & $\pm 1,400$ \\
\hline Northern W isconsiin. & $* 1,400-1,500$ & 1,900 & 1,400 \\
\hline Keweenaw Point...... & A bout 1,350 & 1,469 & \\
\hline Marquette district..... & $1,400-1,600$ & $\# 1,950$ & $\pm 1,300$ \\
\hline Crystal Falls district. & $1,400-1,600$ & 1,940 & 1,120 \\
\hline Menominee district....... & $\mathrm{I}, 200-\mathrm{J}, 400$ & 1,370 & $\sin$ \\
\hline North-central Wisconsin. & $1,30 n-1,500$ & 1,940 & 1,100 \\
\hline Edge of I'otsdam sandstor & ${ }^{*} .1$ bout 1,000 & & \\
\hline
\end{tabular}

a Altitudes marked with an asterisk are accurate approximations based upon railway grades, etc. All other altitudes are averaged Irom accurate topographic maps.

It will be noted (figs. 4 and 5 ) that the general peneplain surface lies between 1,000 and 1,700 feet, though it is a trifle lower locally, and rises in monalnocks to exceptional heights of a little more than 2,300 feet. The maximum relief of the peneplain proper (excluding the basin of Lake Superior) is less than 1,450 feet (900 to 2,320), and these extremes are many miles apart. The maximum local relief of any part of the peneplain at the time of its greatest perfection may be quite safely plareel between 400 and 500 feet, and the arerage relief would be much lesis, perhajes 100 to 200 feet.

The present differences of elevation in the peneplain remnants might be explained as inherited, for the writer does not conceive of peneplains as approaching at all closely to a plane or perfectly base-leveled sufface. Possibly the peneplain in the Lake Superior region when most nearly prefeet stood at levels perhaps corresponding to present elevations of 1.400 feet in central Wrisconsin, 1,350 feet on Keweenaw Point, 1,600 feet in northeastern Mimesota, and 1,400 feet northeast of Lake Superior in Canada, ete. Because there was upon the welldoveloped peneplain a series of old streans whose valleys lay at lower levels than the low intermediate ridges and at slightly different levels with reference to one mother, the surface beveled back smoothly up the stream courses and the lines dividing parallel drainage systems. As we do not know where these ancient trunk streans were, we must regard the rarious preserved peneplain fragments merely as parts of a lowland worn down where meuntains had been; and 


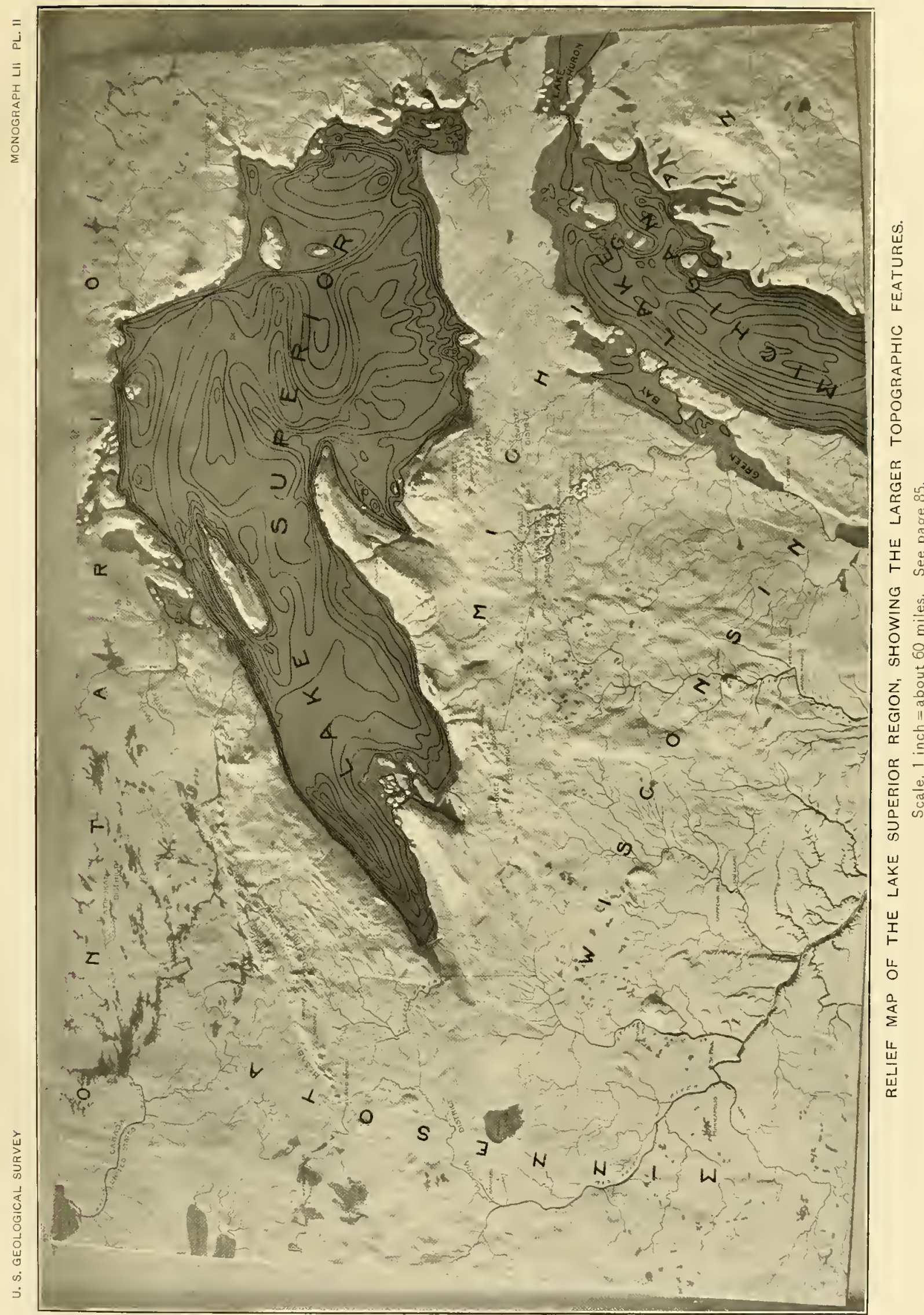



it is quite unnecessary to assume warping to account for their discrepaneies of level, as las been done with regard to numerous peneplains, though warping in this region is indiented on other grounds.

The thief evidence of diastrophic modification of the levels of the peneplain is the rift or graben fuulting indicated by displacenents and by the great esearpments and their drainage conditions. (See p. 113.) One such modification of the peneplain took place when portions of it on the site of the west half of the present Lake Superior were down faulted.

We have excellent evidence that the peneplain has been morlifiod by warping. There are three suggestive conditions: (1) In Wisconsin the peneplain dips down under the Paleozoic cover ${ }^{a}$ being 1,000 feet above sea level at Grand Rapids and 500 feet at Killomme, or 38.5

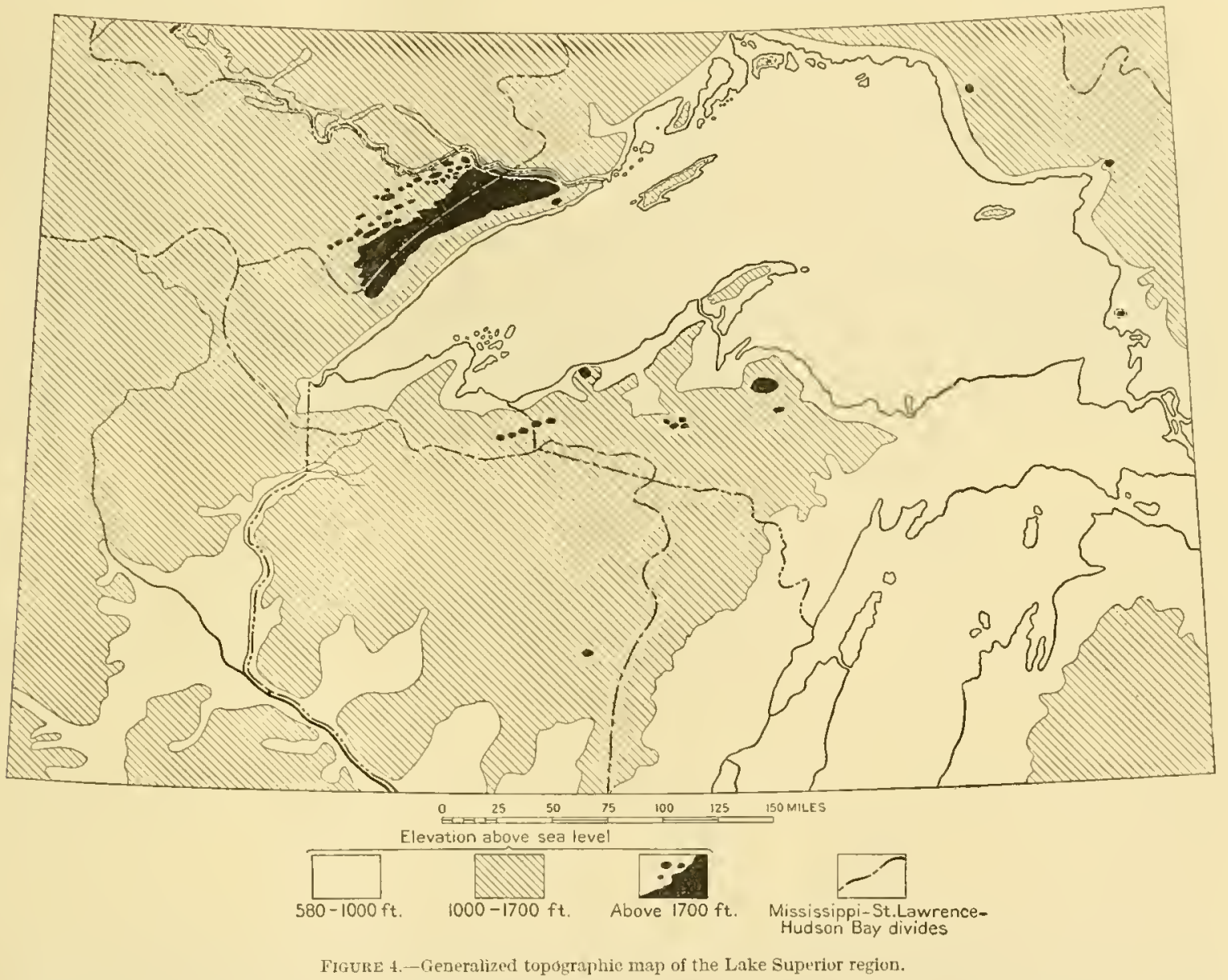

feet below the surface, one of its monadnocks rising through the Cambrian sandstone in the Baraboo range, while at Madison its surface lies 70 feet above sea level, or 810 fect below the present surface; (2) the gradients of the peneplain surface, especinlly in central Wisconsin, are greater than would be normal in aged rivers on a peneplitin; (3) the Paleozoic rocks are in such positions as almost to prove warping, for a broad north-south post-Cambrian anticline is recugnized in Wisconsin. All these suggestive conditions are corroborated by the wellestablished fact, to be described in the chapter on the Plcistocene, that tilting of the originally horizontal shore lines of former glacial lakes definitely proves slight recent warping of the region. The fact that such warping has been and is still taking place is adequate ground for saying that the peneplain remnants are not at their original levels.

a WFeidman, Samuel, Jour. Geology, rol. 11, 1903, pp. 306-307; Bull. Wisconsin Geol. and Nat. Mist. Survey No. 10, 1907, pp. 392-394. 
The peneplain might be conceiverl to represent facets of one or more earlier peneplains, but this does not seem likely unless the main peneplain is Cretacens and parts of it reprenent preserved facets of a late Algonkian or early Cambrian pencplain. Earlier possible peneplain levels-in the Ituronian, lor example-would have been warped or folded by pre-Algonkian deformation from their original nearly horizontal position to almost any conceivalble angle. The several great uneonformities of the region doubtless represent peneplain stages, and the very fine materinl deposited after certain unconformities also suggests a low gradient of river's and a lack of coarse sediments-conditions characteristic of a nearly base-leveled region. Some of these unconformities, now exposed by denulation, reach the surface at low angles, but it toes not follow that a remnant of a lower IImonian peneplain is anywhere visible. In view

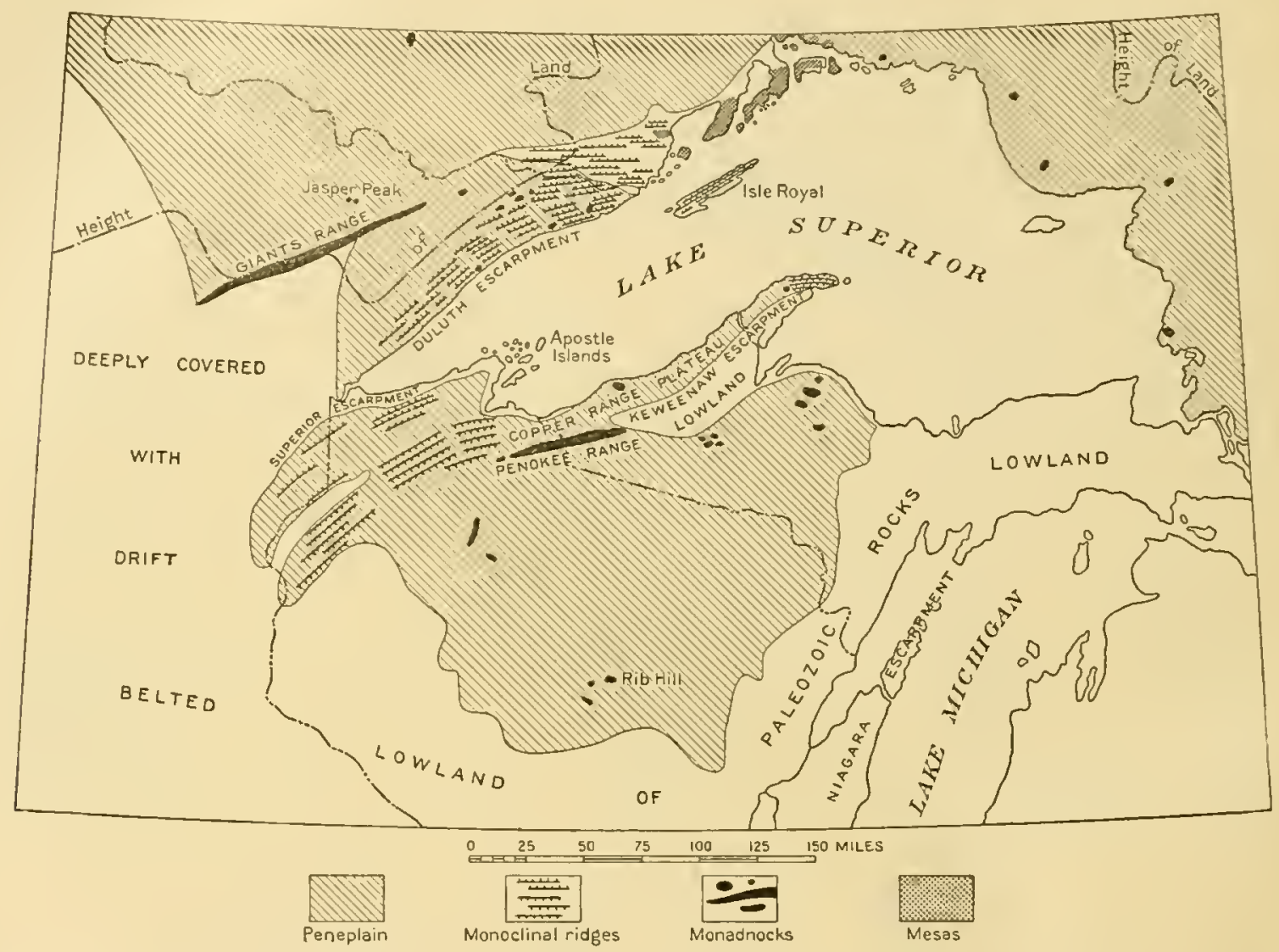

FIGURE 5.-The topographic provinces of the Lake Superior region, with some subdivisions of the peneplain.

of the tremendous pre-Cambrian base-leveling, any such surface, in the writer's opinion, should be regarded as either still buried or else long ago eroded away, unless definite evidence to the contrary can be prodnced. If the peneplain is not Cretaceous but a dissected late Algonkian or early Cambrian peneplain, it seens hardly likely that any facets of its surface represent earlier base-leveling.

The age of the Lake Superior peneplain, where stullied in parts of the area, has been tentatively suggestel by Van Ilise to be Cretaceous. ${ }^{a}$ Weidnan dates the Wisconsin part of it as pre-Potsdam, apparently recognizing it beneath the first Paleozuic rocks (Potsclam or L Lper Cambrian) in Wisconsin. The Laurentian peneplain alescribed by $\mathrm{\Lambda}$. W. G. Wilsonc does nut inchule the Keweenawan areas of northostern Minnesota, Isle Royal, northern Wiseonsin. and Feweenaw Joint, and therefore represents for our area merely the possibility of the screral

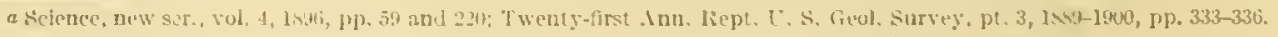

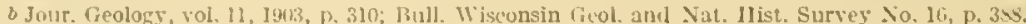

c Jour. Geology, vol. 11, 1903, pp. 615-669. 


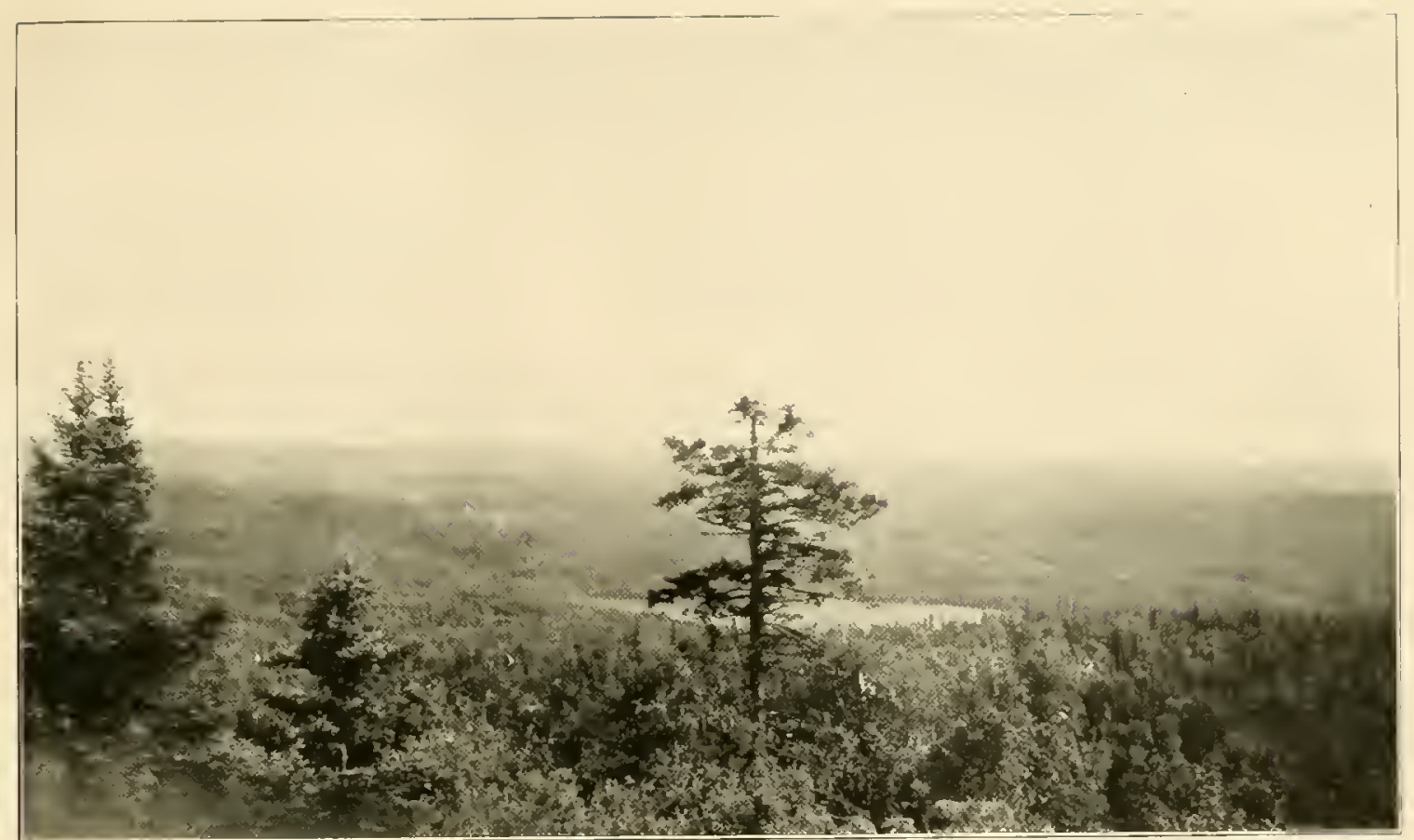

A. PRE-CAMBRIAN PENEPLAIN IN ONTARIO, NEAR MICHIPICOTEN. See page 89.

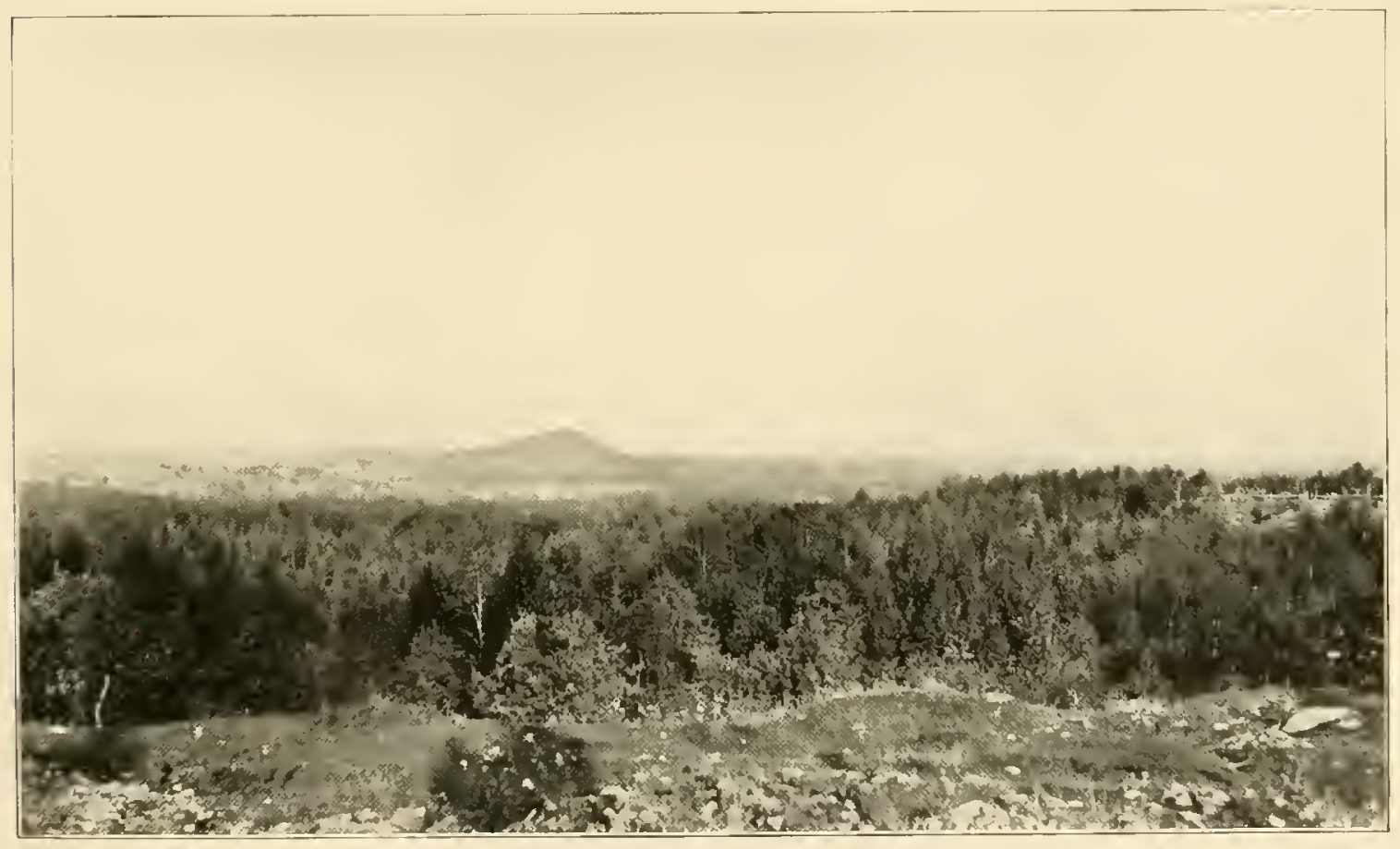

1). JASPER PEAK, NEAR TOWER, MINN.

A monadnock rising above the even upland of the Pre-Cambrian peneplain. See page 90 . 

pre-Keweenawn (Inomian and Archean) peneplains. The more specilic fixing of the age of the whole Lake Superior peneplain depends largely on the age of certain escarpments and of certain faults and on the overlap of certain sediments; the trend of the evidence (see discussion of basin of Lake Superior) suggests an early origin of the peneplain, perhaps late Algonkian or early Cambrian. It is not conclusively established that a liter peneplain, perhaps Cretaceons, was developed in the area, though the regions of low rclief close to or within the basin of Lake Superior may be Cretaceous - as, for example, the lowlands of central Minnesota and eastern upper Mlichigan.

THE HROAD UPI,ANDS.

\section{POSITION, RELIEF, AND SKY LINE.}

The Lake Superior highlands form a broad upland cut by valleys and diversified by monadnocks and other ridges. The upland is male up chiefly of the Archean, but most of its ridges and monadnocks are composed of rocks of Algonkian age. This is so because the Arehean rocks in this region are chiefly granites, greenstones, and other course-grained rocks, together with schists and gneisses, most of which are honogeneous over l)roal areas in their resistance to weathering and erosion and at present generally still preserve the peneplain developed upon them; whereas in the Mgonkian areas, because of folding and faulting, the Iluronian schists, gneisses, quartzites, etc., and the Keweenawan lavas usually present homogeneons resistance to weathering and erosion, not over broal areas but in narow linear belts, so that the former peneplain is dissected in these regions to hilly uplands and lowlands with notable ridge topography. There are some exceptions, however, in the Algonkinn-for example, where the homogeneous, coarse-grained Duluth gabbro of the Keweenawan northeast of Duluth and the similar granite of northern Wisconsin, which is possibly lower Huronian rather thin Archean, form broad uplands.

These brond pre-Cambrian uplands stand above the adjacent relatively lower plains of the Paleozoic and (retaceous and above the deep basin of Lake Superior at an average height of about 1,350 l'eet above sea level (fig. 4). Their local reliel is slight. The following elevations in representative areas are taken from topographic maps:

Northeast-southwest section along the Termition iron range in northeastern Minnesota.

\begin{tabular}{|c|c|c|c|c|}
\hline $\begin{array}{l}\text { llilltops........ } \\
\text { Valley bottoms. }\end{array}$ & $\begin{array}{l}\text { Fect. } \\
1,620 \\
1,380\end{array}$ & $\begin{array}{l}\text { Fect. } \\
1,660 \\
1,360\end{array}$ & $\begin{array}{l}\text { Fct. } \\
1,800 \\
1,480\end{array}$ & $\begin{array}{l}\text { Feet. } \\
2,120 \\
1,760\end{array}$ \\
\hline
\end{tabular}

East-u'est section, west of Marquette, Wich.

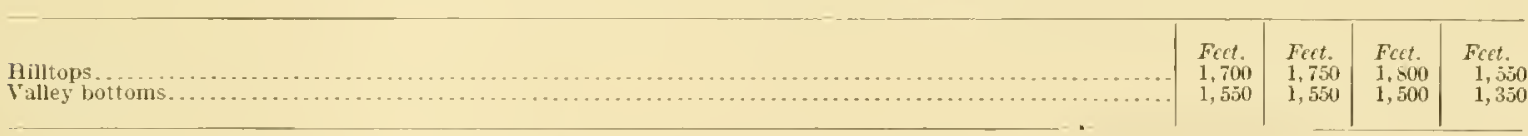

East-uest section in north-central $T_{\text {isconsin. }}$

Hilltops.

Valley bottoms.

\begin{tabular}{l|l|l|l} 
Fect. & Feet. & Fect. & Feet. \\
1,340 & $1,+12$ & $\mathbf{1}, 440$ & 1,400 \\
1,200 & $\mathbf{1}, 200$ & $\mathbf{1}, 160$ & 1,300
\end{tabular}

It will be seen that the average local relief here is about 240 leet. A few hills rise slightly above the general level and many valleys are ent slightly below it, but from an eminence an ohserver views a region of slight relief with an even sky line. (See Pl. III, A.)

\section{RELATION OF ORIGINAL AND PRESEINT TOPOGRAPHY.}

It is of interest now to compare the present surface, which berels indifferently across structural lines, with the surface which must have existed when most of the Archean and Algonkian rocks received their present texture and structure. The granite and similar rocks 
coubl have been mate eourse graind only by cooling under a heary mantle of overlying rock. (See lig. 11, p. 116, and eross sertions on Pl. XV11, in pocket.) Evilenty the sarface when the eranite was intruderl here was liar higher than the present surface. The greenstenes, some of which cooled at the surfiace, are truncated in such positions that the original folds, if restored, would extend high alove the present surface and deep into the earth (ligs. 7, .p. $101 ; 35$, p. 25.3). Some of the gneisses and schists contuin crystals and show structures such as slaty cleavage and schistosity which could have been produced only under a heavy loasl of orerlying rock. Restoration of the missing parts of the folds, as revealed by study of the structure, shows that all the gneisses and schists are parts of the architectural scheme of an edifire entirely different from the present Lake Superior region. (See fig. 54, 1). 360, and structure sections on Pls. 1 , VIII, XVI, and XVIl, in pocket.) In all other sorts of plains lresides peneplains the strata normally lie norly lorizontal, or neally parallel to the surface of the plain. In the Lake Superior region the strata almost nowhere comcide in position with the surface, the dips at many places being almost vertical. The texture, the position, and the relations of the rocks are such as are found in existing mountainous regions. Evidently this peneplain was anciently a region of lolty mountains. ${ }^{a}$

\section{MONADNOCKS.}

In some parts of the region knobs or monadnocks (fig. 5) rise conspicuously above the pencplain surface. Tone of them is of great area or of great height. In fact, many of them would not be noticeable if it were not for the evenmess of the general upland surface of the region. Of these monadnocks, Jasper Peak (1,710 feet), near Tower, גlinn., is a good example (PI. III, B) and will be described as typical of the class. Other monulnocks are Mlinnesota Hill, at Soudan, Minn.; the 2,230-foot peak among the Misquah Hills in Cook County, Mimn., the highest in the Lake Superior region; Eagle Mountain and Brule Mountain, in the same region; Tiptop Mountain ( 2,122 feet), northwest of the Mlichipicoten district, probably the highest in Ontario; Hematite Mountain (1,700 feet), at the Helen mine in the Michipicoten distriet; the Polcupine Mountains and parts of the Huron Nountains in western upper Miehigan; and Rib Hill (PI. IT, A) (1,942 feet), Irardwood Hill, the Mosinee Ilills, and Powers Bluff in northem Wisconsin.

Jasper Peak is an oral eminence about one-lnalf mile long from northeast to southwest and three-eighths of a mile in the shorter dimension. It rises nearly 500 feet above the valleys on either side but only 350 to 400 feet above the general upland of the region. It stands up as a monadnock because the jasper and ferruginous ehert of which it is made are more resistant to denudation than the adjacent rocks. Other resistant rocks to which monadnocks of the Lake Superior region are due are the Archean gneiss in Fiptop Mlountain, ferruginous ehert and irm-bearing formation in Ilembek Mountain in the Michipicoten distriet, mel Ituronian quartzite in Rib Hill, Wis. ${ }^{b}$ Various other resistant lluronian and Keweenawan formations stand up as monoclinal or other ridges. The long ridges of this character that rise high enough above theije surroundings to be called monalnocks inclule the Giants Range of Minnesota, the Penokee Range of Wisconsin, and others which will be specifieally described later.

\section{VALLEYS IN THE PENEPLAIN.}

There are, of course, general inequalities in the peneplain, but there are also vallers cut 100 to 400 feet below the general level, which may be interpreted an evinlence of slight uplift after the completion of the base-leveling that produced the peneplain. In general these ralleys are fairly broad and mature, and most of them are most widely opened along the areas of the weaker rocks. The original consequent drainage of this region was morlified as the mountanous area was worn down, and the streams on the belts of wealser rocks naturally wore their valleys lower, received more water, and captured tributaries from the more slowly egoling streams

a A different opinion has heen advanced by A. C. Lawson (fieol, and Xat. Jlist. Surrey Canada, vol. 1, new ser., 1k5, p. 23cc).

b Van 11 ise, C. R., Science, new ser., vol. 4, 1596, p. 55; Weidman, Samuel, Jour. Geology, vol. 11, 1903, p. 297 

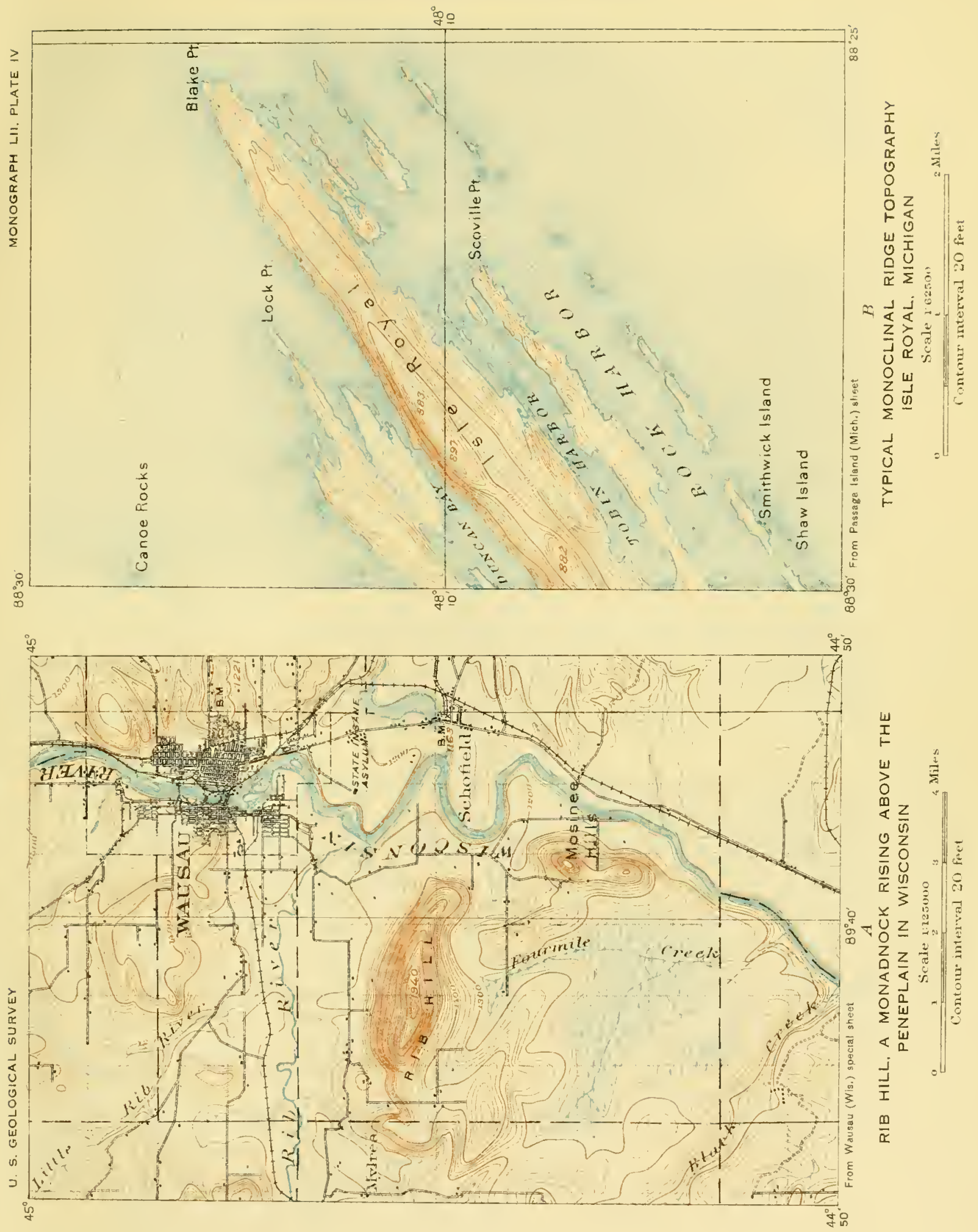

on the durable rocks. 'I'he stream systems are now subseiquent rather than consequent--that is, they are adjusted to the weaker structures-crossing the ridges of resistant strata in nurrow transverse courses and flowing in greater depressions along the longitudinal belts of weak rock. Most of the streans of the pre-Cambrian upland are in this adjusted condition; but Weidman has diseussed evidences of a lack of adjustment of the stream courses in northem Wisconsin, the rivers being superposed indifferently upon weak and resistant beds hecaluse of original courses consequent upon the dip of unconformably overlying Paleozoir sediments.

\section{SOIL AND GLACIAL TOPOGRAPHY.}

A striking feature in the uplands is the absence nearly everywhere of any local or residual soil, such as would be derived from the weathering and decay of the various strata during the very long time necessary to reduce this from a moumtainous region to a peneplain of slight relief. In the driftless portion of the region the ledges are deeply covered with residual soil derived from their decay. Elsewhere the soil is of a different kind from the underlying rock, with which it forms a sharp contact. It shows almost no sign of decay. It is not a resilual but a transported soil, produced through erosion and deposition by the great continental ice sheet. 'This ice sheet removed the residual soil, brought a new and less fertile soil or' left the ledges bare, displaced stream courses from the zones of weaker rock, producing many of the existing waterfalls and rapids, clogged the longitudinal subsequent valleys so as to form one class of lakes, ${ }^{a}$ deepened some of the valleys so as to form lakes of another type, and produeed numerous other eflects, which are described in Chapter XVI (pI. 427-459). It is owing chiefly to this glacial invasion that the region differs from the nomal peneplain type in minor topography, in drainage, and in soils.

\section{DESCRIPTION OF DISTRICTS IN DETAIL.}

The following description of the upland topography in the several districts is designed to exhibit its variations in accordance with the character of the constituent rocks. A geographic order has been alopted, starting with the part of the peneplain at the west end of Lake Superior, north of Duluth, continuing around north of Lake Superior in Ontario, and thence proceeding to the districts south of Lake Superior in upper Michigan and Trisconsin.

\section{GABBRO PLATEAU.}

The area in northeastem Mimesota underlain by the various Keweenawan gabbros, porphyries, ete, is a broad upland or plateau and forms a typical well-developer part of the peneplain. The rocks of the gabbro plateau are prevailingly coarse grained and homogeneous and hence furnish a notable exception to the linear topography commonly developed in the Algonkian. Locally they form ridges grading into the monoclinal ridge or sawtowth country to the east and north, which is mostly composed of granite or felsite or diabase rather than gabbro. The gabbro plateau surface is thus described by Grant: ${ }^{b}$

In general the surface of this area is in the nature of an undulating plain. Many small elevations occur, but few which rise to a hundred feet above the surrounding country. *** While the surface is in general one of low relief, the minor irregularities are prononnced. Steep rock hills are common, and sniall vertical escarpments 10 tc 20 feet in height are of frequent occurrence. Some of the water bodies, none of which are deep, stretch throngh considerable areas. * * * The general plainlike character of the gabbro-covered area can be ascribed to weathering, erosion, and glaciation, acting upon a surface composed of a single rock mass (the gabbro) utiform in constitution, grain, and resistance to disintegrating agents

('lements ${ }^{c}$ refers to it as a peneplained upland with minor irregularities due to joints, eomposition, etc., with irregular shallow lakes. He speaks of it as "reduced almost to baselevel." In places the gabbro forms a more hilly topography.d

a Clements, J. MI., The Vermilion iron-bearing district ol Minnesota: Mon. U. S. Geol. Survey, rol. 45, 1903, pp. 43-46.

o frant, U. S., Final Rept. Geol. and Nat. Hist. Survey Minnesota, vol, 4, pp. 43t 435, 482, 492.

c Op. cit., pp. $37-35,392-400$.

d Grant, U. S., op. cit., pp. $399,420,462$. 
In St. Iouis County, north and northeast of Duhuth, the platean topography is mitua (PI. $T, A$ ), being largely obscured by the gracial drift. X. II. Winchell has referred to this plateau topography ${ }^{b}$ as "very monotonus and neasly flat," with the gabbro "rising in irregrular rocky domes about 10 to 30 feet above the surmunding country." Grant speaks of it in lake and Cook counties, Mlinn., "cs a "loroad undulating plateau," with a "surface which is still rough but has no marked elerations."

The areas of resistant red rock (folsites, porphyries, syenites, and granites) form monalnocks and higher ridges, among these being the Nisquah Hills, one of whose summits, reaching a height of about 2,230 feet, is the highest point in Minnesota and the highest in the lake Superior region. Other monadnocks of the resistant "led rock," including Eagle Mlountain, rise to 2,100 or 2,200 feet. ('ertain anorthosites also form resistant knobs, such as Cirlton Peak, which rises 927 feet above Lake Superior; it has been deseribed by $\mathrm{A}$. C. Lawson. ${ }^{d}$

The diabases generally form monoclinal ridges of the type described on page 99; they do not property form a part of the topographic subprovince here diseussed (the broad uplands) but are located upon its margins.

The whole plateau is deeply covered with glacial deposits, which conceal the ledges and the preglacial topography to some extent and have disarranged the drainage so that there are abumlant lakes, swamps, and muskegs.

The east border of the plateau is the steep escarpment which descends abruptly to Lake Superior (Pl. V, A). The west boundary is obseured by glacial deposits, so that the topographic relationship of the Kieweenawan of the plateau and the upper Huronian slates south of the Giants Range is obscure. The north boundary of the gabbro plateau, as described by Clementse and by Leith, is a "conspicuous northward-facing escarpment overlooking the low-lying area of Virginia slate and iron formation immediately to the north. To this the name "Mesabi Range' $f$ was first applied."g In places the gabbro overlies the granite and there is no intermediate lowland.

\section{ST. LOLIS PLAIN.}

West of the gabbro plateau, in the region dramed by St. Louis River and its tributaries, the homogeneous upper II uronian slates form a broad plain at a lower level, extending north to the Giants Range and in most places deeply covered by glacial drift but still retaining the even peneplain topograplyy.

\section{VEIRMILION DISTIRICT, ${ }^{h}$}

In the Vermilion district, which is separated from the gabbro plateau and the slate plateau of upper St. Louis River by a great linear monadnock called the Giants Range, the peneplain topography is also well developed. Here, however, the even-featured surface bevels across Archean and Huronian roeks rather than Keweenawan gabbros. The truncated folds of conglomerates, slate, iron fornution, etc., and the exposed masses of greenstone, granite, etc., indicate, however, that this was originally the heart of a fofty mountain region. (See structure profiles, Pls. I, XXYT, in pocket.) The peneplain seems to have been base-leveled and subsequently slightly uplifted, so that the streams have incised valleys, between which flat uplands and ridges rise to the peneplain level. The present topography has been described by C. R. Van Ilise ${ }^{i}$ as follows:

\footnotetext{
a See tupographic map of Duluth quadrangle, U. S. Geol. Survey, and maps of St. Louis, Cook, and Lake eonnties in atlas accompanying Final Rept. Vieol. and Nat. Hist. Survey Minnesota.

o Final Rept. Geol. and Nat. Hist. Survey Minmesota, vol. 4, pp. 212, $2(5$.

cldem, pp. 2Lit. 31T.

¿ Bull. lieol. and Nat. Ilist. Survey Jiunesola No. \&, 1893, pp, 18-19.

Tho Vermilion iron-bearing district of Jinnesota: Mon. IT. S. Geol. Surves, vol. 45, 1:*13, pp. 399-401).

t The name "(iants Runge" is generally applied to the high ridge area underlan by the liuronian granite, though there is a tenteney to extend the name eustward to the somewhat disconnected peaks (Mlisyuab IIills, etc..) underlain by the "red rock" (a heweenawan granile). See footnote on 1. 103

0 The Mesabi iron-bearing district of Minmesuta, Mon, L. S. Geol. Survey, rol. 43, 1903, p. IN2.

h 1 brief statement about the topography is ineluded in each of the chapters un the iron-producing districts.

Manuscrizt notes.
} 
The ridges correspond in direction with the greater extent of the district. They are parallel with the major structure and also with the secondary struetures, such as cleavage and schistosity. The trend of these ridges is therefore about N. $70^{\circ} \mathrm{E}$., although locally they vary much from this direction.

These ridges vary in altitude somewhat rapidly in the direction of their trend, and a single ridge is usually no longer than a fraction of a mile to a few miles, ordinarily 1 or 2 miles. The slopes parallel with the trend of the ridges are comparatively gentle. The slopes transverse to the course of the ridges are steep between the ridges, the valleys being deep and many of them narrow. Also the cross section of a single ridge may be complex, so that it consists of a series of minor ridges between which are minor valleys. Though the major features of the region are undoubtedly preglacial, the action of the ice has been very important, so that the hills and bluffs are now round-topperl, the slopes steep, and the valleys flat-bottomed and $U$-shaped. This form is, however, suborlinately due to filling rather than to erosion.

Hany of these valleys are occupied by lakes. The greater number of these lakes are almost exactly parallel to the trend of the ridges and are generally several times as long as broad. This is true not only of the main body of each lake but also of its arms. Characteristic lakes of this class are Long Lake, Fall lake, Mloose Lake, New Found Lake, and Knife Lake.

Where the structure of the district locally is not linear, as in the granites, the lakes also lack the linear character. As illustrating this may be cited Snowbank Jake, Gabimichigama Lake, Gull Lake, and Iake Saganaga.

From high knobs or recently burned areas may be had the best views of the topography. From a point like Jasper Peak, or Disappointment Mountain, or one of the high ridges in the neighborhood of Gunflint, an observer sees in the foreground the linear ridges, rough and partly covered by trees in various stages of growth, in the valley at his feet a lake, and along the range, if the point of view is advantageous, many lakes. From Jasper Peak he may follow nearly all the bays and arms of the largest and most complex of the lakes of the district, Vermilion Lake [Pl. V1]. However, if the observer ignores the immediatesurroundings and looks farther away, he gets an idea of the more anciest topography of the region. South ward from a high point in the western part of the range his view extends over a number of ridges and valleys, and as a horizon line he sees the Giants Range north of the Mesabi district. This range in the western part of the district is composed of the Giants Range granite and in the eastern part of the district of the Keweenawan gabbro. To the north his range of vision is limited by the granitic hills of Basewood Lake.

From the various points of view he learns that, though the Vermilion district has lumerous hills and bluffs not inferior in altitude to the areas north and south of the district, on the whole it is an area in which erosion has played an important rôle, the valleys being wider and deeper and containing lakes in especial abunclance.

Ignoring all these minor irregularities, he is astonished at the apparent horizontality of the sky line. A few points, however, project above this sky line for instance, Jasper Peak [Pl. III, B].

This impressive feature of the topography suggests very strongly that this region was at some time in the distant past nearly base-leveled; that the high projecting points were not reducer to this level; that since that ancient time a new cycle of erosion has far advanced. Into this base-leveled plain the present topography of the Vermilion district has been incised. It almost surely was mainly accomplished by river erosion in preglacial times. However, the glacial erosion has been exceedingly vigorous here. It was preeminently an area of glacial erosion and not of deposition. The hills and bluffs are almost devoid of glacial débris; even the valleys contain comparatively little as compared with moraine areas of Wisconsin and Minnesota. The present forms of topography are not typical river-sculpture forms; they are rather such forms considerably modified by glacial sculpture and glacial deposition.

J. II. Clements reviews the relation between topography and strueture in this distriet, emphasizing many points by local examples. ${ }^{a}$ He refers to the whole region ${ }^{b}$ as "characterized by ridges trending $\mathrm{N}$. $70^{\circ}-80^{\circ} \mathrm{E}$., with interveming valleys, the larger ones usually occupied by streams or lakes. In this area the topography is rugged but the range of altitude is not very great."

Clements ${ }^{c}$ has described in letail the topography characteristic of the various Archean formations in the Vermilion district as follows:

Ely greenstone: Prominent east-west hills and ridges, or broad, low, rounded knolss and ridges.

Soudan formation (iron bearing): No great effect upon topography usually, though locally very important, as where its jaspers form prominent peaks, such as Jasper Peak, Lee and Tower hills, and other notalle knobs and ridges, some of them monadnocks.

Granites of Vermilion Lake: Usually occupies hill crests or "occurs in rounded or oval hills higher than those occupied by the surrounding rocks."

Granites of Trout, Burntside, and Basswood lakes: "Does not seem to affect the topography very materially." Topography rough in detail but with no notable relief. Irregular or rounded lakes contrast strikingly with linear lakes of sedimentary areas. Has small area, possilbly base-leveled in second cycle.

Granites between Moose Lake and Kawishiwi River: Exposures numerous in oval mass.

Granites of Saganaga Lake: Unemphatic topography, with low rounded hills rising to same level and suggesting rather complete peneplaining.

a The Vermilion iron-bearing district of Minnesota: Mon. U. S. Geol. Survey, vol. $4 \overline{5}, 1903$, pp. 431-436.

b Idem, pp. 19, 36-37.

c Idem, pp. 13t-135, 175, 248, 259, 264, 266. 
The several Huronian intrusives of smaller area also produce a typical perneplain topersraphy in the somewhat isolated highlands of the plain of Iluronian siate at the edge of the Leweenawan gablno. Their several eflects are thus described lyy Clements:"

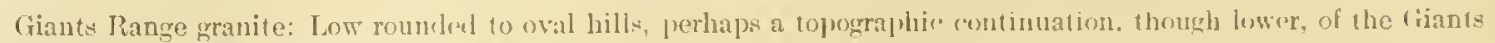

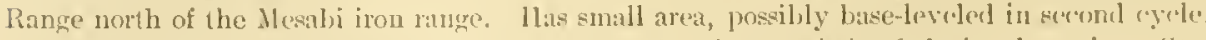

(iranite of Snowbank Lake: Ronnded topograplyy characteristic of glaciated granite. Stands lower topographically than might be expertecl from its position in center of a structural anticliue.

Cacaquabic granite: ()cupies proninent position, with fairly high lills.

Acid dikes: Locally form kuolls anl ridges.

The Huronian beds are nearly always associated with depressions or with minor ridges and the slates form a linear lowland with local ridges and knobs. Clements ${ }^{b}$ has clescribed the topograply developed upon the lower. Huronian sediments as follows:

Conglomerates and slates of Vermilion Lake area: Depressions umlerlying lakes, swamps, ete., or generally" low land befween ridges of Arrhean greenstone and iron formation, trending north-northeast and south-8outhwest.

Conglomernte, iron-bearing Agawa formation, and Kufe Lake slate of Knifo Lake area: Iuch rongher topography: than in Vermilion Lake area to west. Relief of 400 feet or 600 feet including depth of lakes. Normally conglomerates form riılges and slate forms depressions. Ridges and valleys, all on comparatively small scale, trend east-northeast and west-sonthwest. locally siliceons slates form sheer clifis of 100 feet.

\section{RAINY LAKE AND LAKE OF THE WOODS DISTRICT.}

The Rainy Lake and Lake of the Woods region, north of the international boundary, is mnlerlain chiefly by the Archean, but has subordinate linear areas of not clearly separated Huronian. A. C. Lawson has characterized the topography near the Lake of the Woods as one which. "althongh extremety hummocky or mammillated in its surface aspects, presents extraordinarily little variation in level. There are no great valleys or high hills. The whole country is practieally a plateau of very moderate elevation above the sea for so inland a region." c He describes the Rainy Lake region as "remarkably flat and devoid of prominent elerations, although the surface in detail is extremely uneren ant hummocky or mammillated." $d$

He regards the region as probably never having been mountainous, giving as his reasons the lack of proof that plications in general make mountains and the absence of immense ralleys or gorges. Ilis report was written, however, long before the idea was developed that the condition of moderate relief in a peneplain belongs to a later state of denudation than that of the mountains, leep gorges, etc.

Lawson ${ }^{e}$ shows how the variously folded weak and resistant beds form minor ritges and ralleys on the land, or peninsulas ant bays and islands where lake waters wrap around an irregular series of valleys and hillocks produced by subaerial erosion previous to the formation of the lakes. Near Rainy Lake elevations arerage only 100 to 200 feet, though certain exceptional rilges and knobs, which seem to be monalnocks held up on resistant schists, grneisses, and grinites, rise 300 to 500 feet above lake level, the highest being Kishkutena Ridge, approximately 1,700 feet abore sea level and risible for long distances. The lakes arerage less than 50 feet deep, the greatest depth found being 165 feet.

\section{HUNTERS ISLAXNl AND TIIUNDER BAY REGION.}

East of the regions described by Lawson lies the region of IHunters Ishnd and Thunder Bay. IT. H. (. Smith' and William McInnes 9 have described the topography as belonging to the same sorts and having the same relationships as that to the west. The greenstones,

\footnotetext{
a The Vermilion iron-hearing district of IInnesota: Mon. U. S. Geol. Survey, vol. 45, 1903, pr. 354. 361, 364.370.

b rlem, pp. 3i, 2\%, 299.

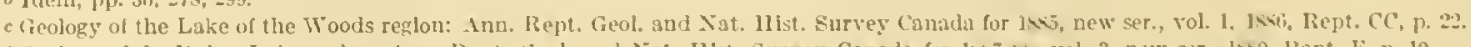

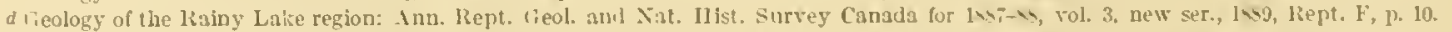

COp. cit., vol. 1, 13ept. CC, pl. 15-25 and 2ti-24: vol. 3, Rept. li, pp. 10-20.

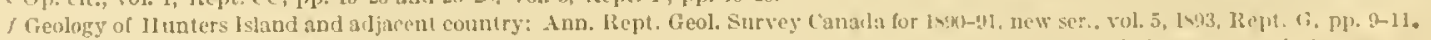

a Geology of the area covered by the Seine kiver and lake shebandowan map sheets: Ann. liept. Leol. Survey Canadia for ivg;, new ser., rol. 10, 18:39, Rept. 11, p1. 6-10.
} 
jaspilites, and iron formation and certain schists form ridges rising at most 300 feet aluve the neighboring lakes, whose greatest depth is 280 feet; the other Arehoan rocks are "charaeterized by low, rounded hills, with softened outlines."

\section{REGLON NORTH OF LAKE SITERLOR.}

W. II. Collins ${ }^{a}$ ieseribes the region between Nipigon Bay and Heron Bay and northwarl to the Height of Land as "a peneplain of rounded hills of erystalline rocks 300 to 400 feet high, terminating abruptly along the south," and with steeply descending streams affording excellent water power.

Collins ${ }^{b}$ aiso describes the Archean area north of the Canadian Pacific Railway and west of Lake Nipigon as possessing "a surface of low relief and morlerate altitude." Water levels vary from 1,149 to 1,382 feet. Few hills reach 250 feet in height. The sky line is excechingly even. The area also possesses the linear topography of the Algonkian in places and the mesa topography of the Kieweenawan near Lake Nipigon and to the west.

\section{REGION NORTIIEAST OF LAKE SUPEIROR.}

J. M. Bell "has characterized the region north of Lake Superior and west of the Michipicoten district to Heron Bay as hilly, with greater ranges of relief than elsewhere in the Laurentian peneplain, with valkeys opened on weak rocks, ridges formed on resistant beds, and with monadnocks rising above the general peneplain level on the site of the still more resistant beds.

\section{MICHIPICOTEN DISTRICT.}

The part of the peneplain that inchules the Michipicoten district has been deseribed as follows: $d$

The topography is of the rugged character usual on the north shore of Lake Superior, and Hematite Mountain, the highest point, rises 1,100 feet above the lake within a distance of 7 miles. In general the hills form steep ridges with a direction of about $70^{\circ}$ east of north, corresponding to the strike of the schists, and traveling is difficult across the line of strike. * * * From the summit of Hematite Mountain, which is situated abont in the middle of the region and rises 200 feet above any of its neighbors, therc is presented more than the usual variety of surface, including long ridges of Huronian schist, rounded hills of eruptives, which sometimes rise like islands out of lacustrine plains, stretches of the hummocky surface so common in glaciated Archean districts, lake basins, rock rimmed or bordered with muskeg, rivers with lakelike stretches of dead water, tumultuous rapids over morainic bowlders and falls over rocky descents, and, finally, the splendid promontories of the shore of lake Superior. * * * The intimate dependence of the topography on the geological history of the country is well brought out in the Michipicoten region, where the folding of the schists has deternined the direction and stcepness of the main ranges of hills; while bosses and irregular masses of eruptives give rise to less uniform hills associated with the ridges or standing isolated. The basis of the topograplyy is to be found in the pre-t ambrian arrangenent and the varying power of resistance to weathering and erosion shown by the different rocks; so that the prominent features may be of very ancient date, even Paleozoic.

\section{REGION NORTII OF SALLT STE. MARIE.}

In the upland north of Sault Ste. Marie and east of Michipicoten relief of as much as 100 to 200 feet is common. Nearer the lake and southeast of Nichipicoten there are several very deep valleys, notably those of Agawa, Montreal, Batchawana, Chippewa, and Goulais rivers. Owing to the considerable relief, some very high and expensire trestles will be required where the Algona Central and Irudson Bay Railway is to cross the first three rivers mentioned; and the building of the railway beyond Pangissin has been hindered by the necessity of high steel bridges, though the railway is graded all the way to the Michipicoten district. Such expense in railroad building in the Lake Superior region away from the lake shore is distinctly exceptional and indicates the high degree of the local relief.

a Summary Rept. Geol. Survey Canada for $1905-6$, pp. $80-81$.

b Idem, p. 103.

cRept. Bur. Mines Ontario, vol. 14, 1305, pt. 1, pp. 2\$1-299.

a Coleman, A. P., and Willmott, A. B., The Michipicoten iron ranges: Univ. Toronto studies, Geol. ser., 1902, pp. 4-6: also Elerenth Rept. Bur. Mlines Outario, 1902, pp. 153-154. 
"ithe areas between these dece valleys are hrowd and relitivoly llat or rouml topperl, and some of the hills "present stecp shopes toward the valleys and often drop ofl in impassable clifls 100 feet or more in lheight. Xone of the hills rise much over 1,000 feet above lake Superior, but many reach 900 feet" $(1,500$ to 1,600 feet aloove sea ievel). "The surface bevels inditlerently across variously clurable structures of gneiss, schist, and granite in a characteristic peneplain surface, with the usual monadnocks. The deep valleys resemble those of the north shore of Lake Superior, which are crossed near their mouths by expensive bridges and trestles of the Canadian Pacific Railway; in both regions they are deep cut because of the low adjacent basc-level of lanke Superior:

\section{MARQUETTE DISTRICT. ${ }^{b}$}

North of Marquette the granite area forms a monadnock group known as the Huron Mountains, rising about 1,200 to 1,350 feet above the lake.c The elevations were thus described by Foster and Whitney:

They do not range in continuous chains, but exist in groups radiating from a common center, presenting a ceries of knobs rising one above another until the summit level is attained. Their outline is rounded or waving, their slope gradual. The scenery is tame and uninteresting.

C. $\Lambda$. Davis ${ }^{d}$ writes with regard to the same region:

The hills are only 150 or 200 feet above the valleys, hence the general level is relatively high and the district is a plateau, or high peneplain, rather than mountainous.

The granite of the Archean south of Marquette was early deseribed by Brooks as having an irregular topography, with low knobs, rilges, and eliffs.e Rominger contrasts the area soutlı of Marquette, $f$ where the granites occupy lower levels than the Huronian, with the northem granite outcrops, which "oecupy the highest elerations anil constitute the most conspicuous ridges." The topography (sce topographic map and structure profiles, PI. XVH, in pocket) characteristic of the Arehean formations in this distriet has been deseribed in greater detail by C. R. Tan Hise and W. S. Bayley 0 as follows:

Northern complex:

Mona schists: Minor rugged hills, strongly glaciated.

Kitchi schists: Rugged hills similar to those of Mona schist.

Gneissoid granites: Rounded knobs, invariably smoothed by glaciation.

Hornblende syeaite: Exactly like that of granite.

Southern complex: Knobs, as in northern granite areas.

\section{MENOMINEE DISTRICT, ${ }^{h}$}

IV. S. Bayley ${ }^{i}$ has described the topography associated with the rarious Arehean rock series in the Menominee district (PI. XXVI, in poeket) as follows:

Quinnesec schist (southern area): Rough and broken, forming deep gorges, with many rilges and elongated hills. Quinnesec schist (westeru area): Without distinctive peculiarities except small rugged knobs.

Granites, gneisses, and schists of northern complex: Irregular rugged knolls, intensely glaciated.

CRYSTAL, FALLS DISTRICT. ${ }^{j}$

The topography characteristic of the Archean in the Crystal Falls district (PI. XXII, in pocket) has been deseribed by J. M. Clements, I. L. Smyth, and IV. S. Bayley ${ }^{k}$ as follows:

Granite: Small rounded isolated knobs, chiefly obscured by glacial drift (gaps in granite range where resistant greenstone likes cross

a Coleman. A. P.. Rept. Bur. Mines Ontario, vol. 15, pt. 1. 1906, pp. 1\%5-17\%.

$b$ For topograply of Marquette and adjacent districts se' also the chapters on these districts.

- Report on the geology and topography of the Lake Superior land district, 1s.50. pt. 1, p. 34.

d Ann. Rept. Geal. survey Michigun, Rute. p. 2 in.

e Brooks, T. B., Geol. Survey Mithigan, vol. 1, 1k73, pp. $72-73$

1 Rominger, Carl, Cieol. Survey Jichigan, rol. 4 , ]\$ะ1, p. 13.

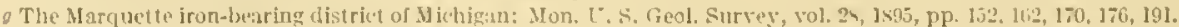

$h$ See also chapter on Menomine district. where topograjhy Is discussed.

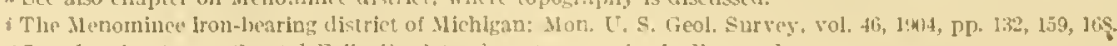

$f$ Ste also chapter on Crystal Falls districl, where topography is discussed.

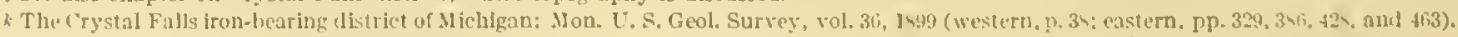


Archean crystallines: Mammillated with rocky knobs separated by bowl-like depressions, the hummocks and bowls being generally elongated cast and west.

Granites, gneisses, schists, and amphibolites of Felch Mountain district: ('haracteristic rough topography with east-west elongated hummocks aud bowls. A topograplic depression always exists along the contact of the Archean and Algonkian, usually holding a swamp or stream.

Gneissoid granites and varions schists of Sturgeon River tongue: Scattered bare knolls.

West of the Crystal Falls, Menominee, and Marquette districts (fig. 43, p. 292; Pl. XXIV, in pocket) there is a general plain produced by erosion upon the homogeneous slates, in places deeply cut by streams and partly obseured by the glacial drift. Through both slates and drist certain knobs of resistant greenstone, ete., project as eminences.

\section{KEWEENAW POINT.}

On Keweenaw Point the highland peninsula, generally referred to in atlases and maps as the Copper Range, has rocks vertical or very highly inclined. Erosion has thus far been unable to significantly alter the plateau ${ }^{a}$ or peneplain ${ }^{b}$ which was developed on these inclined beds in the period of base-lereling. This is the case on the part of Keweeriaw Point (fig. 59, p. 422) that extends southward from Gratiot River to Portage Lake, where the ridges of the eastern tip of the point, as described by Frving, merge into "one broad swell" or "a broad central ridge" which extends west as far as the Porcupine Mountains, beyond which it resumes its continuity to the neighborhood of Bad River, Wisconsin. Upon this long, narrow plateau relief is not wanting, small monadnocks rising above the general level, which otherwise bevels indifferently across the various weak and resistant beds. This plateau surface is also diversified between Porcupine Mountains and Bad River by "rounded ridges and knobs with eliffs facing indifferently in all directions." It is still, however, essentially a peneplain, the valleys cut in it not having notably dissected its surface into distinctive forms like monoclinal ridges or mesas. To the northeast, at the tip of Keweenaw Point, there are monoclinal ridges and longitudinal valleys, replacing the former peneplain surface, above whose level monadnocks like Hounts Houghton and Bohemia still rise, the former owing its eminence to a resistant red felsite.c In the plateau region, where the dips have prevented equally rapid dissection, the peneplain surface remains. It is marginally cut by deep gorges, to be sure, but these valleys are of moderate area and are not separated by monoclinal ridges or by mesas, such as occur where the dips are below $30^{\circ}$ or nearly horizontal respectively. Minor monadnocks rise everywhere above the partly dissected peneplain.

The moderate elevation on the south shore of Lake Superior known as the Porcupine Mountains ${ }^{d}$ forms a monadnock area rising 600 to 1,421 feet above the lake and areraging 1,800 feet above sea level. The highest point is 2,023 feet. These mountains owe their relief to the resistant quality of a body of quartz porphyries and felsites here faulted up agamst the adjacent weaker beds on the south and exposed by denudation. That they form a group of monadnocks was first noted by Van Hise. ${ }^{b}$

\section{NORTILEN WISCONSIN.}

R. D. Irving $e$ in $187 S$ briefly described the topography of the Archean area south of the Penokee-Gogebic range as the "elevated interior" or "interior table-land," with a gently undulating surface, few ledges, low granite domes, and abundant glacial lakes and swumps.

In their report on the Penokee-Gogebic district Irving and Tan Ilise $f$ have not specifically described the topography associated with the north edge of the peneplain within that district, but the Archean gneisses and sehists there may be inferred to have characteristic knobby topography (Pl. XVI, p. 226).

\footnotetext{
a Brooks, T. B., Geol. Survey Michigan, vol. 1, 1873, pp. 69-70; lrving, R. D., Mon. U. S. Geol. Survey, rol. 5, 18`3, pp. 16it-166. 186.

$b$ Van Hise, C. R., Science, new ser., trol. 4, 1896, p. 217.

clrving, R. D., Mon. U. S. Feol. Survey, vol. 5,1883 , pp. 151-182.

d Idem, pp. 206-225, and geologie section 3, pl. 20. Also Wright, F. E., Ann. Rept. Geol. Survey Michigan, 1903, pp. 35-44.

e The geology of the eastern Lake Superior district: Geolugy of Wisconsin, vol. 3, 1873-1879, pp. 61-62, pl. 11.

$f$ The Penokee iron-bearing series of Michigan and Wisconsin: Mon. U. S. Geol. Survey, vol, 19, 1892, p. 104. $47517^{\circ}-$ VOL $52-11-7$
} 


\section{CENTIRA, WHSCONSIN.}

R. D. Irving ${ }^{a}$ wrote as follows regarding the topergraphy of central Wisconsin:

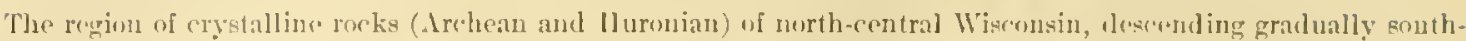
ward, has a gently undulating surface, which is, however, often broken in minor detail hy lww, abrupt ridges with (mitcrop)ing tilted rock lociges.

Ireidnan ${ }^{b}$ las described the toporraphy associated with the Archean formation in north('entral Wisconsin (Pls. IT, A, p. 90; XXXI, A, p. 436) as follows:

The hasal group (gneiss and schists) forms a gently sloping plain, with low crystalline ledgressometimes thinly eovered by sandstone, sometimes by glacial drift, but generally exposed in the river beds.

The IInoninn granite and syenite form the prineipal undiversified peneplain here.

NORTHEASTERN WISCONSIN.

Witl regard to the topograplyy in northeastern Wiseonsin, T. C. Chamberlin ${ }^{c}$ says:

The Archean surfare is very irregular, and here and there knobs rise through the superincumbent formations, giving rise to isolated luils of quartzite, porphyy, and granite in the midst of the areas of lowwr rocks.

Tle infers that these knols are protruding through the Paleozoic sediments, not intrusive in them.

\section{LINEAI MIONADNOCISS AND OTHER RIDGES.}

\section{GENERAI DESCRIPTION.}

Besides the smaller monadnocks which rise above the broad uptands of the peneplain, there are numerous linear monadnocks and elongated ridges below the peneplain level, which are related to the formations that outcrop in narrow bands, notably the Algonkian formations but to some extent also the drehean. A few linear monadnocks also lise abore the level of the peneplain.

Where the rocks are gently inelinol erosion has been able to attack them more suceessfully than in the areas of stceper dips, and has developed the monoelinal ridge (Pl. IV, $b$ ), which has its gentler slope following the dip of the beds and its stecp esearpment on the opposite side. Part of these monoclinal ridges are monadnoeks, but a number are not.

In the Teweenawan rocks of the Lake Superior region these monoclinal ridges are best developed in northeastem Minnesota, on Isle Royal, and at the end of Reweenaw Point; among the Huronian rocks they are well developed in northem Minnesota and southem Ontario, near Gunflint Lake, in the Penokee Range, in the Giants Range, and in all the iron districts, and as monadroeks in the peneplain (fig. 5).

The origin of these monoclinal ridges as specialized forms due to diflerential emsion (fig. 6) upon weak and resistant strata las not been agreed to by all the workers in the Lake Superior region. T. II. Tinchell ${ }^{d}$ ascribed the Sawteeth Mountains of the Minnesota coast to faulting and has been followed by $A$. C. Lawson, ${ }^{e}$ who ascribes the moncelinal ridges of the Animikie in southern Ontario and northern Minnesota to faulting, and by $A$. If. Eiftmann. Irving, $g$ on the other hand, points out that the topography "is just suel as is found in erery region of flat-dipping hard roeks, and especially where softer layers are interleaved, as in this ease." He also cites numerous monoctinal ridges of similar type in equiratent nonfaulted rocks on eastern Kewenaw Point, in northem Wisconsin, and elsewhere, where the sawtooth shape is well developed. I. S. Grant ${ }^{h}$ writes:

The numerons northward-facing clifs suggest the pobability of a series of comparatively recent east and went fault lines, along the north sides of which the strat:a are depressed. * * * The evidonce of profound fanlting in these strata, aside from the evidenee of topography, is small. It seems that the present surfare configuration contel

a Geology of Wisconsin, vol. 2, 14i3-1:77, pp. 453, 4fi2.

o Bull. (ieol. and Nat. Jlist. Survey Wisconsin Jo. 14, 190\%, p. 16i.

c feology of Wisconsin, rol. 2, 1573-15iT, p. $21 \mathrm{~s}$.

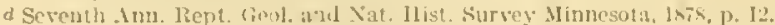

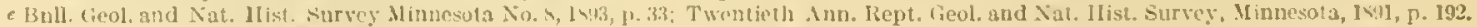

Am. ficologist, vol. $21,1 \mathrm{k}, \mathrm{k}, \mathrm{r}$. 1 . 3 .

g llon. [\%. S. Geol. Surwer, vol. $5,1+3$, pp. 112143.

h Final Rept. Reol. and Vat. 11 ist. Survey Minnesota, vol. 4, 1411, pp. 443, 445. 
have been brought about hy erosion acting on gently inclined strata of lifferent degrees of resistance, the thin-bedded and fissile Animikie slates lueng more susceptible to disintegration and erusion than the diabase sills.

Grant subsequently proved absence of laulting in one of the "supposed lault scarps" to the satisfaction of a number of accompanying geologists, including N. II. Winchell and A. II. Elftmann, two of the adrocates of the lault origin of these monoclinal ridges.

As major faulting has nerer been proved to be associated with the scarps of the monoclinal ridges, as their origin by differential erosion in nonfaulted strata has been repeatedly shown, and as they are associated only with marked eross faults-for instance, on Isle Royal and north of Thunder Bay - the fault hypothesis for the monoclimal ridges (sawteeth) is regarderl as not warranted. Indeed, in the Vermilion monograph I. M. Clements, ${ }^{a}$ who discusses this type of topography, does not even mention the possibility of faulting.

As the strike of the Algonkian rocks is generally northeast and southwest, the trend of the monoclinal ridges and of the subsequent valleys between is in the same direction, the longitudinal valleys that extend parallel to the strike of the rocks being usually broad and persistent, whereas the transverse valleys extending across the strike of the rocks are narrow and irregularly arranged.

Where these ridges and valleys are partly submerged the resulting bays are extremely long, straight, and persistent, and the peninsulas and islands are in long parallel lines, as on the coast of Isle Royal. Glaciation, acting upon this monoclinal-ridge topography, has produced one striking series of lakes in northeastern Minmesota; these, as well as similar lakes in other parts of the region, are due to glacial clogging of the subsequent axial valleys between the monoclinal ridges.

\section{KEWEENAWAN MONOCLINAL RIDGES.}

GENERAL STATEMENT.

In northeastern Minnesota, on Isle Royal, on the end of Kieweenaw Point, and in northern Michigan and northern Wisconsin, the monoclinal-ridge type of topography is so well dereloped that the name Sawteeth Mountains ${ }^{b}$ has been given to these ridges on account of their resemblance to the jagged teeth of a saw when seen in profite. The same name is also applied to the Huronian monoclimal ridges near Gunllint Lake and northward in Ontario. (See fig. 5, p. 88.)

\section{NORTIEASTERN MINNESOTA.}

Ridges of this sort in Mimnesota, near Grand Marais, with back slopes of $5^{\circ}$ to $10^{\circ}$ and steep escarpments, are described by Irving ${ }^{c}$ as forms due to differential erosion on weak and resistunt beds.

ISLE ROYAL AND MICHIPICOTEY ISLAND.

The monoclinal ridges on Isle Royal (Pl. IV,$B$ ) are described by Lane. $^{d}$ No other information concerning the relation of the geology to the minor topography of Michipicoten Island has been obtained by the writer.

a Jton. U. S. Geol. Survey, vol. 45,1903 , pn. $400-10 t$.

b Irring, R. D., The copper-bearing rocks of Lake Snperior: Mon. U. S. Geol. Surrey, vol. 5, 1883, fig. 1, p. 14?; also figs. 16, 20, and 29, on pp. 297,325 , and 326 .

c Idem, pp. 141-143. d Lane, .1. C., Geol. Survey Michigan, rol. 6, 1\$93-1\$97, pp. 1\$0-1\$3. 


\section{KEWEEYAW POINT ANI) NORTIERN MICHIGAN AND WISCONSIN.}

The parallel monoclinal ridges and intervening valleys near the end of Keweenaw Point (fig. 6) were early described by Marvine and later in some detail by Irving." who associated the various valleys and "parallel ridges with difly southern and flat northern faces" with specific gently dipping Keweenawan beds-the valleys with weak amyglaloids and ensily decomposable diabases, the ridges with resistant melaphyres, coarse diabases, and bowhler conglonerates-and showed the topography associated with them in various profiles. ${ }^{c}$ In regard to the east part of Keweenaw Point, Irving ${ }^{d}$ emphasizes the relation of dip to topography:

Wher: the dip flattens the structure comes out finely in a series of botd ridges. Toward Portage Lake, however, the dip becomes as ligh as $50^{\circ}$ or more and the severil ridges merge into one broad swetl. This holds until the Porcupine In untains are rearhed, where, although the lip angle is as high as $30^{\circ}$, the structure is most beautifully illustrated in the onter ridge. $c$ This ridge rises from the take shore somewhat more gradually than the dip to a lieight of over 1,000 feet and then drops off in a botd escarpment of 400 feet into the valley of Carp Lake.

This 'liff $f$ extends nearly continuousty across T. 51 N., R. $43 \mathrm{~W}$., a distance of over 6 miles. The crown of the cliff is from 800 to 1,000 feet above Lake Superior and from 400 to 600 feet above the valley of Carp Lake. The base of the cliff is marked by a tong stope of fragments fatten from the diabase and amygdaloid which forms its upper portions, but through the greater part of its length there is a perpendicular face of about 400 feet above the talus.

Farther west again, as far as Bad River, $g$ the dips are high, often reaching $90^{\circ}$, and the harder rocks constitute merety rounded ridges and knobs with the chiffs facing indifferently in all direetions. Beyond Bad River and alt across Visconsin to the St. Croix the dips flatten once more, and the "sawtooth" shape in the ridges is everywhere well marked. $h$

This is notahly trie throughout Douglas County, Wis. ${ }^{i}$

U. S. Grant ${ }^{j}$ refers briefly to the surface features characteristic of the Keweenawan in Douglas County, Wis., where lour belts of different topography are produced, rarying witlı the part of the Keweenawan exposed, the dip, and the glacial overburden. The more resistant portions of the Keweenawan form two main ranges in northern Wisconsin because of the synclinal structure there. T. C. Chamberlin, writing as editor of the notes of the late Moses Strong, in reviewing the surface leatures of northwestern Wisconsin ${ }^{k}$ silys that the linear topography referred to and represented in profiles shows splendid keweenawan monoclinal ridges.

\section{KEWEENAWAN MESAS.}

On the north shore of Lake Superior the tabular-mesa topography (fig. 5, p. ss) is developed in places where the Algonkian beds lie practically horizontal and weaker strata underlie more resistant beds, so that erosion has been able to open lowlands on the weak rocks and leare isolated highlands or ridges. Three great valleys have been opened up in the weaker beds in the upper Iluronian (Animikie group) and the Keweenawan, and two great mesa ridges have been left letween these valleys. The waters of Lake Superior have sulsequently risen to such a level that they occupy the floors of these valleys and form Thunder, Black, and Nipigon bays (PI. II, p. S6). Thunder Cape, the narrow end of one of the peninsulas, is a characteristic hit of mesa topography, its flat top rising 1,350 feet above the level of the lake. Pie Istand is another mesa of the same kind which erosion has isolated completely, the lake waters covering the valley loottoms surrounding it, and Mount MeKay, south of Mount William, is a similar

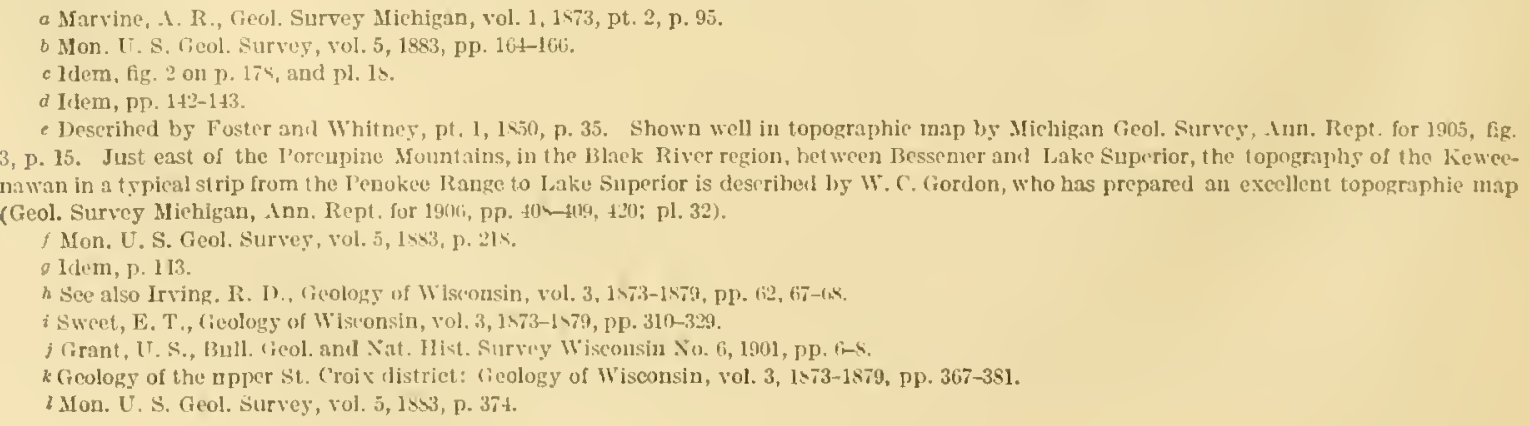


mesa perhaps small enough to be called a butte, rising 980 feet above Lake Superior, and isolated in the broal, unsubmerged valley of Kinministikwia River. William Melunes a refers to the area of flat-lying Animikie rocks near Thunder Bay as showing "table-topped hills, and escarpments with perpendicular faces and sharply angular outlines."

A. C. Lawson, who ascribed the escarpment of the momoclinal ridges near Gunflint Lake to laulting, has also indicated his belief that the east side of Thunder Bay, which "presents a very bold and remarkably straight cliff several hundred feet high compuserl of Kewechawan sandstone resting on Animikie slate, both flat-bedded and in apparent unconformity, * * * is probably originally and genetically a lault searp." "b The writer feels inclined to ascribe this escarpment to subaerial denudation, partly (1) because of the insufficient evidence of larger faulting here, ${ }^{c}$ as pointed out in the discussion of the cliffs of the monoclinal ridges (p. 99), partly (2) because denudation in the region is producing just such escarpments whore resistant horizontal strata orerlie weaker beds, and partly (3) beeause a fault searp in this lucation could not possibly have retained its present position and form since the latest possible date of formation unless it were protected by some lately removed mantle, as the larger possible fault scarps of the northwest coast of Lake Superior and the southeast side of Keweenaw Point seem to have been. (See pp. 112-116.) The clief reason for doubting the fault origin of the east boundary of Thunder Bay is that such an origin would imply the fault origin of the boundaries of all the mesas in this district which have escarpments that are very similar topographically and geologically. Because of the great complexity of block faulting that would isolate Thunder Cape and the adjacent peninsulas, as well as Pie Island and Mount McKay, etc., and the total absence of eviclence of such faulting, it seems far more reasonable to ascribe these lorms to the wellestablished cycle of forms resulting from normal subaerial denulation.

North of Lake Superior, in Ontario, near Lake Nipigon and to the east and west, there seems to be a great many more mesas and valleys of exactly this kind, ${ }^{d}$ all in an area underlain by Keweenawan rocks or by upper Huronian (Animikie) slates and Logan sills, as along the Canadian Pacific Railway east of Port Arthur and especially beyond Nipigon. A. C. Lawsone writes:

It is to the presence of these trap sheets (the Logan sills) that the bold and picturesque topography of Thunder Cape, Mount McKay, Pie Island, Nipiron Bay, and the many sheer-walled mesas and tilted blocks of the region is due.

All these mesas apparently have their present lorm because erosion has had more power to open up broad valleys in a region where the rocks lie practically horizontal than in adjacent regions where the rocks are more highly inclined.

Three topographic types are well represented in the Keweenawan division of the Algonkian, where they seem to form a distinctly graded series (fig: 7) rather directly associated with the

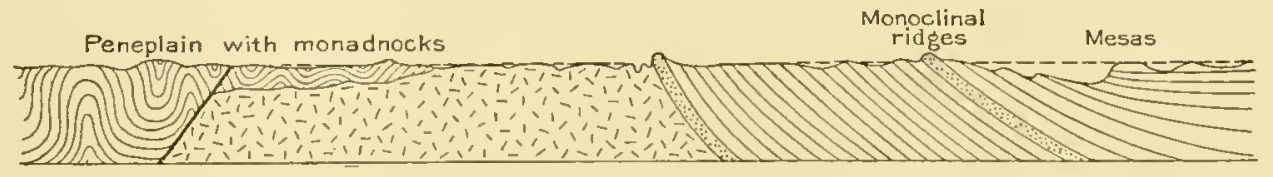

FIGURE 7.-Hypothetical cross section showing relation of secondary lowlands, mesas, monoclinal ridges, ete., to peneplain.

dip of the constituent beds. ${ }^{f}$ In exactly the same length of time precisely the same erosional agencies have been able to produce almost no eflect upon the vertical and highly inclined beds (nerely cutting gorges in the peneplain), to develop longitudinal valleys between monoclinal

a Geology of tbe area corered by the Seine River and Lake Shebandowan map-sheets, comprising portions of the Rainy River and Thunder Bay districts of Ontario: Geol. Survey Canada, new ser., vol. 10, 1s97, Rept. H, p. 6.

$b$ Twentieth Ann. Rept. Feol, and Nat. Hist. Survey Minnesota, 1891, pp. 20i5-266.

c Mlınor faults extending in another direction with smaller possible fault escarpments are descrihed by $\mathrm{R}$. C. Allen in an unpublished thesis (1905) of the ('niversity of Wisconsin. Allen also appeals to fanIting to explain the Mackenzie Valley (1'l. XIII), the depression which nearly connects Thunder and Black bays and is followed by the Canadian Pacific Railway; the writer believes it to be due to normal denudation.

d Collins, W. H., Summary Rept., Geol. Survey Canada, 1906, pp. 103, 105; Coleman, 1. P., Rept. Bur. Mines, Ontario, rol. 16, pt. 1, 190i, pp. 107,110 .

e The laccolithic sills of the northwest coast of Lake Superior: Bull. Geol. and Nat. Hist. Survey Minuesota No. $\$, 1893$, pp. 24, 43.

f Mon. U. S. Geol. Survey, vol. 5, 1ss3, pp. 142-143, 166 . 
ridgess on the gently inclined beds, and to andrance the region where the bask are horizontal to a maturity of form with broad valley's and small isolated uplamels (mesisis).

\section{HURONIAN MONOCLINAL RIDGES AND VALLEYS.}

Inonorlinal rilges, howerer, are not confined to the Kewenawn series of thre Algonkian. In a number of localities in the Iluronian, diabases, quart zites, and other strat an with a moderately gentle diph have developed monoclinal ridges which have the usual unsymmetrical proble with a gentle slope and a steep scarp liace. (See fig. 5, 1). 88.)

\section{(GÜNLLNT LAKE IHSTRITT.}

Near Gumflint lake and in adjacent regions of Minnesota monoclinal-ridge topngraphy, described by I'. S. Cirant, ${ }^{a}$ is dereloped in the upper Hurnian. The slates of the Animikie group are intruded lyy the lieweenawan Logan sills, which are now gently tilted and exposed, forming the crests of monoclinal ridges (fig. 24) whose scarp faces show the weaker slates. These consist of "long parallel ridges rumning approximately east and west, with sharp mural escarpments on the morth sides of the ridges and on the south gentle slopes." "This topography is also described by J. M. Clements, ${ }^{b}$ in eflect as follows:

Upper Huronian (Inimikie group):

Gunflint formation: Lower slope of escarpment in monoclinal rilges.

Rove slate: Weak lower slope of monoclinal ridges, in many places talus-rovered.

Keweenawn Logan sills: Usually cap monoclinal ridges, at many points forming perpeudicular cliffs, above gentler talus-covered slopes of Gunflint formation or Rove slate.

In this region, as in many parts of the lluronian where notably long and narow monoclinal ridges are formed, the drainage, whatever it may have been initially, has become so thoroughly adjusted to the topography that the streams flow in longitudinal (subsequent) courses along the strike of the weaker rocks, generally with rather broad ralleys. In nearly all places where the streams cross the ridges of more resistant rocks they are in much steeper-sided valleys.

\section{PEX̃OKEE RAYGE. ${ }^{c}$}

In the Penokee-Gogebic iron range the hills show this topographic quality most distinctiy. (See structure profile. PI. XVT, p. 226.) The Penokee Range consists of a series of hills, in the north slopes of which are iron mines. North of this range there is a broad longitudinal ralley. The range is not mate up of one continuous ridge but rather of a series of disconnected linear hightands (Pl. XVI) cut through by narrow gaps which cross the strike of the more resistant beds, including the iron formation, and are therefore not so wide as the subsequent valley, which follows the strike of the weaker slates. The northern boundary of the ralley is a range of Keweenawan hills with well-dereloped monochinal ridges, which are also eut through by narrow transterse valleys that continue northwal towarl Lake Superior. The narrow transverse ralleys are probably consequent upon the original slope. The broad longitudinal ralley is a consequent lowland, though not yet druined by any single trunk stream.

South of this principal longitudinal valley another lowland seems to be developing in places; it stands at a rather higher lerel than the northem one and is less continuous from end to cnel, because interrupted by low ridges, which extend back from many of the highes hills in the Penokee Range proper. It is a subsequent lowland in process of formation between the resistant granite and the resistant rocks of the Penoker Range. South of this incipient ralley rises the northern elge of the Archean peneplnin, with rather ragged hills of granite, which in many places reach direetly to the foot of the Penokee Range without any intervening lowland.

R. D. Irving dirst deseribed the topography of the Penokee Range. "the ridge or mountain belt," as well as that of the (opper Range to the north. The former rises to albout 1.500 to

a Final liept. Geol. and Nat. Hist. Survey Minnesotis, yol. 4, 1499, pp. 442-4<3, 492. 49ti.

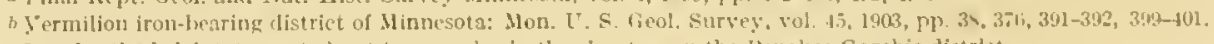

cSer also the brief statement abunt topography in the chapters on the lenoker-Gogebic district.

d (jeology of Wisconsin, rol. 3, 1573-1579. pp. 62-70, 101-103. 
1,\$00 feet, 100 to 300 feet above the lower lant to the south, with a less abrupt north slope, varying from a ridge a few rods wide to a broad swell of a mile. It is a continuous ridgre for neatly 50 miles from the northern half of see. 24, T. 44 N., R. 4 W., Wisconsin, eastward beyond Sunday Lake in Michigan. ${ }^{a}$ Beside this there are detached ridges with the same aligmment to the west and to the east.

In places the rirge rises from 100 to 300 feet above the elevated swampy area south of it and from 100 to 600 feet above the lower area north. In its more western portions this range is wide and has a rather narrow serrated crest, while eastward from Tylers Fork it becomes more and more of a gentle swell until a point weet of Sunday Lake is reached, where there is again a broader ridge. In much of this distance the ridge forms the most prominent feature of the topography of the country, being visible from the waters of Lake Superior in the vicinity of the Apostle Islands as a blue line against the horizon.

At Penokee Gap, where there is a notable fault, there is also a marked offset in the crest of the range ${ }^{b}$ (Pl. XVI).

Irving and Van Hise ${ }^{c}$ have described the detailed topography associated with the rarious Algonkian rocks in the Penokec-Gogebic district in effect as follows, also reriewing in a parngraph the relationship of the various formations to the crest, slopes, etr., of the ridge in various localities and showing the topography by three detailed topographic maps. ${ }^{d}$ (These contours are used in PI. XVI of this report.)

Cherty limestone: In one place forming a bluff 200 feet high and half a mile long.

Quartz slate memher: Conspicuous outcrops forming the base or capping the Penokee Range.

Iron-bearing member: Shares with quartz slate member in forming crest of conspiruous Penokee Range, 100 to 600 feet high.

Upper slate member: Forms great east-west valley between Penokee Range and Keweenawan ridges.

Fragmental rocks south of greenstone conglomerate: Quartzite outcrops in bold exposures.

The greenstones: Form a conspicuous east-west ridge 500 feet high.

\section{GIANTS RANGE. ${ }^{e}$}

The Giants Range' (see PI. VIII, in pocket; fig. 5, p. S8) is one of the most striking features in the topography of the Lake Superior region. It is a long, narrow range extending east-northeast and west-southwest in northern Minnesota for 80 to 100 miles, conspicuous because it rises above low, flat country on either side. It rises 400 to 500 feet above the adjacent country near the east end, the greatest. height above sea level being about 1,900 feet. West of the Duluth and Iron Range Railroad the range gralually decreases in height toward the southwest, and near Grand Rapids, Minn., where it crosses Mississippi River, its height above the adjacent country is relatively small. Beyond Pokegama Lake the Giants Range loses its individuality and is completely buried beneath glacial drift, grading into the general level of the country at 1,400 feet. It is not a continuous range but is "made up of a great number of small hill ranges, having in general the trend of the main range to which they belong." $g$ The west part. is low and the divide at some places is on the quartzite ${ }^{h}$ instead of the granite. There are many gentle bends in the erest ant one marked bend where the range extends southward 6 miles, at Virginia and Eveleth in the "Horn."

The crest of the range is in places broad and flat, in others comparatively narrow and sharp. The southern slope is very gentle; the northern slope is somewhat less so. At frequent intervals both crests and slopes are notched by drainage chanmels. $i$

a Irving, R. D., and Van Hise, C. R., The Penokee iron-bearing series of northern Wisconsin and Michigan: Mon. L'. S. Geol. Survey, vol. 19, 1592, p. 155.

b Irving, R. D., Geology of Wisconsin, vol, 3, 1873-1879, pn. 103-104.

c 1 on. U. S. Geol. Survey, vol. 19, 1892, pp. 145, 188-189, 301, 361, 365, 374, 387, and 410 .

dIdem, Pls. VII, IX, and XI.

e See also the brief description of the topography in the chapter on the Mesabi district.

$f$ Final Rept. Geol, and Nat. Hist. Survey Minnesota, vol. 4, Pls. LXXK-LXIXI; also MIon. IT. S. Geol, Survey, vol. 45, 1903, pp. 35-36; also Mon. IT, S. Geol. Survey, vol. 43,1903, p, 21. The Giants (or Mesahi) Range is called Missabay Heights in many at lases and geographies in America and Europe. See footnote on p. 92.

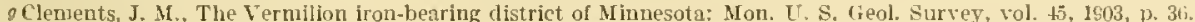

h Spurr, J. E., The iron-bearing rocks of the Mesahi range: Bull. Geol. and Nat. Hist. Survey Minnesotia No. 10, 1 s94, p. 13.

$i$ Leith, C. K., The Mesabi iron-bearing district of Minnesota: M on. U. S. Geol. Survey, vol. 43, 1903, p. 21. 
Several stream valleys cut completely across the Giants Range in (feep, narrow gorges or water gaps, that of the Mississippi heing relatively shallow. Of the deeper water gaps, that occupied by Wine Lake and Embarrass River is the most prominent. Another transverse ralley, not occupied hy a stream, is traversed by the Duluth and Iron Range Railroad; this col or wind gaj) is 100 feet above the aljacent country and 260 feet below the crest of the Giants Range. There are a number of similar wind gaps, each of which was doubtless formed by a stream that abandoned its course while the land surface to the north stood at the level of the gap, having been captured by an adjacent stream that continued to cut its water gap down. The watcr gaps which eross the range are much deeper than the wind gaps, that of Embarrass River (Wine Lake) being cut down to an elevation of 1 , 3.0 feet, or more than 400 feet below the crest of the range; soundings in the lake and diamond-drill records to the south show the ralley to be many feet derper.

C. K. Leith ${ }^{a}$ has described several of the transverse valleys as deep, steep-sided gorges, cut or deepened by glacial waters when a glacial lake to the north overflowed southward across the Giants Range. Some of the gorges are high up in the range and are no longer occupied by streams. One such gorge 40 feet decp is shown on a topographic map) (fig. 5) in Monograph 43 ; that crossed by the railway is well shown on the general topographic and geologic may of the Mesalid district (Pl. V111). It seems possible that these gaps or cols were already in existence when the ghacial streams lound and modified them in the manner described by Leith. The lower wind gaps, especially that followed by the Duluth and 1ron Range Raiłroad, suggest a preglacial origin; no question is raised, however, of their occupation and modification by running water when the marginal glacial lakes referred to existed.

The rock underlying the Giants Range itself is chiefly lower Huronian granite, but Keweenawan granite and Archean igneous rocks are also represented. The topographic anomaly of an exceelingly long, narrow range (figs. 4 and 5) owing its prominence to the resistant qualities of granite is so great that it seems to require a word of especial explanation. It is common for a quartzite or other sedimentary rock to form a long, narrow range of just this kind. It is usual for the protruding edge of a dike or a sill of sufficient resistance to form just such a long, narrow eminence as this. Gramite, however, is not normally intruded in the form of dikes and sills, and we must therefore account for this occurrence by some selective process of folding, faulting, or erosion.

Three hypotheses accordingly present themselves. The first is that of folding. Under this hypothesis it might be conceived that the Giants Range since its intrusion has participated in the folding of a long east-northeast to west-southwest anticline. Such a deformation might result in the production of a long, narrow ridge. In the front ranges of the Rocky Mountains cranites outcrop in long, narrow hands, none of which, however, is so narrow in proportion to length as the Giants Range. Moreorer, there is no eridence in the Mesabi region of any such movement, though N. II. Winchell has conceired ${ }^{b}$ that the Giants Range was uplifted in a contemporaneous isosiatic adjustment with the extrusion of the galsbro, and R. D. Irving implies this sort of origin in his diagram ${ }^{c}$ of the relationship of the Huronian on opposite sides of the Giants Range. The implied equivalence of highly folded and nearly horizontal rocks on opposite sides of the range has since been disproved by the well-established unconformity between these two series.

The second hypothesis supposes that funting has occurred along a line parallel to the Giants Range and that the granite appears in its present position as the edge of a larger faulted granite block which is exposed only along the narrow wilth because other rocks overlie the granite clsewhere. This hypothesis has lit te more support than the first, and it seems probahle from other evidence in the region that no great fault movement such as would form the Giants Range occurred since the upper IIuronian, though the Dututh escarpment of lieweenawangabbro suggests such a faulting.

a Mon. U. S. Gcol. Survey, rol. 43, 1903, pp. 193-191. 199.

Twentieth Inu. Rept. Feol. and Nat. IJist. Survey Minnesota, 1:91, pp. 1:20-121.

c.Mon. ᄂ. S. licol. Survey, vol. 5, 1*3, fig. 34. p. 399. 
The third hypothesis supposes that the granite is the outcropping edge of a great intruded granite mass, exposed for a great distance east and west by erosion upon the granite as a retreating escarpment, and revenlẹl for only a narow wilth because it is, or has recently been, capped and protected by a resistant bed of quartzite. In otler worls, the Giants Range may be regarded as a monoclinal ridge exalctly similar in most respects to the other monoclinal ridges of the Algonkian, but with an immensely greater length and a rather marked relief abore the adjacent region because of the resistant powers of the granite, giving the Giants Range its present topographic prominence.

The Giants Range is the largest monalnock in the Lake Superior region. It is such a barrier to trallie that travel across it is limited to the valleys (Pl. YIII, in pocket). Rather curiously, the railway, in order to cross this range, selocted not a water gap but a wind gap, because the glacier and stream erosion in the lower part of the aljacent water gap (the valley of Embarrass River and Wine Lake) has so deepened it and so steepened its sides that it is not a convenient pass for either a highway or a railroad.

Upon the south slopes of the Giants Range-that is, in the Mesabi iron range-the minor monoclinal-ridge topography is exceedingly well developed in one or two places, and it is suspected that even better development would be apparent in places were it not lor the thick drift mantle nearly everywhere obscuring the preglacial topography. Northwest of Hibbing, lor example, the Pokegama quartzite stands up) as a distinct monoclinal ridge, with a lowland to the north between the quartzite escarpment and the granite and a gentler slope southward toward the iron mines. The topographic map shows this relationship in many places not visited by the writer. Rarely in other parts of the Mesabi iron range the quartzite seems to be weaker than the iron-bearing Biwabik formation, forming a lowland between the older rocks and an iron-formation rilge. In the 1,820-foot hill between Virginia and Eveleth, on the west side of the IIorn (Pl. VIII), there is a fuartzite lowland of this sort witl an escarpment and monoclinal ridge of a resistant part of the iron formation, though the quartzite rises up to form the base of this esearpment. There are other iron-formation ridges on the east side of the Horn and elsewhere.

\section{MARQUETTE DISTRICT.}

In the Marquette district also linear topography is developed (Pl. XVII, in pocket) in the area underlain by the Algonkian rocks, though before detailed studies were made it was said to have a notably hilly surface without obvious systematic relation to the structure. ${ }^{a}$ The relief was said by Rominger to be comparatively slight, 50 to 100 feet and rarely 200 leet, ${ }^{b}$ though the recent topographic maps show greater extremes and an arcrage relief of 200 to 400 feet. Upon the basis of the more detailed work the topography characteristic of the several Algonkian formations in the Marquette district has leen described by Van Hise and Bayley, detailed studies revealing a most laithful correspondence of the low hills and valleys to resistant and weak beds. Tan Hise and Bayley characterize the region as worn down from mountains but now "mercly bluffy," with maximum elevations of 400 fect or less, the valleys and ridges being due to differential erosion of weak and resistant beds. The following classification of the topography and rock formations gives the substance of their descriptions:

Mesnard quartzite: Prominent ranges with minor sharp ravines and steep ridges.

Kona dolomite: Steep hills with vertical ragged cliffs.

Wewe slate: Forms valleys, except in a few places.

Ajibik quartzite: Bold ridges with precipitous bluffs and steep ravines. Some ridges 200 feet high.

Siamo slate: Prevailingly forms valleys.

Negaunee formation: Forms valleys, exrept locally.

a Brooks, T. B., Geol. Survey Michigan, vol. 1, 1573, pp. 70-72.

$b$ Rominger, Carl, Geol. Survey Michigan, rol. 4,1 s 1 , pp. 1-3.

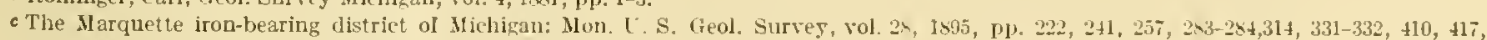
$444+45, \pm 61,4$ 48 $489,499,572-573$; also in Fifteenth Ann. Rept. I. S. Geol. Survey, 1595.

$d$ Fifteenth Ann. Rept. U. S. Geol. Survey, 1895, pp. $644-645$. 


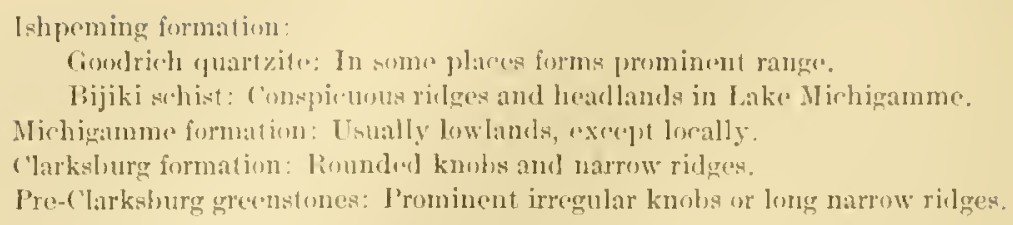

In the Republic trough the topography of the Ardhean uplands, as briefly described by 1I. L. Smyth, shows rharacteristic granite knobs, rounded and glaciated; Micligamme River flows through the lower land underlain by the beded rocks (Algonkian), and the various quart\%ites, mical schists, fertuginous schists, and igneous intrusives form the usual elevations and depressions, nowhere rising to the height of the granite wplands on the east and west except in Republic Mountain.

So many of the ridges are related to resistant beds and so many valleys to weak beds that the character of the rocks may be predicted with some assurance from the general form of topography. Local variations, however, make it impossible always to feel sure, for example, that the same woak slate which in one place forms a valley will also be found in the lowland in an acljacent locality. An exception of this kind is foumd in the Siamo slate of the middle Inuronian. whose outcrop cast of 'Teal Lake, near Negaunee, is marked by a very distinet east-west trending ralley, which is followed farther east by Carp River. Directly south and west of Teal Lake, however, some more resistant members of the Siamo slate are found in the Siamo Hills and adjacent ridges, and for the next 10 or 12 miles westward the Siamo slate locally forms ridges, though more commonly found in the ralleys.

Just south of Negaunee and east of Ishpeming there is a series of rather abrupt knobs which are not exactly of the class characteristic of this region. A number of diorite and diabase masses intrudal in the middle Huronian iron formation have been so resistant to erosion that many of them form knobs which rise above the aljacent valleys. At near-by points, however, the iron formation itself is so resist unt that it stands np as a distmet knob or ridge.

In this region the glacial deposits have not nasked the preglacial topography to a great degree, because the region seems to have had rather marked relief in preglacial times, somewhat in contrast with the Crystal Falls district. Immediately adjacent to the Mlarquette district on the east and south are lowlands where the lack of relief in glacial time is indirectly reflected by the masking of the bed-rock topography almost entirely by glacial deposits.

\section{HEXOMINEE DISTILT}

The topography of the Meuominee district has been clescribed by Bayley ${ }^{b}$ who speaks of the area as lorming two plains (Pl. XXVT, in pocket), one in the bottoms of the present vallers, the other on the level of the tops of the hills. The effect of erosion on the lhuronian beds of the Algonkian system has been to produce a series of east-west trending valleys and ridges which correspond very closely to the weak and resistant members of the Huronian series. There is clear eridence that the ridges and valleys in the Menominee district east of Iron Mountain. Mich., were formed in pre-Cambrian time and that they have been preserved since that time because of their burial bencath the Cambrian sandstone, which served as a protecting mantle. Erosion has recently removed most of these Cambrian overburdens and has reexposed the preCambrian topography. To-day the hills rise approximately 300 to 400 feet above the valley bottons. They are a little higher than they were before the Lpper Cambrian sandstone was deposited, because a cap of sandstone still surmounts most of the hilltops. From the valleys it has been largely renoved. The old cliffs and blull's against which the Cambrian sandstone was deposited are still exposed in the valley slopes; the drainage was in preglacial time almost as well adjusted to the weak and resistant rocks as it had been before the Cambrian transgression, though Bayley has supposed the topography then to have been sharper and mure rugged. Glaciation has, however, somewhat modilied the stream courses, and the perfect adjustment of preglacial time is lacking, as the gorges and waterfalls suggest: 
Bayley a has described the topogralphy associated with the various Algonkian rork formations in the Menominee district in effect as follows:

Sturgeon quartzite: Great hare regular blufi's with smooth tops and aluost preripitous sides.

Randville dolomite (northern belt): Valleys and other dejressions.

Randville dolomite (central belt): Usually insignifirant, forming hases of hills and rorrly little plateans with smal! escarpments.

Randville dolomite (southern belt): Conspicuous irregular clifis or bluffs.

Vulcan iron formation: Either inconspicuous in valleys or clinging to slopes of dolonite. Ledges rarely prominent.

Hanbury slate: Entirely confined to low ground, forming minor protrusions only where the slate is locally harder.

\section{CRYSTAL, FALLS MISTIICT.}

In the Crystal Falls distriet, whose plysiography has been described by J. M. Clements and H. L. Smyth, ${ }^{b}$ the adjustment of ridges and valleys to resistant and weaker structures has heen somewhat similarly (leveloped (Pl. XXII, in pocket), except that here the ridges and valleys are arranged in a less simple and orlerly way. The a verage relief is 200 feet in the western part. The Cambrian has been almost entirely removed. Furthermore, this region seems to have heen, even in pre-Cambrian time, one of less relief than the Menoninee region; certanly it was a region of rary slight relief (ealled by (lements "an approximate peneplain") when the rontinental glacier overrode it, and as a result the glacial deposits are far more prominent and have more thoroughly obscured the preglacial topography than in any other iron district in the Lake Superior region except the Mesabi.

The topography characteristic of the sereral Algonkian formations in the Crystal Falls district has been clescribed ly. J. MI. Clements, H. L. Smyth, and W. S. Bayley, ${ }^{c}$ in effect as lollows:

$$
\text { Testern part. }
$$

Randville dolomite: No marked effect on topography or cirainage (in depressions).

Mansficld slate: Marked lepressions, followed by Mirhigamme River.

Henlock formation: Exceedingly irregular topography; tuffs forming valleys; lava flows or intrusives forming higher gronnd, and resistant tufts forming high hills.

Bone Lake crystalline sehists: Apparently forms knobs, but usually coverel loy glacial drift.

Upper Huronian: In many places covered by glacial drift or by Cambrian sandstone. Shales form valleys and softly rounded hills. Graywackes and cherty rocks form more striking topography.

$$
\text { Eastern part-Folch Hountuin. }
$$

Sturgeon quartzite: Linear ridges, usually lower than those in the Archean, though locally lower than dolomite.

Randville dolomite: Low, steep-sided knolls, occasionally linear ridges.

Mansfield schist: No depressions; oceasionally steep-sided valleys.

Grovelaud formation: Moderately resistant, forming elevations such as Felch Mountain and Groveland Hill, 100 feet high.

Upper Huronian mica schists and (yuartzites: Lowlands and low flat-topped ridges.

$$
\text { Eastern part-Wichigamme Iountain and Fence River. }
$$

Sturgeon formation: Apparently here weak and forming lowlands; Randville dolomite underlying swamp.

Mansficld formation: Indistinguishable topographically in gently rolling plain of dolomite (miniature ridges).

Hemlock formation: Rough topographical details, with abrupt ridges and narrow ravines (in some parts till covered).

Groveland formation: No topographic prominence except in Nichigamme Nountain; in Fence River area topography less important than that of glacial drift.

\section{NORTII-CENTIAL, WISCONSIN.}

Weidman ${ }^{2}$ has described the topography associated with the various Algonkian formations in north-central Wisconsin (see Pls. IV, A, p. 90; XXXI, A, p. 436) in effect as follows:

a MIon. U. S. Geol. Surrey, vol, 46, 1904, pp. 177, 200, 291, 462.

b Idem, vol. $36,1 \times 99$, pp. 29-36, 331-335.

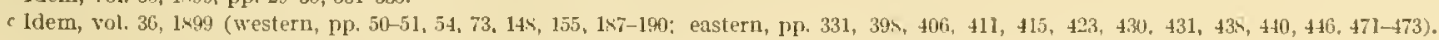

d Bull. Geol. and Nat. Hist. Survey W' isconsin No. 16, 1907, pp. 42, 55, 62, 82, 58, 91, 100, 112, 118, 177, $358,366,371$. 


\section{Lower sedimentary series (lower IIuronian?).}

Ri1, Hill quartzite: Bold knols forming the lighest land in the region in monadnorks, and prominent because surrounding weaker granite and syenitc are base-lixeled.

Wansau graywate: Not prominent, forming very fow low exposures.

Hamburg slate: Not foming valleys lower than aljacent more resistant formations because of lack of dissection of perfected peneplatin.

Powers I3lulf quartzite: Forms notalyle prominenee 300 to 400 feet below surroundingr; rmaller ridges.

Quartzite at Rudolph: Low ridges and knobs.

Junction ("ity gluartzice: No notable topograplyy.

Igneous intrusize formations (rhyolite series).

IV:ausau area : Alsence of slarply rugged topography, though low ledges project slightly through younger formations. Bhyolite schists of Ean (']aire River: Forms striking cliffs in dells of Eau r'laire River, due to joints.

Rhyolite schists of I'ine River: Ifarked gorge, a mile long, lco feet deep, knowu as dells of Pine River, with sharp tributary gorges related to joints.

$$
\text { Cpper sedimentary srries (middle Iluronian?). }
$$

Marshall Hill graywacke: Steep slopes and ledges. grunite.

Arpin quartzite: Low sloping land; less resistant than Pnwers Blufi quartzite and more resistant than adjacent

North Honnd quartzite: Prominent mound rising above surrounding Cambrian lowłani.

\section{MORTHWESTERY WISCONSIN.}

The IIuronian quartzites of Barron and Chippewa counties, Wis. ${ }^{a}$ form notably prominent monoclinal ridges rising as much as 300 feet abore the aljacent plain and having gentle dip slopes and steep esearpment faces with talus at the base.

\section{THE LOWLAND PLAINS.}

\section{AREA.}

The lowland region of horizontal or gently folded post-Algonkian rocks (figs. 4 and 5, pp. S7, SS, Pls. I, in pocket; II, p. S6) inclucles chiefly rocks of Cambrian and ot her early Paleozoic age so generally buried beneath glacial deposits that ledges are comparatively rare throughout the area and the preglacial topography is partly or wholly masked. A small area of drift-covered Cretaceous, also flat lying, is found in northern Minnesota.

The lowland is made up of narrow areas on the south shore of Lake Superior, a broad belted plain in Michigan, Minnesota, and Wisconsin, and another plain in Minnesota. As the map (Pl. I) indicates, there is a narrow strip at the west end of Lake Superior, on the south shore, and a narrow strip fringing the shore from L'Anse to Marquette. Besides this rather small littoral zone, a considerable area now buried by the waters of Lake Superior is, without much doubt, covered by horizontal Paleozoie rocks.

These early Paleozoic rocks corer all of the Upper Peninsula of Michigan east of Marquette and overlap the highland country of northern Wisconsin and upper Michigan, including the Archean and Algonkian areas, in a great semicircle which extends southwestward into Wisconsin to the vicinity of Grand Rapids and thence northwestward through Chippewa Falls, ete., to the region where the Paleozoic overlaps the Keweenawan of northern Wisconsin and sends a narrow tongue northeastward to join the horizontal Cambrian of the head of Lake Superior at Duluth. Very small patches are found on the north shore of Lake Superior.

\section{CIIARACTEIR AND STTIUCTURE.}

These early Paleozoic rocks consist ehicfly of Upper Cambrian sandstone orerlain in places by a conformable or nearly conformable series which extends upwarl to the Silurian in Wisconsin and to Devonian and Carboniferous in lower Michigan. North of the Archean and 
Algonkian of upper Wisconsin and Michigan this Cambrian sandstone (Lake Superior sandstone) lies essentially horizontal and is probably preserved because it is downfaulted. In upper and lower Michigan, in Wisconsin, and in Minnesota, however, there is evidence that the sedimentary rocks lave been thrown into a series of broad folds-a synelinal basin in Nichigan and a broad anticline in south-central Wisconsin. The Cretaceous in northern Minnesota is essentially horizontal.

\section{DENUDATION.}

Earth movements have left some areas of Paleozoic rocks higher than others, and as a result of the elevation and inclination of these beds eroding agencies have removed them entirely from some areas, the boundaries of which have a direct relation to the broad folding. The upper beds of the Paleozoic are almost entirely absent in northern and central Wisconsin and northwestern Michigan (fig. 11, p. 116), from which it is inferred that, though they were once present over the whole of this area, they have since been removed by the active erosion which has taken place in this elevated region. As an evidence of the former greater distribution of the Paleozoic sediments we may refer to the isolated horizontal Cambrian beds that cap the ridges in the Menominee district east of Iron Mountain, Mich. (Pl. XXVI, in pocket), and various outliers of Cambrian age, which form mounds rising above the general peneplain level in Portage, Wood, and Clark counties, Wis., ${ }^{a}$ far north of the area of Cambrian rocks. Quite in contrast to these mounds of the border zone between the Paleozoic and pre-Cambrian in Wiseonsin are the knobs of the older rocks which project through the thin Paleozoic edge. The knobs are inliers; the mounds are outliers. Chamberlin ${ }^{b}$ refers briefly to such knobs that protrude through the Cambrian in northeastern Wisconsin. The Baraboo quartzite ridges and those at Necedah, Waterloo, etc. (figs. 53, 54, and 55, pp. 359, 360, 364), are features of the same sort. Because of their conspicuous positions as monadnocks on the pre-Cambrian peneplain they have been the first of the older rocks to emerge when the Paleozoic sediments which formerly covered their tops were eroded.

\section{THE BELTED PLAIN.}

The distribution of the Paleozoic sediments in a broad semicircle on the south flank of the Archean peneplain is to be explained, therefore, as a result of erosion after unequal uplift.c The lowest bed, the Cambrian sandstone, is distributed in a curving lowland belt around the Archean (Pl. I, in pocket), with outliers scattered far back upon the Archean surface, and the orerlying Paleozoic formations are clistributed in parallel curving belts, the more resistant beds standing up as highlands, the weaker beds being worn down into lowlands. A linear series of minor highlands underlain by the "Lower Magnesian" limestone stretches southwestward in Michigan and eastern Wisconsin (Pl. I), and thence northwestward in central and western Wisconsin. South and east of this is a broad valley which has been eroded upon the weaker members of the Ordorician, especially the Upper Ordovician (Cincimatian) shales and parts of the Galena and Trenton limestones. The waters of Green Bay have filled part of this great lowland valley, which extends southward, including the broad, shallow depression containing Lake Winnebago (Pl. II, p. 86). East of this valley there is a long, low monoclinal ridge, which was produced by the effects of erosion on the resistant eastward-dipping Niagara limestone, and which has a steep searp face on the northwest side and a gently dipping back slope toward Lake Michigan, diversified by minor monoclinal ridges due to weak and resistant members of the Ningara. It is overlain by glacial and lake deposits. It forms an upland ridge (fig. 5, p. 8S) east of Lake Winnebago and extends north in the Door Peninsula, Washington and adjacent islands of Wisconsin, and the Garden Peninsula of upper Michigan; the scarp continues first northeast, then sonth as the Niagara escarpment of Georgian Bay, southern Ontario, and northern New Jork. Fast of this ridge is the lowland of weak rock in which Lake Michigan ies and the upland of the northern part of lower Michigan.

a Weidman, Samuel, Bull. Geol. and Nat. 1 ist. Survey Wisconsin No. 16, 190", pp. 400 , 405-107.

$b$ Geology of Wisconsin, vol. $2,1873-1877$, p. 248.

cldem, vol. 1, 1873-1879, pp. 245-252. 
whole height of the surrounding rim is not everywhere apparent. Some of the other Great Lakes hare such a boundary on one sick, but none is so nearly walled in as dake Superion.

As the subnerged contours (PI. II) show, this basin has a depth of almost 1,000 foet, the deepest sounding being 163 fathoms, or 978 feet, near latitude $87^{\circ} \mathrm{W}$., longitude $47^{\circ} 45^{\prime} \mathrm{K}$., or nearly 400 feet below sea level, without considering the possible filling of recent lake silts or glacial deposits. There is a notable depression between the pre-Cimbrian of northern Wisconsin and the pre-Cambrian of Minnesota and ('anala. This depression consists of a long, narrow trough trending northeast and southwest and limiterl on the north by the great escarpment which extends from Duluth northeastward to the moutl of Nipigon Bay, a clistance of 250 miles. This trough is 25 to 70 miles wide. Its southern houndary is Keweenaw Point and the Michigan and Wrisconsin shore; at Oronto Bay, east of Ashland, there is an angular offset in passing the Apostle Islands, diminishing the wilth of the lake by half. Thence the wall of the depression goes ou parallel to and near the Wisconsin shore, the fault line ronverging westward toward the Duluth escarpment fault line, probably meeting it west of the head of the lakes in Mimesota.

From the mouth of Nipigon Bay the border of the Lake Superion depression extends southeastward to Sault Ste. Marie as a high wall or escarpment of unknown origin. Here it is not a straight line but has great cmbayments and salients. On the south shore a fault escarpment extends southward on the east side of Keweenaw Point. The highland borter thence trends irregularly southeastwarl to the vicinity of Marquette, beyond which it extends south ant a little west of south into Wisconsin. The area between Marquette and Sault Ste. Marie on the south shore is lowland.

The Nonth American Great Lakes are situated in pairs on either side of an escarpment which faces the boundary between the resistant pre-Cambrian and the relatirely weak Paleozoic rocks. In this respect they resemble the great lakes of the pre-Cambrim area of northwestem Europe. An escarpment thus situated and formed is called by Suess a glint line. Lake Superior, however, should not be included among the glint lakes, where it is classified by Suess, ${ }^{a}$ together with Lake Ontario, Georgian Bay, Lake Wimipeg, ete. The sontheastem part of Lake Superior might be considered a glint lake because it has one early Paleozoic and one Archean shore, as was pointed out by $\Lambda$ gassiz, ${ }^{b}$ if it were not known on other-evidence to be chiefly a structural basin.

In the origin of its basin, also, Lake Superior is exceptional. The other great lakes, four to the east in the United States and four to the north in Canada, Jie in lowland areas where differential erosion acting upon alternate weak and resistant beds would produce basins if aided by glacial erosion, glacial clogging, etc., though some of the basins are possibly also in part structural. Lake Michigan, for example, lies between the broad, anticlinal, southwartpitching fold of central Wisconsin and the basin-like syncline of central Michigan, its location suggesting a partly structural basin, as does also the known warping in the basins of the other great lakes, though the structural feature is certainly of minor importance. The correspontence of the Lake Michigan lowland with a belt of weak strata (Silurian and Devonian), perhaps somewhat deepened by glacial erosion, ${ }^{c}$ is probably of principal importance.

The reason for the present depression of the Lake Superior basin is somenhat doubtful, the carliest explanations being regarded as inadequate to accoms for certain features of it. The fact that it is a syncline (see structure sention, Pl. I, in pocket), first pointed out by Foster and Whitney and amplified by leving, e has never been callect in doubt, for there is ample proof of it. But for so old a structural basin to remain unfilled $f$ and for it to retain abrupt boundaries which bear all the characteristics of youth are departures from the normal condition which require special explanation.

a Suzss, Ediard, The face of the earth (Das Intlitz d.r Erda), translated by H. B. C. and W. J. Sollas, vol. 2, Oxford, 190k, p. 65.

b Lake Superior, ete., 18,50, p. 420 .

c Chamberlin, T. C., Feology of W'isconsin, vol, 1, 1873 1,79. np. 253-259.

$d$ Report on the Lake Superior land distric1, pt. 1, 1\$50, p. $1(199$

e Mon. U. S. Gcol. Survey; rol. 5, 185.3, p]p. $410-\$ 1 \mathrm{~S}$.

$f$ Barrell (Jour, Geology, rol. 14, Jomi, p. 335) has computed that it would take Mississipli River only tit, 000 years to counpletely fill Lake Superior if it flowed in to that water body with its prusent rolume and load. 
The hypothesis that the present Lake Superior basin exists berause of a geosyncline, as first stated, needs to be modified, therefore, by consideration of the possibility of graben or rilt faulting. The amplification of this revised hypothesis and its rerification in detail remain for future work. 'The possibility, however, seems worth outlining here.

It is thought reasonable to suppose that after the late Algonkian deformation, whose structural warping produced or redeepened the major syncline, the basin was filled to a considerable extent by lavas and by sediments overlying the Keweenawan flows. Between the close of this period of deposition and the beginning of the Lpper Cambrian a great period of denudation produced the pre-Cambrian peneplain, whose surface of low relief beveled across the weak and resistant members of the Archean and Algonkian, the synclinal basin perhaps being filled witl the material worn away in making the peneplain or perhaps heing replaced by part of the peneplain surface. At some subsequent date, probably also pre-Cambrian, faulting took place, producing the great escarpment which extends northeastward from Duluth and smaller nearly parallel escarpments on the south shore of the lake. These two fault lines bound what is perhaps a great graben or rift, which forms the rectangular body of northern and western Lake Superior (fig. 8). The evidence of the fault origin of these escarpments may be gathered from a detailed consideration of their characteristics.

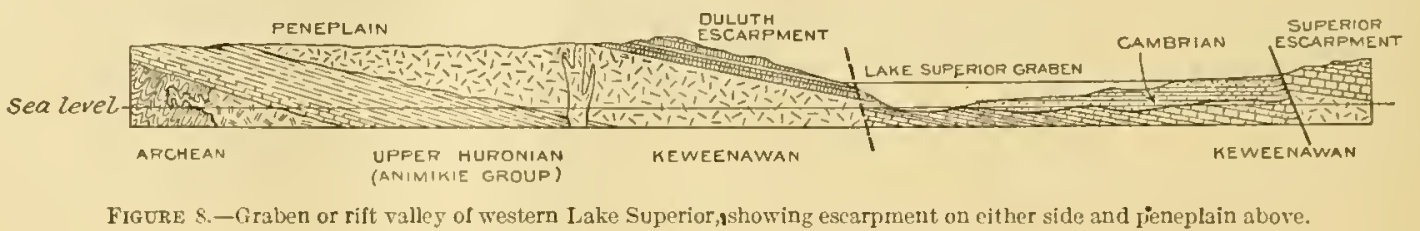

DESCRIPTION OF ESCARPMENTS.

DULUTH ESCARPMENT.

Rising steeply above the waters of Lake Superior for about 600 to 800 feet at Duluth and with diminishing height toward the northeast is the Duluth escarpment (Pl. II, p. S6). It lias a slope at Duluth of 450 to 1,000 feet to the mile, and the steeply ascending face is $1 \frac{1}{2}$ to 2 miles wide (PI. V, A). Above rises the fairly level-topped gabbro plateau, which extends northward as part of the peneplain. The escarpment, which bounds this jlatean on the southeast, is remarkably simple in its outline, with none of the irregularity which characterizes slopes long eroded by streams. This simplicity of outline is shared by the gently curved escarpment of Keweenaw Point and by that of northern Wisconsin, both of which are known to follow fault lines. Lawson has suggested that the Duluth escarpment also follows a fault line. ${ }^{a}$ Te have then to arcount for its fresh and uneroded form, for it is quite inconceivable that a fault scarp could have been produced, as this may have been, in pre-Paleozoic or very early Paleozoic time and not have been more largely altered by weathering and stream erosion.

The streams of the Duluth escarpment descend very steeply to Lake Superior; few of them head more than 4 or 5 miles from Lake Superior (Pl. II), the greatest distance being 12 to 14 miles, in contrast with lengths of 30 to 75 miless on the north and northeast shores of Lake Superior. Many of them lave as steep an average grade as 150 to 250 feet to the mile (Pl. I, A). the general average being 80 to 160 feet to the mile. No one of these rather tumult uous streams has cut a significantly deep valley in the face of the escarpment and most of them have only cut short gorges with small rapids and waterfalls.

Quite in coutrast with these steep-graded, rapidly falling streams of the escarpment are the leisurely flowing streams of the plateau surface above. The Cloquet, the upper St. Louis, and rarious other rivers have an arerage slope of about $s$ or 10 feet to the mile. It is well established that a rapidly flowing stream with a steep grade is able to deepen its valley rapidly and to extend its headwater area so that it encroaches upon the area drained by an adjacent 


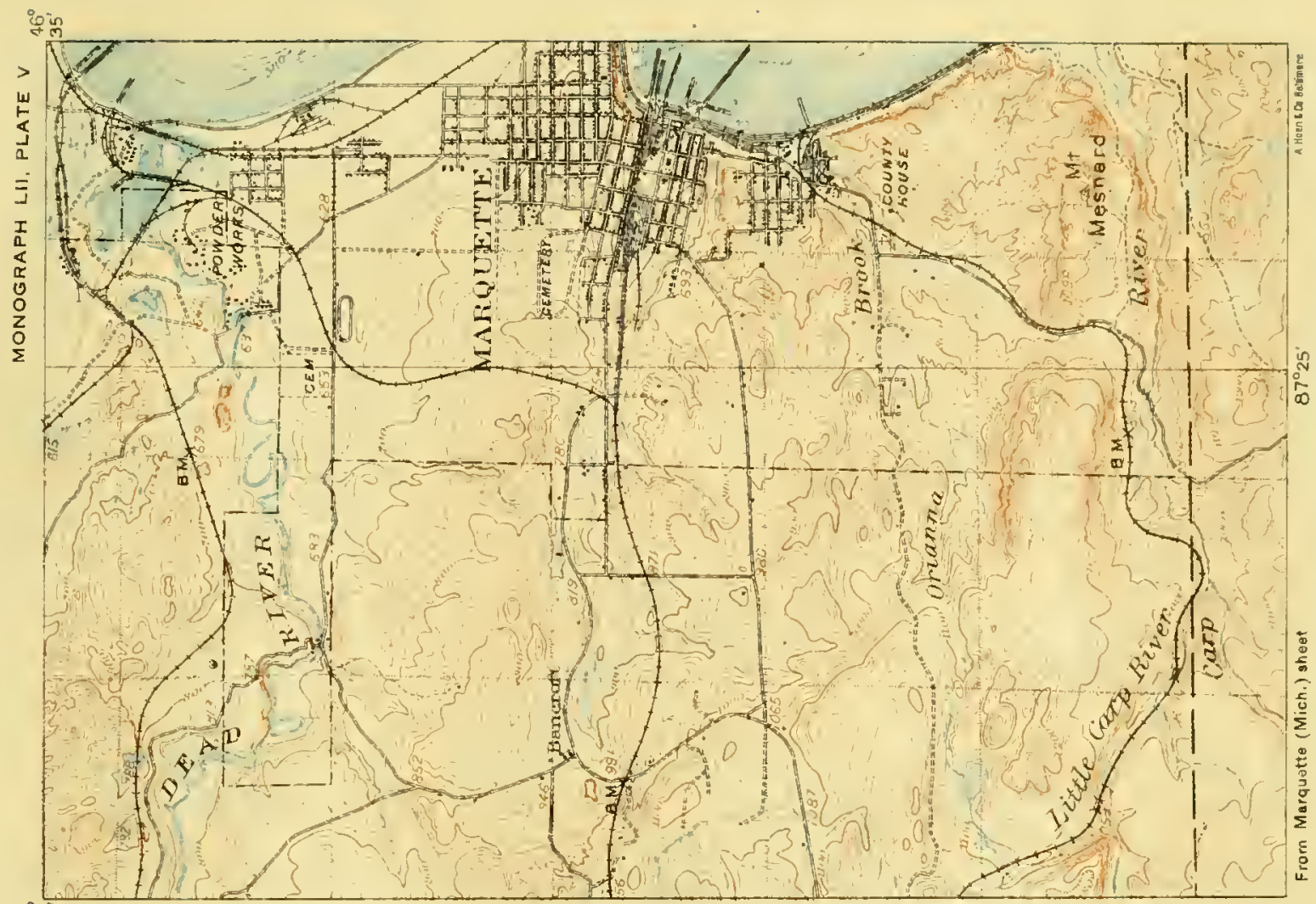

$\frac{0}{2}$

in

点

⿰氵

$z$ o

近发

$\Sigma$

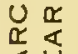

\& 2 乙

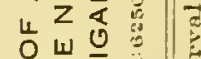

Q

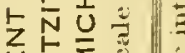

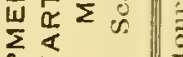

a

x 0

过 $z$

山ᄄ

I

in

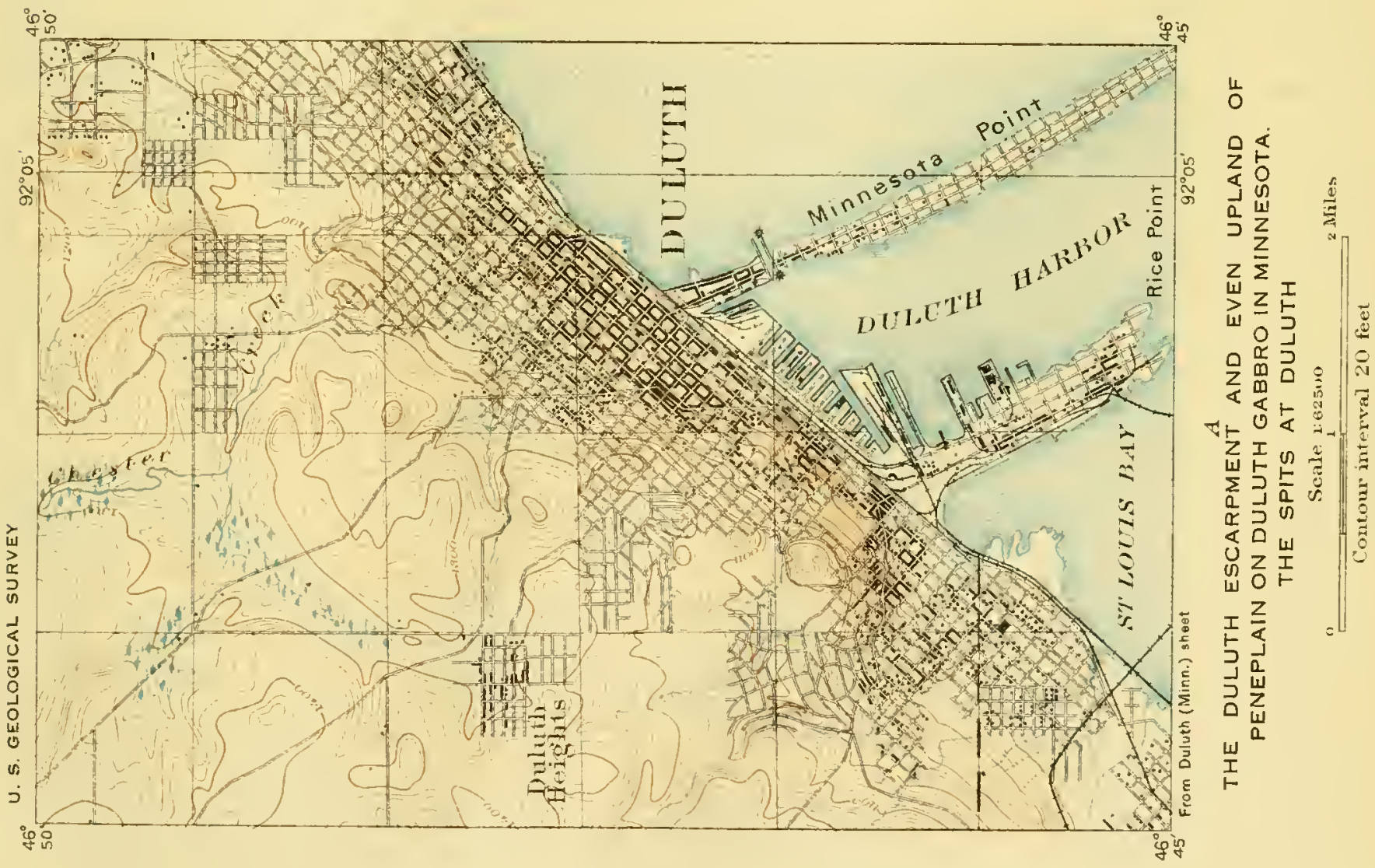



leisurely flowing stream (fig. 9), capturing and diverting the latter or some portion of its headwaters. Stream captures or piracies, as they are called, of this kind are common. We should expect, then, that in the course of stream development for a great length of time several of the swiftly flowing streams of the escarpment would have extended their headwaters back to the region drained by the leisurely flowing streams of the plateau surface and captured part or all of these drainage systems.

The fact that many of the large streams have not done so is evidence of their youth.

The largest stream in the region, however, seems to have already done just what would be expecterl (fig. 10), and it is natural that the largest stream slonld be able to do this first. St. Louis River, cutting back at a point near the end of the escarpment where it is rather low, lias been able to extend its headwater region northwestward until it has captured the southwestward-flowing Clo-

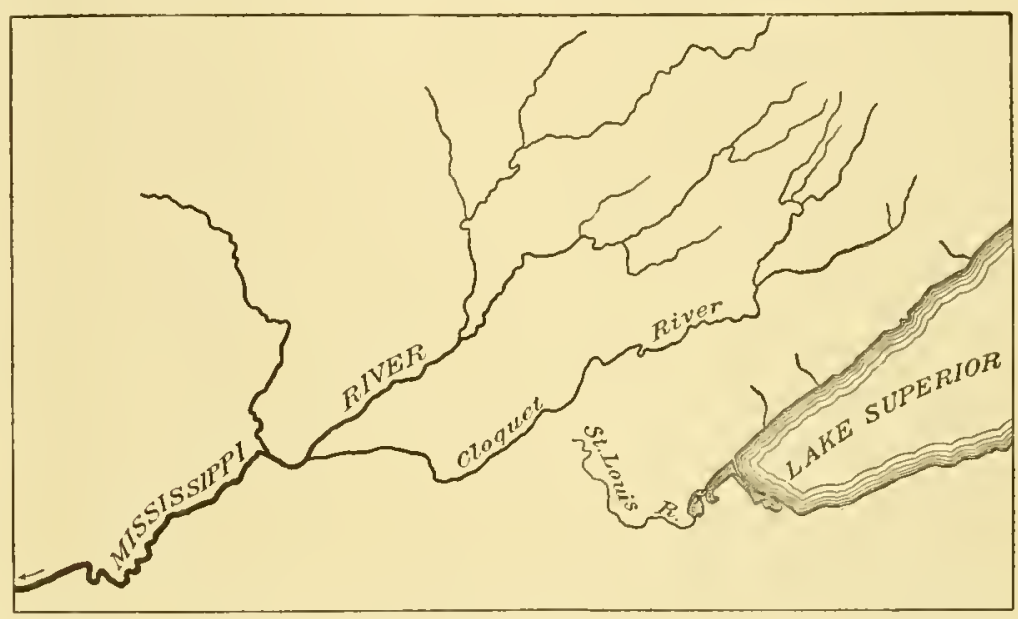

FIGURE 9.-The drainage of the St. Louis and Mississippi headwaters before the stream captures along the Duluth escarpment. quet and the southwestward-flowing stream that forms the present headwaters of the St. Louis itself. These captured streams had been a part of the leisurely drainage system of the plateau surface, and, it seems certain, were within the Mississippi basin (Pls. I and II). Indeed, a large valley extending sonthwestward from the town of Floodwood, where the St. Lonis now turns abruptly to the southeast, indicates that this is probably the latest elbow of eapture at which the piratical St. Louis has been able to divert to the Lake Supe-

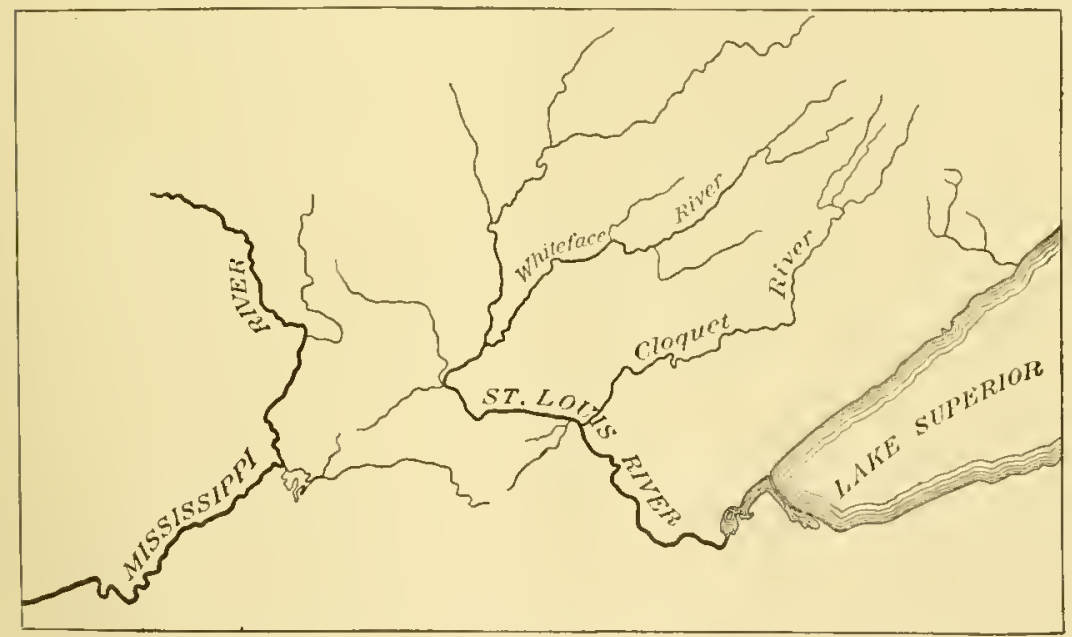

FIGtre 10.-The drainage of the St. Louis and Mississippl headwaters at present, after stream captures and diversions. rior-St. Lawrence drainage syrstem a large headwater tributary of Mississippi River, as it had previously diverted the Cloquet, another Mississippi headwater, or possibly one of the St. Croix.

A study of similar fault scarps acted upon by stream erosion in other parts of the world indicates that this fault scarp has not been acted upon by erosional agencies for a great length of time. If it had been so eroded for a long period, we should find it deeply cut by valleys with outlying knobs on the lower slopes, like the erosion escarpment at Marquette (Pl. $V, E)$, and with stream captures at the upper shoulder, where the escarpment meets the plateau top.

Comparison of this escarpment with the equally abrupt escarpments on the north shore of Lake Superior from Thunder Bay to Sault Ste. Marie emphasizes the freshess of the Duluth escarpment; there is a striking contrast in stream and valley distribution. The north-shore 
escarpment has much longer streams flowing directly to the lake from the north, with deep valleys everywhere cut to lake level. It is a much-breacherl wall; the Duluth escarpment is an unbroken barrier. The dranage of the former proctaims greater length of time for stream dissection in the same language by which the drainage of the latter announces youth.

It seems possible that erosion by the Lake Superior lobe of the I abraclor ire sheet night have so smoothed the face of this escarpment and steepened and intensified it thit topography of the kind suggested would be destroyed or that longer streams draining to Lake Superiur would be diverted by the ire barrier and acfuire new courses. Such modification may lave taken place to a shight legree, but even if the maximum of glacial erosion is assumed the lack of stream diversions is quite unexplained, as is also the resemblance to the acknowledged fault searp on the east side of Keweenaw Point.

Along the line by which this escarpment can be discriminated as a form initially produced by faulting rather than by glacial erosion a scrutiny of the submerged continuation of the same escarpment reveals several significant facts. Fortunately the cletailed soundings male by the Corps of Engineers of the United States Army in charting the Great Lakes give us detailed information (Pl. II) concening the escarpment below present lake level. First, it continues to descend at as steep or steeper angles than on the land, a depth of 400 to 600 feet being found within 2 to 3 miles from any part of the shore. The escarpment, therefore, is not merely 400 to 600 feet but 1,000 to 1,200 feet in height. Second, it extends directly across the mouths of the several large bays (Thunder, Black, and Nipigon) at the north end of the lake, where the escarpment feature in the unsubmerged land surface is interrupted by these broal ralleys, partly drowned beneath the present lake level. These are therefore hanging valleys, entering the lake basin or the linear depression to which they are tributary at levels 400 to 600 feet ${ }^{a}$ aloove its bottom. (See Pl. II.) This submerged hanging valley condition might be explained either by glacial erosion or by faulting.

The facts in faror of glacial crosion are $(a)$ known ice flow along this coast and parallel to it; (b) probably accentuated erosive ability in this portion of the Lake Superior basin, where more rapicl movement would result from the constrietion of the ice between Isle Royal and the mainland; (c) the known ability of glaciers of no greater thickness and less wilth to erorle so deeply that main valleys receive discordant tributaries (hanging ralleys) as much as 500 to 1,000 feet above, as in Alaska, the Swiss Alps, Scotland, Norway, New Zealand, ete.

Points in lavor of faulting are the following: (a) The straightness of the escarpment; (b) the continuation below lake level of a topographic feature whose drainage and other land phenomena are inexplicable by glacial erosion alone; $(c)$ the uniform level at which the submerged hanging valleys stand (Thunder Bay 22 to 23 fathoms, Black Bay 22 fathoms, Nipigon Strait 20 to 21 fathoms). Such uniformity is unusual in glacially eroclecl hanging valleys, where the size of the glaciers in tributary valleys, their width, thickness, and eroding power, produce hanging valleys at diverse levels. Glaciers of the unerpual sizes denoted by these buys would surely have done so. (d) The varying age, character, and resistance of the rocks beveled across by this supposed fault (Cambrian sindstones, Keweenawan lavas and sediments, upper Huronian intrusives and slates, and older rocks).

The escarpment therefore seems to have features inexplieable by glacial erosion alone, but none that do not fit the hypothesis of glacial erosion modifying a faulterl form. The exceptional depth of water just opposite the mouth of Thunder Bay (156 fathoms), making this point 936 feet deep, or more than 300 feet below sea level, and the secombl deepest place in the lake, can be readily explained by glacial scooping at just this point, for such irrecrularity in the bottoms of glacially eroeled channels like the Norwegian and Mlasknu fiords are not uncommon.

The writer accordingly feels that there is a reasonable possibility that the northwest shore of Lake Superior from a point west of Duluth to St. Ignace at the north, with its direct but broadly-curving course, represents the position of a fault line. This fault scarp, with 1,000 feet or more of throw, may either be very reent, though sereral considerations lead to the belief 
that this is not so, or else it may have been faulted long ago and then buried and protecter so that erosion has only recently begun to attack it. Accorlingly it may owe the preservation of its southwesterly portion (Minnesota shore) to protection by (ambrian or later sediments and the dissection of its northeasterly part (Ontario shore) to the earlier removal of such a protecting Cambrian mantle. Glaciation is believed to have modified this esearpment in its minor features only, as in changing a more precipitous slope to the present flaring wall and in locally deepening the depression at its base.

\section{KEWEENAW ESCARPMENT.}

The escarpment of the east side of the Keweenaw Point ${ }^{a}$ very alosely resembles the Duluth escarpment in form and condition of erosion though not so high nor so steep (Pl. II). A northenst-southwest trending escarpment borders the east side of "an elongated promontory," not greatly dissected by erosion nor deeply undulate nor serrate in its crest line," whose flat top has been formed by the basc-leveling ${ }^{\circ}$ of a series of steeply dipping Keweenawan beds and whose western and northwestern sides slope more gradually to the level of Lake Superior; the east side slopes steeply to the open lake near the tip and is elsewhere separated from the lake by the low-lying flat portion underlain by the (ambrian sandstone (PI. XXVIII, p. 380).

This escarpment differs, lowever, from the Duluth gabbro esearpment in one important respect. It is cut entirely through by stream ralleys in at least two places. It is beliered that the great transverse valley of Portage Lake (PI. XXX, $B$, p. 434) and the valley of Ontonagon River were formed before the present Lake Superior existed, by streams which were superposed on this long, narrow peninsula through a mantle of Cambrian (Lake Superior) sandstone, whose remnants are still preserved high upon the fault scarp near the highest part of Keweenaw Point. ${ }^{d}$ Irving and Chamberlin, ${ }^{e}$ after careful consideration of the many earlier lyypotheses, reach the conclusion that the Keweenaw Point scarp is a pre-Potsclam fault modified by wave work, buried, and slightly refaulted in post-Potsulam or post-('ambrian time. (See fig. 75, p. 574.)

\section{ESCARPMENT OF NORTHERN WISCONSIN (SUPERIOR ESCARPMENT).}

The escarpment which forms the boundary of the northern highlands of Wisconsin $f$ and overlooks the basin of Lake Superior from a point west of Duluth eastwarl to the Apostle Islands is a lower and more gently sloping scarp (Pl. II). It has the characteristics of the other two escarpments in being without topographic outliers and in having short, steeply sloping stream courses which have not extended healward much beyond the shoulder of the escarpment.

Chamberling concludes that this escarpment of Bayficld and Douglas counties, Wis., is a pre-Potsdam fault scarp, and Grant ${ }^{h}$ lias supported this conclusion but makes its age postPotsdam. Like the Duluth and Keweenaw escarpments, it seems to have been protected so that its dissection has been somewliat postponed Its youth is therefore not so anomalous as W. M. Davis has suggested. ${ }^{i}$

\section{ISLE ROYAL ESCARPMENT.}

On the north side of Isle Royal there is a submerged escarpment of 400 to 500 fect, suggesting a parallel fault here (Pl. II), which Irving and Chamberlin ${ }^{j}$ conceired of as possibly a continuation of the fault of Bayfield and Douglis counties on the south shore. There is no continua-

a Irving, R. D., and Chamberlin, T. C., Observations on the junction between the Eastern sandstono and the Keweenaw series on Keweenaw Point: Rull. IT. S. Geol. Survey No. 23, 1885, pp. 12, 98-119.

b 1 dem, p. 103.

c Van Ifise, C. R., Science, new ser., vol. \&, 1896, pp. 217-220.

d Bull. U. S. Geol. Snrvey No. 23, 1885, pp, 109-110.

e luem, p. 119.

$f$ Chamberlin, T. C., Geology of Wisconsin, rol. 1, 1\&83, pp. 105-106, Grant, U. S., Bull. Geol. and Nat. Hist. Survey Wisconsin No. 6, 1901, p. 6.

g Geology of Wisconsin, vol. 1, 18\$3, p. 105.

a Bull. Geol, and Nat. Ilist. Surver Wisconsin No, 6, 1901, pp. 17-20.

$i$ Science, new ser., vol. 15,1902 , p. 234.

i Bull. L. S. Geol, Survey No. 23, 15s5, p. 111. 
tion of this steep slope northeast ol" southwest of Isle Royal, which stands on a high base with strep descents on all sides of it, esperially the northwest and southerst. If the channel northwest of Isle Royal is aseribed to block faulting, the island itself must be regarded as a land mass that stands as a horst ahove the deep surromeling basin because of failure to be fatulted down.

Isle Royal and Keweenaw Point accordingly have certain features in common aside from familiar fact that the Keweenawan rocks in Isle Royal dip southeast and those at Keweenaw Point dip northwest. The slopes facing each other seem to be dip slopes, but of the sides facine away from ench other that of Keweenaw Point is known to be a fault line, and that of Isle Royal may possibly be a smaller one. This structural feature, then, woukl be a great syuclinal trough between Isle Royal and Keweenaw Point, with downfaulting on each side.

Mlassing of the contours in other parts of the lake (Pl. II) suggests submerged escarpments east of this trough, but there is not enough information for detailed discussion.

\section{AGE OF ESCARPMENTS.}

For all these subparallel escarpments grouped about the west end of Lake Superior the hypothesis is advanced that they have been formed by faulting. Their later history may have accorded with one of two hypotheses. One supposes that they are old escarpments (pre-Cambrian) slightly modified by stream erosion and in places possibly developed into sea clifs and then buried beneath Palcozoic sediments. During the ensuing long period of denulation the escarpments themselves were protected from erosion by the orerlying sediments. They were gradually uncovered and are now just in the beginning of a cycle of erosion, which was postponed until their rather recent disinterment. The alternative hypothesis that these are much more recent fault searps (post-Cretaceous or pre-Pleistocene) is supported by the evidence of slight post-Cambrian movement along two of these scarps (along which there was surely much greater pre-Cambriun faulting) and by the evidence of post-Cretaccous and of postPleistocene faulting im other parts of the area. The question of the date of this faulting is a large one, involving the determination of the age of the great peneplain of the area and the age of the present Lake Superion basin.

\section{BEARING OF ESCARPMENTS ON AGE OF PENEPLAIN.}

There are three ficlds for attacking the problem of the age of the peneplain in the Iake Superior region. The first is in northern Wisconsin, where the truncated surface of the preCambrian now dips down under the Paleozoic. The conditions here are shown in figure 11.

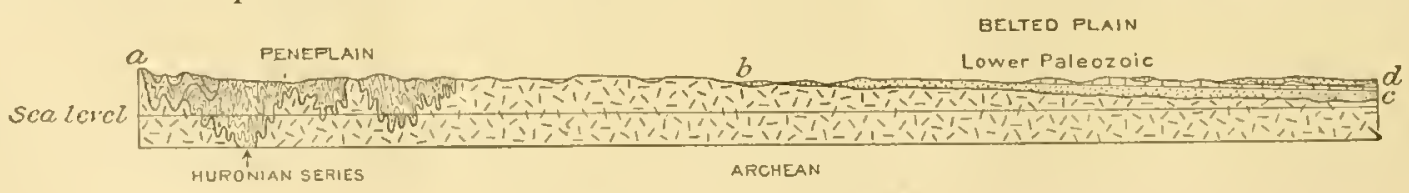

FIGURE 11.-Strueture profile in northern Wiseonsin, showing tho south edge of the peneplain on the pre-Cambrian rocks and the northern part of the belted plain of the Paleozole.

Weidman has demonstrated that $b-c$ is a buried pre-Potsdam pencplain and inferred that $a-b$ is its exhumed equivalent. Tan IIise previously referred to $b-d$ as a Cretaceous pencplain and to $a-b$ as its equivalent. So far as the writer can see, eridence for deciding couclusively between these two liypotheses is not present, though the Paleozoic outliers on the peneplain suggest that it is pre-Potsdam rather than Cretaceous.

The second field of attack is in the region to the west, in Mlinnesota (PI.XIT, p.212). IItre the Cretaceous overlaps the peneplain. Numerous diamond-drill holes through the glacial drift on the Cuyuma range show the Crotareous as a thin mantle on the peneplain of pre-Camblian rocks. Elsewhere the drift covers it deeply, but on the border of the Cinnts Range monatnock, in the Mesabi iron range, Cretaceous outliers are found in ralleys and on ridge slopes. (PI. TIII, in pocket). These are marine Upper Cretaceous, so the peneplain might perfertly woll he cither pre-Cambrian 
or early Cretaceous in age. If the cretaceous can be found in valleys in the peneplain as well as in valleys on the slopes of its monalnocks, the probability of pre-Cambrian age will be strengthened.

The third and most promising field for investigation is in the lault searps themsetves. The escarpments were clearly made after the great peneplain was loveloped, for the nearty baseleveled upland areas now extend neatly up to the edges of these steep slopes (fig. 8, p. 112) and could not have done so when the peneplain was formed. The two latest periods of great base-leveling in the area are thought to be pre-Cambrian (pre-Potsdam) and (retaceous. The known periouls of faulting are pre-Cambrian, post-Cambrian, post-Cretaceous, and post-Pleistocene. The Lake Superior basin was surely here in pre-Pleistocene time, so the post-Pleistocene may be eliminated as a period of major faulting. The choice seems to lie between $(a)$ regarding the pencplain as due to Cretaceous base-leveling and the escarpments as due to post-Cretaceous faulting, to which there are certain objections, and (b) regarding the peneplain as an exhmmed slightly dissected pre-Cambrian surface and the esearpments as due to pre-Camorian faulting. The assumption of protection by Paleozoic sediments is necessary in order to explain the relatively fresh fault-searp forms, and from this assmmption naturally follows the hypothesis of the clearing out of the basin and exhumation of the escarpments during the (retaceous base-leveliug and the glacial period, all the later faulting being considered of slight amount. There are objections to this hypothesis also, but in the mind of the writer they are of less weight. 


\section{CHAPTER V. THE VERMILION IRON DISTRICT OF MINNESOTA. ${ }^{a}$ IOC.ITION, AIEA, ANI) GENERAI, GEOLOGIC SUCCESTION.}

The Vermilion ison-beaning district lies in morthenstern Minmesota, in St. Lonis, Lake, and

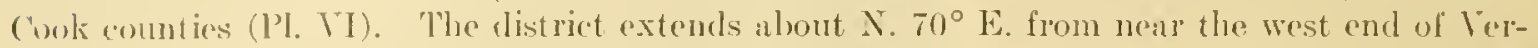
milion Lake, in west longitule $92^{\circ} 30^{\prime}$, to the vieinity of Gemllint Lake on the international bomdary, longitude $90^{\circ} 45^{\prime}$, and lies between $47^{\circ} 45^{\prime}$ and $45^{\circ} 15^{\prime}$ north latitude. The distriet is for the most part 5 to 10 miles broad but locally as much as 12 or 15 miles, and at the castern end it is diviled into two narrow belts by the granite of Saganagal Lake. The lengrth of the distriet is about 100 miles.

The proluctive iron-bearing rocks are hounded on the north by the granite of Bassworl Lake, on the east hy the granite of Saganaga Lake ant the Animikie group, and on the south in tum from cast to west by the Keweenawan Duluth gabbro, lower Iluronian granite, and Arehean granite. On the west the iron-bearing and other formations disalppear under the Pleistocene. Part of the eastern half of the Vermilion range extends north of the international houmlary into Hunters Island. The rocks of the eastern extension of the north arm of the Termilion range are known locally as the Hunters Island iron-bearing series.

The stratigraphic suecession in the Termilion elistrict is as follows, in descending order:

Quaternary system:

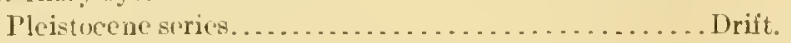

Unconfermity.

Algonkiin systen :

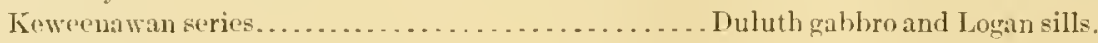

Unconformity.

II uroniau serios:

Upper II ronian (Animikie group) b......... $\begin{aligned} & \text { Rove slate. } \\ & \text { Gumflint formation (iron bearing). }\end{aligned}$

Unconformity.

Lower-middle 11 uronian.....................

Unconformity:

Archean system:

Laurentian series. ........................ Granite of Basswood Lake and of her intrusive rorks.

Keewatin series. Soutan formation (iron bearing). Ely greenstone, an ellipsoidally parted basic igneous and Iargely volcanic rock.

This chapter is primarily concerned with the Arehean and the lower-midlle Huronian, which really constitute the rocks of the Vermilion distriet. The hiegher rocks will be mentioned only so far as it is necessary to do so in order to give a sat isfactory treatment of the lower rocks. The Inimikie gromp, which oceurs at the east end of the district, and the heweenawan series. which borters a large part of the southern portion of the distriet, will be treated in chapters VIII and XY.

a For a further detailed lescription of the geology of this distriet, see Clements, J. M., The Vermilion iron-beariug district of Mlinnesota: AIoa. U. S. fieol. Survey, Vol. 15, 19013, and references there given.

bconfined to eas end of listrict. 



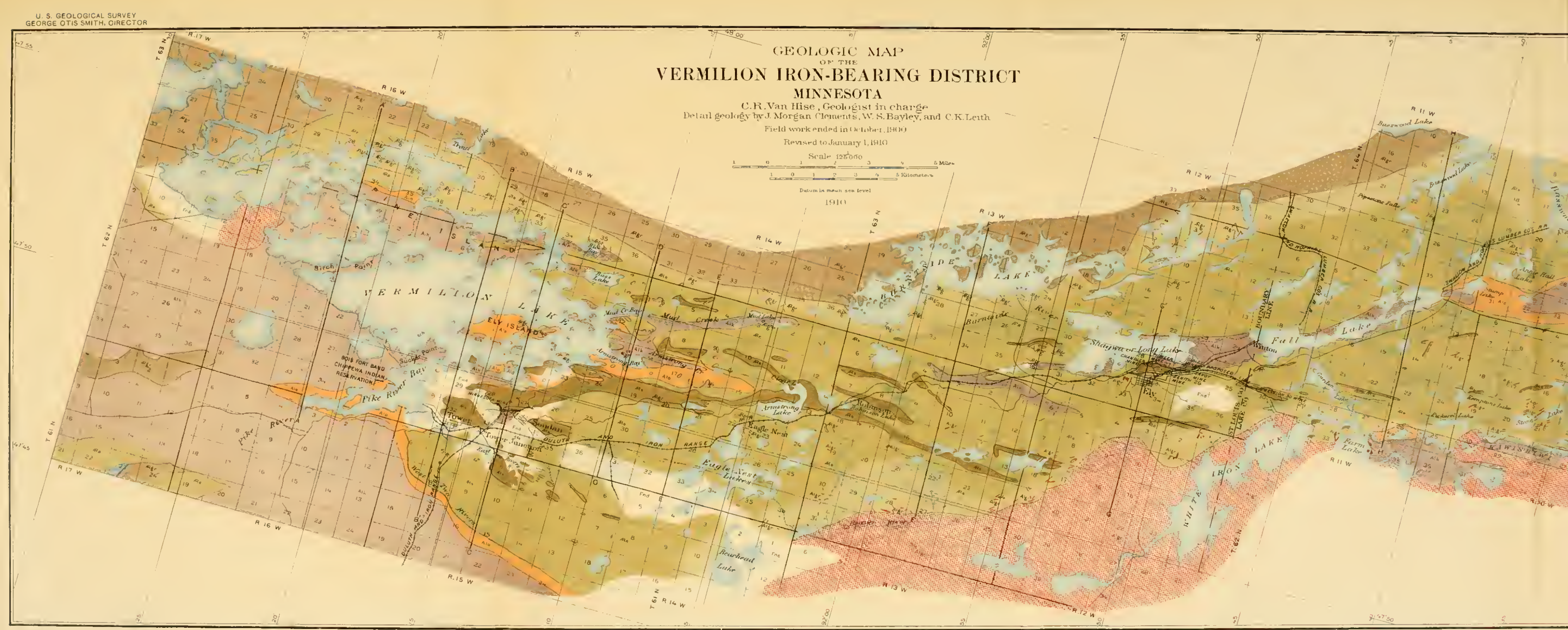




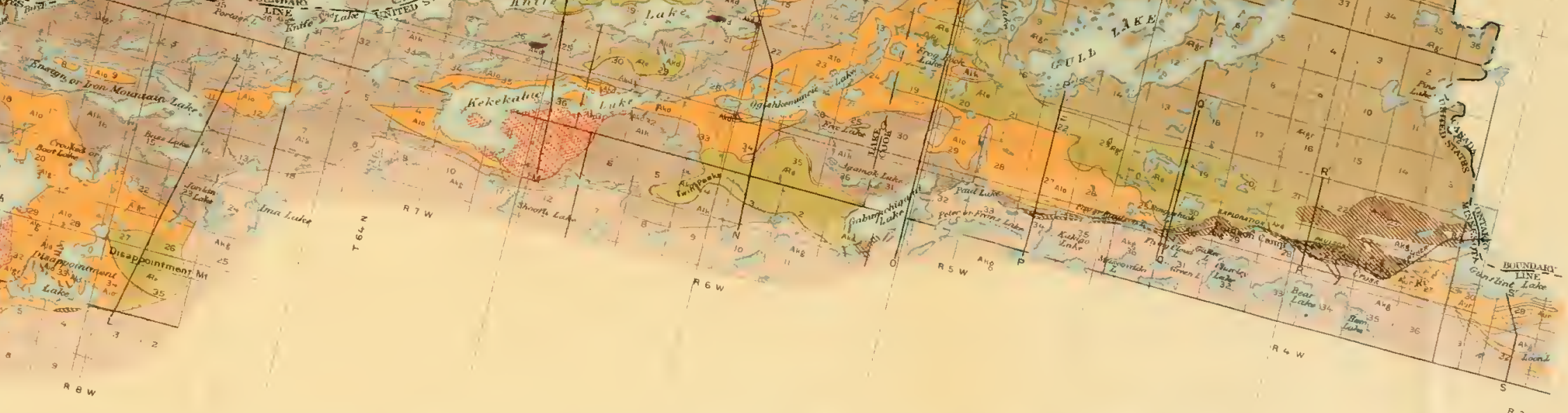

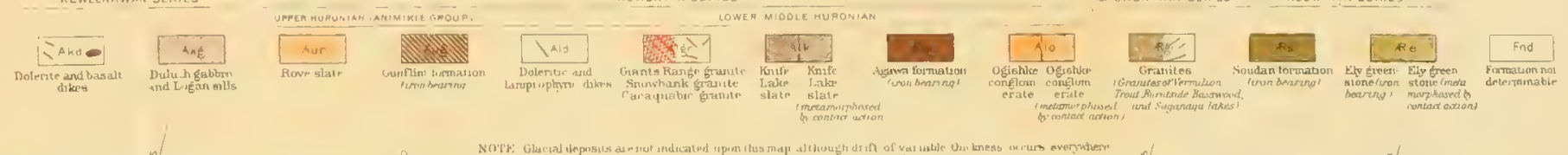





\section{TOPOGRAPIIY.}

The topography of the distriet may be defined hriefly as eharacterized hy linear bluffy ridges, in the depressions between which are numerous linear likes, the whole constituting a relatively eren peneplain with a few monadnocks. The general physiography is discussed in Chapter IV.

The position of the ridges and valleys is determined by the character of the rocks. The more resistant rocks form the ridges, the less resistant the valleys. On the whole the most resistant rock of the region is the Ely greenstone, and this eonstitutes a greater proportion of the bluffs of the district than any other formation.

Next in importance to the greenstone as a blufl-making formation is the iron-bearing Soudan formation. This independently constitutes a number of high blufls, and conjointly with the greenstone helps to make many others.

The elepressions, especially those containing lakes, are mainly engraved in the Kinife Lake slate. This is true of most of the important lakes of the district, such as Vermilion Lake, Long Lake, Fall Lake, Moose Lake, Ogishke Lake. However, some of the lakes, especially those that are roundish, are in other formations, notably the granite, which in this district seems to be not much more resistant than the slate. Important lakes of this class are White Iron Lalie, Basswood Lake, Snowbank Lake, and Saganaga Lake.

The Ogishke congromerate is intermediate in resisting power between the slates and greenstones. In places, therefore, it oceupies the valley, as at Termilion Lake, and in places makes considerable blufs, as in the eastern part of the distriet; but nore commonly the conglomerate is found on the slopes, because it lies structurally between the harder greenstones and the softer sliates.

\section{ARCHEAN SYSTEM.}

The Archean is represented by both the Keewatin series and the Liurentian series. The Keewatin comprises the Ely greenstone and the Soudan formation. The Laurentian includes granites, porphyry, and associated acidic rocks.

\section{KEEWATIN SERIES.}

ELY GREENSTONE.

DISTRIBUTION.

The Ely greenstone is the most conspicuous and extensive formation of the district. From Vermilion Lake to the central part of the district it occupies the larger part of the area between the granites to the north and sonth. In the castern hialf of the district it is less extensive.

The formation is conspicuous not only because of its areal extent, but beciuse of its topographic importance. In gencral its rocks are resistant, and many of the high knobs of the district are composed of them-for example, those about Tower and Ely. They form Disappointment llountain, near Disappointment Lake, one of the most prominent features of the district. They compose the great promontory of Knife Lake, in see. 21, T. $65 \mathrm{~N}$., R. $7 \mathrm{~W}$, so conspicnous a feature along the international bounlary. In fact, most of the high knobs to be seen from almost any commanding point of view between the northern and southern granites are composed of the Ely greenstone. Such knobs are conspicuous aven where the areas of the greenstone are suborlinate-for example, the high bare healland above Moose Lake.

1 few of the important hull's are clur to the resistant quality of the Ely and Soudan formations together-for instance, Soudan and Lee hills, near Tower, and a number of the prominent bluffs of Hunters Island, along the north side of Otter Track Lake, and elsewhere.

appearance and structure.

The Ely greenstone has as its dominant color various tones of green. It comprises greenstones, tufls, and slates, but the litter two varieties of rock are rery subordinate. The dominant rocks of the formation are ealled greenstone rather than a petrographic name because 
many of them have been so nodified by metamorphism that in the ficld it is often impossible to determine their character or to discriminate between the different plases. This alteration is no more than one would expect from their great age. For the most part the changes are dominantly metasomatic rather than dynamic, so that the massive rocks still retain their original structures and textures, though their mineral composition is now largely or wholly changed.

Clements's petrographic study of these greenstones shows that they correspond to intermediate andesites and basic basalts. The massive exposures of this greenstone very commonly show one or more of the three structures - the amygdaloidal, spherulitic, and ellipsoidal. Not only are these macroseopic structures common, but textures such as oplitic, poikilitic, and porphyitic often may be seen. The rocks vary greatly in their fineness of grain from aphanitic to covarse gramed.

Of the structures mentioned as characteristic of the rocks the most common is the amy-gdaboidal, this structure usually being found in the finer-grained rarieties. It is especially noticeable on the weathered surface.

The greenstones not uncommonly show true splerulitic structures, but these are not by any means so common as the amyglaloidal structure. This structure, though rery rare in basic rocks, is exhibited in this ancient formation in as great perfection as in modern acidic rocks.

The third structure, the ellipsoidal, is the most distinetive one of the formation. Almost any large mass of the Ely greenstone encountered between Tower and Gunflint Lake will exhibit this structure. The rock, observed at a distance, seems to be mainly composed of a mass of ellipsoids of rock, varying from a few inches to sereral feet in cliameter (Pl. VII). Ordinarily, however, the elhipsoils range from 6 inches to 3 feet in diameter, and perhaps most commonly they are between 1 and 2 feet in diameter. These ellipsoids are set in a matrix of material not greatly different from the ellipsoirls themselves but usually of slightly different color and texture. In many places they have undergone peripheral alteration, so that they exhibit a zonal arrangement.

If the ellipsoids are examined somewhat more closely, many of them are found to be amygdaloidal; moreover, in many of the splieroids the amygdules are more abundant near the border than in the interior, and not uncommonly all the ellipsoids of an exposure are more amygdaloilal on the same side. The origin of these ellipsoidal rocks is discussed by Clements in the monograph on the Vermilion district and by the authors on pages 510-512 of this monograph.

Within short distances the grecnstones vary from fine to coarse textures and from rarieties which exhibit the structures mentioned to others in which they are absent. In many places these phases alternate at short intervals.

Every gradation may be found from the undeformed ellipsoids to a schist. In the transition the ellipsoids become flatter and flatter, until finally the representative of each is a lenticular area perhaps many times as long as it is broul. Since the exterior of the ellipsoids, as hils already been explained, usually has a different color from the core and a somewhat diflerent texture, an extremely flattened ellipsoid has three bands. The occurrence of this phenomenon in the many ellipsoids transforms the greenstone to a fissile banded schist which has a rery marked sedimentary appearance. Indeed, in dealing with the extremely altered plases it is difficult to believe that the rock is not a sediment rather than a metamorphosed lava.

In many places, without reference to the ellipsoidal structure, the greenstones are schistose. Howerer, this schistosity is not noarly so common as in the Marquette and Mencmince districts. In consequence of the relative lack of schistosity, the original characters of the Arehean greenstone are better exhibited in this distriet than in any other on the American side of the bounlarr. It is not unreasonable to suppose that it may be possible by further detailed mapping to work out the succession of flows for the Ely greenstone.

MINERAL CONSTITUENTS.

A microseopical study of the greenstones shows that the original minerals are largely altered. The following original constituents are dischsed: IIomblencle, aucrite, plagiochase, quartz, titaniferous magnelite, and apatite. The original hormblende is the common brown rariety. The augite raries from yellow to yellowish green and possesses its normal characters. 


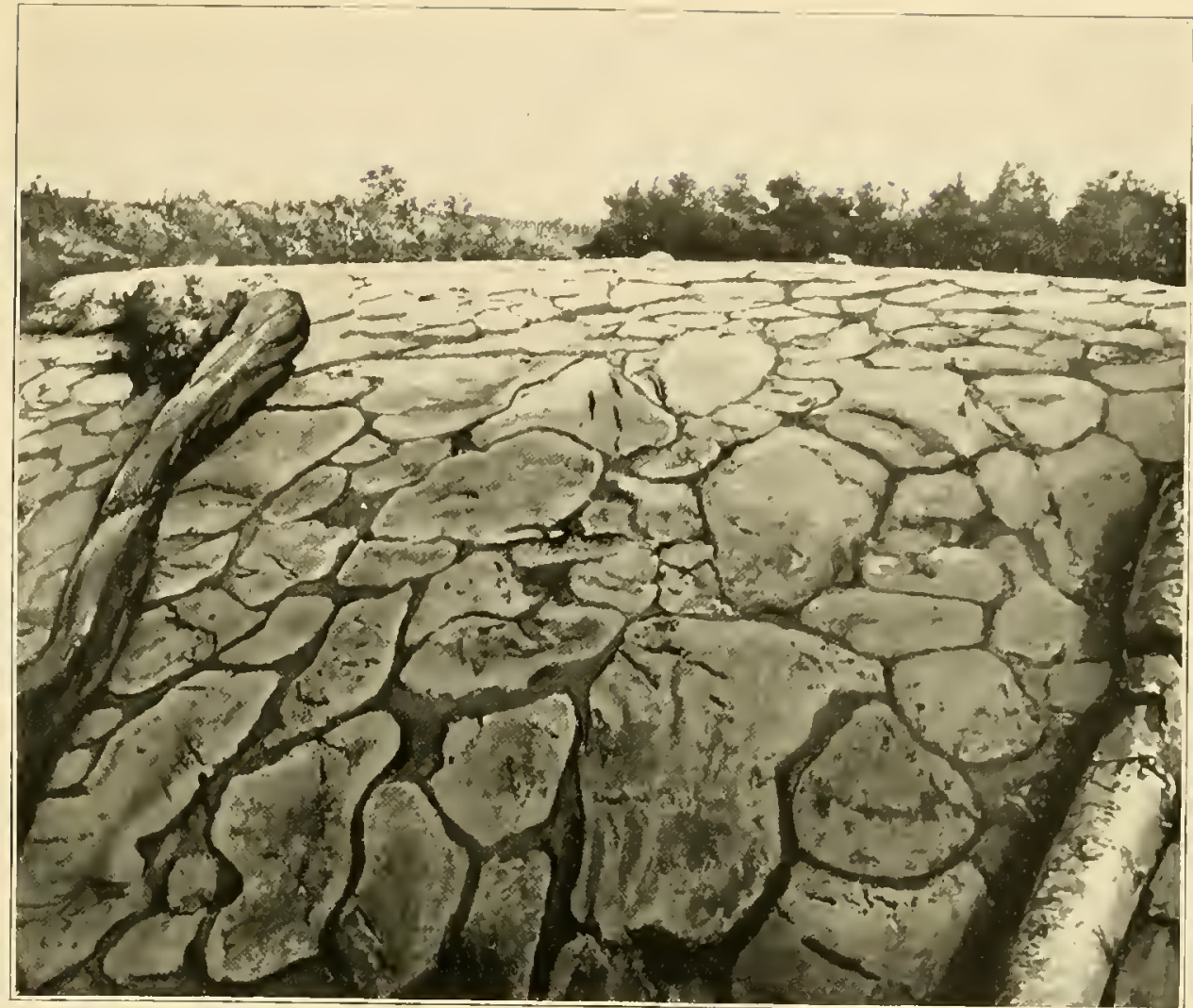

1. ELLIPSOIDAL PARTING IN ELY GREENSTONE. After Clements. See page 120.

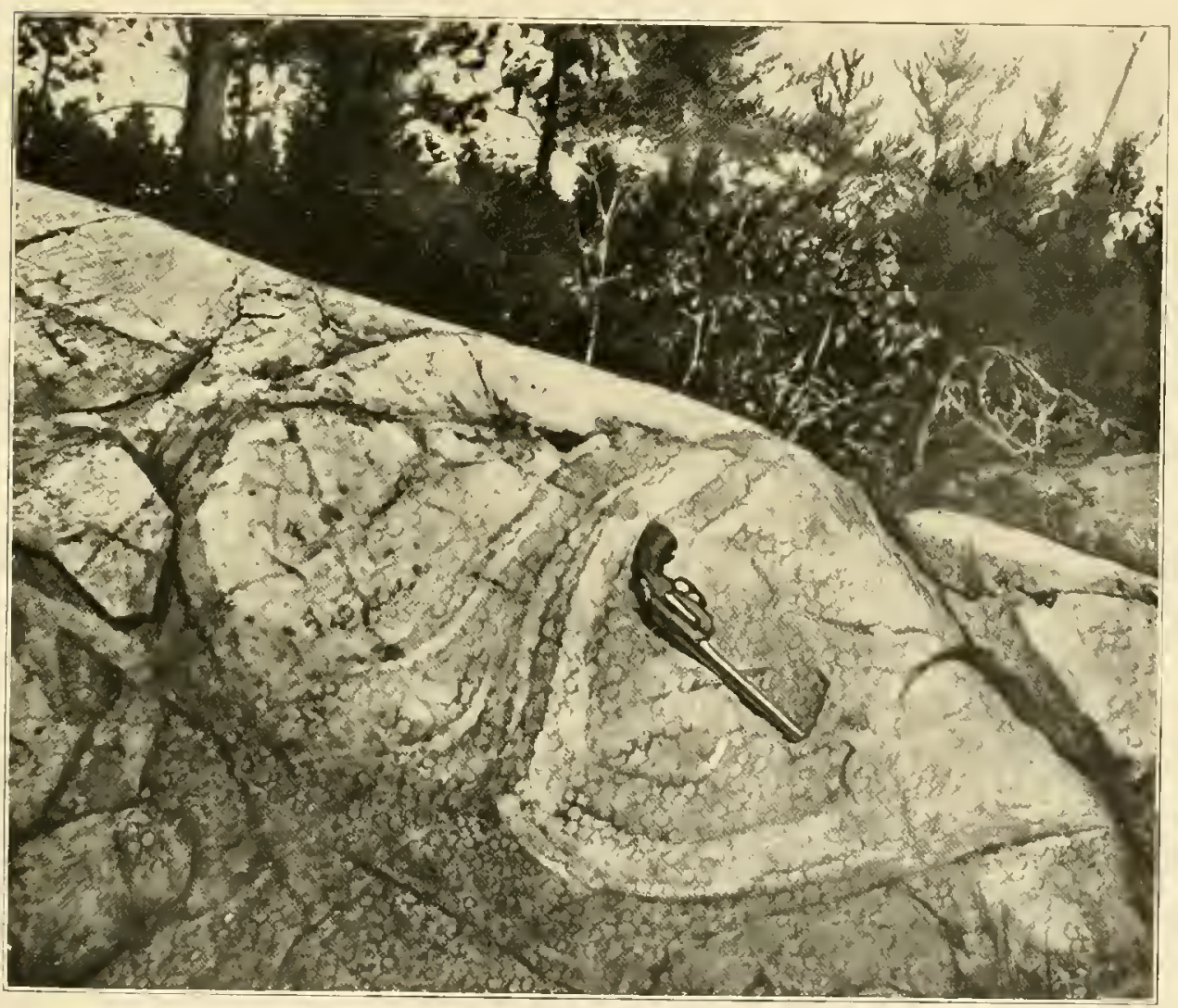

i. ELLIPSOIDALLY PARTED ELY GREENSTONE, SHOWING SPHERULITIC DEVELOPMENT. After Clements. See page 120. 

The feldspar is generally so much decomposed that one can not determine its exact cliaracters. It is presumed to be a labradorite. There is very little quartz, but some was found in micropegmatitic intergrowth with the feldspar and is presumed to be a primary constituent. It may fill irregular interstices between the other minerals as primary quartz representing the last product of the crystallization of the rock.

The secondary constituents are calcite, common green hornblende, actinolite, biotite, chlorite, sericite, epidote, zoisite, sphene, rutile, feldspar, quartz, prite, and hematite. The feldspar has usually altered to a mass of sericite, kaolin (?), felelspar, and quartz. In some places it is completely saussuritized. There were observed occasional irregular but in general rounded serpentinous areas, which strongly suggest aggregates of olivine individuals in which the olivine possesses no definite erystallographic outline. Locally the rock is largely replaced ly calcite. The abundance of secondary calcite is one of the conspicuons features of the formation.

CLASTIC ROCKS.

At a very few localities associated with the greenstones are small masses of tuffaceouslooking rocks which are believed to have been interbedded volcanic clastics. Locally these tuffaceous rocks grade in to fine-grained voleanic ash, and in some places this passes into a wellbanded slaty rock, the material of which was doubtless arranged by water. It is probable that by far the greater amount, if not all, of the material for the slate has been derived from other parts of the Archean Ely greenstone. Parts of the iron-bearing Soudan formation have similar relations to the Ely greenstone. (See pp. 126-128.)

ACIDIC FLOWS.

Interbedled and conformable with the ellipsoilal basalts are frequently to be observed intermediate and acillic flows with surface textures, in many places closely associated with thin layers of the Soudan formation. These acilic flows have been connected with a dike of quartz porphyry similar to the porphyry cutting the Ely ellipsoilal flows, as in secs. 13 and 14, T. 62 N., R. 13 W. (See fig. 13, p. 123.) These flows seem to be later, more acidic phases of extrusion than the Ely basalts and undoubterlly have a close relation to the acidic intrusive rocks diseussed under later headings.

INTRUSIVE ROCKS.

The Ely greenstone is intruded by the great batholithic area of Archean granite of Basswood Lake on the north and by Archean, Huronian, and Keweenawan granites on the south. There is a considerable zone, varying from less than half a mile to $1 \frac{1}{2}$ or even 2 miles in extent, adjacent to these intrusive masses, in which profound metamor] hism has taken place in consequence of the intrusions. The amount of metamorphism is least at a distance from the granite and gradually becomes more intense as the distance lessens.

The first of the changes that are noted in passing from the greenstone towarl the granite area is that the greenstone becomes more schistose and crystalline; also there is a large llevelopment of homblende. Thus the rock Jecomes a homblende schist. With approach to the granite the hornblende schist becomes better and better developerl until it is a coarsely crystalline typical hormblende schist. The schist may be injected parallel to the schistosity, so that there is produced a banded gneiss, a part of the layers of which consist mainly of the modified greenstone in the form of hornblende cchists and the other part of the granite. Both parts are igneous rocks, the more basic parts being dominantly profoundly metamorphosed lava, the more acid parts mainly an intrusive rock. Withm the brealth of a hand specimen there may be a dozen or more alternations of this schist and granite. In many places where the granite can not be distinguished as clear-cut parallel layers in the schist granitic minerals are found along the laminæ, so that the rock has abundant feldspar. There are all transitions from the little-altered greenstone to the homblende schist, and from this kind of rock to rocks in which feldspathic minerals are developed along the lamina, and from this rariety to rocks in which the granite is clearly injected in parallel layers, thus producing a gneiss. 
No better instance is known to us of the production of schists and gneisses the different parts of which arr of diflerent origins and ages. 'The background of the schist or gneiss is an anciont basic or intermerliate lava: another portion is a deep-seated acilic intrusive rock. By combination of dynamic and contact action the profoundly metamorphosed rock las been produced.

A microscopic study shows that the schists and gncisses contain the following constituents in varying proportions: Common green hornblende, actinolite, biotite, muscovite, rhlorite, epilote, calcite, sphene, quartz, fo]lspar, pyrite, and magnetite. The mica is present in very small quantity and is invariably associatel with amplibole.

The more motamorphosed rocks not only contain minute granitic injections lout also are eut by many large and small granite dikes, which may run parallel to the selistose structures or traverse them at any angle.

Also witlin the intrusive rocks are fragments of the Ely greenstone, ranging from small to great. These are usually profoundly metamorphosed and some of them are partly ahsorbed.

The elarater of the contact metamorplism may be particularly well seen on the islands and mainland along the northern part of Tormilion Lake and in the area between Ely and White Jon Lake. The relations illustrated between the granite and the greenstone are identical with those which have been described by Lawson with reference to the Keewatin and Laurentian of the Rainy Lake and Lake of the Woods district.

The Ely greenstone where intruded by the gabbro, at the soutlu sile of the rast end of the district, has been metamorphosed into a spotted hornblendic rock with less schistosity than the rock along the granite contacts.

\section{EXTENSION OF ELY GREENSTONE BEYOND DISTRICT.}

It has already been noted that the Ely greenstone extends to the northeast into IIunters Island. This formation has a very wide extent in that distriet and the Rainy Lake and Iake of the Woods region; in fact, it is the most characteristic roek of the Keewatin of the Lake Superior geologie provinee. It is therefore clear that this volcanic formation is regional rather than local.

\section{SOUDAN FORMATION,}

DISTRIBT'TION.

The chief exposures of the iron-bearing Sondan formation oceur between Tower on the west and a few miles east of Ely on the east, a distance of less than 30 niles. Numerous smaller exposures of the formation are found within the area of the Ely greenstone for 12 or 15 miles farther east, and large exposures are also known to exist in the eastern part of the district, in the vicinity of Emexald Lake. A few of the more important localities in which the formation may be well studied are Tower, Lee, and Soudan hills and Jasper Peak. The Soudan formation is confined to the area of the Ely greenstone and its border. Fren the belts mapped as Soulan formation consist of bands of the iron-bearing formation interbedterl or at least interlaminated with small quantities of clastic roclis and associated with large quantities of the Ely greenstone and later intrusive rocks. From the large belts more than half a mile wide, dominantly composed of the Soudan formation, to rery narrow stringers or patches in the Ely greenstone there are all rariations. Though here and there the large areas are woll exposed, on the whole the formation is relatively soft as eompared with the Ely greenstone, and therefore it usually forms valleys. This is true even of the belt at Ely, which has been so great a producer of irom ore.

Wrestwad and southwestward from lake Vermilion, beyond the limits of the Vernition map (PI. VI), Keewatin, Laurentian, and IIuronian formations have been traced for a considrable distance. An iron-bearing formation, corredaterl with the Somban, forms a considerable belt extending from Tps. 60 and 61 N., R. 22 W., southwestral to T. 55 N., R. 27 IV. It is sparsely exposed and is known principally by its disturbance of the matenetic field. I small amount of exploration has hern clone on this belt. For the most part this iron formation scems to be lean and mupromising. 
DEFORMATION.

The folling of the Soudan formation is of the most complicated charaeter. The major folds extend parallel to the trend of the range. The pressure lias been so great as to give at many places monoclinal clips entirely acruss the formation. For instance, at the section near Tower the dips are almost uniformly to the north, the angles ruming as low as $50^{\circ}$. However, at many places on Tower, Lee, and Souclan hills the thips are nearly vertical, and at one place on Lee IHill, on the south side, they are steep to the south.

The cross folding of the district has been only less severe than the major folding. The pitches of the folls are ordinarily steep, from $50^{\circ}$ to $60^{\circ}$, and at many places are vertical or even orerturned.

Both the longitudinal and the cross folds are composite - that is, folds of the second order are superposed upon the major folds in each direction, and upon these folds are folds of the

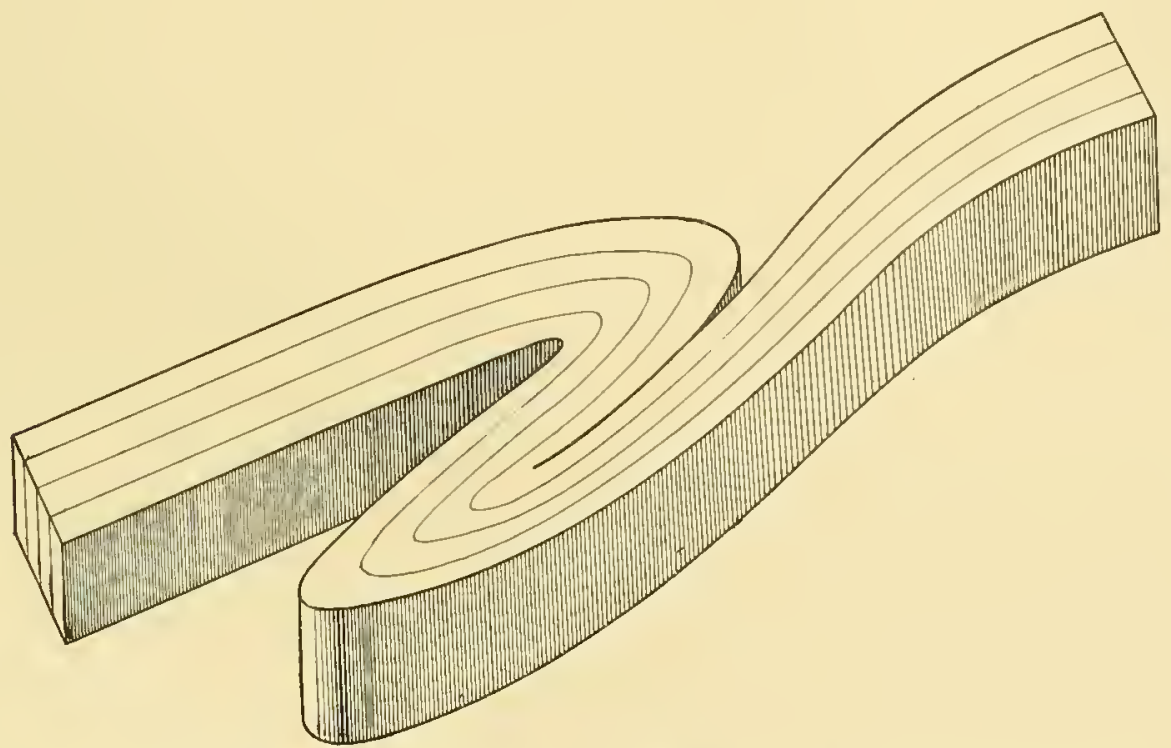

FIGURE 12.-Diagram to illustrate folding of "drag" type, common in the Vermilion and other ranges. Note the Iacts that folding tends to multiply the thickness by 3 and that folding of adjacent beds may not be markel.

third order, and so on down to minute plications. The pressure has been so great as to produce all varieties of minor folds, including isoclinal and fan-shaped. Moreover, these varieties of folds may be almost equally well seen in a ground plan or in a rertical eross section. They are benutifully shown at various places about Tower and Ely, but perhaps the most extraordinary complex folding to be seen is that at the west end of the large island in the east part of Emerald Lake. A common type of fold is a drag fold (illustrated in fig. 12), by which the formation

$\mathrm{N}$

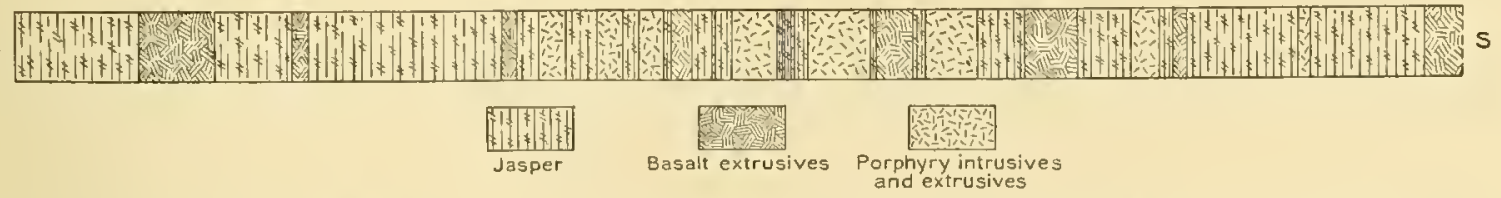

FIgURE 13.-Section across jasper belt in secs. 13 and 14, T. 62 N., R. 13 W., Vermilion iron range, Minnesota, Scale, 1 incln=abont 85 feet.

becomes locally buckled along an axis lying in any direction in the plane of bedding. This type of folding, while leaving great local complexity, does not destroy the general attitude or trend of the bed. It is frequently possible, where these folds are present, to work out the general trend of the formation and its top and bottom-as, for instance, in secs. 13 and 14, T. 62 X., R. 13 W., Minnesota (see fig. 13) - and for other areas it will be possible by close detailed surveys to work out the stratigraphy of the Keewatin series. 
The folding, notwithstanding the extrandinarily britte character of the rock, was accomplished without major fracture. Frecuenty a soliel belt of jasper may be seen bent back iipon itself within its own ratius with no sirn of lineture. The cleformation, therefore, was in the zome of rock flowage, and no better instance is known to us of this kind of earth movement. Though the folding is so complex as to give isoclinal or fan-shaped folds, ordinarily the turns are round rather than acute, as they commonly are in the llenomine district.

Folding without brecciation is the rule, but in some places the soutan formation has been brecciuted in an extruordinary manner. It is broken through and through by cracks and crevices, along which ninor faulting has taken place. In some places the grimling of the fractured fragments orer one another has been so marked as to give them a well-rombleut character, and such a rock resembles a conglomerate, though it is really autochastic. This locul brecciation of the Soudan formation has been favorable to the deposition of the ores, and it may be suggested that the general absenee of the breceiation is the partial explanation, at least, of the very irregular distribution and searcity of the ore bodies.

The Vermilion district affords excellent illustrations of complex folds, or folding in two directions at right angles, and the formation which best exhibits this folding is the Soudan. 'This is because the banding of the formation is very marked, so that the position of bedding is readily determined, and also because for the most part the rock does not take on schistosity. Schistose structure is absent partly because the minerals of the rocks are not adapted to a parallel arrangement. Furthermore, the Soudan rocks are frequently found in eontact with the Ely greenstone, and the contacts give the pitches of the cross folds.

The remarkable complex folding partly explains the distribution of the Soudan formation with reference to the Ely greenstone. As upon the major folds are superposed secondary and tertiary folds, numerous patches of the jasper are naturally found in the greenstone. Mloreover, because of the cross folding these patches may be very narrow at one place, widen out within a very short distance so as to make a thick formation, and again become narow. When the extraordinary complexity of this folling is understood it is only necessary to premise an erosion extending to different depths in the Soudan formation before the lower Huronian was deposited in order to see how in the greenstone there may be patches of jasper ranging from a few feet in width and length to the dimensions of great continuous formation about Tower and Ely. But folding is not the only cause of the present retations, as is shown on page 126.

LITHOLOGY

The iron-bearing Soudan formation comprises two elnsses of rocks. To all the varieties of the first the miners apply the name "jasper," although only a portion of it falls strictly under this designation. This is the dominant rariety of the rock. Locally interstratificd with the "jasper" or under it is an argillaceous variety, which is mainly slaty but in some places is conglomeratic.

The "jaspery" phase of the Soudan formation consists of interlaminated bands of fincly crystalline quartz, iron oxides, and various mixtures of the two. With these preponderating minerals are various subordinate constituents, among which amphibole is the most abumlant, including actinolite, cummingtonite, and grünerite. Pyrite is also present in many places. The' alternate bands of material of different color, combined with the complieated fracturing and hreeciation of the formation, make it a striking rock which always attracts the attention of the traveler, even if he is not ancenstomed to closely noticingerecks. The bands of minterial of dillerent color vary from a fraction of an inch to several inches across. The quart rose bands have various colors-nearly pure white, gray, red of various lues, including brilliant red, and black. The difference in the color is chiclly eaused by the contaned iron. Hematite, if in sulliciently fine particles, gives the brilliant red colors: marnetite and hematite in larger particles give the grays and lolacks.

Between the bands dominanty quartzose are usualty bambs mainly composed of iron oxide This iron oxide may be cither hematite or magnetite or various intermixtures of the two. Occasionally also some limonite is present. 
The chief varieties of the "jasper" are (1) the cherty variety, (2) the black-banded variety, (3) the red-banderl varicty, and (4) the white-banded variety. With these are subordinate masses of (5) the carbonated rariety and (i) the ore bodies.

1. The cherty variety is characterized by the presence of a predominating amount of gray ehert, the iron oxide heing subordinate. The rock is there a slightly ferruginous wellbanded ehert.

2. The black-banded form of the Soudan formation has dark-gray or black chert bands interlaminated with black iron-oxide bands. The iron oxide is commonly in large part magnetite. Usually associated with this magnetite are some of the amphibote minerals alrearly mentioned.

3. In the red-banded kind the quartzose layers are stained with innumerable minute flakes of hematite, whicl give the rock a red color, in many places a brilliant red. The iron oxide between the red bands is ordinarily hematite, usually specular hematite. With this hematite may be some magnetite. This red-banded variety is a well-known jasper of the Lake Superior region, to which Wadsworth has applied the name jaspilite.

4. In the white-banded kind the quartzose bands contain comparatively litte iron oxide. The iron-oxide bands between the layers of chert are generally hematite, but this hematite differs in many places from that of the jaspilite bands in that it is of the red or brown variety. With it also, in many places, there is a certain amount of limonite.

5. The banded carlonate rariety, while subordinate in quantity, is important in reference to the genesis of the formation. It is a gray-banded roek, the light-colored layers of which consist largely of siderite. Between this sideritie rock and the ordinary forms there are all stages of gradation.

6. The positions of the iron-ore bodies will be fully diseussed later. In the iron ores the silica is rery subordinate, the place of the quartzose bands being taken by iron oxide. The iron ore is dominantly hematite.

At the contact of the Soudan formation and Ely greenstone the cherty rariety of rock is very common indeed. In many places the rock at this horizon is much breceiated and commonly has a conglomeratic appearance, which, howeres; is believed to be due to movement rather than to deposition as a conglomerate. Ordinarily this cherty variety of the formation is not more than a few feet thick. Resting upon the cherty zone in many places is the blackbanded kind. Ordinarily at the top of the formation is the red-banded roek, jasper, or the white-banded kind.

The succession given above prevails in many places where the formation is now thick. Where the formation is thin the red and white banded rocks extend from the top to the bottom, and as at many places the formation is rather thin it may be said that the entire Soudan formation for much of tlat district consists of these kinds of rocks, the elerty variety and the blackbanded variety not appearing.

The sideritic rock is notably local in its oceurrence. It is generally found close to the overlying upper Huronian rocks.

The slaty phase of the Soudan formation diflers from the ordinary phases in having between the silica and iron-oxide hands so large an amount of argillaceous material as to make laminx of slate. In some places a slaty cleavage has developed in the clayey layers but does not pass through the iron-oxide bands, and this may be so even where the bands of state are not more than one-fourth inch across. Locally the slate may be in a belt several feet thick without interstratified jaspery material. In some places this slate is graphitic. At a few places at the bottom of the Soudan formation the slate passes down into a fine-grained eonglomerate or into a tuff. A microseopic examination of the argillaceous varieties of the slates shows these sediments to be made up of chlorite, actinolite, epidote, sericite, sphene, quartz, carbonaceous material (graphite), and some iron oxides, in various proportions. The graphitic slates consist. essentially of graphite and quartz in exceedingly fine grains and in some specimens in rery small quantity. 
The conglomeratic phases of the formation, when studied under the mirmseope, are found to be substantially identical with the tufl's of the Ely greenstone. They now consist largely of actinolite, chlorite, epidote, and quartz.

ORIGIN.

From the foregoing lacts it is alear thit the Soudan is a sedimentary formation, mainly of nonclastic character. This would perhaps be evident from the well-bedided character of the formation and especially from the iron cirrbonate. Also, as alrearly indicatorl lyy the description of the diflerent rock varicties, certain phases of the formation have allerillaceous bands between the iron-oxide bands, which are not uneommonly graphitic. Finally, it contains local conglomerates.

There is reason for believing that many varieties of rock in the Soudan formation are derived from siliceous iron-bearing carbonate, precisely as similar rocks are derived from this material in other districts of the Lake Superior region. The analogy between the Soudan formation and the Negaunee formation of the Marquete district is especially close. Substantially every variety of rock which is found in one distriet may be found in the other. I rariety may be somewhat more prevalent, however, in one district than in the other; for instance, the amphibole minerals are less abundant in the Soudan formation than in the Negaunee formation. In the absence of local specific evidence of the original chanaeter of the iron-bearing rocks in the Vermilion district it is probably not safe to put too much stress on the similarities with other districts where the original character of the rock is certainly known. One must admit the distinct possibility that the iron-bearing sedinents may have been originally deposited sul-stantially as banded chert and iron oxide of the jasper type.

\section{RELATIONS OF ELY GREENSTONE AND SOUDAN FORMATION.}

The main mass of the Soudan formation seems to be above the Ely greenstone. In certain places it is known to be in pitching troughs formed by folding, the greenstone forming the walls and bottom, as, for instance, at Ely and Soudan.

Some of the jasper belts of the Termilion distriet are clearly interbedded with successive basalt extrusives. Such beels, but a few feet thick, may be traced for hundreels of yards with uniform widths, even contacts, and lack of folding. Then the adjacent igneous roeks are examined closely it is found that the sedimentary bands lie parallel to the tops and bottonts of separate flows, as marked by amygdaloidal and other surface textures, without intervening fragmental sediments. This is well illustrated in secs. 13 and 14, T. 62 N., R. 13 W., Mlinnesota. (Sce fig. 13, p. 123.)

Many of the jasper bands are associated even more closely with intrusive and extrusive porphyries than with the greenstones. (See p. 12s.) These porphyries are found to be closely related to the extrusive basalts but on the whole to follow them and to be associated with their later phases of extrusion. This association of the iron with the later acidic phase of extrusion is also seen in the Woman River distriet of Ontario. Its significance is discussed on page 513.

The most common contact between the Ely greenstone and the Soudan formation is perfectly sharp-indect, linifelike in its sharpness. The rocks are as sharply separated from each other as il the Soudin formation were intersected by the greenstone by intrusion, and doubtless this is, at least in a few places, the true signilicince of the relations. Contacts of the kind mentioned may be seen at many places in both the west and the east end of the district. They are especially elear and numerous in Hunters Island and at Jasper Lake, Birch Lake, and Emerald Lake. At each of these lakes, almost at every large outerop of Soudinn material, somewhere along the base of the formation the contact may be found.

The kind of contalet next most common to that just described is that in which a brecciated rock occurs between the iron-learing Sondan formation and the Ely greenstone. This breecia ordinarily is not more than a few feet wide. In some plares it involves only the greenstone, elsewhere the Soudan formation only, in still other places both. Thus a conglomerate-like 
rock may show fragments and matrix mainly of greenstone or almost wholly of Soudan formation, or the two intermingled. In the last ease the greenstone is more likely to be the matrix and the Soudan rock to constitute the fragments. A breceia of the greenstone cliss is well seen on an island near the west end of Otter Track Lake. The hrecciated Soudan formation is well exhibiterl in belts of Soudan rock north of Robinson Lake, in see. 7, T. 62 N., R. 13 W. A breccia composed of greenstone and Sondan material is seen at viurious places on Lee Ifill. Here is a green schist matrix containing numerous fragments ol red jasper, each exhibiting its banding, which lies in diverse directions. Some of these fragments are well rounded; others are subangular; many others have angular rhomboidal forms, such as are produced by shearing stresses. Ilowerer, these fragments are not more, angular than those in a basal conglomerate at many localities.

The question may be asked whether the breccias were eonglomerates before they were breccias. At present their dominant structure is cloubtless that of a dynamie breceia, but it is also possible that some of then at least were originally conglomerates and were subsequently brecciated. This question, early asked, is still unanswered. Probably certain of the rocks referred to are wholly breccias, being produced by readjustment along the contact of the two formations during orogenic morements. A sharp contact of the first class might, by close folding and arjustment between the formations, produce a contact of the second class by breceiation and rounding of the fragments, thus forming a pseudoconglomerate.

At contacts of a third kind is a rock which seems to lie a metamorphosed mechanical sediment. Is a rule, this rock varies from a few inches to several fect in thickness. It consists of alternating layers of green schist or slate and light-colored, strongly siliceous, graywacke-like material. These alternations of schist and graywake naturally give a remarkably sedimentary appearance; in fact, it seems as if the banding could have been produced in no other way. The two localities which best exhibit these materials are a neck of land between two small lakes about a mile north of Iloose Lake and one place on Lee Hill. At the first locality alternating bands of slate and graywacke rest against perfectly typical ellipsoidal greenstone, and interstratified with these slates and graywackes are narrow bands of jasper. These alternations are orertain by a broader belt of jasper. The probable interpretation of the phenomena seen here is that a few leet of mechanical sediments were depositerl upon the Ely greenstone before the deposition of the nonclastic material of the Soudan formation. Horeover, it seems that there were alternations hetween the condition of mechanical deposition and the peculiar condition of chemical or organic deposition of the Soudan formation.

The relations at Lee Ifill are substantially the same, except that at this place the folding is so close that a cross clearage ents through the finer-grained sediments, and on account of this close folding and the secondary deavage the phenomenon is more difficult to certainly interpret. However, the slate and graywacke appear to plunge under the jasper of the Soudan formation, and the explanation is with little doubt the same as for the contact north of Moose Lake.

A contact of a fourth kind is marked by a thin belt of greenstone conglomerate. The best localities at which this is seen are north of Robinson Lake and at the pits of the Lee mine. At the first locality, at the west end ol the belt of Soudan formation, the ellipsoidal greenstone is overlain by a layer a few feet thick of greenstone conglomerate, which passes up into graywacke. The pebbles of this greenstone conglomerate are flattened, and it could not be said positively that the rock is not a tufl rather than a conglomerate.

Finally, the Soudan and lily formations may be separated by a thin layer of graphitic black slate, well shown on the southwest side of Soudan Hill.

From the fact that the greater masses of the Ely greenstone were deposited before the larger masses of the Soudan formation it is believed that the great roleanic period of the Ely greenstone had practically ceased helore Soudan time. However, the cxtremely intricate. relations and apparent interstratifieation of the minor masses of the Soudan formation with the Ely greenstone and the fact that both the Ely and Soudan formations locally contain interstratified fragmental material lead to the belief that volcanic activity had not entirely 
died out in all parts of the distriet at the time of the deposition of the arliest soudan rocks. In conserpuene there are intorlaminations of rocks essentially belonging to the Ely with rocks cessentially belonging to the Soudan.

What were the physical conditions which permitied the deposition of the nommechanical Soudan formation upon the Ely greenstone with so insignificant an amount of intervening mechanical sediment and erosion surfaces? If the Ely greenstone was subuerial, it is diflicult to understand how this material andel have got bolow the water without the deposition of an greater thickness of mechanical sediments than exists in the Vermilion distriet. We know that such lavis are very rough in their surface expression and vary greatly in thickness, and therefore in altitude. It is impossible to believe that the sea conld advance orer such an area without the production somewhere of mechanical sediments of considerable thickness. The answer to this question seems to be that the eruptions of the Ely grecnstone were submarine. The ellipsoidal textures are regarded as evidence of submarine flows, for reasons given on pages 510-512. The lack of erosion surfaces in the flows and the absence of fragmental material at the base of the formation itself are evidence of such an origin. If these lavas issuing from the interior of the earth were spreal out below the surface of the water, after the period of rolcanism hat ceased and conditions became quiescent nommechanical sediments of the iron-bearing formation might at once be deposited, provided the conditions were proper. The conditions of serlimentation are further discussed in the chapter on the origin of the iron ores.

\section{LAURENTIAN SERIES.}

PORPHYRY.

Intrusire into the Ely greenstone and Seudan furmation are various Archean felsites and porphyries in dikes and bosses. These are exceptionally well seen in the Vermilion Lake area, especially at Stuntz Bay. As alrealy noted, these intrusives ma be in part connected with acilie flows interbedded with some of the later flows of basalt in the Ely greenstone. (Sce p. 126.)

Petrographically the porphyry comprises rlyolite porphyry, feklspathic porphyry, microgranite, granite, microgranite porphyry, and granite porphyry. In places these rocks hare been metamorphosed into sericite schists and chlorite schists. There is no doubt that these rocks are okler than the lower Iluronian, because they yield fragments to the Ogishke conglomerate, but at various places their relations to the conglomerate are extremely intricate. (See p. 131.) The folding has formed breccias and pseudoconglomerates from the felsites and porphyries, which when very much mished have been sometimes confused with the true Ogishke conglomerate.

GRANITE OF BASSWOOD LAKE.

The granite of Basswood Lake extends as a great continuous formation north of the Ely greenstone and the Huronian rocks from the western to the eastern end of the district, where it is locally known as the "Saganaga Lake grunite." Lakes are lather numerous in this great granitic area, but they are not so numerous nor so regularly ordered as those in the Ely and Soudan formations. On the whole the granite area is one of highlands and divides between the waters running north and south.

Petrographically the granite varies from homblende and mica granite to syernite. Structurally it varies from massire granite through schistose granite to gneiss. Texturally it includes granites and granite porphyries. The mineral constituents are green hornblende, biotite. orthoclase, quartz, and plagionlase, with accessory spbene, zircon, and iron oxide. In many places these minerals lawe been rery nuch altered, so that their places are taken largely ly secondary minerals, of which chlorite is the most prominent and cpidote, seriefite, and secondiry feldspar come next. There is a variation in the mineral character, hornblende being virtually absent in some specimens and abundant in oflers. No specimens were fouml in which quartz was not present. but the amount is small in some of them. 
The granite is intrusive into the Ely and Soudan formations. The field relations are most complex but are practically the same in all parts of the district--that is, the phenomena to be seen in passing from the other Archean formations to the granite are substantially the same whether the traverse be made at Vermilion Lake, at Burntside Lake, at Basswrod Lake, or at any other point.

In approach to the granite from the Ely greenstone side little stringers of quartz first appear in the greenstone, then sparse veins of feldspar, then clean-cut dikes of granite, usually of small size. With closer approach these increase in number and size until they constitute a plexus of granite likes in the greenstone. Still farther north the greenstone and granite may be found in such confused and intricate relations as to make it diffieult to say which is the more abundant. Ilere great knobs of granite as well as dikes oceur in the greenstone masses. In the granite knobs are included fragments of the greenstone, large and small, in many plaees in great numbers. Farther north the granite becomes dominant and finally altogether excludes continuous masses of greenstone. If any greenstone is found it will be only in the form of included masses. In brief, the relations are like those, so clearly described by Lawson, between the batholiths of granite and the contiguous greenstones of Rainy Lake and Lake of the Woods.

The granite has been spoken of as if its intrusion were a single episode. This is not supposed to be true. On the contrary, the relations of the lifferent granites to one another and to the greenstones are very intrieate, lence it is thought that various intrusions were separated by foug intervals of time, that many of the intrusions were of themselves complex and long continued, and that, in fact, this igneous period was a complex and long-continued one.

\section{ALGONIIAN STSTEM.}

HURONIAN SERIES.

LOWER-MIDDLE IIURONIAN.

GENERAL STATEMENT.

The inferior serjes of Inronian rocks occupies the general position of the lower and miultle IIuronian of the south shore. It will be called lower-middle Huronian, with the understanding that it may inchde either or both lower IIuronian and mirhle IIuronian.

The lower-middlle IIuronian consists of four divisions-(1) a lowe clivision, predominantly conglomeratic, which is most typically developed near Ogishke Huncie Lake and is known as the Ogishke conglomerate: (2) a division represented only in the eastem portion of the district, consisting of iron-bearing rocks and known as the Agawa formation; (3) a division which is predominantly a state formation and which is called the Kinife Lake slate because it is well developed and splendilly exposed on and near Knife Lake: and (4) intrusive rocks.

\section{OGISHKE CONGLOMERATE.}

DISTRIBLTION.

The Ogishke conglomerate extends from the western end of the listrict to the east end, though it varies greatly in thickness. In places it is a great formation; in other places it is nearly absent or is so thin that it can not be represented on the maps without a gross exaggeration.

The localities at which the conglomerate can be best studied, beginning at the west, are (1) southeastern Vermilion Lake and especially Stuntz Bay and vicinity; (2) Moose, Snowbank, and Disappointment lakes and ricinity; (3) Ogishke Lake and the extensions of the belt there to the southeast, nor theast, and west.

IEFORMATION.

The Ogishke conglomerate is infolded in an extremely intricate manner with the underlying formations. This infolding is almost if not quite as complex as the infolding of the Soudan formation and the Ely greenstone already described. Owing to isoclinal folding and cross folking with steep pitches, a rock surface cutting diagonally across the plane of contact shows 
the most extraorlinarily irregular distrilution of the Ogishae and the underlying formations. Because of this it was supposed by a number of the eally geologists that the Ely greenstone and the porplyyry of Stmint Bay were intrusive into the Ogishke conglonerate.

LITHOLOGY.

In general all the belts of conglomerates are coarser below and become finer toward higher horizons. 'This statement is, however, only true as an average. There are places where the conglomerate is somewhat fine at the bottom, is courser above for a certain thickness, and thenee beeomes finer upwarl.

The character of the Ogishke conglomerate depends largely on the nature of the underlying formations. These formations, as already noted, are the Ely greenstone, the Laurentian granite of Basswoorl Lake, the Soudan formalion, and the Laurentian porphyry of Stuntz Bay. Where the conglomerate rests on one of these formations the material composing it is mainly derived from that formation. There are four special varieties of the Ogishlie conglomerate-(1) greenstone conglomerate, (2) granite conglomerate, (3) porphyry englomerate, (4) (hert and jasper conglomerate. The common kind of Ogishke conglomerate (5) represents combinations of the special pliases.

Greenstone conglomerate.-The Ogishke is a greenstone conglomerate at those localities where the conglomerate rests upon the Ely greenstone and other lower formations are not adjacent. One of the localities which exhibit this greenstone conglomerate in its typical character is the south side of Ogislake Lake and, peripheral to the Ely greenstone massifs, to the east on Frog Rock Lake. The rock is also found in equally good development on Ilunters Island, at the southwest of Lake Saganaga.

At these localities the greenstone conglomerate consists for the most part of rery well rounded fragments of the Ely greenstone set in a matrix derived from the same source. These fragments are orchinarily of a size to make pebble conglomerates, but at some places many of them are so large as to constitute bowlder conglomerates. Between the howlders and pebbles are smaller fragments of the same material, and between these is a finer matrix derived from the same source. In most places upon the weathered surface the conglomerate character of this rock is evident, but on a freshly broken surface the matrix and pebbles are so similar that the rock seems to be a continuous mass of greenstone. The conglomerate character is especially diflicult to discover in the unbroken forests, where the rocks are covered with moss and other vegetation. The débris, being derived from the Ely greenstone, consists of all the raricties of rocks shown by that formation. There are, accordingly, fragments of dense, massive greenstone, of amygdaloidal greenstone, of various kinds of ellipsoidal greenstone, etc. These rocks grade locally into rocks that may be tulls. In certain places the conglomerate is discriminated from the tuff only by finding that the rock oecupies a definite stratigraplic zone at the base of the lower Huronian sediments. Localiy discrimination is still impossible.

Granite conglomerate. - The granite conglomerate occurs along the west border of Lake Saganaga. At the west side of the south arm of Cache Bay is a great bowler conglomerate the fragments of which are directly derived from the granite. The matrix also came almost wholly from this source. The exact contact of the conglomerate and grinite mir he sech. Tha bowlders and pebbles of the granite conglomerate are well rounded, and in every respect this conglomerate brar's the same redations to the granite that the greenstone conglomerate does to the Ely greenstone.

The granite conglomerute is : issociated with a peculiar variety of rock, which may be called recomposed granite. It appear's that when the Ogishke formation was laid down the granite only locally yielded course débris. For the most part it yiclded the separate individual mincrals of the coarse granite - that is, feldspar, cuartz, etc. As a result a clastic formation was laid down upon the granite, the particles of which were the individual minerals of the granite. Furthermore, these particles were but litte waterworn. The result is that when they were recenented 
a rock was produced which closely rescmbles the granite. This resemblance is, indeed, so close that the roek was first mistaken by a number of geologists for the granite.

This rock is exposed along the west side of Cache Bay, at Swamp lake, at the west side of West Seagull Lake, and at intervening points. For much of this distance this peculiar formation has a breadth of nearly half a mile.

Porphyry conglomerate. - The porphyry conglomerate is confined mainly to the area about Stuntz Bay, the débris being derived from the Laurentian porphyry. In thre past it has been known as the "Stuntz" conglomerate. In places there is a coarse bowlder conglomerate, in other places a fine conglomerate, and in still other places a graywacke composed of the individual minerals of the porphyry, so that the rock closely resembles the originat porphrry. Furthernore, so similar are the bowlders and the matrix that the conglomerate itself has been confused with the breccinted porphyry.

Chert and jasper conglomerate.-The chert and jasper conglomerate is found where the underlying formation is the Soudan. This conglomerate is, however, not anywhere known to be solely composed of the Soudan material. In this respect this variety of rock differs from the varieties already described. Locally, however, the conglomernte is predominantly composed of material derived from the iron-bearing formation. This variety of rock may be seen on Lee Hill, just north of Tower, on the Burnt Forties southeast of Vermilion Lake, and at other localities.

Common Ogishke rock.-The varieties of the Ogishke conglomerate heretofore described, each consisting largely of material from a single source, are, on the whole, rather exceptional, though the greenstone conglomerate and the porphyry conglomerate oceupy considerable areas. It is natural to suppose that the Ogishke would have matcrial derived from more than one of the previously existing formations, and ordinarily it has. 'Thus the normal Ogishke conglomerate consists of intermixtures in various proportions of the materials derived from the Ely and Soudan formations, the granite of Basswood Lake, and the Laurentian porphyry, or two or more of them. Ilence there is every gradation between the average form of the Ogishke conglomerate and the special forms which have been described. Within the Ogishke conglomerate, in addition to the common fragments already enumerated, there are occasional unquestionable shate fragments. These are seen at various places, but are especially abundant south of Moose Lake. It is believed that the source of the fragments of this kind is the slate and graywacke of the Ely and Soudan formations.

METAMORPHISM

The Ogishke conglomerate varies greatly in its metamorphism. In general the processes of the change have been mainly those of metasomatism and cementation, but locally the conglomerate is recrystallized and schistose. These phoses are especially likely to be adjacent to the massive granite, greenstone, or other rock against which they rest. Where the process has gone to an extreme it is difficult to place the exact dividing line between the original and recomposed formations. The difficulty is particularly likely to occur in reference to the greenstone conglomerate and the Ely greenstone.

The extreme pliase of the metamorphism of the Ogishke conglomernte results from the intrusion of igneous rocks, and especially the IJuronian Snowbank granite and the Keweenawan Duluth gabbro. Adjacent to these intrusives the conglomerate is a conglomernte schist or gneiss, the matrix of which is usually miea schist where the IIuronim is of an acidic kind or amphibole schist where it is of a basic kind.

The conglomerate schist adjacent to the gabbro may be found from points east of liay Lake to Lake Gabimichigami. The conglomerate schist near Snowbank Lake and Disappointment Lake has suffered the metamorphosing effect of the Snowbank granite and the Duluth gabbro. The changes in the eonglomerate are analogous to those which have taken place in the Knife Lake slate, which is in a similar position with reference to the granite. (See pp. 133-135.) 
IELATIONS TO ATJACENT TORMATIONS.

The Ogishke conglonerate, as the foregoing description plainly shows, is unconformable with the underlying formations. It may safely be inferred that this uneonformity is one of great magnitude. The evidence is of two kinds-the character of the detritus and the structural relations.

The detritus includes every rariety of each of the formations of the Archan, including the many phases of the Ely and Sondan formations and the granite of Basswood lake. In order to produce these many varieties, the Arehean went through a long and complex history of folding, intrusions, metamorphism, and erosion.

As to the structural relations, the Ogishke conglomerate is here in contact with one of the underlying formations, there with another. It is therefore clear that after the Archean complex was proluced it underwent deep erosion before the dejosition of the Ogishke conglomerate, for some of the formations constituting the Archenn were produced at great depth.

Lpwarl the Ogishke conglomerate grades into finer and finer material and passes conformably into the Agawa formation or the Kinife Lake slate.

THICKNESS.

The thickness of the Ogishke conglomerate varies greatly. It is nowhere possible to make accurate measurements, owing to the general absence of beding and to the cluse folding, but it is certain that the formation has a considerable thickness, certainly several hundred feet, and perhaps in some places more than 1,000 , possibly 2,000. From this maximum thickness the formation varies to a thickness of only a few feet or less, and is absent in places.

\section{AGAWA FORMATION.}

In the eastern part of the district, alove the Ogishke conglomerate, or, where that formation is absent, beneath the Knife Lake slate, is an iron-bearing formation called the Igawa. On the American side of the international boundary this formation is so thin that it can not be regarded as continuous. On the Canadian sile of the boundary, especially at That Mans, Agawa, This Nans, and Other Mans lakes, the formation ranges up to 50 feet in thickness and las all the characteristic rocks of the other iron-bearing formations of the Lake Superior region, including ferruginous carbonate, ferruginous slate, ferruginous chert, jasper, and iron oxides. Interlaminated with the ferruginous varieties are belts of slate. Thus the iron-bearing formation is loth small and impure. There is every reason to suppose that the origin of this ironbearing formation is similar to that of the other Lake Superior iron-bearing formations.

The Agawa formation, so fur as at present known, has no economic importance, but it may have a geologic significance, considering that it is in the lower-middle Huronian. The only iron formation at this horizon in other parts of the Lake Superior region is the Negaunce, and so correlation would be suggester with that formation. The bearing of this suggestion on the position of the group to which the Agawa belongs is pointed out elsewhere (pp. 603-604).

\section{RNIFE LAKE SLATE.}

General statement.

The Knife Lake slate was so named because it occurs in its trpical character at Kinife Lake. Nearly all the long arms of that lake lie withm the slates, and by far the greater number of the many islands and headlands are composed of them.

The slates are found in two great areas, one in the western part of the district and the other in the central and eastern parts. The western area extends from the east end of Vermilion Lalie westward to parts where the rocks are covered by the Pleistocene. It occupies much of the shore and many of the islands of Vermilion Lake. The eastem area hecins west of Long Lake and extends eastward, beeming gradually broader, and in the eastem part of the district is the most extensive formation there found. 
The Krnife Lake slate comprises the following main varieties:

1. Argillaceous slates.

2. Cherty slates.

3. Graywacke slates and grarwackes.

4. Conglomerates.

5. Tuffaceous slates.

6. Micaceous (and, less common'y, amphibolitic) schists and gneisses.

7. Gray granular rocks.

There are also all graclations between these varieties. The matcrials of different coarseness are in many places fincly intellaminated, so that it is easy to ascertain strikes and clips.

The argillaceous slates vary in color from gray to black. They are usuaily very dense, break with a smooth, conchoidal fracture, and have a perfect cleavage, which in a general way commonly follows the trend of the district but whose direction varies much locally, depending on the surrounding rocks, the folling, and other factors.

The cherty slates differ from the argillaceous slates in that they contain an unusual amount of finely crystalline quartz. In many places this quirtz is the dominant constituent. Between the beds of rery siliceous slate in many places there are also pure bands of ehert. These cherty bands in most places appear to he seconciary segregations. In many places the amount of the finely crystalline quartz in the separate cherty bands and in the main mass of the slate is so great as to sugrest that the deposits of fine mud harl mingled with it silica of organic or chemical orimin. Conchoidal fractures are especially characteristic of the cherty shates.

The argillaceous slates and cherty slates pass into varieties which may be called graywacke slate and graywacke. These differ but little from the finer-grained slates except that cleavage is less likely to be developed in them. Cleavige is usually present in the graywacke slates but not in the graywackes.

Not uncommonly the graywackes pass into conglomerates. The fragments found in the conglomerate comprise all the varieties of material found in the Ogishke conglomerate. These, it may be recalled, are the many phases of material derivet from the Archean. Indeed, there is no essential difference between these conglomerate bands and the Ogishke conglomerate, except that the conglomerate bands of the Knife Lake slate are ordinarily fine gramed and are subordimate in quantity to the slates.

During Knife Lake time there was volcanic action, and close to the rolcanoes, as at Lake Kekekabic, ash and larger fragments produced by explosive volcanic action are mingled with the other materials of the Knife Lake slate. These volcanie materials constitute the tuffaceous slates. Between the tuffs and the conglomerates and slates there are all gradation varieties. Indeed, microscopic cxaminations show that the ashy products of the volcanoes were widely distributed and are important constituents of the varieties of the formation already described-the argillaceous and cherty slates and graywackes.

The mica slates, mica schists, and mica gneisses are confuned to areas arljacent to subscquent intrusive rocks. The most important areas are south of Tower, along Kawishiwi River, adjacent to Snowbank, Disappointment, and Kekekabic lakes, and adjacent to the Keweenawan gabbro.

At Snowbank Lake and near it the granite has been intruded into the slates in a most complex fashion, and here next to the granite the Kinife Lake slate is represented by mica schists. Between the mica schists and the ordinary slates there are gradations tirough mica slates. Ilere the granite is found in numerous great dikes intersecting the Knife Lake slate. Moreover, in many places the granite injections have followed the banding of the slate so as to give close parallel injections. In some places there are within a single hand specimen several bands of granite. Also bands are found intermediate in character between the well-recognized granite and the slate. There is no dould that these bands are due to granitization. Where the injection is of the most complex kind the rock is a mica gneiss, the darker-colored bands of which are 
largely the cxtremely metamorphosed granite. However, some material in the black bands has doubtess been dorivol from the eranite and some matrial in the light bands lats been derived from the slate.

The schists and gneisses are especially well exposed on the north side of Snowhank Lake. South of 'Tower, adjacent to the granite, and especially at localities near the Duluth and Iron Range Raihoad, the alterations are essentially the same as at Snowbank Lake, except that the amphibole schists are more prominent. Also the alteration phenomenal at Kakekabie Lake are in the same direction as at Snowbank Lake, but the processes have not gone so far.

At Kawishiwi River southwest of Snowbank, and at J)isappointment and Gabimichigani lakes, the great galbro mass of the Keweenawan has profoundly affected the character of the Knife Lake slate and has produced a peculiar gray granular rock which the Nimnesota geologists hare called "muscorado." These rocks differ from the slates and schists about Snowlank Lake in being almost massire. They are particularly well seen at Disappointment Lake. Between the schists north of Snowbank Lake and the granular rocks of Disappointment Lake there are gralations. These granular metamorphic rocks adjacent to the gabbro are regarded by Grant as the result of contact metamorphism of the Kinife Lake slate. They reerystallized under deep-seated static conditions at high temperature and probably influenced by abumlant moisture. The difference between them and the schists and gneisses of Snowbank Lake shows how important a part orogenic movement probably had in the protuction of the structures of the latter rocks. The schists and gneisses of the Knife Lake slate are the joint product of drnamic and contact action. The granular rocks which are adjacent to both the Snowbank granite and to the gabbro have doubtless undergone two periods of metamorphism, the cartier one at the time of the introduction of the Huronian Snowbank granite and a later one by the Keweenawan gabbro. At the earlier time doubtless selists and gneisses were produced under dynamic conditions which at the eartier time were transformed to granular rocks under static conditions.

MICROSCOPIC CHARACTER.

Clements's microscopic study shows that the rocks of the Knife Lake slate, including argillaceous and cherty slates, graywacke slates, graywackes, conglomerates, and tuffs, have as recognizable primary constituents feldspar, quartz, brown mica, white to green and violent-brown pyroxene, and greenish-brown homblende. The clastic mineral grains very commonly have been extensively altered, an! from these have been produced the following secondary minerals, which, in some places where the rocks are completely recrystallized, are the sole constituents: Chlorite, epidote, sericite, actinolite, massive dark-brown and green hornblende, quartz, calcite, and pyrite. The minerals between the grains in the coarser sediments are sericite, chlorite, epidote, quartz, and feldspar. These are believel to have been produced from the recrystallization of the fine detrital material originally lying between the larger grains.

The minerals constituting the mica slates, mien sehists, and mica gneisses, recrystallized umler the influence of the granite intrusion, are usually biotite and locally some muscovite, hornblende, actinolite, quartz, feldspar, epidote, and garnet.

The granular rocks metamorphosed by the gabbro are mica, homblende, and pyroxene feldspar rocks containing little quartz. The mica (chiefly biotite, but with some muscovite) and homblende together predominate orer the feldspar, and the miea is usually more ahmdant than the hormblende. With these chief constituents there oceur considerable amounts of hypersthene, light-green pyroxene, olivine (?), and magnetite, and with these suborthinte amounts of titanite, epictote, garnet, and chlorite. Fxceptionally in these gabbro contact rocks tho hypesthene is the predomume constituent, when it is usually associated with considerahle mical and magnetite. In general we may say that the production of minerals rich in magnesimm and iron is characteristic of the gabbro contact. 
DEFORMATION.

The Knife Lake slate has undergone the same orogenic movements as the Ogishke conglomerate. The slates have therefore been folled in a compusite and complex fashion. For the most part it is diffieult to make out in detail the strueture of the slates, but enough has been done to show that the folding is exceedingly eomplex. Superinposed upon folds of the first order are those of the second order; on these there are those of the third order, and so on indefinitely. The relations of the Finife Lake slate to the Ogishke conglomerate and to the Ely greenstone diselose in a general way the charaeter of the major folds.

Usually the slates are in synclines between anticlines composed of the Fly and Ogishke formations or one of them. As the formation is relatively nonresistant, many of the lakes are in the centers of these synclines. Such synclines are occupied by the following linear lakes or groups of lakes: Vermilion Lake; Long and Fall lakes; Pine, Moose, New Found, Sucker, Birch, and Carp lakes; That Mans Iake, Agawa Lake, This Mans Lake, and No Mans Lake; Knife Lake and its two prineipal arms; Kekekabic and Ogishke lakes. Not uncommonly the synclines of slate are broken up into two or more minor folds by subordinate anticlines, which may be marked by the appearance at the surface of the Ogishlie conglomerate.

RELATION TO ADJACENT FORMATIONS.

The Knife Lake slate in the eastern part of the district reposes on the Ogishke conglomerate or the Agawa formation. For the western part of the district it lies on the Ogishke conglomerate. In both places the transition to the Knife Lake slate is conformable. The Kinife Lake slate is not in observed contact with the Animikie group within the Vermilion district, but there is almost certainly an unconformity between them. The lower-middle Huronian rocks are characteristically steeply inclined and schistose, contrasting with the less folded and less schistose Animikie rocks. Also, rocks similar to the lower-middle IIuronian of the Vermilion district are on satisfactory eridence found in the Mesabi district to be unconformably below the Animikie or upper Huronian.

THICKNESS.

On account of the complicated folding of the Knife Lake slate it is impossible to determine its thiekness with any degree of exactness. But the extent of the areas which the formation continuously corers in the eastern and western parts of the district-a district which has been profoundly folded-leaves no doubt that the formation is one of great thickness, probably thousands of feet.

INTRUSIVE ROCES.

Later than the deposition of the Knife Lake slate, in several parts of the district many igneous rocks were intruded. These vary from comparatively small masses to those corering very considerable areas. In chemical character they include basic, acidic, and intermediate rocks. In texture they include porphyritic, ophitic, and granolitic rocks. In age the intrusives range from rocks which are slightly later than the Kinife Lake slate, and which therefore suffered orogenic movements and metamorphism with that formation, to intrusive rocks of much later age, which have been but comparatively little modifier.

The more extensive of these intrusive masses are the Giants Range granite, the Snowbank granite, and the Cacaqualic granite. In addition to these there are many smaller areas of acilic and basic intrusive roeks.

The Giants Range granite cxtends for 20 miles or more along the Vermilion range in contact with various formations. It includes a series of granites ranging in color from light gray to very dark gray, to flesh color, pink, and red. The rock varies from very dense fine-grained granites through medium to coarse-grained ones. Though this rock is as a rule granitic in texture, there are also variations to granite porphyries and exceptionally to some that can bespoken of as rhyolite porphyries. The constituents of these granitic rocks as disclosed by the microscope 
are orthoclase (nicrocline), plagioclase, quartz, homblende, mica, tireon, apatite, sphene, and "little iron oxide.

This granite is intrusive into the Arehean and the fower-midde Huronian. The contarts will not be further mentioncel, as deseriptions of them and their resultant metamorphism have been given in connection with the formations which have been intruled.

The Snowbank granite is confined to Snowbank Lake and vichity. It varies from the fine-grained to the coalso-grained form, the medium-grained fardes being most abundant. Porphyritic facies of the granite also occur. Mineralogieally the Snowbank granite valies from a normal mica and hornblende granite to an augite granite and, by loss of quart\%, to a syenite. The Snowbank granite is intrusive into both the Ogishlie conglomerate and the Finife Lake slate. The charactor of the contacts and the resultant metamorphism have been described in commection with those formations.

The Cacaquabic granite has been carefully mappet and describerl by L. S. Grant ${ }^{a}$ and from his report the following summary is taken.

The granite oceupies an oval area somth of Kekekalie Lake; also many of the islands of that lake and a lew small isolated areas in the vicinity of the lake. Petrographlically the rock is an augite granite, rich in soda. Its main mass has a granolitic texture; small masses are porphyritic. Crant inclines to the view that the latter is somewhat later than the former. He also regards the granite as intrusive in the Ogishke conglomerate and the Kinife Lake slate, because where it is in contact with the conglomerate the granite is unilormly finer grained than elsewhere, and because the slate at one place on the north shore of Kekekalic lake is cut by " a smill irregular dike of granite, which sends many stringers into the argillite and also includes fragments of it." $b$ Grant mentions no metamorphic effects of the granite on the Ogishke conglomerate and Kinife Lake slate.

In addition to these grinites, acidic dikes have been found cutting through the formations of the elistrict. They are supposed to have relations with the large eruptive masses, but for the most part this eonnection has not been definitely traced, though it is very strongly indieated by the greater abundance of the aciclie intrusive rocks adjacent to the large granite masses already described than at points remote from them.

At many places in the district are basic intrusive rocks which have a more or less wolldeveloped schistose structure and are otherwise metamorphosed. These intrusives evidently reached their present position before the strong orogenic movements following upper Huronian time harl ceased. A considerable body of these rocks occurs near Epsilon Lake and is called porphyrite by Grant.c Mletamorphosed basic intrusive rucks of upper Huronian age are known, but they are very subordinate and unimportant in this district.

\section{LPPER IITRONLAX (ANIMLIE GROLP) AND KEWEENAWAN SERIES.}

The upper Huronian (Animikie group) occurs in a small area in the eastern part of the district just west of Gunflint Isake and in a few patehes between the lower-midlle IIuronian and the Keweenawan as far west as Gabimichigami Lake. The relations of the Archean and bower-michle Ifuronian to the upper Iluronian in this region are interesting, but they are discusserl more appropriately in Chapter XX (pp. 599 et sef.). It is here meredy to be remarked that in the Vermilion district these relations are not clear, and that for a time it was supposed that the Animikie group represented rocks equivalent to the lower-midlle Inuronian but less metamorphosed. Later studies of the relations of these rocks, especially in the Mesabi and Loon Lake districts, show dearly that between the lower-middle Hurunian and the Animikie' groups there is al very marked meonformity. (See Chapter VIII, pp. 19s-210.)

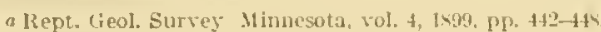

Idem, p. 4 H.

cTlse geology of Kekequabic Lahe in northeastern Minnesota, with special reference to an augitr-sorta granite: Twenty-first Inn. Fept. Geol.

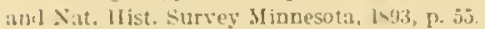


As has been noted, the Kieweemawan Duluth gabloro bounds the aastern half of the Vermilion district on the sonth. In the lower-middle IJuronian and Arehenn rocks are numerous comparatively fresh dolerite dikes and bosses. There are also more sparingly late acidic dikes in the Archean and the Huronian. It is supposed that these fresh rocks, showing comparatively little orogenic movement, are of Kieweenawan age, although they have not been connected areally with the greater masses of lieweenawan rocks. The metamorplusing effects of the Keweenawan gabbro upon the Arehean and Ifuronian have already been considered. The kieweenawan rocks themsclves are discussed in Chapter 11 (1p. 366-426).

\section{THE IRON ORES OF TIIE VERMILION DIS'TIIC'T, MINNESOTA.}

By the authors and W. J. MEAD.

DISTRIBUTION, STRUCTURE, AND RELATIONS.

The iron ores of the Vermilion district occur in the soudan formation, belonging to the Feewatin series of the Archean system. This formation rests upon the Ely greenstone, is in places interbedded with it, is interbedded with and intruded by acidic porphyries, and as a whole has been closely folded, with the result that the iron-lyearing formation stands with contorted and steeply inclined bedling, with steep walls and bottoms of green schist and mashed porphyry. These constitute deep, narrow, pitching trough in which the ores are found. The jaspers constitute for the most part the hanging wall of the ore.

The total area of the ores is but a minute fraction of that of the irom-bearing formation of the district. It is significant that notwithstanding the enormous sums ol money spent in the exploration of the district no ore deposit of magnitude has been developed outside of the two principal series of deposits at Tower and Ely, which were the first discoveries in the district.

One additional deposit in sec. 30, T. 63 N., R. 11 W., about 4 miles east of Ely, has heen considerably explored, leading up to the first shipment ol ore in 1910.

On Soudan Hill near 'Tower the structural relations of the iron-bearing formation to the green schists and mashed porphyries are so complex that it is extremely difficult to follow the ore bodies. The steeply pitching troughs branch, change their pitch, and are duplicated by parallet troughs to such an extent that in spite of the enomous amount of underground exploration to which the hill has been subjected it is not certain yet that all the ore deposits have been found. The Soudan ores may have (a) "paint rock" or "soapstone" as foot wall, below which is jasper, and similar paint rock or jasper as the hanging wall; or (b) they may have jasper both as a foot and a hanging wall, and hence may lie within it and grade in all directions into the Soudan formation. Deposits of this kind are small. The Soudan ores are mainly of the first form. They have now been found to a depth of 2,000 feet.

At Ely there is a single trough of the iron-bearing formation in the greenstone, beginning as a comparatively wide body at the west and narrowing and deepening toward the east. The northeast side of the trough seems to be formed in part by lower Ituronian slates or graywackes. The greenstones associated with the ores are altered to paint rock along the contacts. This trough is a comparatively simple one, but there is also a minor parallol anticline separating the Zenith ore deposits into two portions and separating the trough longitulinally into two great synclines, one between the Zenith and Pioneer mines and the other between the Zenith and Savoy mines. (See fig. 14.) IIere also parts of the formation are found separated l'rom the main mass by greenstone masses in such a manner as to make it difficult to explain them on the basis of occurrence in trough alone. It would seem that the main mass of the ormation here has been infolded in such a manner as to give a steep monoclinal trough dipping northward, but that in addition to this main mass, which originally rested upon the greenstone, minor masses of the iron-bearing formation may be mterbedded with the greenstone, so that after the folding they would be scparated from the main mass by layers of greenstone. 
The deposits of Somban Ilill come to the surface near the crest at an elevation of 1,660 feet, about 150 feet above a cross valley to the east between Soudan Hill and Jasper Peak. The Ely ore deposits ate below comparatively low-lying gromel, the upper part of the deposits being at

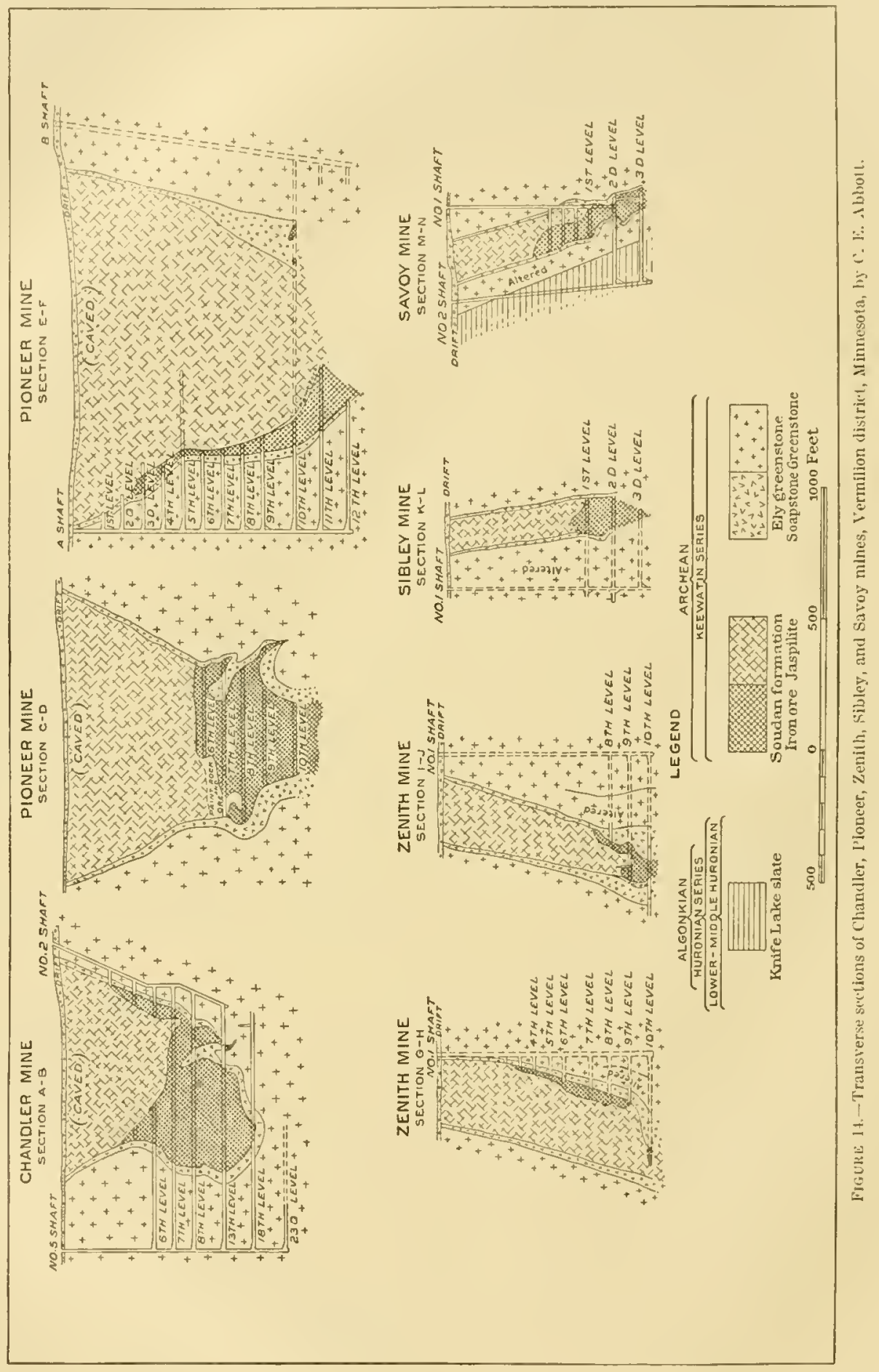

about the 1,400-foot contour, and are surrounded on the north, west, and south by an amplitheater of high ground eomposed of the Ely greenstone, the higher points of which rise to an elevation of 1,500 feet. Farther east is a cross ralley which is somewhat less than 1,400 feet 
high. To what extent the cross valley is filled is unknown, but the drilt covering is moderatcly thick. The pitch of the ore cleposits is parallel to the runge, as it is in the Henominee, Marquette, and Penoken-Gogebic districts and toward this valley. The ores in gerreral are located below erests and slopes.

The newly developed Section 30 mine, in sec. 30, T. 63 N., R. 11 W., is located on a bend of the iron-bearing Soudan formation, trending a little east of south. The jasper is bounded on both sides by greenstone, that to the south probably being basal and that to the north being overlying. The bend in the jasper seems to represent the result of shearing between these two greenstones. Outcrops of rich, highly contorted jasper led to the sinking of the shaft. Below the surface the jasper becomes in general softer and small leads of ore in the jasper widen out into shoots of commercial value. Mining operations have shown the ore to come to the surface where covered by the drift. The ore body is yet too little developed to permit an accurate description of the structure. The ore thus far developed seems to be in two main masses - one in the southeast with an exsterly or southeasterly linear trend, pitching west at the west end, apparently rast at the east end, and with miror rolls between; and another ore body north of the west end of this one, having a similar trend and seeming to pitel to the west. There is little doubt that these ore bodies are developed along the axial lines of the pitching drag folds in the jasper. Their greatest dimersion is in the direction of the pitel.

\section{CHEMICAL COMPOSITION.}

The arerage composition of all ore mined in the Vermition distriet in 1909, obtained by combining average cargo analyses in proportion to their respective tonnages, is shown below. The range for each constituent is from the cargo analyses and represents the variation in conposition of the marketed ore and not of the ore in the nine.

Composition of ore shipped from the Vermilion district in 1909 (1,108,790 tons).

\begin{tabular}{|c|c|c|}
\hline & A verage. & Range. \\
\hline Moisture (loss on drying at $212^{\circ} \mathrm{F}$.) & 5.06 & 0.75 to 5.66 \\
\hline 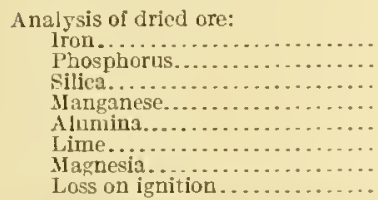 & $\begin{array}{l}63.79 \\
.052 \\
4.90 \\
.11 \\
2.93 \\
.23 \\
.05 \\
.05\end{array}$ & $\begin{array}{l}60.91 \text { to } 15.34 \\
.037 \text { to } .168 \\
3.06 \text { to } 8.07 \\
.09 \text { to } .15 \\
1.40 \text { to } 3.27 \\
.20 \text { to } .47 \\
.04 \text { to } .15 \\
.40 \text { to } 2.18\end{array}$ \\
\hline
\end{tabular}

I'artial average analyses of ores and jaspers.

\begin{tabular}{|c|c|c|c|c|c|c|c|}
\hline & $\begin{array}{l}\text { Average } \\
\text { analyses of } \\
\text { ore irom } \\
\text { Soudan Hill } \\
\text { in } 1906 .\end{array}$ & $\begin{array}{c}\text { Average } \\
\text { analyses of } \\
\text { ore from } \\
\text { Soudan Hill } \\
\text { in } 1909 .\end{array}$ & $\begin{array}{l}\text { A verage } \\
\text { analyses of } \\
\text { ore from } \\
\text { mines at Ely } \\
\text { in } 1906 .\end{array}$ & $\begin{array}{c}\text { Average } \\
\text { analyses of } \\
\text { ore Irom } \\
\text { mines at Ely } \\
\text { in } 1909 .\end{array}$ & $\begin{array}{l}\text { A verage of } \\
10 \text { partial } \\
\text { analyses of } \\
\text { jasper from } \\
\text { Soudan II ill. }\end{array}$ & $\begin{array}{l}\text { A rerage of } \\
\text { severnd par- } \\
\text { 1ial analyses } \\
\text { of jasper from, } \\
\text { mines at Ely. }\end{array}$ & $\begin{array}{l}\text { A verage of } \\
20 \text { analyses of } \\
\text { iron forma- } \\
\text { tion bands } \\
\text { from sees. } 13 \\
\text { and } 14, T .62 \\
\text { N., R. } 13 \mathrm{~W} .\end{array}$ \\
\hline Moisture (loss on drying at $212^{\circ} \mathrm{F}$ )........ & 1.37 & 0.79 & 5. 26 & 5.37 & & & \\
\hline 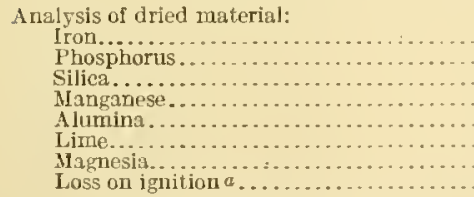 & $\begin{array}{c}60.07 \\
.088 \\
3.43 \\
.10 \\
1.27 \\
.13 \\
.02 \\
.55\end{array}$ & $\begin{array}{l}64.85 \\
.167 \\
4.76 \\
.09 \\
1.57 \\
.36 \\
.08 \\
.47\end{array}$ & $\begin{array}{r}65.00 \\
.046 \\
3.39 \\
.11 \\
1.90 \\
.34 \\
.06 \\
1.24\end{array}$ & $\begin{array}{l}63.70 \\
.049 \\
4.91 \\
.10 \\
3.03 \\
.22 \\
.05 \\
.90\end{array}$ & 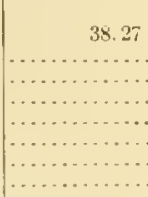 & 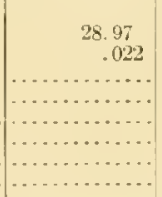 & 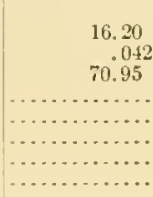 \\
\hline
\end{tabular}




\section{MINERAL COMPOSITION OF THE ORES AND CHERTS.}

The principal iron minerals of the ores are hematite and ninor amounts of magnetite and siderite. The siderite is noticeably abmelant in the ore from the Saroy and sibley mines. In adelition to the iron minerals are quartz, chlorite, calcite, kaolin, pyrite, and small amounts of minerals bearing phosphorus, magnesium, and manganese, not sulliciently abundant to be identified. A variety of copper minerals, including native copper, malachite, azurite, cuprite, and several sulphides of copper, are found hoally in small amounts in loth the Ely mines and the mines at Soudan IIill. These copper minerals are not sufficiently abumlnnt. however, to affect the average composition of the ores.

A pproximate mineral composition of ors and jaspers, calculated from the pertiat analyses giarn above.

\begin{tabular}{|c|c|c|c|c|c|c|}
\hline & \multicolumn{2}{|c|}{$\begin{array}{l}\text { Ore from mines at } \\
\text { Lily. }\end{array}$} & \multicolumn{2}{|c|}{$\begin{array}{l}\text { "irc from mines at } \\
\text { Soudan llill. }\end{array}$} & \multirow{2}{*}{$\underset{\text { jasjy }}{\operatorname{Ely}}$} & \multirow{2}{*}{$\begin{array}{l}\text { Sourdari } \\
\text { jasper. }\end{array}$} \\
\hline & 1906. & $190: 4$. & 1906. & 1909. & & \\
\hline \multirow[t]{2}{*}{ 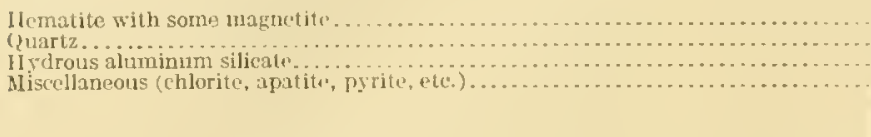 } & $\begin{array}{r}92.8 .5 \\
1.15 \\
1.85 \\
1.15\end{array}$ & $\begin{array}{r}91.09 \\
1.34 \\
7.15 \\
.44\end{array}$ & $\begin{array}{r}94.50 \\
1.93 .3 \\
3.22 \\
.35\end{array}$ & $\begin{array}{r}92.75 \\
2.42 \\
3.97 \\
.31\end{array} \mid$ & $\begin{array}{l}41.40 \\
55.60\end{array}$ & \\
\hline & 100.00 & 100.00 & 100.00 & 1000.00 & $1(0) .(1)$ & 100.00 \\
\hline
\end{tabular}

All the ores of the Ely district are dark red and blue hematites, with a small amount of magnetite and siderite. They are practically anhydrous, the water of hydration averaging less than 1 per cent.

The jasper is a clense, brittle rock marle up of layers of nearly pure anhydrous hematite separated by layers of eomparatively barren chert. The jaspers contain more or less magnetite; in places nearly all of the iron is in that forn.

\section{PHYSICAL CHARACTERISTICS OF VERMILION ORES.}

\section{TEXTURE.}

In texture the Vermilion ores show a complex gradation from dense massive hematite through brecciated or broken ore to fine blue granular ore.

The Soudan ore is massive hematite, all of the ore requiring crushing.

The Ely ores exhibit a complete range from dense hematites with practically no pore space to fine granular hematites with large porosity.

The textures of the ores of the Vermilion district are shown in the following table of screening tests. These screening tests were made by the Oliver Iron Mining Company on three of the typical grates of Termilion ore representing a total of $1,034,221$ tons. For each of the grates samples were taken biweekly and quartered down monthly in proportion to the tonnage mined, and at the end of the scason the entire sample was quartered down to 100 pounds and sereened. A comparison of the textures of the ores of the several Lake Superior districts is shown in figure 72 (p. 481).

Textures of Tirmilion ores as shown by sereening lests.

\begin{tabular}{|c|c|c|}
\hline & Ely ore. & $\begin{array}{c}\text { Solndan } \\
\text { ore. }\end{array}$ \\
\hline 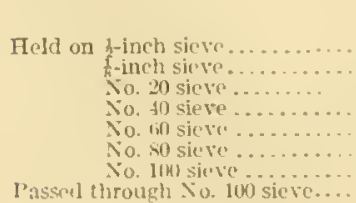 & $\begin{array}{r}\text { Percent. } \\
11.83 \\
41.65 \\
11.23 \\
\text { ti. } .97 \\
3.81 \\
.59 \\
9.32 \\
4.30\end{array}$ & $\begin{array}{r}\text { Percent. } \\
10.40 \\
2.10 \\
+1.40 \\
1.10 \\
.80 \\
.40 \\
.40 \\
2.30\end{array}$ \\
\hline
\end{tabular}


These screening tests show plainly the diflerence in texture between the ores from the mines at Soudan Hill and the ores from the vicinity of Ely. The former are dense massive ores with practically no fine material except what results from the blasting and crushing due to mining. The latter ores are of much finer texture, being easily broken down with a pick.

The average ore of the Ely listrict is well described by the local term "hroken ore," as it is a rubble of more or less unconsolidated fragments of hard hematite, which range in size from small grains to large masses. This rubble or brecciated material is cemented locally by infiltrated hematite and iron carbonate, in some places the infiltrated minerals almost rompletely filling the voids. The bedding of the jasper is plainly preserved in the ore where slumping has not destroyed it. In the \%enith mine a fresh surface of the ore showed perfectly the folded structure of the jasper. No sharp line of contact exists between the ore and jasper, the gradation being complete. The slumping of the ore has in most places produced a drag which destroys the bedding texture in this transitional zone, producing a mixture of broken ore and jasper.

DENSITY.

The mineral density of the ores varies with the iron content and ranges from 5.10 for the pure hematites to 4.40 in the lower-grade ores. The average for the district (1906 production) is approximately 4.85. As the ores consist essentially of hematite and quartz, the approximate mineral density may be readily calculated from chemical analyses.

POROSITY.

Owing to the texture, porosity determinations on the Ely ores are rather difficult to obtain. Ten determinations made on typical specimens of the comented breceiated ore showed an average pore space of approximately 20 per cent of the volume of the ore. If the average moisture content of the ore as given above is assumed to be the moisture of saturation of the ore, calculation shows that it represents a porosity of 21.5 per cent. 'This moisture content, however, is probably less than the moisture of saturation of the ores; hence the porosity of the arerage ore may be assumed to be greater than the moisture determination indieates. Engineers estimate 9 to 10 cubic feet of the ore in place to the ton. If the average mineral specific gravity for the ore is 4.93 , as calculated above, this figure indicates an average porosity of frrm 20 to 28 per cent. Though these estimates of porosity are all approximations, their rather close accordance indicates their probable correctness.

The Soudan ores are much more compact than the Ely ores and have an arerage porosity of less than 10 per cent.

\section{CUBIC CONTENTS.}

Calculations hased on the mineral density, porosity, and moisture of the ores give an average of 8.75 cubic feet per long ton for Soulan ore and approximately 9.5 cubic feet per ton for Ely ore.

\section{SECONDARY CONCENTRATION OF VERMILION ORES.}

\section{PRECEDENT CONDITIONS.}

In the Termilion district the steeply pitching foot walls of lieewatin greenstone and associated porphyry afford imperrious basements and trough for the concentration of waters from the surface. This is especially well shown in the western end of the eastward-pitching Ely trough. (See p. 137.)

Originally the iron-bearing Sondan formation consisted largely of cherty iron carbonate interlayered with more or less of sideritic slates and perhaps landed chert and iron oxide. 


\section{MINERALOGICAL, AND CHEMICA, CHANGES.}

The alteration of the cherty iron carbonate to ore has been accomplished in the general manner described (p. 529) as typical for the region-(1) oxidation and hydration of the iron minerals in place; (2) leaching of silica; and (3) introrluction of scondary iron oxide and minor amounts of iron carbonate from other parts of the formation. These changes may start simultaneously, but the first step is usually far advanced or complete before the second and third are conspicuous. The early products of alteration, therefore, are ferruginous chertsthat is, rocks in which the iron is oxidized and hydrated and the silica is not removed. The later removal of silica is neeessary to produce the ore, except in layers originally rich enough in iron to make ores withont the removal of silica.

It is shown in discussing the secondary concentration of the Hesabi and Gogebic ores that the degree of hydration of the iron-oxide layers in the cherts and jaspers is not changed by the alteration to ore. This appears to be true also of the Vermilion ores, as both the jaspers and the ores are practically anhydrous.

SEQUENCE OF SECONDARY ALTERATIONS AND DHYLLOPMENT OF TEXTLLES.

Before lower Huronian time the iron-bearing formation at the surface at Soudan had been altered to iron ores, cherts, and jaspers, for all these substances were yielded to the conglomerate at the base of the lower Ifuronian. The concentration of the ore may be supposed to have stopped while the formation was covered by the lower Huronian sediments. Close folding following the lower Huronian deposition rendered the ores hard, anhydrous, and crystalline, dereloped green schists out of the basaltic wall rocks and talcose and sericitic schists from the porphyry wall rocks, and in general developed a steep, vertical structure in both ore and wall rock, making it difficult to decipher the structural relations. Erosion later exposed the ironbearing formation, but owing to its refractory character it was not further concentrated.

At Ely also the concentration began before the deposition of the lower IJuronian and was interrupted when the iron-bearing formation was covered by lower Huronian sediments. Later, when the formation was again exposed to weathering, the concentration continuer, and then

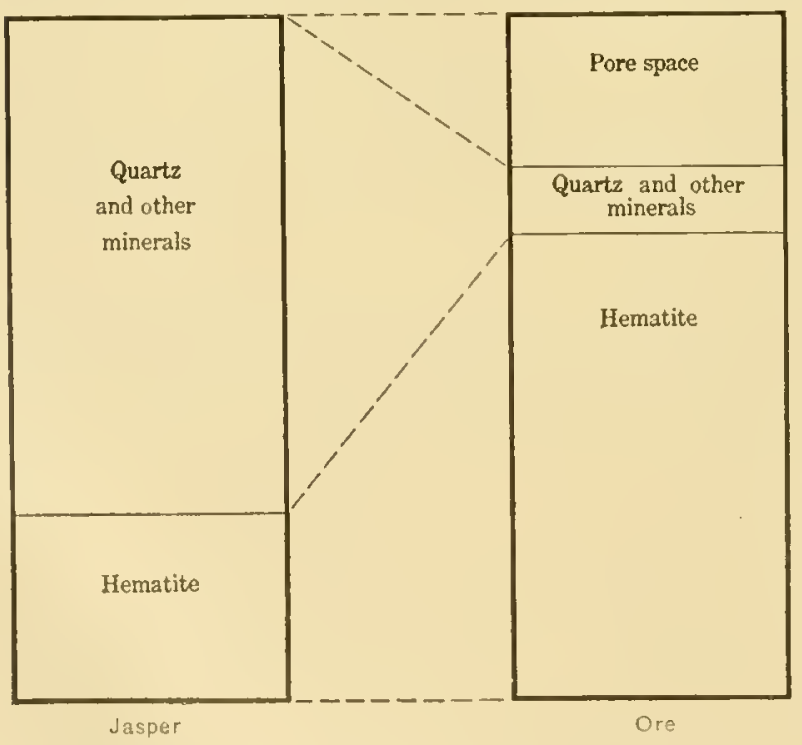

Forive 15.-Diagram illustrating volume changes involved in the alteration of jasper to ore at Ely, Minn. From average analyses and porosity deterninations. necessary that silica equivalent to 63.7 per cent of the volume of the jasper be removed. The that undergone by the ores at Soulan, which were comparatively little affected by the later concentration. The fact that the iron-bearing formation at Ely was less closely folded and rendered less schistose than the iron-boaring formation at soudan, thereby retaining more openings through which concentrating solutions might work, may explain why concentlation was so effective after the folling. That at least a part of the concentration followed the folding is shown by the retention in the ore of the folded bedded structures of the jasper and by the development of pore space as a result of the leaching of silica from the folded jasper, discussed below.

$$
\text { VOLUME CHANGF IX ELY ORE. }
$$

Comparison of the volume compositions of the ore and jasper shows the removal of order to sulliciently reduce the silica content it is

the process differing in this respect frour 
average porosity of the ore is approximately 22 per cent of its volume; hence the remaining space left by the removal of silica, or 41.7 per cent of the volume of the jasper, has been filled by infiltration of iron and by mechanical slmmping of the ore. The relative importance of these two factors can not be definitely determined, but it is known that both lave been eflertive. The broken and breeciated condition of the ore and the drag at the jasper contacts give abundant evidence of slump, and secondary hematite and siderite eementing the ores indicate that a considerable amount of iron lins been introduced in solution. Figure 15 illustrates the volume ehanges above discussed.

\section{DISTRIBUTION OF PHOSPHORUS.}

Phosphorus and iron contents of the Vermilion ores and associated rocks are as follows:

Phosphorus and iron contents of Termilion ores and associated roctss

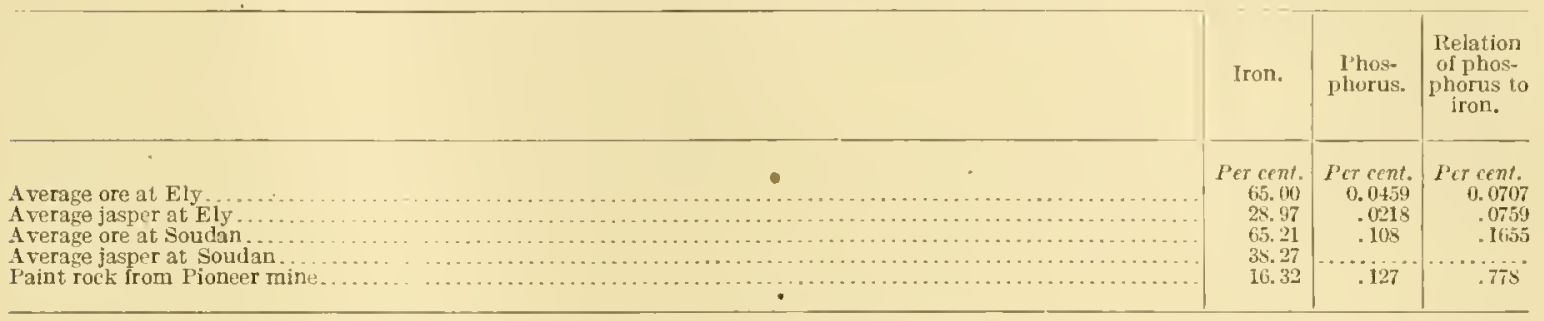

As calculated from the figures of the lake Superior lron Ore Association, 89.3 per cent of the total production of the Vermilion range in 1906 was of Bessemer grade. The lowest phosphorus grade was Pilot lump (iron 67.22 per cent, phosphorus 0.0297 per cent), and the highest phosphorus grade was Termilion lump (iron 66.07 per eent, phosphorus 0.087s per cent). The phosphorus contents of individual samples show a muel greater range than the grade analyses, the ore containing as high as 0.500 per cent of phosphorus locally.

The paint rock is an altered phase of the greenstone and porplyry, eonsisting principally of knolin more or less staned with iron oxide. It is similar both in appearance and composition to the altered like rocks of the Gogebic range. These altered igneous rocks are higher in phosphorus than the ores (the above analysis being a typical one), orving probably to the high phosphorus in the greenstone.

"Chemical maps" have been made lyy the chemists and moineers of the Oliver Iron Mining Company of the mimes on the Vermilion range operated by that company, the phosphorus and iron eontents of the ore being entered in the proper place lirectly on the mime maps. Study of these maps fails to show any relation between the distribution of phosphorus and the wall rocks. The only general conclusion that may be drawn is that in general the phosphorus content is lowest in the largest ore bodies and has a tendency to be high in the small shoots of ore away from the main ore body. The maps show no relation between high-phosphorus ore and paint rock; in fact, in several places ore running as low as 0.030 per cent of phosphorus oecurs in the immediate vicinity of high-phosphorus paint rock.

Owing to the very small amount of phosphorus even in what are termed "high-phosphorus" ores, very little is known as to its mineral occurrence. So far as is known, no phosphorus minerals have been identified in the ores or jaspers; hence any conclusions regarting the chemical combinations in which phosplorus exists are necessarily based entirely on chemical eridence. Phosphorus is present in the ores in at least two difierent forms, known to the iron-ore chenists as "soluble" and "insoluble" phosphorus, part of it being easily dissolved in hydrochloric acid and the remainder requiring ignition before it can be dissolved. Chemical analysis ol" the insoluble resilue shows it to be an aluminum phosphate. This oceurence of both soluble and insoluble phosphorus is common to ores of the other Lake Superior districts, particulary those of the Marquette range. 


\title{
CHAPTER VI. THE PRE-ANIMIKIE IRON DISTRICTS OF ONTARIO.
}

\author{
LAKE OF THE WOOIS AND RAINT LAKE DISTRICT.
}

\section{INTRODUCTORY NTITEMENT.}

The Lake of the Woods and Rainy Lake elistrict includes these large lake's and thre surrounding lunds. The district may be considered ats being bounded on the south by parallel $48^{\circ} 30^{\prime}$, on the north by paralkel $50^{\circ}$, on the east by meridian $92^{\circ} 30^{\prime}$, and on the west by mericlian $95^{\circ} 30^{\prime}$. 'The area which has been most closely studied is an angular one running northwest and southeast. The Canadian Survey lias published detailed reports by A. C. Lawson on the Lake of the Wroods ${ }^{a}$ and Rainy Lake ${ }^{b}$ district and one by W. H. C. Smith ${ }^{c}$ on Hunters Island.

The geology of this region may be sairl to duplieate in most essential respects, save the distribution of the formations, the geology of the Vernilion district of Ninnesota. The rocks therefore include lower-middle Huronian, Jaurentian, and Keewatin.

\section{IRCHEAN SIYTEMM.}

\section{KEEWATIN SERIES.}

The series of Keewatin rocks in the district of the Lake of the Woods is that to which the term was first applied. Lawson's study of it, supplemented by later work of other's, slows that the Keewatin series is dominantly igneous but includes subordinate amounts of sediments, precisely as in the Vermilion district. The igneous rocks comprise ancient lava flows, roleanic clastics, and contemporaneous and subsequent intrusices. They are dominantly of basic and intermediate varieties, exactly as in the Vermilion distriet, and among these the characteristic cllipsoidal greenstones are conspicuous. Locally felsites and quartz porphyries occur. In many areas subsequent dynamic action has gone rery far, so that the rocks uncommonly lare a slaty or schistose structure. These belts of slaty and schistose rocks Lawson has separated into two divisions, ${ }^{d}$ one of which he deseribes as hydromicaceous schists and macreous schists. with some associated chloritic schists and micaceous schists and included areas of altered quartz porphyry, and the other of which he ealls clay slate, micn schist, and quartzite with some finegrained gneiss. Subsequent examinations of the areas by other geologists have led to the conclusion that large areas of these rocks are but altered facies of the ordinary varieties of the Keewatin igneous rocks. Thus the slates are to a large extent mashed varieties of the ellipsoidal greenstones and tuffs. At various places the transition between the ellipsoidal greenstones and slaty varieties of rocks produced from them by metamorphism is well shown. However, there are present with the slaty and schistose rocks of igneous origin subordinate amounts of sedimentary graywacke and slate, including small belts of ordinary black slate which are in some parts carlonaccous. There has not yet been discovered in the Lake of the Woods elistrict any iron-bearing formation corresponding with the iron-bearing Soulan formation of the Veruilion clistriet, and this is the clief difference between the two scries. The only rocks which could possibly be regarded as a correlative of the iron-bearing Soudan formation

a Geology of the Lake of the Woods region, with special reference to the Kicewatin (Iluronian?) belt of the Archean rocks: Antr. Rept. Geol. and Nat. IIist. Survey Canada for 18s5, vol. 1 (new ser.), Iswi, Rept. C(', pp. 5-151, with map.

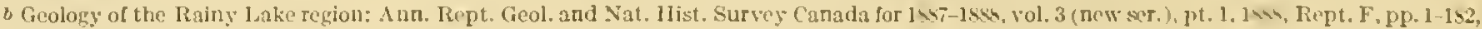
with two maps.

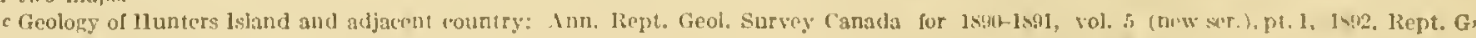

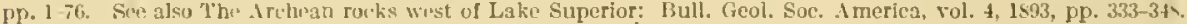

d Geology of the Lake of the Woods region, D. 56. 
are very subordinate beds of limestone which oeeur at various places. The nature of this limestone is represented by that at Scotty lslands, where there are narow bands from a fraction of an inch to 2 feet wide in a schistose and banded greenstone. 'The layers are usually lens-shapech, and along their strike they may becone narrow and pinch out. Commonly the division between the limestone and the greenstone is rather sharp.

For the Lake of the Woods district Lawson ${ }^{a}$ gives various sections of the Keewatin, ranging from 6,500 fect to 23,756 feet in thickness. As this is a volcanic series and practically all the structures are secondary, it may be doubted whether these figures have any leal significance.

In conclusion it may be well to give the statement of the International Geological Committee, ${ }^{b}$ consisting of Messrs. Frank D. Adams, Robert Bell, A. C. Lane, C. K. Lcith, W. G. Miller, and Charles R. Van Hise, eoncerning the Keewatin of the Lake of the Woods:

In the Lake of the Woods area one main section was made from Falcon Island to Rat Portage, with various traverses to the cast and west of the line of section. The section was not altogether continuous, but a number of representatives of each formation mapped by Lawson were visited. We found Lawson's descriptions to be substantially correct. We were unable to find any belts of undoubted sedimentary slate of considerable magnitude. At one or two localities subordinate belts of slate which appeared to be ordinary sediment and one belt of black slate which is certainly sediment are found. In short, the materials which we could recognize as water-deposited sediments are small in volume. Many of the slaty phases of rocks seemed to be no more than the metamorphosed ellipsoidal greenstones and tuffs, but some of them may be altered felsite. Inwever, we do not assert that larger areas may not be sedimentary in the sense of being deposited under water. Aside from the belts mapped as slate, there are great areas of what Lawson calls agglomerate. These belts, mapped as agglomerates, scem to us to be largely tuff deprosits, but also include extensive areas of ellipsoidal greenstones. At a number of places, associated and interstratified with the slaty phases are narrow bands of ferruginous and siliceous dolomite. For the most part the bands are less than a foot in thickness, and no band was seen as wide as 3 feet, lut the aggregate thickness of a number of bands at one locality would amount to several feet.

\section{LAURENTIAN SERIES.}

The Laurentian series is represented mainly by granite, syenite, granite gneiss, and syenite gneiss. These rocks occur in masses varying from small areas to those many miles in diameter. They are intrusive in the Keewatin series and comprise batholiths, bosses, dikes, and stringers. The nature of the contacts between the Laurentian and Keewatin in the Lake of the Woods area is identical with that of the contacts in the Vermilion district. Along the borders of the batholiths the Keewatin is metamorphosed into hornblende selist or gneiss, exactly as it is in the Vermilion distriet. Indeed, between the more metanorphosed varieties of these rocks and their less metamorphosed forms there are all gradations. Included in the great batholiths of granite are various masses of Keewatin which have generally been profoundly metamorphosed and in many places partly absorbed.

The chemical and mineralogical compositions of the batholiths have thus, to some extent at least, been affected by the included material. Similarly the chemical and mineralogical characters of the Keewatin have been affected by the material derived from the granite. Indeed, there are few better examples of endomorphic and exomorphic effects than those furnished by this district. All these relations may be eonveniently studied in the vicinity of Rat Portage. Intrusive into both the Keewatin and Laurentian are later masses of granite and also various basic rocks, including diabase, gabbro, and peridotite.

Lawson's maps of the Keewatin and Laurentian in the Lake of the Woods and Rainy Lake district show certain interesting features which have here been better worked out than anywhere else in the Lake Superior region. The great batholiths have a tendency to a schistose structure, which is parallel to their borders and is more marked at their exteriors than at their interiors. The Keewatin schists around the borders are in bands, the schistosity of which is roughty parallel to the batholith boundary. Very commonly a band of Keewatin widens or narrows within a short distance or separates into two or more bands. This subdivision may go on until a band is lost in stringers in a granite mass. With many large areas of schists there appear subordinate granite batholiths, bosses, and dikes.

a Geology of the lake of the Woorls region, pp. 104-112.

$\checkmark$ Report of the special committee on the Lake Superior region, with introductory note: Jour. Geology, vol. 13, 1905, pp. 95-96.

$47517^{\circ}-$ VOL $52-11-10$ 
The area rovered by the Laurentian granites is much greater than that covered ly the Kecwatin. It is certain that after the linewatin voleanio rocks were once spreat over the entire region, as they doubtless were, they must have been raised in creat domes, pushed aside, and jammed in between the batholithic intrusions. It is probalble that the greater areas of lieewatin which once overlaid these batholiths have bern removed by erosion and that the existing masses of kieewatin are but mere remnants of a great volcanir formation which once covered the cntire district. It has been sugresested also that parts of the Kecwatin may have foundered and sunk in the granite batholiths at the time of intrusion. ${ }^{n}$

The foregoing farts in reference to the relations of the Laurentinn and Feewatin have led Lawson ${ }^{b}$ to his subcrustal fusion theory, his icten being that the Laurentian represents the fused and recrystallized masses of the Keewatin. There is no doulut that along the border of the batholithic masses a certain amount of Kowwatin material has been absorbed, and no doulst that the lieewatin along the borders of the granites has derived material from then; thus there appears in some places to be an approach to chemical gradation between the two.

The known facts, then, are these: The Lieewat in voleanic period antedated the Laurentian. The Keewatin rocks were intruded by the various Laurentian granites and syenites, extending through an enormous period of time. There were important exomorphic and eudomorplic effects. There is difference of opinion as to the amount of the Keewat in which has been absorbed by the Laurentian. Our own riew tends toward conservatism in this matter.

\section{ALGONRIAN SYSTEM.}

\section{HURONIAN SERIES.}

The Huronian rocks in this district belong to the lower-middle IIuronian. They are chiefly confincd to the southern part of the Rainy Lake area. From west to east their northern boundary roughly follows Rainy River, the central body of Raing Lake, and Seine River with its various enlargements. From this line the Huronian extends across the international boundary into Minnesota for distances not yet determined, except at a few points. This is the main mass of rocks to which Lawson gave the name "Coutchiching." In the area under discussion the rocks consist dominantly of mica schists, but there are argillaceous slates, mica slates, graywackes, and conglomerates at the bottom. All the evidences of unconformable relations between these rocks and the Laurentian and lieewatin series are found in many places along the contact. Where the underlying rocks are Keewat in detritus is mainly derived from that series; where they are granite, as at Bad Vermilion Lake, the detritus is mainly derived from granite. In intervening areas both granite and greenstone are found. Also with these materials is found detritus of other kinds, such as felsites, quartz porphyries, and gneiss. The materials include practically all the varieties of the Keewatin rocks. In places the conglomerate passes up into a feldspathic quartzite and this into a micaceous graywacke or slate. Wherever the bedding can be recognized the dip is steep to the south.

The main areas of the lower-midclle Ituronian micaceous selists have been intruded by large masses of granite which may be especially well seen at the end of the soutleast arm of Rainy Lake and in Namakon Lake along the international boundary. From masses of very considerable size the intrusive granite varies to masses of much smaller size, and cutting through the miea schists are very numerous granite dikes, a large number of which are roughly parallel to the foliation. Largely in consequence of the intrusions of the granite the main mass of the lower-middle Huronian has been transformed to a well-crystallized mica schist. As a result of these intrusions, from the end of the southeastern arm of Rainy Lake northwest ward to the base of the series the rocks are less and less metamorphosed. Possibly this gradation was one of the factors in Lawson's conclusion that the Lieewatin series was higher and rested nnconformably upon lis.s "Coutchiching," which exactly reversed the true relation. As the relation

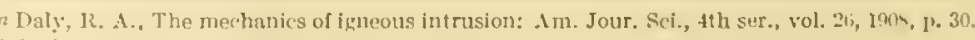
$b$ Geology of the Rainy Lako region, p. 131 . 
of the great mica schist series to the keewatin is one about which there is lifference of opinion, the statement of the International Geological Committee, ${ }^{a}$ consisting of Messrs. Frank D. Adams, Robert Bell, A. C. Lane, C. K. Leith, W. G. Miller, and Charles R. Tan Hise, who visited this clistrict and examined the contact, is here quoted:

In the Rainy Lake district the party observed the relations of the several formations along one line of section at the east end of Shoal lake and at a number of other localities. The party is satisfied that along the line of section most closely studied the relations are clear and distinct. The Coutchiching schists form the highest formation. These are a series of micaceons schists graduating downward into green hornblendic and chloritic schists, here napped by Lawson as Keewatin, which pass into a conglomerate known as the Shoal Lake couglomerate. This congluncrate lics upon an area of green schists and granites known as the Bad Vermilion granites. It holds numerous large weli-rolled fragments of the underlying rocks, and forms the base of a sedimentary series. It is certain that in this line of eection the Coutchiching is stratigraphically higher than the chloritic schists and conghmerates mapped as Keewatin. On the sonth side of Rat Ruot Bay there is also a great conglomerate belt, the rlominant fragments of which consist of green schist and greenstone, but which also contain much granite. The party dicl not visit the main belts colored by Lawson as Keewatin on the Rainy Lake map, constituting a large part of the northern and central parts of Rainy Lake. These, however, had been visited by Van Hise in a previous year, and he regards these areas as largely similar to the greenschist areas intruded by granite at Bad Vernilion Lake, where the schists and granites are the source of the pebblee and bowlders of the conglomerate.

As to the existence of areas of sediments equivalent in age to the lower-middle Huronian in other parts of the Rainy Lake and Lake of the Woods district, no definite statements ean yet be made. It is probable, however, that close struetural stulies of these areas will clisclose such sediments. Indeed, a traverse of the Rainy Lake section by the senior author led him to think that in the belt of rocks mapped as Keewatin, rumning from the southeastern end of Crow Lake to Maniton Lake, there are representatives of this upper series, but the area was not sufliciently studied for its areal distribution to be given. On the other hand, it is certain that some areas which have been mapped as "Coutchiching" on the Rainy Lake sheet of the Geological Survey of Canada, and especially on adjacent sheets, are but the chloritic and hornblendic schists of the Keewatin metamorphosed by the intrusive granite. It is phain that the term "Coutchiching," if it is to have any structural significance, must be restricted to the selimentary series of Ramy Lake, its extensions and equivalents. It must not be used as a term to cover the more schistose varieties of rocks of the region without reference to their stratigraphic position.

As to the thickness of the so-called "Coutchiching," Lawson ${ }^{b}$ gives estimates varying from 23,760 feet to 28,754 feet. These measurements, however, are clearly based on cleavage structures rather than on bedding, and close examination shows that the two do not conform; hence there is grave doubt whether the thickness of the series is more than a fraction of these estimates.

It has already been indicated that in the lower-middle Huronian schists ("Coutchiching" of Lawson) there are intrusive masses of granite which have produced metamorphic effects. In addition to these granitic masses cutting all the formations of the district are later diabases, dikes, and bosses which are supposed to be of Keweenawan age.

\section{STEEP ROCK LAKE DISTRICT.}

\section{GENERAL GEOLOGY.}

The Steep Rock Lake district has been described and mapped by H. L. Smyth ${ }^{c}$ and IT. N. Merriam. ${ }^{d}$ The authors have visited the district for general correlation purposes but have not studied it in cletail. The following account is based principally on Merriam's work.

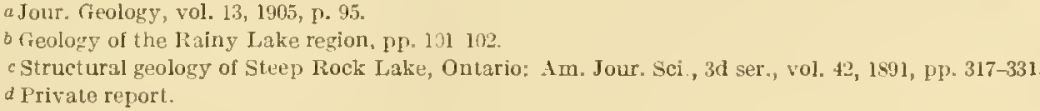


The geology of the Steep Rock Lake district is similar in essential respects to that of the Vermilion and Rany Take districts. The succession, in deseending order, is as follows:

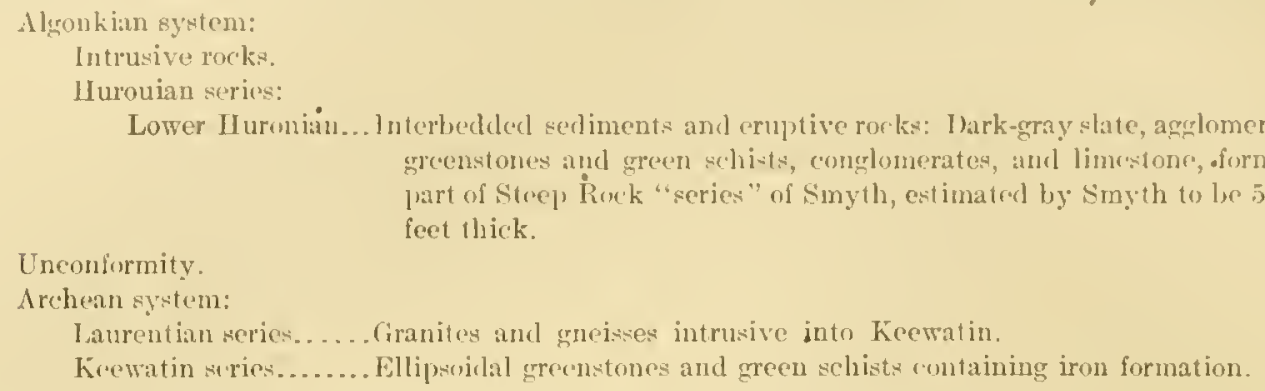

The lake resembles an irregular letter $M$, of which the western arm runs north and south and the eastern arm northwest and sontheast.

The lieewatin greenstones have a wide listribution on the south side of the lake, especially near Straw IIat Lake. They are in isolated areas surrounded and overlapped by the lower Huronian serliments. The principal showing of iron-bearing formation is southwest of Straw IIat Lake. It is in contact with elfipsoidal greenstone on the west side, but the relation on the east is not known. Lean iron ore also outcrops on the west side of the lake and in various other parts of the district. Glacial fragments of iron ore have been found on the south side of the lake opposite Mosher's Point.

The Laurentian granites anl gneisses are exposed principally on the north and east siles of the lake. Along the contact of the Laurentian and Keewatin in the southeastern part of the distriet there is a great series of hornblende schists intricately associated with both licewatin and Laurentian rocks. These are regarded as contact phases of the Keewatin where it is intruicd by the Jaurentian, similar in all respects to those of the Termilion district. Smytl regards them as overlying the lower Huronian sediments and as passing upward into the schists of Atikokan River, which he designates as the "Atikokan series."

The lower Huronian fringes the Laurentian on the southwest. Its principal exposure is on the south and west shores of the lake, but small patches of it rest against the granite on the points projecting from the east and north sides of the lake. It lips at $60^{\circ}$ to $80^{\circ}$ awa from the Laurentian. The basal conglomerate carries fragments of various phases of Laurentim and Keewatin rocks. Where the conglomerate rests against the granite it is made up so largely of granitic débris and has been so metamorphosed that it is frequently difficult to determine the exact contact of the granite and the sediments. According to Smrth, the succession ahove the conglomerate is: Jower limestone, ferruginous horizon, interbedhed crrstalline traps, ralcareous green schists, upper conglomerate, greenstones and greenstone schists, agglomerate, and dark-gray clay slate. Some of the greenstones and green sehists included by smyth in the lower Ifuronian are legarded by Herriam and by the authors as, at least in part, Keewatin unconformable beneath the IIuronian.

Acrording to Snyth, the Steep Rock group is fotded into an eastern synclinal, a middle anticlinal, and a western synclinal, the latter being faulted. The axes of these folds have a high pitch to the south, varying from $60^{\circ}$ to nearly $90^{\circ}$. Throughout the whole area is al regional cleavige which has a nearty uniform direction transverse to alt the members of the Stecp liock group and also to the contact between this group and the basement complex. This has larely obliterated the originat lamination of the sectiments and is now the dominant structure. It is therefore the ellect of the last foree which las left its marks upon the rocks of the lake. Before this hast force acted upon the rocks the Steep Rock group had been foldect into a southwestward-dipping monoctinal, which, uncter the action of the chearage-producing fore in a morthenst and southwest direction, anused the present fluted onterop of the formations of the Strep Rowk group. That the basement complex itself yiotled to this latter force is shown by the irregular outerops of the dikes eutting it.

At least three varieties of intrusives eut the Laurentian and fiecwatin and have supplied pebbles to the ennglomerate at the base of the lower Huronian. Other intrusives cut the 
Keewatin, Laurentian, and lower IIuronian rocks but have been subjected to folding. Finally, a single massive dike appear's to be subsequent to the latest perioul of l'olding.

\section{IRON ORES.}

Lean, banded iron-bearing rocks appear in the Keewatin of the Steep Rork Lake district. The principal showing is southwest of Straw Ilat Lake. The rocks are in contact with ellipsoidal greenstone on the west side, but the relation on the east is not known. Lean iron ore also onterops on the west side of the lake and in varions other parts of the listriet. Glacial fragments of iron ore have been foumd on the sonth side of the lake opposite Mosher's Point. Explorations southwest of Straw Hat Lake are reported to lave recently disclosed an ore deposit.

\section{ATIKOKAN DISTRICT.}

The existence of iron ore along Atikokan River and Sabawe Lake to the east of Steep Rock Lake requires mention of the geology of this area. The area has not been geologically mapped in detail.

As a result of visits to the district Mr. Merriam and the anthors believe the geology to be similar in all cssential features to that of the Steep Rock Lake and Vermilion districts-that is, there are represented in this district Keewatin, Laurentian, and lower Huronian rocks. The ores are in the Keewatin series.

The Atikokan iron ores are 3 miles north of the Canadian Northern Railway, on the north side of Atikokan River, just east of its expansion into Sabawe Lake. Here is a ridge of magnetite, green schist, massive grcenstone, and iron carbonate running approximately parallel to the river. The greenstone is essentially a diorite with a large proportion of hornblende. The magnetite is coarsely crystalline and dense and carries abundant amphibole and iron pyrites and small amounts of the nickel minerals. The relations of the magnetite and greenstones are complex, as in the Vermilion district, but as a whole the greenstone seems to be intrusive into the magnetite. To the west of the main magnetite exposure iron carbonate appears in similar relations to the greenstone. So intricate are the relations of the ore to the greenstone that it is difficult to determine the true shape of the magnetite deposit from the surface outerop. The bands are narrow, at most not more than 44 feet, and extend along the bluff for more than 400 yards. They are now being opened for mining. The ores will be roasted and used in furnaces at Port Arthur.

To the west, down the river, the iron-bearing formation is exposed with similar association to grecnstone and green schist at a number of places.

\section{KAMINISTIKWIA AND MLATAWIN DISTRICT.}

The Kaministikwia and Matawin district is characterized by lean, slightly magnetic cherts and jaspers in rertical bands and lenses, very irregular, closely associaterl with green sehist and ellipsoidal basalt typical of the Kieewatin scries. Granite and quartz porphyry intrude the Keewatin at many places. The association of the jasper' and grecnstone and porphrries presents all the problems of the Termilion district. The principal exposures are along Kaministikwia River between Kamịnistikwia and Mokoman. Just north of the railway, a mile north of Iokoman, is a jasper and greenstone breccia and conglomerate. The rock here exposed has essentially the features of a hreccia, but parts of it contain fragmental quartz ame are truly conglomerate, suggesting that it is perhaps the basal ronglomerate of the lower IIuronian.

Still farther south, near Kakabeka Falls, the flat-lying iron formation and slates of the Animikie group (upper Huronian) are cxposed along the river and at Kakabeka Falls.

Farther west in the same township (Commee) are more extensive outcrops of banded jasper in chert containing impure siderite. It is strongly magnetic.

Farther south in Conmee Township, on the sonth half of tot 7 in the sixth concession, the iron range is found again with a irend of abont northwest and southeast and a nearly vertical dip on a long ridge about 150 feet wide. The silica is mainly jasper, often of beantiful color, banded with magnetite, the bands often folded in complex ways, and here also there is more or less of a peculiar breccia of grained silica or jasper in a fine gray inatrix. 
In the southeast end of $\ln 7$ in the fifth concession there is finely banded jasper and some impure rarbonate intermixed, but on lot 4 in the third concession the rock is unusully black from the presence of magnetite, and some eperimens are heary enough to make fairly good ore. Rands having a wirth of 1 or 2 feet appear to be nearly solich magnetite and seem rich enough to work, though a small amount of pyrite present would lower the grade of the ore. The banding varies in direction from southeast to south; and here again a ronglonerate or breccia is commonly found mixed with the ore, the whole having a length of 10 chains and a width of 135 feet.

Altogether this series of iron depenitw has been traced for about s miles, running frarallet, it is sairl, 10 a similar range lorated by Pumpelly and Smyth 2 miles to the soutluwest; and probably both are continuations of the llatawin ranges, though eurving in al somewhat different direction. $a$

The XIatawin iron belt extends from Kaministikwia station westerly beyond Greenwater Iake. Banded magnetic and hematitic cherts and jaspers outcrop at many places on Matawin and Shebandowan rivers. West of this belt banded iron ores were seen outcropping at Copper Lake, sonth of Shebandowan Lake, and on the eastem shore of Greenwater Lake. Ores which probibly form an extension of the same belt oceur south of Moss Township, on the farther side of the inneiss area of Greenwater Lake.

\section{MICHIPICOTEN DISTRICT.}

The following account of the Miclipicoten distriet is taken largely from the writings of A. P. Coleman and A. B. Willmott ${ }^{b}$ and of J. M. Bell.c The present writers hare made no detailed snrver of the district, but have visited the area and acree with the essential conclusions reached by the men named.

\section{GEOGRAPIIY AND TOPOGRAPIIY.}

The Vichipicoten district, on the northeast shore of Lake Superior, is about 2.5 miles in length from southwest to northeast, with a greatest width of about 7 miles, and runs from the mouth of Dore River, a few miles beyond Parks Lake on the northeast. It lies northwest of Michipiceten River near its entry into the bay of the same name on the northeast side of Lake Superior and shows the rugged topography so characteristic of that shore.

The country rises rapilly from the lake in steep hills, often ridgelike, with the general direction of the strike of the schists about $70^{\circ}$ east of north, and culminates in the ridge of iron-range rock just east of the Helen mine, called Henatite Hill or Mountain, which reaches a height of 1,100 feet above the lake or 1,700 feet above the sea. This is the highest point for many miles around and makes a conspicuous landmark, though other hills reach a level of $s 00$ or 900 fect.

As Inematite Mountain is only 7 miles from Lake Superior, the rise is rapid, and the location of the railway to the Helen mine, which is at a level of 650 feet, just at the foot of the mountain, required some skill in the choice of a route, old lake beaches and sand plains being utilized where possible. $b$

\section{SUCCESSION.}

The succession of formations here given is that of Coleman and Willmott, but the names of the series are changed in accordance with the recommendation of the special committec on the Lake Superior region and the series are grouped into the Algonkian and Archean systems. ${ }^{d}$

Algonkiau system:

Huronian scries:

Lower-middle Iluronian (Basic eruptive rocks.

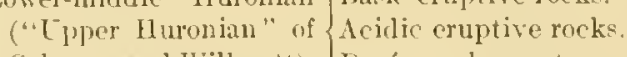

Enconformity.

Coleman and Willmott). (Doré conglomerate.

Archean sysicm:

Laurentian series........... Granites and gneisses intrusive into Keewatin series.

Keewatin serics ("I ower II (u- Eleanor slate.

ronian" "f Colemanand Will- Helen formation (iron-bearing).

mott). $\left\{\begin{array}{l}\text { Wawa tuff. } \\ \text { Giros Cap greenstone. }\end{array}\right.$

a Coleman, A. P., Iron ores of northwestrrn Ontario: Eleventh Rept. Ontario Bur. Mlines, 1902, p. 130.

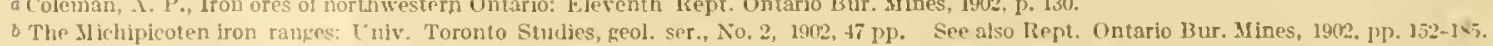

c Iron ranges of Michipleoten 16 est: Rept. Ontario Bur. Mines, vol. 14, 1905 pt. 1, pr. 27is-33\%, with geologic map.

d Report of the special comuittee on the Lake superior region: Jour. Geology, vol. 13. 1905, pp. s9-104. 
The geology of the Michipicoten district is remarkably similar to that of the Vermilion district of Minnesota in regard to lithology, succession, and structure.

\section{ARCHEAN SYSTEM. \\ KEEWATIN SERIES. \\ GROS CAP GREENSTONE.}

nISTRIBUTION.

The Gros Cap greenstone is well exhibited just west of Michipicoten IIarbor and on the trail to the old fishing station at Gros Cap.

The most extensive area of the Gros Cap greenstones is the one extending from Gros Cap east ward to Magpie River and thence north from Michipicoten River to the eastward bend of the Nagpie. Other large areas exist northeast of Eleanor Lake, including most of the shore of Loouskin Lake, and along the Josephine branch railway from mile $13 \frac{1}{2}$ to mile 17 .

Numerous smatler areas have been mapped. There are bands of greenstone and green schist in the Wawa tuff that liave the same characteristies.

PETROGRAPHIC CHARACTER.

The Gros Cap greenstone consists of ellipsoidally parted basic igneous rocks formed partly of lava flows, in all respeets similar to the Ely greenstone of the Vermilion district of Minnesota.

Many parts of the greenstones do not show the ellipsoidal structure and are apparently greatly weathered diabases, while still other parts are distinctly schistose; but the three varieties run into one another and can hardly be separated in mapping. The chloritic schists are probahly tuffs of the volcanoes which poured out the lavas. The whole series is greatly weathêred and saussuritic in thin sections.

WAWA TUFF.

DISTRIBUTION.

The extent of the Wawa tuffs and their boundaries can be given only approximately, partly because of the sand plains covering them and partly on account of the intermixed later eruptive rocks. Beginuing at the southwest is a narrow band of quartz porphyry sehist and felsite schist along the northern boundary of the Lore conglomerate area, between the latter rock and the Laurentian. Where the Dore conglomerates narrow toward the northeast, the northern fringe of quartz porphyry schist seems to widen rorrespondingly, though greatly interrupted by later acid and basic eruptives. Still farther northeast the sand plains of the Iagpie Valley hide the rocks almost completely, not to reappear until near Talbott Lake, where the Wawa schists are extensively developed. From here to the northeast end of the region mapped the Wawa schists are found on each side of the bands of the iron lange as the immediately inclosing rock:, except where broken by masses of greenstone or later diabase, and they extend northeast to the end of the region mapped.

PETROGRAPIIIC CHARACTER.

The Wawa tuff generally has the eomposition of quartz porphyry or felsite, and in some places eridently consists of mashed and rearranged rocks with crystals of quartz and feldspar still to be seen in them. In general, however, the formation ap parently consists of tuffs or ash rocks, probably erupted in connection with the quartz porpliyry and deposited in water, so that they lave a more or less stratified character. A few of them are brecciated, some crushed breecias, other's perhaps agglomerates formed of voleanic fragments larger than the asls. Some rare forms have much the appearance of water-formed conglomerates with rounded pebbles, one singular example of the sort occurring on a steep lill slope at the west end of Lake Wawa. In a general way this resembles a beach deposit witl pebbles cemented by a finer-grained greenish or yellowish matrix, but on eloser examination the apparent pebbles are found to be really concretions.

There is no sharp line between this phase of the rock, which occure in smaller amounts at olher points also, and varieties like ordinary quartz porphyry schist, so that one may suppose it to be merely a phase of the series of acid schist in which there has been concretionary action. 
Since the materials forming the schists were laid down, or ele during their th pusit, important chemical changes

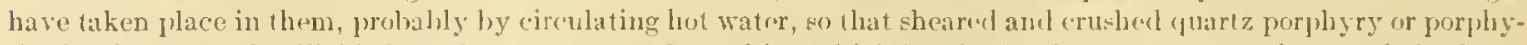
rite has been greatly silicifierl, at limes even trunformed into thick bands of pale-gray or green ehert or chaleedony, with a small amount of sericite. This phase is similar to parts of the Palmer gneise of the dlartfuette flistrict. In other cases a consichable amount of sickerite or of a carbonate like ankerite, dolomite, or calcite has been deposited with cryplocrystalline or microcrystalline silira, sugresting a change to the iron-minge rock which form the uppermet series of the lower lluronian. It is probahle that this change went on at the time when the original iron-range rocks were deposited and under the same conditions.

In a general way it may be stater that the Wawa tuff is aceompanied by lenses or banks of carbonates, including iupure siderites, dolomites, and limestones. In most places some gramular siliea also is present, and it may he that these lenses or bands are chemical sediments.

In a gentral way the Wawa tuffs tend to be more siliceous and to contain more siderite as they approarlh the iron range, and to be sonewhat coarser in grain and gneissoid in look on the sides toward the laurentian, as though the proximity of these rocks had influenced their crystalline character and chemical (omposition. The boundary between them and the Hclen iron-range rocks is sometimes quite sharp, a thin sheet of black slate oreasionally intervening between the two, but in other cases there are schistose varieties of the siderite of the iron range which form a transition toward the quartz-porphyry schists.

STRUCTULE AND THICKNESS.

Thy Wawa tuffa have on the average a strike of $70^{\circ}$ east of north, though with consiclerable local variations, and a dip toward the south of from $50^{\circ}$ to verticality. Near the Helen mine they are shown to form a synchine pitching toward the rast and inclosing in their trough the iron-range rocks. As the dip is much the same on each side of this synclinal axis, the fold must have been a closed one; and since it was formed erosion bas eaten down the Arehean surface until at various points, such as west of the Helen mine and south of Lake Eleanor, the iron range in the central trough has been completely removed, leaving the lower schists across the whole width.

The greatest measured thiekness of the schists is to the south of Sayers Lake, where they are known to reach across Lake Wawa, a distance of about two miles and a quarter, which at a dip of $70^{\circ}$ would give more than 11,000 feet.

HELEN FORMATION.

DISTRIBUTION.

Beginning at the southwest, several bands of the granular silica variety occur on the Gros Cap Peninsula, the largest being at the Gros (ap mine on the south shore of the peninsula. ${ }^{a}$ The materials here are "luert aud granular silica interbanded with hematite, and the width is in all about 150 feet. To the east another narrower band of rusty siliceous rock is seen, and just around the eastern point, near the beacon, is a third still narrower band, differing from the others in containing magnetite and much pyrite. 111 of these bands of iron range run about northwest and southeast and have a dip of perhaps $50^{\circ}$ to the southwest. A similar band is seen on the west shore somewhat south of the portage aeross the neck of the peninsula, probahly an extension of ove of the bands mentioned before. About 150 yards unrth of the portage are several narrow bands of the rock, usually very pyritous, aseociated with quartz porphyry schist and striking about east and west with a dip to the south. This belt probably extends to the east, where an outerop of brown sandy-looking grained silica occurs a little inland from the old fishing station. The band just mentioned is nearly parallel to the great area of schist conglomerate to the north and is the nearest part of the iron range to it, so that it may have furnished part of the jelsbles of granular silica in the conglomerate.

Two or three small patches of the iron range are found in the greenstone east of Hichipicoten Harbor. after which no more is known for alsout 8 miles, when the Helen iron range begins. All of the outcrops mentioned thus far aj'prear to be inclosed in the greenstones as if swept off eruptively.

The principal belt outcrops near the IIclen mine.

Beginning on the west, the iron lange as found at the Uelen mine is in twe long fingers reaching the shore of Tallont Lake, but not crosiner it. The southern finger, long and narrow, possibly reaches a slurt distance into the water of the lake, but does not apjear on the opposite side. It "xtends eastwardly up the valley of a small creek until it reache's the mairs bexly of the formation near Sayers Lake. Following the boundary northward are several minor folds which are seesn to rest on Wawa tnffs. Then crussing the railway track near the nutlet of the lake, the runge extents westward down to the shore of the lake, where it comes to an end within a few feet of the shore, being bottomed by Wawa tuifs.

$\Lambda$ comparatively recent development has been the funding of a large band of iron-benting formation within '2 niles to the northwest of the Helen mine in ath aren which was supposed to have been carefully explored. It is associated with a thick belt of black slate, but most of the inclosing rock is of the Gros ('ap and Wawa formations. 
On the north sicle the range seems to extend quite regularly toward the east, the formation standing almost vertically. [lirom the Helen mine the range] runs for a mile and three-quarters a little north of east, when another interruption occurs, thought by some to be caused by a fault. The evidence for this does not seem conclusive, and more careful exploration may bring to light in the heavily wooded region to the east sone links connerting it with the Lake Eleauor band, which commences after a gap of a mile and a half and runs northeast to the Grasett road between Lakes Wawa and Eleanor. The roacl follows a depression between bills that probably represents a liue or zone of faulting, for the iron range here jogs three-eighths of a mile to the north and then continues the asual strike of about $60^{\circ}$. Between the two main outcrops and just east of the road are two small ridges of rusty granular silica pointing a little east of north, perhaps remmants left during the dragging of the strata in faulting.

The iron range south of Lake Eleanor gives the best exposure of the range between the Ifelen and Jorephine mines. In a general way it suggests that of the Helen mine, though on a smaller scale.

The strike of the irou-range rocks at the extreme southwest end is not far from noth and south, with a dip running from $30^{\circ}$ to $90^{\circ}$ to the east, pointing toward the two hills of granular silica to the east of the road. Less than 100 paces eastward along the top of the ridge the strike becomes $60^{\circ}$ to $80^{\circ}$ and keeps this direetion until the east end of the little lake is passed, when it changes to $45^{\circ}$ ior a shor distance, and the range ends abruptly in a mass of greenstone. lieyond this it has not been traced, but the comtry is very mossy and forest covered, so that it is hard to say positively that there may not be exposures of the iron range yet undiscovered.

The next point at which the iron-bearing rocks have been found is $2 \frac{1}{3}$ miles to the northwest of the Lake Eleanor range, where they begin just east of a long unnamed lake and rum about $60^{\circ}$ east of north past the north side of Brooks Lake almost to Bauldry Lake, a distance of about 2 miles. IJere again a fault of great magnitule has been suggested, the plane of faulting running northwest and southeast; and there is much in favor of this view, though it ean not be said to have been proved, since very little work has been done ou the geology of the country between the two iron ranges. The only rocks known to exist between them are greenstones and green schists.

The iron-bearing formation appears again near the sonth side of Bauldry Lake and extends eastward past the south sirle of Long Lake. Begimning at Goetz Lake and ruming east through Brooks Lake and Kimball Lake is a considerable belt of iron formation, on which the Josephine mine is located. Ore has been found here in small amount by drilling, but has not been mined.

$$
\text { STRUCTURE AND THICKNESS. }
$$

In a general way the rocks of the Helen iron formation, though so narrow, rarely exceeding 1,000 feet in width, are the most distinctive features of the lower Huronian, since they are very easily recogaized and nearly aiways rise as sharp ridges above the surrounding region. Except on Gros Cap, where the bands strike about northwest and southeast, the different ridges have a surprising uniformity of strike, about $\mathrm{N} .60^{\circ}$ to $70^{\circ} \mathrm{E}$., the sane clirection as one finds prevalent in the adjoining schists. Though the general strike is so uniform, it is evident that along with the other rocks of the region the iron formation has been interrupted frequently by eruptive masses, and apparently also by faults of great magnitude, the effert always being to shift the part east of the fault plane toward the north.

It is probable that the bands of iron range are not simple tilted strips of rock but closely folded sheets, only the lower portion of which is still preserved, and it may be that the apparent gaps between the ranges are really due to the erosion of the general rock surface so far down as to cut off the folded upper part of the lower Huronian altngether, leaving only the schists heneath. If this is the case the depth to whilh the iron-bearing rocks descend may be quite limited, though the amount of mining and diamond drilling done on the range does not give very certain evidence in this respeet.

The iron-bearing formation at the Helen mine underlying the Boyer Lake basin is peculiar in that the lake bottom is much below the ontlet. The origin of this is discussed elsewhere (p. 158).

PETROGRAPHIC CIIARACTER.

Five species of rnek may be distinguished in the iron-bearing Helen formation-banded granular silica or fermginons cherts with more or less iron ore, black slate, siderite with varying amounts of silica, grünerite sehist, and pyritic quartz rock. All are foumd well developed at the Helen mine, and all but the grünerite schist have been found in the Lake Eleanor iron range also; granular silica and silerite occur in large quantities in every important part of the range, though small outcrops sometimes show the silica alone. The ferruginous cherts are in many places soft and sandy, like the ferruginous cherts or taconites of the western Mesabi. Jaspery varieties have not been found on this range, but they oceur only a few miles to the north.

RELATIONS TO OTHER FORMATIONS.

The IIelen formation is very closely related to the Gros Cap greenstone and Wawa tuff. Its relations to the associated rocks of the Keewatin series are almost identical with the relntions of the Soudan formation of the Vermilion district of Minnesota to the arljacent Keewatin 
rocks. In general the iron-bearing formetion from its strueture seems to be at upjer norizons of the Keewatin and to rest on the other rocks, being folked in with them; but the formation has been also intruted by basie rocks which have been mapped as Gros Cap greenstone, and some of then may be interbedded with the surface flows of the Gros ('ap greenstome. For a discussion of the problem the reater is referred to the chapter on the Vermilion district and also to the discussion of the origin of the ores. (See Chipters V, pp. 118 et seq., and XVII. pp. 460 et secl.)

\title{
ELEANOR SLATE.
}

In addition to the slates of the Wawa formation, slates of a distinctly sedimentary kind oceur as thin bands in the northeastern part of the region near Eleanor Lake and elsewhere. Slate or shale of the kind describerl is traceable at intervals for a mile along the north shore of Parks Lake, and is found underlying the Dore conglomerate north of Eleanor lake on the Grasett road. They are buff to dark-gray or black rocks with slaty cleavage, sometimes forming an angle of $25^{\circ}$ with the well-marked bedding. Some varietics of them are carbonaceous, and at a point east of 11 awa Lake such a slate waty taken up as a coal mine. Whether the black graphitic slate often connected with the iron ranges belongs with Elennor slates is not certain, nor has it been determined positively whether the slates are older or younger than the adjoining iron-bearing rocks.

\section{LAURENTIAN SERIES.}

The Laurentian series includes rarious types of granite, quartz porphyry, quartz porphrite, felsite, and quartzless porphyry. They are intrusive into the Keewatin series and in part into the overlying lower-miellle Huronian sediments, but in large part also they lic unconformably below the IIuronian, as is shown by the numerous pebbies of Lalurentian gneiss and granite included in the basal conglomerate of the IInronian. It is not desirable that all these intrusives should be classed with the Laurentian, as that term is properly applied only to the pre-IInronian rocks, but they hare not been sufliciently weil discriminated and mapped to warrant al separate classification.

\section{ALGONTIN SISTEM. HURONIAN SERIES.}

\author{
LOWER-MIDDLE HUROYIAY.
}

DORE COIGLOMERATE.

\author{
DISTRIBUTUN, TOPOGRAPIY, AND STRUCTURE.
}

The conglomerate occurs from point to point along the shore as far as Dig River, 10 miles to the west, and eastward to about the third milepost on the railway from Hichipicoten Harbor to the Helen mine, a distance of $t$ miles: while the greatest width measured during last summer's work is about a mile and a half, on a line due north of the harbor.

In general the topography of the conglomerate hand is very rugged and hilly, with numerous suressive ridges running parallel to the strike, which a verages ahout $70^{\circ}$; and with very steep slopes on each side, but especially toward the north, where the narrow hills often drop off vertically or even overhang. The cause of this is to he fouml in the uneqnal resistance of the different layers to weathering and in the fact that the dip is usually very sldep. from $60^{\circ}$ to $90^{\circ}$, averaging ahout $75^{\circ}$ to the south. Dijs to the nortl have only rarely leen noticed. The steep cliffs formed in the way described often have a height of 50 or more feet, and on the north side are frequently nuscalable for considerable distances. Perhaps the most ruggel portion of the region is directly north of Michipicoten IIarhor. where within 2 miles of the shore there are several of these rildges, with talleys between, rising finally to over 600 feet above Lake Superior.

While the general strike is about $70^{\circ}$ there are great local variations, especially in the vicinity of eruptive masses. Near the second mile on the railway the strike is nearly north and south for more than $400^{\circ}$ yards, hut on each side the usual directions of from $70^{\circ}$ to $75^{\circ}$ are found. There is good reason to believe that in general the strike of the schistosity corresponds to that of the sedimentation, for bands of rock frse irom pebbles follow the same direction, but in af few cases the schistose structure seems to (ross the direction of sedimentation, having a bearing of about $45^{\circ}$, while the general course of the ridges is $70^{\circ}$ io $80^{\circ}$.

PETLUGRAPHIC CHARACTER.

The conglomerates are for the most part harge and well romeded. They consist of darkgreen schist, granite, ferruginous elert, spotted grar-green sehist, porphyry, felsite, and congloncrate or breccia. All have been more or less flat tened during the derelopment of schistosity in the rock. 
The conglomerate is in many places penetrated by dikes of quartz porpliyry, or sonetimes quartzloss porphyry, running parallel to the stratification as a rule, and in many cases squeezed or sheared intu folsite suhist in which the porplyyritic structure is almost lost.

In addition to the porphyry dikes there are numerous masses and dikes of rliabase rising through the conglomerate, apparently later in date than the porphyries, since they are seldom squeezed into schists so far as observed. The diabase seems to be the most resistant rock of the region with the exception of the iron range of the IIelen mine, and accordingty forms in many cases the tols of the highest ridges.

\section{THICKNESS.}

The general attitude of the large area of schist ronglomerate just describerl suggests a continuous series of strata, as supposed by Logan, since in most cases the dip and strike are fairly uniform; ancl any marked variations may be accounted for by the presence of eruptive rocks. This would give them a thickness of about 7,500 feet, for the greatest width is 8,000 feet, with an average dip of about $75^{\circ}$.

However, it is not easy to imagine the mass as tilted bodily, and it is more natural to think of the series as forming a close fold, most probably a syncline with the two sides closely squeezed together, and tilted slightly against the Laurentian mass to the north. In this case we may suppose that the schists were to some extent pulled asunder at the base of the fold, which was in tension, allowing the felsites and diabases to penetrate parallel to the cleavage. There is no doubt, however, that some of the diabase dikes are later in age and cut diagonally arross the schistose structnre.

One feature of the arrangement of the conglomerates supports the view that they form a syncline. Toward the western end of the series of rocks we find bands of well-defined conglomerate along each side with gray and green schists showing few or no pebbles between, as if there was an upper layer of finer sediments nipped in between the two sides of the conglomerate. The absence of pebbles in this central area may, however, be due merely to a greater amonnt of compression, flattening them beyond recognition. Toward the eastern end there are very few gaps where pebbles have not been seen.

RELATIONS TO LNDERLYING ROCKS.

The Doré conglomerate near Michipicoten IIarbor is nowhere found in contact with untoubted Archean rocks, though what look like Wama tuffs and have been mapped as such occur as a narrow band to the north between the conglomerate and the Laurentian; and schists with some granular silica, certainly lower IIuronian, are found near the north end of the peninsula of Gros Cap, though a small sand plain separates them from the conglomerate. The Laurentian ernptives have not been seen in actual contact with them on the north, though some belts of green schists in the Laurentian a little way from the bidden contact may be greatly metamorphosed conglomerate swept off at the time of eruption.

The relationship to the sonth is more distinct, and the Gros Cap greenstoves appear to be the underlying rock folded into a syncline with them; so that south of the railway half a mile from the harbor the greenstone seems to overlie the conglomerate, both having a dip of about $70^{\circ}$ to the south.

The pebbles, however, are clearly derived from the rocks of the adjacent lieewatin and Laurentian. Their variety and large size characterize the conglomerate as a basal conglomerate marking a great unconformity.

\section{MICIIPICO'TEN EXTENSIONS.}

Many areas of iron-bearing rocks near the Michipicoten district have been reported and mapped by Coleman, Bell, and others. Their lithology and association are similar to those of the Michipicoten distriet. No attempt will be made here to describe in detail the individual belts. None of them are productive and in few of them have detailed geologic maps been made.

J. M. Bell ${ }^{a}$ has reported on the iron ranges of Michipicoten West, covering the northern and western extensions of the producing Michipicoten iron-range district, adjacent to Michipicoten Bay. The northern range lies between Magpie River and the western branch of Pucaswa River, practically continuous with the old Michipicoten range. The western range, separated from the other by gramite, lies between Otter Ilead and Bear River, on the Lake Superior shore, and extends but a short distance north of Lake Michi-Biju. The lithology and sucession are essentially the same as in the Michipicoten district. The IIelen formation consists of sideritic and pyritous cherts, jaspers, amphibolitie schists, siderite, iron ores, quartzite phyllites, and biotitic and epidotic schists. For the most part the iron-bearing bands are lean ore. Exploration has been carried on somewhat extensively at Iron Lake, Frances mine, and Brotherton Hill, 
at the Leach Lake bands in the northern range, and in Laird's claims, the .Julia River bands, the David Katossin claims, and the lost Lake claims in the western range, but no importanı ore deposits hare yet been found.

\section{TIE IRON ORES OF TILE MICIIPICO'TEN DISTRIC'T.}

By the authors and WV. J. MEAD.

GENERAL STATEMENT.

The Michipicoten district his one producing mine, the Ilelen. The Ilelen ore bouly hes in a great anphitheater opening westwand on Boyer Lake, the east wall of which is formed ly iron carbonate, the north hy ferruginous cherts, aud the south by Wawa tuff. The tuffs and ferruginous wherts stand vertical. Boyer Lake has been drained, and the basin, a yuarter of a mile long and 130 feet deep, is apparently cut out of solid rock. A dike of diabase rrostes the basin from north to south near its east end, as shown by mining operations, and its outcrop on the edge of the basin can now be seen. Most of the ore mined is enst of the dilie, lut ore is known west of it. IIining operations are 300 feet below the original level of Boyer Lake. The ore body seems to dip eastwart as if passing under the siderite hill. A drift under this hill has developed several hundred thousand tons of iron pyrites. Along the soutl marrin of the ore body ocher or paint rock marks the limit against the green schists. To the north the ore runs gradually into lean material, with too much white silica to be worth mining.

CHEMICAL COMPOSITION.

Following is the average analysis of all ore shipped from the Michipicoten district in 1907 :

Average composition of all ore shipped from the Wichipieoten district in $190 \%$.

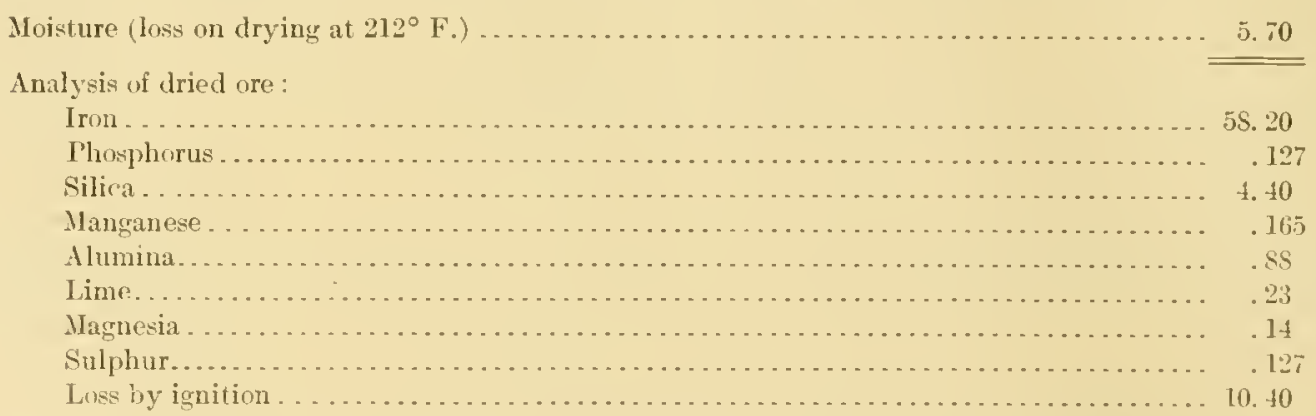

Chemically the ore most rlusely resembles some of the more hydrous Mesabi ores. It is low in alumina and high in combined water, which makes almost all of the loss on ignition.

MINERAL COMPOSITION.

Mineralogieally the ores are male up of hydrated iron oxide and silica, with small amounts of clay and other minor constituents. The following approximate mineral composition was calculated from the above arerage analyses:

Mineral romposition of Michipicoten ores, culculatcd from above analyses.

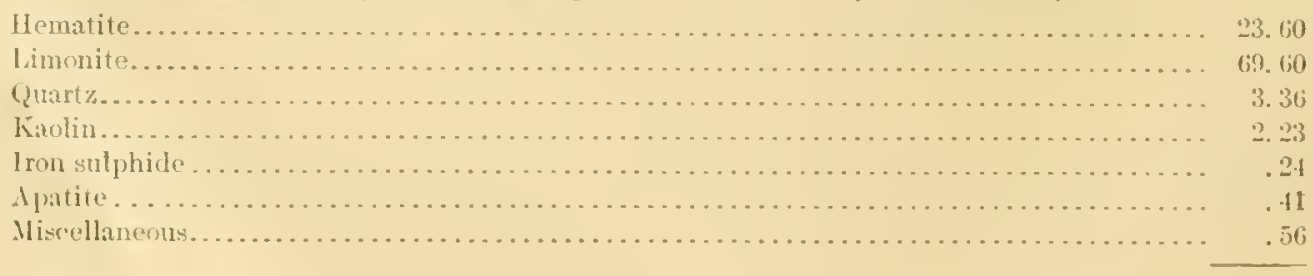


The hydrated ferric oxide is calculated as hematite and limonite in order to afford comparisons with other ores similarly calculated. It is known that hydratad iron oxides other than limonite are present, and it is probable that practically all of the ore is more or less liydrated; hence the amount of hematite present is probably less than is indicuted above. No phosphorus minerals lave been identified, but the presence of ealeium suggests calcium phosphate (apatite). Calculation shows, however, that sufficient calcium is not present to arcount for all the phorphorns as apatite. Iron sulphicle is locally abumdant in the ores, occurring in pockets of "pyritic sand."

\section{PHYSICAL CHARACTERISTICS.}

Color and texture.-In color the ore ranges from light-yellow ocher, suitable for paint, through a variety of slades of red and brown to dark brown or nearly black. In texture the ore varies from soft earthy material to rougl, slaghike limonitic ore, and locally hard blue hematite is found.

Density.-The average mineral density of the ore, calculated from the arerage mineral composition given above, is approximately 3.5 .5 .

Porosity.-The porosity of the ore varies to an extreme degree, ranging from a minimum of less than 5 per cent in the dense ore to a maximum of over 50 per cent (locally 60 per cent) in the limonite. The average is rather difficult to estimate, but is probably between 30 and 40 per cent.

Cubic fot per ton. - Owing to the extent to which it varies in density, porosity, and moisture, the cubic content of the ore ranges within wisle limits. The average is approximately 13.5 cubic feet in ton.

\section{SECONDARY CONCENTRATION OF THE MICHIPICOTEN ORES.}

The Helen mine has impervious walls, but the direction and nuture of the concentrating waters are not yet clear.

The iron-bearing formation was originally cherty iron carbonate. The hill east of the ore body exhibits one of the largest masses of inaltered carbonate known in the Lake Superior region. The alteration of the iron carbonate can be seen in all its stages, first into fermginous chert and then into ore, and locally direetly into ore. The bottom of the lake basin is partly corered with large masses of yellow ocher dissolved from the carbonate and redepositer.

The iron carbonate is thoroughly impregnated with sulphide minutely disseminated through the carbonate and in veins in it. During the alteration of the iron carbonate to the iron ore this sulphide has remained relatively intact, for it is included with the oxiles of iron in large masses. In the deeper levels of the Helen mine the iron sulphide is in such large masses as to constitute a great obstacle to mining. Nerertheless, some of the sulphicle has been altered and is represented in the limonite forming the lake bottom. The waters of the lake are highly charged with sulphuric acid, which has a strong deleterious effect on the pipes.

Associated with the limonite in the lake bottom is a peculiar green mud, the composition of which is as follows:

Analysis of derk-green mud from lake bottom.

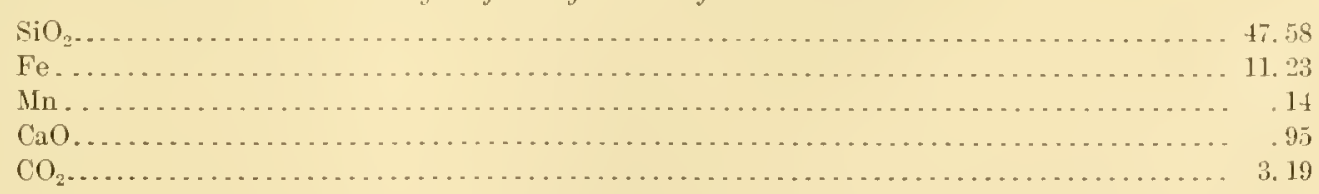


Embedded in this mud was found a glacial bowlder ronsist ing largely of serpentine, showing peripheral alteration to a depth of several inches. Analyes made by $\dot{R}$. D. IIall of the center and outer portions ane as follows:

Anrlysess of allered boulder from bottom of Boyer bake.

\begin{tabular}{|c|c|c|c|}
\hline & $\begin{array}{l}\text { Center of } \\
\text { bowlder. }\end{array}$ & $\begin{array}{l}\text { Nutered } \\
\text { portion. }\end{array}$ & $\begin{array}{l}\text { Atered } \\
\text { jortion, } \\
\text { assuming } \\
\text { Fong } \\
\text { constant. }\end{array}$ \\
\hline 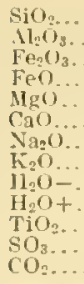 & $\begin{array}{r}3.1 .36 \\
3.45 \\
1.4 \\
1.42 \\
31.42 \\
3.22 \\
.11 \\
.99 \\
.20 \\
7.44 \\
.13 \\
.16 \\
\text { Trace. }\end{array}$ & 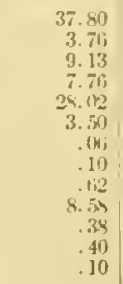 & $\begin{array}{r}28.30 \\
2.42 \\
1.44 \\
5.41 \\
21.00 \\
2.12 \\
.04 \\
.07 \\
.46 \\
0.41 \\
.24 \\
.30 \\
.07\end{array}$ \\
\hline
\end{tabular}

The imer portion of the bowkler was a dense dark-yreen rock and the altered portion a lighter-grcen earthy material. The alteration appears to have becn brought ahout essentially by solution. Oxidation has been practically nil, as has also carbonation. The ferric iron occurs essentially as magnetite. If this mineral is assumed to hare been maltered, it follows from a comparison of the first and third columms in the above tablc that there has been a loss of all constituents except ferric iron, $\mathrm{SO}_{3}$ and $\mathrm{CO}_{2}$. The nature of the alteration difler's essen- . tially from typical weathering.

The abundant evidence of decomposition of the substances of the lake bottom and the presence of sulphuric aciel in the lake waters have suggested to Coleman and Willmott ${ }^{a}$ that Boyer Lake represents a solution basin. The bottom of the lake is ronsiderably below its outlet. Though decomposition has undoubtedly aided in the erosion of the lake bottom. there is also evidence, summarized by Martin (see pp. 430-431), that the lake basin is a glacial cirque developed largely by mechanical means. 


\section{CHAPTER VII. THE MESABI IRON DISTRICT OF MINNESOTA. ${ }^{*}$ GENERAL DESCRIP'TION.}

The Mcsabi iron district lies in the part of Minnesota northwest of I Lake Superior. In shape and trend it is similar to the other iron districts of the lake Superior regrion. (See Pl. VIII, in pocket.) It extends from a point west of Pokegama Lake, in T. $142 \mathrm{~N}$., R. $25 \mathrm{~W}$., east-northeast to Birch Lake, a distance of approximately 110 miles, with a width varying from 2 to 10 miles. Its area is about 400 square miles. To the east from Birch Lake to Gunflint Lake and beyond are small patches of iron-bearing rocks, constituting remnants of an eastward extension of the Mesabi district.

The main topographic feature of the district is a ridge or" "range" parallel to the longer direction of the district, known as the Giants or Mesabi Range. ${ }^{b}$ Mesabi (spelled also Mesaba and Missabe) is the (hippewa Indian name for "giant." In the west end of the distriet the Giants Range merges insensibly into the level of the surrounding country, about 1,400 feet above sea level, or 800 feet above Lake Superior. Toward the cast the elevation with reference both to Lake Superior and to the surrounding country increases; from range is to range 12 elevations of 1,800 and 1,900 feet above sea level, or 400 and 500 feet above the level of the surrounding country, are reached. For many miles both north and south of the range there is a comparatively low, flat area, and the Giants Range, particularly its eastern portion, is a conspicuous feature in the landscape.

While the general trend of the range is east-northenst, there are many gentle bends in the crest line, and in range 17 a spur known locally as the "Iorn" projects in a southwesterly lirection for 6 miles. The crest of the range is in places broad and flat, in others comparatively narrow and sharp. The southern slope is very gentle; the northern slope is somewhat less so. At short interrals both crest and slopes are notched by drainage channels.

The Giants Range for the most part forms a drainage divide, although it is crossed by drainage channels at several places. The drainage of the district is apportioned among three of the great river systems of the country-the Mississippi, St. Jawrence, and Netson.

The succession of formations in the Mesabi district appears in the following statement:

Quaternary system:

Pleistocene series.......... . Deposits of late ITisconsin age.

Lnconformity.

Cretaceous system.

Unconformity.

Algonkian system:

Keweenawan series........... Great hasal gabbro (Duluth gabbro) and granite (Embarrass

Unconformity.

granite), intrusive in all lower formations.

Huronian series:

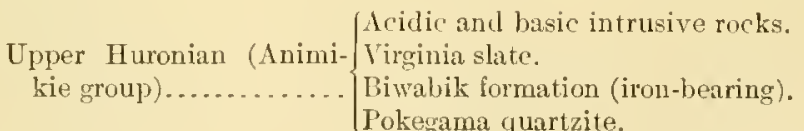

Unconformity.

Giants Range granite, intrusive in lower formations.

Lower-middle Iuronian. . $\begin{aligned} & \text { Giants Range granite, intrusive in lower formations. } \\ & \text { Slate-graywacke-conglomerate formation (equivalent to the } \\ & \text { Ogishke conglomerate and Knife Lake slate of the Vermilion } \\ & \text { district). }\end{aligned}$

$\alpha$ For further detailed description of the geology of this district see Mon. U. S. Geol. Survey, vol. 43, and references there given. Lining men and others have cooperated cordially in the preparation of this chapter, liut we would acknowledge particularly our inclebtedness lo Mr. J. U. Sebenius, who, having been in charge of explorations in the Mlesabi district since its discovery and being now chief engineer of the Lnited States Steel Corporation, has perhaps closer knowledfe of the geology of the iron-l earing rocks here than any other person.

$b$ For the use of the terms "Giants Range" and "Mesabi range" in this report, see footnote on p. 41 , also Mon. U. S. Geol. Survey, rol, 43 1903, p. 21. 


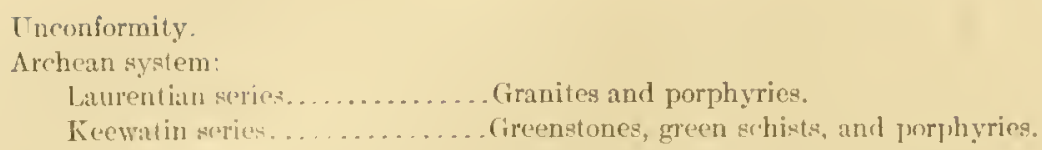

The "ore of the Ciants Range is made up principally of grmute of Iower-middle Ifuronian and Linweenawan age amel subordinately of Archean igneonts rocks. "lo the south of the irneons core, for a pant of the distrid, are lower-middle Huronian sedimentary rocks, with bedding approximately rertieal. Aganst the southern boundary of the lower-middle IInronian, or, where the lower-middle IImonim is lacking, against the igneous core, lie the upper Huronian schimentary rocks (Animikie group). They dip gently to the south and underlie the greater portion of the southerly slopes of the range. On the sontheast tho IImonian rocks are limited by the Keweenawan Duluth gabbro, the north edge of which cuts across the Iluronian formations diagonally from southwest to northeast. The Archean, lower-middle Iuronian, and upper IIuronian are separated from one another by unconformities. Glacial drift covers the district so thickly that rock exposures are rare on the lower slopes of the range and only fairly numerous near the crest.

\section{ARCHEAN SYSTEM OR "BASEMEN'T COMILEX."} DISTRIBUTION.

The Archean rocks of the IIesabi district are confined to its central portion. They are found north ani northwest of Nashwauk; northwest of Hibbing; north and northeast of Jiountain Iron: in the southerly projection of the Giants Range known as the "IIorn," bouncled by the cities of Virginia, Ereleth, Sparta, and McKinley; north of Biwabik; and east ward nearly. to the east line of R. 16 W. With the exception of the portion of the Archean area cast of Embarrass Lake, exposures are sufficiently common to allow a fairly close determination of the boundaries. East of Embarrass Lake the mapping is based on the presence of abuntant Archean fragments in the clrilt.

Included in the areas mapped as Archean north of Mountain Iron are sereral small patches of lower-midtlle Huronian rocks. Exposures are so flew, they are so mixed in the same exposure with Archean rocks, and they are metamorphosed to such difliculty recognizable forms that their accurate delimitation on the general map is not possible.

\section{KINDS OF ROCKS.}

The Archean is represented, abont in order of abundance, by micaccous, chloritic, and homblentic schists, basalts, dolcrites, porphyritic rhyolites, granites, and diorites. The basic rocks lave commonly a green color and are usually referred to locally as greenstones or green schists. They are giren one color on the greneral map of the Mesabi district and are to be correlated with the Kecwatin series (Pl. VIII). The acidic inneous rocks, consisting of the porphyzitic rhyolites and the granites, are mapped under another color and are correlated with the Laurentian.

All these rocks have their counterparts in other iron districts of the Lake Superior region. In the Termilion and Crystal Falls districts, where especially woll developed, Clements has described each phase in great detail. For details of petrography the reader is referred to the description of the Archean rocks in the monographs on the Crystal Falls and the Vermilion (listricts. ${ }^{\circ}$

Nowhere it the district have seliments been found which are demonstrably of Archean age, but state fragments in the basul conglomerate of the lower-micllte Iluronian point to the former existence of Archean sediments. 
STRUCTURE.

Most of the Archean rocks show some cleavage, and perhaps aluout half have enough cleavage to warrant calling them schists. In general the plane of cleavage is nearly vertical' and strikes parallel to the range, about $\mathrm{N} .60^{\circ} \mathrm{E}$. The hornblendic schists north of Mountain Iron have a cleavage of a linear parallel type, and the lines of the cleavage dip steeply to the northeast. In addition to cleavage, there are many joints and faults with displacements of a few inches or feet, but no regular systems have been determined.

\section{ALGONFIAN SYSTEM.}

HURONIAN SERIES.

LOWER-MIDDLE HURONIAN.

DISTRIBUTION.

Sedimentary rocks of lower-midlle Furonian age appear in two considerable areas in the Mesabi district. One with an avernge width of perhaps a mile extends from Eveleth northeast to Biwabik; the other, somewhat less than a mile in width, extends from near the Duluth and Iron Range Railroad northeast to near the center of sec. 11, T. 59 N., R. 14 W. In the former belt there are areas of grcen schist forming the cores of the hills. One of them has been mapped, but others, though their presence is known by isolated exposures, are not sufficiently exposed to warrant their separation on the map. A number of small patches of lower-middle IIuronian sediments are known also in other parts of the district.

Granite of lower-midlle ITuronian age forms most of the core of the Giants Range and, except morth of Mountain Iron, where it is interrupted for a short distance by Archean hornblendic schists, is exposed continuously along the crest to where it is succeeded on the east by the younger Embarrass granite in R. 14 W. This lower-midlle Huronian granite, known as the Giants Range granite, thus bounds on the north the other formations for most of the district. Det ailed work has not gone farther north than the granite boundary.

GRATWACKES AND SLATES.

The interbedded graywackes and slates form the greater part of the lower-mistle Huronian sediments. They are dull clark-gray and dark-green rocks which usually weather to a somewhat lighter green or gray or to a dirty light yellow. The grain is usually fine, although it varies considerably. The bedding, shown by both color and texture, is conspicuous. Parallel to the bedding a secondary cleavage has been developed. As a result of variation in texture, bedding, and secondary cleavage, there appear all gradations between metamorphosed coarse graywackes, banded graywackes, and finely fissile slates. Along the parting plane of some of the graywackes and slates may be seen glistening plates of mica or chlorite, conspicuous because of the fact that they appear in separate spangles on the dark background rather than in continuous layers, although, indeed, some of the more fissile slates show nica and chlorite in the continuous layers characteristic of slates.

The graywackes and slates above described have resulted from the alteration of fine mud and feldspathic sand deposits. Some of the mica, especially that in separate clear-cut plates, may hare been originally deposited in its present position, but most of it, and especially that in continuous sheets on the parting surfaces, is undoubtedly a secondary development due to dynamic movement in the rock.

The intrusion of granite below described has further greatly metamorphosed the graywackes and slates. In approaching the granite they become more chloritic, hornblendic, and micaceous, and a marked and usually much contorted schistosity obliterates the bedding. Under the microscope may be scen abundant development of secondary chlorite and hornblende and a 
lesser development of secondary biotite and museovite. A ceessorios include tourmaline, staurolite, garnet, rutile, ilmenite, magnetit's, and apatite. The alteration of the ilmenite and rutile (1) sphene (titanomorphic) is well exhibited.

CONGLOMERATES.

The conglomerates are abundantly and typically exposed in a belt rumning from the cut aloner the Duluth and Iron Range Railroad, in sec. 22, T. 58 N., K. 17 W., soutluwest throurh secs. 22 and 21 into sees. 20 and 29, T. 58 N., R. 17 W. Similar concrlomerutes are known in small patches bordering the greenstones north of the Genoa mine at Sparta.

The conglomerates are massive roeks for the most part, with various shades of green on fresh surface and a tighter green on the weathered surlace. The pebhles vary in diameter from 6 inches to a small fraction of an ineh. In kind they are, for the most part, identical, hoth macroscopically and microscopiealty, with the rocks of the Archean above described, including diabases, basalts, and granite porphyries. The more basie pebbles are in greater quantity than the acid ones.

The conglomerates, in common with the rest of the lower-mikllte IIuronian rocks, have suflered metanorphism, but the extent of the alteration varies greatly from place to place. East of Mariska, in the railway cut referred to, the rocks show only recrystaltization of the mineral particles, without marked derelopment of schistosity. The alteration of the minesals is the same as that described alove for the rarious rocks of the Archean. To the southwest of this cut the conglomerates have been much squeezed and are now very schistose. The recrystallization accompanying the squeezing has made the rocks very chloritic and mieaceous, and, in many places at least. has completely obliterated the elastic texture in the finer-grained portions. The pebbles have been elongated in the plane of schistosity (rertical and striking N. $60^{\circ} \mathrm{E}$.), and on the weathered surface stand out in lenticular and oral forms from the finer, more sehistose, and more easily croted matrix. Rocks of this character may be traced into sehistose rocks in which, in pebbles and matrix alike, nearly every restige of sediment ary texture has been lost.

GIANTS RANGE GRANITE.

It Birch Lake the lower-midlde Huronian granites are coarse gray and pink hornbtende granites. From the east line of R. 14 W. to the neighborhood of Mount ain Iron the granites are similar to those on Birch Lake. It is noticeable that the coarser phases appear in the eastern ent of this area. The homblente varies in abundance, but is usually conspicuous. Rarely, as near the Maltman eamps, the tark constituent is angite instead of hornblende, or, again, it may be partly biotite. In places the rock becomes very slightly gneissic, and immediately next to its contact with the lower-middle Inronian sediments it becomes very fine grained. Next to the contact of the granite with the Keweenawan Duluth gabbro on Bireh Lake is a metamorphic rock resembling granite, which is sescribed in connection with the gabbro.

From the neighborhood of Mountain Iron westward to the west end of the district the preponderating granite is somewhat finer crrained than the grmite to the east, possibly somewhat. more gneissic, and usually of a pink color. Certain phases of this finer granite are similar to the hornhlende granite to the east, but by far the larger portion shows a considerably greater content of quartz and a smaller content of the basic minerals.

Associated with these two prevailing types are dikes of exceelingly fine-grained pink granite showing very little biotite. They may be well observed in the cuts along the main line of the Duluth and Iron Range Raitroad. Other dikes are pegnuatitic grinite consisting of a pink feldspar with very abundant quartz, and with the ferromagnesian minerals almost totally lacking. They may be seen to advantage at the upper falls of Prairie River.

RELATIONS OF GIANTS RANGE GRANITE TO THE LOWER-MIDDLE HURONIAN SEDIMENTS AND OF BOTH TO OTHER ROCKS.

The Giants Range granite is throughout intrusive into the lower misllle Iluronian serliments. Actuat intrusive contacts are to be observed in a number of places. The lower-midelle 1. Inronian sedinentary rocks show the metmorpthic effects of the int rusion, and near the con- 
tacts no conglomerates are to be observel. The contact of the granite and the sediments is well exposed northwest of Mlesaba station.

Though the evidence is conehsive that the great mass of the granite is intrusive into the lower-middle Huronian sediments and not in to the upper Huronian (Animikie group), it is likely that in minor areas the granites here mapped and deseribed as lower-middle 11uronian may contain granite of later clate, which is known to be present in the district.

The conglomerate forming the great part of lower-middle IIuronian sediments affords conclusive proof that the lower-middle Ituronian sediments rest unconformably upon the Archean rocks. Every kind of pebble found in this conglomerate, with the possible exception of a few cherty slate pebbles, can be matched among the Archean rocks.

Both the lower-middle Ifuronian sediments and the Giants Range granite are unconformably underneath the upper Huronian (Animikie group), as shown both by strueture and by conglomerates at the hase of the upper Huronian sediments. This unconlormity is described in consection with the upper Ifuronian.

STRUCTURE AND THICKNESS.

The lower-middle IJuronian beds now stand on edge, the dip sehlom varying more than $5^{\circ}$ or $10^{\circ}$ from vertical. Superposed upon the original bedding structure is an excellent secondary cleavage. The cleavage planes, for the most part, are approximately parallel to the bedcling planes. The strike of both bedding and cleavage is uniform, about N. $60^{\circ} \mathrm{E}$., though locally varying $10^{\circ}$ to $20^{\circ}$ from this direction.

Both the lower-middle Huronian sediments and the Giants Range granite are jointed, the sediments particularly so. The sediments, moreover, show conspicuous faulting and hrecciation. The breccias at some places might be mistaken for conglomerate. A thiekness of 3,000 to 5,000 feet is prohably as great as can safely be assigned to the lower-midelle Huronian sediments of the Mesabi district.

CONDITIONS OF DEPOSITION.

It is suggested in Chapter XX (pp. 603 et seq.) that the lower-middle Huronian deposits of the north shore may be in part subaerial continental deposits.

UPPER IILRONIAN (NNIMIKIE GROLP).

GENERAL CHARACTER AND EXTENT.

The sedimentary rocks of upper Huronian age occujy practically all the southern slopes of the range from one end of the distriet to the other and extend also an unkmown distance south beneath the glacial drift. The surface widtlı of the Animikie group in the area included in the distriet deseribed varies from less than 1 mile to 5 miles or more. The beds have a flat dip to the south. Their upper edges being truncated, they appear in belts winding along parallel to the range, the northerly belts representing the lower beds and the southerly belts the higher beds of the series.

The exposures of the upper Huronian, particularly on the lower slopes, are so widely separated that the mapping of the rocks would have been an impossibility had it not been for numerous drill holes and pits sunk in search for ore, which were bottomed in the upper IIuronian. These are particularly numerous along the central portion of the range and have enabled the distribution of the upper Ifuronian rocks to be indieated within rather close limits for this part of the range.

The upper IIuronian comprises from the base up (1) the Pokegama quartzite, consisting mainly of quartzite but containing also conglomerate at its base; (2) the Biwabik formation, consisting of ferruginous cherts, iron ores, slates, greenalite rocks, and carbonate rocks, with a small amount of coarse detrital material at its base; and (3) the Virginia slate. Between the Pokegama quartzite and the Biwabik formation there is a slight break indieated by conglomerate. 'The Biwabik formation grades conformably into the Virginia slate both vertically and laterally. 
POKEGAMA QUARTZITE.

The Pokegana quartzitc is the basal formation of the upper Huronian (Animikic group). Because of the southerly dip and truncation of the rocks, the quartzite appears as a belt immediatcly south of and contignous to the lower-middle Iluronian and Archean formations. The belt, varying from a few steps to half a mile or more in witth, extends from the west end of the Mesabi district continuously to a point north of Mountain Iron. lirom liere on to the east end of the range data are insullicient for mapping the quartzite as a continuous belt, and it is accordingly mapped as a number of discontimuous areas of varying width and length. It is likely that future exploration, as in the past, will result in extending and connecting some of these areas, but it is also c'rtain that some of them are really cut off from one another because of the overlapping of the iron-bearing formation.

The Pokegama consists of ritroous quartzites of various colors and textures, with some micaceous quartz slates and conglomerates.

The thickness of the Pokegama quartzite ranges up to 200 feet.

\section{BIWABIK FORMATION.}

DISTRIBUTION.

The Biwabik formation extends along the slopes of the range for its entire length, from T. $1+2$ N., R. 25 W. west of Grand Rapids, to Birch Lake, a distance of nearly 110 miles. The width of exposure arerages perhaps $1 \frac{1}{4}$ miles, but is in places as great as 3 miles and in others as little as a quarter of a mile. The total area is approximately 135 square miles. The bounding formation on the north is for the most part the Pokegama quartzite, but where this is lacking the Biwabik formation comes into contact with the lower-middle Huronian and Archean rocks. To the south the iron-bearing formation is bounded by the Virginia slate, except in range 12 and a part of range 13, at the east end of the range, where the lieweenawan Duluth gabbro laps up over the formation. On the east the iron-bearing formation is cut off by the overlapping Duluth gabbro; on the west it gradually thins out, the overlying slate and underlyng quartzite coming together.

On account of the covering of glacial drift, exposures of the iron-bearing formation, except in the eastern end of the district, are few. But the formation has been reached and pierced in thousands of places by drills and mining excarations, and it is therefore possible, particularly along the part of the range at present productive, to delimit it with a fair degree of aceuracy.

Much attention has been paid in recent years to following up the westward extension of the iron-bearing formation, which, in the vicuity of Grand Rapids and westward, becomes deeply buried under glacial drift. By drilling a large number of holes it has been possible to follow the formation into T. 142 N., R. 25 W., where it becomes thin and apparently clisappears, the slate and quartzite coming together. These results have not seemed to warrant continuation of drilling in this direction, but until sufficient drilling lias been done to demonstrate clearly what the structure and distribution are there it can not be sajd that the possibilities at this end of the district have been exhansted. Folding or faulting or changes in sedimentation might easily cause variations which would make it difficult to follow the formation. Twelve miles to the northwest of the westernmost Biwabik formation (iron-bearingr) of the Mesabi district there begins a magnetic belt which extends from T. 144 N., R. $26 \mathrm{~W}$., through Leech Lake to T. 142 N., R. 35 W., a clistance of about 50 miles. This belt has not bern proved. The few holes that have been put down seem to indicate that the formation is of Vermilion type, but the continuity and the breadth and length of the belt are exceptional for Vormilion iron-bearing rocks. It has been thonght possible that this belt mirnt represent an extension of the Mesahi distrint thrown to the north by a fold or a fault. Whatever it is, its trend indicates that the same general lincaments of structure of the Vermilion and Mesabi districts are following out here to the west, and even if the belt ultimately proves 
to be Vermilion it would then serve to limit the distribution of the Animikie (including the Biwabik iron-bearing formation) on the north, and thus serve as a guide to further explorition.

The iron-bearing formation in general oceupies the middle slopes of the Giants Range, and its north and south boundaries have fairly unilorm altitudes for considerable distances. By an examination of the map, however, it may be seen that the elevation of the formation increases from the west end of the district to the east, the total diflerence amounting to as much as 500 feet. This corresponds with the increased elevation of the range as a whole in this direction, although the bigher elevation of the southern limit of the formation at the east end of the range is in part due to the fact that the lower parts of the formation are overlapped by gabhro. It may be further seen that the elevations of the north and south boundaries show loeal fluctuations as great as 200 feet, due to the folding of the formation and to differences in depth of erosion.

KINDS OF ROrKs.

The great bulk of the Biwabik formation is ferruginous elert more or less amplibolitic, calcareous, or sideritic and gray, led, yellow, brown, or green, with bands and shots of iron ore. It is analogous to the jaspers of the other iron ranges, but differs in certain particulars, as is shown on pages 461-462.

Associated with the chert, mainly in the midlle zone, are the iron ores. Their surface area is only about 5 per cent of the total area of the iron-bearing formation, and the proportion of their bulk to that of the iron-bearing lormation is much less. Near the bottom of the Biwalbik formation is a small amount of conglomerate and quartzite - that is, conrsely clastic sediments. A minute conglomeratic layer has also been observed in the Maloning mine, in about a central horizon of the formation. In thin layers and zones throughout the iron-bearing formation, and particularly in its upper horizons, are layers of slate and of paint rock, the paint rock usually resulting from the alteration of the slate. Between the slate and the paint rock and the ferruginous chert are ummerous gradational varieties, most of which come under the hearl of ferruginous slate. Associated with the slaty layers in the iron-bearing formation or closely adjacent to the overlying Virginia slate are green rocks made up of small green granules of ferrous silicate which are here called greenalite, in a fine-grained cherty matrix. It will be shown later that these are the original rocks from which most of the other phases of the iron formation, including the ores, have resulted by alteration. Finally, certain calcareous and sideritic rocks are present in small quantity, particularly near the upper horizons, associated with the greenalite rocks. The rocks of the iron-bearing formation are described below, beginning with the original typethe greenalite rock.

The origin of the ores and iron-bearing rocks is discussed in Chapter XVIr (pp. 499 et sec.).

GREENALITE ROCKS.

In moderate quantity, just below the Virginia slate or associated with some slate layer in the iron-bearing formation, are dull dark-green rocks of rather uniform fine grain and conchoidal fracture. Layers of slate, iron ore, and other phases of the iron-bearing formation usually mark their bedding. On close examination, particularly when the surface is wet, there may be observed numerous ellipsoidal granules of a green substance of a very slightly lighter green than the matrix in which they lie. They are so small and of a color so nearly like that of the matrix that they are likely to be overlooked unless especially searched for. An occasional one is of much greater size than the arerage and looks like a conglomerate pebble in the rock.

Under the microscope the granules are conspicuous. Their cross sections are round, oval (in some cases with much elongation), crescent-shaped, lens-shaped, gourd-shaped, or even sharply angular. Here and there a curved "tail" seems to connect one granule with its neighbor. Where in contact with a layer of iron carbonate or caicimm carbonate, as many of them are, the granules are more irregular in shape and project into or are inchuded in the carbonate layers as irregular filaments and fragments. The carbonate is largely secondary 
and dearly replaces the granules, but some of it is perhaps origrinal, and in this case the rariation in shape of the ervantes where assoelated with the carbonate layers has a bearing on the origin of the ores, which is discussed elsewhere (p. 187). One humdred and twenty measurements of the grunules slow an average greater diameter ol 0.45 millimeter and an averuge least diameter of 0.21 millimeter, with average ratio of erreatest to least of 100$)$ to 47 . The dianeters rarely reach 1 millimeter and lew are below 0.1 millimeter. Oceasionally certain of the granules may be seen to be aggregated into latger granules with well-rounderl outlines, making the conglomerate-like fragments above mentioned. The greater diameters of the granules, for the nost part, are parallel to the bedding, and in faet this arrangement largely determines the bedding. In ordinary light the granules are green, greenish yellow, brown, or black. The green and yellow ones are transparent and the brown and black are nearly or quite opaque. Under crossed nicols the gramules are either entirely dark or show a very fuint lightening, hardly sufficient to disclose a color. Here and there incipient alterations to chert, grünerite, cummingtonite, or actinolite, scarcely discernible in ordinary light, give low polarization colors in minute spots and make the tem "aggregate polarization" applicable. In refleeted light the transpalrent green and yellow granules appear black, dark green, or dark yellow, while the opaque brown and black granules exhibit a rough light-enreen surface. Were it not for the light-green surface in reflected light, certain of the opaque dark-brown granules would be mistaken for iron oxide in ordinary and polarized light.

The matrix of the rocks containing the unaltered green granules raries widely in amount, from a mere interstitial filling to an abundant mass in which granules are widely separated. The matrix mar be almost pure chert; it may be nonaluminous, monoclinic amphibole, actinolite, grünerite, or cummingtonite; it may be largely iron or calcium carbonate, although where the carbonate is abundant the granules are usually sparse and irregular; it may consist of any combination of chert, amphibole, and carbonate with a snall amount of accessory iron oxile.

Originally the matrix nay have had a somewhat different character. In the rocks containing the least altered granules the matrix is predominantly ehert and subordinately lightcolored ampliboles and carbonate. As the rocks become altered they contain more iron oxide and dark amphiboles, which will be shown on a subsequent page to develop from the alteration of the granules. The lighter amphiboles are themselves known to be a secondary derelopment from chert and carbonate rocks. It seems likely, therefore, that the original matrix of the green granules was largely chert and in snall part carbonate. In the freshest rocks now found the chert is much recrystallized and the original carbonate is largely leached out or replaced by actinolite.

The specific gravity of the unaltered granules can not be satisfactorily determined because of the practical impossibility of separating the granules from the matrix. Determinations of the specific gravity of the rock as a whole give results ranging from 2.7 to 3 . As the matrix is largely quartz in the form of chert, which is known to have a specifie gravity in the neighborhood of 2.65 , the figures above given for the unalterel rock are too low for the granules thenselves, although their incipient alterations to iron oxide and amphiboles tend to raise the specific grarity. So far as the matrix is colorless amphibole it is apparent that the specific grarity of the green granules is lower than the figures obtained for the rock, for the specifie grarity of the colorless amphiboles is above 3 . One exceptionally fresh specimen in which the granules lie in a matrix of chert gave a result of 2.7. The matrix in this case makes up something more than half of the rock mass, and it therefore seems probable that the true specific gravity of the granules is a little above 2.75 .

Four analyses of rocks containing the least altered granules observed have becn made by George Steiger, of the United States Geological Surrey. Ife found that by treatment with hot concentrated hydrochlorie acid most of the granules and their associated alteration products dissolved out, leaving a resiclue of almost clear siliea, which probably mainly represents the matrix. 
Analyses of greenalite rocks.

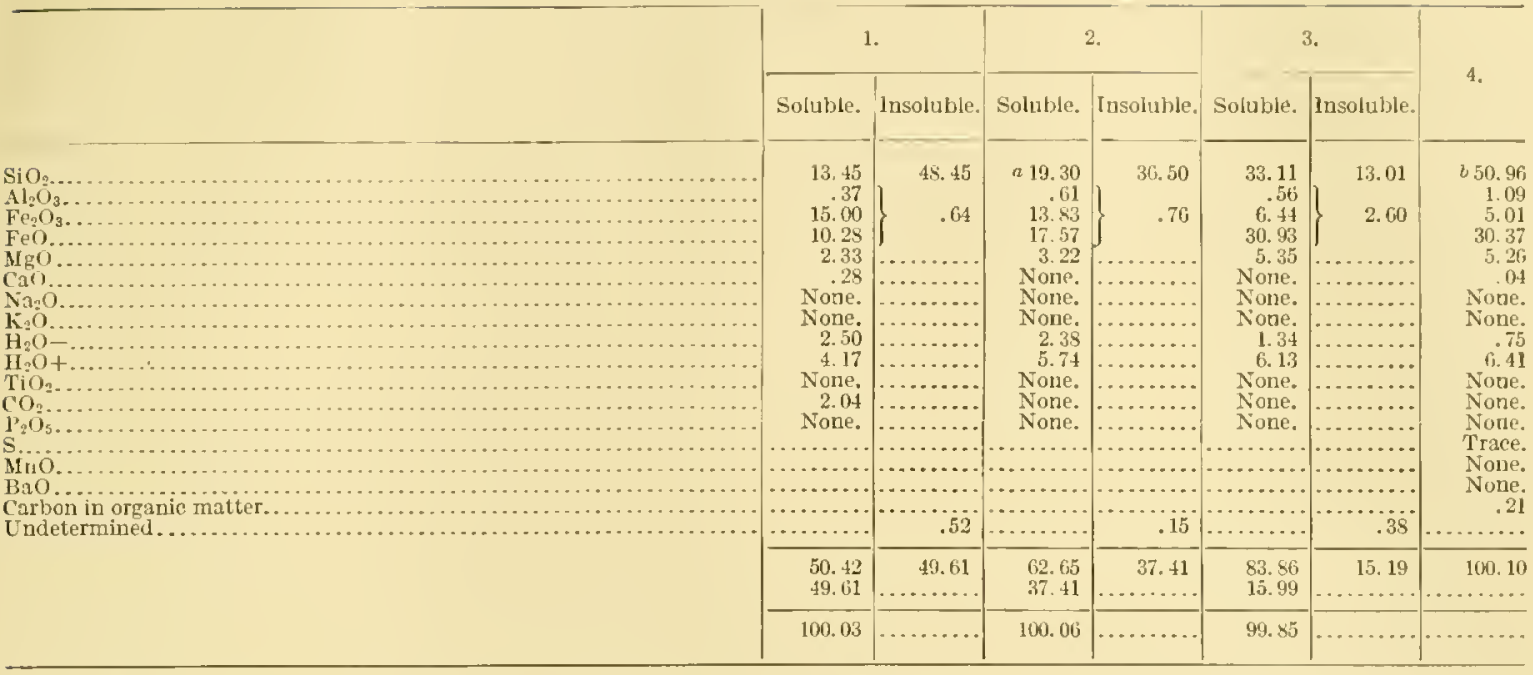

a Of which 3.3 was found in the rock upon treatment with HCl (probably opal).

$b$ of which 23.96 is soluble.

1. Specimen 4575s. From 250 paces west, 53 paces north, of the west quarter post, sec. $35, T .59 \mathrm{~N}, \mathrm{R}, 15 \mathrm{~W}$. The fiuely ground rock was eraporated on the water bath to dryless with $50 \mathrm{cc}$. of $1-1 \mathrm{lcl}$, taken up with watcr slghtly acidified with HCl, and filtered. Soluble sllect was then determined in this residue by hoiling with 5 per cent solntion of $\mathrm{Na}_{2} \mathrm{CO}_{3}$. A determiuation of soluble $\mathrm{SiO}_{2}$ was then made in the rock before treatment with $\mathrm{HCl}$ and subtracted from the first soluble $\mathrm{SiO}_{2}$ fonnd, which gave the figure for $\mathrm{SiO}_{2} 1 \mathrm{n}$ the soluhte portion.

2. Specimen 45765 . From test pit in Cincinuati mine. The soluble partion was found by evaporating to dryness on the water bath with 50 ce.

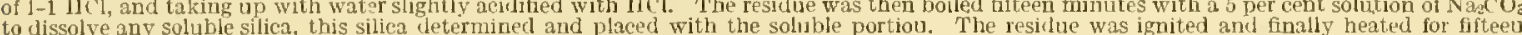
to dissolve any soluble silica, this silica cetermined and placed with the solinble portiou, The residue was ignited and finally heated for Giteeu minutes over the blast lamp, weigbed, and then a rough analy'sis made, Which is found in the second collimin. The small amount of ron shown treatment with $\mathrm{HCl}$ and found to be 3.3 per cent. Subtracting this from the total soluble silica, 16 per cent of soluble silica remains for the part dissolved in $\mathrm{HCl}$

3. Specimen 45766. From test pit in Cincinnati mine. The finely ground rock was evaporatel on the water bath to dryness with 50 cc. of 1-1 HCl, taken up with water slightly aciclified with IlCl, and filtered. Soluble silica was then determined in this residue by boiling with 5 per cent solutiou of $\mathrm{Na}_{2} \mathrm{CO}_{3}$. A determination of soluble $\mathrm{SiO}_{2}$ was then made in the rock before treatment with HCland subtracted from the arst soluble

$\mathrm{SiO}_{2}$ found, which gare the figure for $\mathrm{SiO}_{2}$ in the soluble portion.
4. Specimen 45150 . From 50 paces west, 100 paces north of the southeast corner of sec. $22, \mathrm{~T} .59 \mathrm{~N}$., R. $15 \mathrm{~W}$. Owing to preseuce of organic matter, the determination of ferrous iron is probably high.

From the detailed consideration of these results, which is not repeated here, it appears that the ferric iron occurs in the rock mainly as sesquioxide, for the soluble silica is accounted for by the ferrous iron and magnesia present, leaving none for the ferric iron; that in three slitles of the four of the rocks analyzed the ferric oxide may be olsserved to be present and to be probably secondary, and hence that the iron oxide shown by the analyses is mainly secondary and not to be considered as belonging with the substance of the unaltered granules. It appears further that the alumina and lime are in such small quantity as to be practically negligible. It appears still further that there is far more than enough combined water to combine with the ferric iron to form ferric hydrate, and thus that a considerable portion of combined water shown by the analyses may be taken to belong to the green granules. Finally, it appears that the substances which ean not be accounted for in any other way and which clearly belong with the green granules are silica, ferrous iron, magnesium oxide in small proportions, and water. It is therefore concluded that the substance of the green granules is essentially a bydrous ferrous silicate with a subordinate amount of magnesium, and that if ferric iron is present at all as an original constituent of the green granules it is in small quantity.

This conclusion is essentially in accord with that reached by J. E. Spurr in his report on the Mesabi distriet published in $1894 .^{a}$

Having conchuled the substance of the green granules to be mainly silica, ferrous iron, magnesium oxide, and water, we may aseertain whether or not there is any uniformity in the proportions of these elements. The ratios of the silica, ferrous iron, and magnesium in the four analyses, calculated on the basis of 100 , appear in the table on page 168 . The percentage of water is not included for the obvious reason that, while it is certain that much of it belongs with the granules, no quantitative estimate can be made of its amount because of the uncertainty as to the portion which belongs with the ferrie hydrate. 


\begin{tabular}{|c|c|c|c|c|c|}
\hline & 1. & 2. & 3. & 4. & Iverage. \\
\hline 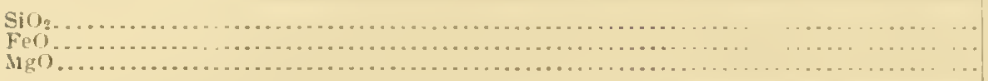 & $\begin{array}{r}55.1 \\
42.1 \\
2.3\end{array}$ & $\begin{array}{r}43.7 \\
4.5 \\
4.5\end{array}$ & $\begin{array}{r}47.7 \\
4.6 \\
7.6\end{array}$ & $\begin{array}{r}40.2 \\
50.9 \\
8.9\end{array}$ & $\begin{array}{r}40.8 \\
+10.3 \\
7.1\end{array}$ \\
\hline
\end{tabular}

The relative proportion of the ferrous iron and silica above shown sugrgests a combination of the two on the basis of one molecule of each. Theoretically the percentages of the two in such a combination would be--

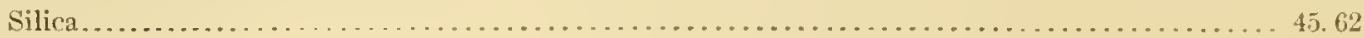

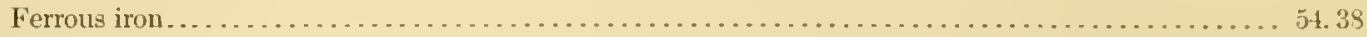

The average of the ferrous iron, 46.3 , is about 8 per cent less than the theoretical percentage. The magnesium oxide, which has a higher combining power than the iron, more than makes up for this deficiency.

On a subsequent page is given an analysis of a rock in which the green granules have been altered to a dark-green and brown amphibole, probably grünerite, apparently through simple recrystallization and dehydration. The alteration has occurred under deep-seated conditions, and it is probable that little if any addition or subtraction of material has taken place other than that inrolred in dehytration. The composition of the amphibole ought to gire a clue to the composition of the original green substance. It is there found that the principal constitucnts of the amphibole are silica and ferrous iron in the following proportions:

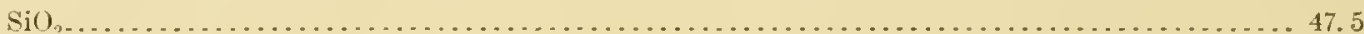

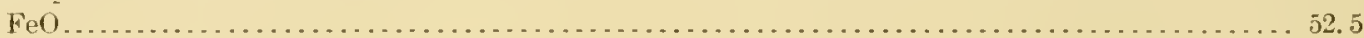

The correspondence of these percentages with those above given is evilent.

The above results are not sufficiently accordant to show that the substance under discussion has a definite and uniform composition. On the other liand, the impurities and alterations cause such variations that it can not be said that the green granules do not have definite chemical composition. If the granules do have a definite composition, the abore results indieate the most probable formula to be $\mathrm{Fe}(\mathrm{Mg}) \mathrm{O}_{\text {. }} \mathrm{SiO}_{2} \cdot \mathrm{nH}_{2} \mathrm{O}$.

Dr. Spurr, after his study of the green granules, concluded to call them "glauconite." In view of the fact that potash is by most mineralogists insisted upon as one of the essential constituents of glauconite, the entire absence of potash in the sulsstance under discussion is taken to preclude the application of the term "glauconite." The substance apparently corresponds to no known mineral species. As a convenient term by which to refer to it the name "greenalite" was coined for use in the monograph on the Mesabi district and is used in this report also.

The origin of greenalite and the details of the similarities and differences between greenalite granules and granules of glauconite, concretions of iron oxide and chert, and other granule and concretionary strictures are diseussed in Chapter XVII, on the origin of the iron ores.

FERRUGINOUS, AMPHIBOLITIC, SIDERITIC, AND CALCAREOT'S CHERTS.

The following deseription applies to the normal types of chert occurring through the central and western portions of the range. The highly metamorphosed chert characteristic of the east. end of the range is given a separate description on a subsequent page.

The cherts are gray, yellow, red, brown, or green rocks, with irregular bands and slots aud granules of iron oxide varying in quantity from predominance almost to disappearance. A slight brecciation thoroughly recemented may be occasionally observed, and a pitted surface, due to the solution of certain of the constituents, is not uncommon. The iron oxide is mainly intermediate between hematite and limonite, and to a subordinate extent is magnetite, aud its color accordingly ranges from red to yollow or to black. The variety of colors of the chert and the iron oxide, their irregular association, and their variation in rolative abundance give the cherts most highly varied aspeets; yet no phase of the cherts is likely to be mistaken for any 
other rock by anyone reasonably familiar with the iron-bearing rocks of the Lake Superior region. To the casual observer the massive lighter-colored cherts, containing little iron oxide, resemble quartzite, and indeed have been frequently so called. However, the splintery fracture of the chert and the absolute lack of rounded clastic grains, aside from the usual content of iron oxide in layers or spots or minute grains, are unfailing criteria for the discrimination of the two. The ferruginous cherts differ from the jaspers or jaspilites of the old ranges of Lake Superior in lacking their even banding and brilliant red color as well as the microscopic features described below.

When studied under the microscope it appears that all the rocks here described as chert are genetically connected. In looknng over 250 slides but few have been observed which do not show some evidence of the derivation of the rock from the greenalite rocks above described. The granule shapes are still largely preserved, ${ }^{a}$ but the alterations have tended in some places to make the shapes more irregular and partly or wholly to obliterate them. The alteration of the granules has been almost entirely metasomatic, for there is little evilence of dynamic movement resulting in the breaking up of the constituents of the rock.

The greenalite has been replaced by cherty quartz, magnetite, hematite, limonite, siderite, calcite, grünerite, cummingtonite, actinolite, epidote-zoisite, or any combination of them. The extent and nature of the alteration replacement vary within wide limits. The granule may be mainly greenalite, showing ineipient crystallization of quartz, grünerite, or actinolite, visible only under crossed nicols. The granules may be represented almost wholly by hematite, limonite, magnetite, intermediate varieties, or any combination of them. The oxides may be arranged irregularly or concentrically. In the iron ores the granules are entirely represented by iron oxide, although their shapes are in part obliterated. The granules may be represented almost wholly by chert, which may be distinguished from that of the matrix by its coarser or finer texture, or, if not by texture, by distribution of pigment. In ordinary light chert granules may be marked by the pigments which in parallel polarized light are completely obscured by the crystallization of the chert, or the granules may not be seen in ordinary light and be conspicuous under crossed nicols because of the crystallization. Or the crystallization of the chert may have entirely obliterated the granules for much of the slide, both in ordinary and polarized light. The granules may be represented entirely by green, yellow, and brown grünerite, cummingtonite, or perhaps actinolite, or all, which in ordinary light may be scarcely distinguishable from the unaltered greenalite granules but which become apparent under crossed nicols by their double refraction. The granules may be represented by calcite or siderite in rhombs or irregular grains, sometimes showing zonal growth, which for the most part aie clearly replacements of the granules. Most commonly the granules are represented by a combination of any or all of the minerals above named. Of these combinations, that of chert and iron oxide stands first. The two substances occur in all proportions with a great variety of arrangement. The two may be irregularly intermingled, or the iron oxide may form a rim about a cherty interior, or, though not commonly, the chert and iron oxide may be in concentric layers in the manner of normal concretions, or polygonal areas of fine chert may contain spots of iron oxide in the center of each as well as a rim of iron about the periphery, suggesting an organic structure. The alteration and replacement of the greenalite and the conditions favoring the development of the different minerals are discussed under the origin of the ores (pp. 187 et seq.).

In addition to the derivatives of the greenalite grannles, there are present a few concentric coneretions of iron oxide and chert about quartz, which may have been secondarily developed from some substance other than the greenalite. These are similar to concretions in the ironbearing formation of the Penokee-Gogebic district, where they have developed from the alteration of an iron carbonate. The secondary concretions in the Mesabi district may also be developments from iron carbonates, which are now associated with unaltered portions of the formation and probably existed formerly in the portions which are at present altered. The secondary concretions are different from the greenalite granules in their beautifully developed concentric 
structure. Though a few of the granules themselves liave a concentric structure resulting from zonal alteration, this is usually poorly developed and there is orlinarily lit to difficulty in distinguishing it from that of the secondary concretion, though in some places it is possible that some of the supposed secondary concretions formed from earbonate may be really secondary alterations of original granules.

Spherulites of epielote, rarely to be observed, though in part replacements of the granules, are also clearly secondary developments in the matrix.

The matrix of the chert may be a sparse interstitial filling between the granules or it may form most of the rock mass and contain but few isolated granules. The matrix is similar to that of the unaltered greenalite rocks in that it is mainly chert, Jut it differs in containing far more actinolite, grünerite, cummingtonite, iron oxide, calcite, and siderite, and rurly epidotezoisite in spherulitic form. Sometimes also green chloritic substances are abuulant, either irregularly distributed through the matrix or forming a definite rim about the granule. In the latter case the chlorite is in part in the fibrous form known as delessite and much resembles uralite. The recrystallization of the rock has in some places marle the chert in the matrix coarser than that of the granules and in other places the reverse. The leaching out of the carbonates and greenalite from the matrix has oceasionally left eavities which give the pitted character to the weathered surface of the cherts.

Accompanying the recrystallization of the chert has been its frequent arloption of radial or sheaf-like forms, giving black crosses under crossed nicols. These sheares, as well as the sheaves of actinolite, grünerite, and cummingtonite, and rarely epidote, frequently lie with their butts against the outlines of the gramules and send their points outward until they interlock with similar projections from aljacent granules. Commonly also one or more of the constituents of the matrix may be observed to lie partly in the matrix and partly in the granule, thus helping to obliterate the granule. Indeed, under crossed nicols the granules may not be observed, while in orlinary light their position may be indieated by the listribution of the fine pigment.

All of the constituents in the matrix are secondary except, perhaps, a part of the ehert, and even this has been thoroughly recrystallized. The amphiboles and iron oxide mar be observed to have developed by the alteration of the granules and some of the lighter ampliboles by the alteration of carbonate and chert in the matrix. The carbonate is largely though not entirely replacement from without, for it may be observed replacing nearly all the other constituents of the rock and occurring in minute veins crossing the rock.

The composition and origin of the ferruginous cherts are discussed on pages 186-187.

SILICEOUS, FERRUGINOUS, AND AMPHIBOLITIC SLATES.

Under this head are grouped a rariety of slaty rocks which are interstratified with the other phases of the iron-lyearing formation. They include dense black, dark-gras, green, or redelish rocks with a tendency toward conchoidal fracture and the slaty parting poorly developed, if at all; rocks showing banding of dark-green, black, gray, red, or brown layers parallel to the bedding and a well-developed cleavage parallel to the same structure; graclational raricties between these two, between them and the ferruginous eherts, and between them and the iron ores. Any of them may be hard or soft, carbonaceous or noncarbonaceous, fine grained or medium grained.

Under the microseope the slates are seen to contain prineipally cherty quartz, iron oxile, either lematite or magnetite, usually in oetahedra, or some hydrated oxide, monoclinic amphibole which may be grïnerite, cummingtonite, or actinolite, and possibly even common hornblente, a small amount of carbonate of calcium or iron, a little zoisite, and possibly also a little chlorite. From the optical properties and from the analysis of the rock it is thought that the amphibole is mainly grinnerite and cummingtonits. There is much rariation in the relative proportion of the prineipal constituents. Some of the slates consist almost enticely of fine cherty quartz, with suborilinate quantities of dark amphibole in radial aggregates or in irregular nasses, and of the iron oxides. Others are composed mainly of iron oxide, showing lut small quantities of the quartz and lark amphibole. Others are composed of a tangled mass of yel- 
lowish, brownish, and greenish amphibole fibers containing minute particles of iron oxide, silica, and other subordinate constituents. The grünerite is far more abundant than the actinolite. The banding shown in many specimens is due to the segregation of the above-named elements into layers. While it may be convenient in description to refer to this or that slaty rock as a ferruginous slate, a siliceous slate, an amplibolitic slate, or an actinolite slate, depending upon the relative abundance of the constituents, usually all three constituents are present in one rock, and the rocks are really amphibolitic, siliceous, and ferruginous slates. Perhaps the most characteristic feature of the slates as a group is the abundance of the dark amphibole.

$$
\text { PAINT ROCK. }
$$

Throughout the iron-bearing formation, and particularly adjacent to the ore deposits, are thin seams of paint rock, which have resulted from the alteration of the slates above described. The paint rocks are essentially soft red or yellow or white clay. 'They retain the original bedding of the rocks from which they were derived, the structure being marked by alternation of bands of different color. In place the paint rocks are moist and soft. When taken out and dried they become harder but retain a soft; greasy feel.

The alteration of the paint rocks from slates is proved by the numerous intermediate phases to be observed. For analyses of paint rock sce page 191.

SIDERITIC AND CALCAREOIS ROCKS.

Associated with the slaty layers in the iron-bearing formation, and particularly with the grecnalite rocks, are carbonates of iron and calcium in small quantity. Most of the carbonate reacts readily with cold dilute hydrochloric acid and is certainly limestone, which, from the analysis of rocks containing it, is doubtless magnesian. Some of the carbonate, however, is certainly siderite, as shown by analysis. The carbonates occur in minute clear-eut layers interbedded with the other rocks of the iron-bearing formation, in reins cutting across the bedding, and in irregular aggregates and well-defined rhombohedral crystals in the layers of the iron formation. In the carbonate bands are small quantities of iron oxide, ferrous silicate, and chert, and in the bands of these minerals are small quantities of the earbonate. In some places the carbonates are coarsely crystalline and fresh and clearly have resulted from the replacement of the other constituents in the rock, particularly the ferrous silicate, or from infiltration along cracks and erevices. In other places, especially where in distinct layers interbedded with unaltered ferrous silicate phases of the formation, the carbonate lavers seem certainly to be original. At the top of the iron-bearing formation and closely associated with the basal horizons of the Virginia slate are several feet of clear calcium carbonate, which is described in connection with the Virginia slate.

CONGLOMERATES AND QUARTZITES.

At the base of the iron-bearing formation is a thin layer of fairly coarse fragmental material consisting in places of conglomernte alone and in other places of conglomerate and quartzite.

THICKNESS.

The average thickness of the iron-bearing Biwabik formation is about 800 feet. This figure is based on average dips of the formation, width of outcrop, and drill records. Local averages are likely to be either larger or smaller. In both the east and west ends of the district the thickness diminishes somewhat, the iron-bearing formation apparently giving way along the strike to slate.

ALTERATION BY THE INTRUSION OF KEWEENAWAN (MRANTTE AND GABBRO.

Through ranges 12 and 13, near Birch Lake, the Biwabik formation is intruded on the north by granite and on the south by the Duluth gabbro and has undergone considerable metamorphism in consequence. This metamorphism has extended even farther west, for, though the gabbro does not come into actual contact with the iron-bearing formation through range 
14, it abuts against the overlying Virginia slate and has metamorphosed both the slate and the iron-bearing formation in this area. ${ }^{a}$

In general through the westem and central portions of the Mesabi district the iron oxide of the iron-bearing formation is mainly hydrated hematite, and magnetite is in subordinate quantity. Eastward from Mesaba station the iron oxide is mainly magnetite, and lematite is in subordinate quantity. Westwarl from Mountain Iron the amphiboles are almost entircly lacking; from Mountain Iron eastward to Mesaba station the amphiboles are present in the iron-bearing formation but are not abundant until Mesaly station is approached; castward from Mesaba station they become abundant and make up an important constituent of the formation. In the eastern portion of the range the chert is correspondingly less abundant than in the western and central portions of the district, and in some places is almost entirely absent. The chert becomes also distinctly coarser in this area. In range 12 the grains commonly reach a diancter of 3 or 4 millimeters, and there are a few smaller particles, and in the central and western portions of the district they are seldom greater than 0.1 millimeter and almost invariably are associated with smaller particles. Toward the east there is a tendeney for the texture to become more even, althougl there are many wide rariations from uniformity. The chert grains, instear of being in irregular, roundish, and scalloped cherty forms, as in the central and western portions of the distriet, are in roughly polygonal shapes and united in a fairly uniform mosaic. Accompanying these changes is a more pronounced segregation of the magnetite and the amphilbolitic chert into irregular layers and lenses, with the result that the iron-oxide layers, instead of containing various other minerals, are comparatively free from them. The characteristic granules of the ferruginous cherts are still conspicuous in the east end of the distriet, but in the most lighly metamorphosed phases of the roeks, as in range 12 , they have entirely disappeared, being obseured by magnetite, amplibole, and chert. In the phases not showing the maximum alteration they are marked by magnetite, either as a rim about the granule, as a solid mass filling it, or in erenly disseminated particles throngh it. Not uneommonly the granules may be observed only in ordinary light and then by distribution of the magnetitic part icles; in parallel polarized light they are obseured by the polarization of the amphilolitic and chert $y$ constituents. Finally, in the eastern portion of the district certain minerals have developed which have not been found in the less altered rocks of the central and western portions of the Mesabi district. In the latter areas the amphiboles are entirely grünerite and actinolite, with little or no hornblende. In the eastern portion of the district the anphiboles inchule grünerite and actinolite, and in addition green and brown hornblende in considerable quantity. Associated with these minerals are small quantities of biotite, glaucophane, andalusite, zoisite, and garnet. Though hypersthene, augite, and olivine are abundant and characteristic in the true gabbro of range 12 and westward, these minerals are nearly if not quite lacking in the Biwabik formation.

Although to the east toward Gunflint Lake the gabbro alone has been able to produce eren greater metamorphic effects on the iron-bearing rocks, it is probable that the metamorphism of the iron-hearing rocks in the region under description has been produced jointly by keweenawan gabbro and granite.

VIRGINIA SLATE.

DISTRIBUTION.

The Virginia slate bounds the iron-bearing Biwabik formation on the south from the west end of the ristrict nearly to the east side of sees. 5 and $8, T .59 \mathrm{~N} ., \mathrm{R} .13 \mathrm{~W}$, where the shate is overlapped by the gabbro. Still farther east, in the SW. $\frac{1}{4}$ sec. 25, T. 60 N., R. 13 W., drilling hats shown altered slate to lie between Keweenawan Duluth gabbro on the south and Keweenawan diabase on the north, but whether it is an isolated mass at this point in the Keweenawan area or is continuous with the slate to the west explorations or exposures do not ret tell. The slate underlies the lower slopes of the Giants Range and continues south under the low-lying swampy

a The metamorphism of the Biwabik formation by the Duluth gabbro in the area adjacent fo Ikirch lake and to the east in the vicinity of A keley and Gunflint lakes has hecn described in detail by U.S. Grant. W. S. Bayley, and Carl Zaptre and has bern briefly considered or nentioned by N. 11. WinchelI, II. V. Winchell, A. II. E.Iftmann. J. E. Spurr, J. Morgan Clements, C. R. Van 11iso, and others. The reader is referred to Chapter VIII, on the Guntlint district (pp. 195-204), for a fuller account of the alterations near the gabbro. 
area south of the Giants Range lor an unknown distance. The area overlain by slate is so thickly covered with drilt that exposures of the slate are almost antirely lacking; its presence and distribution have been determined by drilling and test pitting in the search for iron. Through the central portion of the district enough of such work has been done to show the position of the slate boundary with a fair degree of alcuracy, although even here there are consilferable stretches where records of the occurrence of slate are wanting. In the western and eastem portions of the district the distribution of the slate is less well known, particularly in the western end of the listrict. In drawing the slate line on the map of this portion of the area all that can be done is to connect the separated explorations which reveal slate. Wherever exploration has been detailed it is found that the slate boundary is not straight but in gentle curves, and it is reasonable to expect, therefore, that future work will show numerous additional undulations in the slate boundary for the area at present not completely explored.

SLATE.

The normal Virginia slate is usually a gray rock, though in part black, reddish, or brown, with bedding shown by alternating bands of varying color and textme. Some of the beds are almost coarse enough to be called graywackes. Indeed, in the field the rock has been ralled a banded slate and graywacke. Some of the slate is hard and siliceous; other phases, especially the monsiliceous and carbonaceous ones, are soft and can be whittled with a knife. Near the contact of the slate with the iron deposit in the underlying iron-bearing formation, as at Biwabik and in sec. 3 , T. 58 N., R. 15 W., the slate becomes iron stained and solt and grades into paint rock. The slate in general has a very poor parting parallet $t o$ bedding planes, and there is tittle or no development of secondary chearage. What there is of secondary cleavage has been developed parallel to the bedding planes and is marked by minute particles of mica there found. The rock in general aspect and mineralogical and chemieal eomposition looks like slate, but it differs from true slate in lacking a true cleavage, and as this is me of the essential characteristics of slate it may be doubted whether the term "slate" ought to be applied to the rock. Yet the rock is not a shale, for it is too much metamorphosed and lias too poor a parting parallel to the bedding. In the Cuyuna distriet the same formation slows the characteristies of a true slate, and the formation both there and in the Mesabi district proper has been known locally and in geologie literature as slate. Hence the term is here retained.

Analyses of Tirginia slate.

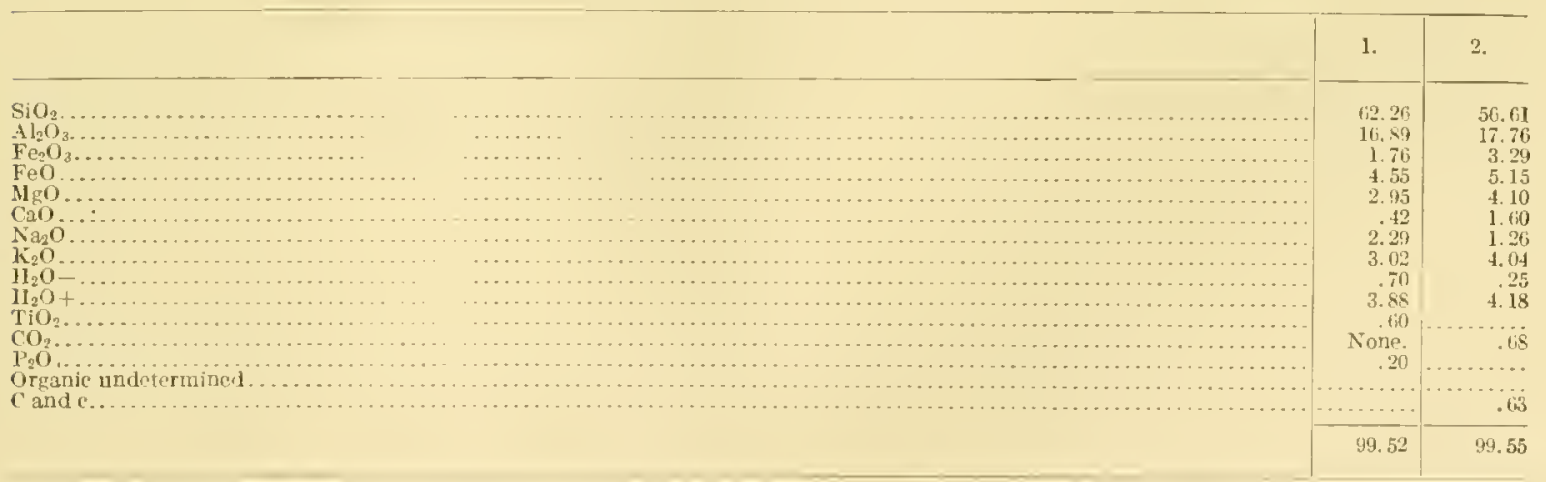

1. Analysis by freorge Steiger, of the United States feological Survey, of a composite sample of the Virginia slate made up by assmbling severa] specimens from two localities (speeimen 4576 from excavation for water tank of Easterm Railway of Minnesota. at Virginis: specinen 4543 from a noint south of the Biwabik mine).
2. Analysis of Virginia slate by $R$. D. Hall, University of Wisconsin, of a sample representing 900 feet of drill core from a drill hole at the southeast corner of sec. 8, T. 55, R. 15 .

CORDIERITE HORNSTONE RESULTING FROM THE ALTERATION OF THE VIRGINIA SLATE BY THE DULTTII GABBRO.

In approaching the Duhth gabbro, which overlaps the Virginia slat in ranges 14 and 13 , the slate becomes more crystalline, harder, and characteristically breaks with a conchoidal fracture, and the color becones darker and in many places is a bluish bluck. The rock, indeed, 
becomes a hornstone. Horeover, there appear minute light-colored specks whiels on the weathered surface are likely to have disappeared and to be represented by pits. Under the microscope the white specks are found to be cordierite in typical development, standing as numerous phenorrysts in a fine-grained matrix of biotite, feldspar, magnetite, and certain doubtful microlites which may be actinolite or sillimanite, or both. ${ }^{a}$

RELATIONS TO THE BIWABIK FORMATION.

Reference has already been male to the fact that the relations of the Virginia slate to the underlying Biwabik formation are those of gradation, both lateral and vertical. It remains to discuss this gradation somewhat fully. The iron-bearing formation contains slate layers throughout. At upper and middle horizons they are perhaps more numerous than at lower horizons. Just below the solid black Virginia slate there is a zone in which there are many interlaminations of iron-bearing formation and slate, the layers varying in thickness from several feet to a fraction of an inch. This zone is of rarying and uncertain thickness. In many places at least the zone of minute interbanding is thin, not more than 15 or 20 feet, but, as already noted, layers of slate are found well down in the iron-bearing formation and layers of the ironbearing formation are found well up in the slate, so that in a broad way the gradation zone may be several hundred feet.

Drilling shows much irregularity in the alternation of layers. Slate layers are more abundant in the eastem end of the district, and westward from Grand Rapids the iron-bearing formation rapidly thins, its place being taken by slate in T. $142 \mathrm{~N}$., R. $25 \mathrm{~W}$. Whether the iron-bearing formation extends indefinitely southwarl under the slate or gires place to slate. in that direction is not known. All drill holes put down near the northern margin of the Virginia slate in the Mesabi district have shown the Biwabik formation below. For reasons eited on pages 517-518, however, it is regarled as not impossible that farther south the iron-bearing formation thins and becomes discontinuous, its place being taken by the black slate.

An examination of the map will show the Virginia slate to encroach on the south margin of the iron-bearing formation to greatly varying distances, with the result that the surface outcrop of the iron formation ranges in wilth from 2 miles or more to less than a quarter of a mile. This is due in part to steeper lips at the narrow places than at the wide places in the ironbearing formation, erosion having thus uncovered less of the iron formation where the dips were steep; it is due in part to faulting, as at Biwabik and eastward; it is due in part to the greater dip of the present plane of surface erosion, either atmospheric or glacial, in places where the formation is wide than where narrow, the greater dip of the surface bringing it more nearly parallel with the dip of the iron-bearing formation, and thus uneovering more of it; but so far as present evidence goes these factors are not adequate to account for the observed rariations in width of the iron formation. The known irregular alternation of iron-bearing formation and slate both across and along the beds is therefore regarded as a cause of the varying widths of the iron-bearing formation.

STRTCTIRE.

Opportunities for studying the structure of the Virginia slate in place are so few that if the observer were dependent unon such observations alone he would be unable to make any statcments concerning the structure of the formation beyond the fact that it dips at low angles away from the higil land arljacent.

THICKNESS.

The thickness of the Virginia slate ean not be determined in the Mlosalbi district. The drift covering is thick, mining exploration stops to the south where the slites are encountered. and the southerly extent of the slate belt is thus unknown.

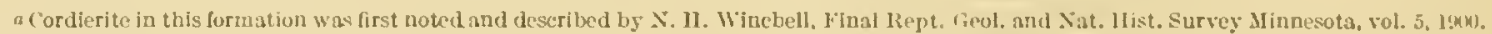


STRUCTURE OF THE UPPER HURONIAN (ANIMIKIE GROUP).

As a whole the upper IIuronian (Animikie group) is a well-bedded series of seliments. The bedding is most pronounced in the middle and upper horizons. The beds have gentle dips, averaging between $5^{\circ}$ and $20^{\circ}$, though locally greater or less, in southerly and southeasterly directions a way from the oller rocks forming the core of the Giants Range, but locally the dips show much variation both in degree and direction. About the southerly projecting tongue of the Giants Range, in the vicinity of Virginia, Eveleth, and McKinley, the dips are westerly on the west side of the tongue, southerly at the end of the tongue, and southensterly on the southeast side-that is, throughout approximately normal to its periphery. Even more conspicuous than the change of dip at such a place are the minor variations between exposures. Seldom is it possible to get two identical readings in dip at exposures of rock separated by even short intervals, although the direction and amount of the dip come within the above limits. These facts indicate that the upper Huronian bels are tilted away from the core of the Giants Range in directions normal to its trend and that the gently tilted beds are not plane surfaces but are gently flexed. By tabulation and comparison of the dips it becomes further apparent that the greater flexures are not random ones but generally have their axes normal to the trend of the range. On examination of the attitudes of the beds still more in detail it appears that the great flexures themselves are not simple but have many subordinate flexures, some of them transverse to the major ones. The complexity of the structure may be likened to that of water waves. On the great swells and troughs there are smaller waves, on the smaller waves there are still smaller ones, and so on down to the tiniest disturbance of the surface. Though perhaps the majority of the minor flexures in the upper Huronian rocks have attitucles similar to the larger ones, many of them vary greatly in direction. They may be observed at almost any single exposure of the upper IIuronian.

The great flexures are very gentle, involving very small changes in degree and direction of dip. Many of the minor flexures superimposed upon the greater ones are sharp and conspicuous. The local dips may vary as much as $50^{\circ}$ within a few hundred feet and change their direction considerably. Dips as high as $45^{\circ}$ or even $60^{\circ}$ may be seen in the layers of the iron-bearing formation in some of the open pits of the mines, as at the Stevenson, the Sauntry-Alpena, the Kanawha, and the Sparta. At the Hawkins and Agnew mines the iron-bearing formation exhibits steep, sharp folds. The iron-bearing formation shows more minor contortions than the rest of the upper Huronian rocks, because of the great chemical changes which it has undergone, but it is not probable that there is any great difference in the major folding.

The prevailing gentle southern tilt of the upper Huronian and the manner in which it laps around the salients in the older rocks suggest that the major features of upper Huronian 'structure may be due partly to initial dip as well as to subsequent folding-in other words, that the upper Huronian sediments are essentially in the position in which they were deposited against an old shore and have undergone minor leformation since.

Accompanying the tilting and minor folding of the upper Huronian there has been a very considerable amount of fracturing, especially in the comparatively brittle Pokegama and Biwabik formations. Indeed, it seems likely that the folds of the two lower formations of the upper Il uronian are mainly the result of relatively small displacement along fractures, and only to a small degree the result of the actual bending of the strata without breaking. The ponding of water beneath the Virginia slate would seem to indicate that this formation has been less fractured than the iron-bearing formation because of its less brittle character, and has thus yiekled to deformation by actual bending rather than by breaking. On almost every exposure of Pokegama and Biwabik formations joints and minute faults are to be observed cutting almost perpendicularly across the bedling. In each case the joints seem to make up two or more systems crossing each other at various angles, but such sets have little constancy of direction in wilely separated exposures, unless we except a set of joints which at a number of places have an average direction of somewhere between N. $60^{\circ}$ and $70^{\circ}$ E. - that is, approximately parallel to the trend of the range. In the massive rocks the joints are clear cut and continuous for 
consideralble distances. In the well-hedted rocks-as, for instance, in the thun-bedked portions of the inon-bearing formation-the joints are usually more inegular, less comtinuous, and less conspicuous. In such plices each individual beal may be more or less jointed without reference to the layers above or below.

The displacencut or faulting along joints has been, in general, small. The displacement is rarely 3 or 4 feet, and commonly it is measured by a few inches.

There is a displacencent of about 200 feet along a nearly vertical fault strike ruming eastward along the north side of the Biwabik mine parallel to the northem margin of the upper IInronian past Embarrass Lake. The south side of the fault has dropped, with the result that the layers of the iron-bearing formation are somewhat tilted along the contact and the width of the outcrop lessened. The eastward extension of this lault carries it through the peculiar point of Pokegama quartzite projecting eastward into the iron-bearing formation east of Embarrass Lake. Though the structure has not been worked out in detail east of Embarrass Lake, it secms not unlikely that the peculiar features of the distribution of the quartzite and ironbearing formation there may be partly explained by faulting, though original configuration of the shore lime in upper Huronian time may have something to do with it. Other great faults are almost certainly present in the district, but evidence for them has not been correlated.

Certain of the joints and faults have been filled with rein quartz and others bave not. It is rather surprising that so little vein quartz is to be observed. In the harder rocks, where the joints are clear cut and continuous, the quartz reins also appear so. In the well-bedded portions of the iron-bearing formation, where the joints are irregular and discontinuous, the distribution of the vein quartz is also irregular and discontinuous, being rather in a confused zone than in a well-clefined plane.

After the upper IIuronian was tilted and folded the upper edges of the beds were eroded away, with the result that the rock surface is now irregular, with dips corresponding roughly in direction but not in degree with those of the underlying rock strata, being in general less sterep.

\section{RELATIONS OF THE UPPER HURONIAN (ANIMIKIE GROUP) TO OTHER SERIES.}

The upper IInronian lies unconformably upon the Archean and lower-midlle IJuronian rocks. The proof of unconformity is as follows:

1. The conglomerates at the base of the upper IIuronian ${ }^{a}$ contain fragments derived from the underlying rocks.

2. There is discordance in dip. The underlying formations, where they have any parallel structure at all, are almost vertical. The upper Huronian is well berleder, with a low dip. Noreover, in approaching the contact no change of dip is to be observed either in the upper IIuronian or in the underlying rocks.

3. There is a difference in the amount of minor folding, fracturing, secondary clcarage, and further consequent metamorphism of the two bodies, the upper IHuronian being much less affeeted thin the older rocks.

4. The upper Huronian belt overlies Archean and lower-middle IHronian rocks indiscriminately. Near Biwabik, for instance, the northern edge of the upper Huronian lies diagonally across the contact of the Archean and lower-middle Furonian rocks.

5. The lower-middle Inronian sediments are intruded by the Giants Range grimite, which composes most of the core of the Giants Range. The upler IImmian is not intruded by the Giants Range granite, and, moreover, in the conglomerate at its base it bears fragments of this granite. The upper Ifuronian in ranges 12 and 13 is in eruptive contact with the lieweenawan granite and gabbro.

CONDITIONS OF DEPOSITION OF THE UPPER HURONIAN (ANIMIKIE GROUP).

The conditions under which the upper Ifuronian (Animikie group) was deposited are discussed for the Lake Superior region in Clapter XX. It may le noted here that the rocks of this group a re believed to be subaqueous deposits graling upward into delta deposits. The Mesabi 
district may represent shore conditions of deposition as contrasted with the Cuyuna district larther south, which may lepresent oflshore conditions. The well-assorted sands at the base of the group in the Mesabi district seem to show variation in thickness and area corresponding to the configuration of the older rock surface. For instance, the point of Pokegama quartzite extending eastward from Fmbarlass Lake suggests a sand spit, though distribution may be complicated by faulting. The peculial conditions letemining the deposition of the ironbearing formation are cliscussed on pages 499 et seca.

\section{KEWEENAWAN SERIES.}

DULUTH GABRRO.

A portion of the great mass of Feweenawan galbbro of northern Minnesota comes within the limits of the Mesabi distriet. The northern edge of the mass lies diagonally across the eastern end of the distriet, extending from near the Duluth and Iron Range track, in range 14, northeastward through ranges 13 and 12 to Birch Lake. Through range 14 the gabbro is in contact with Virginia slate; in ranges 13 and 12 it is in contact with the Biwabik formation, and north of Birch Lake it is in contact with lower-middle Huronim granite. The northern edge of the gabbro forms a conspicuous northward-facing escarpment overlooking the lowlying area of the Tirginia slate and of iron-bearing formation immediately to the north. To this the name "Mesabi Range" was first applied. In the neighborhood of Birch Lake the gabbro comes well up on the crest of the Giants Range, and here it does not stand above the adjacent rocks.

\section{DIABASE.}

There are in the Mesabi clistrict certain rocks associated with the Duluth gabbro which are not covered in the above general account. In range 13 exposures of fine-grained diabase appear in the SW: $\frac{1}{4}$ sec. $25, \mathrm{~T}, 60 \mathrm{~N}$, R. $13 \mathrm{~W}$., and in the central and northern portions of see. 35, T. 60 N., R. $13 \mathrm{~W}$. Bowlders of the same material indicate its extension for several miles east and west, and, taken together with the exposures, indicate a belt with a possible wiclth of somewhat less than a mile, a length of at least 3 miles and probably much more, and a trend northeast and southwest-that is, parallel to the general strike of the formation boundaries in this part of the district. The diabase is a fine-grained dark-gray rock which under the microscope shows a well-developed ophitic arrangement of plagioclase feldspar crystals and the presence of abundant hornblende and less abundant ilmenite and magnetite. The cliabase corresponds lithologically to the diabase sills intruded in the iron-bearing formation in the neighborhood of Gunflint Lake, and there supposed to be either offshoots of the gabbro or intrusives both in the gabbro and adjacent rocks. The trend of recent opinion is toward the former conclusion. In the SW. $\frac{1}{4}$ sec. 25, T. $60 \mathrm{~N}$., R. $13 \mathrm{~W}$., south of the diabase, drill holes have recently penetrated altered slate (cordierite hornstone). The relations of the slate to the surrounding rocks are unknown because of lack of exposures and exploration. If the slate is continuous with that to the west, which had not heretofore been known to extend farther east than sees. 5 and 8 of the same range, the diabase must be a sill intruded in the upper Huronian (Animikie group). If the slate is not continuous with the main belt of slate to the west, it must be an isolated mass in the Keweenawan rocks, and the diabase would belong with the main mass of the Keweenawan. From the analogy of its lithologic character with that of the diabase sills to the east, from its distribution, and from the occurrence of slate to the south it is thought that the diabase is probably a sill, but lack of exposures and of sufficient exploration makes it quite impossible at present to show its boundaries on the map. The area south of the diabase, inclurling that in which the slate has been found. is therefore mapped as Kieweenawan.

A little southeast of the northwest corner of sec. 34, T. 59 N., R. 14 W., E. J. Longyear found diabase at the depth of 984 feet, in a drill hole which had passed through 16 feet of drift, 392 feet of black slate, and 576 feet of iron-bearing formation. Diabase was penetrated for 309

a For a general account of the Keweenawan series of Minnesota see Chapter XV (pp. 366 et. seq.)

$17517^{\circ}-\operatorname{VoL} 52-11-12$ 
feet before the work was stopped. The iron-bearing formation is boumderl on the north by lower-midkle IIuronian graywackes and shtes, upon the eroded edges of which lies the ironbearing formation, with perhaps a thin layer of Pokegama yuartzite betwern. The fact that the diabase rathel than the P'okegama quartzite or lower-micldle II slate was reached by the drill below the iron-bearing formation would be in accord with the supposition that the diabase formed a sill intruded into the iron formation at this place.

In the NE. SE. ser. 13, T. 57 N., R. 22 W., drilling has penctrated 20 feet of cliabase with iron-bearing lormation hoth above and below.

\section{EMBARRASS GRANITE.}

Through ranges 12 and 13 and as far west as sec. 2, T. 59 N., R. 14 W., a distance of 15 ) miles, the granite forming the core of the Giants Range is intrusive into the upper IIuronian. Whether it was intruded at the close of the upper IItronian epoch or cluring the suececting Keweenawan is a matter of cloubt and indeed is a matter of small consequence. The fact that granite dikes cut the Keweenawan series in other parts of northern Minnesota makes it a plausible assumption that the granite was intruded in Keweenawan time, but no relations of the granite to the Keweenawan have been obserred in the Mesabi clistriet. The granite is named the Embarrass granite from its lithologic similarity to granite exposed at Embarrass station on the Duluth and Iron Range Railroad, just north of the Giants Range.

The Embarrass granite is a pink hormblencle granite. It is usually of coarse grain but shows much variation. In general the grain becomes finer towarl the west. The eharacteristic feature of the granite is its large content of quartz in small and large grains, which are rery conspicuous, especially on the weathered surface. The quartzes range in diameter from a few millimeters to more than a centimeter. The large ones have a characteristic purphish-blue color. In its content of quartz the Embarrass granite is reactily distinguished from the lowermiddle Huronian granite (Giants Range granite) in the central and western parts of the range, in which the quartz is exceedingly rnre or entircly lacking. Other eonstituents are pink orthoelase feldspar, which sometimes occurs as porphyritie crystals almost an inch long, and a rather small amount of hornblende. The relative abundance and coarseness of all the constituents of the granite of course show the usual variations of a large granitie mass.

Cutting the granite are a few clikes of finer-grained, lighter-colored quartzose granite, which under the microscope is found to chffer from the one just lescribed only in lacking hornblende and the rare elements mentioned.

In the Mohawk mine and elsewhere near Aurora granite forms the foot wall of the ore bodies, in one place coming within 16 feet of the rock surface. From this rertical dikes cut across the formation. The relations seem to be those of int rusion of granite principally parallel to the bedding but partly across it. These relations may be correlated with those of the Embarrass granite at the east end of the range.

\section{CRETACEOUS ROCKS.}

Distribution and character.-Recent explorations have showu Cretaceous conglomerates, shales, or iron ores as a thin mantle orer most of the western part of the district and in isculated patches as iar east as Emharrass Lake. It is therefore thought inalvisable to attempt to show Cretaceous deposits on the map. Especially noteworthy is the discosery of small conglomeratie Cretareous ore bodies overlying the contact of the iron-bearing Biwalik formation and the Virginia slate. From the distribution of the remnants now known it is certain that. ('retaceous rocks one overlaly all of the distriet west of range 16, that they mat have extended farther east, and that arosion has larecly remored themefrom the area they did occupy. It is not unlikely that some ol these remmants lave been protected because faulted clown in post('retacerous time.

The rorks consist of eonerlomerate and shale. The conglomerate in the oceureneres known orerlies iron-bearing rocks and in some places irom ore. Is would be cxpected, therefore, the 
fragments of the conglomerate are derived from the iron-bearing formation; in the western part of the range the conglomerate is locally rich enough to mine. The conglomerate fragments consist mainly of heavy ferruginous chert and iron ore, both hematite and limonite. Except locally, and especially where the pebbles are of hard material, they are not well rounded. There are present in the conglonerate also fossils which are described below. The fragments are but loosely cemented. When broken out of the ledge the rock is fairly compact, but on being exposed to weathering it soon disintegrates. The cement is lurgely ferruginous, but there is present also a considerable amount of white or yellow substance which $\Lambda$. T. Gordon, chenist of the Mountain Iron mine, found to consist of silica and alumina and hence to be essentially a clay. Occasionally there may be observed also minute greenish-yellow particles in the cement which may be glauconite crains, so common in the Cretaceous. Analyses disclose abundant phosphorus. The general appearance of this Cretaceous iron-ore conglomerate is very like that of "canga" or rubble ores formed subacrially on the surface of iron formations in the Minas Gernes district of Brazil.

The shales are soft, thin-bedded rocks of a bluish-gray color when fresh but in many places are of a light color due to bleaching. These, too, contain fossils.

Fossils.-Selected specimens of the shale and conglomerate containing fossils were submitted to T. W. Stanton, paleontologist, of the United States Geological Survey, for examination. He pronounced them to be "unquestionably Upper Cretaceous forms, not older than the Benton and probably not younger than the Pierre."

In addition to the fossils above noted, the Cretaceous of the Mesabi district has been found to contain small shreds of lignitic miterial. The presence of this material well up on the Mesabi range suggests the possibility of finding lignite deposits in the low area to the west, north, or south of the Mesabi lange.

\section{PLEISTOCENE GLACIAL DEPOSITS.}

The Mesabi district is corered by a mantle of glacial drift, of the late Wisconsin epoch, which effectually conceals the greater part of the underlying rocks. On lower slopes the drift is thick, sometimes reuching 150 to 200 feet, and here of course rock exposures are rare: on middle slopes the thickness commonly does not excecd 50 or 60 feet, and 20 to 50 would measure much of it; on the upper slopes of the range the drift is thin or altogether lacking and rock exposures are correspondingly abundant. In the eastern portion of the district also, where the Giants Range granite has a higher elevation than to the west, the drift is thin and allows numerous rock masses to project through; towarl the west, as the elevation of the Giants Range decreases, the drift becones thicker, until westward from Grand Rapids it buries even the crest of the Giants Range to a depth of more than 100 feet.

The Pleistocene deposits are fully discussed in (hapter XVI (pp. 427-459).

\section{THE IRON ORES OF THE MESABI DISTRICT.}

By the authors and IT. J. MEAD.

\section{DISTRIBUTION, STRUCTURE, AND RELATIONS.}

The iron-bearing Biwabik formation rests on the middle south slope of the Giants Range, with a low dip to the south, $4^{\circ}$ to $20^{\circ}$, affording an exposure of considerable wilt th at the surface. The eleration of this exposure varins between 1,400 and 1,600 feet. The distribution of the Biwabik formation and the possibilities of westward extension are discussed on pages 164-165. Possibilities of extension sunthward are mentioned on page 174. The ore bodies are in patehes along the erosion surface of the iron-bearing formation, generally less than 200 feet thick, but reaching 500 feet at greatest.

The aggregate arca of all the iron-ore deposits of present commercial grade known at this writing at the surface is about 15 square miles, constituting a little less than 8 per cent of the exposed surface of the iron-bearing formation in its productive portion between the east line of 
range 14 on the east and west side of ramge 26 on the west. If low-erade ores were counted the al rea would be approximately doubled.

East of range 14 the nature of the formation is influenerd by the great liewenawan I)uluth

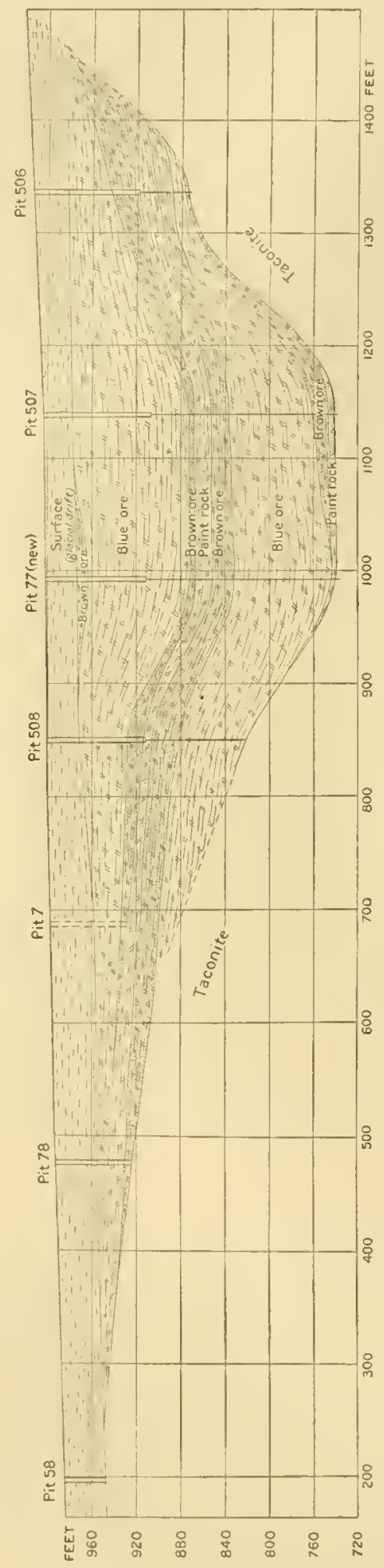
gabbro mass orerlying the east rnd of the district. The are bodies are few and small and are more larely magnetitic and amphibolitie than hematitic. Toward the west end of the distriet also the ores become lower in erade, owing to increasing content of lonsely disseminated cher', locally called sand, so abundant in certain of the ores that they require washing to attain the present commercial grade.

The rocks immediately assiciated with the ores are mainly ferruginous cherts, locally called "taconite," forming both the walls and basements of the deposits. The ores usually do not rest directly upon the quartzite underlying the iron-bearing formation. Their lower limits are locally marked by thin layers of paint rock a few inclies thick. A horizontal plan of the Mesabi ore deposits is execedingly irregular both in major outline and in minor foatures. The deposits are in many places bounded by intersecting plane surfaces of joint or fault planes. In rertical section the ore deposits in general are widest at the top and narrow below, in the form of a shallow basin. The slopes of the basin are rarely symmetrieal and few slopes are uniform; a slope is generally a series of steps, some of them overhanging the ore or projecting into it. The beelding of the iron ores is continuous with that of the adjacent ferruginous eherts of the iron-bearing formation except where there has been local slump or faulting at the contact. The slump is sometimes accompanied by close crumpling of the layers of the iron-bearing formation (PI. LX). It will be shown later that the slump results from the leaching of siliea. Obviously the layers have been originally too long for their present positions and have erumpled to accommodate themselves to the new conditions. The bedding of the ores is thus essentially parallel to that of the upper Iuronian of this district - that is, sloping gently southward at angles from $4^{\circ}$ to $20^{\circ}$, with minor gentle folds whose axes pitch in that direction. $A$ good general conception of the structural relations of the Mesabi ores may be obtained by thinking of the ores as irregular rotted upper portions of the slightly tilted and beveled iron-bearing formation, the rot ting having been favored in certain spots, as will be shown latar, by the fracturing of the formation or by the minner folds in which the formation rests. (See fig. 16: PI. X. which is a north-south cross section; and Pl. Xl.)

\section{CHEMICAL COMPOSITION OF FERRUGINOUS CFERTS AND ORES.}

ANIITSES.

The chenical romposition of the ores and relat ed rocks is here exhilbited hy partial and complete analyses from vallious sourees. A large number of the analyses employed were kindly furnished by the serral mining companies. All the other analyses except those previously pullished were made by Lereh Brothers in therr laborateries at llibbing and 


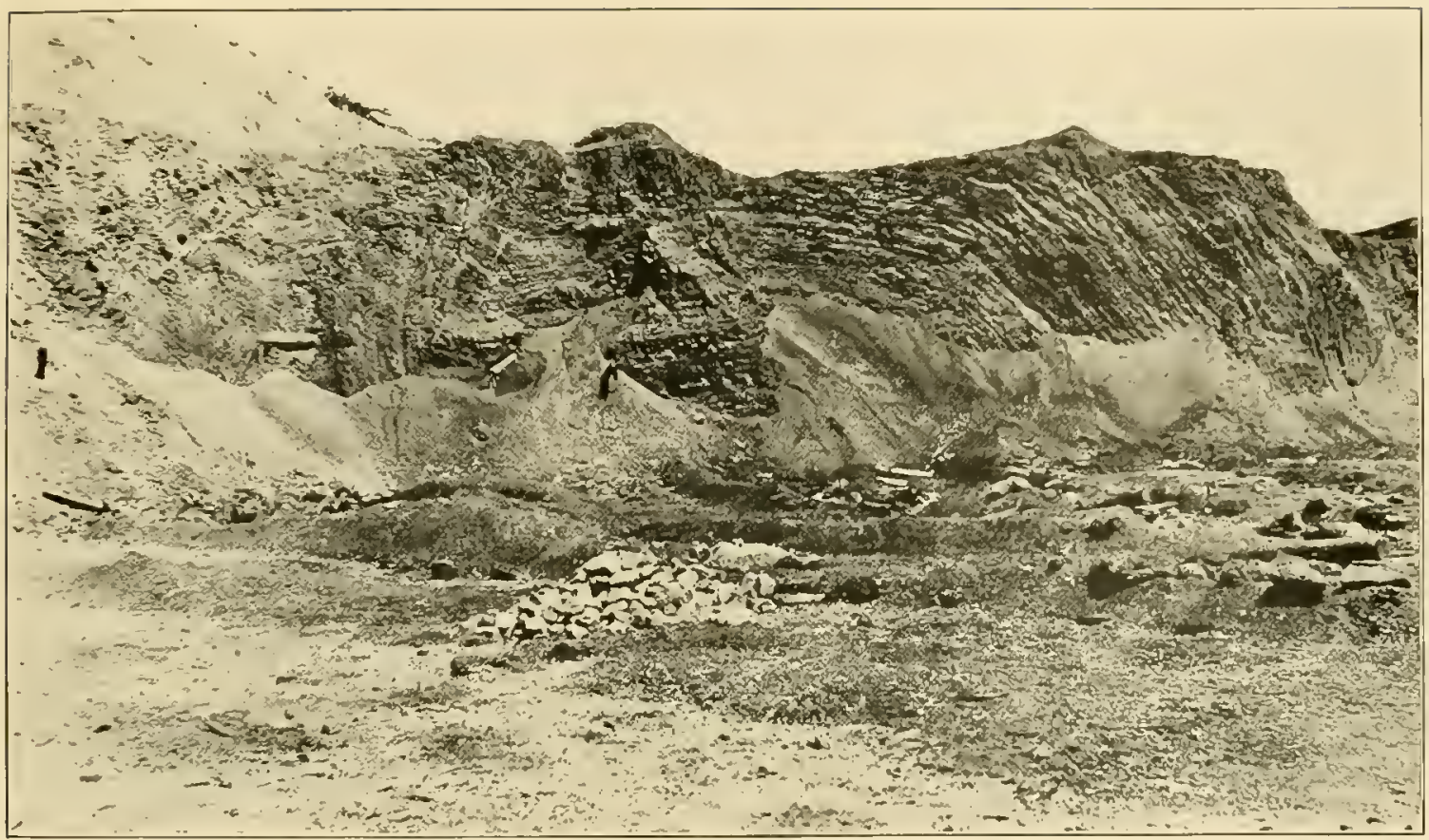

1. HAWKINS MINE.

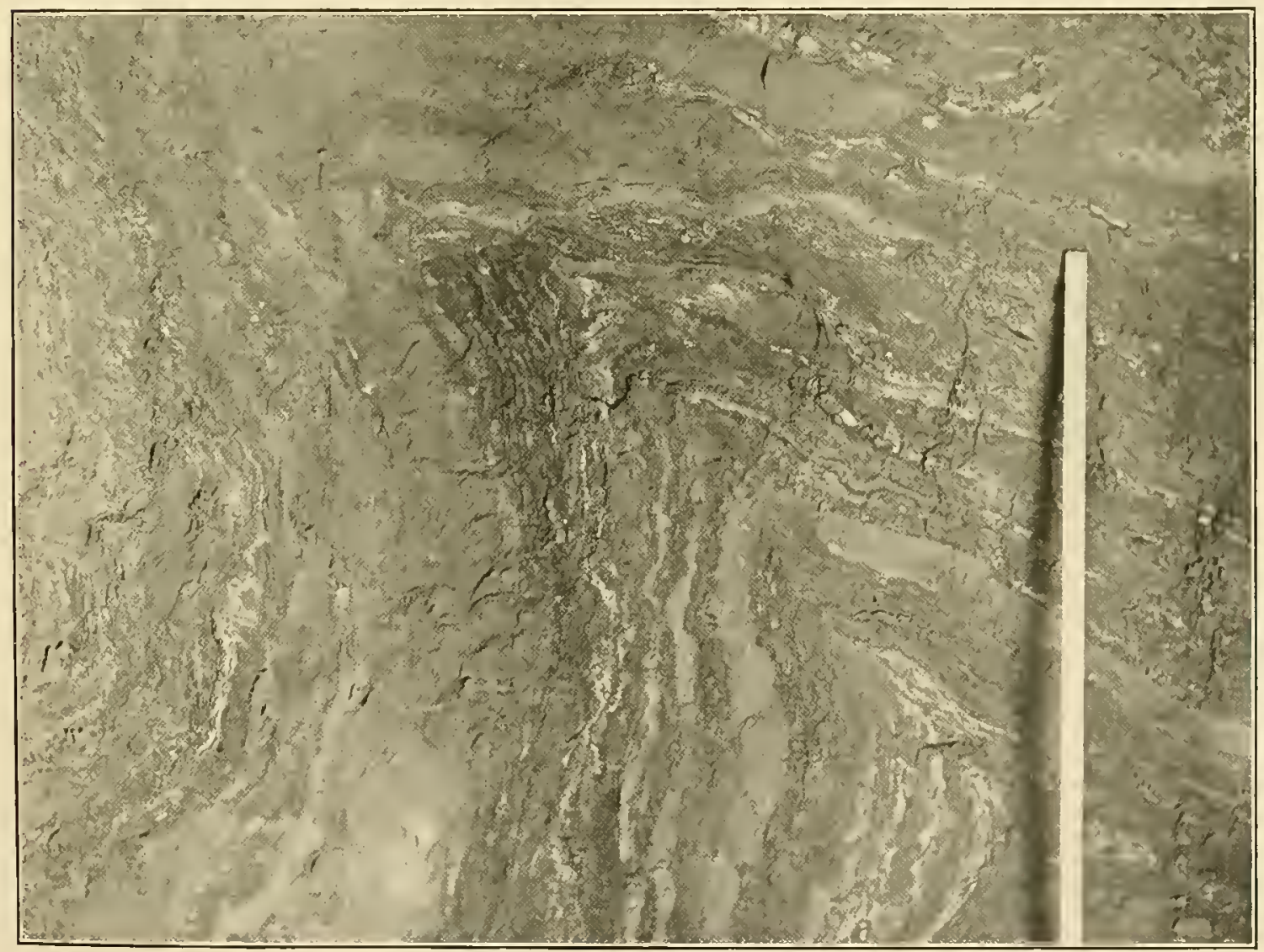

7i. MONROE MINE.

SHARP FOLDING OF BEDS OF IRON-BEARING BIWABIK FORMATION IN MESABI DISTRICT, MINN.

See page 180 



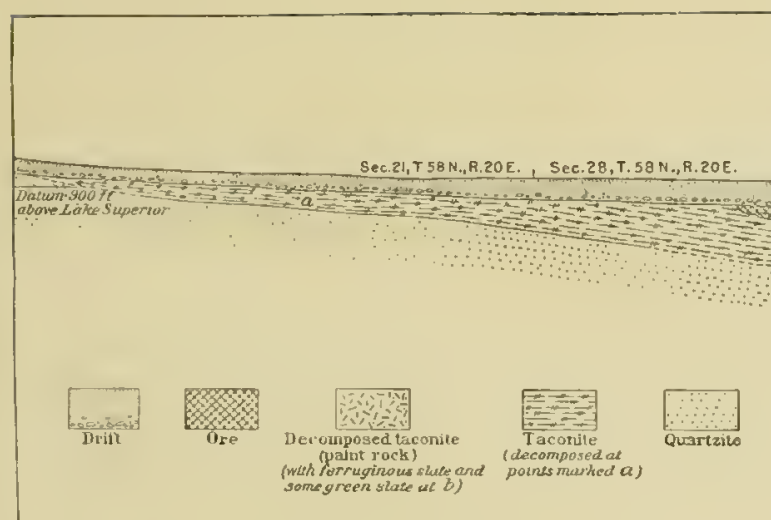

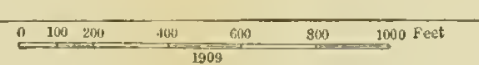

Darum 980 n above Zake Siperiut

NORTH-SOUTH CROSS SECTION THROUGH IRON-BEARING BIWABIK FORMATION, MESABI DISTRICT, MINNESOTA Compiled by O. B. Warren from drill records. 



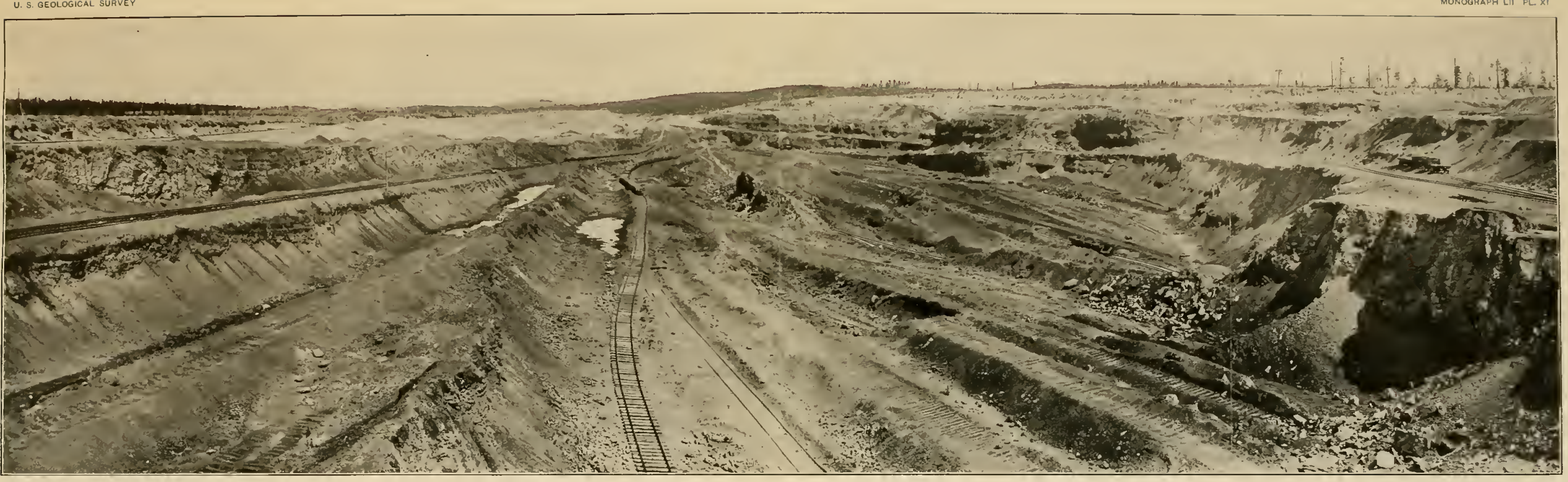

A. PANORAMIC VIEW OF THE MOUNTAIN IRON OPEN-PIT MINE, MESABI DISTRICT, MINN.

PANORAMIC VIW OF THE MOUNTAN I J F Lindberg. Hibbing. Minn. See pares 180, 497.

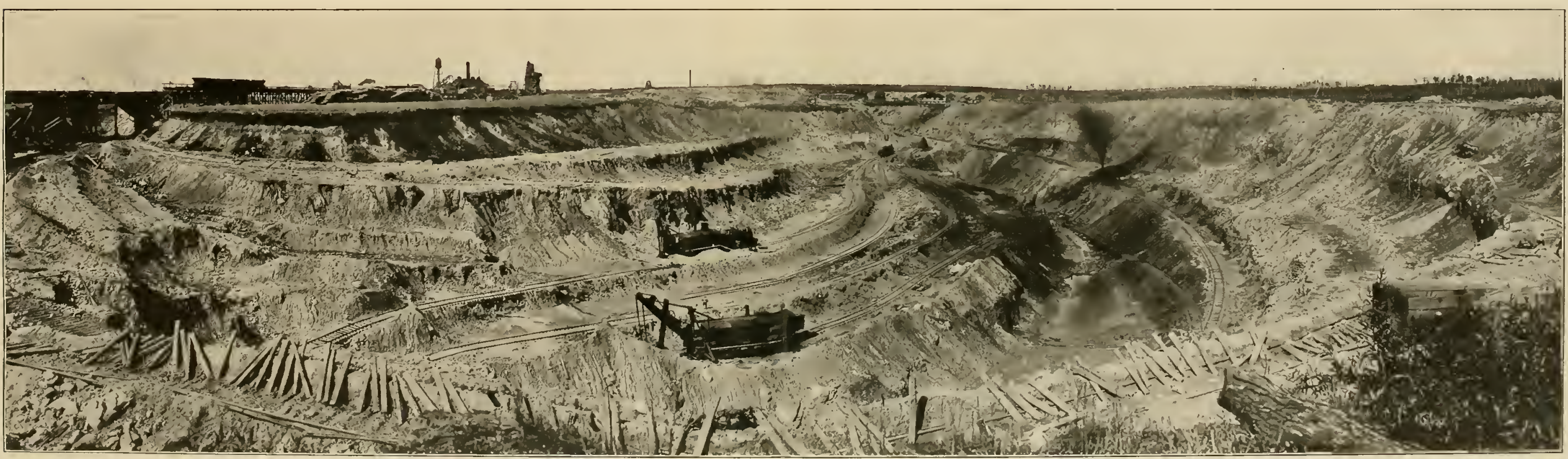



Virginia, Minn. The arerage cargo analyses for the rarious grades of ore were obtained from the list published by the Lake Snperior Iron Ore Association.

Nine typieal analyses of taconite are given in the following table. 'These analyses include carefully selected samples from several drill holes giving complete sections through the formation.

I'artial analyse's of ferruginous chert (taconile') from the Mcsali range.

[Samples dried at $212^{\circ} \mathrm{F}$ ]

\begin{tabular}{|c|c|c|c|c|c|}
\hline & Fe. & $\mathrm{SiO}_{2}$ & P. & $\mathrm{Al}_{2} \mathrm{O}_{3}$ & $\begin{array}{c}\text { Loss 0.2 } \\
\text { ignition. }\end{array}$ \\
\hline 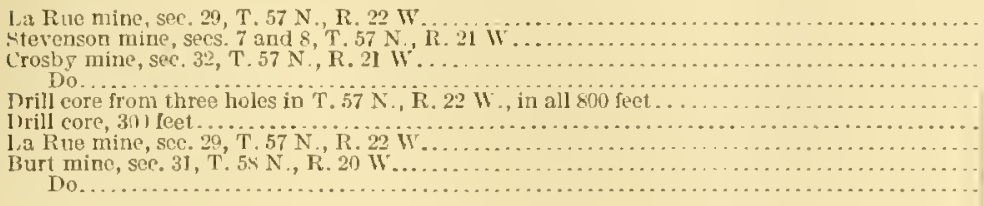 & $\begin{array}{l}32.24 \\
34.99 \\
11.79 \\
19.56 \\
30.24 \\
23.50 \\
32.216 \\
23.99 \\
32.52\end{array}$ & $\begin{array}{l}51.35 \\
\text { (1..38 } \\
\text {-1. } 34 \\
70.27 \\
47.14 \\
50.90 \\
50.75 \\
12.75 \\
52.21\end{array}$ & $\begin{array}{l}0.021 \\
.024 \\
.0110 \\
.013 \\
.034 \\
.030 \\
.01 .4 \\
.013 \\
.020\end{array}$ & $\begin{array}{r}0.37 \\
.21 \\
.26 \\
.33 \\
.44 \\
1.20 \\
.30 \\
.91 \\
.12\end{array}$ & $\begin{array}{r}0.62 \\
.00 \\
.07 \\
.25 \\
5.16 \\
7.52 \\
.45 \\
1.33 \\
1.07\end{array}$ \\
\hline A verage & 25.71 & 58.70 & 101 & .54 & 1.96 \\
\hline
\end{tabular}

The large loss on ignition in the drill-core samples is in part due to the presence of $\mathrm{CO}_{2}$ in carbonates. The samples represent the hard phases of the formation, showing little concentration to ore. When all of the iron-hearing formation outsile of the available iron-ore deposits is averaged, including both the hard lean parts slown in the above table and the partly concentrated portions of the formation, the average iron content runs higher. In average of 1,094 analyses, representing 5,400 feet of drilling in the district away from the available ores, gives 38 per cent. This does not include the ores. Because of the great mass of such rocks as compared with the ores, this figure of 38 per cent represents approximately the general arernge iron content of the entire formation.

The arerage composition of the Mesabi ore for the years 1906 and 1909 was obtained by combining average eargo analyses of all crades mined for ench of those years in proportion to the tonnage represented by each grade. In this manner an arerage inalysis was obtained which represents as exactly as possible the composition of all of the ore mined in the Mesabi district during the years 1906 and 1909.

Alerage composition of all ore mined in the Acsabi district during the years 1906 and 1909.

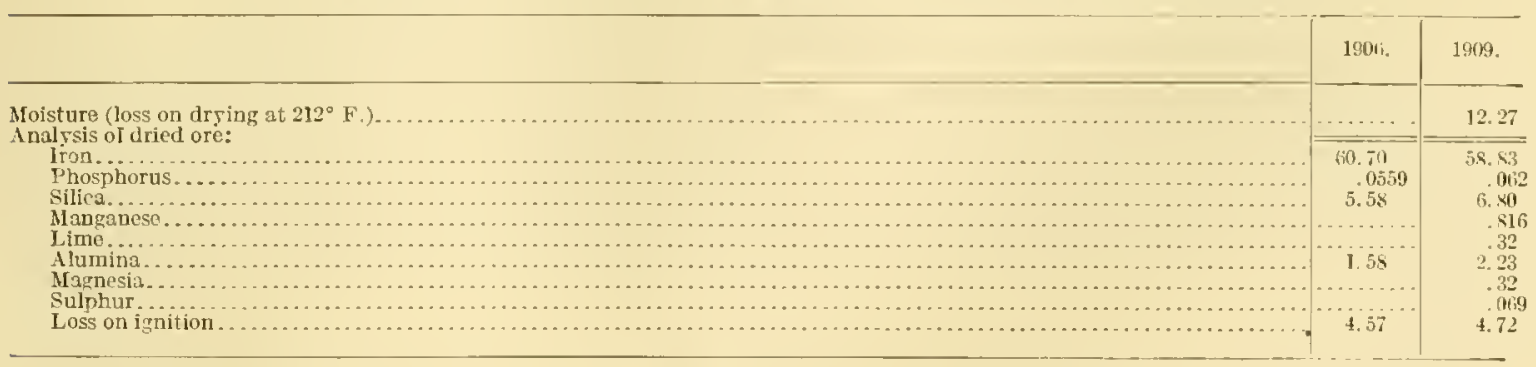

Range in composition of ores mined in the Mesabi district, as shoun by arerage cargo analyses for 1909.

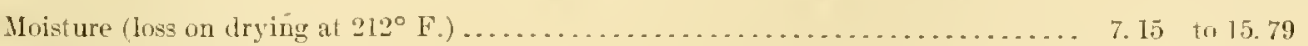
Analysis of dried ore
Iron.
52. $40 \quad$ to64.05
Phosphorus. .019 to .105

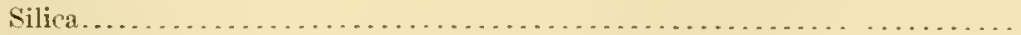
2. 50 to 19.90
Manganese.
.20 to 2.84
Alumiua.............................................. 16 to 5.67

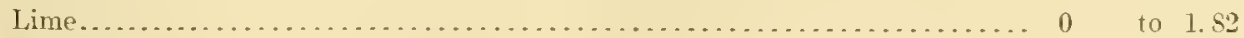

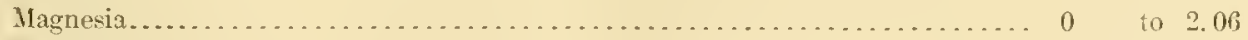
Sulphur. . . ........................................ . 004 to. 440
Loss on ignition. . . . . . . . . . . . . . . . . . . . . . . . . . . . . . 1.71 to 9.45 


\section{JEPRESHNTATION BY MEANS OF THIANGLLAR MIAGRAM.}

In figure 17 the triangulas method of platting is employed to show the chemical composition of the various phases of taconite and ore sumlied. Here atual percentage weights of the constituents are indicated, and no account is taken of volume or porosity. Earch point, ly its position in the triangle, indicates an indivilual analysis. The diagram consists of an erfuilateral triangle erossed by equally spaced lines, 100 parallel to each silde. Distances measured prorpendicularly from tho three sides to any point within the triangle (by means of the divisions in the triangle) represent severally percentages of ferric oxide, silica, and the remaining consit-

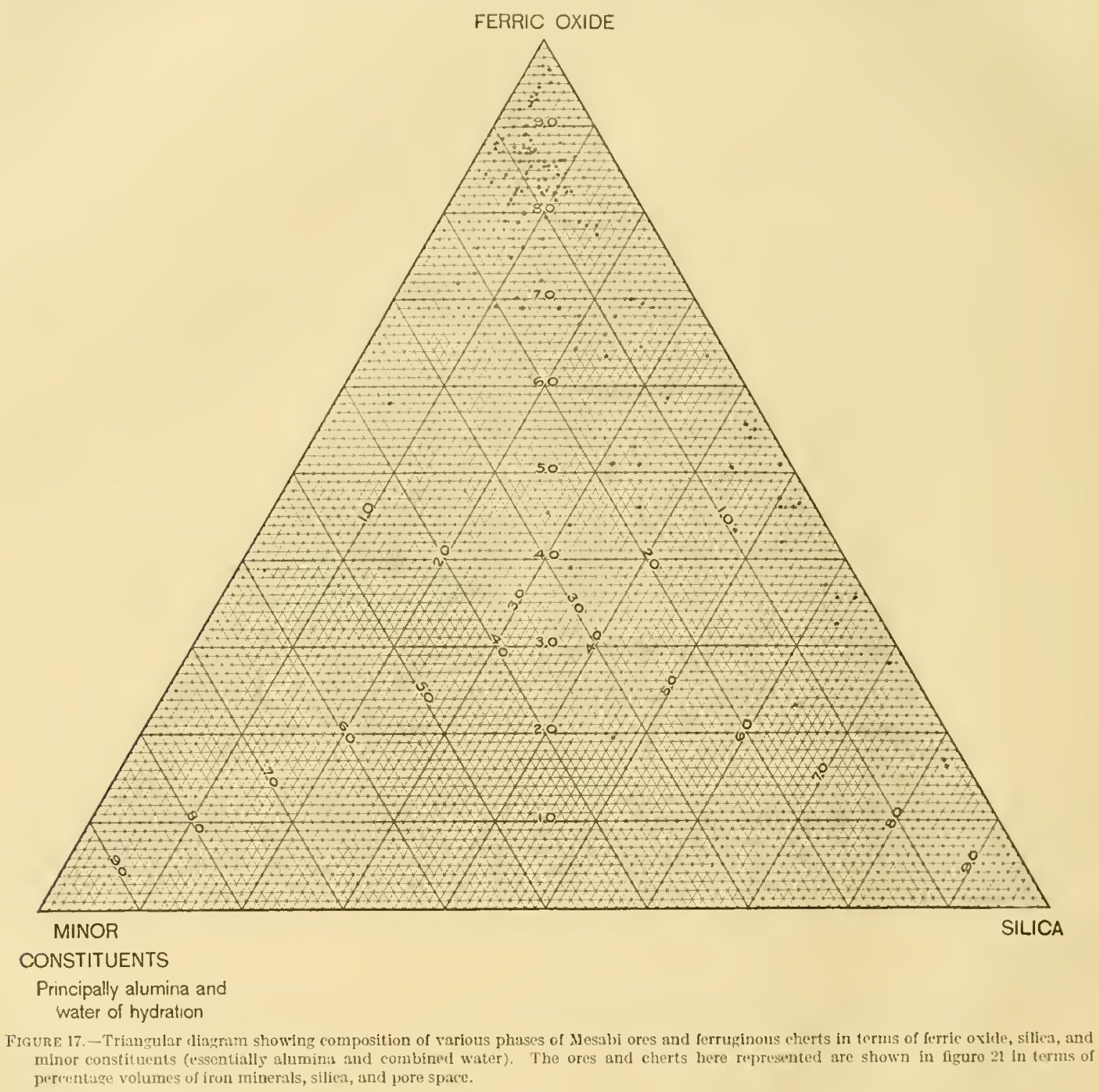

uents. Thus any point in the triangle indicates a certain definite combination of these three farctors. The grouping of the points in the triangle shows that the principal variation in composition lies between the iron and the silica. In the process of concentration of ore from the ferruginous ehert the perentage of iron inereases in proportion to the decrease in silica, while the perentage of minor constituents remains practically constant; hence this coneentration would be represented by a series of points in a line parallel to the right-hatud side of the triangle. A tareonite with in high content of alumina proluces an ore high in kiuslin, amd conversely. 


\section{MINERALOGICAL COMPOSITION OF FERRUGINOUS CHERTS AND ORES.}

Mineralogically both the cherts and the ores consist essentially of hyclrated oxides of iron, chert, or quartz, ahminum-bearing minerals, usually kaolin, and a small amount of minor constituents. In the calculation of the approximate mineral composition of the various rocks and ores these minor constituents-alkalies, sulphur, phosphorus, etc.- were elisregarded, the error thus introduced being small. The iron is present in the ores and cherts as a partly hydrated ferric oxide. To ascertain in each case the particular hydrated iron-oxide mineral present would be impracticable, but by calculating the iron as hematite and limonite the degree of hydration is expressed by relative amounts of the two minerals. The amount of limonite is found by assigning to the volatile matter or water of liydration available the proper amount of iron, the remainder of the iron being calculated as lematite. The practice of assigning to the iron mineral all the water of hydration not in aluminum silicates may introduce minor inaccuracies becanse of the possible slight hydration of the chert.

The mineralogical compositions of the ores and ferruginous cherts of the Mesabi range catculated from the averige analysis by the methods described aloove are as follows:

A pproximate mineral compositions of acerage ores and ferruginous cherts.

\begin{tabular}{|c|c|c|c|}
\hline & \multirow{2}{*}{$\begin{array}{l}\text { Ferrugi- } \\
\text { nous } \\
\text { eherts. }\end{array}$} & \multicolumn{2}{|c|}{ Ores. } \\
\hline & & 1906. & 1909 \\
\hline \multirow[t]{2}{*}{$\begin{array}{l}\text { Hematite... } \\
\text { Limonite. ... } \\
\text { Quartz....... } \\
\text { haolin ...... } \\
\text { S1iscellaueous }\end{array}$} & $\begin{array}{r}26.30 \\
12.22 \\
58.07 \\
1.37 \\
2.04\end{array}$ & $\begin{array}{r}\text { ri3. } 00 \\
2.00 \\
4.10 \\
4.05 \\
1.82\end{array}$ & $\begin{array}{r}61.81 \\
25.95 \\
4.10 \\
5.30 \\
2.84\end{array}$ \\
\hline & 100.00 & 100.00 & 100.00 \\
\hline
\end{tabular}

PHYSICAL CHARACTERISTICS OF THE ORES.

TEXTURE.

The Mesabi iron ores are for the most part soft, somewhat hydrated hematite, though approximately pure limonite ores are present in subordinate quantity. The ores as a whole are of finer texture than those of any other Lake Superior district. Their texture varies from exceedingly fine-grained "flue dust" to a lairly coarse, hard, and granular ore breaking into parallelepiped blocks. Usually the ore needs but little blasting to allow the steam shovel to take it from the bed. The average texture of the Mesabi ores is shown by the following table, representing an average of screening tests on eight grades of typical Mesabi ore totaling 18,313,570 tons in 1909. These screening tests were made by the Carnegie Steet Company and represent the total year's output of each of the grades tested. The textures of the ores of the several Lake Superior districts are compared in figure 72 (p. 481).

Textures of Hesabi ores as shoun by screening tests.

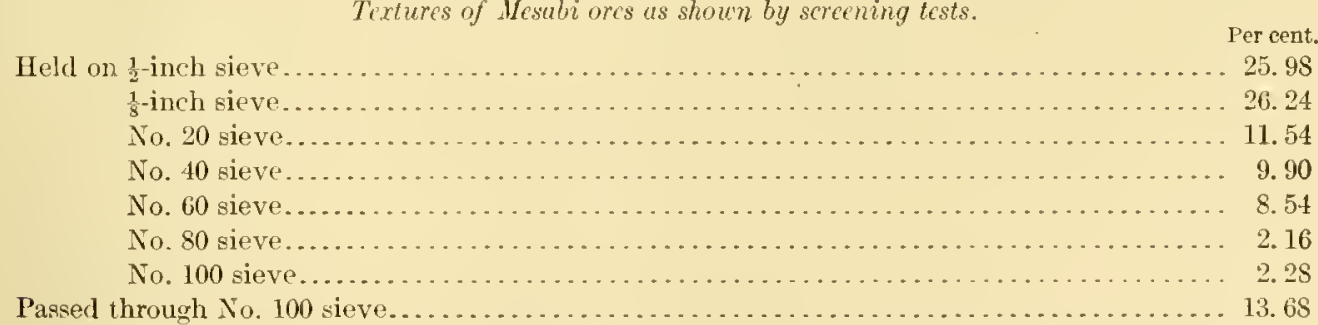

The fineness of many of the ores has required mixture with coarser grades for blast-furnace charges. The average nixture is approximately indicated by the proportions of Mesabi to other Lake Superior ores, whieh lias increased to 69 per cent in 1910. 
HEXSITY.

Sereral methods were employed in the determination of density-(1) determination of density of linely powdered specimen by means of specific-gravity bottla; (2a) doterminations of density from hand specimens by the common method of weighing in air and in water, the pores of the rock being filled with water by prolonged boiling before weighing under water; (3) calculation of specific gravity ol" the roek or ore from mineral composit ion by proper combination of the densities of the several minerals present. The density of the ores or cherts calculated by using the density of the iron minerals given hy Dana was uniformly higher thun the density lound by gravity metheds. The iron minerals in an earthy form have a lower density than thuse in the hard ores, and it was lound that the two methorls could be male to agree ly assigning to lematite a density of 4.5 and to limonite one of 3.6 .

By comlining the specific gravities in proportion to the percentages of the minerals the average density of the ferruginous cherts is found to be 3.27 .

Actual density determinations on eleven specimens of ferruginous cherts gave an average of 3.02. (See table below.) This figure is lower than the average figure computed above, for two reasons: The eleven specimens on which the determinations were made contained a smaller percentage of iron than the arerage analysis above. The close texture of the specimens prevented complete saturation by immersion in water and also prevented complete drying; hence both density and porosity determinations are somewhat lower than they should be. For these reasons it is believed that the specifie gravity as calculated from the average analysis above $(3.27)$ represents most elosely the arerage specific gravity of the taconite.

Tha average specific gravity of the ore, as calculated from the mineralogical composition of the average ore, is foumd to be 4.10 .

\section{POROSITY.}

In all rocks and ores of which hand specimens could be collected the porosity was determinel by comparing the weight of the specimen when saturated with water with its weight when dried. This mannel of determination is formulated as follows:

$$
\begin{aligned}
& \text { Weight of water absorbed } \\
& \text { Veight of rock when saturated }
\end{aligned}
$$

$$
\text { Porosity }=\frac{M}{\frac{1-M}{G}+M}
$$

where $G$ equals specific gravity. From this formula it is obvious that a determination of density is necessary in comnection with each porosity determination.

The porosity determinations on eleven specimens of ferruginous chert hy the method described follow.

Porosity determinations of cheri.

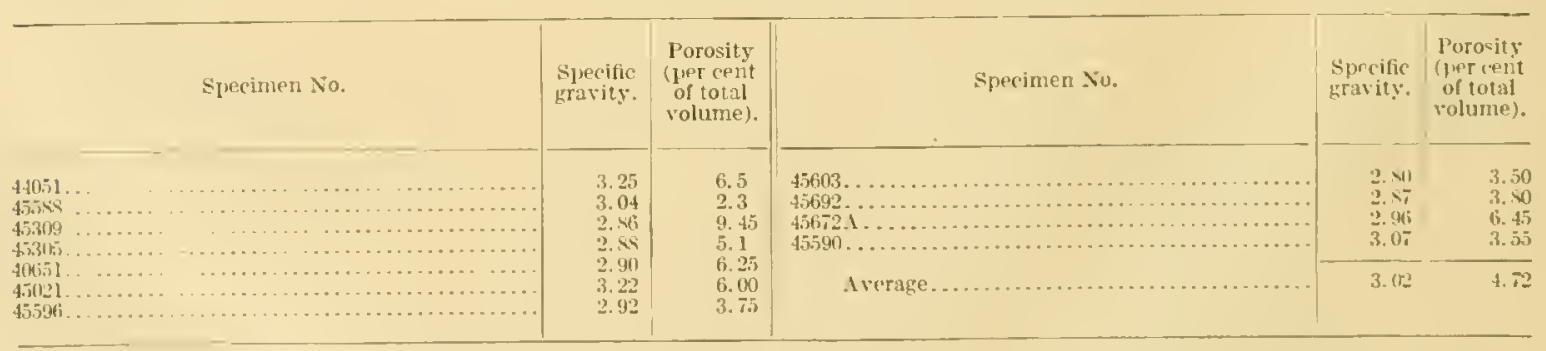

To uncousolidated material, such as a large part of the Ifesabiores, the above method could not be applied. The porosity of such material was found by comparing its antral density when in place, including pore space, with the calculaterl mineral density, which does not indude pore space. The actual density of the material in place was determmed by weighing the 
amount removed from an excaration made on a leveled surface of the ore, the volume of the excavated material being dotermined by measuring the amount of grain necessary to fill the excaration. Another method for the determination of cubic content of the Mesabi ores is one employed by O. B. Warren, of Hibbing, Mim. Mr. Warren used a bottomless box 4 feet long, 3 feet wille, and 1 foot deep. These dimensions were chosen as representing the average rolume of a ton of ore. This box is set up on a leveled surface and thr ore removed from the inside of the box until the sides are sunk to the level of the surface. In this way exactly 12 cubic feet of ore are removed and weiglied, a sample for analysis being taken at the same time.

The porusity of the ore may also be determined by saturating a portion in place by an abundant application of water. Placing a sample of the saturated material immeliately in a closed ressel permits the determination of the moisture of saturation, from which the porosity may be calculated as shown above. Where the ore to be tested is in a vertical wall a small niche should be cut to afford a horizontal surface for the application of the water. It will lue seen that this method does not differ essentially from the determination of porosity of hand specimens, except that the material is saturated in place and not after removal from the ground.

More than 100 determinations by the various methods show the average porosity of the ore

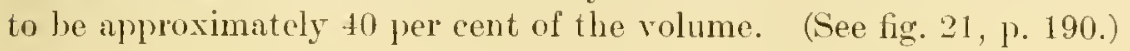

\section{CUBIC CONTENTS.}

Owing to the wide variation in the three essential factors, density, porosity, and moisture, there is a wide variation in the number of cubic feet per ton of the ores. This number ranges from 9 cubic feet per long ton in some of the highest-grale blue granular ores to 17 or 18 in the low-grade limonites. The average for the district is approximately 12 cubic leet per long ton. The method of calculation is discussed on pages $480-484$.

\section{MAGNETIC PHASES OF THE IRON-BEARING FORMATION.}

\section{OCCURREICE.}

Eastward from the town of Mesaba, on the Duluth and Iron Range Railroad, the ironbearing Biwabik formation becomes progressively more manetic, more coarsely crystalline, and the red or brownish tones of the feruginous cherts give way to black and gray colors. Ore deposits are rare. Such as there are consist of mixtures of hematite and magnetite. In the most magnetic and crystalline parts of the formation ore deposits seem to be entircly lacking. In addition to the magnetite and quartz, there are present rarious anlydrous silicates, such as grünerite, actinolite, augite, and others. The parts of the formation rich in magnetite are concentrated into definite layers a fow inches to a few feet in thickness and interlayered with layers less rich in magnetite. Mining would require not only hand sorting but presumably also crushing and magnetic concentration.

CHEMICAL COMPOSITION.

The chemical composition of the amphibole-magnetite rock is about the same as the average of the iron-bearing formation elsewhere in the Mesabi district outside of the iron-ore deposits, as is shown by the following average:

Average chemical composition of amphibole-magnetite rock in the Mesabi district.

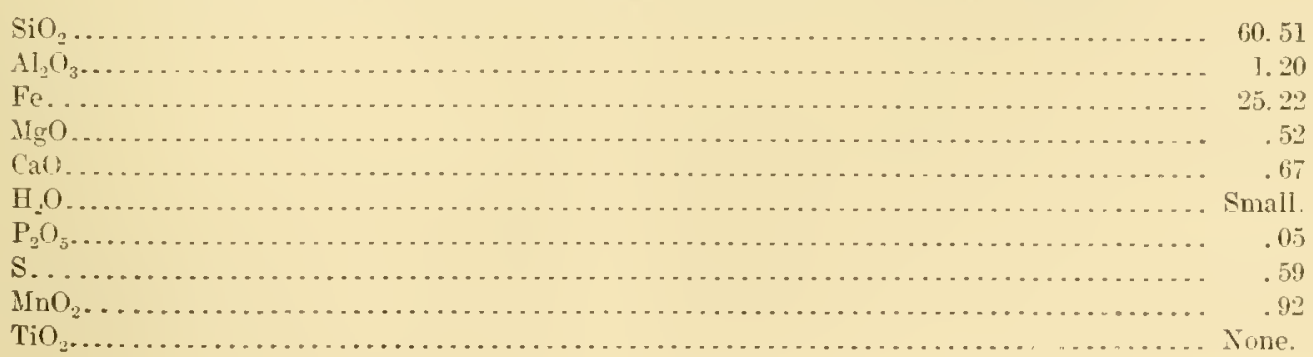


The reasous for the lack of concent lation of ore in this part of the formation are discussed on page 553.

SECONDARY CONCENTRATION OF MESABI ORES.

STIUCTLRAL CONDITIONS.

In the Mesali distriet waters falling on the soutl slope of the Giants Range lave flowed soutluwal, entered the eroded edges of the slightly tilted ITuronian series, and flomed through the iron-hearing formation, following both hedding and joint planes. There are gently pitehing rolls in the formation, but they are so light that their control of the circulation is small as compared with that of the bedding and joints. The result is the extreme irregularity in the shape and distribution of the Mesabi ore deposits.

On the south the iron-bearing formation is overlain by slate. The percolating waters undoubtedly permeate the iron-bearing formation beneath the slate, but it is altogether likely that there they are ponded and have a relatively slow movenent. Drill holes put down through the slate into the iron-bearing formation occasionally meet water under artesian pressure. The principal zone of escape doubtless is the north edgo of the slate-that is, the water overflows to the surface before passing far under the slate (fig. 18). This doubtless explains the comparative lack of alteration of the iron-bearing formation or the existence of ore deposits far under the Virginia slate.

The ponding effect of the slate also probably aids in climinishing any possible effect which the southward-pitching synclines in the iron-bearing formation might have on the localization of the ores, for the reason that near the slate flowage of water is controlled by the point of escape at the edge of the shate rather than by the configuration of the basin in which it might otherwise

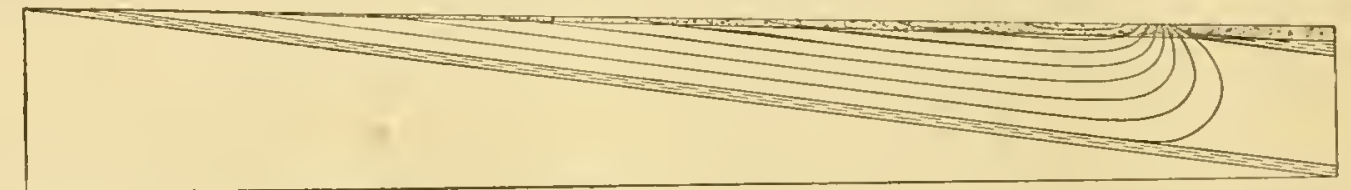

Lines of flow $\quad \square$ Drift $\square$ Irombearing formation

FIGURE 18.-Section through iron-bearing Biwabik formation transverse to the range, showing nature of circulation of water and its relatlons to confining strata.

flow, and this point of escape may be higher than the anticlines in the basement, thus allowing the waters to flow equally well over anticlines and synclines in the basenent.

The inpervious basement in the Mesabi district is usually some layer in the iron-bearing formation itself, commonly a shaly layer which has subsequently been altered to paint rock. In no place does the ore rest directly upon the underlying quartzite.

The grentest depth of the Mesabi ore deposits must be less than the depth of the iron-bearing formation, and as the greatest thickness of the formation is only near the slate margin, where the witers are escaping and are not loing their best work, it follows that the ore deposits are not likely to reach this maximum depth. The greatest depth thus far known in the Mesabi range is 500 feet. The common depths are less than 300 feet.

The Giants Range furnishes the lead for the percolating waters. Toward the west end of the district the range becones lower and the grade of the ore becomes correspondingly lower, suggesting that the circulation of the ore-concentrating solutions was less vigorous at the westeln end because of the lower elevation. The ores have no close relation to the minor hills on the Ginnts Range slope, though they tend to occur in the depressions, principally beciuse in such places denulation is relatively deep owing to softness. Were it not for the irregular covering of glacial drift, their relations to minor valleys would be more apparent.

ORIGINAL, CHARACTER OF THE IRON-BEALINA FORMATION.

The iron-bearing Biwalik formation originally consisted dominantly of greenalite rocks and suborlinately of cherty iron carbonate, the characters of which are describer on pages $165-170$. 
The alteration of these rocks to the ore has been accomplished in two stages, mainfy successive but partly overlapping-first, by alteration to ferruginous chert; serond, by leaching of silica from the ferruginous chert.

ALTERATION OF SIDERITIC OR GREFNALTTC CHERT TO FERRIGINOIS CHERT (TACONITE).

Chemical change.-The chemical change consists of oxidation of the iron areording to the following reactions:

For greenalite-

For siderite-

$$
2 \mathrm{FeSiO}_{3} \cdot 11 \mathrm{II}_{2} \mathrm{O}+\mathrm{O}=\mathrm{Fe}_{2} \mathrm{O}_{3} \cdot n \mathrm{H}_{2} \mathrm{O}+2 \mathrm{SiO}_{2} \pm \mathrm{H}_{2} \mathrm{O} \text {. }
$$

$$
2 \mathrm{FeCO}_{3}+\mathrm{nH}_{2} \mathrm{O}+\mathrm{O}=\mathrm{Fe}_{2} \mathrm{O}_{3} \cdot \mathrm{nH} \mathrm{H}_{2} \mathrm{O}+2 \mathrm{CO}_{2} \text {. }
$$

Mineral change.-The greenalitic cherts or greenalite rocks are composerl essentially of rounded granules of greenalite in a matrix of chert. The tendency to banding is not as distinctive as in the cherty iron carbonates. The greenalite alters to hydrated iron oxide. The silica remains or goes out. Mineralogieally the sideritie cherts consists essentially of sirlerite and chert more or less segregated into altemate layers. The siderite is changed to hychated iron oxide. Either removal or retention of silica may accompany this change.

Secondary siderite, usually differing from original siderite in having coarser grain, is a minor product of alteration of both greenalitic and sideritic cherts.

Tolume change.- Though the alteration is distinctly of a katamorphic nature, the change is from a light to a denser mineral, and hence involves a rechetion in the volume of the iron mineral. Like the oxidation of the siderite, the oxidation of the greenalite involves a change from a lighter to a denser iron mineral and a decrease in the volume. The rolume changes involved in the above alterations are as follows:

Alteration of siderite to hematite, 49.25 per cent loss.

Alteration of siderite to limonite, 18.30 per cent loss.

Alteration of greenalite to hematite and quartz, 24.50 per cent loss.

Alteration of greenalite to limonite and quartz, 9 per cent loss.

As the chert is at first unchanged in the alteration of the greenalite and earbonate to iron oxide, the volume change accompanying these alterations is effective on only a portion of the rock. Chemical analyses of both the sideritic cherts and the greenalitic rocks show that approximately 60 per cent of their volume is chert. Hence the change in volume is effective on only 40 per cent of the total volume of the rock. The loss in volume, then, for the entire rock, taking into account both the iron and the silica, ranges from 3.6 per cent to 19.7 per cent, according as the original rock bore siderite or greenalite and according to the degree of hydration of the resulting product.

Development of porosity. - This volume change, due to oxillation of greenalite or siderite, develops pore space. Determinations of porosity on eight typical specinens of greenalitic rock and sideritic chert showed the average porosity to be $0.96 \mathrm{per}$ cent of the volume of the rock. An average of twelve determinations on type specimens of ferruginous chert (taconite), from which apparently no silica had been leached, gave a porosity of 4.72 per cent. The porosity resulting from the reduction in volume, due to the oxidation of greenalite, in a rock containing 40 per cent by volume of that mineral shoukl be 9.8 per cent of the volume of the rock when the product is hematite and 3.6 per cent when the prochuct is limonite. The ratio of hematite to limonite in the avernge taconite is about three parts of henatite by volume to two of limonite; hence the porosity resulting from the alteration of average greenalite rock to average ferruginous chert should be approximately 7.3 per cent of the volume of the ehert. This figure does not differ greatly from the observed porosity of the ferruginous chert-4.72 per cent. It is to be expected that the observed porosity would be less than the porosity as calculated above, for several factors, such as cementation and mechanical agencies, would tend to close openings formed. 


\section{ALTELATION OF FERREGNOLS CIERTS (TACNTR) TO ORF.}

The alteration of ferruginous eherts (taconite) to ore consists essentially in removal of silica. It has already been shown that the alteration of ferrugrinous dherts to ores is essentially later than that of the original greenalite and carbonate rocks to fermginous cherts.

During the change from the ferruginous cherts to ore the iron oxide remains essentially the same in absolute quantity (not in percentage) and in degree of hydration, as will appear from some of the following antalyses and calculations.

\section{VOLUME CHANGES.}

At many places in the district the actual gradation from ferruginous chert to ore may be observed. In the following table are several serjes of analyses showing this gradation. Each series represents a series of specimens taken from the same layer of taronite. In no case were the members of one-ceries taken from an area greater than 2 feet in extent, so that approximatcly. uniform original composition was insured throughout euch series.

The first member of each series represents the least altered phase, each successive mentber of the same series showing a greater degree of alteration.

Altcrution of frrmginons chert.

\begin{tabular}{|c|c|c|c|c|c|c|c|c|c|}
\hline & \multicolumn{4}{|c|}{ Chemical composition. } & \multirow[b]{2}{*}{$\begin{array}{l}\text { Loss on } \\
\text { itnition. }\end{array}$} & \multicolumn{4}{|c|}{ Approximate volume composition. } \\
\hline & $\mathrm{Fe}$. & $\mathrm{Si}()$ & P. & $\mathrm{Al}_{2} \mathrm{O}_{3}$ & & $\begin{array}{l}\text { Pore } \\
\text { space. }\end{array}$ & $\begin{array}{l}\text { Hematite } \\
+ \\
\text { limonite. }\end{array}$ & Quartz. & Kaolin. \\
\hline $\begin{array}{l}\text { Series 1, Sterenson mine.. } \\
\text { Series 2, Sterenson mine.. } \\
\text { Series 3, La Rue mine.... }\end{array}$ & $\begin{array}{l}29.17 \\
33.01 \\
35.21 \\
4.45 \\
44.33 \\
45.30 \\
4.51 \\
49.15 \\
32.26 \\
35.54 \\
4.49\end{array}$ & $\begin{array}{l}52.49 \\
50.05 \\
43.41 \\
25.03 \\
34.24 \\
31.05 \\
26.42 \\
23.60 \\
50.75 \\
12.69 \\
34.33\end{array}$ & $\begin{array}{r}0.010 \\
.016 \\
.013 \\
.0115 \\
.013 \\
.014 \\
.013 \\
.014 \\
.018 \\
.012 \\
.010\end{array}$ & $\begin{array}{r}0.62 \\
.35 \\
.40 \\
.21 \\
.37 \\
.23 \\
.35 \\
.32 \\
.30 \\
.24 \\
.22\end{array}$ & $\begin{array}{l}2.92 \\
1.415 \\
4.45 \\
3.43 \\
1.41 \\
2.73 \\
2.67 \\
2.14 \\
.45 \\
.74 \\
.119\end{array}$ & $\begin{array}{r}7 . \mathrm{m} \\
1 \mathrm{1} .50 \\
26.30 \\
52.70 \\
3 . . \mathrm{m} \\
39.70 \\
42.40 \\
45.40 \\
4.00 \\
23.20 \\
24.20\end{array}$ & $\begin{array}{l}32.35 \\
31.25 \\
33.51 \\
30.41 \\
33.12 \\
34.15 \\
31.05 \\
35.70 \\
33.55 \\
33.73 \\
39.89\end{array}$ & $\begin{array}{r}5 . .90 \\
51.40 \\
39.30 \\
+16.15 \\
24.10 \\
25.20 \\
30.84 \\
15.25 \\
61.10 \\
42.50 \\
35.35\end{array}$ & $\begin{array}{l}1.74 \\
.93 \\
.93 \\
.31 \\
.71 \\
.47 \\
.70 \\
.15 \\
.90 \\
.61 \\
.57\end{array}$ \\
\hline
\end{tabular}

Series 1. was taken near the top and to one side of the ore body; there was apparently no slump, as is shown by the constant volume of the iron mineral. Figure 10 is a graphic repre-

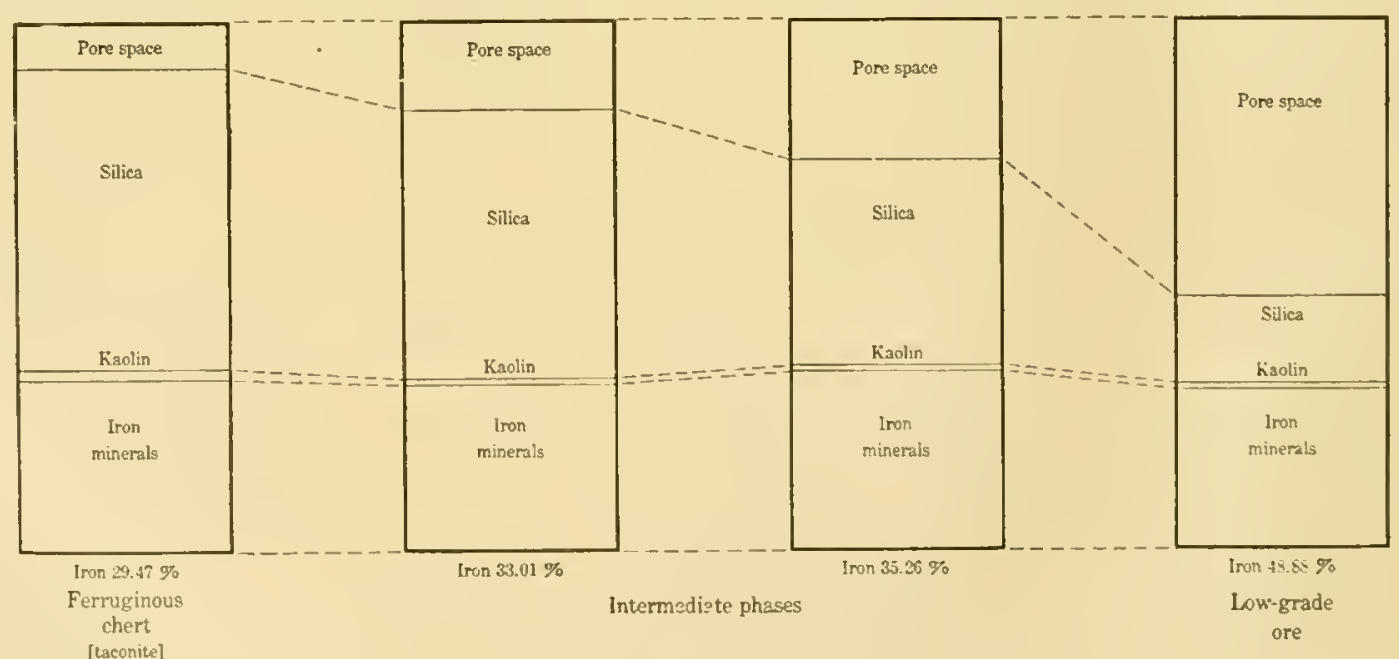

Figure 19.-Diagrum showing volume changes observed in the alteration of Icrruginois chert to ore. The four specimens represented were collected from a single baml of ferruginous ehert in the sterenson mine, Mesabi district, Minnesota. (Nece analyses, abore.)

sentation of the scries. Both the other series showed slight evidence of slumping, the chert bants being thinner at the nost altered ent: consequently the increase in volume of the iron mincral was expectel. 
Figure 19 shows very well that the essential process in the alteration of the taconite is the leaching of silica. This removal of material causes an increase in pore sprace. The development of porosity beyond certain limits weakens the rock and results in shmping or crushing; hence the volume of silica removed may be greater than the porosity observed. In order properly to compare the various phases of taconite and ore studied, it is neressary to consider them in terms of volume composition rather than of weight. By so doing the factor of porosity is included in each phase studied, the volume composition being given in terms of hydrated iron oxide, silica, pore space, and minor constituents (principally kaolin). The alteration as shown by the arerage analyses of greenalite, taconite, and ore is expressed diagrammatically in figure 20.

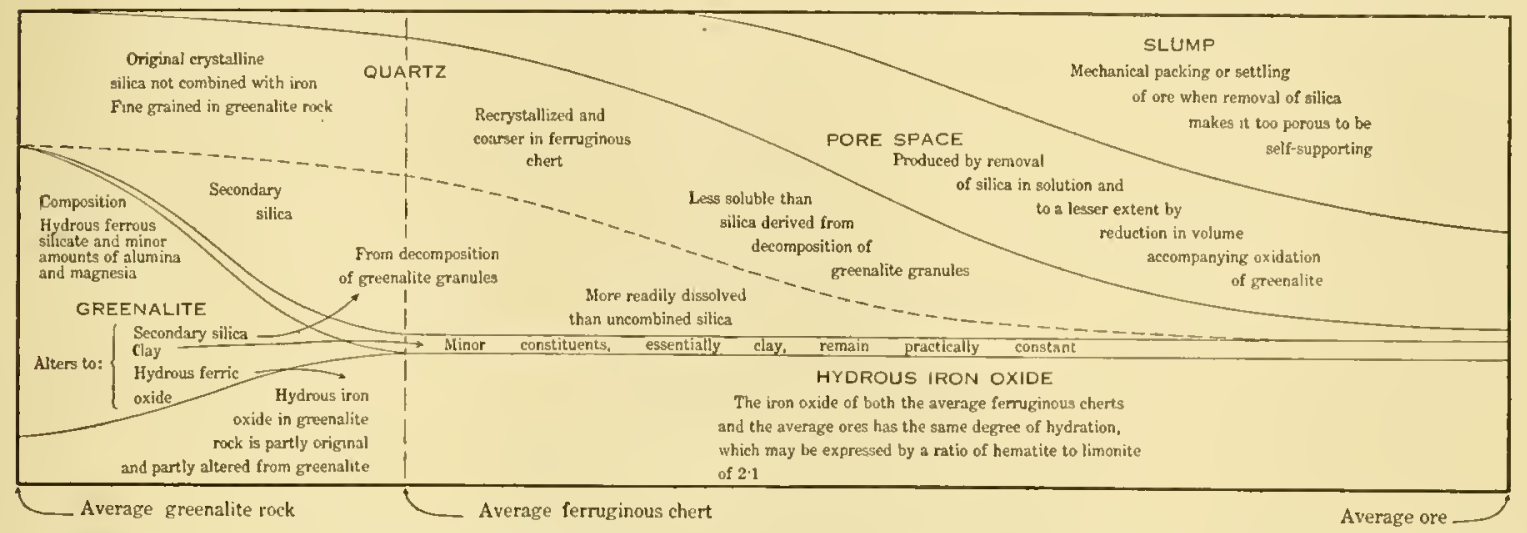

FIGURE 20.-Graphic representation of the changes involved in the alteration of greenalite rock to ferruginous chert (taconite) and ore, Mesabi district, Ninnesota. The mineral composition of the various phases is represented in terms of volume by vertical distances. The mineral composition of the greenalite rock, ferruginous chert, and ore as represented was obtained by averaging a large number of analyses.

METHOD OF EXPRESSING VOLUME CHANGES BY TRIANGULAR DIAGRAM.

While the method of represent ation shown above (figs. 19 and 20) expresses well the average results, it is not a convenient way of handling a large number of detailed figures. In order that many individual comparisons may be made on a single diagram, the volumes of the principal constituents - siliea, iron minerals, and pore space-are platted on a triangle (fig. 21 ) in which all these factors are indicated by position in the diagram. The triangular method of representing percentages of three constituents has been described on page 1S2. In figure 21 the same method is employed to represent the volume composition of the various phases of the iron-bearing formation studied. As is indicated on the triangle, distances measured from the three sides represent severally percentage volumes of iron minerals, silica, and pore space. Thus any point in the triangle represents amounts of pore space, quartz, and iron minerals totaling 100 per cent. In actual analyses, however, it is found that these three factors selciom total 100 per cent, a small percentage of minor constituents being present, principally kaolin, which makes it impossible to represent the volume composition by a single point in the diagram. This difficulty is obviated, however, by representing the percentage volume of each of the three principal constituents by a short line drawn parallel to each side at the proper distance, thus constructing a small equilateral triangle within the larger one. The altitude of this small triangle represents, by the divisions in the large triangle, the percentage volume of the minor constituents. We may then represent by the position and size of a small parallel triangle within the large equilateral triangle the volume composition of any chert or ore in terms of pore space, silica, iron minerals, and minor constituents.

\section{DATA USED IN TRIANGLE.}

Chemical analyses, together with density and porosity determinations, were procured for 120 taconite and ore specimens, including gradation phases between the taconite and ore, slaty phases of the taconite, and paint rock. These data, when platted on the triangular diagram, 
show the relations of the various phases of the iron-bearing formation and enable one to deal with a large number of individual eases as easily as with averages. Each of the small triangles within the large one represents an actual sperimen or simple from the iron formation.

\section{CONSIDERATION OF THE TRIANGULAR DIAGRAM.}

The unaltered taconite is represented by the smull trimgles in the lower left-hand side of the triangle, where porosity is low and silie high. If the taconite represented by any one of these triangles is to be altered to ore, it is necessary that part of the siliea be removel to permit an increase in the iron content. If silica is remored, there must be an increase in the percentuge

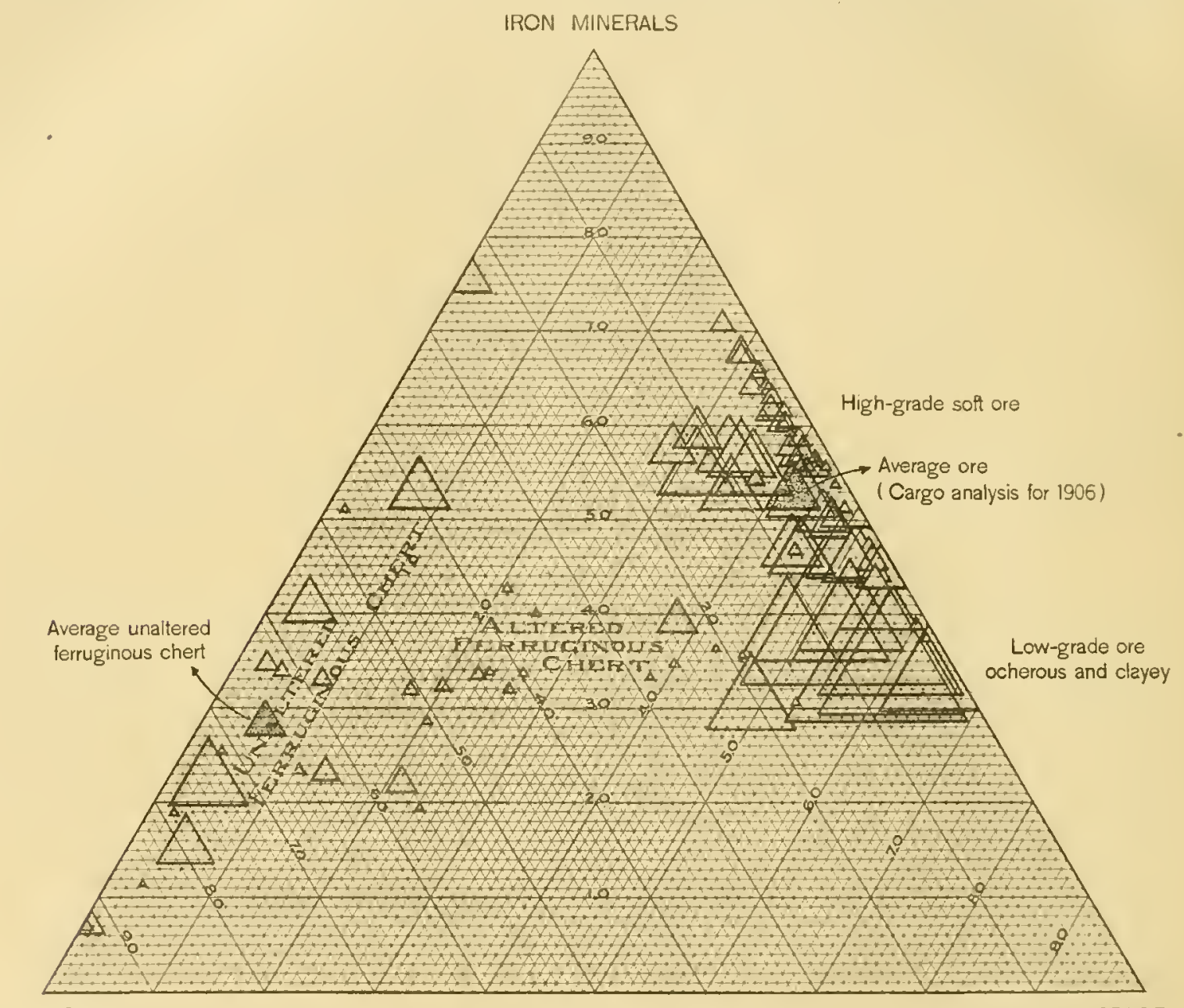

FrgURE 21.-Triangular diagram representing in terms of pore space, iron minerals, silica, and minor constituents (clay, etc.) the volume composition of the various phasis of ferruginous cherts and iron ores of the Jesabi district. For detailed explanation see pase 1 a?.

of volume either af pore space or of iron. If we suppose the change to lie between siliea and pore space, iron being unchanged, the alteration of the ehert will be represented by a sucression of triangles reaching across the diagram to the right at a constant distance from the base, silica derenising and poresity increasing. If the sample selected is high enough in iron and low in siliea, sufficient silica may be removed to produce ore without developing an impersible poresity. On the other hamb, if the small triangle selected is near the base of the dingram, representing a taconite that is composed larecty of silicat and rontains only a small amomint of iron, it is erident that removal of suflicient silica to bring the precentage of iron up to the ore

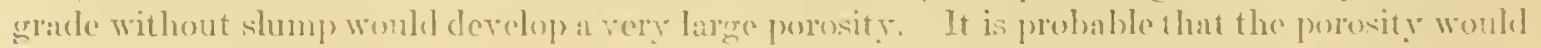
increase until the material berame too porous to support is self and the weight abore, when 
slump would-oceur, deereasing the pore space and increasing the perrontage volume of iron. This change would be represented on the diagram by an upward movement of the triangre selected. Actual infiltration of iron in solution would also cause deerease in porosity and increase in iron, but field observation shows that infiltration of iron is very shight in this district, and hence any shortage of pore space must be explained by slump. Calculations show that on an average this slump amounts to approximately 45 per cent of the volume of the original taconite, which would give a vertical slump of 82 feet for every 100 feet depth of ore. This figure, though apparently large, is well in accord with the observed facts. The degree of slump in an ore body may best be measured by observing the anount of sag in the paintrock layers which have been bent downward by the slump of the unclertying ore. Figure 16 shows a typical cross section of an ore deposit in the ITibbing district; the amount of slump in the ore beneath the paint rock is seen to be of the same magnitude as the above figures. The (liagram (fig. 21) shows that where the original content of iron in ferruginous chert is high the amount of silica to be leached is small and the resulting pore space is small, but that where the iron is low the pore space is proportionally greater. It follows, then, that ferruginous cherts originally low in siliea are much more easily and quickly altered to ore than those high in silica.

It is also seen from the diagram that the ores high in alumina or clay (represented by the larger triangles) have a greater porosity in rough proportion to the alumina content. 'The alumina is very largely in the form of kaolin, a substance characteristically very porous and not so easily affected by slump as the coarser and more granular ores; hence the larger porosity.

ALTERATIONS OF ASSOCIATED ROCKS CONTEMPORANEOUS WITI SECONDARY ALTERATION OF THE 1RON-BEARING FORMATION.

The shaly layers in the original iron-bearing formation become transformed to paint rock or ferruginous slates during the ore concentration. Abundant phases of the formation intermediate between the shales and carbonates or greenalites become, after alteration, either ores or cherts with a pronounced shaly or slaty strueture. These are variously ealled ferruginous slates, slaty ores, or paint rock, according to their iron and clay contents. The nature of the alteration is a leaching of silica and the more soluble bases, leaving a mixture of elay and iron oxide. Following are typical analyses of the phases mentioned above:

Typical analyses of unaltered slaty phase of iron-bearing formation and paint rock.

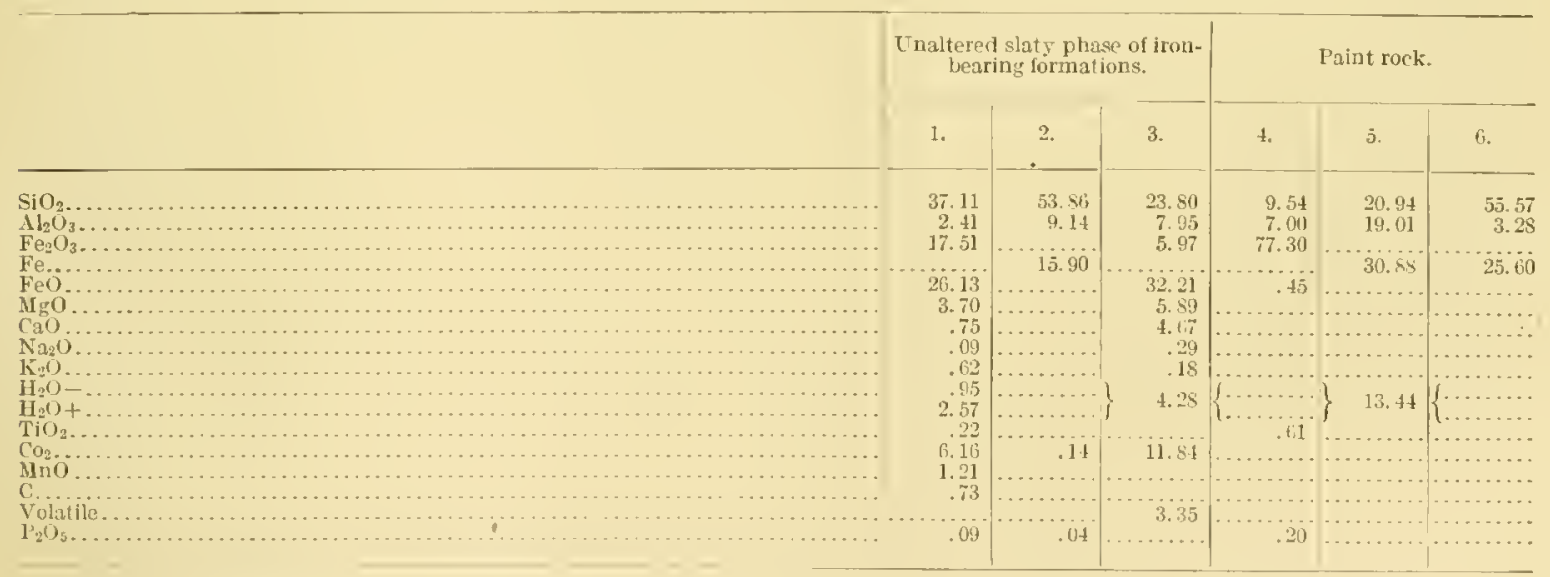

1. Specimen 45461 from Moss mine; analysis by George Steiger

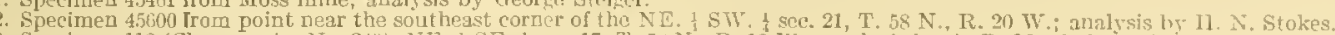

3. Specimen 112 (Chem. series No. 240), NE. $\frac{1}{\mathrm{~S} E}$. 1 sec. 17, T. 58 N, R. 19 W.; analysis by A. D. Mceds fur J. E. Spurr. (See Geol. and Nat.

t. Specimen 406 itil from Mahonins p. 10 .

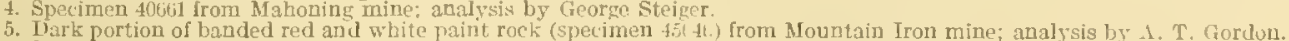

6. Paint rock (specimen 45534) from Ienobscot mine, benteath ore: analysis by H. N. Stokes.

Where igneous rocks have been intruded into the formation before its alteration these have sulfered similar alterations to the slate. Their bases have been leached and they remain essentially as clay, retaining the igneous textures. 


\section{PHOSPHORUS IN MESABI ORES.}

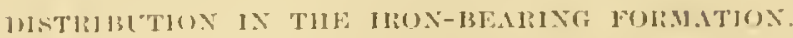

The distribution of phesphones in the various phases of 1 he ibon-lwaring formation is as follows

Phosphorus in iron-buring formation.

Greenulite rock, arerage of six typical specimens

Ferruginous chert

Iron layers in fermginous chert (Specimen 4tosi)

Chert layers in ferruginous chert (Specimen 44051 )

Iron layers in ferruginous chert (Specimen 44010 )

('hert layers in ferruginous chert (Specimen 4.1050 )

Iron layers in ferruginous chert (Specimen 44071 ).

chert layers in ferruginous chert (Spec

slate in iron formation, typical analysis....

Paint rock, typical analysis.

Amphihole-magnetite rock.....
Iron ore, average of 1906 output

\begin{tabular}{|c|c|c|}
\hline Iron. & $\begin{array}{l}\text { Phos- } \\
\text { phorrs. }\end{array}$ & $\begin{array}{l}\text { Jatio of } \\
\text { phos- } \\
\text { phorus } \\
\text { to iron. }\end{array}$ \\
\hline 25.05 & (1) 012 & $0.0004: 9$ \\
\hline $\begin{array}{l}25.71 \\
\text { 6il. } 65 \\
24.50 \\
51.27 \\
11.55 \\
55.39 \\
34.33 \\
29.90 \\
40.40 \\
23.515 \\
60.70\end{array}$ & $\begin{array}{l}.021 \\
.074 \\
.019 \\
.035 \\
.010 \\
.052 \\
.014 \\
.018 \\
.1 \times 4 \\
.0394 \\
.0559\end{array}$ & 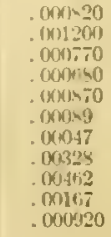 \\
\hline
\end{tabular}

There is a wide variation in the phosphorus content of the several grades of ore. In general it may be saisl that the more hydrous ores tend to run ligh in phosphorus but are not uniformly so. In figure 22 the increase of phosphorus with the degree of hydration of the ore is shown, the data being arerago cargo analyses of all grades of ore shipped from the Mesabi

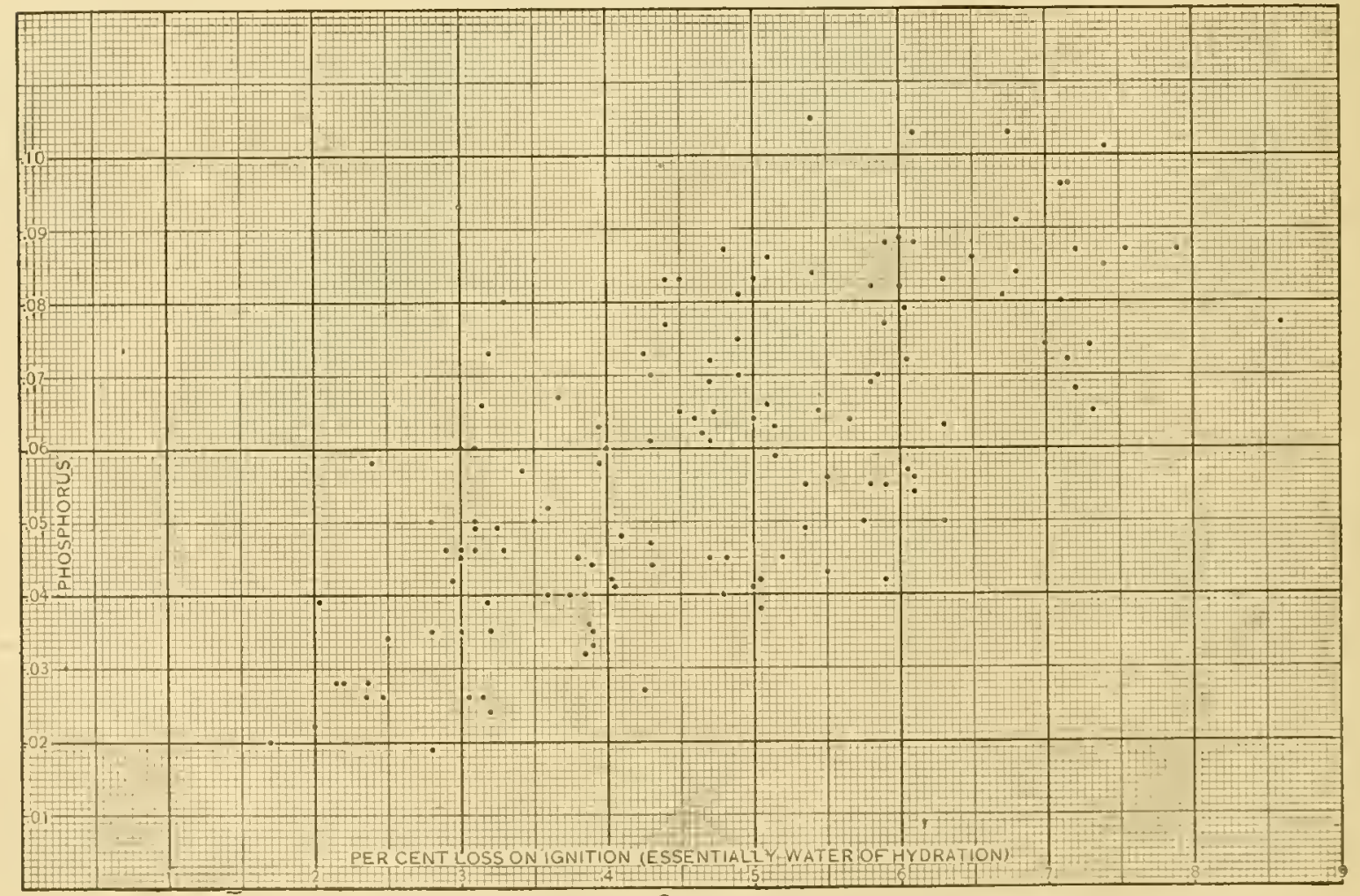

FIGLTE 22,-1) ingram slowing relation of phosphorus to degree of lyclration in Mesali ores.

range in 1906. Percentages of phosplowrus and of water of hydration are platted respectively as orfinates amel alweissas. The arangement of the points on the diagram seems to indicate that high phosphorus is in general associaterl with higl content of combined water.

In the Malooning open-pit mino la rge round eoneretions of rather havd rellow ore are found embeded in dirker ore. The comeretions contain in their ecuters crostalline and botryoilal 
quartz and yellow hydrated iron oxile. Analyses of the outer shell and of the core of the concretions were made from samples representing a number of individuals. The results of the partial analyses given in the following table sliow a marked concentration of plosphorus at the center of the concretion. As the concretions are of a distinctly gcodal structure, the phosphorus in the interior was evidently one of the last constituents introduced.

Analyses of conerctions from Wahoning mine.

Outer shell of concretions.

Ceuter of concretions...

In the Oliver open-pit mime, in 1899 , a vein of limonite could be seen cutting down from the surface, clearly as a result of an alteration by percolating waters along a fissure, and the percentage of phosphorus within the vein was much higher than in the ore immediately adjacent. This occurrence of high phosphorus is smilar to the high phosphorus in the Malioning coneretions, in that it occurs with a more hydrated iron oxide than the surrounding ore, and is evidently later than the concretion of the ore.

Another instance of the occurrence of high phosphorus with hydrated iron oxide was furnished by Mr. A. T. Gordon, who analyzed hard black hematite and soft yellow limonitic ore in the same hand specimen from the Mountain Iron mine with the following results: Hard ore, iron 61.00, phosphorus 0.077 ; soft ore, iron 57.98, phosphorus 0.118.

To obtain further data on the association of phosphorus with the more hydrated phases of the ore washing tests were made on samples of ore from the Sellers and Burt mines at Hibbing, Minn. Each sample was stirred with water in a pail and after the mixture had been allowed to settle for ten minutes the water was poured off and filtered and a very finely divided reddish-yellow sediment was obtained. A portion of the remaining ore was then thoroughly washed with water until free of coloring matter. Analyses made in Lerch Brothers' laboratory at Virginia, Mimn., of the samples thus obtained gave the following results:

Partial analyses from uashing tests on Mesabi ores.

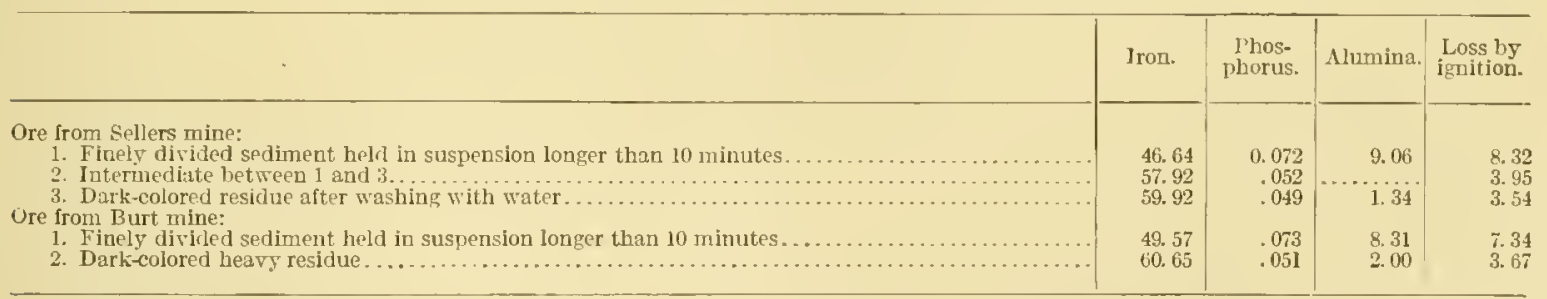

A calculation of the mineralogical composition of Nos. 1 and 3 from the Sellers mine and Nos. 1 and 2 from the Burt mine from these analyses shows that the material is of the same general composition as paint rock, being high in kaolin and hydrated iron oxide. The mineral compositions follow:

Hincral composition caleulated from analyses in the table above.

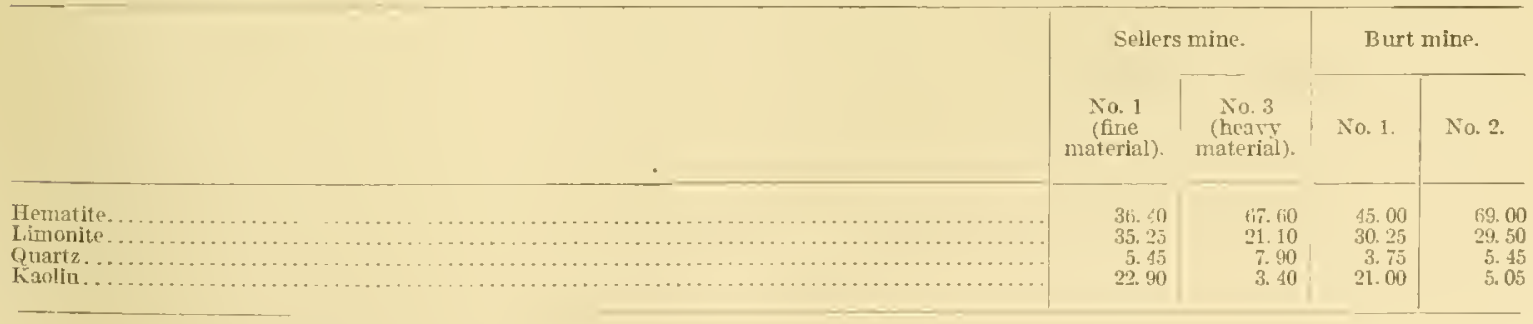

$47.17^{\circ}-10 \% .12-11-12$ 
In the Meadow mine, at Aurora, llinn., ore immediately above an altered granite dike was found to run hicher in phosphorus than the ore farther from the contact. This fact suggests that either the alteration of the granite contributed phosphorus to the ore or the dike acted as an impervious layer above which the phosphorus was concentrated. The tests show that the phosphorus is in some manner associated with the kaolin and hydrated iron oxide and bear out the statement that high phospliorus is related to the degree of hyclration of the ore.

Phosphorus content of rocks associated wilh iron-bearng formations.

\begin{tabular}{|c|c|c|c|}
\hline & Iron. & $\begin{array}{l}\text { Phos- } \\
\text { thorus. }\end{array}$ & $\begin{array}{l}\text { Ratio ol } \\
\text { phos- } \\
\text { phonis } \\
\text { to iron. }\end{array}$ \\
\hline 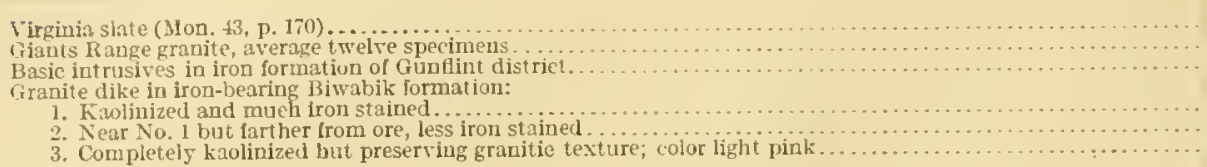 & 4.7 & $\begin{array}{l}0.0 \times 85 \\
.057 \\
.120 \\
.059 \\
.036 \\
.020\end{array}$ & $\begin{array}{r}0.01869 \\
\cdots \cdots \\
\cdots \cdots \\
\cdots\end{array}$ \\
\hline
\end{tabular}

SECONDARY CONCENTRATION OF PIOSPIIORUS.

Present differences in phosphorus content between various phases of the iron-bearing formation may be due (1) to original differences or (2) to secondary changes, producing differences in phosphorus content not due to original differences in composition. These secondary changes may be actual increase or decrease in pliosphorus due to infiltration or leaching, or relatice increase or decrease due to the introduction or removal of other constituents.

A comparison of the partial analyses of the three principal phases of the iron-bearing formation-greenalite rock, taconite, and ore-successively developed during the secondary concentration, shows a continuous increase in phosphorus and in the phosphorus-iron ratio during secondary concentration of the ore. The percentage of phosphorus increases from 0.012 in the greenalite to 0.021 in the taconite and probably to more than 0.0559 in the ore (the average ore shipped being lower in phosphorus than the arerage ore of the range). The corresponding increase in the phosphorus-iron ratio is from 0.00048 to 0.00082 to 0.00092 . In spite of possible rariance of these figures from true arerages, the differences are so marked as to point rery strongly to an actual increase in the percentage of phosphorus during the alteration of the greenalite rock to taconite and of the taconite to ore.

In the discussion of the secondary concentration of the ore it was shown that the concentration was accomplished by the removal of silica and that the amount of iron carried in solution was very small. If the phosphorus were as insoluble as the iron and if no phosphorus had been introduced, the ratio of phosphorus to iron would necessarily have remained constant during the encentration -in other words, both elements would have been concentrated to the same degree. As there is an actual increase in the ratio of phosphorus to iron cluring the alteration, it appears that phosphorus has been concentrated to a greater degree than the iron. As iron has not been largely removed, this increase in phosphorus may be explained only by actual introduction of that element in solution from sources outside of the iron-bearing formation or from other parts of the formation itself. All available evidence seems to indicate that at least part of the phosphorus in the ores is more soluble than the iron oxide; hence without the introduction of phosphorus we should expect an actual decrease in the ratio of phosphorus to iron during the concentration of the ores. This seems to show that the introduction of phosplorus fron without was even greater than the increase in the phosphorus-iron ratio indicates.

Most of the ores were at one time overlain by cretaceous sediments, patches of which still remain as fal east as Virginia, Minn. Analyses from drill holes and test pits disclose al high phosphorus eontent in the Cretaceous beds overlying the ores. Furthermore, they show that there is a gradation in the phosphorus content from the cretaceous down into the undertying ore. A typical series of analyses from a drill hole in the westem part of the Mesabi clistrict 
shows the phosphorus content of the Cretaceous shale to be 1.353 per cent, that of the ore immediately underlying to be 0.180 per cent, and that of lower levels to grade down to 0.045 per cent at a depth of 50 feet below the shale. It seems highly probable, then, that the most abundant source for the phosphorus introdued into the ores of the Biwabik formation was the (retaceous rocks. As indicated in the table of analyses (p. 194), there are other sources for phosphorus in the granites and slates outside of the iron-bearing formation, and it is possible also that the slates of the iron-bealing formation itself have contributed phosplorus to the ore.

FXPLANATION OF PIIOSPIIORUS IN TIIE PAINT ROCK.

The paint rock of the Biwabil formation is a kalinized alteration product formed by the alteration of interbedded slate layers or of the lower layers of the overlying Virginia slate. The change from slate to paint rock is of exactly the sume nature as the alteration of taconite to ore, the soluble bases together with quartz being leached and learing the insoluble residue of hydrated iron oxide and knolin. As there are all gradations between slate and taconite, we find the same continuous gradation between paint rock and ore. The paint rock is characteristically high in phosphorus, the analysis in the table on page 194 being typical, though occasionally paint rock is found with comparatively low phosphorus content. Both the slate of the iron-bearing formation and the Virginia slate are high in phosphorus, so it is believed that the high phosphorus of the paint rock is to a large extent original, phosphorus remaining with the iron oxide and kaolin during the leaching of the silica and other constituents.

But it appears necessary also to account for at least part of the phosphorus in the paint rock as coming from outside sources, and the most obvious source is the Cretaceous, as already indicated for the iron ores.

pHosphorus IN THE AMPHIBOLE-MAgNetite PHASES OF TIE IRON-BEARING FORMATION.

In the Gunflint district the Gunflint formation appears to be an eastem extension of the iron-bearing Biwabik formation, consisting almost entirely of silicated magnetite rock. An average analysis representing $\$ 34$ feet of drill core in the formation showed the average iron and phosphorus contents to be $23.56 \mathrm{per}$ cent and 0.0394 per cent respectively. This gives an average phosphorus-iron ratio of 0.00167 . Comparison of these figures with the analysis of the other phases of the iron-bearing formation (p. 192) indicates that the average iron content is very close to that of both the greenalite and taconite phases. This phosphorus content of the silicated magnetite rocks is, however, much higher than that of either greenalite or taconite. The reason for this high phosphorus in the silicated magnetite phase of the iron-bearing formation may lie either in the original difference in phosphorus content between the different parts of the range or in the introduction of phosphorus from the closely associated intrusives. Present knowledge does not pernit a more definite conchsion. The average phosphorus content of the intrusire gabbros is 0.12 per cent, which is much higher than the phosphorus content of the iron-bearing formation, so that it furnishes an abundant source for the introduction of secondary phosphorus.

MINERALS CONTAINING PHOSPIORUS.

So far as is known, no phosphorus minerals luare been identified in any of the iron-bearing rocks of the Mesabi range. Obviously, then, discussion of the mineral occurrence of phosphorus is entirely a matter of conjecture based on chemical evidence and on the nature of phosphorus-bearing minerals which have been identified in the other Lake Superior inon-bearing formations. It is not unlikely that some of the phosphorus occurs in the form of apatite (calcium phosphate). It seems reasonable to suppose that this mineral may be found in the ironbearing Biwabik formation, although careful search has not yet revealed it. 
In figure 23 percentages of phosphorus in the various commercial grades of ore are platted as ordinates and perecntages of lime as aheissas. 'The clingonul line crossing the diugram indieates the ratio of phosphorus to lime in apatite; hence all points above the line denote an excess of lime over the amount necessary to form apatite and all points bolow the line indicate a deficieney of lime. In other words, phosphorus in ore represented by points ulwofe the line may be combined with lime to form apatite, and ore represented by points below the line necessarily contains somo phosplerus in forms other than apatite. 'This seems to show conclusively that, though there is sufficient ealcium in a large part of the ore to form apatite, in some grades of orr a deficioney of calcium proves the existence of other phosplorus mincrals, possibly of iron or ahminum. Another fact brought out by the diagram is that calcium is deficient only in the ores highest in phosphorus. This suggests the possibility that the original phosphorus

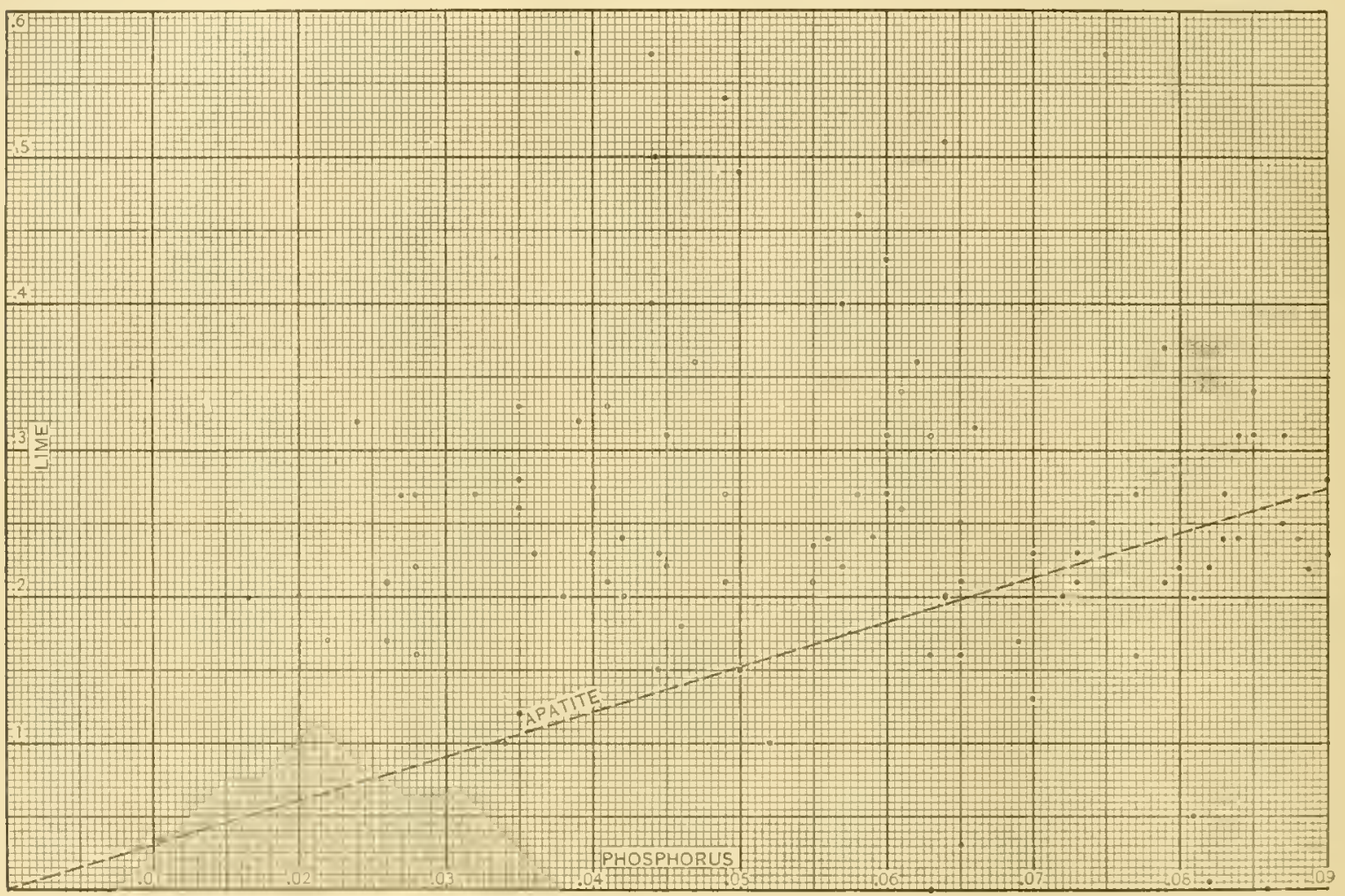

Figure 23:-Diagram showing relative anounts of phosphorus and lime in Mesali ores.

of the ores may be in the form of apatite but that secondary phosphorus takes some other form. The association of high phosphorus with the hydrated forms of iron and aluminum suggests that this excess of phosphorus may be in phosphates of iron and aluminum. It is very probable that at least part of the phosphorus is combined with the iron and aluminum in no definite mineral form.

\section{DETRITAL ORES IN THE CRETACEOUS ROCKS.}

In the western part of the Mesabi district, in T. 56 N., Rs. 23 and 24 W., a considerable amount of detrital ore has been found in the Cretaceons rocks overlying the Biwalik formation and the northern margin of the Tirginia slate. Drilling has shown up several million tons of this ore of the following arerage composition: 
Average composition of Cretaceous ore from the west part of the Mesubi range.

[Samples dried at $212^{\circ} \mathrm{F}$.]

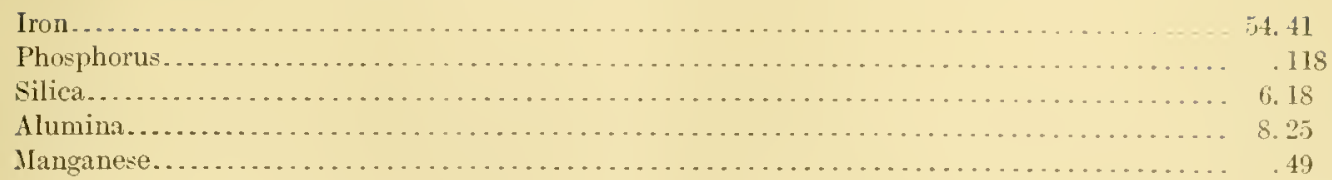

As the ore has not been opened up, the sources of information as to texture, moisture content, and other physical charicteristies are limited to the results of drilling. The drilling shows that the ore is conglomeratic in nature, as is usual in detrital ores. There appears to be considerable opportunity for further discoveries of ore of this character.

SEQUENCE OF ORE CONCENTRATION IN THE MESABI DISTRICT.

The sequence of ore concentration in the Mesabi district is similar to that in the Gogebic district in that the upper Huronian (Animikie group) was but slightly tilted and eroded before the Keweenawan gabbro was intruded into it. The gabbro thus came into contact with the iron-bearing formation only at the east end of the district. Here it found in very small quantity soft ores and ferruginous cherts developed by weathering and changed them to hard ores and jaspers. The original greenalite rocks making up most of the iron-bearing formation were altered to amphibole-magnetite rock. The principal and present productive part of the district was protected from the gabbro by a great mass of slates. The erosion following the post-Keweenawan folding for the first time exposed the main mass of the iron-bearing Biwabik formation from beneath the slates.

By Cretaceous time the concentration of the ore was far advanced, for we find the basal detrital zone of the Cretaceous carrying abundant iron ore in the form of polished pebbles. Since Cretaceous time all the Cretaceous has been stripped off except parts of the western part of the Mesabi district, so that surface agencies have had opportunity to continue the concentration of the ore.

The amphibole-magnetite rocks of the cast end of the district have resisted surface alteration, except local discoloration by oxilation in a thin film at the surface. 


\section{CHAPTER VIII. THE GUNFLINT LAKE, PIGEON POINT, AND ANI- MIKIE IRON DISTRICTS OF MINNESOTA AND ONTARIO.}

Under the three names Gunflint Lake, Pigeon Point, and Animikie is liscussed the strip of territory extending from the east end of the Nesabi and Vermilion districts in the ricinity of Gunflint Iake to Port Arthur on Animikic or Thunder Bay and thence eastward to the Loon Lake district. The districts are geographicalty continuous and the principal geologic features in each, given by the Animikie and Keweenawan rocks, are much the same, but because uf slight variations and because the districts have been studied from different standpoints by: different men they are described under the above three hendings.

\section{GUNFLINT IAKE DISTRICT. ${ }^{\circ}$}

\section{GEOGRAPIIY.}

The Gunflint Lake district includes the lake of that name on the international boundary at the extreme eastern end of the Vermilion district of Mimesota, and extends in a narrow strip about 10 miles east and 10 miles west of the lake. The rock succession and structure are essentially the same as in the Mesabi district to the west and the Animikie district to the east. It is cut off from the Mesabi clistrict by the great overlapping mass of Duluth gabbro. It is connected with the Animikie district by continuous exposure except for the drift.

\section{SUCCESSION OF ROCKS.}

The succession of rocks is as follows:

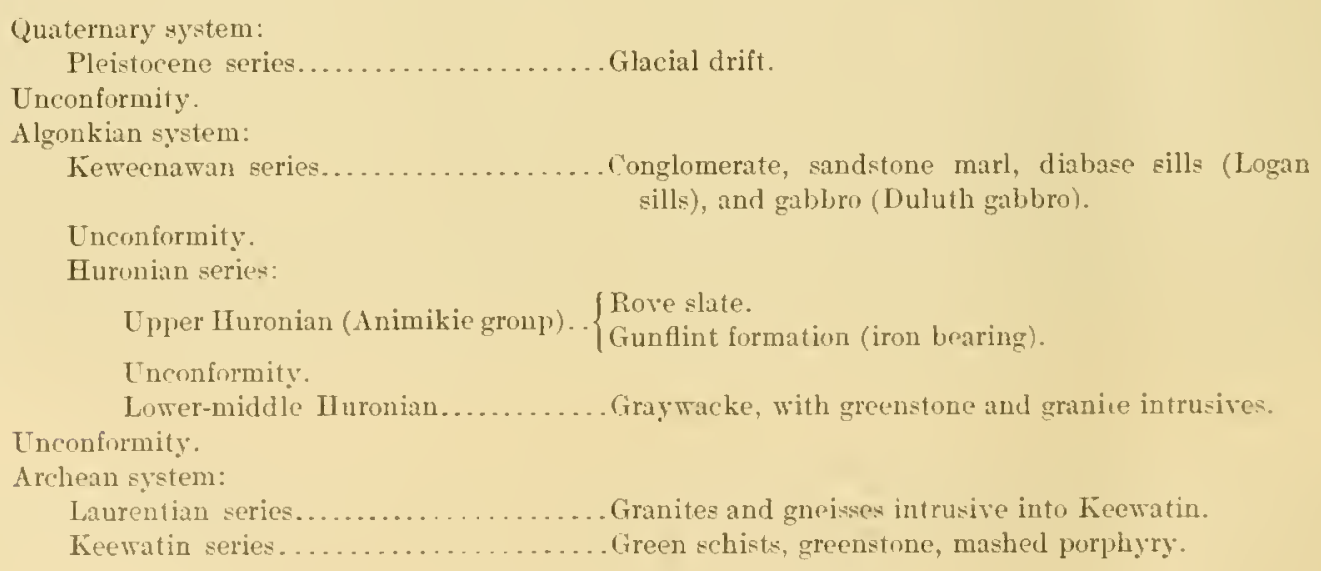

Unconformity

Huronian series:

Upper Ifuronian (Animikie group). $\left\{\begin{array}{l}\text { Rore slate. } \\ \text { Gunflint formation (iron bearing). }\end{array}\right.$

Enconformity.

Lower-middle II ronian............ Graywacke, with greenstone and granice intrusives, Unconformity.

Archean system:

Laurentian series................... Granites and gneisses intrusive into heewatin.

Keewatin series................. Green schists, greenstone, mashed porphyry.

\section{MLGONIIAN SYSTEM. \\ HURONIAN SERIES. \\ UPPER HURONIAN (ANIMILIE GROLP). \\ GENERAI DESCRIPTION.}

The district is oceupied principally by the upper Huronian (Animikic group), dipping to the south at angles of $10^{\circ} \mathrm{to} 65^{\circ}$ (fig. 24). The group laps from the south aeross the eastern end of the Vermilion district and thus rests on the north against the rarious older rocks of that district, including the granite of Saganaga Lake in sees, 23 and 24 , T. 65 X.. R. 4 W., the

a See Clements, J. M., The Vermilion iron-bearing district of Minnesota: Mon. U. S. Geol. Survey, vol. 45, 1903. 
Ely greenstone west of the granite, and the Ogishke congtomerate and the Knife Lake slate still farther west. These rocks have already been described in connection with the Vermilion district and will not again be referred to.

The base of the upper Huronian (Animikie group) is marked by a thin conglomerate which in some places is almost lacking. The uneonformity with the underlying rocks is determined prineipally by the general structure and distribution. The Animikie group has uniform strike and dip, differing widely from those of sedimentary beds to the north and contrasting with the igneous rocks in which no strike and dip are found. It also laps successively across several members of the older rocks without losing its contimuity. Contacts are so poor in the Gunflint distriet that these alone fail to give sullicient evidence of unconformity. In view of the broader features indicated and also indubitable facts in the Mesabi district to the west and the Animikie district to the east, the unconformity may be regarded as certain.

The lowest formation is the iron-bearing Gunflint formation. Above this and outeropping in a belt south of it is the Rove slate, named from its abundant exposures on Rove Lake to the east. Intrusive sills of liabase (Logan sills) are found parallel to the bedding of the slate and the iron-bearing formation. Above and south of the Animikie group is the Keweenawan Duluth gabbro, closely related in age to the Logan sills. The gabbro at the western end of the district laps directly across the Animikie group upon the underlying lower-middle Huronian and Archean. Eastward it laps successively against the Gunflint formation and the Rove slate. Thus the outcrop of the Animikie group widens, V-shape, eastward. In the vicinity of Gunflint Lake itself only the iron-bearing formation is exposed. Eastward more and more of the slate appear's.

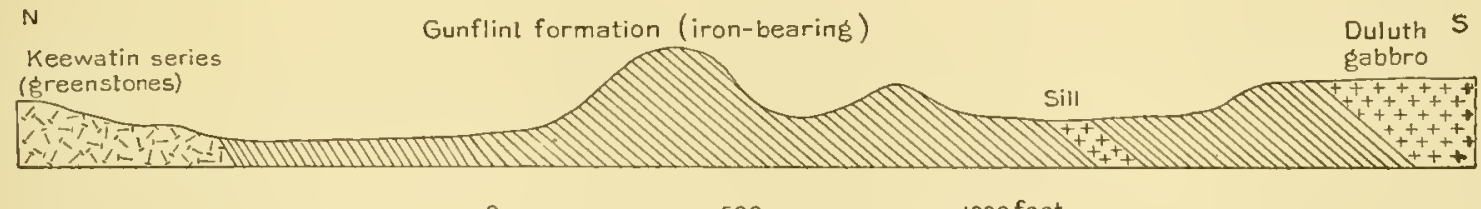

. , ,, $500 \quad 1000$ feet

Figure 24.-Cross section of iron-bearing Gunflint formation east of Paulson mine, Gunfint district, Minn.

GUNFLINT FORMATION.

Distribution.-The iron-bearing Gunflint formation is exposed in a nearly east-west belt 600 feet to half a mile wicle. Northeast of the Paulson mine, secs. 21 and 22, T. 65 N., R. 4 W., there is an east-west tongue of the Gunllint formation projecting westward into Ely greenstone. About three-fourths of a mile east of the Paulson mine, in sec. 27, T. 65 N., R. 4 W., where a great north-south ralley cuts directly across the Gunflint formation, the narrow belt of ironbearing formation joins a wider area of the same rock which extends over the greater portion of secs. 23 and 26, T. 65 N., R. 4 W. The Gunflint formation is widest in these sections, its great width being due chiefly to the fact that a fairly wide synclinal fold has here been stripped of higher formations, leaving exposed an unusually large area of the iron-bearing formation. East of these scetions, toward the international boundary, the willth exposed is less.

Structure.-The structure of the Gunflint formation is not very complicated. A small northeast-southwest trending area of Gunflint formation is exposed on the southeast shore of Disappointment Lake. Ilere the seliments have a strike corresponding very closely to the trend of the area itself-that is, northeast-southwest-and they dip to the south. In rocks of similar age on Gabimichigami Lake the structure is somewhat more complicated. Here the sediments have been folded, and as a result they form in the main a syucline plunging toward the northwest, but with a subordinate anticline near the center which has an axis plunging to the southeast. In the narrow belt extending from sec. $34, T .65$ N., R. 5 W., castward to the great cross valley in sec. $27, \mathrm{~T} .65 \mathrm{~N}$., R. $4 \mathrm{~W}$, the members of the formation rest upon the older rocks and uniformly dip to the soutl. The regularity of this dip is, however, intermpted by a number of minor flexures whose axes plunge southeast. As a result the amount of the 
dip varies considerably, ranging from about $10^{\circ}$ to $65^{\circ}$ to the south, all the greater dips oceurring at the west end of the belt, the dips becoming flatter within short distances eastward. The gradual diminution in the angle of dip as the sediments are followed to the east corresponds. to their less-folded condition in the eastern part of the area. Attention has alrearly bcen called to the areal distribution of the serliments and the westwarl-trending tongue of serliments occurring in sees. 21 and 22, T. 65 N., R. 4 W., which is good evidence of an infolded syncline of the sediments at this place. The dip of the sediments as observed on the outerop in this area gives further evidence of the existence of this syncline.

Some very considerable irregularities have been noter in a few places along the margins of certain enormous masses of dolerite which occur in the midst of the sedimentary area. These dolerites, it may be stated here, are intrusive in the sediments, and this fact sufficiently explains the contorted claracter of the adjacent secliments, for this contorted character is confined to their immediate vieinity, the uniform low southerly dip appearing at a slort distance from such centacts.

Pctrographic character.-Near Gunflint Lake the iron-bearing formation consists of sideritic cherts grading into ferrodolonites associated with minor amounts of ferruginous cherts and ferruginous slates. Westwart toward the Paulson mine the rocks beeme black or dark-grcen, coarsely crystalline, banded rocks consisting essentially of magnetitc, fayalite, cordierite, quartz, and iron carbonate, in varying proportions in different bands and in different parts. Where the iron carbonate is present the other minerals, aside from quartz, are absent. The iron carbonate is regarded as the original phase and the other minerals as their alteration products. (Sec p. 529.) In small and highly varying quantities are hedenbergite. Jronzite, grünerite, pyrrhotite, anthophyllite, lypersthene, actinolite, biotite, apatite, diopside, hornblende, augite, perthite, pleonaste, and crocilolite. Fayalite is conspicuous in association with magnetite lavers. Cordierite, so rare the world over, is perhaps the most conspicuous mineral of the whole series, in many places forming a third of the volume of the rock. It has the pseudohexigonal twinning and staurolite inclusions oriented in a definite manner with regard to the optic axes of the cordieritc, which are characteristic of this mineral. The corclierite for some time has been recognized in the Furonian slates as an intrusive contact effect but has been discovered in the Gunflint formation only recently by Zapffc, ${ }^{a}$ who has also distinguishod a number of the minor mincrals noted. The texture is xenomorphic and the minerals inclurle one another in poikilitic fashion.

Contect motamorplism.-Perhaps nowhere else in the Lake Superior country is there so good an opportunity to sturly the metamorphic effects of the great gabbro intrusion and its associaterl sills. The iron-bearing formation has been coarsely recrystallized and silicated to such an extent that it can be distinguished from the intrusives only with great difficulty. Detailed study of this metamorphism has been made by Bayley, ${ }^{b}$ Clenents, ${ }^{c}$ Grant, ${ }^{d}$ and Zapfe. ${ }^{a}$ Their conclusion in general has been that, though there has been minute intrusion of igneous masses parallel to the bedkling, there has been no consiclerable transfer of solutions from the gabbro to the iron-Jearing formation during the alteration. This sulject is further discussed in connection with the origin of the ores. (See p. 548.)

Thickncss.-The thickness, so far as it can be determined in this district, is approximately the same as that of the Biwabik formation in the Mesabi district-that is, somewhat less than 1,000 feet.

ROVE SLATE.

Distribution.-The westernmost exposures of the Rove slate in the Vermilion district are found in sec. 21, T. 65 N., R. $4 \mathrm{~W}$., where the formation underlies a very narrow area in the south-central part of the section. Eastward it rapidly widens. The northern boundary of the

a Unpublished thesis, I'niversity of Wrisconsin, 190s.

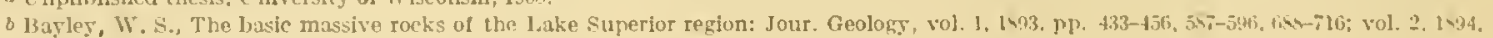
pp. 814-\$25; vol. $3,1895, \mathrm{pp}, 1-20$.

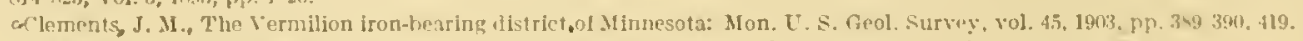

d Grant, U.S., Contact motimnorphism of a basic igneous rock: 13ul. Geol. soe. Anerica, vol. 11, 1900, 112. 513-510. 
slate extends northeastward and is limited by the Gunflint formation and a great dolerite sill. The southern boundary, marked by the Duluth gabbro, trends east-southenst. At the eastern limit of the area mapped (PI. VI, p. 118) the extreme width of the Rove slate area in the United States is only about 2 miles, and a great deal of this width is taken up by intrusive sills of dolerite. Beyond the limits of the distriet the slates have an enormous development in Minnesota and in the adjacent portion of Canarla.

Structure.-The slates have a rery uniform dip of from $5^{\circ}$ to $25^{\circ} \mathrm{SSE}$. As indieated by the variation in dip, the monocline is occasionally varied by minor southward-pitehing rolls, which may be noted by close examination of almost any of the great cliffs that give good exposures.

Petrographic character. - Slates form the bulk of the Rove formation, but with them are assoeiated graywackes, some slaty, others very massive, and also some fairly pure quartzite. These sediments have been divided by Grant, ${ }^{a}$ of the Mimnesota Survey, into a "black slate member" and an overlying "graywacke slate member." In our work no attempt has been made to discriminate between these two petrographic fucies of the Rove slate. They are not separable by any time interval but represent merely slight changes in the conditions of deposition. Macroscopically they are very fine-grained black carbonaceous slates grading up into dark-gray graywacke of medium grain, with oceasional bands of material almost sufficiently pure to be ealled quartzite. Nowhere were any conglomerates, even fine-grained ones, found associated with these. The slates are unquestionably the predominant kind of roek. These carbonaceous rocks are commonly very fissite, but in places they are fairly massive.

Contact metamorphism. - The sediments of this formation have been found within 3 feet of the gabbro - at the southenst end of Loon Lake-but not nearer. Here the rocks are interbanded slates and graywackes, quite erystalline and hard. Microscopic examination of them shows that the gabbro has effected a partial recrystallization of the sediments and diselosed in the serlments a large amount of secondary biotite and muscovite. Both of these oceur in relatively large porphyritic plates inclosing grains of the other materials constituting the slate, recognizable quartz, and ferruginous material. Down the slope the rocks are less indurated, and near the bottom of the section, at the water's edge, about 50 feet below the gabbro, the sediments do not appear essentially different from the ordinary rocks of the same character and age.

Along the southern and southeastern shores of Loon Lake the slate shows a spotted eharacter and is a spilosite, such as is fairly common in sediments near the contret with the great mass of gabbro ßnd such as oceurs also in other districts near great dolerite dikes. This spilosite contains a large amount of chlorite in spots in a matrix of quartz and presumalbly some feldspar. In the Mesabi range some of the slates near the gabloro contact show clearly recognizable cordierite, which forms the white spots; these slates have been metamorphosed to a cordierite hornstone ${ }^{b}$ In general the slate adjacent to these sills in the Gunflint district shows its normal characters, with at most a little metamorphism due to cementation.

Thicliness. - Within the district only about 2,600 feet of the Rove slate is exposed beneatls the gabbro, but eastward the thickness rapidly increases.

\section{KEWEENAWAN SERIES.}

DULUTH GABBRO.

The Duluth gabbro forms the southern boundary of the pre-Keweenawan rocks throughout the greater portion of the Vermilion district. The westernmost points at which the Duhuth gabbro touches the district are in secs. 26 and 35, T. 63 N., R. $10 \mathrm{~W}$, and see. 3, T. 62 N., R. 10 W. From these sections on along Kawishiwi River the gabbro swings off to the northeast with a broad sweep, extending just within the area mapped on Plate VI (p. 118) as far east as the

a Twenty-second Ann. Rept. Geol. and Nat. Hist. Survey Minnesota, 1594, p. 7f; Final Report, vol, 4, 1599, p. 470.

$b$ Leith, C. K., The Mesabi iron-bearing district of Minnesota: Mon. U. S. Geol. Survey, vol. 13, 1903, pp. $171-172$. 
ricinity of the Paulson mine, in sec. 28, T. 65 N., R. 4 W. From this place its edge trends to the southeast, passing beyond the limits of the area mapped toward Lake Superior. Two small isolated outliers have been found nortl of Gabmichigami Lake. The southernmost one is only a quarter of a mile from the northern edge of the main mass of the gabbro, nortliwest of Paul Lake, and the other is about three-fourths of a mile from the nearest point on the edge of the gabbro and lies in the NW. $\frac{1}{4}$ sec. 29 and the NE. $\frac{1}{4}$ sec. 30, T. 65 N., R. 5 W.

The petrographie character of the Duluth gabbro is described on page 372 , in the chapter on the Keweenawan series.

LOGAN SILLS.

The Logan sills lie well within the district, at rarying distances north of the edge of the gabloro mass. The first exposure of such a sill was noticed on the soutliwest side of Gal,imichigami Lake, but this can not be traced far. The next one was seen near Bingoshick Lake. This sill has been followed to the east for several miles to a point east of the Paulson mine, having throughout this distance an almost continuous outerop. Parallel to this sill several small and relatively unimportant sills have been observed. Beyond the Paulson mine the upper Iluronian sediments (Animikie group) begin to widen, rapidly increasing in width eastward, as already described. Corresponding with this widening there is an increasing number of sills which in general trend east and west and lie approximately parallel to one another. During several trips to Gunlint Lake and to the country to the south a number of these sills were followed along their strike for short distances and were also crossed at right angles to the strike. Their relations to the sediments were thus clearly seen. No attempt was made to trice out the individual sills. This work has been done in prerious years by Chanrenet ${ }^{a}$ and Merriam, of the United States Geological Survey, and in more recent years by U. S. Grant, ${ }^{c}$ of the Minnesota Survey.

RELATIONS OF THE REWEENAWAN ROCKS TO ONE ANOTHER AND TO ADJACENT FORMATIONS.

Geologic relations.-The general features of the relations of the lieweenawan rocks are described in Chapter XV, on the Keweenawan series. Here are described certain features of these relations especially well exhibited in this district. These are particularly the superposition of the Duluth gabbro upon all underlying rocks and the relations of the gabbro to the Logan sills intrusive in the Animikie group.

The gabbro and the sills are petrograplically the same, and textural gradations have been observed which indicate their close relationship. The gabbro, though predominantly coarsegrained and granular, is locally fine-grained and poikilitic; in one place it was found as a dike in the Animikie and there graded into a porphyritic facies and even into a fine-grained ophitie dolerite. Locally in the midst of the thick sills the rock is a goor granular gabbro in texture, and it ranges from this througl ophitic poikilitic-textured dolerites into fine-grained aphanitic intersertal-textured basalts upon the selrage. Mineralogically they are the same, except that in the relatively few specimens from the sills which have been studied no olivine nor hypersthene has been observed, nor do the sills show such great mineralogical variation from titaniferous magnetite rocks to cnormous anorthosite masses, though there are small anorthosite masses in the sills. Such differences in variation are, however, easily cxplicable as due to the enormous difference existing between the masses of magma forming the gabbro and that forming the individual sills. The gabbro and sills are therefore regarded as essentially contemporaneous and genetically related.

The gabbro is believed to be a great laccolithic mass which in general follows approximately the contact plane between the Animikie group and the Lieweenawan. In the Vermilion district there are local departures from this relation. Over a great part of the southern edge of the

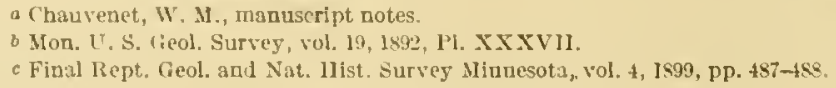


Vermilion district the gabbro followed essentially along the surface of unconformity between the upper Huronian (Animikie group) and the lower-lying sediments, uplifting thereby the upper Huronian sediments, for at several places on the erlge of the Vermilion district and just south of it isolated patches of the lowest part of the Gunftint formation are found included in the Keweenawan gabbro.

In the eastern part of the Vermilion district the gabbro began to rise and cut across the upper Huronian (Animikie group), reaching higher and higher beds to the east, and then spread out essentially along the plane between the Animikie and the base of the lieweenawan, sending sills and dikes into the Rove slate (upper Huronian) and also into the Keweenawan rocks, as can be seen on Brule Lake.

Topography as related to geology.-The line of contact between the gablro and the older rocks adjacent to it is fairly well marked by a slight topographic break. The gabbro normally has a steep north face, in some places showing an escarpment of varying height. It is nowhere very high but is considerably higher than any topographic features in the area extending a considerable distance north of it. The contact at many places is marked by a lake or a stream. This difference between the topography of the gabbro area and that to the north exists at the immediate contact, but in general the gabbro area is lower than that underlain by the older formation to the north. Locally the gabbro area has been reduced almost to base-level. In fact, this area may be described as very nearly a plain, with minor but pronounced irregularities. The uniformity of the surface is due in great part to the homogeneous character of the gabbro mass, owing to which it has been about equally affecter by the rarious agents which have attacked it. Most of the minor pronounced irregularities are due to erosion, which has been controlled rery commonly by the joints of the gabbro, and to differences in composition where they exist. For example, the anorthosite masses usually stand out conspicuously from the surrounding more basie and less resistant portions of the gabbro.

The lakes of the gabbro area are as a rule shallow, and they are also very irregular and can not be said to have miform length in any one direction, as is so markedly true of the lakes of the other portions of the Vermilion district. On the contrary, they spread out in all directions, sending off numerous bays, of which some are very long and narrow and all are very irregular in shape.

The Logan sills exercise a very material influence upon the topography of that portion of the district north of the gabbro in which they occur. It will be recalled that the upper Huronian (Animikie) sediments in this vicinity have a monoclinal dip to the south. The sills have been injected essentially parallel to the bedling of the sediments, though occasionally they are found cutting across the beds at low angles. Erosion has been most active in this portion of the district in a direction parallel to the strike of the beds, and consequently most of the large valleys and lakes trend in agreement with these, approximately east and west. The resistant sills now form the caps of the ridges, the slates having been removed lown to the sills. The massive rock forming the sills breaks off along the joint planes, and as a result perpendicular clifts are formed below the foot of which talus from the sills and from the easily weathering Rove slate gires a gentle slope. These sills are sometimes very nearly concealed by the accumulated talus derived from them.

The eflects of erosion have produced a series of hills with very nearly vertical north escarpments and a gentle slope from the crests to the south. This slope corresponds very closely to the dips of the Rove slate and the upper surface of the dolerite sills.

\section{TIIE IRON ORES OF THE GUNFLINT LAKE DISTRICT.}

In the vicinity of Gunflint Lake the iron-bearing formation (Gunflint formation) is mainly cherty iron carbonate more or less recrystallized and silicated and more or less oxidized and hydrated at the surface and next to fissures and certain bedding planes. No attempt at miniug has been made here. 
The principal hope for ore in the Gunflint formation las been centered in the ricinity of the Paulson mine, 5 miles west of Gunflint lake. Tlere the formation consists of dark-green to black, courscly crystalline rocks, consisting of magnetite, quart\%, amphiboles, cordierite, layalite, augite, pyrrhotite, etc., thinly interlayered in rarying proportions. Fayalite is especially abundant in rocks rich in magnetite.

Titaniferous magnetites in the Duluth galbbro are deseribed on page 561.

\section{CHEMICAL COMPOSITION.}

An analysis representing an average of the rock from a drill hole penetrating 245 fect into the iron-bearing focmation and an analysis of a surface sample taken across the entire width of the formation give the following average:

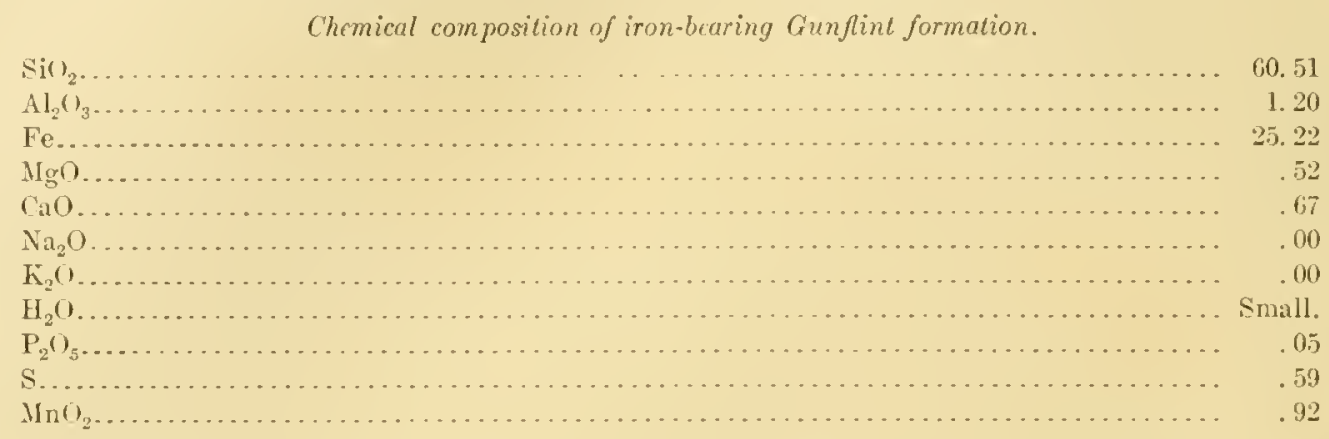

This is almost exactly the composition of the ferruginous cherts or taconites of the Mesabi district. The significance of this resemblance is discussed in connection with the origin of the iron ores, in Chapter XYII (pp. 499 et seq.). Bands of the formation a few feet thiek run as high as 50 or 55 per cent in iron. At the bottom, where it rests against the greenstone, a 3 -foot layer is encountered rumning above 55 per cent in iron. The thinness of the ore bands, the highly erystalline, silicated, magnetic eharneter of the ore, and the loeally high sulphur preclude the use of the ore under present conditions. On the other hand, the total amount is large, the phosphorus content is low, and it lacks titanium, in this respect contrasting with the titaniferous magnetites within the gabbro mass immediately adjacent. Magnetic eoncentration may make these ores available for the future, though the tonnage of low-grade ores requiring no concentration, with which these would have to compete, is so large that the time may be distant, if it erer comes, when these ores can be concentrated and used with a profit.

\section{PHYSICAL CHARACTERISTICS.}

The ores are in some places very conrse grained. The iron-bearing formation is medium to coarse grained, dense, and tough. The pore space is less than 1 per cent and usually almost zero. Specifie gravity, determined by the pyenometer method, on a pulverized drill sample of 245 feet of the formation, is 3.62 , and that for the ore layers is 4.08 .

\section{PIGEON POIN'T DISTRICT. ${ }^{a}$}

The oldest rocks of the Pigeon Point district (PI. XII) are interbedded slales and quartzites of the Animikir group (upper Ifuronian). Cutting the Animikie rocks is an olivine galbhe, which orecupies all the higher portions of the point. It is in all probability the lower portion of a large dike whose upper part has heen removed by denudation. Between the gal bro and the bedded rocks in many places are sucenssively a coarse-grained red roek, a fine-grained red rock (quartz kerafophyre), and a series of contact rocks. The muin masses of the keratophrive oceupy a position Jxewen the Inimikie sediments and the galubo. This rock has all the characteristics

a Sce Bayley, 11 . S., The eruptive and sedimentary roeks on Pigeon Point, Minnnesota, and their contact phenomen: Bnll. U. S. fieol, Survey No. $109,1 \times 93$. 

of an eruptive younger than the gabbro. The coarse-grained rocks between the gabbro and the keratophyre are intermediate in character between the two and grade into them. They are therefore regarded as a contact product formed by the intermingling of the gabbro and keratophyre magmas. Between the keratophyre and the shates and quartzites of the Animikie group there are three zones showing different grades of alteration of the sedinentary rocks due to the contact with the igneous rock.

\section{ANIMIKIE OR LOON LAKE DISTRICT OF ONTARIO. \\ LOCATION AND GENERAL SUCCESSION.}

The Animikie district proper includes the area about Animikie or Thunder Bay, on the northwest coast of Lake Superior, but detailed study has been made prineipally of the part of the district near Loon Lake, at the east end of the bay, about 25 miles east of Port Arthur (see Pl. XIII), and to this part of the district the following description applies. It is taken largely from deseriptions by W. N. Smith ${ }^{a}$ and R. C. Allen. ${ }^{b}$

The succession of rocks is as follows:

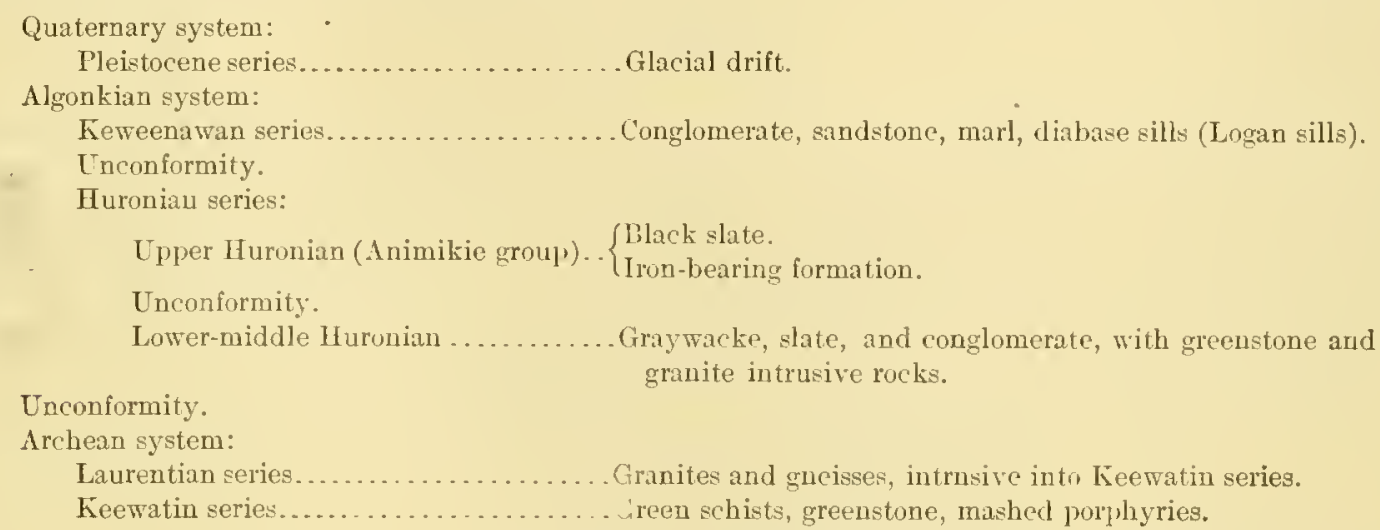

\section{ARCHEAN STSTEM.}

The Keewatin series outerops along Current River 5 or 6 miles northeast of Port Arthur, along the Canadian Pacific Railway, near milepost 119 and west of it about a mile. It comprises a variety of green schists and mashed porphyries. Evidence of the extreme deformation 10 which these rocks have been subjected is found in their folded and schistose structures. The schistosity is nearly rertical with strike N. $70^{\circ} \mathrm{E}$.

Laurentian rocks are not present in the district itself, but form part of the granitie hills to the north.

\section{ALGONTINAN SYSTEM. \\ HURONIAN SERIES. \\ LOWER-MIDDLE IIURONIAN. \\ KINDS OF ROCES.}

The lower-middle Huronian occupies the central part of the area between the upper Huronian (Animikie group) and the Kieweenawan on the east and the Aninikie and the Keewatin on the west. The detrital member of the lower-middle Huronian is represented mainly by a great thickness of graywacke, which is believed to be correlated with the Knife Lake slate of the Termilion distriet of Minnesota. At the base of the graywacke is a considerable thickness of schistose conglomerate carrying fragments of black jasper and of a great variety of green schists. It marks the unconformity between the Kieewatin and lower-middle Ifuronian.

a Loon Lake iron-bearing district of Ontario: Rept. Ontario Bur. Mines, vol. 14, 1905, pt. 1, pp. $25 \div-230$.

$b$ Unpablished thesis, University of Wisconsin. See also Silver, L. P., The Animikie iron range: Rept. Ontario Bur. Mines, vol. 15, 1906, pt. 1, pp. $15 t-172$ 
The eonglomerate grales up into the graywacke, which in its lower horizons is quartzose. The actuil eontract between the lower-niddle Huronian and Keewatin was not olserved, the two usually being sepurated by a slight topogruphic depression, which near milepost 119 is but 14 paces broid.

'The motamorphism of the graywacke has ahnost obliterated the bedding, but where bedling was olserved it was found to be more or less discordant with the cleavage, which varies in dip from $65^{\circ} \mathrm{S}$., a mile or more south of the ('anadian Pacifie Ratway, through the rertical to $65^{\circ} \mathrm{N}$. on and north of the gratywacke ridge which runs parallel to and a shert distance south of the ('anmlian Pacilic Railway.

Neal the base of the graywake is found locally a considerable thickness of volcanic tuff and anyygrlaloil. This formation is best exposed about $1 \frac{1}{2}$ miles south of milepost 110 on the Canadian Pacific Railway, in a strip several hundred yards wide and a mile or more long. In places it appears to be conglomeratic, showing a decided banding which looks rery much like bedding, and in other places it is resieular, the vesicules heing filled with secondary minerals.

The graulation was but imperfectly observed in a single outcrop, but these tuffs and anygdaloids seem to grade both parallel to the strike and across it into the normal phase of the graywacke.

\section{INTRUSIVES.}

The graywacke is intruded by a variety of granites and greenstones. All the granites and some of the greenstones are massive and cut across the strike of the cleavage in the graywacke. Near some of these intrusive masses the graywacke is deciledly more schistose, especially in the area north of the Canadian Pacific Railway, where the intrusion of the granites is more intimate than elsewhere. Here the graywacke locally becomes a hornblende schist.

The granite forms the hills north of the Animikie district and is correlative in age and topography with the Giants Ringe granite of the Mesabi district.

\section{UPPER HURONIAN (ANIMIIE GROUP). \\ GENERAL DESCRIPTION.}

The iron-bearing Animikie group dips gently to the southeast across the steeply inclined structures of the underlying series at angles locally varying widely, but averaging from $2^{\circ}$ to $7^{\circ}$. It outcrops in two main areas, the first between Loon Lake and the head of Thunder Bay, the secoud along the shores of Thunder Bay in the vicinity of Port Arthur.

The Aninikie sediments comprise two distinet zones, as follows:

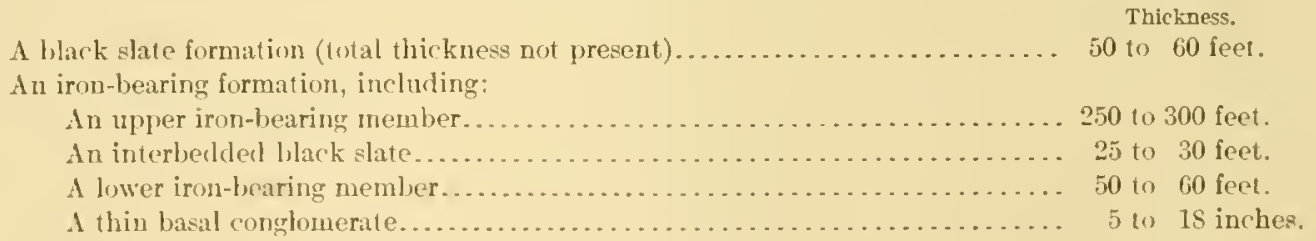

The sediments are intruded by diabase sills varying up to 35 or 40 feet in thickness.

IRON-BEARING FORMATION.

The irom-bearing formation of this clistrict is believed to be the same as the Gunflint formation of the Vermilion district, for it has been seen in almost continnous exposure between this district and the Vermilion distriet.

Conglomerate. - The batse of the dnimikie group is marked by a thin but persistent layer of conglonerate, which, as shown in open pits and by drill cores from borings in the ricinity of Lexon lakke, varies from of to $1 \mathrm{~s}$ inchues in thickness. The pebbles in the conglomerite are small and prestominantly of rein quarts. Small patches of it found on the graywacke ridge cast of Alckenzie and on the Keewatin schists near Current River, about $\bar{j}$ miles mortheast of Port Arthur, attest the original extension of the Animikic group over the entire area. 


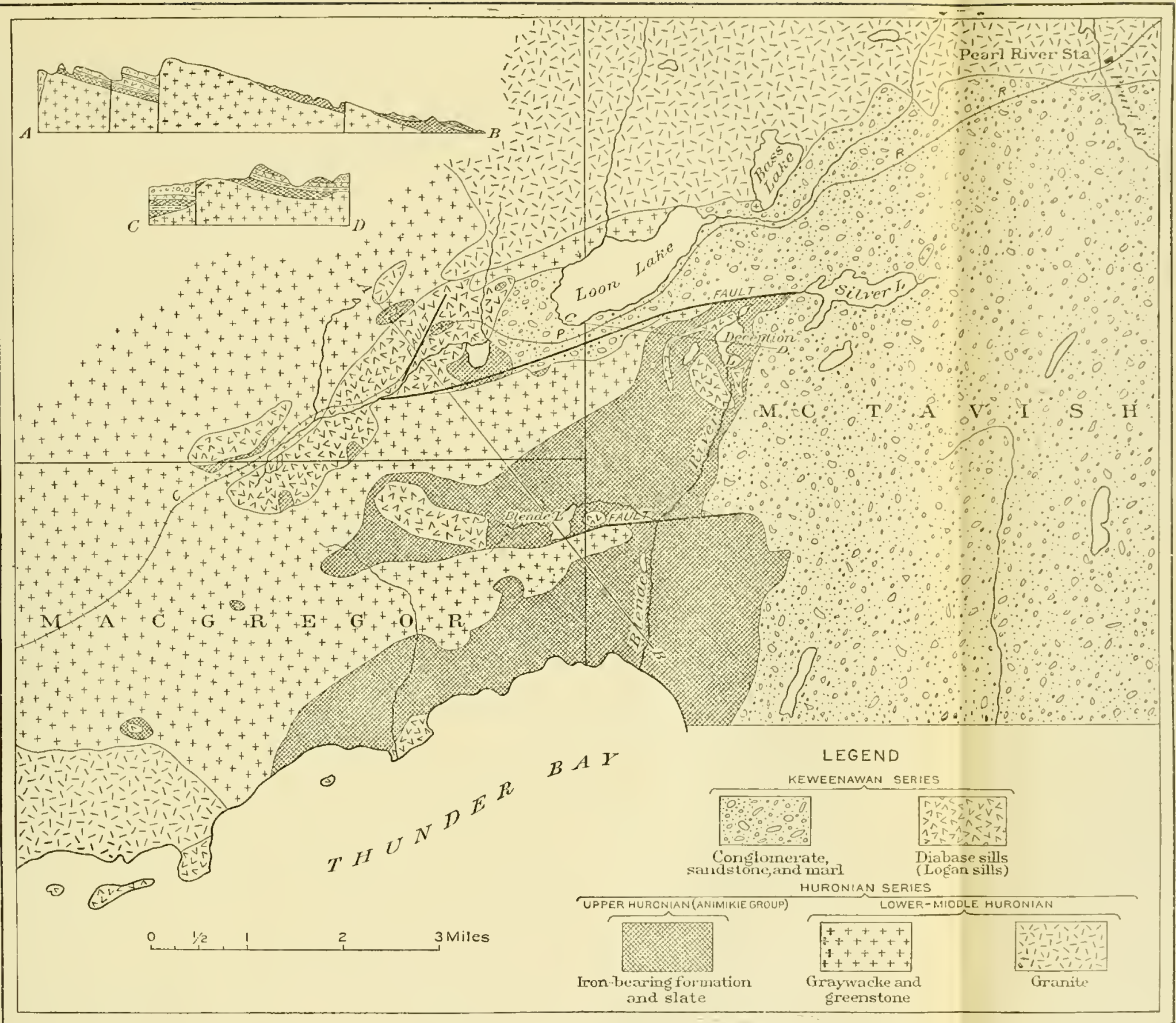

GEOLOGIC MAP OF THE ANIMIKIE IRON-BEARING DISTRICT, NORTH OF THUNDER BAY, ONTARIO. By W. N. Smith and R. C. Allen. See page 205. 

Lower iron-bearing member.-In appearance the lower iron-bearing member resembles the ferruginous ehert or "taconite" of the Mesabi district of Minnesota, hut it is peculiar in that it carries a large amount of calcium-magnesium-iron carbonate. The carbonate may be wholly secondary. It occurs in large part as coarsely crystalline sillerite. $\Lambda$ single hand specimen may be found to contain crystalline siderite, iron ore, and typical "taconite," which contains small granules embedled in a cherty matrix, thus closely resembling the altered greenalite rock of the Mesabi district. However, it may be that both the iron silicate and most of the iron carbonate were deposited simultaneously. In the Mlesabi district the original iron-bearing roek was predominantly a ferrous silicate, in the Pcnokee-Gogebie listrict a ferrous carbonate with very subordinate ferrous silicate. The lower iron-bearing member in the Animikie district may have been originally made up of approximately equal amounts of the silicate and carbonate.

Certain of the layers of this member are sufliciently rich in iron oxille or low in siliceous bands to give thin zones of iron ore. Bands 6 to 8 feet thick enntain 30 to 46 per cent of iron. The grade may be easily raised by sorting out the siliceous bands. The possible commereial value of these deposits is in their wide horizontal extent. Ores also appear in small irregular bodies, following the fault plane north of Deception Lake and extending eastward to Silver Lake and south and east of Bittern Lake.

Interbedded slate.-Near the top of the "taconite" zone is found a black slate interbedded at more or less irregular intervals with the "taconite" below and the iron carbonate above. The relations are those of gradation through continuous deposition.

Tpper iron-bearing member.--The rock making up almost the whole of the upper ironbearing member is a cherty iron carbonate similar in every way to the iron carbonate of the Penokee district. It exhibits all phases of alteration from iron carbonate to iron ore. Some of it is coarsely crystallized, as though from secondary metamorphism.

The iron ores occur principally along the fault zones already mentioned in connection with the lower iron-bearing member. These also cut the upper iron-bearing member.

UPPER BLACK SLATE.

In its normal phase the upper slate is made of thinly bedded layers, black but weathering to a rusty brown. Locally it bears an abundance of mica. Nost of the mica plates lie with their greatest and mean diameters in the plane of bedling, but many of them cut across the bedding at various angles. 'This phase of the rock has not been studied microseopically, but the mica plates look more like detrital fragments than secondary minerals developed in place, for they occur in separated spangles and not in continuous layers, as commonly shown in rocks having a development of sceondary mica. Furthermore, where outerops of the micaceous slate occur there is no evidence of metamorphic conditions such as commonly develop mica; and where it occurs in contact with intrusive diabase sills the metamorphie effects of the intrusion are seen not to extend more than a fraction of an inch from the plane of contact, so the mica is probably not a product of metamorphism attendant upon the intrusion of the diabase. Therefore it is believed to be clastic in origin.

\section{KEWEENAWAN SERIES. $a$}

GENERAL DESCRIPTION.

Uneonformably above the upper Ifuronian (Animikie group) is a suceession of conglomerates, sandstones, and impure marls, to which the term "Nipigon" series has been applied by the Canadian Survey. These rocks, however, are now known to belong to the Kicweenawan scries, and the name "Nipigon" has been abandoned by the United States Geological Survey. This series is most fully developed east of Loon Lake. The unconformity between it and the underlying rocks is marked in various ways. At the base of the Keweenawan is a coarse conglomerate containing waterworn pebbles and bowlders of all the underlying rocks, among 
which, however, granite and the iron-learing formation are prodommant. The firmernawan series shows comparatively little metamorphism, even less than the Animikic group. The strikes and dips of the Iiewennwan are always more or less discordant with the strikes and dips of the underlying formations. The strongest evidence of the great time interval represented by the uneonformity is, however, the fact that the Keweenawan is found sucerssirely overlying both the Animikio group and the lower-midhlle Huronian rocks, thus showing that the entire Animikie group and part of the lower-middle lluronian had been truneated by arosion before the Keweenawan series was deposited.

\section{LOGAN SILLS.}

The Aninikie group is intruded, mainly parallel to the bedting, by a series of dialnase sills of Keweenawan age, which seem to follow preferably the slate horizons. By jointing, these sills have been broken up into great colummar blocks, the breaking off of which where the sills are exposed maintains vertieal clifrs, a characteristic feature of the topography in this district. These sills are laceolithic in character. ${ }^{a}$ At one locality about half a mile south of Deception Lake the diabase outcrops in the shape of a great flat dome, the overlying slates dipping away from it in all directions.

The metamorphic effect of the intrusion on the slates and iron-bearing formation is hardly perceptible more than a fraction of an inch away from the plane of contact. In certain localities the iron-bearing formation in the vicinity of the diabase is very slightly magnetic, inclicating some development of magnetite. The slight metamorphic effect of the diabase intrusions may be aseribed to rapid cooling of the magma. The fineness of grain of the diabase suggests that the sills were not deep-scated intrusives. Thus, being thin and also near the surface, they cooled rapidly, the heat being conducted away from them by the cooler rocks adjacent.

The dialsase which forms the laceolithic Logan sills of the Animikie group is also found both orerlying and cutting the Keweenawan sediments.

\section{STRUCTURAL FEATURES.}

The main structural characteristic of the area is the general dip to the southeast; in this it conforms to its geographic position as a portion of the north side of the Lake Superior srnclinal basin. The upper surface of the Keewatin series and lower-micklle Huronian rocks shares in the general slope to the south, although, as previous? noted, this does not apply to the bedding and schistosity of the rocks. The normal strike of the Animikie group is to the northeast, with an average dip of about $7^{\circ} \mathrm{SE}$. Locally, however, the rocks have bern closely folded and the resulting strikes and dips are widely divergent from the normal. The general strike of the Keweenawan is east of north, with flat dip to the southeast, although it also locally shows the same severe folding and fracturing as the Animikie.

Faulting has been an important factor in producing the present structural and topographic features of the district. The faulting is believed to have been caused by the same general forces that produced the Lake Superior basin. (See pp. 622-623.) The major fracturing occurred along certain approximatele parallel zones, and in the rertical displacenents that followed the several fracture blocks acted as independent units, in which the morthern units becune depressed relative to the southern units, thus producing a systent of "lolock" faults.

The greatest vertical displacenent definitely determined is about 300 feet, as shown from diamond-drill records and surface exposures along the cast-ivest fault a short distance south of Loon Lake.

\section{GENERAL TOPOGRAPIIC FEATURES IN TIIEIR RELATIONA TO GEOI.OGY.}

As seen from a point north of Lon Lake on the high ronge of hills cxterieling from Pear River station berond Mckinzie, the region as a whole presents a general slope toward Lake Superior. To the north the country rises, the grmite hills towering one above nnother, and

a Iawson, .1.C.. The laccolitic sills of the nortbwest coast of Lake Superior: Bull. Geol. and Nat. Ilist. Survey Ninnesota No. \$, Is23, pp. 24 k. 
to the south the lakeward slope is interrupted by the long, narrow Mckenzie Valley, beyond the sonthern rim of which the general slope is continued down to the shores of Thunder Pay. East of Loon Lake the range of Keweenawan sandstone hills forming the southern side of the valley swings at a right angle to the southeast, and the valley emerges on a broad flat timbered with spruee and tamaraek and sloping gently down to Black Bay. 'To the southeast the elevated and much dissected area of Keweenawan sandstone projects into the lake a distance of 20 or 25 miles, forming a peninsula separating the waters of Black and Thunder bays. This peninsula, crowned at its lakeward end by a great protective eap of diabase, terminates in a bold healland over 1,300 feet high, known as Thunder Cape. The great escarpment of sandstone 600 to 800 feet high forming the northwestern side of this peninsula and extending 2 or 3 miles inland is one of the most striking sernie features of the north shore. West of Thunder Cape, Pie Island, with its great flat protecting top of diabase rising 700 or 800 feet above the water, stands like a sentinel at the entrance to Thunder Bay. North of the island, on the mainland south of Fort William, MeKays Mountain, another great llat sheet of diabase, supported on Animikie seliments, rises abruptly from the plain of Kaministikwia River to a height of over 1,000 feet. Thunder Cape, Pie Island, and McKays Mountain are magnificent examples of the mesa type of topography, which is a distinct characteristic of the Thunder Bay region.

The origin of this mesa-like topography is found in the prevalence of diabase sills underlain at varying altitudes by strata of weaker rocks, the sapping of which maintains a progressive undermining of the great columnar bloeks above them, thus producing vertieal diffs with tahus slopes beneath.

\section{WESTWARD EXTENSION OF TILE ANIMIKIE DISTRICT.}

The Animikie group, containing the iron-bearing formation, extends westward from Animikie Bay to the Gunflint Lake district, with struetural and lithologie features like those at its east end, although in the vicinity of Port Arthur and thence westward the amount of slate exposed to the south and above the iron-bearing formation is much larger. The slates with their intrusive sills are beautifully exposed in Pie Island and McKays Mountain and many of the hills to be observed along the line of the Port Arthur and Western Railway. The sawtoothed topography characteristic of both the Gunflint and the Loon Lake districts is everywhere to be seen, with its gently dipping slopes to the south, usually eapped by diabase sills, and abrupt slopes to the north. The drainage for the most part follows parallel to the strike.

The older rocks on which the Animilie group rests include the same kinds as were observed in both the Animikie and Loon Lake districts, but they have not been mapped in detail for all of this intervening area.

\section{THE IRON ORES OF TIIE ANIMIIIE DISTRICT OF ONTARIO.}

\section{OCCURRENCE.}

Iron ores approaching commercial grade are known only in a small area near Loon Lake, 25 miles east of Port Arthur. The ore deposits are thin but extensive layers of hematite in the ferruginous eherts of the lower part of the formation. In one zone, and perhaps in others, ores have developed along fault and joint planes. The thickness of the ore layers which can be mined will depend on the grade which can be utilized and on the suecess with which ehert layers may be eliminated by hand sorting. Eight feet is about the greatest thickness of a bed which would run as high as 45 per cent, but with a small amount of hand sorting two or three times this thickness could be used. The commercial importance of the ores obviously depends on their horizontal dimensions. The ores rest upon ferruginous eherts and grade in to them laterally. One of the beds is capped by a diabase sill intruded parallel to the bedding.

$47517^{\circ}-$ voI, 52-11- 14 


\section{CHARACTER OF THE ORE.}

The ore is a lean, handed siliceous hematite, more or less liydrated. Analyses of samples taken every 3 inches from four exposures representing vertical distances of 6 to 8 feet each are given below. These are from the natural exposures which showed the greatest observed concentration and include both the hematite and associated siliceous material.

Analysis of Inimikic ore.

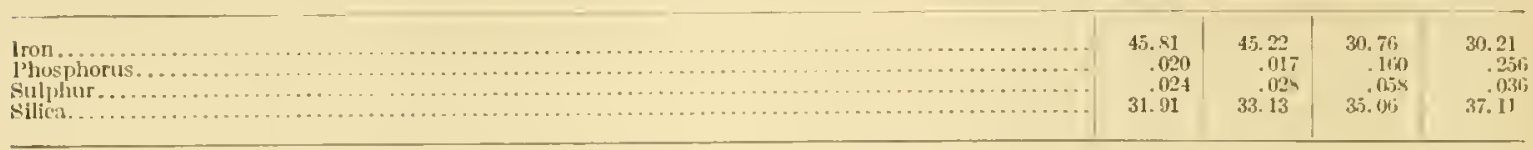

SECONDARY CONCENTRATION OF THE ANIMIKIE ORES.

Structural conditions.-The movement of waters here has olsriously been eontrolled by the bedding, for the ores constitute merely enriched layers with irregular lateral extent. To some extent also the waters have been concentrated in the intersecting faults. The formation i: very thin and is suldivided hy impervious igneous sills, making such movement of water as is possible in the formation essentially a horizontal one.

Original charaeter of the iron-beuring formation.-As described on page 207 , the lower part of the iron-bearing formation of the Animikie group was originally a greenalite rock with some carbonate and the upper part was originally an iron "arbonate with some greenalite.

Vature of alterations.-The original greenalite and carlonate rocks have altered principally to ferruginous cherts in the manner described for other ranges. Loeal and for the most part subsequent alteration of the ferruginous cherts by leaching of silica has developed the ore. Coarsely crystalline secondary iron carbonate is abundant.

\section{SEQUENCE OF ORE CONCENTRATION.}

The alteration of the iron-bearing formation has oecurred both before and sinee Keweenawan time. Evidence of the pre-Keweenawan alteration lies in the abuntant fragments of ferruginous chert and iron ore which oecur in the Keweenawan conglomerates. Evillence of later alteration is the fact that the deformation which produced fracturing and hreceiation of the iron-bearing formation, and which in part determined the localization of the ore concentration, was later than Keweenawn time, as is shown by the similar phenomena of deformation in superjacent lieweenawan beds. 


\title{
CHAPTER IX. THE CUYUNA IRON DISTRICT OF MINNESOTA AND ITS EXTENSIONS TO CARLTON AND CLOQUET, AND THE MINNESOTA RIVER VALLEY OF SOUTHWESTERN MINNESOTA.
}

\author{
CUYUNA IRON DISTRICT AND EXTENSIONS TO CARLTON AND CLOQUET.
}

GEOGRAPII AND TOPOGRAPHY.

The Cuyuna iron district is the most recently discovered range in the Lake Superion region and as such is receiving a large share of attention. It trends $\mathrm{N} .50^{\circ} \mathrm{E}$. along the line of the Northern Pacific Railway, near Mississippi River, in the vicinity of the towns of Brainerd and Deerwood, Crow Wing County; Aitkin, Aitkin County; and Randall, Morrison County, in north-central Minnesota. (See Pls. XFV and XV.) Its boundaries are still being extended and limits can not yet be drawn with certainty in any direction. The area of present greatest activity lies south and east of Mississippi River in Tps. 43 to 48 N., Rs. 28 to 32 W. The length is more than 60 miles and the area for exploration amounts approximately to 32,000 acres.

The general geologic and geographic relations of the Cuyuna district to the adjacent territory appear on Plate XIV. A larger-seale map of the Cuyuna district itself, showing magnetic belts, is Plate $\mathrm{XV}^{\top}$. This map is not colored geologically for the reason that the district is heavily drift covered and the distribution of the underlying rocks is known only incompletely from (rill lwoles. Any map attempting to show geologic houndaries would he sadly out of date by the time of publication. Howerer, the magnetic lines follow approximately the distribution of the iron-bearing rocks.

The country is flat, being not less than 1,150 feet nor more than 1,300 feet above sea level. It is covered with a heavy mantle of glacial drift and dotted with many glacial hills, lakes, and swamps.

The rock surface beneath the drift shows slight local variations in elevation, and between widely separated points, because of the general slope of the sulface, may show a difference of elevation of as much as 250 feet. Frequently the soft slates are found to be at lower elevations, because of erosion, than the larder iron-bcaring formation adjacent-as, for instance, near Pickands, Mather \& Co.'s shaft in see. S, T. 45 N., R. 29 W. Notwithstanding these local irregularities of the rock surface, it is generally flat. At many places in the district and in aljacent parts of Minnesota Cretaceous deposits are found just above the rock surface and beneath the drift, suggesting that this flat surface mily lie part of a pre-Cretaceous hase-level or peneplain.

The Cuy unal distriet has almost none of the extemal aspects (ommonly alssociated with a Lake Superior iron range. The conspicuous topographic ranges are lackiner, as well as the numerous rock exposures.

\section{SUCCESTION OF ROCKS.}

From the information so far available, consisting largely of drill samples, the succession of rocks for the Cuyuni district is as follows:

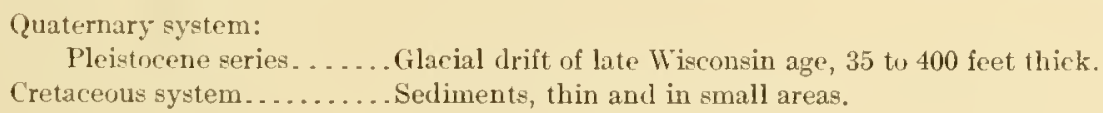




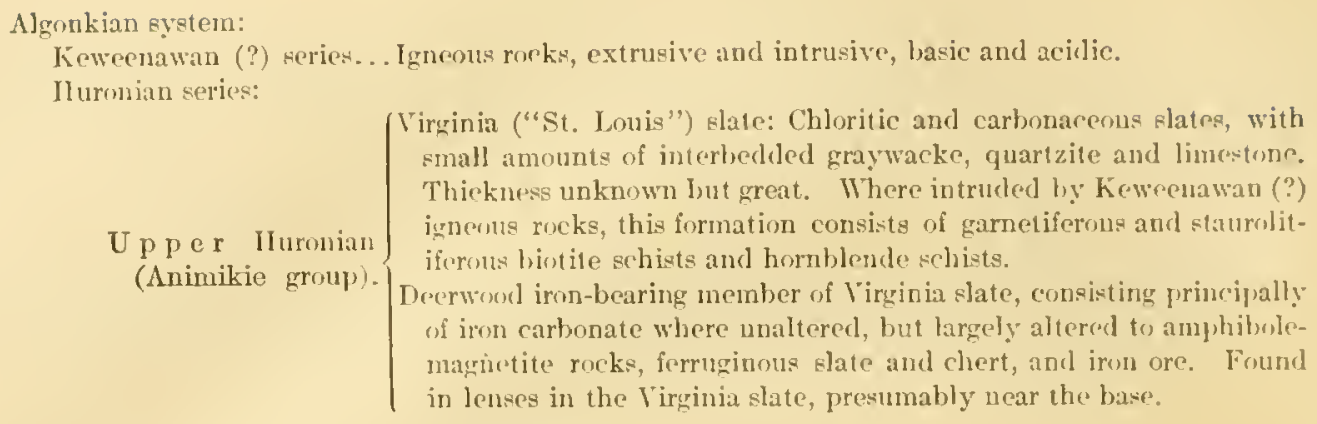

\section{ALGONIIAN LISTEM.}

HURONIAN SERIES.

UPPER IIUTONIAN (ANIMIKIE GROUP).

GENERAL STATEMENT.

The upper Huronian rocks of this district, comprising the Virginia ("St. Louis") slate and its Deerwood iron-bearing member, are not separated for much of the district, but are interbedded and have similar structure. They are aceordingly deseribed together. "The slate, hitherto known as the "St. Louis" slate, has been correlated with the Virginia slate of the Mesabi distriet. The name "St. Louis" as applied to this slate has priority orer Tirginia slate, but it is preoceupied by the well-known Carboniferous formation of the Mississippi Talley. The formation will therefore be ealled Virginia slate in this monograph. The iron-bearing rocks in this district have not been satisfaetorily correlated with the Biwabik formation of the Mesabi distriet, and for them the new name Deerwood iron-bearing member is here introduced, from their trpical derelopment at and near Deerwood, in this district. The irn-bearing beds, being interbedded in the Tirginia ("St. Louis") slate, properly constitute a member of the slate and are so treated in this report.

\section{DISTRIBUTION AND STRUCTURE.}

Sediments of upper IIuronian age oceupy practically all of the rock surface beneath the drift. They hare been bent into repeated folis, as shown by drilling and magnetie work. In the southem part of the district the folding lias been so elose that the beds generally stand at angles of about $80^{\circ}$ with the horizon, though locally rarying at the ends of pitching folds. Toward the north the folding is less close and flatter dips are common. The folding has been accompanied by the development of clearage in the softer layers, especially in the softer slates. Where the clearage can be definitely distinguished from the bedding, there is usually a slight angle between them and the cleavage has the steeper dip. The iron-bearing member itself is less affected by the cleavage than the slate. The axial lines of folds and clearage strike eastnortheast - that is, about parallel with the axis of the Lake Superior syneline.

The iron-bearing nember thus far found seems to be in the form of lenses whose longer dimensions are parallel to the highly tilted bedling of the series. The wall rocks are various phases of the Virginia ("St. Louis") slate. Intrusive rocks locally complicate these relations. Along the strike these lenses pinel out or widen and are loeally buckled ly the dring type of fold (fig. 12, p. 123). It is diflicult to tell from the present state of explorntion just how far the parallel lenses are independent lenses at different horizons in the Virginia slate and how far they may be the result of duplieation by folding. The broader features of distribution are undoubtelly to be explained by folding. There is a narrow zone of iron-bearing rocks known locally as the "south range," extending from a point east of Litkin southwest past Deerwood and Branerd and west of Mississippi River, as shown ly magnetic attractions and by drilling. This is made up of a large number of short parallel and overlapping belts. Whether these minor belts are repeated by folding or whether they are parallel independent lenses at different 


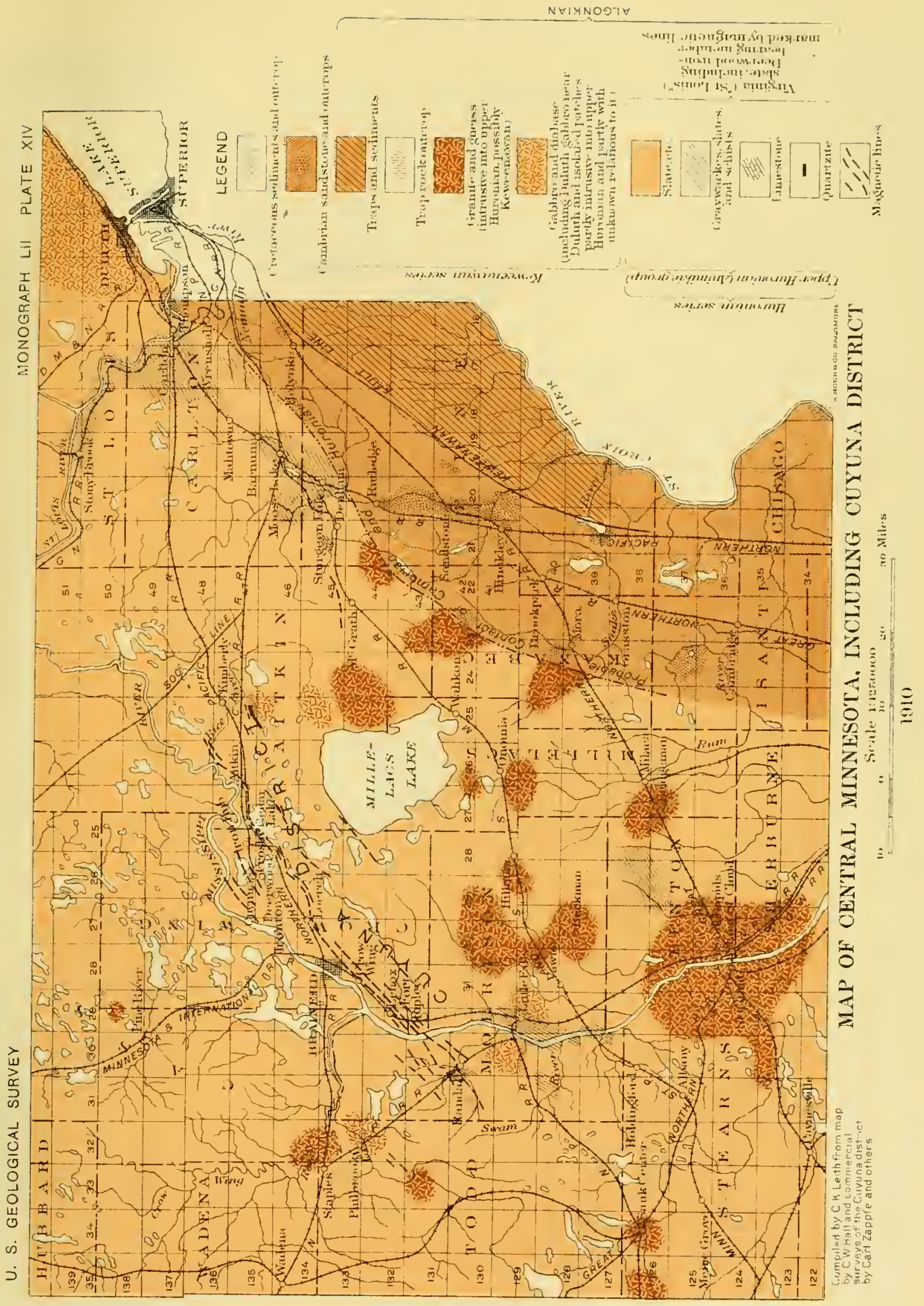



PART OF TIIE CUYUNA IRON DISTRICT OF MINNESOTA Compiled by C. K. Leith and Carl Zapffe from commercial survey

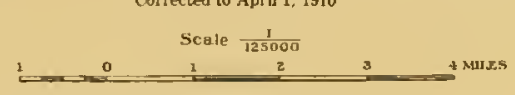

Magnetic belts, shown by black lines, indicate the
distribution and trend of lenses and beds of iron

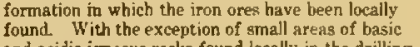

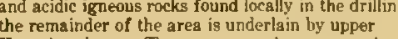

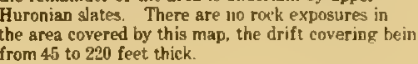

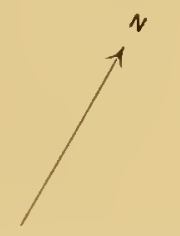

\section{MSSISSIPA}

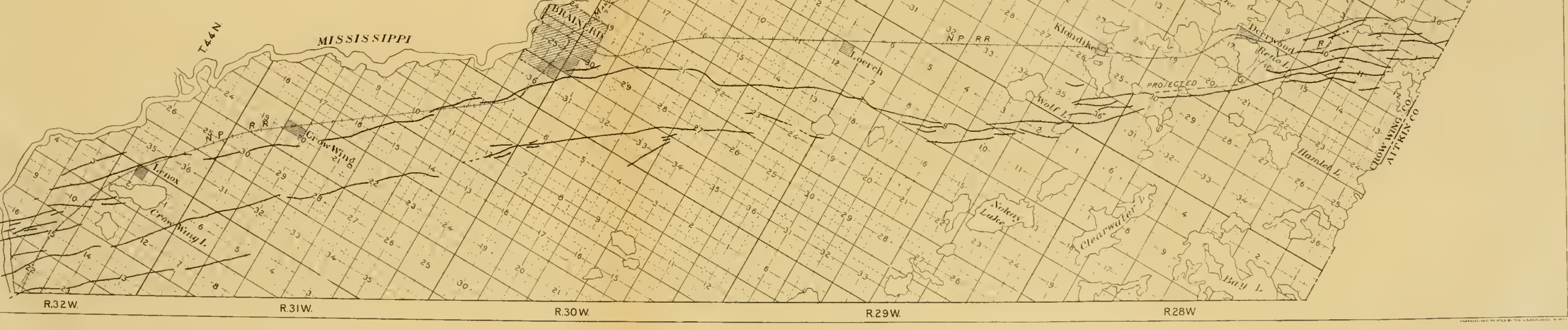
nin $\mathrm{vin}^{\mathrm{R}}$

\section{$\sqrt{x^{2}}$}



horizons in the slate is not known. Six miles to the north, however, in the virinity of Rablit Lake, there is another belt of iron-bearing rocks, known locally as the "north range," which is undoubtedly brought up here by folding, for if it were an independent belt in a monoclinal succession it would imply too great a thickness of interrening strata betwcen the nortli and south ranges. Still farther to the northwest, between Rabbit Lake and Mississippi River, are at least two more belts of iron-bearing rocks repeated by folding. Whether the folds reappear elsewhere prospectors are now trying to determine. Inspection of the map $(\mathrm{Pl} . \mathrm{XV})$ discloses a westward divergence of the south range and the north range belts of iron-bearing rocks. The best ores of the district are found in the angle between them. Divergence of strike to the west is also to be noted between certain pairs of the minor belts, though not in all. These facts may indicate either a general anticlinorium with eastward-pitching axis or a synclinorium with westward-pitching axis. The former is regarded as the more probable.

\section{LITHOLOGY AND METAMORPHISM.}

So far as the seclimentary rocks go, the emphasis in description slould be placed on the altered plases, for they have all been much metamorphosed. Failure to recognize the schists as parts of the sedimentary series has caused confusion in the local interpretation of drill records. The changes in the quartzite and slate to schists are the typical anamorphic changes of the zone of rock flowage and igneous contacts.

Hall has shown how these slates, toward the south and west, where intrusive rocks are abundant, become garnetiferous and staurolitiferous biotite schists and hornblende schists. ${ }^{a}$

When subsequently exposed at the surface, there has been a leaching out of all the basie constituents, learing light-colored, soft kaolinic and quartzose schists. This action is most conspicuous in their upper 15 or 20 feet. It is especially confined to the areas near the ironbearing lenses. Farther south, where anamorphism was more intense, the rocks were made so hard and resistant that they have been af'ected but slightly by weathering where exposed at the surface.

The iron-bearing member, originally mainly iron carbonate, has also undergone anamorphism, resulting in the development of amphibole-magnetite rocks essentially similar to amplibole-magnetite rocks wherever they are found in other parts of the Lake Superior region. This action, lowever, was not sufliciently effective to destroy a large part of the iron carbonate constituting the original mass of the member. Where exposed to weathering the amplibole-magnetite rocks have been more resistant than the iron carbonates, but eren they have become softer, owing to leaching of silica, which has resulted pructically in the concentration of the iron, which remains substantially as magnetite. The iron carbonate has been altered to limonite at the surface. The result is a mixture of hematite, limonite, and magnetite in the iron-bearing member, soft and granular above and becoming harder and more siliceous below and showing more of the unaltered carbonate phases with depth. The gradation phases between the iron-bearing member and the slate have become ferruginous slates.

The anamorphism of the rocks of the Cuyuna district is probably to be cxplained in large part by the existence of intrusives in the area itself and west and south of it.

CORRELATION.

The sedimentary rocks of the Cuyuna district probably belong in the same series with the slates and schists of the Carlton, Cloquet, and Little Falls areas. They show many similarities in lithology, structure, and metamorphism and are geograplically contiguous. Drilling in numcrous places in Crow Wing and Aitlin counties. shows the same pyritic and carbonaceous phases of slate as have been explored for coal in the vicinity of Malutowa.

Succession and lithology are in accord with distribution and general structural relations in pointing to the identity of the rocks of the Cuyuna-Carlton-Little Falls area with the upper Huronian (Animikie group) of the Lake Superior region. The Animikie group as a whole,

a Hall, C. W., Keewatin area of eastern and central Minnesota: Bull. Geol. Soc. America, vol. 12, 1901, pp. 343-376. 
where best known in the Mlesali and Animikie and Gogelde clistricts, consists of a great slate formation 2 miles or more thick, underkin by mol interbedded in its lower portions witl an iron-bearing formation of varying thickness, lut averaging perhaps 1,000 foet, and this in turn umblerlain by quartzite varying from 1 to 200 feet in thickness. Exploration has not yet gone far enough to warrant a satislactory estimate ol the thickness of the formations in the Cuyuna district, but the information so far developed is in areord with the figures given for the Animikie group as a whole, except for the iron-bearing nember, which thus far lans not been found to be as thick as the average for the Lake Superior region. The Cuyuna range is separated from the Mlesabi lange on the northeast by a flat swamp and lake area about s0 miles wide, which completely lacks rock exposures. The Animikie group in the Mlesali district dips to the south under this low, flat area at an angle rarying from $4^{\circ}$ to $20^{\circ}$. It has long leen obvious that the group here disappearing under the surface might somewhere be brought up to the south by folding.

In the Gogebic range, on the south sile of Lake Superior, a similar group dips at an average of $60^{\circ}$ toward the northwest beneath the Lake Superior basin, and it has long been thought that this group represents the Animikie group as it comes up again on the south sicle of the lake. An examination of the general structure of the west end of the Lake Superior basin, howerer, shows that the structure of the area between these two districts is not that of a simple syncline but of a syucline in which there are subordinate anticlines-that is, a synclinorinm. One of these subordinate anticlines runs west and southwest from Duluth toward Little Falls and vicinity on Mississippi River. If the Animikie group comes to the surface anywhere between the Mlesali range on the north and the Gogebie range on the south, it should therefore appear in this subordinate anticlinal fold in the western part of the general synclinorium connecting these two regions, and it was on this hypothesis that the extension of the iron-bearing formation of the Mesabi and Gogelnic distriets was drawn by geologists, prior to its discovery, through the present ('uyuna district, which lies near the north side of this subordinate anticlinal folel. The existence of a quartzite exposure at Dam Lake, near Kimberly, and near Rabbit Lake, as shown by drill records, points to the fact that here erosion has cut down to the lower part of the Animikie group as it would in truncating an antichine. The course of Mississippi liver itself suggests the existence of the anticline in the ricinity of the Curuna range, for after crossing the Mlesabi range it flows south until it reaches the Cuyuna district and then turns suddenly westward as though deflected along the anticline toward a lower point of eseape. Where it does break across, as at Little Falls, roeks are exposed.

The slates of the Carlton and Cloquet districts were early assigned by Irving and nther geologists to the upper Huronian, but they were later referred by Spurr to the lower IIuronian because of their greater metamorphism and folding than that of the upper IIuronian slates in the Mesabi district to the north and because they are intruded by granites supposed to be of lower Huronian age. It is now known that the upper IJuronian (Animikie group) of the Jesabi district is also intruded ly granite. The facts dereloped in the Cuyuna district seem to confirm Irving's view of the correlation.

In view of the probable equivalence of the rocks of the Cuyzuna and Carton areas and the occurrence of small iron carbonate bands and nodules in the slates about Carlton and Cloquet and to the southwesi similar to the broader bands in the Cuyuna area, the question naturally arises why erosion should not somewhere in this great area of exposed slate hetween Carlton, Cloquet, and Little lalls uncover the lower part of the Animilie group-in other words. the iron-hearing member. It may be that the crest of the anticline runs parallel with the Cuyuna district it self, allowing erusion to cut down here only into the main iron-bearing member. while to the south and southeast the thek capping of slates las not been removed, or it may be that the existence of great masses of intrusive granite and diabase and the intense metamorphism which they have accomplished have prevented erosion of the surface or have made the conditions unliavorable for the direct oxilation of the isom-bearing rocks under surface katamorphice conditions. Certainly enough farts are not yet available to warrant the assertion that the ironbearing member may not get be lound in this area. 


\section{KEWEENAWAN SERIES (?).}

Igneous rocks are abundant in the area of the upper Huronian (Animikie group). These include granites and basic rocks, many of the latter characterized hy ophitic structure. Part are schistose; others are not. The granites outcrop conspicuously (therely contrasting with the adjacent upper Ifuronian sediments) in the southern part of the district in a general belt extending from Carlton and Cloquet southwest beyond Mississippi River. Other exposures are known northwest of the district, in the vicinity of Ranclall and Motley. Basic ignoous rocks of diabase and gabbro trpes also outcrop, though less abundantly, over the same area. Dikes of the basic rocks, up to 50 feet in wintl, are conspieuous in the Carlton area. The intrusive character of these igneous rocks as a whole admits of no doubt. Thein netamorphic effect on adjacent sediments has already been described. Within and adjacent to the Decrwood ironbearing member drilling has disclosed much igneous rock, both basic and acidic, of yot unknown extent and with unknown relations. The contacts are sharp, the adjacent members of the upper IIuronian have been locally metamorphosed, and no basal conglomerates have been found in the sediments arljacent to the igneous rocks. From these facts it is concluded that the igneous rocks cut in drill holes are probably intrusive into the upper Iluronian seliments, just as are the granites to the south. The textures and structural relations of some of the basic igneous rocks suggest the possibility that they may be extrusives contemporaneous with the upper Huronian rather than with later intrusives, but until mining operations disclose more underground sections this ean not be determined. In only three localities are extrusives known. An acidic cxtrusive rock with amygdaloidal texture, in beds 15 to 25 feet thick, has been found by drilling to rest across the edges of the Virginia slate and Deerwood iron-bearing nember, in sec. 2, T. 44 N., R. 31 W.; sec. 6 , T. 44 N., R. 30 W.; and sec. 7, T. 45 N., R. 29 W.

The igneous rocks intrusive into the apper IIuronian and the extrusives resting on the upper Ituronian are provisionally classed as Kiewcenawan, because the Kewenawan is the next period of igneous artivity, because abmulant igneous rocks of Keweenawan age are known elsewhere in the region to cut the upper Iuronian sediments, and because they are especially abundant in that part of the Cuyuna district which lies approximately along the central axis of the Lake Superior syncline, lurgely developed during Keweenawan time. (See pp. 421-422, 622-623.)

\section{CRETACEOUS ROCINS.}

Immediately below the surface, in widely scattered parts of the district in Crow Wing County, remmants of a conglomerate have been found. Some consist of small pebbles of the iron-bearing member in a slaty matrix; others of small pebbles of an extrusive rock. Generally the pebbles are about an eighth of an inch or less in diameter, but on two widely separated properties the oval pebbles measure as much as an inch in their longest dimension. This conglomerate is found resting unconformably, apparently in small depressions, on a rather level erosion surface of the upper Huronian. It does not contain fossil remains to identify it, but it is similar to the Cretaceous of the Mesabi range. An excellent opportunity to examine it was offered when an exploration shaft was sunk in the SW. $\frac{1}{4}$ SE. $\frac{1}{4}$ sec. S, T. 45 N., R. 29 W.

More Cretaceous sediments have not been identified, probably bccause, being poorly cemented, they are chopped and brought to the surface in drilling as chmmings. Drillers frequently report unbroken shells in the lower portion of that which is reported as "surface," and clay immediately above bed rock and below the surface, and frequently the top drill samples are light-colored, unconsolidated, and calcareous material, all of which might well be of Cretaccous origin. None of this has been very carefully examined. The common occurrence of large amounts of lignitic material in the glacial drift indicates a once wide distribution of Cretaceous deposits, possibly with remmants here and there such as are found in the Mesabi range to the north. Cretaccous beds continuously cover the pre-C'ambrian rocks of western Minnesota. Those of the Cuyuna district may be regarded as outliers of the main Cretaceous area. 


\section{QUATERNARY SIYSTENI.}

\section{PLEISTOCENE GLACIAL DEPOSITS.}

The glacial deposits in the eastern part of the district belong, according to Upham, ${ }^{a}$ to the eighth moraine and those in the westem part of the district belong to the ninth moraine, counted back from the outermost moraine of the late Wisconsin glaciation. They vary from 35 to 400 feet in thickness. The heavy mantle of weathered material upon the rock surface is a remuant of the product of preglacial weathering, which in the other districts has been removed by gracial erosion. Obviously in the Cuyma district glacial deposition has predominated over glacial erosion.

\section{THE IRON ORES OF 'THE CUYUNA DISTIRICT.}

By the authors and CARL ZAPFFE.

\section{DISTRIBUTION, STRUCTURE, AND RELATIONS.}

The Cuyuna ores are scattered through a eonsiderable area beginning a little east of Aitkin, Aitkin County, Minn., and extending southwestward past Brainerd into Morrison County. (See Pl. XIV.) The limits of the ore-bearing district are not yet known. The district lacks the distinct range or ridge characteristic of the other iron-producing districts, though in general it follows a drainage divide. The area is flat, heavily drift covered, and without exposures.

The development of the Cuyuna district is still in its exploratory stage. At this writing no shipments have been made. In the absence of exposures, information is arailable from about 2,000 drill holes and two shafts and from magnetic readings. The information is still inadequate to warrant any extended discussion. In the following general outline emphasis is placed on the facts thus far dereloped. No attempt at proportional treatment is made. This may be possible later.

The Deerwood iron-bearing member is magnetic as a whole, and henee its distribution is roughly shown by the magnetic belts outlined on Plate XV and by minor belts which do not appear on this plat. Parts of the member, howerer, are rery weakly magnetic; they are found beneath very weak belts of attraction and extend laterally some distance away from the maximum magnetic line. The ore deposits may be more or less magnetic, usually less magnetic, than the associated iron-bearing member, and hence are not ordinarily situated under the belts of maximum rariation, though they are not far from them.

Ore deposits of suflicient size and grade to be commercially arailable have been found in both the north and south ranges, so called. The south-range ores oceur at intervals along the magnetic belts from a place a mile east of Deerwood more or less intermittently to the northeastern part of T. 43 N., R. 32 W., near Mississippi River southwest of Brainerd, a distance of about 30 miles. The north-range ores are in internittent deposits, in a shorter but wider belt, extendling from Rabbit Lake southwestward nearly to Mississippi liver. The tonnage of the deposits thus far found is about ecpual in the two ranges, but on the north range the ores are more largely confined to a few large deposits of good grade, while on the south range the number of deposits is larger and their individual size smaller.

The ores are in nearly vertical lenses and layers from a few inches to 125 feet or more wide. on the south range and up to 400 or 500 feet on the north range. The depths on the two ranges are rariable as the widths. On the north range the greatest depth known is $\$ 50$ feet and it is quite likely that this figure may be excecled, but up to the present time the averige deptlo is about 300 feet. On the south range the greatest depth known is about 250 feet, and it does not seem likely that this will be greatly exceeded. The arerage depth on the south range is about 150 feet, but the higher-grade ores invariably oceupy only the upper 100 feet. The strike is east-northeast for clistunces varying from a few feet to half a mile and to un unknown greater distance. 
Whether these lenses pitch in the direction of strike, following the axes of drag folds, is not yet disclosed by the drilling. (See fig. 49, p. 350.) From analogy with other districts the ore borlies are likely to have a pitch, and this pitch is likely to be more or less uniform in direetion and degree, affording a guide for exploration. The drilling has not shown the piteh, because where they are vertical the holes are stopped as soon as they run out of ore, and if they go into lean rocks rather than ore they are ordinarily not carried far enough to locate any possible extensions of the pitches. Where the holes are put to one side of the ore body and inclined they are stopped as soon as they have penetrated the ore lens. These pitches are, as a matter of fact, extremely diflicult to locate by drilling. Closely associated with the ore on one or both walls, or in layers within the ore, is amplibole-magnetite rock. At varying depths, but usually within 125 feet on the south range, the ores tend to grade vertically into cherty iron carbonate rocks, and at these depths also the amphibole-magnetite rocks contain unch more iron carbonate than at the surface. It may be found that down the pitch the depth of gradation to iron earbonate is much deeper. The ores, with the associated amphibole-magnetite rocks and cherty iron carbonates, constitute the iron-bearing member of this district.

The Deerwood iron-bearing memher as a whole constitutes lenses or layers in the great Virginia ("St. Louis") slate formation, lying parallel, overlapping, or end to end. Each major lens may be divided into minor lenses by intercalated slate layers.

The wall rocks of the ore may therefore be any of the phases of the Deerwood iron-bearing member or uny of the phases of the Tirginia ("St. Louis") slate. Characteristically one wall may be chloritic or black graphitic slate of the Virginia formation and the other wall amphibolemagnetite rock of the Deerwood iron-bearing member. The association of ore with carbonaceous slates finds its counterpart in the Iron River, Crystal Falls, and other districts of Michigan.

Dikes and irregular masses of basic intrusive rocks appear in all parts of this series and are associated with almost every ore deposit yet known. These may constitute one wall of the ore body or may be separated from the ore body on one wall by amphibole-magnetite rock.

A characteristic occurrence of the ores is shown in plan and cross section in figure 25 . It is apparent from this figure that the information furnished from drill holes would depend largely on the angle at which the drill penetrates the iron-bearing member. In a vertical lens a vertical hole will tell nothing of the character of the material a few feet away across the strike. An inclined hole will indicate the proportions of iron-ore, amphibole-magnetite rock, and slate layers, but may not show the greatest depth of the iron-ore lenses, or, on the other hand, it may pass through the carbonate phases of the beds beneath the ore.

The ore, where associnted with magnetite rocks, is in many places also magnetic. The amplibole-magnetite rocks are somewhat more magnetic than the ores thenselves, so that drilling on the maximum magnetic attraction is likely to show amphibole-magnetite rocks with the ores a few feet to one side or the other. A not uncommon relation is amphibole-nagnetite rock on the maximum attraction, intrusive material on one side of the maximum, and ore on the other. The greatest distance from the maximum attraction at which ore has ret been found is one-half mile. It will he shown elsewhere (pp. 552-553) that the magnetic character of the member is not favorable to its richest concentration; this suggests that the best parts of the Cuyuna ore may yet be found farther away from the inagnetic belt.

The fact that the foot and hanging walls of the ore deposits of most of the Lake Superior ranges are uniformly different in their lithology has led to the assumption that the foot and hanging walls of the Cuyuna ore deposits are uniformly different. Beginning in slate a few Inundred feet either side of the magnetic belt, an inclined drill hole penetrates the iron-l,earing member as the magnetic maximum is approached. The slate is ordinarily sproken of as "hanging wall." The drill is then likely to penetrate ore more or less interbedded with slate and amphithole rock. Is the magnetic maximum is approached the amphibole-magnetite rock is likely to be more abundant. The drill may go beyond the maximum attraction into intrusive, which would be spoken of as "intrusive foot wall." (See fig. 25.) The terms "hanging-wall slate" and "magnetic foot wall" or "intrusive foot wall" therefore signify a certain tendency 
towarl uniformity of relations which it is well to identify by such terms. But the assumption of uniformity implied by the use of these terms may lead to misapprehension of the facts. Slate similar to that of the hanging wall may be on either side of the iron-bearing member.

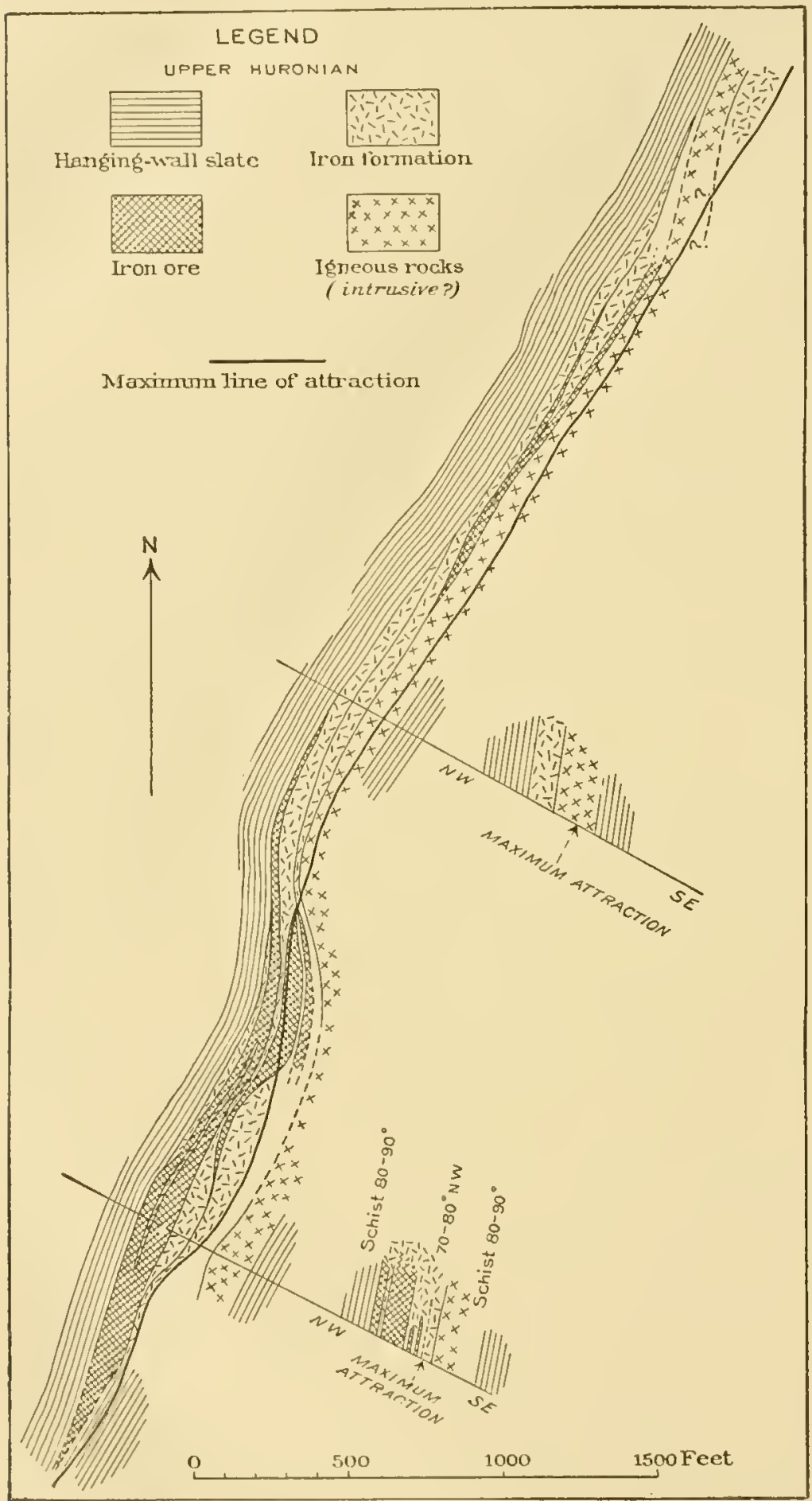

Figure 25. Plan and cross section of the iron-ore deposit in sec. 12, T. 43 N., 1.. 32 W., Crow Wing county, Minn. l3y Carl Lapfle.

If the drills go liar enough, they are likely to find slate in both walls. Slate layers within the iron-bearing member itself, if first penetrated by the drill, woukd be likely to be callet "hanging wall." In short, the nature of the foot and hanging walls will depend on the particular layers in which the drill happens to start and where it stops in the interlaminations of slite and iron-bearing nember. The relations of the intrusive rocks to the ore deposits are still obscure, but it seems not unlikely that these may be found to constitute a definite foot wall for some of the ore borlies.

The facts just given are disclosed by drilling, but the drilling ret done gives a very incomplete view of the structure, and for the larger structural features we must rely prineipally on interpretations of the mannetic field. The existence of fire magnetic belts in a zone 7 miles wide north and south suggests that the iron-bearing nember is repeated by folding. If the dips were monoclinal and the sereral magneticbelts represented separate iron-bearing zones in the slate, the thickness of the series to be inferred would be greater than is reasonable. On the other hand, the thill cores slow variations in the dip of the bedling indieative of folding. The clearage of the slates is inclined to the bedling, and this relation is itsolf evidence of folding. These folds have al strike east-northeast parallel to the Iake Superior axis, to julge from the magnetic helts. Mloreorer, the discontinuity of these helts, their distribution en edhelon, and the varying intensity of the 
magnetie field along a single belt all alecord with the distribution requiresl by pitching folds, which repeat the iron-bearing berk, the number of times dillering with the loculity. If the crests and troughs of the folds were horizontal, the beds would appear as parallel lines upon the horizontal erosion plane, but the actual crest and trough lines of the folds usually have a pitch; in other words, they are cross folderl, so that on the erosion plane the berls appear to converge in the direction of the pitch. With folling of this type it is apparent that the beds may strike with a considerable valrety on the erosion plans, accorling to the section this plame happens to make through the folds.

The magnetic belts fail to give all the information desired as to structure, for two reasons: (1) It is not certain that the iron-bearing lenses in all parts of the district are at the same horizons in the slate; indeed, it is known that within a few hundred yards there may be several iron-bearing bands, so that the question is raised whether iron-bearing layers in other parts of the district belong below, with, or above them stratigraphically. (2) It is diflicult to tell whether two nearly parallal belts close together represent truneated iron-bearing layers on the two limbs of a single fold or the axes of two independent folds. The main belts of attraction several miles apart doubtless represent separate folds, but the closely assoeiated minor belts making up each of the main belts may represent either the two limbs of a single fold or two horizons on one limb of a fold.

It is concluded, in general, that the iron-bearing member constitutes closely associated lenses and layers ilong a single general horizon in the slite. The finding of cuartzite in a few places near the iron-bearing member suggests that this horizon is near the bottom of the slate formation, but this is not proved. The folling of the slates carrying the iron-bearing zones, followed by erosion, has dereloped the present distribution at the surface.

\section{CHARACTER OF THE ORES. $a$}

\section{GENERAL APPEARANCE.}

The Cuyuna ores fall into two main groups, hard and soft ores.

The solt ores are black, brown, and reddish hydrated hematites, soft and earthy and much like the soft ores of the Penokee-Gogehic district. They have large pore space. These soft ores are of two types - a high-grate ore containing 55 to 63 per cent iron, soft and powdery and of a brown to very dark color, and a lean reddish-purple ore containing 45 to 50 per cent iron. The latter ore is not so soft as the former. It is easily broken down with a pick but retains its stratified form and hangs together in fairly large chunks. In this type cherty layers are scattered through the mass at short intervals, the cherty impurity probably accounting for its low grade. This ore also has a large pore space.

The hard ores are also of two types. The bulk of the hard ore is a black to rery dark brown hydrated hematite. It is elosely stratified and has suffered close brecciation as a result of slumping caused by the leaching out of silica. This ore varies in iron content, but is mainly ligh grade, running from 50 to 60 per cent iron. Nlthough this ore is brecciated it holds together in large masses, owing to the partial cementing of the breceiated pieces by the seeondary introluction of iron. Nuch of the ore of this type has been classed as soft ore by the Jrillers because it is fairly easily penetrated by a chum drill and comes to the top broken up in very fine angular pieces. It can be distinguished, however, from the true soft ore, which is washed to the surface of the hole as a fine, even-grained, powdery mass. The Cuy una hard ore describel above must not be compared to Termilion dense blue hematite of that range. It is much softer and more limonitic.

The other type of Cuyuna hard ore, small in amount as compared with that described above, is a hard blue hematite rumning about 58 to $63 \mathrm{per}$ cent iron. It is massive and unbreciated. This is a true hard ore and can only be drilled with diamonds. This ore oecurs in layers in the softer ores and is found more frequently close to the intrusives.

$a$ In the description of the ores the writers have drawn on quantitative data assembled by F. S. Adams (Econ. Geology, vol. 5.1910, pp. $729-740 ;$ vol. 6,1911 , pp. 60-70, 15G-180). 
It is impossible to state at this incomplete stage of exploration the proportion of hard to soft ore on the Cuyuna range. The soft ores prebably form the larger proportion, but the lated ore unust be counted as a large factor and may occur in a much larger percentage than has previously been supposed.

Locally on the north or Rabbit Lake range back, highly manganiferous ores have been developed near the surface. These are unimportant in amount as compared with the other ores.

\section{CHEMICAL COMPOSITION.}

Becanse of the minute interbanding of the ore with lean, magnetie, and shaty phases, the ehemical composition shows rapid alternation across the strike. The percentage of iron of the iron-bearing nember ranges from less than $30 \mathrm{per}$ cent in the lean siderite and amphibole phases to 60 per eent and more in certain of the iron ores. In certain estimates of tonnage which have been made it has been calculated that of the ores running above 40 per cent metallie iron 44.5 rum above 50 per cent in iron and 21.3 per cent above 55 per cent in iron. These figures are based on a sufficient number of drill holes to warrant the belief that this proportion may have some general signifieance for the range. The average iron content of all ores above 50 pere cent in iron on the north range, found by drilting to the time of writing, is about 1 per cent higher than that for such ores on the south range. The ehemical character of the iron ore and interlayered masses as they stand in the ground may best be shown by the following analyses from a drill hole cutting the formition at an angle of $60^{\circ}$ :

Analyses of tron ore und interlayered masses from the Cuyuna district, Mmnesota.

\begin{tabular}{|c|c|c|c|c|c|c|c|c|}
\hline Depth. & $\mathrm{Fe}$ & $P$. & IIn. & $\mathrm{SiO}_{2}$ & $.1_{2} \mathrm{O}_{3}$ & $\mathrm{C}_{3} \mathrm{O}$. & IIgO. & $\begin{array}{l}\text { Loss by } \\
\text { ignition. }\end{array}$ \\
\hline$\underset{175-180}{F r t i}$ & & & & & & & & \\
\hline $180-1.55$ & 59.73 & .547 & $\begin{array}{r}0.2-1 \\
.22\end{array}$ & 3. 23 & 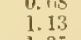 & .15 & .14 & i. 34 \\
\hline $155-190$ & 59.02 & .425 & 20 & 3.78 & 1.35 & . 10) & 11 & \\
\hline-195 & 53. 11 &.+04 & .20 & 4. 10 & 1.25 & .17 & .10 & 7.83 \\
\hline $\begin{array}{l}195-200 \\
300-305\end{array}$ & (i). 32 & .414 & $\begin{array}{r}-10 \\
-31\end{array}$ & $\begin{array}{l}6.35 \\
7.22 \\
7.22\end{array}$ & $\begin{array}{l}. t i 3 \\
.606\end{array}$ & $\begin{array}{l}.10 \\
.08\end{array}$ & .09 & \\
\hline $205-210$ & $\begin{array}{l}54.44 \\
54.45\end{array}$ & .353 & .36 & 7.34 &. & .11 & .111 & 5.35 \\
\hline $\begin{array}{l}210-215 \\
015\end{array}$ & 60.93 & $\begin{array}{r}.264 \\
.209\end{array}$ & .40 & ti. 68 & .49 & .1 .9 & $.0 \overline{8}$ & 3.36 \\
\hline $\begin{array}{l}2.15-220 \\
220-225\end{array}$ & $\begin{array}{l}\text { ti. } 110 \\
5 \div .82\end{array}$ & .287 & .46 & 13.00 & $\begin{array}{l}.14 \\
.47\end{array}$ & 8 & .01 & 3.36 \\
\hline $225-230$ & 57.93 & $.2 \mathrm{nt}$ & .10 & 12. 96 & .48 & 17 & . 118 & \\
\hline 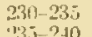 & 55.52 & .337 &.+3 & $\begin{array}{r}15.19 \\
0.79\end{array}$ & 3. 00 & .16 & $\begin{array}{l}n \pi \\
.06\end{array}$ & 2.75 \\
\hline $240-215$ & 49.07 & & & & & & & \\
\hline $\begin{array}{l}215-230 \\
250 \\
2565\end{array}$ & $\begin{array}{l}4 . j .67 \\
4 \leqslant i . \Omega^{2}\end{array}$ & & $.4 S$ & 29.30 & .35 & .13 & .09 & 2.15 \\
\hline $\begin{array}{l}255-2600 \\
200-2615\end{array}$ & 47.85 & & . 40 & 26.01 & .59 & .10 & .10 & \\
\hline $265-270$ & $\begin{array}{l}48 \\
14.25\end{array}$ & & 50 & $26.00^{\circ}$ & 52 & .16 & $.0 t$ & 21.2 \\
\hline $2-7.5-3 \times 0$ & 11. & & .39 & 36,74 & .54 & 17 & $0 \mathrm{~s}$ & \\
\hline $24,-3: 0$ & $\begin{array}{l}4 \pi, 36 \\
36, .30\end{array}$ & & 1.12 & 32.56 & .73 & .42 & 30 & \\
\hline $\begin{array}{l}290-295 \\
275-300\end{array}$ & 37.85 & & 1.05 & 31.71 & 74 & 41 & .37 & $\because$ ii \\
\hline
\end{tabular}

It will be noted that the principal rariants here, as in other districts, are iron and silica. Phosphorus is usually high, averaging about 0.34 per cent, which brings the ore into the class of the Iron River ani Crystal Falls ores. The north range shows less phosphorus than the south range. Loeally on the north range there are streals of Bessemer ore.

Loss by ignition is ligh. This consists prineipally of water combined in the hydrated iron minerals but includes some carbon.

Manganese is usually in small amounts, but locally and near the surface may run up to 10 or 12 pere cent or even up to 28 per cent. One drill hole on the north range averaged 13 per cent for the upper 35 feet. Another had an average of 11.33 per cent for the upper 30 feet.

The percentage of free water in the ore as mined can not be determined through drilling. and the ore has thus far been opened up lyy shafts to such a slight extent that the arerage free moisture for the ores tan int yet be criven. Three determinations from the Rogers, Brown Ore Co. shaft give moisture of (i.80 pere cent, 10.40 per eent, and 14.20 pere cent, with an averace of 
10.46 per cent, not far from the average of the Lake Superior region. Another determination by Pickands, Mnther \& Co. for the ore from their shaft in see. 8, T. 45 N., R. 29 W., gives 12 per cent of free moisture. In analyses of ore from ditl holes the iron content is usually calculated for the clried ore. If the moisture is included the iron content is lower. An average moisture of 10 per cent indicates that an ore appening as a 55 per cent ore in the drill hole will mine as about 50 per cent. As prices are based on standard ores with moisture, this correction is an important consideration.

The slate layers interlayered with the iron-bearing member and intermediate phases between the iron-bearing member and the slate woukl run ligher in alumina. The above analyses are confined to the iron member itself.

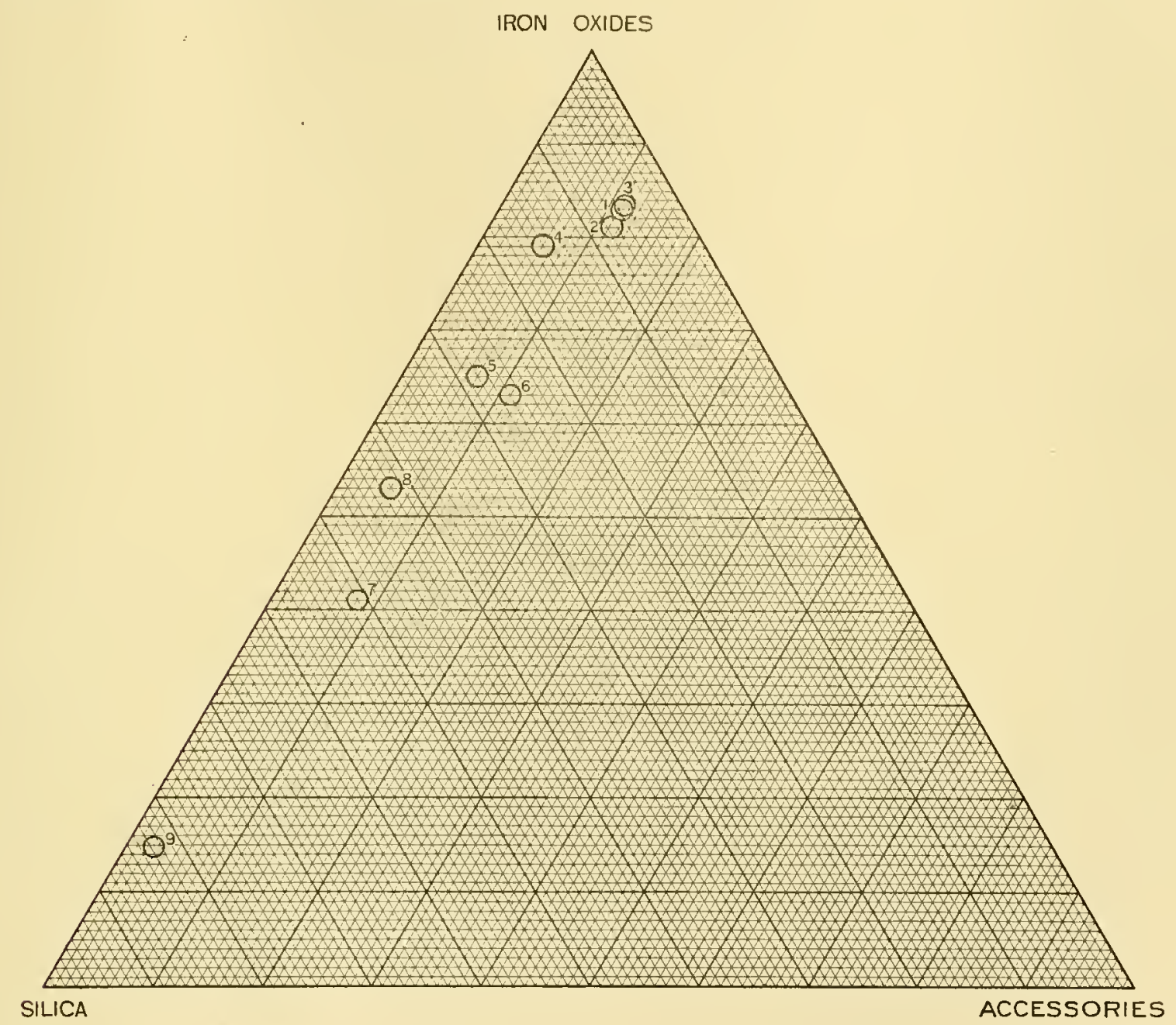

FigURE 26.-Triangular diagram showing mineralogical eomposition of various phases of iron ores and ferruginous cherts of the Cusuna district, Minnesota. After F. S. Adams. For description of method of platting and interpretatiou of diagram, see p. 182, 1, Hard blue ore from the liabbit Lake section; 2, brecciated, hydrated hard ore (Ralbhit Lake); 3, lrard blue ore (sec. 21, T. 46 N., R. 28 W.): 4, soit ore (sec. 21 , T. 46 N., R. 28 W.); 5, lean soft ore (Rabhit Lake); fi, dense, blaek, highly ferruginous chert; 7 , 8 , arerage ferruginous chert; 9 , weatbered highly siliceous chert.

\section{MINERALOGICAL COMPOSITION.}

The Cuyuna ores are more or less magnetic lyyilrated hematite with some limonite. The prineipal impurity is chert in layers. A less common impurity is clay in layers. In still smaller amount are iron carbonate and amphibole, which also show a tenilency toward concentration in layers. The color varies from a light yellow through various brown and redelish tones to black, according to the hydration of the imon and the amount of magnetite in it. The highly 
manganiferous ores contain both the carbonates and axides of mangrunese. They are most. ahundant near the surface. The mineral carrying the phosphorus is not known.

The mineralogical composition, fiumed from the forergoing analyses in which loss lyg ignition was determined, is as follows:

Mincral composition of Decrwood iron-bearing member.

\begin{tabular}{|c|c|c|c|c|}
\hline Depth. & Ilematite. & Limonite. & Q (quartz. & Kanlin. \\
\hline Fret. & & & & \\
\hline $\begin{array}{l}175-1 \times 0 \\
194-145\end{array}$ & $\begin{array}{l}42.10 \\
40.10\end{array}$ & $\begin{array}{l}\text { 45. } 80 \\
\text { ifi. } 190\end{array}$ & $\begin{array}{l}4.60 ; \\
\therefore .63\end{array}$ & $\begin{array}{l}1.72 \\
3.16\end{array}$ \\
\hline $205-210$ & 54.10 & 3.. 35 & (i. ii & 1.57 \\
\hline $21.5-220$ & isi. 20 & 22.10 & 7.65 & 1.11 \\
\hline $230-235$ & 114.10 & 17.4 & 14.102 & 1.2.2 \\
\hline $2-55-250)$ & 53.10 & 11. 210 & 24,49 & .59 \\
\hline 2165 & 54.41 & 110.85 & 25.35 & 1. 49 \\
\hline $295-300$ & 13. & $47 \cdot 5$ & 30.84 & i.si \\
\hline
\end{tabular}

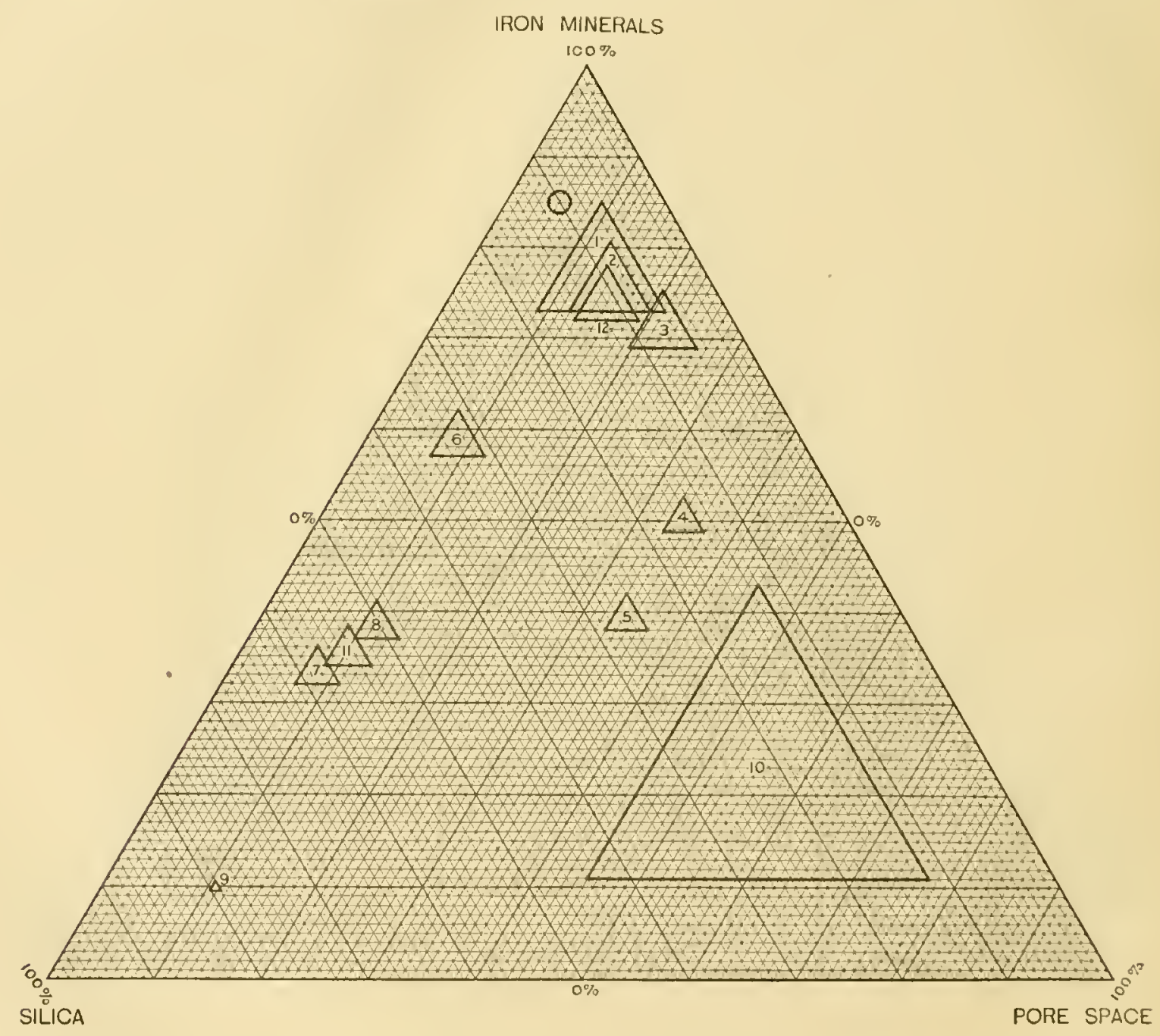

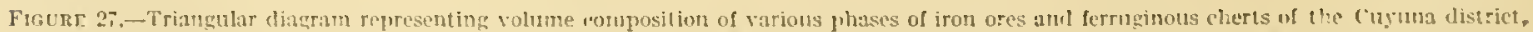

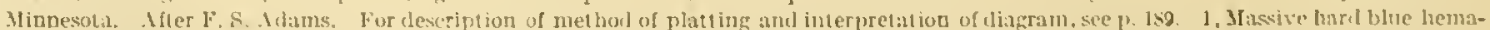

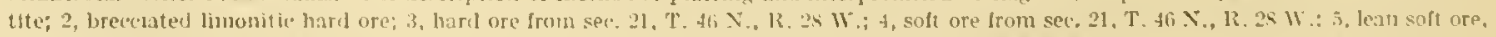
(Rabhit lake); t, dense, black, highly ferruginous elett; $7, x$, banded ferruginous chert; 9, weat herel ehert; 10, trpieal paini rock; 11, arerage ferruginous chert; 12, 13, average soft ore; 11 , average cheriy iron carhonate.

The ore really consists of hematite, limonite, hydrates intermediate hetween hematite and limonite, and magnetite. Is it is almost impossible to determine what decren of hychration some of the minerals may have, the analyese are expressed in terms of hematite ame limonite. 
This is merely a conventional means of showing the degree of hydration for these ores. The amount of magnetite is so small that its calculation as hematite does not materially aflect the result.

TEXTURE.

The density of the hard ores of standard grade arerages 4.09. This includes both types of hard ore. The low figure is due to the lyydrated character of the Cuyuna hard ore. 'The density of the soft ores averages 4.19. The lean soft ore show's an avernge density of 3.73 . The hard blue unbroken type of hematite has an average density of 4.26. The limonitic breceiated hard ore shows a density of 3.95 .

The pore space of the hard ores averages 13.13 per eent by volume. This inchudes both types. The soft ore has an average pore space of 36 per cent. The lean soft ore shows 33.3 per cent pore space. 'The hard ores show a rauge in porosity varying from 9 to 20 per cent by volume.

The hard ores of both types arerage 10 cubic feet per ton. The hard blue hematite varies between 9 and 10.5 cubic feet per ton. The hydrated brecciated hard ore ranges fron 10 to 10.8 cubie fect per ton. The soft ores average 11.5 cubic feet per ton. The lean soft ore runs 12.6 cubic feet per ton.

An arerage figure to use in computing tomage for a large deposit where various ores are represented and a tonnage estimate of each type is out of the question would be about 11 cubic fert per ton.

Notwithstanding the fineness of much of the ores, the texture is not disadvantageous, for there is prolably less of it that will act as flue lust in the lumace than there is of the Mesabi ore, for the reason that it is as a whole less crystalline and more earthy and takes on a more coherent texture when compressed.

\section{SECONDARY CONCENTRATION OF CUYUNA ORES.}

Structurel conditions.- The struetural relations of the Cuyuma ores are still so imperfectly known, that any statement concerning thom must be made with much qualifieation. It is nevertheless obvious here that the concentration has been greatest at the surface and less with depth, and that at least in many places it has been very active next to the intrusives rocks which cut the member or along foot-wall slates or amplibole schist. Also it seems to have followed axes of minor drag folds. All the rocks lave been weathered to a considerable extent. At present glacial drift covers them at depths of 35 to 400 feet, so that water stands much above the rock surfice. The present condition is obviously quite different from that under which the. ores were coneentrated. It may be supposed that when the rock surlace was exposed waters penetrated into the inon-bearing nember as it was exposed on the anticlinal areas between the impervious hanging wall and the impervious foot wall and that where the member was eut by impervious igncous rocks they scrved further to control the circulation. The depth of circulation is not yet known, nor is it clear what topographic features may have been present in the past to control the depth of circulation.

Original elaracter of the Decmood iron-baring momber.- The member was originally eherty iron carbonate interbedcled with slate.

Mineralogical and chemical changes.-The alteration of the original carbonate rocks was in different sequence from that in most of the Jake Superior ranges, because before it was cxposed to weathering it underwent lobling and intrusion, which partly altered the cherty iron carbonate to amphibole-magnetite rock. Subsequently, when rosion had exposed the member, the surface agents of alteration therefore lad two phases of the member to work uponunaltered iron carbmate and amphibole-magnetite rocks. The former went through the ordinary cycle of dhanges to ferruginous eherts and ore. The latter lost some of its siliea and amphibole but as a whole was much more resistant than the carbonate. The net result of the alteration is a soft, liyclrated ore containing much magnetite along certain bands, both containing silica as impurity and in increased amount with depth. 


\section{PHOSPHORUS IN CUYUNA ORES.}

Phosphorus has been conentrated with the iron during the secondary concerstration of the ores. It is probable, for reasons similar to those discussed on pages 192196 for the Mesabi clistriet, that phosphorus, leached from the overtying Cretacenus rocks, las been adderd to the ore durine its secontary concentration. In general there is not sufficient lime in the ore to combine with all the phosphorus as apatite, hence some phosphorus is probably combined with the hydrous aluminum and iron minerals.

\section{MINASOTA RIVER VALLEY OF SOLTHUESTERN MINNESOTA. ${ }^{a}$}

Pre-Cambrian crystalline rocks of the Mlimesota River valley of southwestern Ilinnesota appear in numerous exposures along the river, protruling from the drift, from a point southeast of New [Th to Ortonville on the northwest. The great bulk of the crystalline rocks are granites and gneisses. These appear for the most part in the river bottoms but stand also in a few isolated knobs on the ligher ground south and west of the river. There are many varieties of granites and gneisses and all gradations between them. They are taken as a whole to represent the Archean or basenent complex.

Associated with the granites and gurisses are a nuch smaller number of exposures of gabbrus and gabbro schists. These present many varieties, all of which are believed to have resulted from the alteration of two original forms and their intergradations-a hyperstheucbearing gabbro and a liyperstliene-free gabbro.

Peridotite is found in one exposure only in this valley, 3 miles southeast of Morton. The relations to the other rocks of the area could not be determined. Cutting the gneisses and gabbro schists throughout the area are numerous dilies of diabase. They vary in width from a fraction of an inch to 175 feet. Their age is probably Keweenawan.

Southeast of Redstone and near New Ulm are exposures of quartzite associated with coarse quartzite conglonerate. Near Redstone the strike of the quartzites is $\mathrm{N} .60-70^{\circ} \mathrm{W}$. and their dip raries from $5^{\circ}$ to $27^{\circ} \mathrm{N}$. In New Ulm the strike is N. $15^{\circ} \mathrm{E}$. and the dip raries from $10^{\circ}$ to $15^{\circ} \mathrm{SE}$. The quartzite is beliered to be the same as the quartzite found in a deep well at Minmeopa Falls, near Mankato, Minn., which is covered by a quartzite conglomerate of Mliddle Cambrian age. The (uartzite of Redstone and New Ulm is above the Archean granite and gneiss. It is believed to be of Huronian age, but whether upper or lower is unknown. The crystalline rocks of the Minnesota River valley are separated from the Virginia slate series of the Cuyuna and St. Louis River areas by a drift-covered area at least partly underlain by granite but partly unknown.

Overlying the crystalline rocks are Cretaceous shales and sandstones, which appear in rare exposures in the valley, and glacial drilt.

a For further detailed description see Hall, C. W., The gncisses, gabbro schists, and assoeiated rocks of southwestern Minnesota: Bull. U. S. Geol. Survey No. 157. 1899, 160 pp., with geulogic maps. 


\title{
CHAPTER X. THE PENOKEE-GOGEBIC IRON DISTRICT OF MICHIGAN AND WISCONSIN. ${ }^{\circ}$
}

\author{
LOCATION, SUCCESSION OF ROCKS, AND TOPOGRAPIIY.
}

The Penokec-Gogehic district lies south of the west half of Lake Superior, in the States of Nichigan and Wisconsin. It extends from Lake Numakagon in Wisconsin about $\mathrm{X} .30^{\circ} \mathrm{E}$. to Lake Gogebie in Michigan, a clistance of about 80 miles.

In the accompanying geologic map of the Gugelic range (Pl. XVI) the only essential change noted from carlier maps is in the vicinity of Sunday Lake, where faulting and perlaips folds have caused a marked effect in the iron-hearing formation.

The succession of formations in the district is as follows:

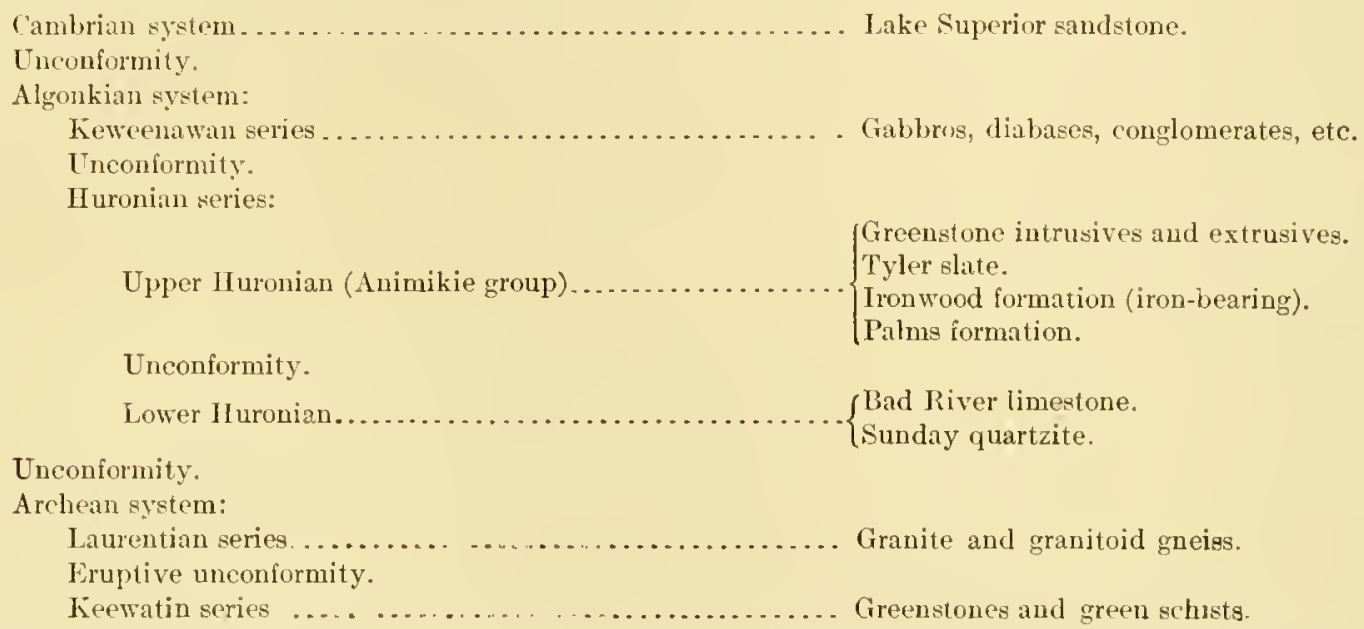

This chapter mainly deals with the Iluronian series and especially with the upper IIuronian (Animikie group). The IJuronian series for most of the district lias a breadth varying from less than half a mile to 2 or 3 miles.

The IIuronian series has a simple structure. It consists of watcr-deposited sediments, the origin of which has been for the most part letermined. The rocks liave simply been tilted to the nortl at an angle which is convenient for determination of the succession of belts. They are without folding so marked that the belts do not follow in regular order from south to north. The series is teminated on the east by the unconformably overlying horizontal Cambrian sandstone and on the west by areas in which it has been entircly swept away by erosion, the Keweenawan serics coming directly against the southern complex. It is marked off from the underlying granitic and gneissic rocks on the south and the Keweenawan series on the north by great unconformities.

The major features of the topography of the district are dependent upon the relative resistance of the formations. The strike of the harder formations largely controls the direction of the ridges. Extending along the southern border of the Inuronian rocks is a prominent ridge, the crest of which in the western and eastern parts of the district is formed by the ironbearing formation and in the central part of the district by the granitic rocks of the Archean. The Kieweenawan igneous rocks north of the Huronian mark a second clistinct ridge, the so-called Trap Range. Between these ridges, in the central two-thirds of the district, the soft Tyler

a For lurther detalled description of the geology of this distrlct see Mon. U. S. Geol. Survey, vol. 19, and references there glven.

$47517^{\circ}-$ YOL $52-11-15$ 
state constitutes level tracts and swampy areas between the more resistant rocks to the south and north.

The major lines of drainage are almost directly transverse to the ridges. All the important streans of the district rise in the basement complex, traverse the entire lIuronian series, and break through the licweenawan Trap Range to the north on their way to Lake Superior. Thus there are many notches in the cast-west ridges. The elevation of the major portion of the district is between 1,400 and 1,600 feet, but a few points reach an altitude of 1,700 or 1,800 feret.

\section{ARCIIEAN SYSTEM.}

GENERAL STATEMENT.

The Archean rocks comprise the Keewatin series (greenstones and green schists) and the Laurentian series (granites and gneisses), the latter being intrusive in the former. When the relations were first appreciated for the Gogebic district the term "Mareniscan" was applied to the greenstones and green schist series. ${ }^{a}$ At that time it was not known that the rocks named "Mareniscan" are equivalent to the licewatin series of the Lake of the Woods district. Inasmuch as the relations between the Keewatin and the Laurentian were worked out by Lawson for the two series of the Lake of the Woods before the term "Mareniscan" was proposed, Liecwatin has precedence over "Mareniscan" as a general term.

\section{KEEWATIN SERIES.}

The Keewatin rocks are found in two principal areas, one in the central and the other in the eastern part of the district. They are mainly schistose basalts, for the most part fine gramed and compact. The strikes and dips of the sehistosity vary greatly, in this respect contrasting strongly with the strikes and dips of the beds of the II uronian sediments. The chief mineral constituents of the Keewatin are quartz, a variety of feldspar, hormblende, and biotite, with chlorite, magnetite, sericite, and epidote as subordinate constituents, although locally any one of these latter minerals may be very abundant. In places the schists have a banded appearance and are true gneisses. For the most part the Keewatin schists are completely crystalline and are allied to igneous rather than sedimentary rocks. Indeed, when the Gogebic district was mapped no material was anywhere found which could be asserted to be sedimentary, although patiently searched for. Ifowever, west of Sunday Lake a biotite schist was found which was stated to present in thin section a "strong fragmental appearance." Later work has shown that south and east of this lake some of the material is banded, weathers white, and appears to be true slate. It seems clear that here there is sedimentary material, but it is difficult to draw a line between the sediments and the greenstones. It is to be noted that the area in which the sediments are found is 2 miles from the Laurentian granite.

The existence of iron formation is reported in the Keewatin area near Marenisco. This, presumably, is analogous to the iron formation belts so common in the Feewatin in other parts of the Lake Superior region. It has not heen exanined by the anthors.

\section{LAURENTIAN SERIES.}

The Laurentian granite occurs in three large areas-in the western, central, and castern parts of the district. The granites of these areas, like all the other granites of the Laturentian of the Lake Superior region, vary greatly in chemical composition, mineral content, and structure. In general, in the district under discussion the granites are of a somewhat acidic trpe. llowever, in the central area, besides the granites there are syenites ind eren gabbros, and the three rocks seem to grade into one another. Structurally the granites range from rocks which have comparatively little schistosity to those which in general are strongly gneissoid. Aside

a Bull. U. S. Geol. Survey No, si, Is:2, p. 490. 



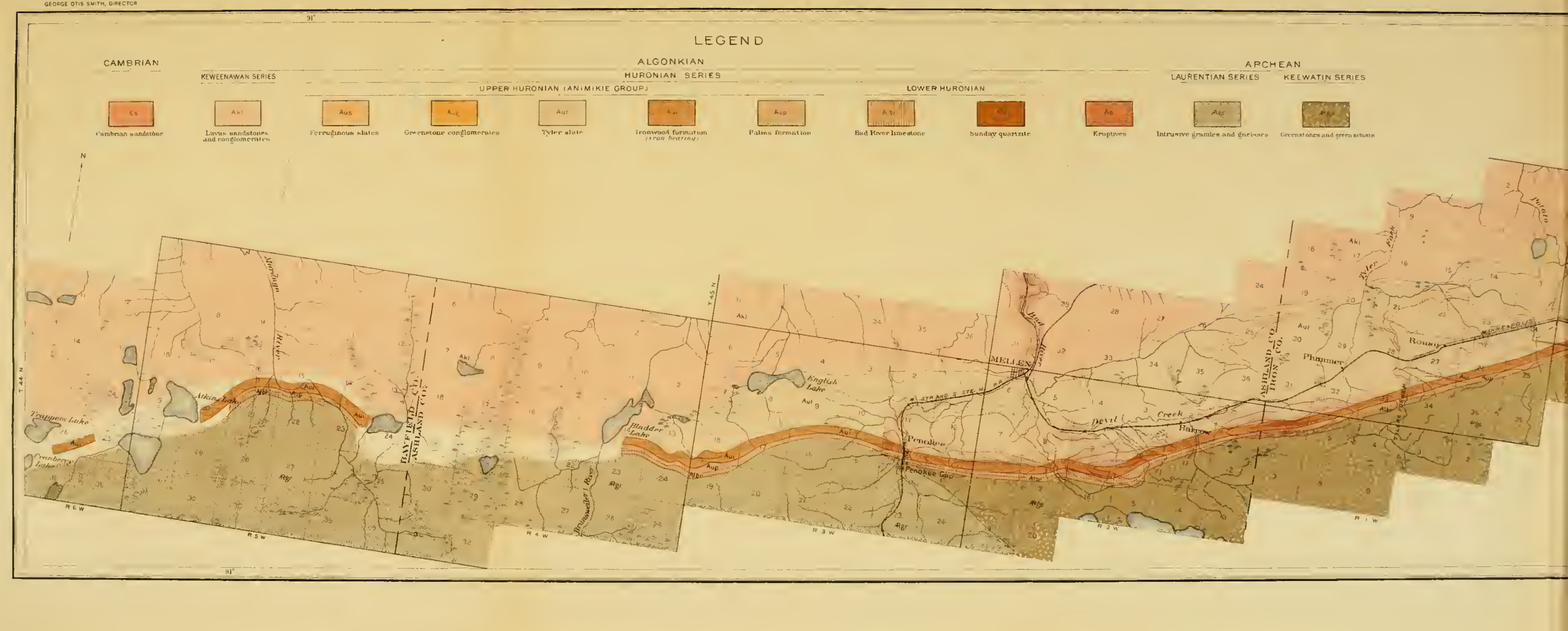




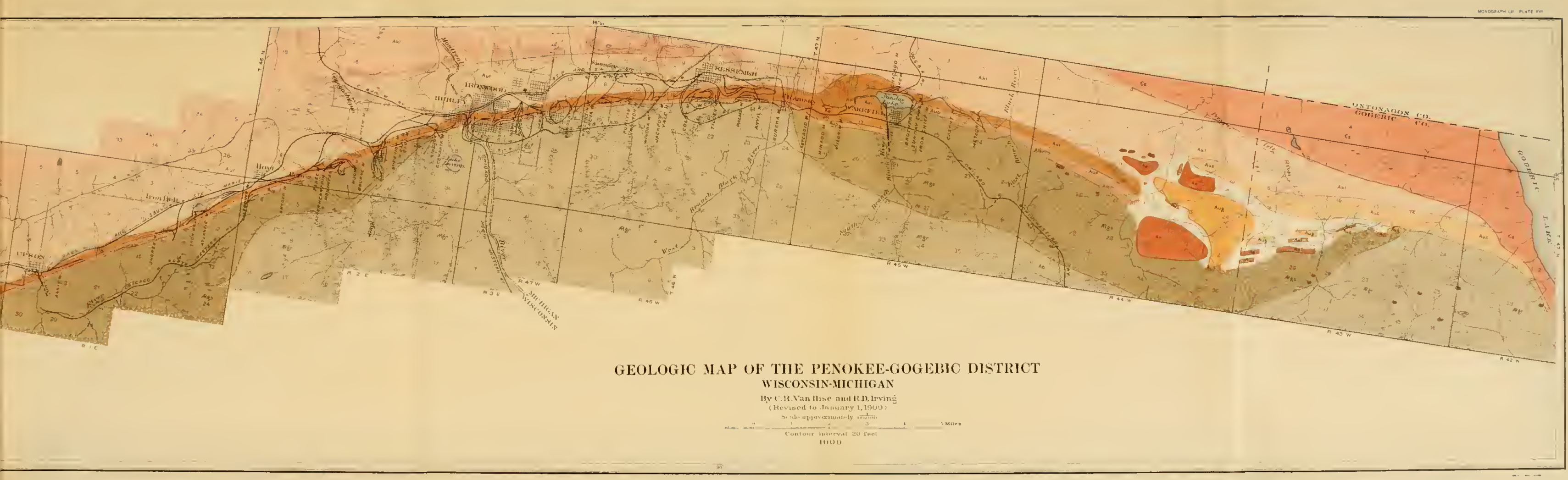



from the varions feldspars and quartz, the most abundant minerals are the micas and hoinblende. There are other subordinate minerals, of which magnetite and chlorite are important. In the dominant, more acidic phases of the rocks the alkaline feldspars, comprising orthochase, microcline, and acidic plagioclase, are invariably the chief constituents and in miny places compose as much as three-fourths of the rock. The gneissoid varieties of the Laturentian may be in part metamorphosed forms of granite. Correlative with the structiral changes are important mineralogical changes. The most interesting is that ly which the feldspars alter into biotite and quartz. There this process has gone far little or no feldspar remains, this mineral being replaced by a funcly crystalline interlocking mass of quartz and biotite. This results in a somewhat coarsely crystalline feldspathic rock (normal granite), chinging into a linely crystalline gneissoid biotite-quartz rock. It is interesting to note that identical changes of a feldspathic fragmental rock in the Tyler slate lave formed a mica schist.

\section{RELATIONS OF KEEWATIN AND LAURENTIAN SERIES.}

The fact has alrearly been mentioned that the Laurentian granites intrule the Keewatin schists. It is characteristic for the district that with approach from the Feewatin rocks to the contact of the Keewatin with the Laurentian granite the former rocks become coarser and finally grade into coarse gneisses, not very different from granitoid gneisses. In many places the granites are found to eut through the schists in dikes and stocks. Indeed, there is betwcen the two series usually a zone of considerable breadth in which the two rocks are in approximately equal proportions. In placing the boundary line between the series on the maps the plan has been to include in the Keewatin a.l those rocks the hand specimens of which do not have a strong granitic appearance. The relations between the two are plainly those which so characteristically obtain between the Laurentian and Keewatin. The former rocks are batholithic intrusions in the latter and have cut them intricately. Along the border the granites lave profoundly metamorphosed the Keewatin, producing marked exomorphic effects, so that the most altered varieties of schists approximate the character of the granite.

\section{ALGONIIAN SYSTEM.}

\section{HURONIAN SERIES.}

\section{LOWER IIURONIAN.}

The lower Huronian in the Penokee-Gogebic district is represented only by the Sunday quartzite and the Bad River limestone.

SUNDAY QUARTZITE.

Lithology and distribution.-The Sunday quartzite is so named because of its exposures east of Sunday Lake. It may prove to be the same as the Mesnard quartzite of the Marquette district, but in the absence of defimite proof that it is the same formation the new name Sunday is here introduced for it. The only known exposures of the formation are those a slrort distance east of Little Presque Isle River and those near the Newport mine. The former are rather extensive and the latter are small. Probably this quartzite is coextensive with the Bad River limestone, although it is not usually exposed. Wherever the Bad River limestone occurs there is room between it and the underlying Archean for the Sunday quartzite to be present. East of Presque Isle River the formation is mainly quartzite, with a thickness of at least 150 feet. Below the quartzite is a basal conglomerate, the fragments of which are largely lerived from the immediately underlying Keewatin sehists. This conglomerate for the most palt is but a fow inches thick, but in places it has a thickness of $10 \mathrm{feet}$. The dip of the quartzite is about $30^{\circ} \mathrm{N}$. Near the Newport mine the Sumlay quartzite is represented by a thim belt of conglonerate clinging to the face of the granite. This conglomerate contains different kinds of granite, 
porphyry, and ranous hasic rocks. From the relations of this conglomerate to the Palms formation it is believer to be the equivalent of the conglomerate east of Prosque Isle River. Relations to adjacent formations.- The relations of the Sunday quartzite to the underlying formations, and especially to the Keewat in east of J'resque Isle River, show thit there is a great unconformity between them. The actual contact between the two is beatifully exposed for some distance. The schistosity of the Keewatin abuts against the bedding of the quartzite at various angles up to perpendicular. The Keewatin had been formed, netunupliosed, and demuled bofore the deposition of the conglomerate. The Sunday quartzite grades upward into the Bad liver limestone.

\section{BAD RIVER LIMESTONE.}

Distribution.-The Bat River limestone is so named beeause of its occurrence at Bad River in the Penokee Gap section. The formation is present at several localities in the western part of the district, at one place in the central part, and in one area in the eastern part. The eastern area shows the most extensive exposures of the district, the formation here being continuous for several miles. Wherever the formation is found it strikes approximately parallel to the formations of the upper Ifuronian, and the dip is always to the north, being as high as $70^{\circ}$ or $50^{\circ}$ in the western part of the district and as low as $30^{\circ}$ in the eastem part.

Lithology.- The formation is ealled a limestone because that is the predominant rock. The limestone is heavily magnesian and in places approaches a dolomite. It commonly benrs silieates, of which tremolite is the most abundant, but chlorite and sericite are not uncommon. The rock is very siliceous. The coarsest varieties of the silica are quartz, but chert is more common. In many places the silica is elosely intermingled with the dolomite. In other places it occurs in bands rarying from a fraction of an inch to a much greater wilth, and im one place a band of siliceous material 45 or 50 feet wide was observed. Thus the ehert and limest one are intermingled and interstratified. The cherty limestone is a water-deposited sediment. Whether the original carbonate was of chemical or organic origin we have no definite evidence, but there is no more reason to suppose that life was not concerned in the deposition of this cherty limestone than of those of later age.

Metanorphism.- The Bad River limestone has been much metamorphosed since its deposition. During its metamorphism the silica recrystallized. It was concentrated into bands. It was rearranged into veinlike forms. During these changes a part of the silica may hare been introduced from an extraneous source or at least from parts of the formation now removed by crosion. The abundant tremolite is evidence that the metamorphism took place under deepseated conditions when the siliea united with the calcium and magnesium to form silicates, the carbon dioxide being released at the same time. This is an anamorphic change which took place with decrease of rolume.

Relations to adjacent formations. - The relations of the Bad River limestone to the Sunday quartzite have already been considered. It is probable that everywhere it grades down into this formation, but whether it does so or not the distribution of the limestone at various places along the southern border of the Huronian, with a strike parallel to the upper Huronian, thus contrasting strongly with the varying strikes and dips of the green schist and gneisses, leares no doubt that between the Arehean and the Bad River limestone there is a great unconformity. Indeed, as chemical sedimentation at several points for a distance of 60 or 70 miles followed so promptly after the burial of the southern complex below the sen, it appenrs probable that when the linestone was laid down the Arehean was reduced to an approxinate plane. The lack of continuity of the limestone formation is due to the erosion which took place after its deposition before the lowest member of the upper Huronian was laid down. Evidenees of this erosion are given under the description of the relations of the Palms formation to aljacent formations. If formations later than the Bad River limestone belonging to the lower Huronian were deposited, they were removed by erosion before the deposition of the upper Ifuronian, as was the larger part of the Bad River limestone itself. The limestone above the quartzite in the western area has a thickness of at least 200 feet, and to the west the thickness is not less than 300 feet. 
UPPER IIURONIAN (ANIMKIE GROUP).

GENERAL STATEMENT.

The upper IUronian comprises the Palms, Ironwood, and Tyler formations. These formations extend continuously from Presque Isle kiver, east of Sunchy laake, several miles west of Bad River. They constitute a northward-dipping monocline. This monocline las various minor plications which give local variations to the strikes and dips, but they are neither abrupt nor large, the extreme variations in strike usually being between $\mathrm{N}$. $60^{\circ} \mathrm{W}$. and $\mathrm{N}$. $60^{\circ} \mathrm{E}$. At various places there are cross faults, the most notable of which are those at Penokee Gap, with a throw of at least 900 feet, at Potato River, with a throw of 280 feet, and west of Sunday Lake. Detailcd studies of the iron-bearing formation, made in comnection with the exploitation of the iron ore, show the presence of very numerous small transverse faults as well as numerous longitudinal faults, with hades parallel to the bedding, or nearly so. The latter were detected by the displaced dikes. Part of the faulting was prior to Keweenawan extrusions because it does not displace the Keweenawan. A notable instance of this appears in the great transverse fault just west of Sunday Lake. Other faults are clearly post-Keweenawan, for they affect both Huronian and Keweenawan beds.

\section{PALMS FORMATION.}

Distribution.--The Palms formation is given this name becanse it occurs in typical development south of the Palns mine. It comprises the lowest of the upper Huronian rocks of the Penokee-Gogebic district.

It constitutes a well-marked zone traceable through its entire extent, except in the voleanic area at the east end. It strikes on the average about $\mathrm{N} .70^{\circ} \mathrm{E}$. Its dip is everywhere north, varying from about $40^{\circ}$ to $75^{\circ}$, the usual dips being between $55^{\circ}$ and $65^{\circ}$. For the larger portion of the district the formation is 400 to 500 feet thick, but east of Sunday Lake it is thicker, the maximum being 800 feet.

Lithology.-The Palms formation consists of three members, of which the lowest is a thin layer of conglomerate, the central and dominant mass of the formation is a clayey slate, and the uppermost is a quartzite. The conglomerate is generally less than 10 feet thick and in many places is not more than 1 to 3 feet. The quartzite layer at the top is about 50 feet thick. The conglomerate raries with the character of the rock with which the Palms formation is in contact. Where it is next to the Bad River limestone, as would be expected, there are in it very abundant fragments of ehert and limestone, but with these are also granite, gneiss, and schist from the Archean. Where the contacts are with the Keewatin, as at Potato River and the west branch of Montreal River, the dominant fragments of the conglomerate are derived from the schist. Where the formation is in contact with the granite, as in the central part of the area, the dominant fragments are from this formation, but in places--as, for instance, south of the Palms mine-with these fragments there are also pebbles of jasper, chert, and quartz.

The central part of the formation is a pelite. It has many facies, varying from finegrained clayey slates through novaculites to graywackes. For the most part the alterations through which the pelite laas gone are mainly metasomatic ones, such as quartz enlargement and the alteration of the feldspar to other minerals, especially biotite, chlorite, and quartz. In the western part of the district the feldspathic alteration and recrystallization are sufficiently important so that in places the rocks have become chloritic and biotitic slates. This greater metamorphism is doubtless connected with the intrusions so characteristic of this part of the district. For the most part there seems to be lithologic correspondence of the main mass of the slate with the immediately underlying Archean rocks, the slate being substantially the same whether north of the Keewatin schists or north of the Laurentian granite.

The upper part of the formation is a psammite which has been indurated by the process of cementation to a clean, typical, vitreous quartzite. As this quartzite approaches the overlying iron-bearing formation it becomes stained with oxide of iron and at the contact it is commonly of a deep brownisli-red color. 
Rrlations to adjucent formations.-In giving the relations of the Palms to the inferior formations it is necessary to consider separately its relations with the Bad River limestone of the lower Huronian and with the Ardiean.

The fact that where the belt of conglomerate at the base of the Palms formation lies above the Bad River linestone it bears much detritus from that linestone shows that the limestone after deposition became indurated and was eroded before P'alms time. In general, the strikes and the dips of the two formations are approximately parallel, as are those of rorrelated formations in the Menominee district, but it is plain that the erosion was sufficient to remove the major portion of the Bad River limestone and also any later formations that may have been tleposited in the lower Huronian. The lack of marked discordance in the bedling of the Bad River limestone and the Palms formation is no evidence that the time gap between the two was not long enough to have produced a pronounced discordance elsewhere, for the Penokee district at this time may have been listant from areas of inportant folling and thrusting which elsewhere may have occurred.

Between the Pams formation and the Archean there is a great unconformity. The proofs of this unconformity may be summarized as follows: First, the Palms formation and the other sedimentary formations of the upper Huronian strike with considerable uniformity across the country, being here in contact with one variety of the Arehean, there with another, everywhere keeping their course, nowhere being penetrated or interfered with l,y any of the Keewatin or Laurentian rocks, whether schists, gneisses, or granites. Second, the Archean rocks are cither massive ones which are presumably igneous or sehists and gneisses in which the extreme of foliation and crystalline character is found, whereas the overlying upper IIuronian rocks are plainly water-deposited sediments. Third, in a dozen places or more above the Archean are basal conglomerntes or recomposed rocks which show the unconformable contacts. The detritus in each place is dominantly the same in character as the rock on which it rests. Where the inferior rock is granite it must be inferred that deep erosion must have cxposed it at the surface prior to the deposition of the conglomerate. Where the basement rocks are fieewatin green schists their foliation had been developel and has been truncated before Palms time. This is well illustrated at Potato River, where the conglomerate contains large; flat fragments of green schists which have their sehistosity lying parallel to the bedding of the Palms, which is at right angles to the schistosity of the Keewatin below. Fourth, the horizons of the upper Huronian with which the Archean is in contact are within a zone not more than 300 or 400 leet thick at most. This is the elearest sort of evidence that the underlying rocks were reduced to a peneplain before the beginning of the deposition of the Palms formation. From the foregoing fact it is clear that the break between the Palms formation and the Archean is profound. It included the time represented by the unconformity between the lower Huronian and the Archean, the time required for the deposition of the lower Huronian, and the time between the lower Jhuronian and the Palms formation.

\section{IRONWOOD FORMATION.}

Distribution.-The Ironwood formation was given this name from the fact that near the town of Ironwood it is well developed, and in this vicinity occur the more important mines. The formation is coextensive in its distribution with the underlying Palms formation. Its strike and dip are conformable with those of the Palms. 'The belt lor the greater part of the district has a breadth of 800 to 1,000 feet. West of Sundar Lake the surface wilth of the formation is greater ${ }^{a}$ and north and east of Sunday Lake the belt is narrower. Faults cross and follow the beds. These affect the distribution of the ores and the iron-bearing formation, as teseribed on page 237. The average thickness of the formation is about 550 feet. In the extreme eastern part of the listrict, where volcanic action prevailed through much or all of upper Inronian time, the Ironwood formation is broken into thin and impure belts. West of Sundery lake it is divided into two or more belts by interealated quartzite and quartz slate bels. In other parts of the distriet, notably near Upson, the formation is diviled by slate layers. In the main, in the western part of the district, except for the gaps where the stroms 
break through it, the Ironwood formation is a continuous ridge, and it was this range which first attracted the attention of explorers at Penokee Gap and vicinity. In the central part of the district the formation is softer and the prominent features are made by the Archean rocks to the south. Still larther east, beyond Sunday Lake, tho Ironwood formation again constitutes prominent bluffs.

Lithology.-The Ironwood is the iron-bearing formation of the district. In the memoir on the Penokee iron-bearing series (MIonograph XIX) it was simply ralled the iron-bearing formation, withont a geographic name. The greater portion of the formation contains more than 25 per cent metallic iron and there are considerable thicknesses in which the amount of iron averages 37 per cent. (See p. 23S.) 'The ore bodies contain a higher percentage of ironl.

The Ironwood formation consists of four main varieties of rock-(1) slaty and commonly cherty iron earbonate and ferrodolomite, (2) ferruginous slates and ferruginous cherts, (3) actinolitic and magnetitic slates, and (4) black slates.

The iron-bearing carbonates are usually found only near the upper part of the formation, where they have been protected by the Tyler slate. The ferruginous slates and ferruginous chorts are characteristic of the central iron-producing part ol the listrict, and the actinolitic and magnetitic shates are characteristic of the western and eastern parts of the district. The latter also form a belt 20 to 300 feet wide bordering the Kieweenawan rocks on the north. In the intermediate areas there are of conrse gradations between the ferruginous slates and ferruginous cherts and the actinohtic and magnetitic slates, as there are also gradations between tho cherty iron carlonates and the feruginous slates and forruginous cherts. Black slates form thin interalated layers in the iron-bearing formation. Quartzite is also found in layers up to 100 feet thick well up from the base of the formation near Sunday lake.

The slaty and cherty iron-bearing carbonates are composed largely of iron carbonate and chert, but with these materials are various amounts of calcium carbonate and magnesium carbonate. Recent reexamination has shown that in these rocks there are also subordinate amounts of greenalite. With these important constituents are other minor constituents, largely secondary, such as limonite, magnetite, carbonaceous and graphitic matter, iron pyrites, and rarely fragmental quartz. The carbonate is both fine and coarse grained and both original and secondary. Coarse-grained recrystallized carbonate is especially abundant near the contact of the Keweenawan in the Sunday Lake area.

The cherty iron-bearing carbonate was the original rock of the iron formation. The origin of this class of rock is fully discussed in another place (pp). 499 et seq.) and therefore the subject will not be considered here. From it the ferruginous cherts and actinolitic cherts have been produced. The actinolitic and magnetitic cherts were formed under deep-seated conditions largely through the influence of the Kewennawan intrusive rocks, and especially of the great western laccolith. These changes are anamorphic ones, which mainly took place in Kieweenawan time. The ferruginous slates and ferruginous cherts formed from the cherty iron carbonates by katanorphic changes largely in the belt of weathering and also in part in the belt of cementation. These changes were mainly post-Keweenawan, after erosion brought the iron-bearing formation to the surface, and they have continued to the present day. Previously formed actinolitic and magnetitic rocks were in a much more refractory condition than the unaltered cherty iron carbonates and have been little allected by the alterations of the zone of katamolphism.

The ferruginous slates and ferruginous cherts have silica as their predominant const it uent in various forms of crystallization, from amorphous through partly crystalline and chalcedonic material to finely crystalline quartz. With the silica are the various oxides of iron. Hematite and brown lyydrated hematite are especially prevalent. Limonite is common and some magnetite occurs. Where the hematite is in large quantity, to the exclusion of the lyydrous oxides, the rocks are genuine jaspers; but this variety is rather unusual in the district. The rocks vary in their stratification from the regular lamination of a slate to irregularity. In many places the laminæ have the appearance of having been disrupted and recemented. 
The actinolitic, grüneritic, and magnetitic cherts and slates, like the rocks of the second variety, have ruartz as their dominant constituent. This quartz is errstalline throughout and clearly nomclastic. The actinolite varies in amount from a rery little to a constituent of great prominenee. The iron oxides are mainly in the form of hematite and magnetio.

The black slates are earbonaceous fragmental slates in layers in the iron-l,earing formation. These exceptionally form the foot wall of the ore deposits. (See p. 242.)

Relations to adjacent formations.--The Ironwool formation rests conformably upon the Palms formation. The change from the clastic quartzite to the nonclastic iron-bearing formation is astonishingly abrupt. Generally it can not be said that there is any evillence of the transition between them. Loeally a thin conglomerate marks the contact. For some reason the clastic deposits of the quartzite censed and the nonelastic deposits of the Ironwood formation began. Above, the Ironwood formation passes gradually into the Tyler slate.

TYLER SLATE.

Distribution.-The Tyler slate was given its name from the typical occurrence of the formation along Tylers Fork. It extends from a point about 6 miles west of Bad River nearly to Sunday Lake-that is, it is confined to the central two-thirds of the district. In brealth the formation varies up to $2 \frac{1}{2}$ miles at Tylers Fork. The strike of the formation is parallel to that of the iron-bearing formation below. Its dip is also similar to that of the iron formation. At this willer part its dip is from $70^{\circ}$ to $75^{\circ}$. It apparently follows, therefore, that for the central part of the district-that is, from Bad River to Hontreal Rirer-this formation lrus a thickness ranging from 7,000 to 11,000 feet. It is plainly the great formation of the district. It is probable that minor plieations partly explain this apparent thickness.

Litholog!.- - Study of the formation as a whole shows that it is dominantly a pelite but locally it is a psammite, including both arkoses and feldspathic sandstones. There is a general connection between the character of the rocks to the south and those of the slate belt arljacent. The greater part of the belt has received its material in part from the granitie and in part from the sehistose areas; the part of the belt west of Penokee Gap has received nearly all its material from the syenitic granite to the south and west. The different varieties of rocks of the Tyler slate may be grouped under three heads-(1) mica schists and mica slates; (2) graywackes and graywacke slates; (3) clay slates or phyllites. Each of these main types has the various phases shown by the following tabulation:

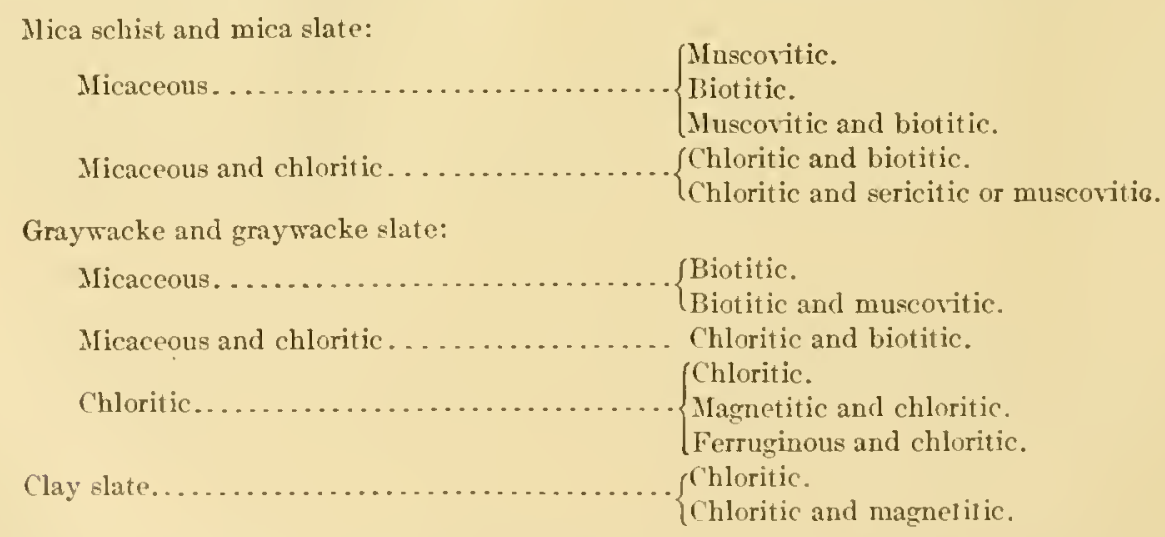

It is not necessary to deseribe in detail the diflerent rarieties of these rocks, except as to their alterations.

Metamorptism.-In the monograph on the Penoker iron-bearing series the alterations of this slate are discussed. ${ }^{a}$ It is there shown that each of the rarieties of rocks mentioned above has developed from pelites and psammites almost wholly by metasomatic changes within the formation itsclf, without the addition or subtraction of material from an cxtraneous source. 
In general, the eastern part of the formaion is less altered than the western part. Here the prevailing rocks are clay slates, graywackes, and graywarke slates. From the central to the western part of the listrict the rocks become more crystalline, and at the extreme west end, especially west of Penokce Gap, only mica slates and mica schists are found. Where the rocks are much metamorphosed cordierite is sparingly developed.

The parts of the Tyler slate which contain large fragmental particles of quartz are those in which the clastic character is easiest to recognize, for the grains of quartz everywhere remain in their entirety. It may be and indeed it is usually true that they have undergone a second growth and have thus become angular; but generally the original cores are easily discovered. In the nearly pure feldspar sediments, on the other hand, where the foldspar has changed to other minerals, it is more difficult and in specimens of the most erystalline mica schist impossible to make out the original fragmental character of the rock.

On the whole, the major modifications of the formation are those of the zone of anamorphism rather than the zone of katamorphism. This is what would naturally be expected, for at the time these alterations took place the rocks were buried to an unknown depth below the overlying Keweenawan rocks.

As the processes by which a clastic roek alters into a fine-grained erystalline mica schist were first described in detail with regard to the Penokec-Gogebic district, ${ }^{a}$ the principles involved in the development of this particular rock will be summarized here. As already indicated, the seliments from which the mica schists were derived were very feldspathic. Without going into details, the process which has resulted in the development of mica sehists has been the alteration of the feldspar into mica, both muscovite and biotite, with the simultaneous separation of quartz. For the cluange into muscovite the feldspar itself contains all the necessary constituents. For the change into liotite a certain amount of iron and magnesium are necessary. For the iron it is not so diflicult to account, as the sediments are ferruginous. In some places also the sediments contain more or less carbonate, and doubtless from this source has been derived at least a part of the necessary magnesium. At the time of the recrystallization the newly forming mica flakes developed with a parallel arrangement. At the same time the quartz recrystallized. The total result was to produce from a somewhat coarsely crystalline arkose a fincly laminated miea slate or mica schist.

The Penokec-Gogebic district is an exceptionally good one in which to work out the changes from the little-altered pelite to a mica schist, because of the very grachal change in the amount of alteration in passing from the central to the western part of the district.

At the time the Penokee-Gogebic monograph was written no reason was assigned for the crystalline character of the rocks at the west end of the district. Later studies on metamorphism have led us to connect this alteration with the great laccolith of the Keweenawan gabbro, which, in the western part of the district, occurs in contact with and cutting the Huronian rocks. The intrusion of this rock essentially parallel to the bedding would result in great pressure, as well as in raising the tempcrature, and it was under these conditions that the recrystallization took place. The absence of similar alterations in the central and eastern parts of the district is explained by the fact that there immediately overlying the slate are the surface Kewcenawan lavas, which are locally interstratified with sandstones. It is plain that the altcrations of the pelites to mica slates and mica schists took place in Keweenawan time.

Relations to adjacent formations.-The Tyler slate rests conformably on the iron-bearing Ironwood formation. It is overlain unconformably by the rocks of the Keweenawan series.

UPPER HURONIAN (ANIMIEIE GROUP) OF THE EASTERN AREA.

In the eastern part of the district-that is, from about 6 miles east of Sunday Lake to Gogebic Lake-the upper Huronian rocks have an exceptional character. In the larger part of the district the conditions were those of quiet sedimentation, but in this eastern area

a Van Hise, C. R, Upon the origin of the mica schists and black mica slates of the Penokee-Gogebie iron-bearing series: An. Jour. Sci., 3d ser., vol. 31, 1556, pp. 453-459. 
throughout the greater part of the upper II uronian there was continueus roleanie action. In consecquence the rocks are lava flows, voleanic: tulls, conglomorates, agrglomerates, and slates, with all sorts of erralations, just such as one would expect if a voleano arose in a sea and volcanic action continued for a great period. Naturally in this area it is not possible to map) any continuous sedinentary belts. The dominant rocks are greenstone conglomerates and lavas and massive eruptives. The uppermost formation for the extreme eastern part of the area is a ferruginoms slate. This ferruginous slate, though dominantly clastic, contains narrow bands of nonclastie sediments, such as chert, cherty ferrodolomite, ferrodolonitic chert. It is believed that the ferruginous slate is probably at the same horizons as the Ironwoorl formation to the west and that its dominant fragmental character is due to the presence in this area of one or more voleanic mountains which rose above the water and upon which the waves were at work after the close of the period of active volcanic outbreaks.

\section{KEWEENAWAN SERIES.}

\section{GENERAL DESCLIPTION.}

Rocks of the Keweenawan series lie north of and are coextensive with the upper Ifuronian rocks; indeed, to the west they extend far beyond the westernmost known outcrop of the Huronian. It is not the purpose here to deseribe this series more than is sufficient to show its relations to the Iuronian. It has already been indicated that for most of the district the appearance of the Keweenawan is marked by a distinet range known as the Trap Range. For the eastem part the Keweenawan rocks first encountered in traveling north are ordinary basie, amygdaloidal lava flows characteristic of that series. One bed follows upon another and it is easy to aseert ain their strike and dip. These bedded lava flows may be very conveniently seen arljacent to Sunday Lake. Their strike and dip are easily determinable as almost exactly parallel to the beds of the underlying Huronian.

In the central part of the listrict the Keweenawan rocks immediately abore the Tyler slate are sandstone's and ennglomerates. These are seen in Michigan north of Bessemer and in Wisconsin a few miles west of the State boundary. Above the sedimentary beds of the lower Keweenawan follow lavas similar to those which occur farther cast.

In the western part of the district the sediments and bedded lavas of the Kieweenawan are replaced by the great plutonic basal gabbro laccolith of Wisconsin, analogous to the laccolith of the north shore of Lake Superior.

\section{REI ATJONS TO ADJACENT SERIES.}

The Keweenawan series reposes upon the upper II uronian (Animikie group) unconformably. As the two series are nearly conformable in strike and dip, this fact was only slowly appreciateil. The proof of the unconformity rests entirely upon lroad field relations. In the central part of the district the Keweenawan is upon a great slate formation (the Tyler slate) which has a maximum thickness of at least sereral thousand feet. At the east and west ends of the district the Keweenawan cuts diagonally across these slates and comes into contact with the ironbearing Ironwood formation. In the west enel of the district this relation might be supposed to be explained by the intrusion of the Keweenawan laceolith, but this can not apply to the castern part of the district, for there the lower beds of the Keweenawan are the surface lara Hows. The time gap betwern the IIuronian series and the Kieweenawau series must have been sufficient for a widespreat orographic morement and decp denudation.

As the Keweenawan series is larely composed of igneous rocks and rests upon the liuronian series, naturally the latter has beren extensively intruded ly the former. The intrusires in the Iluronian series, so fur as known, are manly dolerites. Consilderable masses of them in the eastern and western cnds of the (listrict appear to follow roughly parallel to the range and 
seem to be intrulerl sheets or laceoliths. Some of them may be surface flows contemporaneous in origin with adjacent Ifuronian serliments. In adelition to these interealated masses, numerous dikes cut the IIuronian formations. These dikes are found in all formations, but they have an especial significance and importance in connection with the iron ore. (See pp. 235-23s.) In that part of the distriet which has been the seat of mining operations a large number of these dikes cut the containing formations perpendicularly to the bedding. That these dolerite dikes are the avenues through which have passed from deep within the earth the vast amount of material which formed the overlying basic volcanic flows of the Keweenawan series of the Trap Range to the north can hardly be doubted, for in chemieal composition the lavas of this range are practically identical with the dikes. (See pp. 404-405.) In general, the dolerite dikes are very fresh, except in the lower parts of the Ironwood formation, where they have been subject for a long time to the action of pereolating waters. Analyses of the latter rocks show that they have undergone extensive changes, which have been referred to in connection with the origin of the iron ores.

By far the greatest of the intrusive masses is the great gabloro laccolith at the west of Bad River. This was at first supposed to be a great basal flow, lut all their later studies learl the writers to believe that it is a plutonic intrusive introduced comparatively late in Keweenawan time, the major dimensions of the intrusion being nearly parallel to the beds of the Ituronian and the lava flows of the lieweenawan, which were separated by the inwelling mass of gabbro.

\section{CAMBRIAN SANDSTONE.}

The Cambrian sandstone is found only in the northeastern part of the district, near Gogebie Lake. It is there foum! as a flat-lying reddish sandstone, known as the Lake Superior sandstone. It rests in horizontal position against the Keweenawan, the IIuronian, and the basement complex. In one place a basal conglomerate bears detritus from all the lower formations. It is plain that during and after Keweenawan time the IJuronian and Kerrenawan series were turned up steeply. Lofty ranges, which must have been formed then, were removed by denudation, and the Cambrian sandstone was deposited. Therefore a great uneonformity separates the Cambrian sandstone and all the earlier series.

\section{THE IRON ORES OF TIIE PENOKEE-GOGEBIC DISTRICT.}

By the authors and W. J. MEAD.

\section{DISTRIBUTION, STRUCTURE, AND RELATIONS.}

The iron-ore deposits occupy part of the district, extending from a point about 2 miles east of Sunday Lake in Michigan to within 4 miles of Potato River in Wisconsin, a distance of about 26 miles. Ore has recently been developed in sections 15 and 21 , T. 47 N., R. $43 \mathrm{~W}$., near Gogebic Lake, far to the east of the previously known deposits.

The iron-ore deposits constitute about 1 per cent of the area of the iron formation. This pereentage is less than that in the Mesabi, which is 8 per cent. Ilowever, the vertical dimensions are much greater than in the Mesabi district. Ores have already been found to extend to a depth of 2,500 feet, one of the largest ore bodies in the district now being known at that depth.

In both the east and west ends of the Gogebic district the character of the formation has been influenced by intrusives, with the result that the iron oxicles are largely magnetite disseminated through the formation and not concentrated to a commercial extent.

The ore deposits come to the surface most largely along the north-middle slopes, locally on the lower slopes, of the topographic feature known as the Gogebic Range.

In the Gogebic district the iron-bearing Ironwood formation dips with the other formations of the upper Huronian toward the north at angles averaging about $65^{\circ}$. The underlying rock is the quartzite, at the top of the Palms formation, and it thus forms the foot wall of the iron-bearing formation; the overlying formation is the Tyler slate. Slate and quartzite 
also form interbedded layers in the iron-hearing formation. Numerous greenstone dikes oi Feweenawn age cut the entire series in such a manner that the intersection of the dikes with the bedding usually pitches to the east. The intersections of the dikes with inpervious lavers, principally quartzite of the foot wall, but also slate layers within the iron-bearing formation, constitute eastwarl-pitching troughs at angles from $15^{\circ}$ to $30^{\circ}$, in which most of the deposits are found (fig. 2s).

Westward-pitching dikes intersecting with eastward-pitching dikes or continuous with them, and both intersecting foot-wall quartzite, form canoe-shaped basins for the ore, as illustrated by the Aurora, Palist, and Newport deposits. East of the Bessemer the main dike in the

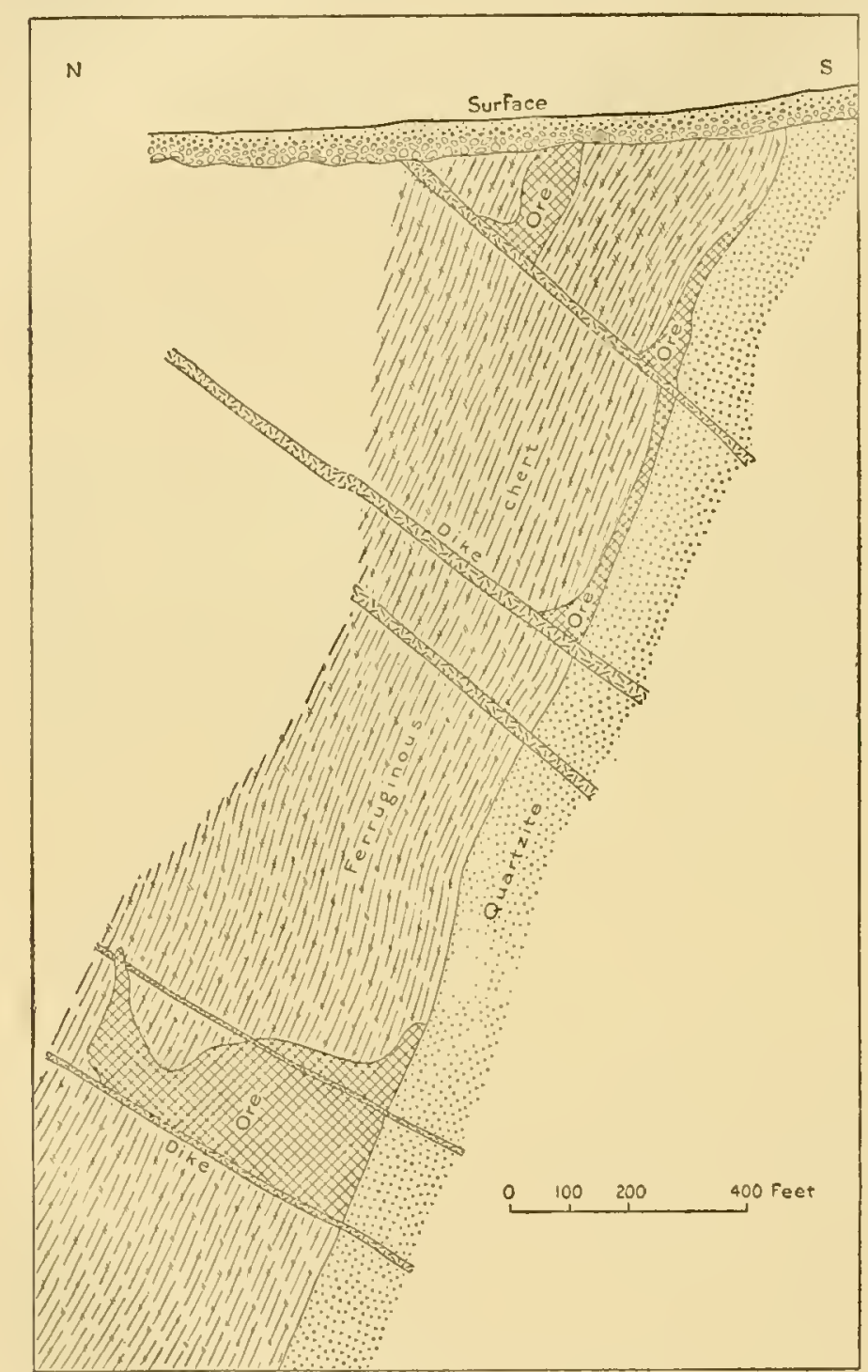

Figure. 28.-Cross section showing the occurrence of ore In pitching troughs formed by dikes and quartzite loot wall, In the Gogeble district. Made up from mine plats and slightly generalized.
Tilden mine laas an eastward pitch and the main dike in the Palms mine has a west ward pitch.

On the south the loot wall of the ore is therefore generully quartzite, locally slate, and on the nortli the ore rests against greenstone dikes. Slate foot walls are seen at the Iron Belt, Mikado, Brotherton, and Sunday Lake mines, from 250 to 2,000 feet north of the quartzite foot wall.

The ore deposits are generally sharply defined along the foot walls and the dike rocks, but in many places vary upward by imperceptible stages into the ferruginous cherts of the iron-bearing Ironwood formation. Where there are a number of parallel dikes, one below the other, there may be several ore bodies one below another-as, for instance, at the Ashland and Norrie mines. (See fig. 29, $a$ and $b$.) After many years of mining on upper likes in the Newport mine one of the largest deposits of the district has been found on a lower dike. The main Norrie dike is over 30 feet thick. The main Aurora-Pabst-Newport dike is from 20 to 25 feet thick. The main Colly dike is over 90 feet thick. Where a st rong dike breaks in to many st ringers at a depth, as in the Colby mine, the ore body is also likely to be broken up and beeome small and perhaps worthless. The clike rocksare altered to soapst one or paint rock alongr their contacts with the ore by the leaching of the bases.

An ore deposit is likely to have its maximum depth in the apex of a trough, and from this apex a belt of ore may extend to the north along the dike and to the south along the foot wall. In many instances the ore bodies follow the foot walls almost exclusively, as at the Norrie mine. (See fig. 29, $c$.) Usually where the deposits follow both the quartzite and dikes the former is larger and more continuous than the latter. Where an ore deposit follows both it may divide before reacling the surface into two parts separated by rock, ealled the south and 
north veins of the mines, but where such deposits are traced below the surface they unite into a single body. The ore grades above or laterally into the ferruginous chert or forruginous slate.

The conspicuous association of the ores with pitching troughs formed by the interscetion of dikes and foot-wall quartzite for a considerable time obscured the importance of fracturing in localizing the ore deposits. From evidence now available it scems likely that this factor also is of great consequence. An exannination of mine sections taken almost at random in the district shows ore cutting through the ferruginous cherts and dikes in a most irregular way and quite independent of the pitching troughs. Much of it may be directly connected with brecciation, fissuring, or faulting to be seen in the ore and adjacent rocks. It is altogether likely that more fractures exist than are known, because the concentration of the ores is of a nature to obscure evidences of them. Therc are fault planes both parallel with and intersecting the bedding. The displacements have both horizontal and rertical components. The faults intersecting the bedding were furst recog.. nized because of the ease of detecting the displacements in the bedding. Those parallel to the bedding were for a long time not observed, and probably there are still many to be detected because of the difliculty of distinguisling the evidence. They may be determined only from the displacements of the dikes, and as the dikes are numerous and of varying thickness a considerable amount of ground must be opened up before the va-

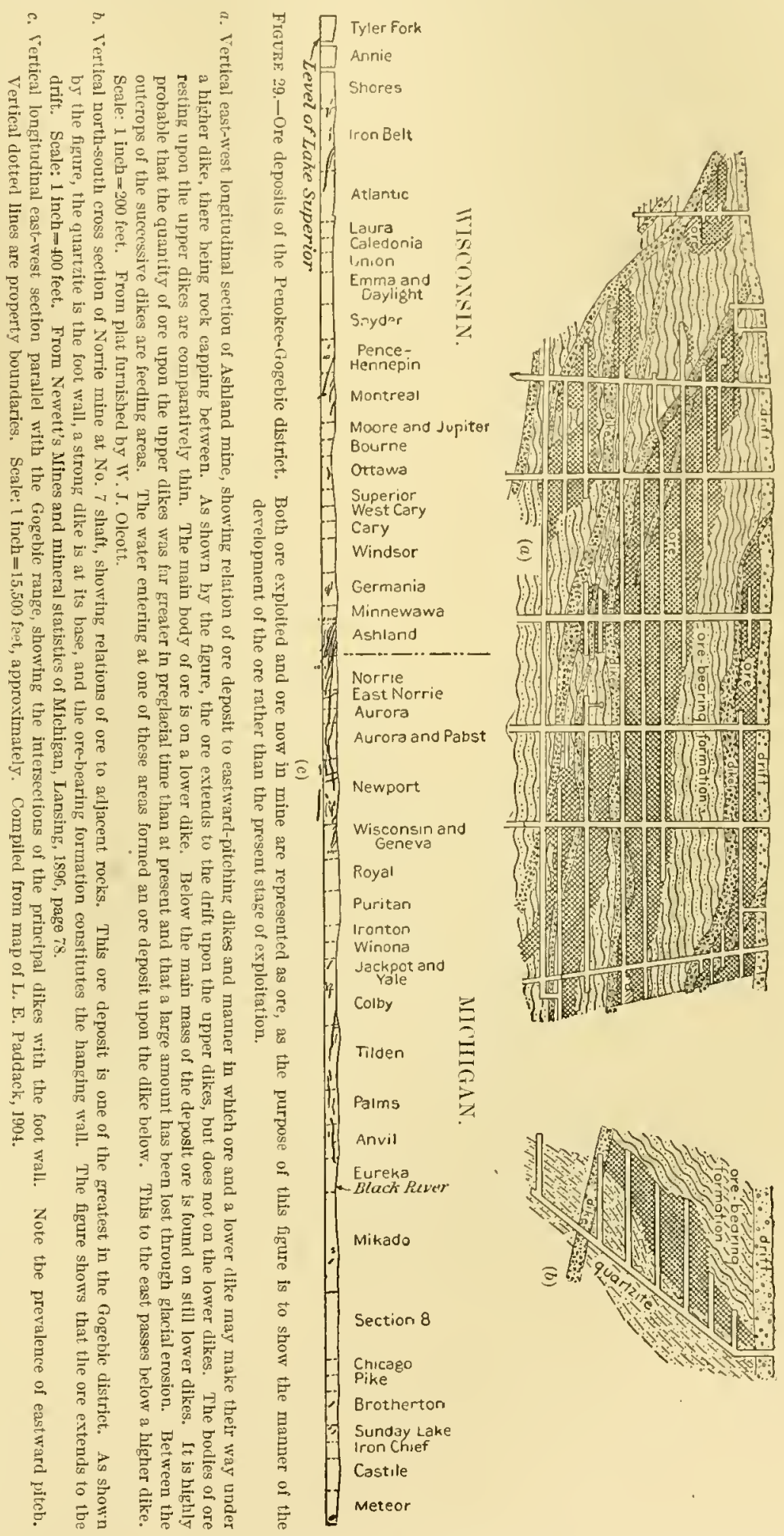
rious fractured dikes may be conelated. The ore in many places lies between the displaced edges of the dike. At the Pabst mine the ore follows down over the broken and displaced ends of the faulted dike toward another dike below, where it again develops into a large body. 
Another important faretor governing the location of the ore deposits has only recently been charly recognized. Certain of the iron formation hyers were originally riedrec in iron than others, and the ores show a distinet temdency to follow these rich original beds. In some d prosits, like those of the Mikado, Brotherton, and Sunday Lake mines, this serens to be a controlling factor, though the ores of the Brotherton and Sunday Lake mines and less certainly of the Mikado min have suffered nore or less secondary concentration along intersections of dike and foot wall and along fissures.

\section{CIIMICAL COMPOSITION OF THE FERRUGINOUS CHERTS AND ORES.}

The following analyses represent two complete sections through the iron-bearing formation. In the Norrie mine a crossent, extending from foot-wall quartzite to the langing-wall slate, entirely in ferruginous chert, was simpled in five sanples, cach simple representing approximately 120 feet of erosseut. In the Athutic mine a crosscut in ferruginous aldert extending for several hundred feet across the formation was sampled. Anaylses are by Lerch Brothers, IIil)l,ing, Minn.

Partial analysis of ferruginous chert, Gogebic range.

[Samples dricd at $212^{\circ} \mathbf{F}$.]

\begin{tabular}{|c|c|c|c|c|c|}
\hline & Fe. & $\mathrm{SiO}_{2}$ & $I^{\prime}$. & $\mathrm{Al}_{2} \mathrm{O}_{3}$ & $\begin{array}{l}\text { Volatile } \\
\text { matter. }\end{array}$ \\
\hline $\begin{array}{l}\text { Norrie mine No. } 1 . \\
\text { Norrie mine No. } \\
\text { Norrie mine No. } \\
\text { Norrie mine No. } \\
\text { Norrie mine No. } 5 \\
\text { Atlantic mine..... }\end{array}$ & $\begin{array}{l}35.33 \\
23.39 \\
30.03 \\
27.62 \\
2.81 \\
29.26\end{array}$ & $\begin{array}{l}43.78 \\
61.22 \\
51.80 \\
54.57 \\
54.62 \\
52.67\end{array}$ & $\begin{array}{r}0.143 \\
.034 \\
.037 \\
.046 \\
.074 \\
.037\end{array}$ & $\begin{array}{l}1.54 \\
.71 \\
1.09 \\
1.78 \\
1.94 \\
.85\end{array}$ & $\begin{array}{l}1.42 \\
1.85 \\
1.48 \\
1.67 \\
1.94 \\
2.89\end{array}$ \\
\hline A verage. . & 28.74 & 33.11 & .062 & 1.32 & 1.66 \\
\hline
\end{tabular}

It is believed that this average represents clos ly the true average composition of the unaltered ferruginous eherts.

A large part of the ferruginous elierts slows partial alterations to ore. An average of 490 analyses, representing 5,890 feet of drilling in this plase of the formation, which is probably nearer to the true average of the formation, is 36.65 per cent.

The arerage composition of the Crogelic ores for the years 1906 and 1909 , calculated from arerage cargo anal yses for each grade, each analysis being weighted in proportion for the tonnage represented, is given in the following talle:

Average composition of ore mined on the Gogebic range in 1906 and 1909.

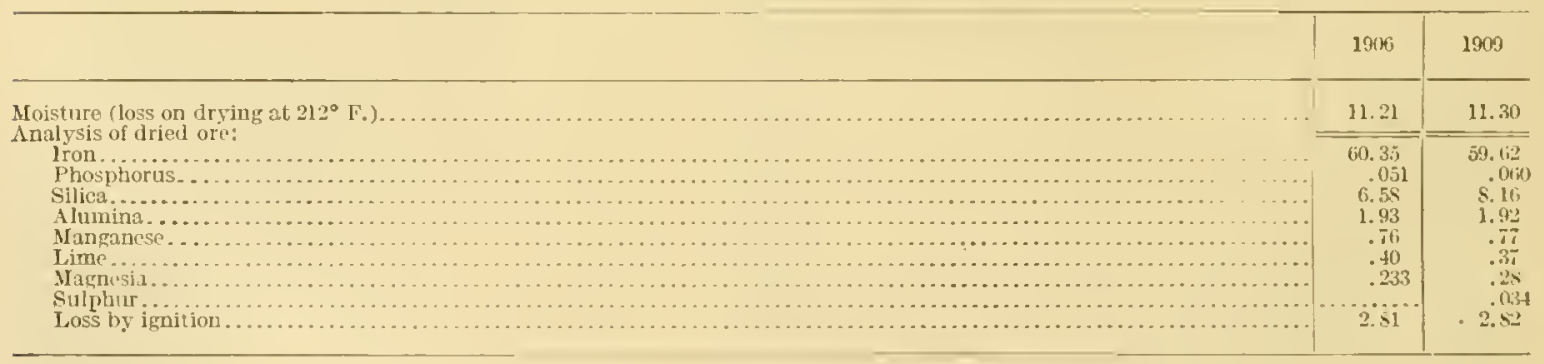


Range in percentage of each constiment in Gogebir ores mined in 1909, as shonn by arrage cargo analyses.

Mloisture (loss on drying at $212^{\circ} \mathrm{F}$.) $4.51 \quad 1015.75$

Analysis of dried ore:

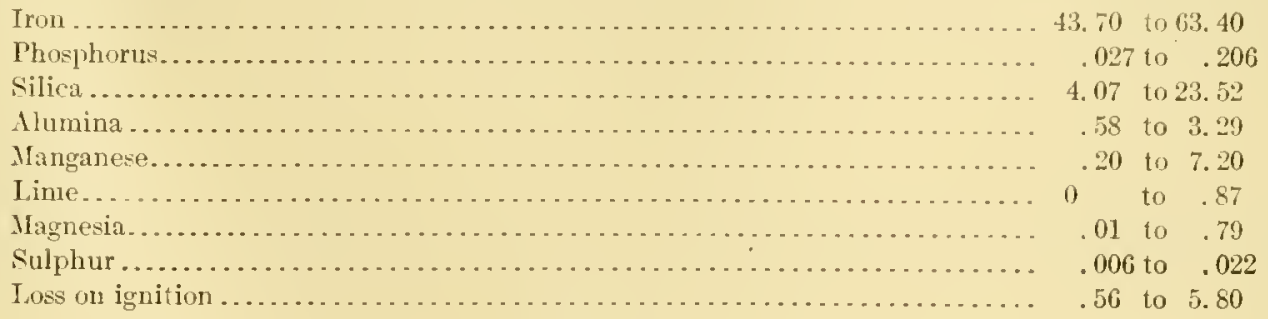

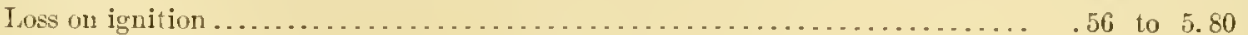

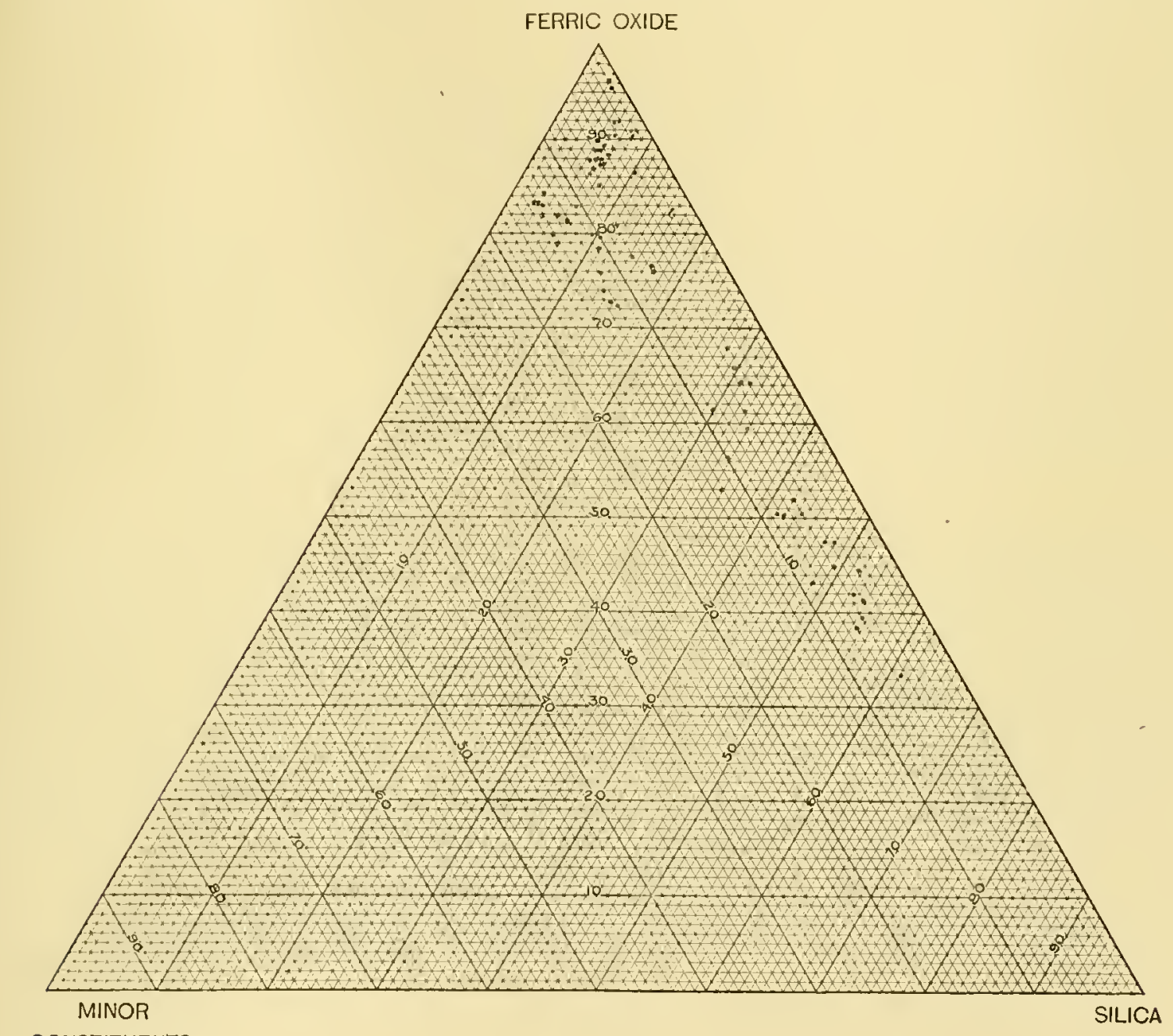
CONSTITUENTS

Principally alumina and water of hydration

Figure 30. - Triangular diagram showing chemical composition of various phases of Gogebic ores and ferruginous cherts in terms of ferric oxide, silica, and minor constitnents (ussentially alumina and combined water). These analyses include all of the ores and cherts shown in figure 32 and also a number of additional analyses.

In figure 30 the triangular method of platting is employed to show the chemical composition of the rarious phases of the chert and ore studied. (See p. 182 for explanation of diagram.) 
MINERALOGICAL COMPOSITION OF THE FERRUGINOUS CHERTS AND ORES.

The approximate mineral composition of the ores and elierts was calculated from the chemieal analyses, an follows:

A proximate minrral emposition of acerage ferruginous chert and average ore of the forgebic range.

llematite (including a small amount of magnetite).

limonite (other hydrated iron oxides calculated as limonite)

vilurtz. .

litiolin.

other minerals.

\begin{tabular}{|c|c|c|}
\hline \multirow{2}{*}{$\begin{array}{l}\text { A verage } \\
\text { chert. }\end{array}$} & \multicolumn{2}{|c|}{ Iverage ore. } \\
\hline & 1906 & IFKS \\
\hline 34.00 & 73.50 & 77.25 \\
\hline 8.20 & 14.70 & 9.30 \\
\hline 51.13 & +.31 & 5.81 \\
\hline 3.3 .5 & 4.89 & 4.70 \\
\hline 2.82 & $2 .(6)$ & 2.9 ? \\
\hline $1(x) .(x)$ & 100.00 & 100.00 \\
\hline
\end{tabular}

\section{PHYSICAL CHARACTERISTICS.}

(IENERAL APPEARANCE.

The iron ore of the Gogebie distriet is a soft red, somewhat hydrated hematite. Mueh of it is so friable that it ean be broken down with a pick, although as taken from the mines a large portion of it is compact enough to hold together in moderately large lumps. These lumps are porous, many of then more or less nodular, and many also roughly stratiform. The strata conform in a general way to the strike and dip of the iron formation. Wingled with this soft hematite in a few mines is a small quantity of aphanitic hard steel-blue hematite, which breaks with conchoidal fracture and is of remarkable purity. In general, this exceptionally hard material is found in contaet with or elose to the diorite dikes of the mines.

DEXSITY.

The specifie gravities of the ores and cherts were determined by the two general methods already discussed (see p. 1S4) - (a) calculated specifie gravity obtained by properly combining the specific gravities of constituent minerals; $(b)$ actual determinations by gravity methods. The speeific gravities of the minerals as used in determining the mineral specific gravity of the ore or chert are as follows: Hematite, 4.5 for earthy ores and chert, 5.1 for crystalline and hard or'es; limonite, 3.6; kaolin, 2.62; quartz, 2.65.

The average mineral density of all ore mined in 1906, calculated from the above mineral analysis, is 4.33 .

Following are six analyses of ferruginous cherts and ores with speeific gravities determined by both methods, as a check on the accuracy of determination:

Density of individual cherts and ores determind by calculation and by mcasurement.

\begin{tabular}{|c|c|c|c|c|c|c|c|c|c|c|c|c|}
\hline \multicolumn{7}{|c|}{ Chemical composition. } & \multicolumn{4}{|c|}{ Mineral composition. } & \multicolumn{2}{|c|}{ Specifie gravity. } \\
\hline Fe. & $\mathrm{SiOg}_{\mathrm{g}}$ & P. & $\mathrm{Al}_{2} \mathrm{O}_{3}$ & $\begin{array}{l}\text { Folatile } \\
\text { matter. }\end{array}$ & Mn. & $\begin{array}{l}\text { Moisture } \\
\text { of satu- } \\
\text { ration. }\end{array}$ & $\begin{array}{c}\text { Hena- } \\
\text { tite. }\end{array}$ & Limonite. & Quartz. & Kaolin. & $\begin{array}{l}\text { Calcu- } \\
\text { lated } \\
\text { from } \\
\text { analyses. }\end{array}$ & $\begin{array}{l}\text { Deter- } \\
\text { mined } \\
\text { by pye- } \\
\text { nometer. }\end{array}$ \\
\hline 3.30 & si. .91 & 0.007 & ii. 81 & $0+1$ & 0.15 & 3.70 & 4.71 & & 79.91 & 17.25 & 2.73 & \\
\hline 30.30 & 45.34 & $.02 \pi$ & 6. 30 & 1.53 & .50 & 9.30 & 43.30 & & +3.24 & 10.95 & 3.35 & 3.38 \\
\hline 4.3. 20 & $32, \mathrm{ks}$ & .022 & +40 & 1.55 &.+5 & 3.35 & til. 70 & & 27.70 & 11.13 & $3 . \infty$ & 3. $\times 15$ \\
\hline 4 ti. $\times 0$ & 29.83 & .015 & 1.32 & 1.08 & .85 & 10.50 & 63.30 & 1.21 & 28. 25 & 3.34 & $3 . .3$ & 3. 49 \\
\hline 52.00 & 12.59 & .029 & 7.40 & 5. 43 & .25 & 7.15 & 57. 70 & 19.38 & $3 . \$ 9$ & 15. 72 & $3.5 y$ & 3.90 \\
\hline 13. 30 & 4.00 & .078 & 2.94 & 1. $7 \mathrm{~s}$ & .70 & 10.50 & 86.30 & 5.24 & .54 & 7.45 & 4.79 & 4.84 \\
\hline
\end{tabular}


Poliositri.

Porosity was determined on hand specimens by the usual method of saturation in water described on page 185 . In arerage of ten determinations on typical specimens of ferrugrinous chert gave 4.1 per cent pore space. The average of the porosity of all the ores examined was approximately 34 per cent.

\section{CUBIC CONTENTS.}

The ores rary in culbic content from 7.5 cubic feet to the ton in the small masses of pure steel ore to 14 eubic feet in the softest yellow ores. The average calculated for the 1906 output is approximately 10.75 cubic feet to the ton.

TEXTLI:E.

The average texture of the Gogebic ores is shown by the following table of sereening tests. These were made by the Oliver Iron Mining Company and represent all of the ores mined by that company in the Gogebic distriet in 1909. Samples of the different ores were taken twice a week, quartered down each month according to the fonnagre shipped, and at the end of the shipping season quartered to 100 pounds of dry ore, on which the tests were macle. The following table represents 10 grades of ore, totaling $1,256,557$ tons. The texture of the ore is seen to be similar to that of the ores of the Marquette district. A comparison of the textures of the ores of the several Lake Superior districts is shown in figure 72, page 481.

Textures of Gogebic ores as shoun by screning tests.

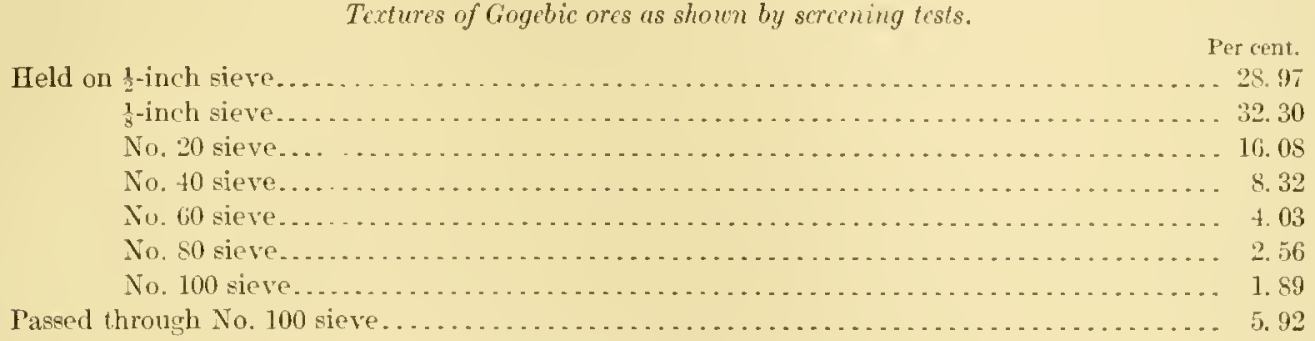

\section{MAGNETITIC ORES.}

At the extreme east and west ends of the Gogehic range the iron-bearing formation consists of dark-gray, green, or black dense crystalline handed rocks, consisting of magnetite, quartz, amphiboles, and other silicates in rarying proportions in diflerent hands and different localities. Ore deposits are rare or altogether lacking. For a discussion of reasons for this condition see pages 552-553. The average chemical composition of these rocks is as follows:

Analyses of magnetitic rocks. ${ }^{a}$

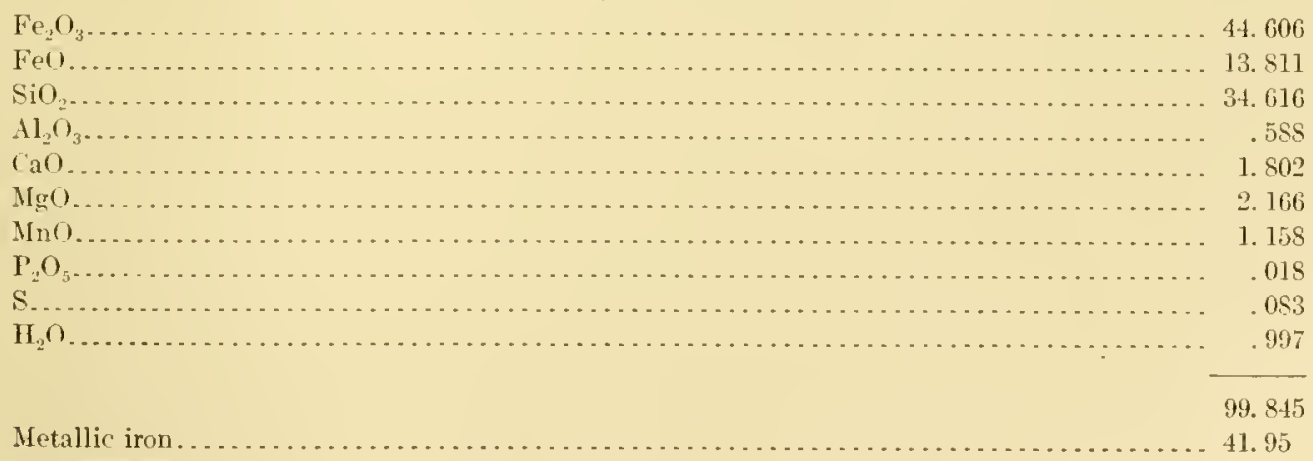


When this composition is compared with that of the forruginous cherts of the Cogebie distriet it is apparent that there is but litte difference between the two.

\section{SECONDARY CONCENTRATION OF GOGEBIC ORES.}

STITCTERAL CONHTTIONS.

The ores of this district are prohably localized in bands of the iron formation which were originally rich in iron, but for most of the district secondary concentrations latve so masked the primary distribution in bands that the evidence for it is not clear. Probably the clearest ease is in the Mikado, Brotherton, and Sunday Lake mines, where the ores seem to follow certain originally rich horizons in the iron formation, the later concentration apparently not haring seriously modified their distribution.

The secondary alterations of the iron-bearing beds are arcomplished (1) by waters following the pitching trough formed by the intersection of the dikes with impervious quartzite or slate beds below the iron formation layers, and (2) hy following fissures or bertling pianes independent of the clikes. The control by the dikes is by far the most conspicuous one for the district as a whole. The morement of the concentrating waters is in general castward toward lower levels, following the eastward pitch of the troughs formed by the intersection of the dikes with foot-wall quartzite or exceptionally foot-wall slate. The waters may thus be brought beneath other dikes. This explains the common oceurrence of ores on sereral dikes one below the other. The morement of the water is controlled to an important degree by bedding planes, by faults, and by joints, and where so controlled the ores are more or less independent of the dikes and foot wall. The control by faults is especially well shown in one locality where faulting parallel to the bedling has displaced the ends of a dike and the ore follows over the broken end of the dike along the fault plane, obviously a zone followed by percolating waters. Faults and joints may give an eastward pitch of the ore bodies, for many of the fissures along which alteration takes place pitch in the same direction as the dikes; in fact, the dikes have been intruded along fissures of this kind. That some fissures were there before the intrusion of the dikes is shown further by the fact that the iron formation near Sunday Lake has been displaced by faulting, whereas the Keweenawan igneous beds to the north, with which the dikes are genetically connected, have not been displaced. These early fissures also preceled the Keweenaw an folding. If fissures were present in the rocks before the dikes, there is no reason why sume concentration should not have been prior to the intrusion of the dikes in the east and west ends of the district, where the cover of slate was not too great to prevent ingress of water; but evidence of this would be extremely difficult to detect beeause of later alterations since the dikes were intruded.

The greatest deptlı to which the waters, and therefore the ore concentration, may be earried by the eastward-pitching troughs or by the fault and joint planes is ret unknown. Large ore boulies have been found to a depth of more than 2,500 feet; one of the largest deposits thus far found in the district was recently developed at this depth. Theoretically the depth of (nncentration is a function of the head determined by the height of the erosion elge of the iron formation and the lowest point of eseape; but the difficulty is to determine where the latter point is, for reasons stated above. Even if the head were known, there would be difficulty in calculating the effective depth of the circulation beeause the medium through which it is flowing is not homogeneous. Further, if the depth of the active circulation could be worked out within reasonable limits, this would give us only the maximum depth of the ore deposits, for it might well be that the waters do not carry oxygen abundantly to the maximum depth to which they penetrate.

Theoretieally the concentration of the ore should be more effective on the midlle slopes of the hills, beeause these would be places where descending waters are effective, whereas valleys are places where the water's are ascending unless prevented by other structural conditions, and not so effective for the purposes of ore concentration. It is unlikely that each of the cross valleys should have the same control of the circulation, and it is dillicult to tell which of the valleys has been most effective. Also it is to be remembered that the pitch of the dikes to 
the east is greater than the surface slope and that therefore the mudround waters, where passing under a valley, would be prevented from escaping by the overtying impervious dikes, except where faultiug would allow the waters to come through. Mining operations actually disclose artesian flows through dikes, as at the Germania mine. Also, ascending waters are actually observed to follow faults across the dikes, as in the Tew]ort mine. From anytling that is now known to the contrary, the faults in the dikes may be sulliciently numerous to allow upward eseape of the water somewhat frecly along the cross valleys at the surlace. 'This is especially likely in view of the fact that the cross valleys are olserved to have developed along fault planes. These planes must ent the dikes, though some of them are not observed to do so. The cross valley under such conditions is simply the surface expression of the weak faulted zone. It is therefore not to be expected that there is a close relation to be observed between the topography and the distribution of the ores. The ore deposits extend below both elevations and minor valleys, but at some of the principal cross valleys ore deposits are small or lacking. For illistration, ores extend abundantly under Montreal River at Ironwood, but east of the Newport mine these ores seem to end at a pronounced cross depression nortliwest of Bessemer, through which Black River flows. It is thought ly James R. Thompson, formerly manager of the Newport mine, that the drainage for the Ironwool-Newport group of mines is probably carried eastward and escapes through this channel.

ORIGINAL CIIARACTER OF TIE IRON-BEARIYG FORMATION.

Originally the iron-bearing formation consisted largely of cherty iron carbonate interlayered with sideritic shates and possibly also with banded chert and forric hyrlrates. (See p. 231.) Some layers were probably richer than others. The alteration of the cherty iron carlonates to ore has been aceomptished in the general manner already described as typical for the region-(1) oxidation and hydration of the iron minerals in place, (2) leaching of silica, and (3) introduction of secondary iron oxide and iron carbonate from other parts of the formation. These changes may start simultaneously, but change 1 is usually far adranced or complete before changes 2 and 3 are conspicuous. The early products of alteration, therefore, are ferruginous eherts-that is, rocks in which the iron is oxidized and hychated and the siliea is not remored. The later remoral of silica is necessary to prorluce the ore.

ALTERATION OF CHERTY MON CARBONATE TO FERRUGINOLS CIERT.

Chemical change.-The alteration of cherty iron carbonate to ferruginous chert involves the oxidation of iron according to the following reaction:

$$
2 \mathrm{FeCO}_{3}+\mathrm{nl} \mathrm{I}_{2} \mathrm{O}+\mathrm{O}=\mathrm{Fe}_{2} \mathrm{O}_{3} \cdot \mathrm{nH}_{2} \mathrm{O}+2 \mathrm{CO}_{2} \text {. }
$$

Vineral change.-The cherty iron carbonate is practically identical mineralogically with the sideritic cherts of the Mesabi range. The constitnent minerals are segregated into alteruate layers of siderite and chert. The oxichation of the siderite involves a change to a heavier mineral. Either introduction or renoval of silica may accompany this change.

Volume change.-The volume involved in the alteration indieated in the above equation is a loss of 49.25 per cent, considering the resulting iron oxide to be anhydrous. If hydration of the iron oxide takes place, the volume reduction is smaller in proportion to the degree of hylration, being only 18.3 per cent when the product is limonite. Approximately 60 per cent of the volume of the eherty iron cirbonate is siliea; therefore the rechetion in rolume caused by the oxidation of the iron is eflective on approximately only 40 per cent of the volume of the rock. The loss in volume, then, for the entire rock, taking into account both iron and silica, ranges from 17.2 per cent to 6.4 per cent, dejenting on the degree of hydration of the resulting iron oxide.

Development of porosity.- The decrease in volume, due to the alteration of the iron minerals, develops pore space in the resulting ferruginous chert. Determinations of porosity on several typical specimens of cherty iron carbonate showed an average of less than 1 jer cent pore space. 
A series of ten determinations on typical specimens of ferruginous chert gave a range of 0.9 to 8 per cent pore space, with an arerage of 4.1 per cent. Evidently the artual porusity is not sufficient to account for the theoretical volume change. This may be explained in the following ways: (a) Part of the iron oxide in the ferruginous chert may have heen original and not al tered from siderite. As the calculated pore space is based on the assumption that all of the iron oxide in the ferruginous chert is the result of the oxidation of siderite, original ferric oxicle in the chert would decrease the resulting pore space. (b) Infiltration of iron oxide or silica subsecpuent to or areompanying the alteration may have closed part of the openings formed. This is certainly true to at least a smalt extent, as shown by microscopic examination of thin sections. (c) The lifficulty of obtaining saturation and perfect drying in the determination of porosity in the specinens of ferruginous chert may have made the results too low. (d) In the rocks under discussion, both original and secondary, the iron minerals tend to be segrregated in parallel layer's separated by comparatively barren chert. The volune changes in the alteration of the iron minerals woukl then be largely confined to the ferruginous layers. If these are assumed to be practically pure iron mineral, the cubical shrinkage should rary between 49.25 per cent and 18.3 per cent (as previously calculated) for the different original and secondary minerals noted above, the linear shrinkage between 6.5 and 20.3 per cent. The slunkage normal to the layers would probably not result in openings to any large extent, as slumping of the flat layers would elose any cavities formed, and as a matter of fact such openings are not observed. On the other hamd, shrinkage parallel to the beds is taken to explain the common intersecting sets of eracks confined to the ore layers and breaking them into small parallelepiped blocks when the ore las not suffered general deformation. These by actual measurement give a volume of openings ranging from $12 \frac{1}{2}$ to 36 per cent of the rolume of the iron layers, which would be approximately 5 to $14 \frac{1}{2}$ per cent of the rohme of the rock.

It is believed, then, that the increase in porosity and development of eracks in the ferruginous chert, together with the slump which has obliterated a jurt of these openings and the infiltration of iron salts, fully accounts for the change in rolume which accompanies the production of these eherts from the eherty iron carbonate.

\section{ALTERATION OF FERRUGINOUS CIIERT TO ORE.}

The alteration of ferruginous chert to ore is almost identical with the secondary concentration of the ores of the Mesabi district. As in the Mesabi coneentration, the essential change is the leaching of silica. The several possibilities resulting in the leaching of silica are diseussed on pages $537-538$. It is seen that the space left by the remoral of siliea maty renain as pore space and may be partly or entirely closed by slump or may be filled partly or entirely with infiltrated iron oxile. To determine the relative importance of these possibilities, quintitative methods similar to those employed in investigation of the Mesabi ore were used.

In order to include the factor of porosity in a comparison of ores and cherts, it is necessary to eonsider their composition in terms of rolume rather than of weight. The rolume composition of any chert or ore is readily calculated from the mineral composition and the porosity.

The volume composition of the average ores and ferruginous eherts is as follows:

A trage volume composition of ores and cherts of Gogebic range.

\begin{tabular}{|c|c|c|}
\hline & Ores. & $\begin{array}{l}\text { Ferrugi- } \\
\text { nous } \\
\text { cherts. }\end{array}$ \\
\hline \multirow[t]{2}{*}{$\begin{array}{l}\text { Hemante... } \\
\text { Limunite... } \\
\text { Q Quartz..... } \\
\text { liaolin ..... } \\
\text { Pore space. }\end{array}$} & $\begin{array}{l}37.30 \\
11.44 \\
10.43 \\
3.25 \\
34.00\end{array}$ & $\begin{array}{r}19.60 \\
-.23 \\
15.00 \\
+.03 \\
+.10\end{array}$ \\
\hline & 99,94 & 99. $99_{6}$ \\
\hline
\end{tabular}


The above volume composition is expressed diagrammatically in figure 31. The most important factor in forming ore from the cherts, as shown by the diagram, is the removal of silica.

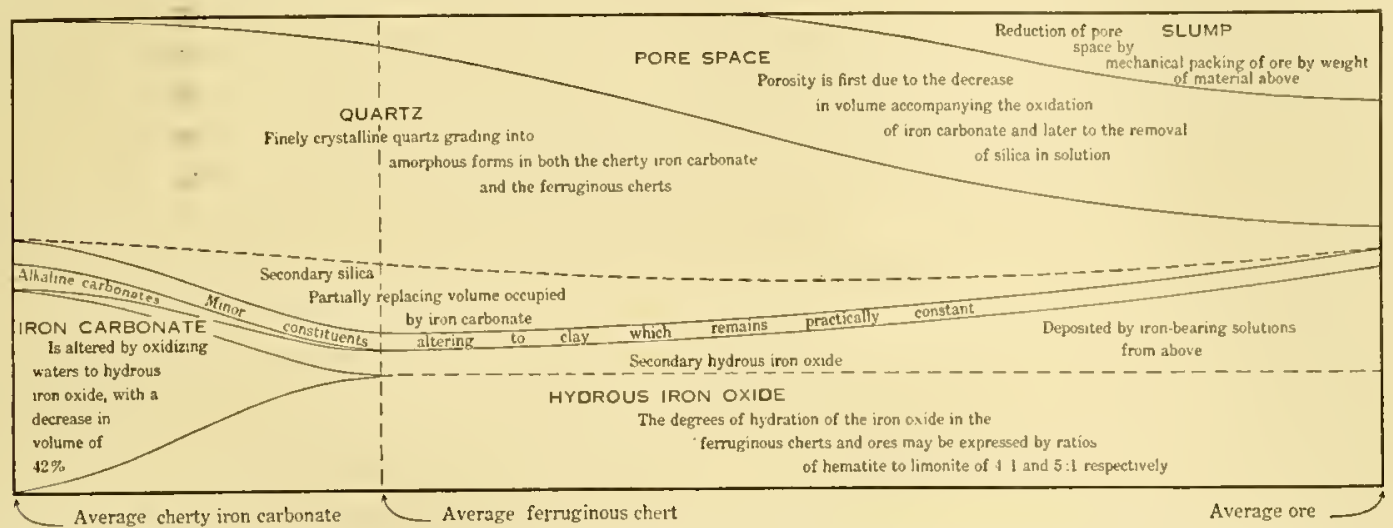

FIGURE 31-Diagrammatic representatiou of the changes involved in the alteration of cherty iron carbonate to ferruginous chert and ore, Gogebic district. The mineral compositions of the various phases are indicated in terms of volume by vertical distances. The compositions of the cherty iron carbonate, ferruginous chert, and ore represented are averages of a large number of analyses,

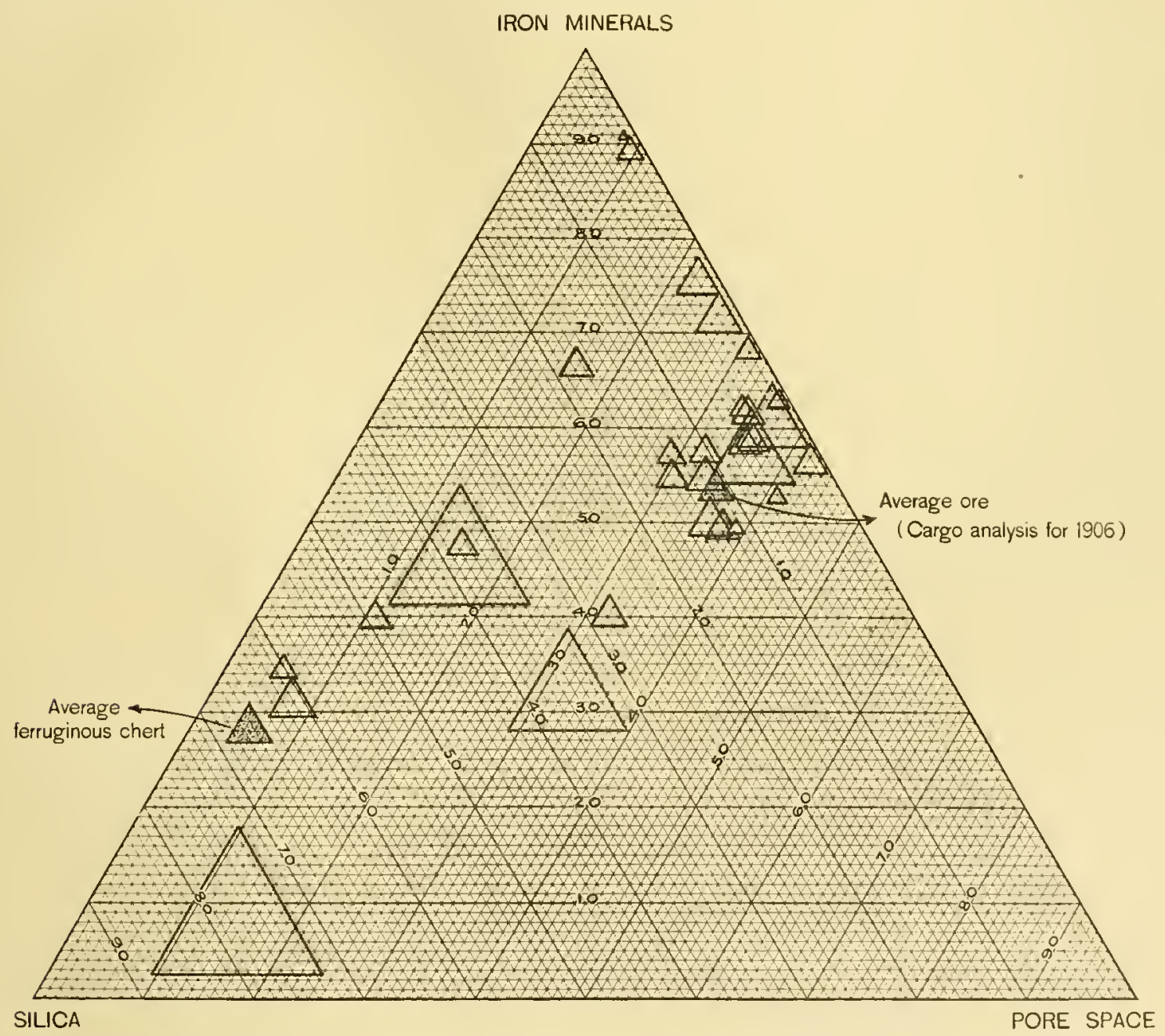

FIGURE 32.-Triangular diagram showing rolume composition in terms of pore space, iron minerals, silica, and minor constituents (clay, ete. of the ferruginous cherts and iron ores of the Gogebic range. See page 1 s9 for discussion of method of platting. 
TRIANGULAR DIARAM ILLESTHATAG SECONDARY CONCLNTLATION OF GOGEBIC OLES.

In figure 32 the triangular method (described on p. 189) of rejresenting the rolume relation of fermginens cherts and ores and intermediate phases is applied to the Gogelic ores. As already explained, each small triangle within the large one represents an individual sperimen and by its size and position indicates composition in terms of the volune of pore space, silica, iron minerals, and minol constituents. The average ferruginous chert, as indicated, is represented by a small triangle in the lower lefthand side of the diagram, with low prore spare and a large content of silica. The average ore is represented in the upper right-hand part of the diagram, and has more pore space, less silica, and more iron than the average ferruginous chert. Scattered about in the area between these two points are intermediate phases lietween ferruginous chert anil ore.

In the alteration of ferruginous chert to ore, as represented in the tringle, the following changes have evidently taken place: (a) J)ecrease in silica, (b) increase in pore space, and (c) increase in iron. Obviously the dominant process has been the removal of siliea, as this is necessary to an increase of pore space and iron. Remoril of silical alone without introduction of iron or mechanical slump would increase the porosity in proportion to the amount of silica removed. Such a process would be represented on the triangle by a series of small triangles in a line parallel to the base, as the relative volume of iron would remain constant. In the actual case known the relative volume of the iron mineral increases from 26.83 per cent in the cherts to 52.18 per cent in the ores. This could be accomplished in two ways-by mechanical slumping or packing of the material, weakenel by too great a porosity, or by infiltration of iron. From the diagram it is impossible to tell which of these processes, slumping or infiltrittion, is more important. Observition shows, however, that slumping has heen important, but that introduction of iron lass taken place to a much greater extent than it did in the concentration of the Mesalji ores.

\section{ALTERATION OF ROCKS ASSOCIATEN WITI ORES DURING TIEIR SECONDARY COXCENTRATION.}

The various conditions and agencies which were effective in the concentration of the ore from the cherty iron carbonates and ferruginous cherts caused alterations of a similar nature in the rarious rocks associated with the iron-bearing formation-namely, the interloclded slates, the basic intrusive rocks, and the slates immediately overlying the iron-bearing formation. The alteration of the slates produced paint rock or ferruginous slate similar to that of the Mesabi range. The alteration of the basic dikes by oxidation of the iron, breaking ilown of feldspars, and leaching of soluble constituents formed a soft kaolinic product, locally termed soap rock or, if iron stained, paint rock. The following analyses of fresh and altered dike rock are typical of this alteration:

- Analyses of fresh and allered dikes associated with ore.

\begin{tabular}{|c|c|c|c|}
\hline & 1 (fress) & 2 (altered 1$)$ & $\begin{array}{l}\text { 1ssimming } \\
\text { IIg( })_{3} \\
\text { consiane. }\end{array}$ \\
\hline 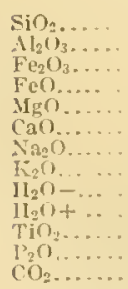 & $\begin{array}{r}4.90 \\
1.510 \\
3.10 \\
5.41 \\
5.11 \\
9.99 \\
2.0 \\
.2 .3 \\
1.5 \\
2.34 \\
.82 \\
.13 \\
.34\end{array}$ & 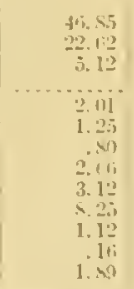 & 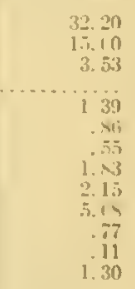 \\
\hline
\end{tabular}

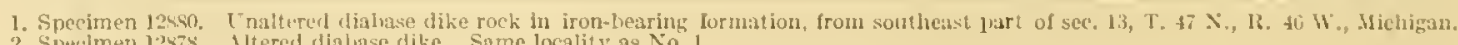
2. Specimeu J2sis. Altered diabase dike. Same locality as No.1. 
A comparison of the two analyses on the assumption that alumina has remainer constant (see third column in the table) shows a loss of silica, iron, magnesia, lime, soda, phosphorus, and titanium and a gain in potassa, water, and carlon dioxicle. Except for the belavior of potassa, the alteration is typical of weathering under conditions of oxirlation, carbonation, and hyclration.

Specific gravity and porosity determinations on the specimens analyzed resulted as follows:

Specific gravity and porosity of unaltered and allered phases of diabase.

\begin{tabular}{|c|c|c|c|}
\hline & & $\begin{array}{l}\text { Specific } \\
\text { gravity. }\end{array}$ & Porosity. \\
\hline $\begin{array}{l}\text { Unaltered liabase ....... } \\
\text { Altered phase of diabase. }\end{array}$ & 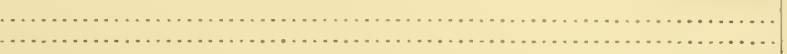 & $\begin{array}{l}2.92 \\
2.76\end{array}$ & $\begin{array}{r}0.50 \\
28.40\end{array}$ \\
\hline
\end{tabular}

On the basis of the specific gravities and the assumption that alumina is constant, the caleulated porosity due to leaching of soluble constituents is 27.1 per cent of the volume $\left(1.00-\frac{15.60}{22.62} \times \frac{2.92}{2.76}=0.271\right)$, which agrees very well with the actual determinations of porosity, and also denotes the approximate correctness of the assumption that alumina is constant.

The approximate mineral composition of the fresh and altered diabise, calculated from the analyses, is as follows:

Mincral composition of fresh and alterd diabase.

\begin{tabular}{|c|c|c|}
\hline & $\begin{array}{l}\text { Unaltered } \\
\text { diabase. }\end{array}$ & $\begin{array}{l}\text { Altered } \\
\text { phase ol } \\
\text { diabase. }\end{array}$ \\
\hline $\begin{array}{l}\text { Feldspars................ } \\
\text { Ferromagnesian minerals. }\end{array}$ & $\begin{array}{l}51.00 \\
40.00\end{array}$ & 6.82 \\
\hline Q 1artz_.......................... & 1.00 & 17.00 \\
\hline $\begin{array}{l}\text { Calcium-magnesia carbonates } \\
\text {. patite. }\end{array}$ & .90 & 4.00 \\
\hline $\begin{array}{l}\text { Apatite } \\
\text { Magetite }\end{array}$ & 5.34 & \\
\hline Ilmenite. ............. & 1.50 & \\
\hline $\begin{array}{l}\text { Kaolin, chlorite, sericite, et } \\
\text { Limonite.......................... }\end{array}$ & & 63.00 \\
\hline vity.. & $2 . \Omega 2$ & 2.76 \\
\hline & .50 & \\
\hline
\end{tabular}

OCCURRENCE OF PHOSPHORL' IN THE IRON-BEARING FORMATION.

PHOSPHORUS CONTENT.

The phosphorus content of the principal phases of the iron-bearing formation is as follows:

Phosphorus content of the iron-bearing Ironuood formation.

Cherty iron carbonate

Ferruginous chert

Iron ore.

The range in phosphorus content in the various commereial grates of ore produced in the district in 1906 was from 0.028 to 0.275 per cent. In the Mesabi ores the phosphorus content was found to depend to a large extent on the chemieal composition of the ore, high phosphorus oceurring as a rule in the more hydrous ore and in ore high in alumina. In the Gogebic ores the inerease of phosphorus with the degree of hyllration is not apparent, as is shown in figure 33, where the relation of phosphorus content to water of hydration is represented graphically. 
The average degree of hydration of the Gogebic ores is considerably lower than that of the Mesabi ores, and the high phosphorus ores of the Mesabi range contain more water of hydration than the most hydrous of the Gogebie ores.

As in the Mesabi range, the phosphorus content of the altered slates or paint rocks and slaty ores of the Cogebic range is high. These phases are high in alumina and comprise a complete gradation fron high-grade ore to ferruginous chy. The unaltered interbedded slates as at rule have a higher phosphorus content than the iron-bearing rocks proper and their alteration products are correspondingly high in phosphorus. Ilence an examination of analyses shows, in a general way, an increase of phosphorus with an increase in the alumina content. The altered dikes, locally termed soap rock or paint rock, are characteristically high in phosphorus, evidently owing to the original phosphorus content of the diabase. (See analyses, p. 246.)

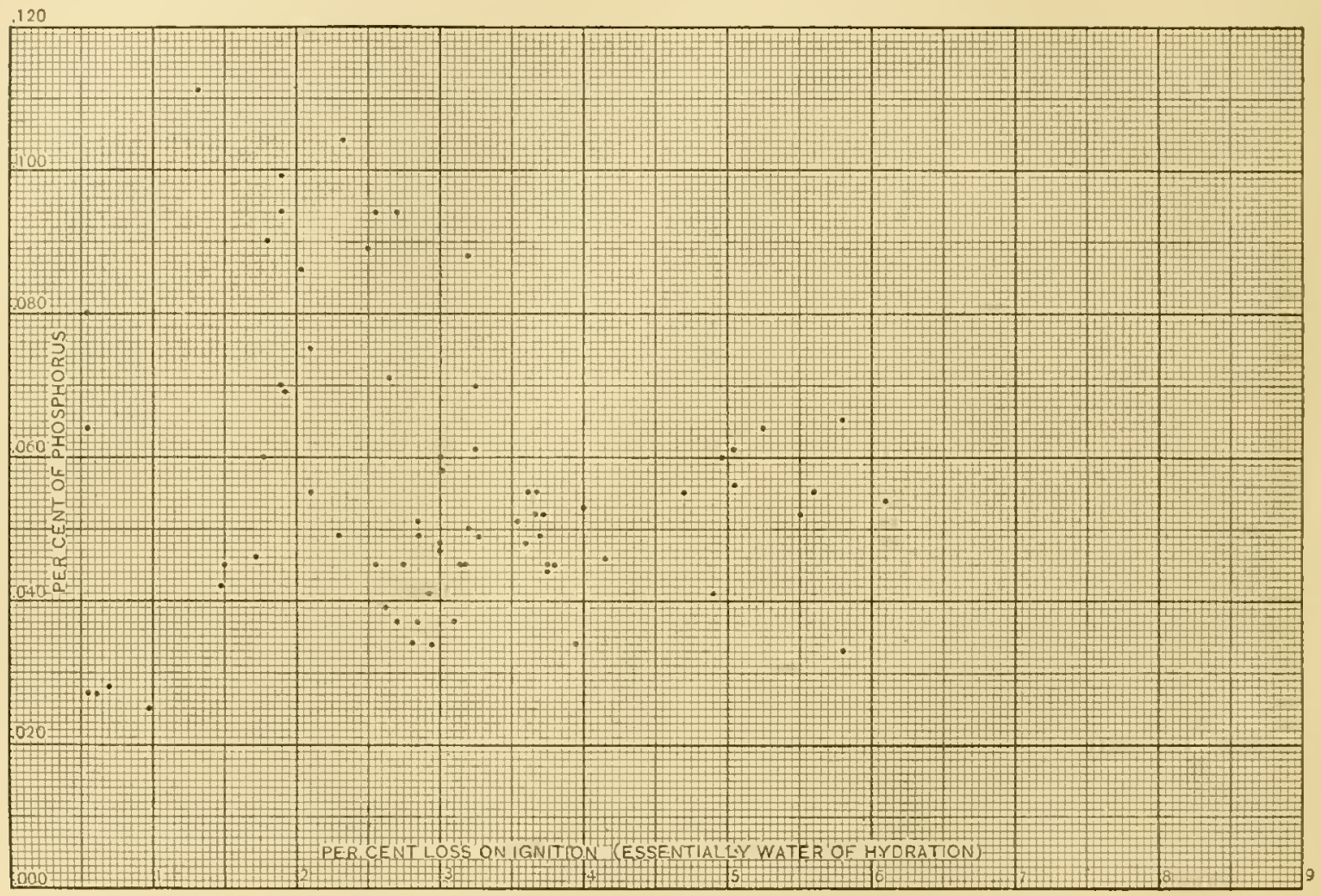

FTgUre 33.-Diagram showing relation of phos phorus to degree of hydration in Gogebic ores.

Hight-phosphorus ores are sometimes found immediately above the dikes and in the angle of the trough formed by a dike and the foot walt. It is not true, howerer, that all ore immediately overlying dikes is high in phosphorus, the opposite being true in many places.

\section{MINERALS CONTAINING PHOSPHORUS.}

The discussion of the occurrence of phosphorus on the Mesabi range (pp. 1n2-1n6) applies practically rerbatin to the Gogebic range. No phosplorus-bearing mineruls have been identified in the ores or cherts; hence possible occurrence of phosphorus must he infered from chemieal crictence. Figure $3 . t$ is similar to figure 23 , showing the retation of phosphorus to lime and the possilility of phosplunus orenring as apatite (calcium phosphnte). The dingonal dotted line indientes the ration of the two elements in apatite. Points falling above the line indicate an exerss of calcium and points below the line an exess of phesplonrus. From the fact thit an muber of andyses show an excess of phosphorus it is to be inferred that phosphorus- 
bearing minerals other than apatite are present. It is highly probable that at least part of the phosphorus occurs in combination with the hydrates of iron and alumina. The cxtremely small percentages present make determination of these minerals pratically inpossible.

BEHAVIOR OF PHOSPHORUS DURING SECONDARY CONCENTRATION.

Examination of the average analyses of the cherty iron carbonates, ferruginous chert, and ore shows that the ratio of phosphorns to iron has remained practically constant during the concentration of the ores; in other. words, both have been concentrated to essentially the same degree.

It was found that in the secondary concentration of the ores of the Mesabi district phosphorus was actually introduced into the ores from the overlying Cretaceous rocks known to be

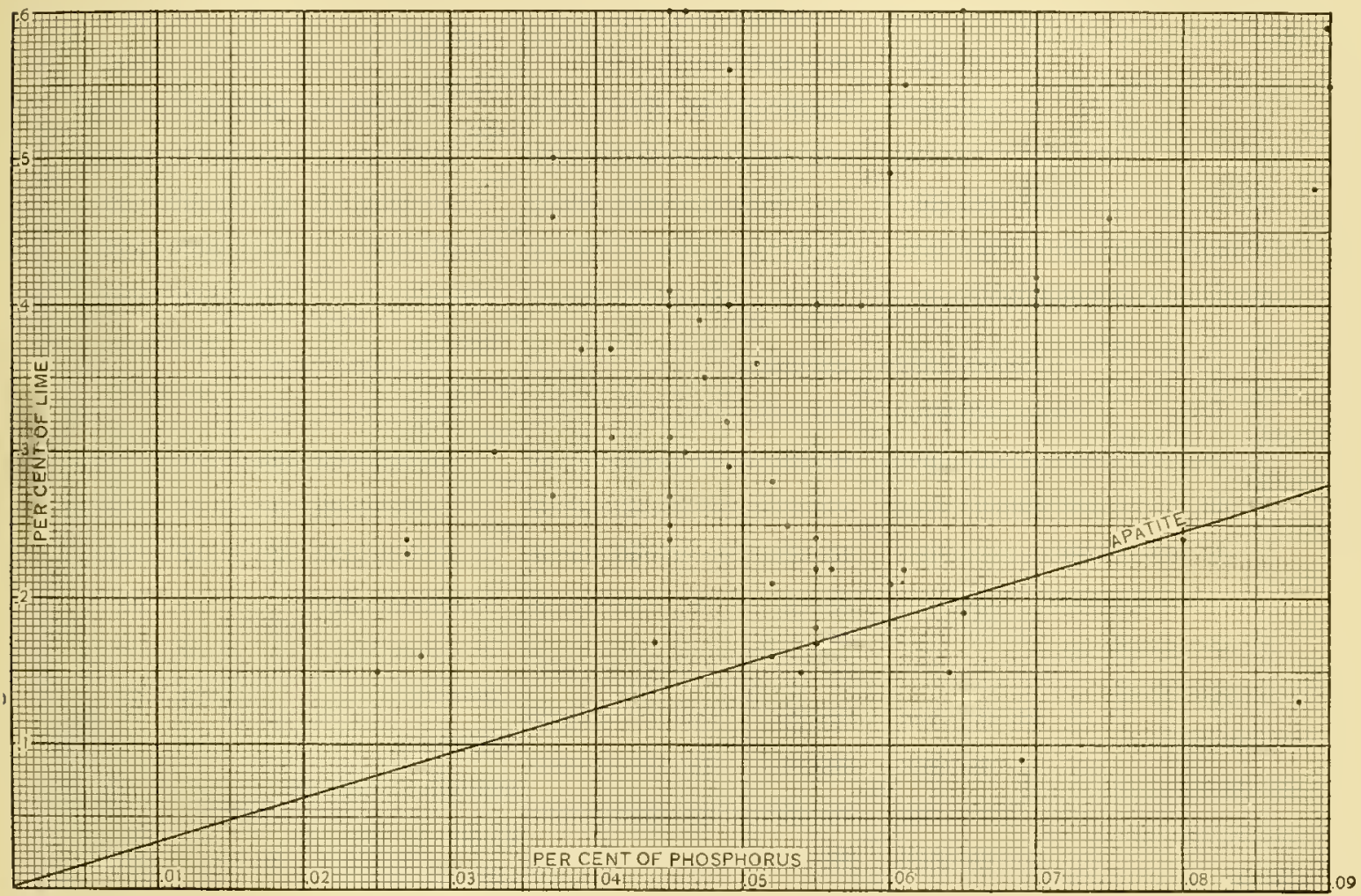

FIGURE 34.-Diagram showing relative amounts of phosphorus and lime in Gogebic ores.

high in phosphorus. The absence of a somree of phosphorus such as the Cretaceous rocks of the Mesabi district may explain why phosphorus has not becm concentratel to a greater degree in the iron in the Gogebic ores.

It was suggested that the hydrated portions of the Mesabi may have had some effect in causing this increase in phosphorus. The Gogebic ores are much less hyclrous than the Mlesabi ores, and this fact suggests a further possible explanation for the increase in phosphorus in one case and not in the other.

Iligh-phosphorus ores commonly occur immediately above or below dikes. The dikes themselves are characteristically high in phosphorus, and, furthermore, the alteration of the dike is accompanical by a loss of phosphorus. (See analyses, p. 246.) It is possible that the high phosphorus in the neighboring ore may be directly contributed by the altering dike rock. 


\section{SEQUENCE OF ORE CONCENTRATION IN THE GOGEBIC DISTRICT.}

Before the deposition of the lieweenawan series there hat been a slight folding of the upper Iluronian (Animikie group) contuining the productive iron-bearing lronwood formation. A gentle syncline was developed along the present productive area with its limbs at the two ends of the district. Erosion then exposed the iron-bearing formation only at the two ends of the district, leaving the central and nonproductive part still covered by a considerable thickness of slate, and solt ores and ferruginous cherts were developed along erosion surface and fissures at the east and west ends of the district to a minor extent. The Keweenawan igneous and sedimentary rocks, laid down upon this gently bowed surface, affected the underlying ferruginous cherts and soft ores at the east and west ends of the district, perhaps deliydrating them, and developed red jaspers and lard ores. The iron carbonates at these places were changed to amphibole-magnetite rocks by contact metamorphism. Igneous intrusives of Keweenawan age are more abundant at these localities than elsewhere in the district. They had no contact effect upon the iron-bearing formation in the eentral part of the district because it was covered by slate. Then came the great post-Keweenawan folding, resulting in the tilting of the upper Iuronian iron-bearing formation (Ironwood) and Keweenawan beds in the Gogebic district to angles of $60^{\circ}$ and $70^{\circ} \mathrm{N}$. The iron-bearing formation underwent dymamic metamorphism at the east and west ends, where it constituted a comparatively thin layer between the hard rocks of its basement and those of the covering Keweenawan. The following erosion exposed not only amphibole-magnetite rocks, hard ores, and jasper's previously formed at the east and west ends of the distriet but exposed for the first time from beneath the Tyler slate the unaltered iron-bearing formation, consisting principally of carbonate, in the central and present productive portion of the region. The concentration of the ore for this district began at this time. It was well alvanced before Cambrian time and has continued intermittently since. (See pp. 557-560.) 


\title{
CHAPTER XI. THE MARQUETTE IRON DISTRICT OF MICHIGAN, INCLUDING THE SWANZY, DEAD RIVER, AND PERCH LAKE AREAS.
}

\author{
MARQUETTE IDISTRIC'T. ${ }^{a}$
}

\section{IN'TRODUCTION.}

Although the following account of the geology of the Marquette district is based mainly on the work of the United States Geological Survey, we would express our indebtedness to Prof. A. E. Seaman, of the Michigan College of Mines, for important modifications in our ideas of the structure and distribution of the rocks. Prof. Somman was the first to prove the existence of an unconformity between what is here called middle Huronian and the lower Huronian, both of which had been treated together as lower IIuronian in the U'nited States Geological Surver monograph on the district. He has also contributed a considerable number of corrections to the geologic map and a detailed plat of the extensive faulting near Teal Lake (Pl. XIX). The Cascade area shows considerable changes in mapping, due to the large anount of careful exploration work accompanied by geologic mapping that has been done by mining companies. Te are especially indebted to Messrs. Oscar Roln, O. B. Warren, and Wr. O. Hotchkiss and to the Oliver Iron Mining Company for changes in this area. Other important corrections on the Marquette map have been furmished by the work of the Cleveland-Cliffs Iron Company, Longyear \& Ilodge, and others.

\section{LOCATION, SUCCESSION, AND GENERAL STRUCTURE.}

The Marquette district extends from Marquette, on Lake Superior, in longitude $87^{\circ} 20^{\prime}$, west to Lake Michiramme, in longitude $88^{\circ}$, a distance of somewhat less than 40 miles. The district roughly follows parallel $46^{\circ} 30^{\prime}$. (See Pl. XVII, in pocket.) It lies wholly in Michigan and derives its name from the city of Marquette. The more important towns besides Marquette are Ishpeming, Negaunee, Champion, and Repulblic. The breadth of Algonkian rocks, which are the special subject of this chapter, varies from about 1 mile to more than 6 miles. From the western part of the main Alsonkian area two arms project for several miles, one to the southeast, the Republic trough, and one to the south, the Western trough.

The succession of the formations for the district, from the top downward, is as follows:

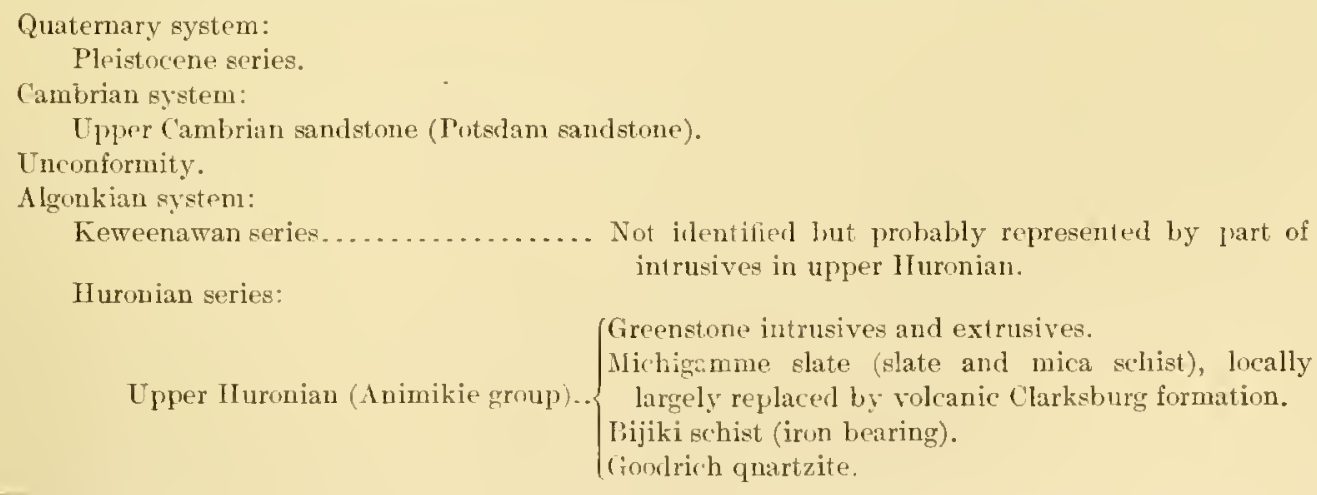

a For further detailed description of the geology of this district see Mon. U. S. Geol. Survey, vol. 2S, 1597, and references thre given. 


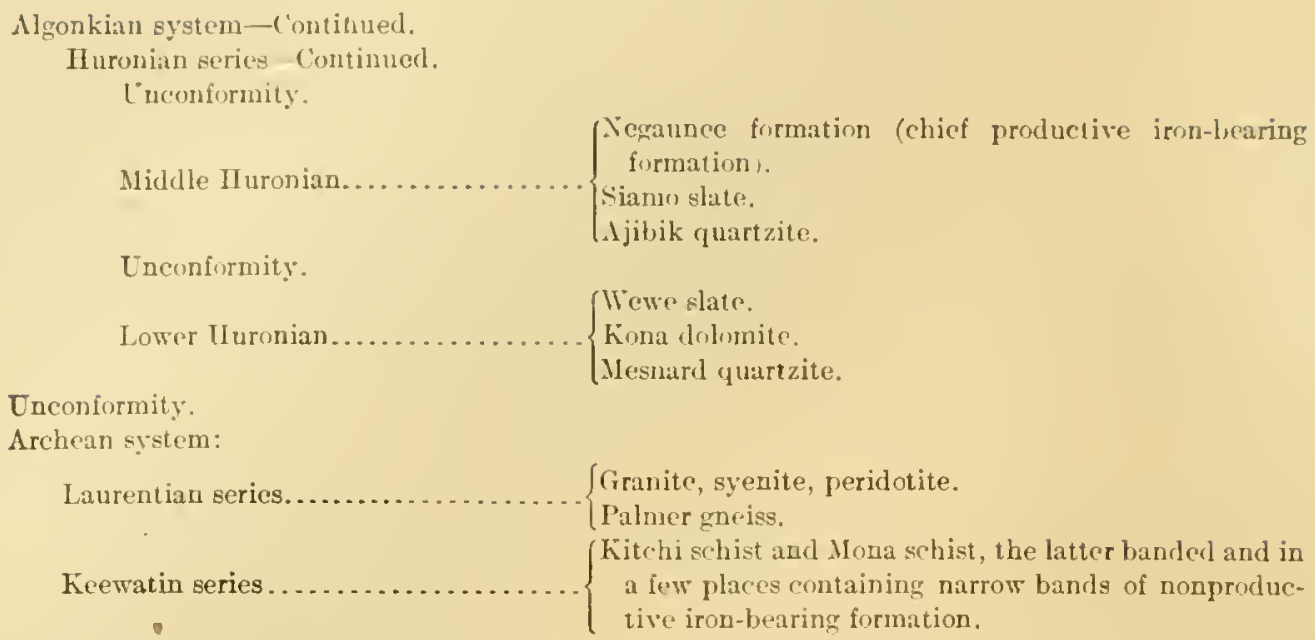

In addition to the rocks tabulated above, basic igneous roks in many dikes and lousses, large and small, intrude all the Archean and Huronian formations.

The contral and western parts of the district are bounded on the north and south by more or less contimuous east-west linear ridges of Algonkian rocks. The area between these ridges is relatively low lying, with minor elerations. Also these ridges on the whole stand above the country north and south of the district. The major portion of the district is a bluffy plateau, for the most part lying between altitudes of 1,400 and 1,600 feet, but it has points that rise hicher and a few points that reach an altitude of 1,800 feet. The eastern part of the plateau slopes rather steeply toward Lake Superior, and for this part of the area the altitudes of the higher points are between 800 feet and 1,000 feet. Each of the formations is locally resistant, and where in this condition constitutes bluff's. One traversing the distriet from north to south is almost constantly either climbingr or descendiner a steep slope.

The drainage is largely transverse to the longer dimension of the district. Branches of Escanaba River, in the Lake Michigan drainage basin, cross the central part of the range at two places. In the eastern part of the district (arp River flows to Lake Superior in a direction roughly parallel to the strike of the rocks. In the western part of the district Micliiramme Lake, the one large lake in the district, and Michigamme River are purely structural in their locations, the main arm of the lake lying cast and west parallel to the strike of the listrict and a north arm swinging toward the south with the cross fold, which appears at this healitr. Michigamme River, the outlet of the lake, follows the axis of the Republic trough and connects with Lake Jichigan waters.

The Archean rocks occur in two areas, one north and one south of the Huronian series. The northern one is called the northern complex and the southem one the southern complex. In a brod way the lluronian rocks constitute a rerat synclinorium between the two areas of Archean. Superimposed upon the larger folds are folds of lesser orders down to minute plications. Though it is therefore clear that the folding is extrenely complex from Lake Superior to Nichigamme Lake, it may be said that the Mgonkian constitutes a great canoe-shaped basin, which comes to a point at the east end of the district lut does not at lichigamme. As a result of this, in passing from Lake Superior to the west, one comes to higher and higher formations and only reaches the highest formation of the district west of Ishpening.

This synclinorium is of peculiar and complicated character. For mucle of the distriet the rocks in the outer borders of the Algonkian belt are in a series of sharply urertumed folds. The Agonkian rocks on either side of the trough have moved up and outward over the more rigid Arehean crranite, and as a consequence on each side of tho Mlgonlian trough a scries of overfolds, esperially in the softer slates, phunge steeply towarl its axis, produeing a strueture resembling in this resporet the composed fan structure of the Alps. There is, lowerer, this great difference between the structure of the Marquete district and that of the .1 ps-that newer 


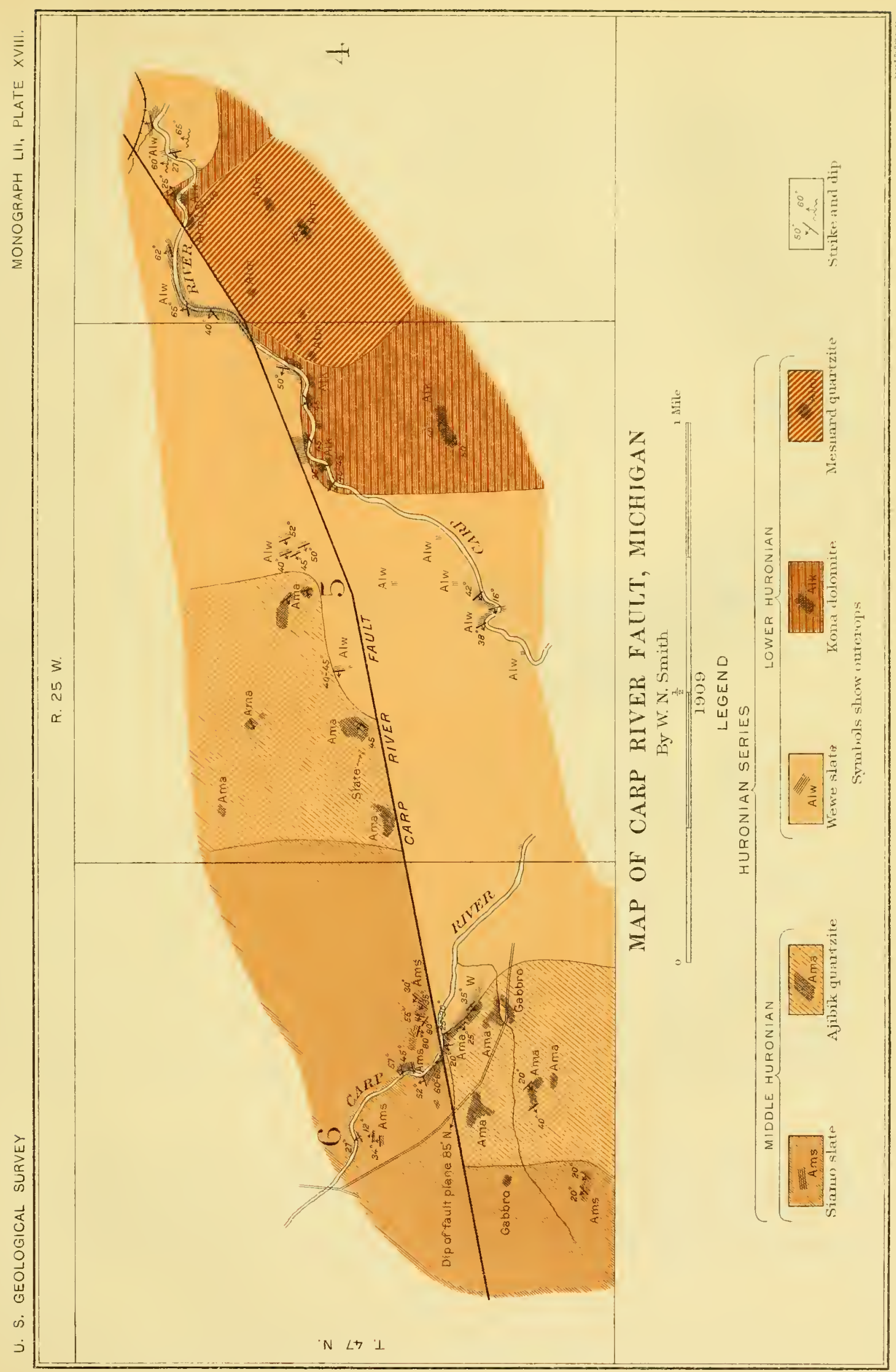



rocks appear near the axis of the trough rather than older ones, as if composed fan folds of Alpine type were sadged downward into a synchinorimm. The structure also differs from the inverted intermont trough of Lapworth. It may be called an abnormal synchorium. ${ }^{a}$ (See fig. 35.) This structure prevails in the central part of the area from Ishpeming and Negaunee westward to Clarksburg, but it does not cxtend to I a ke Superior on the east nor to Lake Michigamme on the west.

Although the more conspicuous folds of the district have in general an east-west axis, the rocks have also been under strong east-west compression, as a conseguence of which the folds are buckled so that many of them show a steep pitch. In places the north-south folds become more prominent than the east-west folds and control the prevalent strikes and dips. This is illustrated by the western trough, at the west end of the district. In certain areas in the southeasterm part of the district the compression has been about ecfually great in both clirections, prorheing most irremular strikes and dips.

Minor fracturing in the district has been pervasive, as will be explained in succeeling pages, but only at a few localities are there faults so extensive that they have been detected in the mapping of the formations. Of these major faults, three at least are of rery considerable displacement, all in the eastern part of the district, one of these being the Carp River fault (Pl. XVIII) and the other two in the Cascarle area. A number of less important faults occur in the quartzite east of Teal Lake (Pl. XIX).

The lower Huronian, comprising the Mesnard quartzite, the Kiona dolomite, and the Wewe slate, is confined to the eastern thind of the district. At the time these rocks were depos-

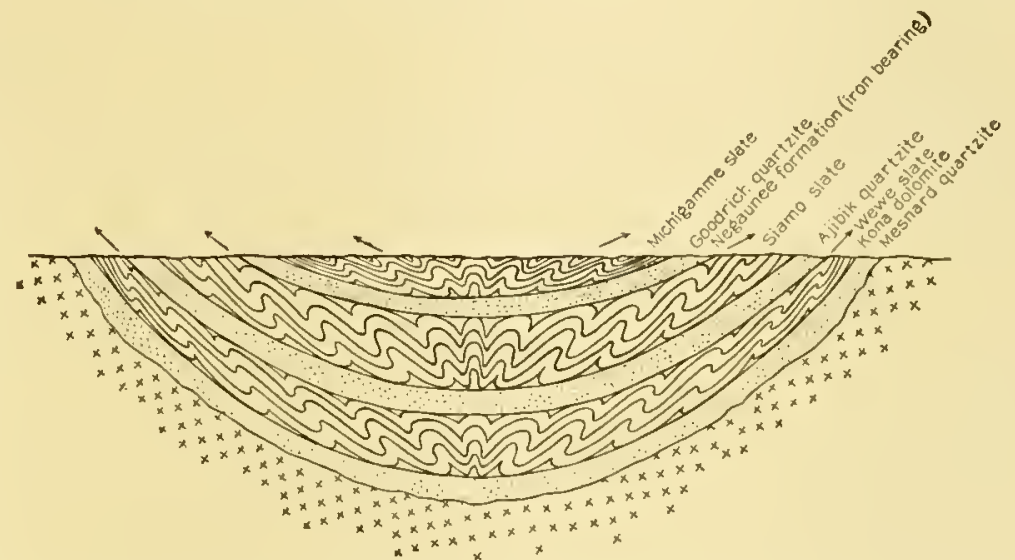

FIGURE 35.-Idealized north-south section through the Marquette district, showing abnormal type of synclinorium. The axial planes of the minor folds conterge downnward. The attitudes of the minor folls are determined by the differential movements in the mare competent strata indicaterl by arrows. In seneral the soft slate layers of the district are the ones hest illustrating the minor folds. The quarizite layers are more competent and therefore more simple in ontline.

ited either the western part of the district was not submerged or else the erosion following this period removed the rocks before the deposition of the succeeding miklle I Iuronian beds.

The middle and upper Huronian rocks west of the central part of the district are in linear belts, one following the other in regular order, but east of the central part of the district the distribution is less uniform and, because of the somewhat equal closeness of the north-south and east-west folds, some of the formations lose their linear character and cover eonsiderable areas.

The Marquette district is the type district for the Lake Superior Huronian in that it is the only district in which the upper, middle, and lower Huronian are well represented. Moreover, the unconformable relations between the middle and lower Huronian and between the middle and upper IIuronian are demonstrated by the clearest evidence, as is also the unconformity between the Huronian and the Archean.

\section{ARCHEAN SYSTEM.}

The rocks of the Archean system are so different in character from the Ituronian sediments that there is really no dilliculty in distinguishing between them. This diserimination was made by Brooks and Irving before it was known that an unconformity separated them. The

a Van Hise, C. R., Principles of North Ameriean pre-Cambrian geology: Sixteenth Ann. Rept. U. S. Geol. Sarvey. pt. 1, 1896, pp. 612, 615-621. 
Archean rocks are all crystalline, comprising both massive and schistose varieties. The different phases lave very intricate relations to one another as compared with the lluronian, and this led Irving to designate the whole mass as the "Basement Complex." The rocks of the Archean are divisible into two series, fiewatin and Laurentian. This was recognized before the International ('ommittee had agreed on the definitions of these terms and to the two dirisions were given the names "Marenisean" and Laurentian, as in the Gogebic distriet.

The northern area and southem area of Arehean will be separately described.

NORTHERN AREA.

KEEWATIN SERIES.

The Keewatin rocks of the northern area were described in the Marquette monograph under two divisions-the Mona schist and the Fitchi schist. The Monat schist comprises both basic and acidic varieties, the former being dominant. The basic sehists comprise both dense and handed forms. In color all are rarious shades of green. They belong to the general eliss which has been described by G. II. Williams ${ }^{a}$ as greenstone schists. The nineral constituents are mainly epidote, chlorite, hornblende, plagioclase (largely albite), leueoxene, quartz, and usually calcite. The chloritic and calcitic character of these sehists is rery widespread, persistent, and characteristic. In general the composition of the schists is very similar to that of basalts. The banded character of these rocks early led to the belief that they were waterarranged sediments, but the later studies have shown that while this is true in part they are largely, though not altogether, schistose basie flows and tuffs.

The basic Kitchi schist differs from the hasic Mona schist mainly in that it clearly shows an agcglomeratic and in some places a conglomeratic eharacter. This appearance is tryically shown at the old Deer Lake furnace. $A$ close study of the rocks of this area shows beyond all question that, while they are largely voleanic conglomerates, some of the material of these conglomerates has been worked orer by water into greenstone conglomerates. Where the material is comparatively fine they approach in appearanee the banded Mona schist.

The change from Mona to Kitchi schist takes place by the appearance of conglomeratic and agglomeratic bands in the Mona. There is reason to believe that the main mass of basic schists composing the Kitchi and Mona schists is the same formation, the main difference being that the Mona schist is more metamorphosed and probably contained a larger proportion of finer material.

In the areas of both the Mona and Fitchi schists are subordinate areas of acidic rocks which are largely sericite sehists. Whether these are contemporaneous with the basie sehists or are later intrnsives is not altogether clear.

In the area of Mona schist are small masses of ferruginous slate, ferruginous chert, and magnetite-grünerite schists which are identical in hand specimen and in microscopic character with similar rocks of the iron-bearing Negaunee formation. These appear in their best derelopment within the banded Mona schist adjacent to Lighthouse Point, but are found also in other localities, especially north of the old IIolyoke mine in sec. 2, T. 45 N., R. $27 \mathrm{~W}$. If these rocks are supposed to be of the same origin as the similar rocks of the Negaunee formation, and there is no eridence that they are not, they indicate the presence locally of conditions of nonclastic subaqueous serlimentation, and if this is so it is probable that much of the banded Mona schist. of this area las been extensively rearranged by water. Therefore, while these schists have the composition of an igneous rock, it is probable that they partly represent fine volcunic ash which lats been deposited in water and arranged by it without much assorting.

Near Mud Lake a series of green schists, graywackes, and slates interrenes between the typical Mona schist on the north and the IJuronian beds on the south. The intervening series is conglonerutic near its contact with the Mona schist and in turn is overlain unconformalhly by the Huronian series, with hasal conglomerate. These green sehists and slates look not 


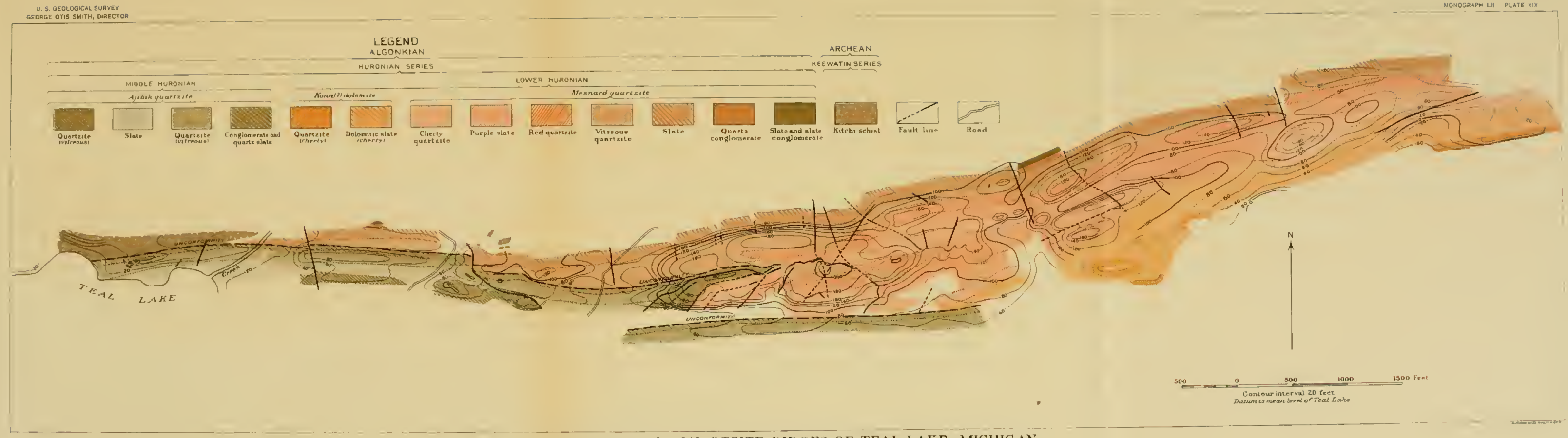

DETAILED MAP OF QUARTZITE RIDGES OF TEAL LAKE, MICHIGAN SHOWING FAULTING AND UXCONFORMITY OF AJIBIK QUTARTZITE
AND MESNARD QUARTZITE 

unlike some of the phases of Kitchi schist farther west, suggesting the possibility that the Kitrhi schist may be partly younger than the Mona schist and mny be locally more largely serlimentary than is apparent in the typical Mona schist area. Indeed, if mapped independently of other parts of the district, the green schists and slates between the Mona schist and the Mesnard quartzite of the Mud Lake area would be mapped as sedinentary, probably lying unconformably below the Furonian and unconformably upon the Mona sehist.

In conclusion it may be said that both the Mona and the Kitchi schists are dominantly igneous in origin, being mainly a set of lava flows and rolcanie fragments which fell upon water and were more or less arranged by it; locally subordinate anounts of material from other sources have been contributed.

\section{LAURENTIAN SERIES.}

The Laurentian rocks of the northern area comprise principally granites and gneissoid granites which include both liotite and muscovite granites. In general these rocks show a considerable amount of dynamie action and alteration, the schistose phases passing into rocks which may be called granitoid gneiss. In the western part of the district the Laurentian rocks are arjacent to the Huronian; in the eastern part between them and the IIuronian are interposed the Kitchi and Mona schists, into which the Laurentian rocks are batholithic intrusions. The boundary between the two sets of rocks is not sharp and defined. Numerous dikes and bosses of gramite are found in the schists along the border, and schist masses are included in the granite.

Another important variety of Laurentian rock is hornblende syenite, which is found in the eastern part of the area. This rock has the same relations to the schists as the granite. It differs from the granite in the absence of quartz, the primary constituents being orthoclase, plagioclase, sphene, magnetite, and biotite. The secondary produets, plagioclase, nicrocline, chlorite, quartz, epidote, muscovite, and lencoxene, have developed to some extent. The structure of the gneissoid syenites is the same as that of the gneissoid granites.

A third class of intrusive rocks in the Keewatin schists is peridotite. One well-known area of peridotite occurs at Presque Isle, but by far the largest area, between 4 and 5 miles in length, is in the central part of the district withim the Kitchi schist. These peridotites are very much altered, the olivine and diallage both being extensively serpentimized and magnetite, dolomite, and other usual products developing; also uralite and chlorite lave formed from the diallage. Incleed, in most of the specimens the olivine and diallage have entirely disapjeared and secondary products have taken their place.

\section{SOUTHERN AREA.}

'The southern area is composed domimantly of granites, granitoid gneiss, and gneissoid granites which are in most respects not different from the granites of the northern area. Schists are subordimate, but are found at several places. They include micaceous schists, chlorite schists, and amphibole schists similar to those of the northern area. The micaceous schists include muscovite schists, biotite schists, feldspathic biotite schists, and hornblende-biotite schists. They have nowhere sufficient extent to be mapped as formations separate irom the granites. The origin of these schists is not clear. Their foliation is secondary, due to mashing and recrystallization. In places they have a clastic appearance and may be, in part at least, sedimentary in origin. Between the diflerent varieties of schists there are of course grarlations. There is every reason to suppose that the chlorite schists and hornblende schists are similar in origin to like rocks of the northern area.

In the eastern part of the district soutlı of the Cascade range and bordering the Huronian is a narrow and distinct belt of Laurentian rocks which has been ealled the Palmer gneiss. It is a gneiss consisting dominantly of quartz with minor quantities of feldspar and mica, the origin of which is in doubt. Phases of it look like metamorphosed sediments; other parts seem to be 
the result of motamorphism of grranitic and pegmatitic rocks. On the carlier map of the listrict $a$ there were included in the west end of the Palmer inneiss belt certain metamorphice schists which have since been fouml to represent motumorphosed phases of the Siamo slate.

\section{ISOLATED AREAS OF ARCHEAN ROCKS.}

In the eastern part of the district, within the Algonkian, are small isulated areas of Archean rocks. These comprise granites, gneissoid granites, and greenstone schists in 110 respect differing from the corresponding rocks of the main northern and southern areas.

Intrusive in all the previously described rocks are dikes and bosses of diabase and diorite which are similar to those which intrude the Huronian rocks, and therefore are unch later in age. They do not properly belong with the Archean.

\section{ALGONIIAN STITEM.}

HURONIAN SERIES.

As already stated, the Huronian series in the Marquette distriet is divided into upper Huronian (Animikie group), middle Huronian, and lower Huronian.

LOWER IIURONIAN.

The lower Huronian consists, from the base upwarl, of the Mesnarl quartzite, the Fiona dolomite, and the Wewe slate. It has been pointed out that these formations appear only in the northeastern part of the distriet.

MESMARD QUARTZITE.

Tame and distribution.-The Mesnarl quartzite is so named because it composes the larger part of the mass of Mount Mesnard, south of Mirquette. The quartzite borders the Huromian rocks from a locality a short distance east of 'Teal Lake east to Lake Superior, thence south and west to a point 2 miles west of Goose Lake. Also patehes of Mesmard are found on the north margin of the Huronian rocks as far west as 2 miles west of Teal Lake. In the eastern part of the district the Mesnard quartzite is repeated by the appearance of a central anticline, so that in making a section north and south just west of Mount Mesnard four belts of the formation are found. The nature of the structure at this locality is shown by the section on Plate XVII (in pocket).

Lithology.-The Mesnard quartzite has three distinct members-a lower conglomerate, a central quartzite, and an upper shate. These members are not separately mapjed because exposures as a whole are not sufficicnt to make this possille.

The lower conglomerate member comprises ennglomerates with subordinate amounts of graywacke, graywacke slate, and quartzites, with all gradations between the different phases. Naturally the finer-grained varieties are more prevalent near the top of this member, and locilly a slate appears between the conglomerate and the quartzite.

The conglomerate adjacent to the southern granite has two different phases. The common phase is a coarse granite conglomerate, but locally the granite of the Archean seems to have been disintegrated so that it yielded indiridual grains of quartz, feldspar, and mica. Where this was the case the recomposed ruck very clusely resembles the original granite. This is especially true where the two together have been anamorphosed to schists. Indeed, at such places it is lifficult to place the exact line between the two formations.

The eonglomerates adjacont to the northern Arehean bear detritus both from the granite and from the Hona schist and therefore carry pebbles and bowhers from both of these formations. The granite pebbles comprise coarse-grained muscovite granite and fine-grainml granite. The pehbles from the Mona schist inchude various kinds of greenstone schists and chloritie sehists idhentical with the phases of the Mona schist, so that there can be no drulbt an to the? soure of the material. 
The second member, constituting the great mass of the formation, is dominantly a pure vitreous quartzite, although locally there are feldspathic quartzites and fine-grained conglomerates. In this bolt is one layer of conglomerate in which cherty jusper, quartz, and ferruginous schist pebbles are characteristic. For the most part the quartzite is indurated by cementation. Toward the top the quartzite member becomes slaty and finally passes into a graywacke slate. This rock is from less than 30 to about 100 fect thick and is in lact a transition pelite member between the quartzite and the Kinna dolomite.

Metamorphism.- The Mesnard quartzite as a whole has been much mashed, and the result is that the conglomerates, quartzites, and graywackes inclule rocks varying from those which are indurated mainly by siliceous cementation to those which are crystalline schists. Some of the rocks have been much shattered, the shat tering extending to the inlividual grains. The ojenings which have been formed by the shattering have been cemented mainly by quartz and by iron oxide. So pervasive have been the dynamic effects that not a single clastic grain has escaper. Where the pressure has been the least undulatory extinction is shown by the quartz grains. A large portion of the quartz grains have been sliced by parallel fractures, some in one clirection, sone in two directions at right angles to each other. Where the formation is feldspatlic the feldspars have very extensively altered into sericite and quartz. In places where the metamorphism is extreme the formation is transformed into a sericite schist by granulation and recrystallization. The schistose varieties of the rocks are especially previlent along the southern border of the southern conglomerate adjacent to the granite.

Partial analyses of the massive Mlesnard quartzite and the schistose phase along its contact with underlying formations are given below:

Analyses of massive and schistose Mrsnard quartzite.

[Analyst, R. D. 1Ia]l, University of Wisconsia.]

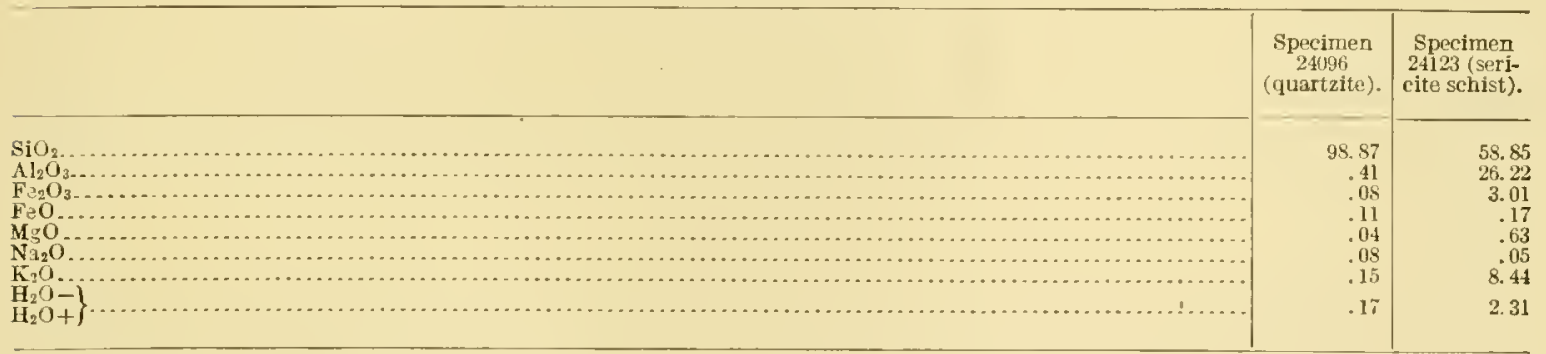

Apparently the principal result of the develojment of schistose structure has been the loss of soda and silica and ferrous iron. Alumina, potassa, ferric iron, water, and magnesia have remained in nearly constant and mutual proportions. This change is similar in all respects to one shown by the Waterloo quartzite of southern Wisconsin. It is believed to be one due to metamorphism, but the possibility can not be excluded that the dilferences are partly those of original composition.

Relations to adjacent formations. - The conglomerates at the base of the Mesnard quartzite, here arljacent to the Laurentian granite, there next to the schists of the Reewatin, show that between the Arehean and the Mesnard there is a very great unconformity. It is clear that the complex history of the Archean was practically complete before the Mesnard quartzite was deposited. The Keewatin schists had been intruded and metamorphosed by the granites and the two together had been deeply truncated before the Mesnard was laid down. One of the conglomerates at the hase of the Mesnard is especially interesting, in that it was the first in which the clear evidence of unconformity was found. This contact is north of Mud Lake and along an old road known as the State road, and the conglomerate has sometimes been callerl the "State Road" conglomerate. Since the discovery of this contact other contacts hare been found along the southern belt of Mesnard at a score of places. The conglomerates adjacent

$$
47517^{\circ}-\text { VOL } 52-11-17
$$


to them are splendid granite conglomerates, many of which contain great well-waterworn bowlders of granite.

On the knobs northeast of the southeast end of Goose Lake quartzite mapped as Mesnard is found to lie directly upon the Kona dolomite. The quartzite with this relation may be an interstratifiel layer in the Fona dolonite similar to quartzite layers seen in this formation in the Mount Choeolay seetion. The boundary between the quartzite overlying the Fona dolomite in this locality and the true Mesnard quartzite is not known.

Thiekness.-As the Ilesnard quartzite was the first formation of a transyressing sea, it naturally varies in thiekness owing to the irregularities of the basement upon which it was deposited. 'The thickness ranges from 150 feet to nearly 700 feet.

RONA DOLOMTE.

Name and distribution. - The Kona clolomite is given the name Kona from the prominent hills of that name east of Goose Lake, where it is exposed.

This formation, like the Mesnard quartzite, is confined to the ensteru part of the district. In distribution it constitutes a westward-faeing $U$, the arms of which terminate a short clistance east of Teal Lake on the north and at the east shore of Goose Lake on the south.

The exposures commonly constitute a set of sharp and abrupt eliffs eut by ravines or separated by drift-filled ralleys. The formation very well illustrates the eomplex folding of the district. In some places the north-south folds are the more prominent, but more generally the east-west folds are dominant.

Lithology.-The Kiona formation is dominantly a dolomite, but interstratified with this are layers of slate, graywacke, and quartzite with all gradations between the mechanieal sediments and the pure dolomites. Thus there are finely crystalline dolomite, dherty dolomite, quartzose dolomite, argillaceous dolomite, dolomitic quartzites, dolomitic slates, dolomitie cherty quartzites, and dolomitie ehert. The dolomite beds range in thickness from a few inclies to many feet, but even the most dolomitic beds contain thin cherty layers, mingled with which in some places is elastie material. In color the rocks rary from pink and red to dark brown. Beeause of the impurities of the dolomite the weathered surface has very characteristically a jagged appearanee, due to the solution of the dolomite and the consequent protrusion of siliceous phases.

Metamorphism.-The rlolomite has usually yielded to the folding without prominent fractures or clearige, but it has suffered a minute shattering and is eemented by finely erystalline quartz or coarsely erystalline dolomite, or the two combined. The slate layers usually lave a slaty eleavage and many of the graywacke, quartz, and eherty quartz layers are breceiated. These breccias where selistose are diflicult to distinguish from conglomerates. The completeness of this shattering and breceiation was appreeiated only by a study of the thin sections, where every one of the numerous slides shows the phenomena mentioned to a greater or less extent. Not a half-ineh eube has escaped.

Relations to adjacent formations.- The Kona dolomite grades into the Mesnard quartzite below. Above, by a lessening of the calcareous constituent, it gradually passes into the Wewe slate.

Thichness.-Because of the complicated folding of the Kona dolomite it is diffieult to give an aceurate estimate of its thirkness, which probably raries greatly. In some places it seems to he a comparatively thin formation, not more than 200 to 250 feet thick. In other places where the whole formation is well exposed it appears to be 650 or 700 feet thick, and it may be thicker than this.

WEWE SLATE.

Distribution.-The Wewe slate, like the Mesmarl quartzite and Fona dolomite, is confuned to the east end of the district, making a westwarl-facing $U$. The slate, heing a less resistant formation than the Kona dolonite below or the Ajibik quartzite above, is in general marked by valleys, and consequently the exposures are few. 
Lithology.--The Wewe slate was a pelite formation evidently varying in its character from a fine mud to a course sandy mud with numerous alteration phases. Is a result of the conpreting and modification of these beds the formation is now a slate, shale, novaculite, and graywacke. The color of these rocks varies from red to black, depending on the quantity and conditions of the iron oxide.

Metamorphism. - In consequence of the folding and metamorphism the slates have developed a cleavage. The rock locally has been sulliciently metamorphosed to become a mica slate and even to approach a mica schist, but usually the alteration has not gone sulliciently far to obliterate the belling.

The rocks have been commonly fractured parallel to the bedding or to the secondary structures which intersect the bedling. At some localities fracturing has loen sufficiently powerful to shatter the rocks throughout, or even to produce friction breccias. Where further movements have rounded the fragments of the breccia the rock becomes a pseudoconglomerate. The openings which have been produced by the fracturing have been cemented by cquartz, by hematite, and by a jaspery mixture of the two. In some places these varieties of material follow one another and locally the amount of hematite in the breccia is so great as to have led to prospecting of the formation for iron ore.

Relations to adjacent formations.--It has been pointed out that the Kiona dolomite grades into the Wewe slate by a clisappearance of the calcareous material. The Wewe slate is overlain unconformably by the Ajibik quartzite. The evidence of this unconformity will be given under the description of the latter formution.

Thickness.-In one place, where there is an almost continuous exposure of slate, the thickness is calculated at 1,050 feet, but it is entirely probable that there are here subordinate rolls. The real thickness of the slate is doubtless much less than this. $\Lambda$ t one place, indeed, the thickness of the formation loes not appear to be more than 100 feet.

\section{MIDDLE HURONIAN.}

The middle ITuronian of the Marquette district comprises the Ajibik quartzite, the Siamo slate, and the iron-bearing Negaunee formation.

\section{AJIBIE QUARTZITE.}

Name and distribution.-The Ajibik quartzite is so named because the predominant rock is quartzite and because typical exposures of it oceur on the bold Ajibik Hills northeast of Palmer.

The distribution of the Ajibik quartzite is practically coextensive with the outlines of the Marquette district. For all of the area west of Negaunee it is the Huronian formation which rests against the Archean. For the area east of Negaunee it is separated from the Arehean by the lower Huronian rocks already described. Along the south side of the district the formation is very thin, locally not more than a few feet. The Ajibik quartzite, being a resistant formation, is for the most part well exposed and at various places it constitutes promment blufls-as, for instance, east of Teal Lake.

Deformation.-In general the folding of the Ajibik is that of a great synclinorimn, the dips being south from the great northern belt and north from the southem belt. The Cascade trough, the Republic trough, and sonthwestern arms at the west end of the district constitute subordinate synclinoria. In detail, as at Broken Blufts, there is secondary infolding of the formation with isoclinal dips.

The formation is lisplaced by at least three great faults - that of Carp River, the east-west throw of which apparently amounts to as much as 3,000 feet; the fault along the south side of the Ajibik Fills, the throw of which is apparently several thousand feet; and the fault at the Volunteer mine, which again apparently has a horizontal throw of 2,000 feet or more. In addition to these there are a number of minor faults east of Teal Lake, the character of which is indicated by Plate XIX (p. 254). 
Lithology.-Petrographically the Ajibik formation has two facies-conglomerate, which is in sulordinate anount and is at the bottom of the formation, and quartzite, which constitutes the major portion of the formation. Associated with the conglomerates are interstratified slates and graywackes.

The congloneratic phase has two main areas-a westem one in which it rests directly upon the Arediean and an eastern one in which it is underlain by lower Huronian rocks. Where the formation rests directly upon the Archean its basal part is a conglonerate or recomposed rock, the material of which is derivel mainly from the rocks immediately subjacent. This conglomerate varies from place to phace as the subjacent rock varies. In general it is a granite conglomerate. In the Cascade range such material is derived from the Palmer gneiss and other igneous formations, and near the Kitchi schist the material is mainly derived from that formation. In the eastern part of the district the $A$ jibik quartzite rests upon the Wewe slate, somewhat farther west upon the Kona dolonite, and still farther west upon the Mesnard quartzite- that is, it cuts diagonally across these three formations. This applies to both its northern and its southem arms. As would be expecterl from this relation, the conglomerate at the hottom of the formation in this area contains dominantly débris from the lower Huronian, but inclucles also material from the irchean.

The basal conglomerates, slates, and graywackes are usually of only moderate thickness, although the congloneratic beds are persistent. These rocks grade up into quartzite.

Mctamorphism.-The major portion of the formation was a quartz sand. By cementation, dynamic action, and recrystallization it has now been transformed to many rarieties, of which normal quartzite, cherty quart zite, fermginous quartzite, ferruginous cherty quartzite, quartz rocks, quartzite breccia, and quartz schists, in places sericitic, are the more promment. The predominant phase is a trpical rather pure ritreous quartzite, which locally is conglomeratic. This least-altered variety of the quartzite is composed almost wholly of rounded grains of quartz of somewhat uniform size, which are beautifully enlarged, the enlargements filling the interspaces. The grains uniformly show undulatory extinction, and some of them are distinctly fractured. From this rariety there are all gradations to the other forms mentioned.

Locally interstratified with the quartzite were mud beds which now have become graywacke slate, mica slate, or mica schist. The micaceous varieties of the rock are especinlly abundant where the psammite was feldspathic, the feldspar altering into mica and quartzor into chlorite and quartz. It the west end of the district, especially in the Republic and Western tongues, the mashing has been so great as to transform the rock to a quartz schist, and where the psammite wis impure there were dereloped typical biotite schists, muscorite schists. and chlorite schists, which are in places gametiferous.

In their very general brecciation, with consequent abundance of pseudoconglomerates: in the secondary reining, both with coarsely and finely crystalline quartz; and in the large quantity of secondary hematite and magnetite, these quartzites difler from the Goodrich quartzite of the upper I Iuronian.

Relations to adjacent formations.-The Ajibik quartzite rests upon both the Archean and the lower Iuronian unconformably. The uneonformity between the Ajibik quartzite and the Archean is conspicuous and was earls recognized, but the unconformable relation between the Ajibik and the lower Huronian was overlooked at the time the Marquette monograph was written. The eareful mapping and studies of Seaman in the eastem part of the district showed the true relation.

It has already heen pointed out that in going from the east end of the Ajibik westward it is found at first in 'ontact with the Wewe slate, next with the Kona dolomite, next with the Mesnard quartzito, which thine westwarl to an edge. West of the last outcrops of Mesnaril quartzite the Ajilik is in contact with the lieewatin, Litehi schist, and with Laurentian rocks. Thus it cuts diagonally aresse the beseded erlges of formations varying in age from Wewe to Keewatin. These relations. fogether with the presence of conglomerates at the base which bear débris from the lower lluminim, show that the lower Huronian was sulliciently indurated 
to yield fragments to the $\Lambda$ jilik before the deposition of that formation. The alsence of the lower Huronian in the western part of the clistrict is doubtless largely if not wholly due to its remoral by erosion between the time of the Wewe slate and the deposition of the Ajibik quartzite.

Where mashing and metamorphism have been sufficient to transform the conglomerate into a schist the Archean has been similarly metamorphosed; consequently the Ajibik quartzite apparently grates down into the Archean.

The $A$ jibik quartzite in the northem belt and in the eastern part of the district grades upward into the Siamo slate. This change takes place by a gradual transition of the psammite into a pelite formation. In the southern belt the Siamo slate is atosent and the Ajibik quartzite grades into the Negaunee formation. This gradation may be particularly well seen in the Cascade area.

Thickness.-The best opportunity to determine the thickness of the formation is at the east end of the $U$, where the apparently secondary folding is alsent. Here the thickness appears to be about 700 to 750 feet. Along the south side of the district the formation thins to a few feet.

\section{SIAMO SLATE.}

Name and distribution.-The Siamo slate is so called because abundant and typical exposures occur on the Siamo Ilills southwest of Teal Lake. The formation appears at the northwestem part of the district, north of the Michigamme mine, and extends in a continuous belt of varying width to a point northeast of Negannee. Here, owing to the cmoe shape of the eastern part of the district, it widens out to broad irregular areas with several arms between the Ajibik quartzite and the Negaunee formation. There is no southern belt of Siamo slate corresponding to the northern belt. The slate, being a soft lormation, is not well exposed, but where it is metamoryhosed into a mica slate or where it is a coarse graywacke ledges are numerous.

Deformation.-The folding of the formation as a whole corresponds to that of the district. In detail it is more complex than that of the associated quartzites. The northern belt, with southern dip, has superimposed upon it isoclinal folds of the second order. In the eastern part of the district, where the broad area of Siamo slate is situated, the formation is folded into a series of rolls, indicated by the sinuous contact between the Siamo and Negaunee formations. The westward-projecting salients of the Siamo constitute the crests of anticlines and the reentrants are the synclines.

Lithology. - The rocks of the Siamo formation are dark gray or greenish gray and some of the coarser are light gray. They vary from a coarse-grained graywacke, approaching a quartzite, through massive graywacke to a very fine grained slate. The slates and fine-grained graywackes are the predominant phases. The finer-grained varieties are in many places affected by slaty cleavage, which is rather uniform in clirection for a given area and thus traverses the becking. Locally morements later than the development of the cleavage have resulted in many partings along this secondary structure, giving the rock a fissility.

The less-alt ered siamo rocks are composed mainly of well-rounded grains of quartz, a few of them finely complex and cherty looking, and of grains of foklspar, between which is a sparse matrix consisting of chlorite, biotite, muscovite, fincly crystalline quiltz, and more or less iron oxide. Usually the chlorite predominates over the muscovite and biotite, but in some of the rocks the micas are as abundant as the chlorite. Some of the quartz grains are distinctly enlarged. Iost of them show pressure effects by undulatory extinction and fracturing, the fractures being locally arranged in a rectangular system. The feldspars comprise orthoclase, microcline, and plagioclase, in places changed into chlorite and quartz, liotite and quartz, or muscovite.

Iletamorplism.-The mineral alterations have been uoted. In proportion as there is dynamic action there is a tendency for secondary leaflets of the chlorite, hiotite, and muscovite to have a parallel arrangement. Where this is well advanced there is also gramulation of the larger quartz grains, and the secondary quartz may become as coarsely erystalline as the original quartz. Where all these changes have gone far the rock becomes a mica slate or a mica 
schist. The process of development thus briefly outlined is the same as for the Tyler slate of the Penoke-Gogebic district, cleseribed in another place. (Soe pp. 232-233.)

Other phases of the Siamo rocks exhibit very woll a fracture or slip cleavage which may be in only a single direction parallel to the bedding, or in two directions interseding at angles varying from nearly right angles where the pressure has been least to acute angles where it has been strong. Tn thin section the latter rock has an appearance tike that of a drawn-out net.

The largest areas of mira schist, representing the most adranced phase of metamenplism of the formation, lie north of Nichigamme. The greater motamorphism of this part of the formation is attributed to the large masses of intrusive greenstone which have been introluced romghly parallel to the contact of the Siamo state and the Negannee formation. Other considcrable masses of greenstone are also found within the area of the Simmo. Evidence of the metamorphic effect of the greonstone is afforded by numerous large secomdary erystals of lumblente in the slate atjacent to the larger masses of greenstone.

Relations to adjacent formations. - At the upper and lower horizons the slates tend to become ferruginous. In these phases there is present a considerable quantity of iron oxile, generally lematite but in many places magnetite. In the upper part of the formation especially these forruginous shates have interlaminated layers of material similar to the ferruginous and sideritie slates and cherts and grünerite-magnetite sehists of the Negannee formation. 'The Ajibik quartzite grades up into the Siamo slate. It is apparent from the appearanee of interlaminated layers of material like the Negaunee formation in the upper parts of the Siamo slate that the transition into the Negaunce is a gradation by interstratification. The fragmental sediments gradually die out and nonfragment al sediments become dominant; this change takes place irregularly, producing interstratifieation of the two forms of sediments.

Thichess. - The area perhaps most farorable for letermining the thickness of the siamo slate is that adjacent to Teal Lake. If the formation were there assumed to be monoclinal. the thickness would be from 1,250 feet to 1,300 feet, but as there are an unknown number of sul)orlinate rolls at this locality, and slaty cleavage has dereloped, it is probable that the real thickness of the formation is not more than half of this amount.

\section{NEGAUNEE FORMATYON.}

Name and distribution. - The prineipal iron-bearing formation of the Marquette district is mamed Negaunce beeause in the town of that name and to the south are typical exposures of the formation.

The Negaunee formation extends from the northwest end of the district along the north side of the IIuronian to the north side of Michigamme Lake. From this place castwart for a distance of 5 miles the formation is eut out by the umeonformity at the base of the Lpper Huronian. Near Ishpeming it widens out into a broad area and occujies a large portion of the famous T. 47 N., R. 27 W., and also a considerable portion of T. 47 N., R. 26 W. From this broal area a short southern arm, known as the Caseade range, extents to the east and a long arm to the west along the south side of the $\Lambda$ gonkian; the fomation is found also on both sides of the Republic and sonthwestern ams. In the western part of the main southern belt and in the Repullic and southwestern arms the formation is apparently absent for clistances rarying from a fraction of a mile to several miles. It is believerl this lack of continuity is due to the fact that the Negaume formation was completely remored by erosion before the deposition of the upper Ifuronian (Animikir group).

Deformation. - The two long arms of the iron-bearing formation of the main bolt, as well as the two belts of iron-bearing formation in the Republic and southwestem betts, are the two sides of a synetinorium. The two main arms join in the large area of Negannee at Ishpeming, slowing that it also is in a broal way an east-west synelinorimm. This trougl pitedes to the west. 'Tlus the lower members of the Negaunce formation outerop on the cast adjacent to the Siamo slate and the higher members out crop on the west adjacent to the Goofrich quartzite. The smuous contacts between the Negannee and the formations above and behw capress its folding. 
The salients to the east into the Siamo slate represent synclines and the reentrants anticlines; the salients to the west into the Goodrich quartzite represent anticlines and the reentrants synclines. The Palmer belt of the Negaunee formation, extending from the main area as a southeastern arm, is also a syuclinal fold, which ends to the east in a canoe witl a westward piteh. The structure of this syncline is modified by a great fault along the south side of the Ajibik Hills and by faulting at the Volunteer mine.

Lithology, including metamorphism.-Petrographically the iron-bearing formation comprises sideritic slates, which may be grïneritie, magnetitic, hematitic, or limonitic; grüneritemagnetite schists; ferruginous slates; forruginous cherts; jaspilite, and iron ores. The fermginous cherts and jaspilite are commonly brecciated, the other kinds less eommonly.

The sideritic slates are most abundant in the valleys between the grecnstone masses in the large area south of Ishpeming and Negaunee. These rocks are regularly laninated, are fine grained, and when unaltered are of a dull-gray color. The purest plases of them are approximately cherty iron carbonate, as shown by two analyses made by George Steiger in the laboratory of the Survey. It is unusual to find exposures of the cherty siderite slates which have not been more or less affected by deep-seated alteration or by weathering processes. The iron calrbonates pass by gradations, on the one hand into grünerite-magnetite schists and on the other into ferruginous slates, ferruginous chert, jasper, or iron ore.

The grünerite-magnetite schists consist of alternating bands composel of rarying proportions of the minerals gr ünerite and magnetite and quartz. Where least modified they hare a structure precisely tike the sideritic slates from which they grade, the grounerite-magnetite belts having taken the place of the carbonate bands. In some places the grüncrite-magnctite schists are minutely banded, the alternate bands consisting of dense green grïnerite and white or gray chert, with but a small quantity of magnetite. Certain important kinds appear to be conposed almost altogether of grünerite, with a little magnetite. In woneral the grüneritemagnetite schists are fonnd at low horizons, below the ferruginous chert and jaspilite-that is, at or near the same horizon as the sideritic slates. In many places also they are below intrusive masses of greenstone.

By oxidation of the iron carbonate the sideritic slates pass into the ferruginous slates, the iron oxide being hematite or limonite, or both. These rocks, in regularity of lamination and in structure, are similar to the sideritic slates, differing from them mainly in the fact that the iron is present as oxide. In the different ledges may be seen every possible stage of change from the sideritic slates to the ferrucinous slates. The only necessary change is a loss of carbon dioxide and oxidation of the iron. On weathered surfaees, along veins, and along some of the bedding planes the transformation may be complete, and between this material and the original rock there are numerous gradations.

From the oxilation of the less slaty phases of the sideritic rocks result the ferruginous cherts, consisting mainly of alternating layers of chert and iron oxide, although the iron oxide bands contain chert and the chert bands contain iron oxide (PI. XXXIII, B, p. 466). This iron oxicle is mainly hematite, but both limonite and magnetite are locally present. Rarely magnetite is the predominant oxide of iron. In such places the silica is usually coarsely erystalline. The rocks are folded in a complicated fashion, as a result of which the layers present an extremely contorted appearance. Many of the folderl layers show minor faulting. On account of the exceedingly brittle character of these rocks, they are very eommonly broken through and through, and some of them pass into friction breccias. In places the shearing of the fragments over one another has been so severe as to produce a conglomeratic aspect. The ferruginous eherts are particularly abundant in the middle and lower parts of the iron-bearing formation, just above or in contact with the greenstone masses. In a number of places they are between the gräneritemagnetite schists or sideritic slates below and the jaspilite above. The rocks here named ferruginous chert are called by the miners "soft-ore jasper" to thiscriminate them from the "hard-ore jasper," or jaspilite, because within or associated with them are found the soft ores of the district. 
The jaspilites ronsist of alternate bands composed mainly of fincly rerystalline, iron-stained quartz and iron axide (Pl. XXXII, p. 464). The exposures present a brillinht appearance, due to the interlamination of the bright-rerl jasper and the dark-resl or black iron oxides. The iron oxide is mainly hematite and includes both red and specular varieties, but magnetite is commonly present. Many of the jasper hands have oval terminations or die ont in an irregular manner. The folding, faulting, and breceiation of the jaspilites are precisely like those of the ferruginous chert, cacept that in the jaspilite they are more severe. The interstices produced by the dynamic action are largely cemented with crystalline hematite, but magnetito is present in subordinate quantity. In the folding of the rock the readjustment has occurred mainly in the iron oxide betwecin the jasper bands. As a result of this the iron oxide has been slieared, and when a specimen is cleaved along a layer it presents a brilliant micaceous appearance; such ore has been called micaceous hematite. This sheared hustrous hematite, present as some form of iron oxide bofore the dymanic movement, is discriminated with the naked eye or with the lens from the latel cristal-outlined hematite and magnetite which fill the cracks in the jasper bands and the spaces between the sheared lamina of hematite. The jaspilite differs mainly from the ferruginous chert, with which it is closely associated, in that the siliceous bands of the jaspilite are stained a bright red by hematite, and the bands of ore between them are mainly specular hematite, whereas in the cherts the iron oxide is earthy hematite. The jaspilite in its typical form, whenever present, usually occupies one horizon-the present stratigraphic top of the iron-bearing formation, just below the Gooḍich quartzite. In different parts of the district it has a varying thickness. With this jasper, or just above it, are the hard iron ores of the district; hence it has been called "hard-ore jasper" by the miners to discriminate it from the ferruginous chert, or "solt-ore jasper."

Relations to adjacent formations. - The iron-bearing formation rests conformably upon the Siamo slate or upon the Ajibik quartzite and grades downward into one or the other of these formations through the increase of clastic material and a lessening of the ferruginous constituents. The gradation may occur within a few feet or may require 100 feet or more. The transition is accomplished ly interlaminations of material which are alternatively chiefly fragmental and chiefly nonfragmental.

The overlying formation, the Goodrich quartzite, rests unconformably upon the Negaunee formation. The amount of folding and erosion of the Negannee formation accomplished before the Goodrich quartzite was deposited dilfers in different parts of the distriet. In some places the crosion has gone so far as to have removed the iron formation entirely. It therefore follows that the contact between the two formations is here at one horizon of the iron-bearing formation and there at another, ranging from the highest known horizon to the lowest.

Thichness.-It is evilent from these relations that the thickness of the formation raries from practically nothing to its maximum. It is, however, difficult to estimate this maximum because of the pervasiveness of the intrusive rocks in the Negaunee. It is ronghly estimated that in the broad area to the east of Islupeming and Negaunee the thickness may be considerably above 1,000 feet, although it is cutirely probable that the maximum thickness is less than this amount.

Intrusive aml eruptive rocks. - Within the iron-bearing formation there are mmerous intrusive misses of "greenstone," really diabase and its altered equivalents. These ocmur in the form of both dikes and bosses, and many of the latter are of large size, suming up to masses 2 miles or more in extent. 'These rocks are especially prevalent in the broad area of the iron-bearing formation near Ishpeming, where they occupy between one-third and one-half of the area. In many plaees the greenstones intrule the sedimentary series in a roughly laccolithic fashion. In consequence of this, where the two have been folded together their relations are roughly similar to those of sedinentary formations, but when examined closely the greenstones are always found to cut the Negaunee formation to a lesacr or greater dewree.

surlace eruptive rocks also appear in the formation in the vicinity of Clarksburg. (See p. 268.) 
UPPEL IIUIRONIAN (ANIMIKIE GROUP).

The upper Huronian is structurally divisible into a lower belt of conglomerate and quartzr ite, called the Goodrich quartzite, a belt of ferruginous rocks called the Bijiki schist, a belt of slate and schist known as the Michigamme slate, and, to the south, a mass of volcanie rocks called the Clarksburg formation. The Animilie group as a whole occupies the center of the main Algonkinn strnclinorium from Ishpeming to the west end of the distriet. In this part of the region it is the chicf surface rock, occupying all the area between the belts of the Negaunce formation.

\section{GOODRICH QUARTZITE.}

Distribution and structure.-The belt of Goodlich quartzite forms a westward-opening $U$, bordered on the outside principally by the Negaunee formation, with its eastern margin near the city of Ishpeming. The folding is similar to that of the Negannee formation, though somewhat less complex. The sinuous contact of the two formations in the vicinity of Ishpeming expresses the complexity of lolding at this end of the synctinorium.

Lithology, ineluding metamorphism.-Petrographically the Goodrich is dominantly a quartzite, although usually there is a conglomerate at the base. As the underlying rock is in most places the Negamee formation this conglomerate is an ore, chert, jasper, and quartz conglomerate. Where the conglomerate is near the Archean this system may furnish material for it-as, for instance, at Palmer, where there are numerous granite, greenstone, and schist. bowklers derived from the Archean.

Where the conglomerate is ore, chert, and jasper conglomerate immediately in contact with the Negaunce formation, the particles have been flattened and schistosity has developed in both the conglomerate and the original basement rock, making it difficult to place the exact line between the two formations. This is illustrated at IImmbolelt. At several localities the conglomerate resting upon the Negaunee formation has had quartz leached out and hematite and magnetite deposited, developing a material rich enough in iron to be an ore. This is illustrated at the Goodrich and Tolunteer mines. The quartzite is mainly quartz but contains many particles of chert and jasper and usually considerable amounts of feldspar. Cementation loy enlargement is an important process in the induration of the rock. In the eastern part of the district dynamic action has not usually been great enough to give the particles more than undulatory extinction, or at most fracturing. Howerer, these eftects are pervasive, not a single clastic particle escaping. The mashing in the central and western parts of the district has been severe and the formation has been transformed to a schist. In the western part of the district, especially in the Republic trough, the alterations have been so great as to transform the feldspathic quartz rocks into micaceous quartz schists, or locally, where the mica is sufficiently abundant, into muscovite-biotite schists or biotite schists. In this change the feldspar has usually altered into quartz and mica, including both muscovite and biotite, especially muscovite.

Relations to adjaeent formations. - The Goodrich quartzite rests unconformably upon the Negaunee formation. The evilence of this unconformity consists both in the discordance of strike and dip, varying from a few degrees up to perpendicularity, as at the Goodrich mine, and in the existence of conglomerates derived from the Negaunee formation at scores of localities along the contact. At many places, as has already been pointed out, the erosion between Negaunee and Goodrich time cut through the Negance formation. In these places the material of the Goodrich quartzite comes from the underlying formations, the Ajibik quartzite or the rocks of the Archean. There are few Lake Superior formations that have a more complete set of conglomerates at the hase or that have clearer proof of unconformity with the rocks upon which they rest. The Goodrich quartzite, by the diminution of coarse fragmental quartz, grades above into the Michigamme slate, the Bijiki schist, or the Clarksburg formation. The nature of each gradation will be mentioned in connection with these formations.

Thickness.-The thickness of the Goodrich quartzite varies greatly lirom place to place. At the Goodrich mine it is calculated to be as great as 1,500 feet, but this is probably much berond the average for the district. 
BIJIKI SCHIST.

Name and distribution. - The Bijiki sehist is given this nume because typieal exprosures orenr near the mouth of Bijiki River. It is confinel to three narrow belts in the northwestern part of the district. North of the northernmost of these beds is the Goodrich quart rite and betwern the north and midlle bedts is the Miehigamme slate. These two helts makr a synclinal strueture. The middle and southern bolts mite at the cast and represent the out (orop of an eroderl anticline.

Lithology, induding metamorphism.--Litholugieally the Bijiki schist comprise's two main varioties, one of which is characteristic of the enstern part of the bolts and the other of the western part.

In the eastern part the least-altered plases consist of a sideritic chert interbedded with the Michigamme slate and probably representing a slightly hicher horizon than the phase of the Bijiki schist described in the following paragrajl. . Fot uncommonly the siderite is the predominating.constituent. This slate has been cxtensively altered by weathering and metasomatic changes into ferruginous shates and ferruginous cherts, with subordinate amounts of grinnerite-magnetite schist. In a few localities, where the ferruginous material is rery abuudant and the conditions of deposition are farorable, small ore bodies have been found. These are illustrated by the North Phenix, Pascoe, Iortense, Northampton, Marine, Plienix, and Bessie deposits. These ores diller from the soft ores of the Tegamee formation in that the irm oxide is largely limonite and the associated slates are carbonaceous and graphitic.

In the western area, which contains the chief exposmes of the formation, the Bijiki is dominantly a banded grünerite-magnetite schist. This rock consists mainly of three minerals-quartz, grïnerite, and magnetite. Ilere and there a small amount of residual siderite is seen. The rock is discriminated from the grünerite-magnetite schists of the Negannee formation chiefly by its exceeding toughness and the difliculty with which it is broken parallel to the stratification.

One of the most conspienous mineralocieal features of the iron-bearing Bijiki formation near Miehigamme is its content of large garnets, up to 2 inches in diameter, dereloped late in the metamorphism. These have been apparently altered to chlorite and amphibute, early deseribed by Pumpelly as chlorite psendomorphs after garnet. ${ }^{a}$ Microseopic examination shows that although much of the matrix material is ehlorite, the garnet is largely replaced by green amphibole and magnetite. Porphyritic biotite in a chloritic matrix is also a rery conspienous mineralogical feature of these rocks, giving them in the hand specimen a brilliantly spangled appearance. The garnet may be really a poikilitic development later than chlorite.

The two chief phases of the Bijiki schist may be in part at separate horizons, but there secm also to be gralations between the fermurinous slates and cherts and the grünerite-magnetite schist. Is the schists are largely confined to the western parts of the bolts, where there are important masses of intrusive igneous rocks, and occur in the part of the district where the Xaganee formation is also changed to a grünerite-magnetite schist, it is believed that the schist represents the origrinal sideritie formation altered under the influence of igneous rocks while deeply buried and largely by the process of silication, whereas the eastern part of the formation, consisting of ferruginous slates and cherts and containing ore bodies, was altered after the formation was axposed at the surface, later than upper IInmian time, by the proc(wsics of weatheringe.

Rilations to adjacent rocks.--Along the northern belt where the buse of the Bijili seluist is exposed, romeded fragmental quartz appears near the butom of the formation, and with an increase of this material the member grades downward into the Goodrich quartzite. The Bijiki schist grades above into the Hichigamme slate.

In the contral and eastern garts of the Mlarquette district the Bijili has not been deterted. Apparently in the greater portion of the district hetwen the time of the Goodrich quantzite

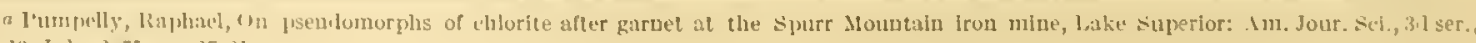

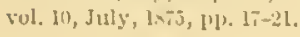


and the Michigamme slate the conditions were not farorable for the deposition of the ironbearing formation.

The iron-bearing Bijiki sehist, though not thick or economically of as great consequence as the Negaunee, is of considerable signifieance in the matter of correlation, for it oceurs at the same horizon as an important iron-bearing formation in other districts-notably the Menominer, Gogebic, and Mesabi.

Thickness.-The Bijiki sehist apparently has a maximum thiekness of alrout 520 feet and from this it ranges down to the disappearing point.

\section{MICHIGAMME SLATE.}

Name, distribution, and correlation.-The name Miehigamme is given to the upper slate and mica schist formation hecause extensive exposures of it oceur on the islands of Lake Michigamme and on the mainlaud adjacent to the shore.

The Nichigamme slate is mainly in a single great area, which extends from a point about a mile west of Ishpening along the axis of the Marquette srnclinorium to the west end of the distriet. To Lake Nichigamme the brealth of this belt is lor the most part less than 2 miles, but at Lake Michigamme it broadens ont into an area 5 miles or more in width from which extend the Republic and southwestern arms. Beyond the limits of the IIarquette distriet proper the formation continues to widen and covers a great expanse of comntry, extending to the Crystal Falls distriet on the south and well toward the Gogebie distriet on the west. It is the equivalent of and is continuous with the slate to whieh the name "Hanbury" has been given in previous reports. It is also probably the equivalent of the Tyler slate of the PenokeeGogebie distriet, to julge from its relations with associated formations and from the probability (indicated by known outcrops) of direet areal comnection, though outerops are not suffieiently numerous to establish this connection absolutely.

Deformation.-The Michigamme slate in most of the distriet forms a great synelinorium, the secondary folds of which are, however, not suffieiently large to bring up the lower rocks to the erosion surface except in a central anticline at the east end of Lake Nlichigamme. where the Bijili schist and Goodrieh quartzite appear at the surface.

Lithology.-The formation is a pelite, which now comprises two main varieties-slates and graywackes and mica sehists and mica gneisses-eacly of which inchudes both ferruginous and nonferruginous kinds. The slates and gravwakes oecur east of Lake Michigamme and the miea sehists and miea gneisses at Lake Miehigamme and to the west, inchuding the Republie and southwestem arms. The slates and graywackes differ from each other chiefly in eoarseness of grain, the two being interlaminated in many exposures. There are all gradations from aphanitic black shales or slates to a graywacke so coarse as to approacla a quartzite or even a conglomerate. In color the rocks vary from gray to black. Where fine grained they have a woll-developed slaty eleavage. In places they are graphitic, pyritie, and fermginous. Two specimens showing the maximum amount of graphite analyzed 15.69 and 18.92 per cent of carborr.

The slates and graywackes differ in no essential respeet from the similar roeks of the Siamo slate (see pp. 261-262) or [rom the Tyler slate of the Gogebic distriet (see pl]. 232-233), therefore they will not again be described.

Jetamoryhism.-The slates and graywackes ly inerease in metamorphism pass into elalorite schists, miea sehists, and even into mica gneisses. The process of alterntion for the miea selisists is identieal with that already described in connection with the development of similar rocks for the Siamo slate and the Tyler slate. (See pp. 232-233, 261-262.) In manr places where the rocks are completely erystalline garnet, staurolite, chloritoid, and audalusite are plentifully present. In the more coarsely errstalline rocks much foldspar lias developed, and the rock thus becomes a gneiss. This material appear's in bands which seem to be altered beds of the formation but which resemble granitic material. The appearance is that of a rock pegmatized throughout. These bands grade into ordinary mica sehists. No independent granites have 
been discovered in connection with this extrmely metamorphosed rariety of rock, but it can not he assertal that such rocks are not somewhere present. Where the rocks have become sehists the ferruginous constituents have been largely trunsformed to magnetite.

lislations to aljacent formations.-.The Michigamme slate grades downwarl into the Bijiki schist or the Goodlich quartzite.

Thickness.-The thickness of the Michigamme slate is considerable, as is shown by the wide area which it covers. There are, lowever, so many subordinate folds and the netamorphism is so "xtreme that it is impossible to make even an approximate estimate of its thickness. Within the area described the thickness of the formation ma not be more than $1,000 \mathrm{or}^{\circ} 2,000$ feet, or may be greatly in excess of this.

\section{CLARKSBURG FORMATION.}

Distribution.-The Clarksburg formation differs from the other Algonkian formations of the Marquete district in that it is dominantly a voleanie formation. It is confined to the south side of the Huronian area, extending from the region north of Stoneville to a point somewhat west of ('hampion, the largest and most typical areas being east of Clurkshurg. It is dearly a local formation, not only in its eastern and western extent but in heing confined to one side of the district. This is explained by its rolcanic character, the rents being on the south border of the Algonkian area.

Lithology.-Petrographically the formation comprises massive greenstones of the general character of diorites; has that are interbedded with sediments and tuffs; tufls that grade ofl imperceptibly into sediments, the material of which is mainly of volcanic origin; and, finally, greenstone conglomerates and fine-gramed sediments, the material of which is mainly rolcanic but has evidently been arranged by water. All these rocks are extremely altered and in places so much so that they are now schistose. The proclastic material may have been partly subaerial, but doubtless a large part of it fell upon the water. The volcanoes of Clarkshurg time were very plainly of explosive type. The center of rolcanie actirity was east of Clarksburg, and in this vicinity are found the largest amounts of massive and coarse mat erial, lavas, breccias, and ronglomerates. Toward the east and west the formation becomes thimer and its material finer, until it dies out in both directions into the Michigamme slate.

It is not the purpose here to describe in detail the many different varieties of rocks of this roleanic formation. These are discussed in Vonograph XXVIII of the United States Geological Surver. ${ }^{a}$ 'This roleanie formation is similar to that of the roleanic formation at the east end of the Gogebic district, the chief difference being that the latter is much less metamorphosed. It is notable that both occur in the upper Inronian and mainly take the place of the great upper slate formation (Michigamme slate), although the beginning of the volcanie outbreak was early in upper lluronian time or earlier. In the eastern part of the district a small amount of volcanic material appears also to be associated with some of the earlier formations, especially with the Siano slate.

Relations to adjicent formations. - The voleanic outbreaks of the Clarksburg began early in Goodrich time, or perhaps eren in late Negaunee time, but the main rolcanic deposits were in Michigamme tince. Later in Michigamme time, by the dying out of rolcanic activity, the sediments becane more largely ordinary material, and thus the Clarksburg arades above into the Nichigamme.

Thichess. There is no way to ascertain the maximum thickness of the formation, but east of Charkburg it must be several thonsand feet thick. From this maximum it ranges down to a knife-celge.

INTRUAIYE IGNEOLS LOCKS.

Into all the formations of the Huronian series igneous rocks are intruded. These are of at least two ages; the older probably belong to the Huronian and the later to the Keweenawn period. Much the larger number of intrusive masses are distinctly of post-lIuronian and

$n$ Van Illse, C. R., and Bayley, W. S., The Marquette iron-bearing district of Mtchigam: Mon. U. S. Geol. Survey, vol. 2S, 1897, np. 4tin-186. 
probably Keweenawan age. Many of them are distinctly bosses, laccoliths, and sills which in their upward movement have been stopped by the massive competent layers of the Negaunee or Goodrich quartzite, and therefore on the present erosion surface are likely to show close areal relations with the Negaunee formation. This is especially conspicuous in the vicinity of Ishpeming, Negaunee, and Spurr.

The intrusive rocks have been deseribed by various authors under the terms diorite, diorite sehist, ehlorite schist, magnesian schist, soapstone, and paint roek. Part of them have been regarded by some geologists as metamorphosed sediments, but microseopieal study of all the varieties shows that they were originally basic rocks of the composition of diabases. The crreat bosses of greenstone, commonly known as diorite, are a prominent feature of the topography in the general area covered by the iron-bearing Negaunce formation, and the relations of these greenstones to the genesis of the ores has already been described. During the folling there was much differential movement between the greenstone masses and the survounding formations, and also the eontact plane is one favorable to the action of percolating waters. As a result of this it is a common thing for the periphery of the greenstone knobs to be sehistose.

In the area around Ishpeming and Negamee the sehistosity has obviously been the result of differential movement between the greenstones and the overlying Goodrich quartzite. The Goodrich quartzite has moved in the usual direetion upward along the limbs of the folds, developing eleavage dipping more stepply than the contact of the greenstone and the quartzite. Where not heavily stained by iron these rocks are commonly called chloritic schists. Adjacent to the iron-benring formation the rocks, besides having a schistosity, have been much leached and modified in composition and are commonly known as soapstones because of their greasy feel. The much-altered greenstones that have a strongly developed schistosity and have been stained by iron oxide are called paint rock by the miners. Even in the massive varieties of dikes, laecoliths, and bosses the original augite has extensively changed to homblende and consequently the rock in the district has generally been called diorite.

In the western part of the district, both within the intrusive.greenstone masses and in the adjacent formations, there have been important contact effects. This is shown by the extensive development of garnet in both the intrusive and intruded formations, by the less common development of biotite, and by the metamorphism of the iron-bearing formation into grünerite-magnetite schist and of the Michigamme slate into a mica schist. Grünerite has formed to some extent within the intrusive rocks also.

The intrusive character of these igneous rocks of Ifuronian age is shown not only by contact effeets but by the manner in which they cut across the bedding of adjacent rocks and project dikes into them. However, evidence of this kind is not available for all the igneous masses, especially those of laccolithie and sheet form, and it is regarded as not at all unlikely that some of them may be really extrusive roeks put down contemporaneously with the adjacent sediments.

The latest intrusive rocks are fresh diabase dikes which are probably of Keweenawan age. They cut all the other formations of the district, ineluding the older greenstones which have just been described. These rocks inchude diabase, quartz diabase, olivine diabase, porphyrites, and basalts.

\section{CAMBRIAN SANDSTONE.}

Upper Cambrian or Potsdam sandstone is exposed in an east-west belt along Carp River to the sonth of the city of Marquette and Mount Mesnard, where it rests unconformably upon the Kiona dolomite.

\section{QUATERNARY DEPOSITS.}

The district is more or less covered by Pleistocene deposits. On the southeast it is so thoroughly covered that the bed-rock geology is not well known. The Pleistocene is diseussed in Chapter XVI (pp. 427-459). 


\section{THE IRON ORES OF 'IIE MARQUETTE DISTRICT.}

By the authors and W. J. MEAD.

\section{DISTRIBUTION, STRUCTURE, AND RELATIONS OF ORE DEPOSITS.}

The chiel ilon-bearing formation of the Marquette district is the Necrannee. It bears ore at various horizons. Ores also oecur at the basal horizon of the Goodrich quartzite, where it rests upon and has derived débris from the Neganne formation. Small quantities of ore are found in the iron beds of the Bijiki schist, associated with the Michigamme slate. Workathe iron-ole deposits have been found at many places from a point east of Negaunce to Itichigamme anel Spurr. The Marquette district differs l'rom the Mesabi and Gogebic districts in not having long stretches of nonproducing iron-hearing rocks.

The maxinum depth of concentration of ores in the Marcuette district is still unknown. On the Teal Lake range the depth is not more than 700 feet; in the Ishpening and Nocranee areas depths as great as 1,500 feet are known. In the Champion area ore has bren followed
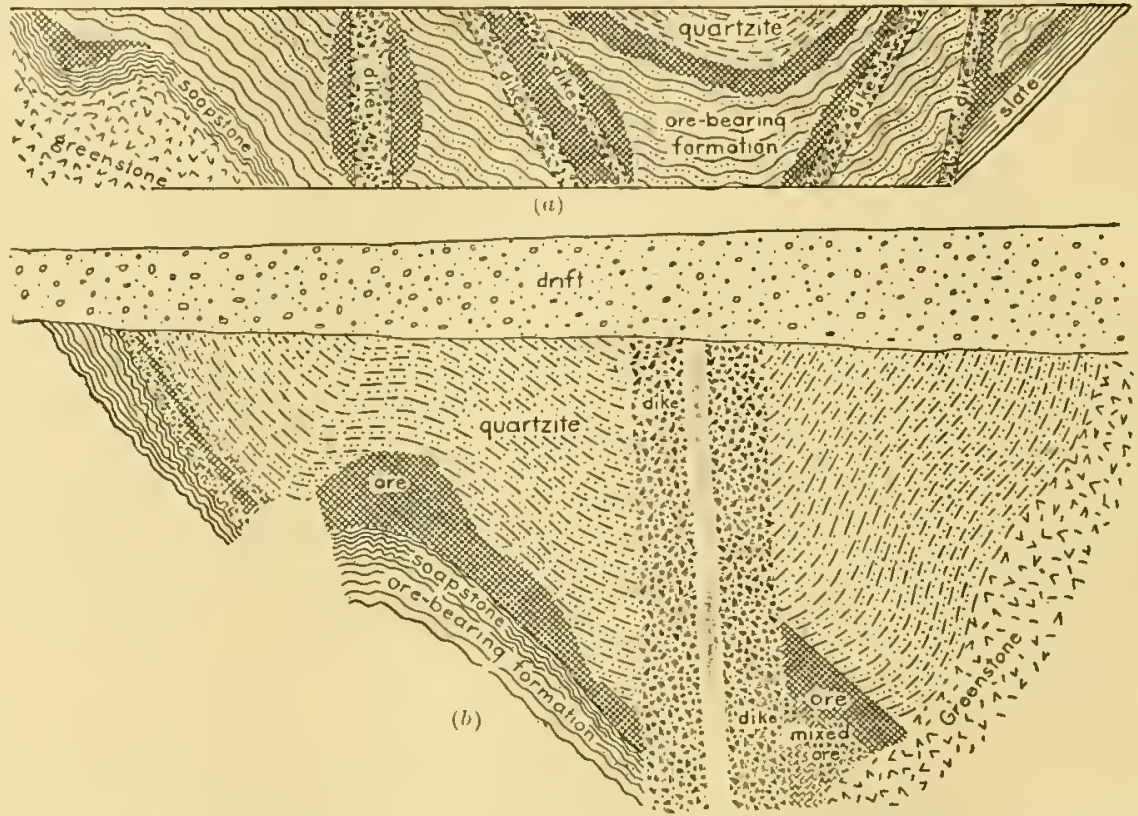

Figure 36,-Ore deposits of the Marquette district. (Both ore exploited and ore now in minc are representer as ore, as the purpose of this figure is to show the mamer of the derelopment of the ore rather than the present stage of exploitation.)

$a$, Generalized section in Marquette district, showing relations of all classes of ore deposits to issoeiated formations. On the right is soft ore resting in a $V$-shneti trough between the Simmo slate and a dike of soapstone. In the lower central part of the figure the more eommon relat ions of soft ore to vertical and inclined dikes cutting the jasper are shown. The ore may rest upon an inclinerl dike, hetween two inclined dikes, and upon the upper of the two, or be on both sides of a nearly vertical dike. In the uppercentral part of the figure are seen the relations of the hard ore to the legibuee fornation and the Goodrich quartzite. It the left is soft ore rest ing in a trough of soapstoue which grates elownward intogreenstone. (From Mon. U. S. Geol. Survey, vol. 24, 1897, Pl. XXYIIl, fig. 1.)

$\delta$, Cross section of Section 16 mine, Lake Superior mines, in the IIarquette distriet. Ou the right is a V-shaped trough made by the junetion of a greenstone mass and a dike. The hard ore is between these and below the Goodrich quarizite. On the left the hard ore again rests unen in saapstone which is upon and contaius lands of ore-bearing formation. The ore is orerlain by the Goodrich quartzite. Scale: 1 inch $=220$ fert. (From Mon. U. S. Geol. Survey, rool. 2s, 1s97, l'1. XXI. fig. 1.)

down 2,000 feet and is known to extend farther. The Negaunce formation constitutes a part of the westward-pitehing Marquette trough, and west of Ishpening and Yegillunee the centril part of the trough goes beneit ha eonsiderable thickness of upper Inuronim sediments. Beciluse of this deep burial lut little drilling has been done to aseertain whether or not the ores go down here, but the discovery of a large ore deposit at the very bottom of the Nerrimer formition neal Negaunee has led to deop drilling west of Ishpeming and Negannee with such results as to indi. cate that the ores extem! to monked-for depths in this direction.

In general the ores conne to the rock surface along the midclle stopes of the hills, but they

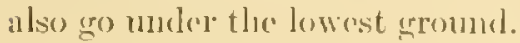


The ore deposits of the Negaunee formation and the associated ores may he divided, according to stratigraphic position, into three classes-(1) ore cleposits at the botom of the ironbearing formation; ( 2 ) ore deposits within the iron-bearing formation (these ores in many places reach the surfice but are not at the uppermost horizon of the formation); (3) ore deposits in the top layers of the Negaunee formation and the bottom layers of the Goodrich quartzite. (See fig. 36.) This last elass of deposits runs past an unconformity. Some of these ore bodies are almost wholly in the Goodrich quartritc. Stratigraphically these deposits ought to be separately considered, but they are so closely connected genetically and in position with the Negaunce ore deposits that they are treated with the deposits of that formation. 'The first two classes of ore are generally soft, and the adjacent rock is fermuinous chert or "softore jasper;" the deposits at the top of the iron-bearing formation are hard, specular ores and magnetite and the adjacent rock is jaspilite, also called "specular jasper" and "hard-ore jasper."

Although the larger number of ore bodies can be referred to one or another of the three classes above given, it not infrequently happens that the same ore deposit belongs partly in one and partly in another. Also the upper part of an ore deposit may be at the topmost horizon of the iron-bearing formation and be a specular ore, whereas the lower part may lie wholly within the iron-bearing formation and may be solt ore. In some places there is a gradation between the two phases of such a deposit, but more commonly the two bocties are separated by dikes, now changed to soapstone or paint rock.

1. The ore deposits at the bottom horizon of the Negaunee formation have been mined principally where the lowest horizon of the formation ontcrops-that is, they are confined to that part of the formation resting upon the Siamo slate or the Ajibik quartzite, along the outer borders of the Negiunee formation. The best examples of these deposits are those occurring at the Teal Lake range and east of Negannee. East of Negamee the ore borlies occur at plices where the slate is folded into synclinal troughs which pitch sharply to the west. Here the ironbearing formation is in places cut by a set of steep vertical dikes, and the conjunction of these dikes with the loot-wall slate forms sharp V-shaped troughs, as in the Cleveland Ifematite mine, where the ore bodies are found between a series of vertical dikes and the Siamo slate. By comparing this ocenrence with the ore deposits of the Penokee-Gogebie district, it will be seen thit they are almost identical, there being on one side of each of the ore bodies an impervious dike, the two uniting to form a pitching trough. The ore deposits of this horizon are being found by deep drilling to be extensive. The opening of the Maras mine at the east end of Teal Lake and the discovery of ore by deep drilling at this horizon in the western part of the Ishpeming area suggest that the beds of this horizon at great denth may ultimately be found to carry a litrger tomage of ore than those of any of the other horizons.

2. The typical area for the soft-ore bodies within the Negaunee formation is that of Ishpeming and Negaunee. Here are the Cleveland Lake, the Lake Angeline, the Lake Superior Hematite, the Salisbury, and many others. The large deposits rest upon a pitching trough composed wholly of a single mass of greenstone or on a pitching trough one side of which is a mass of greenstone and the other sile a dike joining the greenstone mass. The underlying rock is called greenstone where unaltered; that immediately in contact with the ore is known by the miners as paint rock or soap rock or soapstone. The greenstone changes by minute gradations into the schistose soapstone, and this into the paint rock. Nany of the thinner dikes are wholly changed to paint rock or to soapstone, or to the two combined. The larger number of these troughs are found along the western third of the Ishpening-Negaunee area. Plate XVII (in pocket) slows several westwarl-opening bays occupied by the iron-bearing formation in the masses of greenstone. Conspicuous among these are the Ishpening basin, the northern Iake Angeline basin, the southern lake Angeline basin, and the Salisbury basin. The iron-formation embarments open out and pitch to the west. At Lake Angeline an eastward like euts across the basin south of the center, and this combined with the greenstone blufis to the north and to the south forms two westward-pitching troughs, the northern of which has the greatest ore deposits of the Marquette district, containing many millions of tons of ore. 
3. The hart-ore bodies, mainly specular hematite but in some deposits including much magnetite, are at the top horizons of the iron-bearing formation, immediately below and in the basal members of the Goodrich quartzite. Examples of this class are the Jackson mine, the Lake Superior Specular, the Toluntere, the Michigamme, the Riverside, the Champion, the Republic, and the Barnum. Also, as interesting deposits, giving the history of the ore, may be nentioned the Kiloman and the Goodrich. In all these deposits the associated rocks of the jon-bearing formation are jaspilite or grünerite-magnetite schist, usually the former. Miny of these ore deposits weld together the Goodrich quartzite and the Negaunce formation and can not be separated in description. As in classes 1 and 2 , all the large ore deposits belonging to this third class hive at their bases soapstone or paint rock. Where the soapstone is within the Negaune formation it is a modified greenstone mass or this in conjunction with a dike or dikes. Where the ore deposits are largely or mainly in the Goodrich quartzite the basement rock may likewise be a greenstone or it may be a layer of sedimentary slate belonging to the Goodrich quartzite. These diflerent classes of rocks are, however, not discriminated by the miners, but are lumped together as soapstone and paint rock. Wherever the deposits are of any considerable size the basement rock is foldech into a pitching trough, or else an impervious pitching trough is formed by the union of a mass of greenstone with a dike, or by the union of either one of these with in sedinentary slate. Perhaps the nost conspicuous example of this is at the Republic mine, but it is scarcely less evident in the other large deposits. A few small deposits of ore (chimneys and shoots) occur at the contact of the Negaunee and Goodrich formations, where no bascment soapstone has been found.

As examples of ore deposits which are largely or wholly within the Goodrich quartzite may be mentioned the Volunteer, Nichigamme, Champion, and Riverside. These are partly recomposed ores and differ in appearance from the specular hematite or magnetite of the Negaunee formation in having a peculiar gray color and in containing small fragmental particles of quartz and complex pieces of jasper; in many of them also sericite and chlorite are discovered with the microscope.

Ore deposits in the Bijiki schist, associated with the Michigamme slate, have slate as foot and hanging walls. They are ilhstrated by the Beaufort, Bessie, Ohio, and Imperial mines.

Although these differeut classes of ore bodies have the distinctive features indicated above, they have important features in common. They are confined to the iron-bearing formations. They occur upon impervious basements in pitching trouglis. The imperrious basement may be a sedimentary or an igneous rock, or a combination of the two. Where the ore deposits are of considerable size the plication and brecciation of the chert and jasper are usual phenomena. In many places this shattering was concomitant with the folding into troughs or with the intrusion of the igneous rocks.

In any of these classes the deposits may be cut into a number of bodies by a combination of greenstone likes and masses. A leposit which in one part of the mine is continuous may in another part of the mine be cut into two deposits by a gradually projecting mass of greenstone which passes into a dike, and each of these may be again dissevered, so that the deposit may be cut up into a number of ore bodies separated by soapstone and paint rock. Some of the ore deposits love a somewhat regular form from level to level, but the shape of the deposits at the next lower level can never be certainly predieted from that of the level above. Horses of "jasper" may appear along the dikes or within an ore body at alnost any place. The ore bodles grade above and at the sides into the jasper in a variable manner. As a result of the combination of these uncertain falctors, most of the ore bodies have extraordinarily irregular and curious forms when exanined in cletail, although in general shape they conform to the above Iescriptions. 
CHEMICAL COMPOSITION OF MARQUETTE ORES.

The following arerage partial analyses were ealculater from earoo analyses in shipments for 1906 and 1909:

Irerage partial analyses of Marquette ores, a calculated from cargo amalyses for 1906 and 1909.6

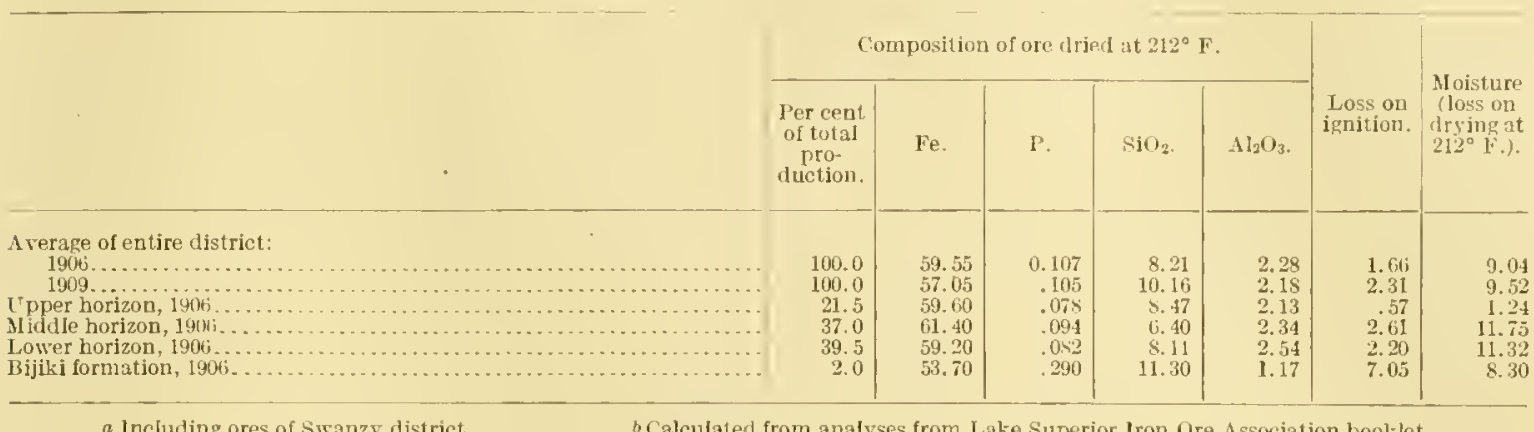

In addition to the constituents listed above the ores contain smrall amounts of manganese, lime, magnesia, sulphur, soda, and potassa. 'The rango for the various constituents of the ores as shown by average cargo analyses for 1906 and 1909 is as follows:

Range of percentage of cach constituent in the Marquctte ores for 1906 and $1909 . a$

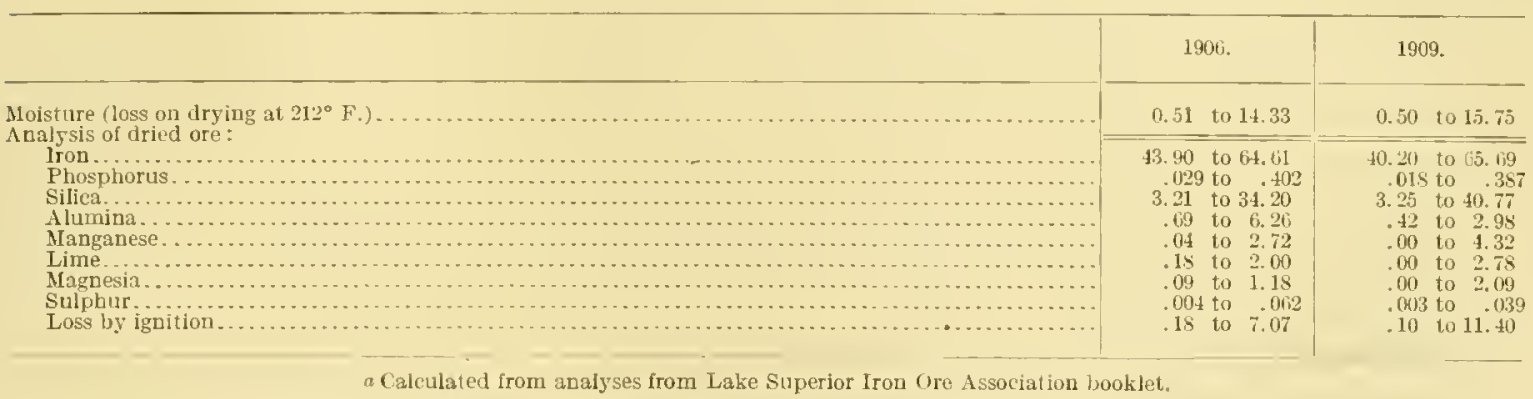

The magnetites do not differ essentially in composition from the dominant hematites and limonites except in having less water.

\section{CHEMICAL COMPOSITION OF IRON-BEARING NEGAUNEE FORMATION.}

An average of 1,727 analyses representing 11,025 feet of drilling from the district away from the available ores gives 35.12 per cent of iron. This includes both the lean jaspers and the partly altered jaspers, but not the ores. Because of their great mass compared with the ores, this figure represents nearly the general average composition of the entire formation. If the unaltered jaspers alone are taken, the average is somewlit lower.

The composition of a typical amphibole-magnetite-quartz rock is as follows:

Aurage analysis of grünerite-magnetite schist.a

\begin{tabular}{|c|c|c|c|}
\hline Loss. & 1.03 & CuO.. & Trace. \\
\hline $\mathrm{SiO}_{2}^{\circ} \ldots$ & 50.02 & $\mathrm{Na}_{2} \mathrm{O} \ldots$. & 0.08 \\
\hline $\mathrm{Al}_{2} \mathrm{O}_{3}$ & .97 & $\mathrm{P}_{2} \mathrm{O}_{3} \ldots .$. & 09 \\
\hline $\mathrm{Fe}_{2} \mathrm{O}_{3}$ & 10.05 & $\mathrm{CO}_{2} \ldots \ldots \ldots \ldots \ldots$ & 1.5 \\
\hline FeO.. & 28.29 & $\mathrm{H}_{2} \mathrm{O}$ (above $\left.110^{\circ}\right) \ldots \ldots \ldots \ldots \ldots \ldots \ldots \ldots \ldots \ldots \ldots \ldots \ldots \ldots$ & .42 \\
\hline $\mathrm{MnO}$. & .74 & & \\
\hline $\mathrm{aO}$ & 2.63 & & 00 \\
\hline $\lg O$. & 4.13 & Total Fe. & 0 \\
\hline
\end{tabular}

It will be noted that this differs but little from the average composition of the jaspers.

$$
47517^{\circ}-\text { VOL } 52-11-1 S
$$




\section{MINERAL COMPOSITION OF MARQUETTE ORES.}

The ores of the MInrfuet te district are dominantly hydrous hemat ites and subordinately anhydrous specular hematites and magnetites. Owing to the presence of macrnet ite, the mineral coniposition can not be calculated from analyses in which ferous and ferric iron are not separated.

The coarse specular hematites are made up mainly of large, closely fitting llakes of hematite, most of which take an imperfect polish and have, therefore, a gray, sheeny, spotted appearance. The fakc's, which are parted along the cleavage, reflect the light like a mirror. 'The large number of individuals of this kind is appreciated only by rotating the sections under the microseope. This hrings successively diflerent flakes of hematite into favorable positions to reflect the light into the microscope tube. In some sections cut transverse to the clearage the schist ose character of the rock is apparent in reflected light, immunerable lamina of hematite griving fine, narrow, parallel dark anel light bands, which are comparable in appearance to the polysynthetic twinning bands of feldspar. As both the magnetite and the hematite are usually opaque, the two minerals in general can not he discriminated, althongh in some sections the eryst al lorms of magnetite are seen and a small part of the hematite, much of it in little crystals, shows the characteristic blood-red color. The important accessory minerals are quartz, grünerite, feldspar, and muscovite. Some of the small, detached areas of quartz and feldspar appear to he fragmental. The muscovite occurs mainly in small, independent flakes, but some of it is apparently secondary to the feldspar.

The fine-gramed specular hematites differ from the so-called micaceous hematites chiefly in that much more of the hematite is translucent and hence at the edges and in spots in the slides is of a brilliant red color. The "slate ores" in reflected light show the laminated character of the rock, while the massive ores give the peculiar spotty reflections, exactly the same as magnetite.

The mottled red and black specular ores in reflected light present a peculiar appearance, the true specular material giving the usual brilliant, spotty reflections, whereas the solt hematite has a brownish-red color.

The soft hematites in transmitted light show in many slides the characteristic blood-red color of hematite, although for the most part the sections are so thick as to give a brownish appearance or are opaque. In the softest ores in reflected light a dark brownish-red color is everywhere seen, which is much less hrilliant than that presented by the same mimeral in transmitted light. In some of the solt hematites, however, within the mass of red material are many small areas which reflect the light in the same manner as the specular ores. The limonitic henatites differ from the pure hematites only in that, in both transmitted and reflected light, in many places the redkish colors are not so bright.

Inder the mieroscope the magnetites are opaque in transmitted light: in reflected light they give the characteristic spotty appearance of that mineral. Where not pure the usual minerals contained in the iron formation appear with their ordinary relations. Those most plentilully seen are quartz, grünerite, muscovite, and biotite. Here and there garnet and chlorite is an alteration product are abundant. On the horders of the included material the magnetite invariably shows crystal outhes. As a result each area of inchuled minerals has a scrratal form. With the magnetite there is always more or less of hematite, al larere part of which in many places results from the alt cration of the magnetite. The hematite ranges from a subordinate to an important amount. Nlso at many places with the magnetife are rarring quantities of prrits and gramet and alteration products of the latter, chlorite and amplibole. The matenetites ranger in color lrom black to grare.

\section{PHYSICAL CHARACTERISTICS OF MARQUETTE ORES.}

The magnet it es and sprecular hematites are calleel hard ores by the miners. and the hydrous

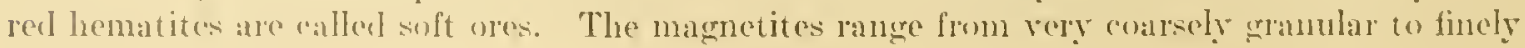
granular magnetite. 
$\Lambda$ s the ores are made up essentially of iron minerals and quartz, the mineral density varies direetly with the iron eontent, ranging from as high as 5.1 in some of the dense laurl ores to as low as 3.5 in some of the low-grade limonitic ores. Owing to the wide variation in the mineral composition of the ores, an average figure for the district would have no significanee. The arerage clensity of the soft hematites, ealeulated from the 1906 cargo analyses, is 4.14.

The porosity varies from less than 1 per cent in the hard specular ores to over 40 per cent in the limonitic ores. The average moisture eontent of the ores of the midlle horizon indicates a porosity of approximately 35 per cent, assuming the mineral density to be 4.14 . This is probably not far from the true figure.

The number of eullie feet per ton varies from 7 in the pure hard hematites to as high as 14.5 in the limonitie ores. The average for the soft red hematites is approximately 11.9 cubic feet per ton, ealculated from a mineral clensity of 4.14, a porosity of 35 per cent, and a moisture content of 11.75 per eent.

The following table, showing an average of a number of screening tests on the soft ores of the Marquette district, gires a good idea of the arernge texture of these ores. A comparison of the textures of the ores of the several Lake Superior districts is shown in figure 72, page 481. The sereening tests, of which the following is an average, were marle by the Oliver Iron Jiming Company on 11 typieal grades of ore mined in the IIarquette distriet in 1909 and aggregating a total of $7+6,779$ tons. For each grade of ore tested a sample was taken biweekly, quartered down monthly in proportion to the number of tons mined, and at the end of the year quartered down to 100 pounds, dried, and tested. The arerage was obtained by combining the results of the 11 screcning tests in proportion to the number of tons represented by each of the 11 grades.

$$
\text { Composite of screening tests on typical soft ores of the Marquette district. }
$$

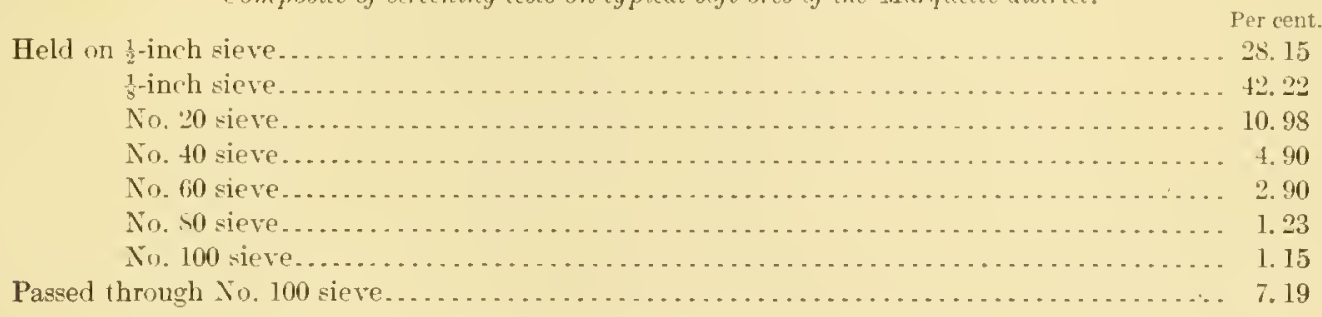

SECONDARY CONCENTRATION OF MARQUETTE ORES.

Structural conditions.-The structural eonditions controlling the circulation of water in the Marquette district are various. At the lower horizons of the Negaunee formation the impervious basement is formed by the pitching folds of the Siano slate, as on the Teal Lake range. At the middle and upper horizons of the Negaunee formation the irregular bosses and intrusive masses of greenstone constitute impervious basements in the reentrants of which the ores are found. The greenstone and its altered form, soapstone, aecommodated themselves to folding without extensive fractures and, while probably allowing more or less water to pass through, acted as praetically impervious masses along which water was deflected when it came into eontact with them. It is a eommon opinion among miners that a few inches of soap roek is more eflective in keeping ont water than many feet of the iron-bearing formation. On the other hand the brittle siliceous ore-bearing formation was fractured by the folding to which it was subjected, so that where this process was extreme water passes through it as through a sieve. It is evident that the tilted bodies of greenstone, or soap rock, especially those that occur in pitching synclines or that form pitching troughs ly the union of dikes and masses of greenstone, must have converged downward-flowing waters. It is also clear that the weak contact plane between the Goodrich quartzite and the Negaunee formation was one of aceommodation and shattering, favorable for the free movement of waters. Finally, the ores in the Bijiki schist of the upper Huronian have been developer! by the pereolation of waters along impervious slate basements with which the Bijiki schist has been folded. 
Chemical and mineralogical clanges in serondary concentration of Marquette ores.- The soft ores and the associated ferruginous cherts of the mildte and lower lowrizons of the Negaunec formation atre similar physically, chemically, and mineralogieally to the ores of the PenokeeGogebie district. They are derived by the same processes, muler similar conditions, from cherty iron carlonate rocks which are practically identical with those of that district.

The hard ores have unclergone not only this change but the alditional anamorphie changes of deep berial and igneous intrusion, the result being that the hard ores differ from the soft ores ehemically only in that they have less water and at little less oxygen, mineralogically in that they have developed in them ertain anhytrous silicates and some magnetite, and texturally in that they are coarsely crystalline and in places schistose. To some slight extent also similar hard ores may have been developed directly from the original cherty iron carbonates by deep burial or igneous contact antion, but it is shown elsewhere that such action usually results in lean silieated irm-bearing rock rather than in rich ore bodies. The associnterl ferm-

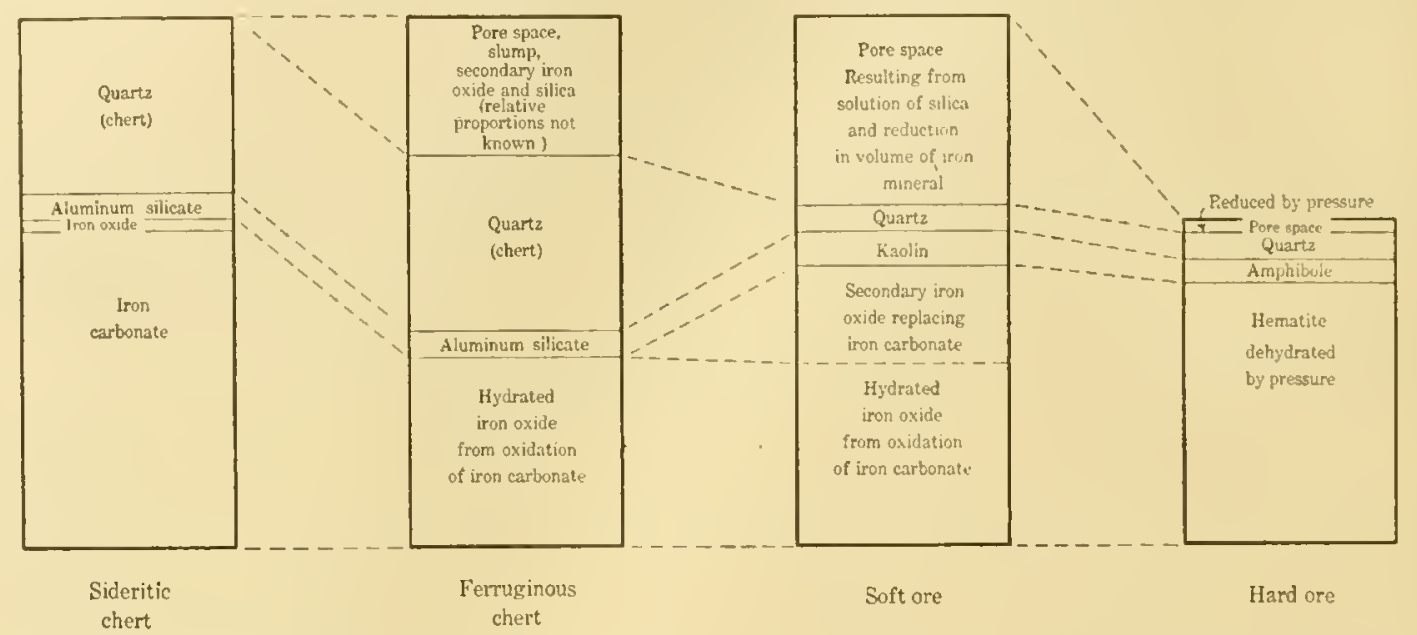

FIGUTE 37.-Graphic representation of the volume composition of the principal phases of the iron-bearing Negaunee formation, showing the changes in volnme and mineral composition involved in the concentration of the ores from the cherty siderite and the prodnction of hard ore from soft ore by dynamic ageneies.

ginous eherts or soft-ore jaspers undergo similar changes so far as the iron oxide larers are concerned. The rhert beds are reerystallized, lut not otherwise changed. The result is a harel-ore jasper or jaspilite differing from the ferruginous cherts in being more crystalline, lawing less pore space, and being less hydrated, and accordingly haring red rather than yellow or brown colors.

Tolume changes in secondary concentration of Marquette ores.-The rolume changes in the concentration of the ores and the development of the hard ores are shown in figure 37 . The rolume composition of the four phases of the iron-bearing formation is represented, thus permitting a consideration of porosity as well as mineral composition. The mineral composition of the sideritic ehert is calculated from a typical analysis. ${ }^{a}$ The mineral composition of the ferruginous chert is ealculated from the sideritic chert analysis, allowing for oxiclation of the iron mineral. The result is about an average for ferruginous cherts, as shown ly anulyes. The indicated rolume compositions of the soft and hard ores represent actual average partial analyses of all ore as mined and averages of porosity determinations.

When suljected to oxidizing solutions, the siderite of the cherty siderite is oxidized to a more or less hyclrated iron oxide, involving a considerable reduction in volume (sec Gogebic discussion, pp. 242 et seq.) langing from 49.25 per eent when the product is hematite to 18.3 per eent when limonite is produced. If no irom were introduced, the actual amount of oxile resulting would be intermediate between these two figures and probably would not difler greatly" 
from the hydrated oxide of the soft ores, which is representerl by a ratio of hematite to limonite of 7 to 1. Even if a considerable amount of iron were introduced, the resulting rock would be banded ferruginous chert having a larger pore space than the original cherty siderite. The reduction in volume of iron mineral accompanying the alteration of the carbonate is partly compensated by several factors, the relative importance of which is not known-by mechanical slump and by the introhuction of secondary iron oxide and quartz.

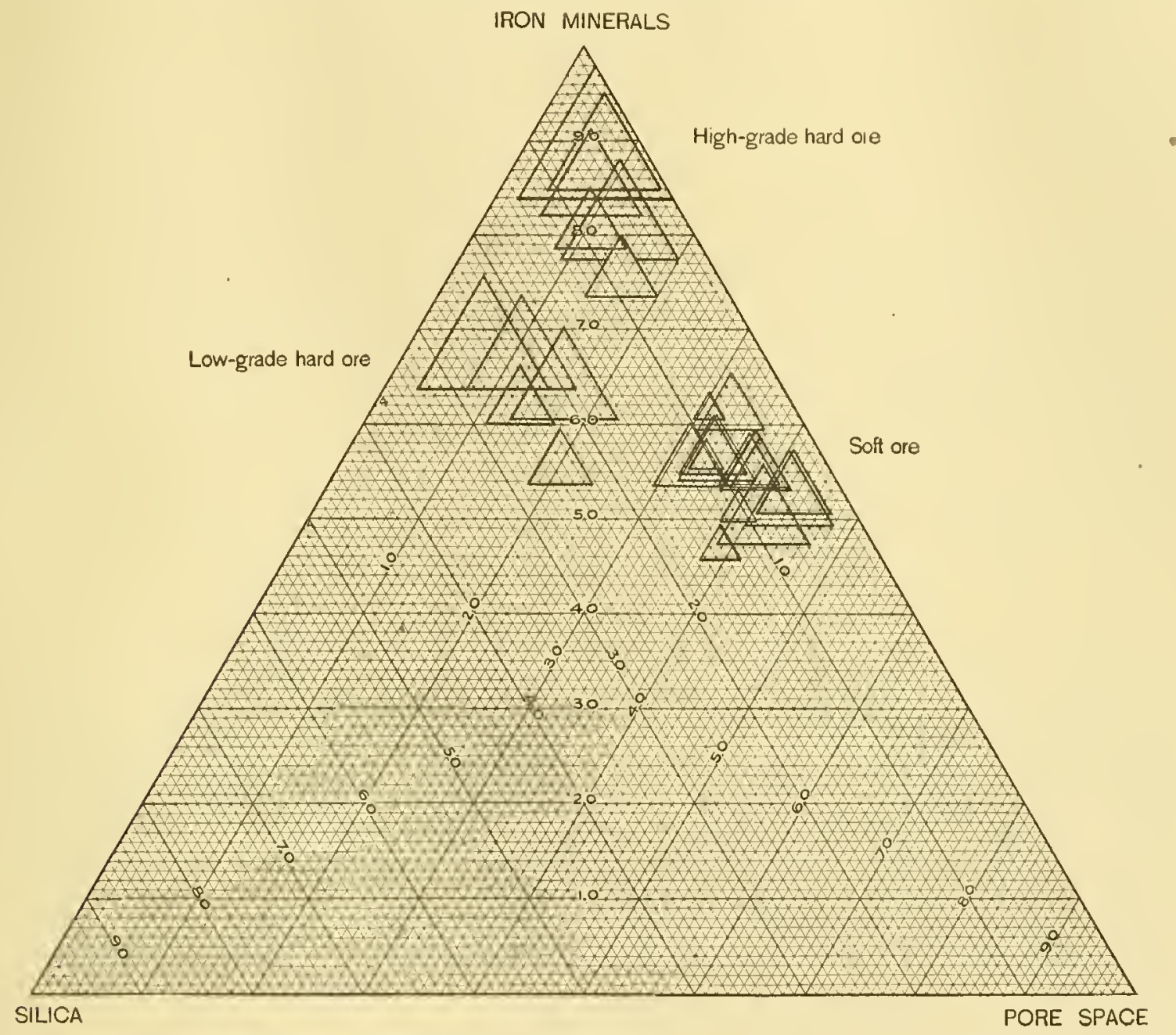

FIGUPE 38.- Triangular diagram showing the volume composition of the several gralles of ore mined in the Marquette district in 1906 , in terms of pore space, iron minerals, and silica. The altitudes of the small triangles show in each case the amount of minor constituents (amphibole, (lay, etc.)

The development of ore from the sideritic chert involves, in addition to the oxidation of the iron in place, the removal in solution of a considerable amount of quartz. This gives a still larger pore space, which again is partly compensated by slump and by infiltration of jron. Observation shows that the oxilation of the iron carbonate in place, producing ferruginous chert, mainly precedes the removal of the larger amount of silica. The oxidation of the iron is chemically more readily accomplished than the solution of silica; and, further, the consequent development of pore space affords opportunity for more abundant flow of solution to accomplish the solution of silica. When the passige of the ore bodies into the chert or jasper is examined in tetail it is found that a siliceous band, if followed towarl the ore, instead of remaining solid becomes porous and may contain considerable cavities. These places in the 
transition zone are lined with iron oxide. In passing towall the ore deposit more and more of the silica is found to lave been remored, and iron oxide las partly replaced it. An examination at many of the localities shows this transition from the banderl ore and jasper to take place as a consequener of the remosial of the silica and the partial substitution of iron cxicle. In many such instances the line-cratued part of the ore is that of the original rock, and the coarse crystaline material is a secondary infiltration. It is not uncommon, lowever, for the ore deposits to teminile abruptly along joint eracks or fractures.

The solution of puartz and the introduction of iron oxide ultimately produce the soft ores from the ferruginous cherts. "These soft ores, as the diagran shows, have an average porosity of about 36 per cent and are marle up essentially of hydrated iron oxide, quartz, and clay. The iron oxide largely represents siderite oxidized in place, but partly represents iron secondarily introduced.

The development of the hard ores is aceomplished by pressure or ignenus contact action on the solt ores, eausing a reluetion in volume of approximately 40 per cent or less, by deereasing the porosity, dehydrating the iron oxide, and developing some mannetite and certain metamorphic lerromagnesian, aluminum-bearing minerals, such as amphibole and garnet.

Representation of ores and jaspers on triangular diagram.- The volume compositions of the various phases of the iron-bearing formation are represented in the triangular diagram, figure 38. (For explanation see p. 189.) The lines of demareation between the hard and soft ores and between the low and high grade hard ores are not as sharp as the grouping of the small triangles would indicate. Typical specimens of each grade were selected and intemediate phases were neglected. If all phases were represented the entire upper corner of the large triangle would be corered with small ones, indicating complete gradation between the rarions classes of ore.

\section{SEQUENCE OF ORE CONCENTRATION IN THE MARQUETTE DISTRICT.}

1. The alteration of the Negaunee formation began before upper Huronian time, when the formation had been slighlily folded, eroded, and intruled by igneous rocks. Prior to upper Huronian time all the phases of the iron-bearing formation now known, except the specular hematites, had been developed, for all of them appear as pebloles in the basal conglomerate of the upper IIuronian, and it is mikely that such closely intermingled diversity of pebbles could have been dereloped from a single trpe of iron-bearing material after it had heen deposited as pebbles in the conglomerate at the base of the upper Ifuronian. Erosion was not deep, and ores seem to have been developed only near the erosion surface which bevels at a low angle the upper beds of the Negaunce formation and now constitutes the horizon exposed nearest to the overlying upper Huronian conglomerate. That ores were formed at this time and place is indicated by the fact that at this horizon occur specular hematites having a sccondary clearage developed during the folding which followed the deposition of the upper IJuronian and which preceded the second great periorl of ore concentration.

2. Inter-Jfuronian alteration of the formation was intermpted by the deposition of the upper IIuronian (Animikie group), the base of which was made up of englomerate carrying fragments of ferruginous chert and iron ore derived from the Negaunee formation. A higher formition (Bijiki schist) contained iron carbonate.

3. The deposition of the upper IIuronian wats followed by serere folding and both int rusion and extrusion of the baxic imnens rocks. Huch of the intrusion preceded the folding, for the cleavage in the sedimentary beds developed during the folding, and, luaving an attitude determined by the diflorential movenent between the folds, allects also the intrusive rocks. Mlany of these post-upper Inronian (Keweenawan) intusive rocks are now found in the area of the Treganner formation. It is certain that some of them-as, for instanec, those in the vicinity of Nichigamme represent laceolithic masses which were unable fo penctrate above the massive Goodrich quartzite and spread ont in the upper portion of the Fegranee formation. The intrusion and folling, with varying relative elfectiveness in dilierent parts of the range, anamor- 
plosed the iron-bearing formations, but with widely differing results, hepending on the conditions of the iron formation before the anamorphism. The ferruginous cherts and ores of the upper horizons of the Negannee formation were changed to hard hematites and jaspers, becoming specular when folded. The iron-bearing conglomerate at the base of the Grodrich quart zite was similarly affected. The iron carbonate of the Bijiki sehist of the 11pper IHronian was changed into a coarsely crystalline amphibole-magnetite rock. Portions of the formations farther remored from the intrusive rocks were less anamorphosed. These would include the part of the Bijiki schist near the Bessie mine and the lower part of the Negaunce formation, both of which up to this time still remained as iron carbonate.

Post-lieweenawan erosion exposed all phases of the iron-lrearing Negaunee formation, together with the ferruginous tetrital base of the upper IHuronian and the still unattered carbonates ligher in the upper Ifuronian. The iron carbonates, both of the lower parts of the Negaunee formation and of the Bijiki sehist, now for the first time exposed, became altered in the ordiniry manner, producing soft ores associated with solt ferruginous cherts, now found typically along the Teal Lake range and in the Bessie mine of the westem Marquette district. The other phases of the Negaunee formation, which had been previously altered to chert, jasper or iron ore, or amphibole-magnetite rocks, were also attacked to some extent, principally by the leaching of silica, which can be conspicunusly observer in the loss of chert pebbles from the conghomerate at the base of the upper Ituronian, and by alteration of garnets and amphibole to chlorite. The total effect of the alteration at this time on these harder phases, however, was probably not so essential in the concentration of the ore deposits as that which had gone on before.

The great varietics of phases of the iron-bearing rocks of the Marquette district are therefore the results of katamorphic and anamorphic processes deseribed in earlier pages, acting alone or successively on different parts of the iron-bearing formations.

\section{OCCURRENCE OF PHOSPHORUS IN THE MARQUETTE ORES.}

\section{DISTRIBUTION OF PIIOSPIORUS.}

The ores of the Marquette range are as a whole higher in phosphorus than those of the Vermilion, Mesabi, or Gogebie districts. They also show a greater range in phosphorus content than the ores of any of these three districts. Of the total shipments of ore from the Marquette range in 1906 approximately 18 per cent was of Bessemer grade. The lowest phosphorus grade was Sheffield ( $\mathrm{Fe}=64.61, \mathrm{P}=0.029, \mathrm{P} / \mathrm{Fe}=0.000448$ ), and the highest phosphorus grade was (ambridge $(\mathrm{Fe}=59.60, \mathrm{P}=0.570, \mathrm{P} / \mathrm{Fe}=0.00957)$.

The phosphorus and iron contents of the ores of the Marquette range are shown in the following table:

Phosphorus and iron content of Ifarquctte ores.

\begin{tabular}{|c|c|c|c|}
\hline & Iron. & $\begin{array}{c}\text { Phospho- } \\
\text { rus. }\end{array}$ & $\begin{array}{l}\text { Ratio of } \\
\text { phospho- } \\
\text { rus to } \\
\text { iron. }\end{array}$ \\
\hline 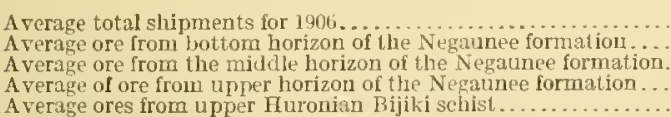 & $\begin{array}{l}59.55 \\
58.38 \\
57.22 \\
59.00 \\
55.91\end{array}$ & $\begin{array}{l}0.1072 \\
.103 \\
.096 \\
.063 \\
.359\end{array}$ & $\begin{array}{l}0.00180 \\
.00176 \\
.00168 \\
.00107 \\
.00642\end{array}$ \\
\hline
\end{tabular}

Six lundred partial analyses of jasper carrying between 20 and 50 per cent of iron, representing 10,450 feet of drill holes in the area south of Negaunee, showed an arerage of 35 per cent of iron and 0.050 per cent of phosphorus. 
The local distribution of phosphorus in the ores is extremely irregular. In many ore bodies the plosplorus content is found to increase as the greenstone or soap rock (altered greenstone) walls are approached. 'This is shown by the following analyses of ore and greenstone collected from the Chicago shaft of the Lake superior Iron Company:

$$
\text { Partial analyses of ore and grrenstone from Chicago shafı.a }
$$

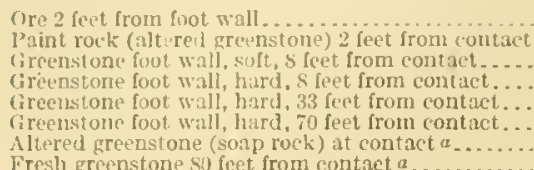

a 'The last two samples were fron another part of the deposit.

\begin{tabular}{|c|c|c|}
\hline P. & $\mathrm{Al}_{2} \mathrm{O}_{2}$ & $\mathrm{CaO}$. \\
\hline $\begin{array}{r}0.112 \\
.192\end{array}$ & $\begin{array}{l}1.12 \\
4.67\end{array}$ & $\begin{array}{r}0.19 \\
.15\end{array}$ \\
\hline .132 & & \\
\hline .134 & 7.89 & .13 \\
\hline IOMJ & & . \\
\hline .141 & 6. 41 & .22 \\
\hline & 15.30 & .14 \\
\hline
\end{tabular}

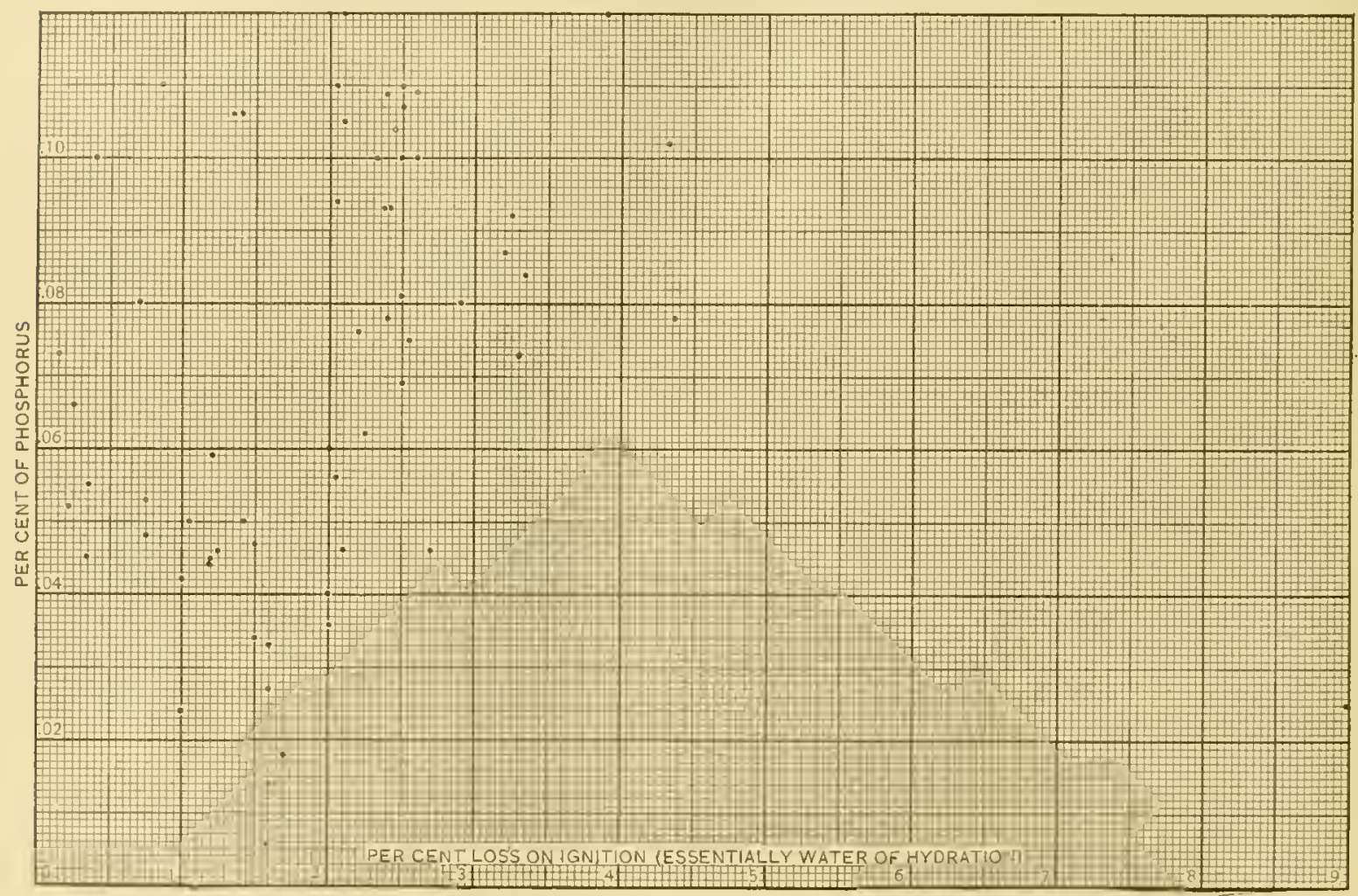

FIGURE 39.-Dingram showing relation of phosphorus to degree of hydration in Marquette ores.

Local rariations in phosphorus also occur apparently independent of relations to greenstone walls or channels of flow, being due, perhaps, to original clifferences in the iron-bearing formation. Typical of this is an oceurrence in the Volunteer mine, where ligh-phosphorus ore is found against hanging-wall jasper and low-phosphorus ore against the jasper foot wall.

'The increase of phosphorus with degree of hydration is shown in finure 39.

Two washing tests similar to those made on Mesabi ores (see p. 193) were made on samples of soft red lematite ore from the Lake Angeline mine and the Hartford mine. The results of these tests alre shown in the following table: 
Partial analyscs from washing tests on Marqucte ores.

Lake Angeline mine:

Heavy residue..

Finest material

Hartford mine:

Heavy residue.

Medium.

Finest material

The test on the Lake Angeline ore gare results similar to those oluained from the tests on Mesabi ore, showing the association of phosphorus with the more hydrated parts of the ore. The washing test on the Hartford ore, however, does not show this relation.

MINERALOGICAL OCCURRENCE OF PHOSPIIOIUS.

Phosphorus is known to occur as apatite, dufrenite, and as ahminum phosphate. It probably occurs in a variety of combinations with iron, magnesium, calcium, and aluminum and in forms too minute to be identified. Apatite has been identified by Prof. Seaman ${ }^{a}$ and others at a number of localities in the Negaunee formation and in the upper Huronian iron-ore deposits. In the chemical determination of phosphorus it is found that only a part of it is solnble in hydrochloric acid, the insoluble portion remaining with the siliceous residue. This seems to indicate that phosphorus is present in at least two combinations. The soluble phosphorus may be present in a variety of combinations, as inon phosphate, calcium phosphate, and some aluminum phosphates are soluble in hydrochloric acid. Charles T. Mixer and H. W. Dubois ${ }^{b}$ analyzed the insoluble residue remaining after treating ore with hydrochloric acid (1.10 specific gravity) and found its composition in percentages of original resiche to be $\mathrm{Al}_{2} \mathrm{O}_{3}$ 9:55, $\mathrm{CaO} 0.92, \mathrm{P}_{2} \mathrm{O}_{5} 4.10$, from which they concluded that the insoluble phosphorus is to a large extent combined with alumina. What this aluminum phosphate is it is impossible to say. It is of interest to note that the relative amounts of soluble and insoluble phosphorus are not uniform in the various ores; in some the insolubie form is entirely absent, but in others it makes up the greater part of the phosphorus present. It is believed by some of the chemists of the iron range that the insoluble phosphorus is highest in ores high in alumina. In order to ascertain the possibility of the phosphorus being present as apatite, the percentages of calcium oxide and phosphorus, in the different grales of ore produced in 1906, were platted as ordinates and abscissas in figure 40. The diagonal line indicates the relative amounts of the two constituents in apatite. It may be seen that most of the points fall below the line, indicating an excess of iine orer the amount required to combine with the phosphorus present as apatite. It is of interest to note that the high phosphorus ores are corresponelingly ligh in lime, indicating rather strongly the possibility of at least a large part of the phosphorus being present in apatite.

PIIOSPIIORTS IN RELATION TO SECONDARY CONCENTRATION.

As shown in the table on page 279 , there is apparently a gradation in the phosphorus content of the ores of the Negannee formation, from comparatively low plospliorus in those of the upper horizon to high phosphorus in those of the bottom liorizon. The lifference is most marked between the hard ores of the upper horizon and the soft ores of the middle horizon. The difference between the ores of the two lower horizons is very small and may be apparent rather than real. In explanation of the difference in phosphorus content between the hard and soft ores may be cited the opportunity for leaching of phosphorus from the upper strata during the erosion interval previous to the leposition of the Goodrich quartzite. Another possibility may be an original difference in the phosphorus contents of the ores at the two horizons. 


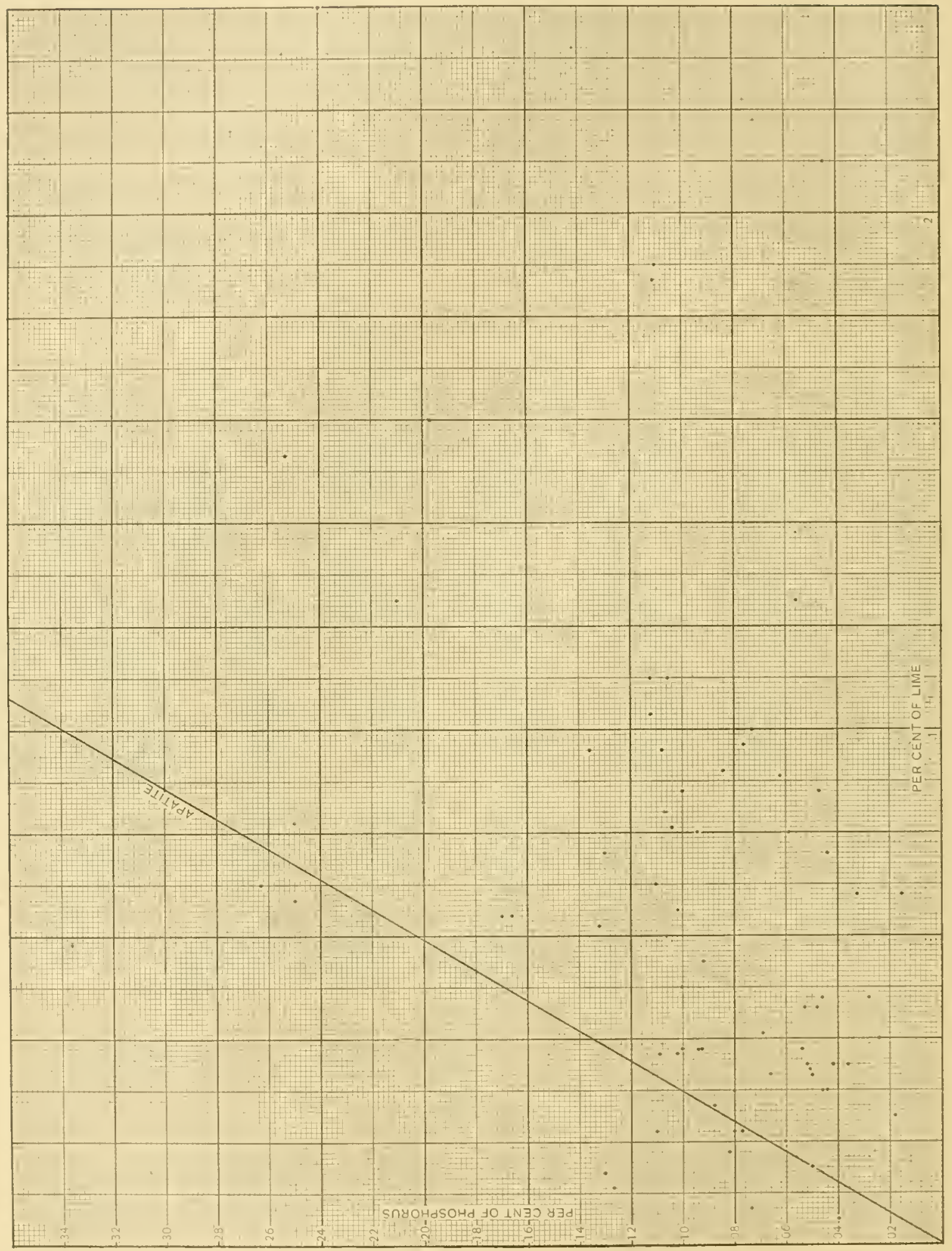


The abundant slaty phases of the Michigamme may have some bearing on the high phosphorus of the ores, as in all the iron districts the slates are higher in phospliorus than the ironbearing formation proper.

The local occurrence of high-phosphorus ore near greenstone contacts is believed to be ilue to direct transfer of that constituent, lcached from the greenstone during its alteration to soap rock or paint rock and deposited in the neighboring ores. 'The analyses on page 280 show that there is actually a loss of phosphorus in the alteration of the greenstone if alumina is assumed to have remained constant, althongh the actual percentage of phosphorus increases.

Local variations, apparently not related to greenstone contacts, are probably due to original differences in the phosphiorus content of the formation and not to secondary transfer or infiltration.

\section{SWANZY DISTRICT.}

\section{GEOGRAPHY AND TOPOGRAPIIY.}

The Swanzy iron district lies about 16 miles south of the city of Marquette, in T. 45 N., R. $25 \mathrm{~W}$. (fig. 41). In 1908 the productive area was less than 2 miles long and about half a mile wide and contained five proclucing mines. Future exploration and development will undoubtedly extend the district to the south and east, but northward and westward extensions are apparently cut off by the granite area that bounds the district on these sides. The towns within the producing area nre Gwinn and Princeton, both reached by the Munising Railway. The district occupies a range of hills typieal of the granite area, and slopes on the south and east to a flat saud-covered plain above which stand a few monadnocks of pre-Cambrian rocks.

\section{GENERAL SUCCESSION AND STRUCTURE。}

The succession is as follows:

Quaternary system:

Pleistocene................... Glacial deposits.

Cambrian sandstone.

Ordovician limestone.

Unconformity.

Algonkian system:

Hnronian series:

Upper Huronian (Animikie group).. $\left\{\begin{array}{c}\text { Michigamme slate. } \\ \text { Bijiki iron-bearing member. In lenses and layers } \\ \text { near late of Michigamme slate. } \\ \text { Goodrich quartzite. Qnartz slate and quartzite, grad- } \\ \text { ing down into arkose or recomposed granite. }\end{array}\right.$

Unconformity.

Archean system:

Laurentian series................. Granite.

The Swanzy district consists of a southenstward-pitching synclinorium of upper Huronian rocks, bounded on all but the southeast side by Archean grinite. It is about 2 miles long; its width is for the most part not more than three-quarters of a mile, and at the narrowest point, near the Stevenson mine, is only half a mile. To the southeast it widens, but in this direction the structure is not known because of the deep overburden. The pitches of the minor folds at the Stegmiller, Princeton, and Swanzy mines are toward the northwest. The slates have dereloped a good clearage, usually crossing the bedding. This structure does not affect the quartzite and the iron-bearing member.

\section{ARCHEAN SYSTEM.}

The Archean forms the basement upon which the IItronian sediments lie. It is represented by granites similar to the basal granites of the neighboring iron ranges.

The Archean bounds the district on the north, west, and southwest sides. Isolated exposures stand as monadnocks above the flat sind plains of the district. 


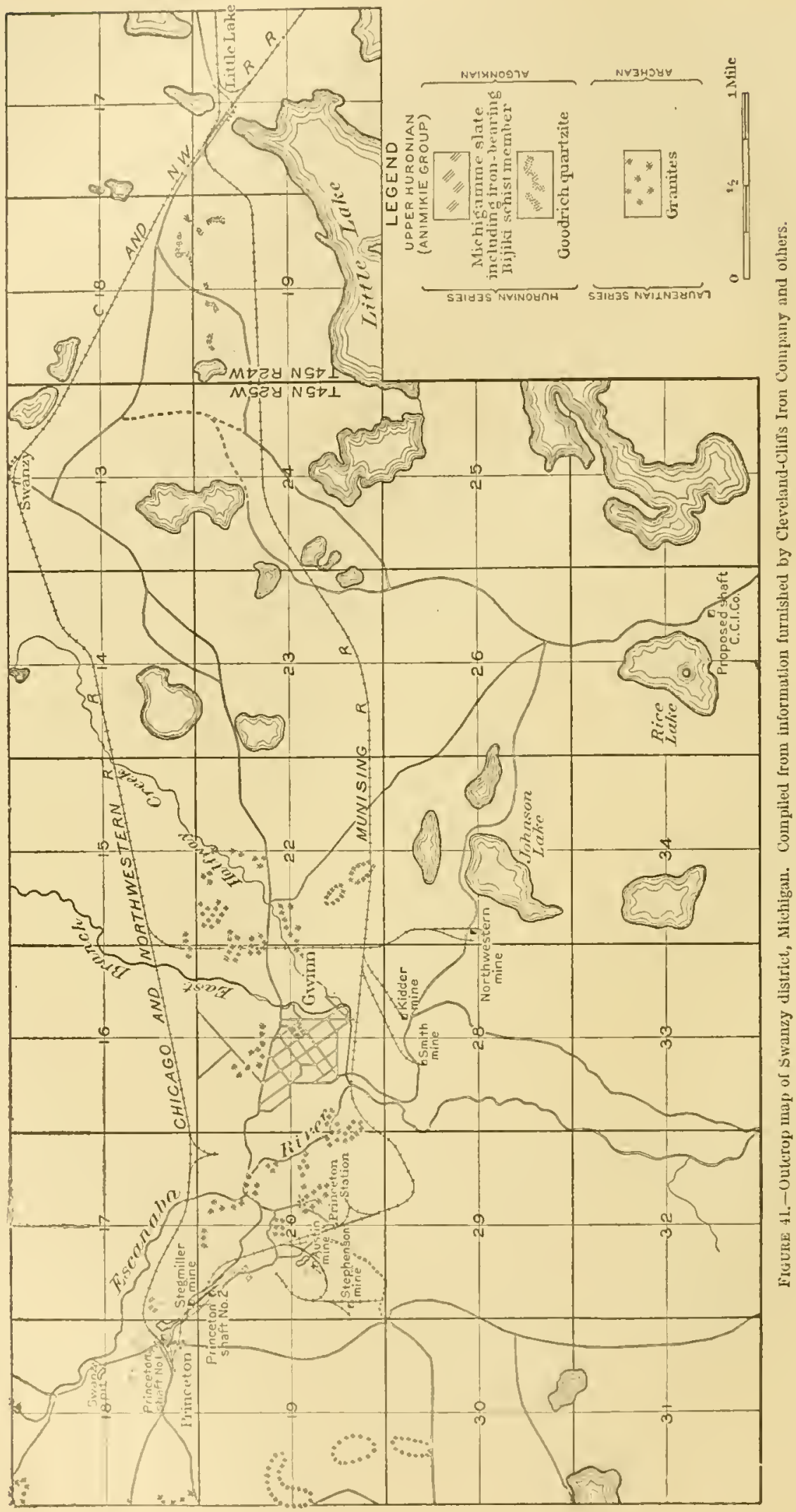




\section{ALGONIIAN SYSTEM。}

HURONIAN SERIES.

UPPER IIULONIAN (ANIMLIE GROUP).

GOODRICH QUARTZITE.

The Goodrich sediments lie unconformably upon the Archean rocks. They consist of a coarse arkose or recomposed granite at the base, which grades upward through quartzite and quartz slate to the Bijiki iron-bearing member of the Michigamme slate. The arkose horizon represents a shore phase of sedimentation where disintegration was very active and rapid transportation of the disintegrated material prevented decomposition. In places the arkose is distinguished from the granite with difficulty. The quartzite is petrographically very similar to the Goodricl quartzite of the Marquette range and exhibits all phases of gradation between the arkose below and a thin-bedded quartz slate above. Both the quartzite and the quartz slate are locally iron stained, and in places the impregnation is so strong as to have attracted prospecting operations. The arkose phase is best exhibited in drill cores. The quartzite and quartz slate phases are well exposed in abundant outcrops on the north slope of the range of hills which crosses sec. 19, T. 45 N., R. $24 \mathrm{~W}$. The quartzite also outcrops in a small hill near the northeast corner of sec. $18, T .45$ N., R. 24 W.

The thickness of the quartzite and the quartz slate varies and locally the slate and jasper lie directly on the recomposed granite or on the granite itself.

MICHIGAMHE SLATE.

The Michigamme slate is best exposed at the old Swanzy open pit, near the center of sec. 18, T. 45 N., R. $25 \mathrm{~W}$, where it is found in contact with the Bijiki iron-bearing member. It both underlies and overlies the iron-bearing beds, which are therefore treated as a member of the slate. The Michigamme forms much the larger part of the upper Iuronian.

The iron-bearing member is a banded ferruginous chert or "soft-ore jasper" similar in appearance to part of the Bijiki schist of the Marquette range. Locally it grades into a ferruginous slate. It apparently occurs in lens-shaped beds in and near the base of the Michigamme slate, and therefore it is treated as a member of that formation. Drilling and mining operations have shown jasper with slate above and below, or slate above and quartzite below, or in places the iron-bearing member is found directly above the arkose and overlain by slate, the quartzite and quartz slate being absent. The iron-bearing member is exposed at several places in the vicinity of the Princeton, Stegmiller, and Austin mines and also in the old Swanzy open pit. An exposure near the center of the SE. $\frac{1}{4}$ sec. 1S, T. $45 \mathrm{~N} ., \mathrm{R} .25 \mathrm{~W}$., shows typical banded soft-ore jasper with a nearly vertical dip. Near the southeast corner of the same section, just west of the St egmiller mine, is a similar exposure. An exposure about 600 feet west of Princeton station shows the member folded and contorted.

\section{PALEOZOIC SEDIMENTS.}

On the east side of the district flat-lying sandstones and limestones belonging to the Cambrian and Ordovician overlap the pre-Cambrian formations unconformably. The nearest exposure of limestone is in the northeast comer of sec. 18, T. 45 N., R. 24 W., where a small hill of quartzite has a few remnants of a limestone capping.

\section{QUATERNARY DEPOSTTS.}

Pleistocene sand flats of glacial origin cover most of the district. (See Chapter XYT, pp. $427-459$. 


\section{CORREIATION.}

The upper Inronian (Animikie group) is very similar, both in stratioraphy and in litholory, to the rpper IIuronian of the Marquette district on the north and the Crystal Falls and Menomince districts on the south.

TIIE IION ORES OF TIE SWANZY DISTIRICT.

By the authors and W. J. MEAD.

\section{GENERAL DESCRIPTION.}

The ores of the Swanzy district are in the Bijiki iron-bearing member, which is interbedded with the lower part of the Michigamme slate of the upper Huronian and rests upon the Archean granite with only a comparatively thin intervening zone of quartzites, quartz slate, or recomposed eranite, constituting the Goodrich quartzite. The upper Huronian constitutes a suutheastwarl-pitching synclinorium, but some of the minor folds on its limbs pitch to the northwest. They are of the drag type so common to the Lake Superior region. (See fig. 12, p. 123.) The iron-bearing member takes part in this general structure. The ores therefore appear as much-folled deposits with foot wall of slate, quartzite, recomposed granite, or granite and with hanging wall of black slate. All the ore deposits reach the erosion surface either at the border of the synclinorium or on the eroded minor anticlines in the main synclinorium.

Five mines are in operation and several adchitional ore deposits are known. (See map, lig. 41.)

The ore is a soft hyllated non-Bessemer hematite containing a rather high percentage of moisture. The following is the average composition of ore shipped in 1906:

Alerage composition of ore shipped from Suranzy district in 1906.

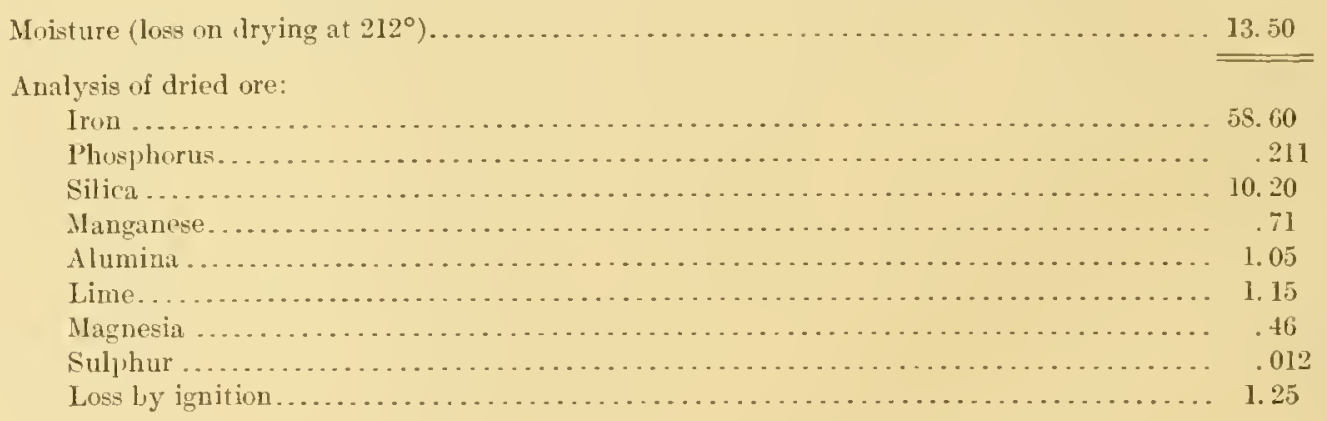

\section{SECONDARY CONCENTRATION OF SWANZY ORE.}

The structural conditions governing the concentration of the ores in the Swanzy district are a foot wall of granite, quartzite, or slate and a langing wall of slate, conforming to the structure of a synclinorium that has a grentle southeastward pitch with many minor vanintions. Erosion has exposerl the iron-hearing member near the borders of the synchinorium and along the arches of the minol anticlines. The circulation of the iron-bearing solutions has obviously been controlled not only by the impervious basement but by the overdapping imprerious formations which detcrmined their points of escape.

The ores and fermugums cherts have heen derived from the alteration of sideritic cherts and slates, accompanicd by the remoral of silica and the development of pore space. 


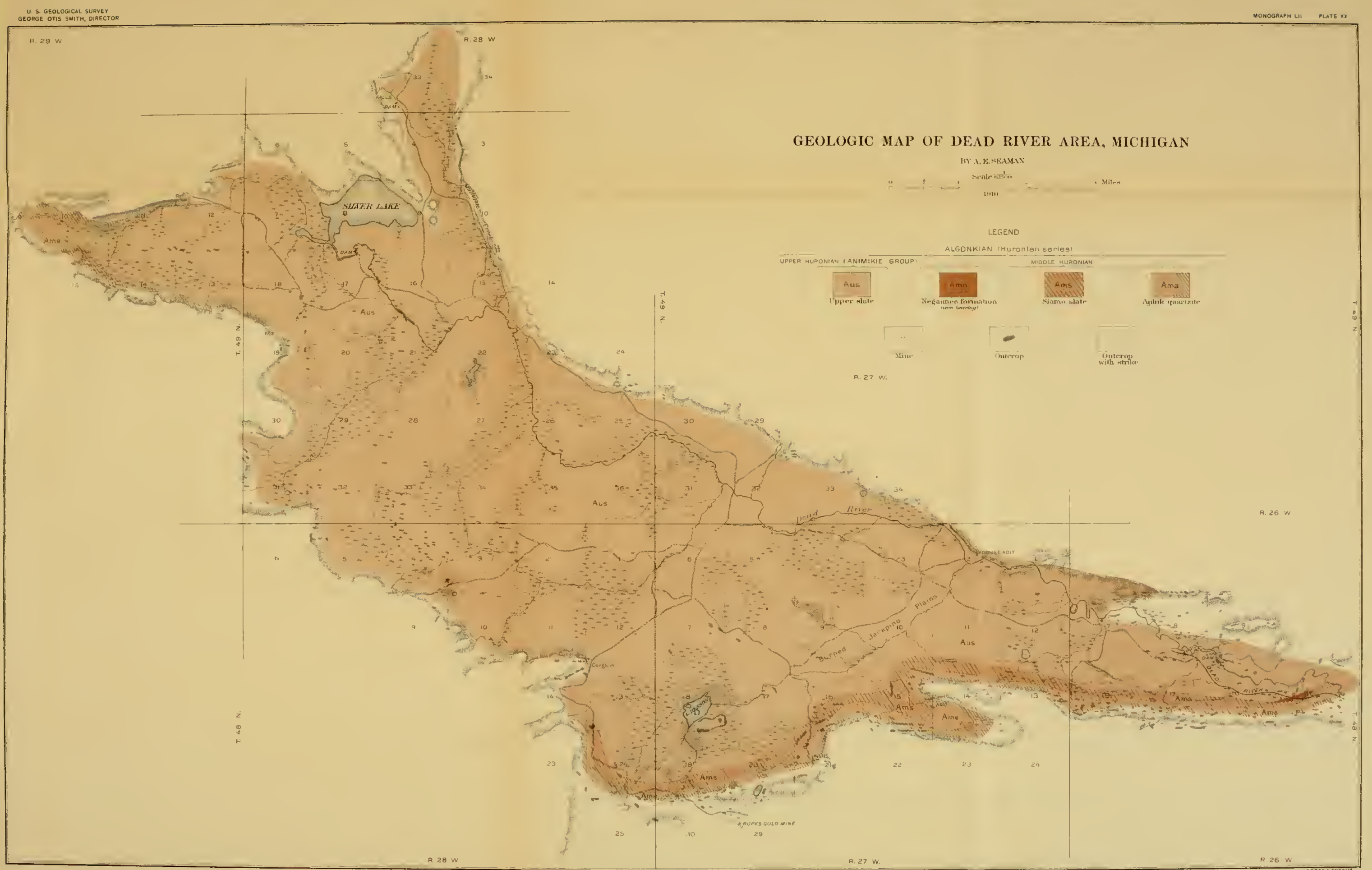





\section{DEAD RIVER AREA. ${ }^{a}$}

The Dead River area lies north of the Marquette district along the Dead River. Its greatest extent is 18 miles west-northwest and east-southeast. Its maximum width is 6 miles. (See PI. XX.) The basin is largely a low, flat sand-covered plain with an amphitheater of rock-exposed lills about it.

\section{GENERAL SUCCESSION.}

The general succession is as follows:

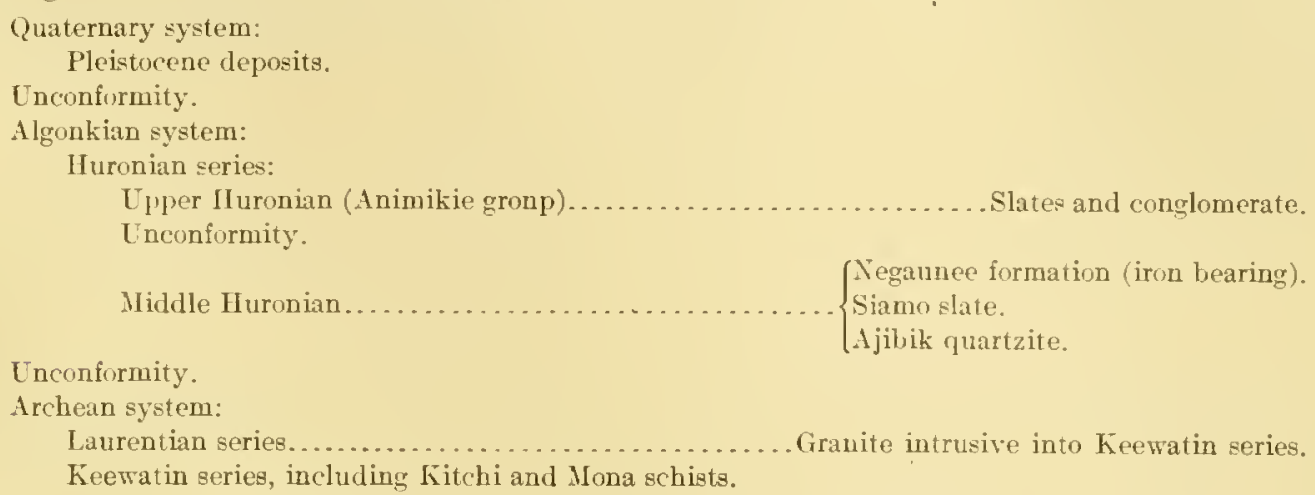

The Lamentian and Keewatin rocks occupy the lills surrounding the basin; the midrlle Huronian rocks outcrop along the margin of the basin, and the upper Huronian (Animikie group) occupies nearly all of the basin itself.

\section{ARCIIEAN SYSTEM.}

\section{KEEWATIN SERIES.}

The Keewatin series forms hills along the northeast and southeast sides of the basin. The series inchudes on the south side the Kitchi and Mona schists, already described for the Marquette district, and on the north side schists entirely similar in aspect, even to their content of iron-bearing sediments consisting of jasper, cherty siderite, and cherty slate. Slate and conglomerate are well exposed at the German exploration in sec. $35, T$, 49 N.; R. 27 W., and in the Holyoke mine on the south side of the liill.

\section{LAURENTIAN SERIES.}

Laurentian granites and gneisses bound the Dead River district on the southwest, west, and northwest and also for a short listance along the southeast end. They are not different from the rocks of the northern complex of the Marquette district.

\section{ALGONLIIN SYSTEM.}

\section{HURONIAN SERIES.}

Ifidlt IIuronian.-The middle IIuronian is exposed along the south and southeast siles of the district and also at the extreme west end bordering the amphitheater of lieewatin an: Laurentian rocks. The best exposed of these rocks is the Ajibik quartzite, forming the base of the middle Furonian, and showing unconformity between Laurentian and middle Ituronian by discordance in structure and by conglomerates.

The Siamo slate outcrops in a narrow belt along the north side of the Ajibik quartzite where it follows the south boundary of the district.

The Negaunee formation (iron bearing) is exposed in only one area, in sec. 15, T. $48 \mathrm{~N}$., R. $26 \mathrm{~W}$, along the railway track and in pits. Here the iron-bearing formation, with the under- 
lying siamo slate and Ajibik quartzite is much folded. Orerlying the iron-hearing formation (in clirect contact in pits) is the basal conglomerate of the upper IJuronian, containing fragments hoth of misllle lluronian and lieewatin.

Cpper IIuronian (Animilic group).--The upper IIuronian consists principally of slates, similar in all resperets to the Michigamme slate of the Marquette district. They outcrope in isolated exposures over the area and their presence is further inclicaterl by the prevailing low relief of the bnsin. The base of these rocks is probably marked by the conglomerate resting unconformably on the kecwatin series at the Iolyoke mine and eastwarl at intervals to the cast ond of the basin; also by the conglomerate covering the Negaunee formation, alrealy roferred to. The slates have not been connected directly with the conglomerate, lout the fact that the conglomerate contains fragments not only of Keewatin hut of milllle Huronian rocks scems to recpuire its correlation with the upper IHuronian.

Greenstone dikes cut the slates. One of them constitutes the falls of Dead River where it cuts througl the slates in sec. 9, T. 48 N., R. 26 W.

\section{PERCH LALE DISTRICT (INCLUDING WESTERN MARQLETTE). GEOGRAPHY AND TOPOGRAPIIY.}

The Perch Lake district includes territory extending west from the Iarquette district and north from the Crystal Falls and Iron River districts to a line extending from Li. Inse Bay on the northeast to the south end of Lake Gogebic on the southwest. The area thus defined inclucles roughly 1,200 square miles. (See fig. 42; Pl. XXI, in pocket.) A topographic maj has been prepared of the area around Perch Lake, extending from $s 8^{\circ} 30^{\prime}$ to $\$ 5^{\circ} 45^{\prime}$ west and $46^{\circ} 15^{\prime}$ to $46^{\circ} 30^{\prime}$ north. The remainder of the country has not been survered topographically. As a whole the country is characterized by morainal topography with much local irregularity, but has no conspicuous ranges characteristic of the principal ore-producing districts.

\section{GENERAL SUCCESSION.}

The succession is as follows, from the top downward:

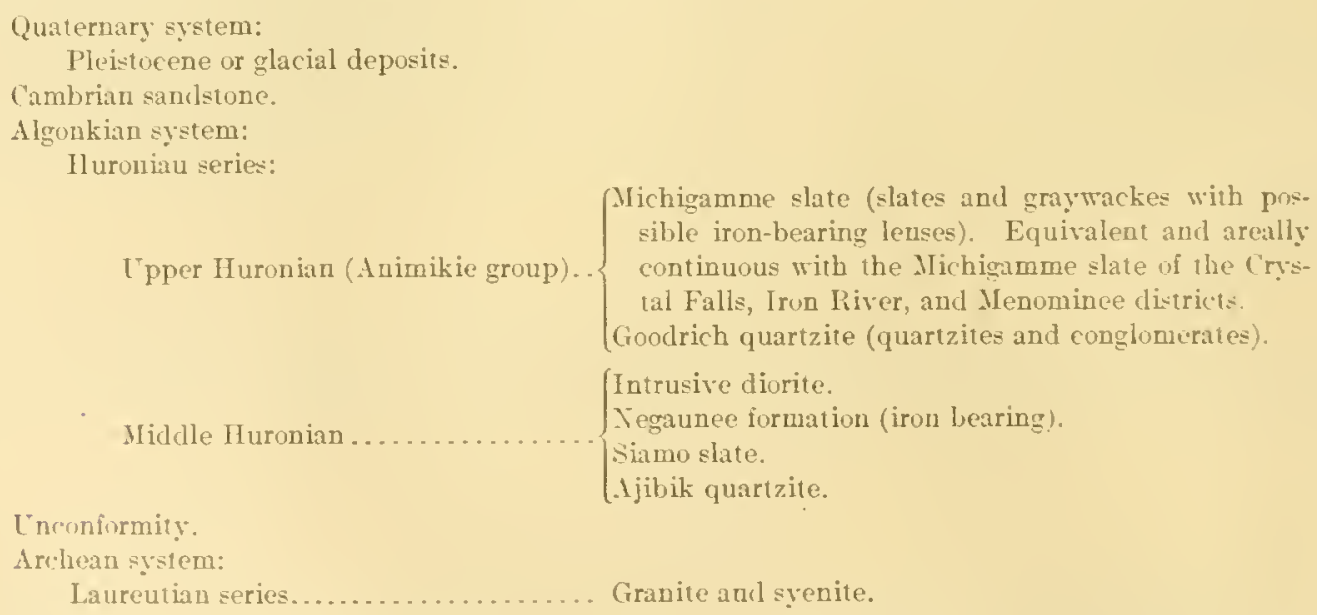

\section{ARCHEIN SINTEM. \\ LAURENTIAN SERIES.}

The Laurentian granite and syenite bound the district on the northeast. They show no features diflerent from the Laurentian of the contiguous Marquette district. The rocks are abundantly exposed. The topograply of the Arehean area is as a whole rougher and more irregular than that of the Algonkian on its southwestem margin, affording a very satisfactory guide for discrimination in the fich mapping. The Archean underlies the Huronian unconformably. 


\section{ILGONIIAN STSTEM. \\ HURONIAN SERIES.}

Middle IIuronian.-Between the upper IIuronian slates and graywackes (Michigamme slate) and the Archean granite on the northeast there appears a belt alout 5 miles long extencling from the Marquette district northwest, in which are exposed middle Huronian sediments and upper Huronian Goodrich quartzite. (See fig. 42.) The micklle Iluronian Ajibik quartzite and Siamo slate show no features different from those of the Harquette district. 'They rest unconformably against the Archean. On the nortliwest and along their trend they become covered by glacial materials until they can no longer be followerl. Presumably they extend

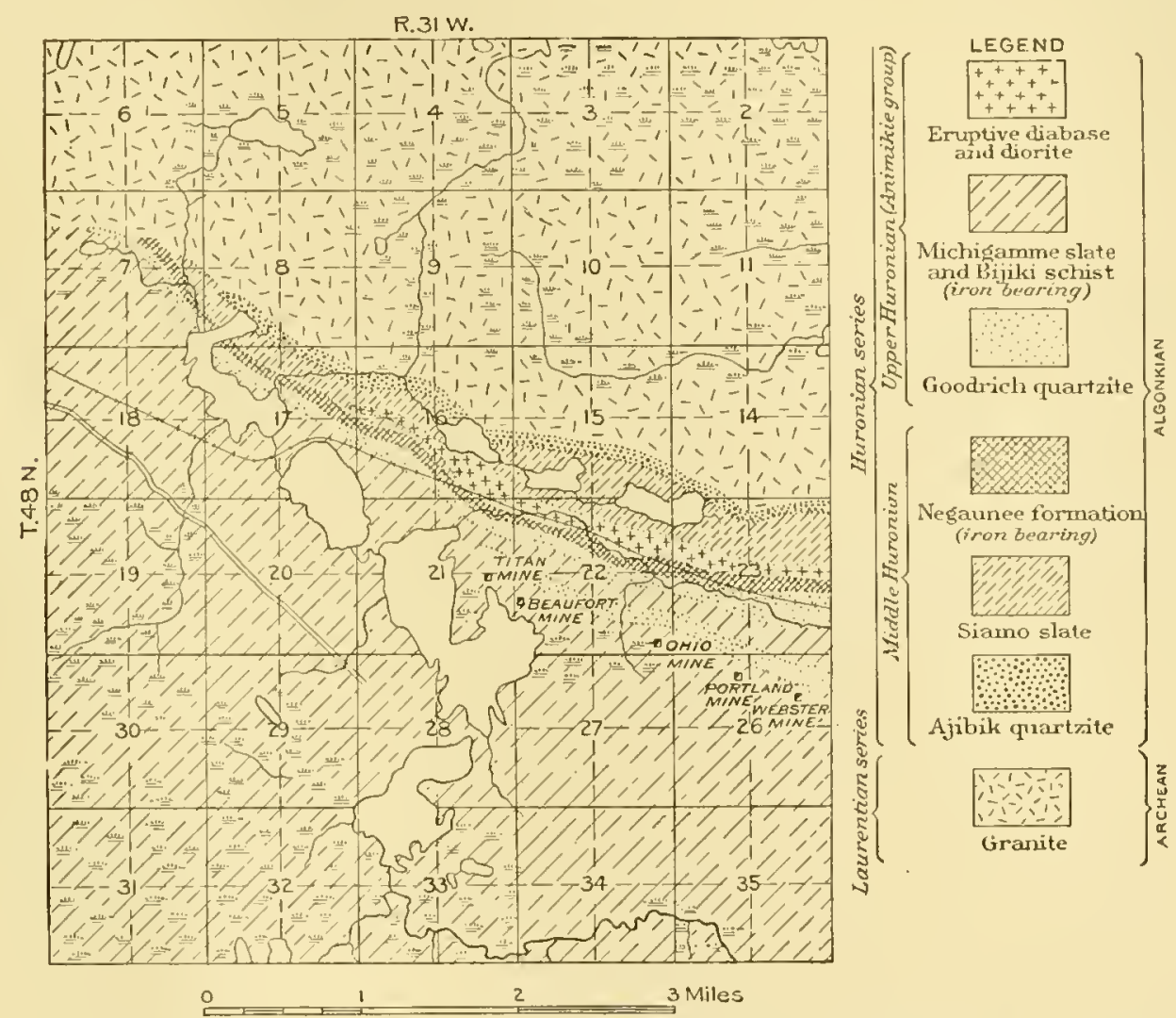

FIGURE 42.-Geologie map of west end of Marquette district, Michigan. By W. N. Merriam and M. II. Newman.

considerably farther than the map indieates. The Negaunee formation also is similar to the Negamee formation of the Marquette district. It is followed, however, principally by magnetie observations to the point indieater on the map, where it is lost beneatl the covering of later drift. Whether it extends farther or whether this represents the end of the originally deposited iron-bearing lens is not known.

Clper II uronian (Animitie group).--The distriet is underlain principally by upper Huronian slates and graywackes, known as the Michigamme slate. On the northeast they rest unconformably against the Archean granite and middle Ihuronian rocks. On the northwest they are overlain by Cambrian sandstone, the relations of the two locally being olsseured by faulting. The Goodrich quartzite of the upper Ihuronian is exposed only in the northeastem part of the area bordering the mickle Huronian and at the northwest end, presumably orer-

$$
47517^{\circ}-\text { IOL } 52-11-19
$$


lapping on the Archean. Its characteristics are similar to those of the Goodrich quartzite of the Marquette district. The Nichiganme slate covers much the larger part of the Perch Lake area. Exposures are fairly abundant, especially in the Perch Lake district. Presumably contemporaneous basic volcanic rocks are associated with these slates, to judge from the facts observed to the south, but their detailed distribution is not known. There is difliculty in identifying horizons in the slate and graywacke, and therefore in working ont the structure of this area. From the abundance of exposures, however, it is probable that this may be accomplished in the future. The locations of most of the exposures have been noted in commercial surveys, but the Geological Survey has not examined this area in detail to work out the structure. From the promising development in similar series in the adjacent Iron River district, it would seem that this area would warrant careful examination for iron-bearing lenses.

\section{QUATERNARY DEPOSITS.}

Pleistocene glacial deposits cover all of this area. (See Chapter XTI, pp. 427-459.) 


\section{CHAPTER XII. THE CRYSTAL FALLS, STURGEON, FELCH MOUN- TAIN, CALUMET, AND IRON RIVER IRON DISTRICTS OF MICHI- GAN AND THE FLORENCE IRON DISTRICT OF WISCONSIN.}

The Crystal Falls, Sturgeon, Felch Mountain, Calumet, and Iron River iron districts of Michigan and the Florence iron distriet of Wisconsin together form the ore-producing area between the Marquette district on the north and the Menominee district on the south. (See fig. 43.) The ores of all these districts occur in the upper Huronian (Animikie group) and have many similarities in kind and relations, and the limits of the several districts are poorly defined. They are accorlingly grouped together in one chapter.

\section{CR TSTAL FALLS IRON DISTRICT. ${ }^{a}$ \\ LOCATION AND AREA.}

The Crystal Falls district is centered in the town of that name in the Northern Peninsula of Michigan. (See Pl. XXII, in pocket.) As the term is here used it includes an area of about 540 square miles, covering all the territory between the Marquette and Menominee districts as these have been limited on the maps of the United States Geological Survey. In commercial parlance the Menominee district includes the Crystal Falls and southwestward extensions, and reports of shipments for the Menominee district include these districts. However, they are geologically and structurally more or less independent and have been treated in two reports, ${ }^{b}$ hence here the Crystal Falls district will be treated independently of the Menominee district. The Felch, Sturgeon, and Calumet troughs bordering the Crystal Falls district on the southeast are also discussed in this chapter, as well as the Iron River and Florence districts, which lic to the south and southwest.

\section{GENERAL SUCCESSION AND STRUCTURE.}

The succession is as follows:

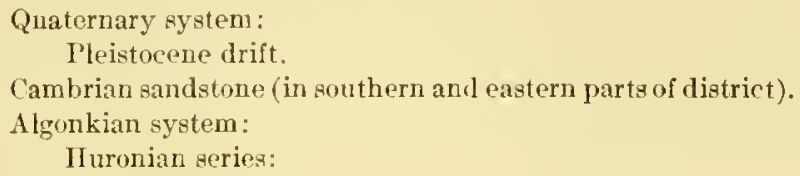

a For further detailed description of the geology of this district see Mon. U. S. Geol. Survey, vol, 3t, 1899, and references there given.

b Clements, J. M., and Smyth, H. L., The Crystal Falls iron-hearing district of Michigan: Mon. U. S. Geol. Surrey, rol, 36, 1s99. Bayley; W. S., The Menominee iron-bearing district of Michigan: Mon. U. S. Geol. Survey, vol. 46, 1904. 
The northeastern part of the aren is undriain by Archean granites. Bordering this main drchen area on the southwest, with longer axes piatllel and striking north-northwest and

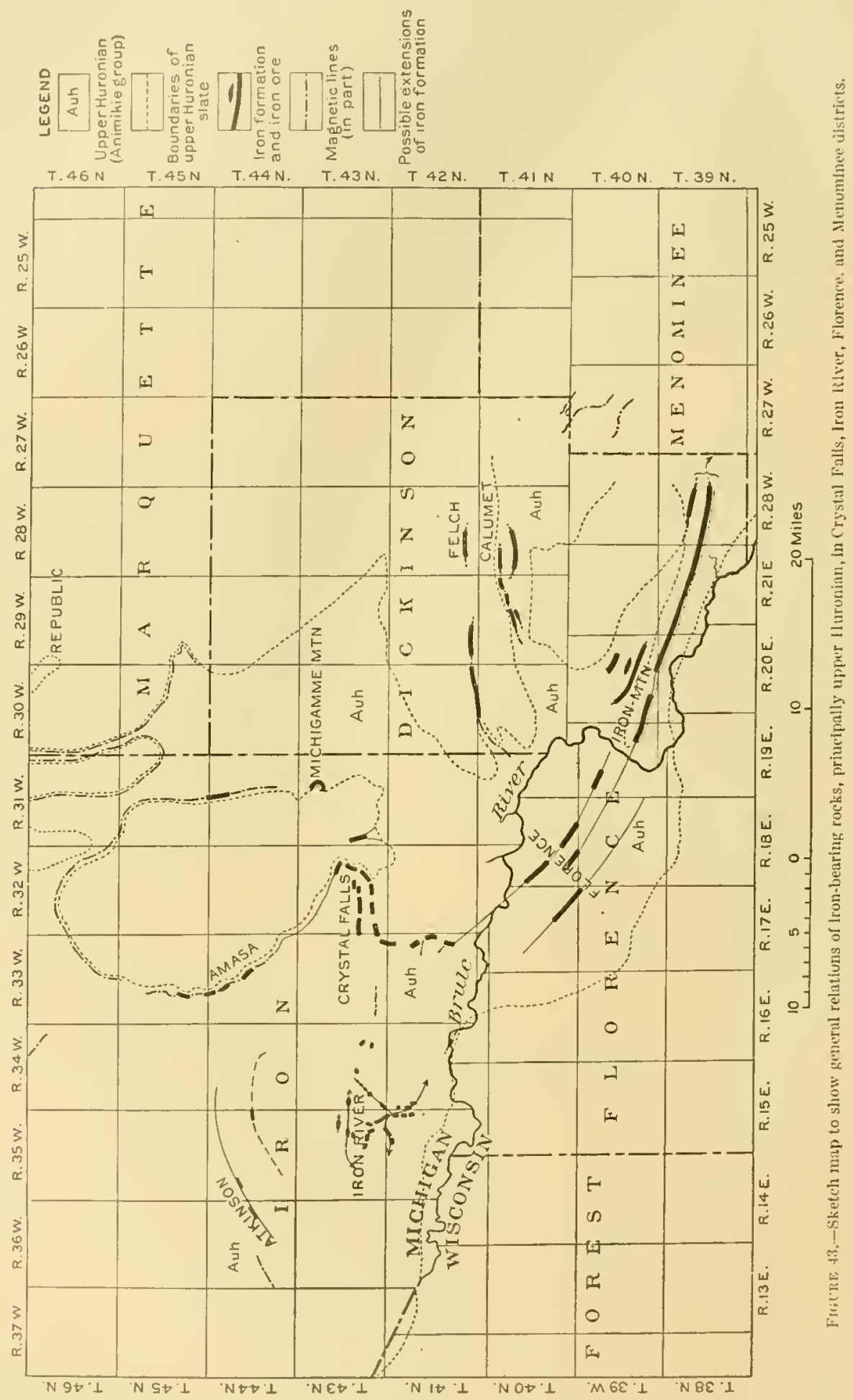

south-southeast, are two minor oral areas of Arehean granite. Huronian sediments and hasic igneous recks, exposed principally in the western part of the distriet. lap around the Arehean ovals and against the main $A r e h e a n$ area to the northeast, and their general structure is deter- 
mined by their relations to the Archean orals. The Crystal Falls and Amasa districts are on the southwest side of one of these Archean ovals. Therefore both the sip and the pitch of the minor folds of the upper IInronian occupying these areas are in southwesterly directions.

\section{ARCHEAN RISTEM. \\ LAURENTIAN SERIES.}

The Arehean or basement rocks occupy the northeastern part of the district, filling the angle between the Crystal Falls and Ifarquette districts. To the west of this they also appear in two elliptical cores with longer axes north-northwest and south-southeast, ajproximately parallel to the axes of the major folds of the district.

The Arehean rocks consist mainly of massive and schistose granites and of gneisses. Nowhere in them have any rocks of sedimentary origin been discovered. They have been cut hy igneous rocks, both basic and acilic, at different epochs. These occur in the form hoth of bosses and of dikes, the lat ter in places cutting but more ordinarily showing a parallelism to the foliation of the schistose granites. The Archean granites and gneisses and the earlier intrusive rocks alike have been profoundly metamorphosed, and at scveral places have been completely recrystallized. In the westernmost oval there is to be olserved a distinct arrangement of feldspar crystals with their longer dimensions parallel to the contact with the II uronian rocks.

\section{ALGONIIAN NITTEMT. \\ HURONIAN SERIES.}

LOWER IIUTONIAN.

STURGEON QUARTZITE.

In the central part of the district the Sturgeon quartzite is represented only by thin fragmental layers at the base of the overlying Randville dolomite. These are too thin to be mapped. Its principal outcrops are to the southeast in the Felch Mountain and Sturgeon districts, described later in this chapter.

\section{RANDVILLE DOLOMITE.}

The Randrille dolomite completely surrounds the Archean oral northeast of the town of Crystal Falls. Here it constitutes the base of the sedinentary series and rests directly upon the Arehean with only thin intervening layer's of fragmental quartzose dolomite and recomposed granite, all more or less altered to quartz sehist and in many places difficult to distinguish from schistose phases of the granite itself.

On the west side of the western Archean oval the dolomite is poorly exposed and its thickness is not estimated. On the east side the belt is alout half a mile wirle and the thickness about 1,500 feet. The formation constitutes here an eastward-dipping monocline with minor plications. In the scattered outerops of the Michigamme Nountain area the dolonite strikes and dips toward all points of the compass as a result of the gentle arching from the general northwest-southeast axis, combined with sharp local folds which run nearly east and west.

Petrographically the formation ranges from coarse saccharoidal marbles, in places very pure but usually filled with secondary silicates, to fine-grained, little-altered limestones, whicl are here and there so impure as to be calcareous or dolomitic sandstones and shales. The prevalent colors are white, but various shades of pink, light and deep blue, and pale green oceur. Some of the varieties are oolitic. This structure does not seem to have been previously noted in limestones of pre-Cambrian age in the Lake Superior region. 
MIDDLE IIURONIAN (?).

HEMLOCK FORMATION.

Distritution and general character.-The volcanic Ilenlork formation occupies a large area in the Crystal Falls district. It is believed almost to surround the westemmost $A$ rriean oval and also to occur in a great area nortlowest of Crystal Falls and in one isolated area near the Nastodon mine, south of Crystal Falls. Its general stratigraphie position is conformably above the Randville dolomite and beneath the upper Huronian slates, but like most rolcanic formations its relations difler in different parts of the district in ways which will appear below. Well-bedied cherty slates, iron-bearing lenses, and limestone are interbedded with the Hemlock formation and also both underlie and overlie it. 'The roleanic extrusions may be regarded as intermuptions of otherwise continuous deposition of sediments. The lack of contimuity of the volcanic flows and of the interbedded sediments, and the difficulty of correlating the beds of either in different parts of the distriet, make it practically impossible to use geologic uames for these sediments which will have anything nore than very local significance. One of the principal local sedimentary units within the Hemlock formation has been described and mapped in the United States Geological Survey monograph on the Crystal Falls district ${ }^{a}$ as the "Mansfield slate." Limestone and slate layers appear abundantly in the Hemlock formation near Hemlock River immediately northeast of the town of Amasa and in several other localities.

Aren south and west of the westernmost Archean oval.-Exposures of the Hemlock formation are numerous west and south of the western Archeun oval, and where erosion has removed the drift the formation has a marked infuence on the topography. The thickness is estinated from the dip to reach 23,000 feet, but this is probably illusory lecause of reduphication due to folding. The formation here consists mainly of bedded surface basic extrusive rocks and crystalline schists derived from them. Sedimentary rocks play a subordinate part. The Hemlock rocks are similar in all respects to the Keewatin volcanic rocks and to the volcanic Clarksburg formation of the Mirquette district. The formation is cut by a few acidic dikes and by numerous dikes and enormous bosses of basic rock. On the former Survey map of the district ${ }^{b}$ certain of these were discriminated, but they are not discriminated on the accompanying map (Pl. XXII, in pocket), because more study has show a most intimate association of extrusive and intrusive phases of the formation throughout the area. The acidic intrusive rocks include rhyolite porphyry and aporhyolite porphyry. The rhyolite porphyry shows interesting micropoikilitic texturial chatracters. Aciclic pyroclastic rocks are scurce and were derived from the aporhyolite. The basic lavis correspond to the modem basalts. They are much altered and are called "metabasalts." The basic lavas include nonporphyritic, porphyritic, and variolitic and ellipsoidal types. Clements ${ }^{c}$ has described the ellipsoidal textures and concludes that basalts possessing this structure were originally very viscous and correspond to the modem aa lavas, probably of submarine origin. The pyroclastic rocks comprise eruptive breccia, including friction breccias and flow breccius, and volcunc sedimentary rocks. The colian deposits, which are deseribed as tufls, grade from fine dust up to those in which the fragments are bowlders. The water-deposited volcanic fragmental rocks are known as volcanic conglomerates, and likewise range from those of which the particles are minute to those of which the fragments are very large. At many places occur clastic rocks which are now schistose and whose exact mode of origin - that is, whether eolinn or water-deposited-could not be determined.

The erystalline schists of Bone Lake include rocks of completely erystalline character, which by fichl and microscopic study have been comected with the voleanic rocks and are considered to have been derived from rocks similar in nature to them.

In genernl some of the volcunic rocks are submarine. The greater proportion, however, were derived from volcanic vents, which could not be located, but were probably situated near the IIuronian shore line. Clements suggested that voleanic activity began in the north and 
moved to the south, and that some of the volcanic deposits to the north are contemporaneous with the so-called "Mansfield slate."

Fence River area.-In the Fence River area the Hemlock formation oceupies a belt between 2,000 and 3,000 feet in width, between the Randville dolomite on the west and the Negilunee formation on the east. The best exposures occur on the sections made by Fence River. No folds have been observed within the formation. The thickness probably ranges up to 2,300 feet as a maximum. The rocks of the formation in this area are chiefly chlorite and oplitic schists, with which are associated schists bearing biotite, ilmenite, and ottrelite, greenstonc, conglomerates or agglomerates, and amygdaloids. As evidence of the origin of these schists several facts may be cited. First, they include no rocks possessing any sedimentary characters; next, lavas and also greenstone conglomerates or agglonerates are undoubtedly present in the series; furthermore, the minerals which compose the schist are those which would result from the alteration in comnection with dynamic metamorphism of igncous rocks of basic or intermediate chemical composition; and finally, the grain and character of the gromdmass and in some slides the presence of plagioclase microlites disposed in oval lines point directly to an igneous origin and to consolidation at the surface. The conclusion is reached that the Henlock formation of the Fence River area is composed of a series of old lava flows varying in composition from acidic to basic.

Other areas of the IIemlock formation.-Other areas of volcanic rocks similar to those of the Hemlock formation appear to the north and west of the town of Crystal Falls, near the Mastodon mine, and elsewhere, as shown on the accompanying general map of the Crystal Falls distriet (Pl. XXII). Whether these are of the same age as the main mass of the Hemlock formation and owe their distribution to folding, or whether they are later extrusions, is not yet known. Tron-bearing slate member ("Mansficld slate") of the Ilemloek formation.-The so-called "Mansfield slate," which is mterbedded near" the top of the Hemlock formation, is best exposed in the vicinity of the town of Mansfield. It here occupies a valley through which flows Michigamme River. Petrographically the member includes graywackes, clay slate, phyllite, sillerite slate, chert, ferruginous chert, and jron ores, with several metamorphic products derived from them. The strike is north and south and the dip on an average $80^{\circ} \mathrm{W}$. The maximum thickness of the belt is 1,900 feet. Southward from the point of maximum thickness it rapidly thins out and disappears.

The iron-bearing beds form a belt 32 fect wide or less between black slate walls. The strike and dip are the same as those of the slate. A single ore body of commercial importance has been mined. (See p. 324.)

The Hemlock formation both east and west of the main belt of this slate carries thin bands of slate with similar strike and dip. In general, in this vicinity, there is a monoclinical westward-dipping succession of volcanic rocks extending 2 miles or more east of Mansfield and about the same distance west, containing interbedded layers of slate, which in the vicinity of Mansfield are in considerable abmdance and include also iron-bearing beds. These rocks may be best seen on the hill just enst of Michigamme River, southeast of the Mansfield mine, where eight or ten layers of cherty slate from a few inches to 10 feet or more in wilth are interlayered with westward-dipping ellipsoidal basalt flows. The centers of the flows are usually homogeneous and coarse gramed, and the ellipsoidal structures appear only within a few fect of the top or bottom of the flow immediately next to the slate. As a whole the contact between the basalt and the slate is a plane surface, making it possible to follow a bod of slate even 2 feet thick for hundreds of feet. In detail, however, the contact may be very irregular, following interstices in the cllipsoidal surface as if deposited upon an initially irregular surface.

Slates mapped as "Mansfield" by Smyth also outcrop on Michigamme Mountain and thence at intervals for 6 miles to the northwest. The area northwest of Michigamme Mountain, mapped as Pleistocene on Plate XXII, is believed to be largely underlain by slate from its appearance in a few pits and exposures. The information is so meager, however, that it is not thought desirable to map this area as slate. On Michigamme Mountain the geologic position of the 
so-called "Mnusfich" rocks is free from doubt. In the principal syneline of see. 32 , T. $44 \mathrm{~N}$., R. 31 W., they overlie the dolomites and pass downwarl into them by a redatively slow graclation; on the borders of the Michigamme Mountain sincline they underlie the iron-bearing Negaunce ("Groveland") formation. The passage to the higher lormation likewise is graded, though rapidly, and is marked in certain hands by an increase in clastic grains and by changes in the character of the matrix in which these are set. The average thickness of the formation in this mountain is not less than 400 fret.

\section{NEGAUNEE (?) FORMATION.}

Magnetic belts northeast of Fence River.-By reference to the map (Pl. XXII, in pocket) it will be noted that there is a magnetir. line marked "A" along the west siche of the inain northeastern area of Arehean rocks. That this magnetie line is caused hy and marks the position of the iron-bearing Negaunee formation there can not be much doubt, according to Smyth, ${ }^{a}$ for that rock outerops in a few scattered localities, occurs abundantly in the drift, and has been found in test pits and drill holes here and there along this line. The underlying quartzite outerops beneath the iron-bearing formation near the north end of the line, but farther south it is cntirely covered by the drift, so far as the territory has been examined. The overlying upper Ifuronian rocks are also known to be present just west of the Negaunee formation as far south as sec. 19, T. 46 N., R. $30 \mathrm{~W}$. The elip along the "A" line is probably therefore, on the whole, toward the west, although the observed dips at the few localities where rleterminations have been made are either rertical or slightly inclined from the rertical toward the east. In an cast-west section of drill holes in sees. 18, 19, 29, and 30, T. 46 N., R. 30 W., cutting the magnetic belt "A," the iron-bearing formation is found to be amphibole-magnetite rock cut by intrusires.

Around the immediately adjacent Arehean oral on the west the magnetic line "B" has been traced for 25 miles without a single exposure. The known facts with reference to the "B" line, accorling to Smyth, are these: (1) It represents a magnetic rock; (2) this magnetic rock completely encireles an Archean core. It may further be inferred with practical certainty that this formation, which carries such constant magnetic propertics for 25 miles, must be sedimentary. With regard to its structure the foregoing considerations would necessarily involve the conclusion that it dips away from the Archean core on all sides, and this conchusion is fortifiel by the unsymmetrical separation of the horizontal maxima on the magnetic cross sections.

East of the "B" line, between it and the "A" line, is found the basal member of the upper" Huronian. The rock which is manifest in the " $\mathrm{B}$ " line must, therefore, be older than any" nember of the upper Huronian. The Negaunee formation, represented in the "A" line, dips west, but the rock of the "B" line dips east. They are both older than the basal member of the upper Huroniun and are both younger than the Archean. They are hoth strongly and persistently magnetic. For 8 or 10 miles they rum parallel to each other less than half a mile apart. Thei broad structural relations to the Archean hasement of the region are precisely sinilar. Therefure, although the rock that gires rise to the " $B$ " line has nerer yet been seen, it may be concluded with confidence that it is the Negaunec formation, and that the " $A$ " and " $B$ " lines represent this rock brought up in the two limbs of a narrow and probably deep synclinal fold.

Negaumce (?) formation at Michigamme Mountain and in the. Fence River area.-The known outcrops of iron-locaring formation (previously mapped as "Grovelmal" formation) in this belt are limited to three localities - the vicinity of Mlichigamme Mountain, in sec. 33, T. 44 X., R. $31 \mathrm{~W}$., and sec. 3, T. $43 \mathrm{~N}$., R. $31 \mathrm{~W}$; the exposures and test pits at the Slooldice exploration, in sec. 21, T. 45 N., R. $31 \mathrm{~W}$; and the test pits at the Doane exploration, in sere 16. T. 45 N., R. $31 \mathrm{~W}$. The last two localities are 1 mile apart, and the more southern is $S$ miles north of Michigamme Mruntain.

a Van Iise, C. R., ('lements, J. M., and Smyth, II. L., The Crystal Falls iron-bearing district of Michlgan: Mou. U. S. Geol. Survey, vol. 3i, 1599, p 453

o Idem, p. 45 . 
Magnetic lines eonnect the outcrops on Michigamme Mlountain with those to the north. The magnetic lime also extends beyond the outcrops around the north side of the western Archean oval. The eastem belt was not traced farther than a mile southeast of Hichigamme Mountain. In the central and southeastem portions of T. 43 N., R. $31 \mathrm{~W}$., however, in the direct prolongation of the anticlinal axis, is a broad belt of slight magnetic disturbance, along the westenn margin of which lie rolcanic rocks, dipping west. In sec. 26, T. 43 N., R. 31 W., this magnetic belt splits into two branches, one of which rums directly east for a mile and then southeast indefinitely, while the other maintains a general southerly con'se to the south line of the township. In see. 26 large angular bowlkers, evidently derived from the iron-bearing iocmation, are found in the zone of magnetic disturbanee, but no outerops lave been discovered. There can be little doubt that these disturbances roughly outline the position of the Tulcan formation in the axial region.

Exrept in Michigamme Mountain, the most elevated point of the district, the iron-bearing formation is not topographically prominent. In the Fence River area it produces a more subdued and somewhat lower-lying surface than the underlying formation, but the rifference is slight and is of little moment in comprarison with the confusing effects of glaciation.

At Michigamme Mountain the iron-hearing formation caps the hill in a well-narked srncline, the axis of which rums northwest and southeast. 'The structure is distinctly shown by the attitude both of the ferruginous rocks and of the underlying plyllites "Mansfield slate"). At the Interrange exploration, half a mile to the south, is found a secondary but more open embarment of the same syncline. These are the only folds of the Michigamme Mountain area sufficiently deep to include the iron-bearing rocks. The thickness of the formation can only be guessed at, as no complete section is exposed, and the data for detemining its upper limit are recidedly sludowy. The magnetie olservations indicate a breadth of 400 to 600 feet, and as in the Fence River area it is certainly much thimner than the two lower formations its thickness may be apjuroximately 500 feet.

The rocks are interbanded ferruginous quartzite and actinolite and grünerite schists, which still contain evidence of detrital origin. The formation contains less iron than the Tulcan formation of the Felch district, and consequently the lighter-colored varieties are more alsundant, it contains more detrital material, and in the Michigamme Mountain area the texture is generally closer and less granular. Moreover, in passing north from the Michigamme Mountain area to the Fence River area we find at the Sholdice and Doane explorations that the lower portion of the formation is composed of ferruginous quartzite, which is succeeded higher up by actinolite schists and grünerite schists similar in all respects to the characteristic rocks of the Negaunee formation in the western Marquette district.

The stratigraphic position of the iron-bearing formation is above the Hemlock formation on Michigamme Mountain; to the west of the mountain the formation is apparently below the Hemlock formation; to the north of the mountain, in the Fence River area, it is above the Hemlock formation. In the last-named area nothing is known of the nature of the overlying rocks.

This iron-bearmg formation is doubtfully called Negamee because of its lithologic character and because it comes within 2 miles of the "B" line of attraction, regarded by Smyth as Negaunee, suggesting that it is the same belt brought up again on the west sicle of this intervening gap of 2 miles by synchinal structure. On the other hand, it is nearly connected by a magnetic belt around the north side of the oval with the Vulcan formation and for this reason its correlation has been regarded as doubtful. However, by reference to the map (Pl. XXII, in pocket), it will be noted that this belt of supposed Negaunee, extending around the north side of the oval and south as far as the north line of T. 45 N., R. 33 IV., fails to conncet by nearly 2 miles with the known Tulcan formation, which is represented ly a magnetic line running as far north as sec. 16, T. 45 N., R. 33 W. Noreover, at the north end, near the Red Rock mine, the Vulcan is associated with eonglomerate carring fragments of an earlicr iron-bearing formation rery suggestive of unconlormity. Still further, the iron-bearing Tulcan formation where last seen 
is associated with red slates and apparently unaltered, while the rocks associated with the magnet ic line to the north, supposed to represent the Negannee, are nicaceous and amphibolitic slates and schists showing a much higher degree of metanorphism.

Ferruginous quatzits associated with iron-bearing formation north of Jichigamme Hountain.Ferruginous quartzite is found in isolated exposures in sees. 27 and 34, 'T. 44 N., R. 31 W., Michigan, lying inmediately east of the eastward-clipping Randville dolomite and west of a belt of attaction forming the southwarl extension of a belt that is taken to represent the iron-bearing Negaturee (?) lormation.

\section{UPPER HURONIAN (ANIMIKIE GROUP).}

The upper Huronian oceupies a large part of the western hall of the district, lapping around the oval areus of older rocks and coming into contact for the most purt with the Hemlock formation. It is clirectly continuous with the upper Huronian rocks of the Marquette district on the north and with those of the Menominee chistrict on the south and also extents far west of the boundaries of the area mapped into the Iron River and Florence districts. The exposures are scinty. The formation influences the topography very slightly, being for the most part heavily ilrift corered.

The upper Huronian in this district is essentially a great slate formation interbedded with small quantities of grinwacke and chert, called the Tichigamme slate, and near its base with iron-bearing lenses called Vulcan iron-bearing menher.

\section{MICHIGAMME SLATE.}

General character.-The formation known as the Michigamme slate consists principally of slates with some graywacke, like that of the Menomince district. In previous reports on this district it has been called upper Huronian slate, but as the formation scems to be equiralent to and continuous with the Michigamme slate of the Marquette district, the name Michigamme will be applied to it in this monograph. True water-deposited conglomerates are usually absent in this formation, being known in only two places in this district, and in these places their stratigraphic position is unknown. For the most part the slates have good cleavage and locally they are highly graphitic, chloritic, sericutic, and micaceous, and rarely staurolitiferous and garnetiferous. The cleavage usually stands nearly vertical, but the bedding may hare gentle dips. In general the rocks may be said to lap in broad folds around the lower Huronian, but everywhere with minor plications. The result is that in the ore-prochucing parts of the district, in the Crrstal Falls and Amasa areas, the dip and pitch of the minor folds are in general westerly and southwesterly directions. Away from the base of the formation it is difficult to identify horizons in the slates, and this fact, together with lack of exposures, has thus far prevented the working out of the structure satisfactorily. In general, however, the strikes and dips at these horizons away from the base of the formation are similar to those near the base; that is, the strikes are in northerly and northwesterly directions, and the dips and pitches of the minor folds are westerly and southwesterly. The exposures immediatcly above Crystal Falls seem to be part of a much cremulated southwestward pitehing syncline. It has been assumed further that the area of volcanic rocks associated with the upper Huronian slates northwest of the town of Crystal Falls is of Hemlock age, and hence that it represents an anticline brought up by folding. If these volcanic rocks should be really later in age than the II (mmlock, as is entirely possible (see p. 299), then there is left no evidence for this anticlinal structure in this locality. As mining explorations furnish more data it shoukl be possille to work out the strueture.

Tulcan iron-bering momber.-The Vulcan iron-bearing member is similar to and is correlated with the Vulcan formation of the Nenominee district. In the Crystal Falls district it consists principally of ferruginous chert, ferruginous slate, iron ore, and iron carbonate, interbedked in layers and lonses in the Michigamme slate. It is therefore treated as a nember of the llichigamme slate in this distriet. The immediately adjacent wall rocks of slate are as a rule highly 
carbonaceous and pyritiferous. The iron-bearing layers range in thickness from a few inches to 300 fect, and are even thicker where repeated by buckling. This buckling is of a drag type, giving steep pitches and not materially changing the dip and trend of the member as a whole. Folds of similar types are characteristic of the Iron River and Menominee districts. (Sce Pp. 324, 347.) Explorations are not yet sullicient to correlnte the individual iron-bearing layers in different parts of the district satisfactorily, and it is impossible now to say whether there are one, two, or moro independent layers separated by slate, though the probalility is in favor of there being at least two principal horizons near the base of the upper Huronian, as in the Menominee district.

The map of the Crystal Falls district (P]. XXII, in poeket) shows that the distribution of the Vulcan iron-bearing member has certain linear characteristics. One belt follows the base of the upper Huronian. Beginning 4 miles north of Amasa, it has been followed by magnetic lines and intermittent mines and explorations southeastward past Amasa and Balsam; thence southeastward to the vicinity of the Hollister and Amenia mines near the east side of T. 43 N., R. 32 W.; thence southwestward and westward througl the Lee Peck, Hope, West Hope, Horrow, May, Kimball, and Tobin mines south of Crystal Falls; and thence southward through the Dumn and Mastodon mines. The real continuity of this belt has not been established at every point, but the probability of continuity is so great that exploration is being vigorously conducted at many points along the belt. Another belt of iron-bearing roeks extends from the Crystal Falls mine east of Crystal Falls westward through the Great Testern, Paint River, Lamont, and Bristol mines. This belt may be at a higher horizon in the upper Huronian. It has not yet been connected with the one previously noted, though it is too early to say that a comnection may not exist. A possibility of connection seems to be indieated by certain explorations between the two belts just east of Paint River east of the town of Crystal Falls. Developments in the Iron River district have shown the iron-bearing member to extend enstward toward the Crystal Falls district, raising the question of connection with one of the iron belts in the vieinity of Crystal Falls, but so far as the Crystal Falls distriet itself is concerned such a connection is not yet shown by explorations.

The magnetic belt marking the extension of the iron-bearing member of the Amasa district to the north and south is eauserl partly by the iron-bearing member and partly by magnetic surface portions of the ellipsoidal basalts of the Hemlock formation near their contact with the upper Iuronian. At certain places, as in the vicinity of the Hollister mine, there are really two parallel magnetie belts rather than a single belt. One of these belts follows the magnetic platse of the greenstone and the other the iron-bearing member immediately adjacent. It is apparent, therefore, that not much reliance may be placed on the assumption that the iron-bearing member exists everywhere beneath the magnetic belt.

It is an unexplained fact that parts of the Vulean iron-bearing member away from the Hemlock formation, particularly near Crystal Falls and larther south, are but slightly magnetic. This is also true of the Vulcan iron-bearing member in the Iron River district to the west.

INTRUSIVE AND EXTRUSIVE ROCKS IN UPPER HURONIAN.

The upper IIuronian is penetrated in this district by intrusive rocks of acidie, intermediate, and basic composition. Some of these have been intruded before the folding and are very schistose. Most of them, however, are later.

Basaltic extrusive rocks, identical in all features with the Hemlock formation, appear in isolated areas in the upper Ifuronian. The principal areas are immediately northwest of Crystal Falls and in the vieinity of the Mastodon mine. There is as yet no evidence to show whether these extrusive rocks are the correlatives of the main mass of Hemlock formation and owe their present distribution to folling or whether they are really later extrusives interbedded with the upper Huronian Michigamme slate. 


\section{RELATIONS OF THE UPPER HUPONIAN TO UNDERLYING ROCKS.}

In general the dip and the distribution of the upper Huronian alwot the cores of older rocks slow it to be clistinctly younger than these rocks. The next underlying rocks for the nost part are those of the flemlock formation.

The upper. Ilumian is doubtfully unconformable structurally with the Hemlock formation. In the ardier Geolengical Survey reports on this district the two were describerl an unconformable, largely hecause of their marked elifference in lithology and because of the fact than an unconlormity exists at the base of the upper II ronian of the Marquette distriet, witl which the upper Iluronian of the (rystal Falls clistrict is satisfactorily correlated. No direct evidence is yet availalble to show that there is not some time break between the Ilemlock formation and the upper Huronian slates, but the apparent structural conformity, torether with the eonformable relations of the upper Iluronian to underly ing formations in the Menominee and Felch Mountain districts, scems to point to the possibility of nearly if not quite continuous cleposition of Huronim sediments heginning with the Randville and Sturgeon fornutions and continuing through the upper IImonian. On the other hand, the existence of an unconformity is strongly suggested by the rehations of the two magnetic belts taken to represent respectively the iron-learing Vulcan and Negaunee formations northward from the lied Rock mine, where there is a break in the magnetic field and a difference in lithology and metamorphism, and where a conglomerate at the base of the upper Ifuronian carries pebbles of an earlier (supposedly Negaunee) ironbearing formation. (See p. 297.)

\section{CAMIBRIAN SANDSTONE.}

In the southern and eastern portions of the district the edges of the tilted ofder rocks are partly covered by a blanket of gently dipping sandstones of Cambrian age, very soft and easily disintegrating. These rocks appear near Michigamme River as detached outliers. To the south and east from that river the separated patches hecome larger and more abundant, until finally a few miles beyond the enstem limit of the Felch Mountain range they unite and entirely cover the pre-Cambrian formations.

\section{STURGEON RIVER DISTRICT. ${ }^{a}$}

\section{LOCATION AND AREA.}

The Sturgeon River area of Algonkian sediments, like the Felch Mountain area, is an eastwest tongue, very narrow at its eastem extremity and widening out toward the rest until it finally plunges under drift deposits that separate it from the large Huronian area of the Crystal Falls district. The tongue occupies the western portions of T. 42 N., R. 27 W., and the central and northern portions of T. $42 \mathrm{~N}$., Rs. 25,29 , and $30 \mathrm{~W}$. The best exposures of the rocks constituting the tongue are found in sees. 7, S, 17, and 1S, T. 42 N., R. 2s W., and sees. 1 and 3, T. 42 N., R. $29 \mathrm{~W}$, on or near the northwest branch of the east branch of Sturgeon Rivar; hence the name Sturgeon River tongue.

\section{GENERAL SUCCESSION.}

The suecession is as follows:

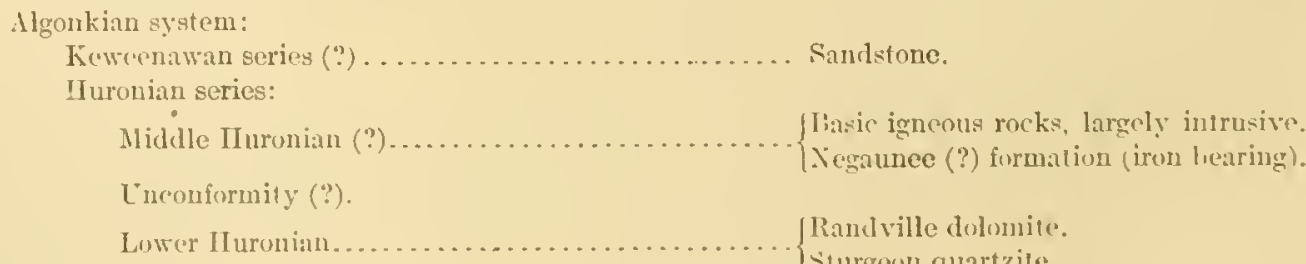




\section{ARCIIEAN SYSTEM.}

\section{LA URENTIAN SERIES.}

Laurentian granites and gneisses bound the Algonkian sediments on the north and south. Also between the northern and the southern boundaries ol the sedinentary area as defined, and in the midst of the sediments, are two areas of granite, the rock ol one of which is unquestionably and that of the other presumably older than the conglomerates vithin the tongue. The better defined of these two areas lies in the norther'm portions of secs. 7 and 8 , T. 42 N., R. $28 \mathrm{~W}$., and sec. 12 , T. 42 N., R. 29 W.

\section{ALGONKIAN SYSTEM. \\ HURONIAN SERIES.}

\section{LOWER IIURONIAN.}

STURGEON QUARTZITE.

In this district the Sturgeon quartzite is represented by schists, eonglomerates, arkoses, and quartzites 1,000 feet or more thick. Nowhere is there any marked disendance between the schistosity of the Archean and Sturgeon rocks, but the conglomerate indicates a marked unconformity.

\section{RANDVILLE DOLOMITE.}

In the Sturgeon River trough the dolomites have relatively more fragmental material with them than in the Felch Mountain trough. Exposures are few and occupy here the central portion of the trough. The dolomites do not themselves show the synclinal structure of the Sturgeon trough, but the fact that they are bounded by the quartzite on the northeast and southwest and this in turm by the Archean granite suggests trough structure. No definite contacts of Archean granites and the dolomites are known.

MIDDLE HUTRONIAN (?).

NEGAUNEE (?) FORMATION.

Bordering the north side of the dolomite in secs. 34 and 35, T. 43 N., R. 29 W., is nonmagnetic red and black hematitic chert, associated with red slate, shown in the Deerhunt mine explorations. Neither hanging or foot wall was determined in the exploratory work and the relations of the iron-bearing formation to the other formations are therefore unknown. The iron-bearing lormation is doubtfully correlated with the Negaunee.

IGNEOUS ROCKS.

Associated with the sedimentary rocks are great masses of basic igneous rocks. Some of these are unquestionably intrusive masses, as shown by their relations to the conglomerates; others appear to be interleaved sheets. A very few, apparently bedded greenstones, on close examination seem to be composed of intermingled sedimentary and igneous material. These may be altered tuffs.

\section{KEWEENAWAN SERIES (?).}

In the SW. $\frac{1}{4}$ sec. 34 , T. 43 N., R. 29 W., are white calcareous sandstones associated with purple slates, with dips ranging from $35^{\circ}$ to $40^{\circ}$. These are similar in all respects to the upper series in the east end of the Felch Mountain trough, and there are the same elements of doulst with reference to their correlation. They are provisionally assigned to the Keweenawan, but they may prove to be of Cambrian age. 


\title{
FELCI MOUNTAIN DISTRICT. ${ }^{a}$
}

\author{
LOCATION, S'TRUC'TURE, ANII GENEIRAL SUCCISSSION.
}

The Felch Mountain district is an east-west synclinorium constituting a narrow strip nowhere more than $1 \frac{1}{2}$ miles and usually less than a mile wide, which as a whole runs almost exactly east and west for a distance of over 13 miles. It lies in the southerm portion of 'T. 42 X., Rs. 28, 29, and $30 \mathrm{~W}$. On the north and south it is bordered by the older Archean. 'The lowest member of the Algonkian occupies parallel zones uext to the Arclean on loth the north and the south and is sueceeded toward the interior of the strip by the younger members. Athough the general structure, therefore, is synclinal, a single fold of simple type has nowhere been found to orcupy the whole cross section of the Algonkian formations, but usmally two or more symelines oceur, separated by anticlines, which may have different degree's and clirections of pitel and different strike's, or may be sunk to different depths, and complicated besides both by subordinate folds and by faults.

The succession is as follows:

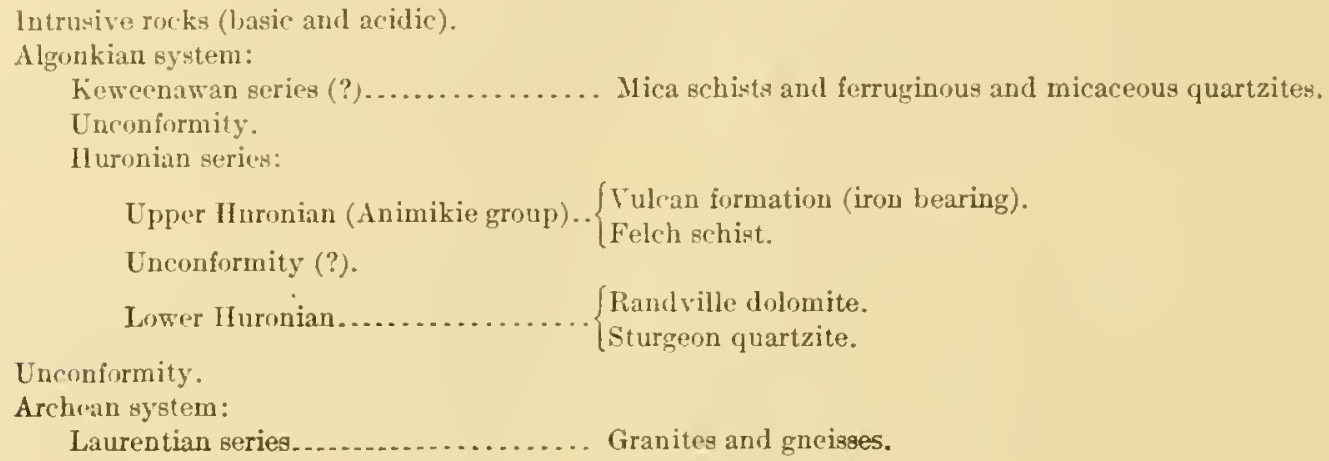

\section{ARCHEAN SYSTEM.}

LAURENTIAN SERIES.

The Laurentian series is the same as that of the other areas in Miehigan here deseribed. The contact between the Laurentian and IIuronian is not exposed, but the existence of conglomerate elsewhere along the contact and the fact that the contact is followed uniformly by quartzite are believed to indicate unconformity.

\section{ALGONKIAN SYITEM. HURONIAN SERIES.}

\author{
LOWFR IILRONIAN. \\ STURGEON QTARTZITE.
}

In the Felch Mountain district the Sturgeon quartzite, less than 500 feet thick, forms two bands in contact with the Arehean granite bordering the Feleh Monntain syneline. It is here principally cuartzite but contains conglomerate near the contact. It is in most places extremely difficult to determine the attitude of the quartzite owing to its massive and homogeneous charactor. Closely associated with the massive quartzites are mashed quartzites or micaceous quartz schists.

RANDVILLE DOLOMITE.

Owing both to its great thickness and to its intermediate position, the Randville dolomite in the Felch Jountain range covers a larger share of the surface than any other momber of tlue Algonkian succession. No aetual contacts between the Sturgeon and Randrille for- 
mations have been found, but from their close association and continuity, as wall as from the structural characters, where these are determinable, they seem everywhere to be strictly eonformable. The best sections give a wide range of thickness, from a minimum of about 500 feet near Felch Mountain to a maximum of nearly 1,000 feet in the western part of the district. Though the discrepancies may be partly due to lack of precision in the data, it is probable that the thickness of the formation is not uniform but really increases from east to west.

UPPER IIURONIAN (ANIMKIE GROUP).

FELCH SCHIST.

In the Felch Mountain district schists not more than 200 feet thick lie between the dolomite on the one hand and the Vulcan formation on the other. They do not outerop but have been pierced by many drill holes. The greater part of them are fine-grained mica schists, containing garnet and toumaline. Near the contact with the overlying Vulcan formation the schists become more siliceous and more ferruginous and there is a passage between the two formations. These schists were called "Mansfield schists" by Smytha and correlated with the slates at Mansfield and Michigamme Mountain. The slates at Mansfield, however, are regarded in this report as older than the schists of the Felel Mountain district, and in any event not certainly to be correlated with them. The new name "Felch schist" is therefore introduced for this formation from its typical development at Feleh Mountain.

\section{VULCAN FORMATION.}

In the Felch Mountain district the Vulean formation is magnetic and has been traced by means of compass and dip needle. Excellent natural as well as numerous artificial exposures render the data concerning the distribution of the formation very satisfactory.

On the west the iron-bearing formation is exposed in ledges and test pits in sec. 5, T. 41 N., R. $30 \mathrm{~W}$, from which a line of attraction extends southwestward through sec. 6 into sec. 12, T. 41 N., R. $31 \mathrm{~W}$., where it is lost. The presence of the Vulcan formation through secs. 34, 35, and 36, T. 42 N., R. 30 W., is shown by one principal and other minor lines of attraction, as well as by test pits and outcrops. The principal line of attraction begins in see. 34 , near the southwest corner, and runs to the northeast, in conformity with the strike of the northern belt of dolomite, finally ending in the northeastern portion of see. 36 . This line of attraction is very vigorous and strongly marked. Two other lines, parallel with the prineipal line but more feeble and much shorter, eross the boundary between secs. 35 and 36 , and on the northern of these lines ferruginous rocks outcrop in the western part of sec. 36 . Another line, marking the west end of the Groveland syncline, begins near the center of sec. 36 and continues for $1 \frac{1}{2}$ miles eastward to the eastern portion of see. $31,{ }^{T}$ T. 42 N., R. 29 W. Along the western portion of this line are many test pits and in sec. 31 occur the fine exposures of the Groveland hill.

Another line of attraction begins 400 paces north of the center of sec. 32 , T. 42 N., R. $29 \mathrm{~W}$, which may be followed eastward without interruption nearly to the east line of sec. 33 of the same township. Along this line, which is comparatively feeble and crosses wet ground, there are but few test pits. In the eastern part of see. 33 , beyond the point at which the attraction ceases, many pits have been sunk to and into the Folch sehist, which is there somewhat ferruginous. From this point eastward for 4 miles the Vulcan formation has not been recognized.

In the northern part of secs. 32 and 33, T. 42 N., R. 28 W., the ferruginous rocks are well exposed on Felch Mountain for nearly a mile along the strike, and may be identified for half a mile farther by the vigorous disturbances profuced in the magnetic needles. In the SE. $\frac{1}{4}$ sec. 33 the Vulcan formation is again cncountered in a small and much disturbed area, in faulted contact with the Arehean.

a Van Hise, C. R., Clements, J. M., and Smyth, H. L., The Crystal Falls iron-bearing district of Michigan: Mon. U. S. Geol. Survey, vol. 36, 1899, pp. 411-415. 
The most prominent hills in the Algonkian belt owe their relief to the fact that they are underlain by the Vulean formation.

Petrographically two main kinds of rock may be recognized in this formation. The more common kind consists of quartz and the anhydrous oxides of iron; the other and much rarer lind consists essentially of an iron amphibole with quartz and the iron oxides as associates. Both of these kinds are clearly of detrital origin. The conclusion is reached, based on certain microscopic structures, that iron and silica were originally present largely in the form of greenalite. Between the ferruginous quartzites of the Vulean formation and the ferruginous cherts of the Mesabi range there is a very close resemblance, especially in structure. The essential difference is that the former contain little or no chalcedony, the silica being erystallized quartz, whereas the latter have a great deal of chalcedonic silica. Also the former contain small amounts of cletrital material, which the latter generally lack; but the essential difference between them is one of clegree of crystallization only.

In Smyth's report on this area ${ }^{a}$ the iron-bearing formation of the Feleh Mountain district was called the "Groveland" formation from its occurrence at the Groveland mine. The evidence is now regarted as sufficient for correlating it with the Vulcan formation of the Menominee and Crystal Falls districts, and hence the name "Grovcland" is discarded.

KEWEENAWAN SERIES (?).

In the east end of the Felch Mountain range the Iluronian rocks are overlain unconformably by a scries of soft iron-stained mica schists, with thin interbanded beds of ferruginous and micaceous quartzite. From their structures and general relations they are believed to have been derived from sedimentary rocks by metamorphism. At an old open pit just west of Felch, on the east side of sec. 33, this series may be seen to rest in unconformable contact with the Ranclville dolomite, the basal conglomerate being heavily ferruginous and having been minct as iron ore. These rocks are tentatively assigned to the Kewcenawan series, although they may prove to be of Cambrian age.

\section{INTRUSIVE ROCKS.}

Basic and acidic intrusive rocks eut the Ifuronian at sereral localities. Some of the basic intrusives are in the form of sheets, some of them highly schistose and greatly altered.

\section{PALEOZOIC SANDSTONE AND LIMESTONE.}

The Palcozoic is represented by the Lake Superior sandstone, supposedly of L'pper Cambrian age, and the overlying ealeiferous limestone. These formations were originally laid down over the upturned edges of the older rocks in flat sheets or with low initial dips and have not since suffered relative displacement to any notable degree. As has already been stated, subsequent erosion has to a great extent removed this overlying blanket and laid bare the older rocks, except for the covering of recent glacial deposits. The Cambrian sandstone and to a less extent the calciferous limestone still, howerer, occupy considerable outlying areas, detached from one another throughout most of the district but gradually coalescing beyond the cast end, where they completely cover the older rocks and linit all further geologic st udy of those rocks in that direction.

\section{CORTELATION.}

Laurentian series.-The correlation of the main mass of granite gneiss north and sonth of the Feleh Mountain distriet with the Laurentian series of the Archean is farly certain in view ol its essential unconformity beneath the Sturgeon quartzite, but granitic dikes also penetrate the IIuronian series, suggesting that a part at least of the Laurentian complex may be int rusive. Such part has not been discriminated. 
Lower Huronian. - The correlation of the Sturgeon quartzite and the Randville dolomite respectively with the Mlesnard quartzite and the Fiona dolonite of the lower I Iuronian of the Marquette district seems to be reasonable, the rocks of both areas buing highly folded, much metamorphosed, and near the base of the lower Iluroninn, and no evidence being known in the Upper Peninsula of the existence of a second dolomite series.

Upper IIuronian (Animikie group).- The Felch schist grades up into the iron-bearing Vulcan formation and undoubtelly constitutes a fragmental base of the iron-bearing formation. Contacts of the Felch schist with the underlying dolomite are lacking. From the sheared nature of the slate it seems likely that the contact is schistose and that any evidence of conglomerate at the base may have been obliterated, but the structure of the Felch anl Vulcan formations is essentially conformable, so far as can be deternined, with that of the Randville dolomite and Sturgeon quartzite below. The two have been folded together. There has been question whether the Felch and Vulcan formations should be assigned to the middle Iluronian, which includes the Negaunee formation, or to the upper Huronian, which includes the Vulean formation of the Nenominee district. Both the middle Huronian and the upper Huronian have an unconformity at the base, and hence the lack of evidence of unconformity at the base of the iron-bearing formation of the Felch Mountain district does not aid in the selection of one of these alternatives. The iron-bearing formation of the Felch Mountain district is geographically separated from both the Negaunee formation of the Marquette district and the Vulcan formation of the Menominee district. At the west end of the Felch Mountain district the formation may be followed by magnetic work to the west under the main area of the upper Huronian. A few miles south, in the Calumet trough, an iron formation similar to the Vulcan and underlain by slate and schist of the Felch variety may be tracel to the west and southwest with reasonable continuity and with uniform lithology into the broad area of upper Huronian joining areally with the upper Huronian of the Menominee district. To the southeast also there is probable connection with the Menominee district. The lithology of the iron formation in the Felch Mountain district is more like that of the Vulcan than that of the Negaunee formation. These facts suggest strongly that the iron-bearing formation of the Felch Nountain district is an eastward projection of the main upper Huronian of Michigan, other eastward extensions of this area being found in the Menominee, Calumet, and Marquette districts. If not, the line of demarkation between the upper lluronian and the iron-bearing formation of the Felch district is not yet known. The evidence for correlating the iron-bearing formation of this district with the Vulcan formation of the Menominee and Crystal Falls districts is regarded sufficient, and the old name "Groveland," as heretofore used in this district, has therefore been abandoned for Vulcan. The apparently conformable relations of the Felch and Vulcan formations with the underlying Randville and Sturgeon formations do not disprove unconformity. The relations may really be the same as in the Henominee and other adjacent districts.

Keweenawan series(?).-The purple sandstones overlying the Vulcan formation at the east end of the trough look in many of their outcrops like Cambrian rocks, and were it not for their dip of $30^{\circ}$ or thereabouts they would probably be mapped as Cambrian, for farther east the Cambrian is flat-lying. It is entirely possible that the Cambrian has been tilted up in this place. However, a similar series of sandstones in the Sturgeon trough is also tilted up, and this, in connection with the reddish-purple color of the beds, suggests the possibility of lieweenawan sediments intervening between the Huronian on the one hand and the Paleozoic on the other. Their position above the Vulcan formation and their friable character, however, seem to preclude the probability of their being Huronian.

$$
47517^{\circ}-\text { rOL } 52-11-20
$$




\section{CALTMET DISTRICT.}

\section{JOCATION ANI GENERAL SUCCENSION.}

The Calumet district is an east-west trough south of the Feleh Mfountain trough, extending through T. $41 \mathrm{~N}$, lis. 27 to $30 \mathrm{~W}$. (Pl. XXIII).

The succession is as follows:

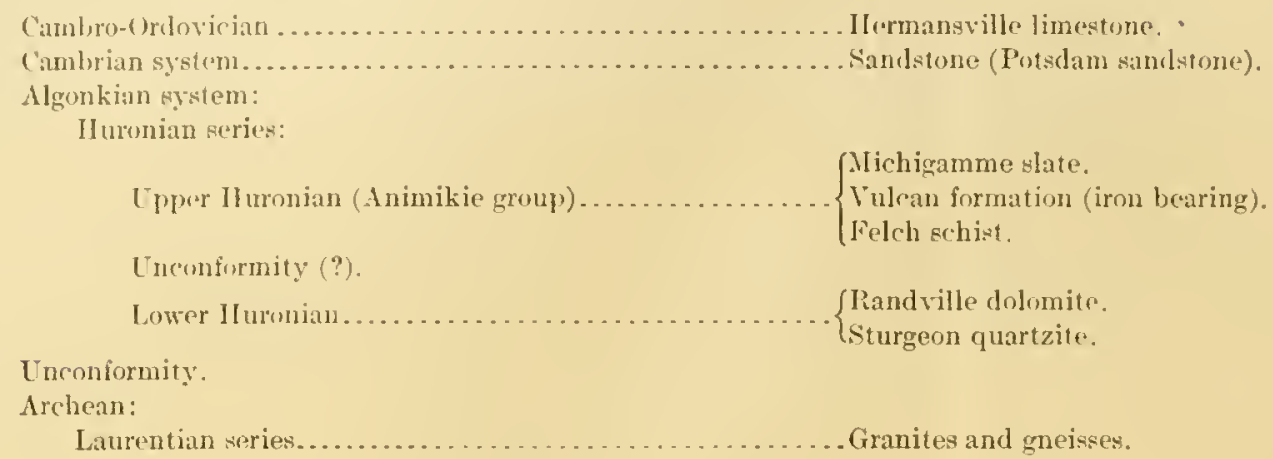

\section{ARCIEAN SYSTEM. \\ LAURENTIAN SERIES.}

The Laurentian series consists of granites similar in all respeets to those of other districts, and will not be here described. It border's the trough on both the north and the sonth and forms a nearly isolated area in the vicinity of Granite Bluff.

\section{ALGONKLAN STSTEM. \\ HURONIAN SERIES.}

LOWER IILROXIAN.

STURGEON QUARTZITE.

The Sturgeon quartzite is exposed principally in the western part of the district. One belt, emintinuous with that of the Menominee distriet, swings northward from the northwest side of the Menominee district into secs. 20 and 29, T. 41 N., R. 29 W. Another belt extends from the southwest end of the somthern Feleh Iountain-Sturgeon quartzite belt and smings sonthward around the rranite mass to sec. 20, T. 41 N., R. 30 W. An eastward embarment carries this belt into secs. 9 and 16, T. 41 N., R. 30 W., and this may possibly also connect still farther east with quartzite in sees. 9 and 16, T. 41 N., R. $29 \mathrm{IT}$. There is some difficulty in all these places in cliscriminating this quartzite from the base of the upper lluronian. On the whole, however, the Sturgeon quartzite is much more massive and cherty and stands at steeper angles than the upper IIuronian quartzite, which is more or less thinly bedded with slate, is infolded into gentle rolls, and has been rendered micaceous and schistose along the saty layers.

RANDVILIE DOLOMITE.

The underground workings at the ('alumet mine indicate at descending suceession of upper IJuronian slate, iron-bearing formation, schist, cherty or quartzitic rock, and dolomite. The dolomite oceurs, with southwarl dip, only a short distance soutl of the Arehean granite, and may with reasonalole certainty be correlated with the laandrille dolomite 


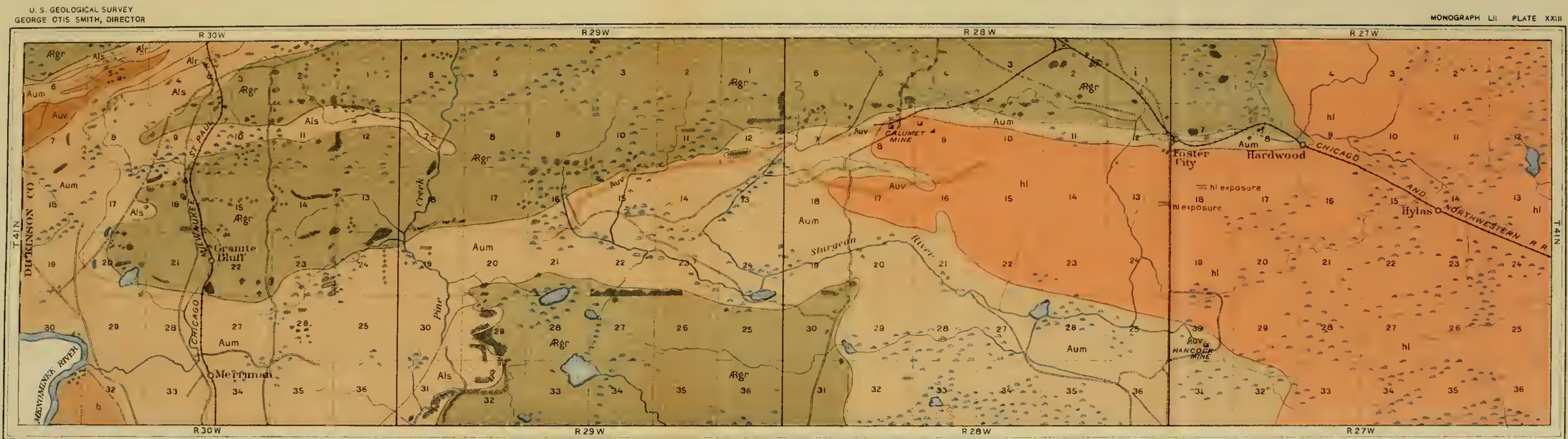

GEOLOGIC MAP OF THE CALUMET DISTRICT, MICHIGAN

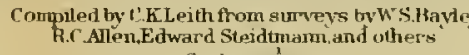

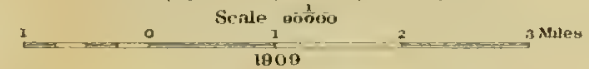

OROOVICIAN ANO CAMBBARN

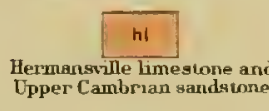

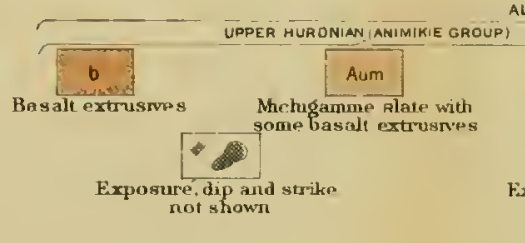

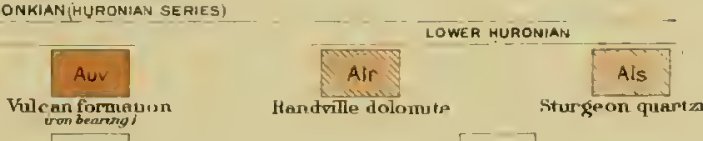

$$
\begin{aligned}
& \text { Shast or pit }
\end{aligned}
$$



UPPER IIURONIAN (ANIMIKIE GROUP).

FELCH SCHIST.

The slate and quartz-schist fornation forming the base of the upper IIuronian is exposed north of the iron-bearing Vulcan formation and south of the Laurentian grainte at cahumet. Its characters here are identical with those of the Feleh schist of the Felch Mountain trough. To the soutl it appears again near the south quarter post of see, 16 and along Sturgeon River in sees. 19, 20, and 21, where it contains somewhat more quartzite but still main tains its essential character as a micaceous slate. The formation extends from this loeality westward into the west end of the Calumet trough, where it opens out into the great area of upper Huronian connecting with the Michigamme ("Hanbury") slate of the Menominee, Crystal Falls, and Florence districts. Quartz schist which may behng to this formation appears in the minor trough extending eastward from sees. 9 and 10, T. 41 N., R. 30 W., but as alrealy indieated in the discussion of the Sturgeon quartzite, it has not been satisfactorily diseriminated from the Sturgeon quartzite in this trough.

\section{VULCAN FORMATION.}

The iron-bearing formation is best exposed at the Cahmet mine, where it has been crossent for 700 feet. It is here interlayered with slate. Its clip is steep to the smoth. IIagnetic attraetions, drill holes, and test pits show iron-bearing formation and ferruginous quartzite also through the northern part of sees. 16 and 17 , a mile to the sonth, where the dip is low to the north, sugresting that this is the same belt as the Cahmet brought up by anticlinal folding. Magnetic work shows that these two belts extend to the west and coalesce agrainst the south margin of the granite through sees. 14 and 15. West of this locality no trace of it has been found. East from the Calumet mine the belt has been shown, principally by magnetic work, to extend for several miles.

To the southeast, in the southwest corner of T. 41 N., R. 27 W., at the Hanenck mine, is a heavily ferruginous micaceous slate and quartzite which may be correlated with the ironbearing formation at the Calmmet mine or may belong at a higher horizon in the upper Huronian. Still farther southeast, in the southeastern part of the same township and the north-central part of T. 40 N., R. 27 W., there is a magnetic field with trend suggesting its enrrelation with tho ironbearing formation of the Cahmet district. A drill hole on the magnetie belt in see. 3 of this township discloses ferruginous slates and quartzites similar to those at the IJancock mine.

MICHIGAMME SLATE.

Slates and micaceous quartzites overlie the iron-bearing formation at the Cahumet mine and occupy most of the Algonkian area of the C'alumet trough. Thence they presumahly extend southeastward through T. 40 N., R. $27 \mathrm{~W}$., and probably connect with the Michiramme ("IJanbury") slate of the Menominer (listrict in this direction. West and soutluwest from the Calumet mine they also connect with the upper IIuronian slate of the Menominee district.

\section{PALEOZOIC LIMESTONE AND SANDSTONE.}

Cambrian sandstone (Potsdam) and Cambro-Ordovician limestone (Hermansville) rest in flat beds over much of the Calumet area and its enstward extensions. They cover most of the upper Huronian of T. 41 N., R. 28 W., and T. 40 N., Rs. 27 and 28 W., and thicken rapidly to the east. These rocks form a serious obstacle to exploration in this district.

\section{COIRELATION.}

The correlation of the rocks of this district is cliscussed in connection with the Feleh trough (p. 305) as well as in the general correlation chapter (pp. 597 et seq.). 


\section{IRON RIVER DISTRICT.}

BY R. '. ALLEN."

\section{DOCITION INI HXTENT.}

The Iron Rirer distriet lies west of the Crystal Falls district and extends southward a few miles beyond Brule River into Wisconsin, to the granites and green schists of the Archean. North, cast, and west of this boundary, which is a natural one, only arbitrary limits may be drawn. Recent detailed stulies lave been made of the area in Michigan extending from Brule River north to latitude $45^{\circ} 15^{\prime}$, east to longitude $8.5^{\circ} 30^{\prime}$, and west to longitude $85^{\circ} 45^{\prime}$, cmbracing an area of 201.5 square miles. (See Pl. XXIT, in pocket.)

\section{TOPOGRAPIY AND DIRIINAGE.}

The topography is of glaeial origin, slightly affected by preglacial forms and modified little by postglacial erosion. In general the area presents a series of hills or parallel chains of hills elongated in a direction about S. $20^{\circ} \mathrm{W}$., which is the direction of ice movement as recorded on striated and grooved rock surfaces in the southwestern and northern parts of the area. The ridges are separated by corresponding hollows, which hold swamps and lakes connected by crecks forming the minor drainage courses. The major alrainage is independent of the natural northeast-southwest "grain" of the country, for the larger streams, Brule, Iron, and Paint rivers, cross diagonally the general southwest trend of the hills and ralleys. Paint River in the northern part of the district follows in general the strike of the underlying rocks, outcrops being comparatively numerous along its eourse. The same may be said of the Brule in the southern part of the district. Both of these streams seem to follow modified preghacial courses. Howerer, this is certainly not true of Iron River, for this stream is known to cross at least two well-defined drift-filled preglaejal valleys which fall towarl the northeast nearly at right ungles to the course of the Iron. These valleys are separated by a rock rilge which protrudes through the drift in Stanbaugh Hill, on which is built the rillage of Stambaugh. (See Pl. XXIV, in pocket.) In contrast to the independence of the major streams, the minor drainage is controlled absolutely by the topography of the drift mantle, which may be readily inferrel from a study of the map. Many of the lakes occupying depressions between the ridges are likewise elongated in a nort heast-southwest direction. The best examples are Stanley and Iron lakes; others are Minnie, Chicagon, and Trout lakes, occupving parts of the same depression in the eastem part of the area. Most of the lakes are drained by streams, but some, as Bennan, Snipe, and Scott lakes, liave no outlets.

The combination of clongated ridges and corresponding depressions above deseribed forms a distinctly drumloid type of topography. However, there are but few typical drumlins. The most perfect example occurs just north of Iron River village, crossing the south line of see. 23, T. $43 \mathrm{~N}$, R. $35 \mathrm{~W}$. It will be interesting to note that a terminal moraine formed by the Langlade lobe (Weidman) of the Wisconsin iee sheet oceurs not far to the south in Wisconsin, following a general course at right angles to the trend of the drumloid hills of this area. This is the claracteristie relation between drumlins and terminal moraine found elsewhere, notal,ly in New York and southern Wisconsin.

The thickness of the drift ranges from a knife-edge up to more than 300 fect. It is of coursc least along the depressions and drainage courses, where the underlying rocks are exposed at many places, and greatest in the hills between them; but this is not everywhere true, as is abundantly demonstrated in brill horings. Some postghlacial and preglacial ralleys coincide in general trend and carry greater thicknesses of drilt than the bordering hills. This is true of the valley extending diagonally northeastward through sec. 1, T. 42 N., R. 35 M., and secs. 31 and 20, T. 43 N., R. 34 W. (Sce map, Pl. XXIY.) Although the eleration of many of

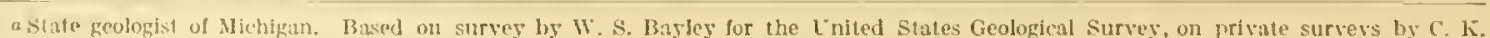
leeth and R. C. Mlen, and on recent survey for the Mlehigan Geologieal Survey by R. C. Allen. See . Allen. R. C., The Iron IRiver iron-bearing district uf Michigan: Michigin ('ieol, survey, L'ub, 3 (Fieol. ser. 2), 1910. 
the hills is accounted for by the relatively great thicknesses of drift under them, there is abundant evidence that the preglacial topography of this region was more rugged and presented greater vertical range between hills and valleys than does the present surlace. The highest hills are in the southwestern part of the district and are of preglacial origin. Sheridan IIill, in sec. 20, T. 42 N., R. 35 W., has an altitude of 1, 440 feet and rises 460 feet above the lowest point in the district, the valley of Paint River, where it leaves the area in ser. 36, T. $44 \mathrm{~N}$, R. $34 \mathrm{~W}$. The eleration of the rock surface near the center of sec. 29, T. 43 N., R. 34 W., is 1,280 foet. Thus the maximum difference in elevation was in preglaciul time at least 100 feet greater than it is now.

\section{CHARACTER OF TIIE GLACIM. DRIFT.}

The ridges and higher lands in general are composed of bowldery till intercalated with lenses of sand and gravel. The till is in many places composed almost entirely of day but is more commonly somewhat sandy and maintains good tilth under cultivation. The soil of the till areas is, in general, excellent and supports a beavy stand of hardwood. Where cultivated it produces good crops of small grains, hay, and vegetables adapted to the chimate. The general abundance of bowlders is the main olstacle confronting the linmer on the till areas, but this is not insurmountable, as is abundantly shown by the many prosperous farms in the central and eastern parts of the district.

The valleys of Brule, Iron, and Paint rivers are partly filled with sandy and gravelly outwash of ghaciofluvial origin. In places sand and gravel plains of considerable extent have formed, notably at the junetion of the Iron and Brule, in the valley of Net River, and north, west, and south of the junction of the north and south branches of Paint River.

GENETAI SUCCESTION. follows:

The general succession of rocks in the Iron River district from youngest to oldest, is as

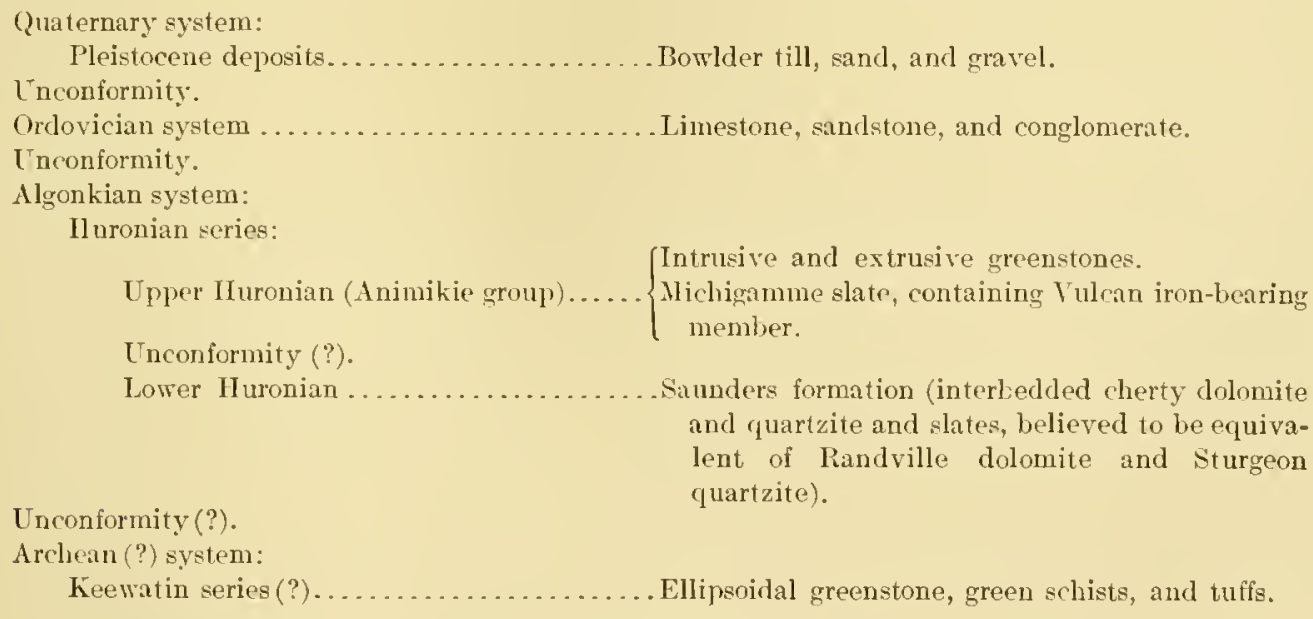

\section{ARCHEAN (?) SISTEM.}

KEEWATIN SERIES (?)

Basaltic extrusive rocks with surface textures similar to those of the Quinnesec sehist of the Nenominee district and the Hemlock formation of the Crystal Falls district are exposed in isolated outcrops north and south of Brule River in an east-west belt across the southeru part of the district. These rocks possess no lithologic or structural characteristics which may safely be used as a basis for their correlation. Most of the outerops are north of the adjacent Saunders formation, but a few are south of it. Ilowever, detailed mapping has not been done south of the Brule, and consequently the extent of the volcanic rocks in this direction is not yet known. They are nowhere exposed in contact with the Saunders formation, hence their 
stratigraphic position an be determined only by their areal relation to the Saunders formution in reference to the structural attitude of the latter. 'The arailable data, though not absolutely conclusive for all parts of the Samders formation, inclicate a general northward (lip. By applying this criterion, the volcanic rocks north of the Saunders are strutigraphically above it and those south of it are stratigraphically below it.

The voleanic rocks in the southern part of secs. 19, 20, 21, and 22, T. 42 N., R. 35 IV., are the only greenstones in the area which are known to lie south of the Saunders formation. Being probably below the Salumers formation they are tentatively correlated with the Keewatin schist. It is possible that they may be interbeded with the Salunders formation or they may be of later age, in which case their occurrence here may be explained as the result of faulting.

The greenstones tentatively refered to the Archean are of basaltic composition. Ellipsoidal structure is well developed. The ellipsoids have been elongated in an cast-west direction parallel to the east-west axes of major folding in this part of the district. Agromeratic structures are less common and in one outcrop the rock is a green chloritic shist.

\section{ALGONKIAN SYSTEM.}

HURONIAN SERIES.

LOWER HURONIAN.

SAUNDERS FORMATION.

Distribution.-The Saunders formation occurs in a belt of varying width extending in a general direction a little north of west across the southern part of the district and westwarel an unknown distance. Outcrops are few, on the whole, and are absent in large areas supposed to be underlain by this formation. It is well developed in sheridan Hill in sec. 20, T. $42 \mathrm{X}$., R. $35 \mathrm{~W}$., and vicinity. This lill owes its altitude, 1,840 feet, to the resistive character of the Saunders formation. East of Saunders village and south of Brule River in Wisconsin this formation again assumes topographic prominence in an east-west ridge about 2 miles long. In sees. 26 and 35, T. 42 N., R. 35 W., slaty and dolomitic phases are exposed in a number of pits and an outcrop tecurs on the west side of Brule River a short distance sontliwest of the north quarter corner of sec. 34.

Lithologic characters. - The Saunlers formation embraces a wide variety of facies. Cherty dolomite and quartzite are the most prominently developed. Associated with them are massive white and pink dolomite, impure carbonate slates, and talcose slates.

Cherty dolonite and quartzite are best developed in Sheridan Hill and ricinity and in the ridge south of Brule River southeast of Saunders. In both these localities the rock is exceedingly brecciated. The crushed and fractured cherty fragments are embedled in the greatest confusion in secondary infiltrated silica and carbonate, silica being dominant. In the Saunders ridge are masses of almost pure quartz associated with pure massive white dolomite and banded chert and cherty dolomite. The more siliceous bands stand out prominently on weathered surfaces, producing a ribbed appearance.

A highly ferruginous phase of the Saunders formation is exposed in a cut on the Connorsille branch of the Chicago and Northwestern Railway about 2,100 feet south of its crossing of Brule River. In general the rock is intensely sheared, with marked slaty structure of nearly vertical dip and an almost east-west strike. Here there are gralations to more massive bluish phases, which are seen under the microscope to consist chicfly of "arbonate with coarse interlocking texture. Inclosed in the carbonate are areas of finely granular silica. Sericite occurs as a secondary mineral, ferric oxide is al)undant, and pyrite occurs commonly in aggregates of small grains. The ferruginous character of the carbonate is evident from the abundance of ferric oxide developed in weathering.

The abundance of iron oxide in weathered portions of these rocks has inrited explorations for iron-ore deposits, particularly in the SW. $\frac{1}{4}$ sec. 26 and the XW. 1 sec. 35, T. 42 X., R. 35 IT., where a number of pits hare been dug. The deepest of these which have penetrated the weathered mantle are bottomed in a bluish carbonate rock described above. Apparenty inter- 
bedded here with the purer earbonate rocks are impure slaty phases showing crumpled bed ling lanina which are cut in general at a high angle by the plane of schistosity.

Schistose slaty phases of the Saunders formation are exposed on the west bank of Brule River, a short distance southwest of the north quarter corncr of sce. 34, T. 42 N., R. 35 W., and on the north bank of this stream in the NW. $\frac{1}{4}$ sec. 19 of the same township.

Talcose ferruginous slates are exposed in pits 400 paces west and 75 paces south of the northeast comer of sec. 20, T. 42 N., R. 35 W.

Structure.-Satisfactory structural obscrvations can not be made on known exposures of this formation. In the cherty and quartzitic phases bedding is destroyed by cxcessive brecciation, in the slaty phases it is obscured by schistosity, and in the purer massive dolonitic phases bedfing is not shown, being doubtless destroyed by recrystallization and rearrangement of the minerals in the rock. In the north face of the ridge southist of Saunders there are banded cherty phases showing steep northward dip, but the folding and brecciation are here of such character as to indicate that these dips may he local. Where developed the sehistosity is as a rule steeply inclined northward and is parallel to the trend of the formation. Distinct bedding is shown in slaty fragments on the dumps of pits in the SW. $\frac{1}{4}$ sec. 26 , T. 42 N., R. 35 W., but here the pits are filled with débris and the rock conld not be observed in place. At this place the schistosity cuts the crumpled lamine nearly at right angles. As the schistosity is elsewhere steeply inclined northwarl, it may be inferred that the dip of the bedsling is here northward at a lower angle. These observations are unsatisfactory, but considered with the position of the Saunders formation between the older rocks south of them and rocks to the north, which are certainly younger, they seem to indicate a gencral northward dip.

East of sec. 21, T. 42 N., R. 35 W., the Saumders formation scems to widen and swing southeastward. This is probably due to flattening of dip on an anticlinal cross fold. If the axis of this fold is extended northward it coincides approximately with the direction of the axis of a broad anticline in the northem part of the district. As will be pointed out later, it is probable that the entire district has been folded on this axis thus extended.

Thickness. - $A$ close estimate of the thickness of the Saunder's formation can not be made. If the width of the formation across Sheridan Ilill is taken at 4,000 feet and the dip assumed to be $75^{\circ}$, the thickness will be 3,750 feet. Doubtless the formation is very thick, but the above figures may be a thousand feet or more too great.

Relations to adjacent formations.-Contacts between the Samders formation and overlying and underlying rocks are not exposed. The dip of the Saunders is, on the whole, steeply north, from which it is inferred that it is probably younger than the Keewatin (?) rocks. Whether the latter are uneonformably below or are interbedlded with the Saunders formation is not here apparent. In the southern part of the Florenee district the Quinnesec schist is bounded on the north by quartzites and conglomerates, which are clearly unconformable upon the Quinnesec schist and whose bedding and contart planes trend northwestwarl toward the Brule River section of the southern Iron River distriet. The quartzites and dolomites of the Saunders formation may be the extension of the quartzite and conglomerate belt of the southern Florence district, and if so they would be unconformably above the Kecwatin (?) rocks.

The Saunders formation is structurally boneath the upper Iluronian, with probable conformity. It is paralleled on the north by a belt of scattered onterops of voleanic grecnstones, by which it is overlain and with which it may be to some extent interbedded.

UPPER HURONIAN (ANIMIKIE GROUP).

MICHIGAMME SLATE.

DISTRIBUTION AND GENERAL CHARACTERS,

The Nichigamme slate oceupies much the larger part of the district. It is limited on the south by the Saunders formation and extends north, west, and cast beyond the limits of the clistrict, on the east connecting with the upper Huronian (Michigammc) sle the the Menominee, Crystal Falls, and Florence districts. 
The rocks of this formation include a wide variety of facies. Grarwackes, with textures rarying from conglomeratic to fine grained, and their schistose equivalents are dominant in the northern part of the area. llere they are interbedded with lenses of black prritiferous and carbonaceous slates, micaceous and chloritie slates, and narrow iron-bearing lenses which oceur in the vicinity of 1 tkinson, in sec. 24, T. 44 N., R. $35 \mathrm{~W}$, and doubtless in other areas which are drift covered. Toward the south the clastie rocks become finer graincel on the whole and prothas less metamorphosed. Slates are dominant and the iron-bearing member is more extensively developol. Iowerer, graywackes and fine eonglomerates are not lacking and are hore and there associated with the Tulcan iron-bearing member. Black pyritiferous and carhonaceots slates are common associates of the iron-bearing member.

The relations between the various facies of the Vicligamme slate are those of cradation and interbedding. Any single type of the rock may grade by mineralogieal and textural variations into any other type. The variations take place both in the clirection of the lrecleng and ilcress it, with the result that in gencral the entire formation is made up of dovetailed lenses of rarious dimensions and compositions, with indefinite gradational borders betwern them. Althongh gradation is the rule, abrupt transitions across the bedding from one type to another are not uneommon, especially between black slates and iron-bearing beds, the former forming the footwalls of many of the ore bodies.

Ellipsoidal, agglomeratic, and tuffaceous extrusive basaltie greenstones are interledded at rarious horizons with the Michigamme slate. They seem to be especially abundant at the base of the formation just north of the Saunders formation and at higher horizons in the northern part of the district. Of less common oceurrence are joneous rocks of similar composition but with well-developed interlocking crystalline texture. These are probably intrusive.

GENERAI STRUCTURE.

In attempting to work out the general structure there is the same difficulty in identifying horizons in the slates which has prevented satisfactory struetural work in the Crystal Falls district. Rocks of identieal charaeter are repeated at different stratigraphie horizons and the same stratigraphic horizon may exhibit, even in a small area, facies which are of very diflerent composition and texture. Inasmuch as this fact is not appreeiated by many who explore for iron ore in this district, it should be emphasized here.

(1) The rocks at any particula horizon of the Michigamme slate ean not be depended on to maintain the same charaeter over any considerable area. It follows that (2) cross sections through the same stratigraphie horizons may difler wilely in a given small area and consequently (3) similar sequence of formations in adjacent areas does not neeessarify imply st ratigraphie equivalence unless the beds are known to be continuous from the one area into the other. Especially is this true if the two areas compared are widely separated. Obserrations in the field and in mine workings and microseopie study of the rocks establish beyond doubt the truth of the above statement.

Guicles to the structure in the southem part of the district are found in the iron-bearing layers and in the strueture of the underlying and presumalyly conformable Saunders formation. In the northern part of the distriet struetures are well brought out by grarwacke phases, abundantly "xposed, exhibiting bedding.

The general cast-west trend of the stceply inclined Saunders formation and the east-west strike of the secondary structures in it and the adjacent greenstones indieate the main struetural line for this part of the distriet. As the upper and lower Ihuronian are probably in structural conformity here as well as farther east in the Crystal Falls and Menominee districts, the Michiganme slate, with its interbedded lenses of the Vulean iron-bearing menber which are best dereloped in the southern part of the area, may he expected to extend beneath the drift west of Iron River, heyond the limits of the district. The westermost exposure of the Vulean member is in the SW. 1 SW. $\frac{1}{4}$ sec. 33, T. 43 N., R. $35 \mathrm{~W}$. 
The folding along the main east-west axis is ronsiderably modified in the rentral and northern parts of the district by folding along an axis tremding north of east and south of west. Beginning on the east side of 'T. 44 N., R. 34 W., along Paint River, the rocks are olserved to strike slightly west of north and to dip vertically or steeply to the northenst. Upstream along Paint River to its junction with the Net and thence westward toward $\Lambda$ thinson, the strike swings sharply westward and then south of west, the dip varying from north to northwest. Soutlywest of $\Lambda$ tkinson, to the limits of the district, and at least several miles beyond, the soruthwesterly trend becomes more marked and the dips are to the northwest. Brit the layers have been crashed by tension cracks, in general normal to the strike. Cleavage is subordinate to bedling in the northeastern part of the district, but toward the west the rocks become more and more sehistose until the bedding is mainly oblitcrated. This is due chiefly to a change in the charncter of the sediments. The rocks in the northeastern part of the area are commonly coarse grained to finely conglomeratic, becoming finer grained toward the west. In this direction the dip of schistosity becomes on the average flatter and where compared with the bedling the two strnetures both dip northward, the schistosity being the more stecply inclined.

From the data given above it seems that the strueture of the northern part of the district is that of a broad northward-pitching asymetrical anticline, with steeper limb on the east and axis trending $15^{\circ}$ or $20^{\circ}$ east of north. If this axis is projected southwestward across the center of the district it will coincide, with slight allowance for change in direction, with the axis of the antichinal cross fold aflecting the Saunders formation and indieated in the widening and the southeastward swing of the formation in the big bent of Brule River.

The existence of this north-south cross axis of folding is further indicated by the trend of the iron-bearing member, which enters the district from the southenst, bends to the west in the central part of the district as it crosses the cross fold, and then extends southwestward.

VULCAN IRON-BEARTNG MEMBER

Distritution and exposures.-There are few exposures of the Vulcan iron-bearing member. Knowledge of its distribution is based mainly on occurrences in undercround workings and in drill holes put down in search of inon ore and therefore is hargely limiterl by the extent to which these operations have been conducted. On the map (PI. XXIV, in pocket) are indicated those areas which are known to be underlain by this member and the position of the trill holes in which the member las been penetrated. Most of the drill cores were cxamined, but some are unavailable; in the latter case it has been necessury to rely on the superintendent's and drill runner's records. In attempt has been made to discriminate between the nore unaltered non-bearing rocks on the one hand and ferruginous cherts and slates and hon ores on the other. There are all gradations between the various plinses of the iron-bearing member, but as the ores and highly oxilized phases are related to structural comditions that largely influence ore concentration, it is thought that the discrimination attempted will have some practical usefulness in suggesting lines for further exploration.

The known main oceurrences of the Vulcan member may be referred to three different areas-(1) the Jumbo belt, just south of Brule River in Florence (ounty, Wis., about $1 \frac{1}{2}$ mites east of Saunders; (2) the central area of unestablished boundaries ext ending north, east, south, and west of Iron River; and (3) the northern area, including the Morrison Creek belt, in see. 24, T. 44 N., R. 35 W., and the Atlinson belt, southwest of Atkinson.

Possible extensions of these belts are to be inferred from the greneral structure of the district already deseribed. These are specifically discussed under later headings. Of especial interest in this stage of development are the possibilities of connection with iron-bearing belts in the Florence and Crystal Falls district, toward which much exploration is being directer.

Relations to Michigamme slate.-All the iron-bearing areas inclurle more or less slate, and interbedded state is shown in many of the drill holes which are indicated as cutting the Vulean member. It will be seen ly a study of the data on Plate XXIV that in the central part of the district the areal relations between slate and iron member are exceedingly complex and 
for the most part it is impossible to exclude the slate from any monideralle area. The explanation lies in the interbedling of the slate and iron-bearing member, compled with complicated folding.

From the foregoing statements it is evident that the Vulcan member is not ronfined to a single horizon in the Xlixhignmme shate. From analogr with the Vulean beds of the Venominee and crystal Falls districts it might be inferred that the member occupies at least two hori\%ons near the base of the Michigamme slate, but it is reasonably rertain that there are at least four lorizons of iron-benring rocks in the Iron River district, witlout making allowances for the possible occurrence of two or more horizons in the producing part of the areas near Iron River and Stambaugh. From the general structure of the district it is probable that the several areas of iron-bearing rocks occupy ns many different greneral lorizons of the Michigamme slate, the southernmost belt being at the lowest horizon, the centril area being somewhat higher, and the northern area being ligher still. In fact, slate and iron-bearing member are interbedded in such a way that the rocks at any horizon of the Michigamme slate maly somewhere becone iron hearing. There are areas where the facts are more nearly expressed by the phrase "Vul"an formation containing lenses of Nichigamme slate" than "Nhichigamme slate containing Vulean iron-bearing nember," and this is especially true of the central and southern parts of the district. Any attempt to unravel the structure of the slate and the iron-bearing member which does not take into accomt these relations will certainly lead to erroneons results.

Thichness and structure.-The iron-formation bands probably do not exceed 300 feet in thickness except where repeated by local buckling. They are closely and intricately folded with the assoriated slates and are as a rule steeply dipping. Erosion has cut deeply into the series, donbtless removing the iron-bearing member over consiclerable areas where it once existed. Where exposed, it occurs at the surface man!y in uarow bands, many of them twisting and contorted, but some retaining an approximately straight course for distances at least greater than 2 miles. With this general idea in mind, it will be readily understood that any attempt to draw boundaries of the Vulcan member will be more misleading than helpful. The major structure of the Vulean member is discussed under the general structure of the distriet.

Lithologic characters.-The Vulcan member is mate uj, of ferruginous cherts and slates, cherty iron carbonate rocks, magnetitic sideritic slates, and iron ores. The various facies possess no characteristics which are peculiar to this district and therefore will not be described in detail. The relations between the different types are those of grachation. The original iron-bearing rock was mainly a cherty iron carbonate similar in all respects to those which oecur in neighboring iron-bearing distriets.

However, there are $f$ wo characteristics which are worthy of notice in this place. Microscopic study of these rocks has revealerl the original presence of small quantities of greenalite. The altered forms of this mineral are abundant in some sections, but generally they are not shown. It is probable that greenalite was originally present in much greater abundance than might be inferred from an examination of the rock sections. It was only after identification of better-preserved forms in a few sections that its original presence in others was determined.

In the more highly altered phases all traces of original greenalite have heen olbiterated by recrystallization and rearrangement in different combinations of the elements forming the minerals in the rock. Various later stages of the alteration of the greenalite granules are obscrvable in thin sections, but nothing approaching unaltered greenalite has yet been found.

I seconl characteristic of the Vulcan member which should be noted is the abundance of assoriater clastic material and resulting alteration profuets. Flagmental quartz grams are abundant in many specimens and are clearly distinguishable from the matrix of crrstalline silicu of fine interlocking texture in which ther are locally inclosed. less mommonly there are grains of feldspar. By increase in the relative proportions of quart\% and feldspar grains the rork takes on the chancters of a graywake. If the intermixed clast ic material is of very finc grain, impure siderite and forruginus slates result and these by decrease in the carbonate an:l the cherty constituents grate inte ordinaly slate. By metamorphism the impurities in the iron-loaring rocks give rise to secon:anry products, mainly chlorite, which is nearly alwals 
associated with hiotite and lesser amounts of sericite. Carlonareous impurities are especially alundant and are responsible for the dark color of much of the chert of the iron-bearing member. Pyrite is a common associate of the carbonaceous impurities but may occur in smaller amount in the purer phases of the irm-bearing rocks. In the least-altered rocks the iron is present mainly as carbonate, being changed to limonite and bematite as oxidation progresses, but by anamorphism occasionally giving rise to magnetitic chloritic slates, usually carrying nore or less resilual iron earbonate. Such rocks occur on the top of Stambaugh Hill near the village of Stambaugh and are indicated in a small magnetic field in the SW. $\frac{1}{4}$ sec. $33, T .43$ N., R. 34 W. (See Pl. XXIV, in pocket.)

In short, the typical iron-bearing rock of the Vulean member-mainly a cherty iron carbonate-shows all possible gradational jhases, on the one hand to slate, which is nearly always highly ehloritic, usually biotitic and sericitic, and in places more or less carbonaceous, grading into highly graphitic varieties, and on the other to graywacke; and further, it is to be noted that the purer forms of iron-bearing rocks are subordinate in amount. A laboratory study of these rocks diseloses the characters that they may be inferred to possess from their intimate field relations to various types of interheded slates and graywackes. It is impossible to describe the rocks of the Vulcan member without ref ence to the clastic rocks with which they are so closely associated.

Distribution and local structure-(1) The only natural exposure on the so-called Jumbo belt occurs on the east side of Brule River about 200 paces east of the southeast corner of the NE. $\frac{1}{4}$ SE. $\frac{1}{1}$ sec. 22 , T. 42 N., R. 34 W. The rock is mainly a finely banded cherty iron carbonate, locally altered to ferruginous chert and interbedded with carbonaceous and pyritic black slate. The strike is east and west and the dip is about rertical on the arerage, although it raries widely on the limbs of the minor folds. From this exposure the member is traced eastward for three-quarters of a mile by numerous test pits of the old Jumbo exploration. The pits are now filled with débris, but the dumps disclose slate and iron-bearing nember of the characters shown in the outcrop. In the dump of the old Jumbo shaft at the east end of the belt are found an abundance of much altered greenstone, black carbonaceous and pyritic slate, roughly banded iron-bearing rocks carrying plentiful pyrite and secondary quartz and a little lean iron ore. The relations between the Vulean member and the greenstone are not shown, but these rocks are probably interbedded. Interbeded siliceous chloritic pyritiferous slate and much-altered grecnstone are well exposed in an outcrop on the south bank of Brule River just north of the Vulcan member and seem to lic conformably above it. The .Jumbo belt of iron-bearing member and slate is overlain on the north, in probable conformity, by extrusive ellipsoidal greenstone, which is well exposed in numerous outcrops north and south of the Chicago and Northwestern Railway. It is underlain by the Saunders formation, which occur's about one-quarter of a mile farther south. The Jumbo belt extends enst and west beyond known limits.

(2) The boundaries of the central area, the iron-ore producing area of the Iron River district, are not yet definitely known and are being lapidly wilened by exploration. If Iron River and Stambangh are taken as a center, the iron-bearing member is known to occur northward to the southern part of sec. $11, T .43 \mathrm{~N} ., \mathrm{R} .35 \mathrm{~W}$.; castward to the Chicagon mine, in the NE. $\frac{1}{4}$ sec. 26, T. $43 \mathrm{~N}$., R. $34 \mathrm{~W}$.; southeastward to the NW. $\frac{1}{4} \mathrm{NW} . \frac{1}{4}$ sec. $16, \mathrm{~T} .42 \mathrm{~N}$., R. $34 \mathrm{~W}$.; and westward to the SW. $\frac{1}{4} \mathrm{SIT}, \frac{1}{4}$ sec. 33, T. $43 \mathrm{~N} ., \mathrm{R} .35 \mathrm{~W}$. The area seems to be limited on the south by greenstone. By connecting the scattered outcrojs of greenstone occurring just north of the Sumders formation a belt of rarying width is outlined extending ncross the entire district. Athough it is certain that this belt as shown on the map (PI. XXIV, in pocket) contains considerable interbedded slate and possibly iron-bearing member, it seems to mark in a general way the south limit of the main Irichigamme slate and Vulcan member. Beginning at the outcrops in see. 23, 'T. 42 N., R. 34 WV., a magnetic line probably marking the north edge of the greenstone extends slightly north of west for about 2 miles and dies out. If extended, this line would pass just north of the greenstone exposure in the NW. $\frac{1}{4} \mathrm{NW} . \frac{1}{4}$ sec. 21. Thence the boundary swings more to the north and passes through the Wikdcat shaft near the center of the S. $\frac{1}{2}$ sec. 18 , and thence just north of the outcrops of greenstone in the 
N. $\frac{1}{2}$ X. $\frac{1}{2}$ sec. 13, T. 42 X., R. 35 TV. Farther westwarl the boundary can not be followed, from lack of exposures and exphoration.

Data for drawing a north boundary of this area are ontirely inadequate. Probably it hats no well-defined north limit. $\Lambda$ fow greenstone outrrops oreur in a broad belt of country several miles wille, beginning abont the middle of the aist side of the distriet, where they conneret with the grenemstone area that extends eastward almost to Crystal lialls, and extemeline thene northwestward to the middle of the distriet and thence southwestwarl. In this belt there are a creater number of square miles of territory than there are outerops, and those that oceur are confined to the eastern, central, and wostern parts. IIowever, the wide distribution of the few outcrops that are known indieates a belt composed dominantly of grenstono catending aress the district in a curving course in line with the structure of the grarwarke and shate area north of it.

() the structure and distribution of the Vulean member within this area the available information is by no means full. Exploration has ben very active for the last few years, but is still far from adequate. Lopally, in the mine workings, the structure is well known, lut it may be very dillicult to connect the structure and stratigraphy shown in workings on a single 40 acres with those of an adjacent 40 acres. The explanation for this complexity has alratly been discusset. In a later publication details of structure and distribution so fur as known will be given, but here a greneral ontline will sullice.

To begin in the southeastem part of the district, the iron-bearing member is found in the drill holes in the NW. $\frac{1}{4} \mathrm{NW}$. $\frac{1}{4}$ sec. $16, \mathrm{~T} .42 \mathrm{~N}$, R. $34 \mathrm{~W}$, and thence, in a curving line parallel to the north boundary of the greenstone, northwestward to the Zimmerman mine. Eastward from see. 16 the iron-bearing member extends in all prohability through secs. 15 and 14 , and perhaps still farther east, but in this direction expluration has not yot been carried. It is a favorable line for exploration. North and east of this belt borings have generally penetrated black slate. From the Zimmerman and Baltic mines the general rourse of the member is northwestward up the valley of Iron River. In detail the structure is exceedingly complex, and thorough understanding would involve a description of the structure and sucression in every mine on the belt. The Tulean member is here very generally underlain and interbedded with black slate and is usually in a highly inclined position. It attains its greatest known width on the Caspian mine location, where, with allownces for repetition by cross folding, it is probably over 300 fret thick. At the Hiawatha mine and thence westward for alout a mile the Vulean member strikes a little north of east and seems to di! on the whole steeply northward. Farther west this belt has not been triced. From the Caspian mine northeast to the SW. $\frac{1}{4} \mathrm{SW} . \frac{1}{4}$ sec. $21, \mathrm{~T} .43 \mathrm{~N}, \mathrm{R} .34 \mathrm{~W}$, drill holes have penetrated what seems to be a more or less continuous belt of the Vulean member. 'This belt is about at right angles to the belt along lron River, with which it and the extension of the Iliawatha bolt form a cross.

North of Iron River the strikes are prevailingly about east and west. The Vulcan member occurs in one main belt at least, more than $2 \frac{1}{2}$ miles long, extending from the . Tames mine slighly south and rast through the Spies and Hall explorations to the NE. $\frac{1}{4}$ see. 19 , T. $43 \mathrm{X}$., R. 34 W., and slightly north of west to the SE. $\frac{1}{4}$ SE. $\frac{1}{4}$ see. 15, T. 43 N., R. 35 II. The thicknexs of this belt in the James mine appears to be not over 250 feet, making due allowance for thickening by minor folling. Black slate here forms both foot and hanging walls. The dip valies, but is rertical or steeply southward or northwarl. Other lenses of the ironbearing member oceur both north and south of the James belt, but their importaner and extent have yet to be proved by exploration.

(3) In the northerm area the Morrion Creek belt is a marrow band of forruginous chert and sideritie state disclosed in the dumps of numerous test pits following the north boundary of

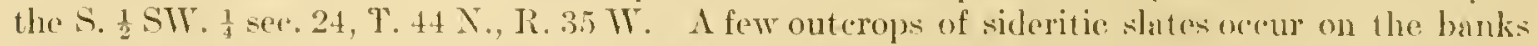
of Morrison Creek in an east-west line with the pits. The lip is vertical or slightly northwart. 'The iron-bearing member is here mulerlain by and probubly interbeded with black carbonareous shate. The orertying rock is a sericitic schist, a metamorphosed equivalent of the gratwarke exposed to the east and north in numerous outerops. On the south the slate secms to 
be underlain by voleanic greenstone, which outerops for alsout a mile to the south along the line between T. 44 N., R. 34 W., and T. 44 N., R. 35 W.

Southwest of Atkinson the Vuloun membrr occurs in a double belt, separaterl by a belt of voleanic greenstone breccia. The dip of the greenstone and associated iron-Jyaring member and slate here seems to he uniformly northwest at an angle of about $55^{\circ}$.

It will be interesting to consider in some detail the Atkinson section, for the interboddnd relations of the various rocks in the Hichignmme slate are here best exhibited. The southernmost rock is mainly black slate, carrying considerable but varying amounts of carbonaceous matter and in places becoming cherty and ferruginous, esperially toward the top of the formation, where it gives place to thin iron-bearing rock about 80 feet thick, accorting to plats of the McColman exploration furnished by the Verona Mining Company. The Vulcan member at this horizon has not been followed beyond the McColman workings. The iron-bearing member, as shown hy an examination of the rocks on the dump of the McColman slaft, includes hard limonitic iron ore, ferruginous ehert, and brownish and gray banded sileritic state. The slaty phases are sericitie, ehloritic, and biotitic, and in one place abundant titanite was found. The ore occurs in lenses in the slaty phases of the member. From an inspection of the Verona Mining Company's plats it appears that the highly sericitic, biotitic, and chloritic slates are abundant just under the orerlying greenstone.

The greenstone belt extents from the northeast corner of see. 18, T. 44 N., R. 35 W., northeastward into the SWr. ${ }_{4}^{1}$ NE. ${ }_{4}^{1}$ see. 9 of the same township and doubtless farther in both directions where exposures are lacking. Its thickness ranges from 700 or 800 feet up to possibly 1,400 or 1,500 feet at the northwest end. In places this roek is very schistose, but usually its original agglomeratic structure is retained. Breceiation is common, but the resulting structures ean usually be discriminated lrom its original agglomeratic structure, the fractures of the former cutting indiflerently across the latter. The rock is extremely altered. Weathered surfaces have the green colors of chlorite and epidote and show abundant secondary calcite and dolomite filling fracture planes and disseminated through the rock.

The greenstone is overlain by a belt of ferruginous slates and cherts, which become more siliceous in the upper horizons. Near the underlying greenstone, black earbonaceous slates are found, but these seem to be less prominent in the higher beds, which are composed dominantly of very lean ferruginous granular chert. Only one natural exposure is known, hut numerous pits and a few drill holes disclose the charncter of the rocks. 'This belt is less than a quarter' of a mile wide. North of it are sericitic slates, and these in turn grade northward into micaceous selists and graywackes, which are the dommant rocks in the northern part of the Iron River listriet.

While little is known of the extent of the Vulean member in the Atkinson distriet, it should be noterl that to the southwest, on the strike of these bects, in the SE. $\frac{1}{4}$ sec. $14, \mathrm{~T} .44 \mathrm{~N}$., R. $36 \mathrm{~W}$. lean ferruginous white granular eherty beds of the character of similar beds at Atlinson are associated with black slate and overhin by micaceous schistose graywacke. Similar white granular ehert occurs on the strike of the Atkinson rocks in the bed of Paint River in the SW. $\frac{1}{4}$ NE. $\frac{1}{4}$ sec. 1, T. 14 N., R. 35 W. These two occurrences seem to be at about the horizon of the beds in the Atkinson district, but it should not be inferred that the iron-bearing member is continuous from one locality to the other along this indieated belt. The probabilities are that the reverse is true.

Local magnetism in the Tulcan iron-bearing member.-Nlthough in general the Tulean member is nonmagnetic, there are a few local areas in which magnetism is well dereloper. Other magnetic areas would probably be discovered were the district carefully magnetically surveyed. Reference has already been male to the magnetic line apparently following the northern edge of the greenstone in secs. 21, 22, and 23, T. +2 N., R. 34 W. Whether this line is eaused by magnetism in the greenstone or in one of the lower members of the Michigamme slate is not known.

A magnetic field of irregular and willely varying strength in different parts covers about 60 acres on the crest of Stambaugh IFill, in the W. $\frac{1}{2}$ sec. 36, T. 43 N., R. 35 W. (See Pl. XXIV, 
in pocket.) IIere the rocks are well exposect in mumerous outcrops. The dip is about vertical and the strike slightly west of nortly, which is the diredion of elongation of the field. Funder the miroseope the rocks are seen to contain innmerable small grains of magnetite associnted with abundant dhorite and fincly crystalline guart\% and considerable siderite.

A macrnetic field of about the same size and shape occurs in the SW. 1 sece. 33, T. $43 \mathrm{~N}$., R. 34 W. (see Pl. XXIV), but here the field is elongated in a northwest-southeast direction, which is likewise bolievol to indicate the strike of the rocks at this place, although no exposures occurr.

Local magnetism occurs also in separated patches in sees. 35 and 36, T. 43 X., R. 34 W. Ilere the magnetic rock is mainly a graywacke carrying albundunt magnetite associated with chlorite, biotite, and siderite.

To the west of the Iron River district proper a belt of magnetic attraction has been

NW

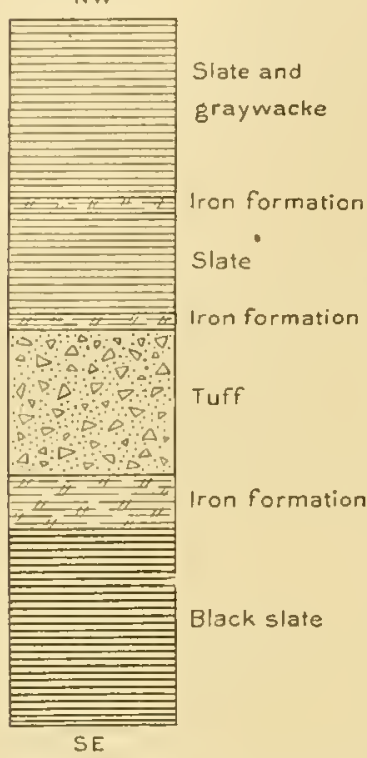

Figcre 4.-Section showing roughly the succession of beds in the Vi:lcan iron-hearing member near it kinson, in the Iron River district Michigan. traced in an area of heary drilt from a point near the center of T. $43 \mathrm{~N}$., R. $37 \mathrm{~W}$, westward to the Michigan boundary and thence probably into Wisconsin.

\section{INTRUSIVE AND EXTRUSIVE ROCKS IN THE UPPER HURONIAN (ANIMIKIE GROUP)}

Igneous rocks of hasaltic type are abundant in the upper Huronian. The distribution of those now known is indicated on the accompanying map of the Iron River district. (See Pl. XXIV, in poeket.) There is much difliculty in determining the general distriluttion of these rocks, because the relations to the slates are so intrieate that it is never safe to conclude that adjacent exposures are or are not separated by slate.

The rocks are principally of extrusive type and have surface textures, especially the ellipsoidal and acrolomaratic textures, that are characteristic of the Ilembock formation and of the rolcanic rocks associated with the upper IJuronian of the Crystal Falls district. Some of these extrusive rocks are distinctly contemporaneous with the slates. Southwest of Atkinson aggiomeratic and tuflaceous phases of the greenstone are interbedded with upper lfuronian slate and iron-bearing member (fig. 44 ). In the southern part of the distriet, in sec. 23, T. 42 X., R. $34 \mathrm{~W}$., ellipsoidal and tuffaceous creenstone occurs north of the upper IIuronian slates in a nortlumerdipping series. From the lack of contact metamorphism and the abmuance of tuffaceous phases and effusive rocks they were probably neary all deposited contemporaneously with the sediments. The deposition was probably submarine. (See pp.510-512.) Definite evidence of relations is lacking for many of the greenstones, especially those not adjacent to shates or some of those which have heen developed by mining operations and explorations.

\section{RELATIONS OF UPPER HURONIAN (ANIMIKIE GROUP) TO UNDERLYING ROCKS.}

No direct evidence of the relations of the upper Huronian with the underlying Saunders formation is yet available. (Certain slates conformable with the Saunders formation in Sheridan Ilill way be upper Huronian slates and may therefore indicate the conformable relations between the upper IImonian slates and the Saunders formation. The fact that rocks of the Saunders trpe form a continuous belt between the upper Huronian slates and the supposed Archean shore to the south is evidence of nearly conformable relations. It is noted in the sections on the Crystal Falls, Henominee, Feld Ifomtain, and Calumet districts that the succession from underlying quartzite and (lolonite w the upper IIuronian shows similar relations. (For discussion of corrclation and nomenclature, see pp. 597 et seq.) 


\section{ORDOVICIAN ROCKS.}

Remnants of flat-lying Paleozoic rocks occur in the southern part of the district, on Sheridan Hill and vicinity and farther southwest in the SW. $\frac{1}{4}$ sec, 27, T. 42 N., R. 35 W., also in the SE. $\frac{1}{1}$ see. 24, T. 44 N., R. 35 W.

The base of these rocks on Sheridan Hill is a conglomerate made up almost entirely of material from the underlying Saunders formation. Angular fragments of chert and ritreous quartzite up to 2 inches in diameter lie in a matrix of materials of the same general composition, but finer grained. The rock is cemented mainly with iron oxide and calcium carbonate. The thickness of the conglomerate is unknown but is not great. The rock has not been found in natural exposure, but is abundant on the dumps of pits which have been sunk through it into the Saunder's formation.

The conglomerate is overlain by a coarse quartz sandstone of buff and red color and generally very friable texture. The cement is mainly iron oxide. ['nder a slight tap of the hammer the rock falls apart into its constituent sand grains. The thickness of this sandstone is not known, hut it probably ranges from a knife-edge up to perhaps 35 or 40 feet.

In the southeast corner of sec. 24, T. 44 N., R. 35 W., a film of red sandstone is found mantling black slate. Here the rock carries considerable iron oxide, doubtless derived from the Vulcan member occurring about a quarter of a mile north of it.

The conglomerate and sandstone of these areas have the lithologic characters of the lowermost Cambrian beds in the Menominee district and were formerly correlated with the Cambrian. Also Seaman has suggesterl that they perhaps represent the base of the upper IIuronian. Recent fossil discoveries, however, in flaggy limestone beds in the S. $\frac{1}{2} \mathrm{SW} . \frac{1}{4}$ sec. $27, \mathrm{~T} .42 \mathrm{~N}$., R. $35 \mathrm{~W}$., have fixed within narrow limits the age of these rocks. In this area there is one natural exposure on the east side of Brule River and several pits, all showing nonmagnesian dore-colored to huff flaggy limestone of the same general characters. The rock seems to be flat-lying, although the beds in the outcrop on the Brule, where olservations were made and where most of the fossils were found, have been disturbel by shmp, following underentting ly the river. From the position of this outcrop in reference to an exposure of the Saunders formation on the west sile of the river about 500 paces south, it would seem that these rocks are not far above the eroded surface of the Saunders formation. Whether they are underlain by the conglomerate and sanistone of Sheridan Hill is not known. The beds are practically undisturber in both areas, but the lowermost known occurrence of the conglomerate on Sheridan Ifill is about 150 feet higher and the uppermost known beds of sandstone are about 300 feet hicher than the limestone outerops on Brule River in sec. 27. It would seem from this that the conglomerate and sandstone on Sheridan Hill are stratigraphically higher than the limestone of sec. 27. Doubtless the conglomerate originally formed a continuous mantle at the base of the Paleozoic rocks, but owing to the rugged character of the surface over which the sea advanced there was probahly a considerable time interval between the submergence of the lower areas and that of the tops of the hills. Consequently the relative age of the basal member formerl at any point is a function of its altitude at that place. The occurrence of sandstone on Sherilan Hill at an altitude of abont 1,760 feet makes it certain that the cntire district was almost if not entirely covered by a Paleozoic sea.

The lowest exposure of the Paleozoic beds is the limestone member in see. $27, \mathrm{~T} .42 \mathrm{~N}$., R. $35 \mathrm{~W}$. This limestone is correlated by E. O. Ulrich on paleontologic grounds with the Lowville of New York and the Platteville limestone of Wisconsin-that is, with the Middle Ordovician. The following is Mr. Ulich's report to T. W. Stanton:

I beg leave to report as follows on the fossils collected in the Iron River district, Nichigan, by R. C. Allen and forwarled to the Survey for examination and report by C. K. Leith November 18, 1909:

This cliscovery of fossils in northern Michigan is of great interest, as it ardds an important link in proving the former connection of the early Mohawkian limestone of Jimnesota and western Ontario across northern Wisconsin. In discussing the Lowville limestone in my paper on revision of Palenzoic systems $\mathbf{I}$ state my conviction that this and perhaps other Molawkian formations must have originally extended from New York through Untario, northern 
Michigan, and northern Wisconsin to Minuesota and Iowa. This direct westerly connection was indicaterl by the great similarity in fama and lithology noted in comparing the Lowville limetone in cow lork and the more typiral part of the l'hateville linwstone of sonthern .Innesota, lowa, southern Wiswnsin, and northwestern lllinois. I objected (1) communication via southeastern Wisconsin because there the leeds supposed to rorrespond in age to the lowrille are dolonites instead of pure limestone, with no inclication of tranition in lithic chararters northward. llitherto the northem consection conkd not be established farther west from New York than Escanaba, Mirh. This

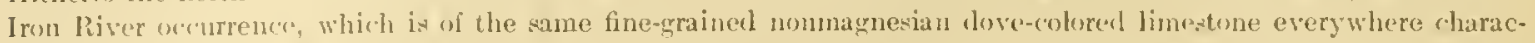
terizing the Lowvile and lying well up on the old "Wisconsin Peninsula," may therefore justly be regarbed as tending to satablish a view hitherto based only" on inference.

The following 20 speries are more or less confidently islentified. All are older than the Trenton limestone and younger than the latest Stones River.

? (ormatocladus densms.

Tetrulium (eellulosum (fragment of tube only).

Rhinidictya ef nicholsoni and mutabilis-minor (frugment).

R. cf. major (fragment).

Eecharopera angularis.

?Homotrypa arbuscula.

Rafinesquina minnesotensis.

Strophomena incurvata (Lowville var.).

Zygospira recurvirostris (Lowille var.).

Cteuoronta sp. undet. (near C. levata).

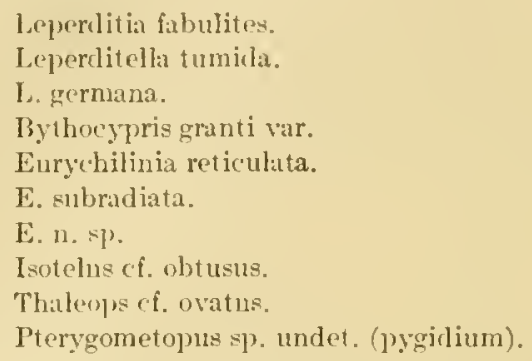

The fossils of the above list inclicate a horizon at the extreme top of the Platteville limestone in the lead distrirt. Compared with the New York section the bed rorresponds in age to the uppermost beds of the Low ville, as described by Cushing, or to the cherty bed at the base of the lilack River limestone, as defined by the saroe author.

\section{FLORENCE (COMMONTEALTH) IRON DISTRICT OF WISCONSIN. LOCATION AND GENERAT SUCCESSION.}

The Florence district is the westwarl geographic extension into Wisconsin of the Venominee district beyond Menominee River. It is essentially included between the two tributaries of the Ilenominee, the Brule on the north and the Pine on the south (Pl. XXV, in pocket). On the east it is separated from the Menominee district, as this is limited on the geologic map, by Menominee River. The area is one of low relief, like the Iron River distriet to the northwest. Exposures are relatively few except along the rivers and lakes.

Part of the Florence distriet has been studied by members of the United States Geological Survey, and a complete outerop map of the distriet has been prepared by Mr. WT. X. Merriam and assistants for the Oliver Iron Nining Company. As yet, however, the district has not been studied with sullicient exhaustiveness to definitely establish the succession and structure. Such a study is now being conducted by W. O. Hotchkiss, State geologist of Wisconsin. So far as the facts are now linown, including those dereloped in recent work of IIntchkiss, the succession in the Florence district seems to be as follows:

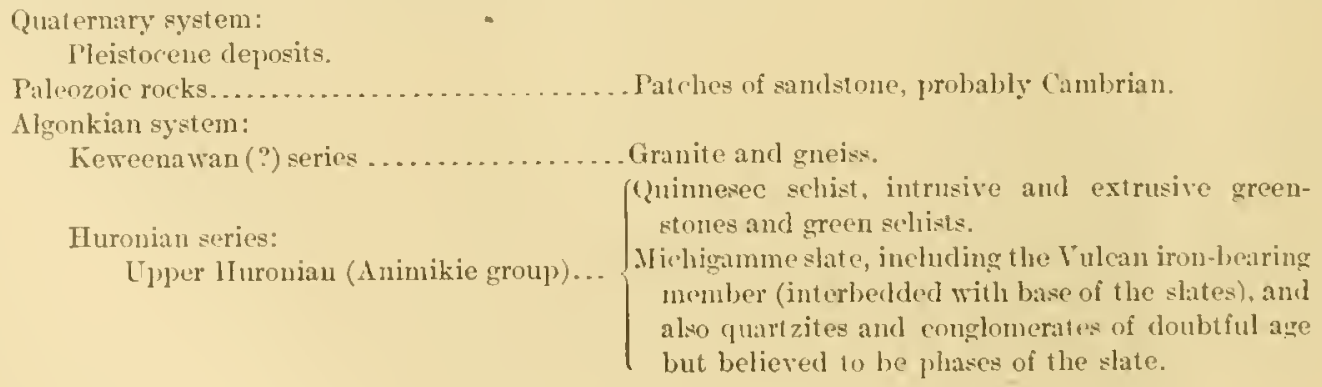




\section{AIGONKIAN STSTEM.}

HURONIAN SERIES.

UPPER IILRONIAN (ANIMIKIE GROUP).

MICHIGAMME SLATE.

General eharaeter and distribution.-The Animikio group seems to oceupy nearly all the area of the Florence district north of the Quinnesec schist belt, except where small patches of intrusive or extrusive greenstone appear at the surface. The rocks are chiefly slate. In less quantity oceur conglomerate, quartzite, tuffs, and iron-bearing roeks. It has not been proved that all these rocks belong to one group, but as yet they have not been certainly separated.

The Michigamme slate is poorly exposed in the district as a whole, except along Brule River, in the vicinity of Keyes Lake, and northwest and southeast of Florence. It is almost identical in petrographic characters with the upper IIuronian slates of the Ilenominee and Crystal Falls distriets, and has been regarded as belonging to the same formation.

Quartzites, associated with more or less conglomerate, appear in three main areas-(1) at Island Rapids, on Nenominee River, in sees. 13 and 14, T. 40 N., R. 1s E.; (2) in a belt running north of Keyes Lake; and (3) in a belt running through sec. 28, T. 39 N., R. 1S E., north of Pine River. The quartzite at Island Rapids stauds rertical or dips steeply to the south, and the top is to the south. In the Keves Lake belt the rock is vertical or dipping steeply to the southwest. The relations of these two belts with the slates are not known definitely, but are probably conformable. The southern belt of quartzite just north of Pine River dips southwestward at a lower angle. It is thought by Hotchkiss to rest meonformably upon the slates to the north of it. If this is true the so-called upper ILuronian of this district consists really of two groups, the correlation of which is doubtful. The southern quartzite is overlain conformably by slates which upward become interbedded with tuffs and eruptives belonging to the Quinnesec schist.

Tulean iron-bearing membrr. - The Vulean iron-bearing formation is somewhat widely distributed through the upper Huronian area, but here it is so interbedded with the slates that it is difficult to map independently. In this district, therefore, as in some other districts, it is treated as a member of the Michigamme slate. In the Florence district there are only five areas in which the ferruginous phases of the upper IHuronian are now known sufficiently well to warrant a separate color on the map-one is immediately northwest of Florence in secs. 20 and 21, T. 40 N., R. 18 E., and in a belt extending northwestward to Brule River; two southeast of Commonwealth, in secs. 33 and 34 , T. 40 N., R. 18 E.; one extending east and west south of the greenstone belt in secs. $S$ and 9, T. 39 N., R. 19 E. These three exposed areas are connected by a belt of magnetic attraction, indicating that the iron formation is probably continuous from Brule River on the northwest nearly to Menominee River on the sontheast. Another area is in the vicinity of the Buckeye mine, just to the soutluwest of Commonwealth. This connects with a magnetic belt running southeastward to Menominec River, in sec. 22, T. 39 N., R. 19 E. To the east, across the river, this magnetic line connects witl the principal iron-formation belt of the Nenominee district. Another belt of iron-bearing formation outcrops west of Keyes Lake, whence it is followed by magnetic lines to the southeast to about the east sile of T. 39 N., R. 18 E., and northwestward toward the northwest comer of T. 40 N., R. 17 E. Belts of attraction not connected with any well-exposed areas of iron formation are known elsewhere in the district. Particularly to be mentioned are the belts extending northwestwanl from Pine River from sec. 28, T. 39 N., R. 18 E.

The iron-bearing nember is magnetic in plitces, especially along the contacts with the intrusive greenstones. The maj shows a number of disconnected magnetic lines which have been traced in this area. Some of these may represent altered iron-bearing rock.

The Vulcan iron-bearing member consists of (1) ferruginous chert, siderite, and hrydrated hematite; (2) various phases intermodiate between theso and the slates, called sideritic slates $47517^{\circ}-$ VOL $52-11-21$ 
and fermginous slates; and (3) grüneritic and magnetic slates. They are similar, except for trye 3, to the rocks of the Vulcan iron-bearing member in the Iron River and ('rystal Falls districts. Iron ores anc exploited at the Fhorence mine, immediately northwest of the tomn of Florence; at the Commonwealth and Badger mines, southeast of the town of ('ommonwealth; and at the Buckeye mine, south of Commonwealth. (Nee p. 323.) The ores seem to be in minor drag folds, pitching stecply northwestward in tho florence and commonwealth mines. The major trend of the iron-bearing exposures of magnetic belts and of exposures of other rocks is north of west in this distriet, a trend which would tend to (x)mect the iron-hearing belts with those of the Menominee district on the southeast and with those of the Mastodon area in the southem part of the ('rystal Falls district on the northwest. (See p. 292.) Exploration has been very slight, as there has heen little to guide it. Howerer, there is a large territory along the trend here noted which must soon receive attention.

The horizon in the upper Huronian slates at which the iron-bearing member of this district occurs has not been detemined. The proximity to the upper Huronian iron formation of the Menomince district suggests its oceurrence near the base of the upper IIuronian.

\section{INTRUSIVE AND EXTRUSIVE GREENSTONES AND GREEN SCHISTS.}

Quinnese schist.-The Quinnesec schist outcrops in an east-west belt 1 to 3 miles wide along the south side of the district, probalyly constituting the northwestern extension of the southern Quimesee schist belt of the Nenominee district. The best exposures are along Pine River, especially in sees. 29 and 30, T. 39 N., R. 18 E. The schists are chiefly hornblendic guciss, locally micaccous. They are eut by basic and acidie intrusive rocks, the lormer being the more abundant. The detailed petrographic description of these schists given in the Menominee chapter will suffice for this district.

The continuation of these schists along the south side of the Menominee district has been assigned to the Kicewatin series of the Archean in previous reports of the United States Geological Survey. $^{a}$ Later work showed this assignment to be a very doubtful one, and the question of the correlation of the schists has been largely left open for the Nenomince district. The work of Hotchkiss along the south side of the Florence district shows clearly an interbedding of upper Huronian slate with tuffs and eruptives of the Quinnesee schist in a manner showing the main body of schist to be later in origin than the upper Huronian to the north of it.

Intrusive and extrusive greenstones and green schists other than Quinnesec.-Massive and schistose intrusive and extrusive greenstones apjear in several small areas in the upper Huronian. Two of them cross Menominee River on the east, where they join the northern Quinnesce schist area of the Menominee district. Another group is exposed along Brule River and others between the Brule and Florence. Isolated outerops of green schistose and tuffaceous rocks of doubtful structural relations are somewhat widely distributed through the district. They are in places associated with amphibole-magnetite sehists, some of which represent phases of the intrusive rocks, but some of which doubtless also are metamorphosed phases of the Huronian ferruginous slates.

Petrographically these rocks are very similar both to the Hemlock formation and to the Quimesec schist, and the description of the northern Quinnesec schist area of the Menominee district will apply to them.

The areas of intrusive rocks are longer from east to west than from north to south. Evidenee of the intrusive characted of the greenstones is found along Brule and llemominee rivers in T. 40 X., R. 18 E. Especially good evidence is the area just west of Keyes Inake. In sere.9, at several points along the Brule, are to be found out repos of the massive greenstones in contact with the slates. Invariably the slates are more micaccous near the contact than elsewhere. In fact, they become micat schists, and here and there is seen a slight development of some secondary mineral, probably gamet. In erery outerop along the Brule the eontacts of the greenstomes and sodiments ane not sharply defined, the erreenstones being schistose and chloritic at the contacts. In siec. 13, T. 40 N., R. $18 \mathrm{E}$, greenstone is found in conteict with a micaceous 
quartzitc. The actual well-defined contact may be scen here, and the intrusive character of the greenstone is clearly shown. A wedge of the greenstone cuts the quartzite at 1,650 paces north and 200 paces west of the southeast corncr of sec. 13, T. 40 N., R. 19 E. The quartzite at this place is much fissured and shattered.

Brule River, where it crosses the E. $\frac{1}{2}$ sec. 9, T. 40 N., R. 18 E., is a favorable place to sce the way in which the intrusive greenstones stand out prominently as hills in the slate area. The river here cuts through the slates and greenstones, giving a well-cxposed cross section. The conchusion is here forced on the observer that the outcrops of the greenstones of this area represent with a very fair degree of accuracy the actual distribution of the greenstones. The greenstone outcrops are many times longer east and west than north and south, as has been noted. This, however, does not justify the correlation of greenstone knobs because they happen to atign in the direction of their long dimensions. The areas mapped as intrusive and extrusive greenstones and green schists on the Florence map (Pl. XXT, in pocket) may therefore be regarded as containing much slate in lower, covered ground.

GRANITE AND GNEISS INTRUSIVES.

Borlering the Quinnesec schist on the south is an area supposed to be underlain by granites and gneisses. Exposures are few, but to the east, south of the Henominee district, they are more abundant. The relations are those of intrusion into the Quinnesec schist, and the roeks are doubtfully correlated with the Keweenawan.

\section{PALEOZOIC SANDSTONE.}

A few patches of Paleozoic sandstone lie unconformably upon the pre-Cambrian rocks. These are well shown just west of the Buckeye mine and north of Keyes Lake.

\section{QUATERNARY DEPOSITS.}

This district is covered by Pleistocene glacial drift. (See Chapter XVI, pp. 427-459.)

\section{THE IRON ORES OF THE CRYSTAL FALLS. IRON RIVER, AND FLORENCE DISTRICTS.}

By the authors and W. J. MEAD.

\section{DISTRIBUTION, STRUCTURE, AND RELATIONS.}

The principal ores of this region are found in iron-bearing layers infolded with upper Iuronian slate in the vicinity of Florence, Commonwealth, Crystal Falls, Amasa, and Iron River, and in the micklle IIuronian slate near Mansficld. These districts are usually considered as a part of the Menominee district in returns of ore shipments, and their ores are similar, geologically and structurally, to those of the Menominee district. Though not directly continuous with the iron formation of the Menomince district, so far as explorations ret show, they mainly belong in a formation which is closely correlated with that iron-bearing formation (the Vulcan), and is given the same name. Also the upper IIuronian slate with which this ironbearing formation is associated is similar to and continuous with the Vichiganme ("IIanbury") slate of the Menominee listrict, and is therefore called by the same name.

The Hichiganme slate over this great area is remarkably uniform in character, and it is difficult to tell at what horizon in the slate formation the ores occur in any particular locality. In the vicinity of Crystal Falls and Amasa the upper Huronian slate rests upon greenstones of the Hemlock formation, so that in this part of the district it is easy to determine the base of the upper Huronian, and the occurrence of the ore at a short though varying distance from the volcanic Hemlock formation shows that for this locality at least the iron-bearing rocks occur at a fairly persistent horizon near the base of the upper Huronian slate.

Most of the ore deposits of these districts are accompanied by black and pyritiferous slate walls, in places associated with greenstone, or they may be separated from such walls, especially the hanging wall, by a small amount of lean cherty iron-bearing rock. Along the trend of the 
iron-baring member and in depth the iron-ore layers pass into lean (derty layers. The ore bodies throughout slow a strong tendency to follow the steeply inclined and uniformly trending bedeling of the iron-bearing member, having thus distinct lincar shape and distribution at the surlace and tiluular or lens slatpe in three dimensions. In certain of the Crystal Falls deposits these chatueteristics are much more apparent than in others. For instance, the ores at the Jembeck mine al Amasa constitute a kns in a marow bind of irm-bearing rock, with considerable extent vertically and horizontally, parallel to the strike of the upper Iluronian. The same is true of the ore deposits in the so-called "Mansfeld slate." Though minor folds are present in both of these deposits, they are subordinate to the general tabular shape of the deposits.

Other ore bolies follow the axial lines of drag folds, thus pitching at various angles beneath the surface. Their shape, considered in thee dimensions, tencls to be linear rather than tabular. As few of these axial lines are uniform for long distances, oflsets of the ore boly are common. The ores of the Florence district seem to be in clrag folds, with pitches to the northwest. Their distribution suggests shinp oflsets by drag folding.

The iron-bearing rocks, and therefore the ore bodies, are usually not more than 300 feet thick, though locally the thickness may be much increased ly buckling. It will be noted by figure 12 (p.123) that folding of that type multiplies the thickness by 3 . The depth to which mining has thus far extended is 1,000 feet, but exploration has shown ore to a greater dejth. It can not yet be said what the maximum depth of the ores may be. At the Florence mine the formation becomes pyritilerous below this depth, although it is not demonstrated that the pyritiferous portion continues indefinitely.

The iron formations near the main area of the IIemlock formation in the Crrstal Falls district and part of those in the Florence distriet are distinctly magnetic. Elsewhere in the Crystal Falls district and in the lron River district the formations are weakly or not at all magnetic.

The structural relations of the ores of this group are less satisfactorily known than those of almost any other distriet in the Lake Superior region, partly because of the lack of sufficient development and partly because of the uniformity of the slate, making it difficult to find recognizable horizons as a basis for working out the structure. Because of the lack of continuity of the iron formation in this great slate area and the covering of a large part of the area by glacial drift, it seems altogether likely that there are still many deposits to be found through the slate. Magnetic work sometimes indicates places to begin exploration, but much of the exploration must begin blinclly.

\section{CHEMICAL COMPONITION.}

The ores of these districts, with the exception of the Mansfield deposit and the AmasaPorter, south of Amasil, are non-Bessemer lydrated hematites of medium to low grade. The arerage composition and lange for each constituent of the ores mined in these distriets in 1907 and 1909 are as follows:

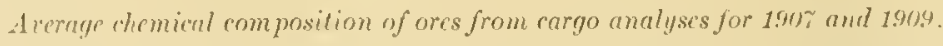

\begin{tabular}{|c|c|c|c|c|c|c|}
\hline & \multicolumn{2}{|c|}{$\begin{array}{l}\text { Crystal Fills dis- } \\
\text { trict. }\end{array}$} & \multicolumn{2}{|c|}{$\begin{array}{l}\text { Iron liviver dis- } \\
\text { Irict. }\end{array}$} & \multicolumn{2}{|c|}{ Florence distriet. } \\
\hline & 1907. & 1909. & $190 \%$ & 1909. & $190 \%$ & $1: 003$. \\
\hline Molsture (loss on drying at $\left.212^{\circ}\right), \ldots$. & $\therefore .4 i$ & S. 42 & x. 23 & S. 34 & 10.36 & 9. $\mathrm{it}$ \\
\hline 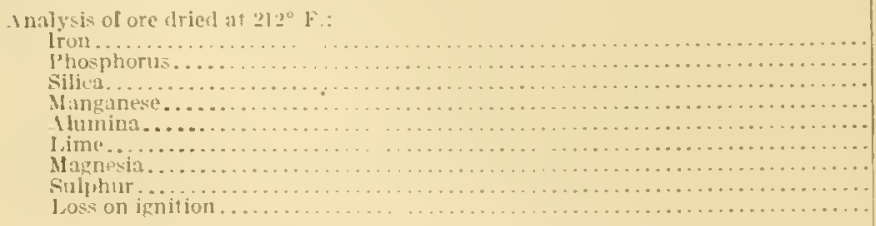 & $\begin{array}{c}54.10 \\
.37 \\
6.27 \\
1.27 \\
2.94 \\
2 .(32 \\
2.15 \\
.054 \\
5 . \times 9\end{array}$ & $\begin{array}{c}54.79 \\
7.715 \\
7.799 \\
2.50 \\
2.63 \\
2.16 \\
.071 \\
4.11\end{array}$ & $\begin{array}{c}55.70 \\
.396 \\
8.62 \\
.20 \\
2.54 \\
.92 \\
.96 \\
.054 \\
5.25\end{array}$ & $\begin{array}{c}54.3 .7 \\
\therefore .101 \\
\therefore .70 \\
3.07 \\
1.31 \\
1.49 \\
.1406 \\
5.74\end{array}$ & $\begin{array}{l}54.30 \\
.32 \\
6.72 \\
.20 \\
3.35 \\
1.51 \\
2.46 \\
.132 \\
\text { i. } 20\end{array}$ & $\begin{array}{l}5.70 \\
.319 \\
6.01 \\
.09 \\
4.17 \\
1.80 \\
2.56 \\
.173 \\
5.20\end{array}$ \\
\hline
\end{tabular}


Range in perrentage of each constituent in ores mined in 1909.

\begin{tabular}{|c|c|c|c|}
\hline & $\begin{array}{c}\text { Crystal Falls } \\
\text { district. }\end{array}$ & $\begin{array}{l}\text { Iron River } \\
\text { district. }\end{array}$ & $\begin{array}{c}\text { Florence dis- } \\
\text { trict. }\end{array}$ \\
\hline Moisture (loss on drying at $212^{\circ}$ ) . . . . . . . & $2 . \$ 3 \quad 1013.75$ & 3. tis to 11. fits & 8.46 to 9.98 \\
\hline 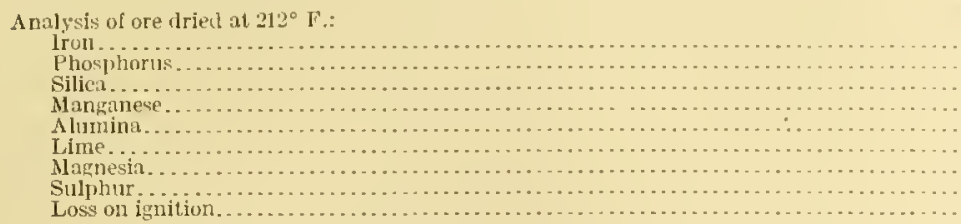 & $\begin{array}{r}35.7 \text { to } 57.20 \\
.020 \text { to } 1.28 \\
5.51 \text { to } 39.53 \\
.15 \text { to } 2.93 \\
1.20 \text { to } 3.41 \\
1.20 \text { to } 4.96 \\
.71 \text { to } 2.81 \\
.017 \text { 10 } .1100 \\
1.56 \text { to } 7.60\end{array}$ & $\begin{array}{r}49.87 \text { to } 5 \text { ti. } 137 \\
.709 \text { to } 3.13 \\
5.35 \text { to } 11.16 \\
.18 \text { to } 2.10 \\
.99 \text { to } 1.23 \\
.40 \text { to } 2.74 \\
.30 \text { to } 2.40 \\
.009 \text { to } .088 \\
2.45 \text { to } 9.02\end{array}$ & $\begin{array}{r}53.30 \text { to } 55.00 \\
.297 \text { to } \\
6.50 \text { to } 8.45 \\
.(115 \text { to } .20 \\
2.82 \text { to } 4.47 \\
1 .(11 \text { to } 2.13 \\
2.71 \text { to } 2.88 \\
.11 \text { to } 1.87 \\
5.05 \text { to } 5.80\end{array}$ \\
\hline
\end{tabular}

\section{MINEIRAL COMPOSITION.}

The ore of these districts is chiefly soft red hematite, though in places it is hydrated and graded as brown liematite (limonite). Goethite has been irlentified at Iron River. In allition, there are quartz and some kaolin, with small anounts of nagnetite, calcium, and magnesium carbonates, and minute amounts of sulphides.

The arerage mineral conposition of the ores of these listricts, calculated from average analyses for 1909 given in the above table, is as follows:

Approximate mineralogical composition of ores, ralculated from the averanc analyses for 1909.

\begin{tabular}{|c|c|c|c|}
\hline & $\begin{array}{l}\text { Crystal falls } \\
\text { district. }\end{array}$ & $\begin{array}{c}\text { Iron River } \\
\text { district. }\end{array}$ & $\begin{array}{l}\text { Florence } \\
\text { district. }\end{array}$ \\
\hline 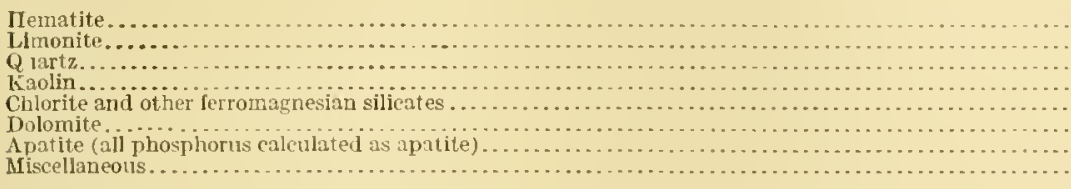 & $\begin{array}{l}71.90 \\
7.50 \\
4.36 \\
4.70 \\
3.50 \\
4.019 \\
2 . \operatorname{lin} \\
1.44\end{array}$ & $\begin{array}{r}54.00 \\
27.80 \\
4.52 \\
5.50 \\
3.80 \\
.45 \\
2.12 \\
1.21\end{array}$ & $\begin{array}{r}62.42 \\
18.10 \\
1.26 \\
7.70 \\
6.20 \\
2.85 \\
1.65\end{array}$ \\
\hline & 100.00 & 100.00 & 100. 18 \\
\hline
\end{tabular}

The alrove mineral compositions are necessarily only approximate, as ferrous and ferrie iron are not separated, and the combined water, $\mathrm{CO}_{2}$, and a possible small amount of organie material are included together under loss on ignition. All the phosphorus with proper amounts of limestone was caleulated as apatite: the remaining lime with proper amounts of magnesia and water was calculated as dolomite. The remaining magnesia with alumina, silica, and water was calculated as chlorite. The alumina not used in the chlorite, together with sufficient siliea and combined water, was taken as kaolin. Sufficient iron was combined with the remaining water to form limonite and the remaining iron figured as hematite. Ilematite and limonite probably do not exist in the ores, but as a means of comprarison and to show the degree of hydration the hydrated iron oxide is calculated in terms of these two minerals.

\section{PIIYSICAL CIIARACTERISTICS.}

The ore is very porous and shows many crystal-lined cavities. At places a hard sterl hematite ore is found, which runs high in metallic iron. It lireaks into a mixture of small blocks and soft ore similar to the ores of the Menominee distriet.

The average mineral density of the ores, calculated from the above analyses, is 4.35 for the Crystal Falls ores and 4.30 for the Iron River ores.

The porosity of the ores ranges from less than 5 per cent to over 40 per cent of their rolume.

The eubie contents of the ores rary from 8.5 to 15 cubic feet to the ton, with an arerage of about 11 cubie feet. The rolume composition of these ores, in comparison with those of the Menominee distriet, is represented in figure 50 (p. 352). 


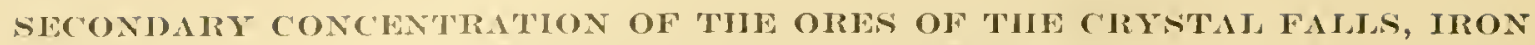
IRIVER, IND FLORENCE DISTRICTS.

Structural conditions. - The ores of the Crystal Falls, Iron River, and Florence districts are enrichnents of narrow beds and lenses of iron-bearing rocks, as a rule not more than 300 feet wide, nsually lectween steeply inclined walls of slate, generally erraplitie and pyritiferous near the contact, and commonly associated with greenstone. The iron-bearing member maty trend in the same direction for consideralble distances and yet be elosely corrugated by minor folds of the drag trpo illustrated in fignre 12 (p.123). These steeply pitching drag folds fumish an inpervious basement of slate along which the waters have followed the openings in the ironbearing member in especial abundance and have effected the concentration of the ore. The iron-bearing rock is brittle, but the slate is not, the result being that breccias are common in sucle troughs, gleatly faroring the flow of water. The folds are of various magnitudes and the concentration may follow eitlier the minor or the major folds.

The circulation has been controlled by the fracture openings in the iron-bearing member and the bedding in it, and the confining strata have heen foot-wall slates, hanging-wall slates, and iron-bearing member. The essential parallelism of the ores to the trend of the iron-bearing member shows the obvious tendency of the waters to follow that trend but to be deflected by the minor bends in it. This is especially well seen along the main belt of iron-bearing rocks along Iron River.

The depths to which the waters have aeted is yet largely unknown. The deepest mines operate to a depth of 1,000 feet in the Crystal Falls district, 500 feet in the Iron River distriet, and 950 feet in the Florence distriet. In certain deposits the ore has apparently given out with depth. It is possible that in some mines it has been lost because of considerable offset by the folding. Deeper exploration is warranted.

The topographic relief of the regrion is so great that different parts of the iron-bearing member may differ as mueh as 300 feet in elevation. The ores are as a rule closely associated with the liills but seem to follow, indiflerently, crests, slopes, and adjacent rallers. In the Iron River district the ores faror especially the valleys. These are discernible with diffieulty through the thiek drift, but are being found by drilling. The depth to which a head given by the observed topography would carry a vigorous circulation through the iron-bearing member can not be worked out theoretically beeause of the uncertainty of the factors involved. Certainly nothing is now known which would prevent exploration as deep as in other districts of the Lake Superior region, although here, as in other distriets, many of the deposits have certainly been found to be only a few liundred feet deep.

Chemical and mineralogical changes.-The iron-bearing member was originally pyritiferous iron earbonate interbedcled witl more or less slate. The alteration to ore has oceurred in two phases-first, the oxidation of the iron without removal of silica, producing ferruginous cherts; second, partly simultaneous and more local, the leaching of the silica, leaving the iron oxide concentrated as ore. The pliysical and chemical features of these alterations have not been worked out cuantilatively as they have for other distriets, but qualitatively they are known to be similar to those of other districts in all respeets.

Time of concentration.--The ores were concentrated after the upper II uronian folding and before the Cambrian deposition, and since their concentration they have been little alfected by further folding.

\section{TIE IRON ORES OF TIIE FELCII MOLNTAIN AND CALLMET DISTRICTS.}

By the authors and W". J. MFAD.

The Feleh Ilomntain and Calumet districts are eastward branches of the Crystal Falls district. Execpt for low grade and low phosphorus, their ores are the same in horizon, relations, and mineralogical and physical character as the ores of the Crystal Falls and Menominee districts.

The shipment from these districts has been small. 


\section{FELCII MOUNTAIN DIS'TRICT.}

Iron ores lave been mined at two lecalities in the Feleh Mountain district near Groveland and near Felch. In both these loealities the iron-bearing Vulean formation lies in a elosely compressed syncline with basement of impervions slate or schist, called "Nansfield" schist by Smyth, but called Feleh schist in this report. The lenses at the east end of the Felch Mountain trough are now largely worked out. At the Groveland mine dikes of granite cut the ore body.

The average conposition of the ores mined in the Felch Nountain district in 1907 is as follows:

Average analysis of ore mined in the Folch Hountain district in $190 \%$.

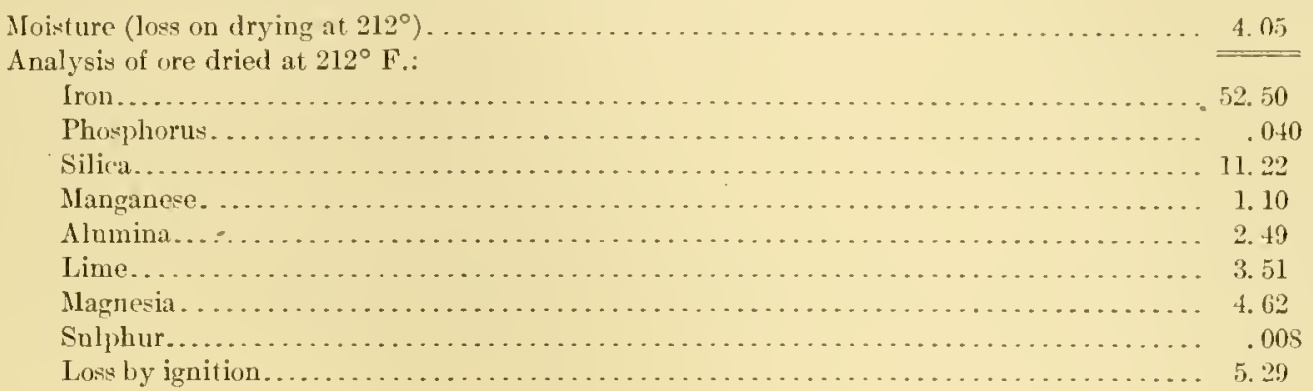

The volume composition of these ores, in comparison with the Crystal Falls, Menominee, Iron River, and Florence ores, is given in figure 50 (p. 352).

\section{CALUMET DISTRICT.}

Ore is mined in the Calumet distriet only at the Calumet mine, a comparatively recent development, where there is a steeply southward-rlipping suecession beginning with Archean granite on the north, followed successively by Sturgeon quartzite, Randville dolomite, Felch schist, Vulcan formation (iron bearing), and Michigamme slate. The strike of the ore body is parallel to the bedding. The bedding trends east and west, but has minor folds with steen pitches parallel to the strike. The ore body with its associated iron-bearing formation is divided longitudinally into three parts by layers of slate, from north to south 60,15 , and 60 feet thick. The foot wall is slate, quartzite, and dolomite. The hanging wall is slate or ironbearing formation. Along the strike the ore abuts irregularly against unaltered iron formation. The depth of mining operations to the date of writing is 200 feet. The possibilities of the extension of the deposits are discussed on page 324. The iron ore is banded cherty hematite and limonite and some magnetite. It is nonmagnetic in indivilual pieces, but collectively it exerts a powerful magnetie pull. The ore runs from to to 45 per cent of iron and is sold on the basis of 0.028 per cent of phosphorus. Its density is about 4 and its porosity 18 per cent; it averages about 10.5 cubic feet to the ton.

The average composition of the ores mined in the Calumet district in 1907 is as follows:

-1verage analysis of ore mined in the calumet district in $190 \%$.

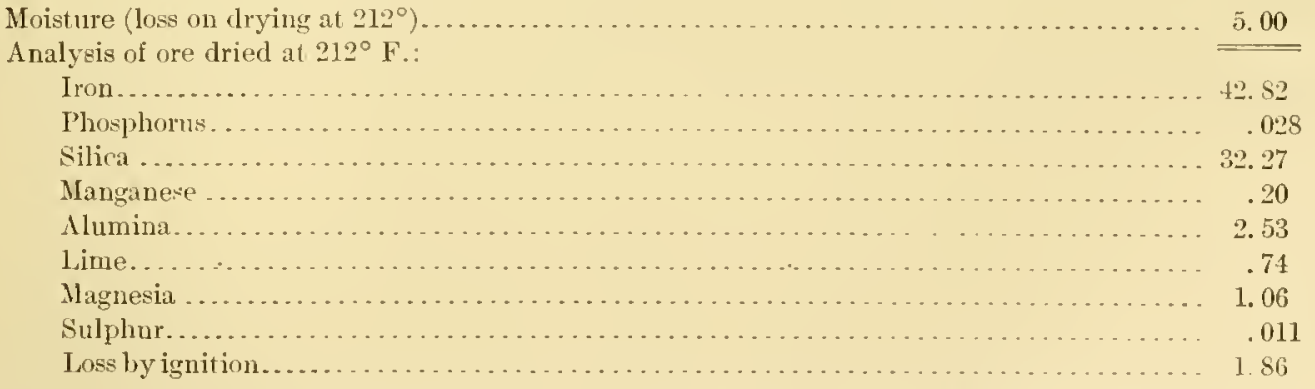

The volume composition of these ores, in comparison with Crystal Falls, Iron River, Florence, and Menominee ores, is given in figure 50 (p. 352). 


\section{SECONDARY CONCENTRATION OF THE FELCII MOUNTAIN AND CALUMET ORES.}

Structural conditions.-The iron-bearing Vulcan formation of the Feleh Mountain district is in closcly compressed synclinal lolds in the upper lluronian Felch schist. It stands out as erosion remnants forming the erests of the hills. The concentration has evidently been controlled by the impervious basements of slate, and also to some extent by the openings along fracture planes, especially north-south fracture planes erossing the axis of the trough. The granite dikes at the Groveland mine may also have been influential in controlling circulation.

In the Calumet district there is no essential difference in the struetural relations governing the llow from those in the Crystal l'alls and Iron River districts. The dip is steep and the formation has the usual drag type of corrugation.

Chemical and mineralogical changes.- The iron-bearing member was originally iron carbonate interbedded with more or less slate. The alteration to ore has oecurred in two phasesfirst, the oxiclation of the iron without removal of silica, producing ferruginous cherts; second, partly simult aneous and more local, the leaching of the siliea, leaving the iron oxicle concentrated as ore. The plysical and chemieal features of these alterations have not been worked out quantitatively as they liave for other distriets, but qualitatively they are known to be similar to those of other districts in all respects. 


\section{CHAPTER XIII. THE MENOMINEE IRON DISTRICT OF MICHIGAN. ${ }^{\circ}$}

\section{LOCATION AND EXTENT.}

The portion of the Menominee district rovered by the accompanying map (Pl. XXVT, in pocket) is bounded on the west by Menominee River, on the south by the same river and the south line of T. $39 \mathrm{~N}$., on the north by the north line of T. $40 \mathrm{~N}$., and on the east by the east line of secs. $10,15,22,27$, and $34, T$, 39 N., R. 28 W. The area tlus outlined constitutes a tongue of sedimentary deposits lying between a granite area to the north and a greenstone sehist area to the soutl.

At about the line between Rs. 27 and $2 S \mathrm{~W}$. the characteristic rocks of the Nenominee trough become so deeply buried under later sediments that they can be traced no farther by outcrop. Lines of magnetic attraction, however, have been ol,tained still farther east, and these are taken to mean that the Huronian deposits continue for a considerable distance beyond the places where they are last seen on the sulface.

The area of sedimentary rocks belonging in the Henominee trough is about 125 square miles, entirely within the State of Michigan. This area is narrowest in the vicinity of Vulcan, where it measures about 4 miles in width from the contact with the granite on the north to the contact with the greenstone schist on Menominee River to the south. To the east the area widens graclually, until in the eastern portion of R. $28 \mathrm{IV}$. its wilth measures about 7 miles. To the west it also widens gradually and finally loses its identity as a distinet trough at about the center line of R. 30 W., where it merges, with the Calumet trough, into the wide area of ITuronian sediments on the west.

\section{TOPOGRAPIIY.}

There are three important ridges in the distriet with axes parallel to its length, a northern one and two others, nearly parallel, near the central part of the distriet. The northern ridge is composed of Archean granite and the Sturgeon quartzite. The central ridges are composed of the Randville dolomite and the iron-bearing Vulcan formation, capped in much of the district by Cambrian sandstone. The higher points of these ridges range in altitude from about 1,000 feet to nearly 1,600 feet. The ralleys between the ridges, as well as the valley to the south of the main central ridge sloping to Menominee River, are composed mainly of the Miehigamme ("Ianbury") slate. The southern lowland area of the Michigamme slate continues into the area of the Quinnesec schist. The lower areas have altitudes varying for the most part from S00 to 1,000 feet.

The minor streams follow to a considerable extent the valleys of the Michigamme slate, and the same is true of the chief stream of the distriet, the Nemominee, for a considerable part of the area, but this and a number of the other more inportant streams, such as Sturgeon River and Pinc Creek and some of its branches, flow transverse to the ridges. Several of eren the smaller branches break through either one or both of the iron ranges and the cuartzite and granite range to the north. Sturgeon River crosses all the formations of the district.

\section{SUCCESSION OF FORMATIONS.}

The rocks of the Menominee district belong to the Archean, Algonkian, Cambrian, and Ordovician systems. The oldest rocks bordering the Menomince tongue are greenstone schists and granite. These are regarded as Arehean. Resting meonformably upon the Archean rocks

a For further detailed description of the geology of this district see Mon. U. S. Geol. Survey, rol. 46, 1904, and references there giren. 
are Algonkian sedinents, which bolong to the Huronian series. These are divisible into lower Huronian, midlle Ifuronian, and upjer I Iuronian, and are separated by unconformities. 'The Paloozoie rocks comprise horizontal Cambrian sandstones and Cambro-Ordovician limestones. These necur in patches on the tops of the hills, cappling the clesely folded and truncated Huronian rocks. The lluronian series is clivisible into a number of formations, each representing a time Juring which the contitions of deposition were approximately uniform. The following table gives the list of the formations arranged in desceneling order aceorting to auge. The members of the Tulcan formation are distinguished in the description but not on the map.

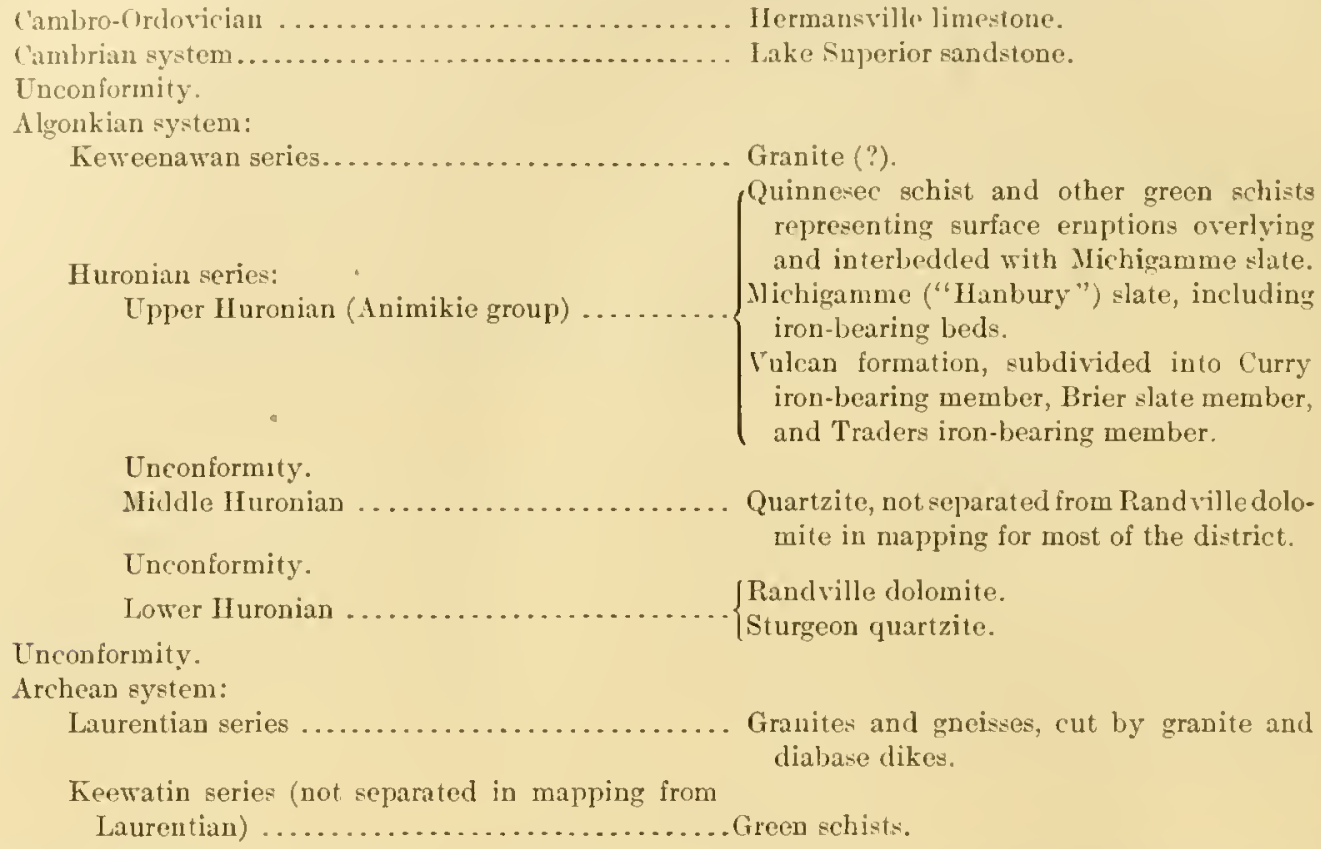
and interbedcled with Michigamme slate.

The Quinnesec schist is so named because the formation is typically deseloped at the Quinnesec Falls, on Menominee River. The Sturgeon quartzite is so called because this formation in the Menomince distriet las been tracerl almost continuously to a like formation in the Crystal Falls distriet which has been ealled the Sturgeon quartzite. The dolomite in the Menominee district is called the Randrille dolomite because it has been practically connected with the Raudrille dolomite of the Crystal Falls district.

In the upper IIuronian the Vulean formation is so nameal because it occurs in typical development witl full succession and fine exposures near the town of Itulean. The "Hanbury" slate was thus named beeause in the ricinity of Lake Hanbury this formation is better exposed than anywhere else in the distriet. 'This shate, however, has been jroved to be equivalent to and continuous, with the Michigamme slate of the Marquette district, and the older name, Michigamme, is therefore used in this report.

\section{ARCIIEAN SISTEM.}

\section{LAURENTIAN SERIES AND UNSEPARATED KEEWATIN.}

The complex north of the Menomince district is composed largely of Laurentian rocks. They are prineipally gneissoid granites and finer-grained banded gneisses. In addition to these there are also present in subordinate quantity homblende schists and certain feldspathic greenstone sehists identical lithologically with some of the minhed emptive rocks among the Quinnesec schist. These are intruded by Laurentian granites and are believed to represent the 
Keewatin series. They have not been separated in mipping. Mica schists are found only in a few exposures in the interior of the Arehean area north of the region shown on the map (Pl. XYYI, in poeket). The grunites, gncisses, and schists are cut by small dikes and veins of granite, pegmatite, anch aplite, by numerous quartz veins, and by coarse granite, massive basalt, cliabise, and gabbro.

Some of the hornblende schists (Keewatin) and some of the gncisses appear to be older than most of the granites. Others of the schists are unquestionably mashed intrusive rocks that are younger than some of the granites. The aplites, pegmatites, and some of the basic intrusives are the youngest rocks belonging exchusively in the complex, but even these, as they are not known to eut through the Huronian deposits, are thought to have taken their present position before the sediments were deposited. The latest of all the intrusive rocks are certain coal'se-grained missive diabases and gabbros. These rocks not only occur as members of the complex but are found also in the lower division of the Huronian series, overlying the Archenn complex. There is no reason to believe that any of these rocks are metamorpliosed sediments. Most of them are clearly of igneous origin.

The massive granites and the gneissoid granites differ from each other in no essential respect. The latter are merely schistose phases of the former. They both embrace mediumgrained to fine-grained gray and pink rocks with a granitic texture that locally approaches in appearance the texture of some quartzites.

The banded gneisses consist of alternate bands of pink and gray material, each band having the look of granite. These bands, though appearing to be approximately parallel in the ledges, are found on close inspection to run parallel to one another for short distances only and then to anastomose or interlace. The red layers eut across the gray gneiss as if they were veins of granitic material. The only diflerence that can be discerned hetween the banded gneisses and the fine-gramed gray gneisses cut by red granite veins is that the latter are irregularly injected by the granitic material, while in the former the injections are largely parallet.

The hornblende schists (Keewatin) are usunlly lustrous greenish-black schists with the normal eharacteristics of such rocks. They are cut by the granites in some places. In other places large blocks are found inchded in granite. Plainly they are ohler than the granites, and probably they are the oldest rocks in the northern complex. A second kind of hornblende schist exists in which the rocks are so related to the granites and gneisses that they must be regarled as dikes. In some places they appear as bands cutting across the banding of the gneisses, and in others as bands conforming in strike and dip with the lighter-colored bands of these rocks. These schists are therefore looked upon as mashed intrusive rocks.

ALGONKIAN SYSTEM.

GENERAL CHARACTER AND LIMITS.

The Algonkian rocks constituting the Menominee trough, though strongly metamorphosed, are recognized as manly sediments. The greater mass of these sediments is mechanieal, chastic textures being still plainly apparent. The iron-bearing formation is largely mechanical, but with the mechanical material an important amount of chenical and organie material was deposited, and some of the jaspers of the formation may be wholly chemical or organic. The limestones are chemical or organic sediments. The selimentary rocks have been intruded by a few coarse-grained and some fine-grained igneous rocks. The latter are now usually schistose. The lowest formation of the Algonkian system has at its bottom basal conglomerates, which rest nnconformably upon the Archean rocks of the northern complex. These eonglomerates may be seen at a number of places along the border of the trough, and notably at the falls of Sturgeon River. 
The formations of the Mgonkian system are likewise separated from the overying Cambrian saudstone ly a profound unconformity. The Algonkian rocks are folded; the Cambrian sandstone is horizontal and thus lies across the truncated ends of the eroded folds. Its lower layer is lormed largely of the debris of the more aneient rocks. Inener the Algonkian rocks formed a land surface for a vast period of time before the deposition of the Cambrian sanilstone.

\section{HURONIAN SERIES.}

LOWER HURONIAN.

SUCCESSION AND DISTRIBUTION.

The lower Huronian is divicled into two formations-the Sturgeon guartzite and the Randville dolomite, the former being the older. These formations are observed only in the center and on the north side of the Ilenominee trough. On the south side of the trough no evidence of their existence is oltainable. This may possibly be due to the thick corering of drift that blankets the rocks north of the southern area of Quimesec schist; but it is thought to be more probable that these formations are not present at the rock surface in this portion of the district.

\section{STURGEON QUARTZITE.}

Distribution.-The Sturgeon quartzite forms a continuous borler of bare hills on the south side of the northern complex. The formation lies between the Archean complex and the northern belt of dolomite. Prominent bluffs of the typical quartzite may be conveniently studied northeast of the Loret to mine.

Lithology.-At many places at the base of the Sturgeon quartzite there is a conglomerate made up of bowlders and fragments of granites, gneisses, and hornblende schists identical with the corresponding rocks in the adjacent Archean complex to the north. The matrix in which these are embedded is in some places a quartzite, in others an arkose composed of the fine-grained débris of granitic rocks. In many places this matrix is schistose and a large quantity of a micaceous mineral has been produced by alteration of the feldspar of the original sediment, so that the matrix is now lithologically a sericite schist.

The major portion of the formation consists of massive beds of a very compact, vitreous quartzite, usually white, but here and there tinted with some shade of pink or green. In its upper portion the cement between the quartz grains is locally calcareous. This calcareous constituent increases in quantity as the overlying dolomite is approached, until the rock becomes a calcareous quart zite and finally a quartzose dolomite. The change from the quart zite to the dolomite is thus a transition. This indicates a gradual deepening of the waters during the later part of the Sturgeon epoch.

Deformation.-The main belt of the Sturgeon quartzite is a nearly vertical sonthwarddipping monocline. The outerop of this monocline varies in strike, thus indicating that cross folding lias taken place to some extent. At the west end of the district the cquartzite turns northward, wrapping around the Archean complex and then passing eastward into the area of the Calumet trough. On the turn to the north several small folds are developed, the synelines of which are now represented by embayments extending eastward into the Archean. The dips of the quart zite beds may vary a few degrees $-25^{\circ}$ in one place-from perpendicularity. There are almost as many northern dips towarl the granite and gneiss complex as there are sonthern dips toward the center of the trough.

lielations to adjacent formations. - The Sturgeon quartzite rests unconformably upon the Archean rocks of the northern complex. This is shown by the character of the lower bed of the quartzite, which, as already sairl, is a basal conglomerate. This basal conglomerate contains almost every variety of fragment derivable from the rocks of the northern complex. Some of this material in its original position must have been formed at great depth in the carth. Therefore there was deep-seated denudation of the Archean before the deposition of the 
quartzite. Upward the Sturgeon quartzite grades into the Randville dolomite. The nature of the gradation is diseussed in the section on that lormation.

Thickness.- Two difficulties stand in the way of determining the thickness of the Sturgenn quartzite. The first is the impossibility of deciding how much of the apparent thickness of the many rock layers in a closely folded district, like the Menominee, is due to the duplication of beds in consequence of close folds. The other difliculty is the inpossibility of fixing the upper limit of the formation. There is everywhere between the quartzites and the nearest leclges of the overlying dolomite a belt of country without exposules of any kind. If we assume that the southward-facing clifls, which in so many places mark the sonthern limit of the quartzites, are cliffs of differential degradation, that the low ground at the base of the clills is underlain by the dolomite formation, and that the exposures are monoclinal, the maximum thickness of the formation is between 1,000 and 1,250 feet.

\section{RANDVILLE DOLOMITE.}

Distribution.-The Randville dolomite occupies three scparate belts, whose positions and shapes are determined by the folding to which the formation has been subjected. These will be referred to as the northern, central, and southern belts of dolomite.

The northern belt is south of the belt of Sturgeon quartzite. Only a few exposures are foumd in this area, but they are so uniformly distributed that on the map (Pl. XXVI, in pocket) the whole belt has been colored for the formation. It is quite possible, however, that in some places erosion has carried away the dolomite and that the upper Huronian rests immodiately upon the quart zite.

The central belt of dolomite borders the north side of Lake Antoine for a portion of its length, passes eastward between the Cuff and Indiana mines, and ends at the bluff known as Iron Hill in the E. $\frac{1}{2}$ sec. 32 , T. 40 N., R. $29 \mathrm{~W}$. This belt is well marked by numerous and large exposures.

The southern belt of dolomite extends all the way from the west side of the sandstone bluff west of Tron Mountain to the village of Waucedah, at the east end of the district. Where not exposed the rock has been found in mines, test shafts, and pits, so that there is a reasonable certainty that it exists thronghout this distance of 16 miles. Where there is any doubt of its existence at the surface this is due to a considerable thickness of overlying Cambrian sandstone. From Iron Mountain as far east as Sturgeon River the country underlain by the dolomite is a range of high hills, broken only at a few points by north-south gaps. On the southern slope of this ridge are the principal producing iron mines of the district.

Lithology.-The Randville dolomite is composed of a heterogeneous set of beds in which dolomite is dommant. With the pure dolomites are siliceous dolomites, calcareous quartzites, argillaceous rocks, and cherty quartz rocks. The Randville dolomite, lying upon the Sturgeon quartzite, grades downward into it. The intermediate rock is a calcareous quartzite.

'The predominant rock of the Randville dolomite is an almost massive, apparently homogeneous, fine-grained white, pink, blue, or buff dolomite, occurring in beds from a few inches to many feet in thickness. This is interstratified with beds of siliceous dolomite in which are observable numerous grains of quartz. In many places on the weathered surfaces of the dolomites are thin projecting hands of vein quartz parallel to the beckling, which the microscope shows to be calcareous quartzite. In other places projecting bands anastomose or run irregularly over the weathered surfaces, here and there intersecting the bedding planes of the rock at acute angles. Their abundance proves clearly that the dolomites, in spite of their homogeneous appearance, have been extensively fractured and crushed. In many places the crushing has produced a hreccia of dolomite fragments in a siliceous matrix. In a few localities the fragments are rounded, so that the rock is a pseudoeonglomerate.

The greater part of the argillaceous rocks interstratified with the dolomite is soft lightgray or dark-gray slate. Another part is typical black slate, still plainly marked by bedding lines. Still other parts are purplish-pink schistose argillaceous dolomite. Many of the thin 
layers of the purplish-pink satelike material between massive cholomite beds appear to low largely the selvagre of the soltar layers of dolomite, renclered schistose by the movement of acemimodation between the stronger beds.

Deformation. - Structurnlly the northern belt of dolonite is a southward-dipping monocline. The central and southern belts are anticlines. The three belts are scparated by two synclines.

In the anticlinal belts the beds at first sight appear to be jocclinal, but a close examination of the southerm bett reveals the existence of a number of minor fokls having almos vertical pitches. In thro western part of the distriet the folds are orerturned to the south, the axial planes clipping northward at high angles. In the central and castern parts of the district, wast of Quimesee, the minor and major folds have their axial planes steculy inclined to the south. Dlthough the minor folds are rather easily recognizable, it is only on the south side of the southern bett that they become promment. Here the syndines open out, forming basins in which the ore borlies lie. The small folds, with a few exceptions, pitch west in the western portion of the range and east in the eastern portion.

The attitude of minor folds is, as is well known, an indieation of the attitude of the major folds on which they are superimposed. By using this principle, it is concluded that the nujor anticlines in this district disappear to the east and to the west by plunging beneath the upper II uronian sediments.

From the above statements it is elear that, in addition to the major east-west anticlines and synchines that are so prominent in the distriet, the dolomite formation is also affected by a gentle but large cross anticlinorium whose axis runs approximately north and south. It is remarkable that erosion has nowhere exposed the Sturgeon quartzite in association with the central belts of dolomite.

Relations to adjacent formations.-The dolomite formation is nowhere seen in actual contact with the Sturgeon quartzite, nor are ledges of the two formations seen in close proximity. It is lnown, lowever, that the upper layers of the quartzite are calcarcous and that the lower beds of the dolomite are quartzose. The inference seems to be safe that the two formations are conformable, and that they grade into each other through caleareous quartzites. The relations of the dolomite to the overlying formations are discussed in comnection with the upper" Huronian.

Thickness.-At no place within the area mapped is the dolomite known to be exposel from the bottom to the top of the formation. On the north side of the trough the formation is bordered by the Sturgeon quartzite on the north and the Vulean formation on the south, but exposures between these limits are so few that it is not certain that the dolomite occupies the entire breadth, and on this account and because of the minor folds it is impossible to give anything like an exact estimate of the thickness of the formation. By making calculations so as to obtain a minimum figure, 1,000 feet or less could be obtained. If, on the other hand, ealculations were made on the supposition that all of the isoclinal beds are different layers, the estimate might be as great as 5,000 feet. Probably the truth is much nearer the lower figure than the higher. The original thickness of the dolomite is probably smewhere between 1,000 and 1,500 feet.

\section{MIIM) E IILRONIAN.}

The ivlentifed middle IItronian of the Menominee distriet consists entirely of cherty quartzite resting in a thin film, from a few feet to 70 feet thick, on the Randville chlomite near its contact with the upper Il uronian (Aninikie yroup), and it is included with the Randville dolomite on the gemeral map of the distriet (Pl. XXTI, in poeket). These rocks were formerly rearderl as a part of the dolomite formation, but recent work has shown them to be separable from the clolomite. 'The quarteite has ben separated from the delomite in the

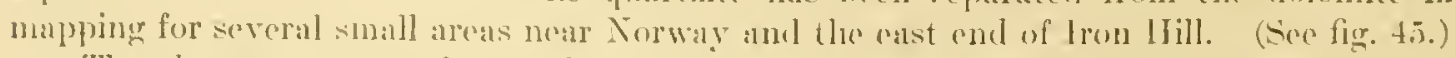

The cherty quart\% rocks are fine crained, drusy in places, and white, light red, or dark purple. The darker colored linds look very much like some varieties of jaspilite. Under the 
microscope the cherty quartz rocks secm to be composed almost exclusively of a fine-grained erystalline aggregate of quartz which incloses a few grains of hematite, magnetite, and other iron compounds. Here and there a fragmental quartz grain may be seen, but usually no trace of fragmental constituents can be discerned.

Pebbles in the conglomerate at the base of the upper IItronian are partly jasper and iron ore, obviously derived from some preexisting formation not now appering. A reasonable inference is that these pebbles represent fragments of the Negaunee formation, which would normally lie above the middle Huronian quartzite. In the previous report on this district ${ }^{a}$ several masses of iron-bearing rocks were doubtfully referred to the Negaunee. Subsequent work has demonstrated these to be upper IIuronian.

The middle Huronian quartzite rests unconformably on the Randville dolonite, with discordance in bedding. The quartzite may be observed to fill fissures and depressions in the dolomite. At Norway IFill crosion cut off 100 fect or more of the dolomite before the quartzite was deposited. On the south sile of Iron Hill there is a thin film of conglomerate, taken to represent the base of the middle Iluronian quartzite, plastered against the dolomite escarpment. The quartzite is not shown directly above the conglomerate but appears a few hundred feet to the east, resting against the dolomite escarpment. (See Pl. XVII, $A$, of Monograph XLVI.) In fact, much. of the middle Huronian quart zite itself on Iron Hill is congloneratic and brecciated, and a considerable part of it may possibly represent a coarsely fragmental basal plase of the middle Huronian. The intricacy of the relations of the midhle Huronian quartzite with the Rand-

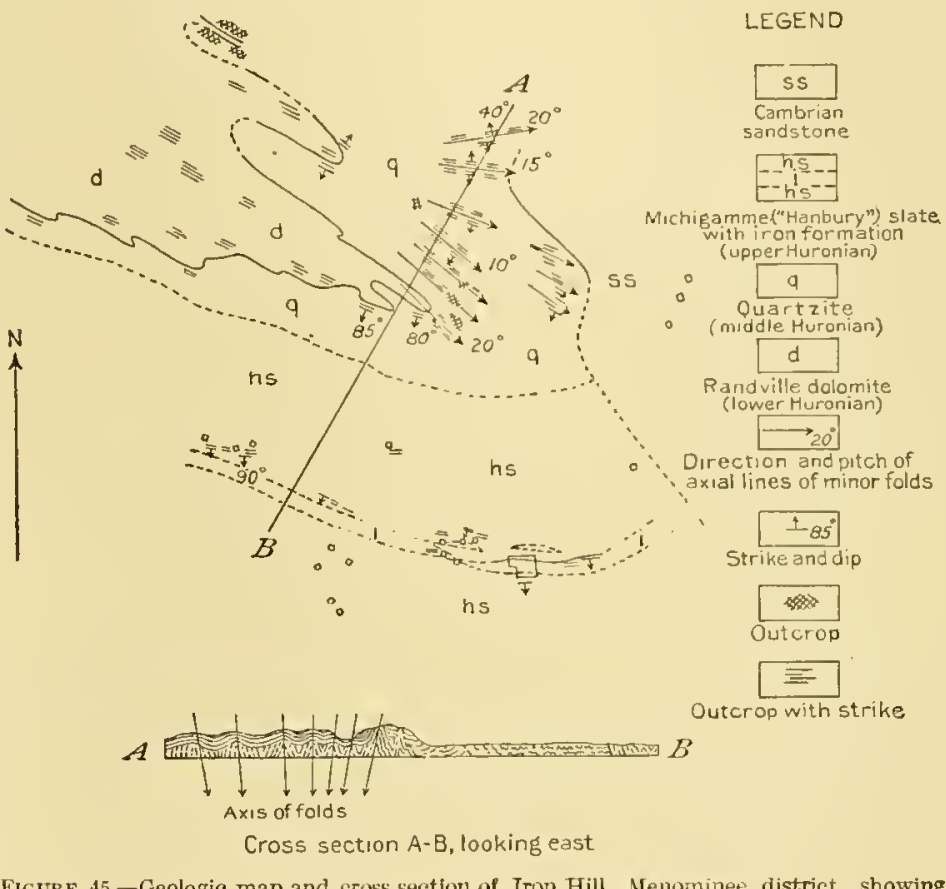

Figure 45.-Geologic map and cross section of Iron Hill, Menominee district, showing relations of lower and middle [luronian. ville dolomite on Iron Hill is represented in figure 45 . The hill is a normal anticlinorium, of the type to be expected in competent formations of this type. It contrasts in every essential feature with the abnormal anticlinorium in the weak, incompetent beds of the Nichigamme slate on IIanbury Hill.

\section{UPPER HURONIAN (ANIMIKIE GROUP).}

All the formations between the Randville dolomite and the meonformity at the base of the Cambrian sandstone arc placed in the upper Ifuronian. For the purpose of the present monograph the group may be chivided into two formations; the lower, the Vulcan formation, includes all the known iron-bearing rocks of the district except the conglomerate beds at the base of the Cambrian; the upper, the Nichigamme ("Hanbury") slate, comprises the great upper slate formation of the upper Huronian.

\section{VULCAN FORMATION.}

Subdivision into members. - The iron-bearing Vulcan formation embraces three members; these are, from the base up, the Traders iron-bearing member, the Brier slate member, and the Curry iron-bearing member. In this monograph the three members are mapped as a single formation because they are not so well exposed that they can everywhere be separatcly out- 
linend. Howerer, at several places the three members are known to exist, and can he separately

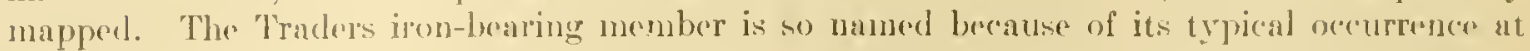
the Traters mine, north of Iron Mountain. The Brier slate is so named loneause it is wedl exhibited at Brier I Hill. The Curry member is so (alled because the Curry mine is located at its horizon.

Distribution. From the position of the Vulan fornation immediately upon the fower and midelle Ihuronian it would be natural to expeet its distribution to be determined by the clistrilution of those rocks, and as a matter of fact, wherever the Tulcan formation oceurs it lies immeriately above the Randville dolomite or middle Huronian quartzite and below thes Hichigamme slate. But at some places within the district the dolomite of cusatrite is in immediate contact with the Alichigamme slate or is separated from exposures of it lye intervals so narrow as to show that the Vulcan beds are lacking.

The principal area of the Vulean formation extends as a belt from 900 to 1,300 feet wide alonge the south side of the southern belt of dolomite for nearly its entire extent. The belt follows the sinuosities of the southern border of the dolomite arcia rather closely, but it is much willer in the reentrants caused by the pitching synclines of the dolomite than dsewhere. The widening of the formation at these places is of course due to the repetition of beds in consequence of chose folding. Along only one stretch, about a mile in length, is the iron-bearing formation known to be absent. This is in the $\mathrm{IT}$. $\frac{1}{2}$ sec. 1 and the E. $\frac{1}{2}$ sec. 2, T. 39 N., R. $30 \mathrm{~W}$., where the Michigamme slate lies upon ledges of the typical dolomite.

On the north side of the southern dolomite belt, in the eentral or western part of the district, the iron-bearing formation has nowhere been found nor has any indication of its presence been detected. In the eastern part of the district the Vulcan formation appears at the Loretto mine in an eastward-pitching syncline. From this place it extends eastward along the north side of the dolomite, as shown by a line of magnetic attractions, to a point within a short distance of the east end of the area mapped, where the thick deposits of Paleozoic beds prevent further tracing.

The second important area of the Vulean formation is that in which the Traders and Forest mines are situated. It stretches for about 5 miles along the south side of the central dolomite belt, rumning north of Lakes Antoine and Fumce and ending, so far as present information indicates, somewhere about the east line of R. $30 \mathrm{~W}$. On the north sile of this same lolomite belt the iron-bearing formation is known to extend for only a short distance on both sides of the Cuff mine, in the southern portion of see. 22, T. 40 N., R. $30 \mathrm{~W}$.

The third strip of country in which the iron-bearing beds are to be expected is that which borker's the northern dolomite belt. This area, howerer, is in the valley of Pine Creck. The surface is thickly covered with sand. There is no indication of the character of the underlying rock anywhere west of the Loretto mine except that afforded by a group of pits near the conter of sec. 14, T. $40 \mathrm{~N}$., R. $30 \mathrm{~W}$, at the western extremity of the belt. These pits lave shown the presence of lran ore associated with cherts, jaspilites, and black slates. The cherts are filled with the "shots and hands" of ore characteristic of the cherts in the Mlichigamme slate and present to some rxtent in the jaspilites of the Curry iron-bearing member. The rocks in this locality are believed to belong to the Curry horizon.

From the foregoing account of the distribution of the Tulcan formation it will be noticed that the belts of iron-bearing rocks are nov eontinuous. From the stratigraphic relations of the inon-bearing formation it would be expected to occur as continuous belts surromeling the dolomite anticlines, hordering the south side of the northern dolomite monocline. In several places, however, these relations do not exist. It is known that in parts of the district the iron-bearing formation is alsont from the position it would naturally be expected to occupy. and that the Nichigamme shte, which stratigraphically overlies the ore-borang strata, is in immediate eontact with the ciolomite that underlies the Vulean formation. It is probable that the larerer parts of the belts mapjed as doubtful the arens in which the underlying rock is unknown are underlain by the Ifichigamme slate rather than the Vulcan formations, but it is possible that the Vulean formation underties a portion of these areas. 
Traders iron-bearing member.--The Traders iron-bearing nember of the Vulcan formation consists of a comformable set of berls composed of ferruginous conglomerates, ferruginous quartzites, heavily ferruginous quartzose slates, and iron-ore deposits. The conglomerates and quartzites are usually at the base of the member, resting upon the Randville dolomite. These rocks vary in thickness from a few inches to 20 feet or more. They contain fragments, usually small but here and there large, of quartzite, jaspilite, white quartz, and rocks that make up the Archean complex. In many places, however, the conglomerate contains so much ore and jasper that it is an ore and jasper conglomerate or quartzite, of which some is so rich that it is mined. In these rocks the matrix is a mass of small grains of hematite, emberled in which are bowlders and pebbles of ore and of jaspilite. The conglomerates and quartzites of this kind are usually schistose. The ore and jaspilite fragments are mashed into lenticular bodies, and the matrix into a mass of thin seales like those characterizing the specular ores of the Marquette cistrict. Typical occurences of the ore-bearing quartzites and conglomerates may be seen at the open pits of the Traders mine and at the bottom and along the west side of pit No. 3 of the Penn Iron Company, in the SW. $\frac{1}{4}$ NE. $\frac{1}{4}$ see. 9, T. 39 N., R. 29 W. In the vicinity of the Forest mine are heary quartzites, some of them white and vitreous, interbedded with what is taken to be the Traders member. This is the largest mass of quartzite developed at this horizon in the district.

The conglomerates and quartzites pass upward into the ferruginous quartzose slates. These consist of alternating layers of heavily ferruginous quartzites, iron oxides, and in some cases jaspilites. The quartzose layers are dark red or purple jasper-like beds, from a fraction of an inch to 18 inches or 2 feet in thickness. Some of them on fresh fractures exhibit the quartzitic texture very plainly. The coarser of them approach ferruginous quartzites. Others, howerer, resemble very closely a typical jaspilite, which a number of them are believed to be. These rarieties are in places mottled by red and purple blotehes that appear to be due to the presence of red jaspilite grains in a ferruginous quartzose matrix. Some of these mottlings are secondary concretions and some are alterations of greenalite granules, more fully described in connection with the Cury iron-bearing member of the Vulcan formation. As a rule the mottling is in small elongated areas and the rock possesses an incipient schistosity in the direction of the longer axes of the areas. This phenomenon is the result of mashing, which flattened the jaspilite grains and the smaller components of the quartzose matrix, producing a parallel arrangement of the particles. It is diffieult to determine with certainty the relative amounts of the detrital material and true jaspilite, which is nonfragmental, but apparently the former is more abundant and it may be dominant.

Brier slate member.-The Brier slate member lies immediately above the Traders ironbearing member. The slates are heary, black, ferruginous, and quartzose, presenting in many places a rery even and fine banding, due either to the presence of layers richer than the average in iron oxides or merely to the presence of small quantities of pigments. On exposed surfaces the banding is emphasized by slight weathering. Where the weathering has progressed very far the slates are stained red. They open along the bedding planes and become very shaly. In this form they yield an abundant talus at the base of all cliff faces in which they are exposed.

Curry iron-bearing member.-The Curry iron-bearing member consists of interbedked jaspilites and ferruginous quartzose slates, with various mixtures of the two, and ore deposits. Many of the jaspilite bands are in the center of the quartzose slate layers, but a few are along one side; all are parallel to the bedding planes. Both the jaspilites and the ferruginous quartzose slates are dark red or purple. The two can usually, however', be distinguished. 'The jaspilites are homogeneous rocks, with a flinty fracture and huster. They consist as a rule of very finely crystalline quartz and hematite, with abundant concretionary and granular structures marked by varying combinations of iron oxide and chert. Some of the concretionary struetures are similar to those figured by Van Hise and Irving for the Gogebic district. ${ }^{a}$ Mnch more numerous granules have the same shape as the concretions but differ from them in lacking 
radial or concentric structures. Such granules are identical in their characteristics with altered grecnalite crranules of the Mesabi district of Mlinmesota described by Leith a and of the Felch Mountain distriet of Michigan deseribed hy Smyth.b

It is concluded that the iron-bearing formation is essentially the result of alteration of grecnalite rocks like those in the Mesabi distriet and of iron carbonates like those in the Gogebic district. None of the original greenalite or: iron carbonate is now present, but pscudomorplis of both of them are abundant.

The ferruginous quartzose slates consist largely of plainly fragmental quartz. The coarser varietics approach quartites. Between the grains of fragmental quartz there is finely crystalline funtz and iron oxide. What part of the matrix is truly detrital and what part, like the jaspilite, is nonfragmental in origin it is difficult to say. Between the bands which are plainly true jaspilites and nondetrital and those which are plainly detritat there are all gradations. It is difficult to ascertain whether the fragmental or the inonfragmental material is the more abundant in the Curry iron-bearing member as a whole, for it is poorly exposed. The ferruginous quartzose slates are believed to have been derived largely from the erosion of the lower Ifuronian. But mingled with this detrital material in many places was apparently a considerable amount of nonfragmental material. There are, therefore, in the Curry ironbearing member all gradations between clastic and nonclastie sediment.

Deformation. - The Vulean formation occupies a position on the upper sides of the dolomite anticlines. Its major folds, or folds of the first order, correspond exactly to the major folds of the Randville dolomite. The folds of the second order correspond also with those of the dolomite. The troughs on the south side of the southern dolomite area are oceupicd by the members of the iron-bearing formation. Mforeover, within the Vulcan formation are numerous still smaller folds of the third order, which, because of the hardness of the rocks and the perfection of the handing, are well exhibited. These small folds may be olserved at nearly every place where mining has progressed to any considerable extent and at many other places where only lean ores have been developed. The folds of the third order pitch in the same direction as those of the second order, upon which they are superimposed, but the strikes of their axes may diverge slightly.

Still smiller folds are superimposed on the folds of the thind order in the same way in which the latter are superimposed on the folds of the second order. On exposed surfaces the folds of the higher orders appear as a series of crinklings or flutings, with heights ranging from one-cquarter inch to 5 or 6 inches from trough to crest. Even in the troughs of these minute folds, under favorable circumstances, iron ore was dejosited, especially where crushing and brecciating took place in connection with the folding.

Wherever folding is observed within the iron-bearing formation it is noticeable that the bedding is best preserved in the siliceous bands. The iron-ore linyers between the siliceous layers, while rielding to the stresses that produced the folding, were mashed and sheared and beeame sehistose. Where the compressing forces were very powerful a slaty cleavige dereloped in both the iron-ore and the siliceous layers.

In the westem part of the south belt of the iron-bearing formation carrying the principal ore bodies the minor folds show considerable regularity of pitch to the west at angles approaching $30^{\circ}$. The ore bodies follow these axial lines. Not uncommonly these minor folds pass into overthust funlts. The distribution of the formation suggests that more orerthrust fiults are really present than have been found. In this area the rocks to the south have moved westward and upward with reference to the rocks to the north, developing drag or buckle folds and thrust faults in the relatively incompetent upper IIuronian beds near the contact with the relatively competent lower IJuronian. The eastern part of the south belt shows sone enstward pitches.

lielations botween the members of the Tulcan formation and the Miehigamme slate. - Where the relations between the Traders iron-beang nember and the Brier slate member are nomal 
the Traders grades into the Brier by diminution of the amount of ferruginous material und by increase in the number and thickness of the quartzose beds. At the same time there is in increase in the proportion of slaty material. Where the ferruginous material is much recluced in quantity the Traders iron-bearing bed becomes the Brier slate memoer. This gradation occupies only a very short vertical range, so that the line between the iron-bearing member and the slate member is usually determinable within a few leet.

Where marked disturbances have oceurred, as in the vicinity of Norway and for several miles to the east, the relations between the two members are very different. Wherever it can be seen the contact between the Traders and Brier members is sharp. In many places the contact seems to be slickensided and locally to be a plane of difierential movement. At the open jits of the Norway mine and those north of the (urry mine and between this mine and the West Vulcan the Traders rocks are in places pseudoconglomeratic. The Brier slate member also may be brecciated. Moreover, the brecciation is not confined to these two members, but the underlying dolomite is at some places likewise brecciated for a short distance beneath its upper surface. The phenomena wherever studied appear to indicate that at the time of folding fault slipping occurred along the contact between the upper Iluronian and the lower Huronian and between the Traders and Brier nembers. The dolonite was brecciated to some extent, the Traders detrital ores were crushed and breceiated, and in several places the lower portions of the Brier slate nember were likewise included witkin the zone of movement and were fuactured and brecciated. Later the breccias were enriched by the dejosition of hematite and other iron compounds, and both the Traders member and the lower part of the brecciated Brier state member became sufficiently ferruginous to warrant mining.

The Brier slate member passes upward into the Curry iron-bearing nember by the diminution of argillacenus material and the introduction of ferruginous material, especially bands of jaspilite, the somewhat ferruginous quartzose Brier slate member thus becoming heavily ferruginous. At one place this transition is seen to occur laterally as well as vertically. No stratigraphic break has been discorered anywhere withim the Tulcan formation.

The relations between the Vulcan formation and the overlying Virchigamme slate are those of conformity. The contact is usually very sharp. No difficulty is experienced in defining the upper limit of the iron-bearing formation. The slates, howerer, are in places so very schistose on the upper side of the contact that their bedding planes can not be recognized, suggesting fault slipping. The bedding of the iron-bearing lormation, on the other hand, is still almost perfectly preserved and is parallel to the contact.

The relations of the Vulcan formation with the lower and middle Huronian are discussed on pages $342-343$.

Thichness. $-\Lambda$ number of sections offer opjortunities for determining the thickness of the separate members of the Vulcan formation, but in only a few can its total thickness be determined. All along the south side of the southern dolomite belt, from the Aragon mine eastward to Sturgeon River, the iron-bearing formation stretches as a narrow belt, which for much of the distance appears to be without important folds. At several places mining operations have afforded excellent sections from the base of the productive portion of the Traders iron-bearing nember to the top of the Curry iron-bearing member, and at a few places the sections extend downward to the top of the Randville dolomite. At Brier IHill, where practically the whole formation can be seen on the surface, its thickness is about 600 feet. At the Curry shaft No. 2 it is 700 feet thick and at the Aragon mine about 675 feet.

At a number of sections the thickness of the individua! members comprising the formation is easily mensured. The Brier slate member has been measured at seven places, yielding results between 100 and 360 feet. Five of these measurements fall between 320 and 360 feet. Eight measurements of the Curry member have given results varying between 100 and 225 feet. Six of these fall between 160 and 225 feet. Measurements of the Traders iron-bearing member have yielded no such concordant results. In the first place, its thickness probably varies widely, as should be expected of a formation composed largely of detrital deposits. 
Moreover, only a few seetions reach as low as the dolomite; hence the exuct position of the contac between this rock and the iron-bearing formation mast be guessed at. Only three measurements have been made from the known top of the dolomite to the known top of the Traders member. These wive 170 feet, 85 feet, and 155 feet.

An interesting feature of these figures appears when the estimated thickness of the Brier and Curry members is compared with the total thickness of the two. In almost every section where the estimated thickness of either of these members falls helow the average of all the measurements for that member the thickness of the other member exeeels the arerage, and the total of the two is fairly constant. Thus, whereas seven estimates of the thickness of the Brier slate member vary between 240 and 360 leet, and eight estimates for the Curry ironbearing member vary between 112 and 225 feet, measurements of the total thickness of the two vary only between 400 and 530 feet. The apparent greater variation in thickness of the two nembers separately than in that of the two combined may be partly explained as due to the gralation between the two and the consequent difficulty of fixing the exact place at which one ends and the other begins.

From a careful consideration of the figures given above and a few others that are not here recorded, it is estimated that the average thiekness of the Vulean formation is approximately 650 feet, divided as follows: Truders iron-bearing member, 150 feet; Brier slate member, 330 feet; Curry iron-bearing member, 170 leet-that is, the two ore-bearing members combined abont equal in thickness the intervening slates. It is conceded, however, that the Traders member departs considerably from this arerage and that the total thickness of the ormation raries accorlingly.

MICHIGAMME ("HANBURY") SLATE.

Distribution.-The Michigamme slate oceurs mainly in three large belts constituting valleys which correspond with synelines between the older rocks. It oecupies nearly all the low ground in the Afenomine trongh, forming a plain broken only by heaps of glacial material deposited upon it, by the protrusions of a few hillocks composed of the harder slates, or by equally resistant greenstones. The slate areas are narrowest at the east and gradually widen toward the west. The northem belt is dirided into two portions by the western area of Quinnesce sehist. The northern part turns northwest and leares the Menominee district at the northern limit of the mapped area; the sonthern portion coalesees with the midlle belt and crosses Menominee River into Wiseonsin. East of Iron Hill the two northern belts again coalesce and extend as a single belt to Sturgeon River. Near the longitude of Waucedah all the slates disappear to the east beneath the Paleozoic beds.

Name.-In previous reports on this district this slate has been called the Hanbury slate, but the formation has been proved to be equivalent to and continuons with thie Nichigamme state of the Marquette district, and the older name, Michigamme, is therefore uscêt in this report.

Lithology.-The formation is dominantly a pelite. It comprises black and gray clay slates, gray caleareous slates, graphite slates, craywackes, thin beds of quartzite, local beds of ferruginous dolomite and sillerite, and rarer bodies of ferruginous chert and iron oxide. The formation is cut by dikes of schistose greenstones, and in one or two places sheets of the same rock have been intruded between the sedimentary beds. The predominant rocks of the formation are gray clay slates and caleareous slates. The latter are more abundant in the lower portions of the formation and the former in the upper portions. The exint rertieal relations of the two rocks have not been made out, beeause of the scareity of exposures and the very intricate folding to which they have been subjected. The elay sintes are normal argillaceons shates, in which there is always more or less ferruginous matter. Those exposed to the weather are liglit in eolor and have a shaly character. IIuscorite then becomes prominent. Their iron compononts are decomposed to red ocherous compounds. Where most altered the rocks are light-red sericite slates or shales. The weathering of the slates that contain small quantities of calcureous components is somewhat diflerent. They tend to bleach to a very palc-errem or white color and to become porous through the loss of their caleareous cement. The ferru- 
ginous components oxidize, forming red ocher, and this lies in an irregular pattern on the lightcolored background. The result of these changes is a red and white or pale-green mottled lriable slate, kinown locally as "alico slate."

By the addition of carbonates the argillaceous slates pass into the earbonate slates. These in places contain as much as 50 per cent of carbonate as a cement. With an increase in the earbonate the slates lose their slaty character, become more massive, and finally pass into beds of ferrodolomite and siderite measuring from a few inches to 20 feet in thickness. On many of the weatlered surfaces both the dolomite and the calcareous slates are coated with a skin of brown ocherous limonite, which on some of the massive dolomites reaches a thickness of an inch or more. Nuch of the limonite is pseudomorphous after the carbonate siderite.

The ferruginous cherts and iron oxides are not known to be present in the Miehigamme slate in large quantity. Indeed, they are as a rule only locally developed in association with the sideritic dolomites and calcareous slates where these have been severely crushed or folded. The source of the iron oxiles is clearly iron-bearing carbonate in the calcareous slates and the dolomites. The cherts are white or yellow massive rocks with finely granular texture. They occur as thin seams and veins traversing the slates and dolomites, and as thin beds interlaminated with the thicker beds of the last-named rocks.

Wherever the cherts occur there is usually fomd also a greater or less quantity of some iron oxile. This occurs as small veins of pure hematite cutting through the cherts, as coatings of hematite on the walls of cracks traversing the slates, as small rugs inclosed in shattered cherts, as druses covering the walls of the cavities in an extremely porous chert, in distinct bands interlaminated with bands of graywacke or quartzite, and in the form of a mixture of oxides and hydroxides inpregnating slaty material. In short, the iron oxides oecur in all forms characteristic of deposits precipitated from percolating waters. The slates impregnated with ferruginous matter are naturally dark red. Those that are but slightly ferruginous still plainly exhibit their true character. In those containing a large proportion of the iron oxides, however, but few traces of the original slate remain and the rock resembles a slaty ocher.

The graphite slates are black, very fissile, thinly laninated rocks. They appear to be limited to the lower portions of the Miehigamme slate. At any rate, they have been seen only in association with the underlying Curry iron-bearing member and at horizons a few hundred feet above the base of the slate formation, but they do not everywhere occur at the base of the formation. Their association with iron-bearing beds at many places in this and other districts probably has some significance as to the origin of the ore. (See p. 502.) The graphite slates appear to grade laterally into the normal gray slates, of which they seem to be loeal modifications. The graywackes and quartzites of the Michigamme slate are normal rocks of their kind, requiring no special description. They both oceur in comparatively thin beds, more commonly in the lower part of the formation than in the upper part. The quartzites are more abundant than the graywackes, but neither are common.

Deformation.-The major folding of the Michigamme slate seems to correspond whth that of the underlying formations, and the slate therefore lies in three major synclines. This structure is inferred from areal relations to older rocks rather than from structures seen in the slates themselves, which are poorly exposed, lack easily identifiable horizons, and have their bedding much obscured by cleavage.

Many of the folds are of the abnormal type characteristic of incompetent strata. The limbs are thinned and the erests thickened, as would be expected in folds of this type, contrasting in every essential detail with folds in the competent quartzites and dolomites, as, for instance, in Iron Hill. (See fig. 45, p. 335.)

The strong north-south compression of the slate beds, producing the elose east-west folds, also produced in all the weaker members of the formation a perfect slaty clearage with a nearly east-west strike and a dip that varies but a few degrees on either side of the vertical. There is also a set of fracture planes or joints at right angles to the clearage. These joints intersect the rocks at approximately equal intervals of several inches. In some places they 
are borkered by narrow shear zones in which the total displacement of the slate beds is an inch or more. On some tlat horizontal surfaees two sets of these joints are seen cutting each other at acute angles, and about each slight faulting has oceurred. Fxtensive thrust faults are suggested by the close folding of cleavage, lut these have not been identified.

Thiskness. - No even approximately correct estimate of the thickness of the llichigamme slate can at present be made. The similarity of the beds and their reduplieation in consequence of the close folding bender it impossible to determine what proportion of the apparent thickness of the lormation is due to folding and what propertion is due to successive deposits. There is mo cloubt that the Michigamne slate is little thicker than any of the other formations in the district.

\section{RELATIONS OF UPPER HURONIAN TO UNDERLTING ROCES.}

lielations betwen Tulean formation and the Tower Ihuromian.-The iron-bearing Tulcan formation, cxeept in very small areas, rests upon the Randville dolonite or midlle Huronian quart zite. If the Vulean formation exists in the dorbtful areas adjacent to the Quinnesec schist, it there rests against that schist. Where the Vuican formation rests upon the midlle Huronian quartzite or Randrille dolomite the lower layers of the younger formation appear to lie conformably upon the older one, with an extremely sharp line of definition between them. In places the contact rock is a tale schist derived from the dolomite or cherty quartzite. The basal member of the Vulean formation is either a quartzite which in places cont ains ore and jaspilite fragments, or an ore and jasper conglomerate containing large and small pebbles of ore, or a breceia containing fragments of all the adjacent rocks. The relative abundaner of autoelastic rocks and true water-deposited conglomerates is uncertain. The Traders iron-bearing member appears to be nearly conformable in attitude with the underlying clolomite, but detailed work discloses distinct though slight discordance.

Contaets between the Randville dolomite or middle Huronian quartzite and the overlying formation are found in many of the mines, but they are nowhere discoverable on the surface. In the little rarine just east of the old Brier Hill mine the dolomite and the lower members of the iron-bearing formation are very close together, but their actual contact is coverecl. The space between the ledges of the two formations is filled with loose fragments, and among these fragments are large pieces of quartzite holding pebbles of jaspilite, quartzite, granite, and other members of the Arehean.

In many of the mimes and the open pits a similar conglomerate or a coarse quartzite is found lying upon the dolomite or quart zite.

The dolomite near the contact is usually schistose, so much so that in most places it is a pure talc schist. The caleium of the dolomite has been removed and mueh of it has been deposited in the ore bodies as calcite, while the magnesium has remained in the talc. A surprisingly similar sehist has been formed from the middle IJuronian quartzite, though on the whole it is more siliceous and less talcose. This talc schist serves as an impervious lining to many of the folds in which the ore deposits lie, and afforded better conditions for the concentration of the ore material than were afforded by the massive and shattered dolomite underlying the ore formation at many places. The selist was probably formed in connection with movenent along the contact plane after the upper Huronian deposits were laid down, contenporaneously with the folding and metamorphism that allected both the lower Huronian and upper Hhronian. The contact between the schist and the superjacent quartzite is cxtremely sharp, and in many places the plane of contact is sickensided.

In those places where the basal member of the iron-bearing formation is not a course quartzite, it is usually a bedded red slate, or more nearly a sehist emposed of small grains of quartz, considerable dolomite, and locally tale. Alternate bands are composed of layers in which dolomite and tale are predominant and those in which siliceous material predominates. The contacts between the schist and the roeks on both sides of it are usually covered. There is in some localities an apparent gradation between these underlying rocks aud the roclss lying above them, but in others the line of division between them is well defined. 
In earlier reports certain dense jaspilites were discriminated from the fragmental and micaceous jaspilites of the Vulean formation above them and were regarded as belonging to the middle Huronian, unconformably below the Vulcan formation. The prineipal evithene of the existence of such a formation is the presence of fragments of jaspilite in the conglomerate at the base of the Vulean formation.

In general, then, there is a slight struetural discordance between the beds of the Vulcan formation and the middle and lower Ifuronian, and sehistosity and autoclastic rocks seem to indicate that this has been a plane of considerable faulting. Also the fracrmental phases of the Vulcan formation point to a preceding erosion interval, though evidence of great differential erosion is lacking, and so far as these fragmental plases are autoelastic this eridence is weakened. The general significance of the unconformity will be discussed in the clapter on general eorrelation (pp. 597 et seq.).

Relations beturen Nichigamme ("Ianbury") slate and the middle or lower IIuronian.-The Miehigamme slate rests upon the Vulean formation conformably. Where the Vulcan formation is absent the slate rests directly upon the Randville dolomite or the middle IIuronian quartzite. This relation is seen for a short distance in the central part of the southern belt of the slate, and it is the relation which prevails generally in the two northem belts, for in this part of the district the Vulcan formation occurs only locally. Contacts are not exposerl.

At Iron Hill, in see. 32 , T. 40 N., R. 29 W., there is at the top of the middle Ituronian quartzite a conglomerate the débris of which is derived largely from that formation and whicl may be a basal conglomerate of the Hiehigamme slate. At other localities also there is a breecia which appears to be a brecciated conglomerate.

The absence of the Vulcan formation east of Quinnesec could be explained by the hypothesis that the Michigamme slate had leen thrust over the lower formation of the upper Ifuronian so as to rest upon the Randville dolomite. The absence of the Vulean formation between the Michigamme slate and the middle Huronian quartzite at Iron Hill might be similarly explained, only here it would be neeessary to believe that folding accompanied the faulting, else the manner in which the slate wraps around the east end of the central belt of dolomite would be inexplicable. There are undoubted minor faults in the Menominee district, but most of them are extremely small, that in the Pewalic mine being the only one of suflieient magnitude to be mapped on the mine plats. It is clear that certain erushed zones of the Traders and Brier nembers near Vulean are due to faulting. Further, there have been marked movements of accommodation between the different formations at their contacts, wlich might be called faulting. All these faults are loeal, and in none of them is the displacement of the faulted beds known to be great.

On the other hand the existence of overthrust folds grading into faults, so clearly indicated in the distribution of the sonthern belt of the iron-bearing formation, is the best of evidence of the extensive relative displacement of the upper and lower Huronian beds, at displacement brought about largely by the close deformation of the lower beds of the upper Iluronian as they are crowded against the competent beds of the lower Huronian. It is entirely likely that more fanlts are present than have been found, and there is little dillienlty in believing that overthrust faulting may have been a large factor in this deformation and may have thrust the slate locally over the iron-bearing formation against the dolomite, or, on the farther side of the fold, may have earried the dolomite up and orer the slate.

Although faulting is doubtless a factor in determining the distribution of the Vulcun formation, from present exidence faulting is inadequate to explain the uniform absence of the formation through such long belts of eountry where it might be supposed to exist.

The presence of doubtful conglomerates at the base of the Michigamme slate where it rests upon the middle or lower Ifuronian suggests unconformable overlap of the Michigamme. It is possible also that the iron-bearing formation was orisinally deposited in diseontinuous lenses, with intervening slate, resting directly upon the lower or middle Ifuronian. 
IGNEOUS ROCKS IN THE ALGONKIAN.

QUINNESEC SCHIST.

The Qumusser schist lies along and adjacent to Menomince River, from the sharp northward bend in the river dne west of Iron Mountain to the eastem limit of the area mapped. The river is bordered by schistose greenstones and various rocks that cut then, except at a few places where rock ledges are alsent. The Quinnesec Falls and Sturgeon Falls are on some of the harder ledges of these rocks. Soutl of the river, in Wisconsin, at a distunce ranging from half a mile to ? miles, is the north side of a large area of granite. This granite sends apoplyses into the greenstone schists, and consequenty is of later age. For the most part the sihists are arranged in belts striking a little north of west at Sturgeon Falls, but trending more toward the north as they pass up the river, until at the Lpper Quinuesec Falts they strike about northwest. Their schistosity is, as a rule, nearly rertical.

The Quinnesec schist is composed of schists of two classes, basic and acidic. The basic schists comprise greenstone schists, chlorite schists, and amphibolites. Ellipsoidal and other extrusive structures are common. The acidic schists comprise gneissoid granites, porphyritic gneisses, felsite schists, and sericite schists. Associated with the schists are both basic and acidic massive rocks. The basic rocks include gabbro, diorites, diabases, and basalts. The acidic rocks include granite and granite porphyry. The greenstones and the hasic selists are closcly allied, as are also the granites and granite porphyries and the acidic schists.

i microseopic study ${ }^{a}$ of the basic sehists shows that they comprise schistose gabbros, diorites, diabases, basalts, and basalt tuffs. Where the schistosity is not strongly developed the original structures of the massive eruptive rocks may be recognized, so that there is no doubt that the greenstone schists, elilorite schists, and amphibolites are merely altered phases of the greenstones. The amphibolites are limited in their distribution to the neighborhood of the great granite mass of Wisconsin, and nearly all of them occur directly in contact with this granite. It is clear that the schistosity in these rocks has developed in connection with the folding of the district and that the extreme phase of metamorphism represented by the amphibolites has taken place in connection with the intrusion of the great batholithic granite of Tiseonsin.

The acidic schists are limited principally to the neighborhood of Horserace Rapids and Big Quinnesee. The sericite schists in many places grade into the felsite schists. They occur mainly in bands parallel to the trend of the bands of basic sehists. The coarser-grained gneissoid granites and porphyritic rocks clearly represent metamorphosed phases of the great granite mass to the south in Wisconsin, but some of the felsite sehists and the sericite sehists may represent acidic lavas contemporaneous with the basic igneous rocks.

From the field relations and microscopic study of the Quinnesec schist and associated rocks it must be conchuded that all are of igneous origin. Many of them were lava flows; some were beds of volcanic ashes, or tuffs; others were dikes eutting through the bedded deposits.

$\Lambda$ few small dikes cutting the schists are normal diabases and basalts, iclentical in composition with some of the rocks cutting through the iron-bearing beds.

Within the Vlenominee district itself there are no contacts between the Quinnesec selist and the IIuronian sediments. A sand plane covers the area of contact. Exposures and explorations indicate that upper Huronian slates are the rocks nearest to the Quinnesee schist, and these have not been found nearer than 200 yards.

In eartier reports on the Ilenominee district ${ }^{b}$ the Quinnesec sehist was provisionally correlated with the Kerwatin series of the Archean because of its relatively high degree of metamorphism and similarity to certain schists in the known Archean on the north sicle of the district. The apparent absence of the Tulcan formation at the base of the upper Huronian was explained by ovcrlap, aud later it was suggested that faulting might play a part. During the summer

a Williams, f. II., The greenst one schist areas of the Menominee and Marquette regions of Nichigan: Bult. C. S. Geol. Survey No. th. 1s90. b.Jon. I'. S. Geol. Survey, vol. 4ti, 1904; Menoninee special folio (No. G2), Geot. Itlas L'. S., L'. S. Geol. Survey, 1900. 
of 1910 the Wisconsin Geological and Natural History Survey, under direction of W. O. Hotchkiss, mapped what is probably the continuation of the Quinnesec schist to the northwest along the sonth side of the Florence listrict of Wisconsin, and determined the green schists there clearly to overlie the upper Huronian sediments to the north of them and to be locally interbedded with upper IHuronian sediments. IIowever, it is yet possible that the Quinnesec schist in the Menominee district may be really pre-IIuronian, for continuous exposures lo not connect the two areas, and green schists of this type are known in at least three different horizons in the pre-Cambrian of Michigan.

\section{GREEN SCHISTS AT FOURFOOT FALIS.}

Another area of igneous rocks of Algonkian age oceupies about 5 square miles, extending from about the center of sec. 15, T. 40 N., R. $30 \mathrm{~W}$., to Menominee River. The Fourfoot Falls are on the south side of the area, and the old village of Badwater" at its northern edge. The rocks of this area are mainly schists, but they are eut by altered diabase dikes.

The schists are grayish-green fine-grained greenstones, in which schistosity is nearly everywhere noticeable. In some places the rocks are well-defined schists, with a eleavage almost as perfect as that in slates; in other places they are nearly massive. On many of the exposures a typical ellipsoidal structure is discernible. The ellipsoids vary in diameter from a few inches to 3 or 4 feet. There is no striking contrast between the material of the ellipsoids and that of the matrix between them. In hoth the roek is a dense grayish greenstone without any distinct textural features. The matrix is usually slightly more schistose than the ellipsoids, but otherwise it is like them. At the Fourfoot Falls the exposures consist of alternating beds of massive, schistose, and slaty rocks, striking about $\mathrm{N} .80^{\circ} \mathrm{W}$, almost at right angles to the course of the river, and yet these rocks are mostly schistose on the Wisconsin side of the river and mostly massive on the Michigan side.

The microscopic examination of thin sections shows that some of the rocks in the western area are altered dolerites still preserving their eharacteristic textures. Others are so much changed that their original nature can only be inferred from the character of their alteration products. Some of these appear to have been fine-grained dolerites and others perhajs glassy basalts. A few others were originally basic tuffs. All are now aggregates of actinolite, uralite, zoisite, epidote, quartz, and other well-known decomposition products of hasie igneous roeks.

This arca of schists, at the time the Menominee monograph was written, was supposed to be equivalent in age with the Quinnesec schist of Menominee River, then regarded as Archean. Later work by G. W. Corey and C. F. Bowen ${ }^{a}$ has shown that they are really intrusive and extrusive in the upper Huronian or in part contemporaneous flows. That these igneous rocks antedate the chief folding of the distriet is shown by the fact that they are so extensively transformed to schists.

The only other large masses of igneous rocks which have been found in the Huronian series are in the Michigamme slate and the Sturgeon quartzite. In each of these formations in a number of places are found greenstones, locally in the form of dikes, in other places as sills, and in others as interbedded eruptives. In the Michigamme slate the form of the igneous bodies is known in but few places. In their present condition they are much-altered diabases or basalts composed of uralitized augite or homblende, decomposed plagioclase, and a considerable quantity of quartz that is probably entirely secondary.

\section{PALEOZOIC ROCKS.}

Small areas of Paleozoic sediments in horizontal sheets lie on the eroded edges of the Huronian and Arehean rocks. The Paleozoie rocks are represented by two formations, one of Cambrian age and the other of Cambro-Ordovician age. The lower formation consists mainly of red sandstone, and is known as the Lake Superior sandstone. The upper formation is a porous arenaceous limestone, identified by Rominger as corresponding to the Chazy and "Calciferous" of the Eastern States, and designated the Hermansville limestone. The sandstones 
and limestones were at one time spread continuously over the entire Menominee district. 'To the enst of the district they still cover all the ohler rocks. West of Wincedal, howerer, they have been generally eroderl from the valleys, leaving remnants as isolated patches on the tops of the higher liills.

\section{CAMBRIAN SYSTEM.}

LAKE SUPERIOR SANDSTONE.

Lithology.-The Lake Superior sandstone consists of a lower portion partly cemented by an iron oxide and consequently red in color and an upper portion in which the cement is partly calcarcous and the color white. The total thickness is estimated by Rominger ${ }^{a}$ at 300 feet. Serral pieces of the sandstone have been obtained, whieh according to reliable authority came from the ledge through which one of the Pewabic mine shafts, near Iron Mountain, was driven. These contain numerous fragments of fossils, some of which were determined by Walcott as "the heads of small trilobites, probably Dierlloceplatus misa; also fragments of a large species of Dicelloceplatus." According to Walcott, "These indicate the Upper Cambrian horizon of the Mississippi Valley section."

Relations to adjacent formations.- The relations of the sandstone to the underlying formations are everrwhere practically the same. Whether on the tops of hills or in the depressions between the hills, the horizontal beds of the younger rock rest unconformably upon the upturned and truncated layers of the older series. Moreover, the basal layers of the sandstone contain a great deal of material derived from the immediately subjacent formations. Where the underlying rocks belong to the Vulcan formation the basal member of the sandstone is an ore and jasper conglomerate, composed of huge rounded bowlders of ore and large slarp-edged fragments of ferruginous quartzose slate and jasper in a n1atrix consisting of quartzose sand, numerous small pebbles and fragments of ore-formation materials, quartzite, and a few peblules of white quartz, of granite, or of other Archean rocks. In a few places t'leir proportion of ferruginous material is so great that they have been ntilized as sources of iron ore.

\section{CAIMBRO-ORDOVICIAN.}

HERMANSVILLE IIMESTONE.

The general cliaracter of the IIermansville limestone "is that of a coarse-rained samlstone, with abundant calcareous cement, in alternation with pure dolomite or sometimes oolitic beds." The limestone may be seen near the top of the hill east of Iron Mountain, on the bhuff northeast of Norway, and at several places on the hills north of Waucedah. Its maximum thickness, according to Rominger, ${ }^{b}$ is about 100 feet, but this maximum is rarely reached in the Menominee district. Only a few fossils have been reported from it. Romincer states that it has rielled a few fragments of molluscan shells. To these may now be atherl a broken Orthoceras. a fracment resembling a piece of a Cyrtoceras, a gastropod, and several other fragmentary forms found in the top layer on the blufl northeast of Nomay.

\section{TILE IRON ORLS OF THE MENOMINEE DISTRIC'T.}

By the authors and W. J. MEAD.

\section{DISTRIBUTION, STRUCTURE, ANU RELATIONS.}

The ore deposits of the Menominee district occur in the two iron-benring members of the Vulcan formation known as the 'Traders iron-bearing member and the curry iron-bearing member. These are separated by the Brier slate member. Wuch the larger tonnage of ore mined has come from the Traders nember, yring south of the southern dolomite leelt. The ores may occur at any horizon within these nembers, but other conditions being equal they are more likely to occur at low and high lorizons than at midella horizons. 1 number of the 

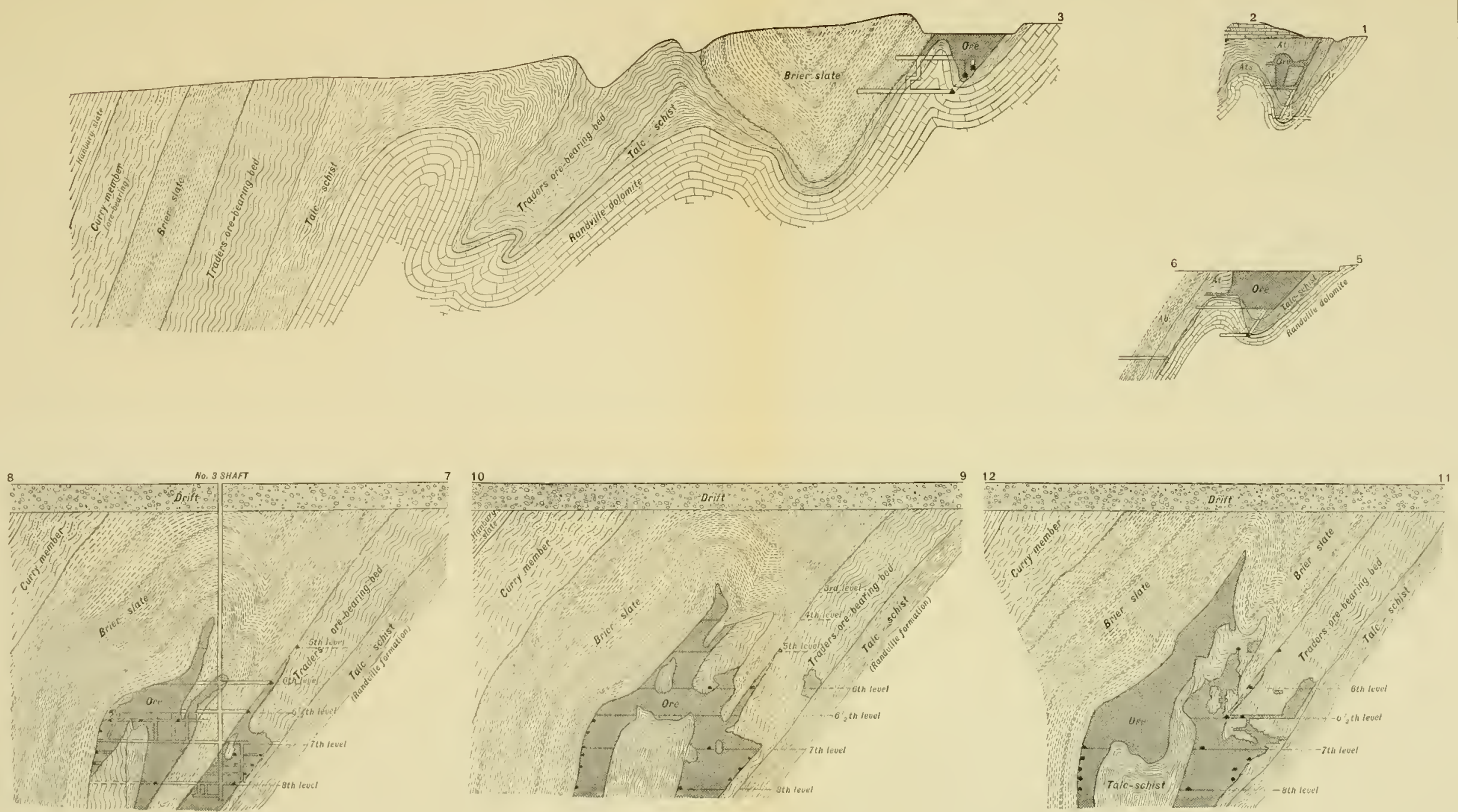

$2000 \quad 200 \quad 400$ feet 

large ore bodies extend entirely across the members in which they occur. The deposits of large size rest upon relatively impervious formations, which are in such positions as to constitute pitching troughs. A pitehing trough may be made $(a)$ by the Randville dolomite or middle Ifuronian, underlying the Traders iron-bearing member of the Vulean formation; (b) by a slate constituting the lower part of the Traters member; or $(c)$ by the Brier slate member, between the Traders and Curry iron-bearing members. (See PI. XXVIJ; figs. 46, 47, 48.) The clolomite or quartzite formation is especially likely to furnish an impervious lasement where its upper portion has been transformed into a tale schist, as a consequence of folding and shearing between the formations.

These pitching troughs are minor folds of the drag type. In the westem and central parts of the south belt of Vulcan formation carrying the principal ore bodies there is consider-

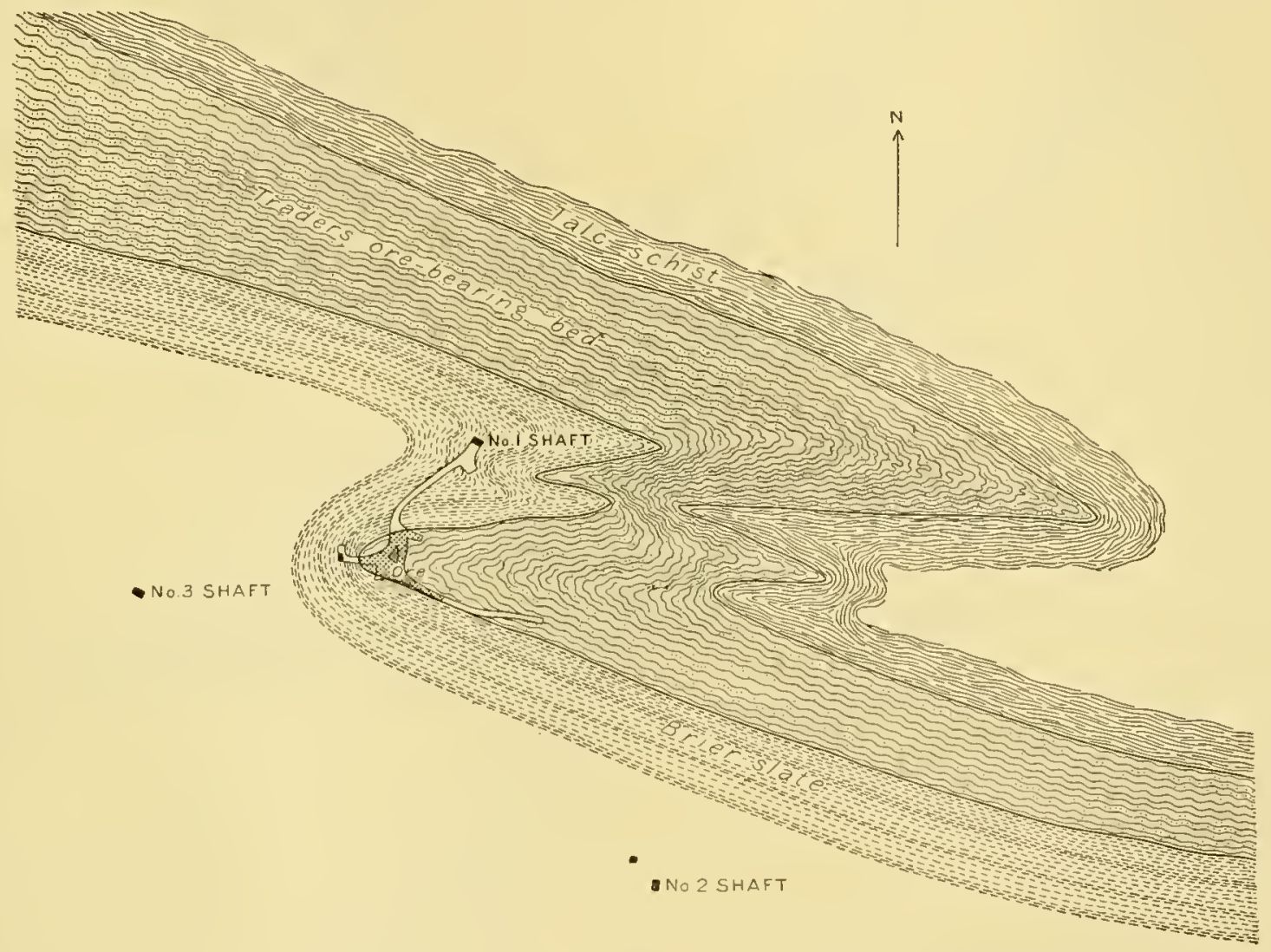

FIgUre 46.-Horizontal section of the Aragon mine at the first level, Menominee district, Michigan. Scale, 1 inch = 250 Ieet. After Bayley.

able uniformity of pitch to the west, resulting from the westwarl and upward shearing of the southerly beds with reference to the northerly heds. At the east end of the district some of the pitches are eastward. Any portion of the iron-bearing member may lave yielded to the shearing by a series of these drag folds. The ore borlies following the axial lines may thus be in a series of parallel shoots, one pitching below the other along the strike. This is well illustrated in the Chapin and Millie mines.

In these folds the strike of the shoots at the surface is at a slight angle from the strike of the bedling, as shown in figure 49 (1).350).

The wall rocks of the ore bodies may be unaltered phases of the iron-bearing member, especially the ferruginous cherts, or any of the rocks forming the impervious basement. The beds in the ore body, when followed along the strike and dip, usually pass into ferruginous cherts or iron carbonates. 
At first sight the forms of the ore deposits might be thought to be exceedingly irregular, but when the above relations are understood they appear to have orderly forms. A main mass of ore is likefy to be at the bottom of a trough, but from this main mass a consiclerable bett of ore may extend along the limbs of the trough to a much lighler altitude than in the center of the trough. Many of the ore bodies in cross sections thus constitute a $U$, which is rery thick at the bottom, the eenter of the $U$ being oecupied by the iron-bearing rocks which have not been transformed to ore. If the fold is very much compressed the limbs of the $U$ may unite at the center and produce a pitching lons, with its lower extrenity romeled to conform with the shape of the trough of the fold and its upper end, where not at the surface, more or less irregular in shape in consequence of the gradual passage of the ore into jaspilite. The deposits at Chapin are good illustrations of such lenses.

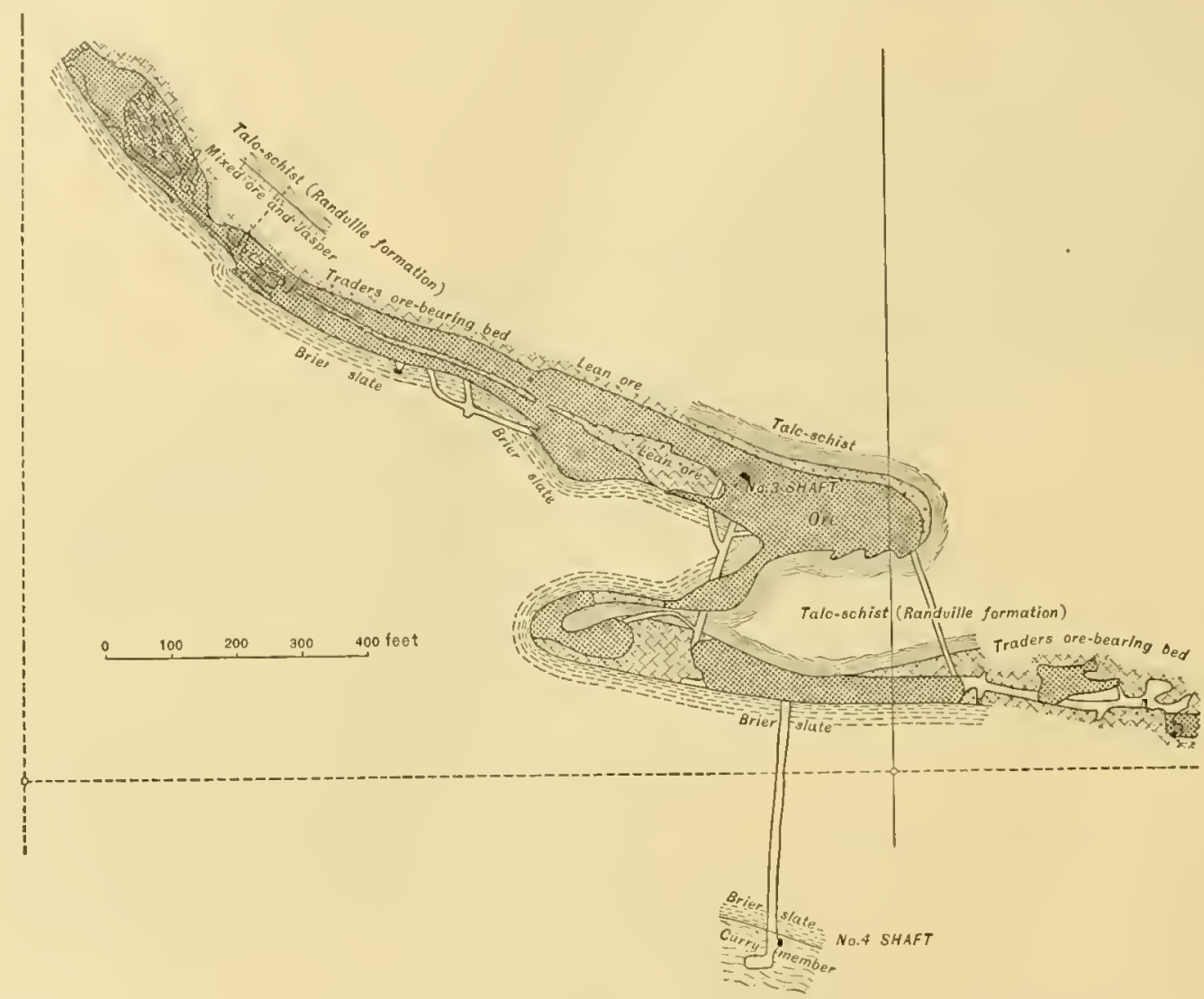

FIg URE 4i.-Morizontal section of the Aragon mine at the eighth Jevel, Menominee district, Michigan. After Bayley.

Though all the largest iron-ore bodies are confined to the pitching troughs with impervious basements of dolomite, quartzite, or tale schist, smaller ore deposits oceur at contacts between the different members and at places within the iron-bearing members where severe brecciation has occurred. The deposits formed at contacts are usually much more irregular than those formed in troughs. In general, they are broarl and thin sheetlike masses with irregular boundaries on all sides. Their lower surfaces are the more even and the better defined, but even these are undulatory. For the most part they remain near the contact of the iron-bearing formation with the underlying rocks, but at many places they leave this contact, rise into the iron-bearing beds, and thus become separated from the base of the formation by considerable thicknesses of jaspilites. The upper surfuces are much more uneven than the lower ones. Not only are they umdulatory to a greatol degree, but ore projections extend upward into the orerlying jaspilites and, ramifying through these in an extremely irregular manner, in places coulesec and inche lenses of jaspilite and then contime their separate courses mil the contact with the overlying 


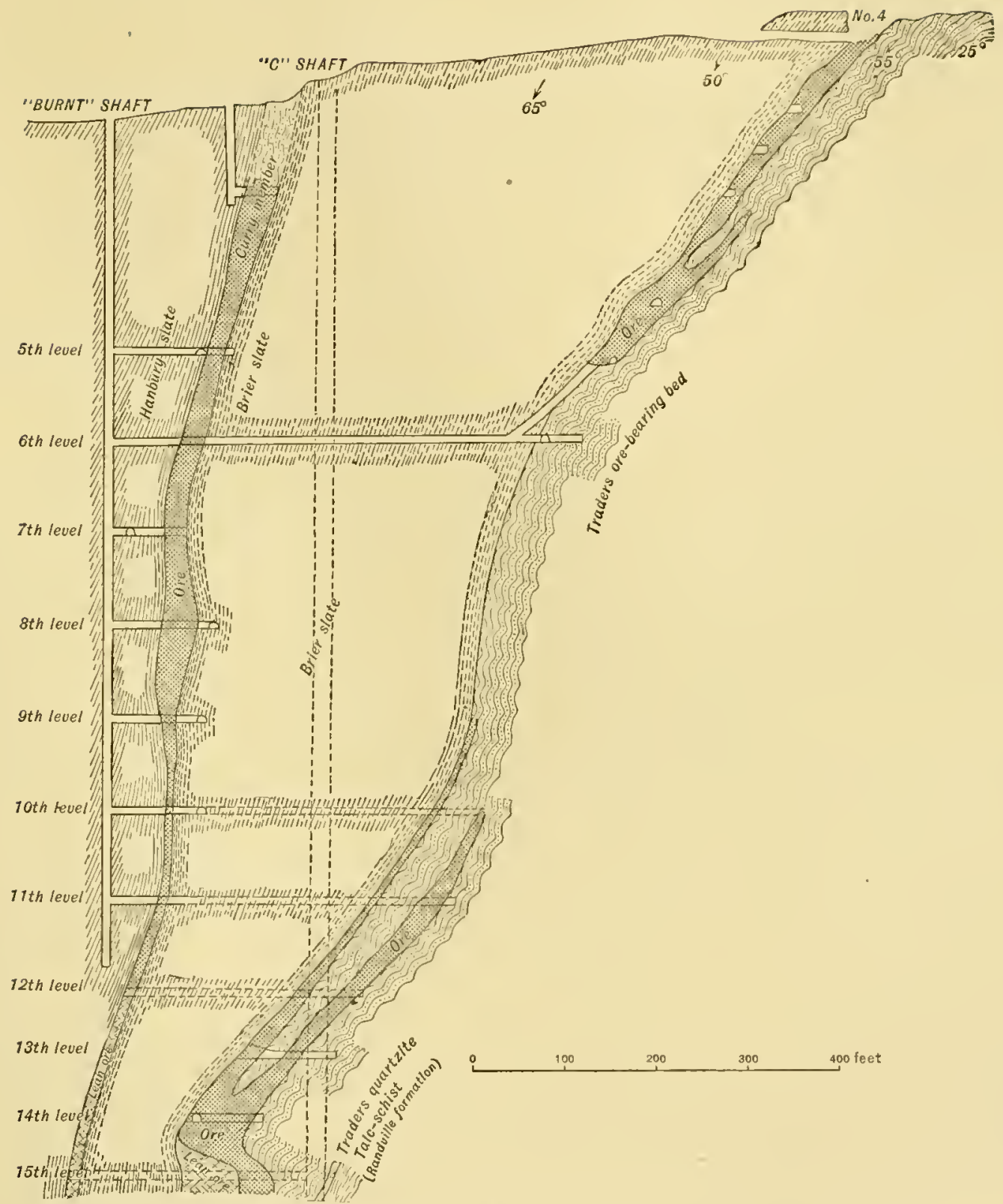

FIGURE 48.-Vertical north-south cross section through Burnt shaft, West Vulcan mine, Menominee district, Michigan. After Bayley. 
slates is reached, where they again coalesce, spreat out, and form a second shcetlike body, which, howerer, is ustally much thinner and much less extensive than the deposit at the lower contact. Deposits of this kind oecur principally in the straight portions of the member, where folling is absent and where the dip is not overturned. A portion of the deposits of the West Vulcan and Verona mines are of this class.

The Menomince ores rest for the most part on the midlle slopes of the ridges formed by the Randville dolonite and middle Huronian quartzite, but they also go beneat the lower ground.

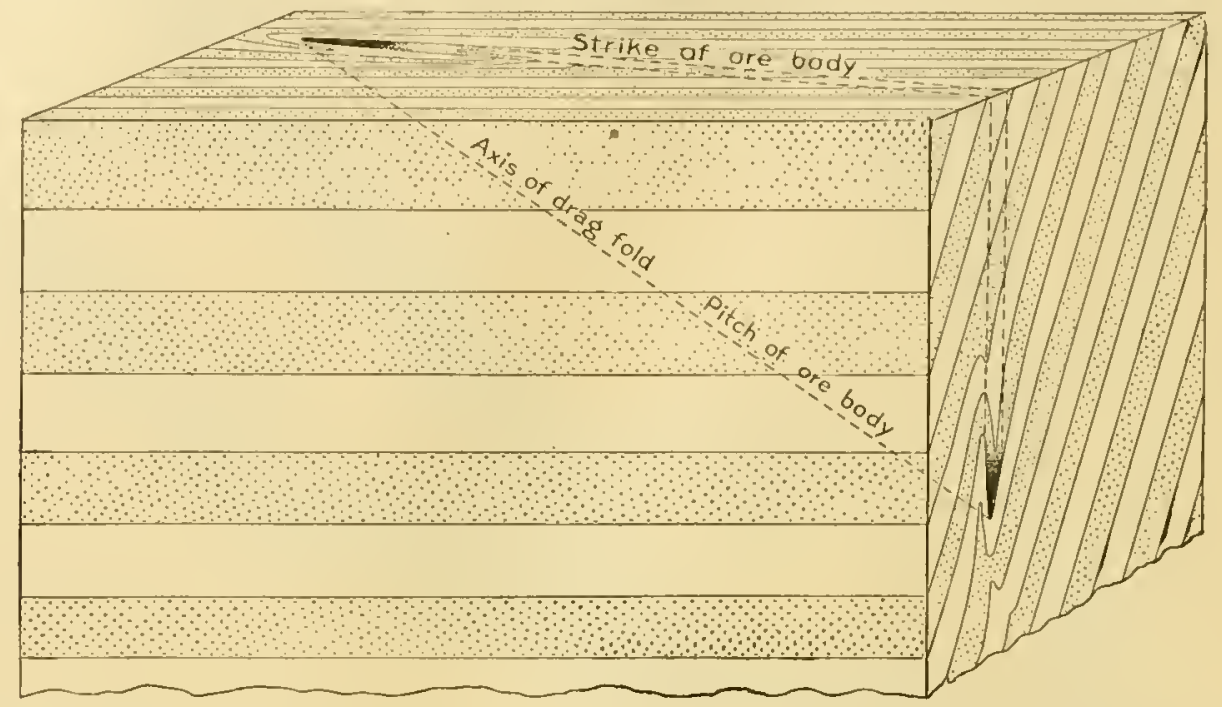

FIGURE 49. - Sketch to show pitch ol a drag fold in a monoclinal succession. Theores in some places lollow the axis ol the lold. It will he noted that the strike of the ore body, measured at th surface, is at a slight angle to the strike of the bedding, notwithstanding the lact that the ore body Iollows throughout a single bed or set of beds.

\section{CHEMICAL COMPOSITION OF THE ORES.}

The averages of the cargo analyses of ore shipped from the district in 1907 and 1909, with the range for cach constituent, are as follows:

Average chemical composition of ores from cargo analyses for 1907 and 1909, w'ith range for each constituent.

\begin{tabular}{|c|c|c|c|c|}
\hline & \multicolumn{2}{|c|}{ Arerage. } & \multicolumn{2}{|c|}{ Range. } \\
\hline & 1907. & 1909. & $190 \pi$ & 1909. \\
\hline Moisture (loss on drying at $212^{\circ} \mathrm{F}$.).... & 5.92 & 6.67 & 2.16 to 7.92 & 1.07 to 5.77 \\
\hline 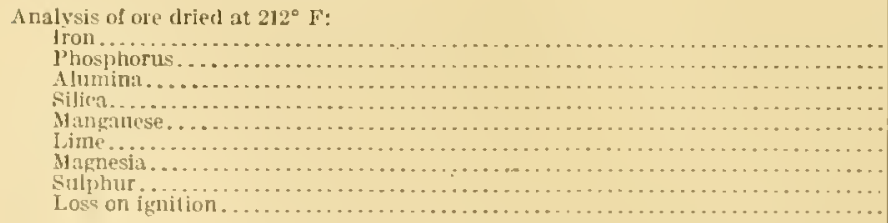 & $\begin{array}{r}50.70 \\
.035 \\
1.54 \\
21.1 .5 \\
.17 \\
.28 \\
2.12 \\
.013 \\
1.92\end{array}$ & $\begin{array}{c}52.23 \\
.074 \\
1.41 \\
16.77 \\
.19 \\
1.31 \\
2.70 \\
.012 \\
3.52\end{array}$ & $\begin{array}{r}39.00 \text { to } 59.90 \\
.010 \text { to } .084 \\
.80 \text { to } 2.73 \\
5.70 \text { to } 41.53 \\
.03 \text { to } .47 \\
.35 \text { to } 1.70 \\
.14 \text { to } 3.71 \\
.005 \text { to } .029 \\
.60 \text { to } 3 . .50\end{array}$ & $\begin{array}{r}38.40 \text { to } 61.26 \\
.005 \text { to } .620 \\
.80 \text { to } 2.25 \\
4.25 \text { to } 39.34 \\
.17 \text { to } 1.27 \\
.63 \text { to } 2.90 \\
.70 \text { to } 3.95 \\
.006 \text { to } .041 \\
.90 \text { to } 4.30\end{array}$ \\
\hline
\end{tabular}

Comparison of analyses of all the ores of the district shows the rich ores to consist principally of slightly hydrated hematite, with additional rarying amounts of magnetite, silica, alumina, lime, magnesia, carbon dioxide, phosphorus pentoxide, and water. Most of the ores eontain also manganese, potash, and soda, and a few of them titanium and carbon. 
Following are three complete analyses of high-grade Menominee ore:

Complete analyses of Menominee ores."

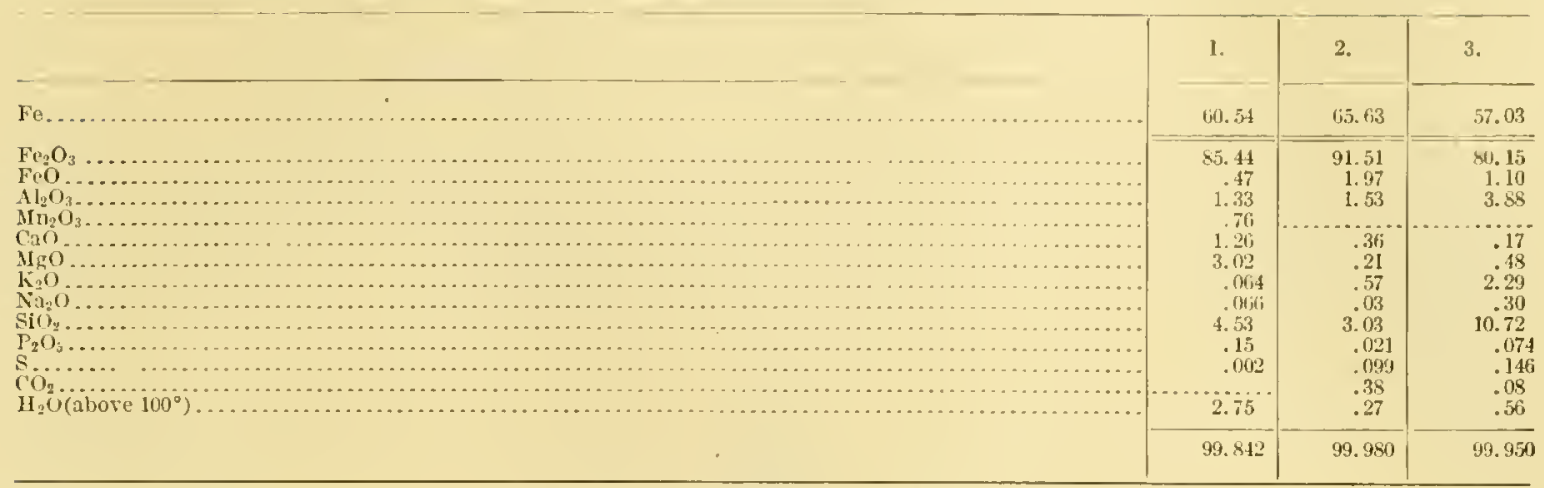

a Mon. U. S. Geol. Survey, vol. 46, 1904, p. 383.

1. Chapin ore: analysis furnisbed by E. E. Brewster.

2. "Soft specular" Quinnesee ore.

AVERAGE IRON CONTENT OF THE IRON-BEARING FORMATION.

An average of 1,681 analyses, representing 5,287 feet of drilling from the district away from the available ores, gives 37.93 per cent of iron. Ores of this class are so much more abundant than the "available" ores that the average of the entire formation, inclucling ores, is not much higher than this figure. The composition of the lean, unaltered jaspers where not altered to ore has not been averaged, but presumably the iron content is about 25 per cent, as in other districts.

\section{MINERAL COMPOSITION OF THE ORES.}

The approximate mineral composition of the average ores of the Menominee district, calculated from the preceding average chemical analysis, follows:

A pproximate mineral composition of average lfenomince ore, calculated from average cnemieal analysis.

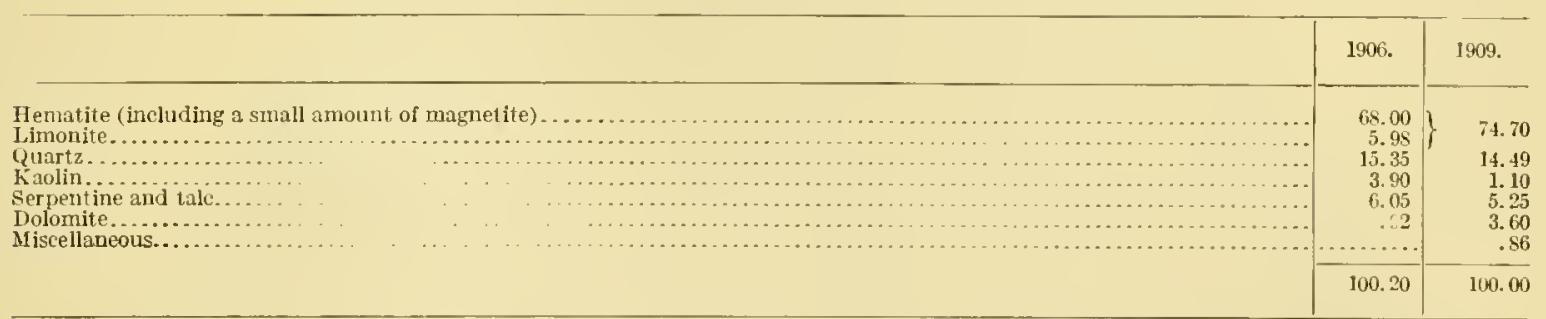

The richer ores are usually bluish black, porous, fine-grained aggregates of crystallized hematite. These rich ores grade into leaner phases containing more or less hydrated hematite, with varying amounts of quartz, scrpentine, tale, clay, and carbonates of calcium and magnesium, ranging in color from the bluish llack of the richel ores through various shades of red and brown to yellow.

All the minerals occurring as constituents of the ores are found also as visille masses eitluer in reins cutting the ore bodies or in rugs or pores within them. Dolomite, calcite, and pyrite occur locally in excellent crystals, and serpentine as large, white, almost pure masses. Talc also occurs in thick seams of almost ideal purity, and chalcopyrite in small crystals associated with pyrite. The carbonates and sulphides are found near watercourses and the silicates mainly in the lower portions of the ore bodies. 
The ores when exposerl to the action of the atmosphere become coated with a white efloreseence, consisting of a mixture of the sulphates of sodium, magnesium, and calcium, in which the sodium sulphate is grently in exeess.

\section{PHYSICAL CHARACTERISTICS OF THE ORES.}

The lean ores differ very little in appenrance from the jaspilites, of which they are essentially a part. They are banded, brecciated, and in plaees specular. The brecciated ores may consist of jasper fragments in a mass of hematite, or of hematite fragments in a mass of dolomite, or fragments of ore, jasper, and slate in a mass consisting largely of slate débris that has been strongly ferruginized.

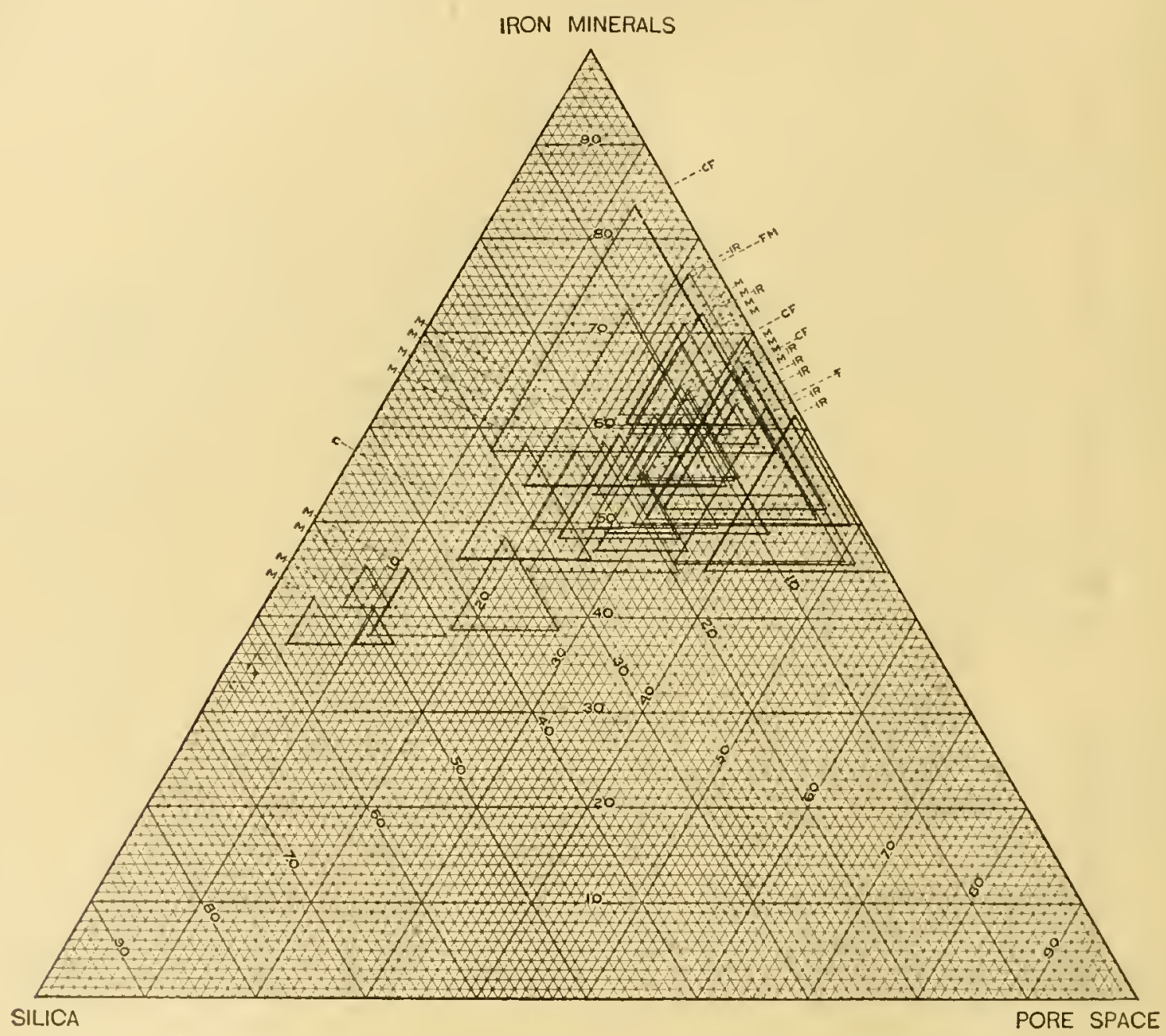

FIGURE 50.-Trlangular dlagram representing the volume composltion of the various grades of ore mined in the IIenominee. Crystal Falls, and neighboring distriets in 190\%. N, Menominec; CF, Crsstal Falls; IR, Iron River; F, Florence; FM, Feleh Mountain; $\epsilon$, Calumet. The pore space for each grade was ealeulated from the average moisture eontent, and hence represents the true pore space only when the noisture ln a particular grade was at a maximum. The true porosity of the varions grades of ore would thercfore he slightly greater than is shown. For descrlption of the method of platting on triangular diagram, see page 189.

The arerage texture of the Nenominee ores is shown by the following table of sereening tests, male by the Oliver Iron Mining Company on six typical grades of ore representing a total of $1,033,491$ tons. Fach test was made on a sample of 100 pounds, representative of the entire year's output of that grate. A comparison of the textures of the ores of the several ranges is shown in figure 72 (p. 481). 
Texturcs of Menomince ores as shown by serecning trsts.

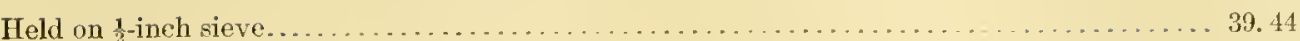

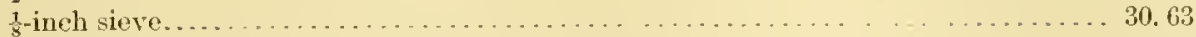

No. 20 sieve. . . . . . . . . . . . . . . . . . . . . . . . 11.50

No. 40 sieve..................................... 4.73

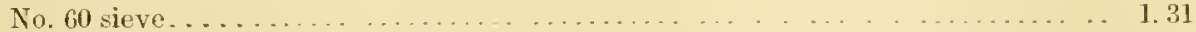

No. so sieve. . . . . . . . . . . . . . . . . . . . . . . . . . . . 1.19

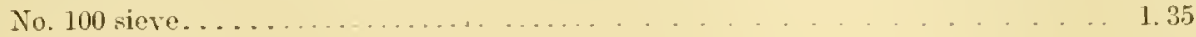

Passerl through No. 100 siere.......

The mineral density of the ores varies with the iron content. The average mineral density of the ores calculated from the average of the cargo analyses for 1907 , by computing the mineral composition and properly comluning the densities of the component minerals, is 4.28.

To test the accuracy of this method of computing mineral density, pycnometer determinations were made on the average pulp samples ${ }^{a}$ of Ajax ant Chapin grade for 1907, with the following results:

Mineral density of Mcnomince orcs.

Determined by means of pycnometer

Calculated from chemical analysis.

Ajaxgrade. Chapin grade.

4. 21.4 .4 .601

The porosity of the ores ranges from 1 per cent or less in some of the lean jaspilite ores to as much as 45 per cent in some of the richer hematites and especially in the limonitic ores.

The cubic contents of the ores vary greatly. The bulk of the ores, however, lies between 9 and 14 cubic feet to the ton.

Volume comparisons of the Menominee ores with each other and with ores of the Crystal Falls, Iron River, Florence, Felch Mountain, and Calumet districts are made in figure 50.

\section{IRON ORE AT BASE OF CAMBRIAN SANDSTONE.}

The basal conglomerate of the Cambrian sandstone where it rests upon the iron-bearing formation contains abundant fragments of that formation. In a few places the proportion of ferruginous material is so great that the conglomerates have been utilized as sources of iron ore. $A$ deposit of this kind was formerly worked by the operators of the Qummesee mine, and another has recently been worked by the Pewabic company. The latter was reached by the open pit in the SE. $\frac{1}{4}$ sec. 32, T. 40 N., R. $30 \mathrm{~W}$., known as the Pewabic pit. Although at this place the rock immediately underlying is dolomite, the amount of iron ore in the conglomerate is so great that the company operating the pit felt waranted in erecting concentrating works on the property for the separation of the ore fron the sandstone.

\section{SECONDARY CONCENTRATION OF THE MENOMINEE ORES.}

Structural conditions.- The ore deposits in the Menominee district rest upon steeply dipping impervious basements of sheared dolomite or slate. The hanging wall may be of slate or ironbearing formation. The greater dimensions of the deposits are parallet to the bedding. Folding, of the type illustrated in figure 12 (p. 123), develops minor corrugations in the foot wall and other rocks, with pitehes parallel to the main strike of the formation. In these piteling folds the ore deposits are likely to be larger and better concentrated than elsewhere. It is obvious that the flow of water concentrating the ore has been prineipally parallel to the bed ling, that it has been especially strong where the bedding has been folded into pitching troughs, and that the fracturing of the brittle iron-bearing rocks during this folding has aicled greatly in the circulation of waters in pitching troughs and elsewhere in the formation. The ores are associated with marked topographic relief, affording abundint head for the waters. The larger number

a Kindly furnished by Mr. J. I. Nitcleus, chief chemist for the Oliver Iron Mining Company at Iron Mountain. $17517^{\circ}-\mathrm{YOL}=2 \mathrm{2}-11-29$ 
of them are on the upper or milllle slopes of the rock elevations, though some of them extend boueath the depressions.

Minulogical and chemical changes. - The iron-bearing formation was originally iron carbonate and greenalite interbedded with more or less slate and containing much detrital ferric oxide at the base of the formation. The alteration of the cluerty iron carbonate and greenalite to ore las been accomplisherl in the general manner already deseribed as typlical for the region(1) oxidation and lyclration of the iron ninerals in place, (2) leaching of silica, and (3) introduction of secondary iron wxide and iron carbonate from other parts of the formation. These changes may start simulaneous ly, but 1 is usually far advanced or complete belore 2 and 3 are conspicuous. The eally prochucts of alteration therefore are ferruginous elerts-that is, rocks in which the iron is oxidized and hydrated and the silican not removed. The hater removal of siliea is necessary to produce the ore.

\section{SEQUENCE OF ORE CONCENTRATION IN THE MENOMINEE DISTRICT.}

The first considerable concentration of ore in the district which is now mined did not take place until the erosion periol lollowing upper Ifuronian time. As indieated in the general discussion, the process was well advanced before Cambrian time and has practically continued to the present. 


\title{
CHAPTER XIV. NORTH-CENTRAL WISCONSIN AND OUTLYING PRE- CAMBRIAN AREAS OF CENTRAL WISCONSIN.
}

\author{
NORTIIERN WISCONSIN IN GENERA.
}

The only work done by the United States Geological Survey in northern Wisconsin is in the Florence district; the southern extension of the Henominee district, in the northeastern part of the State; the Penokee range, in the northern part of the State; and the Keweenawan belt crossing the northwest corner of the State. These districts are described on other pages. Other areas in northerm Wisconsin lave been examined in recomaissunce work by members of the Survey, but no detailed mapping has been done. Outside of the areas named, the distribution of the rocks of northern Wisconsin shown on the general map (Pl. I) is taken from the Wisconsin Geologieal Survey reports, particularly that of Weidman ${ }^{a}$ for north-central Wisconsin. The recent map of Douglas County made by Grant ${ }^{b}$ for the Wisconsin Geological Survey is used in place of the earlier map by Irving.

Granites and gneisses, with subordinate amounts of sedimentury rocks and busic igneous rocks, constitute a highland in the northern part of the State, roughly oval in its outline, extending from the vicinity of Grand Rapids and Stevens Point, on the south, to the State boundary, on the north, and from Barron County eastward to the Michigan loundary. The area is bounded on the northwest by the Keweenawin rocks described in Chapter $\mathrm{XV}$, and on the north and northeast by the Huronian formations of Michigan; on the southeast, south, and southwest it is overlapped on the lower ground hy Paleozoic sediments which outcrop in wide belts surrounding the pre-Cambrian core. The predominating granites and gneisses were called Laurentian and the sedimentary rocks Huronian by the geologists of the first Wisconsin Geological Survey (1882). The highlands as a whole have been often referred to as a "Laurentian highland." The drift cover is heavy, exposures are few, except in certain localities, and much of it has been difficult of access even to the present time. The only published detailed work is that of Weidman, ${ }^{a}$ which is summarized below.

\section{WALSAU DISTRICT.}

\section{LOCATION, AREA, AND GENERAL GEOLOGIC SUCCESSION.}

The pre-Cambrian area in nortl-eentral Wisconsin mapped and described by Weidman includes the counties of Marathon, Portage, Wood, Clark, Taylor, Lincoln, and adjacent parts of Rusk, Price, and Langlade, containing in all about 7,200 square miles. From 90 to 95 per cent of the pre-Cambrian rocks of this area are of igneous origin.

The following table is compiled from the succession worked out by Weidman. The rocks he classes doubtfully as lower and middle Huronian we classify doubtfully as middle and upper Huronian, respectively. The names of the formations are those used by Weidman.

Quaternary system:

$$
\text { Pleistocene series } \ldots \ldots \ldots \ldots \ldots \ldots \ldots \ldots \ldots,\left\{\begin{array}{l}
\text { Wisconsin drift. } \\
\text { Third drift. } \\
\text { Second drift. } \\
\text { First drift. } \\
\text { Alluvial deposits (contemporanenus mith drift) }
\end{array}\right.
$$

a Wejdman, Samuel, The geology of north-central Wisconsin; Bull. Wisconsin Geol. and Nat. IIist. Survey No. If, 1907.

b Grant, U.S., Preliminary report on the copper-bearing rocks of Douglas County, Wisconsin; Bull. Wisconsin Geol.and Nat. Hist. Surrey No. 6,2 d ed., 1901 . 


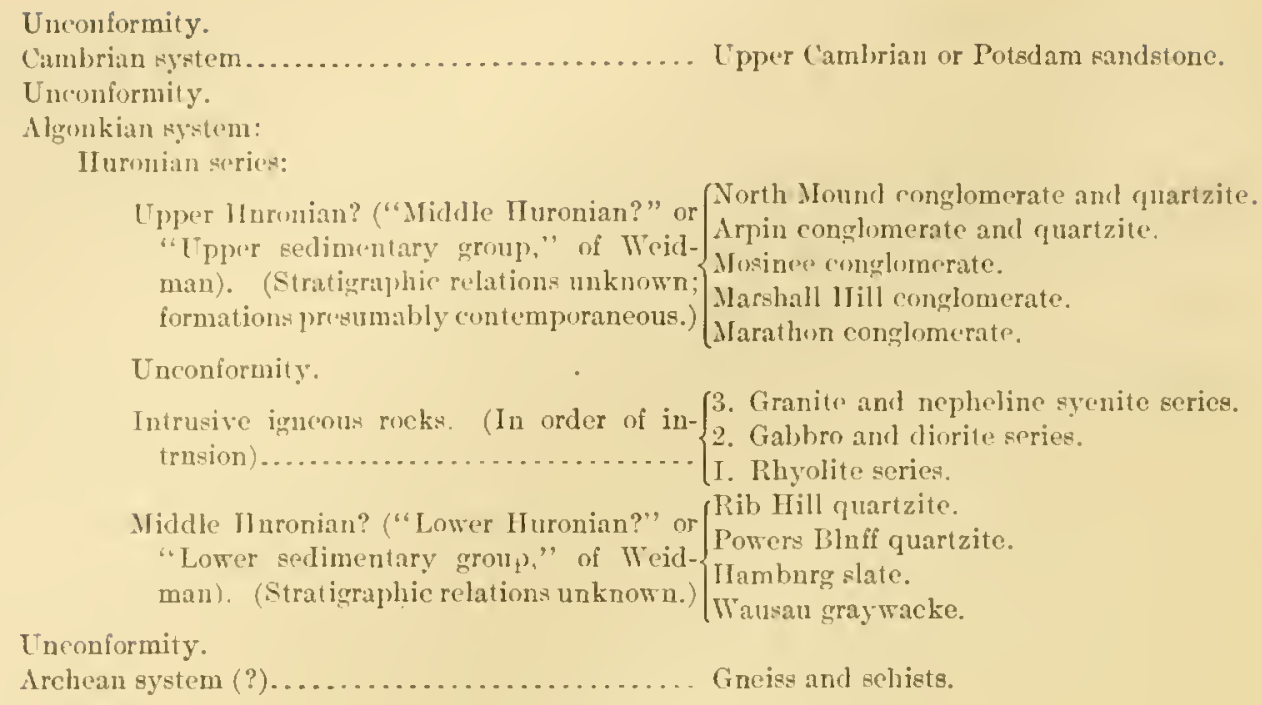

\section{ARCHEAN (?) SISTEM.}

The basal rocks, believerl to be the oldest and to belong to the Arehean system, consist of a complex mixture of rocks, such as contorted and crumpled granite gneiss, diorite gneiss, granite schist, syenite schist, and diorite schist. The gncisses and sclists form a helt which ran be fairly well outlined, extending from the vicinity of Stevens Point and Grand Rapids in a northwesterly direction through Neillsrille. The rocks are closely intermingled with one another, and have been subjected to extensive folding and metamorphism. The zone in which they are largely comprised lies between areas of later igneous and sedimentary rock to the north and to the sonth, ant hence appears to have the position of the arch of an anticline. These basal rocks are intruded by later formations of rlyyolite, diolite, and granite. Sedimentary rocks have not been found in contact with the basal rocks.

\section{ALGONKIAN STSTEM. \\ HURONIAN SERIES.}

\section{MIDDLE HURONIAN (?).}

The rocks next succeeding are of sedimentary origin, and consist of quartzite, slatc, and graywacke. Ther include the quartzite of Rib IIill and viemity, the quartzite of Powers Bluff and in the vicinity of Junction and Rudolptl, a wide belt of slate in nortliwestern Marathon County, and graywackes in the vicinity of Wausau. These rocks are almost cntirely of fragmental origin, and only rarely contain phases of carbonaceous, calcareous, and ferruginous drposits. The basement upon which these sediments were deposited can not be definitely determined, for all the observed contacts with associated rocks are those either of later intrusive igneous rocks or of later orerlying conglomerate. The quartzites are throughout ext remely metamorplosed and to all appearances completely recrystallized. The slates and graywackes do not reveal as much metamorphism as the quartzite, although in places rocks presumably belonging with the slate have been changed to schists hearing staurolite, cordicrite, and garnet. These sedimentary rocks appear to bear the relation of great fragnentary masses intersected and surrounded by later igncous intrusive rocks. They constitute the lowest and oldest sedimentary rocks of this area. 
ROCKS INTRUSIVE IN MIDDLE IIURONIAN (?) AND ARCIEAN (?).

The next younger rocks are of igneous origin. They form about 75 per cent of the rocks of the area, and in the order of their intrusion are (1) rhyolite; (2) a basic series of diorite, gabbro, and perilotite; (3) a series ronsisting of granite, quartz syenite, nepheline syenite, and related rocks. Of these the last-named series is the most abundant, the granite alone forming about 50 per cent of the surface rocks of the area. The three series are intrusive in the Archean(?) of the area and also in the middle Huronian (?). They are in turn overlain by later Algonkian sediments. The period involved in the intrusion of the igneous formations must have been a very long one, aud evidently constituted an important portion of the preCambrian era, for the granite and syenite series itself represents a complex magma of varying though related rocks, intruded at different dates. In the stratigraphy of this area, therefore, these igneous intrusives play an important part and occupy at well-defined position between the upper Huronian (?) and the mirdle IIuronian (?) sediments.

TPPER MLTONIAN(?).

The latest Algonkian rocks of the area consist mainly of conglomerate and quartzite overlying all the other rocks above referred to. North of Wausan, at Arpin, and at North Mound they are represented by conglomerate and quartzite, and at Maratlon City and Mosinee by conglomerate.

\section{CAMBRIAN SYSTEM.}

In the north-central area the pre-Cambrian was worn down to base-level by subaerial erosion before the much later Upper Cambrian or Potsdam sandstone ${ }^{a}$ was deposited upon it. ${ }^{b}$

\section{BARRON, RUSK, AND SAWYER COUNTIES.}

In Barron, Rusk, and Sawyer counties the pre-Cambrian rocks are largely of igneous origin. The nost promment sedimentary areas are the prominent ridge of quartzite at the junction of Flambeau and Chippewa rivers and the numerous quartzite ridges along the divide of Chippewa and Red Cedar livers. In general, these quartzites dip westward, away from the crystalline and schistose area, with strongly marked eastward escarpments overlooking the nearly flat plain of olfer rocks. Although no final conchusion has been reached concerning the relative age of these quartzites, Weidman is of the opinion that there are here represented at least two and probably three series. The quartzite in the small outcrops along the railroad about 3 miles east of Weyerhauser is greatly metamorphosed and is correlated with the Rib Hill quartzite at Wausan. The prominent rilge of quartzite at the junction of the Flambeau and the Chippewa is correlated with the upper sedimentary series in north-central Wisconsin and the Baraboo quartzite. The prominent ridges of quartzite in eastern Barron County and in the adjacent parts of Rusk and Sawyer counties are but slightly metamorphosed, the bedding is in general nearly flat-lying, and the formation has a much younger aspect than the other two quartzite formations in the region and may be Keweenawan.

a The term Potsdam sandstone is here used in a quotational sense from the Wisconsin Geological Survey.

6 Weidman, Samuel, The pre-Potsdam peneplain of the pre-Cambrian of north-central Wisconsin: Jour. Geology, vol. 11, 1903, pp. $282-313$. 


\section{VICINITY OF TAKEWOOD.}

Quartzites are known in the vicinity of Lakewool, indirating the presence of Intonian rocks in this distriet. Practically all that is known conceruing the distribution and strueture of these quartzites is shown on the areompanying sketch (fig. 51). They stand up as monad-

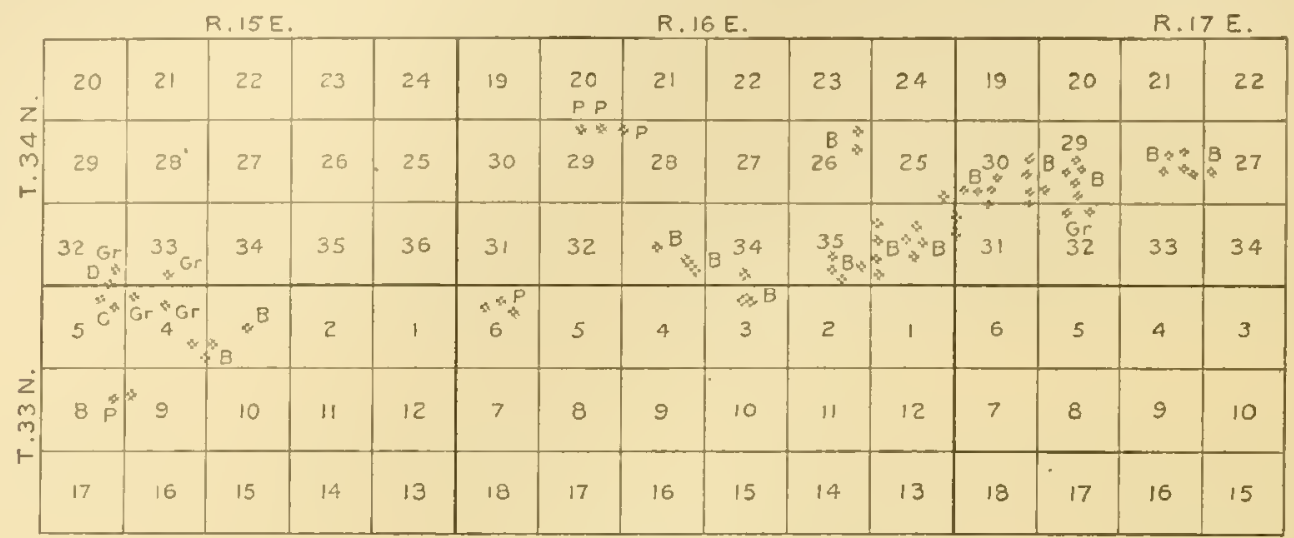

Figure 51.-Sketch map showing oceurrence of quartzites of Huronian age in Tps. 33 and 34 X., Rs, 15, 16, and 17 E., Wisconsin. B. Quartzite and (quartzite brecia; C, conglomerate; I, diabase; (Ar, granite: 1 , norphyrr.

nocks above the surrounding drift-corered surface. Issociated with them are granite, porphyry, and diabase in isolated exposures.

\section{NECEDAI, NORTII BLUFF, AND BLACK RIVER AREAS.}

At Necedah, in Juneau County (see figs. 52 and 53), and at North Bluff, in Wood County, are quartzite exposures projecting though the Cambrian.

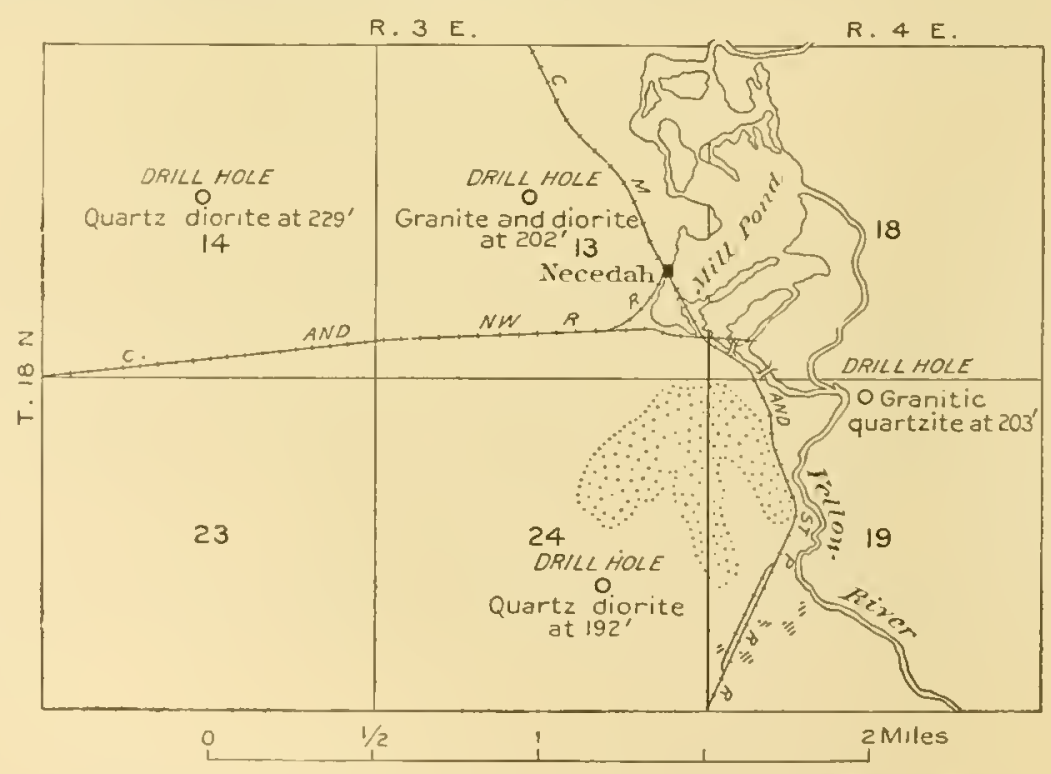

Ficue 52.-Sketrh map showing occurrence of Huronian quartzite near Necedah, Wis.

Drilling at Necedal has disclosed the presence of granite, probably intrusive into quartzite. The quartzite is highly metamorphosed and is lithologically similar to the IInronian rocks. 
In the Black. River valley, north of Black River Falls, are exposures of gneiss, granite, hormblende schist, magnesian schist, and ferruginous quartz schist, mapped by Irving ${ }^{a}$ in 1873 and by Ifancock ${ }^{b}$ in 1901 . The relation of these rocks to one another is not definitely known. All are pre-Cambrian.

\section{BARABOO IRON DISTRICT. ${ }^{\circ}$}

\section{LOCATION AND GENERAL GEOLOGIC SUCCESSION.}

The Baraboo district constitutes an outlier in the Paleozoic rocks and centers in the town of Barabon, in the south-central part of Wisconsin. (See fig. 53.) It is south of the area

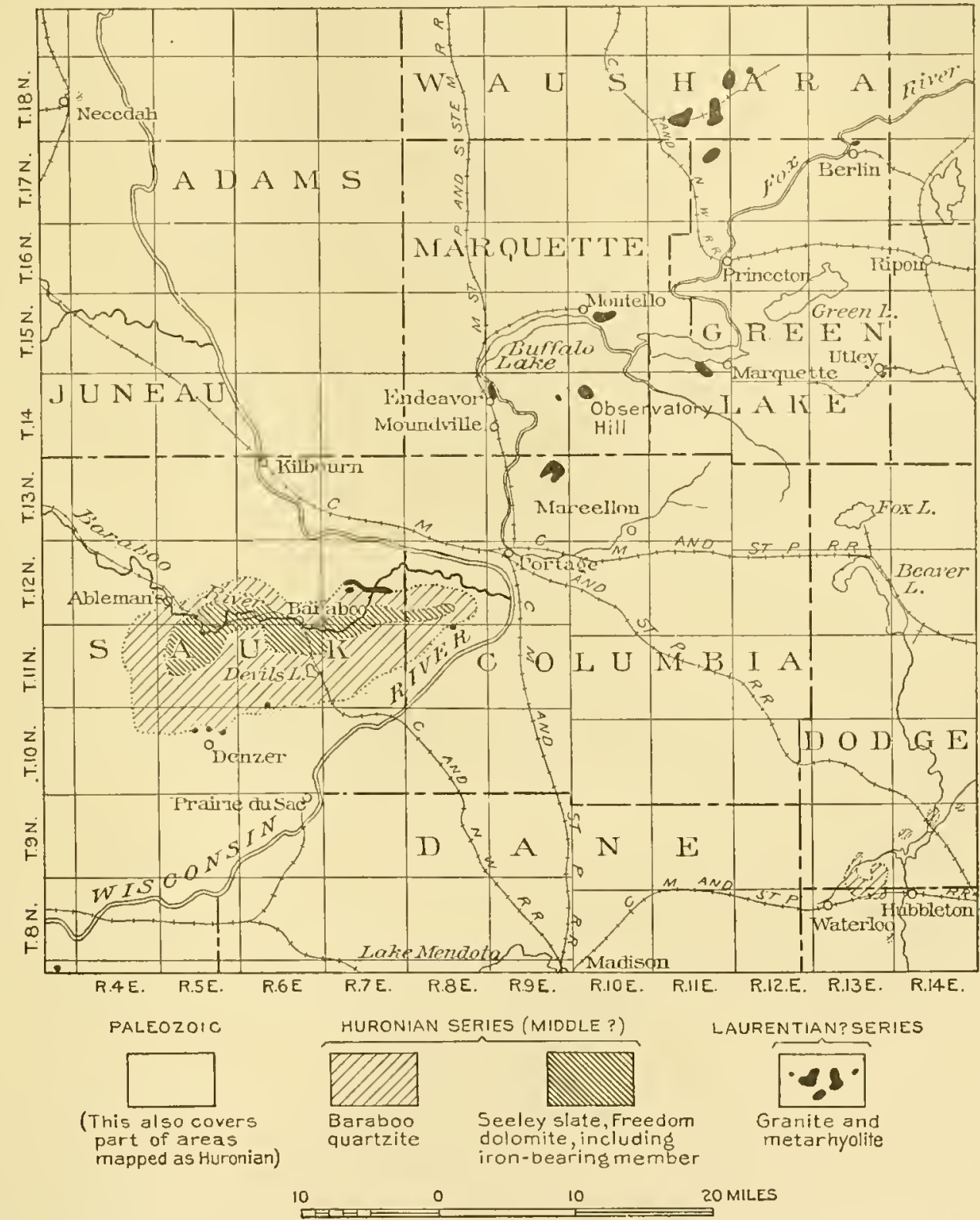

FIGURE 53,-Sketch map showing Baraboo, Fox River ralley, Necedah, Waushara, and Waterloo pre-Cambrian areas of south-central Wisconsin. shown on the general Lake Superior map (Pl. I), but a brief description is here given because the clistrict is producing iron ore and is similar lithologically and structurally to the ironproducing area of the Lake Superior region.

a Irving, R. D., The Neeedah quartzite: Geology of Wisconsin, vol. 2, 1873-1s77, pp. 523-524.

$b$ Hancoks, E. T., The geology of the area at Black River Falls, Wisconsin: Unpublished thesis, Geol. Dept. Univ. Wisconsin, 1901.

c See Weidman, Samuel, The Baraboo iron-bearing district of Wisconsin: Bull. Wisconsin Geol. and Nat. 11ist. Survey No. 13, 1904. 
The area is elliptical in outline, extending 20 miles east and west and ranging in width from 2 to 12 miles. It is essentially a quartzite syncline.

The successiou is as follows:

Quaternary system........... Pleistocene deposits.
Ordovician system.......... $\begin{aligned} & \text { Trenton limestone. }{ }^{a} \\ & \text { St. Peter sandstone. } \\ & \text { "Lower Magnesian" limestone. }\end{aligned}$
Cambrian system ............ Potsdam sandstone. $a$

Unconformity.

Algonkian system:

IInronian series:

Upper ILuronian (?)... Quartzite.

Unconformity.

Mirldle II

Unconformity.

Archean system

I.aurentian (?) series...... Granites, rhyolitcs, tufis, ete.

The principal structural feature is an east-west symelinorium of middle Huronian (?) rocks resting on the Archean basement, carrving in the trough unconformable upper Huronian (?) quartzite and Paleozoic sediments, and surrounded by Paleozoic sediments. The edges of the basin, composed of hard, resisting middle IJuroniun (?) quartzite, form ridges known as the north and south Baraboo ranges, standing 700 to $\$ 00$ feet above the surrounding country and the intervening valley. (See fig. 54.)

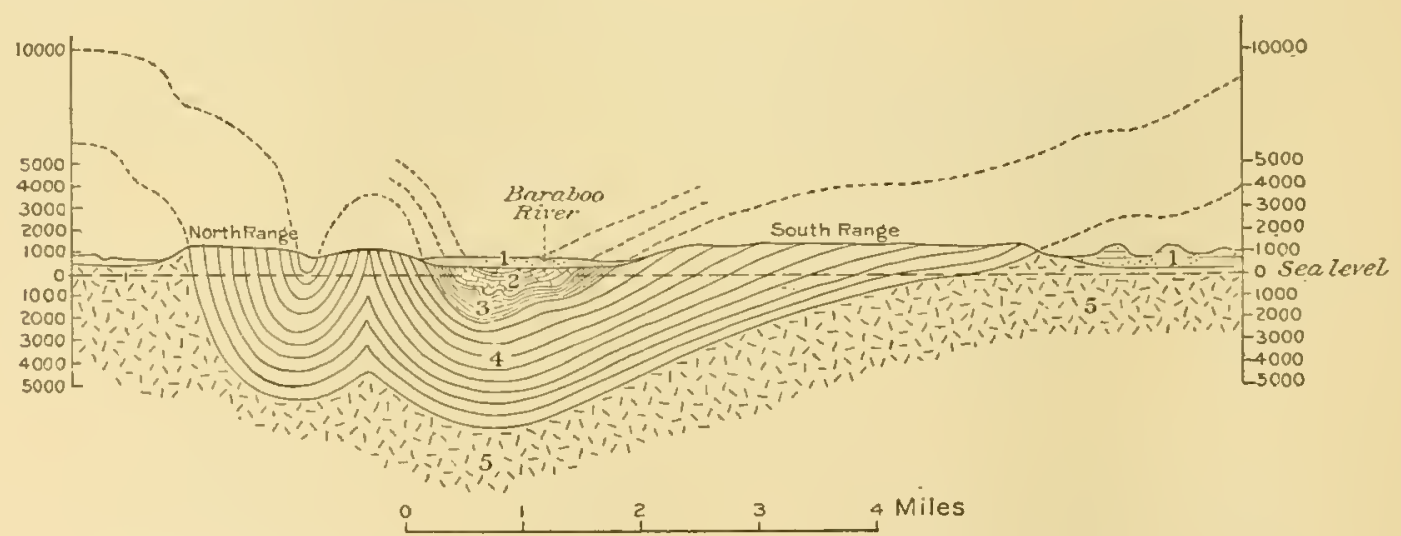

Flgure 54.-Generalized cross section extending north and south across the Baraboo district. 1, Potsdam sandstone; 2-4, Iluronian (2, Freedom dolonite; 3, Secley slate; 4, Baraboo quartzite); 5, rhyolite and granite (Laurentian?). After Weidman.

\section{ARCHEAN SYSTEM. \\ LAURENTIAN SERIES.}

The Lanrentian roeks outcrop in isolated areas bordering the outside of the Baraboo syncline. The surfuce voleanic phases are best exposed west of the Lower Narrows of Baraboo River on the northeast side and near the town of Alloa on the southeast side. They are similar to the surface voleanic rocks of the Fox River valley. Granitic rocks appear in isolated areas on the south side of the belt. Some of these rocks, previously considered as Archean, have recently been found to be intrusive into the middle Huronian (?). 
ALGONKIAN SYSTEM.

HURONIAN SERIES.

MIDDLE IIURONIAN (?).

BARABOO QUARTZITE.

The Baraboo quartzite is a massive though well-bedded formation, considerably jointed, faulted, and brecciated, but showing no cleavage as evidence of rock flowage except along certain thin slate beds in which readjustment has been concentrated during folding. Cross-bedding, ripple marks, and thin conglomeratic layers are numerous. In the north range the beds stand nearly vertical; in the south range they dip gently toward the sonth. Isolated exposures in the north-central side of the trough are thought to be brought up by minor folds. There is, however, a possibility that faulting has been a factor.

\section{SEELEY SLATE.}

The Baraboo quartzite passes up into the Seeley slate, a soft, gray, finely bander chlorite slate, known principally by drilling along the south limb of the syncline. The cleavage is somewhat steeper than the bedding, corresponding to the normal development of cleavage in such relation to a syncline.

FREEDOM DOLOMITE.

The Freedom formation consists principally of dolomite but contains near its base slate, chert, and iron ore and all gradational phases between these kinds of rocks. The lowest member is a ferruginous kaolinitic slate, well exposed in the Illinois mine, rejresenting a ferruginated gradation phase of the Seeley slate into the Freedom dolomite. The next overlying member of the Freedom dolomite is banded ferruginous ehert and iron ore, known principally along the south himb of the syneline, but oceurring also in the east end of the basin and in several explored areas on the north side. Interbediled with the chert, especially near its upper parts, are ealcite, siderite, kaolin, and dolomitic slates. Minor folding and brecciation are conspicuous in this member, part of it at least resulting from secondary elemical changes, causing slump in the formation.

The cherty dolomite making up the upper member and by far the greatest part of the Freedom formation is a fine-grained banded rock similar in some of its phases to the ferruginous cherts but usually softer. It griades locally into ferrodolomite.

UPPER HURONIAN (?).

Upper Huronian (?) quartzite has been found only by drilling in the deeper parts of the east end of the trough. Only recently has it been diseriminated from the Cambrian sandstone above it or the middle Huronian (?) quartzite below. When the drill penetrated the Cambrian sandstone and conglomerate and reached quartzite below it was usually assumed that this was the middle IIuronian (?) quartzite and the drilling was stopped. When this quartzite was penetrated by the drill, however, it was found to overlap the edges of all the middle Huronian (?) rocks and to have conglomerate at its base. The thickness of this quartzite, as shown by the drilling, is not more than 50 feet. Its attitude is not definitely known, but from the way it lies over all the earlier formations it is believed to be not much tilted. No exposures of the formation are recognized as such. It seems to remain simply as a residual pateh in the deeper part of the trough where protected from erosion. However, some of the quartzite on the so-called Baraboo ridges may be upper Iuronian (?) rather than middle IIuronian (?). Still more recently red slate has been found above this upper Huronian (?) quirtzite.

\section{PALEOZOIC SEDIMENTS.}

The Paleozoic rocks consist, from the base upward, of the Potsdam sandstone, the "Lower Magnesian" limestone, the St. Peter sandstone, and the Trenton limestone. The Potsdam sandstone occurs on the lower flanks of the quartzite ranges and in the ralley bottom; the 
suceeding formations lie at higher clevations. The Jaleozoic beds rest horizontally upon the more or less folded II uronian beds, a conspicuous basal conghomernte marking the great unconformity.

\section{QUATERNARY DEPOSITS.}

I'leistocene deposits (over alout the northeast half of the district. (See Chapter XVT, P], 427-459.)

THE IRON ORES OF TIE HARABOO DISTRICT.

By the authors and W. J. MEAD.

OCCURRENCE.

The iron-bearing beds, which are a part of the freedom dolomite, have been productive thus far on the south liml of the basin. They dip nothward at angles ranging from $50^{\circ}$ to $70^{\circ}$. The foot wall is Seeley slate; the hanging wall is cherty dolomite, with small amounts of state and iron carbonate. The iron-bearing menber itself consists of ferruginous chert, iron carbonate, ferrugrinous slate, and iron ore. There is a gradation from this member into both hanging and foot walls. It is thin, for the most part not more than 200 feet thick, and the productive ore bodlies are still thimer, 20 to 30 feet. The ores stand as lenses arranged end for end or overtapping parallel to the hayers of chert. These have been found by drilling at a maximum depth of 1,500 feet, but mining operations do not yet go beyond 500 feet. Their lateral extent has been found to be at least 2,000 feet. Deep drilling down the dip discloses minor folds. Also to the south of the main outcrop the ore may be repented by an additional minor fold.

The iron-bearing nember las been found also on the north side of the basin, where it stands almost vertical or dips south, but so far it is nomproductive here.

Only one mine has operated to the present time, the Illinois mine (see fig. 55), although three other shafts are now being sunk.

\section{CHEMICAL COMPOSITION.}

The following is a complete analysis of the Baraboo ore: ${ }^{a}$

Chemical composition of the Buruboa ore.

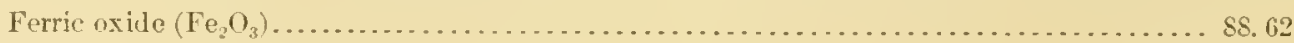

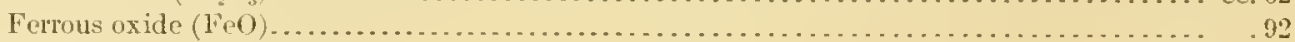

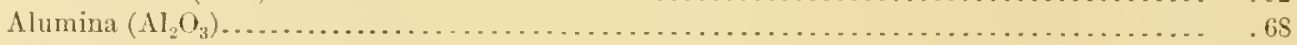

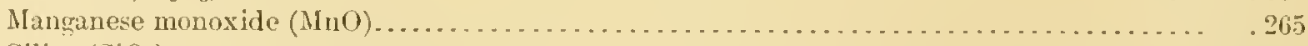

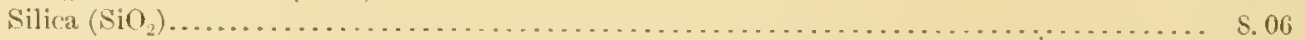

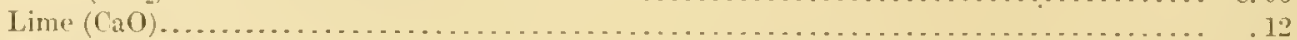

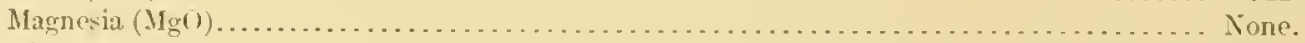

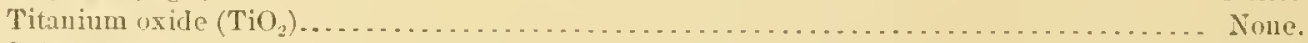

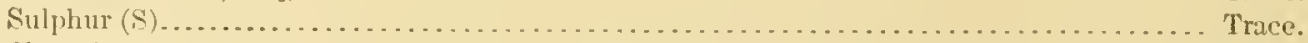

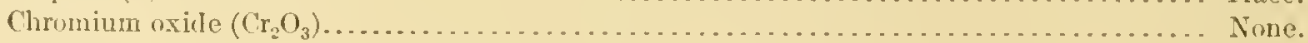

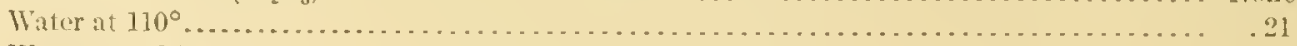

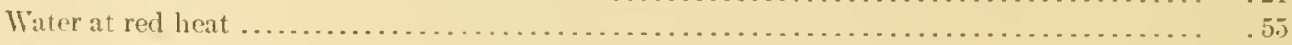

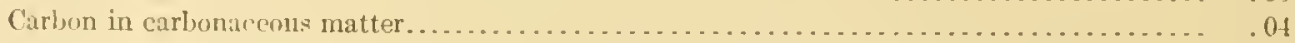

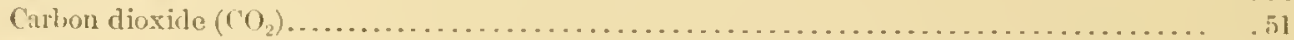

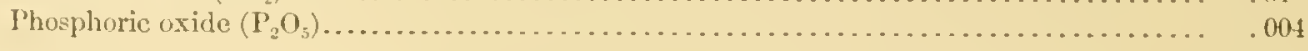

99. 979

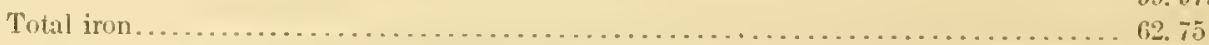

a Weidman, Samuel, The Baraboo iron-bearing district of Wisconsin: Bull. Wisconsin Geol. and Nat. II ist. Survey No. 13, 19n4, p. 12〈. 
A commercial analysis showing the average grade shipped for 1907 is as follows:

Partial analysis showing averuge grade of ore shipped for 1907 .

[Sample dried at $212^{\circ} \mathrm{F}$.]

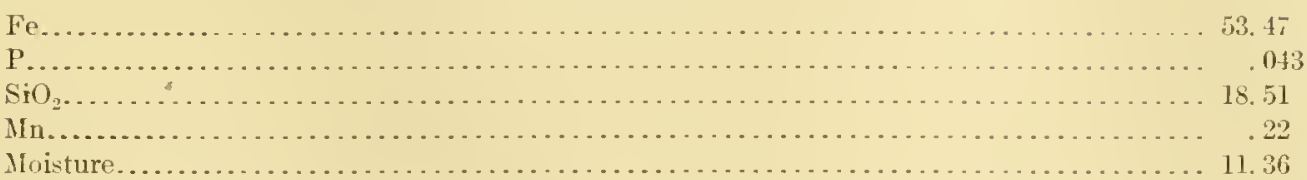

An avernge of 1,517 analyses, representing 4,814 feet of drilling in the iron-bearing member away from the available ores, gives 36.40 per cent of iron. This includes both the lean jaspers and the partly altered jaspers but not the ores. Becanse of their great mass compared with the ores, they represent nearly the general average composition of the entire iron-bearing member.

\section{MINERALOGICAL CHARACTER. $a$}

The Baraboo iron ore is mainly red hematite with a small amount of hydrated hematite. There are also small amounts of iron carbonate in isomolphous combination with varying amounts of manganese, calcimm, and magnesium carbonate. Next to lienatite in abundance is quartz or chert, which occurs either in bands in the ore or somewhat miformly distributed throughout the ore. Chlorite, mica, and kaolin also oceur in the ore in varying but usually small quantities.

The vein material in the ore is to a very large extent quartz, to a small extent calcite or ferrodolomite, and to a very small extent iron sulphide and iron oxide. The quartz of the veins has the usual interlocking grinitic texture of vein quartz and is generally rery much coarser than the finely granular cherty quartz in the ore and in the banded ferruginous chert. The carbonate of the veins is also much coarser than the carbonate of the beds.

\section{PHYSICAL CHARACTER. $b$}

The common phases of the Baraboo ore are soft granular ore, hard banded ore, and hard blue ore. The soft granular phases generally carry the highest percentage of iron, the banded and hard blue ore containing usually a larger anount of silica. The ore in its prevailing aspects is more like the hard varieties of ore of the old ranges of the Lake Superior district than the soft, hydrated hematite ore of the Mesabi district.

\section{SECONDARY CONCENTRATION.}

Structural conditions. - ihe circulation of waters in this district is controlled by the impervious foot-wall slate on the one hand and the impervious dolomite on the other. The zone between is a narrow one. The shaft of the Illinois mine (see fig. 55) goes down in the foot-wall slate. In walking from the shaft in the drift toward the ore body one notes the conspienous dryness of the slate as contrasted with the extreme wetness of the drift where it passes through the iron-bearing member. Water is circulating at the present time through the iron-bearing member with great rapidity. The point of escape of the waters is not known; neither is it possible to tell what the depth of circulation has been. Ores have been found to a depth of 1,500 feet, but the deep ores were not so rich as those at the surface. The Baraboo quartzite ridges control the major circulation. The ores, however, are a considerable distance from the foot wall of these ridges on a comparatively flat area, although the hanging walls are usually in still lower ground.

Original character of the iron-bearing member.-The iron-bearing member was at least in larger part iron carbonate, as shown by the residual iron carbonate into which the member grades below, but it may have consisted also in part of banded ferric liydrate and chert. 
Ifineralogical and chemical changes. The alterations of the iron carbonate have been accomplished through the ustal processes as described on carlier pages. All stages of alteration are to be observed and all criteria for determining these alterations are known to be present. Weidman belicres that the iron ore of the Baraboo district was originally a deposit of ferric hrelrate, or limonite, forued in comparatively stagnant shallow water under conditions similar to throse existing where bog or lake ores are being formed to-lay, and that flurough sulbsequent changes long after the iron was deposited as limmite, while the member was deeply buried below the surfare and subjected to heat and pressure, the original limonite became to a large extent dehydrated and changed to hematite, and that therefore its structural

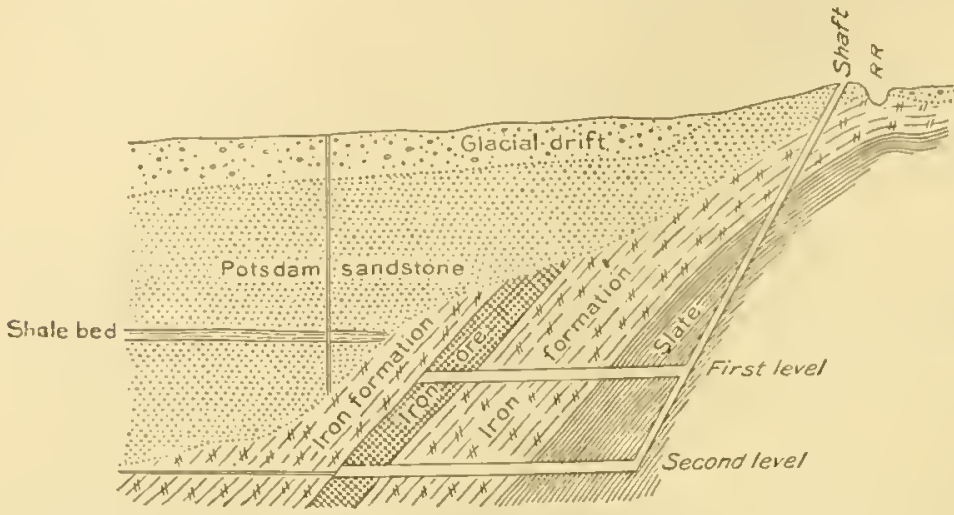

FIGURE 55.-Vertical section ol Illinols mine. (After Weidman, Bull. Wisconsin Geol. and Nat. Hist. Survey No. 13, 1904, fig. 1, pl. 15. relations are not primarily controlled by the necessity of later water circulation.

Though this district is wilely separated from the principal Lake Superior ranges and may have the different origin outlined by Weidman, its close similarity in lithology and strueture to the Lake Superior ranges is believed to be a priori evidence of similarity in origin. The theory of origin of the Lake Superior ores adequately explains the origin of the Baraboo ores and is combated by no facts yet shown in the

Baraboo district. Moreover, recent deep drilling has shown an abundance of original iron carbonate. Certainly development work has not been nearly sufficient in the Barabon distriet to warrant any conclusions at variance with those for the older Lake Superior ranges at the present time.

\section{WATERLOO QUARTZITE AREA.}

The malping of the Waterloo quartzite at Portland, Hubbleton, Mudlake, and Lake Mills (see fig. 53) by Buell ${ }^{a}$ and subsequently by J. H. Warner ${ }^{b}$ slows that the outerops of this quartzite have a distribution and structure such as to suggest that they represent part of a great eastward-pitehing syncline of quartzite. The quartzite is lithologically almost identical with the Baraboo quartzite and its synelinal axis has the same direction as the axis of the Baraboo syncline. There is little reason to doubt that the Baraboo and Waterloo quartzites are of the same age. If this is the case, one would expect to find slate and ferruginous dolomite formations within the Waterloo quartzite synchine, as in the Baraboo srnclinc, but drilling has thus far failed to locate them. Like the Baraboo quartzite, the Waterloo quartzite is referred to the Ifuronian, and its similarity with the midelle Huronian is emphasized. Well drithing outside of the Watertoo syncline shows the presence of a granite hasement.

a Buel1, 1. M., Geology of the Waterloo quartzite area: Trans. Wisconsin Acad. Sci. vol. 9. 1K93. pp. $255-27$.

o Warner, J. II., The Waterloo quartzite area of Wisconsin: Unpublished hachelor's thesis, Dept. Geology Univ. Wisconsin, 1904. 


\section{FOX RIVER VALLET."}

Several small isolated outerops of pre-Cambrian crystalline rocks project through the Paleozoic sediments in the Fox River valley at Berlin, Utley, Waushara, Marquette, Montello, Observatory Hill, Marcellon, and Endeavor. (See fig. 53, p. 359.) The rocks are mainly acidic extrusives: metarhyolites, showing gralation into rocks of nore deep-seated origin; rhyolite gneiss; quartz rhyolite; and granite, all of them cut by basic dikes. The characteristic feature in the metarhyolites is the presence of albundant and well-preserverd surface volcanic textures, such as fluxion, perlitic, spherulitic, and brecciated textures. The lithologic similarities of the rocks, the presence of the surface textures, and their composition, as shown by analysis, indicate clearly their cousanguinity with one another and with certain of the igneous rocks on the north and south sides of the Baraboo range. In the Baraboo distriet these rocks have been found by Weidman ${ }^{b}$ to lie unconformably below the sedimentary rocks, and hence the voleanie rocks of Fox River may be supposed to be pre-Huronian.

a Hohbs, W. II, and Leith, C. K., The pre-Camirian voleanie rocks of the Fox River valley, Wisconsin: Bull. Cuiv. Wisconsin No. 158 (Sci. ser., vol. 3, No. 6), 1907, pp. 247-278.

b Weidman, Samnel, The Baraboo iron-bearing district of Wisconsin: Bull. Wisconsin Geol. and Nat. Hist. Survey No. 13, 1904, p. 21. 


\title{
CHAPTER XV. THE KEWEENAWAN SERIES. ${ }^{a}$
}

\author{
GENERAL, CITARACTERISTICS.
}

The Kewenawan is the upper soliss of the Algonkinn stestem in the Lake Superior region. Its most characteristic feature is that its abundant cflusive rocks ate as widespread as the series itself. Indeed, they probably compose from a third to a half of the series. The Keweenawan contrasts with the Ihmonian in that in the latter series the ellusive rocks are largely concentrated in a number of localities, although in these areas they may be of very great thickness. In short, the Keweenawn was a periorl of regrional volcanic activity and the Huronian was a period of local volcanism. It results from these facts that in the earliest stulies of the Keweenawan the igneous rocks were noted and described. In the Huronian, on the other hand, the sediments were more conspicuous and were especially studied in the early years, and it is only recently that the extent and magnitude of the igneous rocks of that period have been appreciated.

In the following discussion of the Keweenawan no attempt will he made to give detailed petrographic deseriptions. The most salient petrographic features will be mentioned, and a review of the petrography and chemistry, with reference to nomenchature, will be presented by A. N. Winchell. In order to give a sommithat more definite impression of the series, the more important districts will be briefly described.

\section{DISTR IBUTION.}

The Keweenawan rocks border the major part of the shore of the western half of Lake Superior, occupy islands in the eastern half, and are found on the mainland at the extreme east end of the lake. They extend to a maximum distance of 120 miles northwest of I ake Supcrior. To the southwest Kewcenawan roeks have been penetrated by drills at Stillwater, anil still farther southwest, at St. Paul and vicinity, certain red sandstones have been drilled which may be Keweenawan. On the south side of the lake they oceur mainly within 12 miles of the shore. Sandstones, Keweenawan or Cambrian, are known also at the east end of the Felch Mountain trough. This distribution shows that this series once occupied the greater portion of the Lake Superior basin and from it extended for rarying distances. In much of the basin at present the Keweenawan rocks are overlain by Cambrian sandstone.

The total present exposed area of the lieweenawan rocks is approximately 15,000 square miles. To obtain the original. area there must be added a rery large but unknown portion of the Lake Superior hasin. Further, there must be ahled the numerous masses, large and small. of the rocks of lieweenawan age intrusive into the Iluronian and Archean of the Lake Superior region. Irring ${ }^{b}$ estimated the area of the Keweenawan, aside from the rocks intrusive in older series, at 41,000 square miles.

It is thus evident that Lake Superior in Keweenawan time was an area of regional activity extending east and west for more than 400 miles and north and south for searcely a less distance.

\section{SLCCESSION.}

A broarl study of the several lieweenawan distriets leats to the conchusion that a threcfolel division of the sories as a whole may be made, beginning at the bottom, as follows: (1) Lower Keweenawn, comprising conglomerates, sandstones, dolomitic sandstones, shales, and marls;

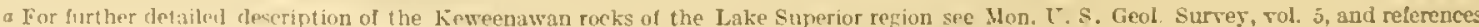
there given. In the descript tons of the several districts accounts of local features of the fiewenawan are given.

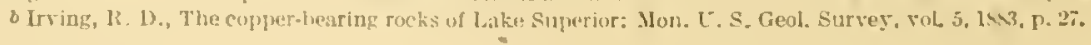


(2) midlle keweenawan, comprising extrusive and intrusive igneous rocks with important zmounts of interstratified sandstones and conglomerates and subordinate amounts of sliale; and (3) upper lieweenawan, comprising conglomerates, sandstones, and shales, represented in northern Wisconsin and Michigan. In only one district, northern Wisconsin and Michigan, is the full suceession fouml. In the area of Black and Nipigon bays and Lake Nipigon, in Minnesota, and at the east end of Lake Superior the lower and midlle lieweenawan appear. On Isle Royal the upper and middle Kieweenawan oecur, and on Michipicoten Island only the midlle Keweenawan is found.

\section{BLACK AND NIPIGON BAYS AND LAKE NIPIGON.}

\section{LOWER KEWEENAWAN.}

The rocks belonging to the lower Keweenawan oceupy the peninsula between Thunder and Black bays and the neek between Nipigon and Black bays from the northwest corner of Nipigon Bay to a point 20 miles west of Black Sturecen River. They consist of quartzose sandstones, dolomitic sandstones, and red marls. According to Logan ${ }^{a}$ their thickness is from $\$ 00$ to 900 feet. Bell, however, estimated it from 1,300 to 1,400 feet. Bell's section ${ }^{b}$ is as follows:

Section of lower Femeenuwan rocks near Black and Nipigon bays.

Alternating red and white dolomitic sandstone, with a red conglomerate layer at the bottom, occurring on Wood's location, Thunder Capec . . . . . . . . . . . . . . . . . . . . .

Light-gray dolomitic sandstone, with occasional red layers ani spots and patches of the same color. These sandstones oreur along the southwest side of Thunder Bay and on Wood's loca-

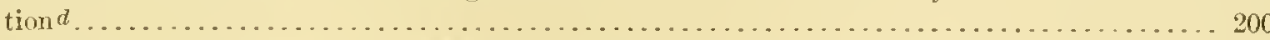

Red sandstones and shales, interstratified with white or light-gray sandstone beds, frequently exhibiting ripple-marked surfaces, and also with conglomerate layers composed of pebbles and bowlders of coarse red jasper in a matrix of white, red, or greenish sand . . . . . . . . . . . 500

('ompact light-reddish limestones (some of them fit for burning into quicklime), interstratified with shales and sandstones of the same color . . . . . . . . . . . . . . . . . . . . . 80

Indurated red and yellowish-gray marl, usually containing a large proportion of the carbonates of lime and magnesia.e This division runs through the center of the peninsula between Thumder Bay and Black Bay, and may, in this region, have a thickness of 350 feet or more . . . . . . 350

Red and white sandstones, with conglomerate layers, the red sandstones being often rery argillaceons and variegated with green spots and streaks, and having many of their surfaces ripplemarked. There rocks are found all along the northwest side of Black Bay as far up as the

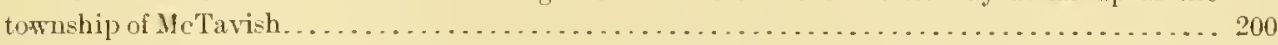

There are no lavas interstratified with the Black Bay and Nipigon Bay rocks, but at numerous places they are cut hy diabase dikes similar to those which cut the upper Huronian (Animikie group)).

The lower Keweenawan oceurs on the shore of the southwestern part of Lake Nipigon in relatively small areas and inland from Lake Nipignn in a large area of which Black Sturgeon Lake is the center. This division is called the Nipigon formation by Wilson ${ }^{f}$ It comprises basal conglomerates which rest unconformably upon the Archean, sandstones, shales, and dolomites-green, ferruginous, and white. For this area Wilson gives the succession, in descending order, as follows:

Section of lower Keucrnawan rocks in Nipigon basin.

Dolomites and dolonitic shales........................

Feet.

Grits and sandstones....

Tasal conginmerate.

a Logan, W. E., Report of progress to 18ti3, Cieol. Survey Canada, 1, \$i3, p. 70.

b Bell, Robert, Report of progress from 180 it to 1869 , Geol. Survey Canarla, 1\$70, p. 319.

c Macfarlane finc's the red sandstone to contain 12.5 per cent of carhonate of lime and 11 per cent of carhonate of magnesia.

d Jlacfarlane found them to contain 13 per cent of carbonate of lime and 12 per cent of carbonate of magnesia.

$\epsilon$ The amount varying, in the specimens analyzed by Macfarlane, from 21 to 34.5 per cent of the carbonate of lime, and from 7.5 to 13.5 per cent of the carbonate of magnesia.

fWilson, A. W. G., Geology of the Nipigon basin, Ontario: Canada Dept. Mines, Gpol. Survey Branch, Memoir No. 1, 1910, pp. 64-70. 
Nothing is said hy Wilson as to the dijes of the lower Keweenawan rocks, but it is apparent from his descriptions that they are relatively flat.

The distriet alore leseribed is of interest as being the only distriet in which the accumulation of detrital material before the outbreak of the Keweenawan lavas covers any consilerable area. It is believed that these rocks really represent the first deposits of the transgressing keweenawan sea and antedate the igneous epoch of the lieweenawan alourether. The absence of material derived from the Keweenawan lavas led some of the earlier geoloristsfor instance, Macfarlane ${ }^{a}$ and IIunt ${ }^{b}$ - to question whether these rocks really belong with the Keweenawan. These lower Kieweenawan rocks pass under' the middle lieweenawan diabases and amyerdalouls, which form the southern half of the peninsula southwest of Black Bay. On the north they are overlain, a'cording to Bell, chy columnar trap.

\section{MIDDLE KEWEENAWAN.}

Aside from the area occupied by the lower Keweenawan sediments the remainder of the Black and Nipigon bays and Lake Nipigon district is oceupied by the middle keweenawan, consisting of basie igneous rocks with subordinate amounts of interstratified clastic material. These igneous rocks are partly flows and partly intrusions.

\section{BLACK AND NIPIGON BAYS AND ADJACENT ISLANDS.}

Black and Nipigon bays are noted for their conspicuous and interesting topography, which has originated in essentially the same way as the topography of Thunder Bay. In both localities the sediments are interleaved with great sills of cliabase, sedimentary and igneous rocks alike being in nearly horizontal attitule.

The rocks of the middle Keweenawan constitute the shores of the outer parts of Black and Nipigon bays and of the adjacent islands, including those from the size of St. Ignace to small rocks, and from the shore they extend considerable but varying distances inland. Over largo areas these rocks present facies which are similar to those of the Beaver Bay area of the Minnesota coast, deseribed on pages 371-374. Locally they show spheroidal weathering, as at Fluor Island. They are cut by red rock, which metamorphoses the diabase to an orthoclase gabbro, just as on the Ninnesota coast. The sediments are subordinate. In places the diabase clearly intrudes the sediments and locally the latter are somewhat modified at the contact, the color changing toward the intrusive rock fiom red to gray or white.

For the most part the dip of the rocks of the areas of Black and Nipigon bays is very gentle, here in one direction and there in another, but near the shore of I ake Superior there is the usual gentle and persistent lakeward slant of $5^{\circ}$ to $10^{\circ}$. Locally, however, the dips go up to $20^{\circ}$ or $30^{\circ}$, to $60^{\circ}$ or $70^{\circ}$, or even to the vertical. These steep dips occur at places where the diabases intrude the sediments or the amygrlaloids, and thus disturb their normal attitudes.

\section{LAKE NIPIGON.}

The middle Kewecnawan igneous rocks extend throughout the Lake Nipigon district, except in the areas of the lower Keweenawan already mentioned. They oceupr about half of the shore line on the enst and north sides of Lake Nipigon, where they mainly constitute the periinsulas and headlands. North of the lake they extend 40 miles or more to the Hudson [Bay divide. They oceupy all the hundreds of islanels of the lake, varying in size from those which are several mikes long and wile to those which are mere rocks.

The midelle Kewernawn of Lake Nipigon consists mainly of great masses of diabase. which Wilson suys are in sheets and dikes, and with these are later acille dikes. Finglish Bay" is an ara of granite prorphyry, which Wilson places with the Arehean, but which, it may be sugrested from the association, may belong with the lieweenawan.

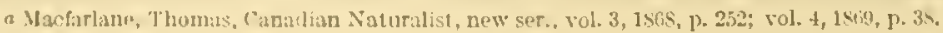

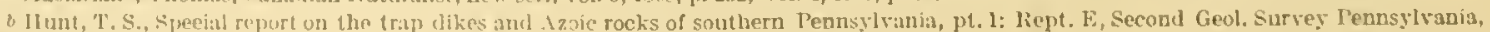
187, p. 211.

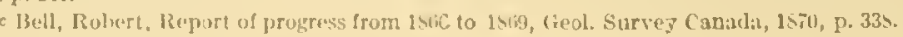


There has been much discussion as 10 whether the great diabase sheets are intrusive or extrusive rocks. Wilson ${ }^{a}$ summarizes the evidence in favor of extrusion as follows:

1. The very widespread oceurence of unconformilies between diabase sheets and underlying furmations.

2. The occurrence of bowlders of granite and gneiss and schist in diabase, the lattrel resting on sinilar rocks in situ in localities where there is direct evidence that before the advent of the trap the underlying rocks were liuried beneath the sediments simitar to those now present, near by, muler the sume dialuase sheet.

3. The occurrence of old soils in situ at the bases and ou the sides of sedimentary rickes, the whole being covered in places with a diabase cap.

4. The nicety of the adjustment by which the diabase sheet have fitted themselves to the underlying topography. While the upper surlices of the resichuls of the capping sheets are everywhere fairly uniform in height, the base of the sheet has adjusted itself to a topngraphy where the relicf was at times as much as 300 feet.

5. The mechanical prol,lem which arises in explaining the numerous unconformities, especially those on the embossed Archean surface, by the theory of intrusion vanishes completely on the theory of surface erosion prior to surface extrusion.

6. The features characteristic of the upper surface of sills-the occurrence of overlying beds or fragments thereof, aphanitic structures, included firgments of an old cover in the upper parts of sheets-are not found.

7. The medium to coarse texture, which characterizes the sheets, would be founcl at the base of thick surface flows as well as in sills, being dependent not on the nature and thickness of the cover so much as on the rute of cooling.

8. A glassy matrix, amygdaloidal or porous structure, basaltic texture, flow structure, and associated volcanics would not be characteristic features of the under parts of surface flows, and the upper parts of these sheets are unquestionably remused, without a single exception.

In lavor of intrusive sills are:

1. Entire absence of any of those features that are usually associated with the upper parts of a surface flow-glassy matrix; amygdaloidal, porous, or basaltic texture; flow structure; associated vilcanic rocks, either lava breccias or pyroclastic rucks.

2. A medium to coarse crystalline texture, usually iudicative of a slow rate of cooling, such as would normally take place only at some considerable distauce below the surface.

From the evidence presented Wilson draws the following conclusions: ${ }^{b}$

It seems that we have no data relative to the actual character of the upper surface of the trap "caps;" surh negative evidence as is available is equally applicable to both theories. With regard to the texture of the residual basal portions of the sheets there are no recorded differences which would indicate that it belonged to a flow and not to a sheet. On the other hanc, numerous unconformities exist, and the dialnses are known to rest successively upon Laurentian, Keewatin, Ilumian (possibly midcle, certainly lower, and Animikie), and Keweenawan (lower, middle, and upper beds), and these uncouformities are very widely distributed. Owing to the mechanical dificulties involved by any other interpretation it seems to the writer that the balance of evidence available is distinctly in favor of considering these capping sheets as the basal residuals of a once very extensive flow or series of flows of a very fluid diabase over the well-clissected topography of a previous cycle.

It may be suggested in this case, as in so many others, that the diabases of the Keweenawan sheets are not exclusively intrusive or extrusive.

It has heretofore been the prevaling view that the capping diabases, so characteristic of the step topography of the Animikie area and of the Keweenawan area on the northwest side of Lake Superior, are sills down to which erosion has worked. Wilson has hehl that some are not sills but are flows upon an oll erosion surlace. His conclusion that the flows are as late as Cretaceous rests on very slender evidence-that is, on the identification of the plane on which the flows rest as of post-Cretaceous age. ITe presents no evidence to slow that the flows are not Keweenawan or some of them even Animikic. The view that they are Ieweenawan is favored by their petrologic, areal, and structural relations with known Keweenawan rocks of the northwest and south sides of the Lake Superior basin.

\section{RELATIONS OF THE IEWEENAWAN OF BLACK AND NIPIGON BAYS TO OTIER IROCIŚS.}

As the sediments of Black and Nipigon bays are at the bottom of the Kieweenawan series their relations to the underlying rocks are important. At the very base of the series occur conglomerates the débris of which is derived from the underlying Huronian series, including the

a Wilson, 1. W. G., Geology of the Nipigon basin, Ontario: Canada Dept. Mines, Geol. Survey Branch, Memoir No. 1, 1910, pp. $9+95$.

b Idem, pp. 95-96.

$$
47517^{\circ}-\operatorname{roL} 52-11-24
$$


Animikie group, showing that there is an unconformity between the normal sediments making 1u) the earliest fieweenawan and the latest IHuronian. One of the hest exposures of this unconformity is at a cliff adjacent to Surprise Lake, a short distance from Silver Islet village. Ilere in act tual contact with the slates of the Animikie group is a conglomerate about 6 feet in thickness, which is larerely composed of angular fragments of slates from the Animikie with, howerer, detritus from granites, mica schists, vein quartz, ete., but no fragments of any of the Keweenawan lavas. The contact between the conglomerate and slate is knifelike in sharpmess. Locally the matrix of the conglomerate is limestone. The conglomerate grades upward into white quartzite interstratified with slaty layers, over which are bands of red and white dolomite. Here, as is common between the Keweenawan and Animikie, the discordance is shown mainly by the eonglomerate and not by an important difference in dip, but in a number of places the conglomerate cuts across the slate bands in a minor way.

Other very satisfactory contacts between the Kewcenawan and Animikie are those in a cut of the Cunadian Pneific Railway about a mile west of Loon Lake and at the sonth shore of Deception Lake. Here the conglomerate of the Keweenawan resting upon the Animikic contains bowlders as much as 2 feet in diameter. At the railway cut the phenomena are very similar to those at Surprise Lake, but at Deception Lake the Animikie rocks have been somewhat sharply folded, and the conglomerate rests horizontally upon the truncated beds of the Animikic.

The débris of the Keweenawan conglomerate at these localitics includes the slates from the underlying Animikie, material from the iron-bearing formation of the Animikic, and granites and schists from the lower Huronian or Archean. At all these localities the completely indurated pebbles of the Animikie as compared with the much less cemented Keweenawan are notable. This, combined with actual discordance, would indicate an important time break betwcen the two series, an inference which is confirmed by the rclations of the two in the Penokee-Gogebic district.

According to Wilson, in the Nipigon basin diabases rest unconformably on the Feweenawan, Animikic, and Archean rocks.

\section{NORTHERN MINNESOTA.}

\section{THE IEWEENAWAN AREA.}

The Kicweenawan rocks of northern Minnesota lie in a great crescent-shaped area, opening lakeward, extending from Fond du Lac, on St. Louis River, at the southwest to Grand Portage Bay at the northeast. Both the lower and the middle lieweenawan are represented.

This area of Keweenawan rocks is undoubtedly the largest continuous area of the series. It corers approximately 4,500 square miles. ${ }^{a}$ As yet this great region has been too insufliciently studied to permit a satisfactory account of it, and many points remain doubtful. Granites and diabases intrusive into the Animikie of the Cuyuna and St. Louis River areas are probably of Keweenawan age.

\section{LOWER REWEENAWAN.}

The lower Keweenawan is represented by the Puckwunge conglomerate. According to Winchell, ${ }^{b}$ this conglomerate is seen in various localities at the top of the Animikie group from Grand Portage Island, in Grand Portage Bay, as far west as the middle of R. 3 E., a distance of about 20 miles. Ile states that the basal rock of the lieweenawan is a conglomemte which grades up into sandstone. The thickness of the conglomerate is not determined, but this formation is just what one would expect between the Animikie group and the Keweenawan series from the character of the lower division of the Keweenawan abont Black and Nipigon bays. Winchell ${ }^{c}$ also states that a quartzite conglomerate which he regards as Puckwunge occurs in

Liftman, A. 11., The geology of the Keweenawan area in northeastern Mtinnesota: Am. lieologist, vol. 21, 1898, p. 175.

b Winchedl, N. I1., The geology of Minnesota, vol. 4 , 1s99, pp. 307, 327, 517-519; vol. 5, 1900, pp. $50-52$.

c ldem, vol. 4, p. 13. 
sec. 1, T. 48 N., R. 16 W., on St. Louis River, and that its total thickness is nearly 100 feet. There are, however, rare peblles of Kewcenawan rocks in this formation. It is ronformable below the younger beds. The pebbles of this conglomernte are largely lerived from the quartz veins of the slates of the underlying Animikie, and the conglomerate therefore lies unconformably on the Animikie. The formation grades into a white sandstone and then into a shale. Thus the sedimentary formation is seen at the base of the Mlinnesota Fieweenawan at both the northeast and the southwest ends. In the intervening stretch of more than 100 miles the exact base of the sedimentary or volcanic Kewcenawan has not been tracel beeause of lack of exposures and because of the intrusion of the great Duluth gabbro to be mentioned later.

\section{MIDDLE IEWEENA WAN.}

The middle Keweenawan rocks comprise all of the Keweenawan in Minnesota except the relatively insignificant Puckwunge conglomerate. They represent the voleanic epoch of the Keweenawan. Broadly the middle Keweenawan of northeastem Minnesota may be divided into two great divisions-(1) the ellusive rocks and the associated sediments and (2) the intrusive rocks.

\section{EFFUSIVE ROCKS.}

The effusive rocks occupy the larger part of the Minnesota const and extend for varying distances inland. The Minnesota coast line, looked at as a whole, presents a flat crescentic shape, with the concavity toward the lake. The same is true of the courses of the effusive rocks, but the crescents formed by them have a smaller radius and hence intersect that formed by the coast line, trending more to the north at the Duluth end and more to the east at the Grand Portage end. In following the coast, then, from Duluth to Grand Portnge,

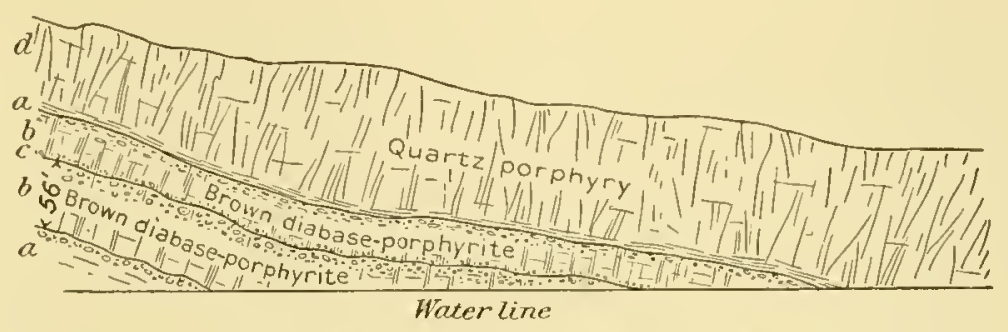

Figure 56.-Section on south eliff ol Great Palisades, Minnesota const. (After Irving.) $a$, Amygdaloist; $b$, columnar diabase-porphyrite; $c$, mingled amygdaloid and detrital matter; d, quartz porphyry.

we ascend in geologic horizon to a point near Two Islands River and descend from a point just east of Temperance River to Grand Portage.

These rocks consist dominantly of a well-stratified series of voleanic flows having a gentle lakeward dip, which commonly is from $8^{\circ}$ to $10^{\circ}$ but locally is as low as $5^{\circ}$ or $6^{\circ}$ and as ligh as $25^{\circ}$ or $30^{\circ}$, or rarely even $45^{\circ}$ or $60^{\circ}$. Numerous minor bowings and corrugations may be seen in the individual layers and sets of layers, which may be followed for some miles. These may be seen rising into arches, loeally of short span, and sinking into synclines to reappear as anticlines a short distance away.

The lavas are diabases which are commonly amygdaloidal. Many of these amygdaloids are very scoriaceous. These rocks are solter than the intrusive rocks and are especially likely to constitute the bays. There are subardinate masses of intermediate rocks, which usually have not been separated on the maps from the basic llows. At one place, east of Kadonces Bay, this intermediate rock has a peculiar spheroidal weathering similar to that of the Ely greenstone, a structure which has been regarded as eridence of subaqueous extrusion.

Associated with the basic lavas are masses of acidic lavas represented by quartz porphyrites and felsites. One of the more notable localities for these rocks is the great Palisades (fig. 56).

The conglomerates and sandstones interstratified with the lavas are subordinate in amount. In the lower part of the series they are either absent altogether or are represented by rery thin beds. In the upper part of the series, especially the portion to which Irving ${ }^{a}$ has given the 
name Temperance River group, the sandstono and conglomerate berls ure numerous. Nost of these beds are only a lew inches to a fow feet in thickness, but there are some beds which are 100 feet thick, and areoreling to Elftman ${ }^{a}$ one which is 250 fect thick. Lawson ${ }^{b}$ estimates that the sandstones and conglomerates oceuly less than 0.5 per cent of the const line.

\section{INTRUSIVE ROCKS.}

The intrusive rocks comprise both basic and acidic types.

BASIC ROCKS.

The hasic: rocks include the Duluth laccolith, the Beaver Bay and similar laccoliths and sills, the anorthosites, and the dike rocks.

\section{DULUTH LACCOLITH.}

Area and character.-The Duluth laceolith is a gabbro. It extends from St. Louis River to the northeast, gradually widening until in the center of the belt it is 30 miles wide. From this maximum hreadth it narrows toward the east until it makes a point at the Minnesota coast.

It is not our purpose liere to give anything more than a most general petrographic account of the Duluth gabbro. It is, for the most part, normal gabloro, but it has many facies. Mineralogically it ranges from a very magnetitic gabbro through olivine gabbro in which the feldspar is subordinate and ordinary olirine gabbro to olivine-free gabbro, or ordinary gabbro, and finally to a rock in which feldspar is the dominant mineral, the rock being a labradorite or an anorthosite. The anorthosite masses vary from those a few feet across to those hundreds of feet in diameter. The anorthosite appears to be but a differentiation phase of the gabluo, there being every gradation between it and both coarse and fine grained phases of the main mass of the rock. These relations are particularly well seen at Little Saganaga Lake. where, according to (lements, ${ }^{c}$ the anorthosite unquestionably shows gradations into the surrounding basic masses. Nowhere is there a sharp line of contact between the two rocks. In these respects the oceurrences are in sharp contrast with the anorthosite and the diabase of the Minnesotin eonst, to be later deseribed.

Structurally the gabbro is ordinarily massive. Howerer, at many places, especially near its borders, it has a sheeted structure. Some of the sheets are rerr thin and strongly resemble bedled rocks. This variety may be very well seen in the north bay of Bashitanequeb Lake. In addition to this sheeted structure there is a banded structure, due to the parallel arrangement of the mineral constituents.

Texturally the gabbro varies from a rock of very coarse grain to one that is almost aphanitic. All rarieties, coarse and fine, are granulitic.

Relations to other formations.- The structural relations of the Duluth gabbro are rery interesting. On the north, in passing from St. Lonis River to Grand Portage, the gabbro is in contact for a long way with the upper [luronian, then for many miles with the sereral members of the lower Huronian and the Archean, and finally for many miles again witl the upper IIuronian. It thus euts cliagonally across the upper Huronian in its northern and southem parts and in passing toward the center of the area goes through the lower Huronian and deep into the Arehean.

Evidence of its intrusive character is afforded by its coarse erystallization; by the presence of numerous subordinate bosses aud dikes, offshoots of the gabbro mass, in the Ifuronian series; by the inclusion of isolated masses of upper Huronian near its margin and the profound metamorphic effects of the gabbro, the rocks being changed to schists or gneisses or even to completely granular crystalline rocks for distances up to half a mile or a mile from the main gabbro mass, an effect not to be expected from a rapidly cooling extrusive: and finally loy the higher density of the gabbro than of the intruded rocks.

\footnotetext{
a Elftman, A. 11., The geolngy of the lieweenawan area in northeastern Minnesola: Am. Geologist, vol. 21, Isgs, p. 145.

b Lawson, A. C., Sketch of the constal topogriphy of the north side of Lake superior: Twentieth .Inn. Rept, Geol. and Nat. Ulist. Survey. Minnesota, 1\$9.3, 1) 130.

c Clements, J. H., The Vermilion iron-lyearing district of Minnesota: Mon. U. S. Geol. Survey, vol. 45, 1903, pP. 402-403.
} 
The relations of the gabbro to the lavas of the coast have not been satisfactorily determinerl. Their contact is mainly in the plateau of the interinr, is very poorly exposed, and hils not been sufficiently studierl. However, it is believed that when these relations are worked out it will be found that the gabbro is intrusive and has produced profound metamorphic effects.

If this inferred intrusive relation is confirmed, the Dulutl gabbro is a great laccolith, which has as a basement the IIuronian and Arehean and as a loof the Keweenawan lava flows. 'The relations of the Duluth gabbro to the Puckwunge conglomerate at the base of the Keweenawan and to the earlier Keweenawan lavas have not been established. Until this is done it is impossible to gain any defnite conception as to how far Kieweenawn time had advanced before the appearance of the gahbro. If the Duluth gabbro is interpreted as a laceolith it surpasses in magnitude any other yet described. With a maximum diameter of 100 miles, if its thickness has approximately the ratio shown in the typical haccoliths of the Henry Iountains, ${ }^{a}$ the thickness would be 75,000 feet. If an average dip of $10^{\circ}$ for 50 miles on the north shore is assumed the thickness would figure 45,000 feet.

The intrusion of so vast a mass of material must lave required a long time. The parts carlier intruded were doubtless solidified long before magma ceased to enter. Thus, offshoots of these later parts would be found as dikes in the carlier solidified parts. There would be great variation in its coarseness of crystallization. Ample tine would be allorded for differentiation by fractional crystallization, separation by gravity, and other processes, and thus is explained the structural complexity of the gabbro and its great rariation in mineral and chemica character.

\section{THE BEAVER BAY AND OTHER LACCOLITHS AND SILIS.}

Intruded in the lavas of the Minnesola coast are a great many laccoliths or sills of diabase. These intrusive rocks are especially prevalent in the lower part of the lavas, ant particularly in the part below the Temperance River gromp. In texture these rocks vary from diabases to gabbros and include the so-called black gabbros of Irving. ${ }^{b}$ The diabases in many places show a remarkable luster mottling due to the inclusion of numerous individuals of plagioclase in large indiviluals of angite. Not uncommonly the augites are several inches in diameter and include hundresls of lath-shaped feldspars.

Many of these laccoliths and sills were supposed by the earlier geologists to be lava flows, but when examined closely they are found to cut the lava beds by passing gradually across their edges and by sending out dike offshoots. In not a few places they show a distinet columnar structure at right angles to their borders.

The local steep dips of the lava bels mentioned in the previous section are apparently all due to the influence of the intrusive masses and thus their exceptional character is explained.

A trpical illustration of these laccoliths is seen at Beaver Bay. The center of this laccolith extends from a point near Bearer Bay to a point near Two Harbors Bay. In this distance it occupies the entire coast. Neither its top nor its bottom is seen. In this part it is not luster mottled but is the coarse black gabbro of Irving. ${ }^{b}$ Its central part is sheeted and in general has a coarse or imperfect colummar stmcture at right angles to the horizon or nearly so. There it is found in association with the lavas farther east and west, as at Split Rock and Beaver Bay, its structure corresponds with the bedding of the amygdaloids, so that it was matural for Irving to regard it as a bedded flow, although even he recognized that at some places it cut the amygdaloids in a curious way. Indeed, locally it cuts the amygdaloisls in a most intricate fashion, following the joints, winding around the blocks, intruding itself as films between the plating of the amygdaloid, but always with sharp contacts. It is a significant fact that near the lavas the laccolith is luster mottled. Very close to the amygdaloil it is locally fine grained. In places it retains its coarse texture, even in narrow stringers. The laccoliths and sills, being resistant rocks, usually make the major headlands of the coast, just as the lavas usually constitute the bays.

a Gilhert, f. K., The geology of the IIenry Mountains, 2d ed.: U. S. Geog. and Geol. Survey Rocky Mtn. Region, 1850, p. 55.

$b$ Irving, R. D., The copper-l,earing rocks of Lake Superior: Mon. U. S. Geol. Survey, vol. 5, 1883, 4 p. 267-268. 
The lugan sills mul capping rocks in the Animikie and Kewernawan of northeastern Ninnesota should be partioularly mentioned. These are doubtless to be correlated with the great gabhro mass. In fact, in the Gunflint Lake district they seem to be direetly connected. To these sills are tue the step topography of this regiem. Wilson "has concluded that farther to the cast in the Nipigon basin some of the capping steps instcal of boing sills are really flows. It is possible that this conclusion may be applied to part of the capping rocks in northenstern Minnesota.

\section{ANORTHOSITES.}

The anorthosites of the Minnesota coast early attracted attention hecause of their lorilliant light color. They may le well seen at Split Rock, Bearer Bay, and Carlton Peak. It these places a large portion of them are inchusions in the basie laccoliths and sills, such as the Beaver Bay laccolith. Indeed, at many places they form a stuce in this diabase laccolith. In size the inclusions range from those which are minute, being no more than indivilual crystats of feldspars, to great masses 50 or 60 feet in diameter. In addition to these masses, which are plainly inchisions, there are other masses which are so large that they can not be asserted to be inclusions. 'These are mantled by the Beaver Bay laccolith, as described by Lawson, ${ }^{b}$ the relations at the bottom, lowerer, not being exposed. Some of these masses on the Irinnesota coast are as large as a cathedral, and the largest masses are found at Carlton Peak, the different points of which are composed entirely of anorthosite. The anorthosite inclusions are not contained in the central part of the Beaver Bay laccolith, but in its upper part, where it is in contart with or near the amyglaloids.

The relations above described conelusively show that the anorthosite, as a rock, antedated the incluling rocks. Lawson ${ }^{c}$ has interpreted this to mean that the anorthosite markerl a pre-Keweenawan terrane, but from our point of view the anorthosite is but a facies of the great Duluth gabbro mass which had been segregated hefore the diabase intrusions (see p. 372), and therefore has been inchuded in the diabase, as above described.

It is conjectured that the rery abundant diabase laccoliths and sills at Beaver Bay and other localities are but later offshoots of the original reservoir of magma from which the Duluth gabbro was also derived. The alliance between the diabase intrusives of the coast and the Duluth gabbro is shown lye their chemical and mineralogical likeness.

\section{BASIC DIRES.}

Diabase dikes cut the lavas and sills at mumerous places. As a rule they are nearly rertical. Inny of them lie approximately at right angles to the coast, and are likely to make projections into the water. Others run approximately parallel to the coast. These dikes conform to the sets of strike and dip fractures which were produced by the deformation. Commonly these diabase likes are less than 50 or 60 feet across. At some places they have a columnar structure at right angles to the walls, parallel to the bedding of the lavas, and consequently at right angles also to the columnar structure of the laceoliths.

\section{ACIDIC ROCKS.}

Along the northwest shore of Lake Superior and back from the coast are many areas of acilic rocks, collectively mapped as red roek, hecanse of their prevailing red color." the red rock consists of intrusives, mainly granite and augite syenite, and their equiralent effusires. quartz porphyry. These are later than the associated hasic extrusive and intrusive rocks. succeding the Duhuth gabloro and the diabuse of the Beaver Bay laccolith. The red rocks range in size from consideralble masses to minute stringers. In many places the intrusives intricately cut the hasie rocks. This is well illustrated at Beaver Bay, where hoth the amyoglaloidal havas and the diabase are intruded. Dikes of the red rock, great and small, cut the diabase

a Wllson, 1. W. G., Feoloty of the Nipizon basin: Canada Dept. Mines, feol. Survey Branch, Memoir No. 1. 1910, pp. 95-9t.

b Lawson, . . C., The anorthosites of the Minnesota coast of Lake superior: Bull. Geol. and Nal. Hist. Survey Minnesota No. S, In93, 13. It. cldem, p. 19.

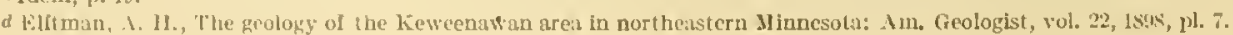


through and through, and have produced an important exomorphic effect. Where thus altered the diabase grades into a rock of a somewhat more acidic aspect and becomes the orthoclase gabliro of Irving. ${ }^{a}$ Wherever we have seen this rock it is but a facies of the diabase, produced through the minute penetration of the acidic magma of the red rock. It is clear that the chemical composition of the diabase las been affected by minute penetration of the aciclic magma and its emanations.

\section{KEWEENAWAN ROCKS IN TIE CUYUNA DISTRICT OF NORTH-CENTRAL MINNESOTA.}

Granite, diabase, and gabbro cut the slates of the Animikie in the great north-central area of Minnesota, including the Carlton, Cloquet, Cuyuna, and Little Falls areas. Being later than the Animikie, they are probaloty to be correlated with the Keweenawan intrusive rocks of northeastern Mimmesota. They are probably to be regarded as the plutonic equivalents of the Kícweenawan flows. In the Curyuna district there is also a thin layer of anygdaloidal acidic rock, 15 feet thick, resting upon the eroded edges of the slates and iron-bearing formation of the $\Lambda$ nimikie group. Drilling in this district discloses many masses of basic and acidic rock intricately associated with the slates of the Animikie, but the relations are not yet determined.

\section{THICKNESS OF TILE KEWEENAIVAN OF MINNESOTA.}

Irving, ${ }^{b}$ in his monograph on the copper-bearing rocks of Lake Superior, makes a formal division of the Keweenawan of the Minnesota coast into six groups, for which he estimates thicknesses as follows, from the top down:

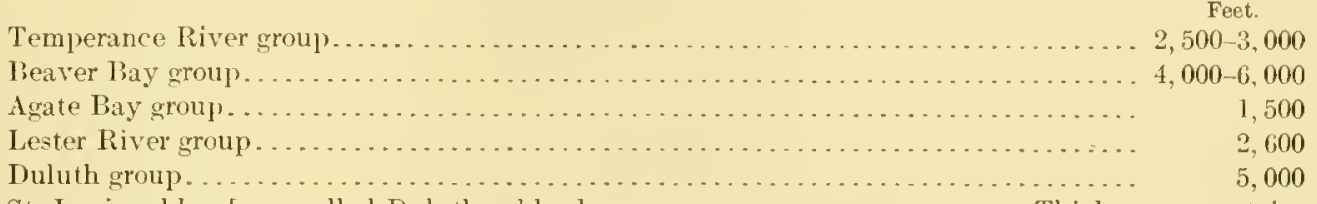

St. Louis gabbro [now ealled Duluth gabbro]..................... Thickness uncertain.

Excluding the gabbro, Irving ${ }^{c}$ estimates the total thickness to be between 17,000 and 18,000 feet. It is to be remembered that these estimates of thickness include large masses of intrusive rocks, as, for instance, the Duluth gabbro and the diabase of Beaver Bay. Also it is far from certain that the lavas on the Minnesot a coast have the regularity of superposition supposed by Irving. Finally, it is uncertain what part of the present dip of the lavas is initial.

Elftman, the one other geologist who has made an extensive study of the Keweenawan of the Minnesota coast, gives the following order: ${ }^{d}$

1. Later diabase member.

2. Temperanee River member.

3. Red Rock member.

4. Beaver liay diabase member.

5. Gabbro member.

This is the structural order. It is clear that the order is only partly one of age, for before the gabbro and other laccoliths and sills could be intruded in the Keweenawan a certain amount of sediments and lavas must have been built up. This succession, as well as that of Irving, ${ }^{b}$ ignores the Puckwunge conglomerate.

Elftman supposed that between the "Temperance River. member" and the "Red Rock" member there is a considerable unconformity, because at the bottom of the "Temperance River member" is a conglomerate 100 feet thick. This conglomerate contains fragments of diabase similar to the diabase of Beaver Bay, and also many fragments of red rock, indicating

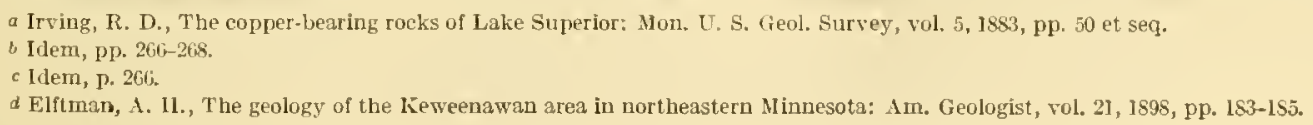


that these lavas were fomed before the deposition of the "Temperance River member." Is the "Temperance River member" is eut by other diabase dikes and by red rocks, howerer, there is no rason to bolieve that the supposed unconformity is different from that marked clscwhere in the Kieneenawan by the appearance of considerable heds of sediments. The rolranic epord had not ceased.

In view of the great uncertainty as to the exact succession, relations, initial dips, and faulting of the Uinnesota rocks, it is amost impossible to give any estinate of their thickness. Probably if the litras and sediments only were considered, the thickness would he very much less than the amount that Irving ${ }^{a}$ mentioned, but if the thickness of the intrusive rocks, including the Duhuth gabbro, were computed, and this addert to the thickness of the extrusives, an amount rastly in exeess of 20,000 feet would be otitained.

\section{NORTHERN WISCONSIN AND EXTENSION INTO MINAESOTA.}

\section{DISTIRIBUTION.}

The Keweenawan roks of northwestern Wiseonsin and their extension into Minnesota include an area estimated at over 5,000 square miles. The greater extent of the area is in a northeast-sonthwest direetion. At the southwest end the Paleozoie strata make a deep embayment, thus partly dividing the area into two belts crossing St. Croix River. Farther to the southwest the Kewcenawan has been found by deep drilling at Stillwater, and it is not inpossible that the red sandstone found at St. Paul and to the southwest may belong to the same division. Granites of probable Keweenawan age occupy a considerable area in the Florence district of northeastern Wisconsin.

\section{STIRUTURE.}

The Keweenawan area of northeastern Wisconsin is a synclinorium, the axis of which extends southwest from (hequamegon Bay and at its southwest end bends more to the south. On the northeast, in the vicinity of Ashland and Clinton Point, the work of Thwaites ${ }^{b}$ in 1910 has disclosed minor folding and possibty faulting in this synclinorium, the stceper dips of the minor folds being to the north. On the southwest end of the district in Minnesota, along St. Croir River, the work of Grout ${ }^{c}$ has disclosed similar complexity of strueture.

The synelinorium is bordered for its entire length on the north by a fault against which the Cambrian is faulted down. The fault plane dips $35^{\circ}$ to $45^{\circ} \mathrm{S}$. It dies out in Bayficld County. The Lake Superior sandstone beds are buckled along the contact. It is not known to what extent the movement has been vertical or horizontal, although striations in at least one place point to a rertical movement. The net result in any case has been to bring the traps up orer the Cambrian or lake Superior sandstone. Minor dip faults have been noted in northern Iron County similar to those on Black River in Michigan.

The dip of the upper as well as the lower divisions of the Keweenawan is as high as $90^{\circ}$, but a rerages about $70^{\circ}$ to $80^{\circ}$ at the east end of the sonthern part of this area. In the bottom of the synclinorium, as has been noted, a series of minor rolls show dips up to $90^{\circ}$ on the north limbs and as low as $25^{\circ}$ on the south sides, while in the Ipostle Islands to the north the overlying quart $z$ sandstone (lake Superior) dips about $1^{\circ}$ to $5^{\circ} \mathrm{SE}$. To the west, along the symeline, the tips become less until inclinations of only $15^{\circ}$ occur, but in Minnesota much higher ones are recorded. On the north limb in Douglas ('ounty are found dips of $30^{\circ}$ to $70^{\circ} \mathrm{S}$.

\section{LOWER REWEENAWAX.}

At only one place in northern Wisconsin is the lower lieweenawan known to be exposed. This is in the southeastern portion of secs. 11 and 12, T'.45 N., R. 1 W., West of a small lake. At this point there is a considerable mass of coarse conglomerate, the pebbles of which are mostly

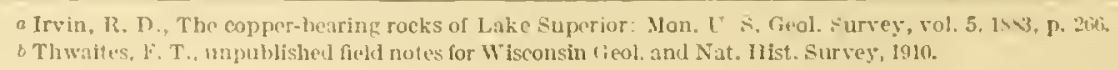

c Cirant, F. F., Contribution ta the petrography of the Keweenawan: Jour, Feology, vol. is, 1910, pp. $633-65 \%$. 
white quartz, some of them being 8 or 10 inches in diameter. Flint and black lornstone pebbles are also plentiful. This conglomerate gradesup into a coarse quartzite, and this into a fine-grained compact quartzite. Immediately to the north of the latter formution are the basic flows of the middle Keweenawan, and 400 or 500 feet south of the conglomerate are upper Huronian micaceous graywackes. The thickness of the conglomerate and quartzite cxposed is probalbly f $\mathrm{mom}$ 300 to 400 feet.

The quartzites adjacent to the Keweenawan in Barron County, Wis., may be in part liewecnawan. There are here at least two scries of pre-Cambrian quartzites, the upper of which is reddish, feldspathic, and not strongly consolidated, and has comparatively low dips. These facts, together with the position of the quartzites on the southeast side of the Feweenawan synchine, have suggested to Weidman ${ }^{a}$ the possibility that they represent lower Keweenawan sediments, but this has not been proved.

\section{MIDDLE KEWEENAWAN.}

The general characters of the middle Keweenawan in this region are substantially the same as those of northeastern Minnesota. The igneous rocks comprise both plutonic and voleanic masses. The volcanic series covers a much greater area than the plutonic rocks. It the sections which have been studied, Potato River, Tylers Fork, and Bad River, the igneous rocks, according to Irving, ${ }^{b}$ consist dominantly of beds of diabases, cliabase amygdatoids, and melaphyres. With the basic igneous rocks are subordinate masses of felsite and quartz porphyry. Interstratified with the lavas are subordinate beds of conglomerate and sandstone. Nlong the north sile of the Keweenawan of Wisconsin, in Douglas county, the lower part of the series is composed wholly of igneous rocks, but at higher horizons in the southeastern part of the dist rict conglomerates are interstratificd with lava flows. On the whole the interbedded detrital rocks of this area are apparently less abundant than on Keweenaw Point but more abundant than in Minnesota. The hithology of the interstratified conglomerntes and sandstones is in no respect peculiar.

So far as we know, there has been no approximately aceurate determination of the entire thickness of the lava flows and interstratified sediments of the mildle Kieweenawan in Wisconsin. Berkeyc has estimated the thickness of the Keweenawan eruptive rocks exposed along the St. Croix Dalles as 4,000 feet. Fall ${ }^{d}$ estimates a thickness of 20,000 feet on Snake and Kettle rivers in Minnesota.

On the south side of the syncline at the base of the Keweenawan in Wisconsin is a great basal gabbro, which in every respect is equivalent to the Duhuth gabbro deseribed on pages 372-373. This gabbro has been traced from Black River in Michigan as far west as R. $7 \mathrm{WV}$, but how much farther it extends is unknown. Thus it has an extent northeast and southwest of 60 miles or more. For most of the distance the belt is from 2 to 5 miles broad. The rocks of the underlying upper Ifuronian along most of this galbbro belt dip about $75^{\circ} \mathrm{N}$. If the thickness of the gabbro mass were calculated at right angles to the dip of the underlying Iuronian rocks, this would give a thickness of 9,500 to 25,000 feet.

It has been explained in connection with the Penokee-Gogebic district that this gabbro ents diagonally across all the formations of the Huronian series and down into the Archean; also that adjacent to the contact the upper Huronian rocks are profoundly metamorphosed, the Tyler slate into mica slates and mica schists, the iron-bearing Ironwood formation into actinolite-magnetite schists, the Bad River limestone into a coarsely crystalline tremolitic limestone. Further, within the Huronian and the Archean are smaller masses of intrusive gabbro which doubtless are offshoots or necks of the main mass. Thus in every respect the relations of this basal gabbro to the underlying rocks are the same as in northern Minnesota.

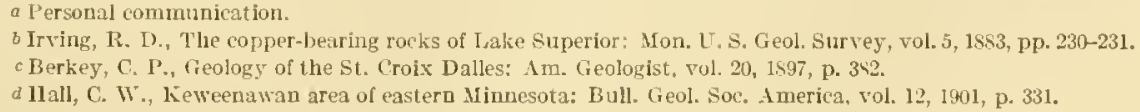


Unfortunately the relations between the gabloro mass and the lavas of the Keweenawan have not been closely studied. Irving ${ }^{a}$ pepresents this galbhro as feathering out into a series of points to the cast, sugresting rery strongry its intrusive character. However, his descriptions scarcely correspond to that distribution. He salys: ${ }^{a}$

The coarso gray gabloros os lurgely developed in the Tart liver country of Wisconsin, at the base of the series, present the appearance of a rertain sort of unconformity with the overlying beds. These gabbros, which lie immediatuly upon the Iluronian slates, form a belt which tajers out rapilly at both ends and seems to lie richt in the rourse of the diabase belts to the cast and weat, siure these belts, buth westward toward Lake Numakagon and eastwarch toward the .Iontreal IRiver, lie directly against the older rocks, without any of the coarse gal,bros intervening.

The coarseness of grain, the perfection of the erystallization, the abrupt terminations of the belts, the complote lack of structure, and the presence of intersecting areas of crostalline granitoid rocks led Irving ${ }^{b}$ to the belief that these rocks were not ordinary laras, but had solidificd at a great deptl.

The acidic rocks cutting these coarse gabbros are clearly intrusive.

The gabbro in Wisconsin, like the Duluth gabbro, is believed to be a great laceolith, which was intrulcel in Keweenawan time after a considerable thickness of Keweenawan lava beds had been built up, and, as in Minnesota, it roughly followed the contact at the base of the Keweenawan and penetrated diagonally across the lower formations as well as irregularly across the Keweenawn bels themselves. It has since been turned up at angles of $75^{\circ}$ or $80^{\circ}$ and truncated by erosion.

Gabhro on the north side of the Keweenawan trough in Douglas County, Wis., is deseribed by Grant, ${ }^{c}$ but its extent has not been deternined. It dips to the south and its relations to the lavas are similar to those of the gabbro on the south side of the Douglas County srneline. It is faulted on the north against the Cambrian rocks, which are on the duwnthrown side. It dips in the same direction as the Duluth gabbro, and the displacement of the fault is in such a direction as to show that it may have been originally entinuous with the Duluth gabbro.

\section{UPPER KEWEENAWAN.}

The upper division of the Keweenawan in this area consists of red sandstones, shales, and conglomerates, divided, in the eastern part of the district, into sereral distinct members. Beginning at the base are found conglomerate 300 to 1,200 feet in thickness, black shales up to 400 feet, about 19,000 feet of red arkose sandstone, grading up to more siliceous sandstone, red and green shales, and coarse arkose. Abore this is quartz sandstone, somewhat feldspathic at the base, nearly 4,000 feet thick, here called the Lake Superior sandstone. These beds appear to thin rapidly toward the wrst. These figures make no allowance for initial dip.

\section{RELATIONS OF THE KEWEENAWAN TO OTIER SERIES.}

The only places at which the relations between the Kieweenawan and lower series are shown are in Wisconsin. Here, as has been seen, the lowest formation of the Keweenawan is made up of conglomerate and coarse sandstone and is overlain by the lara flows of the middle Keweenawan. The coarse conglomerate of Potato River is evidence of the crosion interval between the Keweenawan and the upper IJuronian, but the magnitude of the uneonformily is realized only by a stuly of the relations of the two along the strike, which gives evidence of a large amount of prosion of the Huronian series before Keweenawan time. The details proving the grratness of this unconformity are given in the chapter on the Penokee-Grogebic clistriet (pp. 234-23i).

As to the relations of the middle Keweenawan with the Tpper Cambrian sandstone along St. Croix, Kettle, and Copper rivers (of llinnesota), there is no difference of opinion. The LPper Cambrian sandstone, in horizontal attitule, rests upon the steeply tilted and eroded

a dlon. L. S. ficol. Survey, vol, $5,1 \times+3$, pp. 155-15\%.

blem, p. 1.11.

c Grant, $I^{*}$. \& . I'reliminary report on the copper-bearing rocks ol Douglas Counly, Wis.: Bull. Wisconsin Geol. and Nat. Ilist. Surrer No. 6 (2d ed.), 1901, Dp. 31-32. 
edges of the middle Keweenawan rocks and bears abundant detrius from them. It is therefore perfectly clear that before the sandstone was laid down the middle Koweenawan had been placed at its present angles and had been profoundly eroderl. The relation is very well illustrated at Taylors Falls on St. Croix River, where the Cambrian sandstone is fossitiferous and las been ecrtainly determined as of Upper or Vliddle Cambrian age. The relations between the diabases and the Cambrian here are shown by figure 57 .

The relation of the upper Keweenawan feldspathic sandstone and the quartz sandstones, here called the Lake Superior sandstone, has long been a subject of dispute, but the discovery by Thwaites in 1910 of onterops on Fish Creek near Ashland has thrown new liglit on the question. At this point the layers are steeply inclined to the north, exposing about 1,400 feet of strata and diselosing a transition between the red shales, arkose sandstones, and conglomerates of the upper Keweenawan and the Lake Superior sandstone. A deep well at Ashland passes into these red shales at a depth of 2,670 feet.

A reexamination of Middle River in Douglas County north of the great fault showed that the sandstone berls are inverted. ${ }^{a}$ About 3,100 feet of strata have been turned up by the faulting, exposing mul-cracked and ripple-marked green and red shales and arkose sandstones of the usual Keweenawan aspect, grading above into the Lake Superior sandstone such as is found in horizontal attitude along the shore of the lake. On St. Louis River, Minnesota, ${ }^{b}$ a similar transition oceurs between red shales and brown sandstones. Clinton Point, where somewhat quartzose sandstones are found, does not belong to the Lake Superior sandstone but is the crest of a minor anticline in the lower beds. Nearly 2,000 feet of similar rocks lie some distance beneath the red shales on Fish Creek.

The contact with the flat-lying quartz sandstones (Lake Superior sandstone) along the north side of the area of middle Keweenawan in Douglas County has long been known to be a fault. The best exposures are on Black, Copper, Amicon, and Middle rivers. That on Middle River has been described above. At all other points the sandstone is turned up sharply for a short distance to the north of the fault, which dips, where exposed, $35^{\circ}$ to $45^{\circ} \mathrm{S}$. At all places the trap is intensely brecciated, but the sandstone is much less affected. On Black

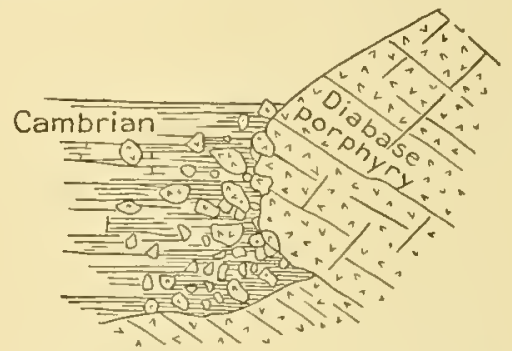

Figure 57.-Sketch showing unconformable contact hetween Keweenawan diabase porphyry and Cambrian sandstone at Taylors Falls, Minn. (After Strong.) and Amicon rivers the sandstone is conglomeratic for a few feet from the contact. The pebbles are usually small and are not matched in the neighboring igneous rocks.

Within the trap breccias are found large blocks of sandstone. The view in the past has been that this contact was an meonformable one along a fault scarp, and that movement had taken place along the fault since the deposition of the sandstone, thus complicating the simple unconformable relations. An alternative view, supported by considerable evidence, is that the conglomerate has been faulted up by parallel faults from conglomerate found at lower horizons in the sandstone, and in part draggerl up along the fault plane. The displacement must be at least equal to the thickness of the berls turned up at Nidlle River- 3.100 feet.

The significance of the relations of the Keweenawan to the Lake Superior sandstone is discussed on pages $415-416$.

\section{KEWEENAWAN GRANITES OF FLORENCE COLNTT, NORTHEASTERN WISCONSIN.}

The granite along the sonth side of the Florence district of northeastern Wisconsin is intrusive into green schists which are interbedded with upper Ifuronian slates. These granites are probably part of the same mass that intructes the Quinnesec schist of the Menominee district, where the relations are similar. These granites of northeastern Wisconsin, therefore,

a Grant, U.S., Junction of Lake Superior sandstone and heweenawan traps in Wisconsin: Bull. Geol. Soc. America, rol. 13, 1902, pp. 6-9.

o Winchell, N. H., A rational view of the Keweenawan: Am. Geologist, yol. 16, 1895, p. 150; Geology of Minnesota, vol. 4, 1899, p. 15. 
like those south of the Curuma district in central Nlinnesota, are to be regarded as the plutonic equivalents of igneous flows. In both areas these plutonic masses have greatly met amorphosed the invaded strata.

\section{NORTIERN MICIHGAN.}

\section{DISTRIBUTION.}

The Keweenawan rocks of northern Michigan ocenpy a broad belt running continuously from Ilontreal River, the boundary loctween Michigan and Wisconsin, along the bake shore to the outer extrenity of Liewernaw Point and including Manitou Island and Stannart liock. This belt ranges in breadth from 15 or 20 miles west of Lake Gogebie to about 6 miles at the onter part of Kewernaw Point. Approximately one-half of Keweenaw Point is occupied by rocks of the Kewecnawan series. The general strike roughly follows the coast. In passing

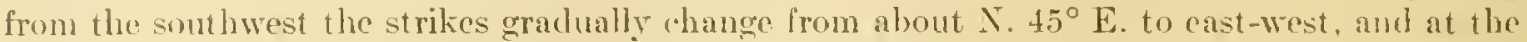
extreme outer part of the point the rocks swing south of east, here having a northwesterly strike. This curved outer area of the end of Keweenaw Point beyond Port age Lake corresponds almost exactly with the strike of the rocks. Except in one fold in the Porcupine Hountains the dips are always to the north or northwest.

The dips of the middle and lower divisions are in general lower toward the east end of Kewcenaw Point, the steepest dips ranging from nearly vertical on the Gogebic Range to $27^{\circ}$ at the end of the point. There is a somewhat regular decrease in the dip of each of the sections in passing from lower to higher horizons. The best illustration of this is furnisher by the section at Black River in Dlichigan, which shows a continuous succession from the base of the series to and inchuding a part of the upper sandstone. Aecording to Gordon, ${ }^{a}$ at the base of the series the dips are from $75^{\circ}$ to $78^{\circ} \mathrm{N}$., whereas the lighest strata show a dip of about $20^{\circ} \mathrm{N}$. The change in dip in passing from the lower to the higher members is gradual. Further illustrations are furnisherl by the sections on liewcenaw Point; for instance, at the Portage Lake section the dips of the lower beds are as high as $5.5^{\circ}$, whereas in the lower part of the upper series they have dropped as low as $7^{\circ}$. At the outer part of Kewcenaw Point the dips of the lowest part of the series there exposed are from $51^{\circ}$ to $57^{\circ}$, but according to Iubbard. ${ }^{b}$ the dips of the higher beds constituting the outer front of the point do not average more than $23^{\circ}$.

In this region, as in northern Wisconsin, the lower, midelle, and upper Keweenawan are all represented. The gencral characterization which has been made for these dirisions (see pp. 376-379) applies to the northern Michigan area.

The Keweenawan of Michigan will he more specifically discussed below.

\section{KEWEENAW POINT.}

\section{SUCCESSION AND CORRELATION.}

On account of the occurrence of great and raluable deposits of copper on Keweenaw Point, more detailed studies hare been marle of this than of any other of the Kewecnawan districts, with the possible exception of Isle Royal. Areas which have been studied with considerable detail are the outer part of Lieweenaw Point, especially Eagle River, by Marvine cand Hubbard: ${ }^{c}$ Mount Bolsemia, by Wright: ${ }^{e}$ and the Portage Lake area, where the important deposits of copper oecur, by Pumpelly and IIubhard.d Studies of intermediate nreas have hecn less detailed but still sullicient for Irving, $g$ Seaman, ${ }^{h}$ and others to attempt to correlate the different formations for Kéweenaw Point. (Soe Pl. XXYTII.)

\footnotetext{
a cordon, IV. C., assisted by A. C. Lane, I geologieal section from Bessemer down Black laver: Rept. Michigan fieol. Surves for 19ki, 1907, 1. 4 tiis. 

Below are given the successions of Irving $^{a}$ for the entire point and of Ilubbard ${ }^{b}$ for the outer part of the point, with their correlation.

$$
\text { Scetions of rocks on Kewecnaw J'oint. }
$$

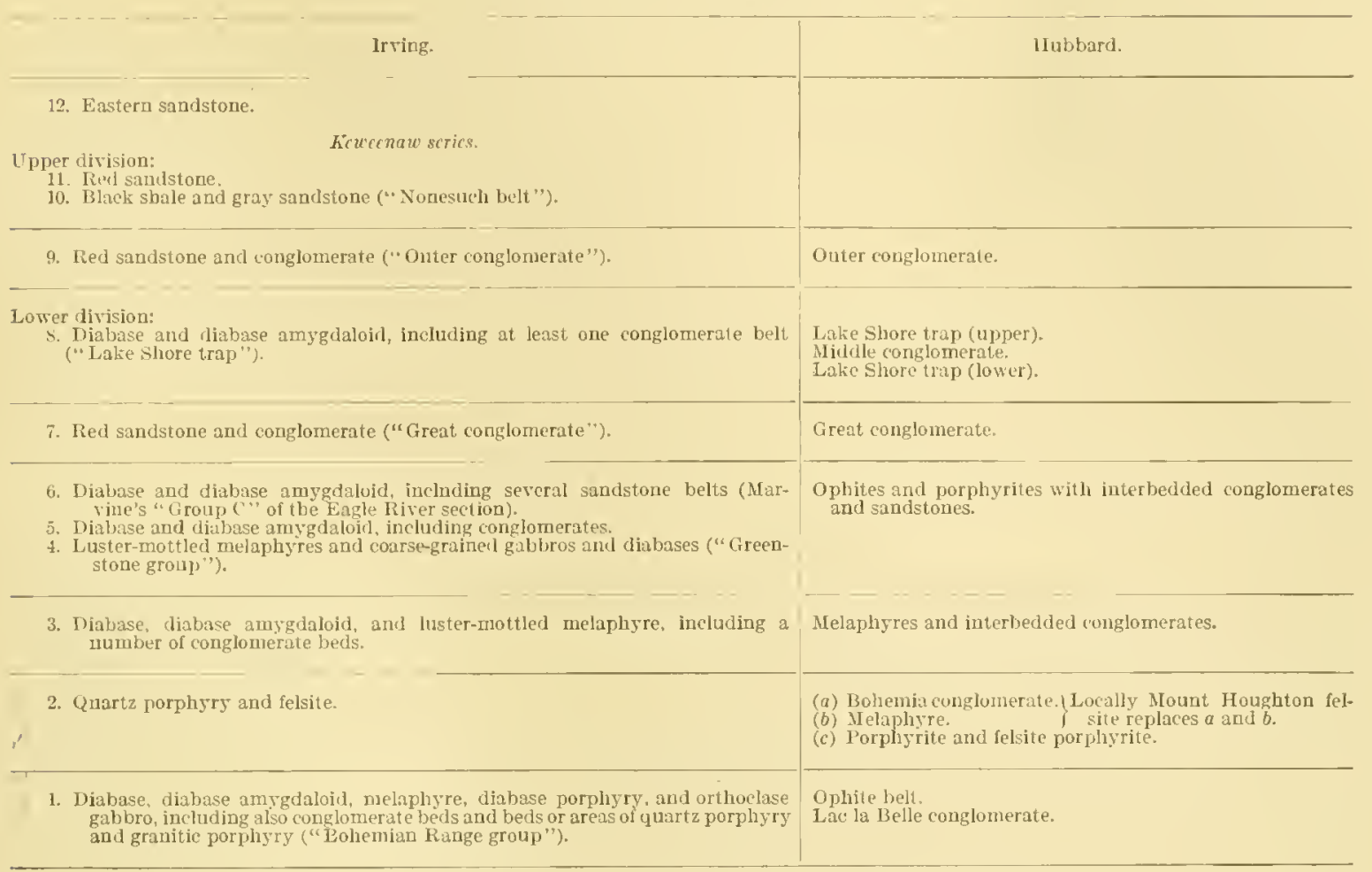

LOWER AND MIDDLE KEWEENAWAN OF KEWEENAW POINT.

ORDER OF EXTRUTSION.

Hubbard ${ }^{c}$ has studied the order of extrusion for the outer part of Keweenaw Point. He finds the oldest lavas to be melaphyres and these are interstratified with melaphyre conglomerates. Following the melaphyres are porphyites and interstratified with the porphyrites are porphyrite conglomerates. Next come the felsites and interstratified with these and above them axe the felsite conglomerates. All these rocks are at very low horizons. Above them lies a great mass of melaphyres, ophites, and porphyrites with their rarious interbedded conglomerates and sandstones. Still higher are the "Great" conglomerate and the "Lake Shore" trap with the "Niddle" conglomerate. Thus IIubbard's studies of Feweenaw Point led him to the conclusion that there was a regular order of extrusion of the igneous rocks-(1) basic melaphres, (2) intermediate porphyrites, (3) aridic felsites and porphyries, and (4) the upper basic rocks represented by melaphyres, ophites, porphyrites, etc.

\section{PRESENCE OF BASIC INTRUSIVE ROCKS.}

Curiously the descriptions of the basic rocks of Keweenaw Point mention no interstratified intrusive sills, all the basic rocks being assumerl to be flows. However, certain groups, as for instance the greenstone group, are described as contrasting sharply with the rocks above and below them. They contain no intercalated amygdaloidal beds. They consist of massive layers. In texture they vary from diabases to gabbros. Although this and other masses were not sufficiently examined to make any positive assertion possible, it is our impression that a large part of the greenstone is an intrusive sill. The other masses of rocks which have been described as gablbro or orthoclase gabbro, especially those on the southwestern part of the point, are intrusive. 
On Nount Bohemia the intrusive gabbro has produced contact effects on the invader ophites. The problem of separating the intrusive basic rocks from the extrusives remains partly to be accomplished.

ACIDIC INTTRESIVE ROCKS.

IIubbard's ${ }^{a}$ studies show that the felsites of Bare Hill and West Pond at very low horizons are intrusive. The [olsite of Bare Hill, when mapperl in cletail, is seen to cut across the berls of other rocks, although in a single section near its center it would seem to be interstratified. The felsite of West. Pond has disturbed the beds in its immediate area. 'They are broken into frachments and in places are even changed into typical breccias, some of which are almost undistinguishable from the conghomerates. These intrusive rocks were perhaps correlative with the extrusive felsites of Mount IJoughton and others of approximately the same age found at higher horizons. The intrusive nature of these felsites explains the absence of pebbles derived from them in the melaphyre conglomerates interstratified with the melaphyres adjacent to and at horizons above the felsites. Thile some of the felsites and porphyries are extrusive, even these have a very minor extent. This is very well illustrated at Mount IJoughton, where the felsite locally replaces the "Bohenia" conglomerate and the melaphyre flow below. (See preceling table.)

NATURE AND SOTRCE OF DETRITAL MATERIAL.

It is well known that the felsite and porphrry pebbles are very prevalent and in places dominant in the numerous conglomerate beds interstratified with the basic rocks at the higher horizons of Keweenaw Point, and even in the "Great" conglomerate, "Middle" conglomerate. and "Onter" conglomerate. There seems to be an enormous amount of felsite and porphyry detritus in the sediments as compared with the known original areas from which it may have been derived. Doubtless a part of the acidic detrit us of Keweenaw Point may have been derived from porphyries farther east and west than the point, as, for instance. those of the Stannard Rock area to the east and the Poreupine Mountains to the west. But also the lack of large areas of felsites may be due to the exceptional erosion to which they have been subjected because of their viscons and bunchy character, which raised them and made them the objects of excessive attack. Finally, a considerable portion of the acidic detritus may have been in the form of voleanic fragmental material that was scattered far and wide from the original cones from which it was ejected and therefore never formed a part of any continuous solid intrusion or extrusion.

Lane ${ }^{b}$ states that the detritus of several conglomerates, especially of the "Great" conglonerate, inchules numerous pebbles of intrusive red rock and gabbro. He sars that if he is correct in his identification of the materials there is eridence of an erosion of sufficient magnitude eluring millle Keweenawan time to expose these plutonic rocks at the surface. He also finds agite pebles which he believes to have formed in the lavas lower in the series, and thus he concludes that extensive metasomatic changes have taken place in this part of the series hefore the higher interstratified conglomerates were kaid down.

\section{VARIATIONS IN THICKNESS OF SEDIMENTAIR BEDS.}

Close studies of Keweenaw Point show rapid rariations in the thickness and character of the interstratified sedimentary bets. These have been especially studied in the mineralized area. Many illustrations could be given, lut perhaps one of the clearest is that of the "Great" conglomerate which IJubbarl ${ }^{c}$ says thins 400 to 700 feet in passing from Copper Harbor to a point 7 miles farther east. Not only do the beds change in their character, but a single seclimentary berl may be split into several beds separated by laraflows. Thus in the Bohemia hasin a conglomerate is first split into two parts by a bed of melaphyre and the lower part is in turn split into two beds by a mass of felsite. The beds are in general lenticular, broadly considered, hut some of these lenses may be only a few miles in length, as illustrated by the Calumet and llecla conglomerate.

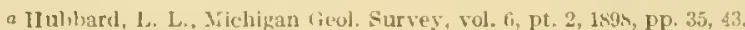

o Lane. A. C.. (icology of Keweenaw l'oint: I'roc. Lake Superior Min. Inst., vol. 12, 1907, p. 93.

c Up. cit., p. t.s. 
FAULTS.

Hubbard's ${ }^{a}$ detailed studies of small areas have led also to the conclusion that the midlle Keweenawan has been displnced by a very large number of dip faults, the throws of which, however, are of ninor extent. These have been worked out in great detail with reference to the melaphyre and melaphyre conghomerates at West Pond. Here are figured no less than twelve cross faults, the throws of which, lowever, are not sufficiently great to be traced into the thick overlying formations, and hence they do not appear on his general map. Similarly Lane ${ }^{b}$ states that there are a large number of small transverse faults in the mining district. The throws of most of these faults are not more than 25 feet and very few exceed 50 feet. However, the presence of many faults at each of the two areas that have been closely studied on Keweenaw Point suggests very strongly that when like thorough studies are made of other areas on this point similar faulting will be found.

In the mining district there are also many slide faults. According to Lane, ${ }^{c}$ the dip of many of these slide faults is somewhat steeper than the bedding, so as to cut diagonally across the beds at acute angles. As to the direction of movement along these dip faults, he thinks it is more commonly down than up on the hanging-wall sicle, for berls are more likely to le cut out than repeated. Hubbar ${ }^{a}$ described one very important slide fault, the major movement of which, instead of being parallel to the dip, is nearly parallel to the strike. This is the fault at the top of the Kearsarge conglomerate, which is well illustrated in the Central mine. Hubbard makes a calculation of throw and reaches the conchusion that "the part of the Keweenawan series that lies above the Kearsarge conglomerate has moved from its original position, in a northerly direction, horizontally, about 2.7 miles, or along an inclined plane its equivalent distance of about 2.9 miles." Such a slide fault as this approaches the ordinary strike faults, the chief difference being that of hade, the bedding fault having such a hade as not to intersect the bedding, whereas ordinary strike faults do intersect the bedding. Although the Kearsarge slide fault is nearly in the direction of the strike, it is believed to be probable that the most common direction of movement in the fuults of this area is parallel to the dip. In this case the movements are largely explained by the natural adjustments which are necessary when a set of beds. is folded.

\section{UPPER KEWEENAWAN.}

The upper Keweenawan consists, from the base upward, of three members-(1) the "Outer" conglomerate, (2) the Nonesuch shale, and (3) the Freda sandstone.

The "Outer" conglomerate is found at the north side of the enst end of Keweenaw Point as far as Gate Harbor, where it passes under the water; it reappears on the point some miles west of Eagle River and continues along to the point and westward through Michigan into Wisconsin. It is in no respect different from the underlying "Great" conglomerate or other conglomerates interstratified with the Keweenawan, except that, according to Lane, ${ }^{d}$ it contains near its top fragments derived from the jaspery and other furonian formations.

The Nonesuch formation ranges from a soft, fine-gramed, highly argillaceous shale to a sandstone. The shale is predominant, the sandstones being interbedded. In color the shale is dark purplish gray to nearly black and the sandstone dark gray to black. The thin sections of the sandstones show detritus from the porphyries and other acidic original rocks of the Keweenawan. With these materials in all the sections is mingled more or less basic detritus. Indeed, the basic material is usually abundant and not uncommonly becomes dominant. The basic material is more abundant in the darker-colored rocks. In these rocks there is also a plentiful calcite

a Hubbard, L. L., Michigan (reol. Survey, vol. 6, pt. 2, 189s, pp. 87-91.

b Lane, A. C., Geology of kieweenaw Point: Proc. Lake Superior Mlin. Inst., vol. 12, 1907, pp. 83-84.

c ldem, pp. $84-85$.

d Lane, A. C., Jour. GeologJ, vol. 15, 1907, p. 690. 
cement filling all interstices between the fragments. The basic cletritus appears in the shape of partickes of the balsic jocks. showing more or less plainly the several ingredients, always mucle altered, and of purticles of the singrle minerals - augite, almost wholly altered to a greenish substance, triclinic foldspar, and maenetite. The formation also contuins materials which must late bern contributed by the IIuronian, Kieweenawan, and Laurentinn rocks. The Nonesuch shale therefore dillers from the sedinents interstratified with the Keweenawan in the grtatly decreatsed amount of acidie material, the abundance of basie material, and the presence of detritus derived from othere formations than the keweenawan.

The Fredat sandstone is in no respect dillerent from 1 he sandstone of the lirger areas in Wisconsin, which are al cont inuation of the sandstome in Alichigan. It need here be only remarked that the materials have the same varieties of sources as the Nonesuch shale, but the muteria derived from the basic lavas secms to be even more prominent.

\section{RELATIONS TO CAMBRIAN ROCKS.}

On the north and west sides of the Keweenawan the series nowhere comes into contact with the C:ambrian. The possible relations between the two are discussed in another place. (Sec pp. $41 ;-116$.

On the sonthenst side the Fewecnawan is in contact with the Cambrian. Irving and Chamberlin, ${ }^{a}$ in their bullet in on this contact, conclude that the sandstone was deposited unconformably against an ancient fault scarp of Kicweenawan rocks and that it was subsequently faulted down along the old fanlt plane. This relation is apparently similar to those observed at the fault on the north side of the Keweenawan sycline in Douglas County, Tis., and thence southwest ward into Minuesota.

\section{MAIN IREA WEST OF KEWEEAIW POINT, INCLUDING BLACK RIVER AND TIE PORCUPINE MOUNTAINS.}

A rery detailed stuly of the entire Keweenawn section at Black River has been made ly Gerdon. ${ }^{b}$ Accorling to him, this river shows the following descending succession, ${ }^{c}$ the classification into middle and lower Keweenawan being added by us.

Section of Kewenawan rocks at Black River, Mich.

Upper Keweenawan:

1. Upper sandstone lacking. Feet.

11. Nonesuch formition . . . . . . . . . . . . . . . . . . . . . . . . . . 500

III. Onter conglomerate................................. $5,0,0$

Midlle Keweenawan:

IT. Lake Shore trap, consisting of five flows, having from the top downward the following thicknesses: $35,35,115,85,130$ feet, resiuetively......... 400

V. Conglomerate.................................... 350

V1. Nlixed eruptives and sedimentaries . . . . . . . . . . . . . . . . 5,500

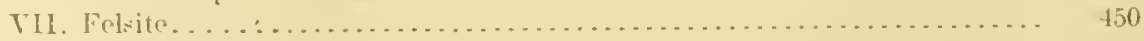

VIII. Eruptives with very few sedimentaries. . . . . . . . . . . . . . . 26,000

IX. Mixml eruptives among which are conspicuous labtalorite porphyrites.... t, s00

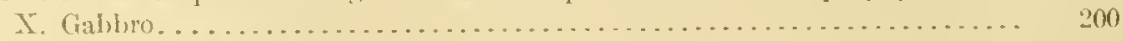

XI. Melaphyres and labradorite porphyrites that are not conspicuous....... 4,500

$-42,200$

Lower hewennawan:

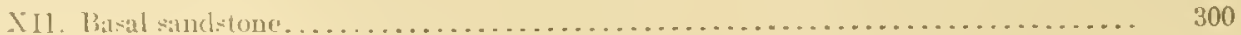

a frving. 13. D., and ("humberlin, T. C, Ohservations on the junction hetween the Eastern sandstone and the Keweenaw series on Keweenaw

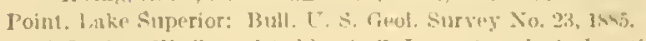

biorton, W. C.. assisted hy . . C. Lane, A geologieal section from Bessemer down Black River: Kept. Michigan Geol. Survey for 19Mi, 1907, pp. 3978.517.

cLlem, 1). 421. 
Throughout the Black River section there is no evidence of a physical break in the Keweenawan. Lane, ${ }^{a}$ becanse of the character of the formation, suggests that possibly there might be a slight break at the base of the Nonesuch shale, but Gordon's iletailed descriptions give no evidence in support of this view.

It is known that in this district dip faults occur. According to Gordon, ${ }^{b}$ at least four such faults traverse the Trap Range north of Bessemer, the throws of three of which are 80, 350, and 1,500 leet, the throw of the fourth not being determinable. It is very likely that strike faults occur, for great strike faults oecur elsewhere in the Keweenawan. (See p. 383.) Though such laults have not been detected, they may very readify oceur at any of the very numerous stretches of the river where exposures are lacking. The presence of fanlts at these places is very probable because of the brecciation and consequent more easily erosible condition of rocks along fault planes.

In the Porcupine Monntains the same divisions of rocks oceur as in Keweenaw Point, but the order is only in a general way similar to that on the point, the diflerence being that comparatively high in the series are large masses of quartz porphyry and felsite, and the acidie rocks at these horizons perhaps larrely explain the source of the abundant felsite, quartz porphyry, and angite syenite pebbles in the "Great," "Mliklle," and "Outer" conglomerates.

In the Porcupine Mountains the great synclinal basin of Lake Superior, which controls the general dip of the Kieweenawan rocks about the lake, is disturbed by a subordinate fold, so that in a section diagonally northeast and southwest across the mountains the lower beds are regarded by Irving ${ }^{c}$ as repeated. Ile shows a subordinate anticline and syncline between the monoclinal beds north of Lake Gogebic, at the south sicle of the middle division and the northward-dipping beds at the lake. This area is a forest-covered one in which the exposures are somewhat imperfect, and it is hinted by IIubbard ${ }^{d}$ that possibly the abundant felsite and porphrry here are intrusive, as they are at Bare Hill and West. Pond, and that the unusual structure may be explained by these intrusive masses rather than by exceptional orogenic morement. This suggestion is made because of very considerable disturbances in the regular bedding of the rocks about the intrusive felsite of Bare IIill. The Porcupine Mountains are now being studied in detail by F. E. Wright for the Michigan Geological Survey, but the results of his work have not been available in the preparation of this monograph.

The upper Keweenawan of this area is the same in all respects as that described for Keweenaw Point.

\section{THE SOUTH RANGE.}

Beginning in T. 47 N., R. 44 W., Michigan, from the lower Keweenawan, which there consists of diabase, diabase amygdaloid, melaphyre, and a few coarse interbedded thin conglomerates, an arm projects to the east and south nearly to Gogebic Lake and east of this lake again for some distance. This is the so-called South Range. It is separated from the main range of the Keweenawan by the Jacobsville or "Eastern" sandstone. At the enstern point the South Range is 18 miles south of the northern area of the Keweenawan. This range varies from less than half in mile to 2 miles or more in brealth. The rocks of the South Range dip to the north at angles of $30^{\circ}$ to $50^{\circ}$. At sone places at the base of the Keweenawan series in the South Range there is a coarse sandstone. At other places the lowest rock is a basic lava. Locally sediments are interstratified with the lavas. Thus the conditions prevalent in early Keweenawan time, as indicated by the rocks at the base of the Keweenawan of the Sonth Range, are similar to those of other districts. In no respects do these rocks differ from those near the base of the Keweenawan to the west. West of Gogebic Lake the Keweenawan rocks rest directly upon the upper Inuronian. The western part of this belt of Keweenawan rests directly upon the Tyler slate. When followed to the east it is seen to pass diagonally to lower and lower horizons, until at Sunday Lake it is in contact with the Ironwood formation. These relations have been more fully lescribed in connection with the Penokee district.

a Lane, A. C., Jour. Geology, vol. 15, 1907, p. 691.

$\checkmark$ Op. eit., pp. 464 465.
- Irving, R. D., Mon. U. 8. Geol. Survey, vol. 5, 18*3, pp. 209-225.

d Hubbard, L. L., Geol. Survey Michigan, vol. 6, pt. 2, 1898, pp. 5-S.

$47517^{\circ}-$ VOL $52-11-25$ 
It is believed that the separation of the South Range from the main range is due to a great strike fault between the two which results in a repetition of the beds of the main range in the South liange.

\section{ROCKS OF POSSIBLE IEWELNA WAN AGE IN OUTLYING AIEAS.}

Certain recklish feldspathic and little-consolidated sandstones of low dip, lying unconformably across the end of the upper Ituronian of the Felch dlountain trongh, may possibly be chassed as lieweenawan. Similar rocks are known also in the Sturgeon trough to the north.

\section{TIICINESS OF THE IEWEENAWAN OF MICHIGAN.}

Irving ${ }^{a}$ gives an estimate of the thickness of the Keweenawan of northern Michigan at Eagle River and Portage Lake, and Gordon ${ }^{b}$ estimates a section on Black Rircr.

\section{EAGLE RIVER SECTION.}

Irving's section at Eagle River, ${ }^{c}$ based largely on the detailed work of Marvine, is as follows:

Upper division:

Section of Keweenawan rocks at Eagle River, Michigan.

Outer conglomerate; porphyry conglomerate and sandstone; ahout............. 1,000

Lower division:

Lake Shore trap; very plainly bedded fine-grained diabases, strongly marked amygda-

loids, and one or more thin porphyry conglomerates; about. . . . . . . . . . . . . 1,500

Great conglomerate; porphyry conglomerate and sandstone................. 2,200

Marvine's group "c;" plainly bedded and separable fine-grained diabases, with strongly marked amygdaloids, predominatingly calcitic; and some 850 to 900 ieet, in all, of interstratified sandstones. . . . . . . . . . . . . . . . . . . . . . . . . . . . . . . . .

Marvine's groul "b," or the Ashbed group; made up mustly of thin, fine-grained diabases. which vary a good deal in appearance, but are generally provided with distinct amygdialoids; including some beds of the peculiar type known as ashbed diabase; also severa] scoriaceous amygdaloids, being interningled sandstone and amygdaloid; also one thin

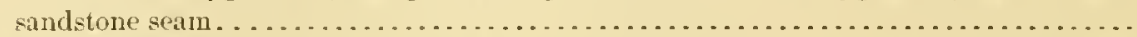

Marvine's group "a;" made up of relatively heavy heds without strongly devcloped anygdaloids; including one thin seam of sandstone . . . . . . . . . . . . . . . . . . . .

Greenstone group; made up of relatively heavy beds, without amygdaloids, of rocks for the wost part relatively conse grained; these belong mostly to the conrse-graincel olivine-free diabases and gabbros and to the luster-mottled molaplyzes, or fine-grained olivine-diabases, the greenstone at the base of the group leing of the last-named class. .

Sulggreenstone grou\}, in which all of the fissure-vein mines are working; having at top a thin conglomerate, the equivalent of the "Allouez" and "Albany and Boston" conglomerates in the Portage Lake district; composed of fine-grained diabases, with not very strungly developed amygdaloids; about. . . . . . . . . . . . . . . . . . . . .

Central Valley heds; the layers not well exposed, but evidently chiefly fine-grained diatbases and anygdaloids, with a number of thin porphyry conglomerates, in all respects like the overlying group; about . . . . . . . . . . . . . . . . . . . . . . . . . .

Bohemian Range beds; made up chiefly of dialoses and melaphyres in all respects like the higher layers, and including some of the usual purphyry conglomerates; but also in part made up of quartziferous porphyry, felsite, nonquartziferous porphyry, and coarsegrained orthoclas gabloro; in all, aluut. . . . . . . . . . . . . .

26,000

Of this thickness, the "Great" conglomerate and the ten eonglomerates and sandstones in "group c" together constitute 3,100 feet. These seliments are all in the upper 5,000 feet of the lower Keweenawan. The lower part contains only a few scams of detrital material. The lower five-sixths of the lower Keweenawan for this section is therefore almost exchusively voleanic, and of the total lower Keweenawan somewhat less than one-ninth is sedimentary, the remaining eight-ninths being igneous.

a Irving, R. D., The copper-bearing rocks of Lake Superior: Mon. U. S. Geol. Survey, vol. 5, 1s\&3, pp. 16r-197.

b Gordon, W. C., assisted by A. C. Lane, A geological section Irom Bessemer down Black River: Rept. Michigan Geol. Survey" for I9hk, 1907. p. 421 . 
PORTAGE LAKE SECTION.

At Portage Lake the section is as follows:

Upper division:

Section of Kewcenawan rosks at I'ortage Lake, a

Largely covered, but apparently for the most part red shales and sandstone; toward the base there is a considerable thickness (upward of 200 feet) of dark-colored, fine-grained sandstone and black shale, in which the nsual porphyry detritus is mingled with more or less basic detritus; the lowest layers are also conglomeratic; in all about..........

Lower divi:ion:

Covered space of some 1,200 feet, in which must be the equivalents of the outer trap of the eastern part of Keweenaw Point, corresponding to a thickuess of about...........

The Great conglomerate, including the sandstone and conglomerate at the Atlantic mill and conglomerate 22 on the south side of Portage Lake, with some intervening ex-

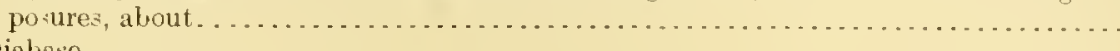

Diabase. . . . . . . . . . . . . . . . . . . . . . . . . . . . . . . . . . . .

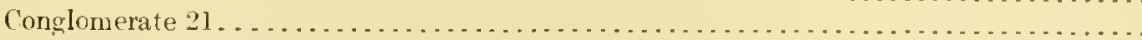

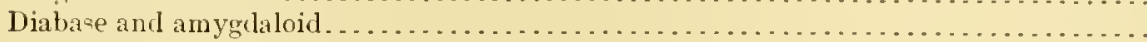

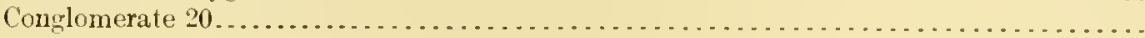

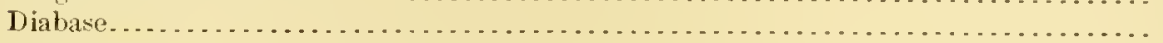

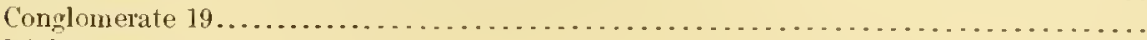

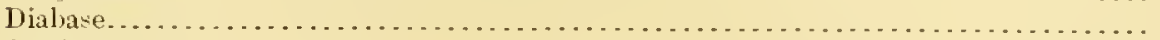

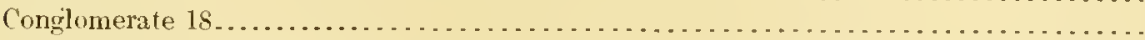

Diabases and amygdaloids. . . . . . . . . . . . . . . . . . . . . . . . . . . .

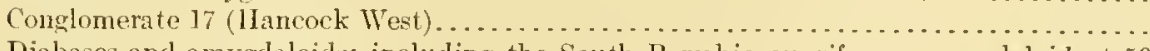

Diabases and amygdaloids; including the South Pewabic cupriferous amygdaloje at 50 feet below 17

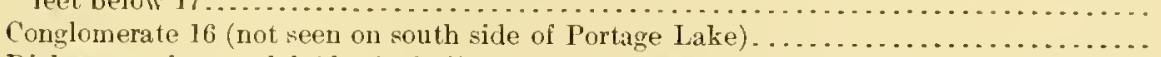

Diabases and anygdaloids; including, at 400 feet above conglomerate 15 , the Pewabic cupriferous amygdaloid or "lode" so largely worked for copper on the west side of

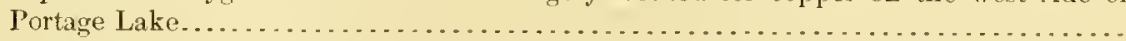

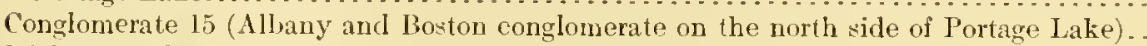

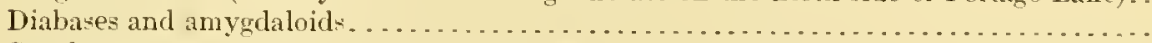

Conglomerate 14 (the 1Ioughton conglomerate of the north shore).................

Diabases and amygdaloids. . . . . . . . . . . . . . . . . . . . . . . . . . . . . .

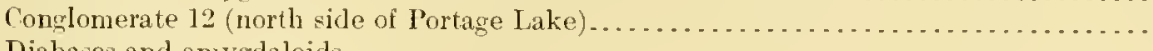

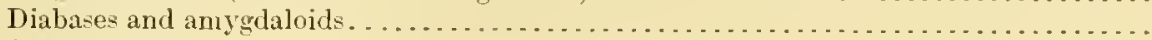

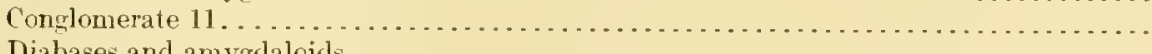

Diabases and amygdaloids . . . . . . . . . . .

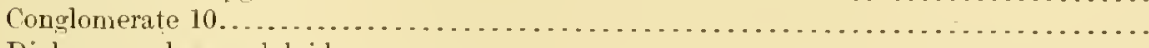

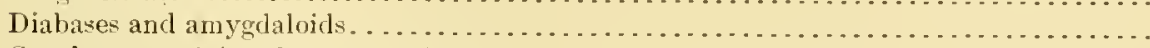

Conglomerate 9 (sandstone seam).

Diabases and amygdaloids; including, at 670 feet above conglomerate 8 , the Grand Portage cupriferous amygdaloid, and at 510 feet the Isle Royal cupriferous anygdaloid, largely worked on the south shore of Portage Lake. . . . . . . . . . . . . . . . . . .

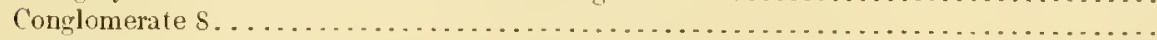

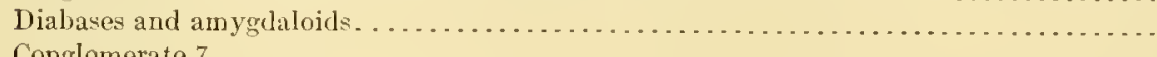

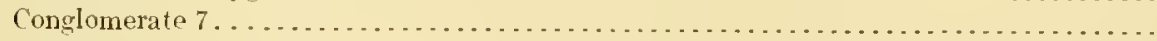

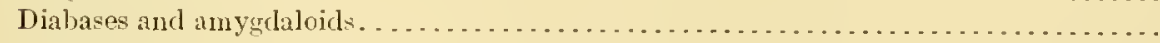

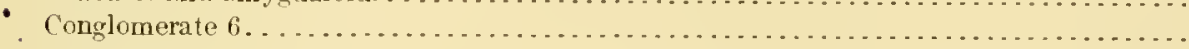

Diabases and amygdaloids . . . . . . . . . . . . . . . . . . . . .

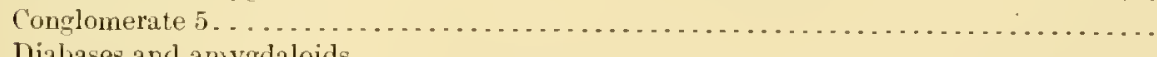

Diabases and anygdaloids. . . . . . . . . . . . . . . . . .

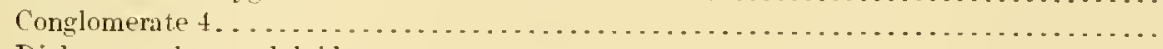

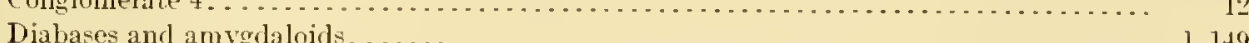

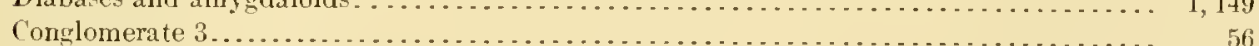

Diabases and amygdaloids. . . . . . . . . . . .

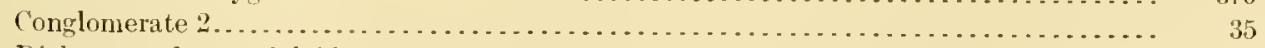

Diabases and amygdaloids. . . . . . . . . . . . . . . . . . . . . . . . . . . . .

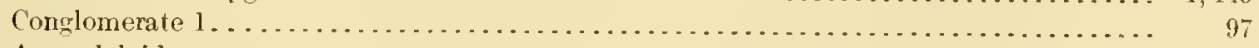

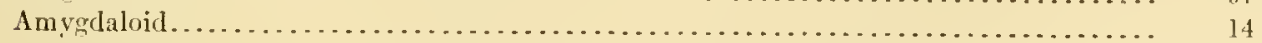


In the above section of the lower Keweenawan the thickness of the conglomerates an!ounts to 2,125 feet, lewring $11,5.55$ lect for the igneus rocks. Thus the lower Keweenawan is about one-sixth sediment and about live-sixtlis igneous.

The Portage lake section dillers in one important respect from the Eagle River section. At Portige Latie the interstratilied conghomerates extend to the botton of the section, whereas int bagle River the conglonerates and sandstones do not occur in the lower live-sixtlis of the section, the thickness of which as a whole is about the sime as at Portage Labke.

\section{BLACK RIVER SECTION.}

In the Black River section the total thickness, arcording to Gordon, ${ }^{a}$ is 48,000 feet. Irving ${ }^{b}$ estimates the thickness of the upper sundstone at Montreal River, a few miles west of Black River, at 12,000 fect. This part of the seetion is absent on Black River, and if it were alded to the Black River section this would give for this district a thickness of 60,000 feet for the entire Keweenawan series.

In the midlle Keweenawan of the Black River section ( 1 . 384) the sedinents are mainly in the upjer 6,000 feet, and of this amount sediments are known to make up 575 feet, distributed as follows:

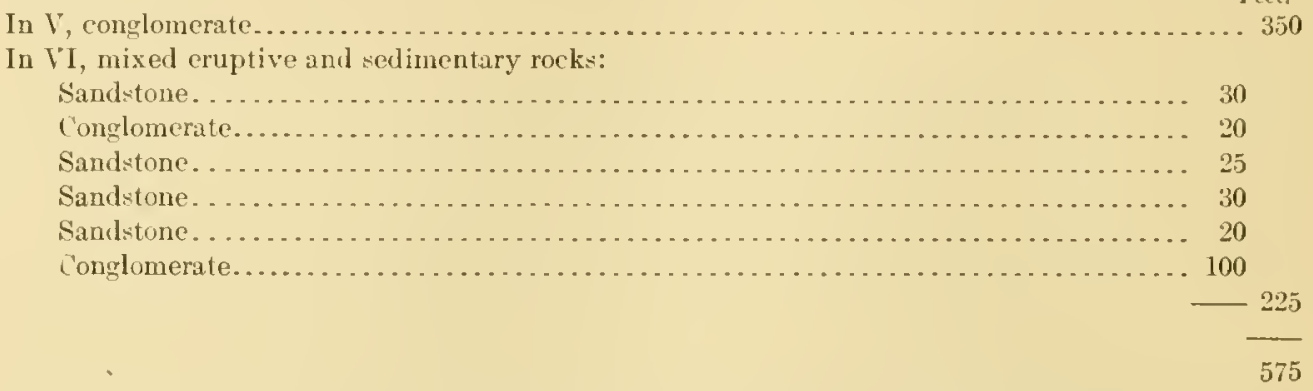

As a space corresponding to 3,000 feet is not exposed, donbtless the total thickness of the sediments is much greater than this, though a part of this 3,000 feet is certain to be volcanic. However, the udition of all of it would make the miximum possible thickness of secliment 3,575 feet. Thus the sediments at most make up only about one-twelftli of the middle Keweenawan and are largely concentrated in the upper sixth of the division.

The question now arises whether this apparent thickness for the several sections represents the real thickness of the series as laid down. It is believed to be probable that the real thickness is less than the apparent thickness. The reasons for this belief apply as well to the estimated thicknesses of other districts, and therefore they are given later. (See pp.41s-419.)

\section{RELATIONS OF TIE GEWEENAWAN OF MICIIGAN TO UNDERLYING AND OVERLYING FORMATIONS.}

The only loeality in which the relations of the Keweenawan with the underlying formations are shown is in the Penokee-Gogebic district. It lias been stated (pp. 234-235) that these rehtions are those of unconformity, erosion amounting to several thousand fret having taken flace alter Iuronian time and before the deposition of the Keweenawan. Still, the strike and dip of the two series are very nearly the same, and the greatness of the break between the two appears only by their stratigraphe relations.

The (Ppper Cimbrian ("Eastern") sandstone comes against the lower part of the Fieweenawan from the outer end of heweenaw Point to the region west of Gogebie Lalke. It is agread by all who have stmlied this contact that it marks a great fanlt. The lieweenawan along the contact has its usual steep northern dips. The sandstone at the contact is bent and locallybroken, so that it strikes and dips in rarious directions, in some places diphing away from the

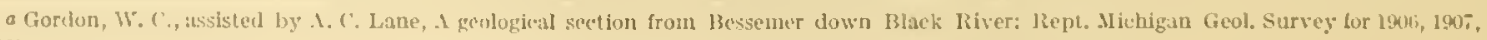
p. 421. 
Keweenawan and in others apparently dipping under it. A slort distance away from the Keweenawan, usually within a few hundred feet, the sandstoue assumes its normal horizontal attitude.

At only a few localities has the Upper Cambrian sandstone been found in close relations with the rocks of the South Range. Irving ${ }^{a}$ concluded that in the South Range this sandstone rests uneonformably against the Keweenawan rocks. However, the particular locality he described as showing unconformable relations has been interpreted differently ly Seaman, ${ }^{b}$ who finds there a dike of igneous rock penetrating the so-called "Eastern" sandstone and spreading out above. Seaman regards the "Eastern" sandstone here as prolably Feweenawan and believes that there is no way of proving that it is of diflerent age from the "Western" sandstone (npper Keweenawan).

\section{ISLE ROYAL.}

Isle Royal is 45 miles in length and varies in width from 3 to 8 miles. From the Rock of Ages, the farthest outlying reef to the southwest, to the Gull Island rocks on the northeast, the distance is 57 miles. The island lies off Thumder Bay, northwest of the outer part of lieweenaw Point. The strike of Isle Royal and Keweenaw Point are substantially the same, northeast and southwest. This island has been mapped geologically by Lane. ${ }^{c}$ Itis succession in descending order is as follows:

\section{Section of Keweenawan rocks on Isle Royal.}

Sandstone and conglomerate ("the Great conglomerate"?).

Ophites down to Island mine conglomerate (Marvine's group C).

Intercalated sandstones and conglomerates.

Melaphyre porphyrites and scoriaceous conglomerates ("Ashbed" group).

"The greenstone" - thickest ophite.

Amygdaloids and thin ophites down to Minong breceia (Keararge conglomerate).

Minong porphyrite and Minong trap.

Ophites and conglomerates, including Huginnin porphyrite, down to felsite.

It is clear from the general character of the succession that it is like that of the middle Keweenawan of the remainder of the Lake Superior region; that is to sar, it consists of igneous rocks and sediments. The igneous rocks are dominantly basic. They are all regarded as extrusive by lane. ${ }^{d}$

However, the same question may be raised with reference to the greenstone, which is given a thickness of 233 feet, as was raised concerning that of Keweenaw Point. Is it an cxtrusive or is it a later intrusive? Certainly it has all the characteristics of the diabase of Beaver Bay on the Minnesota coast, which is almost certainly intrusive.

The intercalated sandstones and conglomerates, from lowest to highest, contain a much greater proportion of material from acidic rocks than would be expected from the small proportion of original acidic rocks. The sandstones and conglomerates are subordinate in amount in the major portion of the section and only become of great volume with the appearance of the "Great" conglomerate. The field terms for the igneous rocks and their relations are expressed by Lane ${ }^{d}$ as follows:

$\begin{array}{ccc}\text { Felsite } & \text { Mlaphyre } \\ \text { Porphyry } & \text { Amygdaloid } & \text { Trap-nonamygdaloidal dark rocks } \\ \text { Porphyrite } & \text { Ophite }\end{array}$

Lane ${ }^{e}$ gives one very detailed section based largely on drill records. Its thickness is 9,000 fect. In this section the felsite flows are confined to the lower 150 fect, but at a high horizon one bed of porphyry tuff 10 feet thick is noted. This tuff may be regarded as a confirmation

a Irving, R. D., The copper-bearing rocks of Lake Superior: Mon. U. S. Feol. Survey, rol. 5, 1883, pp. 360-361.

b Personal communication.

$c$ Lane, A. C., Geological report on Isle Royale, Michigan: Geol. Survey Michigan, vol, 6, pt. 1, 1898, $281 \mathrm{pp}$.

d lem, p. 53.

$\varepsilon \mathbf{I d e m}, \mathrm{pp} .27$ et seq. 
of the suggestion made in another place (p. 382) that voleanic fragmental rocks of the acirlic type are numeh more abundant in the Kewernawan than laal bern supposed. Chost of the interstratified sedimentary lowls are conglomerates and, with three exeeptions, thay l'ange from a knife-edge to 50 feet in thirkness. Two of the thickerbeds arr mainly sandstome. In addition to a nmmber of seams which wre too small to be neasured, the total number of sodimentary beds in the distriet is 21 and the total thiekness is 430 feet. To the "Great" conglomerate is given a thicknoss of 2,600 fent, making a total thickness of sediments of 3.030 feet. 'This leaves 5,970 feret for the lavas.

In the matter of correlation, Lane " assumes that the thick eonglomerate at the top of the series is a continuation of the "Great" conglomerate of fiewernaw Point, and with this horizon as a starting point he attempts to correlate somewhiat closely the béls of lslo hoyal with those of Keweenaw Point, as is indieated hy thr succession given on page 359, the names in parntheses being those of formations on Keweenaw Point. Although it is probable that the top conglomerate corresponds to the "Great" conglomerate of Keweenaw Point, and although it may be possible that the formations are to some extent equivalent, it may perhaps be doubted whether the correlation of individual thin beds, such as the interstratified conglomerates, is justified, especially as there is so remarkable a likeness in the petrography of the berls of the lieweenawan at different horizons in the several districts of Lake Superior. If the bed of greenstone more than 200 feet thick is really intrusive, as suggested, its correlation with the greenstone of Keweenaw Point on a stratigraphic busis is very questionable.

In any section on Isle Royal there is a lessening of the clip in passing from lower to higher horizons, just as at Keweenaw Point and at Michipicoten. For instance, at the west end of the island on the north side the dips are $16^{\circ} \mathrm{S}$. and on the south sicle in the "Great" conglomerate $s^{\circ} \mathrm{S}$., a difference of $S^{\circ}$. Toward the east end of the island the dips on the north sicle are. $26^{\circ}$ and on the south side $15^{\circ}$, again a difference of $8^{\circ}$.

\section{MICHIPICOTEN ISLAND.}

The following account of Michipicoten Istand is taken almost wholly from Burwash, ${ }^{b}$ who alone has made a chose study of this area. However, it should be said that Logan's general aecount of this district ${ }^{c}$ is remarkably aceurate.

The island is roughly ellipsoidal in shape, about $16 \frac{5}{8}$ miles long by 6 miles in greatest wiilth. Its longer axis lies east and west parallel to the coast, and its west end is south and a little west of Pukiskwa River.

The Keweenawan rocks occupy the entire island as well as the row of smaller islands off its south shore. They are confined wholly to the middle lieweenawan. The igneous rocks overwhelmingly dominate in mass. They are deseribed as extrusice, no int rusive rocks being mentioned. Lithologieally they include all the varieties of the ordinary extrusive rocks. ophitic and diabasic melaphyres, amygdaloids, porphyrites, felsites, and quartz porphyries. The acilic: rocks are much more realily eroded than the basic rocks. In consequence they usually accupy depressions, whereas tie basie rocks constitute the ridges. In this respect there is a contrast between Nichipicoten Island and Keweenaw Point, where the acidic rocks constitute clevations. It may be suggester that the difference is due to the fact that the Michipieoten acilic rocks are largely extrusive, while those of Keweenaw Point are largely intrusive. No order of extrusion of the lavas is suggested, the acilic and basic rocks both occurring from the highest to the lowest horizons. As to volume, there does not seem to be much difference between the basie and acidie varieties. Selwyn and Coleman state that pyroclastic rocks occur on Michipicoten Islanel, but such rocks were not observed by Burwasha and if present are certainly extremely insignifieant in amount. The lava beds attain their maximum thickness in the eastern and rentral parts of the island and are thimer toward the

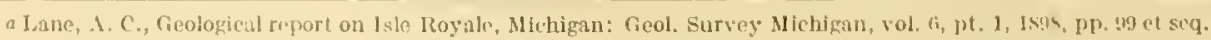
6 Burwash, L. N., The greology of Michipicoten Island: Univ. Toronto Studies, Geol. ser., No. 3, Torouto, 1905, with map. c Logan, W. Li.. Report of progress to isti3, Gcol. Survey Canada, Isci3. dOp. elt., pr. 27,47 . 
west, where they are interstratified with the conglomerates. The lower beds strike approximately northeast and southwest. In passing to higher horizons the strike approaches east and west. Thus there is an appearance of minor unconformity between the lower and upper beds.

The débris of the conglomerates is as usual deriverl largely from the acidic rocks, but with them are inchuled granites, greenstones, and biotite gneisses derived from pre-Keweenawan formations. Abundant material derived from the basic rocks is also recognized. The sedimentary rocks occur mainly at lower horizons, although one conglonerate is found at a comparatively high lorizon. These conglomerates are confined to the northwestem part of the island, being thickest at the west and thimning out to the northeast.

These facts suggest that the central and eastem parts of the island formed a center of voleanic dispersion, that the lavas flowed toward the west, and that in the part of the area somewhat removed from the main volcanic outbursts there was opportunity to build conglomerates between the successive lava flows.

The dip of the beds on the north and northwest sides of the island is $55^{\circ} \mathrm{S}$. From this there is a steady decrease in dip until on the islands off the south shore of Michipicoten the dips are about $14^{\circ} \mathrm{S}$, the lessening of dip across the series being therefore $40^{\circ}$.

Burwash ${ }^{a}$ gives the following descending succession:

Section of Keuecnawan racks on Michipicoten Island.

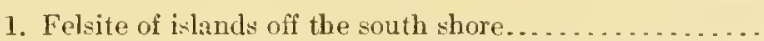

Feet.

2. Pitchstone bed..................................................... 530

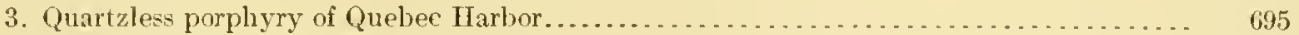

4. Melaphyre porphyrites of Channel Lake........................... 1,660

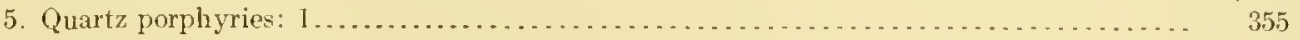

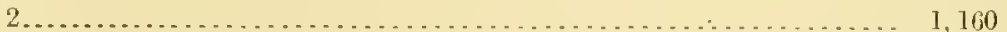

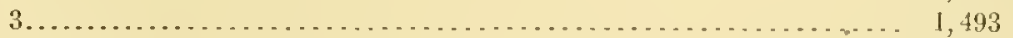

6. Beds exposed at lake on road..................................... 1,575

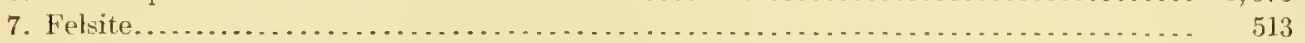

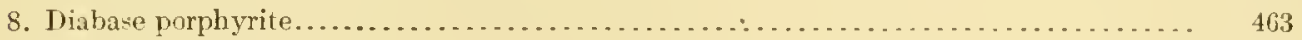

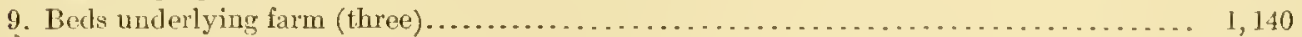

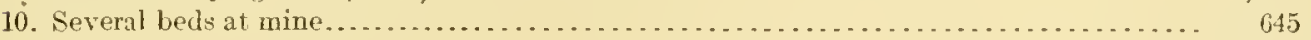

11,230

This result, obtaincd by accurate measurement of thrce sections and by careful sturlies, is a remarkable confirmation of the judgment of Logan, ${ }^{b}$ who states that the thickness of the formations developed in Michipicoten Island, at the most moderate dips observed, would not fall far short of 12,000 feet.

It is stated that on the mainland near the mouth of Pukaskwa River there are rocks of Keweenawan age, and this leads to the suggestion that the Keweenawan constitutes a monoclinal succession from the north shore of Lake Superior to the soutl sicle of Michipicoten. For the intervening distance between the mainland and the island an estimated thickness is given of 34,000 feet, and thus a suggested thickness for the entire Keweenawan series of 45,000 feet. But it secms to us nore probable that between Michipicoten Island and the main shore there is a strike fault and that therefore the Michipicoten rocks may be near the bottom of the Keweenawan series. This idea is perhaps confirmed by the presence in the conglomerates of the Michipicoten district of material from pre-Kieweenawan sources.

\section{EAST COAST OF LAKE SUPERIOR.}

Several prominent points along the east coast of Lake Superior exhibit Keweenawan rocks. While none of these areas are large, they are significant, extending along nearly the entire cast coast of Lake Superior from Cape Choyye, near Michipicoten Harbor, to Gros Cap, intervening localities being Cape Cargantua, Pointe aux Mines, and Mamainse Peninsula. At all these local- 
ities the rocks belong to the middle kewrenawan. They consist of hasic lavas, including melaphyres, porplyyrites, and amygrdaluids, and interstratified sandstones and conglomerates. The sandstones and conglomerates diff'r from the ordinary sediment ary rocks interstratified with the lavas in that they contain a considerable amount of detritus derived from the subjacent Arehean rocks. This is particularly noticeable at Mamainse. For the most part the masses exposed are small, but Logan ${ }^{a}$ estimates the thickness of the series at Pointe aux lines to be 3,000 fect. At Mamainse Peninsula the Keweenawan rocks occupy much the largest area along the east coast. Macfarlane ${ }^{b}$ calculates a total thickness in this locality of 16,208 feet, of whirli interstratified conglomerates make up 2,138 feet. Macfarlane's section, from the base upward, is as follows:

\section{Scction of Keweenawan rocks on Mamainse Peninsula.}

1. Granular melaphyre, colisisting of a small-grained mixture of dark-brown feldspar with angular yrains of a dark-green chloritic mineral. It varies frequently in its structure, and in the upper part contains amygdules of cale spar and delessite (iron chlorite)....

2. Brown argillaceous sandstone, striking N. $20^{\circ} \mathrm{W}$. and dipping $35^{\circ} \mathrm{SW} \ldots \ldots \ldots \ldots \ldots$

3. Compact greenish-gray melaphyre, with grains of feldspar, iron chlorite, and hematite;

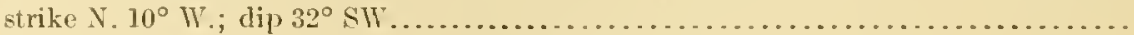

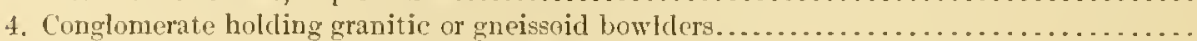

5. Granular melaplyye, containing feldspar, which weathers white, and dark-green chlorite.

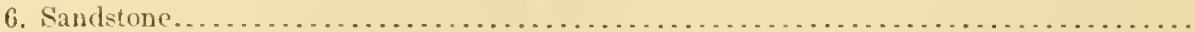

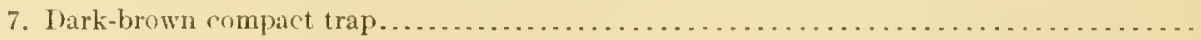

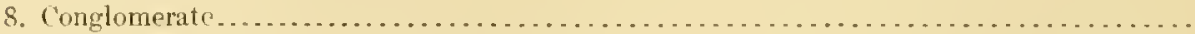

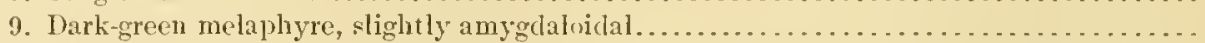

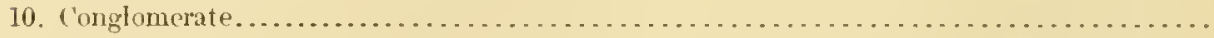

11. Nelaphyre, striking $\mathrm{N} .5^{\circ} \mathrm{W}$., dip $30^{\circ} \mathrm{W}$; fine grained and of a dark-brownish color.....

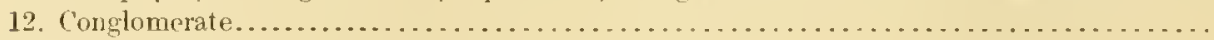

13. Granular melaphyre, coutaining brownish-red feldspar and ahundance of delessite......

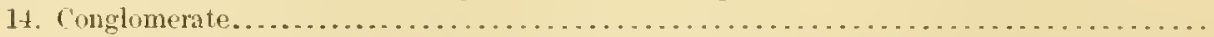

15. Fine-grained greenish-red melaphyre, heconing amygdaloiclal in the upper part of the bed. Strike N. $20^{\circ} \mathrm{W}$, dip $35^{\circ} \mathrm{SW}$, where it adjoins conglomerate N. $15^{\circ} \mathrm{W}>45^{\circ} \mathrm{SW}$.

16. ('onglomerate, with a small layer of sandstone, the latter striking $\mathrm{N}$. $17^{\circ} \mathrm{W}$., dip $40^{\circ} \mathrm{SW}$..

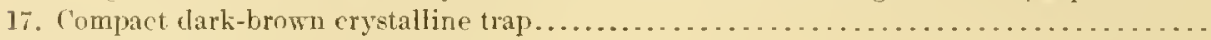

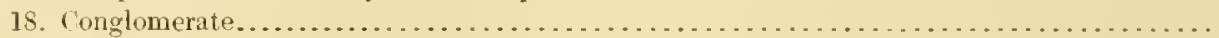

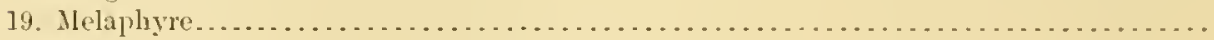

20. ('onglomerate, striking $\mathrm{N} .5^{\circ} \mathrm{W}$. and dipping $42^{\circ} \mathrm{W}$. at junction with overlying rocks....

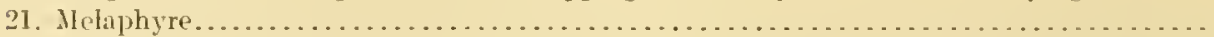

22. Conglomerate, striking N. $12^{\circ}$ W. In this bed the bowlders are smaller than in those

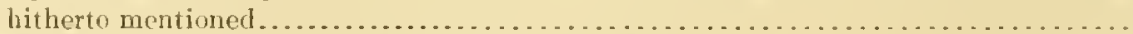

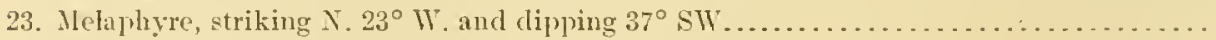

24. Conglomerate and sandstone, striking $\mathrm{N} .14^{\circ} \mathrm{W}$. and dipping $44^{\circ}, \mathrm{W} \ldots \ldots \ldots \ldots \ldots \ldots$

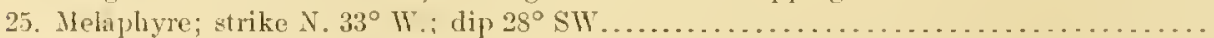

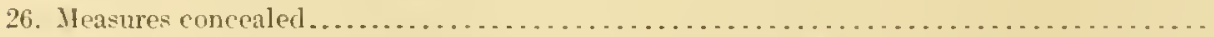

27. Melaphyre, granular and of a reddish-green color, striking $X .30^{\circ} \mathrm{W}$. and dipping $18^{\circ} \mathrm{s} \mathrm{W}^{\circ}$.

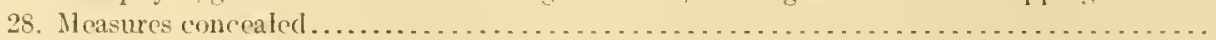

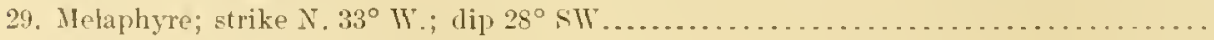

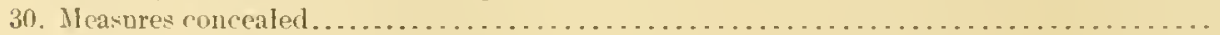

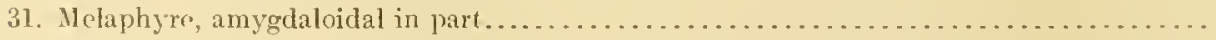

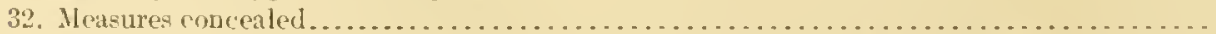

33. Concrlomerate, consisting of bowlders of laurentian rocks in matrix of red kandstone....

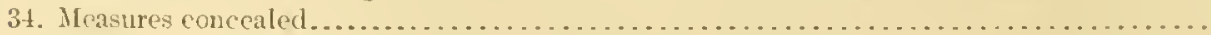

35. Melaphyre, striking $\mathrm{N} .35^{\circ} \mathrm{W}$. and dipping $20^{\circ} \mathrm{SW}$..

36. (ongfomerate, in which the bowlders comsist to a much greater extent than heretufore of amygdaloidal and other varieties of melaphyre. Strike $\mathrm{N} .20^{\circ} \mathrm{W}$; dip $25^{\circ} \mathrm{SW}$. at the

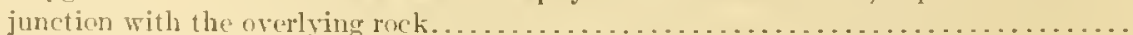

37. Redelisll-gray grantar metaphyre, becoming amygdaloidal in the upper part..........

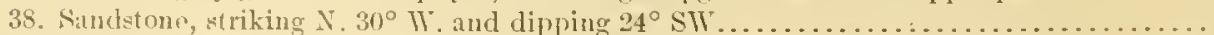

39. Conglonerate, contaning here and there lavers of sandstone, striking $\mathrm{X} .40^{\circ} \mathrm{II}$, and

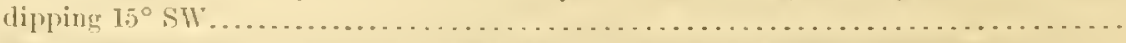


40. Dark-green glittering melaphyre, striking, at its junction with the underlying ennglom-

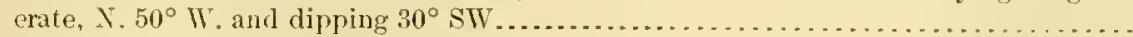

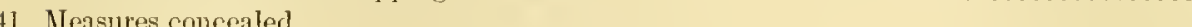

42. Melaphyre, striking N. $50^{\circ} \mathrm{W}$. and dipping $29^{\circ} \mathrm{SW} \ldots \ldots \ldots \ldots \ldots \ldots$

43. Measures concealed........................................... 114

44. Nelaphyre, dark reddish green, striking N. $50^{\circ}$ to $55^{\circ} \mathrm{W}$. and dipping $21^{\circ}$ to $25^{\circ} \mathrm{SW}$.... 300

45. Dark-green and glittering melaphyre; N. $25^{\circ} \mathrm{W} .>20^{\circ} \mathrm{SW} \ldots \ldots \ldots \ldots . . . . . . . . . . . . . . .250$

46. Compart fine-grained trap, containing geodes of agate, in which cale spar frequently

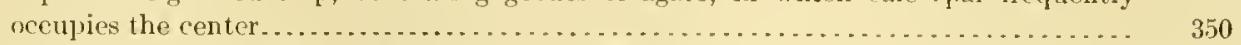

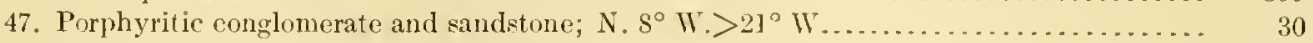

4S. Compact fine-grained trap, containing agates in many places...................... 72

$16,20 \mathrm{~S}$

This thickness does not include the basal sandstone to be mentioned below. It is to be noted that in the 5,729 feet at the bottom of the section there is only one layer of scdiment - a sandstone 12 feet thick. In the remainder of the section, 10,479 fect, conglomerates and sandstones are interstratified at several places, the thickest bed being 852 feet thick and lying at the bottom of the part containing sandstones and conglomerates. Thus the lower third of the middle Keweenawan is essentially igneous and the upper two-thirds consists of igneous and seclimentary rocks.

At Mamainse, Pointe aux Mines, and Cape Choyye the lower Keweenawan beds are conglomerates and sandstones. At Mamainse these basal beds of sandstone, aecording to Macfurlane, ${ }^{a}$ seem to have a very considerable thickness. At Pointe aux Mines, according to Logan, ${ }^{b}$ there are sandstones at the base of the scries nearly in contact with the gneiss. At Cape Choyye the basal bed is a red sandstone of considerable thickness. However, at Cape Gargantua and at Batchewannng Bay the amygdaloidal trap rests unconformably upon the Archean, and thus at these points igneous rocks are at the lowest horizon of the Keweenawan series.

Thus for eastern Lake Superior the Kewecnawan may be divided into lower Feweenawan and mildle Kisweenawan, the former being represented by the sediments at the botton of the series and the latter by the lavas and interstratificd seiliments.

The dips at Mamainse are $20^{\circ}$ to $30^{\circ}$ lakeward, and from these amounts on the east coast they range up to $60^{\circ}$, as at Gros Cap. In general direction the strike of the strata of the Fieweenawan of the east coast curves in and out, corresponding to the ninor folds of the synclinorium, but the average strike is somewhat west of north, corrosponting with the gencral clirection of the east coast, and the dips are to the west, varying from as low as $10^{\circ}$ at Cape Choyye to as high as $45^{\circ}$ or even $60^{\circ}$ at Gros Cap. The usual dips, however, run between $20^{\circ}$ and $35^{\circ}$.

From the general retation of the Cambrian sandstone (Sault Ste. Marie, "Eastern" or Potsdam sandstone of several writers) and its extensions adjacent to the Keweenawan, Logan conchuled that there was an unconformity between the two. IIe says: ${ }^{c}$

The contrast between the general moderate dips of these sandstones and the higher inclination of the igneous strata at Gargantua, Mamainse, and Cros Cap, conbined with the fact that the sandstones always keep to the lake side of these, while none of the many dikes which cut the trappean strata, it is believed, are known to intersect the saudstones (at any rate on the (anadian side of the lake), seems tosupport the suspicion that the sandstones may overlie unconformably those rocks which, associated with the trap, constitute the copper-bearing series.

\section{GENERAL CONSIDERATION OF TIIE KEWEENAWAN SERIES.}

\section{LOWER KEWEENA WAN.}

In reference to the lower Keweenawan, it need here only be remarked that these sediments are in no way peculiar. They are derived from the preexisting I Iuronian and Archean preciscly as similar detrital formations are built up. At the bottom are conglomerates; over these lie sandstones; and in the Bhek and Nipigon bay districts above these are interstratified marls, limestones, shales, and sandstones. 
Though it is not known that sedinents were everywhere deposited at the hase of the Fewerenawan, it is a remarkable fact that in most places where the actual contact letwern the nonintrusive parts of the Kewernawan and the next underlying rocks can be seen such sediments oceur. These deposits lase their greatest rolume and widest cixtent in the region about Black and Nipigon bays, where the thickness is variously estimated from 5.5t) to 1.400 fret. In northcastern Minnesota, at the base of the series is the Puckwunge conglenerate. In Michigan, at Bialek River, at the bottom of the suecession is a basal sundstone known to be 300 feet (lick, and it may be considerably thicker than this, oceupying a part of the mexposed area to the sonth. How far this sandstone extends east and west is not known, as the formations next underlying the Feweenawan are not usually exposed. IIowever, the formation is known to be present north of Ironwood and also in sec. 11, T. 45 N., R. 1 W., near Potato River, in Wisconsin, more than 20 miles west of Black River (Mlichigan). At the latter place the conglonerate and quartzite below the lavas are probably as thick as at Black River. On the east sicle of Lake Superior the actual contacts between the pre-Keweenawan and the Kieweenawan are found at a number of localities, and at the more extensive of these exposures the lowest formation of the Keweenawan is a conglomerate, although at other localities the laras lie directly anainst the gneiss. Where the lowest Keweenawan rock is an intrusive, as for instance the Duluth gabbro, this must of course be exeluded from all consideration in connection with the oldest formation of the Liewenawan. Also there must be exchuded from consileration the localities, such as Keweenaw Point and western Wisconsin, where the base of the Keweenawan is not exposed.

\section{MIDDLE KEWEENAWAN.}

The midlle Keweenawan was the great epoch of combined igneous and aqueous activities. There are two divisions of its rocks-original igneous and derived sedimentary.

\section{IGNEOUS ROCKS.}

\section{VARIETIES.}

The inneous rocks constitute a province of rather remarkable uniformity. The different kinds and their relations are substantially the same in each of the important distriets. Chenically the igneous rocks include basic, acidic, and intermediate varieties. The basic maturials overwhomingly dominate, the acidie rocks are considerable in quantity, and the intermediate rocks are few and local. Each rariety of rocks includes both intrusive and extrusive fac'ies, so that the basie, acilic, and intermediate groups all have textures characteristic for plutonic and volcanic rocks. Barring the work of Kloos and Streng, ${ }^{a}$ which was limited in scope, Pum$p^{e} l y^{b}$ made the first careful petrographic study of the Keweenawan rocks. In general Irving ${ }^{c}$ followed Pumpelly in the use of terms, but his studies were more extensive and disclosed new variations.

Accorling to Irving, the hasic plutonic igneous rocks comprise olivinitic and nonolivinitic gabbros, olivinitic and nonolivinitic diabases, and "anorthite rock." The surface varieties inclute melaphyres, porphyrites, and amygdahids. The coarser-grained melaphyres have often been called dolerites, diahases, or ophites, depending on their texture. The deepr-seated phase of $t_{10}$ acidic rocks is granite, augitic, or hormblendie, and the extrusive phase is made up of porphyry, quartziferous and nonquartziferous, and felsite. The intermedinte rocks occur in subordinate anounts. The most important intrusive phases of them are described by Irving as angite syenites and orthoclase gabbros, and the extrusive varieties as porphyrites. The torm "trap" is used by Irving in its usual sense to include both basic and intermediate fine-grained rocks.

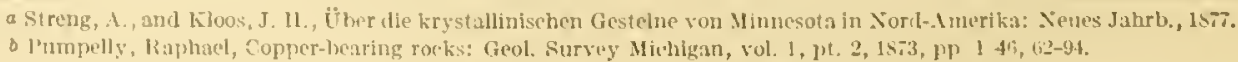

c lrving, 12. 1)., 'The copper-bearing rocks of Lake Superior: IIon. U. S. Geol. Survey, rol. 5, 1.w3. 
The plutonic igneous rocks are very little altered. The very rearlily changeable olivine may be altered to chlorite, serpentine, etc., to a small extent. The augite and placrioclase are locally cliloritized, but. still these alterations are purely subordinate.

The voleanic rocks are much altered. This is especially true of the vesicular amygdaloidal basic lavas. In these rocks the original minerals, which were dominantly angite, olivine, plagioelase feldspars, magnetite, and chlassy hase, have been extensively altered and the vesicules of the amygrdaloids filled with secondary products. These are mainly alterations of the belt of cementation in the zoue of katamorphism. A complicated set of secondary minerals has been produced, of which the following are very common: Various zeolites, such as laumontite, thomsonite, stilhite, and mesolite; also calcite, chlorite, epidote, quartz, prehnite, orthoclase, hematite, and limonite.

The acidic rocks, the original minerals of which were manly quart $z$, orthoclase, plagioclase, and glass, have also been extensively decomposed, with the development of much secondary quartz and other alteration products, which are not always completely determinable but which certainly include epiclote and chlorite. IIematite and limonite are common. Many nicroliths have formed, the exact nature of which it is dillicult to determine.

REVIEW OF NOMENCLATURE OF KEWEENAWAN IGNEOUS ROCKS. ${ }^{a}$

By Alexander N. Winchell.

The Keweenawan igneous rocks of the Lake Superior recrion have been studied and diseussed by many geologists during the past thirty years. At the beginning of that period mieroscopic petrograply was in its infancy and minor errors, due to faulty mothods, inevitably resulted. In the course of the years these have been gradually corrected, involving changes of nomenclature. Some variations in nomenclature have resulted from the varying points of views of the authors. But the general progress of petrography has brought more numerous and important modifications.

In order to make the names used by the prominent writers on the subject more readily intelligille, a correlation of these names is presented herewith. It must be remembered that, since the basis of petrographic classification used by the authors has varied somewhat, such a correlation can be only an approximation, but it will nevertheless serve the purpose of showing the various changes that have occurred and of presenting, at least in its outlines, the main iacts of nomenclature of each writer.

In order to give precision to such a correlation, it is lesirable that the nomenclature of each writer be compared, not simply with that used by other authors but also with an expressed and definite classification. Therefore the following classification has been prepared, on the basis of textures and mineral composition. It is not a general classification of imneous rocks but is intended to include merely the types represented in the lieweenawan of the Lake Superior region. 
Mincralogical elassifuration of Kcuefnawan igneous rocks of the Latie Superior region.

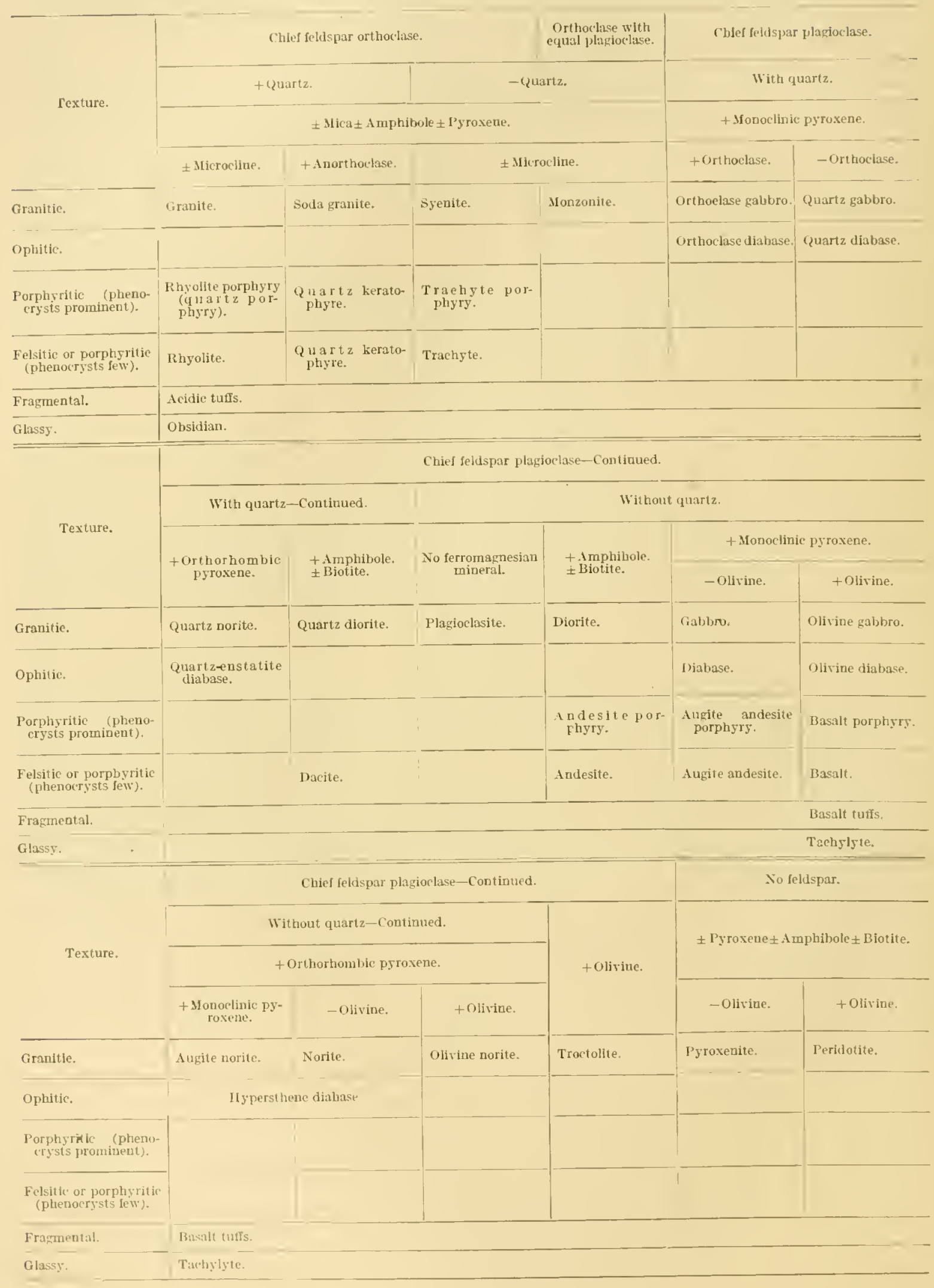


Macfarlane, ${ }^{a}$ in 1866, described the Keweenawan rocks of Michipicoten Island. He found melaphyre, trap, amygdaloid, quartz porphyry, porphyrite, and trachytic phonolite. II is "quartz porphyry," which oceurred at the contact of the sandstone and trap, was doubtless a modificd quartzite. His "trachytic phonolite" is not fully described, and correlation is uncertain.

Kloos, ${ }^{b}$ in 1S71, described gabbro or hypersthenite, black porphyry or melaphyre, porphyry, and amygdaloid. The first named was probably a gabbro and the secont a diabase.

Pumpelly, in 1873, described melaphyre, trap, and anygdaloid without microscopic study; he distinguished three kinds of melaphyre coarse grained, fine grained, and melaphyre porplyyry. Correlations of these names are impracticable and woukl be misleading rather than helpful.

Marvine, ${ }^{d}$ in the same year, described melaphyre, trap, diorite, and amycrlaloid. Pumpelly later claimed, probably correctly, that Marvine's diorite included samples of diabase, melaphyre, and gabbro, but no true diorite.

Streng, $e$ in 1877 , described melaphyre, melaphyre porphyry, and hornblende gabbro from the Keweenawan of Minnesota. IIe published chemical analyses of two of these, which permit their correlation on the quantitative basis. (See table on p. 402.)

Pumpelly, $f$ in 1S7S, described the alterations which some of the Keweenawan rocks had suffered in great detail, but brought to light no alditional varietics of the unaltered rocks.

The same author, $g$ in 1850, identified eight or ten kinds of igneous rocks in the Keweenawan. (See table on p. 400.) He distinguished diallage from augite by means of the parting in the former, and, in accordance with the usage at that time, called a massive igneous rock containing plagioclase and diallage a gabbro, while one containing plagioclase and augite he called a diabase. But all the diabase covered by his descriptions and illustrations seems to have an ophitic texture. Ifis identifications of the plagioclase feldspars were all based on incorrect methods, so that his so-called albite and oligoclase are actually andesine-oligoclase, his labradorite is andesine, and his anorthite is chiefly labradorite with some bytownite.

Irving ${ }^{h}$ followed the practice of Pumpelly, but described about twice as many petrographic varieties. He protested against the practice of basing rock names on any such distinction as that between diallage and angite, but followed the custom, nevertheless, in the main, although he tried to discriminate between diabase and gabbro on the basis of coarseness of crystallization, assigning the name gabbro to the coarser grained varieties. Irving's orthoclase gabbro has been ealled hormblende gabbro by Wadsworth and porphyritic gabbro by N. H. Winchell; it is nearly the same as Lane's gabbro-aplite; recently it has been called oligoclase gabbro by F. E. Wright. ${ }^{i}$

N. If. Winchell, ${ }^{j}$ in 1881 , described thin seetions of dolerite, labradorite rock, hyperite, and gabbro. He made the name "dolerite" so general in meaning as to include gabbro, diabase, olivine gabbro, olivine diabase, augite andesite, and basalt. IIis "labradorite rock" was called "anorthite rock" by Irving and is now called plagioclasite (or anorthosite); his hyperite is now known as norite.

Wadsworth ${ }^{k}$ in 1857 , proposed a new classification of the Keweenawan igneous rocks on the basis of the alterations which a given type has undergone. Thus a gabbro whose augite had altered to hormblende he would call a gabbro-diorite. A peridotite may by alteration become a serpentine or a talc schist; in cither case Wadsworth would call it still a peridotite, adding a name to indicate its present condition. Conserpuently, a rock called, for exauple, a

a Mlacfarlane, Thomas, Report of progress from 1863 to 1sifi, fieol. Survey Canada, 1stiti.

b Kloos, J. H., Zeitschr. Deutsch. geol. Gesell., 1571, p. 417.

c rumpelly, Raphael, Geology of Michigan, vol. 1, pt. 2, 1 1 73.

d Marvine, A. R., idem.

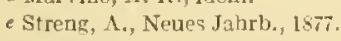

f Pumpelly, Raphael, Proc. Am. Acad. Arts and Sci., vol. 13, 1S:\$, n. 255

$g$ Pumpelly, Raphael, Geology of Wisconsin, rol. 3, 1980, pp. 27-49.

$h$ Irving, R. D., feology of Wisconsin, vol. 3, 1:880, pp. 167-206; Mon. U. S. Geol. Surrey, vol. 5, 1883; Geolosy of Wiseonsin, vol. 1, 1883, p. 3*0.

i Wright, F. E., Science, vol. 27 , June, 1905, p. 992.

j Winchell, N. II., rroc. Am. Assac. Adv. Sci., rol. 30, 1881, p. 160.

$k$ Wadsworth, M. E., Bull. Geol. aud Nat. Ilist. Survey Miunesota No. 2, 1857. 
gabbro by Wadsworth may belong to any one of a dozen types as commonly recognized. Nevertheless, Wadsworth's names as actually applied in this case may be correhated approximately with the names of other writer's, as shown in the table on page 400 .

Winlsworth indorsed Irving's protest against using the distinction between augite and diallage as a basis of lock classification, and yet, like Irving, he used it. He did not aliscriminate sharply between the ophitic and the poikilitic textures, both of which may he found, sometines together, in Mimnesota diabases.

Bayley, ${ }^{a}$ in 1859-1897, deseribed the gabbro batholith of Minnesota in considerable detail and also stulien the peripheral phases of the gabbo. To emphasize the close connection in origin between the peridotite and the gabbro of the district, he called the former nonfolsspathic gabbro. Although some of the peripheral phases described by Bayley may be of later date than the crabbro, if we assume that they all belong in the Keweenawan, we fund that Bayley recognizes not only the augite syenite of Irving, hut also a porphyritic equivalent which he ealls quartz keratophyre on account of the presence of anorthochase. IIe speaks of olivine-pyroxene aggregates which should apparently be correlated with wehrlite, dunite, and pyroxenite.

In the peripheral phases he finds a texture which he considers somewhat claracteristic; it consists of the presence of many rounded grains of the more important constituents inclosed by other minerals. Bayley calls it the granulitic texture. It has been called the contact structure by Salomon and the globular by Fouqué. It is well described by the term globular or globulitie.

Grant, ${ }^{b}$ in 1893 and 1894 , described gabbro, liabase, granite, and fune-grained rocks previously called nuscovadites in the Minnesota reports. Grant's granite is the equivalent of Irring's augite syenite, later called soda-augite granite by Bayley. (See table on p. 400.) The finc-grained rocks, called muscovadites, include border facies of the gabbro mass of various types, but especially norite, fune-grained gabbro often with hypersthene, olivine norite, cordierite norite, etc.

Hubbard, ${ }^{c}$ in 1898, described various types of the Keweenawan of Keweenaw Point. Ilis melaphyre is chiefly andesite or basalt; his doleritie melaphyre is a coarser basalt or a gabbro; his ophitic nielaphyre is a poikilitic and luster-mottled diabase; and his porplyyrite is chiefly andesite and trachyte.

Lane, ${ }^{d}$ in 1898-1906, described the Keweenawan rocks of Isle Royal and northern Michigan. IIis melaphyre porphyrite is the equivalent of Pumpelly's "Ashbel" liabase and Irving's diabase porphyrite, Lane's melaphyre ophite is an olivine diabase, luster-mottled by means of poikilitic textures; his doleritic melaphyre is a basalt porphyry. Lane would confine the name diabase to dike rocks. His augite syenite is said to be at least in part an equivalent of Bayley's quartz diabase. He uses the term ophitic in a narrow sense, not justified by the original definition of Michel Lévy, e nor by his usage. He applies it to those luster-mot thed rocks in which single pyroxene individuals inclose several plagioclase crystals, usually lath-shaped and irregularly placed. It denotes thus, for Lane, a variety of the poikilitic texture. In its original meaning, still commonly used by many and adopted here, it refers to that texture of a basic igneous rock prorluced when the plagiochase erystallizes in lath-shaped forms before the pyroxene solidifies.

A. N. Winchell, $g$ in 1900 , described in cletail a few samples of the lieweenawan rocks of Minnesota. He used the new term plagioclasite for the rocks previously known usually as anorthosites.

a Bayley, W. S., Im. Jour. Scl., 3 ser., vol. 37, 1589, p. 54; vol. 39, 1890, p. 273; Bull. U. S. Geol. Survey No. 109, 1893; Jour. Geology, rol. 1, 1993, p. 433 ; vol. 2,1894, D. \$1 ; vol. 3,1895, p. 1; llon. U. S. Geol. Survey, vol. 25, 1897, p. 519.

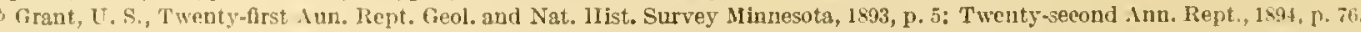

c llubbard, L. L., fieol. Survey Míchigan, vol. 6, pt. 2, 1 s9s.

d Lane, A. C., Gcol. Surver Michigan, vol. 6, nt. 1, 1898; Bull, Geol. Soc. America, rol, 14, 1903, pp. 369, 355: Jour. Geology, vol, 12, 1904, p. 33: inn. lept. Geol. Survey $\mathbf{M}$ iehigan for 1903, 1905, pp. 205, 239; idem for 1904, 1905, p. 113; 1'roc. Lake Superior Min. 1nst., vol. 12,1906, p. $\$ 5$.

e 13ull. Soc, géol. l'rance, vol, 13, 1R78, 1). 158.

Minéralogie micrographique, $18 \% 9$, Pl. XXXvi. See also p. 153.

g Wluchell, A. ㅊ., AIn. (ieulogist, vol. 26, 1900, pp. 151 (197), 261, 348. 
N. II. Winchell and U. S. Grant ${ }^{a}$ published in 1900 by far the most complete accounts of the petrography of the Keweenawan igneous rocks. Their nomenclature varies very little from that commonly in use at present. They described practically all the petrographic types of the Keweenawan previously known and added some half dozen new varieties. They used diorite-porphyrite or diabase-porphyrite to designate more or less ophitic types of andesite porphyry or augite andesite porphyry. They used Wadsworth's name zirkelite for a deritrifierl basalt, basaltic tuff, or tachylyte; devitrifed obsidian they called an apobsidian, and a devitrified rhyolite an aporhyolite, as suggested by Bascom. Wadsworth's quartz-hiotite diorite is ealled syenite by Grant. It is an intermediate type corresponding to a monzonite. 

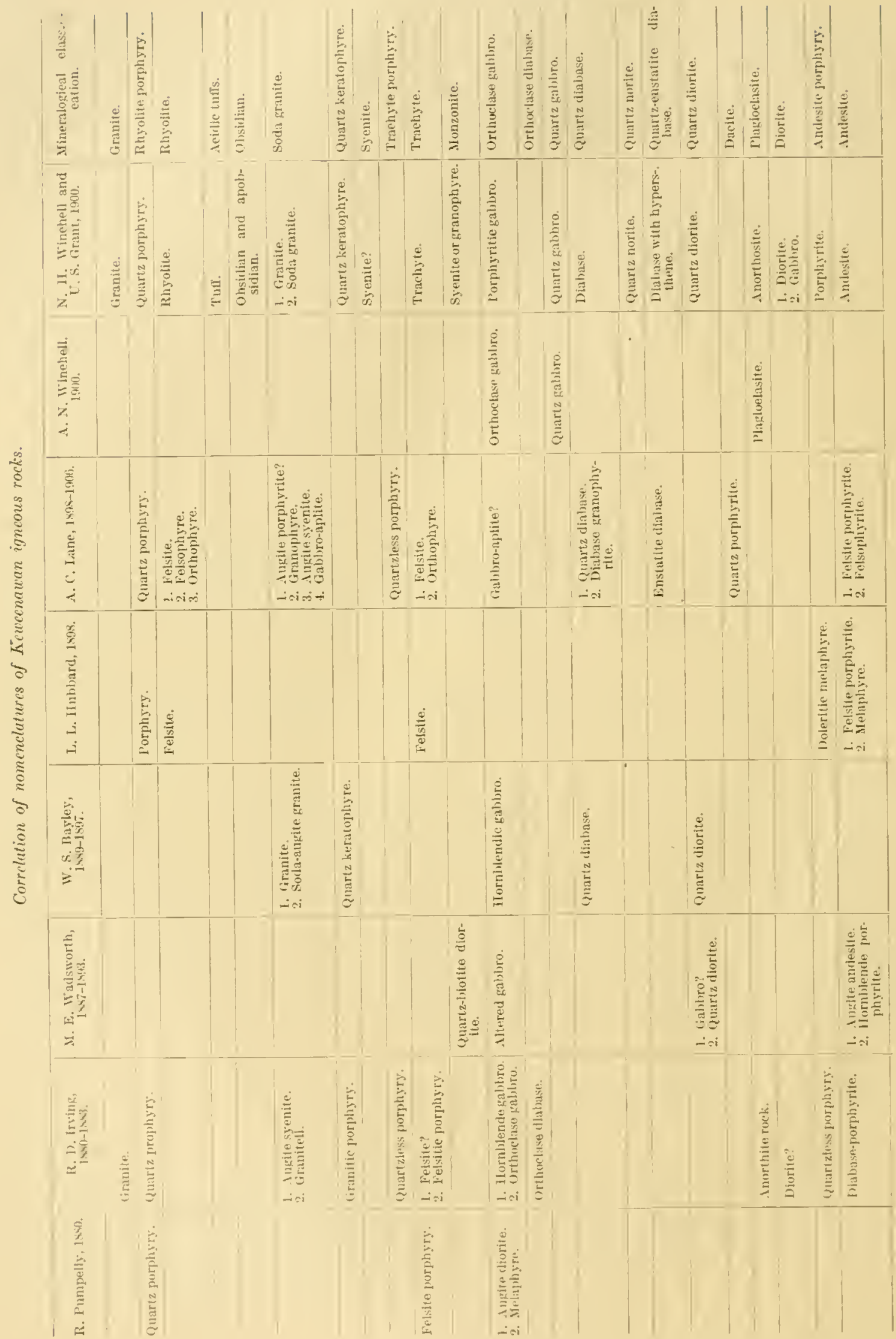


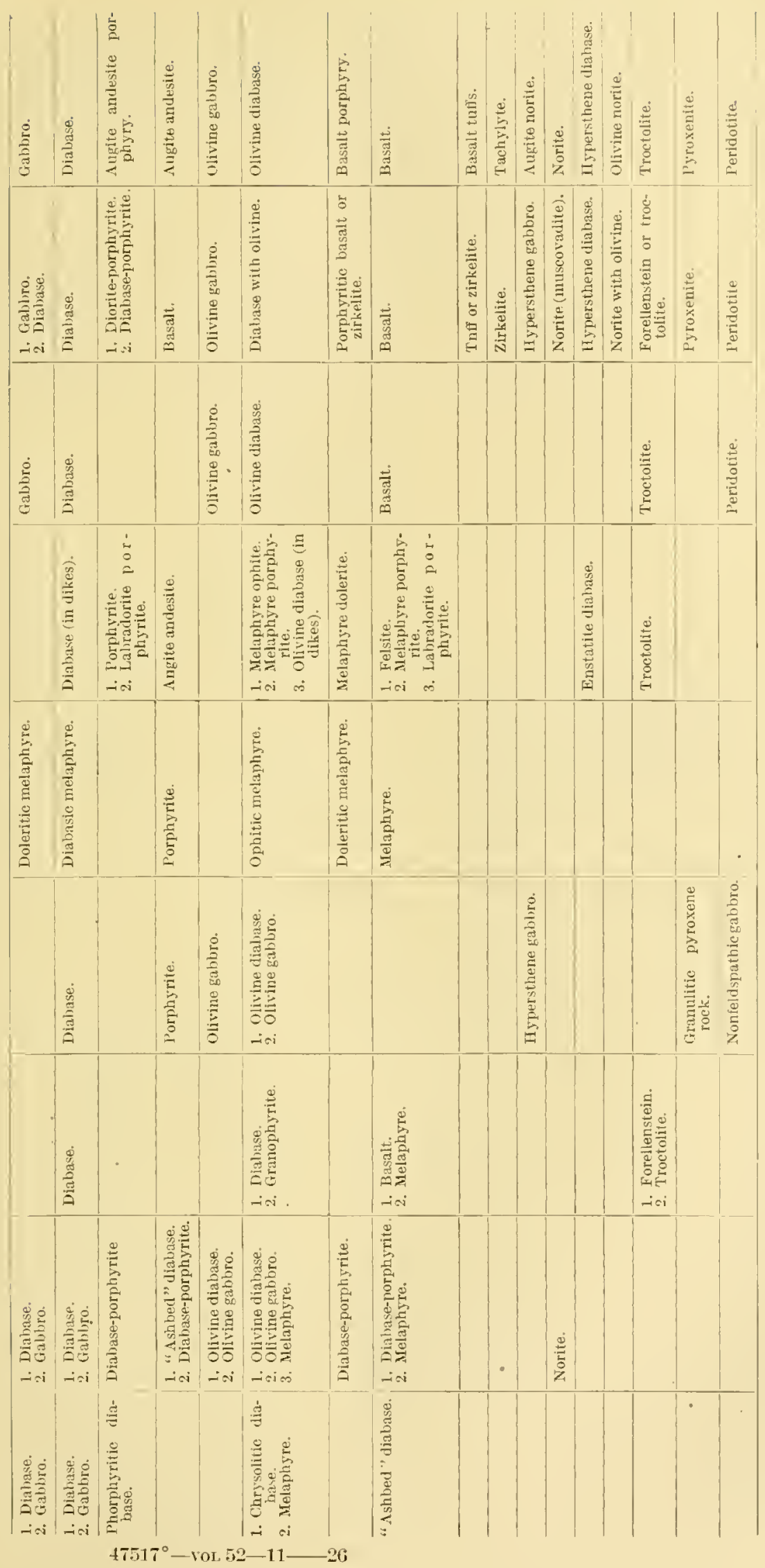




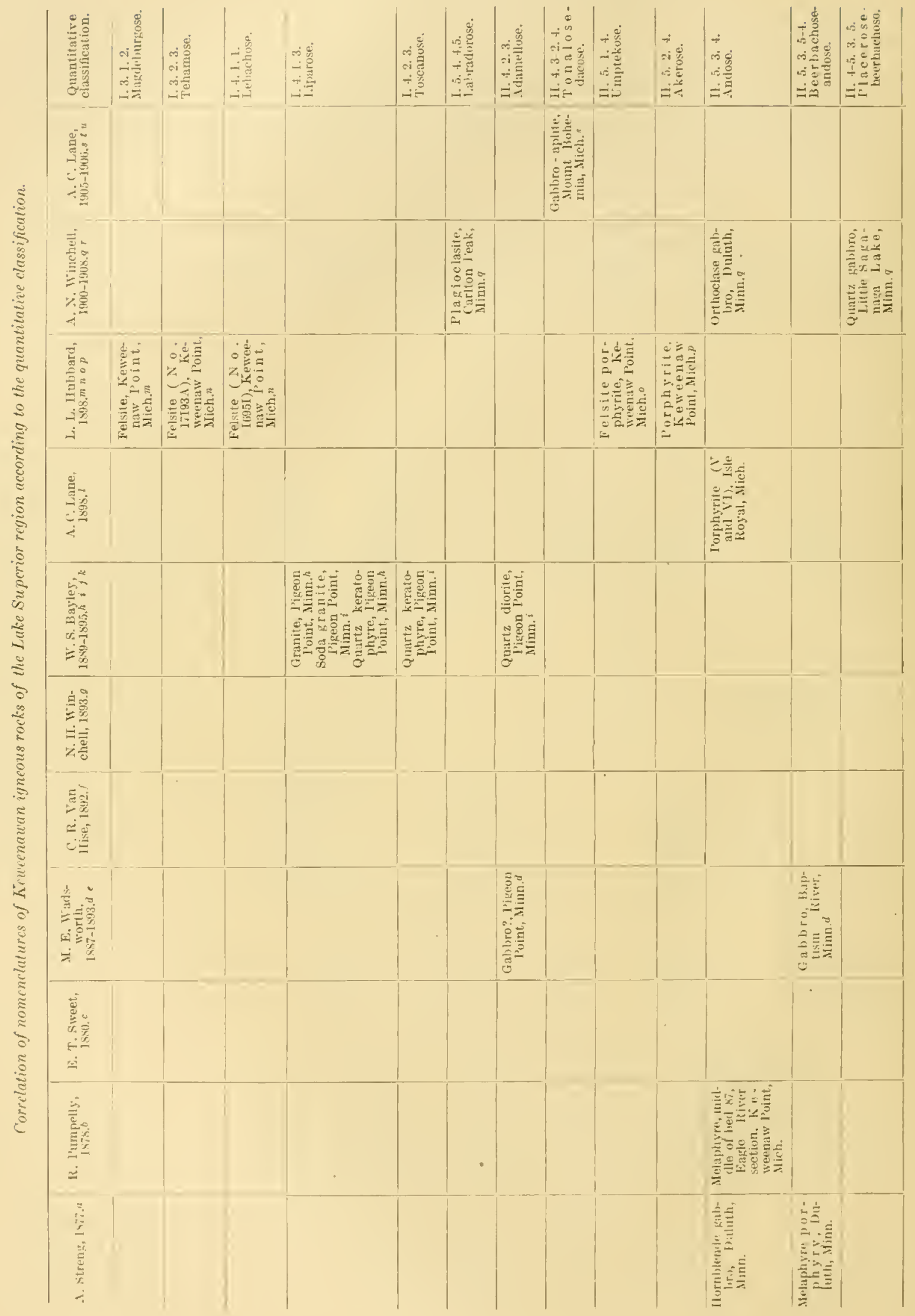


THE KEWEENAWAN SERIES.

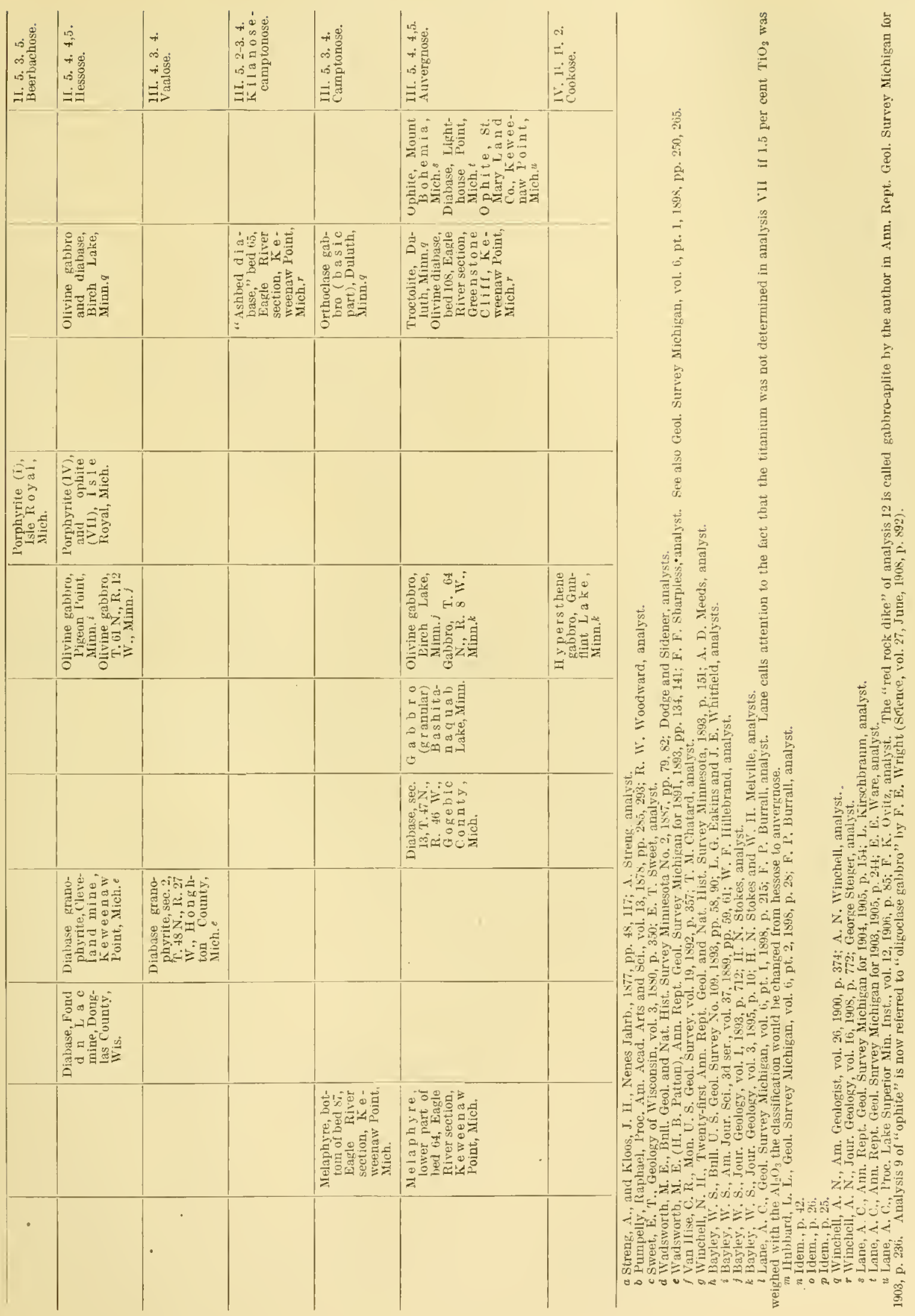


The quantitative chassifieation of igneous locks as proposed by Cross, Mllings, Pirsson, and Washington may be userl as the basis of a correlation of the Keweenawan igneons rocks. With respect to chenical composition such a correlation (sce table on pp. 402-403) is more exact than one based on the mineral composition and texture, but it can include only those rock types of which satisfactory quantitative analyses are available.

An eximination of the table of correlation on this basis will reveal the fact that the number of satisfactory analyses available is not great, esjecially when compared with the descriptions previously mentioned. Several of the early analyses are not included in the tabulation because of manifest inaceuraey or incompleteness.

The analyses of Streng and Pumpelly are good for the time at which they were made. Caleulation of the norms of the analyses made for Pumpelly by R. W. Woodwarl yields the results tabulated below in columus 1,2 , and 3 :

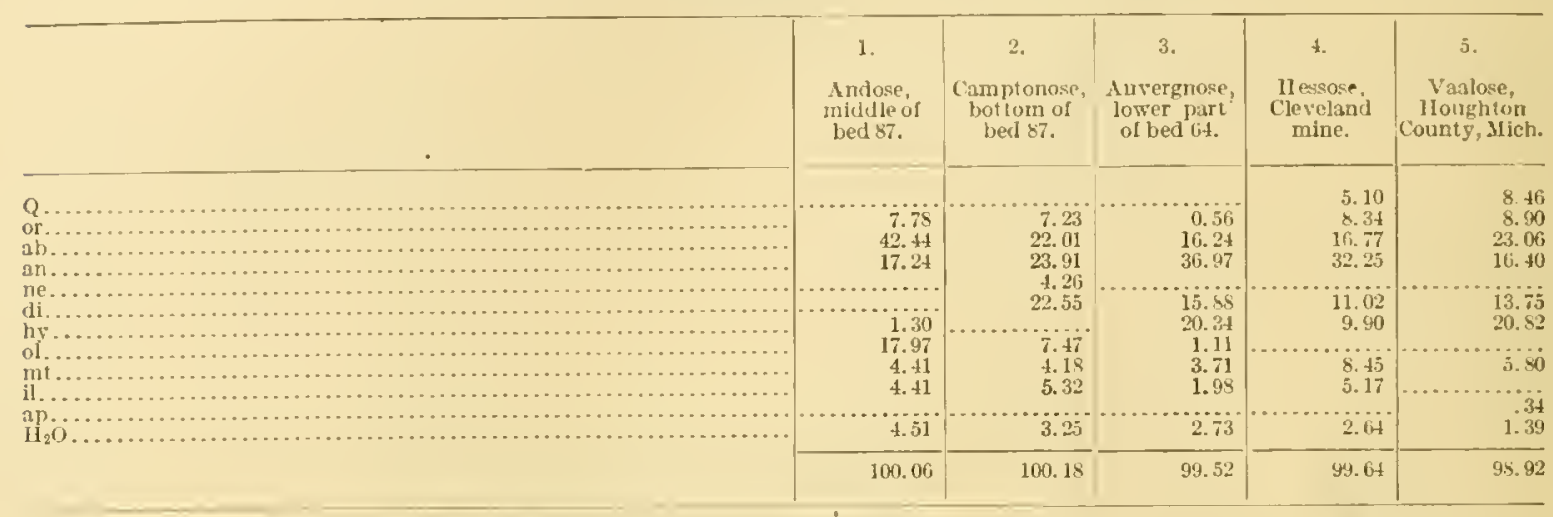

Sweet published two analyses of Keweenawan rocks. One, of diabase from the Asliland mine, Ashland County, Wis., is wholly unsatisfactory; the other, which represents a "greenishgray diabase" from the Fond du Lac copper mine, Douglas County, Wis., seems to be approximately correct. As it stands it classifies as bandose, but this is on the basis of a content of 13 per cent of magnetite and 10 per eent of quartz. Botlu of these figures are extremely improbable for this rock, and point to an error in the determination of the state of oxidation of the iron. If the analysis is corrected in this particular it classifies as hessose.

The analyses of gabbros published by Wadsworth are recalculated in Wrashington's tables of ehemical analyses of igneous rocks; ${ }^{a}$ the norms of his diabasc-granophyrites from the Cleveland mine and from 1 Ioughton County are given in columns 4 and 5 of the table above. Washington's tables give full details regarling the reealculation of the analyses of Keweenawan rocks pullished by Van Hise, N. II. Winchell, and Bayley.

The norms of the analyses reported by Hubbarl may be summarized as follows:

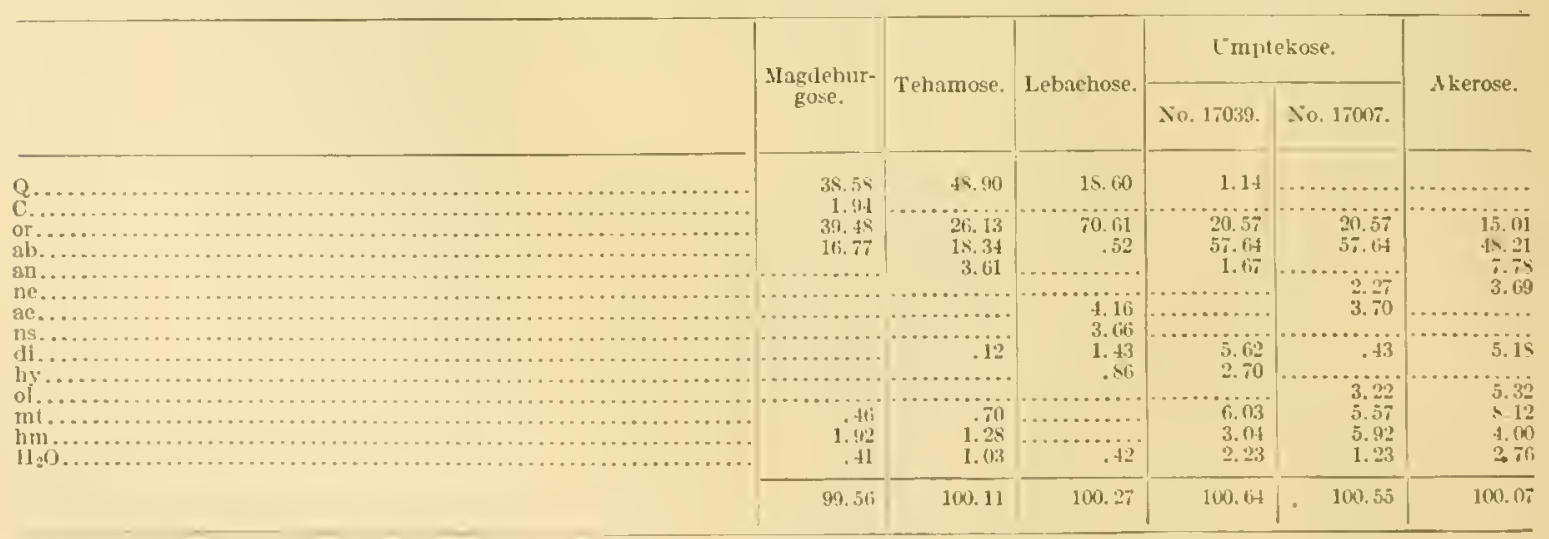

a Wishingtou, II. S., l'rol. I'aper Č. S. Geol. Survey .̌o. 11, 1903. 
It is to be remarked that not one of these rock types described by IIubluarl corresponds chemically with any varicty lescribed by any other anthor. The fact suggests possible inaceuracies in Hubloard's analyses.

Lane's analyses, as well as Hubbart's, were overlooked and omitted from Washington's tables. Recalculations of the analyses given by Lane yicld the following norms:

\begin{tabular}{|c|c|c|c|c|c|c|c|c|c|}
\hline & \multirow[b]{2}{*}{$\begin{array}{c}\text { Tonalose } \\
\text { dacose. }\end{array}$} & \multicolumn{2}{|c|}{ Andose. } & \multirow[b]{2}{*}{$\begin{array}{l}\text { Beerba- } \\
\text { ehose. }\end{array}$} & \multicolumn{2}{|c|}{ Ilessose. } & \multicolumn{3}{|c|}{ Auvergriose. } \\
\hline & & No. V. & No. VI. & & No. $1 \mathrm{~V}$. & No. V11. & $\begin{array}{l}\text { Jo. S } \\
\text { Light- } \\
\text { honse } \\
\text { l'oint. }\end{array}$ & $\begin{array}{l}\text { St. Mary } \\
\text { Land Co. }\end{array}$ & $\begin{array}{c}\text { Mount } \\
\text { Bohenia. }\end{array}$ \\
\hline Q.... & 13. 08 & & & & & & & 1.80 & \\
\hline & $\begin{array}{r}1.02 \\
17.79\end{array}$ & 6.12 & 6.12 & $2.7 x$ & 1.67 & 2.78 & 3. $\$ 9$ & 1. 67 & inoi \\
\hline 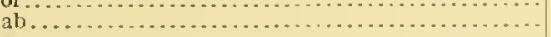 & 36.15 & 28.82 & 23.58 & 45.59 & $25 . \times 2$ & 21.45 & 15.35 & 20.96 & 1s. 34 \\
\hline an......... & 16.96 & 24.19 , & $\begin{array}{rl}30 . & 30 \\
4 & 30\end{array}$ & 20.02 & 34.19 & 41.14 & 36.14 & 31.41 & 31.69 \\
\hline 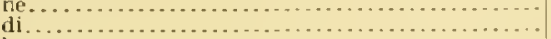 & & $\begin{array}{l}2.81 \\
3.80\end{array}$ & $\begin{array}{r}4.20 \\
18.41\end{array}$ & 1.30 & 10. 66 & 10.64 & 13.52 & 12.74 & 1.36 \\
\hline …............. & 11.06 & & & 2. 76 & 1.56 & 5.76 & 10.77 & 12.20 & 21.62 \\
\hline$\cdots$ & & 23.25 & 2.10 & 12.58 & 12.97 & 6.01 & 13. $06 i$ & & 2.05 \\
\hline $\begin{array}{l}\mathrm{mt} \text {. } \\
\mathrm{hm} \text {. }\end{array}$ & 2.32 & 3.94 & 11.14 & 11.37 & 6.50 & 10.44 & 3.71 & 10.67 & $7 . \pm 2$ \\
\hline & 1.98 & & $\cdots \cdot{ }^{\prime}$ & ....... & …... & ............ & 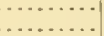 & $\begin{array}{l}2.27 \\
4.10\end{array}$ & 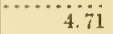 \\
\hline $\log _{2}$ & ........ & & & & & & 34 & .34 & $\cdots \cdots$ \\
\hline & ......... & .90 & 2.30 & 2.00 & $\cdots \cdots$ & .70 & & 1.10 & $\cdots \cdots$ \\
\hline \multirow[t]{2}{*}{$\mathrm{H}_{2} \mathrm{O} \ldots \ldots$} & & 5.01 & 3.49 & 2.82 & 3.90 & 1.83 & & .67 & (n......... \\
\hline & 100.36 & 95.87 & 101.62 & 101.22 & 100.27 & $100.7 s$ & 100.11 & 100.00 & 97.23 \\
\hline
\end{tabular}

Lane's gabbro-aplite differs in its norm from the orthochase gabbro of Duluth in having a greater abundance of quartz and also a greater proportion of alkalies as compared with salic. lime. His porplyyrite VI, on the contrary, belongs to the same type (anclose) as the orthoclase gabloro. His porphyrite No. 1 is a becrbachose; the others belong to the classes hessose and auvergnose, so well represented in the Keweenawan.

The analyses published by $\Lambda$. N. Winchell in 1900 were recaleulated by Washington with the exception of that of the troctolite, the norm of which is given with those derived from the new analyses of diabase in the second table below.

In view of the scarcity of analyses of the typical volcanic rocks of the Keweenawan the following new analyses are of much interest. They were made by George Steiger in the laboratory of the Survey.

Analyses of Keneenawan diabase.

\begin{tabular}{|c|c|c|c|c|c|}
\hline & 1. & 2. & & 1. & 2. \\
\hline 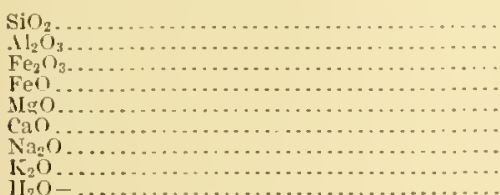 & $\begin{array}{r}47.69 \\
16 ., 02 \\
2.41 \\
8.70 \\
8.31 \\
10.54 \\
2.44 \\
\text { None. }\end{array}$ & $\begin{aligned} 50.07 \\
12.63 \\
3.54 \\
10.30 \\
5.23 \\
6.55 \\
3.53 \\
1.90 \\
1.86\end{aligned}$ & 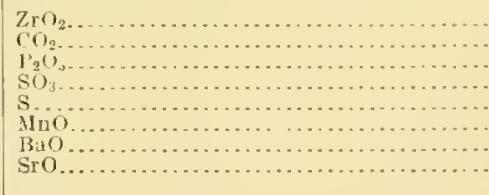 & $\begin{array}{l}\text { None. } \\
\text { None. } \\
\text {.06. } \\
\text { None. } \\
\text { None. } \\
.26 \\
\text { None. } \\
\text { None. }\end{array}$ & $\begin{array}{l}\text { None. } \\
\text { None. } \\
.22 \\
\text { None. } \\
\text { Nonp. } \\
.42 \\
.02 \\
\text { None. }\end{array}$ \\
\hline 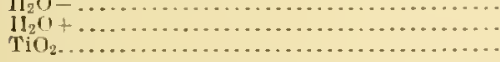 & $\begin{array}{l}. .44 \\
1.35\end{array}$ & $\begin{array}{l}.80 \\
1.96 \\
2.50\end{array}$ & & 100.29 & 100.03 \\
\hline
\end{tabular}

1. Olivine diahave from bed 108, Eagle River section, Greenstone Cliff, Keweenaw Point, Mich. Sample No. 5 of Rohn's collection of Lake

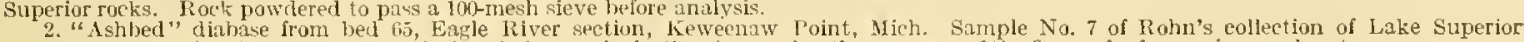
rocks. Rock powdered to pass a 100-mesh sieve hefore analysis, thus improving the accuracy of the figures for ferrous iron and water. 
Recaleulation of these analyses, together with that of the troctolite, on the basis of the quantitative chassification gives the following norms:

\begin{tabular}{|c|c|c|c|}
\hline & $\begin{array}{l}\text { Ulivine } \\
\text { Jialiase. }\end{array}$ & $\begin{array}{c}\text { "Ashbed" } \\
\text { diabrase. }\end{array}$ & Troctolite. \\
\hline 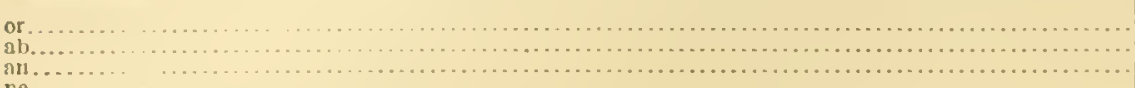 & $\begin{array}{l}20.41 \\
32.40\end{array}$ & $\begin{array}{l}11.12 \\
23.87 \\
13.07\end{array}$ & $\begin{array}{r}2.22 \\
7.86 \\
25.633\end{array}$ \\
\hline $\begin{array}{l}\text { ne........ } \\
\text { dl....... }\end{array}$ & 15.60 & $15 . j 2^{-1}$ & $\begin{array}{l}\text { b. } 91 \\
5.91\end{array}$ \\
\hline hy. & 15.64 & 15.32 & \\
\hline 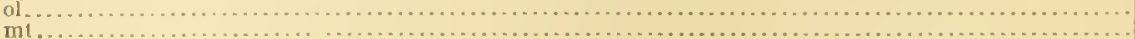 & $\begin{array}{l}7.01 \\
3.48\end{array}$ & $\begin{array}{l}2.100 \\
5.57\end{array}$ & $\begin{array}{l}30.21 \\
10.67\end{array}$ \\
\hline il... & 2.74 & 4.71 & 4.41 \\
\hline $\sin .$. & .14 & .50 & \\
\hline \multirow[t]{2}{*}{ 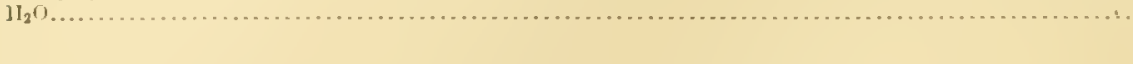 } & 2.4 & 2.82 & 5.23 \\
\hline & $100.3 k$ & 100.10 & 100.43 \\
\hline
\end{tabular}

The olivine diabase belongs to the same class as the olivine gabbros of Bireh Lake, the diabase of Lighthouse Point, and several others-that is, to the auvergnose type, which seems to be the dominant type of the lieweenawn, although the hessose type, which differs only in having a greater proportion of salie minerals, is also fairly abundant. But the "Ashbed" "liabase elassifies as a camptonose, very near a kilauose. It is therefore related to Irving's molaphyre of bed 87 of the Eagle River section, and to the more basic phases of the orthoclase gabloro of Duluth.

On summarizing the results of this correlation of chemical analyses of kieweenawan igneous rocks on the basis of the quantita tive classification, it appears that eight analyses belong to Class I, the persalanes, in which less than one-cighth of the rock consists of ferric minerals; 2-2 analyses fall in Class II, the dosalanes, in which more than one-eighth and less than three-eighths of the rock consists of ferric minerals; 14 analyses belong in Class III, the salfemanes, in which the salic and ferric constituents are in nearly equal proportions; while the single remaining rock represents Class IV, the clofemanes, in which the ferric constituents make up about three-fourths of the whole.

Barring the peculiar analyses of IIubbard and the hypersthene gabbro of Bayley, which is known to be a border facies, several general characteristics of the Keweenawan igneous rocks appear. The salic constituents always make up at least one-half of the rock; they are usually all feldspar and everywhere are dominantly feldspar; quarty is nowhere very abundant and the lenads are almost unknown in the norms, as they are also in the modes. In all except the Pigeon Point rocks and one sample from Mount Bohemia, the anorthite molecules either equal or dominate over the alkali feldspar molecules and the albite molecules dominate orer orthoclase.

Still other relations may be brought out by considering separately the analyses belonging to each class.

Chass I. The eight persalanes fall in six subrangs, half of which are due to Hubbard's analyses. They range from the quartz-rich felsites of Hubbard to the quartz-free plagioclasite. The four intermediate types, belonging to two subrangs, are all derived from Pigeon Point. In all the rocks of this class except the plagioclasite, alkali feldspar molecules greatly predominate orer anorthite, and orthoclase is notably abundant in only two of the rocks.

Class II. The 22 dosalanes fall in nine subrangs, but these would be rerluced to seven if compound names like beerbachose-andose were omitted. These rocks are chicfly perfolic, containing no quarty, but four samples are quardofelic, from the presence of small amounts of quart\%. The silica in no rase falls so) low as to produce lenads. IIere, as in ('anss I, the anorthite molecules dominate over the alkali feldspars in only one subrang, in this case hessose. The albite molerules always dominate orer the orthorlase.

Clas: 111. 'The 14 salfemanes fall in four subrangs, and 10 of them fall in a single sulurang. namely auvergnose, which uidoubtedly represents the prevailing rock trye of the fiewernawan of the district. The commonest rariation from this type is an increase of salic constituents, with no other change. This proluces hessose, of which eight analyses are recorded. The silica contrut of the rocks of (lase III is high enough in all cases to plevent normative lenalk: 
dnly one analysis shows any normative quartz. In the feldspars the albite molecules again dominate clearly over the orthoclase.

Class IV. The single analysis lalling in Class IV is elearly not representative; it is a loorder facies of the great gabbro intrusion. "It is characterized by doninance of ferric constituents, of which pyroxene is the most important. It is low in soda and lime and high in ferrous iron, and especially in magnesia.

It is to be expected that additional analyses of the Kewecnawan volcanie rocks would disclose still ofluer types, especially such as would parallel the known plutonic types. The parallelism in composition already established is remarkable, considering the relatively small number of analyses available. Thus it appears that Lane's porphyrite ( $\mathrm{N}_{0}$. IV) and oplite (No. VII), as well as Sweet's Douglas County diabase and Wadsworth's diabase-granopliyrite from the Cleveland mine, are the chemical equivalents anong the volcanic and dike rocks of Bayley's olivine gabloro from Pigeon Point and from T. 61 N., R. 12 W., and of A. N. Winclell's olivine gabbro and diabase from Birch Lake among the plutonic rocks. Again, Pumpelly's melaphyre from the iniddle of bed 87 and Lane's porphyrite (Nos. V and VII) firom Isle Royal correspond chemically with the coarse hornblende gablbro and orthoclase gabbro from Duluth. Finally, the same chemical type, auvergnose, includes plutonie rocks such as Bayley's gabbro and olivine gabbro from Birch Lake, N. II. Winchell's gabbro from Bashitanaqual, Lake, and $\Lambda$. N. Winchell's troctolite, together with volcanic or dike rocks, such as Pumpelly's melaphyre from bed 64, Van IIise's Gogebic County diabase, and Lane's ophite from the property of the St. Mary Land Company and from Mount Bohemia.

\section{TIE GRAIN OF KEWEENAWAN IGNEOUS ROCKS-TIE PRACTICAL USE OF OBSERVATIONS. ${ }^{a}$}

A. C. Lane has found that the grain of the Keweenawan igneous rocks has sufficiently close relation to the size and thickness of the masses to be of some practical importance in exploratory work. Lane's theory of the causes of the variations in grain is not here discussed; it nay be found in his papers. ${ }^{b}$ The facts which he has developed are loriefly as follows:

The Keweenawan igneous rocks most commonly occur in dikes, sills, sheets, and lava floods. It is found in most places in the Lake Superior region that crystallization in such forms has resulted in finer grain near the margin and coarser grain near the center. "The relative coarseness of crystallization may be determined by measuring grains of any mineral, but experience shows that in the Keweenawan rocks of the Lake Superior region measurement of the grains of pyroxene (augite) is usually most feasible and most satisfactory. Such measurements show that the size of grain in narrow dikes increases from the margin to the center, the size at any point being approximately proportional to the distance from the margin. In wider dikes measurements slow a coarse central zone of variable width in which the pyroxene grains have approxinately equal size or increase much more slowly. On each side of this central zone the law already stated is found to loold approximately. In surface flows, where convection was probably active, the size of grain of the augite increases usually all the way from the margin to the center. In wide dikes and thick flows the augite is found to increase in size at a rapid rate near the margin and at a much slower rate noar the center. The rapid rate of increase is confined to a marginal zone, usually less than 10 fect wide. The slower rate of increase is fairly uniform for any one flow, and in the luster-mottled melaphyres or ophites is usually between 1 millimeter in 10 feet and 1 millimeter in 20 feet, or say 1 millimeter in 3 to 5 meters. In more feldspathic flows it is less. The very highest rate of increase in the inner zone is 1 millimeter for each 8.5 feet, but in most cases the rate comes out as 1 millimeter in 11 to 16 feet. This refers to tho linear cliameters of the augite grains, as indicated by the mottlings on the drill cores. It makes some difference whether they are measured in this way, or by the luster nottlings due to the flashes in the sunlight, or by the knobs in the weathered surface.

a Adapted from article by $\perp$. C. Lane.

6 Bull. Geol. Soc. Ameriea. vol. ¿, 1896, pp. 403-407; Geological report on Isle Royale Geol. Survey Michigan, rol. 6, 1s9s, pp. 10ti-151; Am. Jour. Sci., 4th ser, vol. 14, 1902, pp. 393-395; Bull. Geol. Soc. America, vol, 14, 1903, pp. 3r9-406; Ann. Rept. Geol. Survey Michigan Ior 1903, 1904, pp. 205-237; idem for 1904, 1905, pp. 147-153, 163; idem for 1908, 1909, pp. 3\$0-384; Am. Geologist, vol. 35, 1905. Pp. 15-72; Jour. Canadian Min. Inst., vol \&, Wie Korngrosse der Autergnosen: Suppl. to Rosenbusch Festschrift, Imo: Tufts' College Studres, II, pp: 41-42. 
The practical applications of this stuly of the size of augite grains in mining have been numcrous, especially where contacts of igneous rock are an important factor, as in the Keweenaw copper mines, where the desire is to fund the anygdaloids at the tops of massive lava flows.

1. One may distingruish in drill cores between anygdaloid streaks or inclusions in the body of a How and the main amyodinloid top by the fining of the grain of the rock as a whole toward the latter. There is also a finer grain just around individual amygdules, but in a zone of only nic roscopic breadtl.

2. Extra wide flows may be identified by the relatire coaseness in all parts, the maximum grain, and the rate of incrense of grain. Of course such flows will run out or grow thinner in a sullicient distance. For instance, an ophite attaining an alugite grain of 7 millimeters is rather persistent just about 200 feet above the Baltic lode. The coarsest ophite of all, attaining a uaximum augite grain of 76 millimeters ( 3 inches), is several hundred feet thick out on Keweenaw l'oint and runs over to Isle Royal, but diminishes in thickness to 50 feet at Portage Lake. It lies just above the Allonez conglomerate and a group of former mines, and where thickest is easily identified by its grain.

3. With due regard to the possibility of being deceived by an extra feldspathic bed, it is possible from a slow increase in coarseness of grain in the diamond-drill cores to infer that the led is being traversed obliquely and to obtain an iclea of its true dip. L. L. Hubbard had to open the Challenge exploration through a heavy covering of drift in a region where no outerops were near. The first drill hole was put down rertically. The rate of coarsening of grain in normal-looking ophites being about half what would be expected, a dip of about $60^{\circ}$ was inferred-correctly, as it proved later.

4. A shaft sinking through drift entered massive trap. The question arose, Which way lies the nearest anygdaloid? A drift in the direction of the finer grain soon found it.

5. A crosscut encountered a clay seam in a heary trap, which was proved to be more than a mere seam, a displacement, by a marked difference in the coarseness of grain on the two sides. This difference acted as a guide until the displaced locle was found.

6. It is possible to tell how far one has to go through a bed already more than half penetrated. For instance, Kiearsarge shaft 21 of the Calumet and IIecla did not strike the lode where it was expected, owing to an unknown displacement. Search was made in two opposite directions. Neither drill hole reached the lode, but it was possible from the grain to say that the lode was probably about 30 feet beyond the end of one hole, which had penetrated the foot-wall trap.

7. A regularity and harmony in grain may listinguish obscure outerops from casulal bowlders. In the case just mentioned some insignificant outcrops were found which passed this test and indicated from their fineness that they were in the langing wall of the lode, a little above it. The lode was thus found in a week, when it might have taken months without this mons of testing.

S. Conversely a very coarse grain indicates a heary bel of trap, and thus galps and covered spots in a section may be bridged.

9. The ways of recognizing extremely feldspathic beds and intrusives have already been mentioned.

T11E EXTRTSIVE MLSSES.

The extrusive rocks are almost altogether lava beds, piled one upon another, the rolcanic clastic rocks being unsignificant in quantity. The total rolume of the extrusires is rast.

The basic lavas greatly predominate. They occupy about 6,000 square miles. It is scarcoly necessary to describe them in full, for notwithstanding their age they show all the textures and structures characteristic of the Tertiary roleanic hasalts of the Wrest, the only important difference between the two being that the keweenawan lavas have suffered extensive metasomatic alterations. The beds rary from those less than 2 feet to those which are 100 leet or more in thickness, although lava beds thicker than 100 feet are rather rare and those 
200 feet thick very rare. Lane ${ }^{a}$ mentioncd two ophites in the Black River section, each of which, according to him, has a thickness of at least 500 feet, and Wilson ${ }^{b}$ describes a known thickness of more than 500 feet of apparently one mass in the Nipigon basin.

The textures exhibited by the lavas are to a considerable extent a function of the thickness of the flows. The surfaces of the flows show an aphanitic or glassy texture. In the thin beds the aphanitic texture may prevail to the center of the How. In many of the beds of moderate thickness, from 10 to 20 feet, there is a well-developed ophitic texture. As alrearly noted, Lane ${ }^{c}$ has worked out very carefully the relations between the textures exlibiter] by the lava flows and their thickness, and he holds that the textures are definite functions of the thickness.

The borders of the flows are commonly anygdaloidal. As a rule the amycraloidal borders are thicker at the upper parts of the flows than at the lower parts. This texture may extend 2 to 10 feet, or even to 20 feet, from the tops of the flows. The anyglules decrease in size in passing from the surface inward. In many places the lower borders showing this texture exhibit the peculiar type known as the spike anygdule. Where the lava beds are thin the amygdaloidal texture may extend to the centers, but this is not common.

The lavas show in places the usual volcanic structures. Many of the beds are columnar. Some flows prescnt ropy surfaces. 'The upper parts of many flows have a fragmental appearance. In some flows this is due to the breaking up of the upper part of the lava mass while it was still liquid or semiliquid, and in such places the lébris is likely to be cemented by the other parts of the lava. Here and there the broken material at the top of the lava beds secms to be truly rolcanic. In other places the broken fragments, whether formed by flowage or by the action of air and water, are cemented by their own clébris. Nore rarely volcanic fragmental deposits, bombs and ashes, seem to have been laid down upon the surface of one flow between the time of its consolidation and the extrusion of the next flow. While there is undoubtedly some volcanic fragmental material, as, for instance, the tuff at Taylors Falls on St. Croix River described by Winchell, ${ }^{d}$ on the whole for the basic lavas this is extraordinarily small in amount, considering the great extent and volume of the igneons series.

The (listance for which a single bect ean be followed is to a considerable extent a function of its thickness. The thin flows have a very moderate extent, and even the thicker flows for the most part have not been tracel for any great distance. The greatest distances for single flows which have been recorded are 30 miles, by Irving, ${ }^{e}$ for the greenstone, and 22 miles, by Grant, $f$ for one of the melaphyres of the St. Croix Range. Irving $e$ says that he has traced individual flows with certainty on the Minnesota coast for 10 to 15 miles. Groups of lava beds have been traced for much greater distances. For instance, the thin belt of amygdaloils and diabases above the "Great" conglomerate of Keweenaw Point has been traced uninterruptedly for 150 miles. Although a group of lava beds may be tracel throughout a distriet, no group is known to be regional in extent; so that in general it is impossible to correlate lava groups from district to district, as, for instanee, those of Kewernaw Point with those of the Minnesota const. The only such correlation yet at empted is that by Lane $g$ between the flows of Keweenaw Point and those of Isle Royal.

The aciclic flows differ physically from the basic flows. In general they appear to have been much less fluid, and therefore have a much shorter lateral extent in proportion to their thickness. In fact, a bunchy or lenticular form is characteristic of these flows, as is illustrated by Mounts lloughton and Bohemia on Kícweenaw Point. Amygdaloidal textures are not so conmon in the aciclic as in the basic lavas. A flowage structure, on the other hand, is much more prevalent in them than in the basic lavas, and glassy textures are exceedingly common.

a Gordon, W. C., assisted by A. C. Lane, I geological section from Bessemer down Black River: Rept. Geol. Survey Mijhigan for 1906, 1907 , p. 461

b Wilson, A. W. G., Trap sheets of the Lake Nipigon basin: Bull. Geol. Soc. Ameriea, vol. 20, 1909, p. 198.

c Geol. Survey Michigan, vol. 6, pt. 1, 1998, pp. 123 et seq.

$d$ Winchell, N. 11., The significance of the fragmental eruptive débris at Taylors Falls. Minn:: Am. Geologist, vol. 22, 1898, pp. 72-78.

CIrving, R. 1)., The copper-bearing rocks of Lake Superior: Mon. U. S. Feol. Survey, vol, 5, 1ss3, p. 140.

$f$ Grant, U. S., Preliminary report on the coper-bearing rocks of Douglas County, W' is.: Bull, Geol, and Nat. IIist. Survey Wisconsin No. 6, 2 d ed., 1901, p. 12.

g Lane, A. C., Geological report on Isle Royale, Mich.: Geol. Survey Michigan, vol. 6, pt. 1, 1898, pp. 99-102. 
The basic and acidic: extrusives may correspond roughly to the gabbro-like intrusives, which are regarded by Wright a and others as differentiates from the same magma.

As a rule the dips of the lava beds range between $10^{\circ}$ and $45^{\circ}$, but locally they go beyond these extremes, sinking to horizontal and rising to $80^{\circ}$ or even to vertical. $\Lambda$ mass of rock mate up of lava berls having moderate dips gives a very characteristic topography, which may be described as strplike or sawtoothed. Where the beds are thin the steps are fow; where thick, they are high. When one walks across a set of lava beds in the direction of the dip, as he approaches a lava flow he finds a steep slope, or even a precipitous wall, which inclieates approximately the thickness of the flow. As he climbs to the top of this wall he finds a gentle slope, which corresponds roughly with the dip of the rocks, and down which he may travel until he comes to the next flow, where he will encounter another steep wall, and so on. The character of this topography has been very well figured by Irving ${ }^{b}$ for the sawtooth range of 1 linnesota and for the Eagle River section of Keweenaw Point.

\section{THE INTRUSIYE MASSES.}

Chemically the intrusive rocks include basic, acidic, and intermedinte varieties. Structurally they comprise every known form of intrusive rocks except batholiths. There are great laceoliths, many large bosses, numerous and extensive sills, and abundant dikes, from those of small size to those humbreds of feet across. Many of the dikes and sills beautifully show a columnar structure. In some of the earlier studies the sills were not separated from the lava flows.

As to magnitude, the masses vary from the Duluth gabbro of Minnesota, which, as showr in another place, has an exposed area of 2,000 square miles and a possible diameter of 100 miles, to emanations so small as to be lost in the intruded rocks. It appears probable that the volume of the intrusive rocks within the previously formed extrusive lavas and conglomerates is really greater than the rolume of the laras themsclves.

The greatest of the intrusions of late Keweenawan time are basic. These are represented by the gabbro laceoliths of Mimmesota and Wisconsin. Some of the acidic masses also are large, but they are likely to occur in bosslike forms. Representatives of these are the masses at Bare Hill and West Pond on Keweenaw Point.

In the description of the areas of Huromian and Arehean rocks it has been shown that varying quantities of the Keweenawan igneous rocks intrude all the previous formations. In these great series throughout the Lake Superior region is a mass of Kiereenawan rocks which is perhaps as great as the lavas. The most conspicuous examples of this class are the intrusive sills of the Animikie group, ealled the Logan sills, which are conspienously illustrated at Thunder Bay. Larger masses of granite intrude and highly metamorphose the Animikie rocks westward from St. Louis River in central Minnesota through the Cuyuna and Little Falls areas. The granite of northeastern Wisconsin intrudes green schists, which are interbedted with the Animikic group, and is probably of the same age as the central Minnesota granites. Both are regarded as Kiweenawan.

Wright a regards the aplite of Mount Bohemia as differentiation from the gabbro magma. The aplite antedates the calblyo slightly in its period of erystallization. The aplite occurs not only as a central harge mass but also as small dikes and patches in the gabbro mass itsilf and as small apophyses of gabbro in the adjacent ophites. Wright suggests that the gabbro and aplite are respertively the deep-seated equivalents of the basic and acidic flows of the Keweenawan series.

The close genetic association of the aplites and gabbros has becn recognized at many places in Mimnesota, Wisconsin, Mlichigan, and Ontario. The aplite Was regarded as eflused ardilic soliment by Bayler ${ }^{c}$ in his studies on Pigeon Point and by Bowend in his studies on

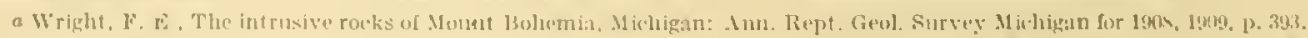

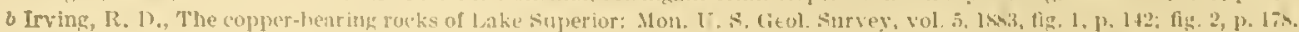

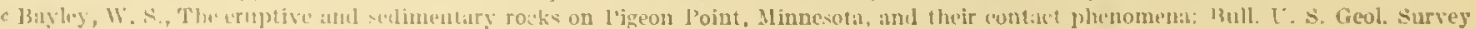
o. $1101,1 \times 13$

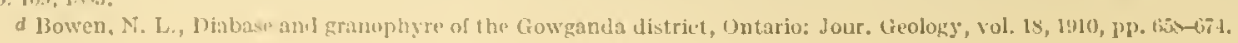


the Cobalt district, but practically all others who have studicd the subject, including Wriglit, Collins, ${ }^{a}$ and the authors, regard the aplites and gabbros as magnatic differentiations from a single magma.

In general, the later intrusives have not greatly metamorphosed the early Keweenawan roeks intruded by them, but there are some exceptions. The far-reaching metamorphic effect of the great laccoliths and bosses upon the lower series has alrealy been rescribed in eonnection with the Penoke, Vermilion, and Animikie districts. It is probable that future studies will also show pronounced metamorphic eflects of these laceoliths on the intruded Keweenawan rocks. Already this lias been found to be true for the gabbro ol Black River.

In several places the acidic and especially the granitic rocks have produced notable metamorphic eflects on the Keweenawan as well as on the lower series. Indeed it is believed that the so-called orthoclase gabbros of Irving $^{b}$ at several places, at least, along the Minnesota coast are due to the granitization of ordinary gabbros by the acilie rocks.

\section{SOURCE OF LAYAS.}

As to the location of the fissures from which the lavas issued it is not possible to make any very definite statement. It has been suggested that they were situated along the south shore of Lake Superior. It seems to us that a much more probalble suggestion is that the entire border of Lake Superior; with the possible exception of the south side of the east end, was the locus of a series of great fissures which extended inland from the lake for a very considerable distance, certainly in Wisconsin and Minnesota for at least 100 miles. That such fissures existed on an extensive scale is shown by the numerous dikes cutting the Huronian of the Gogebie distriet, presumably constituting neeks for the flows of the Keweenawan just to the north. Some upper Huronian dikes in the Iarquette district may also be so classed. Along the north shore of lake Superior are many dikes which may well be related to the flows as necks. Farther to the west both basie and acidic intrusive dilies cut the flows of the Mesabi and Cuyuna districts. The convex outline of the Duluth gablro laccolith away from the Lake Superior shore suggests a source somewhere in the direction of Lake Superior. It is not certain that similar vents may not underlie the lake.

No evidence has been found of voleanic vents. Fragmental ejectamenta of volcanoes are very subordinate in the Keweenawan lavas, and the extent of the lavas is greater than is usual for lavas coming from ordinary volcanoes.

So far as evidence is available, the lavas welled through widely distributed fissures certainly bordering and possibly underlying the present area of the lake.

It is well known that rolcanism is a function of orogenie movements. In this connection it is to be noted that Keweenawan volcanism followed in general the axis of the Lake Superior synchinorium. Plutonic intrusives, probably equivalent in age to the Keweenawan flows, are the large granite masses cutting the slates of the Animikie group in the Cuyuna and St. Louis districts in central Minnesota, near the principal axis of deformation of the Lake Superior syncline. The lavas issuing from the many known fissures bordering the synclinorium doubtless flowed down the slopes toward the Lake Superior basin. The morement would be to the south from the north side, to the northwest from the south side, and to the west from the east side, and not improbably northeastward from the west end of the basin.

How far out into the basin of what is now the lake the orifices went is uncertain, but Stannards Rock, Michupicoten, and Isle Royal show that if they diid not extend some distance beyond the shore the lavas have flowed a considerable distance. As the orogenic movements which produced the Lake Superior basin occurred largely cluring middle Kieweenawn time the conditions would continue to be favorable for the further issuance of lava and the slopes would

a Collins, W. II., The quartz diabases of Nipissing distritu, Ontario: Econ. Fenlogy, vol. 5, 1910, pp. 538-550.

$b$ Irving, R. D., The copper-bearing rocks of Lake Supet ior: Mon. U. S. Geol. Survey, vol. 5, 1s\$3, pp. 50-56. 
remain adequate to control its flows, notwithstanding the tendeney for the earlier lavas to lessen the slope. It is believed that the analogry of the Keweenawan lavias is with the Tertiary volcanic rocks of the West, such as those of the Snake and Columbia River plateaus, which were pourerl out from parallel aud interserting lines of fissures scattered over a broad area. In short the middle Kewcenawan is believed to have been a time of fissure cruption, comparable with the great Tertiary outbraks rather than with local volcanism, such as occurs at the present time.

\section{SEDIMENTARY ROCKS.}

\section{SOLTCE AND NATURE OF MITERIAL.}

The sedimentary rocks of the middle Keweenawan are dominantly conglomerates and sandstones. Shales are sulordinate. A light-red to dark-red color is very characteristic for the Keweenawan detritus interstratified with the lava beds. Among these rocks wray sandstones are unknown. The conglomerates range in coarseness from great bowlder conglomerates to fine conglomerates and these grade into sandstones and the sandstones into shales. All the. sediments are interstratified with the lava beds.

The detritus of the sundstones and conglomerates is dominantly derived from the Keweenawan igneous rocks themselves. It comprises bowlders, pebbles, and grains of sand and includes materials from all varicties of the basic, intermediate, and acidic rocks. The ease of recognizing the fragments, which are of considerable size, has led to a closer study of the conglomerates than of the sandstones and shales.

Usually the coarse detritus of the conglomerates is larrely or even dominantly from the acidic group of lavas-felsites, porphyries, and granites-and in places also from the intermediate rock, augite syenite, even where the sediment ary beds are between basic lavas. This is doubtless explained in a measure by the more resistant character of these formations as compared with the basic rocks, but it is also probable that the explanation rests partly in the fact that the acidic lavas were viscons and therefore they built up mountains which rose to great height and were subject to exceptional erosion, while the basic lavas formed areas of relatively low relief. Not uncommonly, however, where the conglomerates immediately overlie basic or intermediate rocks, detritus from this source is especially likely to be present and may be dominant. In some places, as in the localities near the mouth of Little Montreal River on Kewecnaw Point, described by Hubbard, ${ }^{a}$ the pebbles and bowlders are derived wholly from the earlier beds of lava. Thus between beds of melaphyre are melaphyre conglomerates and between beds of porphyrite are porphyrite conglomerates. Similarly between beds of felsite are felsite conglomerates. There are, however, all gradations from conglomerates whose pebbles and bowlders are derived largely or exclusively from the immediately subjacent flow to those in which the pebbles are from various sources and thus comprise basic, acidic, and intermediate materials all mingled in different proportions.

In the conglomerates the finer material between the pebbles is usually composed of detritus from the same rocks as the pebbles themselves. IIowever, in a particular conglomerate the matrix may include material from different sources and in different proportions from that of the pebbles. Thus even in the melaphyre and porpliyrite conglomerates described by Iubbard ${ }^{b}$ the matrix is derived largely from acidic rocks.

Commonly many of the particles, even in the matrix, are sufficiently coarse to be composed of more than one mineral. But where the mechanical subdivision of the material has gone far, the origrinal rocks are broken inte their constituent minerals and thus in the matrix of the conglomerntes there are likely to be minerals from the chief varieties of the original igneous rocks. Generally the original minerals from the acidic rocks are more noticable, as the basic constituents are more subjert to alteration. Still it is usually easy to roognize constituents from the basic rocks. Of these, magnetite, being the least destructible, is esprecially likely to be conspicuous. 
As a rule there have been extensive alterations of the constiuents of the conglonerates. These are more perrasive in the matrix than in the original peblbles, Jut may extend throughout even large bowlders. As a result of this alteration there are commonly present the serondary minerals zeolite, chlorite, epilote, calcite, quartz, and in places copper', whirh have becn brought in by infiltrating waters or have formed in place by metasomatic changes. Lane ${ }^{a}$ has discussed the chemical features of one of these alterations.

The sandstones, so far as they have been studied, seem to have about the same variations as the conglomerates. In general the particles are composed largely of fragments of the same acidic rocks whose fragments compose the conglomerate. This means that their clominant constituents are foldspar and quartz, with which there is always more or less elayey material and abundant ferrite. Ordinarily also there are subordinate contributions from the basic rocks, which furnish felelspar, angite, and magnetite. Hematite staining the grains is also pervasive. Perhaps thcir most characteristic feature as compared with common quartzose sandstones is the fact that quartz is not a dominating constituent. As in the conglomerates, so also in the sandstone beds, secondary alcite, chlorite, epidote, and the other alteration products of the original rocks are common, and even ropper is to be found here and there.

\section{DXTENT OF SEDIIENTS.}

As to the extent of the sediments interstratified with the lavas, the same statements may be made as with reference to the lavas; none of them are regional. In proportion as they are thick they naturally have a greater lateral extent. The thickest of these formations, the "Great" conglomerate of Kicweenaw Point, which has a maximum thickness of 2,300 feet, has been traced for over 100 miles, and one of the comparatively thin conglomerates lying immediately under the greenstone of Keweenaw Point has been traced for a distance of 50 miles. A conglomerate bed may vary greatly along the strike in the proportion of the constituents from a particular source; also in thickness and coarseness. At many places where ronglomerate beds thin they run laterally into sandstones or shales, the conser lragments failing altogether. Finally, a single sedimentary bed along the strike may be split into more than one bed by interleared lavas.

\section{UPPER KEWEENAWAN.}

The upper lieweenawan is confiner to northern Wisconsin and Michigan, where it constitutes a great sedimentiry livision, consisting of conglomerates, sanrlstones, and shales. It extends from Manitou Island, east of Keweenaw Point, along the border of the outer end of Keweenaw Point, where its strike carries it out into the waters of Lake Superior at Gate Harbor. It reappears about 6 miles west of Eigle Harbor and extends continuously as a northwestwarddipping monocline to the head of Chequamegon Bay in Wisconsin, the other side of the synclinal fold being under the waters of Lake Superior. The peninsula north of Chequamegon Bay brings to the surfnce the north side of the syncline, so that inland to the southwest in Wisconsin the full fold is present in a canoe-shaped area.

The upper Kreweenawan consists from the base up of the "Outer" conglomerate, the Nonesuch shale, and the Freda sandstone.

The "Outer" conglomerate on Keweenaw Point has a thickness of 1,000 feet. To the west it increases in thickness and at Black River apparently attains 5,000 feet. Farther west it becomes thinner, the thickness at Potato River being $\$ 00$ to 1,200 feet and at Bad River only 350 feet. The "Outer" conglomerate has thus been traced from the enst side of Manitou Island to Penokee Gap, a clistance between 175 and 200 miles. Petrographically this conglomerate is like the conglomerate interstratified with the lavas and is therefore composed mainly of detritus from the acidic rocks.

Above the "Outer" conglomerate is the Nonesuch shale, which has been traced from Portage Lake to Bad River, a distanere of 125 miles. Its thickness at Portage Lake is about 
200 feet, at Mlontreal River 500 feet, at Potato River from 250 to 400 feet, and at Barl River 125 feet. Nthough this formation is ehielly shale it las interstratified sandstone layers, and unlike the sandstone's and conglomerates interstratified with the lavas it contains large amounts of basic detritus. In places, indeed, tho basic material is so abundant as almost to cxelude the acidic. Thus at the base of the Xonesuch shate there is an important change in the character of the material of the Kewernawan sediments.

The Freda sandstone composes much the larger portion of the upper division of the Keweenawan. The apparent thickness of the entire formation is not less than 19,000 fret. Irving ${ }^{a}$ gives the thickne'ss of the sandstone exposed at Montreal River as 12,000 feet, and 7,000 feet of overlying bects are seen near Ashland. Aceorling to Irving it is a characteristic feature of this sandstone that quartz is very subordinate. Indeed, in places it is nearly quartyless. The detritus has therefore been derived dominantly from the basic igneons rocks and only subordinately from the acilic igneous rocks of the Keweenawan, and apparently the pre-lieweenawan rocks have contributed but small amounts of material. However, Lane ${ }^{b}$ states that pebbles of handed jaspery hematite and other iron-bearing rocks oceur abundantly in the "Outer" conglomerate and further that the detritus of the sandstones themselves is derived predominantly from the Iuronian and Keewatin rocks. Probably the statements of Irving and Lane were made with different areas in mind, and more extensive studies of the upper Keweenawan are perhaps necessary in order to make exact general statements concerning the sources of its detritus.

As the upper Keweenawan is confined to Michigan and Wisconsin, it, like the middle and lower Leweenawan, fails to be regional in extent, although it has a greater linear and surface extent than the other two divisions. It is probable, however, that the upper Keweenawan originally occupiel a large part of the Lake Superior basin. It is the softest division of the series and was therefore more deeply eroded than the others. At present the area once probably covered by this sandstone is necupied by the Cambrian sindstone or the waters of the lake.

\section{RELATIONS TO UNDERIYTNG SERTES.}

The Keweenawan rests unconformably on all of the lower sories with which it comes into contact. This unconformity is so perfectly clear for the Arehean gneisses that it has been recognized since the diys of Logan, ${ }^{c}$ that great geologist having noted this relation at Granite Island, on the north side of Lake Superior, and at several points on the east shore of the lake. The Keweenawan has unconformable relations with each of the Inronian divisions with which it comes into contact, but in earlier days the unconformity hetween the Keweenawn and the upper Juronian was not recognized.

The relations of the Keweenawan series and the Animikie group have been especially studied north of Thunder Bay, and here the Inimikie was indurated and rielded well-rounded fragments to the Keweenawan basal conglomerate at many points. Details as to these relations are more fully given on pages 207-205. In the Penokee district the Kewenawan extends for many miles along the upper Huronian, and here there is evidence of even a greater erosion intervil hetween the two series than on the north shore.

It has been noted that the Duluth gabloro at its bottom is in contact at many places with the IJuronian and with the Arehean. Tear its border, in areas oecupied by the rocks of these periods, are numcrous dikes and bosses which are idtentieal in chemical composition and even correspond very (Josely in mineralogical character with the Duluth gabluro. Indeed, some of the misses may be actually comeeted with the Duluth gabbro. There can seareely be any doubt that these intrusive rocks in the lowel series are of Fowenawan age.

The Keweenawan age of the great dikes and sills of (liabase, which are so abumbant in the Animikie group, is scarrely less clear. These dikes and sills are irlentical in their chenieal and

a Mon. U.S. Feol. Survery, rol. $5,1 \times 3$, p. 230.

o Jour, Geology; vol. 15, 1907, p. 690. c Logan, WF. E., Report of progress to 1563 , Geol. survey Canada, 1563, p. is. 
mineralogical composition and in their structural and textural characters with those which are found in the Keweenawan itself east of the Animikie at Thumler and Black bays and west of the Animikie in Minnesota. Some of the capping diabases of the Nipigon lasin may be flows resting unconformably upon lower Keweenawan, Huronian, and Archean rocks.

In the Penokee-Gogebic district numerous diabase dikes cut the iron-bearing formation. These have attitudes at right angles to the dips and in chemical composition are like the basic lavas on the overlying fieweenawan traps. It can hardly be doubted that these are the pipes through which the lavas issued.

The Animikie group, including the latest IIuronian formations, is cut by acilie intrusive rocks which are almost certainly Keweenawan. The largest of these that has been recognized is the Embarrass granite of the Giants Range, the granites south of the Cuyuma district of Minnesota, and the granite intrusice into the Quinnesec schist of northeastem Wisconsin. Dikes of granite are known to eut the Animikie group along the Giants Range.

\section{RELATIONS TO OVERLYING SERIES.}

The lowest fossiliferous Cambrian rocks in the Lake Superior region are of Upper Cambrian age. These rest unconformably upon the middle Keweenawan in the St. Croix Valley and on the southeast side of Keweenaw Point. In the former locality an actual unconformable contact is observed, but in the latter the relations are complicated by faulting. The middle Keweenawan throughout is considerably tilted, while the Upper Cambrian beds are uniformly flat-lying. These facts prove only that the midlle Keweenawan is pre-T pper Cambrian.

The upper Keweenawan is in contact only with the Lake Superior sandstone (supposedly Upper Cambrian), a red, quartzose sandstone outcropping along the southwest shore of Lake Superior. The feldspathie sandstones and sluales of the upper Keweenawan grade conformably up into the red quartzose Lake Superior sandstone. Exposures of the gradation are observed on Fish Creek, on Middle River, and on St. Louis River. The only possible doubt about the gradation is the fact that the feldspathic sandstones and mud-cracked shales have not been absolutely proved to be Keweenawan, although from their character, distribution, and relations to the Kieweenawan there is every reason to believe that they are the uppermost Keweenawan. At no place are there fragments of the Keweenawan sandstone within the Lake Superior sandstone. Finally, the upper Keweenawan sandstone and the Lake Superior sandstone are closely related in their deformation, for while the upper Keweenawan as a whole is folded, and the Lake Superior sandstone as a whole is flat-lying, along the axis of the synclinorium in the vicinity of Ashland and eastward, both are tilted. The western Lake Superior sandstone seems to be areally connected with the known Upper Cambrian of the St. Croix River valley and has been correlated with the Upper Cambrian. Howerer, it is nonfossiliferous, areal continuity with the known Cambrian is not established, and it is entirely possible that the western Lake Superior sandstone as a whole may be older than the Upper Cambrian. If the Lake Superior sandstone is Upper Cambrian, as it is now correlated, then the upper Keweenawan is pre-Upper Cambrian.

In the absence of the Middle and Lower Cambrian, it is difficult decisively to prove that the Keweenawan is pre-Cambrian rather than Middle or Lower Cambrian. It has seemed to us, as it has to Irving, ${ }^{a}$ to Chamberlin, ${ }^{b}$ and, in faet, to most of the geologists who have studied this area, that in lithology, lack of fossils, deformation, and separation of the midlle Keweenawan from the Upper Cambrian by unconformity the Keweenawan series as a whole is much more closely allied to the pre-Cambrian than to the Cambrian. Another group of geologists, while adnitting all these differences, nevertheless hold that the Keweenawan is probably Cambrian.

Our reasons for assigning the Keweenawan as a whole to the pre-Cambrian rather than to the Middle or Lower Cambrian are summarized below. While we assume the Upper Cambrian 
age of the Lake Superior sandstone, these ronchusions ane not wholly dopendent upon such interpretation ol age of thr lake superior sandstone.

'Tho Cambrian is fossililerous: the Krweremawan is not.

'Tho Cambrian is largely a subaqueous deposit; the liewecnawan is larecly subaerial.

The Cambrian contrasts with the Koweenawan in lacking rolanism.

'The known Cpper Cambrian is almost flat-lying. The same is true for most of the lake Supcrior sandstone. The Koweenawan as a whole is tilted. In the few localities where the Jake Superior sandstone and upper Feweenawan are tiltod together, this may lue due partly to movements as late as the Cretaceous. Also, as alrealy noted, there is possible doubt about the Tppres Cambrian nge of the Jake Superior sandstone. It is agreed by all that the known Upuer Cambrian rests unconformably upon middle Kewerenawan beds.

The Cambrian rests upon a peneplain of continental extent, orer which the Paleozoic sea swept and deposited Paleozoic sediments, with overlap relations to the pre-Cambrian rocks. 'This sea did not reach the Lake Superior country until Upper Cambrian time, and parts of Canada were not reached until Ordovician time. If the Feweenawan is Cambrian it constitutes a marked local variation from the general uniform conditions of overlap. The upper Keweenawan sediments rest on a plane which cuts the pre-Cambrian peneplain at a considerable angle, as is well shown on Kieweenaw Point. (See p. 97.) If the Kieweenam were to be regarled as Middle or Lower Cambrian, it would be necessary to conclude that the Midchlo or Lower Cambrian in this district had taken on remarkable local characteristies different from those of the Midkle and Lower Cambrian elsewhere. On the other hand these local characteristics are accordant with those of the pre-Cambrian rocks of this area.

The sinilarity of lithology and accordance of stmeture between mper Keweenawan and Cambrian are the natural sequence of transgression of a sea over flat-lying seliments. The conditions are not different from those that would prevail if the ocean were to transgress to-day lrom the Gulf of Mexico across the flat-lying and little-consolidated Paleozoic serlinents of the upper Mississippi Valley. It would be extremely diflicult to prove the unconformity in any limited area, especially where exposures are not numerous. In fact, it is known that the Lake Superior basin was formed during Keweenawn time, and it is entirely probable that local sedimentation within this basin would merge upwards into the sedimentation from the overlapping Upper Cambian ocean, while upper Kiewernawan beds may locally have unconformably overlapped the lower-middle member, from whose detritus they are in large part built up. It is concluded that the Keweenawan is mainly pre-Cambrian.

Our view of the sequence of deposition is this: The main portion of the Keweenawan was put down in pre-Cambrian time. During and subsequent to its deposition folding dereloped the Lake Superior basin. In late Keweenawan time erosion of the lower beds near the rim of the basin and deposition of the upper beds within the basin were going on simultaneously. The deposition within the basin continued nearly or quite to the time that the Paleozoic sea, encronching from the south, reached the basin. The Palrozoic sea then deposited its beds with marked structural discordance upon the lower-middle Keweenawan, and with substantial accorlance upon upper Kewecnawan beds in parts of the Lake Superior basin in which deposition was continuous up to the time of the arrival of this sea.

\section{CONDITIONS OF DEPONITION.}

'The question now arises as to the phrsical eonditions under which the Kewernawan was laid down. Acoording to the standard interpretation the widespread sindstones and congromorates at the bothom of the Keweenawan would be taken as evidence that at the begrinning of Kincentwan time this region was submerged. I'nder this interpretation the oceurrence of sundstones and conglonderates between the laras has been taken as evidence that the eflusive rocks were labere! submarinc. 'The persistence of sedimentary beds such as those that oceur

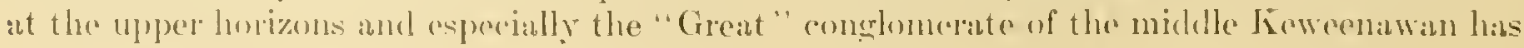

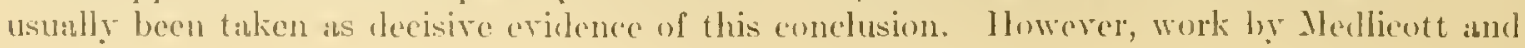


Blanford, ${ }^{a}$ Walther, ${ }^{b}$ Passarge, ${ }^{c}$ Davis, ${ }^{d}$ Iuntington, ${ }^{e}$ Johnson, ${ }^{f}$ Barrell, ${ }^{g}$ Chamberlin and Salisbury, ${ }^{h}$ and others has emphasized the importance of continental sedimentary deposits. As yet the criteria for discriminating continental and submarine deposits have not been fully worked out, and therefore there must be considerable uncertainty as to our conclusions upon this matter concerning the Keweenawan, especially as the Keweenawan sediments have never been studied with reference to this particular point.

The following evidence we take to favor the terrestrial origin of ut least a part of the Keweenawan:

1. The thickness of the sediments.

2. The repetition of conglomerate beds at many horizons through several thousand feet. This would involve too rapid fluctuation of water level for the beds to be satisfactorily explained as aqueous deposits. The continuity of thick heds of eonglonerate also is in accord with terrestrial sedimentation, for subaqueous sedimentation is more likely to develop thick beds orer only local areas, as about steep shores.

3. The feldspathic, poorly assorted, and almost completely oxidizerl character of the Keweenawan sediments, as shown by their prevailing red colors and lack of graphitic material. They also show locally alternating beds of red, yellow, and purple, suggestive of seasonal variations.

4. Many ripple marks in the Freda sandstone are of the horseshoe shape made by rills of water at the surface. These contrast with the ripple marks made by wave action.

5. The fact that except for alterations, the basic flows are in all essential respects like the subaerial basaltic lava flows of Tertiary time. Their upper and lower surfaces are anygdaloidal. Although in places their surfaces have a broken or pseudoconglomerate appearance, they usually lack the peculiar ellipsoidal structure which is characteristic of the liewatin and IIronian basic lavas described in another place (pp. 510-512) and which has been shown to be especially characteristic of subaqueous basic lava flows.

6. The fact that the matrix of the basal conglomerate on the north shore is in places a limestone, suggesting deposition of evaporation under surface arid or semiarid conditions, as may be observed to-day in the Bighorn Mrountains and elsewhere in the West.

7. The lack of fossils.

S. The general contrast with the underlying Furonian seriments, in which evidence of water deposition is fairly good.

9. Ifud cracks are common in some shales.

10. The rapid alternation of thin beds of coarse unweathered lébris with fine red mudcracked and ripple-marked shales.

We are therefore inclined to believe that terrestrial deposition has played an important part in the development of this portion of the Keweenawan, but with the information now arailable we are unable to say how much of a part it has played.

The truth probably lies between the two extremes of the subaqueous and subaerial hypotheses; that is, the Keweenawan livas and sediments were neither exclusively terrestrial nor exclusively subaqueous, though too little is known to warrant definite statements concerning their origin. For the middle and upper Keweenawan it is believed to be largely subaerial, but also in considerable measure subaqueous. When the orogenic movement and the period of rolcanism of middle Keweenawan time were well under way it would be rery natural that the areas where

a Medicott, II. B., and Blanford, W. T., Geology ol India, 2d ed., rerised by R. D. Oldham, 1879, pp. 149-156, 391-458.

6 Walther, Johannes, Das Gesetz der Wüstenbildung, Berlin, 1900.

c Passarge, Siegiried, Die Kalahari, Berlin, 1904.

d Davis, W. M., The Iresh-water Tertiary formations of the Rocky Mountain region: Proc. Am. Acad. Arts and Sci., rol. 35, 1900, pp. 345-373; Bull. Geol. Soc. America, rol. 11, 1900, pp. 596-601, 603-604; A journey across Turkestan: Carnegie Inst. Washington, I’ub. 26, 1905. e Huntington, Ellsworth, Pulse of Asia, 1907.

$f$ Johnson, W. D., The High Plains and their utilization: Twenty-first Ann. Rept. [T. S. Geol. Survey, pt. 4, 1901, pp. c09-741.

- Barrell, Joseph, Origin and significance of the Mauch Chunk shale: Bull. Geol. Soc. America, vol. 18, 1907, pp. 440-176; Relations between climate and terrestrial deposits: Jour. Geology, vol. 16. 1908, pp. 159-190, 255-295, 363-384.

h Chamberlin, T. C., and Salishurs, R. D., Geology, rol. 2, 1906.

$$
47517^{\circ}-\text { TOL } 52-11-27
$$


the flexures were large and where the lavas were issuing rapidly, that is, aleng the boreler of the lake, should be abore the witcr. Ilowever, the movement producing the syolinal basin would cortanly make a depression in the enter of the lake which woukl nat urally be filled with water. Thus along the borders of the Fineenawan the conditions may have fabored terrestrial deposits and in the basin of the lake the conditions may luve farored subaruenus deposits, and at the shore zone there were various combinations of the two.

If these tontative conchusions are correct, the question still remains open as to whether the water-deposited parts of the Kewernawan were sulmarine or continental, for deposits laid down in great lakes are nsully classed as continental. Whother this basin connecter with a sea or was inclosed there is now no means of knowing, mless the possible cxtension of the Keweenawn into central Minnesota, cited on pages 376-379, may incliente such ib connection.

\section{THICINESS OF TIIE IEWEENAWAN IROCKS.}

In the deseriptions of the individual districts the estimated thicknesses of the Keweenawan have been given. Wherever there is a full section the estimated thickness is very large. For northern Minnesota it is $17,000 \mathrm{or}^{\circ} 18,000$ feet exclusice of the gabloro laceolith, for northern Trisennsin and Michigan a maximum of 60,000 feet, and for Mamainse, at the east end of Lake Superior, 16,000 feet. Only relatively small parts of these thicknesses are made up lyy the serliments. There are a number of factors which make all these estimates of very uncertain aceuracy. The more important of these factors are faults, intrusive rocks, and initial dips.

It has been seen that duing the formation of the Lake Superior syncline strike, dip, and bedeling joints and faults were produced, and that some of the strike faults are of great magnitude. The different conglomerates and lava beds of the middle Keweenawan are very similar lithologically and it is therefore extremely difficult, indeed usually impossible, to recognize the individual beds except those of large size, like the "Great" conglomerate. Hence, it has only been in the vicinity of the mining areas, where studies of the most lletailed nature have been male, that the extent of the faulting is appreciated. There can be no doubt that strike faults have repeated the beds at numerous localities. It is to be said that the close studies of Hubbard ${ }^{a}$ on Keweenaw Point, those of Gordon ${ }^{b}$ at Black River, those of Lane ${ }^{c}$ on Isle Royal, and those of Burwashd at Michipicoten have not discovered faults which have repeated the beds of these areas to any consiclerable extent. It has been seen, howerer, that the strike fault between the north and south ranges of Keweenaw Point reproduces the lower parts of the rocks of the Keweenawan in the south range. Similarly it is probable that hetween Isle Royal and Black and Nipigon bays is a great strike fault which results in the repetition of the Black and Nipigon bays Keweenawan on Isle Royal.

In the estimates of the thickness of the Keweeniwan the intrusive rocks have been ignored. It is certain that in northern Hinnesota the intrusive lavas constitute a considerable proportion of the igneous rocks of the Minnesotal coast. Also it is suspected that closer sturlies will show that the intrusive rocks are more extensive in other areas, as, for instance, at Keweenaw Point, than has been supposed. Indeed, the recent studies of Ilubbard ${ }^{a}$ hare shown this to be true for the acidic rocks, but as yet studies have not been made along the same lines for the basic lockis.

In estimating the thickness of these rocks no aecount has been taken of initial dips. It is well known that the initial dips of basie lavas and all coarse conglomerates are in many plares higher than $10^{\circ}$, and they mily be more than $20^{\circ}$. This statement applies both to subaqueous and to subacrial deposits.

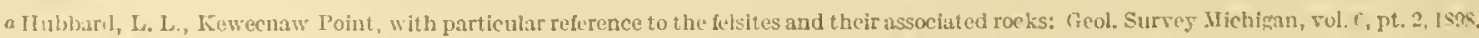

b Gorton, W. '.., assisted by A. C. Lane, A geological scetion from Bessemer down Black River: Rept. Gcol. Survey Michigan for 19ki, 1907, Гp. $39 \%-50 \%$.

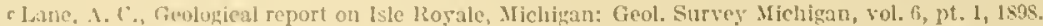

a Burwash, E. ‥, The geology of Michipicoten Island: Luiv. Toronto Studies (Geol. ser.), No. 3, 1905; with map. 
There thus arises, in connection with the niddle Keweenawan especially, the same problem that arises in determining the thickness of a delta deposit, the larger portion of which (the foreset beds) in a great delta has rather steep initial dips. If such a delta could be truncated through its central part and the thickness of the berls determined on the basis of dip it miglit be calculated that the delta represents many thousands of feet of strata, although as a matter of fact the deposit might not be vertically more than a few hundreal feet thick. (Sce fig. 58.) However, there are reasons for believing that a large angle of dip is due to orogenic movements, and such an angle is sufficient to allow a large thickness.

Because of the factors named above it is extremely probable that all the estimates of the thickness of the Keweenawan based on appearances are excessive. To what extent they are ex-
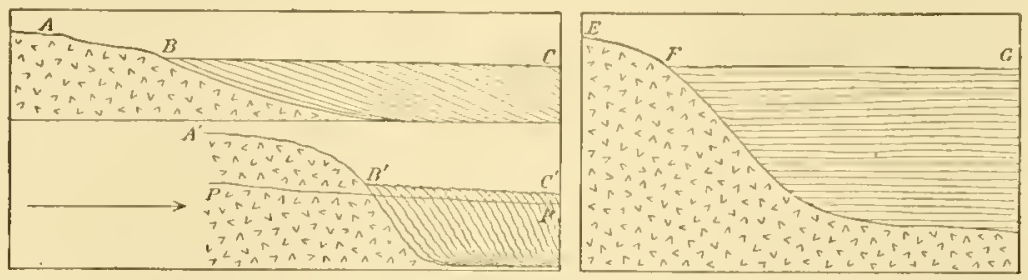

FIGURE 58.-Ditgrammatic section illustrating the assigned change of altitude of a series of beds, like the keweenawan, from an original depositional inclination $(B-C)$ to a more highly inclined attitude $\left(B^{\prime}-C^{\prime}\right)$, a comparatively simple change. If the beds wero laid down horizontally in a sinking basin, as illustrated at the right $(F-G)$, it is obvious that a greater and a more complicated novement would be necessary to bring the buds into the attitude represented in tho lower figure at the left, which represents the present attitude of the keweenawan beds. (.Ifter Chamberlin, T. C., and Salisbury, R. D., Geology, vol. 2, 1906, fig. 110.) cessive is a matter of conjecture, but we suspect that the vertical thickness of the Keweenawan at the time it was formed was probably not more than half and possibly only a third of the apparent thickness.

\section{AREAS OF KEWEENAWAN ROCKS.}

The areas of the diferent phases of the Keweenawan in square miles are as follows:

North shore:

Basic intrusive rocks.............................. 2,170

Acidic intrusive rocks............................. 550

Basic extrusive rocks................................. 1,950

Serliments. . . E .

South shore:

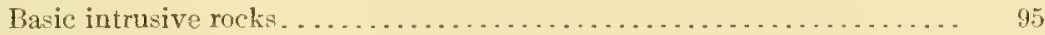

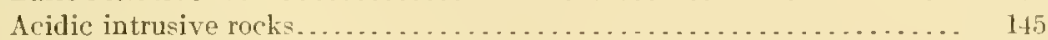

Basic extrusive rocks................................. 500

Sediments.................................... 2,070

6,810

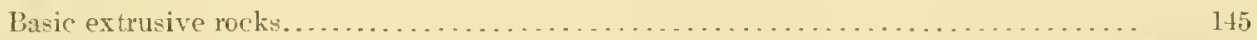

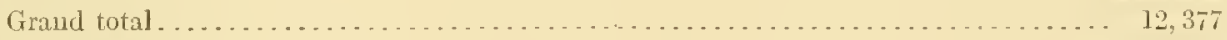

Total area of ba ic intrusive rocks................................. 2, 265

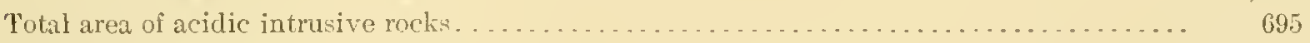

Total area of basic extrusive rocks................................... 6,595

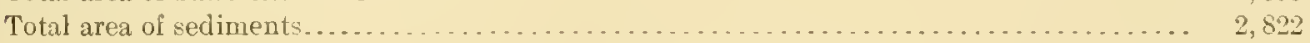

\section{VOLUME OF TEVEENAWAN ROCKE.}

From the foregoing figures of thickness and area it is apparent that the rolume of the Kewcenawan rocks is very large. For the extrusive rocks an area of 6,000 square miles and a thickness of 4 miles would give a volume of 24,000 cubic miles. For the sediments an area of 2,800 square miles and a thickness of 4 miles woukl give a volume of 11,200 eubic miles.

These figures leave out of account the enormous masses of intrusive rocks. If the gabbro has a circular outline, as indicated by the convex border of Minnesota, and if its sonthern border is indicated by the Gogebic district, the diameter woukl be about 100 miles. With the 
ratio of thickness to diameter given by Gillort ${ }^{a}$ for the Jlenry Mountains the maximum thickness woukl be 15 miles. On calculating the thickness in another way, by assuming an arerage dip of $10^{\circ}$ for a distance of 50 miles on the north shore, a maxinum thickness of $8 \frac{1}{2}$ miles is obtained. With a thickness of $8 \frac{1}{2}$ miles at the center and a diameter of 100 miles approximately 30,000 cubie miles may be figured for these intrusive rocks.

Although these figures merit little consideration as actual measurements, it is believed that they are of value in showing the enormous dominance in volume of the igneous rocks over the sediments and of the intrusive igneous rocks over the extrusive igneous rocks. Reduced to terms of mass, these figures would be somewhat changed, but the essential conclusions would not be altered.

\section{LENGTII OF IEEWENAWAN TIME.}

Because of the facts discussed in the foregoing section on thickness it is of course impossible to give any estimate of the time involved in the deposition of the Keweenawan series, but allowing a wile margin for overestimates of thickness we can hardly escape the conclusion that the Keweenawan probably required as long a time for its formation as the arerage geologic period, such as the Silurian, Devonian, and Carboniferous, and it may have been as long as the Cambrian.

\section{JOIN'TING IND FAULTING.}

Commonly, where the dip of the lava beds is consillerable, the beds are cut by two sets of joints, one of strike joints and the other of dip joints. Both sets are approximately at right angles to the beds, but the plane of the strike joints contains or does not vary greatly from the line of strike, and the plane of the dip joints contains or does not vary greatly from the line of dip. These positions for the joints have been noticed by Grant ${ }^{b}$ for northern Wisconsin and by Hubbard ${ }^{c}$ for northern Michigan. In many places there are also joints parallel to the beds or between them, and these may be called bedling joints. Where the intrusive rocks have disturbed the lava beds the jointing is very much less regular.

As would be expected in a fractured series of rocks, there is also somewhat extensive faulting. Indeed, faulting has been discovered in almost every locality where close studies have been made, but usually the greater number of the faults are not of sullicient magnitude to be an important factor in the stratigraphy. Like the joints, the common faults may be divided into strike faults and dip faults, there being a general correspondence between the planes of the faults and those of the joints. IIost of the dip faults have no great throw, although locally the displacement may be very considerable. A beautiful illustration of the dip faults is furnished by Ihubbard for the West Pond area on the south side of Kieweenaw Point. (See p. 3s3.) F. E. Wright's detailed mapping of the Porcupine Mountains and vicinitye discloses a large number of both strike and dip faults.

Some of the strike faults are of great magnitude and extent. The greatest of these known is that at the southeast side of the Keweenawan series, extending from the end of Keweenaw Point along the border of the Keweenawan to Gogebic Lake. Another great strike fault is known in Douglas County, in northern Wisconsin, ant in Minnesota along the northern border of the Keweenawan. Both of these faults are at the contacts of the Keweenawan and the Lake Superior sandstone, and it is believed that the newer series represents the downthrow sile. If so, this downthrow was to the south of the Keweenawan at Keweenaw Point and to the north of it in Douglas county. The latter fault plane dips $35^{\circ}$ to $45^{\circ} \mathrm{S}$. and in Wisconsin at least has aspects of an werthrust fault.

Martin (see pp. 112-115) concludes on physiographic grounds that there is a fault along the Minnesota const liaving a throw of at least 1,000 feet. There is nothing to show that the throw

a diilsert, G. K., The geology of the llenry Mountains, 2 d ed.: U. S. Geog. and Geol. Survey Rocky Mtn. Region, 1 sso, p. 35.

b Grant, U. S., l'reliminary report on tbe copper-bearing rocks of Douglas County, Wis.: Bull. Wiseonsiu Geol. aud Nat. Uist. Surver No. 6, $2 d$ ed., 1901, p. 21.

cllulbbard, L. L., Keweenaw l’olat, with particular reference to the felsites and their associated rocks: Geol. Survey $\mathbf{3 i c h i g a n , ~ v o l . ~ 6 , ~ p t . ~ 2 , ~}$ 1898, pp. 19, 2i, 35 .

d Idem, pp. 87, 97 .

e Ano. Rept. Geol. Survey Michigun for 1908, 1909, I'l. I. 
is not much greater than this amount. The evidence given by Mlartin confirms what was before a belief as to the existence of this fault, based on the fact that if there were not such a fault between Isle Royal and the mainland, repeating the beds, it would be necessary to accept an almost incredible thickness for the Keweenawan. The faults in the zone between Isle Royal and the Ninnesota coast are probably an extension of that in Douglas County, Wis., or, if not, they accomplish for the Minnesota area corresponding arljustment of the Keweenawan during deformation.

Just as there are bedkling joints there are also bedding faults. These are especially likely to occur between the diflerent beds of lava or of lava and conglomerate. In many of them the dip is slightly steeper than the bedkling. The direction of movement along these bedding faults may be parallel to the strike, parallel to the dip, or at any angle between them. Although this is true, it would be natural to expect that the most common movement along the bedding faults would be approximately parallel to the dip, this being the natural direction of diflerential movement between beds in a folded series. As to the direction of movement along the dip, by differential movement in a fold of ordinary magnitude the higher bed moves upwarl as compared with the lower bed, but it is far from certain that this rule would hold in a great simple synchinorium like that of Lake Superior. It might be that gravity would be more important than the strength of the beds and that the upper members would move downward as compared with the lower.

Ilubbard ${ }^{a}$ and Lane ${ }^{b}$ conclude from their close stndy of the Keweenawan district that beckling faulting or slide faulting is very common. IIubbard finds that at least one slide fault substantially parallel to the dip has a very large movement. Lane ${ }^{b}$ says that many of the slide faults have a slightly steeper hade than the dip. The details of these occurrences are given in the section on Keweenaw Point (p. 383).

Along any of the faults there may be slickensides or even brecciation. Such brecciation is especially prevalent at the bedling faults, which follow an amygdaloidal lava surface, ono of their most common positions, because the amygdaloidal belts are planes of weakness.

It will be seen on pages 575-576 that the several classes of fractures and faults have a very important bearing on the development of ore bodies.

The time of the fracturing is partly contemporaneous with the folding of the series and partly later; how much later is not known. Some of the faults, notably the great faults bounding the Keweenawan series on Keweenaw Point and in Douglas County, Wis., are partly post-Cambrian. It has been suggested by Wilson ${ }^{c}$ and Weidman, ${ }^{d}$ from work in other areas, that faulting may have affected these rocks as late as Cretaceous time.

\section{THE LAKE SUPERIOR SYNCLINAL BASIN.}

It is little short of certain that the great Lake Superior synclinal basin beg.n to form during middle Keweenawan time. The general character of this syncline is admirably exhibited in figure 59, from Irving, and by the sections on the general map, Plate I. This synclinal basin is rather remarkable for its simplicity. Indeed only at one place does Irving figure a subordinate fold, that at Porcupine Mountains. Tho strikes and dips of the rocks show several prominent flexures, however, as, for instance, along St. Croix River of Wisconsin, near Ashland and Clinton Point at the head of Lake Superior, and at Michipicoten Harbor. Later strike faults have considerably modified the syncline. Doubtless future close studies will show that the Lake Superior synclinorium has a greater complexity in detail than has been supposed. Certainly one very important subordinate basin, that of Lake Nipigon, must be attached to the major synclinorium. It is to be remembered that along the main shore line and outer islands of Black and Nipigon bays the middle Keweenawan is found with lakeward dips at angles of

a Op. eit., pp. 87-91.

$\checkmark$ Lane, A. C., Geology of heweenaw Point, a lrief description: Y'roc. Lake Superior Min. Inst_, rol. 12, 1907, pp. \$3-84.

c Geol. Soc. America, winter meeting, December, 1908.

$d$ l'ersonal communication. 


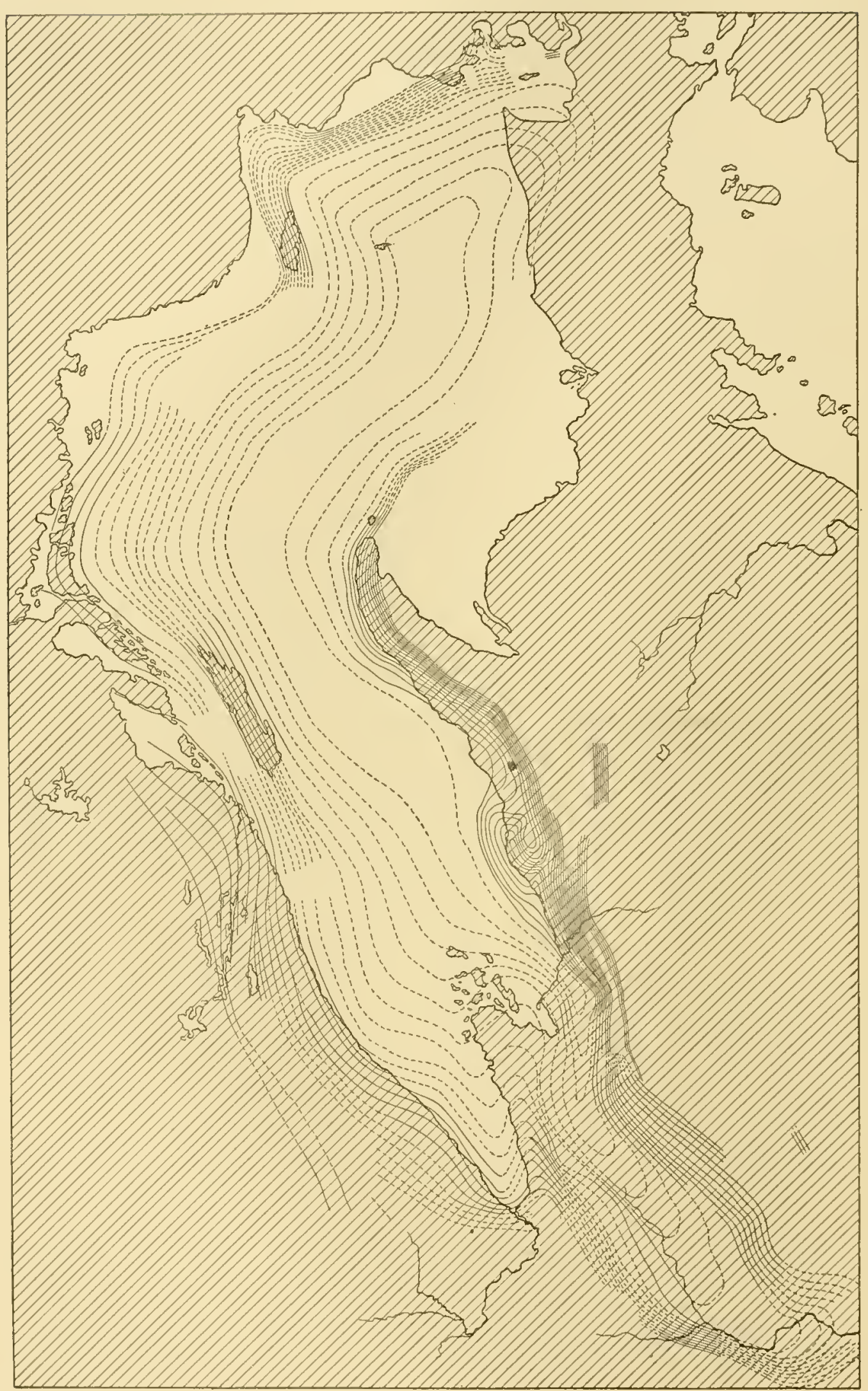

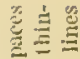

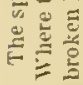

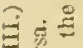

至

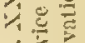

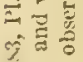

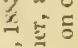

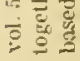

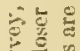

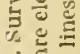

递要

政

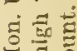

을

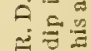

돌을

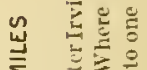

$\bar{\Sigma}$

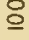

]

棓然

紋

论

요-

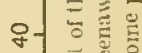

ㅇ-

ㅇ-

i

어 홀 뭉

o]

要

言

ติ

홍

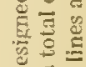

돌

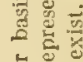

点

量最

कs

S.

올

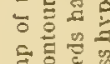

행ㅎㅇ

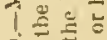

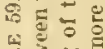

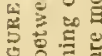


$8^{\circ}$ to $10^{\circ}$. In the peninsulas between Thunder, Black, and Nipigon bays the lower Keweenawan lies substantially flat. Farther to the north the middle Keweenawan reappears, overlying the lower division with northern dips. It thus appears that at Black and Nipigon bays there is a subordinate anticlinal arch, which separates the great synclinal fold of Lake Superior from the subordinate synclinal fold of Lake Nipgon. The latter lake is in a subordinate basin of Keweenawan rocks, just as Lake Superior is in a great basin of that series.

Similarly Batchewanung Bay, at the east side of the Lake Superior basin, is a subordinate synclinal fold. A part of the shore is Arehean. Inside of this is a fragmentary border of I Iuronian almost cut away; inside of this a partial border of Keweenawan, and the center of the hasin is filled with Cambrian. In short this bay is a miniature of the Lake Superior basin, containing the four great divisions of rocks of the region-the Archean, Huronian, Keweenawan, and Cambrian - in a synclinal basin.

It has been seen that in general in any one section the dips are much steeper at the lower horizons than at the higher horizons. It is certain that the present dips at the lower horizons are largely due to the folding which formed the Lake Superior basin. To illustrate: The Keweenawan lava flows and sediments north of the Gogebic range have the same dip as the upper Huronian sediments, and therefore the main dips of both must have been produced by orogenic movements. Indeed it is thought probable that in general the major portion of the dips of the most stceply inclined lavas is due to orogenic movements, for the natural position of repose for basalts, such as those of Kilauea, is with dips of $10^{\circ}$ to $18^{\circ}$. It is reasonably certain that if $15^{\circ}$ is subtracted from the lakewald dip of the basic lavas the remaincler of the dip is due to orogenic movement. The steadily lessening dips of the lavas at higher horizons are therefore to be largely explained by the progress of the orogenie movement which produeed the Lake Superior basin, although they are cloubtless in part explained by the natural lessening of the dip towarl the center of a synclinal fold.

To illustrate again: In the Black River section the dips at the base are from $75^{\circ}$ to $78^{\circ} \mathrm{N}$., and at the highest strata exposed on the "Outer" conglomerate only $20^{\circ}$. In the Keweenaw Point section the lavas at the south side dip $55^{\circ} \mathrm{N}$. and those of the midlle dirision at the north side dip $25^{\circ}$, and it may be supposed that during the time in which the lavas and conglomerates of the middle Keweenawan in this area were built up the synclinal movement had tilted the lower beds $30^{\circ}$ as a maximum, but from this amount to ohtain the actual tilting there must be subtracted the unknown amount which is due to the normal decrease in dip toward the center of a syncline. Similarly at Michipicoten, on the northwest side of the synclinorium, the basal beds have a dip of $55^{\circ} \mathrm{SE}$., and at the top of the exposed sections on the islands south of Michipicoten the dip is $14^{\circ}$, a maximum difference of $41^{\circ}$, which may be attributed to orogenic movement during the formation of the middle Keweenawan in this part of the region. The same thing is illustrated at Isle Royal, where at the southwest end of the island the dips on the north sile are $16^{\circ}$ and on the south side $5^{\circ}$, and at the east end of the island the dips on the north sile are $26^{\circ}$ and on the south side $18^{\circ}$. It thus appears that the decrease in dip from the north to the south side is $8^{\circ}$, without reference to the steepness. This fact strongly suggests that the steeper dips at the northeastern part of the island as compared with the southwestern part are to be explained by greater orogenic movements in that part of the island, and thus gives a confirmation to the suggestion male that the steep clips are mainly due to orogenic movement rather than to the original angle of deposition. 'The folding of the basin was practically complete at the end of Kewcenawan time, but in post-Cambrian time and possibly in post-Cretaceous time the region suffered the great strike faulting alrealy noted.

\section{METAMORPHISM.}

For the most part the metamorphism of the Feweenawan igneous rocks is that of the zone of katamorphism. The alterations, fully deseribed by Pumpelly ${ }^{a}$ and Irving, ${ }^{b}$ have produced very extensive changes in the lavas, especially those which were scoriaceous. The

a Pumpelly, Raphael, Metasomatic development of the copper-bearing rocks of Lake Superior: Proc. Am. Acad. Arts and Sei., rol. 13. 1878, pp. $253-309$.

bIrving, R. D., Mon. U. S. Geol. Survey, vol. 5, 1883. 
important secondary mincrals produced in the basic rocks are the zeolites, epidotes, chlorites, calcite, quartz, laumontite, prehnite, datolite, ete. Nany of the thin resicular beds are largely transformed to these substances and the vesieles have heen filled with them, forming anygdules. Althongh the porous beds are extensively altered, the massive renters of the thick lava flows, the dike rocks, and the sills and laceoliths are very fresh; indeed some of them are alnost as lit the altered as sinilar rocks of 'Tertiary age. The ledsite and quartz porphyries have undergone the usual metasomatic alterat ions for ancient acidie lavas. The grasses have devitrified. A wide variety of secondary minerals have formed, but they occur usually in such minute particles as to be determinable with dilliculty.

The alterations of the fieweenawan lavas doubtless began as soon as they were consolidated. The process continued through Keweenawan time and the great erosion period between the Keweenawan and Cambrian, and indeed is still going on.

The alterations of the sedimentary rocks vary greatly in degree. The lower and middle Keweenawan sediments are much more changerl than those of the upper Keweenawan. In the sandstones and conglomerates interstratified with the lavas the same metasomatic change took place as in the lavas, resulting in the formation of a like group ol secondary minerals. The filling of the openings between the grains and pebbles, strictly analogous to the filling of the openings in the vesicular lavas, has been nearly complete, thus thoroughly indurating the rocks. The cementing materials in the sandstones and conglomerates interstratified with the lavas are much more varied than those of ordinary cementation. It was in these rocks that the senior author first noted the secondary enlargenent of detrital feldspar. So thoroughly lave the clastic materials been cemented that where the rocks have not been weathered fractures commonly pass across both pebbles and matrix. The sandstones are intermediate between sandstones and quartzites in their cementation. Though these sediments are well indurated they certainly are less metamorphosed than similar seliments of the Animikie group. Inasmuch as the conditions since they have been lail down have been practically the same as those that have affected the Animikie beds, upon which they rest, this difference in metamorphism confirms the conclusion as to a considerable time break between the two series.

The cementation in the sandstones of the upper Keweenawan has not proceded so far as in the detrital rocks of the midklle division. Indeed these sandstones are very similar to those of Cambrian age. The individual particles of these sandstones, bemg largely basic, are usually much altered, but it is difficult to say what part of these changes have taken place since they were deposited as sandstones and what part took place before they were broken from the lavas from which they came.

The segregation producing copper ores was an incident of the metasomatic changes above summarized, and the details of it are considered in another place (pp. 550 et seq.)

The intrusive rocks, especially the great basal gabbros, and the large masses of acidic rock, as has been noted in another place (p. 411), produced profound anamorphic changes in the pre-Keweenawan rocks which they cut. It is believed that later studies will show that in connection with the deep-seated batholiths of Minnesota and Wisconsin anamorphic changes will be found in the intruded Keweenawan lavas and sediments, but as yet studies lave not been made along the borker of the gabmos in order to ascertain whether or not this conjecture is correct. This suggestion gains much probability from the fact that along the borlers of the much smaller laccolith of Black River in Jichigan F. E. Wright has found the intruled Keweenawan lavas and sediments to be greatly metamorphosed.

\section{REAUME OF KEWEENAWAN HISTORY.}

From the facts which lave been presented we may make the following general statements:

After the great epoch of upper Huromian deposition the Lake Superior region was raised above the sea and was subjected to denudation for a long time, during which the erosion amounted to thousands of fect. The Kewernawan perion was beran by the depesition of sediments, consisting of conglomerates, sundstones, shales, and limestones, now found generally at the base of 
the known intrusive part of the Kieweenawan where it has been looked for. These may be subacrial deposits.

After the deposition of sediments of very moderate thickness occurred the events of the middle Keweenawan, which especially charactenze the series. The chief event was the outbreak of regional volcanism in the larger part of the Lake Superior basin.

In a large part of the region, and perhaps all of it, igneous rocks practically excluded sediments in the lower portion of the miklle Keweenawan. Igneous roeks, with an almost inappreciable proportion of sediments, constitute the Minnesot a coast, the lower eight-ninths of the Eagle River section, nine-tenths of the Portage Lake section, all of the Douglas County range of Trisconsin, all of the 4,000 feet of the Taylors Falls section, more than eleven-twelfths of the section at Black River, and about 4,000 feet, or one-fourth of the section, at Mamainse. It does not follow that the time represented by the sediments may not be as long as or even longer than that represented by the laras. Niter the period of dominating volcanism had continued until thousands of feet of lava had been built up, there was a decrease in volcanic activity and the sediments again became of suflicient importance to be recognizer in the section. This was the later part of the midhle Keweenawan.

The change in conditions in the middle Keweenawan by which the sediments, insignificant in the lower part, became important in the upper part is not supposed to have occurred at the same time over the entire Lake Superior basin. Indeed, it seems extremely probable that the change was not simultaneous in all parts of the region. This may be illustrated by the Portage Lake and Eagle River sections on Keweenaw Point. The alterations of notable masses of sediments with the lavas seem to have become important in the Portage Lake section before they did in the Eagle River section, for at Eagle River lavas, to the practical exclusion of sediments, constitute all but the upper 5,000 feet of the midlle Keweenawan, whereas at Portage Iake the portion containing sediments is much thicker.

As the middle Keweenawan epoch neared its close igneous activity ceased. In northem Michigan the longest cessation of volcanism was marked by the deposition of the "Great" conglomerate, which is locally more than 2,000 feet thick. After this conglomerate was hid down there were further outbreaks of voleanic activity, which resulted in the "Lake Shore" trap. But the outbreaks represented by this formation were relatively feclle, as is indicated by the fact that the lava berls are separated by conglomerates of considerable thickness. For Michigan this "Lake Shore" trap represents the last dying eflort of the epoch of regional volcanic activity.

Thus middle Keweenawan time witnessed a sudden beginning of volcanie activity, which was dominant for a long time, then intermittent volcanic activity, then total cessation. Evidence has been presented which seems to favor the vicw that the middle Keweenawan was deposited largely under subaerial rather than subaqueous conditions.

The present distribution of the middle Keweenawan shows that much, if not all, of the Lake Superior basin must have been covered by volcanic flows, for the igneous material, besides occurring along the rim of the lake, constitutes Isle Royal, Mlichipicoten, and Stannard Rock, off Marquette.

During middle Keweenawan time there were at least two alternations of basic and acidic rocks, and locally between basic and acidic rocks of the first cycle there were intermediate rocks, as on Keweenaw Point and Isle Royal. Whether these cycles were general for the Keweenawan over the Jake Superior region and whether there were more cycles than two is as yet undetermined.

As already stated (p. 410), during middle Keweenawan time, contemporaneous with and following the extrusions of the lavas, there were also intrusions, and these intrusive rocks are of very great quantitative importance. In many places in the lava series the intrusions in the form of beds and dikes compose a considerable percentage of the mass. Although the intrusives to a large extent rose into the micklle Keweenawan beds, still greater masses spread out approximately along the contact between the Kieweenawan and the lower rocks, and also 
between the layers of the lower fomations. The vastest intrusive boty of this chass is the great Duluth laceolith, which extencts from Duluth to the international loumdary and has a breadth reaching 30 miles. Another of these great intrusive masses is that at Bad River. The bodies intruded between the beds of the Animikie group are so prominent that they have been culled the Lorim sills. The so-ealled crowning overflow of Thumler Cape may fall here. The peculiar topography of the steep cliffs about Thunder Bay and Pie Island is clue largely to these intrusive flat-lying sills. The acidic rocks intrusive in the lower Keweenawan are also important. Granite bosses of consirkerable size intrude upper Huronian rocks in central Minnesota and northenstern Wisconsin.

1) uring midlle Keweenawan time progressive folding of the Lake Superior basin went on, with the result that the upper beds have a lower clip than the lower ones.

Conformably upon the rocks of the midlle division were built up the sediments of the upper Keweenawan. These sediments consist, in ascending orler, of the "Outer" conglomerate, having a maximum thickness of 5,000 feet; the Nonesuch shale, having a maximum thickness of 500 feet; and the Freda sandstone, having a maximum thickness of 19,000 feet. As the "Outer" conglomerate lies directly upon the basic lavas and in its main mass is lithologically like the conglomerates interstratified with the lavas there is no reason to suppose that the conditions at the time this conglomerate was deposited were in any way different from those prevailing at the time of the eartier conglomerates, except that late in the epoch detritus from pre-Lieweenawan rocks appeared. Beginning with the Nonesuch shale, the sediments are of a different character from those lower in the Keweenawan series. This formation and the Freda sandstone are largely and in places mainly composed of detritus derived from the basic lavas. Also, they contain contributions from the Huronian, Keewatin, and haurentian rocks. This means that by the erosion of the basic lavas, or by this cause combined with uplift, the pre-Keweenawan became the subject of attack by atmospheric agents. The relative lack of abundance of material from the acidic laras may also mean that the rolcanic mountains composed of acidic rocks lat by late Kerreenawan time become so reduced as to yiekl only a small amount of material.

As the change in the nature of the matcrials of the scliments from those interstratified with the lavas to the Freda sandstone was graclual, there is no reason to place a break at any defuite horizon. Volcanic activity gradually died out, orogenic movement and crosion continued, and these afford suflicient explanations for the increasing varicty of the detritus of the upper Keweenawan.

As the Nonesuch shale and Fireda sandstone together are of very great thichness and are makle up of fine-grained sediments, there must have been steady and long-continued subsidence of the basin where these formations were deposited. Also, their rolume is so great as to indicate steady uplift in some other part of the region, exposing the lavas and other rocks to crosion.

The development of the Lake Superior syneline continued to the end of Keweenawan time and was then substantially complete. The basin was modified afterwards only by post-Cambrian faulting.

Keweenawan sedimentation was largely subaerial, but it may have become subaqueous towarl the close of the periof in the water-filled fieweenawn syncline and may have ultimately nerged into Upper Cambrian subaqucous deposition. 


\title{
CHAPTER XVI. THE PLEISTOCENE.
}

\author{
By Lawrence Martix.
}

THE GLACTAL EPOCH.

\section{PLAN OF PRESENTATION.}

The statement that the Lake Superior region has been invaded and profoundly modified by a continental glacier or ice sheet does not require proof. It will suffice to name some of the localities in which the proofs are found and to describe the glacial phenomena and their effects on the present topography and the life of the region. ${ }^{a}$

The ice, which advanced from two centers, one east and one west of Hudson Bay, in a series of lobes, oscillated so that glacial deposits thought to be of two or more ages were produced. The latest of these are called the deposits of the Wisconsin stage of glaciation and cover the greater part of the area here diseussed. In advancing, the ice produced strix, roches moutonnées, circues, broadened, deepened, and hanging valleys, etc. It transported great quantities of the materials eroded in producing these forms. As the ice melted, these materials were deposited as an overmantle of glacial drift. The drift, which is partly stratified, was formerly known as modified and unmodified drift. Later studies show, however, that the largely unstratified (ummodified) drift, including terminal or recessional moraines, ground moraine, and drumlins, was deposited directly by the ice. The drift deposited by running water either under or in front of the ice or in standing water is stratified, though not essentially modified, and inchudes outwash deposits, lake deposits, loess, kames, eskers, ete. Most of these varieties of drift are found both in the older and in the latest glacial drift, as will be discussed. In all the glaciated area the drainage was greatly modified by the erosion and deposition lue to the ice. During deglaciation there was a great series of marginal glacial lakes, the ancestors of the present Great Lakes. Since the glacial period there has been warping in the region, resulting in tilting of the shore lines of the former lakes. Streams have made slight modifications of the glacial drift and of the topography of the land. The lake shores, especially those of Lakes Superior and Michigan, are the seat of active work, and in these lakes the detritus carried from the land by the rivers and from the shores by waves and currents is being deposited.

\section{ICE ADVANCES.}

The scratches and grooves upon the ledges in the Lake Superior region afford the principal evidence of the direction of movement of the glaciers, and the sketch map (fig. 60) is a generalization based on these marks. It will be seen that in general the ice moved in a series of lobes of which those in the Lake Michigan basin, the Lake Superior basin, and the valley of Red River were the most important, the lobes between these, especially one extending from the highland region of northern Wisconsin, known as the Chippewa-Keweenaw lobe, and one extending from the highland region of northern Minnesota, known as the Rainy Lake lobe, being less extensive.

a The author is indebted to Messrs. Frank Leverett and IV. C. Alden, of the United States Geological Survey, who have more recently done detailed work on the glacial leatures of the south coast of Lake Superior and in eastern Wisconsin, respectively, Ior critical suggestions concerning this chapter. The author, howerer, assumes responsibility Ior any errors in interpretation. 
The ice which overspread the I ake Superion region came from two principal sources, one in the highlands of eastern Canada, generally ealled the Labralor glacicr, and one in the region west of IJudson Bay, usually known as the Keewatin glacier. It serms probable that fully two-thirds of the iee which corered the Lake Superior basin came from the I abrador glacier. It is supposed, however, that this glacier was not the first to spread over the region, but that the Keewatin glacier, white largely synchronous and confluent with the Labrador glacier, arrived earlier and staynd longer, probably atvancing over parts of the region formerly covered by lobes of the Labrador glacier after these lobes liad retreated to the northeast. Whether or not the ice adrance from the northwest eovered all the Lake Superior region is unknown.

In the area eorered by this monograph the glacial lobes were profoundly affected by the areas of hightand and lowland, and, as would naturally be expected, the ice was the thickest and mored fastest in the deepest iepressions; consecpuenty, the Lake Michigan lobe of the Labrador glacier (figs. 4, p. 87, and 60) extended farther south than any of the others, and the

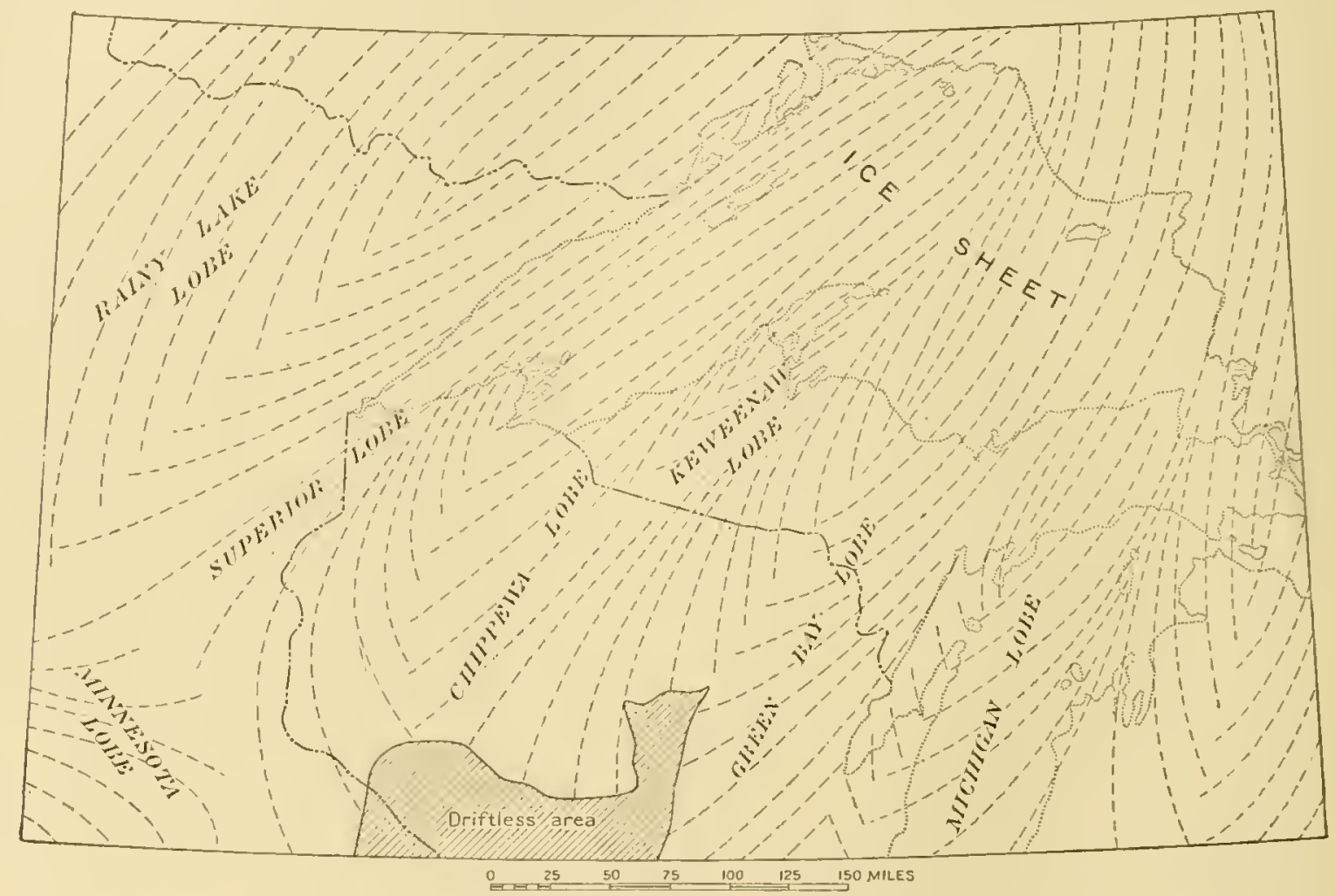

FIGUTE, 60.-Sketeh map showing the glaciation of the Lake Superior region, giving names of lobes and probable directions of ice now. There may have been an earlier stage with iee advance from the northwest through a large part of the area.

Green Bay lobe of the Labrador glacier, also having a deep axis of flow, extended nearly as far south as the Lake Miehigan lobe. The Keweenaw and Chippewa lobes of the Labrador glacier, boing obliged to adrance over the highland region of upper Michigan and northern Wisconsin, did not advance as far south as the lobes to the east, though the Chippewa lobe orerrode the part of Keweenaw Peninsula west of Ontonagon River and advanced farther south than the aljacent Keweenaw lobe. The Lake Superior lobe of the Labrador glacier, turnet westward by the topography, advaneed to the west end of Lake Superior, where it eseaped from the confining walls of the rift valley or trough near Duluth and spread out in a much broader lobe (fig. 60), part of which advaneed nendy westward in the region south of Leech Lake, probably moving southwest in the region of Mille Lacs and swinging round to the south, and even to the southeast in the vicinity of St. Croix Falls. The Rainy Lake lobe, which seems to have come partly from the Labrador and partly from the lieewatin center, moved south and southwest 
over the hills of northern Minnesota (fig, 4). The Red River lobe, the principal division of the Keewatin glacier, often referred to as the Minnesota lobe, advanced southward in the valley of Red River. Although these lobes are deseribed and disenssed as somewhat separate glaciers, too much emphasis should not be placed on their separate existence. It would naturally be true that as the Labrador glacier advanced from the northeast it would project farthest where the deepest valleys existed and would have reentrants where the hills caused obstruction to free glacial adrance. It therefore seems probable that the Lake Nichigan and Lake Superior lobes actually did advance independently over the regions described; but it must also be remembered that with farther advance to the south the lobes in the Great Lakes basins and those on the hills would coalesce until the hilly region was completely covered by one confluent ice sheet. For exanple, after the Lake Superior lobe had advanced westward from Duhth and the Rainy Lake lobe had advanced orer the highland area of nortliern Minnesota and the international boundary, their farther advance would cause these short lobes to become confluent and form one great ice cap.

\section{DRIFTLESS AREA.}

If there was not time enough for two lobes to become confluent before the retreat of the ice, there would be left between them an area where the soil, the ledges, and the drainige bore no evidence of the glacial advance. Such an area might have been formes in northern Minnesota if the Lake Superior lobe and the Rainy Lake lobe had never coalesced. They did conlesce, however, but in one small area at the extreme northenstern part of Mimmesota, described by N. H. Winchell ${ }^{a}$ and U. S. Grant, ${ }^{b}$ the drift is so thin that, although the topography, striated rock surfaces, and scattered foreign bowlders definitely prove glaciation of the area, the fact that the residual soil has not all been removed and the absence of nearly all glacial deposits have led to the description of the locality" as "a possibly driftless area." Part of the Marquette district is an area of very thin drift, as near the Mansfiedd nime, on Michigamme River. Similar areas of thin drift are described as occurring in Canada.

In western Wisconsin and the adjacent parts of Amnesota and Iowa there is a true driftless area, and this was recognized in 1852 or earlier by D. D. Owen ${ }^{c}$ and has been studied and fully described by Chamberlin and Salisbury. ${ }^{d}$ A portion of the Driftless Area (fig. 6., p. 453) is included in the southwestern part of the region described in this report. Recent stuclies by Weidmane and by Leverett and Alden are somewhat modifying the ideas previously held as to the shape and boundaries of this area, althougl the main fact of its existence and the assignment of its cause to insufficient time for the reduced supply of ice from the north, retarded by the highlands, to reach this driftless region still stand approved.

\section{RETREATING ICE.}

The so-called retreat of the ice sheet was not an actual backwarl motion, the opposite of the forward motion of the adrance, lut a melting back of the front of the ice sheet. While the front of the continental ice sheet was retreating from this region, the highlands first emerged from the ice cover because the ice was thimnest above their tops, and valley glaciers or lobes lingered longest in the valleys beeause it was there that the ice was thickest and, after thinning by ablation, most protected by the loar of soil and stones which it was carrying. Accordingly during the retreat the ice front was always lobate. The lobes in the Lake Michigan and Lake Superior basins were much more extensive than those in the northern Minnesota and northern Wisconsin highlands, as the glacial deposits that have been left in the region prove. There were probably slight readvances during the retreat of the ice sheet south of Lake Superior.

a Fifteenth Ann. Rept. Minnesota Geol. and Nat. Nist. Survey, 1\$s;, p. 350.

b Im. Geologist, vol. 24, 1599, pp. 37T-381; Final Rejt. Minnesota Geol. and Nat. Mist. Survey, 1899, pp. 421, 437-438

c Geological survey ol Wisconsin, Iowa, and Minnesota, 1852.

d Chamberlin, T. C., and Salisbury, R. D., The driftless area of the upper Mississippi Valley: Sixth Ann. Rept. U. S. Geol. Survey, 1884, pp. $199-322$.

e Bull. Wisconsin Geol. and Nat. Hist. Survey No. 16, 1907, pp. 548-565. 
A study of these deposits also suggests that the ice lofe which advanced down the Red River valley, moving southward and southeastwarl in the area discussed in this monograph, eame after the dake. Superior and lake Michigan lobes had letreated for some distance " perhaps into the hasins of the present lakes. Moreover, glacial grooves and strix on the leclges seem to show the same thing. In the At. Croix Dalles region glacial scratches on the rock are associated with the deposits made by the Lake Superior lobe of the Labrudor gracier in such a way as to sugrest that they were made during a first glacial alvance, while striations associated with overlying alacial deposits made by the Red River lobe of the Kcewatiu glacier differ in direetion and were probably male after the first set. ${ }^{b}$ The relation of moraines of red and of gray drift neal the south boundary of the upper peninsula of Michigan, west of Crystal Falls, suggested the possibility to I. C. Russell ${ }^{c}$ that the Chippewa (or Keweenaw) lobe of the Superior glucier was still advancing after the Green Bay lobe of the Lake Michigan glacier had partly retired from the areal.

That there were slight realvances of the ice during its general recession is indicated in several places, as in rastern Wisconsin, where red till morames of the Green Bay and I atke Michigan lobes overlie the earlier moraines of the Wisconsin glaciation. Certain stages of the marginal glacial lakes discussed later also iudicate a halt in Lake Michign in the latitude of Manistec and a subsequent slight readvanee. These readvances during the deglacintion of the region, however, do not seem to have been very many or very great, so far as the preliminary studies thus far made give eridence.

\section{CONTRASTED GENERAL EFFECTS OF GLACIATION.}

In general the glacial invasion stripped the peneplain of its soil in the area north of Lake Superior, while south of the lake, in the highland region of northern Wisconsin, it remored the soil but left a heary mantle of glacial deposits. Nevertheless, throughout this area the influenee of glaciation on topography was minor, while the effects on soil, drainage, forests, and the subsequent pursuits of man were most profound. What was a hill in this upland area north of the lake before the glacial alvance is still a lill; what was a valley is almost without exception still a valley, but it may be marsh or lake, or stony soil, and so useless for agriculture. It may have had a fertile soil before glaciation, or may have contained some evidence of an adjacent body of iron ore, and this the glacier has taken away, leaving as compensation perhaps a sandy soil supporting a sjlendid jine forest, possibly a ledge from which the location of the ore body may be inferred, perhaps only a clogged valley, a chain of lakes, and broad, loiterinc strean courses along which the prospector or geologist may travel by canoe, and so reach regions of mineral wealth that otherwise might have lain hidden to this day. Quite in contrast to this pre-Cambrian area, the horizont al Cambrian rocks of the south shore of Lake Supcrior near Duluth and Ashland and eastward from Marquette to Sautt Ste. Marie, the belted plain of Wisconsin and Michigin, and the fhat-lying Cretaceous deposits of cast-central Minnesota are deeply obscured by glacial (lrift. Throughout nearly all these areas the rocks were so readily abraded by the ice and the hills were so little higher than the aljacent ralleys that the glacial deposits have entirely (overed the preglacial topography and molded a new topograply. of their orn. Moreover, the draining of the glacial lakes which orcupied the basin of the mesent lake Superior and overlapped its shores has permited streams to produce a peculiar toprography of sculptured lialic clays. ${ }^{d}$

\section{DESTILUCTIVE WORK OF TIE GIACIERS.}

Remeneal of wethered rock.- Glacial crosion removed quantities of weathered rock. inchuling the nonresistant iron ores, perhaps truneating the iron-bearing rocks to a lower level in Canada than in the United Stales, and hence making the Canalian mines less productive, als

a Weidman, Samuel, Bull. Wisconsin Geul. and Nat. 11 ist. Survey No. 16, 1907, fig. 21, p. 434, and maj in pucket. Berkey, C. F., Jour. Gsology, vol. 13. 1:11:5. 121). 35, 39.

bchamberlin, R. T., Jour. Geology, vol, 13. 1905, pp. 219-25l.

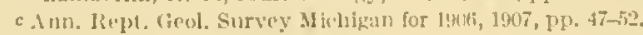

dirving, 1. D., fieology of Wisconsln, 1×73-1879, vol. 3, 1880, p. 69. 
Van Hise ${ }^{a}$ has suggested. Lawson ${ }^{b}$ however, brings evidence to show that there was no very material reduction of level.

Strix and roches moutonnées.-The scratches or stria and the smootlily polishorl surfaces which were made by the ice advancing over the region are to be found throughout the Lake Superior region wherever there are ledges of hard rock which will preserve them. On the Archean and Algonkian ledges these strix are exceedingly common. The advance of the glaciers over these ledges modified them, producing the rounderl forms known as roches moutonnées. Some of these have longer axes in the direction of ice morement and stecp or even precipitous slopes on the lee side, che to a process called plucking, $\mathrm{m}$ which large blocks of ire are rasped or torn away by the glaciel. In the pre-Cambrian areas these roches moutomées are exceedingly common, although in the main rather low and not very prominent.

Broadened and deepened valleys.-In certain farorable localities, either where the ice flow is very strong or where the rock is exceptionally weak, glaciers hroaden and deepen their valleys. Clements ${ }^{c}$ suggests the possibility that in the Vermilion district "glacial erosion was also active in wilening and deepening these preglacial valleys, changing $V$-slaped into U-shaped valleys." The orerdeepening of certain parts of the bottoms of valleys results in the production of basins in the solid rock, and these are afterward occupied by lakes. (See Pl. VI, p. 118.) 'The rock basins of this description are very common in the Lake Superior region, and glacial erosion has probably caused the deepening of many of the lakes in the granite area of northeru Minnesota, where it is possible to go all around the lake shores on ledges, demonstrating that the lake basins are lower than the surrounding country. Lake Superior was somewhat deepened by glacial erosion at the time when the ice was advancing through it (Pl. II, p. S6), and Lake Michigan and Green Bay, ${ }^{d}$ like the Winmebago Valley, were also somewhat deepened in this way, although, as previously stated, these depressions must have existed before the glacial ice advanced through them.

Glacial erosion also broadened and rounded out the great transverse valley of Portage Lake, which crosses Kieweenaw Point at Houghton, as well as many other valleys in the region, especially in the more litly areas. The overdeepening may be seen west of Houghton, where Huron Creek occupies a hanging valley (Pl. XXX, $B$, p. 434).

The effect of glacial erosion on the Duluth escarpment northwest of Lake Superior, where Thunder, Black, and Nipigon bays occupy submerged hanging valleys, has alrearly been discussed (p. 114).

Glacial rock basins.-The rock-basin lakes occupying depressions produced by glacial erosion are numerous in the areas of pre-Cambrian rocks. (See Pl. VIII, in pocket.) Their character and origin may be inferred from one specific illustration. In the Michipicoten district a series of lake basins entirely rimmed by rock has been studied by Coleman, who concluded that these basins have been formed by chemical action and are not due to glacial erosion.

The writer visited the Miehipicoten district during the summer of 1907 and after a study of these rock basins came to a conclusion different from that of Coleman. For a number of reasons it seems probable that Hematite Mountain, at whose base is the Helen iron mine and one of the rock basins, was the seat of a local glacier that probably came into existence as the ice was advancing over southern Ontario and lingered as the ice sheet was retreating, becanse of the leight of the litl $(1,700$ feet). The north and northwest slopes of the hill would receive less sunlight and heat than the south slope and the snow and ice would therefore linger there longest. The local glacier would naturally be on that side. The shape of the depression in which the Ilelen mine is situated is such as to suggest that it is a glacial cirque (fig. 61), and the rock basin is of exactly the kind which is made by small glaciers in their cirques. A

$a$ Van IIse, C. R., Twenty-first Inn. Rept. U. S. Feol. Survey, pt. 3, 1901, pp. 411-412.

b Lawson, A. C., Bull. Geol. Soe. America, vol. 1, 1\$90, p. 169.

c Clements, J. M., Mon. U. S. Geol. Survey, vol, 45,1903, p. 43.

$d$ Winchell, N. H., Am. Jour. Sci., 3d ser., vol. 2, 1871, pp. 15-19.

e Coleman, A. P., Rock basins of Helen mine. Michipicoten, Canada: Bull. Geol, Soc, Amerien, vol. 13, 1902, pp. 293-304; Znir. Toronto Studies, 1902, pp. 5-6, 26; Rept. Bur. Mines Ontario, vol. 15, pt. 1, 1906, pp. 187, 18s; Econ. Geology, rol. 1, 1904; p. 522. 
ledge separates it from an aljoining rock basin a little farther down (a normal glacial rock basin relation of which many examples are known) and a rather marked hanging valley (Pl. XXIX, $A$ ) connects the depression in which these two lakes are situated with a lower trunk valley in which lies still anotloer lake (fig. 61). The existence of this lianging valley indicates glacial erosion in the region. The glacial strix in the upper part of the valley, which oecasioned one of Coleman's dilliculties in believing this a glacial rock basin, are oblique to the trend of the ralley, as would be natural during the higher stages of the eontinental glacier, but the lowerstrix run in the proper direction for the later stages of a local ghacier. Ice would naturally exearate

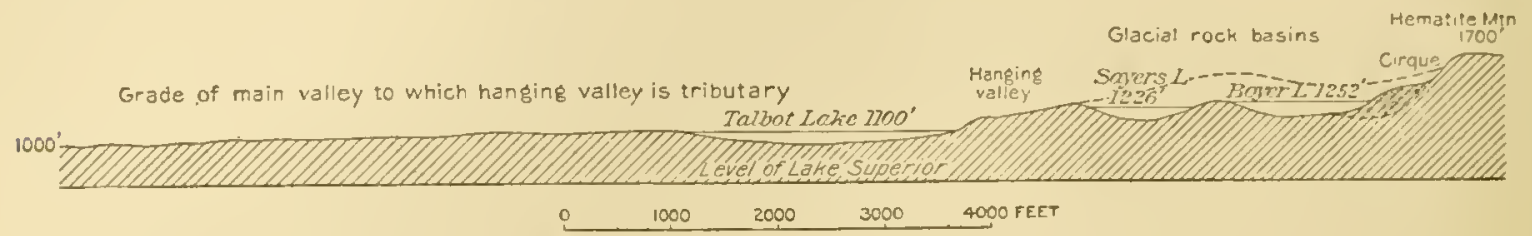

Figure 61.--Sketch showing the glaclal eirque, the rock basins, and the hanging valley near the Helen mine, Michipicoten.

along the zone of weak iron-bearing rocks, which were possibly somewhat prepared for the exearation by chemieal action of the sort that Coleman suggests. ${ }^{a}$

The real crux of the determination of these lake basins as of ehemical or glacial origin lies in the fact that the iron ore remaining in the basins is found in just that locality where a small glacier in a cirque would protect it, although removing the rest of the iron ore, whereas if a chemical origin is thought plausible, the selective chemical action in preserving the ore at just this point and removing it elsewhere in the basin must be accounted for.

\section{TRANSPORTING WORK OF GLACIERS.}

It is well established that the deposits carried by the glaciers have been worn br the ire from the ridges orer which the ice shect alranced and that in any place where glaciers have been the rocks brought by them are apt to be of an entirely different sort from the ledges which unclerlie them, although a large part of the material in the drift may be of local derivation. This transportation of foreign material was early observed in this region, though explained by Bigshy ${ }^{b}$ as the to "an earthquake sea wave" or "loaded icebergs." When rocks of a distinctive kind are found in an area where no similar rocks nomally occur and the strix indicate that the glaciers mored in the proper direction to earry these rocks, it may be considered demonstrated that glacial ice has mored the material from one place to the other. The eary students lacked this conception of moving glaciers. Devonian limestone with fossils was thus bronght into the Michipicoten district from a locality some 150 miles to the northeast, and iron ore was thus transported in the upper peninsula of Michigan. ${ }^{c}$ Cambrian or Silurian limestone pebbles ${ }^{d}$ from ledges in Manitoba seem to have been brought to the Lake of the Woods region of old crystalline rocks by a later movement of the Keewatin glacier after the chief northeast-southwest movement of the Labrador ice sheet. Many fragments of the granites and gneisses of the Archean and the porphyrites and quartzites and jaspers of the Lake Superior region were transported by the glaciers and are now found in the region of horizontal Palcozoic rocks to the south, fragments of this kind coming from both the north and the south shores of Lake Superior. It is sometimes an ail to the iron prospector to study the stones in the glacial drift in order to determine where possible ledges of iron-bearing formations may be foumd. The most notuble case of glacial transportation of iron ore is that of the 30,000 -ton mass south of the Fayal mine, on the Mesabi range, which Leithe describes as being entirely inclosed in the glacial chift and hence evidently transported bolily from the ledges to the north.

a Coleman, A. P's, Rept. Bur. Mines Ontarlo, vol. 8, pt.'2, 1899, pp. 156-157

$\checkmark$ Bigsby, J. J., On the erraties ol Canada: Quart. Jour. fieol. Soc., rol. 7, 1.51, pp. 215-238.

c Brooks, T. B., Geol. Survey Michigan, vol. 1, 1873, pp. 76-79.

dlawson, 1, C., Geol. and Nat. llist. Survey ('anada, vol. 1, 185, p. 132cc.

e Loith, C. K., The Mesubl iron-bearing district of Ninnesots: Mon. U. S. Geol. Survey, vol. 43, 1903, p. 263. 


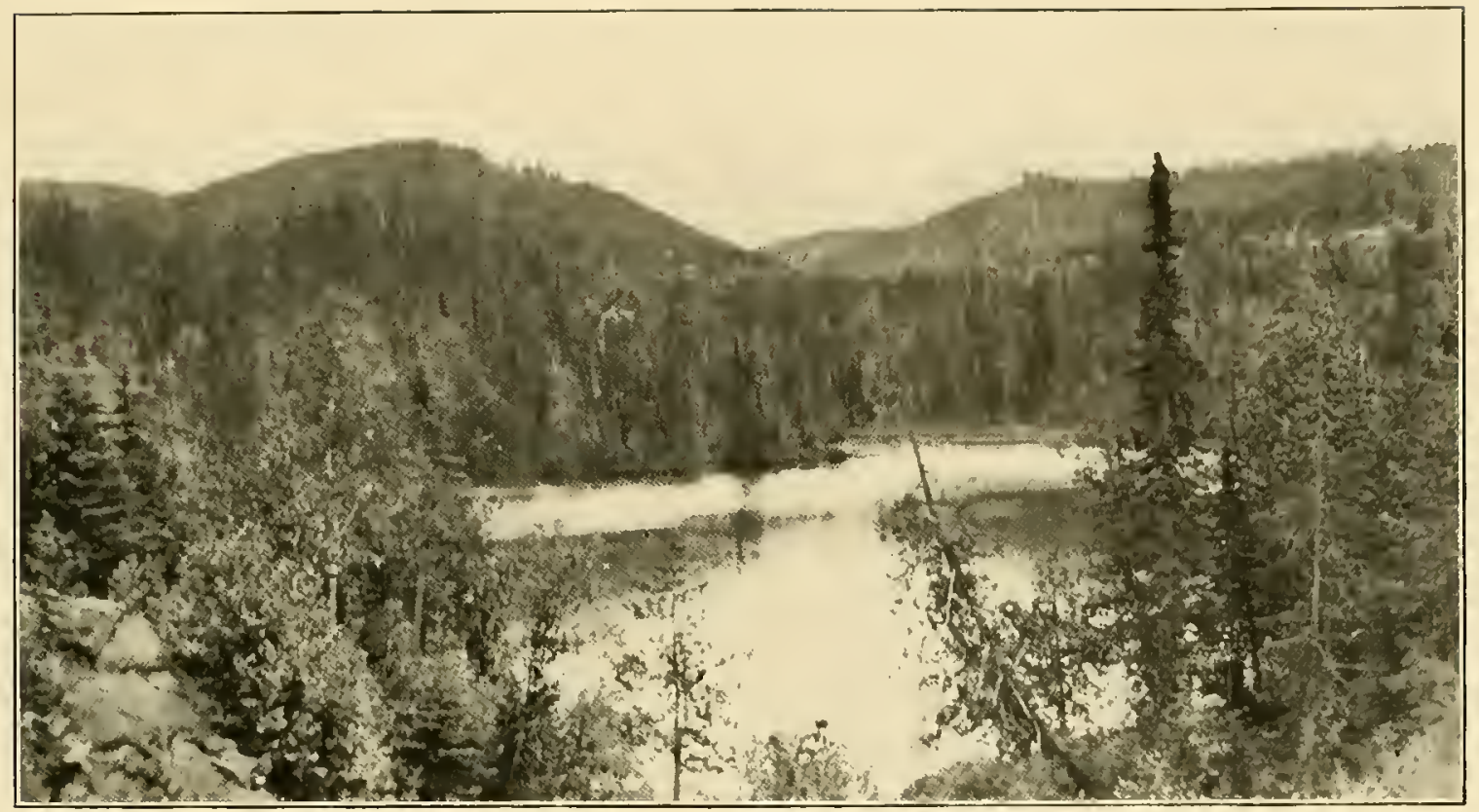

A. HANGING VALLEY NEAR HELEN MINE, MICHIPICOTEN.

Talbot Lake in foreground. See page 432.

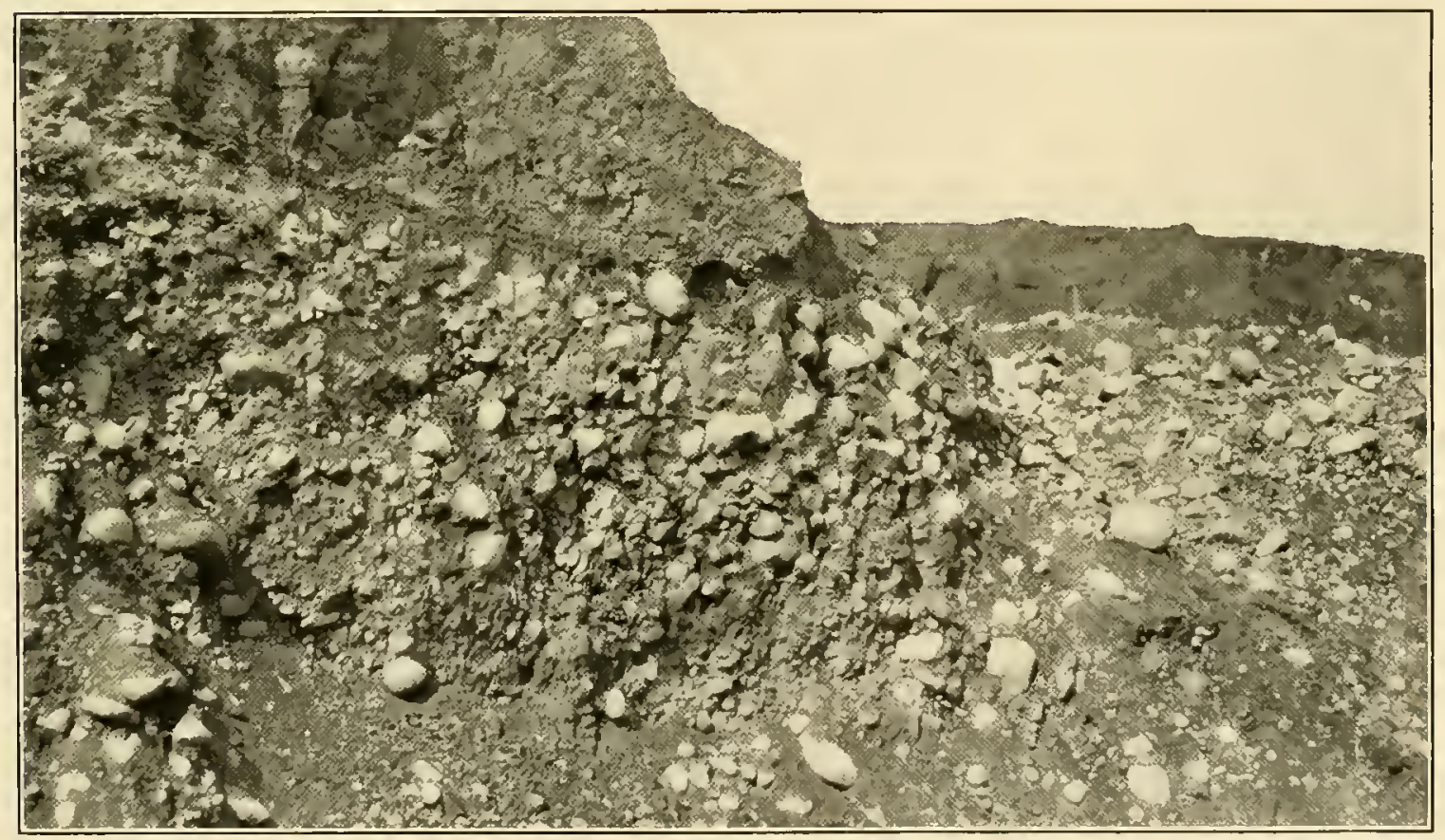

B. LAKE CLAY OVERLYING STONY GLACIAL TILL IN MOUNTAIN IRON OPEN PIT, MESABI RANGE, MINN.

See page 443. 

Among the distinctive materials which are found in the glacial drift are diamonds and native copper. The copper is of course traceable to the copper-bearing rocks of northem Wisconsin and Michigan and Michipicoten Island, but the source of the dianonds is not known. ${ }^{a}$

\section{CONSTRUC'TIVE WORI OF GLACIERS.}

\section{GROUND MORAINE.}

Nuch of the material carried by the ice sheet is ground finer and finer until it is rerluced to elay, and this clay with the included stones of various sizes which were not ground up so fine forms the most widespread of the deposits left by the glaciers. It is generally caller till or bowlder clay and was formerly known as unmodified glacial drift. It reached its present position simply by being dropped from the melting ice, and forms the great mantle of ground moraine and parts of the ridges of terminal or recessional moraines. The present thickness varies with the former thickness of the ice, the amount of such débris which was contained in the ice, and the amount of erosion hy rumning water either in connection with the melting ice or subsequently. This glacial till is found with varying thicknesses in every part of the Lake Superior region, overlying the Archean, Algonkian, Paleozoic, and Cretaceous rocks, being entirely absent or represented only by scattered stones in some rock ledges, and covering other areas and completely obseuring the bed rock by an overburden 200 to 300 feet thick.

The type of topography produced by the glacial till in the ground-moraine areas depends largely on whether enough of it accumulated to bury the preglacial topography or not. Many hills in the glaciated area still have the form of their bed-rock cores or are merely thinly veneered with the bowlder clay. Many valleys also are only partly filled by the till (fig. 55, p. 364) and remain as valleys, though not now as deep as before the glacial arlvance. On the other hand, more commonly the topography was so mild before the glacial advance and the accumulation of glacial deposits was so thick that an entirely new topography is modeled by the ice. (See Pls. XI, p. 180, and XXXI, A, p. 436.) This topography is generally of the "moderately rolling." "undulating or rolling," and "flat or undulating" types described by Warren Upham and others."

\section{DRUMLINS.}

$\Lambda$ class of till, or unassorted ground moraine, which deserves special mention is the drumlin. Drumlins in only one or two areas within the field of this report have yet been described, but they doubtless exist at numerous other points. The drumlins of the Lake Superior region are lenticular hills of bowlder clay or till, varying in shape from that of half of an egg that has been bisected lengthwise to that of half of a cigar eut in two in the same way. They characteristically have one rather steep side and one gentle slope, the steep slope being on the side from which the ice came. The long axis of the drumlin is invariably parallel to the direction of the latest ice movement.

Three areas of drumlins in Michigan have been described. The first is in the Menominee district, ${ }^{c}$ where the drumlins are found over an area of about 150 square miles and have an average height of about 40 feet. The second area is also in the upper peninsula of Michigan, including Les Cheneaux Islands and a portion of the arljoining mainland on the north shore of Lake IInron. ${ }^{d}$ The third drumlin area is in the Grand Traverse region, ${ }^{e}$ in the northwestern part of the southern peninsula of Michigan.

a Salisbury, R. D Notes on the dispersion of drift copner: Trans. Wisconsin Acad. Sci., Arts and Letters, vol. 6, 1S86, pr. $42-50$. IIobbs, W. П., Emigrant diamonds in America: Ann. Bept. Smithsonian Inst., 1901, pp. 359-366; An. Geologist, vol. 15, 1894, pp. 31-35; Jour. Geology, vol. 7,1899 , pp. 375-38s. Farrington, O. C., ( orrflation of distribution of copper and diamonds in the glacial drift of the Great Lakes region: Proc. Am. Assoe. Adv. Sei. vol. 58,1908, p. 288.

${ }_{b}^{b}$ Final Rept. Geol. and Nat. II ist. Survey Minnesota, text accompanying county maps.

c Russell, 1. C., The surface geology of portions of Menominee, Dickinson, and lron counties, Mich.: Ann. Rept. Geol. Surrey Michigar fcr 1906,1907 , pp. s-91.

¿Russell, 1. C., $\Lambda$ geological reconnaissance along the north shore of I akes II uron and Michigan: Ann. Rept. Geol. Survey Michigan for 1904, 1905, pp. 39-150.

e Leverett, Frank, Scjence, new ser., rol. 21, 1905, p. 220; Water-Supply Paper U. S. Geol. Survey No. 183, 1907, pp. 333-33it.

$47517^{\circ}-$ VOL $52-11-2 S$ 
Geologists have not thoroughly agreed as to the origin of chumlins. Two theories have been heli. One holes that the drumlins are constructed under the ice by the accumulation of material there, the material being derived by tho ice sheet from the land from which it is alvaneing and the drumlins being built somewhat like bars in a river. The alternate hypothesis ascribes drumlins to a destructive action, the ice sheet being supposed to carve drumlins from a preexisting mass of till laid down by a previous ice sheet. The drumlins of the first two areas described seem to have been formed by the destructive process, as very decisive evidence by Russell proves, but Leverett thinks that some of the drumlins in the Grand Traverse region are constructional rather than destructional.

\section{ESKERS.}

Another glacial feature to be described, the esker, is a fossil stream course formed in or under the ice by a stream flowing in a tunnel and depositing its load of sediment, which is preserved on the surface as a low winding ridge after the ice has melted away. Eskers in many parts of the Lake Superior region, as in northeastern Minnesota ${ }^{a}$ and the Menominee district, ${ }^{b}$ have been described. Russell describes them as low, serpentine gravel ridges in the valleys between the drumlins. They are doubtless also present in many other areas. They are mentioned here rather than with the other stratified drift deposits, like outwash plains, because in this area they are commonly associated with the ground moraine rather than with the outwash of the valleys.

\section{TERMINAL MORAINES.}

The deposit piled up at the end of the ice tongue or lobe is called a terminal moraine, and the name is applied not only to the deposit made at the farthest advance of the ice but also to those made at any point where the ice halts. The latter are also sometimes called recessional moraines. The only terminal moraines in the Lake Superior region which mark the farthest advance of the ice lie around the borders of the Driftless Area, but recessional moraines are more abundant. Some of them, so far as mapped, are shown in figure 68 (p. 453). These recessional moraines may be made up of two rather different kinds of material - the glacial till, or unmodified drift, and the drift which is assorted and stratified by running or standing water. A terminal or recessional moraine in the Lake Superior region usually consists of a series of ridges or knolls (PI. XXX, A), in general constituting a long, narrow zone of hilly country, which may be in a single ridge, but is more commonly an irregular belt of ridges and valleys. The characteristic terminal moraine is made up largely of knobs and kettles. The belts of terminal moraine range from sereral hundred yards to several miles in width but are rarely over 4 or 5 miles wide and generally a mile or less. A great terminal moraine of course indicates that the edge of the ice remained at one point for a considerable length of time. During this time, if the glacier ras moring, it would be constantly bringing material up to this point, dropping the material there, and perhaps, by slight readvancos, shoving ahead the material which had previously been deposited by the melting ice, and all this material would be subject to constant removal or rearrangement by the running water that issued from the ice as the glacier was melting. These terminal morames are therefore made up of a mixture of unmodified till and stratified sand, gravel, and clay deposited by rumning water, with variations of the two as the ice may have adranced, or as the water may hare cut channels in the deposits, or as portions of the ice may have been buried beneath the deposits made by the melting of the upper ice layers or laid down by the streams. The subsequent melting of these buried ice blocks has caused the glacial drift to slump down, forming broad hollows and steep-sided pits. This is the general origin of the kettles which are found in terminal moraines.

a Elftman, A. II., Am. Geologist, vol. 21, 1898, p. 97.

o Russell, I. C., The surfice geology ol portions of Menominee, Dickinson, and Iron counties, Mich.: .Inn. Rept. Geol. Survey Michigan for 1906, 1907, pp. S-91; 1m. Geologist, vol. 35, 1905, p1. 177-179; Science, new ser., vol. 21, 1905, pp. 220, 221. 


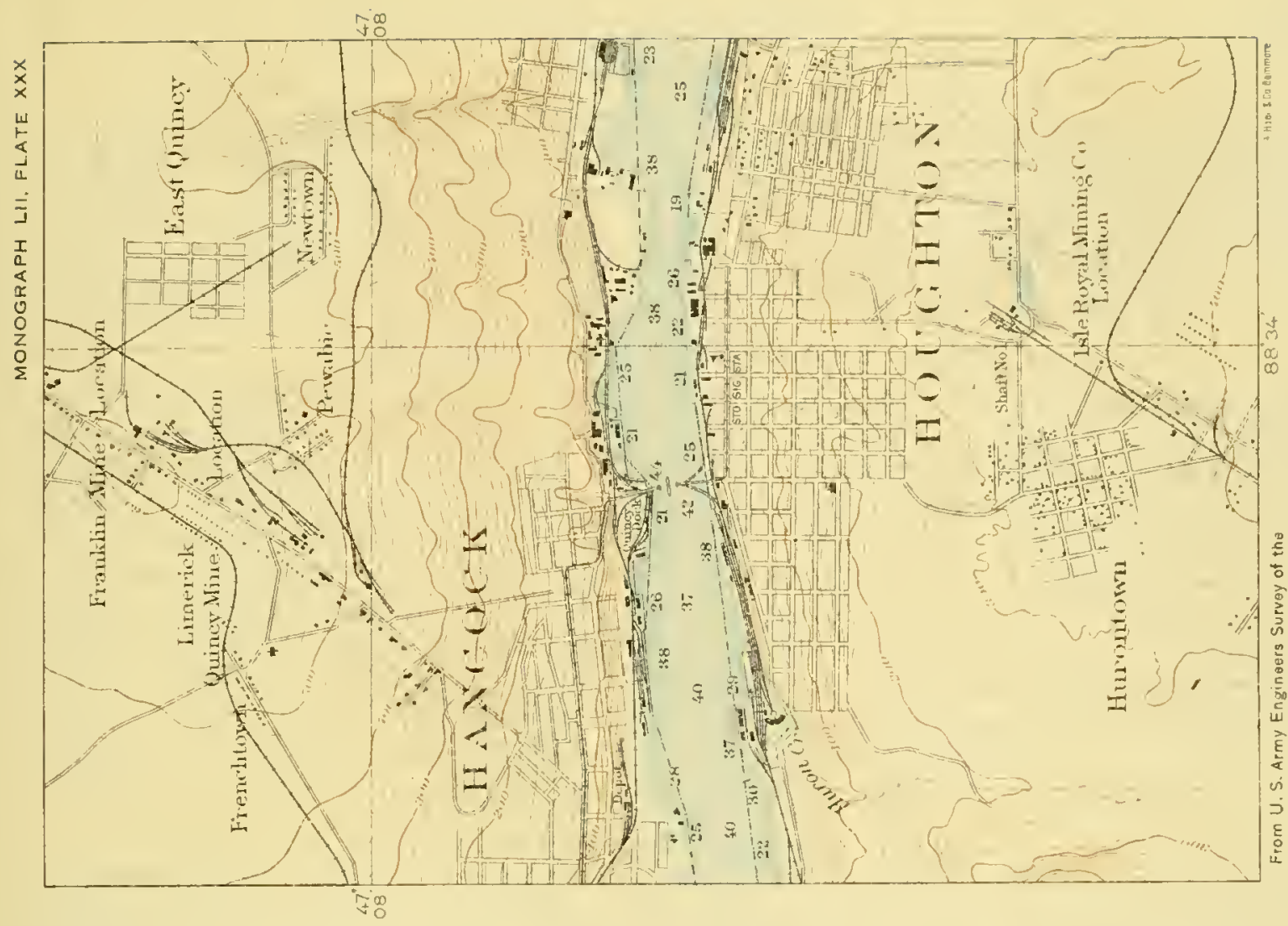

3z荘

w

㟧㟔改

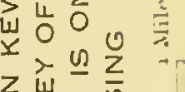

乙出口包

山这음

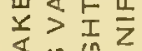

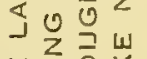

山嵌呈

\&ZI

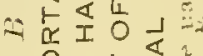

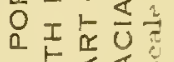

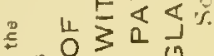
\%

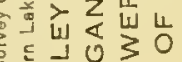
造

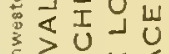

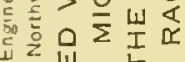

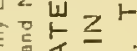

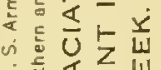

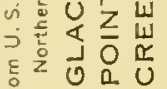

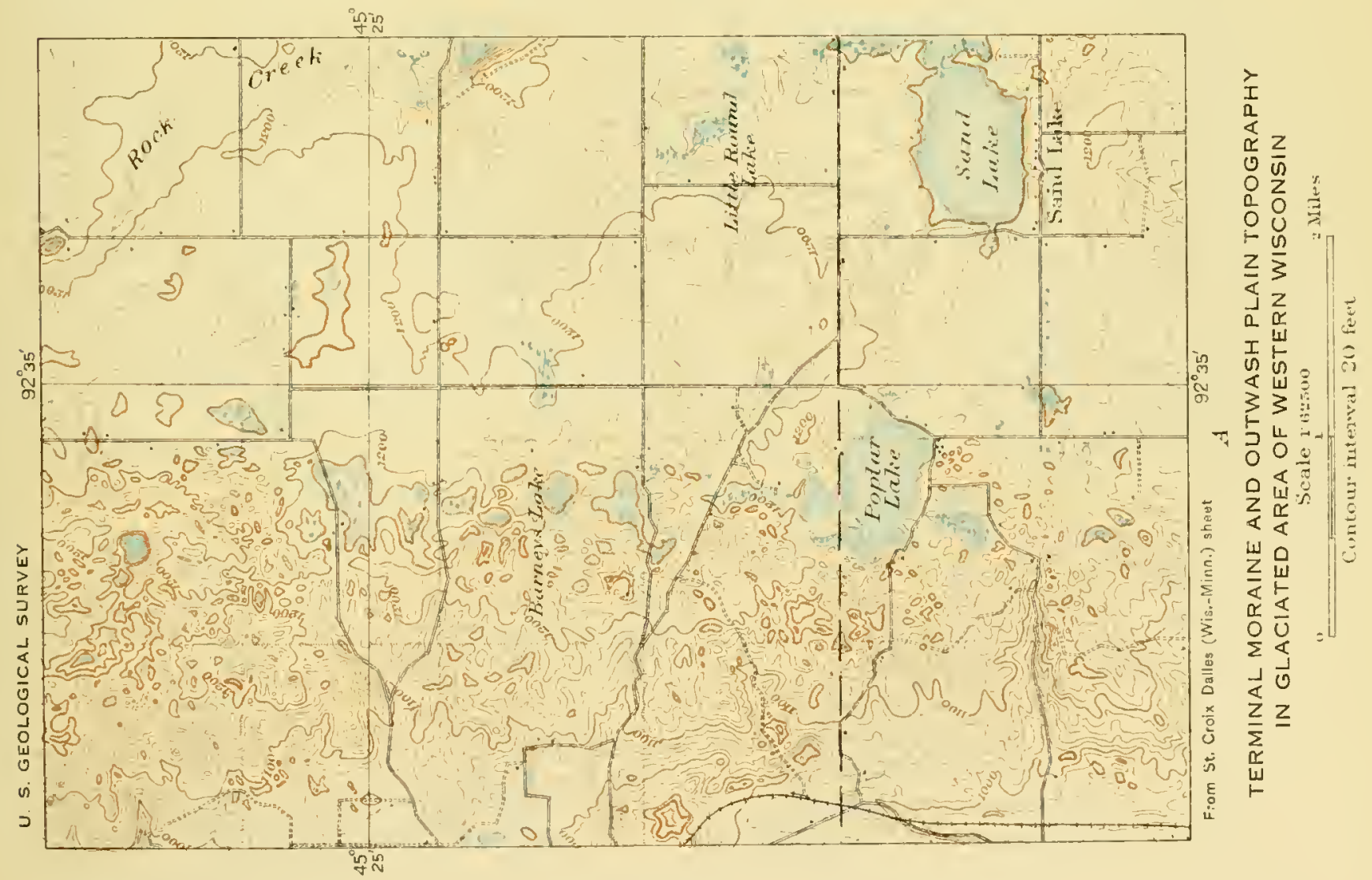



KAMES.

Kames, or irregular hummocks of waterworn sand and gravel, are present throughout the moraine belts of the Lake Superior region, many of them at the borders of valleys, as if formerly at the margin of an ice sheet whose melting has caused the edges of marginal terraces to slump down into irregular liummocks and kettles. Russell deseribes irregular hilloeks of rounded kame gravels in the Menominee area and aseribes them to accumulation beneatl wells, or moulins, in the ice sheet, where streams on or in the glacier fell vertically and deposited their load.

\section{RECESSIONAL AND INTERLOBATE MORAINES.}

The recessional moraines formed at temporary terminal points of the ice sheets during the Wisconsin stage are seen from the map (fig. 68, p. 453) to be definitely related to the larger lowland and highland areas, and it is by a study of these moraines that some of the conclusions as to the behavior of the different ice lobes in the Lake Superior region have been reached.

As the ice retreated from the maximun stage of a confluent ice cap and once more resolved itself into lobes, some very distinctive deposits were formed between the adjacent lobes, and these are called interlobate moraines. An example of the moraines of this kind is found in the interlobate (kettle) moraine of eastern Wisconsin, which was aceumulated between the Green Bay lobe and the Lake Michigan lobe. Other interlobate mornines were formed between the Chippewa lobe and the Superior lobe in Bayfield and Douglas counties, Wis., west of Ashland, and between the Superior and the Rainy Lake lobes in northeastern Mimnesota.

\section{DRAINAGE OF DRIFT-COVERED AREAS.}

The accumulation of till orer this great area has modified the drainage, and one of the most prominent effects of this accumulation is the destruction of mature or submature preglacial drainage and the superposition of young drainage on the drift, causing gorges, waterfalls, and the great numbers of lakes and swamps for which the region is noted. (See PI. XXII, in pocket.) These lakes and swamps are due to a common cause-interference with the free run-ofl of rain by the irregular deposition of the drift. Among the most common linds of lakes and swamps or muskegs (Pl. XXXI, $B$ ) are those which are prodneed by the accumulation of water in shallow depressions in the undulating or mildly irregular till sheet. As the material of the till was largely clay, it would naturally be difficult for the water to escape through it. Another common cause of lakes is the accumulation of a greater thickness of the glacial till in one part of the valley than in another, producing an obstruction to dramage. Many of the streams were also forced out of their preglacial courses by the deposits of glacial till, and numerous rapids and waterfalls are due to this displacement. Clements ${ }^{a}$ has described Deer River, Michigan (Pl. XXII), as typical of a stream with associated swamps and lakes in a till-eorered area and has ontlined the life listory of such a drainage system. The normal type of preglacial drainage of the entire Lake Superior region is illustrated in Plate XXXI, A, showing part of the Driftless Area. Plate XXXI, $B$, slows the young dramage of the glacial drift which now eovers the greater part of the region.

\section{DIFFERENCES BETWEEN YOUNGER AND OLDER DRIFT.}

There is eridence in the central United States which has been interpretel as indicating that the glacial period, instead of being simple, was decidedly complex. It is thought that the ice did not advance from the Labrador and Keewatin centers once and retreat once, but that instead it underwent a series of oscillations so that glacial deposits were laid down under or in front of the ice, the ice retreated from them, and then the weathering and erosional agencies acted upon these deposits. This is the reason why the lakes among the older glacial deposits are largely either filled or drained, the till-vencered hillsides are cut by streams, the stones in the drift are weathered and disintegrated, and the soluble constituents have been leached out of the soil by percolating water. After all this had taken place the glaciers are thought to have readvanced and corered the older drift with a sheet of $12 \mathrm{ew}$ till, ete., which in some places extends 
further ont than the older drift and in others has left a broad zone of it exposed. This fresh, unweathered, young till forms a derided contrast to the older drift.

Only the extreme southwestern part of this recrion contains any of what lats been interpreted as older drift. In the engeater part of the region the drift seems to be solely the work of the Wisconsin ice sheet. The drift neal the louders of the Driltless Areal has been ascriled to

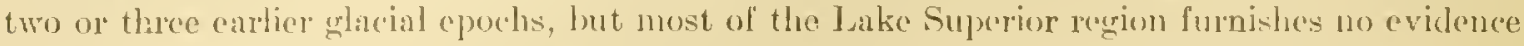
whatever of more than one glacial advance, either in the eleposits or in the topography.

\section{EFFECT OF NUNATAK STAGES ON DISTRIBUTICN OF DRIFT.}

In spite of the lack of detailed studies in a large part of this region, it seems probable that the hehariog of the ice in retreating can he somewhat eliscriminated. When an ice slieet covers an irvecenlar land surface, there are two ways in which it may retreat. It may disappear gradually lrom the lowlands and linger longest in the upland regions, as is the case in the Rockies, in Torway, in Alaskin, and in Switzerland to-day. It does this, however, only where the elevated areas are ligh enough to become centers of local glaciation and to supply new ice. The contrasting condition is found where the highland areas are not sulliciently elevated to retain snow through the summers and therefore to supply ice. Where the latter condition prevails, the glacier does not continue to be active up to the very time of its extinction, as in the Rocky llountains at present, but becomes stagnant hecause there is no fresh supply of ice. When an ice sheet becomes stagnant, the high areas are first exposed by melting, because orer them the ice is thimmest, and they rise out of the ice sheet as nunataks. These nunataks gradually increase in size, and eventually the ice shrinks until it is found only in the valleys, where it was thickest.

The conditions just described seem to have prevailed in parts of the Lake Superior recrion. Northwest of Lake Superior the Giants Range was a nunatak (figs. 60 and 6\%), emerging in the interlobate area between the Rainy Lake glacier and the Lake Superior glacier. These lobes gradually retreated to the Lake Superior basin and to the valley of Red River, respectively, marginal lakes being formed as described in another section (p.441). North and northeast of Lake Superior, in Ontario, the conditions may possibly have been similar, the ice shrinking away from an interlobate area near the Hejght of land and occupying the basin of Lake Superior largely as a stagnant mass.

South of Lake Superior, however, the highland area seems to have had a somewhat different history. The ice from the Chippewa and Keweenaw lobes, which advanced over the hichlimel region of northern Wisconsin and somewhat down its southward slope, probably retreated northward over the same slope without the emergence of the northern Wisconsin highland as at nunatak area, although the Porcupine Mountains were probably uncovered as a nunatak region about the time the glacier became lobate in the ralleys east and west of lieweenaw Point. The Huron Mountains seem also to have first emerged as a nunatuk area, ${ }^{a}$ lying between the keweenaw and Green Bay lobes. Some of the earliest drift deposits were developed about these emerging nunataks.

\section{VARIATION OF DEPOSITS WITH SLOPES.}

When a glacier is retreating- - hat is, melting lack faster than the ice advances, or melting back with no advance, as in a stagnant ice sheet - two rather different kinds of deposits are made in associntion with two diverse topographic conditions. One kind is formed where the laud slopes away from the ice, allowing a free run-ofl of the gracial streams which are fed by the melting ice. The other kiml is formed where the land slopes toward the ice and the lrainage from the ice is letaines in a glacial lake until it rises to a sufficiently ligh level to flow over a meighboring divide. The first condition was well exemplified by the ('hippewa-Keweenaw lobe as it retreated from the highland region of northern Wisconsin, when its streams llowed freely away, carrying great quantities of gravel, sand, and clay that were deposited in outwash plains 

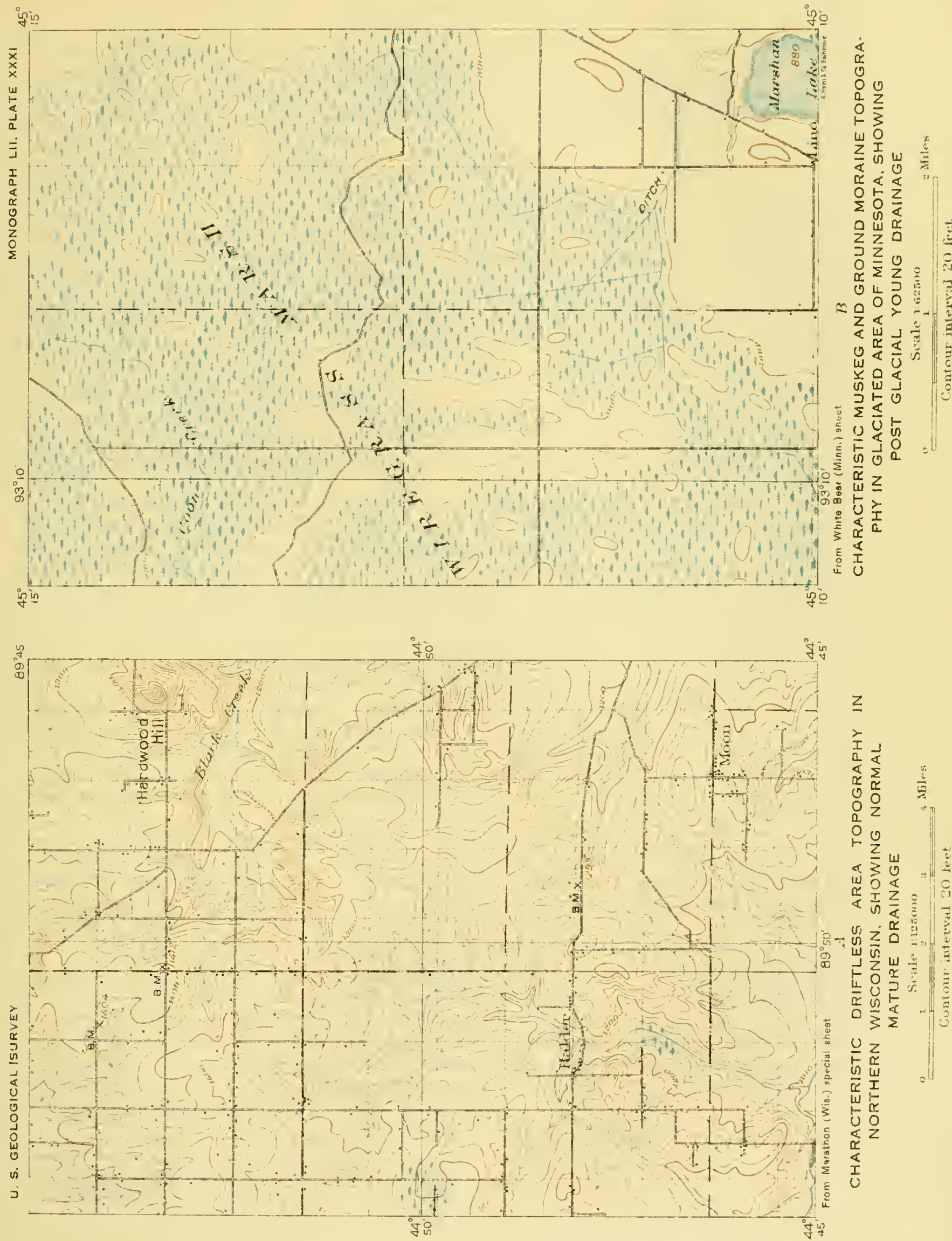

or valley trains, a number of which cross the Driftless Area of Wisconsin. At later stages such ontwash gravels are likely to be so dissected by stream erosion that terraces are formed at higher levels than the present stream. This is believed to be the origin of the terraces in the valley of Wisconsin River near Wausau, in that of the St. Croix near the Dalles, and along several other stream courses of the regrion.

\section{OUTWASH DEPOSITS.}

When several streams flowing out side by side build up a hroad plain of the same kind as the valley trains, but not confined to a valley, the deposit is called an outwash plain (PI. XXX, 1 ). Outwash plains of this type are found in the Upper Peninsula of Michigan, in Ontario, in Minnesota, and in northern Wisconsin. Weidman ${ }^{a}$ has described some of them as "alluvium" and beheves that these deposits are associated with $(a)$ uplift of the land, rejurenating the streams and causing intrenchment; (b) lowering of the land, permitting aggradation, during which these so-called alluvial deposits were lais down; and (c) later uplift, permitting reintrenchment of the streams, and terrace cutting. The age of this alluvium lie is inclined to place as perhaps pre-Iowan, between his "Second" and "Third" drift shcets. It may be pointed out that the aluvium is in places directly associated with terminal moraines, and Weidman has not brouglit forward evidence to show that it extends beneath them or is plowed up by them. After short field studies by the writer it seems more probable that nearly all of this material is normal outwash.

In view of some of the most recent conclusions concerning the conditions that determine stream work, it may be conceived that the volume and load of the streams have varied, rather than the grade. The advance of ice sheets, with increased supply of water, would perform the same work of intrenchment as the uplift postulated by Weidman, if indeed this intrenchment is not preglacial. Later the increased load of the streams, supplied with débris from the melting ice, would necessitate aggradation and the formation of outwash deposits, exactly similar to Weidman's alluvium and such as are known in association with existing ice fronts the world over. Still later the diminution of the debris furnished to the streams by melting ice would result in their relief from overloading and in a return to processes of intrenchment and terrace cutting. Nore than this, Weidman's alluvium, where supposedly overiden by the ice depositing the "Third" drift in the Wisconsin River valley, seems to lack entirely the broal truncation and grooving characteristic of gravels overridden and eroded by ice, as they are known in Alaska. Again, Weidman has not shown that the terraces are gullied or the drift in them weathered and leached as it should be if they are pre-Wisconsin in age. Lasty , if these so-called alluvial deposits are not outwash and mostly of Wisconsin age, it may be asked, What became of the water and débris from the melting Víisconsin ice sheet?

I. C. Russell ${ }^{b}$ described a series of interesting outwash deposits in the valley of Menominee River (Pl. XXVI, in pocket). They lie in a series of steplike levels associated with moraines, marking receding stages of the border of the Green Bay lobe. The angular turns of Menomince River seem also to be related to these receling stages.

At Grantsburg, Wis., in the valley of the St. Croix, C. P. Berkey ${ }^{\circ}$ has studied a series of laminated red and gray clays, judged to have been formed in a glacial lake whose deposits orerlie Wisconsin till. He reaches the conclusion that the clays were derived from the melting of an oscillating ice sheet and estimates a greater length of time than is usually thought of since the retreat of the ice, on the theory that each of the lamine represents a year of melting interupted by freezing and supply of finer sediment. He has also compiled an excellent sketch map ${ }^{d}$ showing the relation of recessional moraines west and south of the end of Lake Superior in Wisconsin and Minnesota.

a Weidman, Samuel, Bull. Wisconsin Geol. and Nat. 11ist. Survey, vol. 16, 1907, pp. 41s-421, 425, 477, 497-495, 501, 504, 506, 514-547, 569-571, $609-610,622-624$

b Ann. Rept. Michigan Geol. Survey for 1906, 1907, p. 65.

c Jour. Geology, rol. 13, 1905, pp. 35-44.

d Idem, fig. 1, p. 43 . 
PITTED PLAINS.

There is one phase of the building of outwash gravel deposits or valley trains which deserves special mention. In numerous places these gravel deposits are deeply pitted. Such pits or kettles are well developed, lor example, near Negaunee, in the Marquette district; all through the valley of Miehigamne River; in the Pereh Lake district (Pl. XXI, in pocket); in the Crystal Falls district, between Randville and Witheck (PI. XXII, in pocket); in the valley of Menominee River south of Iron Mountain (PI. XXVI, in poeket); in the lowland region of the northern peninsula of Nichigan, east of Marquette; in the Michipienten tistriet of Canada; and doubtless elsewhere. As the glaciers in these regions retreated small tongues or isolated blocks of ice were buried beneath the gravels of the glacial streams. Subsequently, when these detacherl ice blocks melted, the gravel layers slumped and the kettles which pit the surface of the gravel plain were formed. Many of the gravel kettles contain lakes (Pl. XXX, A, p. 434) and a considerable number of the small lakes of northern Michigan and Wisconsin are of this origin.

\section{LOESS.}

In the southwestern part of the area is a fine clayey or sandy material called loess, formed possibly from the rock llour earried by the streams flowing from the retreating glaciers or transported by winds. Its distribution within this area is not well known as yet.

\section{VALLEY LAKES DUE TO VARIATION IN STREAM LOAD.}

There is a striking contrast between the streams that were the outlets of marginal glacial lakes and the streams that flowed directly from the ice, the former being relatively clear streams and the latter being heavily loaded with sediment. Accordingly it was possible for Chippewa River, with its heavy load of ghacial material, supplied direetly by the melting ice, to build its outwash plain right across Mississippi River in western Wiseonsin in spite of the fact that the volume of the Mississippi was probably much larger, so that it should have been able to carry away the sediment supplied by a small tributary like the Chippewa. Many of the streams feeding the upper Mississippi were, like the ontlets of Lake Agassiz, Lake Nemadji, and Lake Duluth, outlets of glacial lakes in which the sand, gravel, and clay had all been strained out. Accordingly the small Chippewa, with its heary load, aggraded at its confluence with the Mississippi and was able to dam back the Mississippi itself in a narrow, lakelike expansion more than 25 miles long, called Lake Pepin (PI. II, p. S6).

Farther up the Mississippi, on the Wisconsin-Minnesota boundary near St. Paul, the process just outlined was reversed, the main stream having more loarl as well as more volume than its tributary, the St. Croix (Pl. II). Accordingly the Aississippi outwash plain and more recently the modern flood plain have retarded the outflow of the St. Croix, so that a lake is formed in its valley from the mouth, where a molern sandbar surmounts the flood plain, to a point about 30 miles upstream, the head of the present Lake St. Croix.

Similar valley lakes on the Minnesota side of the Mississippi have been deseribed by Winchell. ${ }^{a}$ During the summer of 1908 the writer observed a similar series of lakes in the tributary valley months on the Wisconsin shore of the Mississippi. These are in the Driftless Area. They were formed during glacial time by the greater building up of the main glacier-fed Irississippi (through outwash) than of its rain-fed tributaries. The assumption by Winchell of a long, narrow ice tongue in the Mississippi Valley, however, seems to the writer umecessary. The outwash itself, carried by the great volume of water from the melting glaciers and not by the more slender stream of the modern Mississippi, could perfectly well account for these glacial materials in the Driftless Area and for the shallow lateral lakes, like Waumandee Lake in Wisconsin, across the river from Winona, and muncrous umnamed ponds and swamps in side valley mouths. 


\section{DISTRIBUTION OF GLACIAL DRIFT.}

The detailed work on the distribution of the morainie deposits in this region has not covered anything like the whole area. It is of interest to note that the first man to present a correct explanation of the glacial phenomena in Ameriea, Louis $\Lambda$ gassiz, ${ }^{a}$ was one of the first to make observations in the Lake Superior region, as did James IIector, ${ }^{b}$ Sir William Logan, ${ }^{c}$ J. J. Bigsby ${ }^{d}$ J. W. Foster and J. D. Whituey, ${ }^{e}$ E. Desor,${ }^{f}$ D. D. Owen, ${ }^{g}$ J. G. Norwood,${ }^{h}$ C. Whitthesey ${ }^{i}$ B. F. Shumard, ${ }^{j}$ G. M. Dawson ${ }^{k}$ C. T. Jackson, ${ }^{l}$ W. A. Burt, ${ }^{m}$ and many other early observers who observed many of the facts of transported bowlders and soil, waterworn materials, smoothed and striated rocks, ete, without recognizing or being willing to accept their glacial origin, as Agassiz and some others had done.

The Pleistocene deposits of the Ashland region, Penokee range, etc., in Wisconsin, were early described by R. D. Irving, ${ }^{n}$ who distinguished the glacial trift and the lacustrine clay and showed their distribution on his map. E. T. Sweet ${ }^{\circ}$ briefly refers to the unstratified glacial deposits, the moraines, and the stratified drift (lake clays) farther west, in Bayfield and Douglas counties. T. C. Chamberlin ${ }^{p}$ made a report based on notes of Moses Strong, ${ }^{p}$ eoncerning the glacial features in the upper St. Croix district, including the strix, the kettle moraine, the bowlder clay, and the "barrens." The glacial deposits, lakes, moraime belts, ete., in the upper Flambeau Valley of Wisconsin are described by F. H. King. $q$ The glacial deposits in eastern Wisconsin are described by T. C. Chamberlin. ${ }^{r}$ The glacial features of an area in the upper Wisconsin Valley are briefly described by T. C. Chamberlin from notes by A. C. Clark. ${ }^{s}$ R. D. Irving ${ }^{t}$ described and mapped the glacial deposits in central Wisconsin and part of the Driftless Area. The glacial phenomena of all Wisconsin are reviewed by T. C. Chambertin, ${ }^{u}$ who has also correlated the glacial features of the southern part of the Lake Superior area in Minnesota, Wisconsin, and Michigan. ${ }^{v}$ Samuel Weidnran has recently done detailed work over an area of about 7,200 square miles in north-central Wisconsin, and has published deseriptions $w$ of the terminal moraines, the ground moraine, the older drift, etc. He has also surveyed the glacial geology of a nearty equal area west of this, within the region diseussed in this monograph, but his report on it is not yet published. C. P. Berkey ${ }^{x}$ and R. T. Chamberlin ${ }^{y}$ have each discussed the glacial geology of a small area near the St. Croix Dalles. The detailed mapping of the glacial deposits of the south half of the Green Bay glacier by W. C. Alden, of the United States Geological Surver, not yet published, extends up to the south boundary of the area here discussed.

The glacial deposits in Michigan were exmined in the early surveys by T. B. Brooks, ${ }^{z}$ Carl Rominger, ${ }^{a a}$ and others. More recently $\Lambda$. C. Lane ${ }^{b b}$ lias described the glacial deposits on

a A gassiz, Louis, Lake Superior, its physical character, vegetation, and animals, 1850, pp. 395-410.

b Quart. Jour. Geol. Soc., vol. 17, 1861, P. 393.

r Geology of Canada, 1863, pp. 8S5-893, 904-908, 912-913, and plate in atlas showing superficial deposits.

$d$ On the erratics of Canada; Quart. Jour. Geol. Soc., vol. 7, 1851, pp. 215-238.

e Report on the geology and topography of a portion of the Lake Superior land district, rol. 1, 1850, pp. 186-218.

fldem, vol. 2, 1851, pp. 232-247.

g Report of a geological survey of Wisconsin, lowa, and Minnesota, 1552, pp. 32, 36, 141-145, etc.

$h$ Idem, pp. 298, 329-330, 348, etc.

ildem, pp. $426-429,435-436,462-406$, etc.

jIdem, Pp. 515,517 , ete.

$k$ Geology and resources of the region in the vicinity of the forty-ninth parallel, 1875, pp. 217-254.

$l$ House Ex. Doc. No. 5, 31 st Cong., 1st sess., pt. 3, 1849, pp. 388-389.

$m$ ldem, p. $\$ 20$.

n Geology of Wisconsin, 1873-1879, vol. 3, 1850, pp. 211-214, Pl. X..

o ldem, pp. 352-356.

p ldem, pp. 382-387, PL. IISVIT.

$q$ Idem, vol. 4, 1882, pp. 611-613.

r Idem, 1873-1877, vol. 2, 1877, pp. 199-246.

S Tlem, 1873-1879, vol. 4, 18s2, pp. 717-721

t ldem, 1873-1s77, vol. 2, 1877, pp. 60s-1335.

u Idem, 1873-1879, vol. 1, 1883, pp. 261-298.

v Terminal moraine of the second glacial epoch: Third Ann. Rept. U. S. Geol. Surves, 18\$3, pp. 315-330, 381-393.

$w$ Bull. Wisconsin Geol. and Nat. Hist. Survey No. 16, 1907, pp. 433-513.

₹ A m. Geologist, vol. 20, 1897, pp. 355-369.

$y$ Jour, Geology, rol. 13, 1905, pp, 238-25G.

z Geol. Survey Michigan, vol. 1. pt. 1, 1873, pp. 72, 76-79

aa Idem, vol. 1, pt. 3, 1s73, pp. 15-20; vol. 4, 1S81, pp. 1-2, 40-11.

bb 1 dem, vol. 6 , pt. 1, 1898, pp. 183-184, 193. 
Isle Royal aud has publislonl some hrief notes on the glacial deposits of parts of linerenaw Point. ${ }^{a}$ Besides this he has written a short description and published a glacial map of the deposits in the Lower Poninsula, the northwestern part of which comes within the ared of this report, from publisherl and unpublished data by Mlessers. Condon. T.everett, Sher\%er, and Lane. He also treats the drift in his summary of the surface geology of Michigane ${ }^{c}$ T. C. Russell has studied the gracial foatures of the south horder of the Upper Peninsulu from St. Dinry River to a point west of (rystal Falls. Ilis map shows the distribution of the moraines in this begion, and his work has been continued by C. A. Davis ${ }^{d}$ we'st of Marpucte and south of the lluron Mountains. Frank leverett has studied in detail the glacial deposits there and in the castern lowland portion of the Upper Peninsula, but has published no report as yet except a brief review. ${ }^{e}$

The glacial deposits north and northeast of Lake Superior in Ontario are not known in detail, though A. B. Willmott, ${ }^{f}$ A. P. Coleman, ${ }^{g}$ E. S. Moore, ${ }^{h}$ and J. M. Bell, ${ }^{i}$ have macle olserrations in the Michipicoten district. Coleman also briefly refers to the erlacial deposits near Lake Nipigon, ${ }^{j}$ as does E. S. Moore ${ }^{k}$ to those in the Windegokan district east of Lake Nipigon ${ }^{k}$ and W. II. Collins ${ }^{l}$ to those west of Lake Nipigon.

Northwest of Lake Superior the ghacial phenomena in the Lake of the Woods region have been described by G. M. Dawson, ${ }^{m}$ and the glacial features there and in the Rainy Lake recrion have been treated fully by $\Lambda$. C. Lawson. ${ }^{n}$

To the east, north of the international boundary, the glacial geology of Hunters Island has been deseribed by W. 1I. C. Smith ${ }^{\circ}$ and that of the area corered by the Seine River and Lake Shebandlowan map sheets by William MeInmes. ${ }^{p}$

In Mimesota the glacial deposits have been studied extensively by Warren Lphan, N. II. Winchell, U. S. Grant, .J. E. Todkl, A. II. Elftman, and others. Their discussions are found in the ammal reports of the Minnesota Geologicul Survey and in the volumes of the fintl report, including a series of detailed county maps and descriptions. This is the most detailed scries of studies of the glacial deposits thus far made within the area here considered, though without sufficient correlation. II. V. Winchell and U.S. Grant lave described some of the glacial plicnomena in Minnesota, near Rainy Jakeq

In a preliminary report ${ }^{r}$ Warres Upham has described the moraines of northeastern Mlinnesota and published a map of part of the Lake Superinr area. The location of the chief morainic deposits on this map seems to have been aceurate, but there have been some differences of opinion as to the interpolation between morainic belts and the correlation and interpretation of the moraines. Uplam indicated by his map that the ice all retreated northward, no special influence being exerted by the Lake Superior basin, the valley of Red River, or the highlands of northern Himnesota and the intemational houndary. But this would mean that the Mesalbi, Itasca, and Leaf IIills moraines had the ice on the wrong side, as is proved by the superposition of lake clay on glacial till south of the Mesabi range, a relation that would not exist if the jee had retreated northward over the range. (See figs. 62, p. 443: 68, p. 453; and Pl. XXIX, B, p. 432.) J. E. Todhs subsequently pointed ont this discrepaney and $\mathrm{A}$. II.

a Proc, Lake Superior JIin. Inst., vol. 12, IM07, pp. 101-104.

b Water-Supply P'aper U. S. Geol. Survey Nu. 30, 1899, J'l. 11, pp. 5\&-67, 75-77

r.tnn. Rept. Geol. Survey Michigan for 1907, 190s, pp. 97-143.

d Ninth Rept Michigan $\Lambda$ cad. Sci., 1907, pp. 132-135.

C.Sixth Rept. Michiga Acar Scl. 1904, pp. 100-110; Water-Supply Paper U. S. Geol. Survey No. 160, 1906, pp. 29-53, with contour map; Water. Supply Paper U. S. Gicol. Survey No. 183, 1907, pp. 4 fi.

$f$ kept. Bur. Mines Ontario, vol. 7. 1\$94, pp. 204-205.

e Ielem, vol. 15, pt. 1, 1505, pp. 192-193.

$n$ Irlem, p. 206

ildem, vol. 14, pt. 1, 1905, p. $2 \mathrm{ss}$

jlden, vol. 1ti, pt. 1, 19Mi, p. 135.

* 1 dem, pep. 14t-1.4.

1Sumuary fiept. Geol. Survey Cannda, 1906, pp. 103-104, 108.

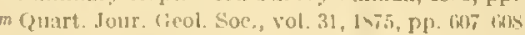

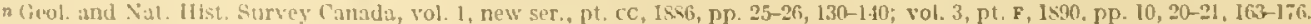

o fidol. Survey Canala, new ser., vol. 5, pt. 1, 1,493, pp. il(i-7fl.

p Idem, vol. in, 1:32, pp. sl II-541]

q Twenty-thirl Imn. Rept. Minnesota Cerol. and Nat. Hist. Survey. 1895, pp. (as-69.

r Twenty-secomd Ann. Rept. Ninnesolih Geol. and Nat. llist. Survey, 1s94, pp. 31-51.

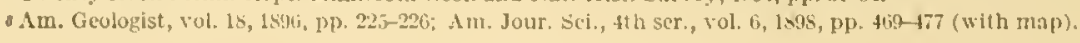


Elftman ${ }^{a}$ has siscussed it further and published a reviser map of the moraines northwest of Lake Superior.

The geologists of the United States Geological Survey have referrel brielly to the glacial deposits, ${ }^{b}$ and their work is eited more specifically in other parts of this report. On only two of their geologic maps ${ }^{c}$ are glacial deposits separately slown (Pls. XVII and XXII, in pocket), though a special map ${ }^{d}$ of a third region shows the distribution ol the recessional moraines, and there are detailed maps for the Marquet te distriet.

The map of the Marquette district (PI. XVII) gives a separate color to "mulivided Pleistocene" without specifically stating of what this consists. The areas sn mapped are those in which no ledges whatever are found beeause of the thickness of the glacial drift and modern stream and swamp deposits. Accorlingly it is evident that these areas do not include all the Pleistocene deposits of the district, but merely the places where they are continuous and thick, completely obscuring the older rocks. Pleistocene deposits are found throughout the district, but in other places are discontinuous or very thin. The undivided Pleistorene of the Mrarquette area, which is confined chiefly to the lowland sonth and east of Marquette, inelucles, where mapped, ghacial till, morainic deposits, stream-assorted glacial outwash deposits, beaches of higher levels of Lake Superior, and lake-bottom clays, besides small areas of modern swamp accumulations, like peat and marl, and stream deposits.

The undivided Pleistocene of the Crystal Falls area (PI. XXII) where mapped in the Nichigamme River valley west of Floodwood and farther south near Channing and Sagola includes glacial till, recessional moraines, flat sandy outwash-plain deposits, and various swamp and stream deposits.

On the sketch map (fig. 68, p. 453) it has been thought wise to distinguish three facts concerning the distribution of the drift and the terminal moraines-(1) the distribution of the outermost moraine, whether of the last glacial advance or of an earlier one; this is the bomdary of the Driftless Area; (2) the boundary of the Wisconsin stage of glaciation, the latest stage; (3) some of the more prominent recessional moraines, so far as their location is known. 'The locations assigned to the more important recessional moraines inside the border of the terminal moraine of the Irisconsin stage are of varying degrees of accuracy, because, although the recessional inoraines in Minnesota are fairly well known and well mapped, those in Wisconsin, Michigan, and Ontario hare been mapped only in small areas. In fact, comparatively little is known of the episodes accompanying the withdrawal of the ice sheet from the portions of the Lake Superior region not lying in Minnesota, save in regard to the association of the ice with the marginal lakes that were the predecessors of Lake Superior and Lake Michigan.

\section{MIARINAI IATES.}

In places where the land slopes towarl the ice so that glacial lakes are formerl, deposits of a quite different type from the outwash are accumulated, and deposits of this kind were formed in the glacial lakes now to be rescribed.

While the ice shect was retreating into the basin of Lake Superior marginal lakes were formed between the ice front and the adjacent higher land. Such lakes were of course formed also during the advance of the glacier, but the evidence of them was later destroyed. An early muatak, already referred to as rising through the ice, was the long, narrow Giants Range (figs. 4, p. 87; 5, 1. 85; 62, p. 443), which had been completely buried by the glacier, but because it stood highest in the ice was the first to emerge after the ice became stagnant and began to melt. The emergence of this rango divided the ice sheet into two separate glaciers-the Keewatin or western continental glacier (Rainy Iake or Red River or Minnesota lobe) and the

a Am. Geolosist, vol. 21, 1898, on, 91-109.

b Mon. I. S. Geol. Survey, vol. 36 (Crystal Falls district), 1599, pp. 29-30, 332-333; vol. 43 (Mesabi district), 1903, pp. 22, 24, 191-19ł, 199; rol. 45 (Vermilion district), 1903, pp. 39, 425-430; vol. 46 (Menominee district), 1904, p. 500; Nineteenth Ann. Rept. U. S. Geol. Sturvey, pt. 3, 1s99, pp. 25-26; Menoninee special folio (No. 62), Geol. Atlas .U. S., 1900, Г. 12.

cTan Ilise, C. R., Bayles. W. S., and Smyth, H. L., The Marquette iron-hearing district of Michigan: Mon. U. S. Geol. Survey, rol. 28, 1597, atlas, sheets 4, 25-39. Clements, J. M., Smyth, I. L., and Bayley, W. S., The Crystal Falls iron-bearing district of Miehigan: Mon. U. S. Feol. Survey, vol, 36,1899 , Pl. III

d Clements, J. M., The Vermilion iron-bearing district of Minnesota: Mon. U. S. Geol. Survey, vol. 45, 1903, fig. 23, p. 427. 
Laurentian glacier (Lake Superior bobe), the two probably coalescing some distance to the northeast, perhaps north and east of Gunflint Lake. The Lake Superior lobe filled all of the Lake Superior basin, extending down over part of the Archean area of northern Wisconsin and southwestward beyond Carlon, Mimn. The Minnesota or Red River lole extended uortl and west from the Giants Range.

\section{GLACIAL LAKE AGASSIZ.}

In the valley of Red River, where the Red River lobe of the Keewatin glacier probably retreated some time after the Lake Superior lobe had gone back, the topographic conditions were such that a great marginal glacial lake was formed. These conditions consistrel in the presence of a broad ralley with gently sloping silles and a slight slope toward the north, and of a low divide between its headwater region and the headwaters of the Mississippi. Until the ice had retreated up to this low divide, which was in the vicinity of Bigstone and Traverse lakes, northwest of St. Paul, near latitude $45^{\circ} 30^{\prime}$, the streams from the melting Red River glacier had a free outflow to the south (glacial River Waren) and built up valley-train deposits of the kind already described. As soon as the ice had retreated to this divide, however, an entirely different condition was introduced. The ice sheet was now retreating down the ralley and the waters emerging from it were temporarily detained in a marginal glacial lake. With successive stages of retreat of this glacier the lake became enlarged, although probably continuing to overflow southward through the valley into Mississippi River until some lower outlet to the northeast, whose location is as yet unknown, had been uncorered. To this great glacial lake (fig. 65, p. 446) the name Lake Agassiz has been given. Warren Upham has described the lake and its abandoned, tilted shore lines, etc., in a monograph ${ }^{a}$ that contains a full bibliography of earlier publieations on the lake. The whole lake as commonly shown on maps probably never existed at one time. It is not definitely known to have been contemporary with glacial Lakes Duluth and Chicago, as the sketch maj (fig. 65) shows it for convenience.

The features associated with the several stages of Lake Agassiz were beaches and lakebottom clays. The beaches are found in the Lake Superior region as far east as Red Lake and Rainy Lake, ${ }^{b}$ northwest of Lake Superior; the lake clays overspread all the areas below these beaches and form the fertile lowland in the wheat lands of the Red River valley in Minnesota, North Dakota, and Manitoba.

\section{MARGINAL GLACIAL LAKES.c}

Before or (luring the early st ages of Lake Agassiz in the area just north of the Giants Range the glacial Lakes Norwood, Dunka, Elftman, and Onnamani were the first ones held between the cast end of the Giants Range and the Rainy River lobe of the Red River glacier, outflowing southward and cutting channels across the Giants Range. (See fig. 4, p. s7; 5, p. SS; Pl. II, p. S6.) The present I aake Vermilion is a small remnant of the last of these glacial lakes. Glacial Lake Nicollet ${ }^{d}$ was held in by the Red River glacier and the encircling land. Leech, Cass, and Winnibigoshish lakes are remnants of it. To the north glacial Lakes Big Fork, Beltrami, and Thompson were small marginal stages of glacial Lake Agassiz. Rainy Lake and Red Lake probably occupy parts of the basm of Lake Thompson and of the later Lake Agassiz, as do also the Lake of the Woods, etc. All these glacial lakes were held between a northwestwardretreating ice front and the.IJeight of Land, overflowing southward to the Mississippi Irainage basin.

South of the Giants Range the Superior lobe similarly held up glacial lakes, the first notable one being a long, narrow marginal lake, as yet umamed, parallel to the Giants Range (fig. 62). 'This lake received the dramage from glacial lakes north of it, as described by Leith,e and in

The glacial lake Agassiz: Mon. I*. S. Geol. Survey, vol, 25, 1596 .

Lawson, A. C. Report on the geology of the Lake of the Woods region, with special reference to the Kecwatin (1Iuronian?) leelt of the Archean rocks: Ann. Rept. Gieol, and Nat. Ilist. Survey Canada for 1Ns, vol. 1, new ser., Isvi, pp. 139-I4nCC; Report on the geology of the Rainy Laie region: Idem for 1 thi- $\rightarrow$, vol. 3 , new ser., $181 \%$, pp. $160-176 \mathrm{~F}$.

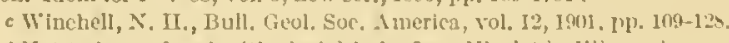

d Not to be confused with glatal lake Jesn Nicolet in II isconsin.

e Jlon. L. s. Geol. Survey, rol. 43, 19xi3, pp. 193-19!. 
it were deposited the lake clays that overlie the stony (lrift in most of the open-pit mines on the Mesabi range. The relation of stony till and lake clay shown in Plate XXIX, $B$ (p. 432), is explained by the halt of the ice front south of the Giants Range and the building of the Nesabi moraine (fig. 62, a), after which a withdrawal of the ice towarl the south made possible the formation of the glacial lake and the deposition of the clay overlying the till (fig. $62, b$ ).
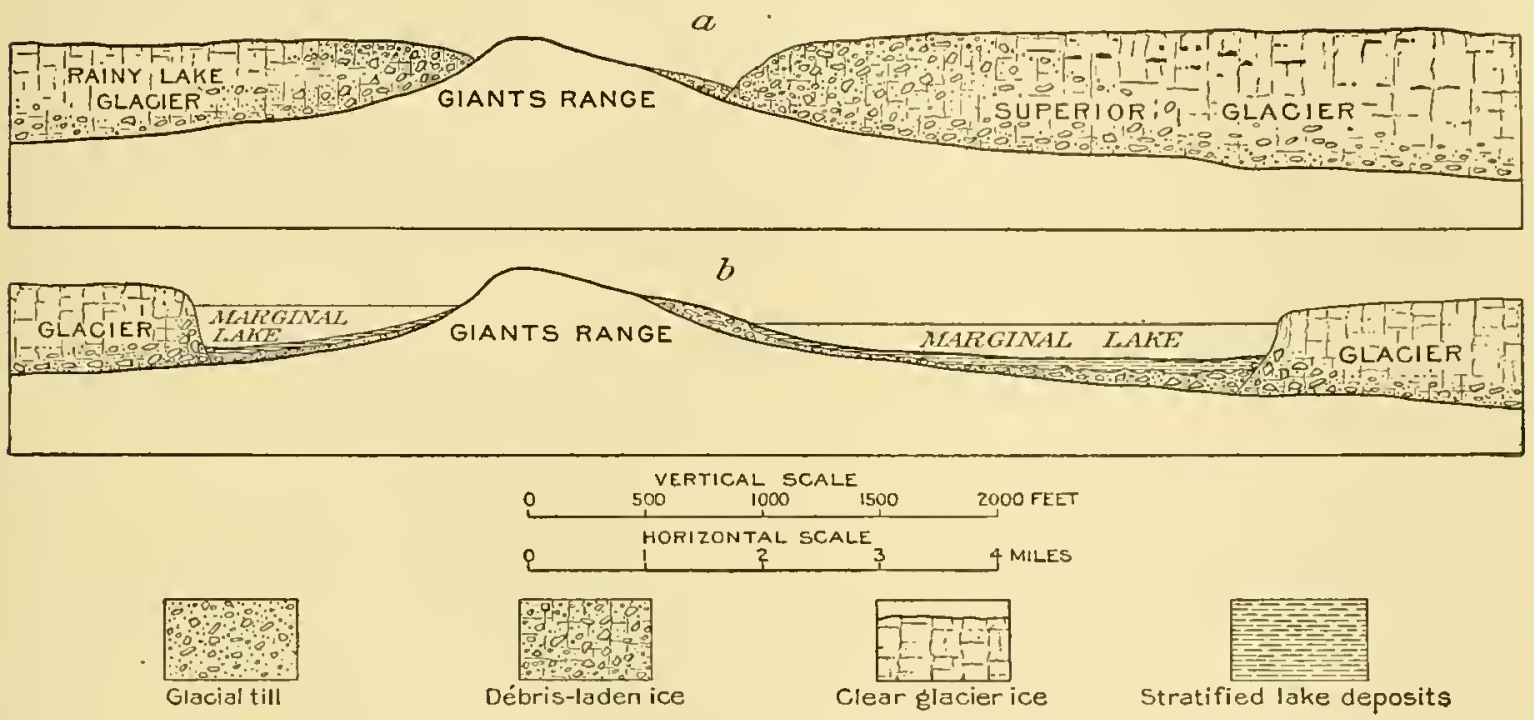

FIGURE 62.-Sketch showing the origin of the drift deposits overlying the ore in the Mesahi iron range.

With farther retreat of the Lake Superior glacier southeastwarl, the unnamed marginal lake mentioned above was drained and a new glacial lake, Lake Upham, was formed, its southernmost ice barrier being near the upper bend of the present St. Louis River, while the gabbro highland to the east, the granite range to the north, and the morainic highland to the west and south held it in. Lake Upham had an elevation of about 1,300 feet and its bottom forms the flats traversed by the Duluth, Missabe and Northern Railway in the great muskeg area where the railway is so straight. At about this same time glacial Lake Aitkin was formed farther west. The obstruction on the site of Mille Lacs produced glacial Lake Issati. Afterward glacial Lake St. Louis was formed in the St. Louis Valley, draining out over a low col near Barnum and Carlton, at an eleration of about 1,135 feet, and having an area of about 40 square miles.

Many glacial lakes, ineluthing Lake Minnesota, were formed in southern Mimnesota in association with the Red River lobe. Lake Agassiz, already referred to, was similarly formed in the Red River valley at a little later stage, and glacial Lake Jean Nicolet ${ }^{a}$ occupied Green Bay and the Fox River valley in Wisconsin, draining westward into Wisconsin River at Portage. The present Lake Winnebago lies in its basin.

\section{LAKE NEMADJI. $b$}

Glacial Lake Nemadji (fig. 63) was formed between the ice barrier of the Lake Superior lobe on the northeast and east and the higher land west of Lake Superior in Nimnesota. This lake, which was about 65 feet lower than Lake St. Louis and may lave had a slightly greater area, drained through another col near Barnum and Pickering, sonthwest of Carlton, into the Mississippi.

As the ice retreated still farther to the northeast ${ }^{c}$ there were changes in the levels and in the outlets of the glacial lakes that lie between ice dams and the surromding land. The first

a Upham, Warren, Am. Geologist, vol. 32, 1903, pp. 105-115. 330-331.

$b$ Winchell, N. 11., Final Rept. Geol. and Nat. Hist. Survey Minnesota, vol. t, 1599, pp. 2-3, 18-20.

c F. B. Taylor (A short history of the Great Lakes: Studies jn Indiana geography, 1897, chapter 10, pp. 1-21) has written a review of the various lake stages and the outlets, ete., associated with the different positions of ice fronts and levels of the land. 
consequene of the retreat of the ice harrier would be that lower valleys across the liblls to the soutl or cast might be exposerl, and as a result of this the water's of the lake would find a way out through the new divide and the lake would fall to a new level. The carliest glicial lakes in northern Wisconsin, like the predeeessor of Iake Gogebie and the great margmal lake in the Ontonagon Valley, ${ }^{a}$ probably began to exist before or during the Lake Tomalji stage.

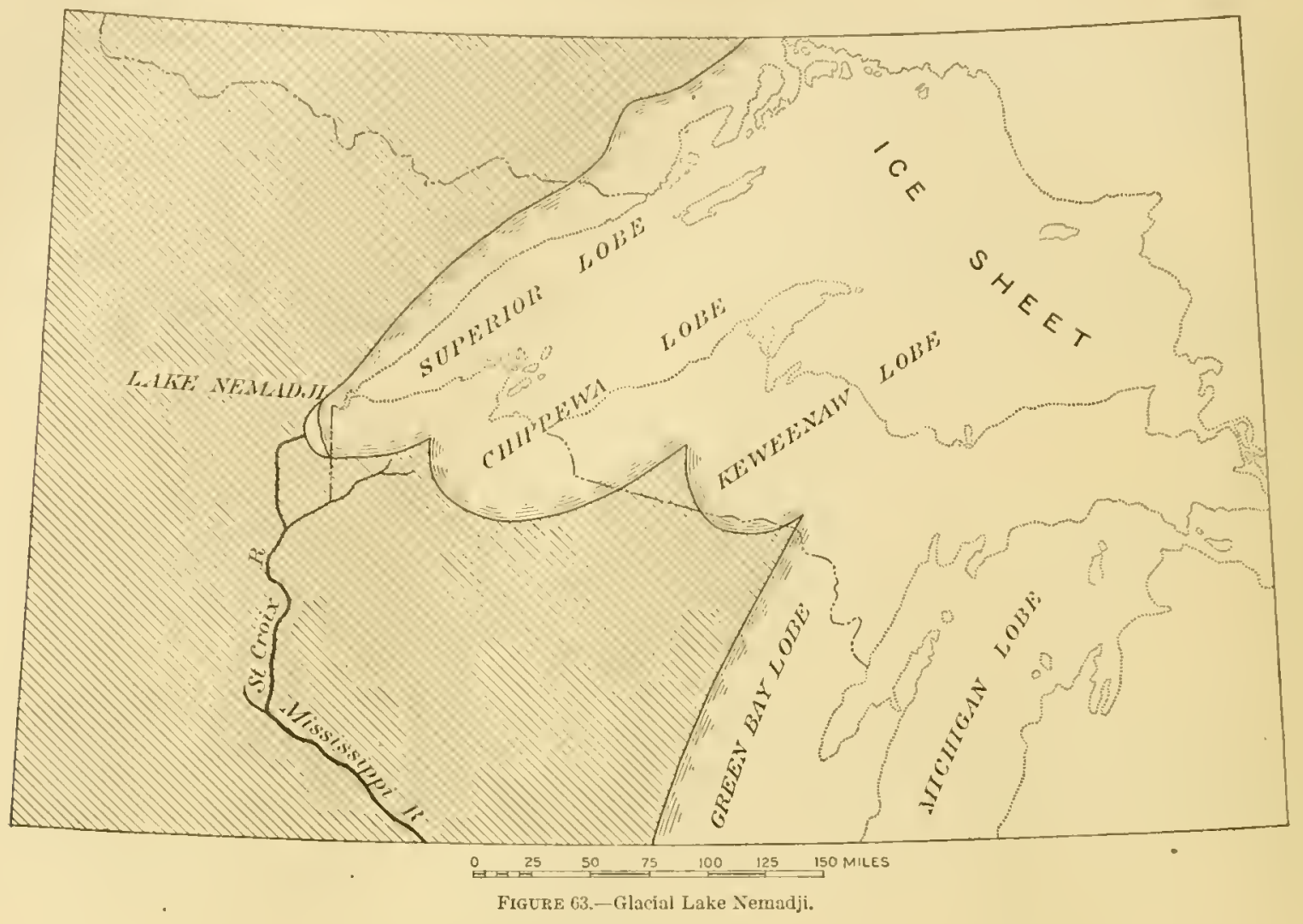

LAKE DULUTH.

As the ice retreaterl northeastward, after the Lake Nemadji stage, it soon retired to a point far enough to the northeast to expose the col now erossed by the Chicago, Minneapolis, St. Paul and Omala Railway. As a result the outlet near (arlton was abandoncd and the waters of this lake out flowed directly southward through the St. Croix to the Mississippi (fig. 64) through a channel ${ }^{b} 419$ feet above the present Lake Superior, between the headwaters of the Brule and those of the St. Croix. Exactly where the ire tront of the Lake Superior glacier stood at this stage can not be stated, but it probably halted at several points east of the Apostle Islamls and perhaps as far east as lieweenaw Point, the other margin resting against the north shore of laake Superior at several points in Mimesota, smaller marcinal lakes being held on each shore between the ice and the land in Minnesota, Wisconsin, and Michigan.

The great gracial lake of this stage is ealled Lake Duluth, ${ }^{c}$ alt hough Uphand ${ }^{d}$ had previously named it the West Superior glacial lake. It is erident that this lake existed for a long time, and there are three kinds of deposits which indicate that this was so. One kind ronsists of the elerated beaches which are still fommd along the hillsides at the level of the St. Croix outlet and which are so broad and well teveloped on the escarpment face above Duluth that the lboulerard

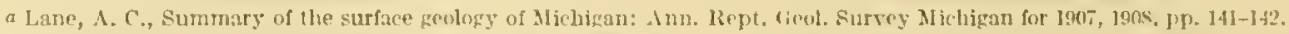

6 The elevation of this chimnd is given as 1,070 feet by Warren lpham (Twenty-second Ann. Rept. Geol. and Xat. Ulist. Survey Mfinnesors.

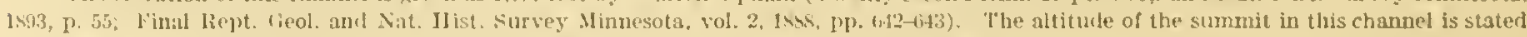
by heverett to be 1,021 fert, as shown in a profile in 11 ous Doc. 330, 54 th Cong. 1 st sess., 1491 .

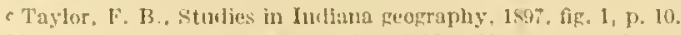

d Twenty-second Inn. Rept. Geol. and Xat. Ilist. Survey llinnesota, 1s.4, pp. $54-55$.
} 
Drive follows one or two of them for miles. This shore can be tracel from a point east of Ashland westward to Brule River and on the other side around the head of the lake to a point sone distance east of Duluth. Similar beaches or terraces in the Lake Superior hasin were observed early in the exploration of the region ${ }^{a}$ and were explained as ware-wrought lorms.

The second class of deposits inclieating that the glacial lake at Duluth existed for a long time comprises the deltas that were built where streans flowed into the lake at the level of the Boulerard beaches, as at Thompson east of St. Lonis River, on Tischers ('reek, and on Chester (reek at Duluth. ${ }^{b}$

The third class of these deposits consists of the lake clays, which without question accumulated in later periods as well as in this, but which would of courso have formed to a considerable depth when the ice front stood across the lake and was discharging icebergs with glacial material, and whon streams from the hills to the north, south, and west contributed their load of sediment.

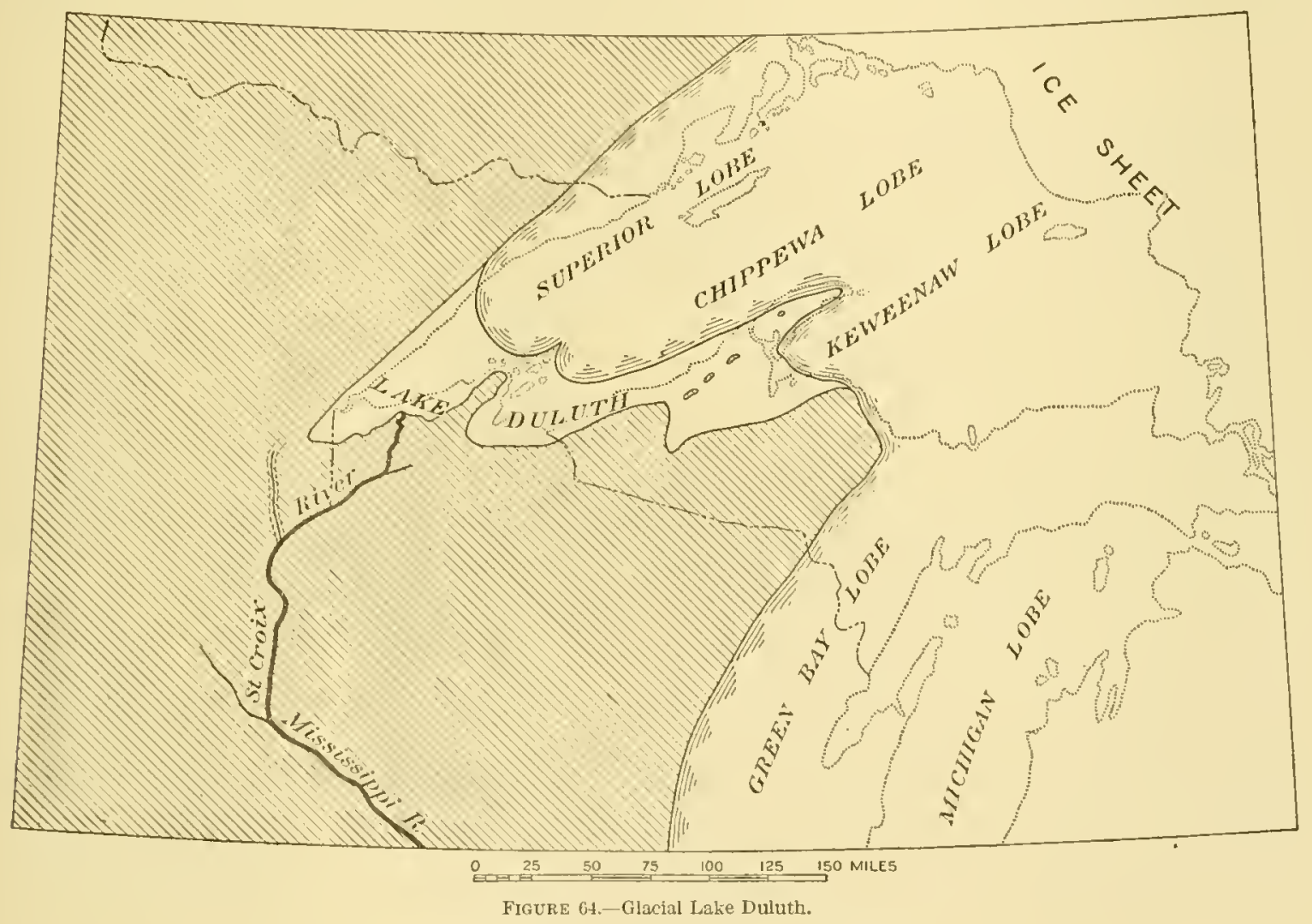

INTERMEDIATE GLACIAL LAKES.

As woukl naturally be expected, with the continued retreat of the Lake Superior and Lake Michigan ice lobes, the lake levels were falling lower and lower. One of the next levels at which there was a notable stand of the ice was when the waters of the western Lake Superior basin escaped past Chieago through Illinois River to the Mississippi. This was probably some time after the early Lake Duluth stage (fig. 65). Whether there were intermediate outlets between the two stages referred to is not known, but it seems probable that the ice in retreating northeastward gradually exposed the highland of northern Wisconsin and Michigan so that

a Logan, W. E., Report on the geology of the north shore of Lake Superior: Geol. Surrey Canada, 1s47, p. 31. Hubbard, Bela, House Ex. Doc. No. 1, 31st Cong., 1st sess., pt. 3, 1849, pp. 910-911. Foster, J. W., and Whitney, J. D., Report on the geology and topography of a portion of the Lake Superior land district, rol. 1, 1850, pp. 191-197, 211-213. Desor, E., idem, vol. 2, 1851, pp. 248-255, 208-270. Whittlesey, Charles, idem, pp. 270-273. Agassiz, Louis, Lake Superior, 1550, pp. 60, 66, 100-101, and frontispiece.

O Upham, Warren, Twenty-second Ann. Rept. Geol. and Nat. Hist. Survey Minnesota, 1s93, pp. 65-66. 
eventually the waters from the enlarged Lake Duluth abandoncl the St. Croix outlet for some lower ones in northern Wisconsin and Michigan, and still later outflowed southward along the margin of the ice sheet into Lake Jean Nicolet, in eastern Wisconsin, which drained into Wisconsill and Mississippi rivers. Still later the drainage went into the enlarged Lake Chicago. It is known that there were a number of intermediate stages due either to lowering of the ice barrier, to discovery of lower outlets, or to tilting of the land, beeause the beaches preserved on the hillsides below the upper Lake Duluth beach indicate other stands of the lake waters for considerable periods of time. The beaches associated with these intermediate stages are found at several levels below the Boulevard Beaeh, as shown in the table (p. 451).

It seems likely that some of the intermediate stages, like the Lake Duluth stage, were of considerable duration, because the beaches that were built are broad, the eliffs that were cut are well marked, and good-sized deltas were formed at the mouths of the streams. Of these deltas that of Dead River at Forestville near Jarquette and those of Swedetown and IIuron crecks near Houghton are good examples. ${ }^{a}$ The fine material carried beyond the deltas into

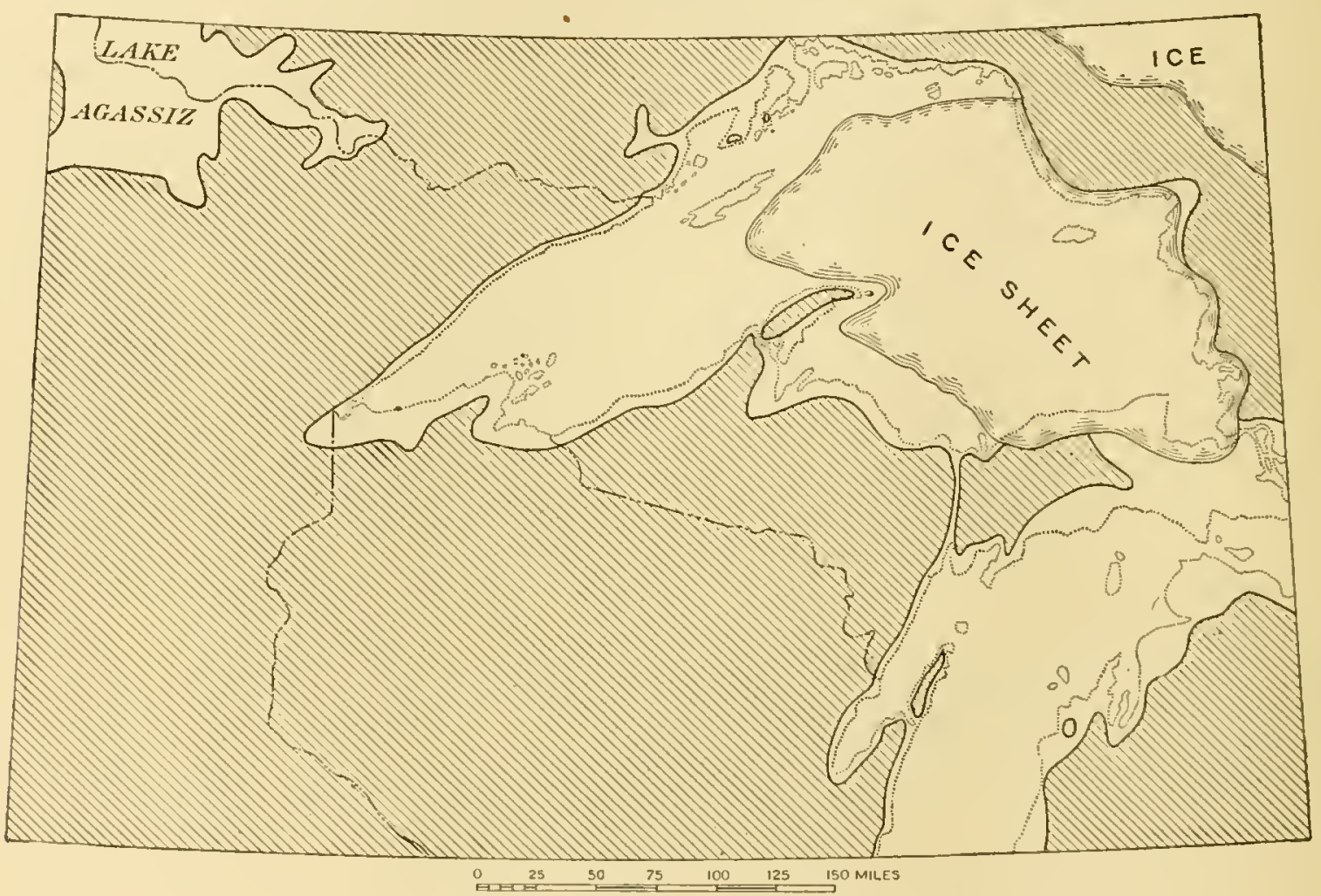

ligURE 65.-IIypothetical intermediate stage with the expansion of glacial Lake Chicago and the later stage of glacial Lake Duluth; part of glacial Lake Agassiz near the northwest corner. An isolated stagnant ice block is shown in the Lake Superior basin.

the lake formed thick deposits of glacial elays, of which some are now exposed and others are still below lake level.

\section{LAKE ALGONQUIN.}

After the episode of the Cnicago outlet the glacial barrier eontinued to retreat to the northeast, and the glacial lake, which came into existence gradually, occupied all of the basin of the present Lake Superior, its waters eovering parts of the peninsula of upper Michigan west of Iarquette and being confluent with those in the basins of the present Lakes Michigan and Huron (fig. 66). This is called the Lake Algonquin stage. . At this time the ice barrier stood east of North Bay in the Ottawa Valley, and had retreated from Lake Superior north of the Height of 
Land. Possibly there was a stagnant isolated ice block in the Lake Superior basin at this time or just before. During the Lake Algonquin stage, which of course came after a series of intermediate stages in which Lakes Chicago and Duluth were enlarged as recorded by the successive beach levels one below the other, the waters deserted the outlet past Chicago to Illinois and Mississippi rivers because lower outlets were uncovered to the east. Lake Algonquin had two such outlets. The first led past Port Huron through the present Lake St. Clair and Lake Erie into glacial Lake Iroquois, which covered more than the basin of the present Lake Ontario; the second outlet also led into Lake Iroquois through the Trent River valley from Georgian Bay. There were several oseillations with one or both of these outlets running during the Algonquin stage. The Lake Iroquois waters flowed eastward through Mohawk River to Hulson River and New York Harbor. All around the Lake Superior basin the strongest Lake Algonquin beaches are well-marked shore lines elevated high above the waters of the present lake. At this stage glacial lakes probably occupied the Kaministikwia and Nipigon River valleys, including all the basin of the present Lake Nipigon.

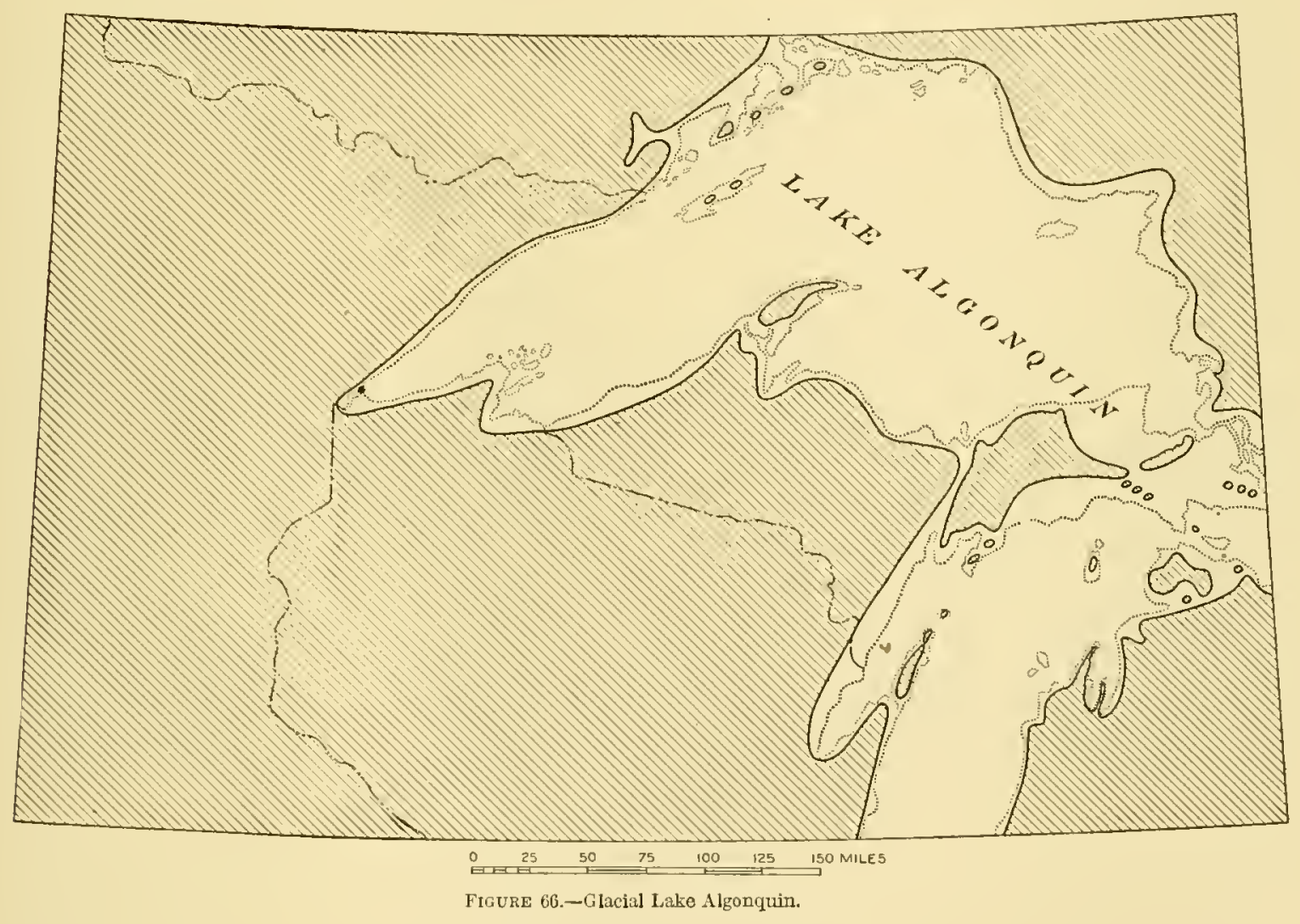

NIPISSING GREAT LAKES.

With the continued retreat of the ice sheet to the northeast, a still lower outlet than that through Hohawk and Hudson rivers was exposed. 'This was along the present Lake Nipissing near North Bay and down Ottawa River to the lower St. Lawrence. This is called the stage of the Nipissing Great Lakes. With the uncovering of the Ottawa River ontlet the waters of the Lake Superior basin fell to a considerably lower level than that occupied before and accordingly regions about the shores of Lake Superior which had been submerged or had groups of islands were wholly uncovered. The largest area of this sort was the lowland east of Marquette, in the Upper Peninsula of Michigan (fig. 67). Rominger, who described the superficial deposits of this region, ${ }^{a}$ was somewhat at a loss to explain the mixture of ground moraine, reces- 
sional noraines, assortod drift, and lake clay with which the rerion is covered as a result of its occupation first by iec, then by melting ice fronts, and later by glacial lakes.

One notable change was the trupporary abandonment of the outlet liom Lake Ihuron past Detroit to Iake lifie. Iake Erie continted to drain into Jake Ontario, which may have been an arm of the sea, while lakes Superior, Michigan, and lluron (the Nipissing Great Lakes) drained independently to the Ottawa. Another marked change was the disconnection of the Lake Nipigon basm so that hake Nipigon at this time first assumed somewhat its present form and was independent of Lake Superior. Isle Royal, the site of several small islets at the Algontquin stage, assumed form as one large istand of nearly its present area. All about the lake slore the witers stood at lower levels. The beaches built at the Nijissing st age seem to be the largest that were formed at any time in the history of the Iake Superior bisin. These beaches are so broad and the clifis cut by the Nipissing waves are so high that it has been inferred that this stage of the lake was continued for a very long time-longer, in fact, to judge from the strength

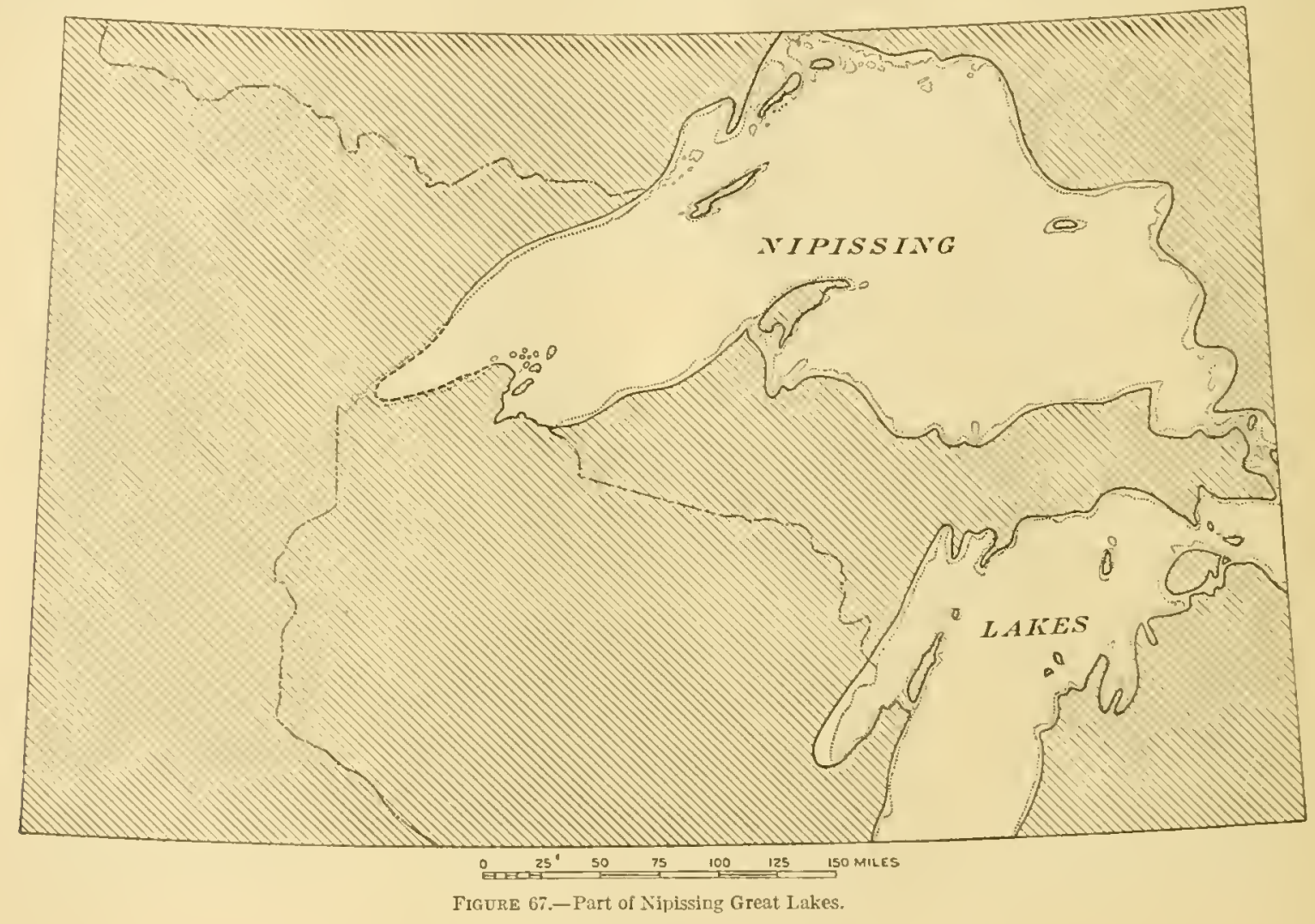

of the shore lines, than the present level of Lake Superior has been maintained as ret, though postglacial gorges are cut back much farther at the present level than they were at the Xipissing stuge.

\section{EFFECT OF TILTING ON GLACIAL LAKES.}

Up to this point in the histery of the Lake Superior basin the lake waters fell erery time a lower outlet was exposed by the northeastward retrent of tho ice sheet. For some time before this there had leen going on a broad warping which was protucing an uplift of the region to the north or a sinking of the region to the south. The evidence of this disturbance is found in the fact that the beaches of the gracial hakes, which must have heen originally horizont al in position, for the waters of the lake were horizontal, ane now inclines Trom north to south at a slight angle. It was not until after the elwe of the Nipissing stage that this warping of the lake basin hat any very profound effects, exeept to produce a fanlike splitting of ghand-hake shore lines and to 
cause temporary oscillations in the outlets of the Algonquin and Nipissing stages. During and after the Nipissing stage, however, the tilting became sufficient to hring about a new and rather dramatic change in the history of the glacial lakes. It has been stated that the lake levels had fallen because lower and lower outlets toward the northeast were exposed by the ice sheet (figs. 63-66). The nornal result of such a series of changes woukl be the establishment of a permanent outlet of the Great Lakes along the line of greatest depression between the uplands of New England and the Arlirondacks on the one hand and the Ileight of Land of Canada on the other. The Lake Nipissing and Ottawa River outlet was so situated; but alter the occupation of this outlet for what may have been a longer time than the present St. Lawrence outlet has been occupied, to judge from the strength of the bearhes, as alrealy stated, the uplilt of the land toward the north became sufficient to raise the Nipissing-Ottawa Valley to a higher level than another valley farther south, and the latter valley became the outlet of the Greut lakes. The three upper Great Lakes at this time, instead of draining through Lako Nipissing to Ottawa River or through Trent River and Georgian Bay to Lake Ontario, were once more turned southward and drained through Lake St. Clair past the present site of Detroit into Lake Erie, whence the water's of the four upper lakes once more passed orer Niagara Falls to Lake Ontario and down the St. Lawrence by the present route. The amount of tilting necessary to accomplish this result was not very great, although that it was greater than the previous tilting is proved by the fact that in places these lower beaches are more highly inclined than any above them. That it did not affect the whole region is shown by the horizontality of some of the beaches.

This tilting has continued up to the present time and is still going on, as is proved by several kinds of evilence. One proof is lound in the fact that on the south sirle of Lake Superior and the other Great Lakes the waters are being canted into bays and river mouths, so that what were formerly valleys are now becoming bays and estuaries (Pl. II, p. 86), as noted in northern Wisconsin by the land surveyor G. R. Stuntz ${ }^{a}$ in 1S69. In these southern rivers the lake water extends backward far enough to make river marigation possible for some distance, as from Duluth 17 miles up St. Louis River to Fond du Lac; but in all except the largest rivers on the north side of the lake the water cascades down in falls and rapids almost directly into the basin of the lake itself. The lower courses of many river's on the soutly side of Lake Superior are so broad that it requires a double line to represent them on the map, whereas on the north side of the lake practically all the rivers are so narrow that they are represented by a single line. 'This canting of the lake waters into the river valleys on the soutl side of the lake has had a very important effect in connection with man's occupation of the region, by producing goou harbors, and of such harbors that at Duluth and Superior is the best (figs. 69, p. 457, and 70, p. 458; Pl. V, A, p. 112), haring been protected by the subsequent builting of great sandbars. To the submergence of old stream valleys during this tilting are due the Apostle Islands, which have been briefly described by Whit tlesey and Irving. ${ }^{b}$

\section{PRESENT POSITION OF RAISED BEACHES.}

The effect of the tilting of this elevated shore line has been to submerge some of the beaches of the former lakes, so that the Nipissing shore line, for example, is elevated many feet above the level of Lake Superior on the north shore of the lake, whereas on the south sliore it is now submerged in places by the lake waters. It has been estinated that the shore line of the Nipissing stage in Lake Superior is 25 feet below the present water surface at Duluth and that this shore line appears above the present water surface at Beaver Bay, beyond which it rises with sn average slope of about 7 inches to the mile. ${ }^{d}$

Numerous observations and notes on these abandoned strands were made by pioneers in the region. Some of these by Sir William Logan, Foster and Whitney, Bela Hubbard,

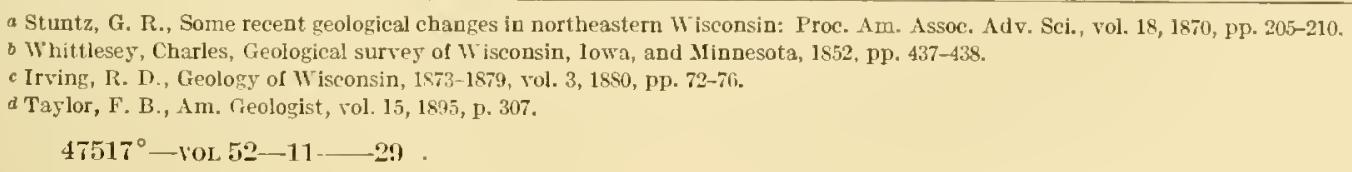


W.A. Burt, Agassiz, Desor, Whittlesey, and others liave already been alluded to. None of these furnish very specific data or eontain more than scattered observations. A. C. Lawson, ${ }^{a}$ however, male a very painstaking stuly and instrumental measurement of these elerated shore lines on the northern shore of Lake Superior, and concluded that these strands were horizontal and were formed in a great lake, held in by a land barrier that was progressively lowered by warping. Ile rejected the irlea of an ice barrier. Subsequently F. B. Taylor bointed out that Lawson and also Warren Upham, ${ }^{c}$ who supported Lawson's conclusion as to the borizontality of these shore lines, though recognizing the glacial-lake condition, had not sufficiently considered the possibility that the shore lines observed from point to point along the shore of Lake Superior were inclined instead of heing horizontal. By field study Taylor demonstrated that the shore limes which Lawson interpreted as horizontal were indeed inclined at a small angle, and pointed out conclusively that they were formed in a glacial lake whose barrier was an ice dam to the east. ${ }^{d}$

These raised beaches on the north shore of Lake Superior, especially in the Michipicoten distriet, have also been studied by A. B. Willmotte and by A. P. Coleman, who has noted very many more shore lines than were measured by Lawson. Near Lake Nipigon Coleman has also measured many new shore lines, ${ }^{g}$ and a number were noted by C. R. Van IIise and J. M. Clements ${ }^{h}$ in a trip around northern Lake Superior in 1901. Observations on the raised beaches in northern Lake Michigan, Green Bay, and western Lake IIuron have been made by Taylor ${ }^{i}$ Russell, ${ }^{j}$ Gollthwait, ${ }^{i}$ and others.

The writer took a hasty trip around the north shore of Lake Superior from Duluth to Sault Ste. Marie in 1907 and risited a number of the localities deseribed by Lawson. Although feeling that Lawson's observations in general were most thorough and accurate, he believes that the conclusion suggested by Taylor is fully warranted and that at least the lower beaches of this region show a decirled tilt to the south and southwest. In evidence of the tilting and the long duration of the Nipissing stage established by Taylor, he found that near Duluth and northward from that city to Beaver Bay the mouths of the small postglacial gorges contain no bed rock but are uniformly" either filled with gravel deposits or oceupied by the waters of the lake, as at Lester Creek, north of Duluth. Northeast of Bearer Bay most of the small strean valleys are found to have no gorges extending down to or below the present lake level, but instead the streams flow over the bare rock surface of the hillsile. An especially good illustration of this is Current River, northeast of Port Arthur, Ontario. Good evidence was found that the Nipissing shore line dips under the lake at Beaver Bar, Minnesota.

It has been shown by G. K. Gilbert that the canting of the lake basins is still in progress, and his estimate of the rate of tilting is that the north end of a south-southwest line 100 miles long in the Great Lakes region would in a century be tilted 0.42 foot above the south end. This amount of tilting, of course, is small, but it would be sufficient to divert the waters of Lake Superior again, just as they were once diverted from the Nipissing Valley to the St. Lawrence Valley, turning them southwarl to Chicago River, where the waters would once more flow southward rather than over Niagara and through the St. Lawrence. More recent studies

a Sketch of the eoastal topography of the north side of Lake Superior: Twentieth. Inu. Rept. Geol. and Nat. Mist. Survey Minnesota, Is33, pls. 230-282,

o The Nipissing Beach on the north Superior shore: . Im. Geologist, vol. 15, 1s95, pp. 30t-314.

c. Im. Jour. Sci., 3d ser, vol. \$9, 1895, p. 7; Twenty-seconl Ann. Rept. Geol. and Xat. Uist. Survey MInnesota, 1894, pp. 5t-66; Bull. Geol. Soc. Americi, vol. 6, 1895, pp. 21-2i.

d Taylor, F. 13., Im. Cicologist, vol. 15, 1895, pp. 304-314; vol. 20, 1597, pp. 111-128.

e Rept. I3ur. Mines Ontario, vol. $7,1 \% 98$, p. Lis.

Idem, vol. \&, pt. 2, 1s99, pp. 150-156; vol. 9, 1900, pn. 175-176; vol. 11, 1902, p. 184; vol. 15, pt. 1, 1906, pp. $193-199$.

lltem, rol. 16, pt. 1, 1907, p. 135.

h I npurblished IS.

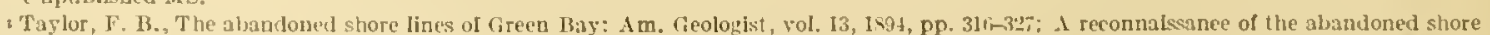

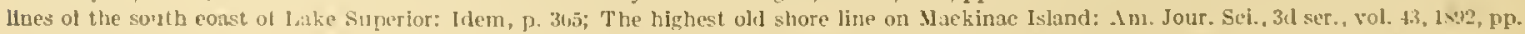
210-21;; The Munuscong Islands: Im. (ieologist, vol. 15, 1*95, pp. 2t-33; The great ice dams of Lakes Maumee, Whitulesey, and Warren: lilem, vol. $24,1,99$ pp. $6-38$.

fRussell, I. C., Ann. Rept. Michigan Geol. Survey, for 1904, 1905, pg. \$3-93; ilem for 190ti, 1907, l'l. LI1.

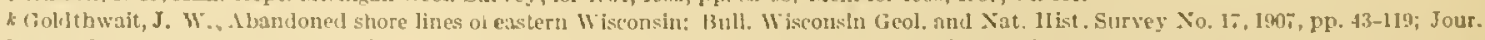

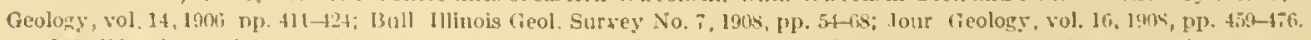

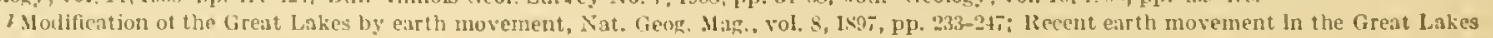

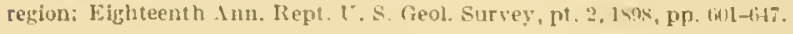


by J. W. Goldthwait ${ }^{a}$ indicate that the abandoned shore lines in the southern part of the Lake Michigan basin are horizontal. The axis of tilting runs south of Green Bay. The effect of the presence of this hinge line will be to postpone very much the time before the tilting can be sufficient to divert the Irainage of Lake Superior and the other Great Lakes to the Chicago outlet.

A series of observations as to the fluctuating level of Lake Superior have been made by Capt. J. I. Darling, of the United States engincer office, at Duluth, who comes to the conchusion that so far as eridence from two stations nearly on an east-west line, Duluth and Marquette, for eighteen years indicates, there is no adequate proof of a change in the level of the present water surface. It seems possible to the writer, however, that this fact of no variation at two points, one almost directly west of the other, would indicate that the axis of tilting runs nearly east and west in the Lake Superior hasin, as it seems to run in Lake Michiyan.

One of the great unsolved problems of the glacial-lake history in the Superior and upper Lake Michigan basins concerns the stages intermediate letween Lake Duluth and Lake Chicago or Lake Algonquin. Between the time of the St. Croix outlet and the Hudson River outlet Lake Duluth must have had an outlet to Lake Chicago through a series of lakes and straits, including Portage Lake on Keweenaw Point, the possible marginal channel east of Marefuette in the Au Train and Whitefish valleys to Green Bay, ${ }^{b}$ and perhaps a cliannel through Sturgeon Bay in the Door Peninsula of Wisconsin. Nothing conclusive can ret be said as to the halts of the ice front or the time of shifting from the St. Croix outlet to the temporary initial Lake Algonquin outflow past Chicago, a stage which preceled the double outlets to Lake Iroquois and thence to the IIudson. Further observation, however, will settle these questions.

Another interesting possibility, at present merely a hypothesis, is that which supposes stagnant ice in the deep eastern part of the Superior basin with retreat southward from the Height of Land, imstead of northward toward it as has always been inferred. No evidence known to the writer disproves this possibility and certain unusually high beaches in the Marquette and Michipicoten districts suggest it. It is possible that this stagnant mass may have become completely detached from the retreating ice slseet. At the beginning of this withdrawal marginal lakes of high level were formed in the Michipicoten district, just as Lakes Onini and Kaministikwia were formed earlier on the northwest side of the lake.

The following table shows some of the present altitudes of the abandoned shore lines, the discrepancies in elevation in the same beach proving the tilting and indicating low the warping varied from the earlier to the later stages and from one part of the region to another. Not all the ligher isolated beaches are listed, and some of the correlations are tentative.

Elevations above Lake Superior (602 feet) of some of the abandoncd beaches.

\begin{tabular}{|c|c|c|c|c|}
\hline & $\begin{array}{l}\text { Clacial Lake Duluth (or } \\
\text { highest early lake recorded). }\end{array}$ & Glacial Lake Algonquin. & $\begin{array}{l}\text { Nipissing } \\
\text { Great } \\
\text { Lakes. }\end{array}$ & Sault stage. \\
\hline 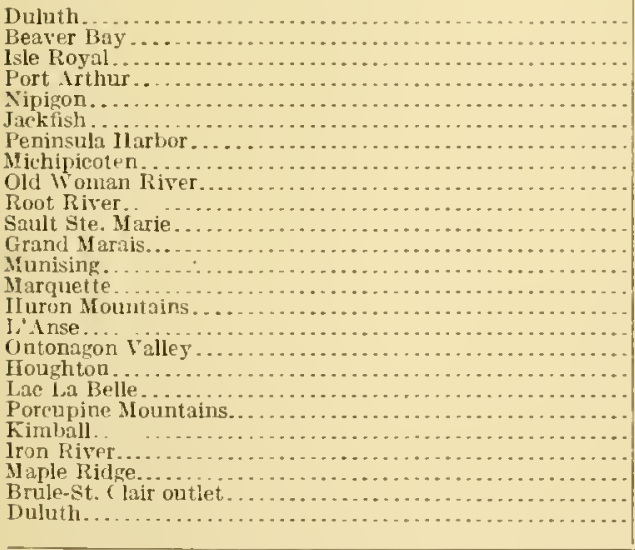 & 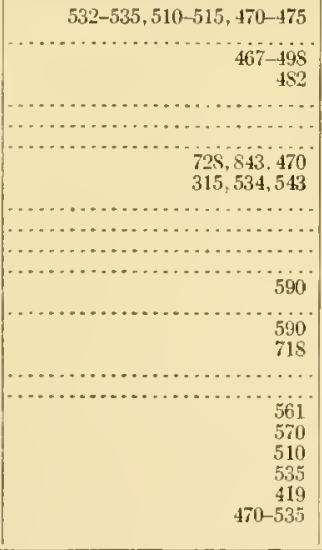 & 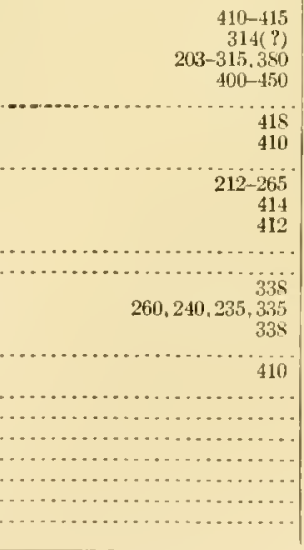 & 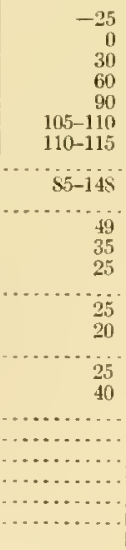 & 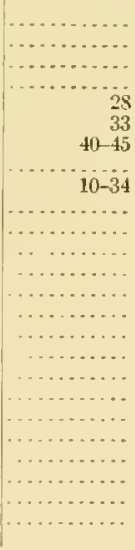 \\
\hline
\end{tabular}

a Bull. Wisconsin Geol. and Nat. II ist. Survey No. 17, 1907, p. 42; Jour. Geology, vol. 14, 1906, pp. 411-424, vol. 16, 1908, pp. 459-476. b Winehell, N. 11., Am. Jour. Sel., 3d ser., vol. 2, 1si1, p. 19. 
Fiterutions abor Lake Vichigan (sit) fret) of some of the abendoned beaches.

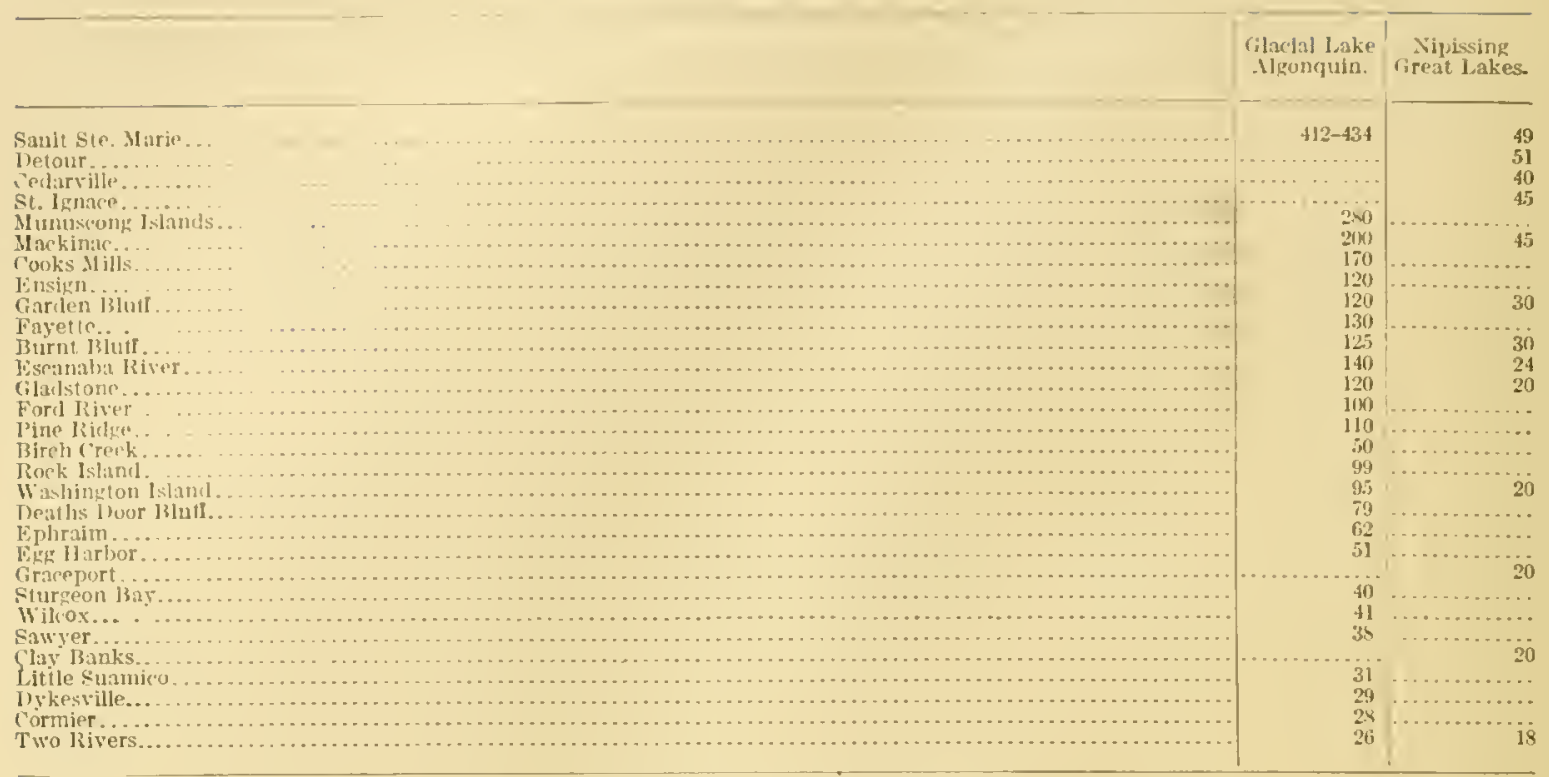

GLACIAL LAKE DEPOSITS.

The deposits laid down in the glacial lakes differ from the deposits now being made in the Great Lakes in the rapidity of accumulation and in the character of materials laid down in water which was fed by melting ice and in which icebergs floated. The cleposits made in these glacial lakes were predominantly clay, although sands and gravels were laid down near the lake shores. Great thicknesses of these clays were accumulated at the west end of Lake Superior during the Nemadji. Duluth, and Algonquin stages and acquired a prevailing red color by derivation from the Keweenawan rocks. These clays form a distinctly different soil from that found in the region not covered by marginal lakes. Well horings near Ashland and Superior, Wis., show thicknesses of 100 to 150 feet or even more of red clay, in places with a little blue clay, gonerally without any stones, orerlying what is reported as sand and "harelpan," the latter possibly glacial till. The total thickness of clay and sand in one boring is 193 feet and in others is over 200 feet. West of Duluth and Superior and extending eastwarl from Superior on the somth shore of the present lake, these thick lake chays, overlying the horizontal Cambrian sandstone, form a plain which apjears horizontal though sloping imperceptibly northward. This plain has been cut by postglacial streams into a series of rather leep, steep-sided gullies, which necessitate the building of a great number of bridges by the railroals: for example, the Duluth. South Shore and Athintic between Ashland and Duluth and the Northern Pacifie and Grat Northern between Duluth and Carlton, Minn. The highways extending east and west across this region, where the streams generally llow from south to north, are continually going up and down hill in crossing ridges and valleys. West of Duluth and soutl of Fond du Late, Winn, these gullies are of very great depth, some as deep as 200 feet, so that the railroads swing far southwarl in oreler to cross the gullies near their heads, redueing the number and height of the bridges which must be built. The bridges on the Great Northern Railway ane in striking contrast with those on the Northern Pacific, both in their number and in their height abore the streams, the latter railway erossing nearer the headwaters of the streams. The flat plain of these ditys is not especially suited for agrieulture and has not been cleared. The clays were covered with timber, hut have heen derastated by fire and at present constitute a rather desolate country that is laversed in the first hour of the risle from Duluth to St. Pand. 
North of Duluth, as previously indicated, the ice retreated southward toward the Lake Superior basin, and between the Miesabi range and Lake Superior the area of flat-lying lower Huronian rocks was the bed of a great glacial lake, called Luke Upham, which gradually increased in size as the icc retreated, and in which great quantities of clay were accumulated. The interference with drainage in this lake-clay plain has brought about the great prevalence of muskegs along the Duluth, Missabe and Northern Railway, which pursues an almost mathematirally straight course for over 25 miles because of the levelness of the lake-bottom plain. Nearly all of this distance is through muskeg swamps, intcrrupted here and there ly low gravel ridges, which are believed to be portions of recessional moraines built at tempormy halts of the ice during this southward retreat and liter partly submerged by the accumulation of lake clay. The bed of glacial Lake Agassiz is similar in nature.

\section{THE FOUR PLEISTOCENE PROVTNCES.}

\section{GROUNDS FOR DISTINCTION.}

In review of the conditions prevailing in the Lake Superior region as regarls minor topography and soil, it may be stated that this region includes four distinctive provinces-(1) the Driftless Area, (2) the area of the older dritt sheets, (3) the area overlan by the till and the

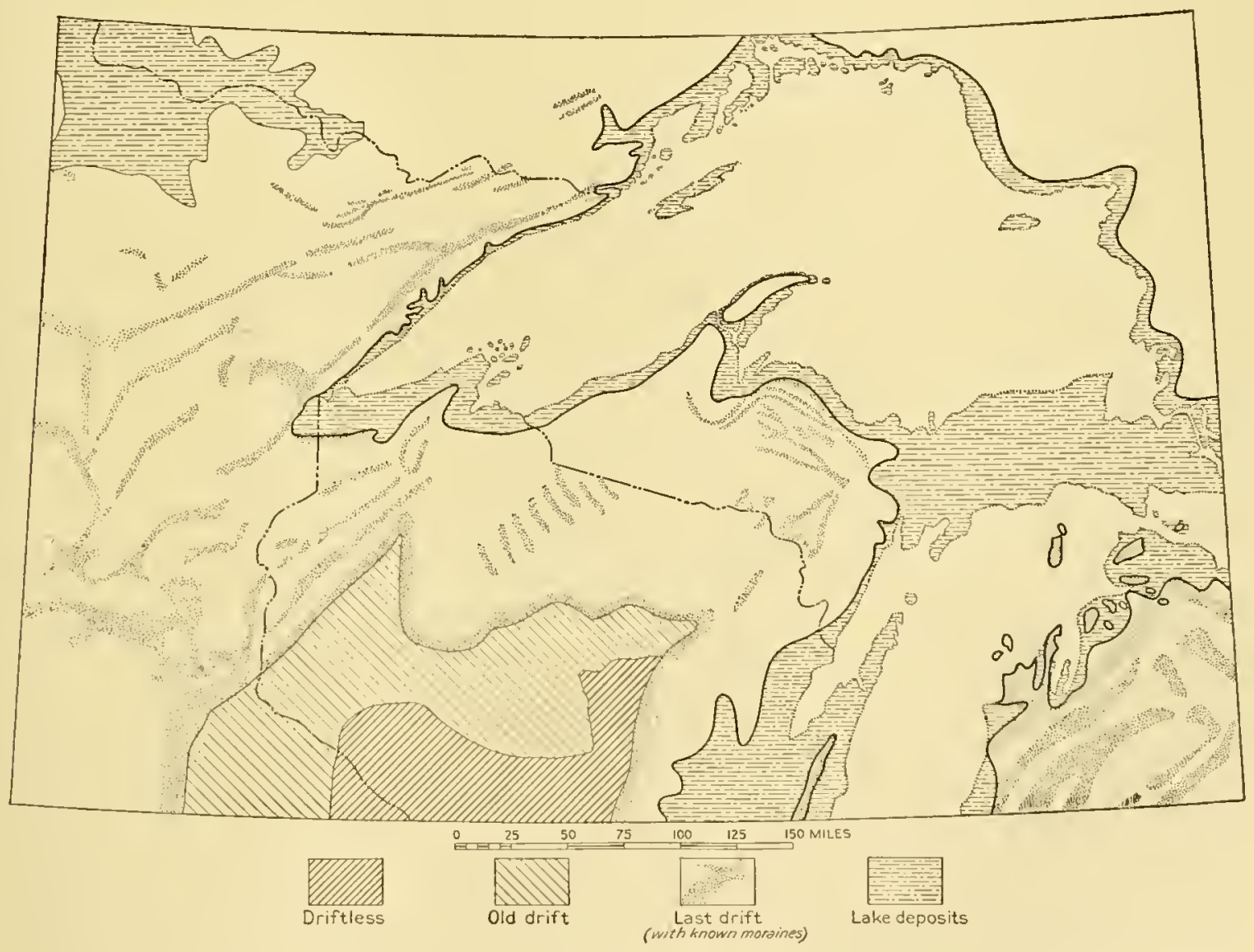

FIGURE 6s.-Sketch map showing Driftless Irea and regions of older drift, last drift, and lake deposits.

assorted glacial deposits of the last (late Wisconsin) stage of glaciation, and (4) the area where glacial-bake deposits predominate. (See fig. 6s.) These provinces are boumled respectively by the terminus of the outermost of the older drift aleposits, by that of the glacial lobes of the Wisconsin stage, by the horker of the highest shore lines of the great glacial linkes in the Lake Superior and Lake Michigan basins, and by the highest shore of Lake Agassiz. Tot all the 
glacial lohes, and by no means all the glacial lakes, were contemporaneous, so the map should not be understood as representing comblitions that were produced at any one time. It merely rejresents four groups of areas within each of which the average conditions are strikingly sinilar and which contrast with one another.

\section{DRIFTLES'S AREL.}

In the Driftless Area the minor topographic conditions are intimately related to the underlying rork. The drainage is mature (PI. XXXI, $A$ ). The valleys are eut almost entirely by streams. Resistant rocks make prominent ledges with castellatcd forms, and weak rocks are worn to insignificant relief. Waterfalls and rapicls in the streams are rare. Lakes are absent. The soil consists of the materials of the umborlying rock or of some arljacent material lrom a source uphill from its present location. It usually grades downward with coarser and coarser fragments to the undecayed ledge from which it has been derived by disintegration. It is a typical local or residual soil.

\section{AREA OF OLIDER DRIFT.}

The province of older drift includes the regions adjacent to the Driftless Area where deposits were left by one or more of the carlier glacinl advanes before the Wisconsin. The topography and soil of this province are contrasted with that of the Driftless Area on one hand and with that of the area of Wisconsin glaciation on the other. The preglacial topography is partly obscured. The valleys are due in part to inequalities in glacial accumulation as well as to stream cutting. The streams may have rapids or waterfalls, thougl these are rarer than in the region of latest drift. Lakes are rather rare, and many lakes and swamps have been filled and drained. The glacial topograplyy has slumped down to a softened outline. The soil is distinctly a transported soil, containing foreign fragments quite different in composition from the underlying bed rock, overlying it unconformalbly as glacial soils always do, and not grading into it. This soil, however, contrasts with the soil of the area of youngest drift, which is fresh and unweathered. Indeed, the soils of the areas of older drift are leached of their soluble constituents to some extent by the action of pereolating grouml water, although the degree of solution is naturally less than in the Driftless Area. This might be called a modified, transported soil.

\section{AREA OF LAST DRIFT.}

As already described, the minor topography in the province of latest drift is of the varions kinds characteristic of a region overridlen by glaciers. The province has a mildly irregular surface, coverel by the till or groumel mornine, which in some places completely mantles the ledges (Pls. XXIX, A, p. 432; XXXI, B, p. 436), in others covers them thimly (Pls. V, p. 112; XII, in pocket), and in still others is almost absent (Pls. IV,$B$, P. 90; XVII, in pocket). It contains drumlins, terminal and recessional moraine deposits (PI. XXX, $A$, p. 434), and the many assorted glacial deposits like the outwash. These minor topogriphic forms and the transported soil, which is fresh and still retains its soluble constituents, make up the surface of the great province of the Wisconsin drift, which inclules the greater part of the Lake Superior region. The important feature about this province is its contrast with the adjacent areas, where there is either no drift or the older drift or where even this youngest drift is overlain by glacial-lake deposits. The contrast with the topography of the older drift has already been emplasized and may be dismissed with the statement that here the irregularity is greater amd the aspect of the topography is distinctly fresher. The young streams have cut relatively insignificant courses in the latest drift, except along the largest rivers, and the lakes and swamps mostly exist as at the close of the glacial perioul, though some are partly filled.

\section{ATEAS OF GLACIAL-IAIE DEPOSITS.}

The fourth Pleistorene provine inclucles not the areas covered hy the numerous small inland lakes, but the area formerly occupiod by the larger glacial lakes which oversprend the margins of Lake Superior and Lake Michigan and extended some distance northward from Duluth, as well as the bed of the large glacial Lake Agassiz. 
In this province the deposits consist chiefly of assorted glacial drift of lacustrine types, showing a predominance of clay and silt, although in the region between Marquette and Sault Ste. Marie sandy deposits cover large areas. The minor topography in this province contrasts strikingly with everything else in the whole Lake Supcrior region. In places there is an exceerlingly smooth, monotonous surface of lake clay or sand covered with muskegs or forests, with insignificant stream valleys, as south of the Mesabi range, in Minnesota, and in the eastern part of the northern peninsula of Michigan; elsewhere there is a similar clay or sandy surface which stands at a high enough level above the present lake for streams to have cut deep, steepsided gorges and gullies in the clays, as west and south of Duluth. The soils of this lake-bottom plain vary greatly in character, being in some places exceetingly fertile, as in the valley of Red River and on the bed of the extinct Lake Agassiz; in others sandy, originally supporting an excellent forest, as in the eastern part of the northern peninsula of Michigan; and in still others of the clayey character which is here fertile and there sterile, as near Superior, at the head of the lakes, and around Green Bay and Lake Winnebago. The distribution of these varieties of soil has not yet been determined in the greater part of the Lake Superior region.

\section{POSTGLACIAL MODIFICATIONS.}

Since the retreat of the ice normal processes have begun to work upon the region. These are chiefly the atmospheric agencies that accomplish weathering and denulation, including the chemical work of air, of surface water, and of ground water; the work of vegetation and animals; and the erosive and constructive work of streams and waves. The most notable results thus far accomplished are the modification of the glacial drift and the bed rock by weathering and by stream work and the work of lakes in their beds and on their shores.

\section{MODIFICATIONS ON THE IAND.}

The modification of the glacial deposits since the retreat of the Wisconsin ice sheet has been exceedingly slight. Weathering has done relatively little, not even erasing delicate glacial striæ except on the more friable rocks.

The deposits of older drift, however, as described by Samuel Weidman ${ }^{a}$ and others, seem to have been much more modified since their formation. The older drift now contrasts with the last drift in showing a greater amount of modification by stream action and very much less relief. Its composition has been changed, the more soluble constituents of the clay in the till and of certain of the bowklers having been leached out by percolating water. Streams have filled or drained the many shallow lakes which may have existed in inequalities in the older drift sheets, and swampy areas are much less prevalent.

The Wisconsin drift shcet, which cover's the greater part of this region, eontrasts strikingly with the older drift in standing at a higher elevation, in being essentially ummorlified by streams and in having relatively few of its lakes and swamps filled or drained. Many of the shallower lakes, however, have probably been converted into swamps by silting up and by encroaching regetation. Doubtless many of the muskeg areas of the Lake Superior region were previously areas of shallow water. Hall has estimated that in northern Minnesota the shallow glacial lakes, whose numbers have probably been greatly exaggerated, are being extinguished at a rate of about sixty a year. ${ }^{b}$ The outwash deposits are in places the only ones that have been very much modified by stream work, and the change in these consists principally of the cutting of terraces, ${ }^{c}$ as in the lower St. Croix distriet of western Wisconsin and along Wisconsin, Chippewa, Mississippi, and other rivers. The greater part of these terraces were probably developed during and at the end of the glacial period, when the streams carried much more water from the melting of the retreating ice sheet. There has been considerable postglacial stream gullying, especially in the lake deposits. The composition of the glacial drift of Wisconsin age has

a Bull. Wisconsin Geol. and Nat. II ist. Survey No. 16, 1907, pp. 435-48s.

b MalI, C. W., The geology and geography of Minnesota, 1903, pp. 178, 181-183.

c Wooster, L. C., Geology of Wisconsin, 1873-1s79, vol. 4, 1882, pp. 134-138. 
remained escentially unchanged in the comparatively brief time since the retreat of the ice. Alluvial deposits are present and are being formed constant!y, but are confined largely to the valleys. As alseady staterl, howerer, part of what Werdmana discusses as alluvial material is certainly glacial outwash.

\section{MODHEICATIONS IN AND AROUND THE GREAT IAKES,b}

Since the Nipissing stage, as ahrarly stated, the waters of Lake Superior have been markedly fluetuating in level, ocenpying lower and lower points on the north slore of Lake Superior and higher and ligher points on the south shore of Lake Superior and the shores of the adjacent parts of Lakes Michigan and Ituron, as the warping of the earth's surface in this region gratually tilted the water southward. This tilting has caused a graclual postglacial emergence of the northern coast and a gradual submergence of the southern coast. In northern Viehigan, for example, A. ('. Lane has olserved dead trees now standing out in the water's of Lake Superion:

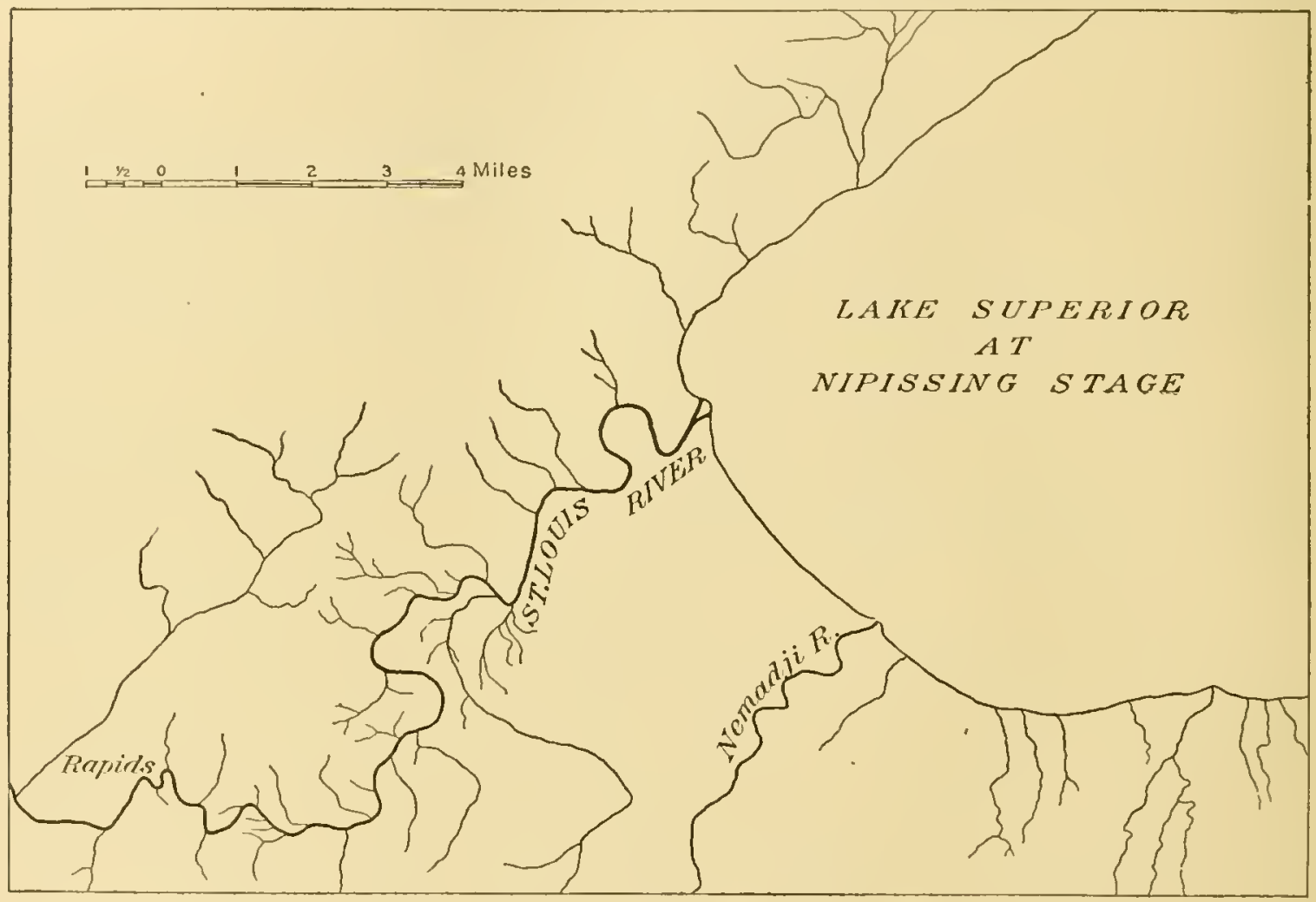

JuGUE 69.-St. Louis River at the stage when it cut its valley and emptied directly into Lake Nipissing.

Although the recent beach levels have not all continued to be occupied by the lake waters at exactly the same level, some rather distinctive shore deposits of the normal type have been built up. On the headlands cliffs hare been eut, and of these cliffs those on the south shore of Lake Superior in the Pictured Rocks region ${ }^{c}$ are famous. Because of the character of the Lake Suprior sandstone, the attack of the wares upon it has developer orerhanging clifts

e Weiln:in, Samuel, Bull. Wisconsin Geol. and Nat. Hist. Survey No. 16, 1907, pp. 51 \{-517.

b Etount? [M.sor was the first in describe the Lake Superlor shore leatures (Foster, J. W., and Whit ney, J. 1), Geology of the Lake Superiur

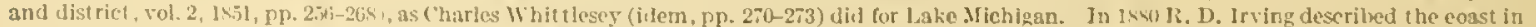
the Ashland region (Geology of the eustern Lake Superior district: Geology of Wisconsin, 16i3-1si?, vol. 3, 140, pp. in-i2). 1. C. Russell has descrilned some recent changes on the north shores of Jahes Huron and Michigan (.Inn. Rept. Michigan Geol. Survey for 1!k4, 1905, pp. 102-105). 1. C. Lawson has described the mokiernelits, beaches, nte., of the north shore of Lake Superior (Twent iell . Inn. Rept. Minnesota Geol. and Nat. II ist. Sisrvey, 1473, p). 19-230), disenssing the shore contours and the coastal profiles in the various hinds of rochs. G. L. Collie (Bull. Reol. Soc. Ameriea, vol.

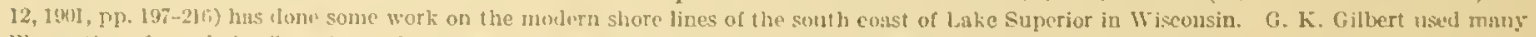
Illustrations from lake Superior and northern lake Michlgan in his Topographic Features of Late Shores (Fifth Ann. Rept. 1 . S. Geol. Survey, $1 \$ 3, p$, $75-123)$,

cFoster, J. W., and Whitncy, J. D., op. cil., PP. 121-I29, plates. 
and eares, as well as isolated stacks and, stilf farther out in the lake, recfs. The attack of the waves upon Cambrian samlstone, upon the Keweenawan lavas, and upon the Algonkian and Arehean rocks has produced different styles of coastal topography, and the cliffs cut in the ghacial drift are different from all others. On the north shore of Lake Superior the relative position and resistance of certain dikes and sills have molified the shore topograpliy, as was long ago described by Agassiz. ${ }^{a}$ Logan ${ }^{b}$ earried the idea of coast rontrol by dikes still furtherfurther, indeed, than Irving ${ }^{c}$ thought justified. The bold north const forms a striking scenic contrast to the mild south shore of Lake Superior, as Irving dhas pointed out.

Between the heallands beaches have been formed, and these beaches are of the usual sand and gravel and bowkler type, associated with spits, hooks, bars, and sand dunes. In places where such beaches have been built across the mouths of ralleys or bays and separated them from the lake, ponds lave leen held in, as on the south shore of Lake Superior or the

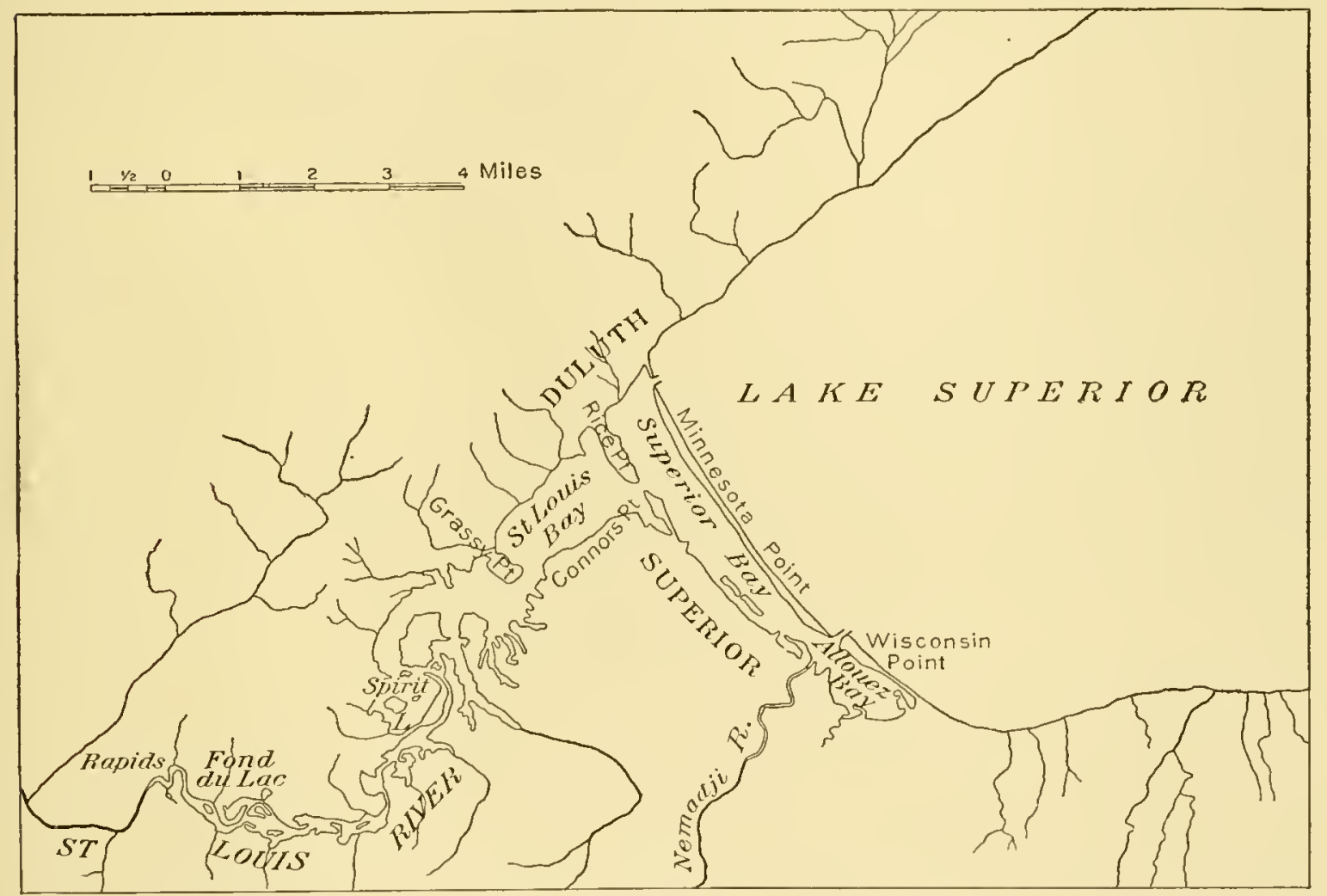

FIGURE 70.-The present St. Louis Rirer, which has lefn converted into an estuary by post-Nipissing tilting. The figure also shows the two sets of sand spits which hare been built.

east shore of Lake Michigan near Grand 'Traverse Bay, where some very large ponds of this sort are found. Elevated examples of these ponds were observel by C. R. Van Hise and J. M. Clements in 1901 on the north shore of Lake Superior, along the Black Bay coast, forming a peculiar type of lakes associated with the raised beaches. ${ }^{c}$ In the Michipicoten district a bar of this kind was thrown across the bay now occupied by Wawa Lake at the time of one of the higher lake stages, as described by A. P. Coleman. $f^{\prime}$ 'The modem and abandoned beaches, cliffs, cares, and skemies on Isle Royal have been describer hy Lane, $g$ and the older and modern beaches at Pigeon Point, Minm., by Bayley. ${ }^{h}$

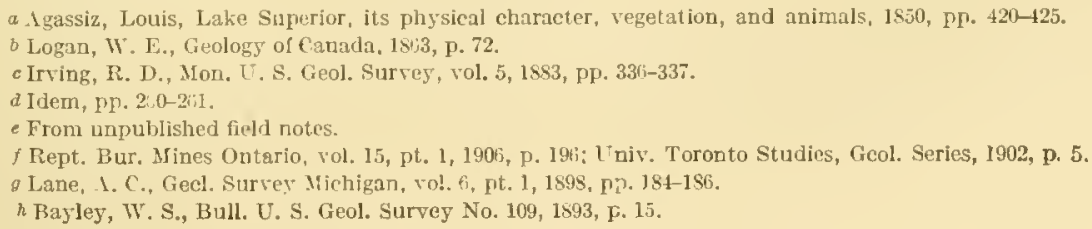


Among the striking shore leposits of Lake Superior now being formed are the two great bars or spits which extend aeross the head of Lake Superior at Duluth-Mimesota Point and Wisconsin Point. (See figs. 4, p. S7, and 70, p. 457.) Their ends are separated by a narow channel which formed the only entrance to the Bay of Superior until the Goremment dredged the canal near the Duluth shore. These bars have a total length of about 10 miles (Minnesota Point $6 \frac{1}{2}$ miles, Wisconsin Point $3 \frac{1}{4}$ miles) and a width varying from a little over an eighth of a mile to less than a hundred yards (Pl. V, A, p. 112). They lave been built up abore the water by a combination of two causes. The first and more important is the interference of the slallowing lake bottom with the passage of waves, causing waves to be overtmined on the site of the present Minnesota and Wisconsin points. The orerturning stirrerl up the deposits at the bottom of the lake and caused the wares to heap up material at this locality. The continued accumulation of material along this narrow line gradually built up a deposit that approached the surface of the water and was augumented by the deposits of the second kind, namely, the materials derived from the shores of the lake, which were transported outward along the submerged embankment, under the influence of the shore currents. The combination of these two agencies soon carried the spits a great distance out from the lake shores, and they were eventually built up above water for a greater part of the distance and finally connected, except for a narrow ontlet.

Drill holes put down near the Government canal at Duluth and at the newer jetties between Tisconsin Point and Minnesota Point have shown that the points are built upon a base of fine lake clay, overlain near the shore by very coarse material, which a short distance out is replaced by fine sand. On the Minnesota side no pebbles are found on the present beach at a greater distance from the shore than three-(puarters of a mile, showing that the contribution of the coarse along-shore drift in the middle of the point is not very great and that the larger part of the material is washed up by the waves, although probably augmented by the material drifted along the beaches. The higher parts of these points, which rise 20 or 30 feet alove the lake level, consist of very fine sand, built up into sand dunes by the wind, and upon these dunes evergreen trees have been able to grow.

$\Lambda$ bout a mile back from Minnesota and Wisconsin points another pair of points (Rice Point and Connors Point) has been built, separating St. Louis Bay, where most of the ore boats are loaded, from Superior Bay. These were doubtless formed as spits at an earlier date, in an exactly similar manner to the outer spits, though they have never been connected.

Still l'arther up St. Louis River there are projections from the sides of the ralley, like Grassy Point and others, in some respects similar to these points but probably of an entirely different origin. It seems probable that in the post-Nipissing tilting of the lake waters into the ralleys the St. Louis Valley, which had been rather deeply cut in the lake-clay plain and which had developed to the stage of a flood plain with a meandering stream (fig. 69), has been drowned, so that portions of the spurs on the valley sides now emerge from the water and resemble bars (fig. 70). Farther up the St. Louis the deposits in the vicinity of Spirit Lake and above to Fond du Lac form a very characteristic drowned flood plain.

Smaller hass, similar to these at Duluth, have been formed in several bars on the shores of Lake Superior, especially on the south shore, where the rocks are weak and easily suplyly material for the wares and currents to move. The most notable of these spits is Chequamegon Point, ${ }^{a}$ near Asluand, and there are numerous smaller ones, as on Au Train Island. In Grand Traverse Bay, Lake Michigan, a great look is formed by the curring of a similar spit.

It is a rinther notable fact that almost none of the streams flowing into Lake Superior have been able to huild deltas. Naturally the streams on the south side of the lake, like St. Louis River, could not build deltas fast enough to keep up with the gradual submergence of the region in connection with the tilting of the land. On the north shore, however, there seem to be special conditions which prexent the building of deltas by seceral large streams. Nipigon River would not build a delta because it is a relatively clear stream, having been strained of all sediment 
before it flows out of Lake Nipigon. This is also true of Michipicoten River and of a great number of smaller streams which at present carry rather small amounts of sediment because they flow through so many lakes. The Kaministikwia, at Fort William, has the only delta of any notable size in Lake Superiol, and this seems to have been formed mostly at an eartier time, relatively little sediment being carried by the Kaministikwia at present.

Of the offshore deposits less is known specifically. As ahready suggested, these deposits are accumulating more slowły than when melting glaciers lumished both water and serliment in greater quantities and when stones dropped by floating icebergs differentiated the silts from those now going down. Coarse deposits like gravel and sand predominate near the beaches and the river mouths, and rocky accumulations are probably growing near the chiffs. In deep water fine clay and silt predominate, as the detailed sountlings of the Lake Survey charts show. The several areas of sand, clay, etc., on the lake bottom show appropriate relationships to the rocks and the glaciat deposits of the adjacent shores, the drainage basins, the lake currents, cte. Deposition here contrasts with the postglacial weathering, erosion, transportation, and slighter deposition on the land.

\section{SUMMARY OF TIIE PLEISTOCENE HISTORY.}

The Pleistocene epoch in the Lake Superior region witnessed four rather different sets of conditions-(1) in preglacial time, when the topography was much as it is now except for certain valleys that have since been deepened by glacial erosion, broad areas that have been covered by glacial drift, and an entire eontrast of drainage; (2) in the time of advancing ghaciers, when the tand was gradually being covered and croded ly an ice sheet, drainage was being modified, and plants and animals were being driven out; (3) in the time of retreating glaciers, when from an extreme stage of glaciation with nothing uncovered except the Driltess Area the present topography was revealed by the graduat melting of a largely stagnant ice sheet, with the several marginal lake stages, etc., and the attendant warping of the earth's crust; (4) in the present stage of modification of glacial deposits, buikling of stream and lake deposits, return of plants and animals, and a generat attempt to restore the normal conditions that were prevalent before the interruption by glaciation. 


\title{
CHAPTER XVII. THE IRON ORES OF THE LAKE SUPERIOR REGION.
}

\author{
By the authors and W. J. MEAD.
}

\section{HORIZONS OF IRON-BFARING FORMATIONS.}

The ages and names of the iron-bearing formations of the Lake Superior region are as follows:

Brown ores associated with Paleozoic and Pleistncene deposits (Spring Valley, Wis.).

Cretaceous detrital ores of the western Mesabi district of Minnesota.

Clinton ores of the Silurian of Dodge County, Wis.

Algonkian system:

Keweenawan series: Titaniferous gabbros of Cook and Iake counties, Minn.

Huronian series:

Upper IIuronian (Animikie group):

Biwabik formation of the Mesabi district of Minnesota.

Animikie group of the Animikie district, Ontario.

Ironwood formation of the Penokee-Gogebic district, Michigan and Wisconsin.

Vulcan formation of the Menominee and Calumet districts, Michigan.

Vulcan iron-bearing member of the Crystal Falls, Iron River, and Florence districts, Michigan and Wisconsin.

Gunflint formation of the Gunflint Lake district, Canada, and Termilion distriet, Minnesota.

Bijiki schist of the Marquette district, Michigan.

Deerwood iron-bearing member of the Cuyına district, Minnesota.

Middle Huronian:

Negaunee formation of the Marquette district, Michigan.

Freedom dolomite of the Baraboo district, Wisconsin.

Archean system.

Keewatin series:

Soudan formation of the Termilion district, Minnesota.

Ilelen formation of the Mishipienten district, Ontario.

Unnamed formation of Atikokan district, Ontario.

Several nonproductive formations in Ontario.

The ores of these horizons fall into natural groups on the basis of general (haracters and origin as follows:

(1) The ores of the Lake Superior pre-Cambrian sedimentary iron-bearing formations, including practically all the ores produced from the Lake Superior region.

(2) 'Titaniferous magnetites constituting magmatic segregations in Keweenawan gabbros. Nonproductive.

(3) Magnetic ores representing pegmatite intrusions in basic igneous rocks. Doultfully represented by Atikokan and cortain nonproductive Vormilion ores.

(4) Residual or bogr ores of the Paleozoic at Spring Valley, in northwestern Wiscousin. Slightly produrtive.

(5) The Clinton ores of the Paleozoic in Dodge County, southeastern Wisconsin. Slightly prosluetive.

160 
GENERAL DESCRIPTHON OF ORES OF TIE IAKE SI'TERIOR PRE-CAMBRIAN SEDHMENTARY IRON-BEARING FORMLTIONS.

\section{IN'TRODUCTION.}

The ores of the pre-Cambrian sedimentary type eomprise 99 per cent of the productive ores of the region. They oceur in the Keewatin series, the midclle Ituronian, and the upper Huronian (Animikie group). The following table shows the perentage of ore which has been mined from these rocks, by districts, from the opening of mining in the district to the close of 1909:

Percentages of ores mined from pre-Cambrian sedimentary rorks in Lake Supcrior rigion to close of 1909.

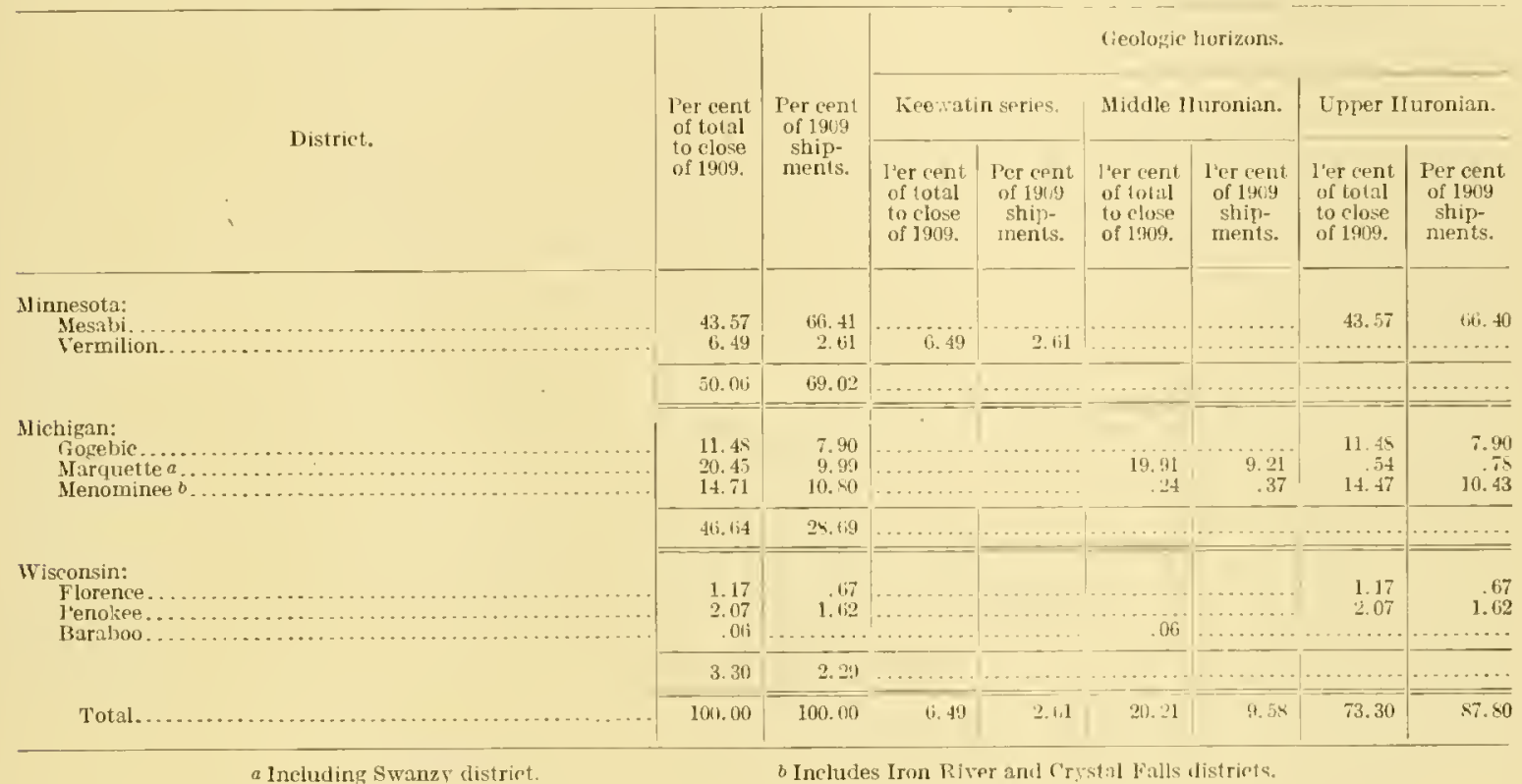

A comparison of the total production from each of the geoloceric horizons with the production for 1909 shows that in the past the Feewatin and middle Huronian iron-bearing formations were more productive relatively than they are now: and that the upper ILurmian is increasing its proportion. A further increase in pereentage of the upper Juronian ores is probably to be tooked for.

Notwithstanding the fact that the iron-hearing formations are contained in three different groups, separated by great unconformities, they are remarkally similar in their lithology, making it possible to discuss them essentially as a unit. These formations are unique among most of the sediments of the globe with which we are familiar. The early geolocic "onclusions relating to their structure were based on the assumption that formations so peculiar were developed at one and the same time, an assumption which of eourse led to much confusion in the interpretation of the stratigraphy of the region.

An attempt is made under the following headings to summarize the salient features of the ores of the region as a whole. In earlier chapters the ores of the several clistricts are separately discussed.

\section{IIINDS OF IROCIX́' IN TIIE IRON-BEARING FORMATIONS.}

In the simplest terms the iron-bearing formations of the Lake Superior region consist essentiafly of interbanded layers, in widely varying proportions, of iron oxicle. silica, and combinations of the two, variously ealled jasper or jaspilite, where anlyydrous and crystalline 
(Pls. XXXll and XXXIII), and ferruginous ehert ${ }^{a}$ (I'I. XXXIT, $A, B$ ), taconite, or fermuginous slate (PI. XXXIV, C), where softer and more or less hychrous. These rocks become ore by local emrichment, largely by the leaching out of silica and to a less extent by the introduction of iron oxide. There are accordingly complete gradations between them and the iron ores. Many of the intermediate phuses are mined as lean siliceous ores. In the following deseriptions, therefore, the ores are not in all cases slurply differentiated from the iron-bearing rocks. Local phases of the iron-bearing formations are amphibolitic and magnetitic cherts and slates (Pl. XXYT), cherty iron carbonates (Pl. XXXVI), ferrous silicate or greenalite rocks (Pl. XXIVII), pyritic quartz rocks, and detrital iron-bearing rocks derived from older iron-bearing formations. AIl these phases are found in each district, but in considerably varying proportions. One of the most significant variations with reference to the origin of the ore is in the relative abundance of greenalite rocks and siderite.

\section{CHEMICAL COMPOSITION OF TIE IRON-BEARING FORMATIONS.}

The arerage iron content of all the original phases of the iron-bearing formations for the region, not including interbedded slates, as shown by all available analyses, is 24.8 per ecnt. The average iron content of the ferruginous cherts and jaspers, from which there has been but little leaching of silica, as shown by all available analyses, is 26.33 per cent. The amplibolemagnetite phases of the formations show approximately the same percentage. The arerage irom eontent of the formations, as shown by all available analyses, different phases, including the ores, being taken in proportion to their abundance, is 35 per cent for the Lake Superior region. (See table, p. 491.) A comparison of this figure with 24.5 per cent for the original siderite and greenalite (see pp. 167, 527) and 26.33 per cent for the ferruginous cherts and jaspers from which silica las not been removed (see pp. 181, 23S) will show what has been accomplished in the secondary concentration of the ores. It is possible, howerer, that the ores have in part been derived from the richer phases of the iron-bearing formations. So far as this is true, the secondary concentration accomplished has been less than the comparison of these figures might indicate.

\section{RATIO OF ORE TO ROCK IN THE IRON-BEARING FORMATIONS.}

It may again be noted that the iron ores, though important commercially, form but a very smatl percentage of the rocks of the iron-bearing formations. The deposits are very large, but are relatively insignificant as compared with the great adjacent masses of ferruginous cherts and jaspers making up the bulk of these formations.

The pereentages of iron ore to rock, by weight (see p. 492 for depths), calculated from estimates of tonnage given on other pages, are as follows:

Proportions of ore to rock, by weight, in the iron-baring formations of the Lake Superior region.

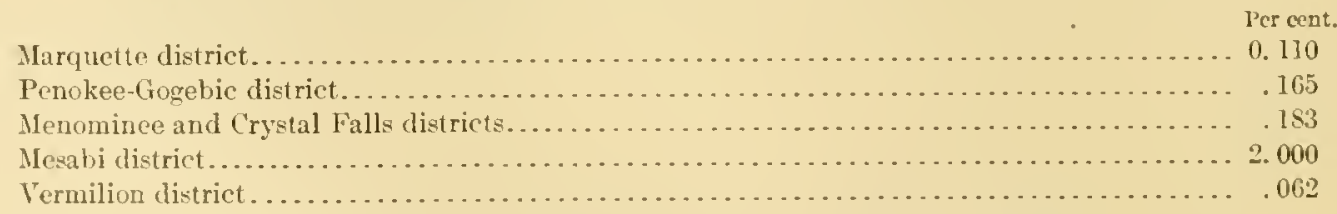

\section{STIRUCTURAL FEATURES OF ORE BODIES.}

It will be shown later that the iron ores are the result of subsurface alt erations of richer layers of the iron-bearing rocks and are localized at places in these layers where these alterations have been most effective, particularly where the ordinary ground waters are converged within

a chert, as defned in the text-books, is an amoryhous and hyolrous rariety of quartz, but in the field the term has been very renerally applied to silicrous bunds, steh as thoso fonnd in limestone, with little regard to their microscopie or chenical characteristics. Some of the so-ailed eherts and limestones are very fine grained or anorphons. The elerts of the iron-bearing formations are similar in every respect to those of the limestones. They show the same irrogularity of texture, interlocking of quartz grains, and in places very fite grains. IJowever, it ean not be said that any of the su-callerl chert in the Iake Superior region has been found to be truly amorphous and hydrous 
PLATE XXXII. 


\section{PLATE XXXII.}

\section{JASPILITE.}

A. Folded jaspilite from Jasper Bluff, Islpeming, Marquette district, Michigan. The illustration beautifully shows the secondary infiltration of iron oxide and deformation by combined fracture and flow. By close observation iron oxide of three different ages may beseen. The oldest is the dark-gray hematite. Intersecting this is the more brilliant steel-gray hematite and magnetite, and cutting both of the former are other veins of hrilliant henatite and magnetite. The history of the rock seems to be briefly as follows: Banded hematite and jasper was bent by folding, probably while the rock was deep seated. During this folding the hematite was mashed. In a later stage, when the rock was more rapidly deformed near the surface, fracturing occurred. This gave the conditions for the first infiltration of iron oxide, and later, when the rock was perhaps still nearer the surface, further deformation resulted in new fractures. Finally, the crevices thus formed were filled with the latest iron oxide.

$B$. Breceiated jaspilite from Jasper Bluff, Ishpeming, Marquette district, Michigan. The illustration gives evidence of the history as shown by $A$. However, during the final process the layers of jasper, which were bent at the earlier stage, were broken through and through, producing a breccia. The same evidences are seen of three stages of iron oxide as in $A$. The less brilliant gray is the earliest-mashed hematite; the intermeliate gray represents a first infiltration; after this there was shattering; and finally the breccia was cemented by l,rilliant steel-gray hematite and magnetite. 

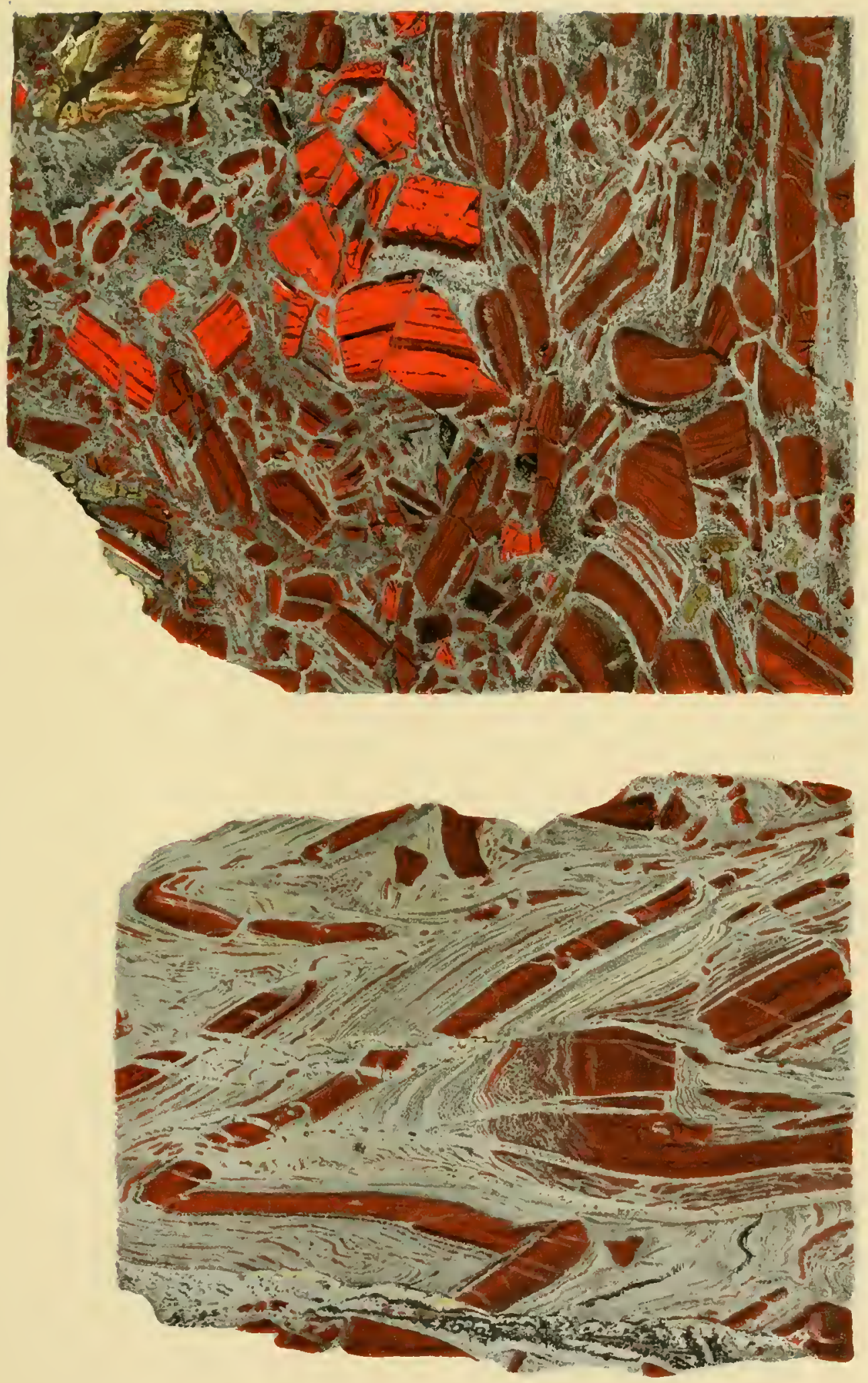



\section{PLATE XXXIII.}




\section{PLATE XXXIII.}

\section{JASPILte AND hematitic chent.}

A. Folded and brecciated jaspilite of the Soudan formation, Vermilion district, Minnesota. (After Clements.)

$B$. Hematitic ehert from Negaunce, Marquette district, Michigan. The bands of chert are so broken by movement that they are in some places diffieult to follow. Many of the fragments have roundish outlines, due to their partial solution and replacenent by iron oxide. The material illustrated is irequently found very close to the ore bodies. If a portion of the remaining silica were removed and iron oxides introduced in its place, it would beeome iron ore. The hematite is soft and the material illustrated is therefore called soft-ore jasper by the miners. 

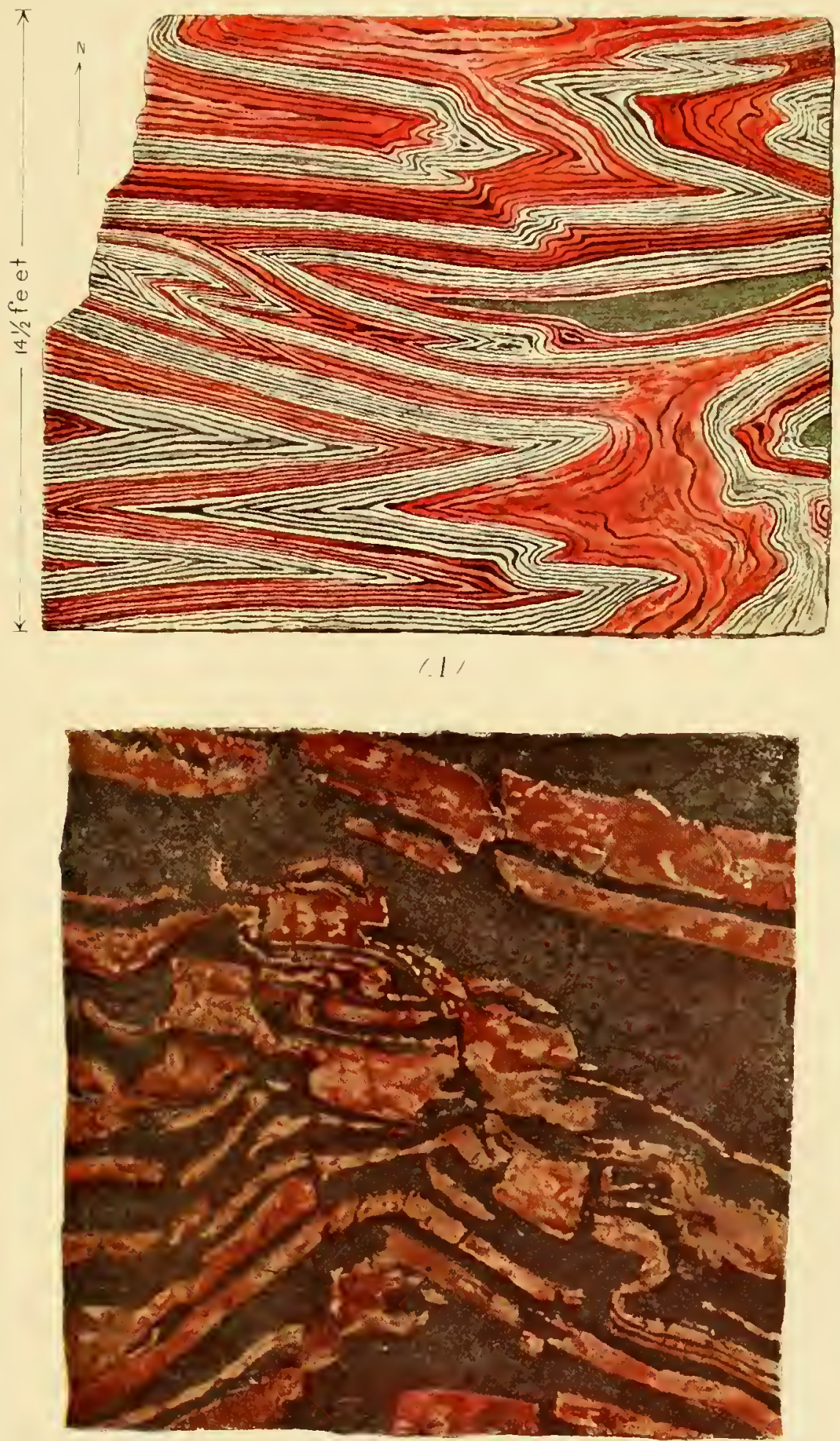

(B)

(d) FOLDED AND BRECCIATED JASPILITE OF THE IRON - BEARING SOUDAN FORMATION, VERMILION DISTRICT, MINNESOTA.

(B) HEMATITIC CHERT FROM NEGAUNEE, MARQUETTE DISTRICT, MICHIGAN 



\section{PLATE XXXIV.}




\section{PLATE XXXIV.}

\section{Ferruginous cinete and slate of IRON-bearing Biwabik formation.}

1. Gray ferruginous chert (specimen 45027) from ('hicago mine, in sec. 4. T. 58 N., R. 16 W. Mesabi district, Minnesota. Natural size. This is one of the characteristic aspec ts of the ferruginous cherts of the iron formation. Under the microscope irou oxicle and chert can be seen still marking the shapes of the greenalite granules. Described on pages $168-170$.

B. Ferruginous chert (specimen 4558s) from Mlahoning mine, Mesabi district, Minnesola. Natural size. The rock shows interbanding of ehert with iron oxicle. Described on pages 168-170.

C. Banded ferruginous state (specimen 45594) from Penobscot mine, 298 feet below ferruginous chert. Mesalii district, Minnesota. Natural size. Described on pages 170-171.

468 


$$
2
$$





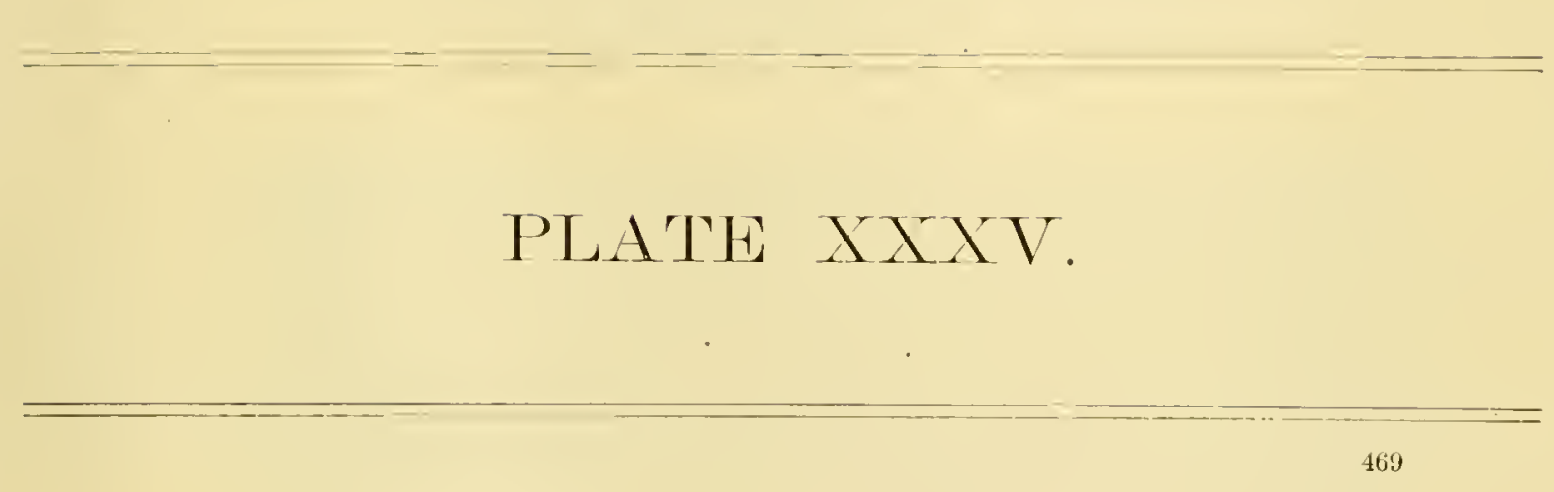




\section{PLATE XXYV.}

\section{Ferruginot's cheit and schist.}

A. Amphibole-magnetite chert (specimen 48571) from Republie, Mich. Note coarsely crystalline anhydrous character as compared with ferruginous cherts and jaspilites. For discussion of origin, see pages 545 et seq.

B. Sideritic magnetite-grünerite schist from sec. 13, T. 47 N., R. 27 W., Marquette district, Michigan. The different bands consist mainly of grünerite, hematite, magnetite, and quartz, in varying proportions. The darker-colored bands contain much of the iron oxide. In the lighter bands grünerite is abundant. In all the layers there is a sufficient amount of residual siderite to show that from this mineral and silica the grünerite formed, and from the grünerite, with partial or complete oxidation, the magnetite and hematite developed. Mlost of the hematite is of the specular variety, but in places blood-red fleeks of hematite may he seen, and parts of the specimens are stained by limonite. This is doubtless the result of weathering. Natural size. 


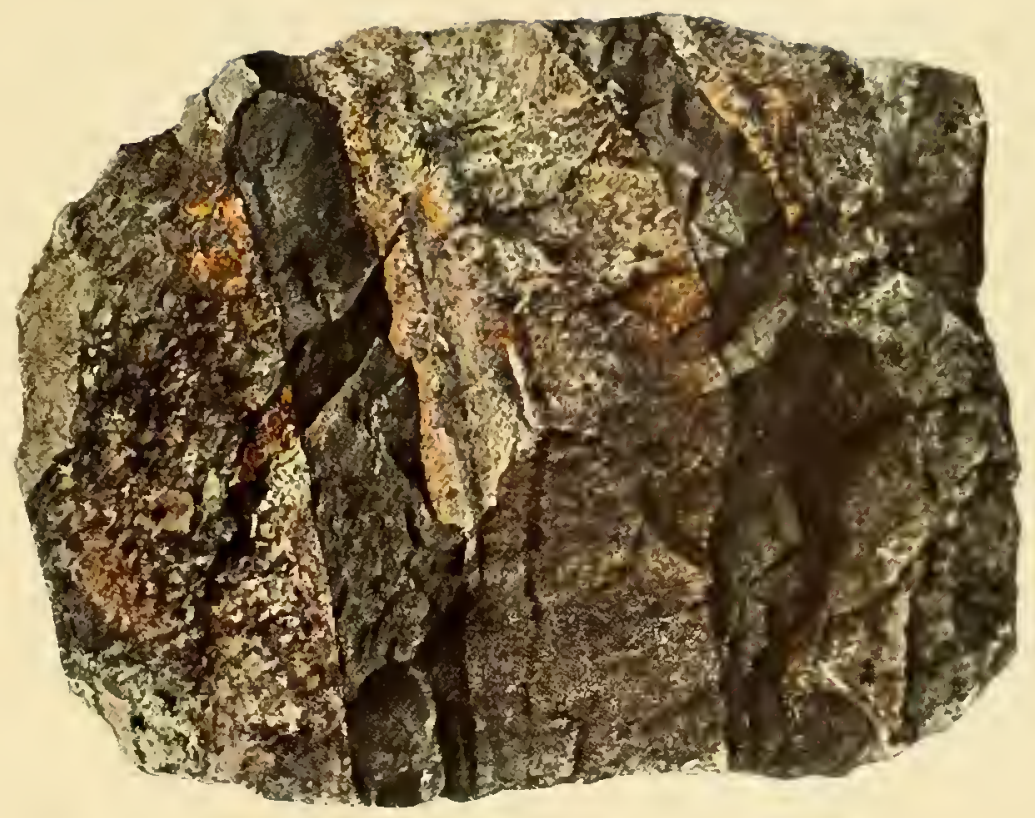

(A)

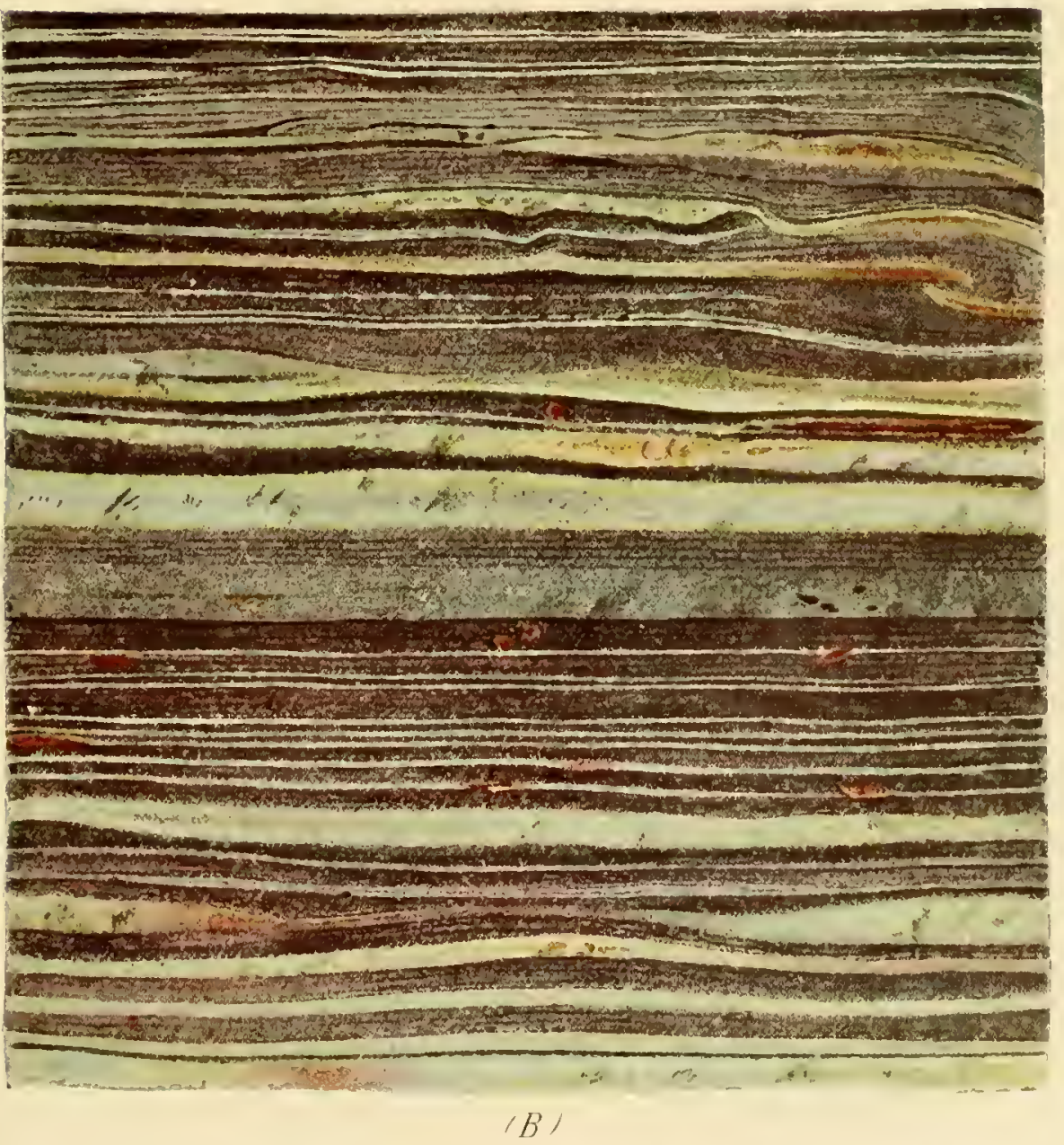

(A) AMPHIBOLE-MAGNETITE CHERT FROM REPUBLIC, MICHIGAN.

(B) SIDERITIC MAGNETITE-GRUNERITE SCHIST FROM MARQUETTE DISTRICT, MICHIGAN 

PLATE XXXVI. 


\section{PLATE XXIVI.}

\section{JASPERT FILLING IN AMYGILLES AND CIERTY SIDERITE.}

A. Jaspery filling in amygdules from ellipsoidal hasalt of the Crystal Falls distriet, Michigan. (Specimen 47554.)

$B$. Clerty siderite from sec. 19, T. 47 N., R. 27 W., Marquette district, Michigan. This is one of the purest cherty siderites found in the Narquette district. The gray material consists almost wholly of very finety crystalline and opaline silica and of siderite. The bluish-gray layers contain some silica, the greenish layers some siderite. On the weathered surface the siderite is entirely deconiposed and in place of it is hematiteand limonite. The lseginning of the same kind of alteration may be seen to affect some of the siderite belts quite to the center of the specimen. As examined in thin section the secondary limonite is found to be in pseudomorphous areas after the siderite. Between the unaltered siderite and that which is completely decomposed there is every gradation, different granules showing all stages of the transformation. Natural size.

C. Cherty siderite from sec. 13, T. 47 N., R. 46 T., Penokee district, Michigan. (See Mon. U. S. Geol. Survey, vol. 19, IS92, Pl. XXI, fig. 4.) The original cherty siderite of the Penokee district is represented perfectly by the grayish-green material. Its very close similarity to that of the Iarquette siderite represented in $B$ is noticeable. The leginning of the transformation of the siderite to limonite and hematite is beautifully shown. The transitions between the two are clearer than in $B$. The processes of change begin along the bedding planes and along intersecting veins. These two together make two sets of nearly right-angle planes, which doubtless are shearing planes. The veins are entirely filled with limonite and liematite and therefore are minute layers of ore. The changes along the bedding illustrate the beginning of the process which results in the formation of the iron-ore deposits. It is noticeable that, as a result of the alterations, the original banding of the rock is emphasized, althongh the emphasizing bands are not so regular as the original sedimentary laminie. This emplrasizing of the original banding of the iron-hearing rocks by metasomatic changes is a general law for the iron-bearing formations of the entire Iake Superior region. Natural size. 

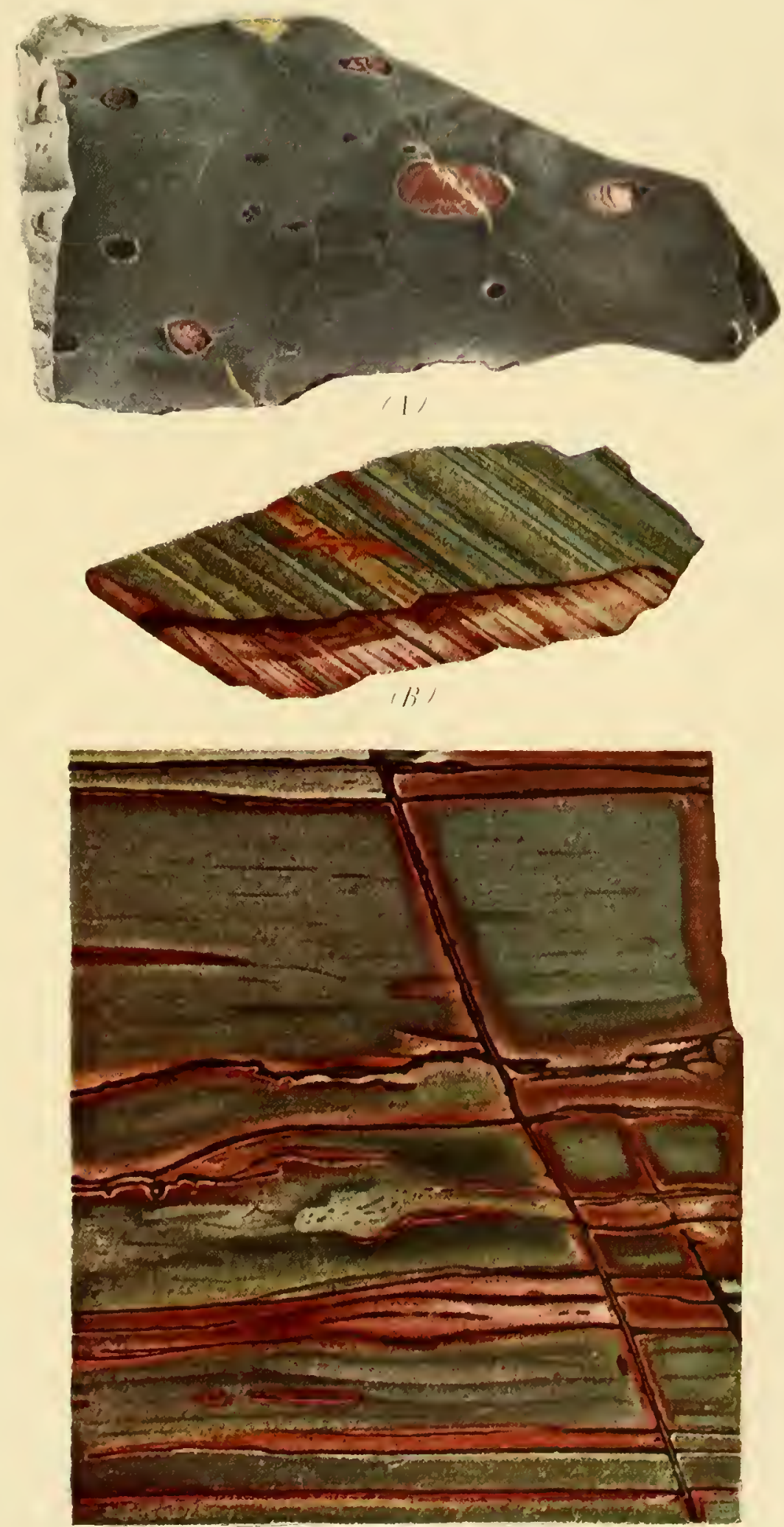

$\left(r^{\prime}\right)$

(d) JASPERY FILLING IN AMYGOULES FROM ELLIPSOIDAL BASALT OF THE CRYSTAL FALLS DISTRICT, MICHIGAN

(B) CHERTY SIDERITE FROM MARQUETTE DISTRICT, MICHIGAN

(C) CHERTY SIDERITE FROM PENOKEE DISTRICT, MICHIGAN. 

PLATE XXXVII. 


\section{.PLATE XXXVII.}

\section{Greenalite rock.}

A. Greenalite rock (specimen 45647) from locality near Duluth, Missabe and Northern Railway track, 1 mile south of Virginia, Mlesabi district, Minnesota. Granules of greenalite, but little altered, stand in a matrix of chert. Described on pages 165-168.

$A^{\prime}$. Portion of surface of specimen shown in $A$, slightly magnified to show greenalite granules to better advantage.

$B$. Interbanded greenalite and slate rock (specimen 45176) from 100 paces north 500 paces west of southeast corner of sec. 22, T. 59 N., R. 15 W., Mesabi district, Minnesota. Natural size. The black portion of the rock is slate and the green portion is made up of greenalite granules lying in a matrix of chert. Greenalite is characteristically associated with slaty layers in the iron-bearing formation; indeed it is clue to their protection that greenalite has been retained in comparatively unaltered form. Deseribed on pages 165-168.

474 

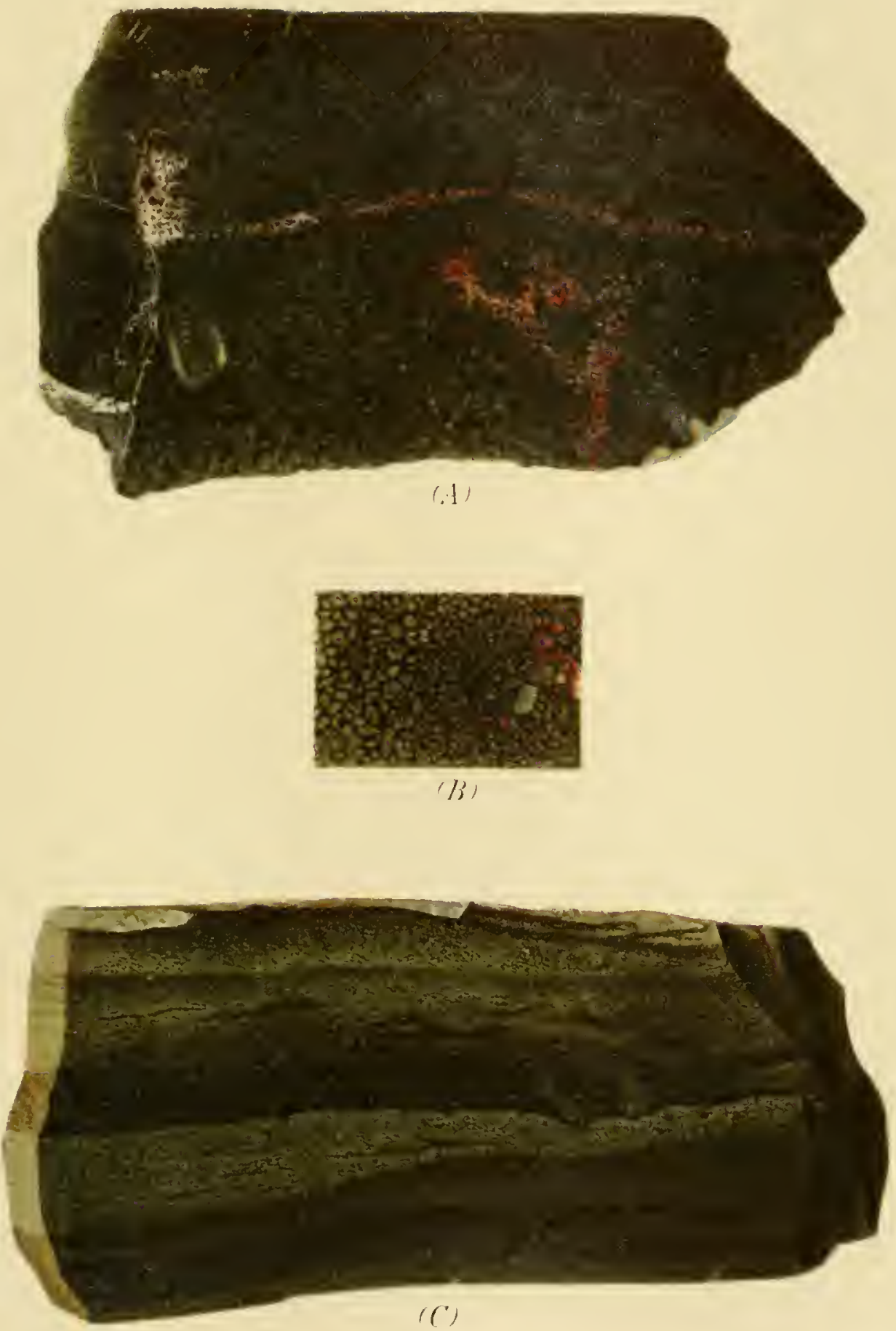

the formation, owing to various structural conditions. Rarely are the original layers of iron formation rich enough to be mincd when they have suffered only minor secondary concentration. Because of secondary concentration the ores are usually in the upper parts of the formations and always extend to the surface, though they may reach depths of 2,000 feet or more. It may readily be conceived that there are a great variety of struetural conditions which determine the circulation of the altering waters and therefore the localization and shapes of the ore deposits within the formations. Sucl structural features are joints, faults, lolds, intersection by igneous rocks, impervious sedimentary layers within or below the iron-bearing formations, and area of exposure.

The structural features of the ores are described principally in the detailed descriptions of the ores of the several districts, but some of the more salient features of the structural relations are summarized below.

The development of ore within the richer layers of the iron-bearing formations depends on their accessibility to altering solutions from above, and the largest result is given by a wide area of exposure of the formations, which is in turn a function of the dip. The flat-lying iron-bearing formation of the Nesabi district exposes a greater surface to concentrating agents than the stecply dipping formation of the Gogebic district, of similar thickiess and character, with the result that the proportion of the formation altered to ore is much greater in the Mesabi district. A comparison of the actual areas of the different iron-bearing formations with their total shipments to date and with their probable reserves shows a close relation between area and amount of ore developed.

Of more immediate and practical importance in relation to the distribution of the ores are the structural conditions, such as impervious basements and fractures, which determine the location of ores within a given area of the iron formation.

Impervious basements for the ore body may be formed (1) by the intersection of the footwall quartzite with an igneous dike, as in the Gogebic district; (2) by irregular intrusive masses of basic igneous rock, as in the Marquette district; (3) by dolomite, as in the Menominee district; (4) by slate, as at the lower horizons of the Negaunee formation in the Marquette, Crystal Falls, Iron River, and Florence districts, and at the upper horizon of the Vulean formation in the Menominee district; (5) by slate layers within the iron-bearing formation, locally developed in the Gogebic and Mesabi districts; and (6) by granite, as in the Swanzy district of Michigan and very locally in the Mesabi district. Most of these basements have the configuration of pitching troughs.

The ores are likely to be elosely associated with fractures in the iron-bearing formation which give access to-altering solutions, as is particularly well illustrated by certain of the deposits of the Mesabi district and by parts of the deposits of the Gogebic district which pass through faults in the impervious basement, and indeed is illustrated to a greater or less extent by practically all the iron deposits of the region.

The relative importance of the several struetural features of the ore deposits varics widely from place to place. In the Gogebic district the existence of impervious basements in the form of pitching troughs seems to be the essential structural feature of the ore deposits. Localization of the ores within and arljacent to fissures in the iron-bearing formation is also apparent. On the other hand, in the Mlesabi district the conspicuous feature is the localization of the ores by fractures in the iron-hearing formation, the impervious basement heing so gently flexed as to make it difficult to ascertain whether or not it forms pitching troughs that control the localization of the ore body.

\section{SHAPE AND SIZE OF THE ORE BODIES.}

Because of the wide variety of conditions outlined under the preceding heading, the shapes of the deposits of this region are so various that they may collectively be designated by the term "amoboid," though there are several groups of more uniform shape, as described below. They may be roughly tabular in a horizontal plane, as in the Mesabi district, or 
roughly tabular in steeply inclined planes, or in steeply pitehing linear shoots, as in the Menominee clistrict, or they may assume almost any combination of these shapes. The mine cruss soctions (Pls. X, XXVIl; figs. 14, 29, 36, 46, 47, 48) will give the best notion of the shapes of the ore bodies.

The horizontal dimensions known at the surface range up to a mile. Indeed, in the Hibbing area of the Mesabi district the deposits are more or less comected for a distance of 10 miles, and the horizontal area would range up to 2 square miles. The maximum depth of iron mining in the Lake Superior region at the present time is 2,200 feet, in the Gogebie district.

It is therefore apparent that the size, shape, and structural relations of the Lake Superior ores are of willest variety. In the flat-lying formations of the Mesabi district the ore bodies have wide lateral extent as compared with depth, have extremely irregular outlines partly controlled by jointing, abut irrecularly on the bottom and sides against unaltered portions of the iron-bearing formation, and when the glacial overburden is removed are accessible to surface operations with steam shovels. Steeply dipping formations, comprising most of the formations of the districts other than the Mesalbi, have greater vertical dimensions as compared with horizontal dimensions, usually abut not only against unaltered parts of the iron-bearing formation but agrainst well-defined impervious walls consisting of slate, quartzite, dolomite, or bosses or dikes of greenstone, and must be worked by underground mining.

\section{TOPOGRAPIIC RELATIONS OF TIIE ORE BODIES.}

The ore deposits are associated with hills or ranges, a fact that explains the common use of the term "range" in connection with the ore-proucing districts. There are, howerer, exceptions to this relation in the Cuyuna district of Uinnesota and perhaps elsewhere, as shown in the detailed descriptions. The ore deposits occur in places on the top of the hill, as in the Vermilion district; commonly in the midclle slopes, as is well illustrated by the Mesabi district, and on the low ground adjacent to the hills, as in parts of the Gogebic, Marquette, and Menomince districts. In general the middle slopes seem to be favored, but there are so many exceptions to this that there is no warrant for limiting prospecting to such localities. As the formation of the ore bodies is a function of the rapid circulation of waters from above, it is believed that the common association of the ore dèposits with lills may be due to the fact that these are places where the circulating waters have considerable liead. It would not follow that ore deposits should for this reason be confined entirely to the vicinity of hills, for circulation, perhaps less deep, seems to be effective also in relatively flat areas, as in the Cuyuna district of Minnesota. The eflectiveness of the head at different elevations and with different structural relations is not well known. It is to be remembered, also, that the ore deposits have not been concentrated entirely in relation to the present topography, but that when these deposits were formed the topography was more or less different, and that, therefore, ore deposits now found independent of topographic elevations may still have originated under control of an eleration which has since been removed. Notwithstanding these various linitations, to be considered in the interpretation of the relation of ore deposits to topography, the present prevalence of hy far the greater number of ore deposits on the middle slopes of the ranges is extremely suggrestive, for these are the places where the flow of meteoric waters dircetly from the surface should be at a maximum.

\section{OUTCROPS OF TIIE ORE BODIES.}

By far the greater number of the Lake Superior ore deposits are softer than at least one of their walls. They therefore oceupy depressions which are largely covered with gracial arift and generally they do not outcrop. I few of the ores, such, for instance, as the hard ores of the lermilion and dlarquette districts, are nearly or quite as hard as the wall rock, have resisted erosion, and here and there project above the miantle of arift. Considering the number of ore bodies in the hake superior region and their variety of structural relations, it is surprising that so few lave been found to outcrop. The tean siliceous and magnetic parts of the iron-bearing formations lave withstool crosion to such an extent that they outerop rather commonly. These, together 
with magnetic variations, have served as guides to the location of the iron-bearing formations and have led to the discovery of ores in the covered areas by underground work.

In the iron-ore deposits that have their greatest dimensions on the erosion surface the ratio of area of iron ore to area of iron-bearing formation is greater than the ratio of tonnage of iron ore to tonnage of iron-bearing formation. In the Mlesali district the former runs up to nearly $\&$ per cent for the producing part of the district; in most of the other runges it is far smaller, usually less than 1 per cent.

\section{CHEMICAL COMPOSITION OF TIE ORES.}

The average composition of the iron ore mined in the Lake Superior region during the years 1906 and 1909 , as shown in the table below, has been calculated from the cargo analyses published by the Lake Superior Iron Ore Association, of Cleveland, tugether with analyses of ores of different mine grades furnished by individual mining companies. The averages are olstained by combining all grades in proportion to their tonnage, and the table represents more nearly the average composition of all the ore mined in the Lake Superior region in any one year than anything before attempted. Analyses of iron ore used in other parts of this report are also taken from the Lake Superior Iron Ore Association's tables unless otherwise stated.

Analyses of iron ore may represent the composition of a dried ore (dried at $212^{\circ} \mathrm{F}$. or $100^{\circ} \mathrm{C}$ ), or ther may show the composition of the ore in its natural moist condition as it comes from the ground. The latter are designated natural analyses and include the moisture or uncombined water as one of the constituents of the ore. The natural iron content is the basis on which the value of ore is figured commercially. It may he computed from the iron eontent of the dried ore and the moisture, as follows: Percentage of natural iron = percentage of iron in dried ore $\times(100$ - percentage of moisture). The following average analyses represent the dried ore:

Average composition of total yearly production of Lake Superior iron ore fur the years 1906 and 1909.

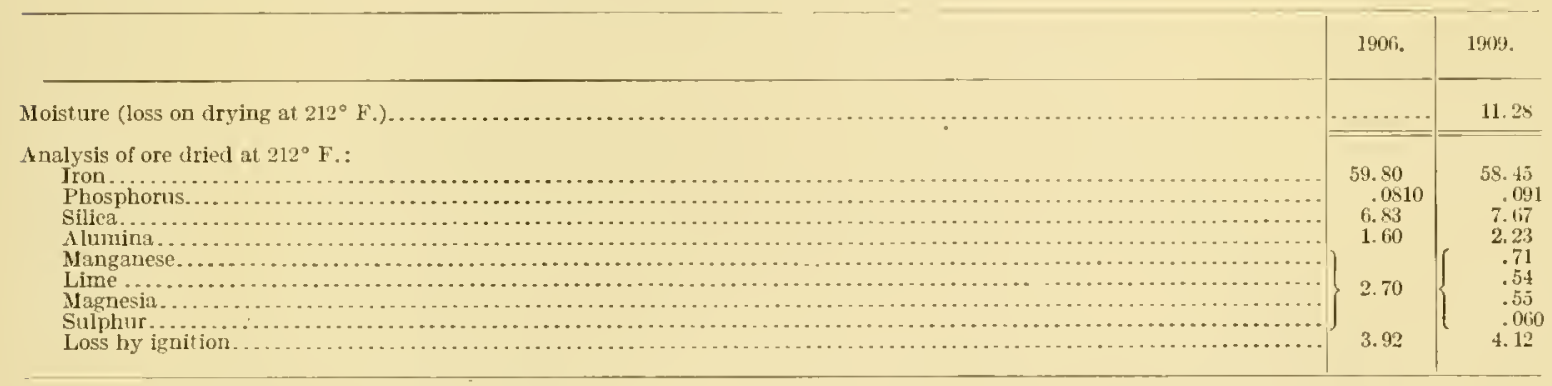

The range in percentages shown by the analyses from which the foregoing averuges are derived is as follows:

Range in percentage for each constituent of ores mined in 1906 and 1909 , as shown by average cargo analyses.

\begin{tabular}{|c|c|c|}
\hline . & 1906. & 1909. \\
\hline Moist ure (loss on drying at $212^{\circ} \mathrm{F}$.) ............. & ........ & 0.50 to 17.40 \\
\hline 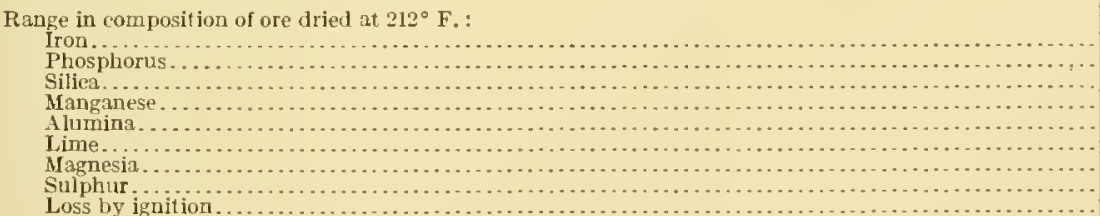 & 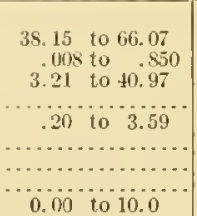 & $\begin{array}{l}35.74 \text { to } 65.34 \\
.005 \text { to } 1.25 \\
2.50 \text { to } 40.77 \\
.00 \text { to } 7.20 \\
.16 \text { to } 5.67 \\
.00 \text { to } 4.96 \\
.00 \text { to } 3.98 \\
.003 \text { to } 1.87 \\
.10 \text { to } 11.40\end{array}$ \\
\hline
\end{tabular}

The sulphur in the Lake Superior ores ranges from a trace to 1.87 per cent and in some of the ores of the Florence, Iron River, and Crystal Falls districts it is present in sufficient quantity to affeet the value of the ore. Titanium is not present in the Lake Superior sedimentary ores in amounts suffieient to be harmful. The titanium content of the ores varies from 0.1 to 0.2 per cent, $\mathrm{TiO}_{2}$, but in some of the hard magnetite ores of the Marquette district it is found to run as 
high as 1.6 per cent. 'Titanim is higher in the paint rocks and interbedded slates than in the ores themselves.

The proportions and ranges of the constituents for the individual districts are given under the discussions of the districts. Fignre 71 slows the chemical compositions of all grades of ore mined in the region in 1906, in terms of ferricoxide, silica, and minor constituents. This arerage is lower in iron than those of previous years. (See pp. 493-494.)

The grade of ore shipped and its general unifornity for given districts and periods are primarily cont rolled by the nature of the ores available, yet the commercial conditions to some extent

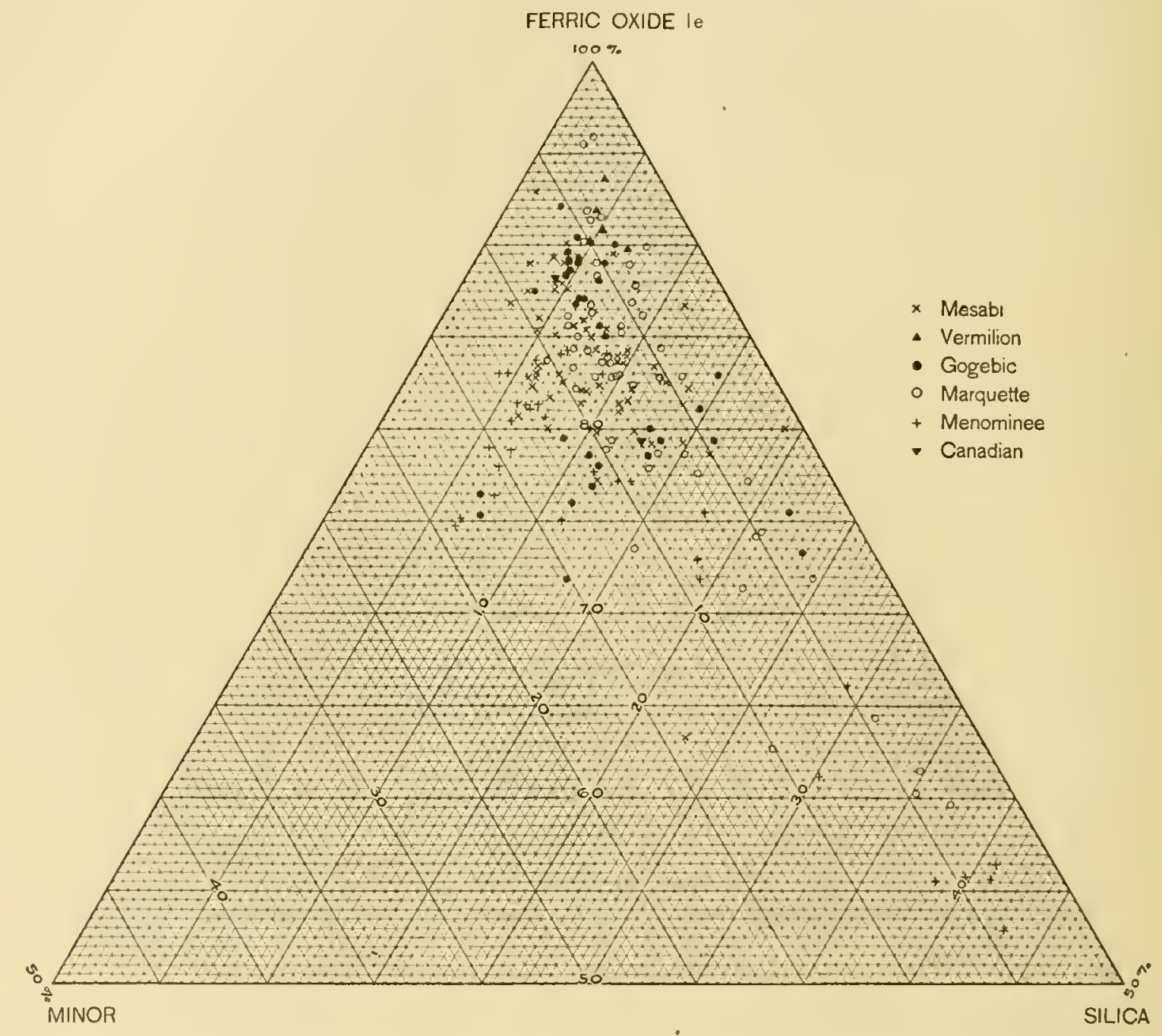

CONSTITUENTS

FIGURE 71 , - Trianguiar diagram showing chemical composition, in terms of ferric oxide, silica, and minor constituents, of all grades ol iron

ore numed in the Lake Superior tegion in 19hk. The ores of each district are indicated by distinctive symbols. lior description of this method of platting, see p, 182 .

determine the grale shipped. For instance, if high, medium, and low grale ores are arailable, a period of financiat depression may make it possible to ship only the highest grade ores, whereas business prosperity may make it possible to mix consilerable quantities of lower grate ores with those of higher gralde, thereby lowering the average grade. This control by enmuereial conditions is further illustratod by the fact that the acid Bessemer sted process for vears determined that an unusually bigh proportion of low-phosphorus ores were to be shipped. ${ }^{a}$ "The

a A Bessemer ore is one which will with a proper flux and coke make a pig iron in which the phosphorus does not exceel 0.1 per cent. $1 \mathrm{t}$ is approximntely true that a Bessemer ore is one in which the content of phosphorus divined by the content of iron gives a guotient not exeeding

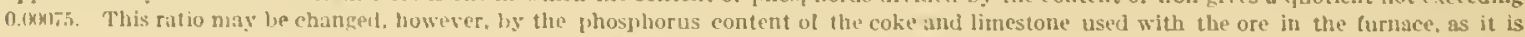
necessary 10 tigure on the phosphorus in the nux and fuel as well as that in the ore itself. 
recent rapid development of the open-hearth prucess has allowed shipment of ores lrigher in phosphorus. The development of the hasic open-learth process depends ultimately on the arailability of large reserves of non-Bessemer ore, but in turn the development of the open hearth reacts upon and determines the grade of ore shippen from any district or for any period.

\section{MINEIRALOGY OF TIIE ORES. .}

The iron-ore minerals in general are as follows:

Magnetite: Magnetic oxide $\left(\mathrm{Fe}_{3} \mathrm{O}_{4}\right)$, including titaniferous magnetite. Theoretical iron content of the pure mineral, 72.4 per cent; generally containing some bematite.

Hematite: Anhydrous sesquioxirle $\left(\mathrm{Fe}_{2} \mathrm{O}_{3}\right)$, including specular hematite, red fossil ore, oolitic ore, ete. Theoretical iron content of the pure mineral, 70 per cent.

Brown ore: Hydrous sesquioxide $\left(\mathrm{Fe}_{2} \mathrm{O}_{3} \cdot \mathrm{nI}_{2} \mathrm{O}\right)$, including turgite, limonite, goethite, or a mixture of these minerals, known locally as brown hematite, bog ore, gossan ore, ete. Theoretical iron content of iron minerals, 59.8 to 66.2 per cent, depending on degree of hydration.

Carbonate: Siderite, iron carbonate $\left(\mathrm{FeCO}_{3}\right)$, known locally as spathic ore, black band ore, etc. Theoretical iron content of the pure mineral, 48.2 per cent.

The Lake Supcrior iron ores are (1) soft, brown, red, slaty, hydrated hematites; (2) soft limonite; (3) hard massive and specular hematites; (4) magnetites; and (5) various gradations between the other classes. The proportions for the entire region of these different classes shipped in 1906, as ealculated from average cargo analyses, are as follows:

Total production of iron ore in Lake Superior region, by yrades, for 1906.

\begin{tabular}{|c|c|c|}
\hline Class of ore. & Tons. & $\begin{array}{l}\text { Per cent } \\
\text { of total. }\end{array}$ \\
\hline \multirow{2}{*}{ 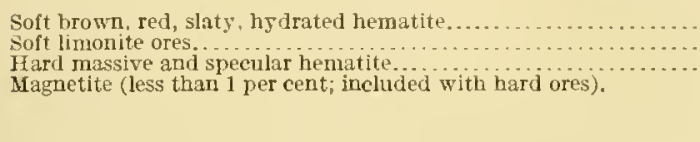 } & $\begin{array}{r}35,652,174 \\
2,7+1,323\end{array}$ & $\begin{array}{r}93 \\
7\end{array}$ \\
\hline & $38,393,497$ & 100 \\
\hline
\end{tabular}

The approximate mineral composition of the average ore of the entire region for the years 1906 and 1909 , calculated from the average analyses, is as follows:

A proximate mineral composition of average iron ore of Lake Superior region for 1906 and 1909 .

\begin{tabular}{|c|c|c|}
\hline & 1906. & 1909. \\
\hline 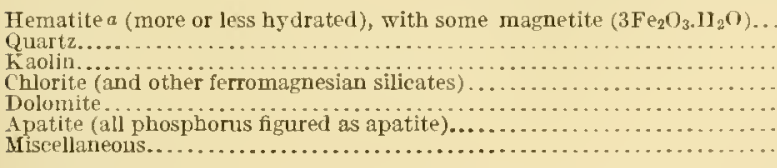 & $\begin{array}{r}88.60 \\
4.53 \\
6.87\end{array}$ & $\begin{array}{r}86.45 \\
1.89 \\
5.25 \\
1.01 \\
.81 \\
.48 \\
1.11\end{array}$ \\
\hline & 100.00 & 100.00 \\
\hline
\end{tabular}

a The iron minerals may be expressed in terms of hematite and limonite as follows: 1906, hematite 66.60, limonite 22.00; 1909, hematite 66.75, limonite 19.70. These minerals do not, in fact, exist in these proportions, there being a number of hydrates between hematite and limonite.

The mineral compositions above given are necessarily only approximate, as ferrie and ferrous iron are not separated in the chemical analysis, and water, carbon dioxide, and possibly a small amount of organic matter are all included uncler loss on ignition. The mineral compositions were ealculated from the average analyses, as follows: All phosphorus was figured as apatite; the remaining lime was combined with the proper amount of magnesia and $\mathrm{CO}_{2}$ to form dolomite; the remaining magnesia was combined with the proper amounts of alumina, siliea, and water to form chlorite; the alumina not rused for ehlorite was taken with sufficient silica and water to form kaolin; the remaining water, combined with the iron figured as ferric oxile, was figured as hydrated hematite.

The proportions of the different minerals for the individual districts calculated in the same way are given in the discussion of these districts. 
In the above table are mentioned the abundant mincrals associnted witl the iron, such as quartz, kaolin, and chlorite. Many of the minemls termed miscellancous in the table are present in small announts at a few places. Some of these minerals are apatite, adularia, wavellite, calcite, dolonite, sillerite, pyrite, marcasite, chalcopyrite, tourmaline, masonite, ottrclite, chlorite, mica, garnot, rhodochrosite, manganite, pyrolısite, barite, gypsum, martite, aplurosiderite, analeite, gocthite, and turgite.

Though many of the Lake Superior ores are slightly magnetic, there are only two mines in the region which ship ores classed as magnetite ores, the Republic and Champion, and even these ores are largely specular hematite with considerable quantities of magnetite. There are in the region, however, great quantities of lean nontitanferous magnetic iron-bearing roeks, as at the east end of the Mesabi range and in the Gunftint district, where the Duluth galubro cuts and overlies the iron-bearing formation; at both the east and west ends of the Gogebie range, where Keweenawan intrusive rocks cut the iron-bearing formation, and in parts of the Marcquette district.

The magnetite ores consist of coarse-grained magnetite-quartz rock carrying a considerable rariety of metamorphic silicates, including amphiboles, pyroxenes, garnets, chlorites, olivines, cordierite, riebeckite, dumortierite, etc. (See pp. 545 et seq.) Locally pyrite, pyrrhotite, and iron carbonate are present. The minerals show greater rariety and more complex chemical constitution than those of other phases of the iron-bearing formation. Where altered at the surface the magnetite may be locally coated with limonite and the silicates may hare gone over to chlorite, epidote, and calcite. The yellowish-green colors so developed are extremely characteristic of the surface of the exposures.

\section{PIIYSICAL CIIARACTERISTICS OF THE ORES.}

\section{GENERAL CHARACTER.}

The ores range from the massive and specular hematite and magnetite through ores which are partly gramular and earthy and partly in small hard chunks to ores which are almost entirely soft and earthy (Pls. XXXVIII and XXXIX). There is no rery sharp distinction between the hard ores and the soft ores. The latter make up the great bulk of the annual shipments; of the ore shipped in 1906 fully 93 per cent would be classed locally as soft ores. The principal liurd ores come from the Vermilion district and from the upper horizons of the Negaunee formation in the Marquette district. Most of the soft ores contain small hard chunks, usually bounded by parallelepiped phases due to being broken up in the bed by minute joints. Screening tests showing the textures of the typical ores for each of the districts are given in the chapters on the individual clistrists. A summary of these screening tests for atl the Lake Superior ores is shown graplically in figure 72. The data of the sereening tests on the different ores were kindly furnished by the Oliver Tron Mining Company.

There is a striking contrast in the coarse texture of the magnetite ores and the fine cherty textures of the other phases of the iron-bearing formation. The quartz grains in the jaspers of the eastem part of the Marquette clistrict average from 0.01 to 0.03 millimeter, whereas in the western and southwestern portions of the same district in the amphibole-nagnetite phases of the iron-bearing formation the quartz grains a verage about 0.1 to 0.4 millimeter and run as high as 1 millimeter. The quartz grains of the amphibole-nugrnetite rocks may thus have a nillion times the volume of those of the jaspers. The quartz grains near the grabbro in the eastern part of the Mesabi district reach a diancter of 3 or 4 millineters, but in the central and western portions of the district they are in general not greater than 0.1 millimeter. In a given amplibolemagnetite rock the grains are fairly uniform in size and have a tendeney toward polygonal shape (sce Pl. XLVII, A, p. 54s), whereas in the other parts of the formation they are most irregular in size and slape (see PI. XIIV, p. 534) and show the characteristic scalloped boundaries of cherts.

The mineral density of the ores ranges from 3.5 to 5.0 and averages about 4.30 ; the pore space ranges from less than 1 per cent to 60 per cent and averuges about 35 per cent: and the free moisture held in this pore space ranges from 0 to 16 per cent and averages about 10.42 per cent. 
PLATES XXXVIII-XXXIX. 


\section{PLATE XXXVIII.}

CuARACTERISTC SPECIMENS OF IRON ORES.

1. Suft hematite from Mlesabi district, Minnesola.

B. Hard hematite from Ely, Minnesota.

C. Hard lematite from Gogebic district, Michigan.

Ures of these kinds forn 93 per cent of the Lake Supurior shipments.

\section{PLATE XXXIX.}

\section{CHARACTERISTIC SPECIMENS OF IRON ORES.}

A. Harrl hematite from Marquelte district, Michigan.

b. Sipecular hematite from Marçuetle district, Michigan.

('. Magnetite from westem Marquette dis'rict. Michigan.

These ores form 7 per cent of the lake Superior shipments. 

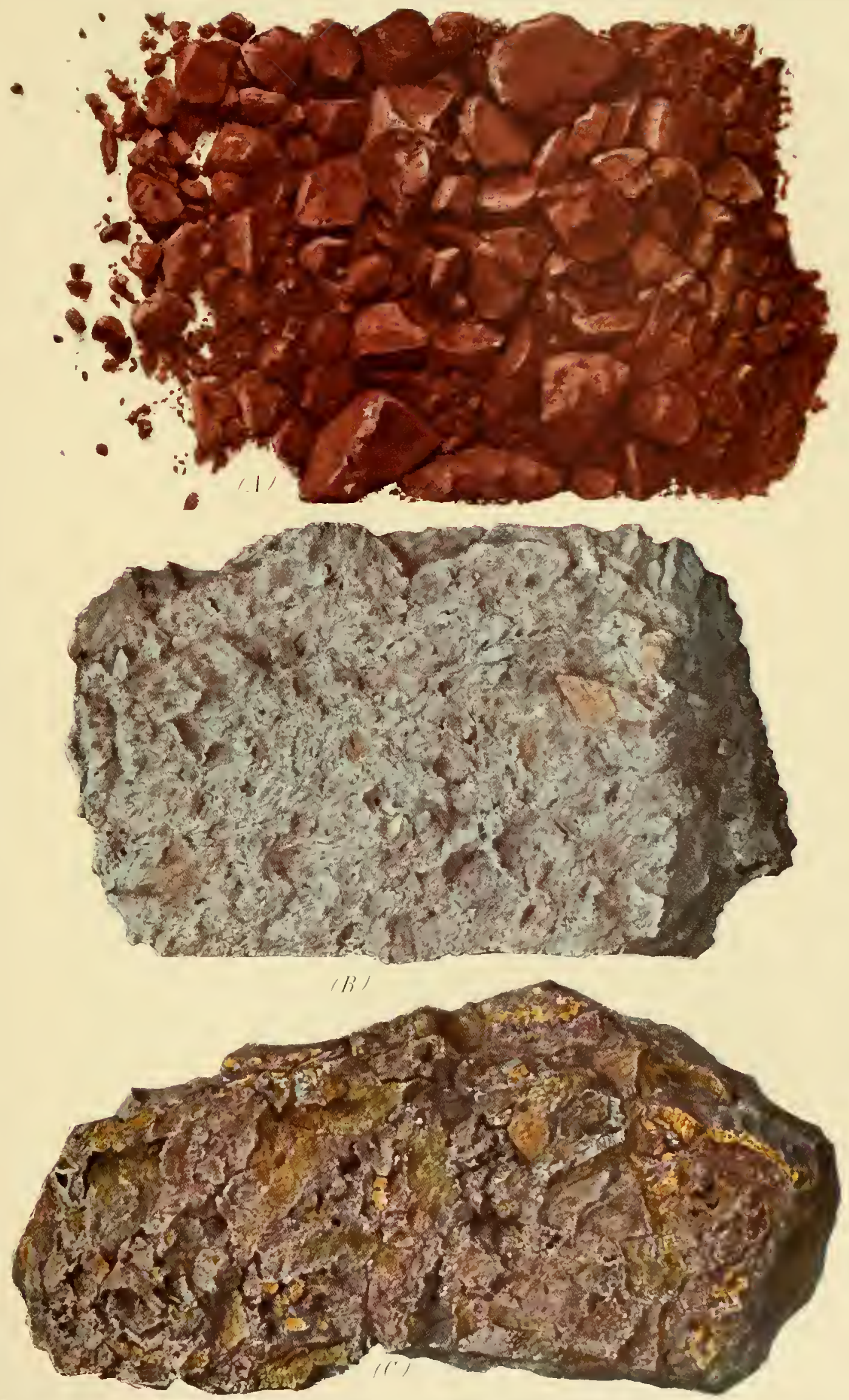

CHARACTERISTIC SPECIMENS OF IRON ORES 


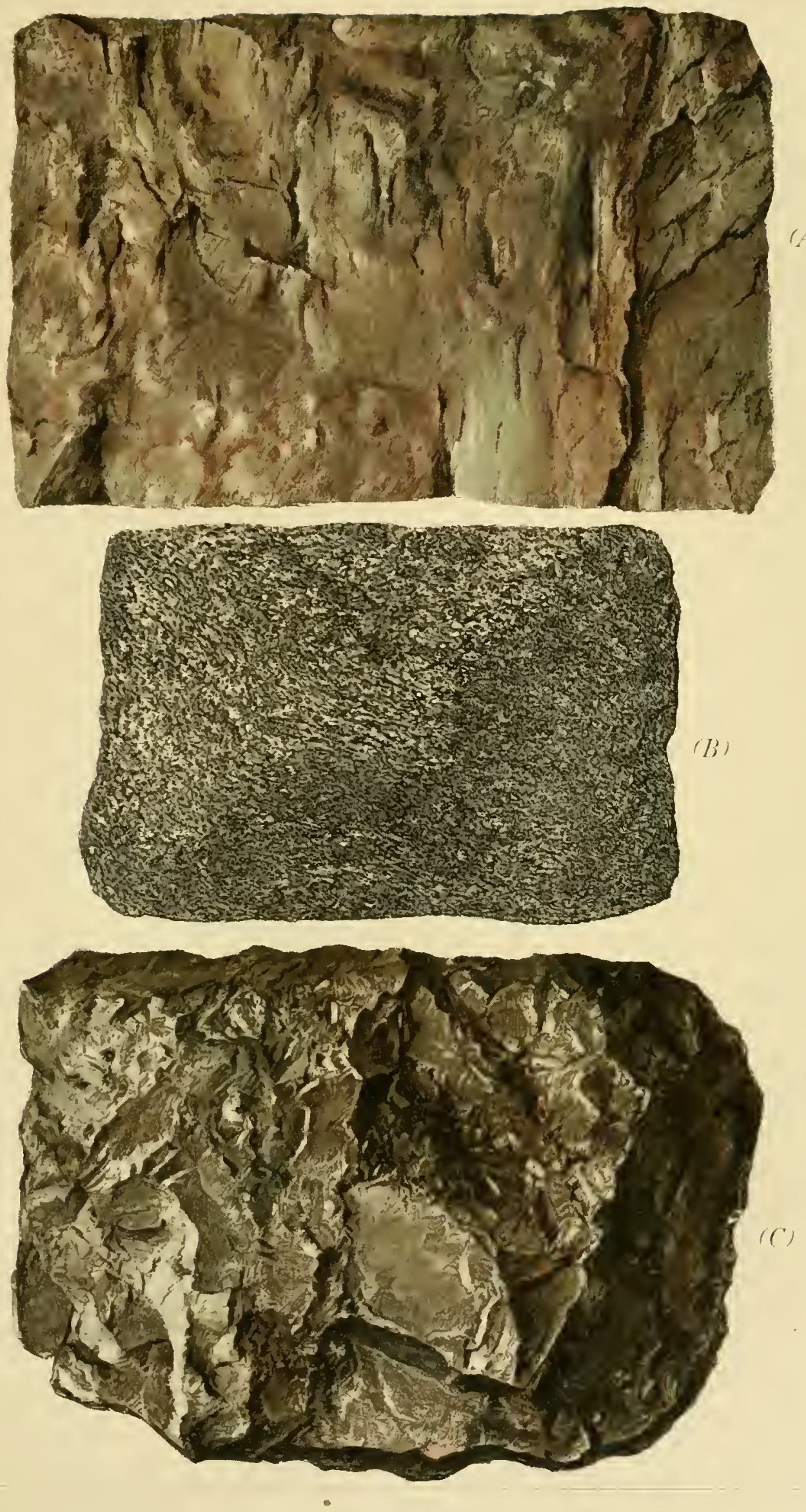


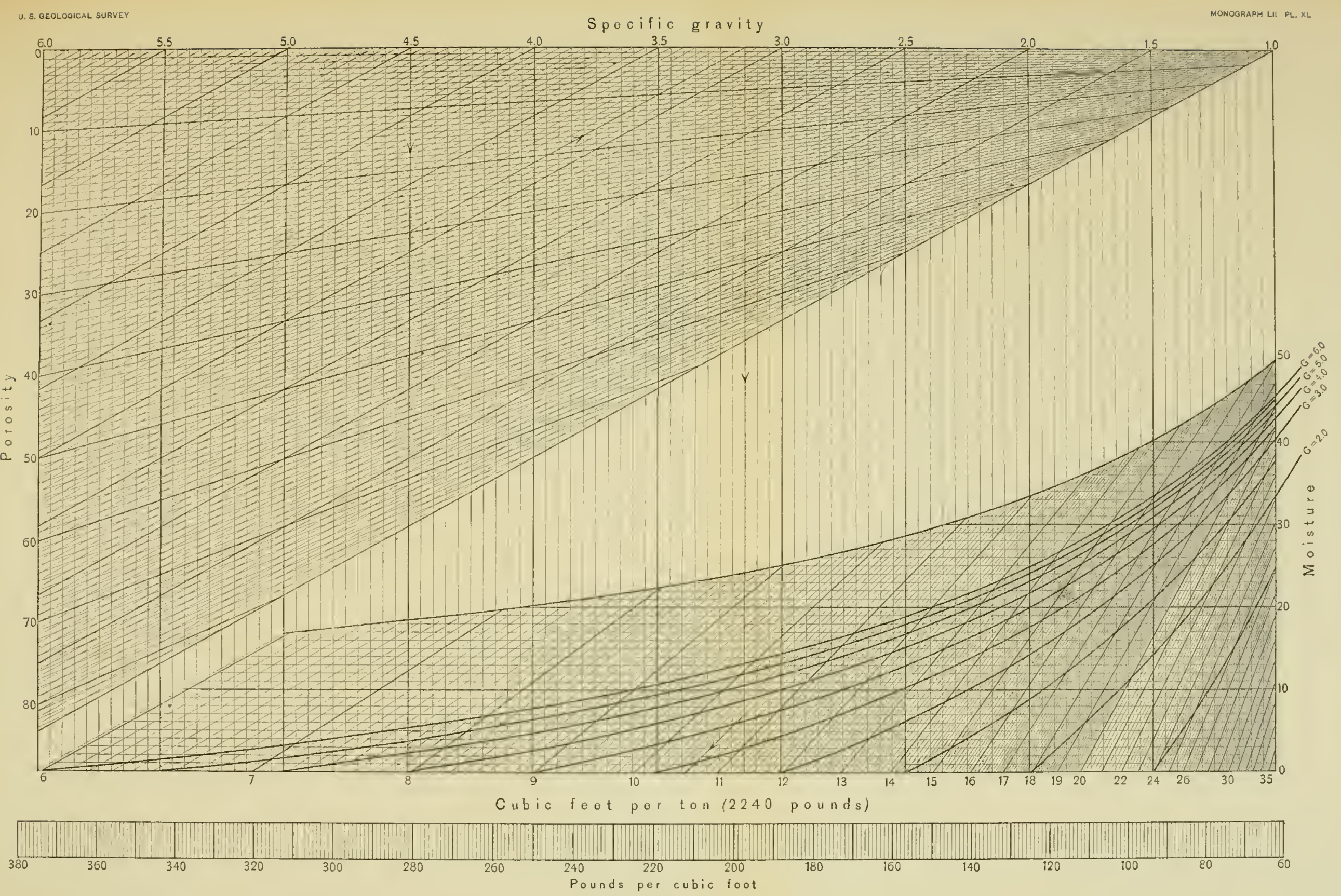

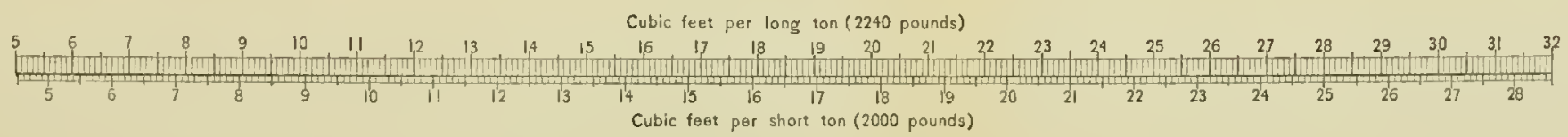

DIAGRAM SHOWING RELATION OF DENSITY, POROSITY, AND MOISTURE TO CUBIC FEET PER TON. 

THE IRON ORES.

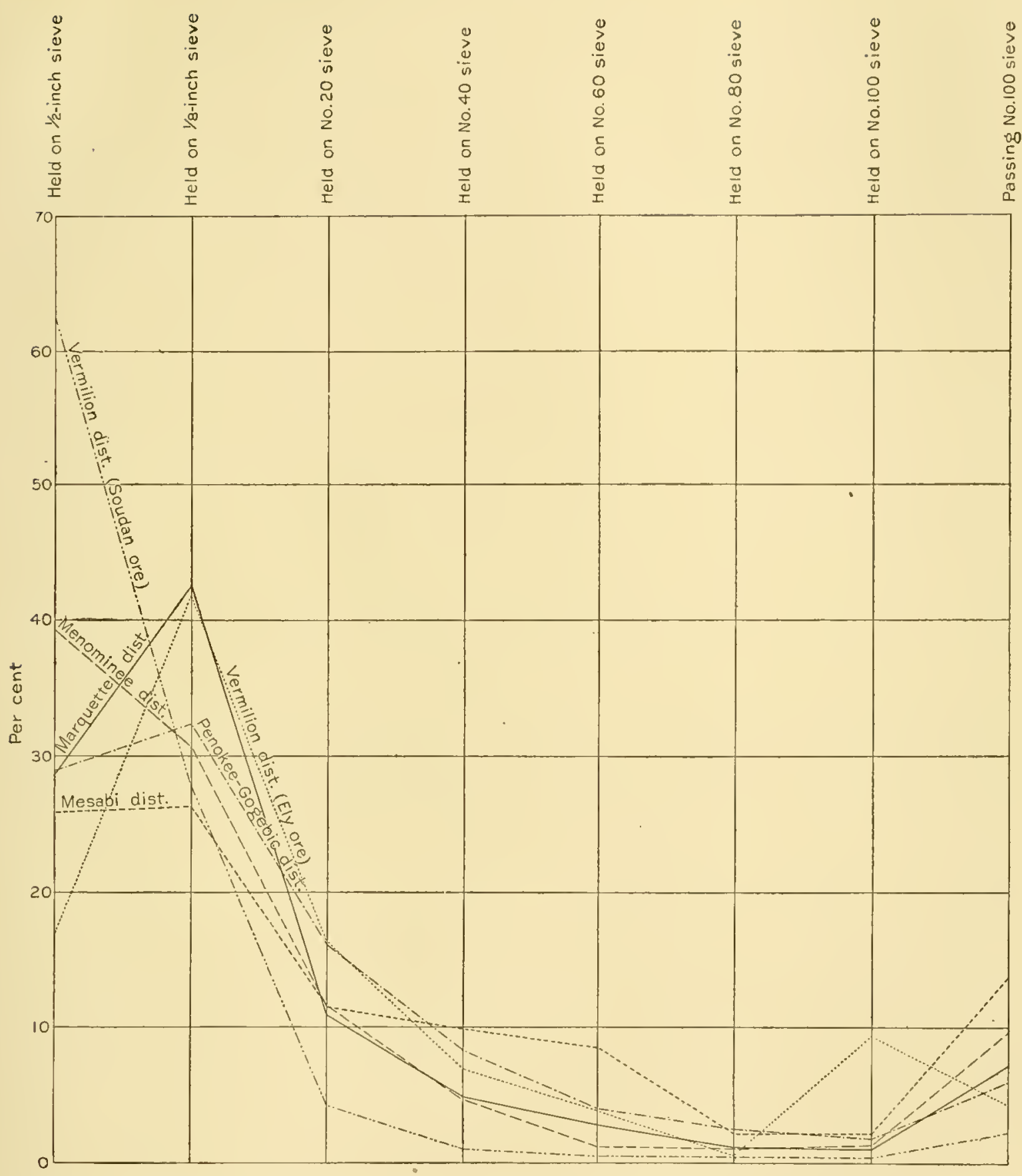

Figtre 72,-Testures of Lake Superior iron ores as shown by screening tests. Bimeekly samples, representing 43 grades of ore and an aggregate of $22,376,723$ long tons, were taken by the Oliver lron Mining Company during 19n9, and tests were made on the arerage year's sample. The results of mine tests are averaged for each district in proportion to the tonnage mined to give the figures shown on the diagram.

\section{CUBIC CONTENTS OF ORE.}

RANGE AND DETERMINATION.

The cubic content per ton ranges from 7 cubic feet for the hard ores to 17 cubic feet for the soft ores. It depends on the density, the pore space, and the moisture and may be calculated directly accorling to the method following.

$$
47517^{\circ}-\text { VOL } 52-11-31
$$


The cubie content of an ore is a direct function of (a) true specific gravity of the materialthat is, the specific gravity unaffected by porosity or moisture; $(b)$ porosity of the material, in terms of percentage of volume occupjed by pore space or voils; $(c)$ pereentage of moisture in the material-that is, the percentage loss in woight on drying at $110^{\circ} \mathrm{C}$.

To facilitate the determination of the cubic content of ores the diagran or graphic equation shown in Plate XL was devised, expressing the relation between these three fuctors and the number of eubic feet per ton. Aetual determinations in the ground are unsatisfactory in that they do not show the individual effects of the three factors mentioned, especially moisture content, which may vary widely at different times and places. By use of the dingram the three factors are consilered separntely and their individual, relative, and net effects may be observed. The use of the diagram is not confined to iron ores but is also applicable to other ore or mineral substance in the ground.

\section{USE OF THE DIAGRAM.}

The operation of the diagram may perhaps be male clear most easily by applying a concrete problem as an illustration. Given an ore with a specific gravity of 4.5 , porosity 30 per cent, and moisture 7 per cent. Select a point on the upper edge of the diagram indieating the given specifie gravity (4.5); from this point move downward, as indicated by the clotted line, to the line representing the given porosity. (There are two sets of inclined lines crossing the upper part of the diagram; the less steeply inclined set, numbered at the left side of the diagram, indicates degree of porosity.) From this point move upward to the right along the more. steeply inclined lines to the edge of the diagram. This point (3.15) indieates the specific gravity as correeted for porosity. From this point move directly downward to the lower edge of the diagram, where the number of cubic feet per ton is indicated. This shows 11.4 cubic feet per ton of dry material. The factor of moisture has not yet been considered. When moisture is present the material is heavier and consequently the volume per ton smaller. To introduce this factor of moisture, move directly upward from the last point (11.4) to the horizontal line indicating the given percentage of moisture ( 7 ), and from this point down the inclined line to the lower edge of the diagram, where the number of cubie feet per long ton is found to be 10.6 .

At the lower elge of the plate is a transformation table showing the relation between cubie feet per long ton $(2,240$ pounds) and cubic feet per short ton $(2,000$ pounds). For example, 10.2 cubic feet per long ton is equivalent to 9.1 cubie feet per short ton.

\section{CONSTRUCTION OF TIIE DIAGRAM.}

The following discussion of the deriration of the diagram is given with the idea that one cesiring to make use of it woukd first wish to be assured that it rests on a rational mathematical basis.

The top and bottom lines of the diagram proper, labeled respectively "Specific grarity" and "Cubie feet per ton" and connected by parallel rertical lines, constitute a transformation table by means of which the number of cubic feet per ton of a material of a given density may be at once determined (or vice versa) by moving vertically between the upper and lower edges of the diagram. Immediately helow the edge of the diagram proper is a scale of pounds per cubic foot, which may be used by moving vertically downward from any point on the "specific gravity" or "eubic feet per ton" scales.

Effect of porosity.- The effeet of porosity is to decrease the density of a substance, hence rock speeific gravity is less than mineral specific gravity in proportion to the degree of porosity of the material considered. To introduce the fuetor of porosity in the diagram, the upper line was extended to the right to the point indicating a specific gravity of zero (not shown on the diagram). The line at the left edge of the diagram was drawn perpendicular to the upper edge and divided into 100 equal divisions, representing percentages of pore space. Each of the points of the vertical "porosity" line was then connected with the point indicating a specific gravity of zero. Henee on moving vertically downward from any point on the "specific gravity" line, a succession of equally spaced lines are crossed inclieating percentages of pore space. To enable the dingram to show automatically the change in specific gravity resulting from a given porosity of a substance ol known mineral specific gravity a set of parallel lines was drawn, properly connecting points on the "porosity" and "specific gravity" lines. These lines were 
drawn parallel to the line conneeting 100 per cent porosity with zero specific gravity and agree with the following formula:

$$
\dot{G}_{r}=r_{m}(1-P)
$$

where $C_{r}^{\prime}=$ rock specific gravity, $G_{m}=$ mineral specific gravity, and $P=$ porosity. The diagram then automatically shows the relation between mineral specific cravity, porosity, aud cubic feet per ton. To illustrate, a certain ore with a mineral specific gravity of 5.0 has 40 per cent of pore space. Beginning at the point 5.0 on the upper elge of the diagram, move downward to the line indicating a porosity of 40 per cent; from this point move along the parallel inchned lines upward to the right, to the elge of the dingram, where the specifie gravity as reduced by pore space (rock specific gravity) is found to be 3.0 ; inmediately below this point, on the lower edge of the diagram, it is seen that the ore runs 11.95 cubic feet per ton and 157.25 pounds per cubie foot.

Effect of moisture.-The diagram so far takes no account of moisture and hence is applicable only to perfectly dry material. Moisture when present in an ore or similar substance occupies the pore space. When the pore space is filled with moisture the material is said to be saturaterl. As the moisture occupies the natural openings in the ore, its presence aflects the weight of the ore and not its volume, hence its effect is to increase the density and decrease the number of cubic feet per ton. Moisture is expressed in percentage of total weight.

Let $D=$ density as affected by porosity; then, as a culic loot of water weighs 62.5 pounds,

$$
\text { Cubic feet per ton }=\frac{2,240}{D \times 62.5}
$$

When moisture $(\boldsymbol{M})$ is present the above equation becomes-

$$
\text { Cubic feet per ton }=\frac{2,240(1-M)}{D \times 62.5}
$$

The lower part of the diagram is crossed by a set of parallel horizontal lines indicating percentages of moisture, as shown at the right-hand edge of the diagram. Following the above equation, a set of inclined lines were drawn, properly connecting points on the "moisture" and "cubie feet per ton" lines. Given the number of cubic feet occupied by a ton of any porous material when dry, the effect of any percentage of moisture is indicated automatically by the diagram. For example, a certain ore when dry occupies 12 cubic feet per ton; it is desired to know the effect of 10 per cent of moisture. From the point 12 on the lower edge of the diagram move vertically upward to the horizontal line indicating 10 per cent moisture; from this point move downward along the inclined line to the edge of the diagram, where it is found that the moist material occupies 10.8 cubie feet per ton.

Moisture of saturation.- Up to this point it has been shown that, given the mineral specific gravity, porosity, and moisture content of an ore or similar substance, the diagram automatically indicates the number of cubic feet per ton. In many classes of ore the factor of moisture is the most variable of the three named alove. The mineral specific gravity and porosity of an ore determine the amount of moisture which it ean hold. This Inaximum, or moisture of saturation, may be calculated as follows:

$$
\begin{aligned}
& G_{m}=\text { mineral specifie gravity. } \\
& D=\text { density of dry porous material. } \\
& P=\text { porosity. } \\
& M I=\text { moisture of saturation. } \\
& D=G_{m}(1-P)
\end{aligned}
$$

from which $P=1-\frac{D}{G_{m}}$ and $M=\frac{P}{G_{m}(1-P)+P}$

Substituting the value above given for $P$ -

$$
\boldsymbol{M}=\frac{1-\frac{D}{G_{m}}}{D+1-\frac{D}{G_{m}}}
$$


By substituting values for $D$ and $G_{m}$ in the above equation the curves for moisture of saturation were const ructed across the lower part of the diagram. These curves cmable one to detcrmine at once the moisture of saturation of any material, given the mineral specifie gravity and porosity. Each curve corresponds to a certain mineral specific gravity, and the moisture of saturation is found by moving vertically from the point indicating the number of cubic feet per ton of the dry material to the proper curve for moisture of saturation. For example, an or' with a mineral specilie gravity of 4.0 and a porosity of 36.0 per cent oceupies 14 cubic feet per ton if dry: its moisture of saturation is found by moving upward from the point 14 to the eurve $G^{\prime}=4.0$, and reading the indicated moisture-12.2 per cent; that is, 12.2 per cent of moisture would fill the pore space of this ore.

Excess of moisture handled in mining.-It frequently happens in mining that ore as hoister to the surface contains a larger percentage of moisture than it did before it was mined; in fact, it may contain a percentage of moisture greater than the moisture of saturation of the unmined ore. This may be caused by the landling of broken ore on undrained mine floors. The ore after being broken down has a much larger percentnge of voids than before and hence a greater ability to absorl, and retain moisture. The diagram is useful in this comnection in showing, from determinations of specific gravity and original porosity of hand specimens, the moisture of saturation of the ore in place. This figure compared with the percentage of moisture of ore as it leaves the mine tells at once whether or not an unnecessary amount of water is being hoisted with the ore, owing to improper drainage.

\section{EXPLORATION FOR IRON ORE.}

The location of explorations within the areas of the iron-bearing formations is determined by outcrops, by magnetie lines, by mining, and by general geologie structure. It has been possible to confine most of the explorition to the area of the iron-bearing formations, but in certain districts, notably the Cuyuna, Florence, Crystal Falls, and Iron River districts, the distribution and limits of the iron-bearing formation are so uncertain that much exploratory work has had to be done even to locate the formation. All the faets bearing on the distribution of the iron-bearing formation discussed in this monograph are taken into account in cloosing areas for exploration. Some of the larger mining companies employ their own geologists to make special reports on the geology of given areas as a preliminary to underground exploration, and nearly all the explorer's make liberal use of all the geologic information arailable in localizing their work.

As the few ore deposits exposed at the surface were foumd years ago, explorations are now largely conducted by drilling and sinking test pits and shafts. The large size of the iron-ore deposits makes it possible to find and outline them by drilling to an extent not possible in smaller ore deposits, with the result that the greater number of ore bodies, especially in recent years, are thoroughty explored by drilling before mining begins. It lass usually been assumed that if drilling does not locate an ore body it is useless to sink a shaft for this pupose. Mining operations have necessarily diselosed much ore which had not previously been found by Irilling, especially in certain distriets like the Menominee or the Gogebic, where the struetural conditions are such as to make the location of ore by drilling extremely dillicult. In the region as a whole mining operations have almost evervwhe diselosed greater rescrves of ore than the drilling had indicated.

The great dependence placed on drill work has resulted in enormons expenditure for this purpose. Aceurate estinates of the amount of drilling done so far in the region can not be male, but a rough estimate compiled from tentative estimates of engineers of the screral districts is as follows: 
Drilling done for iron ore in the Lake Superior region.

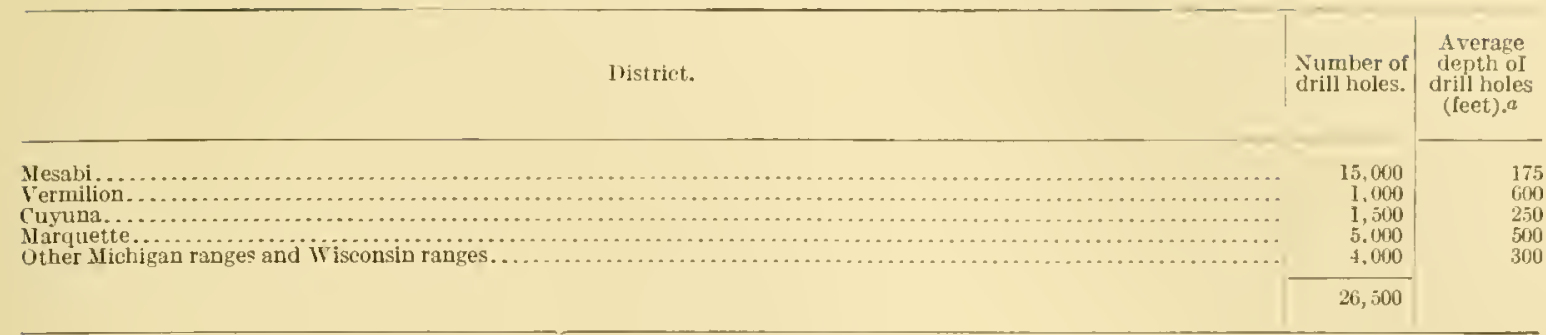

a Estimates probably low.

This totals $7,200,000$ feet, or about 1,363 miles of drilling. At an average cost of $\$ 3$ a foot, which is a low estimate, the total expenditure has been rough $h_{1} l_{y} \$ 21,600,000$.

It is estimated that at the present time there are 400 drills in operation in the region. In the earlier days of exploration test pits were relied upon to a large extent, especially in areas where the surface drift is thin and the water level below the rock surface. This method of exploration, however, is unsatisfactory because of the great depth of the drift at many places, the difficulty of handling water, and the difficulty after finding the ledge of penetrating it by this method. In later years the use of test pits has been largely superseded by drilling.

Both diamond and churn drills are in use. Through surface and soft-ore formations the churn drill is used. Much of the Mesabi district may be so explored. The cost of churn drilling has ranged from $\$ 1$ to $\$ 3.50$ and areraged about $\$ 2.50$ a foot, varying from district to district according to accessibility and cost of transportation and other factors. The cost of diamond drilling has ranged from $\$ 2.25$ to $\$ \$$ a foot and arerages at present about $\$ 3.75$, but varies from district to district. 'Test pits are cheap, averaging perhaps $\$ 1.25$ a foot.

The necessity for the most careful study of the structural geology in drilling is illustrated by the frequent failure of drills to locate ore dejosits even after what seemed to be careful drilling and the subsequent discovery of the deposits either by further drilling or by mining operations. Indeed, as one comes to realize the varicty and complexity of underground structural conditions, he is likely to become more and more disinclined to submit a negative report on any property, no matter how extensively it has been drilled. This difliculty is illustrated by the ore shoots in the Gogebic and Menominee districts, many of which hare been missed by drilling and picked up in mining operations. Nany of the ore shoots in the Tulcan member of the upper Huronian slate of Michigan pitch beneath the surface, following the axes of drag folds, and it is easy for drills to pass one side or the other, or, if the lrill hole is inclined, to go above or below them. On examination of drilling plats of exploration areas it is easy to see where linear shoots of ore might pass through at places not penetrated by the drilling. In fact, drilling in some of these localities is almost as uncertain as shooting a birl on the wing. There are many ways of missing the ore. As knowledge of structural conditions increases, however, adverse chances diminish, with the result that in certain areas after the local structural problems are solved, it is possible to drill with a high degree of success.

A higher average of success in drilling woukl unquestionably result if greater care were taken in the interpretation of drill records. The drill runner is often allowed to report the character of the drillings and the samples are not kept, with the result that many rahuable inferences that might be drawn from the lithology, the dip and strike of bedling and cleavage, and other features are lost. Not infrequently also failure to plat drill records in such a manner that they may be considered in three dimensions may cause promising chances for ore to be overlooked.

There has been a considerable tendency to generalize the principles of ore occurrence and in exploration to carry such principles from one district to another. As a matter of fact, although some of the basic principles are general for the region, the local variations of structure require the most careful sturly of each area to prevent mistakes in interpretation. When explorers of the Gogebic clistrict, where the ores lie in regular, impervious, pitching basins, went to the 
Mesabi distriet, where the rocks are of the same age, they naturally attempterl to use the same methods in axploration. But here the flatter dip of the formation, the shallowness of basins, the effect of overlying slates in ponding waters, and the unusually large influence of joints in localizing the concentration of ore made the finding of ore largely a new problem, which was solved at much expense and troulle. Recognizing the danger of carrying the methorl of cxplolation of one distriet into another, certain explorers lave gone to the other extreme and have attempterl to disrogard all guides derived from the study of the structural geology, with results even more unsatisfactory than if they had used principles developed for other districts.

Much the greater part of the exploration of the region lans been conducted without taking the fullest alvantage of all geologic knowledge araibable, but there has been a rapilly increasing tendency to follow geologic structure and therefore an increasing demand for geolugic information, as shown by the cordial support that the mining men have griven to the eflorts of the United States and State surveys in this region and by their considerable expenditures for private gcologic surveys. Certain of the drilling companics doing contract work now have geologists on their staff to aid in the interpretation of records, notwithstanding the fact that such interpretation is primarily in the hands of their clients. The problems of undergromed exploration are followed keenly, intelligently, and energetically by a large number of skilled men in the employ of mining companies, with the result that adrances are being made with a rapidity which is sometimes almost bewildering. Six months may sec the development of new facts requiring changes in the interpretation of the drilling of a district. The statenents as to structural conditions presented in another chapter of this book may require some modification by the time the book is given to the public, because of the amount of rapidly accumulating information in the interval between the writing and the printing.

\section{MAGNETISM OF THE LAKE SUPEIRIOR IRON ORES AND IRON-BEARING FORMATIONS.}

All ores of iron are found to be magnetic when tested by sufficiently delicate menns. Ordinarily magnetite is the only iron mineral which causes conspicuous disturbance of the magnetic needle. Practically all the Lake Superior iron-bearing formations contain at least minute quantities of magnetite, and hence all exert an influence on the magnetic necdle, but in widely varying degree. The non-bearing formation of the Vermilion district and other Keewatin areas is strongly magnetic. The same is true of the formation in the east end of the Mesabi district, the Gunflint district, the Cuyuna district, and the east and west ends of the Gogehic district, and of most of the Negaunce formation of the Marquette district. Less magnetic parts of the iron-bearing formations are those producing principally hematite and limonite, as the central and western parts of the Mesabi, the central part of tha Gogebic, and parts of the Ilenominee and Crystal Falls districts. The iron-bearing member of the Iron River district of Michigan affects the magnetic needle only 'ucally and slightly.

Every known iron-bearing formation $i$, the Lake Superior region, with the exception of that in part of the extreme west end of the Mesabi district, has been outlined partly as a result of magnetic surveys. In some of tae districts, as, for instance, the Iron River district, the magnetic ratriation is slight, but careful observations will detect it. In addition several magnetic belts are known in which exploration has not yet shown the character of the ironbearing formation. On the general map) (Pl. I, in pocket) magnetic belts are not indicated over all of the iron-bearing formations. They are shown only in places where the formation is not naturally exposed or uncovered by exploration.

Strong magnetic distubance does not necessarily mean orc, and, vice versa, ore does not necessarily cause strong mianctic disturbance. Lean amphibolitic schists may be highly magnetic, while rich hychated solt ore has but little effect on the needle. Although magnet ic disturbance is usually caused by an iron-bearing formation, it is also caused by certain basic igneous rocks, like the ellipsoidal basalts of the Keewatin or gabbro intrusives. There is little 
difficulty in ascertaining the cause of the attractions, however, for somewhere along most of the magnetic belts in the Lake Superior region there are outcrops which indicate the wature of the rock causing the disturbance. If the rock is entirely covered, it may still be possible to letermine whether the disturbance means iron-bearing formation or some other rocks. The ironbearing formations are selimentary deposits with certain limear characteristics of distribution, giving even lines or "belts" of magnetic attraction, whereas the basic igneous rocks are likely to cause a much more irregular magnetic field.

Because of the conditions above outlined, it is seldom practicable in the Lake Superior region to draw from magnetic observations inferences with regard to the shapes of the irouore deposits themselves as distinguished from the rest of the iron-bearing formation-such inferences as have been drawn by magnetic surveys of deposits in eastern Canada, Sweden, and elsewhere. In those regions the ores consist of magnetite associated with relatively nonmagnetic wall rocks, and the magnetic disturbances are produced by the iron ore itself, not by iron ore and wall rock; hence it is possible to draw satisfactory inferences as to the shape and attitude of the iron-ore deposits. In the Lake Superior region the magnetic attractions are useful in locating iron-bearing formations and thus ultimately the iron ore by underground exploration, but do not directly point out the iron-ore deposits themselves. The highly developed Swedish methods of determining both the intensity and the direction of the magnetic pull are therefore unnecessarily detailed and slow for use in the Lake Superior region, and when attempts have been made to locate ore deposits by them the results have been disappointing

Although the iron ores may not be discriminated by means of the magnetic disturbances, it is possible under some conditions to draw useful inferences from them as to the dip or folding of a buried iron-bearing formation. A sharp, narrow belt of magnetic attraction leading up to a definite maximum usually means a highly tilted formation presenting a narrow erosion edge at the rock surface, as in the Gogebic or Vermilion district. A wide, more irregular, and less well defined belt of attraction is ordinarily associated with a flatter dip, exposing a greater area of iron-bearing formation to the erosion surface. The producing part of the ironbearing Biwabik formation of the Mesabi clistrict illustrates this. Unequal magnetic gradient on two sides of a maximum may indicate the direction of dip of the iron-bearing beds. The outward dip of the iron-bearing formation about the Archean ovals of the Crystal Falls district is so indicated. Several roughly parallel, more or less discontinuous magnetic belts, here and there converging and joining, may indicate repeated pitching folds, as in the Cuyuna district.

General laws of interpretation of magnetic attraction require much local modification. It is usually necessary to ascertain for each locality the magnetic character of the iron-bearing formation, to correlate this with known facts from outerops or underground workings, and from the knowledge thus obtained to interpret the results of the magnetic formations in covered parts of the area where the magnetic readings alone are available. II. L. Smyth, ${ }^{a}$ in connection with much magnetic field work in the Lake Superior region, has developed mathematical relations between magnetic fields and various attitudes of the roek bects which may serve as a useful guide in detailed surveys.

The instruments which hare been used in Lake Superior magnetic surveys are the dip needle and the dial compass. "The dip needle determines the vertical component of the magnetic pull, as well as the direction of the horizontal pull; the dial compass deternines only the direction of the horizontal pull. Metlods of using and interpreting these instruments are discussed in detail by Smyth. The dial compass is essential in most of the work because it aflords means of keeping accurate directions necessary for location and of reading the horizontal component of the magnetic variation. It may be used only on sumy days, and thus magnetic work in the Lake Superior region is likely to be slow and expensive. The dip needle may be used at any time, but in a listurbed field it affords no means of keeping horizontal directions, and hence location. This is an essential defect in a country in which the roads and other works of man afford little aid in keeping location.

In theory the use of the magnetic needle is simple, but much practice is required to insure uniformly accurate observations. The unskilled observer finds many pitfalls in the mechanism 
of the instrument, in the manner of holding it, in the effects of temperature, in electrifieation from rubbing the glass, ete. There is much opportunity for the exercise of good jurlgment in the determination of the intervals at which realings shall be taken, the direction and number of runs, ete. These should be varied for different areas, depending on the structure found or suspected. Finally, the interpretation of the results calls for consileration and careful balancing of a great rariety of factors, capacity for which is acquired only by wide experience and painstaking observation.

\section{MANGA NIFEROUS IRON ORES.}

All the Lake Superior iron ores contain minute quantities of manganese, and certain ores carry as bigh as 20 to 25 per cent. In the Cuyma district of Minnesota a drill hole in the iron-bearing member averages 13 per cent for the upper 35 feet and about 2 per cent below. Another hole, in see. 28, T. 47 N., R. 29 W., has an arerage of 11.33 per cent for the upper 30 feet. Similar results hare been obtained from drilling in the Baraboo district.

The larger part of the manganiferous ores shipped so far have come from the Gogebic district. Manganiferous ores are often not discriminated from the iron ores in figures of shipment, and this makes it difficult to estimate the tonnage of manganese iron ore and the average percentage of manganese in so-ealled manganiferous iron ores. E. C. Eckel ${ }^{a}$ estimates that during 1906 the Lake Superior region produced about 1,000,000 long tons of low-manganese iron ore with an arerage manganese content of about 4 per cent and ranging as shipped from 1 to 8 per cent. According to Burehard, ${ }^{b}$ the total produetion of manganiferous iron ore in the Lake Superior region from 1885 to 1909, inclusive, has been $8,968,449$ long tons, or about 77 per cent of the total production for the United States during that period.

The pereentage of manganese in the manganiferous ores of the Lake Superior region is so low that the ore may not be classed either as a manganese or a highly manganiferous iron ore like those of Arkansas and Colorado. It produces a basic pig. None of the ore shipped from the Lake Superior region has been high enough in manganese to be arailable for ferromanganese or spiegeleisen, which require at least 15 per eent of manganese.

Nineralogically the manganese is mainly in the form of pyrolusite $\left(\mathrm{InO}_{2}\right)$. In the Cuyuna district this has been found at the surface to be mixed with rhodochrosite $\left(\operatorname{In}\left(\mathrm{O}_{3}\right)\right.$. The psilomelane so commonly associated with pyrolusite in the Appalachian manganese ores has not been especially looked for in the Lake Superior region but is probably present.

The conspicuous association of manganese with the upper parts of the iron-ore deposits seems to prevail in the Lake Superior region, as in deposits of manganiferous iron ore in other parts of the United States.

\section{IRON-ORE RESERVES.}

\section{DATA AVAILABLE FOR ESTIMATES.}

Up to 1910, 335 mines hare been in operation in the Lake Superior region, and many thousands of test pits and chum and diamond drill holes have been sunk. The mines and explorations, together with natural exposures, afford data for a fair estimate of ore reserves in the producing areas. There are considerable areas not yet explored.

\section{AVAILABILITY OF ORES.}

Eridently the question of the present and future arailability of the iron ores is one of costsin mining, in transportation, and in the fumace. The costs are determined-

(1) By the character of the ore itself, its pereentage of iron and deleterious const it uents, and the nature of its principal gangue material.

(2) By the cost of mining, whether, for instance, by open pit or underground methoul.

(3) By whether or not the ore must be concentrated, as, for instance, the sandy taconites of the western Ilesabi.

a Mineral Resources U. S. for 1906, IT. S, Geol, Surves, 1907, p. 10i,

o Burchard, E. F., The production of manganese ore in 19u9: Extract from Mineral Resources L. S. tor 1902, L. S. Geol. Surrey, 1911 , p. 10. 
(4) By the cost of transportation to the furnace. Between Vermilion and Marquette ores there is a difference of about 75 cents a ton in the cost of transportation to the lower lakes. Viewed in another way, the cost of transportation is the amount necessary to bring together the coal, limestone, and iron and to transport the finished product to consuming centers. This introduces another set of costs for ores smelted at the upper lakes.

(5) By the cost of reduction in the furnace, depending on the character of the ore and on the success in modifying and applying furnace practice to local conditions. For instance, the use of by-products from coke in certain furnaces in the Lake Superior region makes approximately the difference between profit and loss for the combination of conditions there existing.

(6) By the nature of the ownership. A large corporation holding a variety of ores and equipped to assemble the raw material under the existing conditions can handle ore which would not be available to a smaller company not equipped to control the situation in a large way.

In recent years the average percentage of iron in the ore shipped has varied between 60 and 54 per cent for the ore in the natural state (see pp. 477, 493), the grade on the whole lowering. These grades may be regarded as approximately the lowest average grades a vailable under the conditions prevailing in those years. Low-grade, high-silica ores, ruming as low as 40 per cent in iron, favorably located for cheap mining and transportation, have been used to a small extent for mixtures, as, for instance, ores in the Palner area of the Marquette district and in the Menominee district. In most of the region at the present time ore running 50 per cent (natural) in metallic iron is considered of about as low grade as is at present arailable, and estimates are made accordingly. Locally ores of lower grade are included as available ores, either because of favorable conclitions of mining and transportation, because of differences in the policy of the companies making the estimates, or because they may be concentrated by washing, as in the western Mesabi.

The table of production (see pp. 49-69) shows what has been the relative availability of ores of the different districts, all factors considered.

\section{RESERVES OF ORE AT PRESENT AVAILABLE.}

\section{ESTIMATES.}

The authors have made no independent detailed estimates of Lake Superior iron-ore reserves for this monograph. 'They have, however, had access to the detailed estimates of the principal mining companies and to the records of the Minnesota Tax Commission and are from their field study familiar with most of the large deposits or groups of deposits. The estimates here given represent their judgment as to the approximate tomnage of ore now arailable, based on the above information. The variations in the independent estimates of mining companies and the difference of opinion as to how low a grade of ore in any given place is to be included in the arailable ores give latitude for considerable variations in estimates. The authors can claim no finality for the figures published. Thej are what seem to them reasonable approximations.

Estimates of the available pre-Cambrian iron ore of the Lake Superior region.

\begin{tabular}{|c|c|}
\hline Marquette district. & $\begin{array}{l}\text { Long tons. } \\
100,000,000\end{array}$ \\
\hline Gogebic district........ . & $60,000,000$ \\
\hline Menominee and Crystal Falls districts.......... & $75,000,000$ \\
\hline 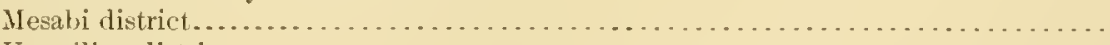 & $1,600,000,000$ \\
\hline 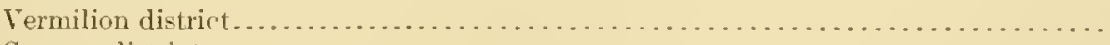 & $30,000,000$ \\
\hline 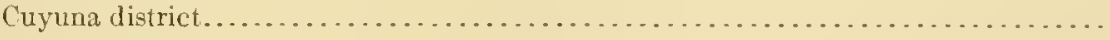 & $40,000,000$ \\
\hline
\end{tabular}

The reserve reported inchides about $130,000,000$ tous of washable ores from the western Mesabi, averaging 46 per cent of iron (dry) of non-Bessemer character. Of the remainder of Mesabi ores, approximately 40 per cent are Bessemer.

There is a further low-grade reserve in the Clinton ores of Wisconsin which may be of considerable magnitude. (See pp. 566-567.) 
IJFE OF OlF LESERVES AT P'IESENT AVAILABLE.

Figure 73, prepared by II. M. Roberts, shows the total probluction of ore from the lake Superior region for 30 years before 1907 and the rate of increase of production. To the close of 191020.5 per cent of the known reserves had been consumed. If the above astimates of

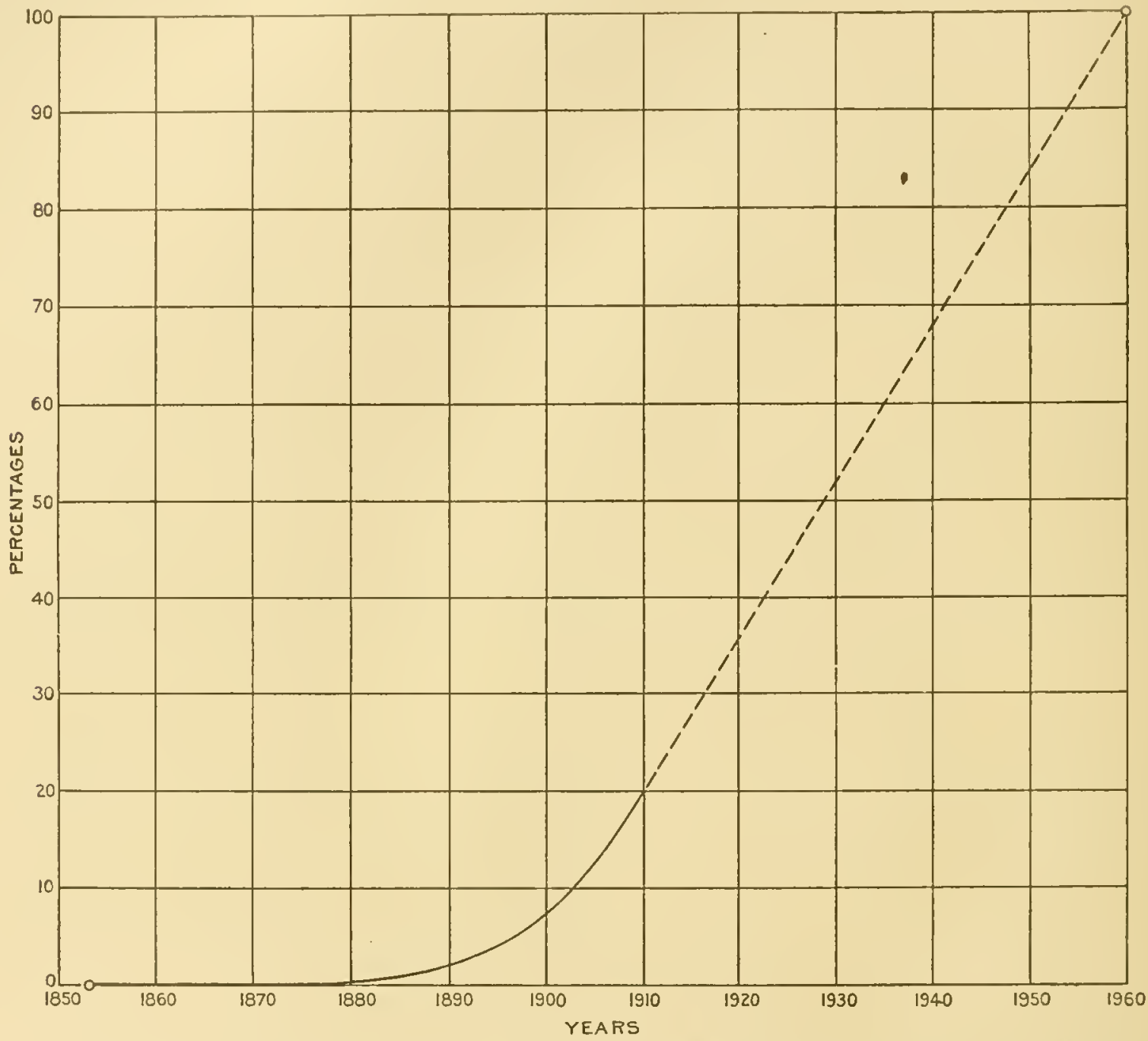

FIGURE 73.-Diagram showing relation betreen estimatel ore reserves of the Lake Superior region and rate of productlon. The estiniated reserve, $1,905,000, n 0$ () tons, plus the total amount of ore mined to the end of 1910 , is represented as 100 per cent on the vertieal line. For each year there is shown the percentage of this total whieh had been remored to the end of that year. For example. 15.9 per cent of the known ore was remored to the elose of $190^{-}$. For the last five rears, 1905 to 1910 , the curve is practleally a straight line. If this line is projected at a uniform slope, it indicates complete exhaustion of the known reserves in 1960. Reasons are given in the text, howerer, for the belief that the date of exhaustion will be later.

reserves at present available are eren approximately correct and the rate of production remains the same as that in 1910, the life of the ore deposits as now estimated will be 45 rears - that is, to 1956. If the rate of production increases in the future this time will obviously be shorter. Ls some inerease in the rate of production seems likely in spite of the probable temporary recessions due to business depressions, if only high-grade ores are mined the cxhanstion of the existing deposits, or, if not these, of the amount of high-grate ore equivalent to that now in sight, will probably oceur earlies than this date. Jut even this conchusion must be modified by the fact that in proportion as the inadequate supply of high-grade ores becomes 
depleted there will be an increased use of lower-grale ores with the high-grade material, whose life will be thereby prolonged. This factor is regarded as so important as to render it probable that the use of the high-grade ores will be distributed through a much longer perior thas 45 years, just as there will be first-growth white pine remaining uncut long after the date when all the white pine would be gone at the present rate ol use. Also new liscoveries of ore of present commercial grade are made yearly. Prior to 1911 the discoreries have kept well ahead of the shipments. The region is now so well known that there is little likelihood of discovering another Mesabi range. Though it is not impossible that in the next few years the reserves may be sufficiently increased by discovery to keep pace with the shipments, this is rather unlikely. Still less likely is it that the increase of reserves will keep pace with an acceleration of production. If, for instance, the increase of production for a year amounts to 2,000,000 tons, and it is estimated that the present reserves will last 20 years at the lower rate, it will be necessary in that year of increase to discover $40,000,000$ tons of ore in order that the life of the reserves may not be lessened.

\section{RESERVES AVAILABLE FOR THE FUTURE.}

ESTIMATES.

Reserves available for the future must be considered as having a present small and intangible value, for the reason that the estimates of ores at present available include all ores which can be immediately mined or which will be taken out in the normal course of development of present mines. When we remember that iron is one of the most widely disseminated metals of the earth's crust (by actual analysis constituting 4 per cent of all the rocks of the earth), it is apparent that only the most arbitrary limits can be placed on future reserves. In the following estimates of future reserves are included rocks containing a percentage of iron lower than the percentage in the reserves at present available but sufficiently higher than that in the common rocks of the earth'scrust to give them future priority in use as iron ores orer the average rocks of the earth's crust. It will probably be many hundreds of years before any but an insignificant portion of these reserves available for the future are utilized. The additional discovery of high-gracle ores-as, for instance, those of the great field in Brazil - the enormous quantities of low-grade ores now arailable from Alabama and Cuba, the extension of the known high-grade reserves of Lake Superior, and the increased use of scrap iron and steel will postpon the use of the bulk of the low-grade Lake Superior reserves available for the future. On the other hand, the diminution in supply of the reserves at present available will lead gradually, and probably in the not far listant future, to the drawing on minor amounts of these future reserves for mixtures.

It is to be remembered that the available ores are associated with iron-bearing formations, which differ from the ore mainly in having more silica and which show all gradations to the ore. The character of these formations, so far as iron is concerned, is best shown by the following table of analyses from drill sections compiled by the Oliver Iron Mining Company:

Character of iron-bearing formations in Lake Superior region (not including available ore).

Diamond-drill Averages.

\begin{tabular}{|c|c|c|c|c|c|}
\hline & Range. & $\begin{array}{l}\text { Number of } \\
\text { holes. }\end{array}$ & $\begin{array}{c}\text { Total } \\
\text { number } \\
\text { of fent. }\end{array}$ & $\begin{array}{c}\text { Number of } \\
\text { analyses. }\end{array}$ & $\begin{array}{l}\text { Arerage } \\
\text { percentage } \\
\text { of iron. }\end{array}$ \\
\hline $\begin{array}{l}\text { Gogebic..... } \\
\text { Baraboo... } \\
\text { Marquette. } \\
\text { Henominee. } \\
\text { Mesabi..... }\end{array}$ & & $\begin{array}{l}15 \\
30 \\
32 \\
30 \\
24\end{array}$ & $\begin{array}{r}5,890 \\
4,814 \\
11,025 \\
5,287 \\
5,400\end{array}$ & $\begin{array}{r}490 \\
1,517 \\
1,726 \\
1,681 \\
1,094\end{array}$ & $\begin{array}{l}36.65 \\
36.40 \\
35.12 \\
37.93 \\
3 \leftarrow .00\end{array}$ \\
\hline
\end{tabular}

Other Sources.

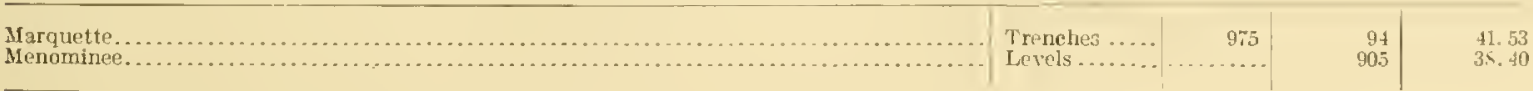


These analyses inchule both the lein and the partly concentrated purts of the iron-bearing formations, but do not include the arailable ore. If the partly concentrated parts of the formation are left out of consideration, the average would be 25 per cent of iron.

In the following table column 4 contains a rough estimate of the tonnage of all ironbearing formations outside of "arailable" ore to a depth of 1,250 feet for thesteeply dipping formations and to a depth of 400 feet for the Mesabi district, where the thickness ranges from a knife-edge to 900 feet. Column 5 contains a rough estimate of the tonnage of the part of the iron-bearing formations which will run above 35 per cent in iron.

Total tonnage of iron-bcaring formations to given depths and tonnage estimated to run 35 per cent or more in iron.

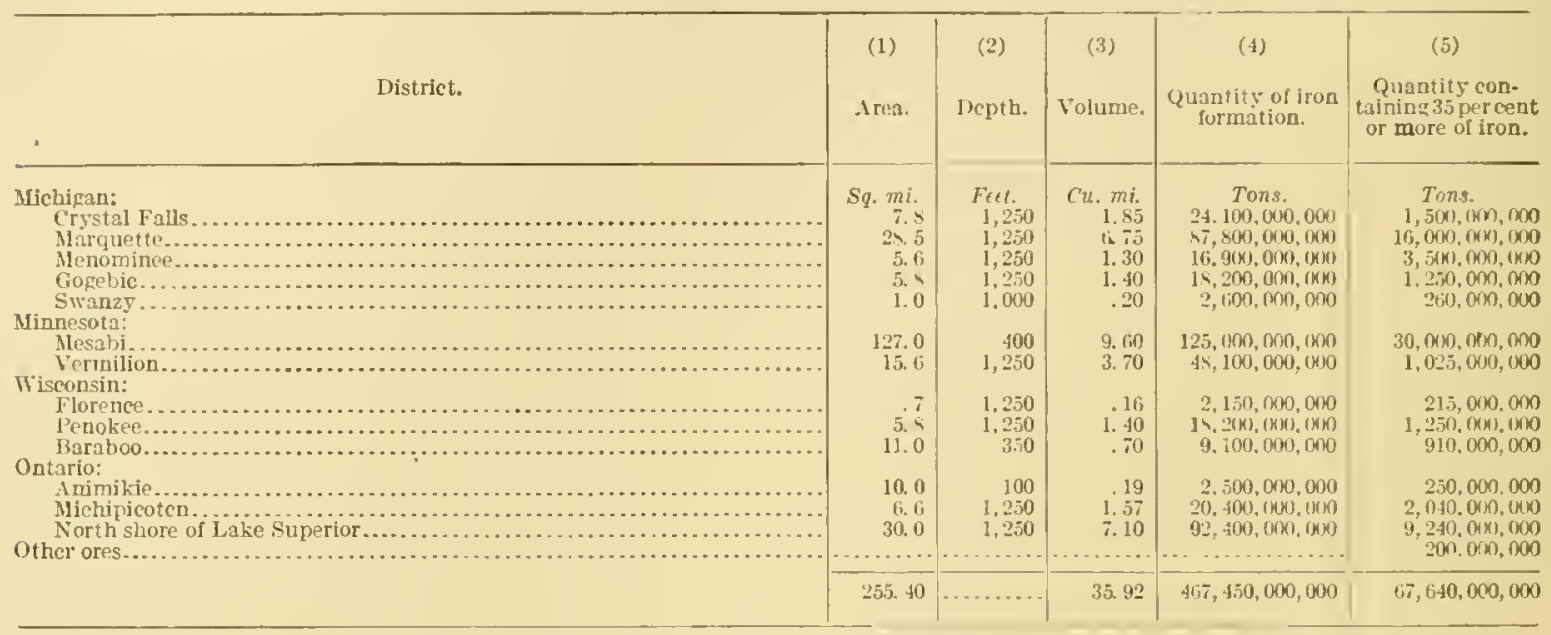

We may conclude, therefore, that while the ores at present arailable would probably be exhausted within about 50 years if they alone were draw from, the increasing use of lowergrade ores, alrealy begun, will lengthen this period many times.

COMPARISON OF LAKE SUPERIOR RESERVES WITI OTIER LESERYES OF THE TNITED STATES.

For comparison a table showing ores available at present and in the future in different parts of the United States is giren below. The figures, with the exception of those for Lake Superior, are those of the National Conservation Commission. ${ }^{a}$

Iron-ore reserves of the Inited States available at present and in the future.

\begin{tabular}{|c|c|c|}
\hline Conmercial district. & $\begin{array}{l}\text { Ore at present } \\
\text { arailasule. }\end{array}$ & $\begin{array}{l}\text { Ore arailahle } \\
\text { in the future. }\end{array}$ \\
\hline \multirow[t]{2}{*}{$\begin{array}{l}\text { 1. Northeastern.... } \\
\text { 2. Soutbeastern...... } \\
\text { 3. Lake Suprorior } \\
\text { 4. Mississippi Valles. } \\
\text { 5. Rock Monntain. } \\
\text { t. Hacific slope...... }\end{array}$} & $\begin{array}{r}\text { Long tons. } \\
* 294,000,0 \times 0 \\
535,440,0 \times 1) \\
1,905,000,000 \\
315,000,0 \times 1 \\
55,760,0 \times 1 \\
65,9.50,000\end{array}$ & 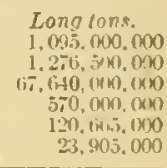 \\
\hline & $3,1 \times 3,150,000$ & $70,726,070,000$ \\
\hline
\end{tabular}

1. Virmont, Mlassachusut 15, Connecticul, New York, New Jersey, Pennsylyania, Maryland, Ohio.

2. Virminia, West Virginia, castern Kentueky, North Carolina, Sonth Carolina, Georgia, Ilabama, eastern Tamessee.

4. Northwest .labana, Western Tennessee, western Kentucky, Iowa, Missouri, Arkansas, eastern Texas.

5. Iluniana, liaho, Wyoming. (oolorado, Ctah, Jevada, New Mexico, we'stern Texas, . Irizona.

(i. Wishington, 1)regori, ('aliforni:

It appears from this table that the Lake Superior region contains approximately 60 per cent of the reserves at present arailable and 96 per cent of the future reserves, as figured in tons. If measuret in units of iron, the Lake Superior reserves form a still larger proportion of the totsl. 
LOWERING OF GRADE NOW MISCERNIBLE.

Lower and lower grades of ore are being included in successive estimates of available ores. A comparison of the iron-ore tonnage of the United States with the production of pig iron for the last 20 years shows a distinet inerease in the mumber of tons of iron required to make a ton of pig iron, and thus a lowering of the grade of iron ore mined. Figure 74 , prepared by H. II. Roberts, compares the pig iron and tons ol ore used and shows an arernge annual drop in grade of the ores for the last 20 years of 0.35 per cent in iron. Each temporary increase of

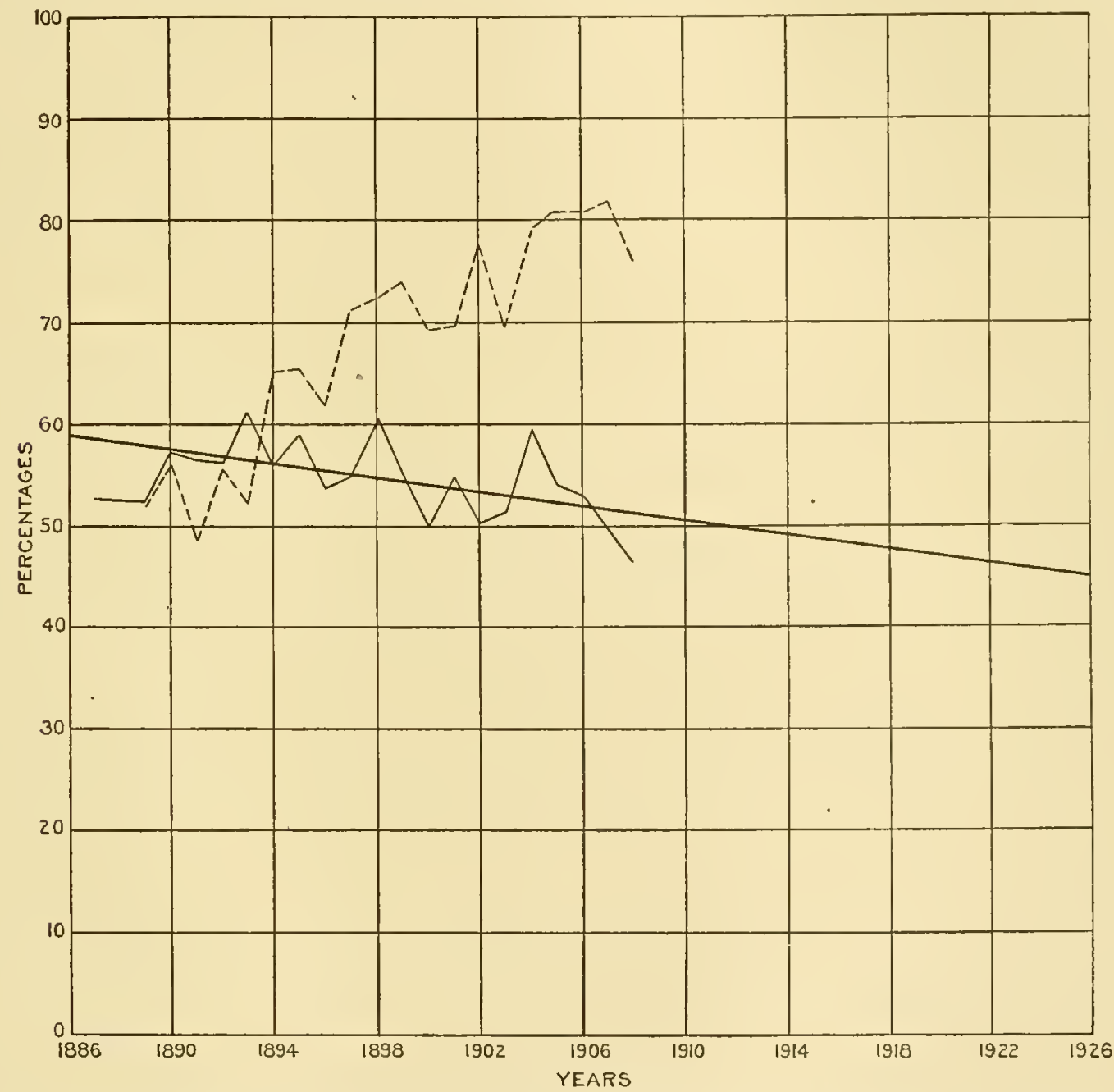

FigURE 74.-Diagram representing decline iu grade of Lake Superior iron ore since 1889. The light black line represents the approximate a verage percentage of metallic iron in the total production for the United States for each year. The heavy black line is the average slope computed hy method of least squares, Irom the variations of the light continuous line. It represents the arerage decline of grade since 1589, which amounts to about 0.35 per cent per year. The hroken line shows the percentage of the entire production of the United States which comes from the Lake Superior region. As this proportion has steadily increased, it is apparent that the drop in grade of the iron ores, figured for the entire United States, is shared by the Lake Superior ores.

production has been followed by a lowering in grade, and decrease of prodnction has meant raising of the grade in about the proportion that might be ealeulated from the general drop) in grade with increase in produetion for the last 20 years. It is not likely that the grade will lower as rapidly in the future as in the past, for as successively lower grades of ore are utilized the amounts a vailable are larger.

As the Lake Superior region produces nearly 80 per cent of the iron ore of the United States, the conclusion as to lowering of grade drawn from the diagram may be taken to apply conspicuousty to this region. 
The present marked tendency toward the use of lower-grade ores does not necessarily mean that the higher-grade supplies are exhausted, but simply that they are being conserved for the future. In working a series of deposits ranging from the lighliest to a low grade, in strong financial hands, it is regarded als the best business policy not to rob the deposits of their highest grade, as wis formerly done, but so to mix the high and low grades as to grive the maximum tonnage of an ore just rich enough to be commercially available. The prospeetive slort life of the highest-grade ores, probably not more than 50 years, is undoubtedly influencing the present conservative action. The conservation of the higher-grade supplies is farored by the marked concentration of eontrol of the industry in a few hands. When the ore was held by many owners the range of grade available to each owner was neessarily limited; when it is in few hands the l'ange is greater and correspondingly greater care can be taken in the proper mixing of grades in order to yield a maximum amount of the lowest grade which the market will stand. In the discussion of mining methods (p. 498) some reference is made to the care taken in getting out the proper grades from iny indiridual deposit. 'The same generul methorls are applied by the Cnited States Stcel Corporation in apportioning the desired ores among the diflerent deposits inailable.

\section{EFFECT OF 1NCREASED USE OF LOW-GRADE URES.}

If it is established that the high-grade ores have a limited life and that the direction of the development of the ore industry is now toward the use of lower-grade ores and is likely to be more so in the future, and that this tendency will lengthen greatly the life of the ore deposits, there are certain consequences which may be expected.

1. The distribution of the production of iron ore is likely to be modified and the relative importance of iron-mining centers will rary somewhat. As the grade falls, new "low-grade" districts will come into existence and some old districts which have had a somewhat precarious existence in competition with higher-grade distriets will be enabled to meet them on less unequal terms. This will be the effect not only locally within the Lake Superior region, but also in the relations between the Lake Superior and other regions. Western iron ores not now mined will come into the market. Appalachian ores, which can even now, in spite of their low grade, compete with Lake Superior ores becuuse of farorable conditions of transportation and proximity to smelting materials and consuming centers, may in the future attain an even stronger position, for the difference in composition of the ores marketed is sure to beeome less, in view of the fact that the change toward low grade in the Lake Superior region is likely to be much more rapid than it is on the large low-grade supplies of the Southeast. 'The same general arguments will apply to the large Cuban reserves.

This increased use of lower-grade southern Appalachian ores is further favored by the distribution of the population of the United States and the prevailing freight rates. In a personal communication Judge E. II. Gary, chairman of the board of directors of the Uniter States Steel Corporation, says:

Under the existing freight rates for the cruder forms of steel products, if the freights from Birmingham be taken to a series of points extending approximately east and west, so selected that the rate from Birmingham to each point is the same as the rate from Chicago to that point or the rate from Pittsburg to that point, and a line be drawn connecting these points, more than 30 per cent of the population of the United States lives in the territory south of the line so formed, and the rail freight rates from Birmingbam to all points in this territory are lower than the freight rates from either l'ittsburg or Chicago to these points.

If a line be located approximately north and south hy selecting the points reached at equal freight rates from Chirago and Pittburg, about 32 per cent of the population of the Inited States lives in the territory west of this Piltsburg('bicago line and north of the Birmingham line, and about 38 per cent of the population of the United States lives east of the Pittsburg-Chicago line and north of the lirmingham line.

The preeminence of the Lake Superior region is due to the richness of its ores, which offsets relatively adverse conditions of distance and transportation. The fowering of the grade of ore will undubtedly for a time firror other regions more than the Lake Superior region, but it would be rash to assume that the preeminence of the Lake superior region will be lost. 'The lower-grade supplies of the Lake Superior region will not be called into use until long after those from other districts, and this will make it possible to maintain for a long time a ligher griade of output in the halke Superior region than in other clistricts. 
2. As a result of the increasing use of low-grade ores, the distribution of blast furmaces and steel plants may be ehanged. At present the higher transportation eharges on wes to lower lake ports as compared with upper lake ports are just about counterbalancell by inereased cost of fuel and flux for smelting at upper lake points as compared with lower lake points. As the grade of ore is lowered this equilibrium will be listurbed.

3. As a result of decrease in reserves of low-phosphorus ores, the change from the acid Bessemer process to the open-hearth process of steel making will continue. The amount of high-grade Bessemer ore now in sight is seanty. Attention should be ealled, however, to the fact that the low-grade ores which may be drawn upon in the future are not necessarily high in phosphorus. In fact, the ratio of phosphorus to iron remains substantially the same whether the ore is lean or rieh, the difference between grades of ore being mainly in the percentage of siliea present. Lowering of grade may call into use new methods of smelting iron.

t. The lowering of the grade of the ore may favor combination of eapital in the mining industry if such combination will make possible additional economies and the use of a wider range of ores.

\section{COMIPARISON WITH PRINCIPAL FOREIGN ORES.}

The large deposits of low-grade limonite in Cuba have already been mentioned. These will doubtless be largely developed for use of the iron industry along the east coast of the United States. The local ore supplies of England and Germany are of low grade. Botll countries import ligh-grade ores for mixture, partly hematites from Bilbao, Spain, and partly magnetites from northern Sweden and Lapland. The high-grade Bilbao deposits are nearly exhausted. Swerlen limits the exports of its magnetite ores. Bessemer hematites of the highest grade are known in enormous quantities within 300 miles of the const in Minas Geraes, Brazil. Steps are now being taken to develop these deposits. They are likely to be an important factor in the future in the British and German markets, and it is not improbable that they may be used on the east coast of the United States, especially for mixture with the Cuban ores.

\section{TRANSPORTATION.}

The transportation of the Lake Superior ores is one of the most important factors determining their availablity. They "have been able to stand high transportation charges because of their high grade.

\section{MINE TO BOAT.}

The following table shows the principal ore-carrying railways, distances, rates, and the total tonnage hauled to December, 1908:

\begin{tabular}{|c|c|c|c|c|c|c|}
\hline Railroads. & $\begin{array}{l}\text { Ranges supplying } \\
\text { traffic. }\end{array}$ & $\begin{array}{l}\text { Principal range shipping } \\
\text { points. }\end{array}$ & $\begin{array}{l}\text { Lake termini at which } \\
\text { ore docks are located. }\end{array}$ & $\begin{array}{l}\text { Arerage } \\
\text { haul. }\end{array}$ & $\begin{array}{l}\text { Approximate } \\
\text { average cost } \\
\text { per ton from } \\
\text { mine to dock. }\end{array}$ & $\begin{array}{c}\text { Total iron } \\
\text { ores hauled } \\
\text { to December, } \\
1908 .\end{array}$ \\
\hline Duluth and Iron Range. & Sermilion. . & Tower, Fly .............. & ITwo Harbors Minn & $\frac{\text { Miles. }}{70-90}$ & $80.90-\$ 1.00$ & Tons. \\
\hline Duluth, Missabe and Nortbern. & MLesabi......... & $\begin{array}{l}\text { Eveleth, Sparta,Biwabik- } \\
\text { Virginia, Hibbing, Cole- }\end{array}$ & Duluth, Minn......... & $\begin{array}{l}6 \\
1\end{array} \quad 80$ & $\begin{array}{l}.80 \\
.80\end{array}$ & $\begin{array}{l}75,153,936 \\
79,118,051\end{array}$ \\
\hline Great Northern. - & & $\begin{array}{l}\text { Virginia, Hibbing, Nash- } \\
\text { wauk. }\end{array}$ & & 120 & .80 & a $40,268,854$ \\
\hline Chicago and Northwestern. . & 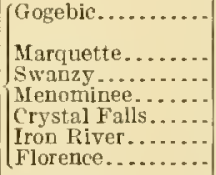 & 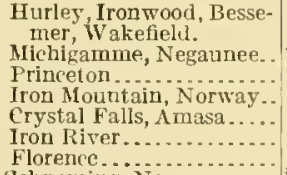 & Escanaba, Mich. & $\begin{array}{l}40 \\
70 \\
45 \\
45 \\
80 \\
83 \\
63\end{array}$ & .40 & ${ }^{b} 131.219 .397$ \\
\hline Duluth, South Shoreand Atlantic. & Marquette... . & $\left\{\begin{array}{l}\text { Ishpeming, Negaunee.... } \\
\text { Wichiganime............ }\end{array}\right.$ & Marquette, Micb. & $\begin{array}{r}12-15 \\
35\end{array}$ & .25 & $28,493.359$ \\
\hline Lake Superior and Ishpeming.... & $\left\{\begin{array}{l}\text { Marquette......... } \\
\text { Swanzy .......... }\end{array}\right.$ & $\begin{array}{l}\text { Negaunee, Ishpeming.... } \\
\text { Gtinn................. }\end{array}$ & Marquette, Mich. & $\begin{array}{r}12-15 \\
3 t\end{array}$ & .25 & $17, \pm 21,3,3$ \\
\hline Wisconsin Central.............. & Gogebic................ & $\begin{array}{l}\text { Bessemer, Hurley, Iron- } \\
\text { wood. }\end{array}$ & Ashland, $W$ is.... & 50 & .40 & 16.592 .713 \\
\hline Chicago, Milwaukee and St. Parll. & Menominee...... & $\begin{array}{l}\text { Crystal Falls, Iron Moun- } \\
\text { tain. }\end{array}$ & Escanaba, Mich. & $20-1: 0$ & .40 & \\
\hline
\end{tabular}


Eighty-five per cent of the tommage has been hauled 50 miles or more and 15 per eent has been laauled less than 50 miles. The average cost for hauling the ore to the lake has been 60.42 cents in tor.

Four of the railways hauling the ore are controlled directly by the companies owning or mining the ore. The Tinited States. Steel Corporation owns the Duluth, Missalye and Northern and the Duhth and Iron Range railroads; J. J. Ilill controls the Grent Northern Railway; and the Cleveland-Cliffs Company the Lake Superior and Ishpeming Railway.

DOCKS.

The docks and their capacities are as follows:

liecord of ore docks on the Great Lakes.

[Revised to Ntay 1, 1909. Table furnished by Oliver Iron Mining Co.]

\begin{tabular}{|c|c|c|c|c|c|c|c|c|c|c|c|}
\hline Railroad. & Location. & $\begin{array}{l}\text { lock } \\
\text { No. }\end{array}$ & $\begin{array}{l}\text { Num- } \\
\text { ber of } \\
\text { pock- } \\
\text { ets. }\end{array}$ & $\begin{array}{l}\text { Stor: } \\
\text { eapac }\end{array}$ & $\begin{array}{l}\text { Height } \\
\text { from } \\
\text { water to } \\
\text { centcr } \\
\text { linge } \\
\text { lole. }\end{array}$ & $\begin{array}{l}\text { 1leight } \\
\text { from } \\
\text { water to } \\
\text { deck of } \\
\text { dock. }\end{array}$ & $\begin{array}{l}\text { Wilth } \\
\text { of dock } \\
\text { from out- } \\
\text { side to } \\
\text { outside of } \\
\text { partition } \\
\text { posts. }\end{array}$ & $\begin{array}{l}\text { Length } \\
\text { of } \\
\text { spouts. }\end{array}$ & $\begin{array}{l}\text { Length } \\
\text { of } \\
\text { doek. }\end{array}$ & $\begin{array}{l}\text { Angle } \\
\text { of } \\
\text { poekets }\end{array}$ & $\begin{array}{l}\text { Capacity } \\
\text { per } \\
\text { pocket } \\
\text { to bot- } \\
\text { tom of } \\
\text { stringers. }\end{array}$ \\
\hline 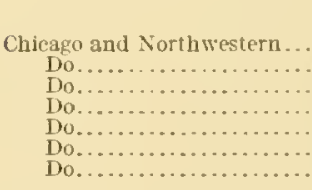 & 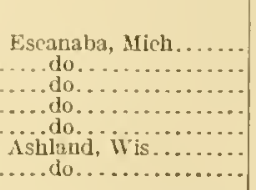 & $\begin{array}{l}1 \\
3 \\
4 \\
5 \\
6 \\
1 \\
2\end{array}$ & $\begin{array}{l}154 \\
2206 \\
250 \\
202 \\
320 \\
234 \\
234\end{array}$ & $\begin{array}{l}21,143 \\
28,792 \\
34,925 \\
29,310 \\
69,760 \\
42,120 \\
42,120\end{array}$ & $\begin{array}{cc}F q & \text { in. } \\
28 & 10 \\
31 & 2 \\
36 & 0 \\
28 & 6 \\
40 & \\
40 & \\
40 & \end{array}$ & $\begin{array}{cc}F t & \text { in. } \\
44 & 0 \\
52 & 8 \\
59 & 2 \\
53 & 3 \\
70 & \\
70 \\
70\end{array}$ & $\begin{array}{cc}F t . & \text { in. } \\
37 & \\
37 & \\
37 & \\
37 & \\
50 & 2 \\
50 & 2 \\
50 & 2\end{array}$ & $\begin{array}{l}\text { Ft. in. } \\
21 \\
27 \\
30 \\
21 \quad 5 \\
30 \\
30 \\
30\end{array}$ & $\begin{array}{l}F c e t \\
1,104 \\
1,351 \\
1,500 \\
1,212 \\
1,920 \\
1,4104 \\
1,4114\end{array}$ & $\begin{array}{lc}0 & 1 \\
39 & 30 \\
45 & \\
45 & \\
40 & \\
45 & \\
45 & \\
45 & \end{array}$ & $\begin{array}{r}\text { Cubic feet. } \\
1.911 \\
1,919 \\
2.191 \\
2 ., 32 \\
4,114 \\
3,915 \\
3,915\end{array}$ \\
\hline 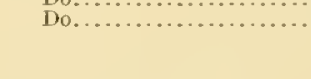 & & & 1. $1 \mathrm{i} 50$ & 268,170 & .. & ... & ... & 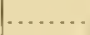 & & & \\
\hline \multirow[t]{2}{*}{ 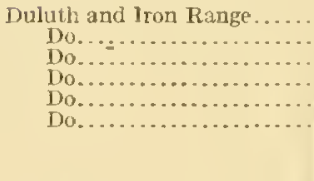 } & 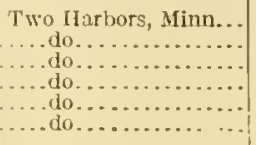 & $\begin{array}{r}1 \\
2 \\
3 \\
4 \\
5 \\
06\end{array}$ & $\begin{array}{l}202 \\
208 \\
170 \\
169 \\
165 \\
145\end{array}$ & $\begin{array}{l}40,+100 \\
41,600 \\
34,0001 \\
36,960 \\
35,450 \\
43,246\end{array}$ & $\begin{array}{ll}35 & 5 \\
33 & 5 \\
40 & \\
37 & \\
39 & \\
40 & \end{array}$ & $\begin{array}{ll}59 & 6 \\
57 & 6 \\
666 & \\
62 & \\
66 & 9 \\
73 & \end{array}$ & $\begin{array}{l}49 \\
49 \\
49 \\
49 \\
49 \\
53\end{array}$ & $\begin{array}{l}27 \\
27 \\
27 \\
29 \\
30 \\
32 \\
\end{array}$ & $\begin{array}{r}1.364 \\
1.240 \\
1,051 \\
1.012 \\
1,050 \\
920\end{array}$ & $\begin{array}{ll}34 & 42 \\
38 & 42 \\
43 & 32 \\
3 n & 42 \\
43 & 32 \\
45 & \\
\end{array}$ & $\begin{array}{l}3.0 \times 16 \\
3.0 \times 6 \\
3.0 \times 67 \\
3,270 \\
3.126 \\
4.272\end{array}$ \\
\hline & & & 1.064 & 231,656 & & $\cdots$ & . & $\cdots$ & & & \\
\hline \multirow[t]{2}{*}{ 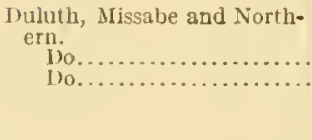 } & Duluth, Minn... & $\begin{array}{l}2 \\
3 \\
4\end{array}$ & $\begin{array}{l}354 \\
354 \\
384\end{array}$ & $\begin{array}{r}69,120 \\
50,640 \\
119,274\end{array}$ & $\begin{array}{ll}32 & \\
40 & 7 \\
41 & 91\end{array}$ & $\begin{array}{ll}57 & 6 \\
67 & \frac{1}{2} \\
72 & 6\end{array}$ & $\begin{array}{l}49 \\
59 \\
57\end{array}$ & $\begin{array}{ll}27 & 9 \\
27 & 9 \\
30 & 1 \frac{11}{2}\end{array}$ & $\begin{array}{l}2,336 \\
2,304 \\
2,304\end{array}$ & $\begin{array}{l}45 \\
45 \\
45\end{array}$ & $\begin{array}{l}2,363 \\
2.2-2 \\
3.456\end{array}$ \\
\hline & & & 1.152 & 269.034 & …....... & $\ldots \ldots \ldots$ & ...... & .... & & $\ldots$ & \\
\hline \multirow[t]{2}{*}{$\begin{array}{l}\text { Great Northern... } \\
\text { Do.............. } \\
\text { Do............ }\end{array}$} & $\begin{array}{l}\text { Superior, Wis.... } \\
\ldots \ldots \text { do............ } \\
\ldots \ldots \text { do......... }\end{array}$ & $\begin{array}{l}1 \\
2 \\
3\end{array}$ & $\begin{array}{l}374 \\
350 \\
326\end{array}$ & & $\begin{array}{l}40 \\
40 \\
40\end{array}$ & $\begin{array}{l}73 \\
73 \\
73\end{array}$ & $\begin{array}{ll}62 & 5 \\
62 & 5 \\
62 & 3\end{array}$ & $\begin{array}{ll}32 & 4 \\
32 & 4 \\
32 & 4\end{array}$ & $\begin{array}{l}2.244 \\
2,100 \\
1.956\end{array}$ & $\begin{array}{l}45 \\
45 \\
45\end{array}$ & $\begin{array}{l}4.972 \\
4.972 \\
4.972\end{array}$ \\
\hline & & & 1,050 & 283,500 & …...... & …....... & …....... & ...... & ...... & …..... & .. \\
\hline \multirow[t]{2}{*}{$\begin{array}{l}\text { Duluth, soutb Shore and At- } \\
\text { lantic. } \\
\text { Do.. }\end{array}$} & Marquette, Mich... & $\begin{array}{l}4 \\
5\end{array}$ & $\begin{array}{l}200 \\
200\end{array}$ & $\begin{array}{l}2,0000 \\
50,000\end{array}$ & $\begin{array}{ll}27 & 9 \\
40 & \end{array}$ & $\begin{array}{lr}47 & 3 \\
70 & 10\end{array}$ & $\begin{array}{l}368 \\
51\end{array}$ & $\begin{array}{ll}21 & 1 \\
32+ & +\end{array}$ & $\begin{array}{l}1,200 \\
1,236\end{array}$ & $\begin{array}{l}39 \\
45\end{array}$ & \\
\hline & & & 400 & $7 \times 000$ & ............ & ............ & ............ & .......... & ....... & ......... & 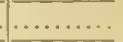 \\
\hline $\begin{array}{l}\text { LakeSuzerior and Ishperning. } \\
\text { W' isconsin ('entral........... }\end{array}$ & ....do ................. & $\begin{array}{l}1 \\
1\end{array}$ & 314 & $\begin{array}{l}31,0100 \\
4 \times, 350\end{array}$ & $\begin{array}{l}30 \\
40\end{array}$ & $\begin{array}{ll}54 \\
66 & 2\end{array}$ & $\begin{array}{l}50 \\
36\end{array}$ & $\frac{27}{27} 7$ & $\begin{array}{l}1.232 \\
1.4018\end{array}$ & $\begin{array}{ll}3 & 40 \\
\text { 30) } & 4 j\end{array}$ & $\begin{array}{l}\frac{22.713}{2.735} \\
2.435\end{array}$ \\
\hline \multirow[t]{2}{*}{$\begin{array}{l}\text { Chicugo, Milwauke and St. } \\
\text { Paul. } \\
\text { Do . . . . . . . }\end{array}$} & $\begin{array}{l}\text { Escanaba, Mich. } \\
\ldots \text {.................... }\end{array}$ & $\begin{array}{l}1 \\
2\end{array}$ & $\begin{array}{l}240 \\
240\end{array}$ & $\begin{array}{l}50,400 \\
63,500\end{array}$ & $\begin{array}{lr}10 & 2 ! \\
40 & 11 \frac{1}{2}\end{array}$ & $\begin{array}{ll}\text { (fit } & 6 \\
69 & 2\end{array}$ & $\begin{array}{l}52 \\
54\end{array}$ & $\begin{array}{l}12027 \\
12029 \\
30 \quad 41\end{array}$ & $\begin{array}{l}1,500 \\
1.500\end{array}$ & $\begin{array}{l}45 \\
45\end{array}$ & $\begin{array}{l}2.9(k) \\
3.150\end{array}$ \\
\hline & & & 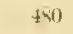 & 113,900 & $\ldots$ & ........ & $\cdots$ & ........ & ........ & .......... & $\cdots$ \\
\hline $\begin{array}{l}\text { Algoma Cent ral tnd Eudson } \\
\text { Bay, } \\
\text { Cunidian Nort hern. . . . . . . }\end{array}$ & $\begin{array}{l}\text { Michipicaten, Ontario. } \\
\text { kicy Harbor, Ontario.. }\end{array}$ & $\begin{array}{r}1 \\
c 1\end{array}$ & $\begin{array}{l}12 \\
20\end{array}$ & $\begin{array}{c}2,000 \\
\ldots \ldots \ldots\end{array}$ & 34 & $\begin{array}{ll}43 & 4 \\
61 & 9\end{array}$ & $\begin{array}{l}25 \\
28\end{array}$ & $\begin{array}{l}22 \\
30\end{array}$ & $\begin{array}{l}3119 \\
240\end{array}$ & 44 & \\
\hline
\end{tabular}

a 312 feet single pockets: 1.07 i feet double pockets.

c Pockets filled by belt conveyor from stock pile trestle 30 fret high.

The cost of unloading from train to doek and from dock to boat agreregates 4 cents a ton. Most of the structures up to the present time have been made of wood and are so inflammable us to require almost prohibitory insurance rates, are ensily choked in cold weather by the freezing of the water in the ore, and are easily tied up by strikes. The destruction or tring up of a dock is a most serious setback to the iron-ore industry and one which ean be less easily 

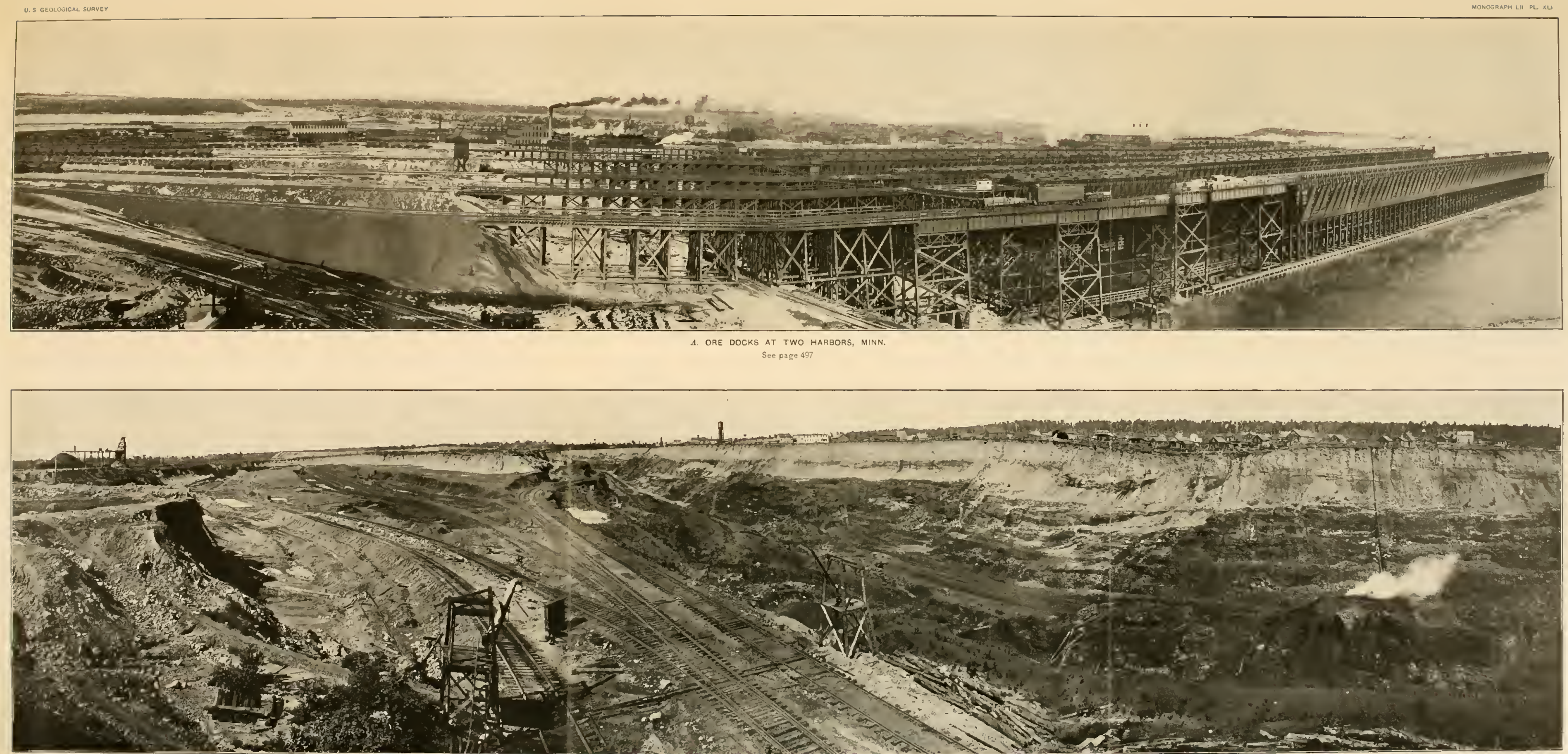
B EXCAVATIONS at SteVEnson, minN. 

a voided and less quickly remedied than any other of the misfortunes affecting the industry. Steel is used in new docks at Two Harbors, Minn. (Pl. XLI, A), and this may be the beginning of a revolution in dock building. The docks have undergone little structural modification since they were first used in the Lake Superior region. There is still room for mechanical improvement to make the movement of ore more certain and continuous between the train and the boat.

BOATS.

The ore is carried on the Great Lakes by a fleet of vessels mumbering $660 \mathrm{in} 1907$. Of the total tonnage which has gone down the Great Lakes much the largest pereentage has gone to Cleveland and a small percentage to Chicago. The proportion going to Chicago is constantly increasing. The following table shows tomage and rates from upper Lake ports in 1907:

Quantity of ore shipped from upper Lake ports in 190\%, with ratrs per ton.

\section{ERRATUM.}

The rate stated on page 497, in the last sentence uncler the lieading "Dock to furnace," is incorrect. In 1910 the rate per ton from Lake Erie docks to the Youngstown district was 64 cents, to Pittsburgh $\$ 1.04$, and to Philadelpluia $\$ 1.53$.

\section{DOCK TO FURNACE.}

Still another transportation charge to be added to the ore is that of unloading at the Lake docks and short rail transportation to lower Lake furnaces. From Conneat and Ashtabula to the furnaces the distance is 50 miles and the charge 50 cents a ton.

\section{TOTAL COST OF TRANSPORTATION.}

The average cost of transporting Lake Superior ores to the furnaces during 1907 was $\$ 2.14$ a ton. When it is remembered that approximately three-fourths of the transportation is done by companies controlling the ore and that this transportation charge contains a considerable profit for the mining companies, the real cost of carrying ore to the furnaces is seen to be considerably lower.

Although the cost of transportation for the ore has been high, on the other hand the furnaces have been located fairly close to the distributing centers for finished materials, so that transportation of the finished material has been correspondingly less. As the center of population has mored westward, the smelting in the ricinity of Chicago has become proportionally more important and the cost of transportation of the ore proportionally less.

\section{METHODS OF MINING.}

It is the purpose here merely to mention some of the most elementary features of the mining methods used in the Lake Superior region. The ores in general are taken from the ground by open-pit and underground methods or some combination of them. By far the larger number of mines are underground mines. Most of the open-pit mines (see Pls. II, p. 180; XLI, $B$ ) are in the Mesabi district, where, in $1908,63.7$ per cent of the ore was so produced. The production of the Mesabi open-pit mines is so large that, notwithstanding their small number as compared with the total number of mines in the region, they produced, in 1908 , 42 per cent of the $47517^{\circ}-10 L 52-11-32$ 


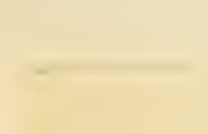


aroided and less quickly remedied than any other of the misfortunes affecting the industry. Steel is used in new docks at Two Iarbors, Minn. (Pl. XLI, A), and this may be the beginning of a revolution in dock building. The docks have undergone little structural modification since they were first used in the Lake Superior region. There is still room for mechanical improvement to make the morement of ore more certain and continuous between the train and the boat.

\section{BOATS.}

The ore is earried on the Great Iakes by a fleet of vessels numbering 660 in 1907. Of the total tonnage which lias gone down the Great Lakes much the largest percentage has gone to Cleveland and a small percentage to Chicago. The proportion going to Chicago is constantly increasing. The following table slows tonnage and rates from upper Lake ports in 1907:

Quantity of ore shipped from upper Lake ports in 1907, with rates per ton.

\begin{tabular}{l} 
Port. \\
\hline
\end{tabular}

The arerage cost per ton of transporting all the ore shipped in 1907 from the upper to the lower Lake ports was 72.16 cents.

\section{DOCK TO FURNACE.}

Still another transportation charge to be added to the ore is that of unloading at the Lake docks and short rail transportation to lower Lake furnaces. From Conneaut and Ashtabula to the furnaces the distance is 50 miles and the charge 50 cents a ton.

\section{TOTAL COST OF TRANSPORTATION.}

The average cost of transporting Lake Superior ores to the furnaces during 1907 was \$2.14 a ton. When it is remembered that approximately three-fourths of the transportation is done by companies controlling the ore and that this transportation charge contains a considerable profit for the mining eompanies, the real eost of earrying ore to the furnaces is seen to be considerably lower.

Although the cost of transportation for the ore has been high, on the other hand the furnaces have been located fairly close to the distributing centers for finished materials, so that transportation of the finished material has been correspondingty less. As the center of population has moved westward, the smelting in the vicinity of Chicago has become proportionally more important and the cost of transportation of the ore proportionally less.

\section{METHODS OF MINING.}

It is the purpose here merely to mention some of the most elementary features of the mining methods used in the Lake Superior region. The ores in general are taken from the ground by open-pit and underground methods or some combination of them. By far the larger number of mines are underground mines. Most of the open-pit mines (see Pls. XI, p. 180; XLI, $B$ ) are in the Mesabi district, where, in $1908,63.7$ per cent of the ore was so produced. The produetion of the Mesabi open-pit mines is so large that, notwithstanding their small number as compared with the total number of mines in the region, they produced, in 1908, 42 per cent of the 
entire Lake Superior shipments. Stripping operations in the IJesabi district, taking into account the removal of ore, are far more extensive than the work conducted at the Panama Canal, the total material removed during 1909 in the Mesabi district being 49,750,000 culic yarrls as compared with $35,100,000$ eubic yards at the Panama Canal. ${ }^{a}$

The underground methods have in common the general use of gravity in milling the ore to lower levels from which it ma be trammed to the shaft and then hoisted to the surface. The ores are taken out by square-set rooms running up from sublevels, or by top and side slicing downward from the upper parts of the deposits, or by milling through untimbered chutes to levels below after the surface material has been taken from the top. The cost of this work las ranged from 40 cents to $\$ 1.60$ a ton, or even higher. An average figure would be perhaps $\$ 1$ it ton.

The essential feature of open-pit mining is the removal of the surface material and the trinsfer of the ore directly to railway cars without the intermediate use of the tram or shaft, and without the loss due to leaving pillars. The thickness of drift remored ranges up to 100 feet or more. The general method of work is much more scientific than would at first appear, for it is not a matter of shoveling ore at rundom onto cars. The character and physical conditions of the deposits are determined by drilling, and the steam-shovel cuts and tracks are distributed so as to reach the desired grades of ore by handling the least possible amount of waste. The possible grades which the mine may produce are ascertained, and when a certain grade is desired by the market the greatest care is taken to extract this grade from the ore body without leaving undesirable ores which must be later mored at a loss. It would be obviously undesirable to take out a ligh-grade ore and leare a low-grade ore adjacent which could not be sold because of its low grade when by mixing a high and low grade it would be possible to get a medium grade which could be sold. Extreme care is taken to match the different grades in such a minner as to leave them accessible at proper times. The problem is primulily an engineering problem and is worked out by engineers from most careful measurements and calculations. When a request for a certain grade of ore comes to an openpit mine, orders are sent out to load so many cars from a certain cut and so many ears from another cut, or to make a steam-shovel eut in a certain position; and it is known in advance that the analysis of the ore thus ordered will run very close to that required. The grading of the ore is becoming closer every ycar. In the utilization of expert engineering help the open-pit mines are fully as far adranced as any other form of mining.

In connection with grading the ore accurate analytical chemical work on a very large scale is necessary. The work of sumpling and analyzing the ores, both at the mines and at the works, has been developed to a remarkable degree of accuracy. An llustration of this is slown by the following pairs of analyses, representing the total avernge of 21,030,909 tons of ore shipped by the Oliver Iron Mining Company from the Lake Superior region in 1909 . The average from mine analyses was iron 59.19 , phospliorus 0.068 , moisture 12.22 , silica 6.38 ; and the average of the same ore as analyzed at the smelting plants was iron 59.04, phosphorus 0.068 , moisture 12.33 , silica 6.60 . This is an exceedingly close chcek on perhaps the largest piece of quantitative chemical work recorded.

The cost of open-pit work depends primarily on the amount of orcrburden to be remored and the ratio of this to the size of the ore boly. The average cost of loading on the car miny be only 4 or 5 cents a ton. The arcrage cost of stripping, howerer, to uncover a ton of ore may run from 20 to 30 cents. It is obrious that the figure would be small where the drift is thin or where the annount uncovered is large in proportion to the thickness of the cover, so that the cost of surface removal may be charged against a large number of tons. In general the cost of steam-shovel mining has probably averaged less than 30 cents a ton.

With this great difference in cost in faror of the open-pit methorl of mining, the question may naturally be asked why any of the Lake Superior ores are mined by undergronud methods. For many of the deposits the answer is obvious. Their larger limensions are vertical ranther 
than horizontal, requiring hoisting apparatus to get them to the surface. But even in the Iesabi district 37 per cent of the ores are mined by underground methorls and for such mines the reason is perhaps not so obvious. It may be that the drilt is too thick; that the topography does not afford a suflieiently gentle slope for the approach of the track; that adjacent land for a proper approach is owned by others; that the deposit may have a considerable amount of low-grarle material on top which must be moved before the material of better grade can be obtained. It may be that the company has insuflicient financial resources to make the large initial expenditure necessary for the open-pit method before ore is mined or sold, or it may be that the deposit is not sufficiently large in proportion to the expense of preparing it for the open-eut method to warrant piling up this great advance charge against the ore deposit.

It may be noted that the percentage of ore uneovered by open-pit methods is being rapidly increased and that conditions which a few years ago were regarded as insuperable obstacles to open-pit handling are now easily managed. It may be pointed out further that this change in methods has accompanied the combination of mining eapital, strong concerns being able to do what the weaker concerns coukl not attempt.

\section{RATES OF ROYALTY AND VALUE OF ORE IN TIE GROUND.}

The ores of the Lake Superior region are leased at royalties ranging from 10 cents to $\$ 1.35$ a ton. The average for the region is somewhere between 30 and 50 cents a ton. The higher figures appear in the later leases. The Mesabi range has the highest general average of royalties. IIere the Oliver Iron Nining Company pays the J. J. Fill ore interests a royalty of 85 cents a ton on a miuimum of 750,000 tons for 1907 ; this minimum to be increased by 750,000 tons annually until it reaches $8,250,000$ tons a year, after which it remains constant, the royalty to increase 3.4 cents a ton per year for ore carrying over 59 per cent in iron.

The royalty rate practically measures the value of the ore in the ground to the fee owner. The fee owner demands on an arerage as high a price as the leascholder can afford to pay for the ore. On this basis the value of the ore in the ground is between 10 cents and $\$ 1$ a ton. The ralue is ligh in proportion as grade is high and costs of mining and transportation are low. The Minnesota State Tax Commission has adopted an excellent elassification of ore rescrves, based on compulsory returns from the mining companies, and has valued the ores for purposes of taxation at $S$ to 33 cents a ton, this valuation being 40 per cent of what is regarded as the real value. The tax-commission figures would therefore indicate that the value of the ore in the ground is from 20 to 75 cents a ton in Mimnesota.

The present cash value of a ton of ore is obriously less than the value which will ultimately be realized from royalty after a period of years. If it be assumed, for instance, that the ore must lie in the ground 15 years before the royalty is received, its present cash value would be ronghly 42 per cent of its ultimate royalty value.

\section{ORIGIN OF THE ORES OF THE LAKE SUPERIOR PRE-CAMBRIAN SEDIMENTARY IRON-BEARING FORMLATIONS.}

\section{OUTLINE OF DISCUSSION.}

Under the above heading are included all the productive pre-Cambrian ore deposits of the Lake Superior region. It is proposed to show in the following discussion-

That these iron ores are altered parts of ehemically deposited sedimentary lormations, originally consisting mainly of cherty iron carbonate and greenalite.

That a fow of the iron-ore deposits represent originally rich layers of iron formation, in which secondary concentration has made only minor changes.

That in by far the greater number of deposits, including all the larger deposits, the secondary concentration has been the essential means of enriching iron-formation layers to iron ores.

That the conditions of sedimentation of the iron formation may be roughly outlined. 
That the weathering and crosion of bed-rock surfaces of average composition would be inadequate as a source of the materials of the iron-bearing secliments, and that the materials for these formations have been derived largely from basic igneous rocks.

That some parts of the sedimentation accompanied or inmediately followed the several introrluctions of pre-cambrian basic igneous rocks into the outer zone of the earth and another part came under ortimary weathering conditions later than the extrusions of the parent basic igneous rocks.

That the chemistry of deposition of the iron-bearing formations under such conditions may be approximated and that original phases of the sedimentary iron-bearing formations: may be synthesized in the laboratory.

That the subsecpent oxidation of the iron-bearing formations, the transfer of iron salts, and the leaching of silica by agents carried in the meteoric waters have secondarily concentrated the ores and developed all but an insignificant portion of the ore deposits now mined.

That this second concentration has been localized by a considerable variety of structural and topographic conditions.

That in some places before and in other places after concentration the iron-bearing formations have been extensively modified by mechanical leformation or by igneous int rusions, with contact effects such as to prevent the further concentration of ore deposits.

That the sequence of events developing the present features of the ore deposits may be outlined for each district and for the region as a whole.

That the development of the ores in general represents a partial metamorphic cycle.

\section{TIE IRON ORES ARE CIIEFLY ALTERED PARTS OF SEDIMENTARY ROCKS.}

The iron-bearing formations are bedded and locally cross-bedded. The IIuronian ironbearing formations are conformable to other sedimentary formations-quartzite, conglomerate, slate, and limestone-and are not different from those of the Keewatin, which are associated with but little fragmental sediment. They contain recognizable sedimentary material, such as iron carbonate, greenalite, shale, sand, and conglomerate. Te may anticipate our discussion of the secondary alterations of the ores by stating that the original constituents of the ironbearing formations were dominantly cherty iron carbonate and iron silicate (greenalite), with minor amounts of hematite and magnetite and with rarying anounts of the constitnents of the mechanieal sediments-mud, sand, and grarel. In tracing the derelopment of the iron-hearing formations we must therefore inquire principally into the derivation of the cherty iron carbonate and greenalite. These two substances are nonclastic, though locally some clastic material appears in them; as will be shown later, they are chemieal sediments.

The sedimentary nature of the iron-bearing formations searcely needs more elaborate proof. It is so obrious in the field that it has been douhted by only three geologic observers. Whitney, Wadsworth, Winchell, and Hille have helel these formations to be of surface igneous origin (see pp. 569-570), but as these views are not now regarded scriously by most men who hare studied the subject, and as they have been abandoned by Watsworth, it will be unnecessary here to marshal evilence against them.

\section{CONDITIONS OF SEDIMEN'TATION.}

\section{IRON-BEARING FORMATIONS MAINLY CHEMICAL SEDIMENTS.}

The iron-bearing formations are regarled mainly as chemical seclinnents (1) becaluse they consisted orginally of iron carbonate and ferrous silieate and possibly some iron oxide, similar to substances known elsewhere to be deposited as chemical sediments: (2) becanse they may be synthesized in the laboratory by the simple chemical reagents which were probahly present where the iron-bearing rocks were formed: and (3) because they usually lack framental particles. To a miner extent they are fragmental sediments derived from the erosion of earlier iron-bearing and other formations. 
ORDER OF DEPOSITION OF THE IRON-BEARING SEDIMENTS.

The greater mass of the Keewatin iron-bearing rocks, as exhibited in the Vermilion distriet, lies above the Keewatin basalts and porphyries and is infolded with them. Another part is interbeded with the basaltic flows. This general association is believed to loold as a rule for the Keewatin of the pre-Cambrian shield of North America. The Keewatin iron-bearing formations are in beds of limited and irregular extent and thickness. It is concluded that the deposition of a few feet of iron-bearing sediments directly in shallow depressions bottomed by basalt was followed by the superposition of another lava flow, and this in turn by more ironbearing sediments, and so on. Later, when the outflow of lava practically ceased, the main mass of the iron-bearing formation was deposited. Locally a little fragmental material went down immediately upon the basalt basements before iron deposition began.

The deposition of the mildle Huronian, containing the iron-bearing Negaunee formation of Michigan, began with a coarse conglomerate and sandstone ( jibik quartzite), changing somewhat gradually into a mud (Siamo slate), and this in turn into a chemically deposited ironbearing formation (Negnumee). In the Cascade or Palmer portion of the Marquette range fragmental quartz sand and ripple marks are conspicuous in the iron-bearing formation. South of the Marquette distriet the fragmental beds underlying the Negaunce formation are thin or lacking. In certain districts the iron formation is replaced over large areas by basie volcanic rocks (Clarksburg and Iemlock formations and perliaps others unknown). In general, then, during midlle Ifuronian time local sedimentation of sand and clay was followed by more widespread deposition of chemical iron-bearing sediments lacking fragmental material and by simultaneous igneous flows.

The iron-bearing formations of the upper Ifuronian are the most widespread of the preCambrian. Quartz-sand deposition (Pokegama quartzite, Palms formation, and Goodrich quartzite) was followed suddenly by the widespread deposition of ehemical iron-bearing sediments (Biwabik, Ironwool, Bijiki, Iulcan, etc.), with very insignificant amounts of clastic material, and this in turn gave way somewhat gradually to the deposition of mud of probable delta origin (see pp. 612-614) in masses so thick that the thin iron-bearing formations and quartzites previously deposited may be regarded as forming the lower selvage of a mud formation. Thin slate layers and a few quartzite layers are interbedded with the upper Huronian iron-bearing formations, especially in their upper portions, and the formations locally show a tendency to be replaced along the strike by slate, as in the Mesabi, Gogebic, and Menommee districts. In the Menominee district slate divides the iron-bearing formation, and in addition there are considerable quantities of fragmental quartz sand, iron oxide, and ferruginous slate near the base of the iron-bearing formation.

In the Crystal Falls, Florence, Iron River, and Cuyuna districts the ore is in siderite lenses in the upper Ifuronian slate, and the basal fragmental quartzite has been only locally recognized. These occurrences are apparently farther from the base of the formation than those in the Ifesabi, Gogebic, Felch Mountain, and Menominee districts, where quartz sand, iron-bearing formation, and slate were successively deposited as distinct formations.

On the south side of Lake Superior, in the western Marquette, eastern Gogebic, and northwestern Menominee districts the deposition of the upper IIuronian iron-bearing formations was interrupted by the contemporaneous extrusion of great masses of submarine ellipsoidal basalts. These extrusions may have been more extensive than now appears, because eridence of them may be buried or may have been removed by erosion.

\section{ARE THE IRON-BEARING FORMATIONS TERRESTRIAL OR SUBAQUEOUS SEDIMENTS?}

It is believed that the iron-bearing formations are subaqueous for the following reasons:

1. They were originally ferrous compounds in major part. Terrestrial sedimentation usually produces ferric oxides-hematite or limonite and laterite, except in bogs-and reasons are advanced elsewhere to show that only a part of the Lake Superior iron-bearing formations may be so developed. 
2. The midlle and upper I Iuronian irom-bearing formations are parts of sedimentary groups containing quartzites and slates of probable subaqueous origin. The slates are essentially delta deposits.

3. All the iron-bearing formations are associated with basalts having conspicuous collipsoirlal structures, which can be best explained as doveloped by flowing out under water. They contrast in this regard with the basic lavas of the Keweenawan serirs.

4. Between the underlying basalts, which are probably subaqueous extrusions, and the iron-bearing formations in the Keewatin series neither weathering nor "rosion has taken place except very locally. The two are conformable.

\section{BOG AND LAGOON ORIGIN OF PART OF THE IRON-BEARING ROCKS.}

The iron-bearing members of the Crystal Falls, Iron River, and Cuyuna districts are associated with slates of probable delta origin, which near the iron-bearing rocks are so uniformly blark and graphitie and generally pyritiferous that black slate is usually regarded as a farorable indication in prospecting for ore. Wuch black slate in the upper Ituronian is not associated with the iron-bearing formations, but ore is almost never found without the black slate. The iron-bearing rocks in such associations with black slate are originally carbonate. Smaller amounts of graphitic slates are found also in connection with the Keewatin iron-bearing formations. The thicker iron-bearing formations of the Mesalsi, Gogebie, Marquette, and Menominee districts are associated with black slates to a less legree.

It is suggested elsewhere that some of the slates most abundantly associated with the iron-bearing formations may represent delta deposits, and that the carbon content of the iron formations is probably to be explained as urganic. So far as direct evidence is concerned, the organir origin of the graphite and sulphicles in the black slates, notwithstanding its probability. should not be regarded as proved, although there is no reason to doubt such an origin. Similar associations elsewhere, as in the Carboniferous, have been shown to be truly of organie origin. On the other hand, in the Lake Superior black slates, as in all other Lake Superior pre-Canbrian furmations, no organic forms have been found.

These facts raise the question whether the carbon of the slates may not have been effective in the original deposition of the iron-bearing formations, as bog or lagoon deposits, in the manner of Carboniferous and Cretaccous carbonates - that is, by the progressive burial of ferric oxicle with organic material, resulting in the reduction of the oxide and the formation of iron carbonate. The way in which reducing organic substances aids in dissolving and transporting iron salts is discussed on pages 519-520.

This is probalbly the origin of the diseont inuous carbonate lenses in the carbonaceous slates of probable delta origin in the upper IFuronian, but difficulties appear when we attempt to explain in the same way the main, thick, continuous masses of iron-bearing formation of the Keewatin. middle Ituronian, and upper IIuronian.

HYPOTHESIS OF BOG AND LAGOON ORIGIN NOT APPLICABLE TO THE MAIN MASSES OF THE IRON-BEARING SEDIMENTS.

The main masses of the iron-bearing sediments are not elosely associated with carbonaceous slates; they are not characteristically discontinuous or lens-shaped, but are extensive and thick; they rest with sharp contacts on quartzite, conglomerate, or basalt. The Lake Superior ironhearing formations also carry more chert than deposits of known bog origin of the carbouate type.

The bog theory of origin involves the assumption that the Lake Superior region may lave been, churing each of the iron-lepositing periods, covered by great hogs or lagoons in which regetable matter could grow at or noar the surface of the water over great areas, as in lagoons in advance of barriors thrown up by the sea encroalding orer a gently sloping surface, or under delta conditions. As a process neecssurily confincel to a shallow zone near the surface, its continuous operation would involve continuous and uniform subsidence at a rate commensurate with the deposition of the iron salts in order to produe the thicknesses now known. Nlthouerh 
this theory is probably applieable to some of the thin lenses of small extent associated with earbonaceous slates, it is not clear how this process could produce a thousand feet of iron-bearing sediments showing uniformity of lithology and bedding and having so lit te extraneous material through humdreds of square miles.

\section{HYPOTHESIS OF GLAUCONITIC ORIGIN NOT APPLICABLE.}

The greenalite of the iron-bearing formations of the Mesabi and other districts is so similar to glauconite as to suggest similarity in conditions of origin-that is, as fillings of cavities in or replacements of Foraminifera in deep-sea deposits. Dredgings have brought up glauconite from decp and quict waters but not from places of rapid sedimentation. No glauconite is known with so little foreign material as the greenalite beds of the iron-bearing formations. The thickness of the decp-sea glauconite beds is not known. In geologic sections the thickest known deposit is 35 feet. The deposition of 1,000 fort of greenalite beds in the same manner as glauconite is known to be deposited would require a development of Foraminifera in the pre-Cambrian not known in any other geologic period.

\section{IRON-BEARING SEDIMENTS NOT LATERITE DEPOSITS.}

In many parts of the workl, especially in tropical climates, there are bedded iron ores of the laterite type, presumed to develop from the katamorphism of basalt or other basic igneous rock in place. They are characteristically associated with bauxite, clay (lithomarge or bole), usually resting on it. Gradational types between lateritic iron ore and igneous rock have been deseribed. The Lake Superior iron beds associated with basalts can not in any considerable part be referred to decomposition of the basalt in place after the manner of laterite deposits; the almost complete absence of clay associated with the iron ores and the presence of abundant chert preclude this explanation. Although lateritic decomposition of basalt surfaces may have ben an ultimate partial source of the iron ore, transportation and sorting have eliminated the clay, which would be present if the iron beds resulted from lateritic decomposition. The principal impurity in the Lake Superior iron is silica. This could not have developed from decomposition of the basalt in place.

In reading accounts of the origin of iron beds associated with basalts in different parts of the world, ${ }^{a}$ one notes a tendeney to ascribe a lateritic origin to the iron beds, even in places where the iron lacks the associated clay to be expected from such a mode of origin. It would seem necessary at least to introduce the factors of sorting and transportation to explain these ores. Clay is as stable as iron oxide under surface conditions, and so far as quantitative evidence goes, it remains with the residual iron oxide in a more or less uniform proportion throughout a cycle of decomposition.

Finally the evidences of water sedimentation and physical separation of most of the iron formations and basalts are not in accord with the hypothesis of lateritic origin.

\section{IRON-BEARING SEDIMENTS NOT CHARACTERISTIC TRANSPORTED DEPOSITS OF ORDINARY EROSION CYCLES.}

The oxidized carbonate lenses associated with the graphitic slates (see p. 501) may be regarded as one of the incidental results of a normal erosion evele. The fragmental bases of the Vulcan formation in the Menominee district, of the Bijiki schist in the Marcpuette district, and of the Cretaceous rocks in the Mesabi district contain a great deal of detrital ferruginons chert and iron ore derived from the breaking up of iron-bearing rocks that lie unconformably below, but all these phases of the iron-bearing rocks are ol minor importance as compared with the thick masses of iron-bearing formation derived from the alteration of iron carbonate and greenalite rocks.

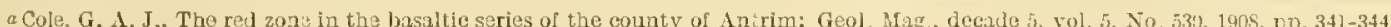


1. It has long been recognized that there are difliculties in the way of explaining the thick and uniform masses of chemieal sediments constituting the thicker iron-bearing formations, accompanied by so little mechanical sediment, on the assumption that the iron-bearing formations have been derived from the weathering of average land arens. If the peculiar character of chemical sediments depends on depth of water and distance from the shore, then the great thickness of the formations involves uniform subsidence over a great area to keep the ronditions uniform.

2. The iron-bearing formations may or may not be associnted with ordinary clastic sediments. In the Keewatin they usually are not. The midille Huronian eonsists, from the base up, of quartzite, slate, and iron-bearing formation. The upper Ifuronian where best exposed consists of quartzite, iron-bearing formation, and slate. The association of the Feewatin ironbearing formations with extrusive basalts and not with other sediments shows that the iron ores of the Keewatin, at least, are not the result of deposition in any ordinary eycle of erosion and deposition, and this strongly suggests that the variety of succession in the sedimentary iron-bearing formations of the Huronian is also not due to ordinary cycles of erosion and deposition, and that the deposition of the iron-bening formations probably was not uniformly related to sea transgression or recession or any other one phase of a topographic cycle.

The fact that in many places the sediments above and below the lluronian iron-bearing formations are different is the only feature which suggests that the deposition of iron-bearing sediment is a part of a cycle of erosion and deposition, though it is conceivable that rolcanism itself would cause this change, either by eflecting changes of levels of land and water or by introducing new rocks for erosion to work upon.

Until inrestigation has disclosed all the different combinations of factors which may produce a particular order of sedimentation, it is unsafe to be too positive in concluding that the varied relations of the iron-bearing formations to the order of sedimentation indicate their deposition under exceptional conditions. The conditions producing alternations of iron-bearing sediment with other sediments in varying succession may not be necessarily different from those faroring the deposition of limestone with a variety of associations-for instance, the Paleozoic limestones, which in some places orerlie sand and in others mud and are in turn followed by sand or mud. But the lack of uniformity in the relations of the iron-bearing formations above noted is taken to indicate a probability that conjunction of their deposition with a certain phase of a topographic cycle is not an essential condition to their development.

3. Were the iron-bearing formations derired from the weathering of the older rocks against which they lie, it would be diflicult to explain the complete absence of weathered material between certain bands of Keewatin iron-bearing formations and the associated basalts, or of erosion irregularities in the underlying surface.

4. The surface streams are only locally earring iron in quantity at the present time. All available analyses of river waters show a lack of iron, with the exception of minute quantities in Ottawa and St. Lawrence rivers. Many of the springs carry iron, but this is conspicuously deposited at the point of escape and does not join the run-off. These facts are correlated with known observations of the manner of weathering of rocks. The ferrous iron becomes oxidized and, next to alumina, is the most stable of all substances under surface conditions. In fact, so little iron is lost hy weathering that IIerrill, Watson, and others have used both iron and alumina as a basis against which to measure the loss of other constituents.

5. If it is regarded as possible that the iron-bearing formations are dericed from the weathering of ordinary land surfaces, why should the iron-bearing formations not be reproduced on the same scale in the Paleozoic rocks, which were deposited on pre-Cambrian rocks similar to those beneath the iron-bearing formations? The deposition of the Paleozoie rocks was preceded by perhaps the longest period of weathering of which there is record in the Lake Superior country. In many parts of the United States Paleozoic and later sediments contain thin beds of sedimentary iron-benring formation, but these beds are at their maximum insignificant in thickness as compared with those of the Lake Superior region. 
6. A comparison of the composition of the iron-bearing series with the possible sources from which they might be derived by ordinary weathering further shows that the iron is present in higher percentage in the iron-bearing lormations than in the rocks from which they may have been so derived.

The jaspers of the Keewatin series of the Vermilion district average between $2 S$ and 38 per cent in iron, but the associated basalts arerage 9.56 per cent. The jaspers lave little other sedinentary material with then to be figured in this comparison. Therefore the jaspers probably derived their iron from some other source than the weathering of the adjacent basalts, or the complementary fragmental detritus was washed away.

The middle Huronian, containing the iron-bearing Negaunee formation, has an average iron content of 11.72 per cent, as indicated by the available figures of composition of the three formations of the middle IIuronian and their relative thickness. Because of the unconformity at the top there is a question as to what factor should be added for materials that have been eroded, but there is no evidence that any large amount of material has been taken away, and as part of the material which has been removed belonged to the iron-bearing formation, this factor can not be assumed to cause much change in the figures given.

The composition of the rocks of the ancient land area from which the middle Huronian may have been derived by weathering is not definitely known, but it may be supposed to be not far from the average given by Clarke ${ }^{a}$ for igneous and crystalline rocks, in which the iron content is 4.46 per cent. Were the shore made up of basie rocks such as the Kitehi schist or Mona schist the iron content would be about 9 per cent. It is thus apparent that, whether we regard average igneous rocks or basic rocks as representing the original land from which the middle Huronian may have been derived by weathering, the sediments contain a considerable excess of inon not accounted for.

The iron content of the upper Huronian of the Mesabi and Gogebic districts ranges from 6 to 9 per cent, depending on the thickness of slate which is chosen for the calculation. The smallest percentage is higher than that of the average igneous rock that may be supposed to represent the land area from which these sediments were derived. The highest is about equal to the percentage of iron in the greenstones.

In general, then, if it is assumed that all of the iron of the ancient land areas was transferred and contributed to the iron-bearing formations that were being deposited in neighboring submerged areas (which, as above shown, it was not), this would not be enough to account for the iron in the iron-bearing rocks when the associated sediments are taken into account and allowance made for complementary sediments deposited clsewhere.

The major part of the iron of the iron-bearing formations was originally deposited as a chemical sediment from solution. In view of the fact that in weathering only a small proportion of the iron present is observed to be carried ofl in solution, the rest remaining as insoluble ferric oxide, it becomes even more apparent that the iron-bearing formations were not derived by chemical solution and deposition of the materials of average land areas. A similar conclusion is to be drawn from the siliea content in the iron-bearing formations.

Silica of conrse is derived abundantly from the weathering of rocks in cold solutions and is precipitated principally in the form of chert in limestones. The part mechanically carried is deposited as quartz sand, differing in texture from the chert. The latter mode of derivation is practically excluded for the iron-bearing formations of the Lake Superior region because they contain only small amounts of fragmental quartz at a lew localities and horizons. If we attempt to ascribe the cherts of the iron-bearing formations to weathering, we may look oniy to the silica carried in solution. To have produced the thick iron-bearing formations containing an average of about 70 per cent by volume of chert, the. solution of silica must have proceeded on an enormous seale, probably too large to be explained by ordinary weathering. That some chert was so derived, just as some iron and some fragmental quartz were so derived, is altogether likely, and it would be diffieult to prove the contrary. The percentage of chert in the iron-bearing groups described on page 461 ranges upward from 63 per cent in weight, 
white ('larke's arerage of iencous and erystalline rocks, which might represent the composition of an aredage surface under weathering, is a little less than 62 per ('nnt in silica aud the basic grecustones contain less than 50 per cent in silica. Hence, even if all the silica had been leached (together with the iron) from these rocks (which nerer happens), it would not yicld a percentage of silica as large as that known in the iron-beariug groups. Organic agencies might localize precipitation of silica in certain areas, but not enough to account for existing proportions over the entire region.

The calcium-magnesium eontent furnishes still another argument. In the average crystalline or igneous rocks or in the basic igncous rocks or in sediments derived from the igneous rocks, ealcium preponderates over maguesium, but in the iron-bearing formations the arerage proportion of magnesium to calcium is over 5 to 1 .

It appears in general that the composition of the pre-Cambrian sedimentary groups containing the iron-bearing formations differs from that of the arerage erystalline rocks which formed the shores at those periods in having a higher content of iron and silica and in having a different calcium-magnesium ratio. It might be that the extensions of these iron-bearing sedimentary groups outside of the Lake Superior region would be of such different composition as to bring the arerage more nearly down to what would be expected from derivatives of the crystallme rocks. I t it is believed that the excess of certain constituents in the Lake Superior sedimentary groups that carry the iron-bearing formations over those which seem to have been probably available from ordinary weathering is not counterbalanced by corresponding deficiencies elsewhere, for the reason that the sections on which these figures are based are taken through a wide area in the Lake Supcrior region, and for the further reason that this peculiar composition is repeated over this wide area in the rocks of three successive geologic epochs. If the occurrence of iron-bearing formations in the Lake Superior region is simply a matter of areal segregation and concentration of the normal products of weathering, it is very remarkable that this areal concentration should always have resulted in bringing these peculiar ironbearing phases in the same region. We conclude, therefore, that the excess of iron and silica and the reversal of the calcium-magnesium ratio in the sedimentary groups carrying the ironbearing formations, as compared with the average crystalline rocks from which they might have been derived by erosion, is probably to be regarded as evidence that some unusual source of material was available.

7. It appears, then, from the foregoing paragraphs that there are objections to regarding the iron-bearning formations entirely as sediments produced by wathering of the rocks that were most abundant in the adjacent lands. It is not meant to imply that ordinary erosion and katamorphic processes which are known to segregate iron-bearng sediments were set aside in this region. Indeed, as already indieated, there is definite evidence that some of the iron-bearing sediments were so produced. But it seems that these processes are not adequatc to explain the facts. In character and size the iron-bearing formations are unique as chemical sediments and differ from other chemical sediments derived by normal weathering processes. Some unusual and additional factor scems to be required to explain them. Such a factor is discussed under the following headings.

\section{ASSOCIATION OF IRON-BEARING SEDIMENTS WITH CONTEMPORANEOUS ERUPTIVE ROCKS.}

All the Lake Superior iron-bearing formations are more or less closely related in time and place to basalt flows, usually rich in iron at present and giving evidence of having exuded ifrul salts at the time of their consolidation. The iron-bearing formations of the Keewatin serie's have such relations to the associated cllipsoidal basalts as to point to their deposition in the short periods separating the successive flows of basalt or immediately following the prinripal extrusions. Detailerl evidence of this has been noted in a number of places and repecially" in the Termilion district. (Sce pp. 126-127.) The Negaunce formation of the middle II uronim is alssoriated with abumlant contemporaneous igneous activity. producing ellipsoidal basalts of submarine origin and other extrusse rocks similar to those in the licewatin series in many 
places in the Marquette distriet, especially at the west end (the volcanic Clarksburg formation), and in the Crystal Falls and adjacent districts (the IIemlock formation). The ironbearing formations of the upper Huronian (Animikie group) are associated with igneous activity similar to that of the preceding periods in the Marquette district (the Clarksburg formation), in the Gocebic district (the volcanic rocks of the east and west ends of the (listrict), and in the Menominee, Florence, and Iron River districts. The iron-bearing formation of the Animikie group on the north shore of Lake Superior is not associated with basic greenstones of known contemporaneous development, but as shown on pages 213-214 there is little doubt of its direct continuity with the rocks of the Cuyuna district and the upper Huronian of the south shore, which are associated with basic volcanic rocks.

Especially remarkable are the evidences of the close association of iron-bearing sediments and basaltic flows in the upper Huronian of Michigan. Here ellipsoidal basalt, basalt tufis, and ashes are so intermingled with the iron-bearing formation and stained by secondary alteration that there is difficulty in discriminating them. Recent work has shown the existence of more of the igneous rocks than had before been suspected. Drill holes in the Iron River and Amasa areas of Michigan pass through igneous beds from 2 to 50 feet thick in the midst of the iron-bearing formation. In these places the eye can scarcely detect the break between the grayish and greenish carbonate slates of the iron-bearing sediments and the fine-grained greenish basalts and tuff's. Under the microscope the surface of contact is seen to be an extrenely irregular one, the carbonate apparently irregularly replacing part of the greenstone. This replacement las not been accompanied by any oxidation. It is found in drill holes hundreds of feet beneath the surface, apparently in an association determinerl at the time of the deposition of the ironbearing formation. In the Keewatin of the Vermilion district of Minnesota similar close association may be observed between the jaspers and the basalts. (See Pl. XLVIII, p. 564.)

The significance of the apparent gradation of carbonate of iron and silica and their alterathion products into the greenstone is not yet fully apparent. It can scarcely be doubted that this relation was developed at the time of the deposition of the iron-bearing formation, probably soon after the extrusion of the igneous rocks. It is suspected that these phases represent a transition between reactions associated with the hot igneous masses and the normal precipitation of a sedimentary formation. Attempt has been made in the laboratory to reproduce these remarkably close relations by some combination of igneous and sedimentary processes, but thus far without successful results.

Probably of significance in comnection with the derivation of the iron-bearing formations is the fact that in many places acidic intrusive and extrusive rocks of the porphyry type closely follow extrusive basaits and are locally even more closely associated with the iron-bearing formations than the basalts themselves. This relation is well illustrated in the Vermilion district, where, in a series of interbedded basalt flows, jaspers, and amygdaloidal porphyries, the igneous rock immerliately next to the jaspers is commonly porphyry as well as basalt. (See fig. 13, p. 123.) Similai conditions appear in the Toman River district of Ontario ${ }^{a}$ and elsewhere. It is suspected that this relation is more general than is yet known. (See p. 513.)

The amount of igneous material extruded is not measured by the areas of upper Huronian voleanic rocks now exposed, for extensive extrusive rocks were undoubtedly present in parts of the formation that have been remored by erosion and exist in parts not fet uncovered. It is suggested in the chapter on the Keweenawan (Chapter XV) that the present shore of the Lake Superior basin was the locus of the extrusion of the Keweenawin igneous rocks. If the basin began to form in Animikie time, as is thought possible (sce pp. 622-623), a similar suggestion. for similar reasons, might be made for the Animikie group, in which case the north shore Animikie may really not be so distant from igneous rocks as now appears. The iron-bearing formation of the Animikie group of the north shore is thus associated in time with igneous extrusions, but may be somewhat distant in place. 
The deposition of the lower IIuronian was not accompanied by basic flows, and it does not contain a well-developed iron-bearing formation. The Paleozoic of the Lake Superior region lacks basic igneous rocks and also lacks iron-bearing formations like those of the pre-Cambrian.

\section{ASSOCIATION OF IRON-BEARING SEDIMENTS AND ERUPTIVE ROCKS OUTSIDE OF THE LAKE SUPERIOR REGION.}

The derivation of the iron-bearing formations from the associated ignoous rocks is suggester by the alose association of these rocks not only in the Lake Superior country but in other parts of the world.

Practically all the numerous iron-bearing sediments extending through the Height of Land conntry of Canada, as far east as the Quebec boundary, an interbedcled with basalt flows. Most of these belts, in the writers' judgment, belong in the Kieewatin.

On the east coast of IIudson Bay there are younger Algonkian rocks containing an ironbearing formation, interbedded with fragmental sediments and ellipsoidal basalts. As Low $a$ had called attention to the similarity of these iron-bearing seliments to those of the upper Huronian or Animikie of the Lake Superior region, the junior autlor visited them in 1909 and found a very close sinilarity, even to the possession of carbonate and greenalite phases. Freedom from regetation and precipitous shores aflord fine exposures for stuly. Fragnental sediments of the type now being formed along the shores are interbedded with extrusions of cllipsoidal basalt which give evidence by their textures and associations of haring been cxtruded along ticlal flats, and by their ligh content of jasper and magnetite of having been rich in iron salts at the time of their extrusion. Immediatcly following the basalt comes the iron-bearing formation, closely associated with volcanic muds. It requires no preconceived hypothesis to lead the observer to the view that the extrusion of the igneous rocks was the rariant in the normal conditions of sedimentation ncecssary to produce the iron-bearing formations. The story is so clear that it is possible to outline the probable conditions of sedimentation in some detail. ${ }^{b}$

Gcikie ${ }^{c}$ remarks concerning lower Carboniferous basalts of the Fife coast:

These lavas are thin sheets, often not more than 15 or 20 feet in thickness, and they, as well as the associated tuffs, are intercalated among shallow-water deposits, such as cyprid shales and linestones, coal seams with fire clays, thin sandstones, and ironstones. Some of the basalts have caught up portions of the mud on the sea bottom, but in others the nuddy, sandy, or ashy sediment of the next deposit has fallen into the interspaces between the pillows.

IIe also says ${ }^{d}$ concerning the basaltic lavas of County Tyrone, Ireland:

These greenish lavas are occasionally interleaved with gray flinty mudstones, cherts, and red jaspers, which are more particularly developed immediately above. In lithological character, and in their relation to the diabases, these siliceons bands bear the closest resenblance to those of Arenig age in Scotland, but no recognizable Radiolaria have yet been deterter in them.

Deseribing the Carboniferous voleanoes of the Isle of Man, Geikice says:

Pauses in the succession of eruptions are marked by the intercalation of seams of limestone or groups of limestone. shale, and black impure chert. Such interstratifications are sometimes curiously local and interrupted. They may lie olserver to die out rapidly, thereby allowing the tuff alove and below them to unite into one continuors mass. They seem to have been accunulated in hollows of the tuff during somewhat prolonged intervals of rolcanic quiescence, and to have heen suddenly brought to an end by a renewal of the eruptions. There are some four or five such intercalated groups of calcareous strata in the thick series of tuffs, and we nay regard them as marking the chief pauses in the continuity or energy of the rolcanic explosions.

Again, Geikic $f$ states that in the Carboniferous roleanoes of Devonshire-

Bands of hlack chert and cherty slale are interpolated among the tuffs, which also contain here and there nodular lumps of similar black impure earthy chert-an interesting association like that alluded to as occurring in the (arloniferus wlcanic series of the Isle of Man, and like the occurrence of the radiolurian cherts with the Lower silurian volinuic series.

a Low, 1. P., Report on an exploration of the east coast of IIudson Bay from Cape Wolstenholme to the south end of Janes Bay: ana. liept Geol. Survey Catadia, vol. 13, new s(r., pt. [1, 1903, J). 45-4ti.

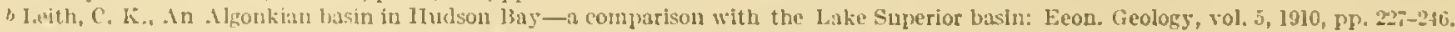

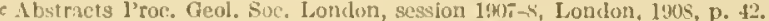

4 (ivikie, Archibald, Ancient volcanoes of Grant Britain, vol. 1, London, 1s97, pp. 210-2.11.

linim, rol. 2, 189\%, p. 24

f llem, vol. 2,1597 , p. 36 . 
The following section in Tertiary volcanoes of the Antrim Plateau of Ireland is described by the same author: ${ }^{a}$

Upper basalt, compact and often coltumar sheets.

Brown laminated tuff and volcanic clays.

Laminated brown impure earthy lignite, 2 feet 3 inches.

Brown and red variegated clays, tuffs, and sandy layers, with irregular seams of coarse conglomerate composed of rounded and sulangular fragments of rhyolite and hasalt, 3 feet 4 inches.

Brown, red, and yellowish laminated tuffs, mudstones, and bule, with occasional layers of fine conglomerate (rhyolitic and basaltic), pisolitic iron-ore band, and plant leds, 8 feet 10 inches.

Lower basalt, amygdaloidal.

The pale and colored clays that occur in this marked sedimentary intercalation have doubtless been produced by the decomposition of the volcanic rocks and the washing of their fine detritus by water. Possibly this decay may have been in part the result of solfataric action. ***

* * * The original area over which the iron ore and its accompanying tuffs and clays were laid down can hardly have been less than 1.000 square miles. This extensive tract was evideutly the site of a lake during the volcanic period, formed by a subsidence of the fluor of the lower basalts. The salts of iron contained in solution in the water, whether derived from the decay of the surrounding lavas or from the discharges of chalybeate springs, were precipitated as peroxide in pisolitic form, as similar ores are now being formed on lake bottoms in Sweden. For a long interval quiet sedimentation went on in this lake, the only sign of volcanic energy during that time being the dust and stones that were thrown out and fell over the water basin or were washed into it by rains from the cones of the lava slopes around.

\section{Concerning the Tertiary volcanoes of the plateau of Small Isles, Geikie ${ }^{b}$ writes:}

It is a noteworthy fact that the sedimentary intercalations among the Canna basalts generally end uptard in carbonaceous shales or coaly layers. The strong currents and overflows of water, which rolled and spread out the coarse materials of the conglomerates, gave way to quieter conditions that allowed silt and mud to gather over the water bottom, while leaves and other fragments of vegetation, blown or washed into these quiet reaches, were the last of the suspended materials to sink to the bottom.

The Arenig eruptions in the Silurian of North Wales contain interesting sediments, described by Geikie ${ }^{c}$ as follows:

Many of the tuffs that are interstratified with black slates (? Lingula flags) at the foot of the long nortliern slope of Cader Idris consist mainly of black-slate fragments like the slate underneath, with a variable proportion of gray volcanic dust. ***

One of the most interesting deposits of these interludes of quiescence is that of the pisolitic ironstone and its accompanying strata on the north front of Cader Idris. A coarse pumiceous conglomerate with large slaglike l, locks of andesite and other rocks, seen near Llyn-y-Garlr, passes upward into a fine bInish grit and shale, among which lies the bed of pisolitic (or rather oolitic) ironstone which is so widely diffused over North Woles. The finely oolitic structure of this band is obviously original, but the substance was probally deposited as carbonate of lime uncler quiet conditions of precipitation. The presence of numerous small Linguly in the rock shows that molluscan life flonrished on the spot at the time. The iron exists in the ore mainly as magnetite, the original calcite or aragonite Inaving been first replaced by carbonate of iron, which was subsequently broken up so as to leave a residue of minnte culses of magnetite.

Radiolarian cherts aro characteristically associated with sandstones and basalts, partly ellipsoidal, at Point Bonita, Angel Island, $c$ and at many other points in the Coast Ranges of California. In alescribing the eruptive rocks of Point Bonita, Ransome says: $f$

Spheroidal basalt, apparently similar to that described, Ihas been noted by the writer at Tiburon, Marin County; at Port IIarford, San Luis Obispo County; and on the summit of the north jeak of Mount Diablo. It is noteworthy that in these widely separated occurrences the rock is always associated witl the red jaspers, and witl what is apparently the San Francisco sandstone.

These cherts were called "phthanites" by Becker" ${ }^{g}$ and regarded as due to secondary silicifieation. Lawson ${ }^{h}$ and Ransome, ${ }^{i}$ on the other hand, regard them as original siliceous deposits

$a$ Geikie, Archibald, Ancient rolcanoes of Great Britain, vol. 2, 1807, pp. 204-205.

i Idem, vol. 2, 1897, p. 223.

c ldem, vol. 1, 1897, pp. 1s0-1 1s1.

d Ransome, F. L., The eruptive rocks of P'oint Bonita: Bull. Dept, Geology, Univ. California, rol, 1, 1593, pp. 71-114.

e Ransome, F. L., The geology of Angel Island: Bull. Dept. Geology Univ. California, vol. 1, 1s94, pr. 193-240

$f$ Ransome, F. L., The cruptive rocks of l'oint Bunita: Bull. Dept. Geology Univ. California, vol. 1. 1893, pp. 109-110.

2 Becker, G. F., Geology of the quicksilver deposits of the Pacific coast: Mon. U. S. Geol. Surrey, vol. 13, 18.4, [pp. 105- 108.

$h$ Lawson, A.C., Sketch of the geology of the San Francisco peninsula: Fifteenth Ann. Rept. 1. S. Feol. Surrey, 1895, pp. 420-42G.

t Ransomc, F. I., The geology of Angel Island: Bull. Dept. Geology Unir. California, vol. 1, 1891, p. 200. 
which are changed into red jaspers and ghancophanic jaspers here and there at igneous contacts. These cherts locally pass into iron ore and are characteristically associated with manganese heds. ${ }^{a}$ The cherts are characterized by minute oval spots found in part to represent racliolarian rennins, but in part of unknown origin. Lawson ${ }^{b}$,liscusses their origin as follows:

It thus seems to the writer that the bulk of the silica can not be proved to be the extremely altered debris of Radiolaria. "lhe direct petrographical suggestion is that they are chemical precipitates. If now we accept this hypothesis, it hecomes apparent that there are three possible sources for the silica so precipitated, viz, (1) eiliceons springs in the bottom of the ocean, similar to those well known in voleanic regions; (2) rarliolarian and other siliceous remains, which may have become entirely dissolved in sea water; and (3) volcanic ejectamenta, which may have become similarly dissolved. The last is the least probable, because we are not actually familiar with such a reaction as the solution of volcanic glass by sea water. Our ignorance is, however, no prof that such solution may not take place under special conditions. * * *

The hypothesis of the derivation of the silica from siliccous springs and its precipitation in the bed of the ocean in local accumulations, in which radiolarian remains became embedded as they dropped to the bottom, secms, therefore, the most adequate to explain the facts, and there is nothing adverse to it so far as the writer is aware. 'The aluundance of the Radiolaria may be due to the favorable conditions involved in the excessive amount of silica locally present in the sea, or simply to the favorable conditions for preservation afforded by this kind of rock. If the springs were strong, the currents engendered might in some plares have heen sufficient to deflect sediment-laden connter-currents, and this may serve to explain the general absence of clastic material in the chert.

The Pilot Knob deposits of Missouri are interbedded with porphyry flows, tuffs, and ashes, suggesting close genetic relation between igneous rocks and sediments.

Illustrations could be multiplied, but enough have been eited to show that basalts, especially the ellipsoidal phases, are characteristically interbedded with more or less graphitic slates, clay's, cherts; jaspers, rolcanic tuffs, iron ores, and in places sandistone. Practically all the features of the association of basalt with sediments described for the abore-mentioned districts are to be seen in the Lake Superior region. The explanations of these associations in other regions therefore become significant in the study of the origin of the Lake Superior ores.

In general there seems to be little doult that some genetic relationship exists among surface basalts, curbonaceous slates, cherts, and jaspers, to which attention has been called by several writers working from different standpoints. ${ }^{c}$ They agree that most of the carbonaceous materials are organic, that the deposition is largely subarueous, and that some of the associated iron is deposited partly through the agency of weathering assisted by organic means. Lawson suggests that the cherts and jaspers may be the result of inorganic chemical deposition by hot solutions. In the Lake Superior region the iron-bearing formations are much thicker and they have certain phases, notably the greenalite or ferrous silicate phase, which are not common clsewhere, all these fentures seeming to favor the hypothesis that the iron formations are in part related to the more or less direct contribution of the iron-bearing materials by hot concentrated solutions from the igneous rocks.

\section{SIGNIFICANCE OF ELLIPSOIDAL STRUCTURE OF ERUPTIVE ROCKS IN RELATION TO ORIGIN OF THE ORES.}

The basalts associated with the iron-bearing formations have so commonly the peculiar ellipsoidal or pillow strueture that one is led to assume that conclitions farorable to the development of the ellipsoidal strueture may be also favorable to the deposition of the iron ore in this listrict. Clements ${ }^{d}$ has described the strueture in some detail for the Crystal Falls district, and from comparison with ocenrences elsewhere concludes it to have been probably a submarine cxtrusive, similar to the a havas of IIawaii described by Dutton.c Daly feaches the same

We have recired too late for discussion a paper on British pillow lawas and the rocks associated with them, by IIenry Dewey and J. S.

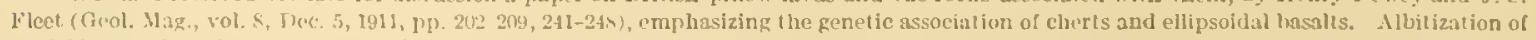

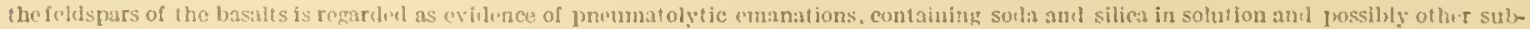
stances. The cherts are elepusiled by those cmanations. This independent eonclnsion is remarkably in accord with tho inferences drawn in this monograjh

dClements, J. M., The Crystal Falis iron-benring district of Michigan: Mon. U. S. Guol. Survey, rol. 36, 1899, PD. 112-124.

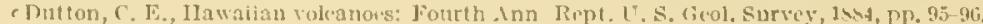

f Daly, R. A. Varioltic pillow lava from Newfounelland: Am. Geologist, vol. $32,1903, \mathrm{p}, 77$.
} 
conclusion for the variolitic pillow lavas of Newfoundland. Later, from a personal study of IIawaiian volcanoes, Daly ${ }^{a}$ regards the ellipsoidal and aa lavas as different, though he is not disposed to question the subaqueous origin of ellipsoirlal lavas. Geikie ${ }^{b}$ repeatedly cites the probable subaqueous origin of the ellipsoidal structure, bised on lis observations in Great Britain and Ireland. Clement Reid " has recently concluded that the pillow lavas near Port Isaac in C'ornwall are of submarine origin, and in the discussion of Reid's paper Geikie ${ }^{d}$ remarked that all the examples of pillow lavas with which he was acquainted were undoubtedly true lavas and belonged to submarine eruptions. Some of them, however, must have been poured out in shallow water, as is particularly observable in the case of the lower ('arboniferous basalts of the Fife coast. (See quotation on p. 508.)

Fenner ${ }^{e}$ concludes that ellipsoilal and other structures in the traps of the Newark group are evidence of flowage of the traps into lakes. He says:

When we came to examine the lava itself we saw that it carried in its own mass plain eviclences of the structural changes which were produced by the presence of the lakes and of the water-bearing strata beneath. Whereas leyond the borders of the lakes the lava was of a close, firm texture and showed a condition of quiet and tranquillity during the process of cooling and hardening, over the area of lake bottom there was evidence of violent agitation having affected it during the initial flows, and rapid cooling and the production of much glassy material during succeeding flows, followed still later by the crystallizing effects wrought by heated waters and the production of secondary minerals.

By others the ellipsoidal structure has been regarded as the result of rapicl cooling or rapicl flow developing large blocks that have rolled one over another, a process which may have been subaerial or subaqueous, or both. This is the explanation offered by Cole and Gregory. $f$ Ransome ${ }^{g}$ concludes for the ellipsoidal structure in the basalt of Point Bonita, California, that one sluggish outwelling of lava was piled upon another to form the whole mass of the flow, the blocks or ellipsoids being incidental to the cooling and movement. He makes no reference to submarine or subaqueous origin. Russell ${ }^{h}$ observes that the ellipsoidal structure found locally in the Snake River basalts is developed by the flowage of the hasalts into lake basins, but concludes ${ }^{i}$ that whether the lava develops the ropy or pillow or block structure is determined by-

the ratio between rate of cuoling and the rate of motion. But this ratio is not the same for different lavas. When a lava sheet cools without motion, neither a characteristic pahoeline nor an aa surface is produced. Nany of the older sheets of Snake River lava illustrate this; they are simply plane surfaces, composed of either vesicular or compact granular basalt.

The explanation of the origin of aa adopted above was not accepted by Dana, $j$ who suggests that the breaking of a lava crust may be due to moisture derived from the rocks over which lava flows and leading to quicker cooling in certain areas than in others. Such an occurrence, however, even if proved to exert an influence, seemingly introduces a variation into a more general process without supplanting the controlling conditions.

Dr. Tempest Anderson and Dr. Flett ${ }^{k}$ describe such structure developing subaerially at Mount Pelee, and Anderson ${ }^{l}$ describes it also developing subaerially in Iceland.

The evidence seems to be that the ellipsoidal structure is both subaqueous and subaerial in its development, that it is produced by the rolling of blocks cleveloped during the flow of the lava as a result of cooling, and that its development is therefore determined by the speed of flow and the rate of cooling, which in tum may bo aflected by entrance into water. Where associated with sediments, the structure seems to be with little doubt subaqueous in origin, as concluded by Geikic. In the Lake Superior region the interbedding of ellipsoilal basalts with sediments of subaqueous origin, according well with the associations of basalt flows and sedimentary rocks that are observed elsewhere, seems to be adequate evidence that the

a Verbal communication.

$b$ Geikie, Archibald, Ancient rolennoes of Great Britain, London, 1897.

c Reid, Clement, and Dewey, Nenry, The origin of the pillow lava near Port Isade in Cornwall: Alustracts l'roe. Geol. Sac. London, session $1907-8$, London, 1908, p. 42 .

d ldem.

eFenner, C. N., Features of trap extrusions in New Jersey: Jour. Geology, rol. 16, 1908, p. 326.

$f$ Cole, G. A. J., and Gregory, J. W., On the variolitic rocks of Hont Generre: Quart. Jour. Geol. Soc., rol. 4t, 1890, p. 316,

$g$ Ransome, F. L., The eruptive rocks of Point Bonita, (alifornia: Bull. Dept. Geology, Univ. California, vol 1, $1 \mathrm{k} 93, \mathrm{n} .112$.

h Russell, I. C., Feology and water resources of the Snake River plaius of Idaho: Bull. U. S. Geol. Surrey, No. 199, 1902, I'P. $\$ 2$ el seq.

i Irlem, p. 9S.

jDana, J. D., Characteristics of voleanoes, New York, 1890, pp. 242-244.

$k$ Cited in Abstracts Proc. Geol. Soc. London, session 1907-8, London, 190\%, p. 42.

lIdem, p. 44. 
ellipsoidal structure of the Lake Superior basalts is largely of subaqueous origin. It should not be assumed, liowever, that all the ellipsoidal basalts of the Lake Superior region are necessarily subaqueous. The region is a large one, the conditions are varied, the ellipsoidal structures are locully ussocinted with struetures ordinarily regarded as of subnerial origin, ellipsoidal structure is known elsewhere to develop subaerially, hence it is rather likely that a part of the structures in the Latie Superior region are of subacial origin. There is little prospect that evilence will be forthcoming to determine exactly the quantitative inportance of the subacrial deposit as compared with the subaqueous deposit; incleed, there scems to be little need of such detormination when it is recognized that both are present. Qualitatively the evidence favors the subacpueous origin of the major part of the ellipsoiclal basalts.

ERUPTIVE ROCKS ASSOCIATED WITH IRON-BEARING SEDIMENTS OF LAKE SUPERIOR REGION CARRY ABUNDANT IRON.

Abundant sulphides and associated magnetite are disseminated in quart $\mathrm{z}$ veins and irregular quartz masses through the ellipsoidal greenstones of the Lake Superior region and of much of the pre-Cambrian shield of Canada. The abundance of those sulphides through all parts of these greenstones has been noted by many observers. They are exceptionally conspicuous in the Canadian part of the region, where erosion has cut down into the fresh rocks and exposed suphide veins that hare not had time to be deeply oxidized at the surface since the glacial epoch. That certain of the sulphides and the associated magnetites of the basic igneous rocks crystallized soon after the crystallization of the igneous rocks, and are not later secondary replacements of such rocks, is shown by evidence of several kinds, as follows:

1. They are minutely disseminated through the greenstone and grade into pegmatitic reins.

2. The sulphides and the greenstones of this type are colimital, and the sulphides are not found so abundantly in any other rocks, a fact which would be diflicult to explain were the sulphicles the result of later introduction by percolating meteoric waters or by later extrusions.

3. The matrix of the ellipsoidal basalt flows is in places so highly charged with magnetite as to disturb the magnetic needle greatly, and the anount of magnetite is much less at the ellipsoids. Illustrations of this are found in the Hemlock formation in the ricinity of the Armenia and Mansfield mines, in the Crystal Falls district of Michigan, and in the Keewatin basalts associated with jaspers southwest of Ely, in the Vermilion district of Mimnesota. The matrix being the last part of these masses to crystallize, the magnetite is obviously introduced late in the extrusion of the mass. Sulphide of iron is present in the same relations.

4. Many of the amygdules in the basalts are wholly or partly filled with magnetite or jasper, or both. Near the Gibson mine, south of Amasa, in the Crystal lialls district of Michigan, red jasper fillings in anygdaloids are rery conspicuous. The amygdule fillings in general are characteristic of hot solutions such as would accompany the extrusion of the mass and not of cold meteoric solutions. (See Pl. XXXYT, A.)

5. Plate XLVIII (p. 56.4) shows a Keewatin basalt with gradation plase through siliceous basalt into banded siliceous iron-bearing formation. In the area from which these specimens were taken, as well as in other parts of the Ticewatin, it is practically impossible to draw a line between unaltered basalt and the iron-bearing formation. This gradation seems to be one developed on the original solidification of the mass. The freshess of the basalt, the lack of latamorphism along the contact with the quartz, and the extrenely rague surfaces and general lack of vein structures a re not characterist ic of later introductions of the quartz after wenthering.

6 . Some parts of the magnetic iron-bearing formations are so related to the associated basalts as to suggest that the iron represents pegmatitic vein material which developed directly from the igneous rock. Such instances are cited for the Atikokan and Vernilion districts.

Evidence is everywhere to be found that these various iron salts associated with the surface extrusive rocks represent remnants of outpourings of concentrated iron solutions af 1 er the main mass of the basalt had crystillized. Deep-seated equivalents of the bisaltic axtrusive rocks are leclieved to be the gabbros which carry large masses of titaniferous magnetite representing iron salts that did not have an opportunity to escalpe at the surface. 
The fact that in some places the iron-bearing formation seems to be related to late acidic phases of extrusions, as has been noted on page 507 , suggests the extrusion of the iron and the acilic phases as extreme differentiation products from the magma. The association of extrenes of this type is not uncommon.

\section{GENETIC RELATIONS OF UPPER HURONIAN SLATE TO ASSOCIATED ERUPTIVE ROCKS.}

The iron-bearing formations of the upper IIuronian are so closely associated with slate that evidence bearing on the origin of the slate throws light on the origin of the associated iron-bearing formations. In figure 76 (p. 612), prepared by S. II. Davis, the minerulogical composition of the upper Huronian slate, calculated from chemical composition, is compared graphically with that of a variety of other clays and soils. It appears from this comparison that the slate as a whole gives evidence by its composition of being less leached of its bases than average slates or residual clays and that it has been derived from basic rocks. It maly be due partly to weathering of the greenstones, to direct contribution of volcanic atsh and muds, and possibly eren to direct reaction with sea water. (See pp. 610-614.)

\section{MAIN MASS OF IRON-BEARING SEDMMENTS PROBABLY DERIVED FROM ASSOCIATED ERUPTIVE ROCKS.}

The close association of iron-bearing sediments with contemporaneous basic eruptive rocks in the Lake Superior region and in other parts of the world, the riclmess of these eruptive rocks in iron salts, and the probable derivation of the upper Ituronian slates associated with the iron-bearing formations from the eruptions make it a plausible hypothesis that these ironrich eruptive rocks were the principal source of the iron in the iron-bearing sediments. As to the manner in which the iron was transferred from the eruptive rocks to the place of sedimentation, there are several possible hypotheses. (1) It may have been transferred in hot solutions migrating from the eruptive material during its solidification, carrying iron salts from the interior of the magma which had never been crystallized; (2) so far as the lavas were subaerially extruded, iron may have been transferred by the action of meteric waters working upon the crystallized iron minerals in the magma, cither hot or eold; (3) the iron may have been transfered by direct reaction of the hot magma with sea water, in which the iron-bearing sediments were deposited.

\section{DIRECT CONTRIBUTION OF IRON SALTS IN IIOT SOLUTIONS FROM THE MAGMA.}

That the igneous rocks contributed some of their iron solutions direetly to the water in which the iron-bearing sediments were being deposited is suggested by the fact that basic extrusive rocks have a widely developed ellipsoidal structure, which has been ascribed by many observers to submarine extrusion. (Sce pp. 510-512.) If these lavas are submarine, then any iron salts extruded must have been contributed directly to the ocean. It will be shown in the following pages that if the salts were so contributed simple and probable chemical reactions would develop the original greenalite or iron silicate phases of the iron-bearing formations. Such phases largely lack the carbonaceous slates so closely associated with the carbonates. It was found in the laboratory that the precipitation of the greenalite phase of the iron-bearing formations required heat in the presence of earbon dioxide and the proballe presence of salt water, in both contrasting with the precipitation of iron carbonate, which goes on in cold solution, favored by the presence of reducing organic agencies. Direct contribution would favor the deposition of the iron salts in a ferrous condition in the absence of reducing carbonacenus material and would avoid the oxidation and precipitation which they would undergo if partly carried subaerially.

Further, the fact that iron-bearing formation seems to be lacking in association with certain similar greenstones in the Lake Superior region and Canara may be evidence that the iron-bearing formations derive their materials by direct magmatic contributions. Such con-

$$
47517^{\circ}-\mathrm{vo1} .52-11-33
$$


tributions are known to be local and variable in composition, and this may explain the localized distribution of the iron-bearing formations. If deriver entirely by woathering of basic igneous rocks, iron-bearing formations should be more abundant in association with igneous rocks outsicle of the Ialke Superior recrion.

The pereentages of both iron and silica in the iron-bearing formations seem to be too high for direct derivation from crystallized basalt by weathering. 'They seem to aceord better with the hypothesis that the iron and silica, especially the silion, were precipitated from concentrated solut ions coming directly from the magna. The lecal presence of acidic igneous rocks between the liavas and the basalts and the fact that the acilie rocks are slightly later than the basalts sugerest that the development of the iron-bearing formation came at at the when acilic phases of the extrusion were eoming out. The irm salts and the acidic phases then might represent the extreme clifferentiation produets of a primary magma of which the basalt was the first extrusion.

Faroring the hypothesis of direct contribution of the iron salts from the lava to the sea water into which it was poured is the lack in many places of any fragmental material between the iron-bearing formation and the eontemporaneous lava on which it rests, the mutual conformity at these places, and the absence of any erosion channels in the greenstones. In the Vermilion distriet of Minnesota bands of iron-bearing formation have been traced for considerable distanees resting directly upon the anygdaloidal upper surface of a lava flow, showing no evidence of intervening erosion and having a contact like a knife elge.

The subaqueous extrusion of igneous rocks would mean the sudden destruetion of any organic material in the near-by sea, to judge from results observed near present-day extrusions. It has been shown that after an eruption the sea floor has been covered to a depth of several feet off II waii by dead fish and other organic material. It is entirely possible that this may explain the origin of some of the carbonaceous materials so closely associated with the ironbearing formations, especially in the Keewatin, where seams of rich graphitic slate are locally associated with the iron-bearing formation and the basalt. It is possible also that this material might be a source for the carbon dioxide necessary for the formation of the iron carbonates. Quantitatively it is probably inalequate to explain either the amount of carbon dioxide necessary for the formation of the iron carbonates or the amounts of carbon to be seen in the associaterl slates. It is mentioned merely as a possible source of a part of these substances. Its importance can not be quantitatively demonstrated.

So far as the parent igneous rocks were extruld subaerially, the eseaping iron solutions would be mingled with meteoric waters, perhaps deriving alditional iron salts from the breaking up of crostallized minerals described under the next heading.

CONTRIBUTION OF IRON SALTS FROM CRYSTALLIZEN IGNEOLS ROCKS 1. METEORIC WATERS.

Some of the basaltic extrusive rocks have textures indicative of subacrial crystallization. Atmospheric agencies, therefore, have been applied during the transfer of the iron solutions to the ocean. Weathering agents would ellectively attack sulphides at or aloove the surface of the water, especially when aided by organic material and residual heat. Inder ordinary weathering these sulphides oxidize and form soluble iron sulphate, which beemes arailable for the sedimentation of the iron-bearing formations. The same reaction liberates free sulphuric acid, which matack the iron in the aldjacent rocks. Still further, it has heen found that acidic ariseous cmanations from igneous rocks attack readily the adjacent rocks. leachingre from them their iron, partly depositing it in place as hychated oxide and partly carrying it awa in solution as a sulphate. A highly instructive quantitative study of the IIawailin basalis by Maxwell a shows the effertiveness of acdic solntions of this lind in decomprosing the rocks and secregating the iron. The marked softening and disintegration of the rocks nay furnish a soure for the unusually large amount of basic mud associated with

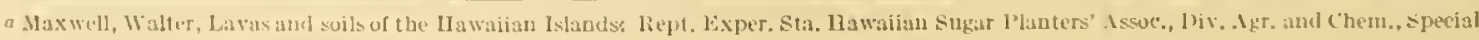
Bull. A, Ilonoluli1, 1:205, pl. S-22. 
the iron-bearing formation. It is entirely conceivable that sone of the thin bands of the iron-bearing formation interbedded with basic flows, with little other sedimentary material, may be essentially residual iron oxile or laterite deposits developed in this way. This seems especially likely where the iron-bearing formation is high in alumina, as, for instanee, in some of the hormblendic Keewatin belts or in the iron ranges near lake Nipigon, where E. S. Moore $^{a}$ has found dumortierite. However, the generally low pereentage of alumina in the iron-learing formations seens to show that for the most part they may not be regarded as metamorphosed residual products of roek alteration.

Vegetation is known to develop on basic extrusive laras with great rapidity, as indicated by the cultivation of the slopes of Vesuvius and Hawailan voleanoes in an incredilhy short time after eruptions, and hence organic ageneies may have aided in the transfer. The chemistry of the transfer of iron salts through these agencies is discussed clsewhere (pp. 519-520). Favoling the view that weathering is a faetor in the proeess is the fact that parts of the original roeks of the iron-bearing formation are made up of iron earborrate assoeiated with black carbonaceous slates, such as may have dereloped in delta deposits. (See p. 502.) There is no more reason to doubt the organic origin of the carbon in these slates than that of the carbon in the carbonaceous slates, iron-bearing formation, and basalts in County Antrim, Ireland, and elsewhere, except that definite organic forms are lacking.

The iron-bearing formations grale locally into phases rich in ealcium and magnesiun carbonates, as at Gunflint Lake and in the east end of the Gogebic district. It is usually assumed that ealcium and magnesium carbonates are ordinary produets of weathering and sedimentary deposition.

It may be asked why weathering did not also deposit iron abumdantly in the Paleozoic sea when it advanced later on these same rocks. To some slight extent iron was so deposited at the Clinton horizon. The answer is believed to lie partly in the essential contemporaneity of the basic extrusive rocks with the associated iron-bearing formations, indicating that the process of derivation of the iron salts and deposition went on soon after the extrusion of the igneous rocks, very rapilly at first owing to juvenile contributions and to leaching during the residual heat, but slowly later when the rocks were colder and the easily alcessible sulphides had been reached. Still later, when the Paleozoic sea came over the area, while it derived some iron from these rocks, it was unable to do the work on the same scale as was accomplished immediately after their extrusion. Sinee glacial time alteration of prrites in the pre-Cambrian shield has penetrated only a fraetion of an inch or at most a few inelies below the striated glacial surfaces, indicating a relatively slow alteration of these substances under ordinary weathering - probalbly too slow to account for the heavy and rapid ehemical deposition of iron-bearing formation without admixture of fragmental material.

Powdered Keewatin roeks eontaining abundant iron sulphide have been treated with oxygenated waters and kept agitated for a period of six weeks. A slight amount of sulphuric acid was also introduced to accelerate the alteration. At the end of this time barely enough iron liad gone into solution to be detected by the most refined methods.

The slate that is so abundantly present with the upper IIuronian iron-bearing formations gives evidence in its composition of derivation from the greenstone. (See p. 612.) It is in part doubtless derived by weathering of the type here described. In part also the slate represents volcanie dust and mud directly deposited from the rolcanic extrusions, and in part it may result from reaction between the hot lavas and sea waters described below.

CONTRIBUTION OF IRON SALTS BF REACTION OF HOT IGNEOUS ROCKS WITII SEA WATER.

When basaltie magmas are extruded into the ocean there is reaction with the salt water. The behavior of basic lavas when extruded into salt water has not been earefully observed. There seems to be a tendency in Hawaii and Teeland for rapid powdering and disintegration at these contacts. What the chemical results are is not apparent. When pottery is sprayed 
with salt water while hot, a glaze of sodimm silicate (water ghlass) is formed, which is more or less soluble. In connection with the present study fresh basalts were heated in a muffle furnace to a temperature of $1,200^{\circ} \mathrm{C}$., a temperiture sufficient to fuse the exterior, and then plunged into salt water of the composition of sea water, the result being a violent reaction, producing principally sodium silicate (sce p. 525) but also bringing a small amount of iron into solution. From the an vilable eridence it seems likely that such a process may account for part of the solium silicate which, by reaction with ferrous salts, produces the grenalite with cxcess of silica. (See pp. 521-523.) The experiment does not seem to suggest an adequate source for the iron in this reaction. There was also during this reaction a tendeney toward disintegration. 'This may inclicate $x$ partial source for some of the muds so closely assuciated with the iron-bearing formations.

\section{CONCLUSION AS TO DERIVATION OF MATERIALS FOR THE IRON-BEARING FORMATIONS.}

Ordinary processes of weathering, transportation, and deposition of iron salts from trranes of average composition were as effective in the pre-Cambrian of the Lake Superior region as in other times and places, but these processes account for only thin and relatively unimportant phases of the iron-loaring rocks; for instance, the lenses of iron carbonates associated with graplitic slates of the upper Huronian, probably deposited in lagoons and bogs of a delti. For the derivation of the unique thick and extensive iron-bearing formations of the Lake Supcrior region it is necessary to appeal to some further agency. This is beliered to be furnished by the farge masses of contemporaneous basic igneous rocks. The association of sedimentary iron-bearing formations and basic igneous rocks is known in many localities outside of the Lake Superior region. 'The iron salts have been transferred from the igneous rocks to the sedimentary iron-bearing formations partly by weathering when the igneous rocks were hot or cold, but the evidence suggests also that they were transfered partly by direct contribution of magmatic waters from the igneous rocks and perhaps in small part by direct reaction of the sea waters upon the hot lavis.

\section{VARIATIONS OF IRON-BEARING FORMATIONS WITH DIFFERENT ERUPTIVE ROCKS AND DIFFERENT CONDITIONS OF DEPOSITION.}

The basalts cont ributing the iron being both subaerial and subaqueous in their extrusion, it is to be expected that the contribution of iron to the body of water in which the iron-bearing formations were being deposited was both direct and indirect. Evidence is not available which will clearly discriminate iron-bearing formations contributed to the ocean in these two ways. In general the parts of the iron-bearing formations originally consisting of earbonate seein to be related to the indiret contribution from the igneous rocks through the agencies of wenthering, and the parts of the iron-bearmg formations originally consisting of greenalite or iron silicate seen to have been contributed in the main directly to the waters without intervening atmospheric or organic agencies. The locally close association of these two types of the original iron-bearing rocks indicates the close association of direct and indirect methods of contribution of inon-bearing materials. The fact that the upjer IImonian iron-beang formation in the Desalbi distriet was largely greenalite, while the upper Iluronian iron-bearing formation of the Gogebie district was lingely carbonate, might therefore signily simply that in one district the salts had been derivel primarily from subacrial weathering and in the other from sulpaqueous contribution, but in each district party in both ways and in both districts essentially from the same rocks. It is noted elsewhere that in many places where the greenalite and carbonate occur together the greenalite ocempies the lower horizon. This might be explained not only by conditions of subaerial contribution succeeding subaqueous contribution, but, as explained dsewhere, by the more rapid settling of the greenalite when precipitated simultancously with the carbonite.

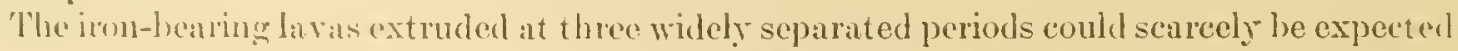
to produce iron-bearing formations of exactly the same character, eren were the conditions of 
deposition the same, for in so far as the ores were directly contributed by magmatic solutions, they were subject to extreme variations in composition.

The conditions of deposition of iron salts were also different during theso threc periods of volcanism. The Keewatin lavas were extruded in larger quantities than at any later time and the associated iron-benring formations constituted only discontinuous beds between the hot extrusives, but in the middle and upper Ifuronian the extrusions were much less abundant and sedimentation proceeded on a larger scale and less directly under the influcnce of igneous rocks. Although some of the differences between these three formations are explaincd by later alteration, it is believed that the highly amphibolitic and magnetitic character of the Kicewatin was partly determined at the time of, or soon after, its deposition, in contrast with the prevailing deposition of ferrous carbonate and ferrous silicate at the later periods. In the discussion of the secondary concentration of the ores it will be shown that the ores of the Kecwatin have undergone far less secondary concentration than the later ores. This is certainly in part due to anamorphic changes before the katamorphic agents had an opportunity to work, but possibly in part also to original differences in texture and composition, possibly because the Keewatin as a whole seems to contain a lower percentage of iron than the succeeding formations, and partly because of the small area of the formations exposed to concentrating agencies. (See pp. 474-475.) The Keewatin series had produced only 6.5 per cent of the total shipments to the close of 1909. The Keewatin secms to occupy the same subordinate position in Canida, and as the arca of Keewatin in Canada is relatively greater than that of later iron-bearing formations, the chances of finding ore there are relatively smaller than in other parts of the Lake Superior region.

It would be expected also that the iron salts closely associated with the igneous rocks would be less regular in their thickness and more generally separated into different belts by intercalited igneous rocks than those at a distance from the arcas of extrusion. The latter seem to be illustrated by the Animikie ores, which attain their maximum development on the north shore of Lake Superior, the nearest known extrusive rocks being west of the lake or possibly under the lake. The remarkably uniform character of the iron-bearing formation and the rest of the Animikie group, distinguishing it from all other pre-Cambrian iron-bearing formations, may well be clue to its distance from the contemporaneous volcanic activity, for, in view of the connection of the ores with igneous rocks alsove outlined, it would seem to be more than a coincidence that the most uniform and widespread of the iron-bearing formations should be the farthest removed from volcanic activity. Variation in the iron-bealing formations with varying listance from the igneous rocks is more defmitely shown by the iron-bearing formation of the Gogebic district, which at the east end of the range, where associated with extrusire rocks, is extremely varied in its composition and is broken into difierent belts by other sediments and by igneous beds. The material of this portion of the formation may also originally have been deposited in small part as magnetite or hematite rather than siderite or greenalite. The irregularity diminishes toward the west, though still existing at Sunday Lake. For many miles west of Sunday Lake the iron-bearing formation was deposited as a continuous thick formation with less amounts of other sediments. These differences may be partly clue to varying conditions of tempernture and materials present, as discussed on page 526, and are undoubtedly due in part to the fact that near the extrusions there were sudden and violent oscillations in level, requiring frequent alternations of sediments, while farther away these oscillations were less marked and the movement was a comparatively uniform one of sinking, perhaps due to the general extrusion of the lavas from the region.

Moreover, shore conditions of deposition may well have been different from those offshore. It has been noted that the upper IIuronian iron-bearing formations in the Ilesabi, Gogebic, Menominec, and Felch Mountain districts are clearly defined formations originally containing greenalite and carbonato between quartz sand below and shale above, and that in these districts they come relatively close to the older rocks, suggesting a possible shore condition. In the Cuyuna, Florence, and Iron River districts the iron-bearing members, originally sideritic, are 
in numerous layers and lenses in the states. These are probably higher in the series and may "slise represent offshore conditions.

It may be arrued that similar basic igneous rocks elsewhere extruded near or under the sea are not accompanied by deposition of iron-bearing formation on such a scale. That iron-benting rocks are present on a smaller seale in such association elsewhere is shown on pages 508-510. It should be remembered that only very exeeptionally do igneous rocks of any sort cary ores with them. There are many areas of Tertiary eruptive rocks and but few Coldfichl camps. So far as the hake Superior iron-bearing formations derive their materials from direct magmatie contribution of igneous rocks, they are likely to be localized by reason of these exceptional contributions. This may explain why all of the similar pre-Cambrian basalts in Canada or elsewhere in the Lake Superior region are not associated with iron ores, though the geologic conditions are upparently the same. It follows from the foregoing statements that the ores are not derived from basic igneous rocks in general but from certain ones.

It may be further algued that while the iron-bearing formations of the Keewatin may have realily been derived from the relatively abundant associated greenstones, the iron-bearing formations of the Huronian are so extensive as compared with the contemporaneous rolcanic rocks that they could seareety have been clerived from those rocks. Such an argument would be without definite basis, however, because there is no known quantitative relation between rolume of igneous rock and volume of materials derived from it as igneous after-effects. The iron ores of the Iron springs district of Utah show a wide range in abumbance as eomparerl with the parent igneous rocks. The contemporaneous voleanic activity in the middle IIuronian wis extensive, being represented by the Hemloek, part of the Clarkshurg, and other volnanic formations. That in the upper Huronian was less in amount, but is represented by most of the Clarksburg, in the eastern part of the Gogebic distriet, and some of the greenstones of the Menominee district: moreorer, it may well be that the present Lake Superior basin was the locus of mueh more abundant upper IIuronian flows, for reasons which are mentioned on pages $507-50$ s.

\section{CHEMISTRY OF ORIGINAL DEPOSITION OF THE IRON-BEARING FORMITIONS.}

\section{NATURE OF THE PROBLEM.}

The experiments specifically described in the following paragraphs, if not otherwise creclited, have been made in the geological and ehemical departments of the University of Wiseonsin, principally by M. E. Diemer, in cooperation with W. J. Mead, R. D. IIall, and others, to meet conditions speeified by the authors.

The problem is to explain the original deposition in thick formations of greenalite ([Fe)[g] $\left.\mathrm{SiO}_{3}, \mathrm{nI}_{2} \mathrm{O}\right)$, siderite $\left(\mathrm{FeCO}_{3}\right)$, chert $\left(\mathrm{SiO}_{2}\right)$, and perlaps some hematite, mngnetite, and limonite, in interealated larers of virying proportions, under conditions, if our preceding conclusions are ralid, ranging from orlinary cyeles of weathering, transportation, and deposition to direct contrilution of iron solutions from the hot igneous extrusives to the water in which the sediments were deposited.

Ohriously a wite range of chemical processes has been involved in the development of the iron ores. It is unlikely that all are known. It is the aim of the following paragraphs to indicate as definitely as possible certain processes which seem likely to have been important, without implieation that these are neessarily the only ones contributing toward the olserved results.

The iron may have been earried as a ferrous salt of silicic, carbonic, sulphurie, hỵlrochloric, or other aciuls present, of as FeO in presence of $\mathrm{I}_{2} \mathrm{O}$ at high temperatures it may have been in excess of the available acid raticles. It appears now as an originat constituent of hasic extrusive rocks in the form of sulphides, mannetite, hematite, chlorite, and the proxenes and amphiboles. The absence of greenalite and ferrous carbonate as such among these original constituents, ant also the absence in the ferrous silicate and earbonate of alkalies, which are associated 
with the iron as original constituents in the igneous rocks, seem to preelude the direet contribution of the iron as ferrous silicate or ferrous rarbonate from the igneous rocks and to require certain sifting and simplifying reactions by outside agencies to explain the composition of the original iron-formation rocks. It will be assumed in the following discussion that the iron is carried as a ferrous salt. From the abuntance of iron sulphides in the original igneous rocks and in their pegmatitic after-effects it will be assumed further that the acil radicle is sulphuric. This is done also for convenience in experimenting. It is not meant to exclule otluer possible combinations of the iron above mentioned. Carbonic acid was doubtless present. Other combinations than these would serve fully as well in the essential steps of the process below outlined.

\section{FORMATION OF IRON CARBONATE AND LIMONITE.}

The close association of many of the thinner carbonate bands of the upper Huronian with black carbonaceous and pyritiferous slates, an association similar to those found in the "Coal Mealsures" and elsewhere, sugrests that the iron carbonate may be the result of reduction of ferric hyclrate by organic material buried with it in deltas, bogs, or other similar places. Hydrogen sulphicle characteristic of these conditions would react upon part of the carbonate of iron, producing the iron sulphide, thereby giving both iron carbonate and iron sulphile in association with carbonaccous rocks.

Van Hise ${ }^{a}$ says:

As to the form in which the iron salts enter the seas, we can judge only by analogy, but if the present be a guide to the past, the iron was chiefly as a carbonate and to a subordinate extent as a sulphate, although it might have been in part in the form of other salts. When the iron salts reach the lagoon, they are precipitated under farorable conditions as ferric hydrate or possibly in part as basic ferric sulphate. Supposing the iron salt to be carbonate, it would be precipitated according to the following reaction:

$$
4 \mathrm{FeCO}_{3}+3 \mathrm{H}_{2} \mathrm{O}+2 \mathrm{O}=2 \mathrm{Fe}_{2} \mathrm{O}_{3} \cdot 3 \mathrm{H}_{2} \mathrm{O}+4 \mathrm{CO}_{2} .
$$

Where this process goes on, on an extensive seale, limonite bodies are buil t up.

It was formerly supposed that this reaction took place as a result of the work of oxygen and moisture alone, and this is true to some extent. But recent observation has shown that where in lagoons iron carbonate is abundant the oxidation is largely performed through the agency of a class of bacteria called the iron bacteria. It has leen found that these bacteria are unable to exist without the presence of iron carbonate or manganese carbonate, but the iron carisonate is the chief compound used. This material they absorb in to their cells. There the iron carbonate is oxidized and the limonite is precipitated. Says Lafar:

"The decomposing power of these organisms is very great, the amount of ferrous oxide oxidized by the celts being a high multiple of their own weight. This high chemical energy on the one hand, and the inexacting demands in the shape of food on the other, secure to these bacteria an important part in the economy of nature, the enormous deposits of ferruginous ocher and bog iron ore, and probably certain manganese ores as well, heing the result of the activity of the iron bacteria." $b$

Evidence is furnished of the precipitation of the limonite of bog irou-ore cleposits in this manner by the discovery in some of them of large numbers of the sheaths of the iron bacteria.c Further evislence of the importance and activity of these bacteria is furnished by their partly or completely closing water pipes of cities where the water contains a considerable amount of iron carbonate. $d$

The iron part of the salts carriel down to the sea as a sulphate would be likely to be thrown down as basic ferric sulphate, $e$ according to the fullowing reaction:

$$
12 \mathrm{FeSO}_{4}+6 \mathrm{O}+(\mathrm{x}+9) \mathrm{H}_{2} \mathrm{O}=\mathrm{Fe}_{2}\left(\mathrm{SO}_{4}\right)_{3} .5 \mathrm{Fe}_{2} \mathrm{O}_{3} \cdot \mathrm{xH}_{2} \mathrm{O}+9 \mathrm{H}_{2} \mathrm{SO}_{4} .
$$

The material thrown down as a hydrated ferric oxide and basic ferric sulphate is mingled with more or less of organic material, ant a deposit of considerable thickness may thus be built up. This deposit is below the level of ground water and is therefore in the zone of incomplete oxidation, or is under the conditions of the belt of cenentation. The oxygen required for the partial oxidation of the organic material is derived in part from the ferric oxide, and the iron is reluced to the ferrous form; but probably this reaction does not take place on an important seale at the surface. The redncing agent may be regarded as carbon, carbon monoxide, or some of the hydrocarbons, such as methane. The result is the same in any case. The oxygen and the carbon produce carbon dioxide, and thus the conditions are reproduced for the production of iron carbonate. A representative reaction may have been as follows:

$$
2 \mathrm{Fe}_{2} \mathrm{O}_{3} \cdot 3 \mathrm{H}_{2} \mathrm{O}+3 \mathrm{CO}_{2}+\mathrm{C}=4 \mathrm{FeCO}_{3}+3 \mathrm{H}_{2} \mathrm{O} \text {. }
$$

a Van Hise, C. R. A treatise on metamorphism: Mon. U. S. Geol. Survey, vol. 47, 1904, pP. 825-827.

$b$ Lafar, F., Techrical mycology, vol, 1, 1,ippincott if Co, 1,998, p. 361.

c Fischer, A., The structure and functions of bacteria, trans, by A. Coppen Jones, Clarendon Press, Ox ford, $1900, \mathrm{p} .69$.

d Lafar, F., op. cit., p. 361 .

e Pickering, S. P. U., On the constitntion of molecular compounls; the molecular weight of basic ferric sulphate: Jour. Chen. Soc. London, vol. 43,1893, p. 1 \$s? 
Beck summarizes the conditions of solution, transportation, and leposition of iron under weathering processes, especially with reference to organic agencies. In lis discussion of the origin of lake and bour ores, he says:

What was the nature of the solutions? The following are the chief solvents:

1. Sulphuric acid formed by the decomposition of iron-bearing sulphinles.

2. Carbonic acid supplied by the air and by decaying organisns, and to enme extent by the living animals. This enables it to attack various silicates.

3. Organic acids also plity a part. These are, moreover, transformed into carbonic acid lyy oxidation, when ropetable masses decompose. In the presence of decaying regetal,le matter deprivind of all adequate oxygen supply, iron Res(puioxide is reduced to ferrous oxide, which forms soluble double salts, with humus acids and ammonium.

The precipitation of iron from these dilute solutions may take flace in varions ways.

In solutions of iron sulphate the mere addition of ammonium humate, which is always present in the brown waters of peaty areas, effects a precipitation of iron cxide and later on of ferric hyclrate.

From carbonated solutions the iron is precipitated as ferric hyclrate by the escape of carbonir acirl in to the air, or by its absorption by plant cells. The deposition of iron carbonate is only possible when the air is excluderl or in the presence of organic matter, which seems to harmonize with the known facts concerning spherosilerite and black-band ores.

From humates and other organie componds the ferric lydrate is precipitated by the oxidation of the humus acids and their decomposition into carbonic acid and water. Here, too, the plant cell accelerates this process by furnishing oxygen. Lastly, by the mingling of iron humates and sulphates, the sulphuric acid, which kept the iron sesquioxidle in solution, unites with ammonium, and iron is precipitated as hydroxide or as ferric humate.

In this action, the life processes of plints take a part, entirely independent of any products of plant decay. According to Ehrenberg, the algie, especially the sn-called iron algae, Galionella fermuinea Ehrenb., are actire ore precipitants, coating their cell walls with ferric hydrate and opaline silica. This alga is abundant on the sea bottoms. According to the recent works of Mlolisch and Winogradsky, these and most other supposed algre are ciliated bacteria of different kinds, especially. Leptothrix ochracen.b

The silica of these ores may originally have been held in solution as alkaline silicates, which are supposerl to be decomposed by carbonic acid. This silica is precipitated simultaneously with the ferric hydrate. The phosphoric acid was certainly present as ammonium phosphate and is precipitated at first as iron phosphate and as calcium phosphate in calcareous ores. $* * *$

We saw that in the case of lake ores the deposition took place quite slowly. This process is more rapid where the drainage from the gossan of a large pyrite deposit is carried into a lake basin, or into the sea, or where mining operations produce an inflow of great quantities of iton-bearing mine waters. Thus the bottom of Lake Tisken, near Falun, is covered with a layer of ocher mud several meters thick that has been furnished by the neighboring pyrite stuck. The bed of the Rio Tinto carries ocher mud and diatoms derived from the waters of the copper mines as far as Palos in Huelra Bay. That this was the case even beiore mining began at that locality is proved by the deposit of iron ore on the 11 esa de los Pinos and the Cerro de las Vacas. These limonite deposits were formed in a bog which was afterwarls dissected by the river. The ironstones contain plant remains of the same character as the present flora. Slabs of this ore were used by the Romans for tombstunes.c

Iron carbonate is known to be directly precipitated when a ferrous salt comes into contact with calcium carbonate, as, for instance, when ferrous solutions from intrusives penetrate a limestone. The presenee of any calcium carbonate in the waters or sediments at the time of the deposition of the Lake Superior iron formations may have reacted with any ferrous salts present to produce carbonate, but we have no direct evidence of this.

The above-noted processes do not secm adequate to aceount for all the iron carbonates of the Lake Superior region, for some of them, as, for instance, in the Gogebic clistrict, are in much thicker masses than have been found clsewhere associated with carbonaceous seams, are comparatively free from carton and sulphides, and, moreover, show remarkably elose assuciation with certain iron silicates called greenalite, to which they are partly secondary and which are thought to develop in another way. Laboratory reactions between iron silicales, iron carbonates, and carbon dioxide, discussed under another heading (1).526), suggest other processes of iron carbonate deposition.

\section{NATURE OF CARBONATE PRECIPITATE.}

The precipitate of ferrous carbonate is apple-green in color, is floceulent, settles stowly, and shows a distinct tendency in settling to segregate into hands separated by greater or less

a Beck, Richarl, The nature of ore deposits (tr. by W. 11. Weed), rol. 1, 1905, pp, 101-103. Sueslso lan 1lise, C. R., I treatise on nuetamor plusm: Mloa, U. S. fieol. Survey, vol. 4i, 1904, p. 550.

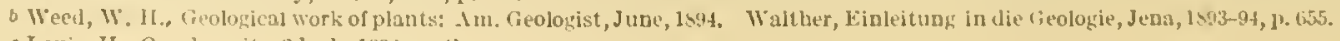

c Louis, H., Ore deposits, 2 d ed., 1896, p. 41. 
amounts of free silica. No tendeney is observed in this substance toward the development of giobular forms, and in this connection it is suggested, in viow of Lehmann's inferences cited on page 525, that the iron carbonate has a strong tendency to crystallize.

PRECIPITATION OF GREENALITE.

PROCESSES.

Evidence has been presented clsewhere (pp. 166-16s) to show that greenalite $\left(\mathrm{Fe}(\mathrm{Mg}) \mathrm{SiO}_{3} \cdot \mathrm{nH}_{2} \mathrm{O}\right)$ is different from glanennite and probably from other green silicate granules which have been described. It may be reproduced in the laboratory.

In all the reactions and experiments in which silicic acil was used, it was in aqueous solution aloreg with sodium chloride. This was for two reasons: (1) The silicic acid was prepared by neutralizing sodium silicate of the composition $\mathrm{Na}_{3} \mathrm{O} .3 \mathrm{SiO}_{2}$ with hydrochloric, acid. Thus:

$$
\mathrm{Na}_{2} \mathrm{O} .3 \mathrm{SiO}_{2}+2 \mathrm{IICl}=2 \mathrm{NaCl}+3 \mathrm{SiO}_{2} \cdot \mathrm{II}_{2} \mathrm{O} \text {. }
$$

(2) The methods of experimentation chosen approximated the natural conditions under which the greenalite was deposited, and, to our belief, this was in the presence of sea water. On starting with a soluble ferrous salt, for convenience ferrous sulplate, the following reactions are found to be significant with reference to the origin of greenalite:

1. I solution of ferrous salt when boiled with silicic acil (prepared as above stated) produces (in the absence of air) no precipitate, showing that silicic acid and a ferrous salt do not react to form greenalite.

2. Ferrous sulphate reacts directly with solutions of silicates of the alkalies, producing a gramular precipitate corresponding in composition to the water glass used in the precipitation. Thus:

$$
\mathrm{FeSO}_{4}+\mathrm{Na}_{2} \mathrm{O} \cdot 3 \mathrm{SiO}_{3}=\mathrm{FeO} .3 \mathrm{SiO}_{2}+\mathrm{Na}_{2} \mathrm{SO}_{4} .
$$

It is shown on page 522 that this precipitate is composed of ferrous silicate $\left(\mathrm{FeSiO}_{3}\right)$ and free silica.

If a soluble magnesium salt is present with the ferrous salt in the above reaction, it will be precipitated as $\mathrm{AlgSiO}_{3}$ (or the silicate corresponding to the composition of the water glass used), explaining the presence of some $\mathrm{MgO}$ in the greenalite.

3. That the precipitate $\mathrm{FeO} .3 \mathrm{SiO}_{2}$ consists of ferrous silicate $\left(\mathrm{FeSiO}_{3}\right)$ and free silica is shown by the following experiments:

When the precipitate $\left(\mathrm{FeO} .3 \mathrm{SiO}_{2}\right)$ formed under the given conditions is dissolved in strong $\mathrm{NaOH}$ and reprecipitated by neutralization of the large excess of alkali by hydrochloric acid, the composition of the resulting precipitate is $\mathrm{FeSiO}_{3}$ (by analysis), and the remaining silica of the $\mathrm{FeO} .3 \mathrm{SiO}_{2}$ is held in solution as colloidal silicic acist.

Furthermore, when $\mathrm{FeO} .3 \mathrm{SiO}_{2}$ is boiled with water silica is taken into solution, while the iron remains in the precipitate, and the ratio $1 \mathrm{FeO}: 3 \mathrm{SiO}_{2}$ lecomes gradually less and approaches $\mathrm{FeO}: \mathrm{SiO}_{2}$. This process can not be carried to the extent of $\mathrm{FeO}: \mathrm{SiO}_{2}$, however, as the iron of the compound oxidizes, and when it oxitizes the combined silica becomes soluble, so that no distinction can be made between the silica of the compound and the uncombined excess siliea. When greenalite $\left(F \mathrm{eO} \cdot \mathrm{SiO}_{2}\right)$ alone is boiled with water no silica goes into solution.

The composition of the greenalite is shown further by the fact that when boiled with water through which carbon dioxide is being passed, iron and silica go into solution in the proportions $1: 1$.

4. When the proportions of silica and alkali are varied in the water glass, there is variation in the total amount of silica precipitated.

5. When the ferrous salt is in excess, in the precipitate the proportion of the iron to total silica precipitate is relative to that of the sorlium silicate, but when the water glass is in excess, the proportion of iron and silica is variable, depending on the temperature at which it is former. This is shown by the precipitates resulting from mixing solutions of ferrous sulphate and water glass. 
The precipitates are mixtures of formos silicate and frere silica:

(a) The precipitate from cold solutions with ferrous salt in excess may be expressed as $\mathrm{F}\left(\mathrm{O} .3 \mathrm{SiO}_{2}\right.$.

(b) The precipitate from cold solutions with water grass in excess may he expressed as $\mathrm{FeO} .5 \mathrm{SiO}_{2}$.

(c) The precipitate from loot solutions witl ferrous salt in excess may be expressed as $\mathrm{FeO} .3 \mathrm{SiO}_{2}$.

(d) The precipitate from lut solutions with water glass in excess may be expressed as $\mathrm{FeO} .10 \mathrm{SiO}_{2}$.

6. Regardless of the various proportions of iron to total silica obtained under the conditions stated in paragraplis 4 and 5, the iron silicate formerl has the character of greenalite and the rariation in composition is antirely in the amount of free silica precipitated.

7. The precipitation of ferrous silicate requires neutral or slightly alkaline conditions. The substance is soluble in acids and strong allkalies. When water glass is added to a forrous solution which is acid with hydrochloric or sulphurie acid, there is no precipitat ion. but when this is neutralized with alkali, a ferrous silicate precipitate results. Tnder strongly alkaline conditions it will not precipitate, being held in more or less of a colloidal solution, which las a greenish mulily appearance.

Thus the materials necessary to make greenalite might be carried for some distances in acid or alkaline solutions before precipitation. Ifydrochloric acis is formed simultancously with the sodium silicate. This would act as a solvent. If the solution were alkaline, deposition would come by neutralization with an acid, such as carbon dioxide.

8 . The iron of the ferrous silicate precipitated in the absence of oxygen is entircly in the ferrous condition. The freshly precipitated ferrous silicate was thoroughly wished, dissolved in sulphuric acid, and the ferrous iron titrated. This gave the ferrous iron of the salt- 0.154 per cent. Then the total iron was calculated as FeO, the result being 0.159 per cent.

9. When oxygen is arailable, variable percentages of ferric oxide develop in the silicate.

10. Greenalite may also be produced by using other ferrous salts as chloride, according to the reaction-..-

$$
\mathrm{FeCl} l_{2}+\mathrm{Na}_{2} \mathrm{SiO}_{3}=\mathrm{FeSiO}_{3}+2 \mathrm{NaCl}
$$

11. As first precipitated the greenalite and silica are hyolrous. If they are allowed to stand and dry, out of contact with the ail, the percentage of water becomes progressively less. Presumably this loss may go on for an indefinite time and to an indefinite extent. Inalyses of greenalite rocks of the Mesabi district show considerable variation in the amount of combined water.

12. Greenalite may be formed by the reaction of alkaline silicat a and iron bicarbonate. ${ }^{a}$

\section{NATLRE OF GREENALITE PRFCIPITATE.}

When formed by any of the processes above mentioned the greenalite and associated silicat first constitute a green, flocculent precipitate. As this precipitate settles a gramular structure practically identical with that observel in the Mesabi slicles is developed. The opt ical properties also are the same. The precipitate has been pressed and dried, a slide cut from it, and a photomicrograph taken (Pl. XLII, B). A comparison of this plate with one taken of the greenalite rock (Pl. XLII, A) shows identity of textures which can not be mistaken, in spite of the imperfections of the granules developed artificially in cutting the slides. As the precipitate settles, there is also to be observed a distinct tendeney toward banding.

The only feature in which the artificial greenalite glanules differ from those of the Mesabi district is in lacking the small perecutage of magnesia found in Mesabi granules. No attempt was made to introduere magnesia artilieially, but there would secm to be no inherent chemical dilliculty in the association of the magnesium with the iron, an association chatracteristic of silicate rocks. 
PLATE XLII. 


\section{PLATE XLII.}

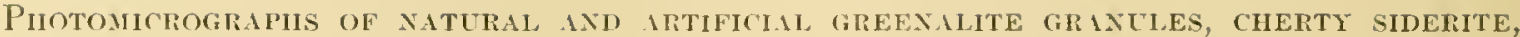 WND CONCRETIONARY FERILGINOT'S CIIFRT.}

A. Greenalite granules (speeimen 45765 , slide 16395) fron Cineinnati mine. Without analyzer, $X 40$. The granules are for the most part unaltered, and are dark green, light green, or yellow. Some of them show alteratiuns to iron oxide and to dark-green chloritic material. There altered they become dark brown, black. or dark green. The matrix is entirely chert. Evidence of crushing is to be observerl in minute cracks ramifying through the slide. Tote the remarkable similarity in shapes of these granules to thuse of the green granules in Clinton ores, illustrated in Plate XLV (p. 536).

$B$. Greenalite granule in matrix of silica artificially produced in the laboratory. Withont analyzer. See description (p). 522-523),

C. Photomicrograph of eherty siderite altering to ferruginuus chert (specimen 6138, slide 1173), irom north shore of Gunflint lake, T. 65 N., R. 3 W., Minnesota; Animikie group. In ordinary light, $\times 25$. The figure illustrates the formation of iron oxiles, psendomorphous after siderite. A barkground of chert eontains numerous small roundish and rhombohedral areas of siderite and hon oxide. Between the little-altered and wholly-altered siderite a rumplete gradation is seen.

D. ('meretionary fermginous chert, developed from alteration of cherty siderite (specimen 904s, slide 2556 ), from the SE. $\frac{1}{4}$ sec. 27 . T. 46 X., R. 2 E., Wisconsin. In ordinary light, $\times 25$. In a cherty backgrund are beatiful concretions, which are composed of coucentric rings of iron oxide and chert. One concretion particularly is very fine, shwwing many closely packed concentric rings. Silica is seen hreaking across these rings in a lew places. 
U. S. GEOLOGICAL SURVEY

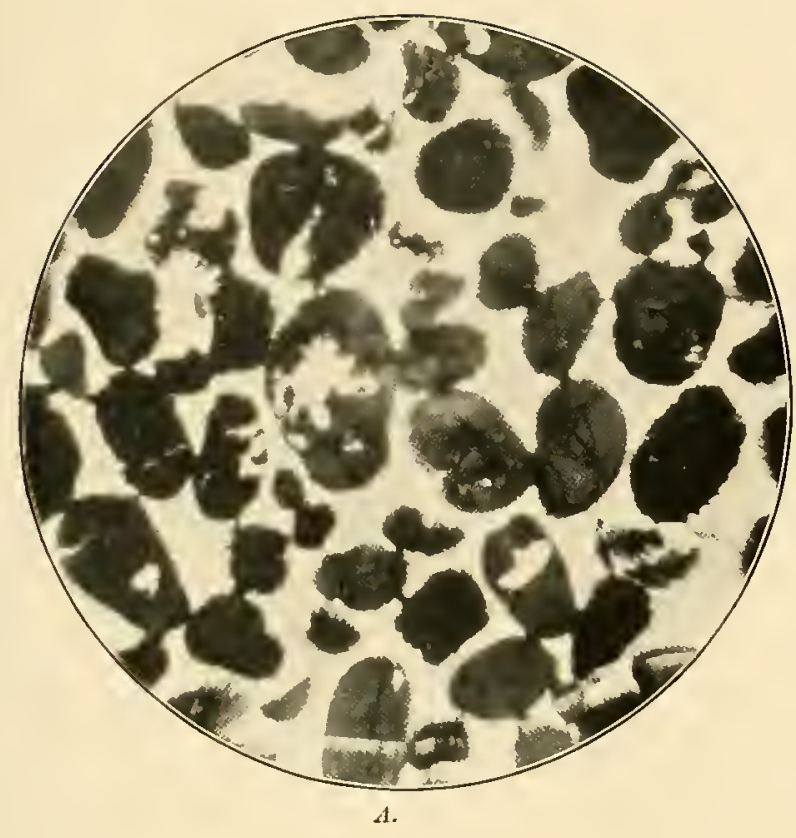

MONOGRAPH LII PL XLII
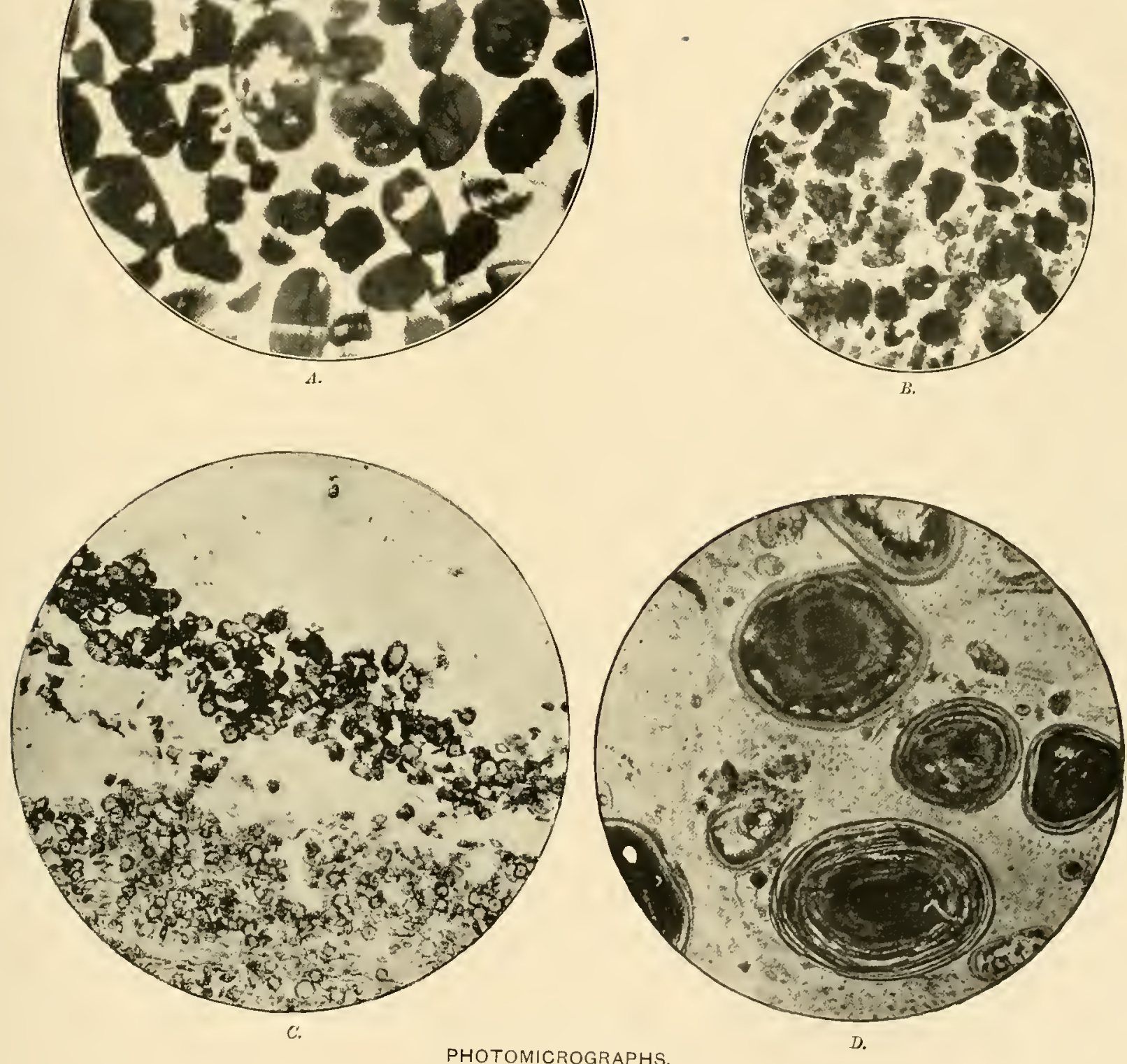

The reason for the greenalite taking the globular form is probably found in the surfuce tension between the precipitate and the liquid, which tends to make the smallest possible surface of contact between them, just as mercury in contact with the air will tend to take a globular form in response to surface tension. Such forms are commonly observed in precipitates. Lehmann ${ }^{a}$ has investigated them extensively and finds them to develop characteristically in precipitates which lack strong crystallizing tendency. He also finds such forms in other precipitates to be intermediate steps toward crystal form, and prescuts interesting photomicrographs of incipient development of these forms from these int ermediate globular stages. He has used the expressive term "liquid crystals" for these intermediate globular stages. Correlating the development of liquid crystals as intermediate steps in the formation of crystuls, where the substances are of strong crystallizing power, with the fact that similar forms and not crystals are likely to be the permanent form taken by substances of low erystallizing power, he is led to suggest that the permanent retention of globular forms is a consequence of low erystallizing power, the substance in its attempt to organize itself baving reached the stage of a liquid crystal but not haviug gone further.

Hydrated iron oxide also temls to take on globular forms when precipitated.

SOURCE OF AlKAlINE SILICITES NECESSAIT TO PRODLCE GREENALITE.

The above-described reactions indicate that it is necessary to account for the presence of alkaline silicate rather than free silicic acid to produce the desirerl results. Soluble alkaline silicates are lnown to be one of the common results of rock decay, but a comparison of the amount of silica arailable from the basic rock by weathering with that concentrated in the iron formations shows such an excess in the iron formations, as well as absence of alkalies, as to kad us to search for another possible source for the alkaline silicates. Sodium silicate is furnished by the reaction of sea water upon hot silicate magmas of extrusive basalts or porphyries or upon the siliceous solutions coming from these extrusires as igneous after-effects or forming a part of them. Abundant rein quartz inclosing iron sulphides in the basalts and porphyries is taken to represent remnants of siliceous solutions which dirl not escape. These reactions were suggested by the common practice in pottery making of producing a water-glass glaze by spraying salt water against the hot silicates. Under ordinary conditions hydrochloric acid is much stronger than silicic acid, decomposing many of the silicates, but when heated hydrochloric acid is volatile and silicic ncid is not, hence silicic acid may then displace hydrochloric acil from its salts and produce alkaline silicates.

By neutralizition of water glass with hydrochloric acid a solution of silicic acid is obtained, along with sodium chloride formed in the reaction. To obtain the neutral point-that is, the point where the sodium silicate is just decomposed-methyl orange may be used as an indicator. This solution is boiled for some time, and the inclicator shows that the solution has become alkaline, showing that alkaline silicate has formed. If again neutralized by bydrochloric acid and strongly boiled, the alkalinity returns. A solution of sodium chloride when boilerl without the addition of the silicie acid shows no such alkalinity.

A solution of silicic acid and sodium chloride, if eraporated to dryness and heated, but not to fusion, has considerable alkalinity when redissolved in water, showing that alkaline silicate has formed.

From these experiments it appears that sodium chloride can be slightly decomposed by silicic acid or silica in boiling solution, forming sodium silicate, but when heated to a higher temperature sodium chloride decomposes more readlily.

In adlition to conducting the reactions with free silicic acid, salt water was sprayed upon a lot Keewatin hasalt, with the result that a water-ghass glaze was produced by reactions similir to those above described.

a Lehmann, O., Flüssige Kristalle sowie Plastizitït von Kristallen im Allgemeinen, molekulare LTmlagerungen und Aggregatzustandsünderungen, Leipzig, 1904. 


\section{REACTIONS BETWEEN GREENALITE AND IRON CARBONATE, OR CARBON DIOXIDE.}

1. A soure of the iron cartronate appens in the reaction of carbon dioxide upon the ferrous silicate (greenilite), cither cold or hot, as follows:

$$
\mathrm{FeSiO})_{3}+\mathrm{CO}_{2}=\mathrm{FeC}_{3}+\mathrm{SiO} \mathrm{O}_{2} \text {. }
$$

2. Solin fesio, and free silica boiled with water through which capton dioxide is passed shows iron and silical in solution in the ratio Fe():Si() $2: 0.0320) 0.0362$, indicating that the grecenalite, and free silica to only a slight extent, are taken into solution.

3. If carbon dinxide is passed through water in the cold containing solid greenalite $\left.(\mathrm{FeSiO})_{3}\right)$ for twenty hours, iron and silica are taken into solution in about the proportions 1 to 1 . Less, lowerel, is dissolved than when the solution is hot.

4. If precipitater ferrous carbonate and precipitated ferrous silicate of the composition Fe( $3_{3} \mathrm{SiO}_{2}$, instead of ferrous silicate and cartoon dinxide, are boiled in water, curbon dioxide is given off and greentite remains according to the following reaction:

$$
2 \mathrm{leC}^{\prime}\left(\mathrm{O}_{3}+\mathrm{FeO} .3 \mathrm{SiO}_{2}=3 \mathrm{FeSiO}\right)_{3}+2 \mathrm{CO}_{2} \text {. }
$$

In the cold solution both remain. This reaction is similar to 5 , below, as it is probable that part of the silica is in the form of silicie acid and not combined with the iron.

5. A solution of silicic acid was boiled with precipitated ferrous carbonate. The composition of the precipitate from several deteminations was variable but in each case showerl deomposition of the ferrous carbonate by the silicic acid, producing greenalite. This decomposition continues until the silicic acil is entirely precipitated as ferrous silicate.

6. Alkaline silicate and iron bicarbonate react to form iron silicate ${ }^{a}$

These results show that carbon dioxide will break up precipitated ferrous silicate, either cold or hot, producing iron carbonate, which is probibly in solution as the soluble bicirlonate. The precipitation of the iron carbonate would follow from the loss of carbon dioxide.

The experiments show furt her that when carbonate is actually thrown out it may be reacted upon by silicic acid or alkaline silicates when heated, driving off carbon dioxide, indicating than the silicate is the more stable under such conditions. In the cold no reaction takes place; the silicate and carbon dioxidie miry exist side by side. In short, there is a constant tendency for the development of a bicirbonate and the precipitation of a carbonate of iron in the presence of carhon dioxide, but the precipitate is stable only when cold.

It appears, therefore, that the probable chemical result of the extrusion of the igneous rock jnto salt water carrying ferrous salts, with or without free silicic acid, is the formation of ferrous silicate with the simultancous precipitation of free sitiea in proportions varying with conditions; that of the soluble salts of the bases which may have been simult aneously delivered the silt of magnesia would form an insoluble compound with the alkaline silicate and he precipitated with the iron; that such iron silicate is the first and most stillye salt to form under conditions of heat: that so far as carbon dioxide is present it will tend to deconpose the silicate, taking the jon into solution as iron hicarbonate, wheh, howerer, will renain as iron carbonalte after precipitation only when cold, being decomposed when hot by reaction with silicic acisl, w alkaline silicates. The first precipitate after the extrusion of the lava would therefore tend to be greenalite, unless the solution is acid or strongly alkaline, preventing precipitation

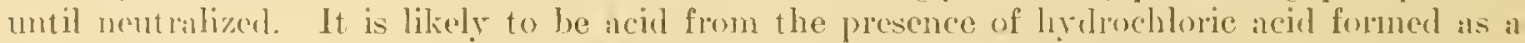

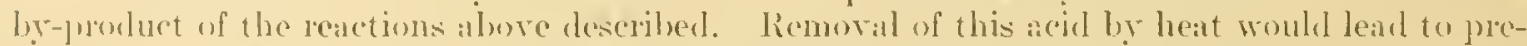
cipitat ion of grwenalite. The presence of a liarge anuount of carbon dioxide, also, would prevent the precipitation ol ereenalite, loblung the substance in solution until loss of carbon dioxide from the hicarbonate allowed the precipitation of the carbonate. The aleposition of greenalite therefore elepends on the alsence of carbon dioxicle or other acid; the deposition of

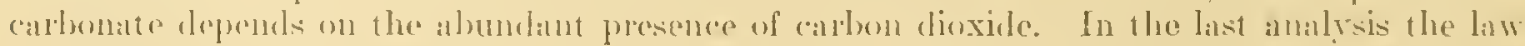
of mass aletion dotomines which of the two shall form. Iron carbonate replateinger greenalite is

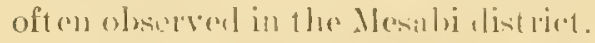


SOURCE OF CARBON DIOXIDE FOR REACTIONS WITH GREENALITE.

The reactions above described require a source for the carbon dioxicle. One source may be the carbonaceous slates so abundantly associated with the carbonates. Their listillation cluring the period of deposition of the carbonates would furnish carbon dioxide for these reactions. Another source ma be the igneous rock from which the greenalite solutions are held to have come. To quote Chamberlin and Salisbury, "The data now at command seem to indieate that carbon dioxide increases greatly in relative alundance as volcanic action dies away. Great quantities of this gas are often given forth long after all signs of active voleanism have disappeared."

DEPOSITION OF HEMATITE, MAGNETITE, AND SILICA DIRECTLY FROM HOT SOLUTIONS.

Certain facts have been described for the Keewatin iron formations indicating that the present hematitic and magnetic jaspers may not be the result of alteration of earlier ferrous compounds, but are original precipitates in the present form. The same kinds of solutions from these igneous rocks being postulated as seem to be required to produce the greenalite and carbonate, the iron oxides could be produced by the following reactions:

$$
\begin{aligned}
& 6 \mathrm{FeSO}_{4}+3 \mathrm{O}=2 \mathrm{Fe}_{2}\left(\mathrm{SO}_{4}\right)_{3}+\mathrm{Fe}_{2} \mathrm{O}_{3} . \\
& 9 \mathrm{FeSO} \mathrm{O}_{4}+4 \mathrm{O}=3 \mathrm{Fe}_{2}\left(\mathrm{SO}_{4}\right)_{3}+\mathrm{Fe}_{3} \mathrm{O}_{4} .
\end{aligned}
$$

Nagnetite may be formed in high temperatures by the reaction of ferrous iron and water, according to the following reaction:

$$
3 \mathrm{FeO}+\mathrm{H}_{2} \mathrm{O}=\mathrm{Fe}_{3} \mathrm{O}_{4}+\mathrm{H}_{2} \text {. }
$$

This reaction is reversible. As it does not require change in volume, probably pressure does not control it. As the derelopment requires erolution of heat, the formation of magnetite is farored by lowering of temperature. Travers ${ }^{b}$ and, later, R. T. Chamberlin ${ }^{c}$ have shown that the free hydrogen in rocks may be developed in this manner by artificial heating.

This carries us a step farther back toward the direet pegmatitic after-effects and magmatic segregations producing the magnetites diseussed on pages 561-562.

\section{DEPOSITION OF IRON SULPHIDE.}

Iron sulphides are exceptionally abundant in connection with the carbonaceous slates and iron carbonates, presumalyly deposited in bogs or deltas. Hydrogen sulphide characteristic of these conditions would react upon iron carbonate and produce iron sulphide.

Hydrocarbon distillates from muds or shales, such as are commonly given off in marshes, would accomplish direct resluetion of soluble iron sulphates to iron sulphides.

The existence of iron sulphides as magmatic segregations and deep-seated contact minerals points to another mode of origin of iron sulphicle. The ferrous sulphate and silieic acil solutions coming from extrusives being again postulated, the reduction of ferrous sulphate directly to the sulphide could be brought about in the presence of hy drogen sulphide or hrdrogen, hoth of which might be emanations from the same mass.

The reaction of ferrous sulphate and magnetite would produce iron sulphide, according to the following reaction:

$$
\mathrm{FeSO}_{4}+8 \mathrm{Fe}_{3} \mathrm{O}_{4}=\mathrm{FeS}+12 \mathrm{Fe}_{2} \mathrm{O}_{3} \text {. }
$$

\section{CORRELATION OF LABORATORY AND FIELD OBSERVATIONS.}

It appears, therefore, that the principal original iron-bearing constituents of the iron formations, greenalite and carbonate, as well as the subordinate ones, may be produced in the lahoratory with comparatively simple reactions under eonditions ranging from those similar

a Chamberlin, T.C., and Salisbury, R. D., Text-book of geology, rol. 1, 1904, p. 590 ,

b Travers, M. M. P', Proc. Roy. Soc., Yol. tit, 189s, pip. 130-142.

c Chamberlin, R. T., The gases in rocks: Pub. Carnegie lust. No. 10i, 1404. 
to weathering, transportation, and deposition at ordinary temperatures, aided by organic relucing materials, to conditions of direct contribution of iron-benring salts from the hot igneons rocks to the locus of deposition. Carbonate or grenalite night develop under either set ol' conclitions, but on the whole the former set secms to be more favorable chemically to the drvopment of iron carbonate associated with the carbonaceous slates and the latter set more favorable to the ilevelopment of greenalite. It also appears that iron carbonate may develop from reactions of greenalite with carbon dioxide, and this is regarded as an adequate though not necessary means of precipitation of iron carbonate known to be more or less free from carbonaceous material and in close association with greenalite. Iron carbonate secondary to gremalite is commonly observed. It may be noted that when earbon dioxicle reacts upon greculite, carbon dioxicle is introduced and nothing is taken away. The pereentage of silica in the cherty carbonate is therefore less than the percentige of free silica in the original cherty greenalite. The exact difference in percentage will depend on the proportion of greenalite to free silica chosen for the reaction. An arerage of all the iron carbonate analyses arailable from the Lake Superior iron formations gives iron 24.56 per cent, silica 41.15 per cent. An arerage of all the greenalite-clert analyses gives iron 25.05 per cent, silica 55.80 per cent. These figures are lerived from a suffieiently large number of samples to make them fair arerages. Their validity is strengthened also by their accordance with the composition of the alteration products, the ferruginous cherts and jaspers, the average composition of which has been closely ascertained. The lower relative silica content of the iron earbonates is thus suggestive though not decisive evidence of the derivation of some of the carbonates from the greenalite rocks.

$A$ condition also pointing to reactions between iron silicate and carbon slioxide to procluce iron carbonate is the conspicuous absence in the greenalite and in some of the iron carbonate of the bases which form soluble compounds with the silicates, especially calcium and the alkalies, and the presence in the greenalite and iron carbonate of magnesil, a substance which forms an insoluble compound with the alkaline silicates. The average content of these minor constitnents in the greenalite and earbonate is as follows:

Arerage magnesium, calcium, sodium, and potassium content in grecnalite and cherty carbonate.

\begin{tabular}{|c|c|c|}
\hline & $\begin{array}{l}\text { Greenalite } \\
\text { rock. }\end{array}$ & $\begin{array}{l}\text { Cherty } \\
\text { carbonate. }\end{array}$ \\
\hline $\begin{array}{l}\text { Magnesinm } \\
\text { Calcium ............... } \\
\text { Sollium and potassium. }\end{array}$ & $\begin{array}{r}\text { Percent. } \\
4.20 \\
\text { vone. }\end{array}$ & $\begin{array}{r}\text { Percent. } \\
5.20 \\
\text { rotie. }\end{array}$ \\
\hline
\end{tabular}

The above argunent will not apply to the exceptional iron earbonates which show gratations into limestones and ferrodolomites, as, for instance, at Gunflint Lake and at the east end of the Gogebic district.

Whether iron carbonate develops by reaction of greenalite upon carbon dioxide or under the orlinary sufface weathering comlitions in the presence of organic material, when we look into the probable sequence of events following the extrusion of the original iron-bearing igneous rocks and leating up to tho deposition of the iron formations, we note that in either ease the probable tendeney would be to develop greenalite first and then earbonate. Also so far as the two are precipitated at the same time, the higher density of the greenalite would make it settle first, the earbonate following later, is show by laboratory experiment. When the ingredients of the upper Huronian (cuartz saud, mud, greenalite, and iron carbonate) are shaken up together in a ressel of water and allowed to settle, a clean layer of sand is formed at the bottom. showing a most distinet contact with the layer next above. Then follows greenalite with some arlonate and mud, then carbonate and mud witl some greenalite, and finally mud with some (nilbonate.

Thus, whatever emphasis is put upon the different ways of producing iron carbonate, it secms probable that in any iron-bearing formation greenalite materials would be more abumelant near the bottom of the formation, or near shore. and the earbonate higher up, or offshore. 
The distribution of the greenalite and carbonate rocks in the upper Huronian is remarkably in accord with inferences drawn from the chemistry of their deposition. Greenalite is as yet known only at the lowest horizons of the upper Huronian and is exposed in the Mesabi, Felch Mountain, and Menomince distriets and to a slight extent in the Gogebic district. In the upper part of the iron formation of the Mesabi district iron carbonate becomes relatively more abundant, and just beneath the overlying Virginia slate forms a layer up to 20 feet in thickness. In higher parts of the upper Huronian associated with the slate in the Cuyuna, Crystal Falls, Iron River, and Florence districts the iron formation consists dominantly of iron carbonate.

The presence of the carbonate near the base of the series in the Gogebic district would imply under the above principles a proportionally greater abundance of carbon dioxide there than in the Mesabi district, for unknown reasons.

\section{SECONDARY CONCENTRATION OF TIE ORES.}

\section{GENERAL STATEMENTS.}

The secondary alteration of the iron formations to ore has been accomplished by both chemical and mechanical processes, under conditions of weathering, with modifications due to folding, deep burial, and proximity to igneous intrusions.

All the ores are partly the result of secondary concentration, but some have suffered more and some less concentration. Layers of iron formation originally rich in iron hav become iron ores by less concentration than have layers of iron formation originally poor in iron. In a few places in the region, as in the east end of the Gogebic district and in parts of the Mesabi district, there is evidence that certain layers of iron formation were originally nearly rich enough in iron to be mined as iron ores, after only a slight amount of secondary alteration. In such places the shape and dimensions of the original layers determine essentially the shape and dimensions of the iron ore deposits. Where secondary concentration has been largely effective in producing the iron ore, as it has in most of the larger deposits of the region, the shape and distribution of the ore bodies are determined by the structural conditions which loealize the secondary concentration, rather than by the primary bedding of the iron formation.

The essential secondary changes in the development of the ores liave been effected by weathering. The ores once formed, alterations effected by dynamic action, igneous intrusion, or redeposition as fragmental sediments may be regarded as for the most part subsequent and modifying factors, tending to change somewhat the character of the ores and ore deposits, but adding little to their size or richness. Dynamic and igneous metamorphism acting before the concentration of the ores tends to inhibit ore concentration by making the iron formation refractory to weathering agencies. In the following treatment emplasis will be placed accorlingly.

\section{CHEMICAL AND MINERALOGICAL CHANGES INVOLVED IN CONCENTRATION OF THE ORE} UNDER SURFACE CONDITIONS.

\section{OUTLINE OF ALTERATIONS.}

It requires only the most general field observation to bring out the fact that the iron formations are being and have been rapidly altered by percolating waters carrying oxygen, carbon dioxide, and other constituents from the surface and that the present characteristics of the formations are considerably different from those they had when they first beeane consolidated. Now they consist mainly of ferruginous chert and jasper, with subordinate quantities of iron ore, paint rock, greenalite, iron carbonate, amplibole-magnetite rock, etc. Formerly they were more largely cherty iron carbonate or greenalite. Fortunately the alterations have not everywhere gone far enough to obliterate all the original phases of the iron formations. Gradations may be observed between original cherty iron carbonate or greenalite phases of the formations and the dominant alteration products, ferruginous cherts and jaspers and iron ores. The 
former are fomd in protected places beneath slate or other impervious cappings; the latter ocenr in portions of the formations exposed to percolating oxidizing waters. The former are ferrous compounds, unstable under conditions of surface weathering; the latter are the stable oxilfes, end products of weathering. The ferruginous eherts, jaspers, and iron ores furthermore retain textures characteristic of carbonate and greenalite, therehy betraying their derivation from these substances. This is especially noticeable in the ores and cherts derived from greenalite, the peculiar granular shapes of the greenalite being conspicuous in its derivatives. The red, lrown, and yellow colors of the altered phases of the formations, the ores and ferruginous cherts, contrast strongly with the gray and green of the original cherty carbonate and greenalite, making the alterations conspicuous to the eye, especially along fissures in the original rocks.

The secondary alterations of iron carbonate and greenalite rocks to iron ore inrolve (1) oxidation and liydration of the iron minerals in place, (2) leaching of silica, and (3) introduction of secondary iron oxide and iron carbonate from other parts of the formations. These changes may start simultaneously, but the first is usually far advanced or complete before the other two are conspicuous. The early products of alteration therefore are ferruginous chertsthat is, rocks in which the iron is oxidized and hydrated and the silica not remored. The later removal of silica is necessary to produce the ore. The secondary introduction of iron oxide and iron carbonate in cavities left by the leaching of silica is of little importance in the alteration of the greenalite rocks to ore. In the alteration of the carbonates to ore it is frequently a conspicuous feature. The alteration of the original rocks of the iron formations to ore may therefore be treated under two main heads-(1) oxidation and hydration of greenalite and siderite, producing ferruginous chert; (2) alteration of ferruginous chert to ore by leaching of silica, with or without secondary introduction of iron.

OXIDATION AND IIITRATION OF THE GREENALITE AND SIDERITE PRODLCING FERRLGINOLS CIIERT.

The oxilation of the cherty iron carbonates and greenalites to hematite or limonite produces ferruginous cherts of varying richness. (See Pls. XLII, C, D; XLIII-XLV.) During these changes the iron minerals for the most part are altered in place, but iron may also be transported and redeposited. Evidence of this is abundant in the stalactitic and botryoidal ores lining eavities or inerusting secondary quartz erystals and numerous veins of ore eutting across the bedding of the formation. It will be shown in the following discussion, howerer, that the principal enrichment of the ore takes plaee in connection with the removed siliea, although in several distriets the introduction of iron is very important. The oxidation and hydration of the original iron minerals are expressed in the following reactions:

$$
\begin{aligned}
& 4 \mathrm{FeCO} \text { (siderite) }+\mathrm{nH}_{2} \mathrm{O}+2 \mathrm{O}=2 \mathrm{Fe}_{2} \mathrm{O}_{3} \cdot n \mathrm{I}_{2} \mathrm{O}+4 \mathrm{CO}_{2} . \\
& 4 \mathrm{Fe}(\mathrm{Mg}) \mathrm{SiO}_{3} \cdot \mathrm{nH}_{2} \mathrm{O} \text { (greenalite) }+2 \mathrm{O}=2 \mathrm{~F}_{2} \mathrm{O}_{3} \cdot \mathrm{nH}_{2} \mathrm{O}+4 \mathrm{SiO}_{2} .
\end{aligned}
$$

The alteration of the iron minerals is facilitated by small amounts of acils carricd by percolating waters. Carbonate of iron is soluble with difficulty in pure water and not easily soluble with an exeess of carbon dioxide. On the other hand, it is easily soluble in either of the stronger acids, sulphuric or hydrochloric. Sulphuric acid results from the decomposition of the iron sulphicle in the original earbonates and in the adjacent pyritiferous greenstones and slates. The reaction may be-

$$
\mathrm{FeS}_{2}+\mathrm{H}_{2} \mathrm{O}+7 \mathrm{O}=\mathrm{FeSO}_{4}+\mathrm{H}_{2} \mathrm{SO}_{4} \text {. }
$$

This is aided in turn by carbon dioxide in the water. Thus the iron sulphide is oxidized to ferrous sulphate, with the simultaneous production of sulphuric acid, which attacks the iron carbonates and changes them to soluble ferrous sulphate. In the Michipicoten district, where glacial crosion has eut deep, sulphides are found abundantly with the carbonates. Sulphinte of iron is present in reins in the ores of the Iron River district. Bayiey a found the white efforesence claracteristic of Menomince ores to be essentially sodium sulphate with the formula of Glauber salt, $\mathrm{Na}_{2} \mathrm{SO}_{1}+10 \mathrm{H}_{2} \mathrm{O}$, which he regards as the result of decomposition of prrite

a Bayles, W. S., The Menominee iron-bearing district of Michigau: Mon. L: S. Cieol. Survey, vol. 46, 1904, pp. 390-391. 
PLATE XLIII. 


\section{PLATE XLIII.}

\section{Photonicrographs of greenalite granules.}

$A$. Greenalite rock (specimen 45178 , slide 15652 ) from 100 paces north 500 paces west of the southeast corner of see. 22 , T. 59 N., R. 15 W., Mesabi district, Minnesota. Without analyzer, $X 50$. The slide is selected to show both the fresh and the slightly altered granules. Note the peculiar greenish-yellow color of the graunles, their irregular shape, and their curving tails, some of which seem to connect with adjacent granules. The homogeneons greenish yellow colors represent the unaltered parts. The bright-green and dark-green colors represent grünerite which has been developed from the alteration of the greenalite. The dark greeu is perhaps in small part iron oxide. Described on pages $165-168$.

$B$. The same with analyzer, $\times 50$. The nnaltered portions of the granules are nearly or quite dark under crossed nicols. Where the granules have altered to grünerite the polarization colors appear. The matrix consistz nf fine-grained chert in which the individual particles are very irregular in shape and size. Described on pages 165-168. 

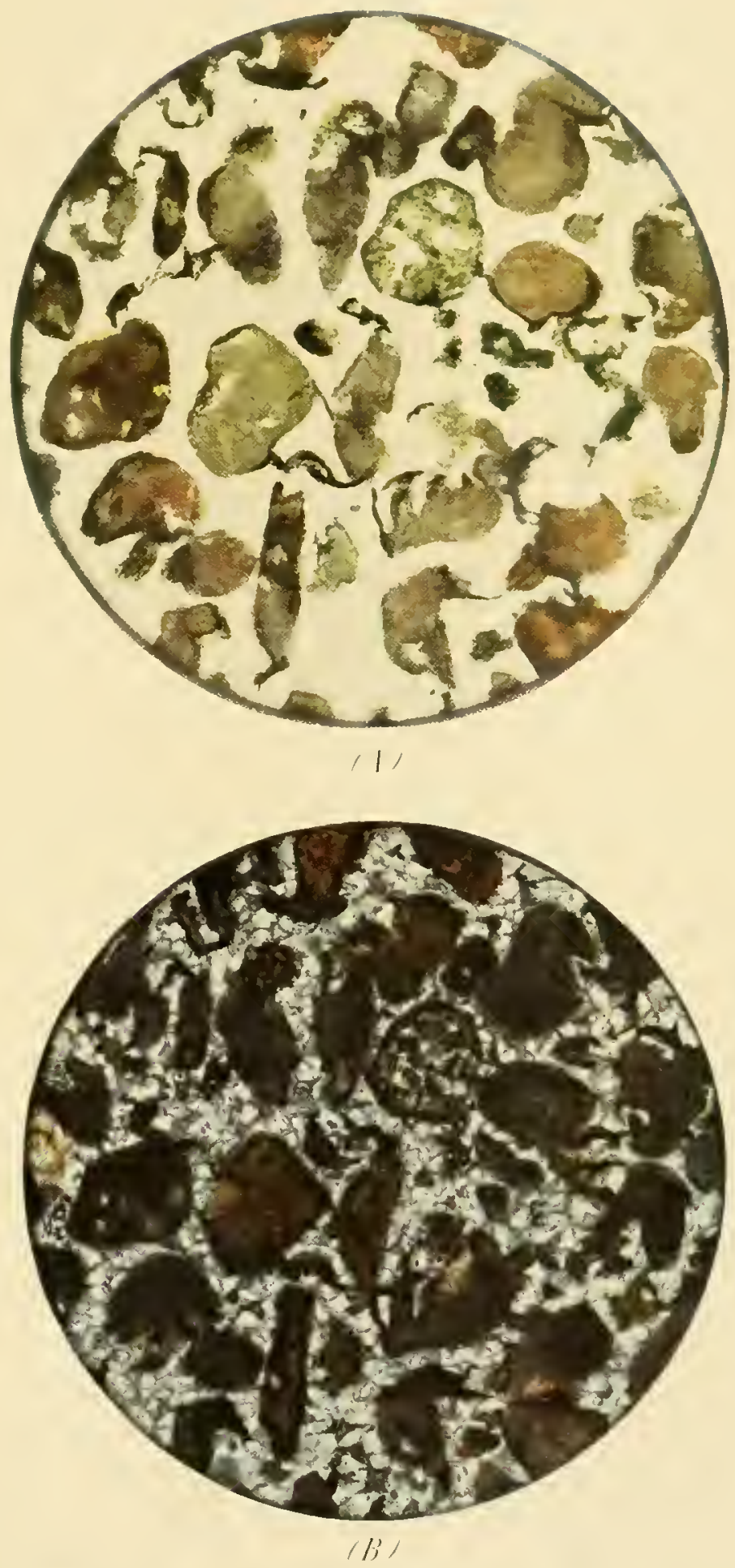

PHOTOMICROGRAPHS OF GRUNALITE GRANULES. 

PLATE XLIV. 


\section{PLATE XLIV.}

Photonicrograpis of Ferruginot's cilert silowing later stages of the alteration of GREENALITE GRANULES.

A. Ferruginous chert with granules (specimen 45063, slicle 15563) from near center of sec. 22, T. 60 N., R. 13 W. Without analyzer, $\times 50$. The granules are outlined and in part replaced by iron oxide. The matrix is cluert. The complex nature of one of the granules is to be noted. Apparently one complete small granule is entirely inclosed in anotlier large one. Described on pages 168-170.

B. Grüneritic ferruginous chert (specimen 45603, slide 15974) from Clark mine. With analyzer, $X 50$. The rock consists of chert and iron oxide and grünerite. The iron oxide is a yellowish-brown hydrated variety, which is with difficulty distinguished from the grünerite. The granules have been entirely obliterated. Described on pages 168-170.

534 

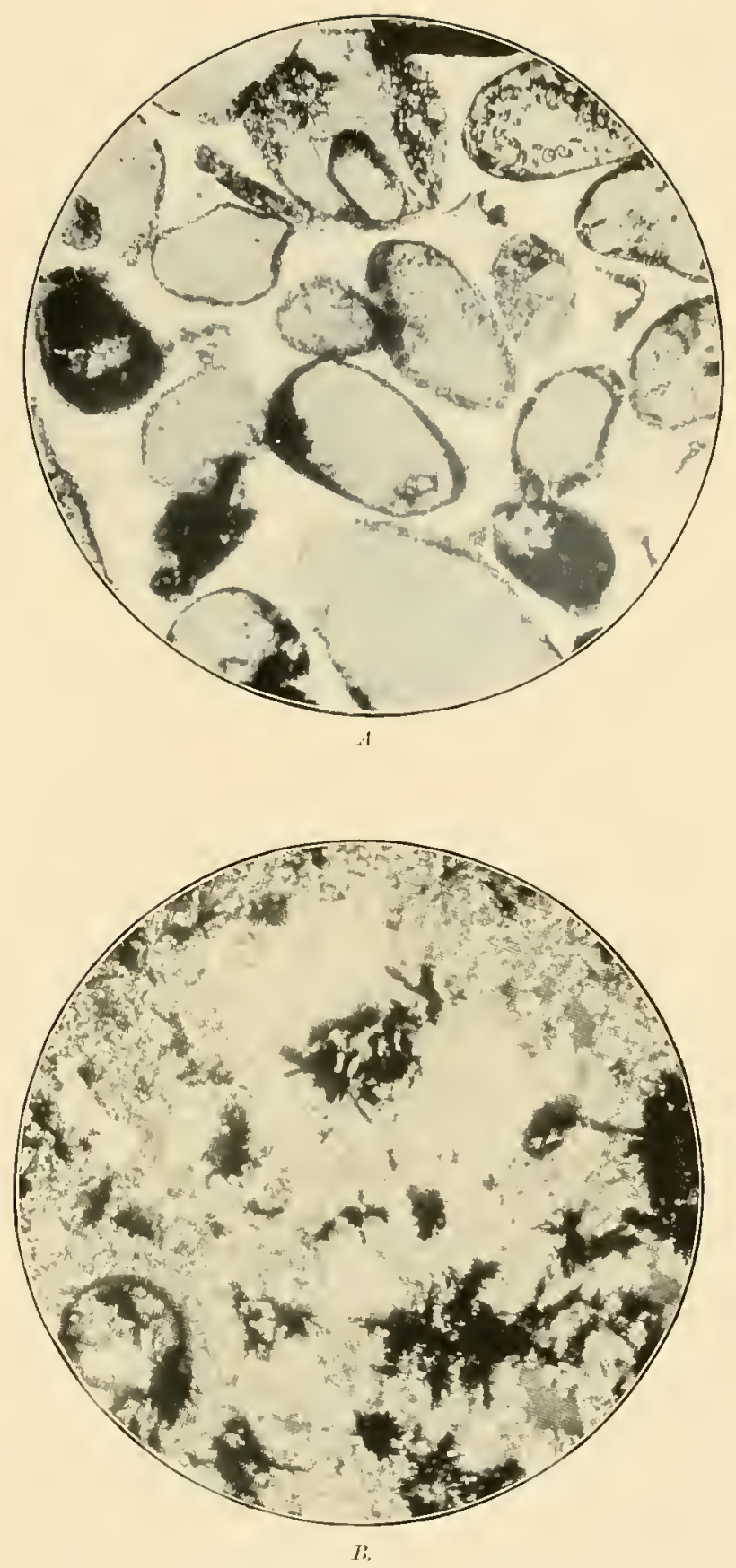

PHOTOMICROGRAPHS. 

PLATE XLV. 


\section{PLATE XLV.}

\section{Photonfcrographs of graneles and concretionary structures in Clinton inos ores.}

A. Granules in Clinton iron ore, from lower bed, Sand Mountain, New England City, Ga. Loaned ly C. Il. Smyth, jr. Without analyzer, $\times 40$. Granules of black and dark-brown hydrated hematite stand in a matrix of calcite. The latter areas within the granules are also calcite. Traces of organic shells in these slicles are abundant. The granule a little to the right of the center shows this especially well. There can be no doubt as to the fact that ine granules are for the most part replacements and accretions about shells and particles of shells. It is apparent also that there is a marked tendency for the granules to take on rounded and oval forms regardless of the shape of the original particles of shell. Note the remarkable simitarity of these granules in shape to the greenalite granules illustrated in Plate XLII, $A, B$.

B. Green oolites in Clinton ore, from Clinton, N. Y. Loaned by C. H. Smyth, jr. With analyzer, $X 40$. Concentric layers of chloritic and siliceous substance, of various shades of green and yellow, surround angular, subangular, and rounded grains of quart $z$. The concentric greenish and yellowish bands under crossed nicols show black crosses characteristic of concretionary structures. The matrix is mainly calcite, but there are present also small particles of quartz.

536 

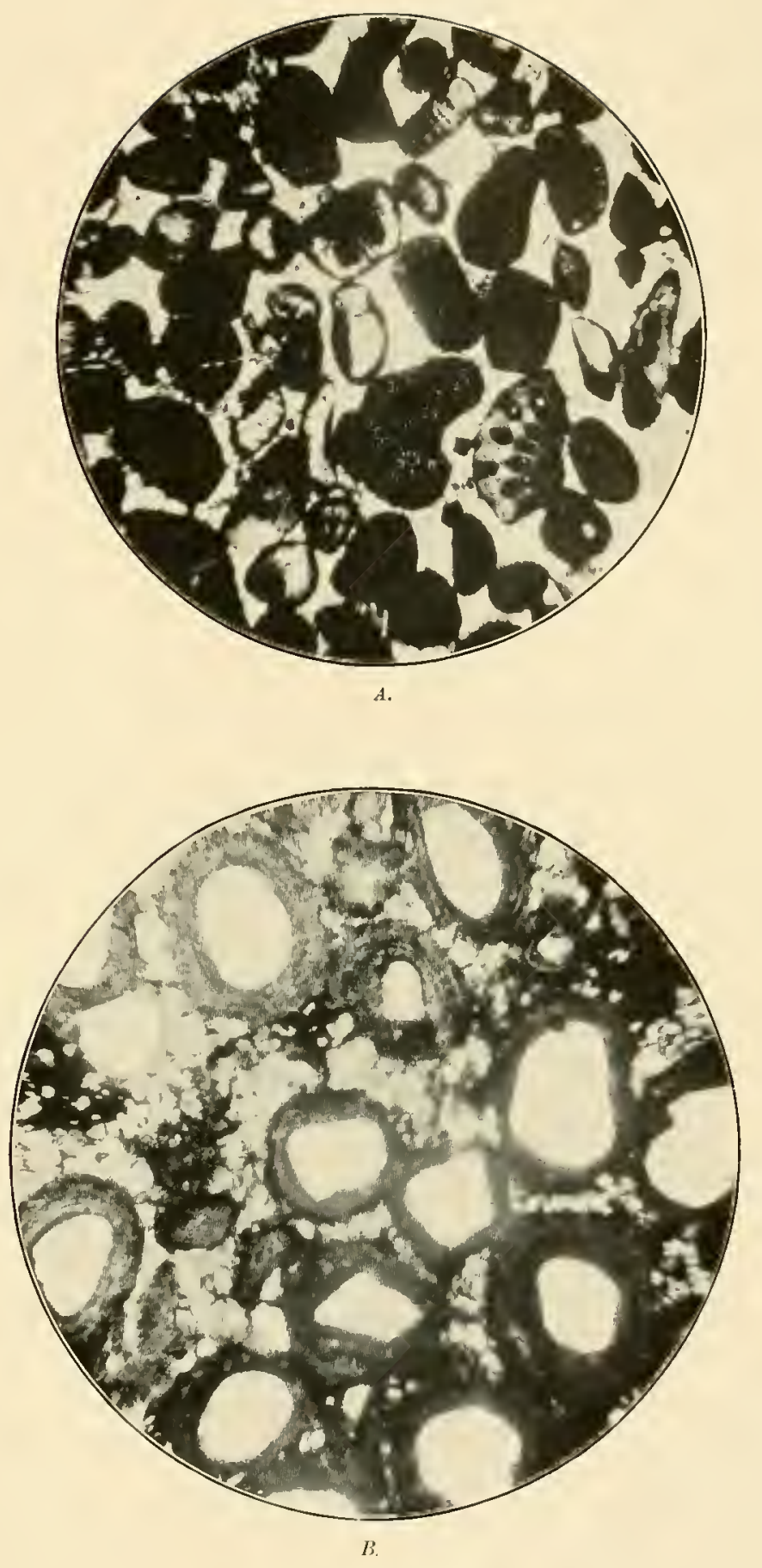

PHOTOMICROGRAPHS. 

and muscovite. Tron sulphides and chalcopyrite are also common as vein fillings. Sulphates are found in mine waters. (See pp. 543-544.) Humus acids are also well known to aill in the solution of the iron.

Precipitation of the iron from ferrous solutions would be caused (1) by direet oxidation and precipitation as limonite; or (2) by reaction with alkaline earbonate, producingr iron carbonate, whieh in this form in the presence of oxygen alters almost immediately to hydrated iron oxide; or (3) by loss of carbon dioxide. A small amount of secondary iron carbonate, where iron is carried in solution as bicarbonate, olserved locally in each of the districts, is incidental to the main process of oxidation producing ferruginous cherts.

The oxidation of the iron in the carbonate and greenalite goes on much more easily and rapidly than the remoral of the silica and may affect most or all of the carbonate or greenalite, producing ferruginous cherts, belore the renusal of the siliea has gone far enough to be appreciable. An epitome of the story lor the lormation is presentod by almost any hand specimen of iron carbonate or greenalite. The ferruginous cherts are, therefore, intemediate phases between the original greenalite or siderite and the ore, and the principal removal of the silica is subsequent to the formation of the ferruginous cherts. Given sufficient time and the other necessary favorable conditions and any part of them may become ore. In distriets where greenalite is the dominant original iron compound, so far as can be determined, the layers of chert in the ferruginous cherts prior to their alteration to ore are not very different in number, iron content, and degree of hydration from those in the greenalite rocks, indieating but little transfer of iron, though locally the segregation of silica and iron oxide into bands is more accentuated. In districts where earbonate is an important original iron salt, the rearrangement, transportation, and introduction of 1 ron salts are quantitatively important. This is probably due to the struetural conditions deseribed on page 538. Slight rearrangements of the iron ore are to be seen in the concretions composed of alternate concentric layers of chert and iron oxide developed during the alteration. These develop both from the iron carbonate and from the greenalite.

Not uncommonly axidized greenalite cherts are found alongside of unoxidized iron carbonate cherts. At first thought this would seem to indicate the readier oxidation of the greenalite than the carbonate, but it is not certain that this is the case, for it is sometimes found that the carbonate in these relations is secondary, and another possibility is that the greenalite was oxidized at the time of its precipitation rather than secondarily.

ALTERATION OF FERRUGINOUS CHERT TO ORE BY TIE LEACHIYG OF SILICA, WITH OR WITHOLT SECONDARY WTRODUCTION OF IRON.

PROCESSES INVOLVED,

Ore may be formed (1) by taking away silica from the ferruginous eherts, learing the iron oxide; (2) by taking out silica and introducing iron in its place; or (3) by adding iron to an extent sufficient to make the percentage of silica a small one. In the last case there would necessarily be a large increase in volume. Quantitative tests show that (1) is of greatest importance, that (2) is effective only in some of the ores derived from carlonates, and that (3) is practically negligible.

Measurements of pore space of the ores derived from the alteration of ferruginous cherts of greenalitic origin bjing out the facts that pore space approximates the rolume of silica which has been removed (see pp. 1st-1S5), when there has been little slump; in other words, the filling of the pore space in the ores by silica would nearly reproduce the composition of the ferruginous cherts. It will be shown also that the leaching of silica from the ferruginous cherts derived from greenalite alterations does not materially affect the character of the iron oxicles, esperially their degree of hydration, and that therefore the nature of the ore of the deposit is primarily determined by the changes which the greenalite undergoes when it alters to the oxide bands of the ferruginous cherts.

Measurements of pore space in ores derived from ferruginous cherts, which in turn have been derived from the alteration of iron carbonate, show that the pore space is less than the 
volume of the silica which has been removed. (See p. 241.) This is due party to slump, but mainly to the fact that secondary iron oxide partly fills the openings.

The range in which there is conspicuous alsence of evidencre that iron has been transported to any considerable extent is the Mesabi, where the flat dip exposes a large portion of the formation directly to oxidizing waters, and axidation works down more or less uniform] from the surface, leaving few moxidized portions to contribute soluble iron salts to be carried down and mixed with derper oxidizing solutions following channels from the surface. In the other districts, where the evidence of the carying of iron is flan, the formations are so tilted that the underground courses of oxidizing waters from the surface pitch deeply, fearing unoxidized iron lormation above as a source for solulble iron salts, which may be taken into solution and earried down, and, by reaction with widizing waters, precipitate the iron oxide. This (leep circulation of oxidizing waters afforded by steeply tilted formations permits the leaching of siliea at depth, thus provilling openings in which the iron earried in solution from the upper unoxidized portions of the formation may be deposited. It is in this essential that the Mesabi conditions differ from those of the other ranges.

Silica dissolved from the iron formations has been in small part redeposited in veins, both in ore and rock and in the erystallized quartz linings of many cavities in the ore, and in part has joined the run-off. The process is going on to-day, for mine and surface waters earry silica (see pp. 540-544), and quartz linings of cavities may be secu to have developed since mining cxplorations began. It has been suggested that the abundant chert in the ferruginous cherts themselves might represent materials previously leached from other parts of the formations and redeposited. As the cherts are very lense (see p. 545), there would be no room for the addition of secondary siliea except that made by the volume change in the alteration of iron minerals or by the previous leaching of silica. Untoubtedly cavities of both sorts have heen filled to a certain extent by silica. But the process of the average increase of silica would involve a reversal of the one which is actually observed to occur-that is, the leaching of silica from the ferruginous cherts, producing the ores. We are forced to the conclusion that while as in any metamorphie process in the belt of weathering silica is remover and silica is deposited, the former change is predominant. A parallel may be cited in the development of caves in limestone by solution and deposition, the process of solution predominating.

CONDITIONS FAVORABLE TO LEACHING OF SILICA.

The loss of silica from the fermuinous cherts on a large scale requires exceptionally farorable conditions. Thesc conditions seem to be (1) the reacly access of dissolving solutions to large surfaces of the clert and (2) the alkaline character of the dissolving solutions.

The fine and irregular grain of the quartz in the ferruginous cherts affords large surfaces of contact with the water, thereby favoring solution. It is noted that where the cherts have been coarsely recrystallized under the influence of intrusives there is much less tendency for the silica to go into solution. Much of the silica in the cherts is cherty or opaline and thus easily soluble.

The conditions favorable to rapid and abundant flow of water are due largely to structural causes, which are discussed on pages 474-475. A large amount of water is needed to effect the removal of silica. Merrill a estimates that the removal of a unit of siliea requires 10,000 times its wright in water. The removal of a larre amount of siliea from the iron formations which has been necessary to produce the ore deposits has therefore required a large amount of water for each unit removel-in other words, free and vigorous flow. Thus is explained the concentration of the ores along zones of easy flow where water is abundantly conecntrated.

\section{SOLUTION OF SILICA FAVORED BY ALRALINE CHARACTER OF WATERS.}

The solution of silica is favored by the alkaline character of the waters. Alkaline carbonates reaet upon quartz, forming soluble alkaline siliotles with release of carbon dioxide. Sodium carbonate may not stand in a ghass bottle without dissolving it. Well waters in the 
vicinity of Ironwood, Mich., obviously the same waters that are entering the formations, are throughout alkaline in their reaetions. Many solution cavities left by the leaching of silica are lined by adularia crystals (potassium feldspars), as in the cavities left by the leaching of quartz pebbles from the ore at the base of the upper IIuronian of the Marquette district.

All the ore deposits of the Lake Superior region are close enough to igneous rocks to have been altered by waters which have probably derived an alkaline content from the leaching of the igneous rocks. In the Mesabi district all the waters entering the iron formation have previously come down across the Giants Range granite and in a few places have met granite dikes within the formation and thoroughly leached them of their bases. In the Gogrebic district the dikes (see analyses, p. 246) closely associated with the ores have been so thoroughly leacher of their bases that the residual clayey material is known as paint rock or soapstone. A glance at the map of the Marquette district (PI. XVII, in pocket) will show the abundance of basic intrusive rocks in the iron-bearing areas. These again near the contant with the ores have been altered to soap rock and paint rock, thereby delivering their bases to the solutions which have developed the ore. In the Crystal Falls distriet the relation is not less obvious. The ores are throughout not far from the basic enuptive rocks. In the Cuyuna district intrusive rocks are everywhere associater with the ores. In the Menominee district the relation is not so obvious, although the igneous rocks appearing on both sides of the Henomince trough may well have affected the character of the water in the ores. Probably, however, the waters have been rendered effective principally by solution of the dolomite associated with or immediately underlying nearly all the deposits. It is noted in nearly all the districts that where the ore comes into contact with slate the slate has been altered to paint rock. A comparison of the composition of paint rock and the unaltered slate shows that alkalies have been taken out in the development of the paint rock. IIere again, then, is a factor favoring the alkaline character of the waters.

\section{TRANSFER OF IRON IN SOLUTION}

So far as iron is carried in solution it is probably in the early stages of the alteration of any particular part of a formation, when there are still ferrous compounds to work upon. When nothing but ferric iron remains, this is insoluble and the principal further alteration is the removal of silica. If the iron finds lodgment in the formation before the silica is taken out it can be only on a small seale, for the voids are not large enough to contain much ore. When iron is introduced after all the silica is taken out, its introduction may not materially change the percentage of iron in the ore. It will merely reduce the pore space.

\section{SECONDARY CONCENTRATION OF THE ORES CHARACTERISTIC OF WEATHERING.}

Quartz is ordinarily regarded as practically insoluble in surface waters. It might be argued that the conditions above cited are not peculiar to iron formations alone but may be found elsewhere, and the question is raised whether elsewhere quartz is largely taken into solution. We believe that quartz is taken into solution under ordinary conditions of weathering to a larger extent than is generally recognized, and that it is apparently stable because it is usually associated with more soluble constituents, therehy contrasting with the iron formations, where the quartz is associated with less soluble constituents against which the loss of quartz may be measured. A series of three analyses of fresh granite, partly altered granite, and much weathered granite from Georgia published by Watson, ${ }^{a}$ when recalculated in terms of minerals, shows that in the early stages of the alteration the quart $z$ is but little affected, but that in the last stage there is unquestionable evidence of considerable leaching of free quirtz.

In general comparison of analyses of fresh and weathered igneous and other rocks shows that iron and alumina are the two most stable constituents and that in weathering under oxidizing conditions silica is lost more readily than the iron. The iron formation, comsisting prineipally of iron minerals and silica and lacking alumina, would therefore be expected to retain its iron 
under weathering to a greater extent than the silica, and in so doing has followed the general laws of katamorphism. The absence of evidence of transfer of iron during secondary concentration on a large seale is in strong contrast with its transportation in large amounts in the primary concentration. The secondary local transfers of iron in the ferrous condition before it is oxidized to the stalle form are characteristic of both the iron formation and igneous rocks and do not disprove the general principle alrove statel.

In general the same processes of weathering that have proluced residual clay from igneous rocks are the ones which have secondarily eoncentrated the iron ores. Most igneous rock contains so little iron and so much alumina and siliea that secondary concentration fails to produce an iron ore directly from it; it produces an iron-stained clay. Exceptionally, howerer, as from the serpentine rocks of Cuba, which have a low content of alumina, secondary concentration has produced a mixture of iron ore and clay, and the clay, by extreme weathering at the surface, has broken down further, by loss of siliea, to bauxite. The result is a lateritic iron ore. ${ }^{a}$

\section{MECHANICAL CONCENTRATION AND EROSION OF IRON ORES.}

The loosening of siliea grains ly solution loeally makes it possible for them to be carried merhanically by the meteoric waters. This process becomes one of some importance when the openings have been made sulliciently large by solution. Where the mine waters are dammed, there is very commonly a considerable sediment of fine-grained chert sand. This process probally also explains the occurrence of finely gramular chert sand in seams and crevices in certain Mesabi ore deposits. The process is probably more enspicuous now than it was before mining openings gare a chance for the acemulations of these silica sands. It is dillieult to see where, under original conditions, these sands could have been deposited. They are found filling openings molerground only to a very small extent, and it is unlikely that they would follow the underground waters into the run-off.

So far as pore space has been lessened by mechanical slump anywhere through the iron formation, this amounts to a decrease in volume and increases the amount of iron in a given volume of iron formation. It is shown in the chapters relating to the diflerent districts that this process has gone on to a eonsiderable extent.

Locally, as at the base of the Vulan formation in the Nenominee district, at the base of the Goodrich quartzite in the Marquette distriet, and in the ('retaceous of the Mesabi district, there is fragmental detritus derived by the processes of disintegration, transportation, and sedimentation from earlier-formed iron-bearing formations. Where this includes sorting, it amounts to mechanical coneentration (Pl. XlN1).

Artifieial concent ration of ore by remoral of the ehert through washing is now being praeticed on the western Mesabi, where the chemical processes have gone just far enough to loosen the chert. There is an enormous mass of material arailable. In fact, this is the party altered iron-bearing lormation itself, rather than concentrations within the formation. A considerable amount of iron is lost during the process, because the iron and chert are attached to each other. Inch of the silica in the ferruginous rherts is so very fine grained and so intimately associated with the iron that it could probably never, be separated by crushing and washing. That separation is possible on the western MIosabi is due to the handed nature of the ferruginums chert and the fact that the finer-grained portions have been remored hy solution, learing the larger pieces of rhert loose.

\section{GENERAL CHARACTER OF MINE WATERS.}

The mine waters of all but the lecpest parts of some ol the mines are characterized by considerable contents of carbonates of the alkalies and alkaline earths, together with siliea. Iron is usually present only in trateces or entirely larkinge.

The shallower mine waters are represented by the following analyses:

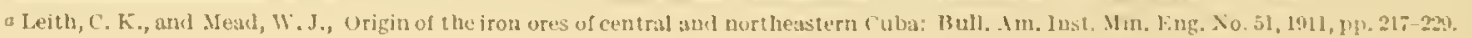


PLATE NLVI. 


\section{PLATE XLVI.}

\section{ORE AND JASPER CONGLOMERATE AND FERRLGiNot's CHERT.}

Ore and jasper conglomerate from Saginaw range, Marquette district, Michigan. This is a typical basal conglomerate of the Goodrich quartzite of the upper Huronian. The detritus consists almost wholly of varions materials derived from the Negaunee formation, including jasper, chert, and ore. There is present, however, some quartz derived from the Archean. A close examination of the illustration shows that secondary hematite and nagnetite have largely formed in the spaces between the grains about many of the jasper fragments, and, indeed, have partly replaced the jasper fragments themselves. This is beantifully shown at the lower left-hand corner of the figure, In the places where the basal conglomerate is fine grained these replacements by iron oxide may be almost complete, in which case an iron-ore deposit is formed. Of such an origin is the iron ore of the Volunteer and some other mines.

Ferrnginous chert from point south of Jackson mine, Marquette district, Michigan (sec. 1, T. 47 N., R. 27 IT.) The iron oxide and chert were largely concentrated into bands before the last folding. At the time of the folding radial cracks were formed, especially in the chert layers, owing to the position of the rock on the crown of an anticline. Along these cracks the silica has to some extent been leached out and iron oxide introduced. One light-colored area of chert appears to be a secondary infiltration, but it was apparently present before the lasi folding, as it is fractured in the same way as the other layers. Natural size. 

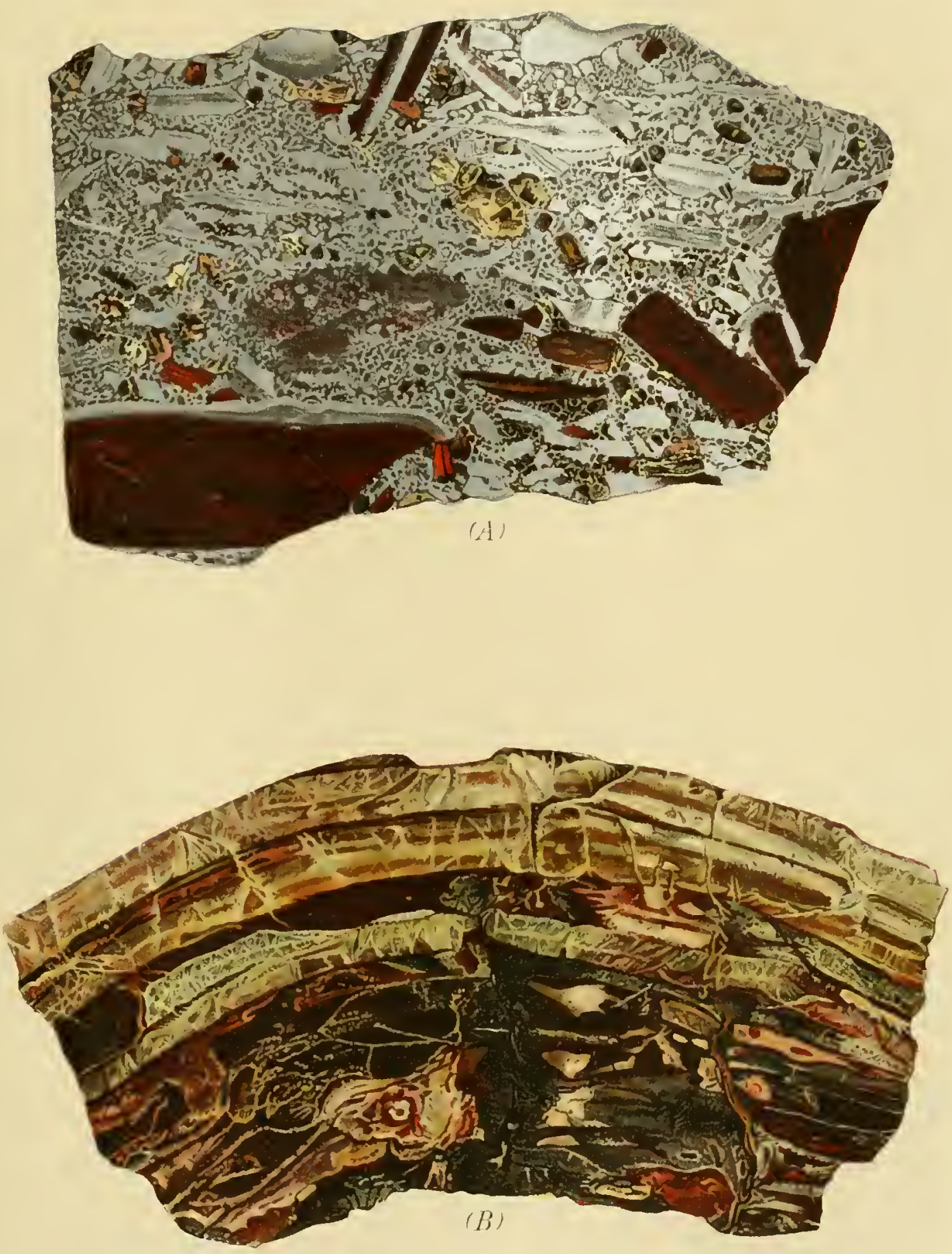

(A) ORE AND JASPER CONGLOMERATE FROM MARQUETTE DISTRICT, MICHIGAN

(B) FERRUGINOUS CHERT 

Anulysis of water from a drift between the Thull and Rust mines west of Uibbing, Mesabi district."

[Parts per million.]

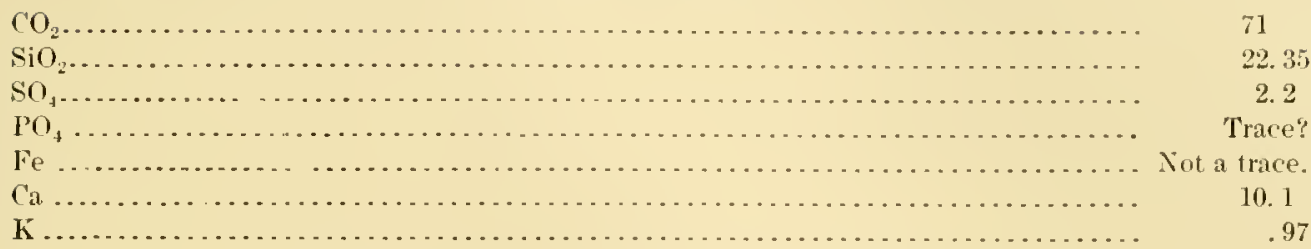

Analysis of water from Neuport mine, Gogebic district.

[Parts per million. Analyst, R. D. liall, University of Wisconsin.]

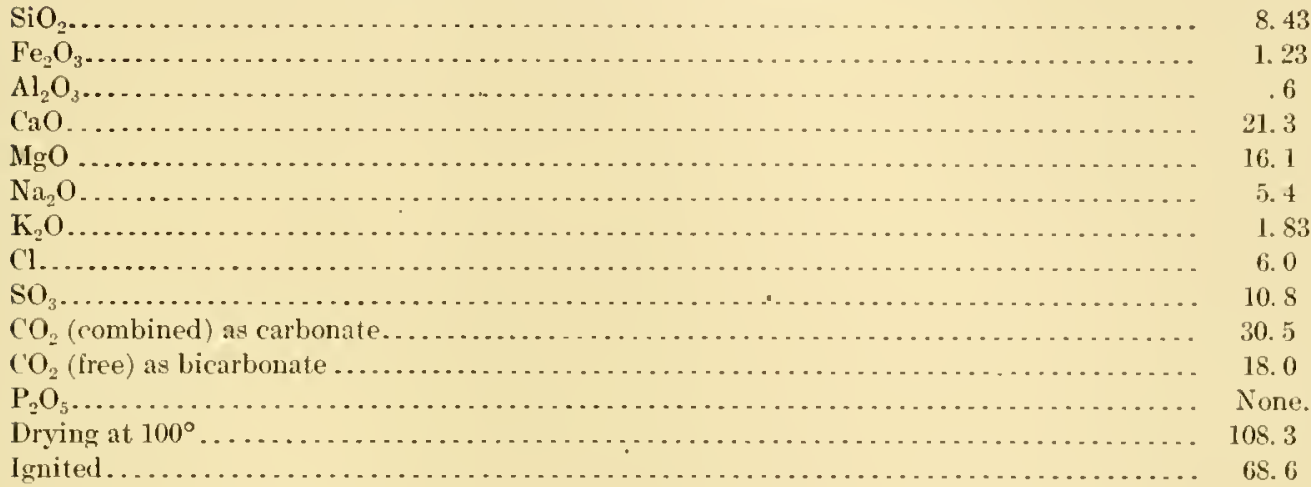

Some of the deep mine waters have been found to be highly concentrated solutions of calcium and sodium chlorides, according to the following analyses. Such waters are extremely corrosive in boilers and pumps.

Analyses of Michigan iron mine waters.

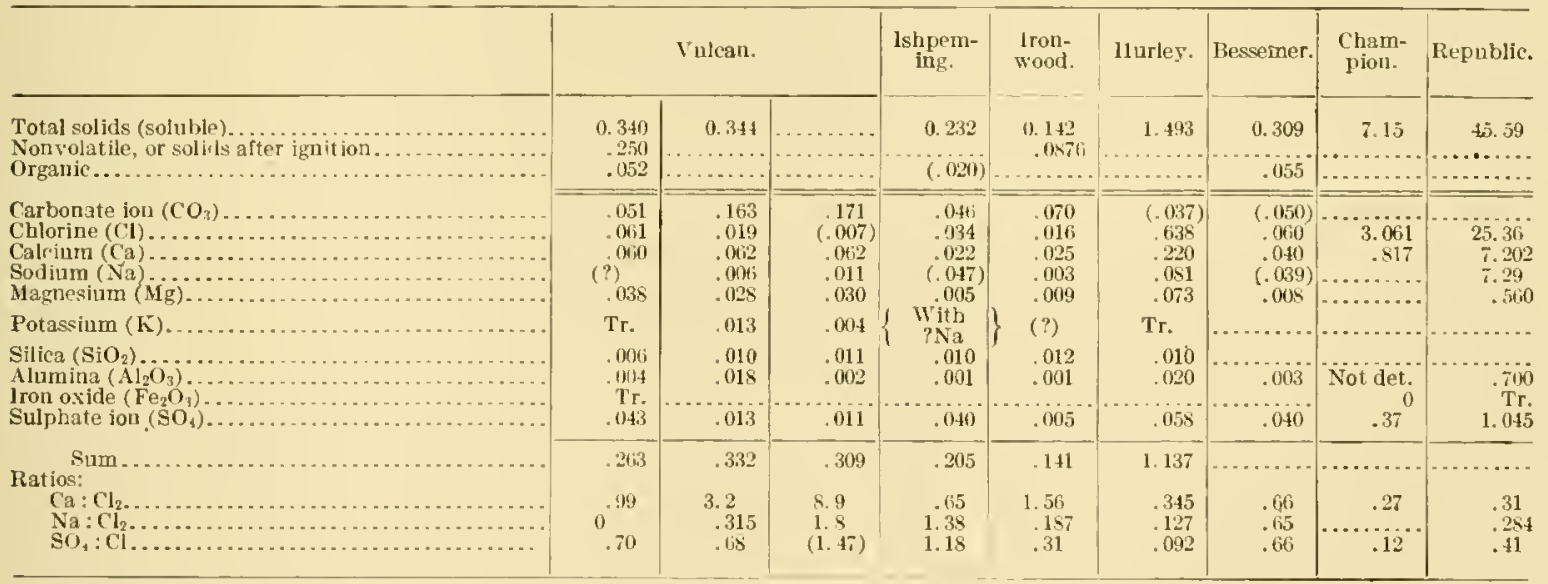

a Furnished by 1. C. Lane, State geologist of Michigan, March, 1909.

Higlly mineralized waters have also been found on the eighth level of the Great Western mine, in the Crystal Falls district of Michigan. No analyses are arailable, but tests by the mine chemists showed the presence of calcium cliloride and magnesium sulphates.

The upper carbonate waters are abundant, rapidly flowing, dilute, and more or less direct from the surface, carrying gases of the atmosphere. They are the waters which accomplish the major part of the secomdary concentration of ore, as shown by the limitation of the ore deposits to places of rapid circulation of these waters and further by the known chemical effects of waters of this type upon the original iron-bearing formation. 
The deep chloride waters are relatively minute in quantity and highly concentrated. Their distribution is very irrecular. Snall reservoirs may be tapped and exhausted alongside of llows of fresher water. Waters of very similar characteristies are found in the deep copper mines of the Lake Superior region, in the decp levels of the Silver Islet silver mine, ${ }^{a}$ on the north shore of Like Superior, in deep wells in the Paleozoic of the upper Mississippi Valley, in the granites of the Piedmont area of Georgia, and elsewhere. Their rharacteristics sem not to be related to cortain kinds of rocks or ore deposits, but to depth and stagnant conditions. Chlorine is present in minute quantities in original igneous rocks and in nearly all surface waters. Its salts tend to remain in solution, while the salts of other acids are more largely precipitated. With a given amount of water, there seems likely to be, therefore, a progressive relative accumulation of chlorine salts. Such is the case in salt waters at the earth's surface, where a large factor in the accunulation is the lack of suffieient circulation to carry off and dilute the salt waters that are developing by evaporation. In deep underground waters there is essentially the same condition of stagnancy, and therefore we suggest progressive accumulation of soluble chlorine salts. In the shallower mine waters the rapid circulation and accession of fresh waters from the surface prevent such aecumulation of salt.

The proportion of sodium chloride to calcium chloride in deep mine waters in the Lake Superior region becomes relatively less with increase in depth, indicating that the inereasing content of chlorine is able to hold not only all sodium present but larger amounts of calcium. The materials in solution under any conditions must be regarded as representing the residual solutions from which alt possible insoluble minerals have already crystallized out. All the Lake Superior mines, botl iron and copper, are associated with basic rocks in which ealcium greatly predominates over the sodium, so that whenever the sodium is taken care of by the chlorine present there should always be a considerable excess of calcium available.

Lane, who has given special at tention to deep mine waters and who has brought together the analyses above quoted, ollers quite another explanation for the characteristics of these deep waters. He believes them to be comnate or fossil sea waters, included in the rocks, both igneous and sedimentary, during submarine deposition. The fact that they differ from present sea water in having so large a proportion of calcium chloride he ascribes to a possible change in composition of the sea water during geologic time in the direction of increasing the proportion of sodium chloride as compared with calcium chloride to the present known proportion of sea water. We do not follow him in this conclusion because of the fact, already cited, that these peculiar salt waters seem to be characteristic not only of marine sediments but of sediments of subaerial origin, of surface eruptives, and of plutonic igneous rocks. They are related to depth and stagnaney rather than to kind of rock or geologic horizon. There seems to be no adequate reason for regarding these waters as fossil sea waters, for all the essential kinds of conditions which produce the salt water of the ocean are present.

\section{LOCALIZATION OF THE ORES CONTROLLED BY SPECIAL STRUCTURAL AND TOPOGRAPHIC FEATURES.}

From the foregoing diseussion it appears that the iron ores constitute concentrations in the exposed parts of the iron-bearing forma tions accomplished on the average mainly by the removal of associated silica, lcaving the iron oxidized and in larger pereentage, but to an important extent aceomplished also by solution, transportation, and redeposition of the iron when it was still in its soluble ferrous condition. The agents of alteration are surface waters earrying oxygen and carbon dioxide from the atmosphere. The accessibility to the iron-bearing formations of these agents therefore determines the location, shape, and size of the deposits. The structural conditions faroring such accessibility have been summarized in the earlier part of this chapter (ser pp. 474-475), and are discussed in some detail in connetion with the ores of the indivitual distriets. They may be merely mentioned here. The most favorable condition is aflorded by witle area of exposure of the formation, which in turn is a function of the elip. Fractures, 
impervious basements, and varying porosity also serve to concentrate the eirculation. Ores are not found, however, in some places where area, fractures, and impervious basements seem to be favorable for ore coneentration. This is believed to be due in some part to the denseness of the cherts in these places, preventing access of water. Wherever the rocks are dense the silica is not removel. The amphibole-magnetite cherts, the unaltered greenalite and siderite rocks, and the quartzites associated with the iron-bearing formations all have very little pore space, as shown by a considerable number of determinations. Silica is not removed directly from these rocks. On the other hand, the ferruginous cherts, resulting from the alteration of eherty iron carbonates and greenalites, contain pore space averaging about 5 per cent, developed by the lessening of the volume of the iron minerals during their altoration from the ferrous to the ferric form. This pore space is so distributed as to give the water access to all parts of the rock mass. The size of grain is so small that for each grain there is a large surface in proportion to volume. But even the ferruginous cherts are locally so dense that they do not allow ready access of water. Several possible reasons may be suggested for this unusual density. (1) The ferruginous cherts at these places may not have been derived by alteration from cherty carbonates or greenalites but may have been deposited directly in their present form as chenical sediments with small pore space. It has been shown that this could easily go on with the deposition of greenalite and carbonate. This explanation would seem to be especially likely to hold for certain of the amphibolitic cherts of the Iieewatin, which are intimately associated with basalt flows both above and below and which it is entirely conceivahle night have been originally deposited in a condition different from those of the cherty carbonates and greenalites of the later iron-bearing formations. (2) Metamorphism of the cherts under pressure after pore space had been developed by oxilation of the iron minerals may have elosed the openings before the silica had been taken ont. Cherts which have been much folded and contorted at so great depth as to be deformed without fractures are almost invariably dense. The Reewatin ironbearing formations are the oldest and have naturally suffered more from such metamorphism than the later formations, and this may be a factor in the barrenness of the Keewatin. On the other hand, larger areas of the upper Iuronian are comparatively little deformed and pore spaces formed by the oxidation of the iron minerals have remained substantially open since upper Huronian time. (3) The openings may have been closed by infiltrated silica and iron. In the $\mathrm{M}$ arquet te jasper, secondary materials completely heal the rock. The relative import ance of these conditions affecting pore space varies from place to place and between the different iron-bearing formations, and this variation is believed to account in large measure for the marked differences in enrichment of different formations and different parts of formations.

Undoubtedly the processes of secondary concentration above described tend to affect to a greater or less degree all the exposed surface of the iron-bearing formations. It is not unlikely that in long periods of slow denudation ores may have actually covered all of this surface. It is equally obvious, however, that the covering had various depths, depenting on a considerable variety of structural conditions. The glacial denudation has scraped off ore which may once have developed at the surface, and little has developed since. There remain only the lower parts of the deposits left by denudation. A discussion of the structural conditions governing the ore deposits is therefore really a discussion of the conditions determining their lower limit and configuration. The struetural and topographic conditions of each of the districts are summarized in other chapters.

\section{QUANTITATIVE STUDY OF SECONDARY CONCENTRATION.}

The nature of the secondary concentration of Lake Superior iron ores has been in the past inferred almost entirely from qualitative evidence. The extensive commercial development of the ores of this region during recent years now makes available data for cuantitative study of the origim and concentration of the ores. Although there is a great similarity in the secondary concentration of all the iron ores of the Lake Superior region, certain local differ- 
cnces require that ench of the soveral districts be discussed independently. This is clone in the chapters on the several distriets.

The arerage change in secondary concentration, based on all available analyses (see p. 1S1), is gruphically expressed in figures 20 (p. 189) and 31 (p. 245).

\section{ALTERATIONS OF IRON-HEARING FORMATIONS BY IGNEOUS INTRUSIONS. ORES AFFECTED.}

The changes alescribed in the foregoing sections have completed the development of the ore deposits of the Mesabi, Gogebic, Menominee, part of the Marquette, Crystal Falls, Iron River, Florence, and Cuyun: districts, which yield roughly 93 per cent of the total ore mined annually in the region. Other ores, such as the hard ores of the Marquette and Vermilion districts and the magnetic rocks of the Mesabi and Gogebic, have suffered certain arlditional vicissitudes of anamorphic alterations by igneous intrusion, thus becoming the hard, dense, reerystallized, more or less magnetic, dehydrated, and silicated ores described below. (See Pls. XIXY, p. 470, and XLYII.) The development of some of these characteristics may have been synchronous with the deposition of the iron-bearing formation under the influence of contemporaneous igncous extrusives, discussed on page 527, but whaterer the probability of this there is no doubt that characteristics of this kind have been developed mainly by later intrusives.

The intrusion of small masses of igneous material, as the dikes in the Gogebic district and certain of the bosses in the Marquette district, has apparently but slightly metamorphosed the iron-bearing formation. Where great masses of igncous material have come into contact with the iron-bearing formation, however, marked results have followed, as near the Duhth gabbro, the gabbro of the western Gogebic district, and the intrusives of the western Narquette district.

\section{POSSIBLE CONTRIBUTIONS FROM IGNEOUS ROCKS.}

The characteristic features of the amphibole-magnctite rocks of the iron-bearing formations described above become more accentuated in approach to the igueous rocks, leaving no doubt that they are the metamorphic result of the intrusion of the gabbro. The facts available indicate to some extent also the processes through which this result is accomplished. The question first to be answered is whether or not the iron-bearing formation owes its characteristics near the contact to direct contribution from the hot intrusives or to the recrstallization of substances already in the iron-bearing formation. The essential similarity of composition of the amphibole-magnetite rocks with that of the ferruginous cherts (see p. 204) argues against large introduction of materials from the gabbro. IIad such materials been introduced on a large seale they would probally have considerably changed the proportions of the elements present, for otherwise it would be necessary to assume that the materials contributed from the gabbro had been in the same proportion as those originally present in the iron-bearing formation. The magnetite in the gabbro is titanic, while that in the adjacent iron formation is not. The higher sulphur content in the amphibole-magnetite rocks may indicate direct contribution of sulphur, though this may also be original in the iron-bearing formation. (See pp. 550,552.) Whether or not there was some small introduction of materials from the gabbro, the bulk analyses of the amphibole-magnetite rocks are so similar to those of the other phases of the iron-bearing formation as not to require the assumption of delivery of hot solutions from the gabbro to the iron formation.

Furthermore, there is no regular variation in the composition of metamorphic plases of the iron-bearing formation through the several hundred feet from the contact for which these fhases are known in many places to extend. Finally, the very fact that the metamorphic phases of the iron formation extend so far and so unilormly from the gabbro contuet argue against their development by aceession of materials from the gabbro.

It is conclueled, therefore, that the principal cffect of the intrusion of the gabbro into the iron-bearing formation was that of recrystalization ol substances already present and not by contribution of solutions. 
PLATE XLVII. 


\section{PLATE XINII.}

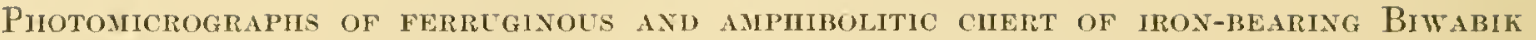 FOLMATION NEAR CONTACT WITH DULUTI GABBRO.}

A. Actinolitic, grüneritic, and magnetitic chert (specimen 45141, slide 15621) from southeast of center of sec. 17. T. 60 N. R. $12 \mathrm{~W}$., Mesabi district, Minnesota. Without analyzer, $\times 50$. This rock is close to the contact with the Duluth gabbro and shows the typical alterations characteristic of the contact. The chert is in much larger particles than in the western portion of the range away from the contact. The particles fit in somewhat regular polygonal blocks. The iron oxide is magnetite instead of hydrated hematite, and actinulite and grünerite are present. The amphiboles are in small quantity in the slide slown, but the slort actinolite needles may be seen inclosed in the quartz. (See Pl. XXXV.)

B. Actinolitic slate (specimen 9555, slide 3190) from Penokee Gap, NW. $\frac{1}{2}$ sec. 11, T. 44 N., R. 3 W., Wisconsin. In polarized light, $\times 165$. The section is a typical actinolitic slate. The quartz is completely crystallized. The magnetite has mostly well-defined crystal ontlines and is manifestly the first nineral to crystallize, being scattered uniformly through the section without any regard to the actinolite and quartz and therefore inclucted by both of them. The actinolite is in its characteristic blades and sheaf-like forms, having a radial arrangement of its fibers. It is as plainly the second mineral to crystallize, as needles of actinolite everywhere penetrate the quartz, but never the magnetite. The quartz constitutes a backgtound for the magnetite and actinolite and includes them in such a manner as to make the. conclusion certain that it must in the main liave crystallized subsequently to the formation of the magnetite and actinolite. (See Pl. IXYV.) 

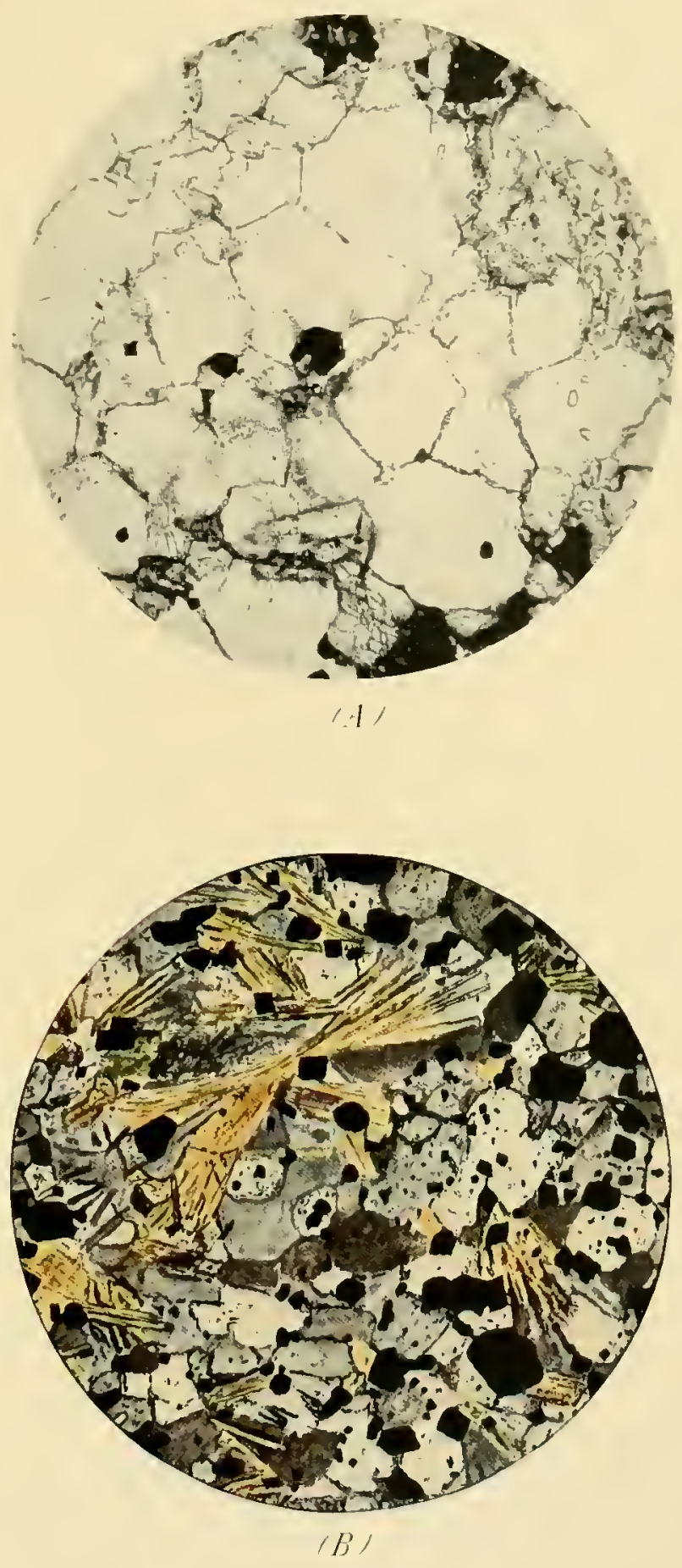

PHOTOMICROGRAPHS OF FERRUGINOUS AND AMPHIBOLITIC CHERT OF IRON-BEARING FORMATION NEAR CONTACT WITH DULUTH GABBRO. 



\section{TEMPERATURE UNDER WHICH CONTACT ALTERATIONS WERE EFFECTED.}

The significant discovery by Wright and $\mathrm{Day}^{a}{ }^{a}$ of the geophysical laboratory of the Carnegie Institution of Washington, that quartz crystallized below $575^{\circ}$ diflers in its properties from quartz crystallized above this temperature affords a satisfactory means of determining the temperatures at which the quartz of the iron-bearing formation has crystallized. Doctor Wright has kindly determined for us the properties of the quartzes in specimens from different parts of the Lake Superior iron-bearing formations, some of them clearly developed under katamorphic conditions, some of them near the contact with the gabbro. His observations are as follows:

Properties of quartz crystals from iron-bearing formations.

\begin{tabular}{|c|c|c|c|c|c|c|c|c|c|}
\hline \multirow{2}{*}{$\begin{array}{l}\text { Speci- } \\
\text { men No. }\end{array}$} & \multirow{2}{*}{$\begin{array}{l}\text { Number } \\
\text { of sce- } \\
\text { tions cut. }\end{array}$} & \multirow{2}{*}{$\begin{array}{l}\text { Average } \\
\text { diameter } \\
(\mathrm{mm} \text {.). }\end{array}$} & \multicolumn{4}{|c|}{ Circular polarization. } & \multicolumn{3}{|c|}{ Twinning, etch figures $a$} \\
\hline & & & R. & L. & R. + L. & $\begin{array}{l}\text { Charaeter } \\
\text { of inter- } \\
\text { growth. }\end{array}$ & $\begin{array}{l}\text { Number } \\
\text { not } \\
\text { twinned. }\end{array}$ & $\begin{array}{l}\text { Number } \\
\text { twinned. }\end{array}$ & Character of twinning. \\
\hline $\begin{array}{r}A \\
B \\
29955 \\
29450\end{array}$ & $\begin{array}{l}5 \\
6 \\
4 \\
6\end{array}$ & $\begin{array}{l}7 \\
5 \\
1.5 \\
2.0\end{array}$ & $\begin{array}{l}3 \\
3\end{array}$ & $\begin{array}{l}4 \\
1 \\
3\end{array}$ & $\begin{array}{l}1 \\
6\end{array}$ & 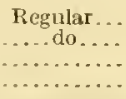 & $\begin{array}{l}2 \\
\cdots \\
2\end{array}$ & $\begin{array}{l}3 \\
6 \\
4 \\
4\end{array}$ & $\begin{array}{l}\text { Regular large patches. } \\
\text { Do. } \\
\text { Regular. } \\
\text { often irregular and small. }\end{array}$ \\
\hline
\end{tabular}

a Etched $I_{1}^{1}$ hours in cold commercial hydrofluoric acid.

A. Crystalline quartz in ore from Vermilion distriet.

B. Crystalline quartz in ore from Mesabi district.

29955. Coarsely recrstallized iron-hearing formation, 300 feet from gabbro contact, northwest of Paulson mine camps, Gunflint district, northeastern Minncsotz.

29450. Coarsely recrystallized iron-bearing formation in actual contact with Duluth gabbro at east end of Fay Lake, Gunflint district, northeastern Minnesota.

The quartz of Nos. $A$ and $B$ occurs in clear crystals and free from fractures. The usual + and - unit rhombohedrons are present; also the prisn faces. On $A$ crystals there is also present the rhombohedron (1121) and a trigonal trapezohedron form; this in itself is proof that the $A$ quartz was formerl below $575^{\circ}$.

The above observations show conclusively that the A, B, and 29955 quartzes [distant from gabbro contacts] have not been heated above $575^{\circ}$; that they were formed helow that temperature. Specimen 29450 [at gabbro contact] is less regular in its behavior and resembles in that respect the quartz of some pegmatites. It is not as slattered as granite quartzes usually are and yet is not so regular as the definitely lower temperature quartzes. I conclucled that in the pegmatites such quartz was formed probably near the inversion teuperature $575^{\circ}$, because pegmatite dense qnartz is definitely the low $a$ form while some pegmatite quartz is definitely $h_{1} h_{1} b$ quartz. This was proved on one and the same dike.

It seems to me probable, therefore, that the temperature of formation of the quartz band in specimen 29450 was not far from $575^{\circ}$.

It is obvious from these results that the iron-bearing formation as a whole has not been fused, for its fusion temperature is certainly higher than $575^{\circ}$. This conclusion, together with the one above referring to the lack of transfer of material from the gabbro to the iron-bearing formation, emphasizes strongly the probability that the metamorphism of the iron formation near the gabbro was primarily the result of recrystallization below fusion temperature, with the aid of heat from the gabbro.

\section{CHARACTER OF IRON-BEARING FORMATIONS AT THE TIME OF INTRUSIONS OF IGNEOUS ROCKS.}

What were the constituents originally present in the iron-bearing formations at the time of the intrusion? Were they the ferruginous cherts earlier developed from the alteration of cherty carbonates or greenalite rocks, or were they the cherty carbonates and greenalite rocks themselves? If prior to the intrusion of the igneous rock the iron existed as ferric hydrate, then the change to magnetite involved deoxidation. 'This, according to Moissan, ${ }^{b}$ will occur at $300^{\circ}$ in 30 minutes in a hydrogen atmosphere. The presence of an actirely reducing agent of this type along igneous contacts, while perhaps locally probable, can not be proved on any 
large seale. If prior to the intusion of the igneous rock the iron was in the ferrous condition, either as greenalite or carbonate, then molerate heat was suflicient to produce magnetite by rohbing the associated water of part of its oxygen. (See p. 526.) 'This alteration is thought in general to be a more common one than the reduction of iron to magnetite from the ferric state. In the Lake Superior region there is field evidence also that the development of the amphibole-magnetite rocks has been more largely accomplislied by partial oxidation of the ferrous iron than by the reduetion of ferric oxide. In places in the Lake Superior region, where there is good field evidence that the iron-bearing formation had been exposed and altered to ferruginous cherts before the introduction of igncous rocks-as, for instance, in the eastem part of the Marquette district or at Sumday Lake in the Gogebie distriet - it is lound that the contact efleet of the intrusives has been to produce the bright-red banded specular jaspers or black magnetitic jaspers rather than amphibole-magnetite rocks. In the Marquette district it was long ago noted that the lower parts of the Negaunee formation in contact with intrusives dereloped amphibole and magnetite, while the upper parts developed the banded specular jaspers. The rement in these rocks is usually magnetite. Smyth a argued that this present difference in the character of the rocks at upper and lower horizons, especially for the Republic trough, is so uniform as to indicate an original difference in the beds at these horizons. The magnesia content of the amphibole-magnetite roeks for the most part seems to be like that of the original greenalites and carbonates rather than that of their altered derivatives, fermginous cherts. In the alteration of carlonates or greenalites to cherts magnesia is lost. (See p. 528.) Had the amplibole-magnetite rocks developed from the ferruginous cherts, it would be necessary to assume that magnesia had been introduced in just the percentage of the original siderite and greenalite rocks.

Sulphur is also more abundant in the original phases of the iron-bearing formation than in its katamorphosed products, though no figures are available to show what the arerage sulphur eontent is, because analyses have ordinarily been made of the greenalite and siderite where free from sulphur. Contact or deep-seated metamorphism would not remore this sulphur, and this is thought to be the probable explanation of the high sulphur in the amplibolemagnetite rocks. The alternative explanation is that sulphur had been introduced directly from the igneous rocks.

\section{CHEMISTRY OF ALTERATIONS.}

The ehemistry of the alterations from original ferrous compounds, greenalite and siderite, to amphibole-magnetite rocks presents less difficulty than that of the alteration of ferruginous cherts, or ferric compounds, to the amphibole-magnetite rocks. The former alteration requires partial oxilation of a ferrous compound; the latter requires reduction of a ferric compound, which is thought to be much less common.

On the assumption that the amphibole-magnetite rocks had dereloped directly from the cherty iron carbonates and greenalites, the changes would be substantially as follows: ${ }^{b}$

Where the earbonate is nearly pure siderite, grünerite is produced, according to the following reaction:

$$
\mathrm{FeCO}_{3}+\mathrm{SiO}_{2}=\mathrm{FeSiO}_{3}+\mathrm{CO}_{2} \text {, }
$$

with a decrease of volume of 32 per cent, provided the silica be a solid and the carbon dioxide escape. Where the original material was hydrous ferrous silicate, greenalite, simple dehydration only is necessary to form the grünerite.

Where the iron-bearing carbonate bears calcium and magnesium in considerable quantity, instead of grünerite being produced sahlite or actinolite may be formed. Supposing the carbonate to be normal ankerite, fahlite is produced, accorling to the following renction:

$$
\mathrm{CaFeC} \mathrm{O}_{6} \text {. ( } \mathrm{aMgC} \mathrm{Og}_{6}+4 \mathrm{SiO}_{2}=\mathrm{Ca}_{2} \mathrm{MgFeSi} \mathrm{O}_{12}+4 \mathrm{CO}_{2} \text {, }
$$

with a decrase in volume of 37 per cent, provided the silica be solid and the carbon dioxide escape.

From ankerite actinolite may be produced, according to the following reaction:

$$
3\left(\mathrm{CaFeC}_{2} \mathrm{O}_{6^{-}} \mathrm{CaAlgC}_{2} \mathrm{O}_{6}\right)+8 \mathrm{SiO}_{2}=\mathrm{Ca}_{2} \mathrm{Mg}_{3} \mathrm{Fe}_{3} \mathrm{SiO}_{24}+8 \mathrm{CO}_{2}+4 \mathrm{CaCO}_{3}
$$

with a derrease in volume of 23 per cent, provided the silica bo a solid, the $\mathrm{CaCO}_{3}$ formed remain as a solid, and the carbon dioxicle escape.

Mon. IT. S. Geol. Survey, vol. 2s, 1597, p. 530.

bVan Hlis", C. R., A treatise on metamorphism: Mlou. U. S. Geol. Surrey, vol. 17, 190-I, Pp. \$31 \$37. 
If a nore ferriferous and less caleareous iron-bearing carbonate be taken, it would not be necessary to supjose any calcium carbonate to bave separated.

The iron-bearing carbonates may be very impure, just as limestones may be impure; and in this case there may develop varions other minerals. In proportion as impurities are mingled with the carbonates, other ampliboles and the pyroxenes, micas, garnets, and other beary minerals such as olivine may abundantly develop; and thus there may be produced a great variety of rocks, such as garnetiferous magnetite rocks, micaceons grünerite rocks, ete. As the impurities become abundant and the silicates other than grumerite, sahlite, and actinolite more prominent, the alterations become nearly those of the fragmental rocks. Between the two there are, of conrse, all gradations.

But as a matter of fact, the two silicates which most extensively form by the alterations of the iron-bearing carbonates in the zone of anamorphism are actinolite and grüerite. Where these reactions are complete we may have, in place of the iron-bearing carbonate, actinolite rocks, grimerite rocks, and all gradations between them.

Where the iron-bearing formation is originally greenalite, the alteration to the amphiboles would be simply one of dehydration.

The derelopment of magnetite directly from the iron earbonates is possible by the following reactions:

$$
\begin{aligned}
& 2 \mathrm{FeCO}_{3}+\mathrm{FeS}_{2}+2 \mathrm{H}_{2} \mathrm{O}=\mathrm{Fe}_{3} \mathrm{O}_{4}+2 \mathrm{I}_{2} \mathrm{~S}+2 \mathrm{CO}_{2},{ }^{a} \\
& 3 \mathrm{FeCO}_{3}+\mathrm{H}_{2} \mathrm{O}=\mathrm{Fe}_{3} \mathrm{O}_{4}+3 \mathrm{CO}_{2}+\mathrm{H}, \\
& 3 \mathrm{FeCO}_{3}=\mathrm{Fe}_{3} \mathrm{O}_{4}+\mathrm{CO}+2 \mathrm{CO}_{2},{ }^{a} \\
& 3 \mathrm{FeCO}_{3}+\mathrm{O}=\mathrm{Fe}_{3} \mathrm{O}_{4}+3 \mathrm{CO}_{2},{ }^{a}
\end{aligned}
$$

Carbon dioxide is driven off at temperatures probably as low as $400^{\circ}$. At these and higher temperatures the ferrous iron remaining will rob the water of its oxygen, forming magnetite.

Siderite at red heat passes into a magnetic oxide with the formation of both carbonic acid and carbonic uxide. According to Döbereiner this reaction takes place as follows: $a$

$$
5 \mathrm{FeCO}_{3}=3 \mathrm{FeO}, \mathrm{Fe}_{2} \mathrm{O}_{3}+4 \mathrm{CO}_{2}+1 \mathrm{O} \text {. }
$$

Glasson, $b$ however, says that $4 \mathrm{FeO} \cdot \mathrm{Fe}_{2} \mathrm{O}_{3}$ results, at first giving two parts of $\mathrm{CO}_{2}$ and one of $\mathrm{CO}$, but that later the proportion changes to five parts of $\mathrm{CO}_{2}$ and one of $\mathrm{CO} \cdot \mathrm{c}$

Van Hise ${ }^{a}$ says, again:

Observation in the field shows beyond question that the change from iron carbonate to magnetite takes place on an extensive scale. Thich of the above reactions is the more important may be an open question.

The alteration of greenalite to magnetite is possible by the following reaction:

$$
3 \mathrm{FeSiO}_{3} \mathrm{nH}_{2} \mathrm{O}+\mathrm{O}=\mathrm{Fe}_{3} \mathrm{O}_{4}+3 \mathrm{SiO}_{2}+\mathrm{nH}_{2} \mathrm{O} \text {. }
$$

Which of the above rocks develops at a given place depends not only upon the original composition of the rocks, but upon the nature of the alteration. For instance, where in the original rock silica is subordinate and nearly pure siderite abundant, a quartzose magnetite may develop, as at various places in the Lake Superior region. Where the conditions are such that the silicates form, the development of the actinolite or grinerite uses up both the iron carbonate and the silica, and an actinolite rock or a grünerite rock may be produced. Where silica was originally an abmndant constituert both magnetite and the silicates are likely to develop. Thus we lave various profortions of all the minerals, prodncing the magnetite-ryuartz rocks, the actinolite-magnetite-quartz rocks, the grïnerite-magnetite-qnartz rocks, the actinolite-quartz rocks, and the grünerite-quartz rocks,d

\section{BANDING OF AMPHIBOLE-MAGNETITE ROCKS. $e$}

Usually a given formation, or member, does not show a perfectly homogeneons arrangement of the mineral particles. The original sedimentary rock is banded, and the different bands have different compositions. Naturally the transformation of these bands produces different combinations of minerals. Nloreover, during the recrystallization there is a tendency for minerals of the same kind to segregate. Hence, in any of the above cases, where as a whole a certain set of minerals are dominant within a rock, a single nineral, or two combined, may be largely segregated in bands; and in the alternate bands the other minerals be largely segregated. Thus a banded rock, consisting mainly of magnetite and quartz, may bave a landed appearance as the result either of the segregation of the quartz and magnetite in separate bands or, more commonly, the segregation of more quartz and less magnetite in one band and less quartz and more magnetite in another band. In a similar manner alternate bands may be made up of actinolite or grünerite with quartz

$a$ Van Hise, C. R., op. cit., p. 838.

$b$ Cited by Gmelin-Kraut, Anorganische Chemie, rol, 3, p. 319.

c Chamberlin, R. T., The gases in rocks: Pub. Carnegie Inst. No. 106, 1908, p. 51.

$d$ Van Hise, C, R., op. cit., p. 839.

e Idem, PP. $839-8+0$. 
in various proportions, and of actinolite or grünerite with magnetite in various proportions. In still other instances the banding may be dus to the combining of actinolite or grünerite, maguetie, and quartz in various proporlions. In general, therefore, the ait erafions of the rock do not destroy the original sedimentary handing, but, on the contrary, emphasize it. The stiking banded appearance of actinolitic and grüncritic rocks is one of their most characteristic features.

\section{RECRYSTALLIZATION OF QUARTZ.}

The recrystallization of quartz under these anamorphic reactions has multiplied the size of the grain many times, as mentioned in the diseussion of the individual districts. The recrystallization of quartz has largely followed the development of magnetite, for magnetite with crystal ontlines is often observed to be completely inelosed in large elear quartz crystals with no strain effects.

\section{HIGH SULPHUR CONTENT OF AMPHIBOLE-MAGNETITE ROCKS.}

The amphibole-magnetite rocks usually carry a higher percentage of iron sulphide than other phases of the iron-bearing formations. If iron sulphicle plays the important part assigned to it in the early portion of this discussion (see pp. 518-519), iron sulphicles may be supprosed to have been locally deposited throughout the iron-bearing formations with the carbonates and greenalites. These woukl be the first substances to be altered by the surface waters and, going quickly into solution, would greatly accelerate the concentration of the ore, but during the alteration of iron carbonate or greenalite to amphibole-magnetite rocks there is no opportunity for oxidizing solutions to get at the sulphides and hence they remain. The refractormess of the amplibole-magnetite rocks also prevents subsequent oxidization. In the Gunflint Lake distriet of Minnesota the sulphile is in the form of pyrthotite, which, according to Moissan ${ }^{a}$ and Allen, ${ }^{b}$ is developed through the application of heat to pyrite.

An alternative explanation of the high sulphur is that it was secondarily contributed by the hot intrusives. For this there is no direct evidence.

\section{SECONDARY IRON CARBONATE LOCALLY DEVELOPED AT IGNEOUS CONTACTS.}

In a few localities, as at Gunflint Lake, Minnesota, in the Animikie district, and at Sunday Lake, in the Gogebic district, coarsely erystallized iron carbonate is found close to the igneous rock, this material doubtless being produced by recrystallization of the original finer carbonate.

\section{CONTACT ALTERATIONS NOT FAVORABLE TO CONCENTRATION OF ORE DEPOSITS.}

The anamorphic changes above described do not favor the transfer and segregation of constituents of the iron-bearing formations. They tend rather to combine them. Locally there is evidence that iron is earried in solution under these conditions, in the fact that cements in fractures are largely magnetite and the iron is usually in coarser bands. If the intrusions come before the original iron-benring formation has become porous through the loss of its siliea, the rocks do not have the openings for the transfer of solutions. Even had openings existed in some places, the deep-seated pressures exerted by great batholiths, like the Duluth gabbro, have been sufficient to make the rock undergo rock flowage, thereby closing openings. If other conditions were favorable there would still be the lack of abundant surface waters to leach the silica. So far as the iron-bearing formation hal been previously altered and concontrated to ore under weathering conditions, the intrusions of the igneous rocks would have the eflect of delnydrating and recrystallizing the ores, but not of further coneentrating them.

There are but two highly magnetic deposits in the Lake Superior country which have been mined as ore. In the Republie district of Michigan magnetitie specular hematite is interlavered with bright-red and black jaspers in which the iron oxide is hematite and magnetite. Near the base of the formation amphiboles are abundant and the formution is lean in iron. The upper part of the formation seems to be essentially the result of anamorphism of a previously 
formed iron oxide and jasper zone in which there has been some concentration of iron ore. The lower portion of the formation is regarded as the result of the anamorphism of an original carbonate formation not exposed to weathering prior to the introduction of the igneous rocks. In both cases conditions of rock flowage incident to the folding and intrusion have aider the direct contact effects. The upper part of the formation has suffered most from the realjustment along the surface of the contact between the unconformable middle and upper Huronian. The probable sequence of events is discussed on pages 277-279.

At Champion, Mich., in the Marquette district, the derelopment of the magnetite-ore deposit is explained in much the same way. These ores have been found to contain a larger percentage of titanium than is usual in the Lake Superior ores ol the serlimentary type, some samples of the Champion ore containing as much as 1.66 per cent of $\mathrm{TiO}_{2}$. It is possible that this may represent a direct contribution from the intrusive.

The titaniferous magnetite deposits in the Lake Superior region are not results of the contact alteration of an iron-bearing formation, but are rather magmatic segregations in the igneous rocks. Also certain of the black magnetite rocks of the inon-bearing formations closely associated with surface extrusive rocks may have been the result of direct contribution from the igneous rocks and not contact metamorphism, as already indicated. (See p. 527.)

The alterations above described are essentially constructive or anamorphic in their nature, tending to produce more complex mineral substances, and do not accomplish simplification and segregation sufficiently to develop ore deposits, in these respects contrasting markedly with weathering alterations which the formation undergoes at the surface away from the influence of igneous rocks.

Therefore, so far as the amphibole-magnetite rocks contain ores, these ores are probably originally rich iron layers in the iron formation which may have been partly concentrated during katamorphism preceling anamorphism. The anamorphic processes have not aided their concentration.

\section{SURFACE ALTERATIONS OF AMPHIBOLE-MAGNETITE ROCKS.}

After the grïneritic or actinolitic rocks have developed in the zone of anamorphism, in consequence of denudation they may pass into the zone of katamorphism, or eren into the belt of weathering. 'Then will begin the processes of oxidation, hydration, and carbonation, as a result of which the magnetite is slightly changed to hematite or limonite and the amplibole or other silicates may decompose into chlorite, epidote, and calcite. However, as magnetite and the iron-bearing amphiboles are very refractory, this process is exceedingly slow and usually has affected only comparatively thin layers of materials adjacent to the surface or adjacent to openings in the rock. Indeed, the reactions of the belt of weathering and the upper part of the belt of cementation, which may produce large iron-ore bodies where they have the original iron-bearing carbonates or the hydrous ferrous silicates to work upon, have nowhere in the Lake Superior region formed large ore bodies where they are working upon the grüneritic and actinolitic rocks.

The iron content of the amphibole-magnetite rocks is not materially different from that of the ferruginous cherts, allowance being male for a slight difference in degree of oxidation and hycdration of iron. The leaching of silica from this rock would produce.an ore as rich as that derived from the alteration of cherts, but as a matter of fact the silica is usually not leached from these rocks and ore deposits derived from them are small and rare. The external conditions for their alteration are essentially the same as those for the alteration of the cherts: topographically, structurally, and chemically, and so the failure of the waters to leach the silica. from them and concentrate the iron must be ascribed to the condition of the rock. Microscopic examination shows that the quartz is much more coarsely crystallized than in the ferruginous cherts. The grains will average a thousand times the mass of those of the cherts. (Compare Pls. XLIV and XLVII.) It has undergone marked recrystallization, which has completely obliterated the minute particles or any pore space that the cherts may have had, and also 
erystallized any amorplous chert originally present. The pore space is less than 1 per eent, as compared with about 5 per cont in the forruginous cherts. The result is that the waters have fewer openings into which to penetrate and far less surface of quartz upon which to work. This fact alone is believed to be suflicient to account for the lack of leaching of silica. However. it may be also pointed out that some of the silica has combincd with the iron in resistant ampliboles which do not yich readily to the surface waters. The rocks are hard, lense, and crystalline, being obviously much more diflicult for the waters to attack cither mechunically or chemically than the ferruginous cherts. They usually stand at a higher elevation, other structural conditions being approximately the same, inclicating their resistance to erosion. In the Ahesabi clistrict the elevation of the upper Iluronian iron-bearing formation where it is altered to amphilole-magnetite roek at the east cnd of the district is fully 200 feet ligher on an average than that farther west, where the rock is altered to ferruginous chert.

It follows from the foregoing that anamorphic processes of the original iron carbonates and greenalites producing amplibole-magnetite rocks are not only unfavorable to the chrect development of ores, but they put the formation in condition to resist the action of ordinary katamorphic concentrating agencies.

\section{SUMMARY OF ALTERATIONS OF IRON-BEARING FORMATIONS BY IGNEOUS INTRUSIONS.}

As a result of igneous intrusions, iron-bearing formations become recrystallized and coarser in grain.

The arerage chemical composition is not essentially changed except by dehydration, and perhaps locally by introduction of sulphur or other constituents, but the mineral composition is greatly changed.

The density has been increased and the pore space lessened.

The alterations of the carbonate and greenalite rocks have produced amphibole-magnetite rocks. The alterations of the ferruginous cherts and soft ores have produced banded red jaspers and liard ores.

The changes under the influence of intrusions are those of anamorphism unfavorable to the development of ore deposits, lut originally rich iron layers may remain as ores. The anamorplic products, once formed and exposed at the surface, are found to be too refractory to undergo alterations to ores.

\section{AITERATION OF IRON-BEARING FORMATIONA BY ROCK FLOWAGE.}

Mechanical deformation has accomplished difterent changes in the iron-bearing formations, depending on whether it is eflected by fracture or by flowinge and whether the iron-bearing formation was in its original carbonate or greenalite form at the time of the leformation, or had becn altered to ferruginous chert and ore or to actinolitic and grüneritic rocks. Fracturing has opened up avenues for water circulation, as diseussed on pages 474-475. Here is considererl the effect of rock flowinge only.

The iron earbonates and greenalites were not considerably altered ly rock flowage, for subsequent to the folding they underwent the normial alterations to ores and ferruginous cherts. This is especially well illustrated by the folded upper II urouian iron-bearing formation, in which original carbonates are still found where the surface alterations have not reached them.

The alterations of the ferruginous cherts and ores under mechanical pressure have been rery conspicuous in the Feewatin ores of the Vermilion district, in parts of the Negaunee formation nearest the contact with the upper ILuronian in the Marquette district, and elsewhere. (See PI. XXXIX, B, p. 4, S.) The Vermilion ores have been rendered hard, crystalline, dehyrated, locally somewhat schistose, more or less magnetic, localy brecciated, and cemented by rein quartz and later by iron oxide (hematite and magnetite). As the ores stand in the Ely trough they contain murh pore space because of their coarsely breciated condition. The ferruginous cherts of the Vermilion district have simulameously been recrystallized and cemented, and the iron minerals have gone through the same series of physicat and chemical 
changes as in the ores. The net result is the production of a rock having a composition similar to that of ferruginous chert, with a large proportion of magnetite and with a small amount of pore space.

In the Marquette district the post-Huronian folding developed a marked shear zone at the contact of the Negaunee formation with the overlying detrital ferruginous base of the upper Huronian, with the result that the ore was delyclrated and rendered crystalline, developing coarsely crystalline specular henatite or micaceons hematite and porphyritic magnetite, accompanied by a marked elmination of pore space. The extent of the mashing is lest indicated by the quartz pebbles in the detrital hase of the upper Iluronian, some of which are much flattened.

The effect on the feruginous cherts or jaspers has been to make the iron bands brightity specular.

Aside from these effects noted near the contacts of the upper and middle Inronian, the later folding has not essentially changed the characters of the iron-bearing formation. Smytha liscusses it thus:

It has been said that the grimerite, quartz, and iron oxides of the iron-learing member have a very distinct banded arrangement and yet are not original minerals, and that this banding is parallel to the upper and lower bonndaries of the formation. It is probable that a set of parallel structural planes has controlled the segregation of the present constituent minerals during the changes through which the rock has passed, and that these planes must have been original bedding planes. Is the parallel banding is confined to this one direction, it is certain that during its development no other system of parallel planes existed in the rock. The last severe folding, which has determinerl the larger structural features of the Marquette district, has also affected the rocks in a more intimate way. In certain lucalities strong minor, even minute crenulations have been produced, and also parallel cleavage, which sometimes traverses the banding of the ruck at right angles. The little folds are often broken and faulted and the siliceous bands reduced to fragments. Nlong the parallel cleavage planes morement has often taken place, as is shown by the displacement of a particular band on the two sides. Along this secondary cleavage, which dates irom the period of general folding after upper Marquette time, no great development of new minerals, except the iron oxides, has taken place, while the displacement which the minute faulting has caused in the banding conclusively proves that this structure was present before the folding.

Allen ${ }^{b}$ finds similar conditions in the Woman River district of Ontario, where riebeckite and magnetite are cut by later cleavage.

The effects of mechanical deformation in the zone of flowage may be summarized as follows:

As a result of mechanical deformation the ores have become dehydrated, crystalline, in some places specular and schistose, lacking pore space, locally brecciated, and in part recemented by quartz and iron oxide.

The ferruginous cherts have become recrsstallized and dehyclrated, in some places slightly deoxidized, tending to produce the banded red and black jasper's. These alterations of the cherts are not certainly discriminated from those due to the intrusion of igneous rocks.

Deformation by flowage does not aid concentration by surface waters, but on the other liand it does not so affect the original carbonates and greenalites that surface waters may not later alter them to ores.

\section{- CAUSE OF VARYING DEGREE OF IIYDRATION OF LAIE SUPERIOT ORES.}

The Lake Superior iron ores include both hydrous and anhydrous varieties-magnetite, hematite, limonite, and several intermediate hydrates. The iron ores of the region as a whole are low hydrates of iron, containing an average of about 2 per cent combined water. The most hydrous of the pre-('ambrian ores are those of the Mesabi range, which average an anount of combined water equivalent to a ferric hydrate having 4.5 per cent. Locally ores containing almost as much water as limonite are found, but this is exceptional. Some of the ores are crystalline hematite and magnetite.

Are the differences in hydration of the diflerent beds due to differences in original character, or to differences in secondary alterations? These questions are answered only in part.

a Smyth, H. L., The Republic trough: Mon. U. S. Geol. Surrey, vol. 2\$, 1897, pp. 531-532.

b Allen, R. C., Iron lormation of Woman River: Eighteenth Ann. Rept. Ontario Bur. Mines, pt. I, 1909, pp. $25 t-262$. 
Guy H. Cox has assembled the various experincutal data on the subject and supplemented them by laboratory experiments of his own.

From meteorie solutious under ordinary lemperatures at the surface the precipitates of iron are forric hychates containing 29 per cent of water, which rupidly changes in contact with water into limoinite. containing 14.44 per econt of water.

The presence of alumina, lime, and magnesia to combine with the iron may prevent dehydration. ${ }^{a}$ If left for several years, the ore becomes dehydrated and crystalline. ${ }^{b}$

Increase in temperature and pressure on the solutions at the time of preeipitation will lower the hydration of the precipitated salt. At a temperature of $500^{\circ}$ magnetite may be precipitated directly from solution. Slight rariations in the alegree of liydration in a precipitate are determined by the form in which the iron is held in solution, by the precipitating agents, and by the strength of the solutions, though so far as experimental data go the range of variation due to these causes is small.

Secondary alterations have little eflect on anhydrous ores, but hydrous ores may easily lose part of their water by moderate increase in temperature and by pressure such, for instance, as that involved in freezing, where the water is allowed to escape. It appears also that in an ore containing various hydrates, solution will dissolve the highest hydrates, leaving the residue in a lower state of hydration, but that the redeposition of the dissolved part as a higher hydrate may result in net increase of hydration for the residue and dissolved parts combined.

It appears, therefore, that conditions of high temperature and pressure, either during the original deposition of the iron salts or during their secondary alterations, favor the development of anhydrous salts, thereby explaining the oceurrence of crystalline hematite and magnetite in the iron-bearing formations near igneous contacts or where dynamieally metamorphosed. It is shown elsewhere that magnetite, perhaps even hematite, may have been precipitated rirectly from the hot solutions coming from some of the basic igneous rocks, or that the iron salts may first have been deposited as greenalite and iron carbonate which subsequently altered under conditions of high temperature and pressure to magnetite and hematite, or that the iron salts were first deposited as greenalite and hematite, subsequently altered to limonite, and then dehydrated by the high temperature and pressure of anamorphic conditions to hematite and magnetite. In all these eases the heat from some adjaeent igneous rock or the pressure developed from rock flowage seems, from fiekl evidence, to be an essential factor.

However, hematite and various hydrates are found minutely interbedked in parts of the iron-bearing formations where there is no eviclence of the effect of unusual heat or pressure. A hand specimen may show several layers of iron oxides with varying degrees of hydration. These differences persist in the ferruginous cherts and jaspers and in the ores into which the ferruginous eherts and jaspers grade. Moreover, they seem to be independent of distance from rock surface and of dip of beds. In steeply inclined beds layers with different degrees of hydration may be found to continue from the surface to great depth with no relative change in liydration.

These remarkable and persistent variations in hytration in elosely associated layers may have been due to-

1. Differences in the original substances in different layers, whether carbonate or greenalite. The iron-bearing formations were originally anhydrous iron carbonate and hydrous silicate, both of which have altered when weathered to hydrous oxides. It has not been ascertained that there is any specific difference in degree of hydration of the alteration products of the greenalite and carbonate, though on the whole the beds in the Mesabi district, containing the most greenalite, are the most hydrous.

2. Diflerence in time of alteration of the greenalite and carbonate, with accompanying slight variations of temperature and pressure. The hydration of different layers has taken place at

a Spring, W., Neues Jahrb, vol. 1, 1499, pp. 47-ti2 (cited by Moore, E. S., Eighteenth Ann. Rept. Ontario Bur. Mines, pt. 1, 1909, p. 194).

o Wiltstein, f. C., Vierteljahresschrift tür Pharmacie, rol. 1, 1852, p. 275 (cited by Moore, E. S., Eightcenth Anu. Rept. Ontario Bur. Mincs, pt. 1, 1000, p. 194). 
different times when the temperature conditions and pressure conditions may have been slightly different, although of these differences we have no knowledge.

3. Selective secondary alterations of the hydrates formed loy the first alteration of the greenalite and carbonate. Freezing (seasonal and glacial) and moderate clepth of cover may tend to dehydrate the ores and probably have contributed to the low average degree of hydration of the bedded hematites. So far as experimental eridence goes, these ores would have their highest degree of hylration at the time of precipitation, and all influences acting upon them subsequently, even moderate seasonal variations in temperature and moderate depth of burial, would tend toward lowering the degree of hydration.

It might be expected that the result of seasonal variations in temperature and the pressure of overlying rocks would result in a uniform variation in hydration from the surface downward. No evidence of this sort has been found in the ore bodies. It should be noterl, however, that the effect of freezing would be toward dehydration at the surface and the effect of pressure would be toward deliydration with depth. Instead of uniform change in hydration one way or another from surface to depth, the most conspicnous change in hydration is between closely interbedded layers of the iron-bearing formations.

The selective effect of solution and redeposition might lave influence; for instance, waters percolating rapidly along a certain bed or fissure might dissolve the more hydrated ores, carry them off, and redeposit them, leaving the residue with a lower degree of hydration. Slight original variations in hydration would thereby be emphasized. Other unknown causes may be operative.

According to Stremme, ${ }^{a}$ hydration is favored by salt content and carbon dioxide content of the altering solutions. The salt and acid content apparently influence the degree of hycliation of the iron axide by lowering the rapor pressure of the solution. Each iron hydrate is supposed to have its own vapor pressure, which is the minimum pressure of water vapor with which the hydrate can remain in equilibrium at any given temperature.

We may conclude in general that the liydrous ores of the Lake Superior region have developed under ordinary conditions of temperature and pressure near the surface, that the anhyJrous ores exhibit the effects of heat and pressure, and that the differences in hydration of closely intermingled layers of the iron-bearing formations have required some influence of a selective sort, the nature of which may be suggested but not proved.

\section{SEQUENCE OF ORE CONCENTRATION.}

We hare touched upon each of the factors going to determine the present character and structural relations of the ores. To complete the picture we have now to clwell upon the chronologic derelopment of the ores.

The beginning of the processes of secondary concentration must be placed for the Archean ores in early IIuronian time and for the middle Iuronian ores in the time between the midclle and upper IIuronian. Iron-formation fragments in the basal conglomerutes of these divisions tell to some extent what had previously happened to the iron-bearing formations of the older land. At the base of the upper Huronian rich ferruginous detritus was formed at the beginning of upper Huronian time. In certain places the iron-bearing formation within the upper Huronian was exposed by erosion before Keweenawan time and went through a set of changes in the time interval between the IIuronian and Keweenawan similar to those that affecter the lower Iuronian iron-bearing formation in inter-IHuronian time. This is shown by the detritus of the Keweenawan basal conglomerate and by the development of red jaspers and hard ores from the soft varieties near the contact of Kieweenawan and upper IIuronian in eastern.Gogebic district. In those districts in which great masses of Keweenawan rocks were laid down upon the Hluronian rocks before the iron-bearing formation had been exposed to weathering, the concentration of the ore could not have begun until the Keweenawan was cut through in the crosion

a Stremme, Il., Zur Kenntnis der wasserhaltigen und wasserfreien Eisenoxydbildungen in den Sedimentgesteinen: Zeitschr. prakt. Grologie rol. 1s, No. 1, 1910, pp. 1S-23 (reviewed in Econ. Geology, vol. 5, 1910, p. 499). 
period preceding Cambrian time, and it is rather probable that this limitation also applies to other districts. Clearly the process in each clistrict began when, als a result of the great orogenic morements and the attendant denudation, the iron-bearing formation was exposed to the wenthering forces. In most of the districts this occurred in the great time gap represented by the unconformity between the Keweenawan and the Cambrian. At this time were concentrated most of the great ore deposits of the upper II ronian of the region and the ores at the midhle and lower horizons of the Negannee formation of the middle Huronian.

Wherever the Cambrian remains in or near the iron districts it contains iron-ore fragments, jaspers, and cherts in its basal conglomerate. In the Menoninee district these are rich enough to be mined. The process of ore concentration was therefore well advanced before C'ambrian time.

In the Iesabi district remunts of Cretaceous bels overlie some of the ore deposits, particularly in the westem parts of the range. At the basal horizons of these beds are detrital iron ores derived from the Biwabik formation. Here, then, the concentration was well antranced as early as Cretaceous time, and there is little loubt, from the similar relations of the ores to the Cambrian in other regions, that the ores of the Mesabi district were well concentrated even by Cambrian time.

The process of enrichment has undoubtedly continued until the present time. It therefore appear's that the circulating waters have had eras in which to perform their work; indeed, a part of pre-Paleozoie time and all of the Paleozoic, Mesozoic, and Cenozoic.

Frequently during pre-Cambrian time the iron-bearing lormations were metamorphosed by igneous intrusions, the principal effect of which was to recrystallize the original phases of the iron-bearing formations, yet unaltered, to refractory amphibole-magnetite rocks able to resist the ordinary katamorphic ore-concentrating agencies. The alteration to ores of portions of the iron-bearing formations so modified was practically stopped at the times of the intrusions.

In all the districts since the beginning of final concentration many thousands of feet of strata have been removed by erosion. Durmg the process of denudation the ore deposits in each district began to be secondarily concentrated shortly after the iron-bearing formation was exposed at the surface and for a long time they continued to inerease in size. It is probable that after a sufficiently long period the growth of the deposits practically ceased, for denuclation would finally remove the ores at the surface as fast as they formed below the surface. However, change would not stop. The ore deposits formed would continue to migrate downward pari passu with denudation. On account of the pitch, lateral migration would accompany downward migration. At any given time the masses of ore would extend from the surface to the depth at which descending waters were effective. We therefore must conceive of the secondarily concentrated iron-ore deposits as slowly migrating downward through thousands of feet, being always just in advance of the plane of erosion. So far as the original iron-formation layers were rich enough to be ores without secondary concentration, these statements do not apply. The amount of ore existing at any one period through much of preglacial time may have bcen roughly constant, although there was doubtless considerable variation depending on topographic and climatic conditions.

At times the processes of clenulation would go ou rapidly; at other times they would be stayed for long periods, depending on the post-lieweenawan history of the Lake Superior region.

The important steps of this history are (1) the great pre-Cambrian mountain making and erosion, (2) subsidence and Palcozoic sedimentation, (3) the post-Paleozoic uplift and denudation, (4) the deposition of Cretaceous rocks upon parts of the region, (5) the post-Cretaceous uplift and succeeding denudation, and (6) the Pleistocene iee incursions.

1. In the pre-Cambrian period of mountain making and denudation the ore deposits probably reached their full development, and indeed they may during the latter part of this aneient time have been of greater magnitude than they are at present, although possibly not so rich. In the Menominee district the Upper Cambrian sandstone and the Ordovician limestone cap the Huronian formations and eren some of the ore leposits. The upward extension 
of the iron-bearing formation was removed before Upper Cambrian time. It is clear, therefore, that the main concentrations of iron oxide for these deposits must have taken place in preCambrian time. The basal conglomerates of the Cambrian carry ore fragments from previously altered formations. If, as is probable (see below), Cambrian and Ordovician or Silurian strata capped the beds in other iron-bearing clistricts of the Lake Superior region, it is all but certain that ore concentration was equally advanced in these other distriets, although where erosion has extended farther below the Paleozoic than in the Menominee district later events have had a greater influence upon the present condition of the ore deposits. The later stages of this period of denudation were marked by the development of a great peneplain, over which, it may be assumed, the ore-concentrating processes acted slowly.

2. After this period of denudation the Paleozoic sea encroached upon the Lake Superior region. Where the iron-bearing formations were reached by the sea, detrital ores were formed at the base of the Cambrian. The entire region was deeply buried beneath the Paleozoic deposits. Probably so long as the region remained below the sea the processes of concentration practically ceased and the mass of the ore deposits remained nearly stationary. Sea water does not chemically affect the iron oxides.

3. When after Paleozoic time the region was again raised above the sea and denudation began, little enrichment took place until the major portion of the Paleozoic rocks was stripped from the region. Over much of the region these Paleozoic rocks were entirely removed, and the pre-Cambrian Huronian surface again emerged from below the Cambrian deposits. In the Dlenominee distriet and the southeastern part of the Crystal Falls district the Paleozoic deposits were not completely removed from the iron-benring formations, and here consideralule quantities of cletrital ores are foumd at the base of the Cambrian. In most of the region erosion did not stop, at the Paleozoic but extended downward for a greater or less depth into the Iuronian rocks, and it is presumed that where this took place the ore deposits migrated downward precisely as during the pre-Cambrian period of clenuclation.

4. Erosion continued until the end of the Cretaceous period of base-leveling, when the area was again reduced nearly to an uneven plain and locally was overridden by the sea and capped by Cretaceous rocks, at least as far east as the Mesabi district. The basal strata of these beds carry detrital iron ore from the Biwabik formation. At the end of this period the processes of downward denudation and concentration were greatly diminished in speed.

5. During the period of the post-Cretaceous uplift denudation and the migration of the ore deposits again went on, but to what extent is uncertain. It is highly probable that in the Ifenominee district the topography of the Huronian rocks is Inrgely pre-Cambrian and the present lepressions to a large extent are recxcavated pre-Cambrian valleys. The same is true of the Felch Mountain tongue of the Crystal Falls district. On the borders of the Marquette district, also, Cambrian deposits are found. ILowever, it is now a matter of conjecture as to how far the present topography is redeveloped pre-Cambrian topography and how far it is post-Cretaceous.

6. The last great event in the development of the ore deposits was the glacial incursion of Pleistocene time. So far as the ore deposits are concerned, the work was of two kinds, glacial denudation and glacial deposition. The quantity of ore which was removed during the first stage of Pleistocene time, that of glacial erosion, was enormous. Almost the entire zone of decomposed rocks which must have been adjacent to the ores has been removed. The ore deposits were certainly truncated to at least an equal depth. Glacial erosion also in many places cut deeper into the soft ore bodies than into the adjacent hard rocks, and thus produced subordinate valleys, as is finely illustrated in the Mesabi district. The abundant fragments of hard iron ore in the glacial drift furnish evilence of the large amount of ore which has been removed by the glaciers. It is certain that still greater quantities of soft ore have been removed, although on account of its softness it has been broken into mimute fragments and therefore furnishes little evidence of its removal. The foregoing considerations learl to the certain conclusion that the glacial truncation seriously reduced the amount of available iron ore in the Lake Superior region. While the process of concentration has continued since glacial time and has tended to 
enrich and deepen the deposits, there is no doubt that the gain since the glacial incursion is insignificant as compared with the loss of rich material during the ghacial period. When the glacier's recederl, the elent-cut ore bodies were covered to a greater or less depth by deposits of glacial drift. 'This relation may be seen to the best advantage in the great open pits of the Mesabi district, where the soft, clean ore extends directly to the drift, not derivel from the ore but brought from the north. The contacts in many places are of almost knifelike sharpness, there being practically no ore in the basal layers of the drift.

It appears from the foregoing discussion that while the quantity of ore in the Lake Superior region has always been large since Cambrian time, there have been numerous vicissitudes in its history during which the quantity of ore alternately increased and decreased.

\section{ORIGIN OF MIANGANIFEROUS IRON ORES.}

Manganese exists in a series of minerals remarkably similar to and usually in association with those of iron. The origin and secondary concentration of the manganese minerals have been regarded in general as following very elosely those of the iron. The subject has not been specifically studied for the Lake Superior region. It may be noted here merely that the manganese tends to be concentrated in the upper parts of the Lake Superior iron-ore deposits, and that as secondarily coneentrated it consists principally of manganese dioxide (pyrolusite) and subordinately of manganese carbonate. In the general study of the nanganese deposits of the Appalachians and other parts of the United States it has been found that this is a common but not invariable relation of iron and manganese. In some deposits also the relation is reversed, the iron being above, the manganese below. Where ther are associated with clay, not in the Lake Superior region, there seems to be a tendency for the concentration of clay at the surface relatire to the manganese. Iron and manganese oxides and clay are the most stable of the common constituents of the belt of weathering, and hence all of them tend to become residually concentrated as compared with other substances originally associated with them. The vertical distribution of these three substances is taken to be a function of their relative stability under various conditions of weathering, but the available information does not seem to warrant more specific statements.

\section{PART OF THE METAMORPHIC CYCLE ILLUSTRATED BY TIIE IAKE SUPERIOR IRON ORES OF SEDIMENTARY TYPE.}

Starting with the ferrous iron and dominance of silicates in the original igneous rocks, the development of the ore deposits is a process of continuous katamorphism. From the original igneous rocks and their included reins containing a small percentage of iron there is dereloped an iron-bearing formation-cherty iron carbonate or greenalite-containing 25 or 30 per cent of iron, which, on further alteration at the surface, becomes concentrated to 50 or 60 per cent or more. The iron-bearing formation and included ores may themselves be broken up to rield materials for later sedimentary iron-bearing formations. The upper Huronian iron-bearing formations, the greatest and most productice of the Lake Superior region, may be regarded as including materials not only from the chemical alterations of the older greenstones but from the destruction of the older iron-bearing formations of the middle IItronian and Arehean. These formations have undergone the cxtreme of katamorphism. Nature's great concentrating mill has developed a ligh-gridle end product, both chemical and mechanical, through a series of concentrations. The changes have been those of simplification and segregation of mineral compounds, marked increase in volume, when all substances entering into the reaction are taken into account, incolierency of substance, and net liberation of heat, all of them typical of the katamorphism or destructive processes affecting the earth's surface.

No sooner have the ores reached their maximum incoherency through katamorphie changes than constructive agencies begin their work. It may be more correct to say that they begin before the destructive agencies have fmished. The ores become cemented and strengthencel; they tend also to become dehydrated and more or less nagnetic. As they become buried 
beneath the surface, owing to the deposition of later sediments, and as they become folded, their volume is decreased by an elimination of pore space and moisture, they are recrystallized, ane slightly deoxidized to magnetite, in small part combine with siliceous and other impurities to produce silicates, and are frequently rendered schistose, producing the hard specular ores. 'The mineralogical ehange is one froin simple to less simple compounds. The net change in energy is loss, due to the energy given off in volume decrease. The process is a characteristic one of anamorphism, which aflects all rocks under similar conditions. The anamorphic changes in the ores are best shown in the oldest or Archean iron-bearing formations.

More marked anamorphic results are produced under the influence of igneous intrusions.

The contrasting katamorphic and anamorphic changes aflecting the ore deposits constitute a partial metamorphic eycle. ${ }^{a}$ Beginning with a coherent igneous rock, incoherent ore deposits are developed through katamorphism and in turn a part are rendered coherent again through anamorphism. The mineralogical changes are at first from complex to simple and later from simple to complex. The changes at first are essentially those of simplification and segregation and later this process is arrested and on a smaller scale reversed in the development of the complex silicates. The ores are not essentially dispersed to again become constituents of igneous rocks, although certain of the amphibole-magnetite rocks associated with the ores are not easity distinguishable from igneous rocks. The cycle, therefore, so far as observation goes, is not complete. There is throughout a net loss of energy.

\section{TITANIFEROUS MAGNETITES OF NORTHERN MINNESOTA.}

The great gabbro mass of Lake and Cook counties, Minn., contains much magnetite, both disseminated and segregated into ore deposits. Complete gradation may be observed between gabbro carrying little magnetite and magnetite carrying little of the ferromagnesian constituents and feldspars. The known deposits are extremely irregular, with gradations between themselves and the gabbro and containing within themselves much gabbro material. They weather very much like the gabloro and might be easily unnoticed on the weathered surface. There has been little exploration for these ores. A few drill holes have been sunk in the region south of Gunflint Lake, some of them revealing depths of ore aggregating several hundred feet. The known deposits seem to be distributed in irregular zones roughly parallel to the north or basal margin of the Duluth gabbro.

The composition of the ore areraged from 3,556 feet in 14 drill looles is 43.8 per cent of iron. The range is from 54 to 20 per cent. The ligh titanium content renders the ores of doubtful value for the present.

Where the gabbro comes into contact with the iron-bearing Gunflint formation both formations carry magnetite so similar in texture that it is difficult to tell one from the other. However, on analysis the gabbro magnetite is found to be titaniferous, while that of the Gunflint formation is not titaniferous. This fact seems to argue against any considerable transfer of material from the gablso to the iron-bearing formation during its alteration.

The titaniferous magnetites of northeastern Minnesota are direct magmatic segregations in the Dulnth gabbro, according to all geologists who have studied them, including Irving, Merriam, Bayley, Grant, Winchell, Clements, Van IIise, Leith, and others. The complete gradation from gabbro with a small amount of original magnetite to a magnetite with small amounts of amphibole and other gabbro mimerals can be seen in almost any part of the titaniferous magnetite deposits. It is scarcely necessary to repeat the detailed petrologic evidence so fully given by the writers named.

Evidence is given elsewhere for the intrusive character of the Duluth gabloro. It cooled far beneath the surface, where there was not easy escape for its solutions. This fact is taken to explain its retention of its iron oxides. It has been argued under an earlier heading that where basic rocks of similar composition reached the surface large quantities of iron eseaped and beeame arailable for ordinary sedimentary deposition.

a Leith, C. K., The metamorphic escle: Jour. Cieology, vol. 15, 1907, pp. 303-313.

$47517^{\circ}-\operatorname{vOL} 52-11-36$ 


\section{MAGAETITLS OF POSSIBLE PEGMATITJC ORIGIN.}

The ore in the Atikokan district is a magnetite, highly impregnated with amphiboles and sulphides and showing extremely close and intricate relations to associnted diorite. It differs from the magnetite of the gabbro of Minnesota in being nontitaniferous and in being separated by definite boundaries - in many places plane surfuces-from the adjacent wall rock. The apparent absence of iron-bearing formation, the general lack of banding, the high content of amphibole corresponding to that in the associated diorite, the content of sulphides, and the extremely intricate structural association with the diorite are not easy to explain if the ore is sedimentary and owes its character to complex intrusion by the basic igneous masses. Nowhere in the Lake Superior region is intrusion known to completely destroy banding, nor does it develop so much coarsely crystalline amphibole and iron sulphide with lack of parallel texture. On the other hand, both character and relations suggest pegmatitic intrusion or igneous aftereflects, similar to those described by Spencer ${ }^{a}$ for the New Jersey magnetites or by Leith ${ }^{b}$ for certain western magnetites.

The evidence for pegmatitie origin of the ores of the Atikokan district is weak. This district lies outside of the principal area studied in connection with this report, but from our examination of it we suggest this origin as a plausible one from the facts available. Certainly this district seems to show marked variations from most of the distriets of the Lake Superior region-variations which seem to call for another mode of derivation.

Minute pegmatitie veins of quartz or iron oxide or both are common in the ellipsoidal basalts of the Termilion district. In the coarser phases they may be seen to be intimately and irregularly mixed with the rock, and grading out toward the finer phases they tend to take on more definite vein outlines. In the Keewatin series as represented in the Vermilion district it is in many palces diffrcult to determine whether the iron-bearing formation is a magmatic segregation of greenstone, a vein material of a pegmatitic nature, or an ordinary iron-bearing sediment derived from them. In Plate XLVIII are shown gradations from the basalt through siliceous and jaspery phases to ordinary banded iron-bearing formation. These intermediate phases seem to be of a pegmatitic nature.

\section{BROWN ORES AND HEALATITES ASSOCLATED WTTI PALEOZOIC AND PLEISTO- CENE DEPOSITS IN WISCONSIN.}

\section{ORES IN TIE POTSDAM.}

In the driftless portion of the Potsdam area north of Wisconsin River in western Wisconsin there are many small patches of hematite and brown ore, closely associuted with upper horizons of the Cambrian (Potsdam) sandstone. Many of these patches lie on the tops and slopes of hills, but some of them follow the valleys. During the early days of mining in Wisconsin these ores were smelted locally at a furnace in Sauk County, but for 30 years they have not been mined, principally because of the small amounts available.

The origin of these ores is not clear. Occurring near the upper horizons of the Potsdam, some of them may represent residual accumulations due to erosion of the overlying Ordovician limestone. Samuel Weirman ${ }^{c}$ believes that part of them at least are results of later valley filling by spring and bog solutions.

\section{BROWN ORES IN "LOWER MAGNESIAN" LIMIESTONE.}

At Spring Viller, in Pierce County, Wis., are nodules and irregular masses of limonite in clays, resting upon the erorled surface of the "Lower Magnesian" limestone, particularly in old drainage courses on the surface of this limestone. Quoting from Allen: ${ }^{d}$

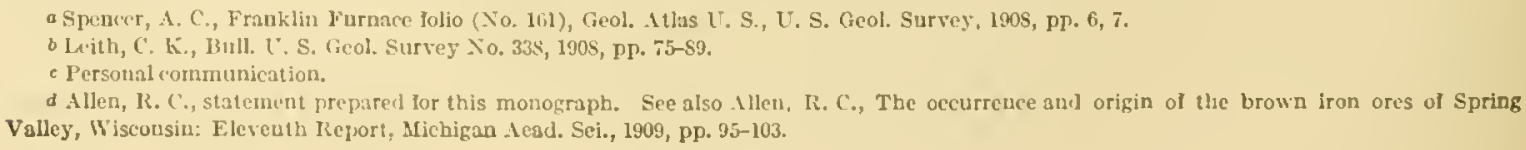


PLATE XLVIII. 


\section{PLATE XLVIII.}

\section{Ferreginols chert or maser, of posshibe pegmatitic origin, in Basilt.}

A. Partly silicified basalt (sperimen 28564) from Vermilion district, Jlinnesota. In the ledge this is olserved to grade imperceptibly into the little-altered basalt of the region.

B. Chert, green silicate, and iron oxide (specimen 25565) irom Vermilion district, Minnesota, more definitely serrregated into bands, grading imperceptibly into the rock shown in of on the one hand and intu that shown in $r$ on the other.

( . Same (specinen 28566), with larger proportion of iron in bands. This is an amphibolitic ferruginous ehert or jaspilite of a type often seen in the iron-bearing formations.

In the ledge from which this series of specimens was collecterl, it was quite impossible to find any plane of separation between basalt and iron-hearing formations. 

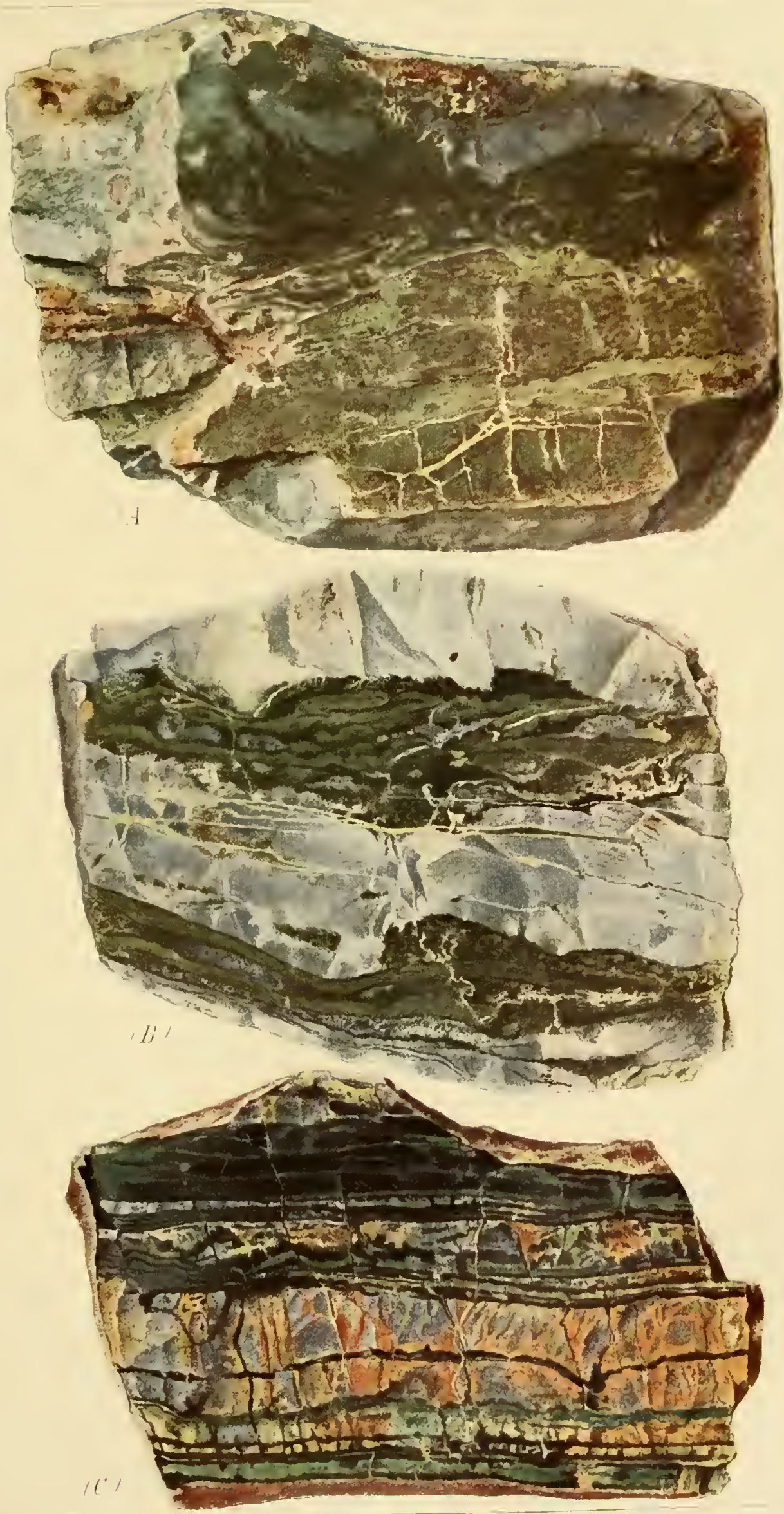

FERRUGINOUS CHERT OR JASPER, OF POSSIBLE PEGMATITIC ORIGIN, IN BASALT. 

Spring Valley is a small town on Eau Galle River reached hy a spur from Woodville, on the (hicago, St. Paul, Vinneapolis and Onaha Railway. Iron ores were discovered in the vicinity of Spring Valley about 20 years ago. Thorough prospecting developed a number of deposits, two of which, known as the Gilman and the Cady dejosit., are being mined. The Gilman was opened about 1890 and has been in operation more or less continuonsly since that time. In 1893 a furnace was erected at Spriug Valley for utilizing the Gilman ores and numerous charcoal ovens were built in the vicinity for supplying fuel for the furnace. Wond soon became scarce and coke supplanted charcoal as a fuel. The original plant has been partly replaced by a more modern one.

\section{GEOLOGY AND TOPOGRAPHY.}

The Upper Cambrian sandstone underlies the valleys and lower hill slopes. The uplands are formed by limestone of Lower Ordovician age. The strata are conformalle and flat-lying.

The topography is that of the maturely dissected platean, and is essentially of precrlacial origin. Eau Galle River and its tributary creeks are flowing through partly filled valleys. If the valleys were to he fillerl to the average height of the ridges the resulting surface would be a plain. A plain prolsably once existed here as jart of a greater one which extended over a surrounding broad area. The present topography nay be explained as resulting from the uplift of this ancient plain, giving the streams new erosive power. Liefore glacial time the streams harl sunk their valleys through the Ordovician limestone and well into the underlying Cambrian sandstone. During the glacial epoch the valleys were partly filled by glacial wash.

\section{GILMAN BROWN-ORE DEPOSIT.}

The Gilman deposit rests upon an eroded surface of the Ordovician limestone, near its base, on the upper slopes of a ridge above the valley of a small creek tributary to Ean Galle liver. It is on the railroad and is $]$ ? miles west of spring Valley. The deposit covers several acres and in ontline is very irregular, as shown by the mine workings, which are open shallow excavations, the deepest being not more than 30 feet. The ore is a brown hydrated hematite and occurs as nodules and concretions mixed irregularly with ocherous clay, sand, chert fragments, and nodular coneretions of sand and elay. Locally the deposit shows rough and irregular bedding, but the general absence of bedding is conspicuous. The limestone presents an uneven surface to the bottom and sides of the deposit. In one place a wall of limestone some 6 or 8 feet high, showing undoubted evidence of having been eroded while exposed to the air, abuts directly against the ore. In places the ore comes quite to the surface, but as a rule it is covered by a foot to several feet of clay. All the mining is done by hand. The larger nodules of ore, called "ruck" ore, are picked lyy hand from the clay and sand in which they are embedded. Some of them are very large and need to be broken up by blasting. But most of the ore in the Gilman mine is removed with the impurities in which it occurs and put through barrel washers. The following is the analysis of a three months' sample of "rock" and "wash" ore:

Analysis of ore from Gilman mine.

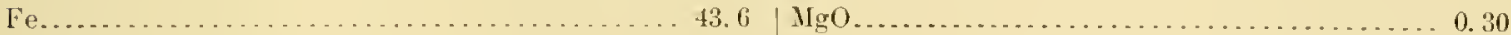

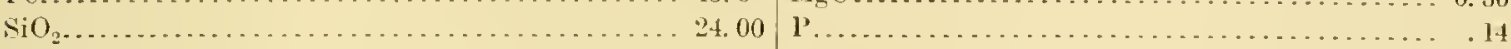

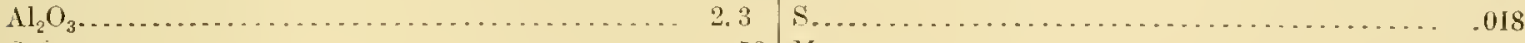

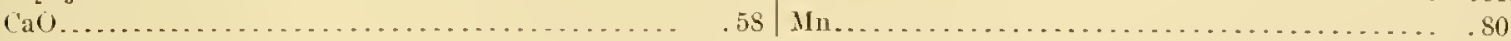

CADY BROWN-ORE DEPOSIT.

The Cady deposit is $2 \frac{1}{2}$ miles north west of Elmword and about 5 miles southeast of Spring Valley. It covers several acres on the top and upper slopes of a hill that rises steeply some 200 feet alove the valley of Cady (reek. As in the Gilman deposit the ore rests on the Ordovician limestone. At the time of visit in 1906 the deposit had not been opened, but the ure was exposed in numerous pits and trenches. Accorling to $\mathrm{W}$. H. Foote, a shait went down through 80 feet of ore and struck a face of limestone at that deptl which was at an angle of $60^{\circ}$ with the horizontal. Ore was followed down this face for 40 jeet more with no bottom. The following analyses indicate the character of the ure in this shaft:

Analyses of Cady Creek ore.

\begin{tabular}{|c|c|c|c|c|c|}
\hline & $\begin{array}{l}\text { Thickness } \\
\text { (feel). }\end{array}$ & $\mathrm{Fe}$. & $\mathrm{SiO}_{2}$ & In. & P. \\
\hline 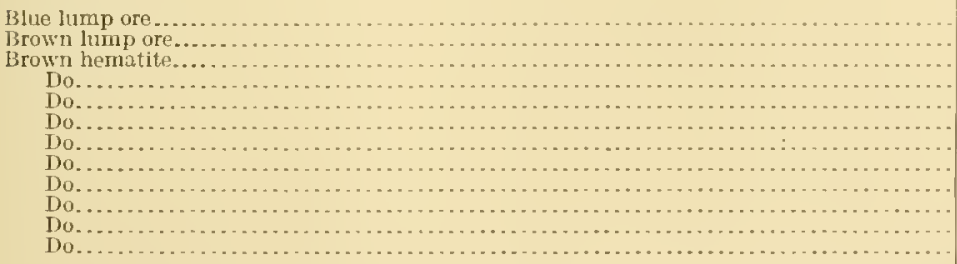 & $\begin{array}{l}10 \\
10 \\
16 \\
22 \\
25 \\
34 \\
40 \\
45 \\
50 \\
55 \\
60 \\
65\end{array}$ & $\begin{array}{l}59.12 \\
49.96 \\
47.79 \\
32.96 \\
41.56 \\
52.02 \\
37.01 \\
55.11 \\
53.56 \\
52.02 \\
52.22 \\
34.15\end{array}$ & 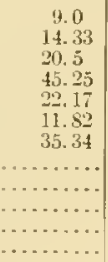 & $\begin{array}{l}2.03 \\
.83 \\
1.39 \\
2.13 \\
2.47 \\
2.51 \\
1.52 \\
1.73 \\
2.72 \\
2.25 \\
1.91 \\
1.32\end{array}$ & $\begin{array}{l}0.075 \\
.073 \\
.078 \\
.076 \\
.077 \\
.054 \\
.068 \\
.062 \\
.062 \\
.062 \\
.068 \\
.060\end{array}$ \\
\hline
\end{tabular}


'The core contains a Emmewhat higher perentage of iron, has a greater proportion of rock ore, and is associated with a less amount of impurities (sand, clay, etc.) than the Giman ore, but is otherwise exartly sinnilar to it. Ilining has recently bogun. The ore is dolivered to the bins at the hase of the hill by an aeriat tram. The descending loaded buckets return the empties to the top of the hill.

\section{ORIGIN OF SPRING VALLEY BROWN-ORE DEPOSITS.}

The ores near Spring Valley are of superlicial origin, being deposited upon the eroded surface of limestone and other rocks. Allen has shown, from a consideration of the thickness of the stratia once overlying the present ores and their probable content of iron, that the now known deposits were probably not the result of direct downward slump of resilual materials but are rather sediments transported laterally along drainage channels after the country had been cut down to the elevation of the ores. Allen shows further that sinee the formation of these deposits erosion has cut through them and around them, with the result that the adjacent territory has been lowered, leaving the deposits on the tops or slopes of hills. He concludes that the ore deposits of Spring Talley were laid down in lakes or marshes that existed along the drainage courses on the old post-Devonian peneplain, or on the valley bottoms, as may have been the case in the Gilman and Cady deposits, where the ore abuts directly against eroled limestone faces. The marshes and lakes were finally drained as a result of uplift of the land which enabled the streans to erode vertically at a greatly increased rate. Narrow valleys were fornted in the older, broader ones. The outer margins of the old valleys correspond with the upper slopes of the hills forming the present valley sides. It is on these upper slopes that the ores characteristically occur. As erosion progressed ore-covered areas would naturally come to occupy higher and higher relative elevations, owing to the resistant nature of the ore beds. In this way would result ore-covered lifltops, as illustrated by the Cady deposit.

Weidman, ${ }^{a}$ who has made a survey of the region surrounding Spring Valley, while accepting the general view that the Spring Valley wres are of superficial origin and were deposited upon the eroded surface of the limestone and associated rocks, is inclined to place the date of their origin long after the period of peneplanation of the region. This alternate hypothesis supposes the ore to have been formed in these valleys after they were eroded to a considerable depth200 to 300 feet -in the peneplain and perhaps even at the still later stage when the vallers were in the process of being filled again with alluvial material. The deposits lie in secondary and tertiary valleys and on slopes opening outward toward larger valleys, and the massive, lumpy character of the ore indicates that it may very well have originated in the mamer of iron-spring deposits, accompanied by more or less slope wash and slumping of clay and sand while the valleys were being filled. Since the valleys were partly filled and the ores formed, erosion has removed 30 to 40 feet of alluvial material from the valleys and a variable amount of the ore. This explanation as to the date of origin of the ore-namely, at the time when the valleys were well developed - seems to apply very well to the Gilman ore deposit, where most of the ore has been removed and where the relation of the ore deposit to the topography can be clearly observed, and it jrobably also applies cuailly well to the Cady deposit, where mining is not sulliciently advanced to show the actual conditions.

\section{PONTGLACIAL BIROWN ORES.}

Postglacial iron ores are known in many parts of the Lake Superior region. They are ordinary bog deposits to which iron is being contributed in solution unler the inflnence of organic material and deposited by oxidation. Nowhere is their thickness known to be over a few foet. Lying, however, directly at the surface, they frequently attract attention and for many years hisve been subject to internittent explorition. 


\section{CLINTON IRON ORES OF DODGE COUNTY, WIS.}

\section{OCCURRENCE AND CHARACTER.}

Iron ores of Clinton age, similar to ores of the same lorizon in the Appalachian region, appear in Dodge County, in sontheastern Wisconsin. The shipments to the end of 1909, which figure in the total for the Lake Superior region, lave aggregated 570,886 long tons. ${ }^{2}$ The ores outerop in a narrow belt extending for about a mile north and soutl on a westward-facing starp cilused by the overlying Niagara limestone. The underlyng rock is Ordovician shale. The dip is eastward at the rate of about 100 feet to the mile. The beds are lens shaped along the outerop and range in thickness up to a maximum of 37 feet. Mining operations have followed them $t 00$ feet down the dip, and they are known by drilling to extend farther. Wells have shown the occurrence of ore in the southeast corner of the county and near Hartford in thicknesses ranging from 4 to 20 feet, and a diamond-drill hole near Kenosha, 60 miles to the southeast, cuts 18 feet of ore. The iron beds, if continuous eastward to Lake Michigan, a distance of 35 miles, are nowhere more than 800 feet below the surface, for the Niagara limestone which overlies them has this thickness and it outcrops all the way to the latke.

If we assume an average thickness of 10 feet, an extension down the dip of 2,000 feet, and continuous extension southward to Kenosha (which is doubtful), the amount of ore in these deposits would be $600,000,000$ tons.

The ore is a slightly hystrated hematite, running from 29 to 54 per cent in iron and averaging perhaps 45 per cent, high in phosphorus, with the typical granular, oolitic, or flaxseed forms so characteristic of the ores of the Appalachian area. The matrix is calcite. Bedding is distinct and false bedding is common. The granules lie with their flat sides parallel to the bedding. The indivilual granules have been worn shiny by water action and aggregates of them lave been rounded into peb])les.

Under the microseope the iron-oxille granules are found in part to be amorphous and in part to have the concentric structure of oolites. Clastic grains of quartz or of iron oxide commonly form the nucleus, surrounded by alternate layers of iron and silica. On treatment with hydrochloric acid the iron is dissolved, learing little globular particles of amorphous silica, forming at first casts of oolites but on drying falling in, giving a basin-shaped indentation on one side. In the Clinton formation of the East some of the granules have the structures of replaced marine shells, but these have not been notal in the iron-bearing formation of this horizon in Wiseonsin.

The origin of some of the amorphous granules is observed in experimental precipitation of ferric hydroxide in laboratory solutions where the precipitate is allowed to settle slowly. There is then observel a marked tendeney for the aggregation of iron oxicle into granules identical in shape and size with the granules observed in the Clinton ores. These granules are of the type regarded by Lehmann ${ }^{b}$ as liquid crystals, a globular form preceding development of erystal structure and indefinitely griding into it. In materials that have strong crystallizing power this globular stage is soon passed or is not even observed. In substances weak in crystallizing power, such as iron oxide, the tendency inherent in the substance itself to group or crystallize does not go beyond this stage of globular aggregation.

Along the top of the ore body, at the contact with the overlying limestone, is a thin layer, ranging from less than an inch to 6 inches in thickness, of a hard, compaet bluish hematite, heavier than the oolitic ore and ruming about 10 per eent higher in metallic iron than the main body of oolitic ore. In this hard bed there is no trace of the oolitic structure. IIowever, there is an apparent gradation from one to the other.

The contact between the ore and the Niagara limestone might be termed a "knife-edge," as it is perfectly well defined, showing no gradation whatever from the iron into the limestone. The lower contact of the ore body with the underlying calcareous shale is similar to the upper contact. Under the nicroscope some of the calcite grains in the limestone near the contact are

a Lake Superior iron ore shipments for 1909 and previous years, compiled by Iron Trade Review, Cleveland.

o Lehmann, O., Flüssige Kristalle sowie Plastizität von Ḱristallen im Allgemeinen, molekulare Umlagerungen und Aggregatzustandsänder, ungen, Leipzig, 1904. 
observed to be partly replaced by iron oxide, while other large calcite grains are the result of recrystallization. Ilowever, these are not common. In the lower contact the calcite is discolored by the iron oxide, but where this iron stain occurs we do not always find any evilence of replacement. For the most part the surface of contact of ores and overlying limestone is even, but locally the beds finger into one another.

\section{ORIGIN OF THE CLINTON IRON ORES.}

For a fuller discussion of the origin of the (linton iron ores the rearler is referred to the publications of the geologists who have studied the Clinton ores of the Appalachians, especially to the recent work of Burcharel in Alabama. ${ }^{a}$ The ores are not mined on a large scale in the Lake Superior regrion and have not been studied in the same detail as those of the Algonkian and Archean.

Howerer, a comparison with the ores of the Algonkian and Archean in the Lake Superior region discloses certain contrasts, which are probably significant of origin. The ('linton ores constitute beds uniform in lithology, with no evidence of local concentration or replacement or residual masses of unaltered material, and the adjacent beds are not altered or iron stained, as they are where secondary concentration has occurred. The hematite is therefore probably not the resilual result of the alteration of precxisting rocks. On the other hand the granules and aggregates of granules making up the ore are distimetly weatherworn and lie with their flat sides parallel to the strongly marked bedkling and current bedding, pointing strongly to the deposition of the iron in essentially its present mineralogical condition in shallow waters.

The Clinton ores therefore differ Irom the Lake Superior Algonkian and Arehean ores in being deposited as ferric hydroxide under shallow-water or shore conditions rather than as some ferrous compounds in quiet water, as is characteristic of the pre-Cambrian iron deposition. That the waters were marine is indicated by the character of the bels both above and below, carrying marine fossils, and also by the similarity of these ores to Clinton ores of the eastern Uniter States, in which marine fossils are plentiful. It is also clear from the waterworn granules, current bedling, and oolitic structure that the waters were moving, suggesting shore eonditions. The discontinuity of the beds and their variation in thickness also suggest locally rarying shore conditions. But many features of the history of the deposition of these ores are yet obseure. No satisfactory answer has yet been made to the question why these ores have developed at this particular horizon in the Paleozoic and not at other horizons.

The final answer to this problem must involve the study of the Clinton ores of all of North America.

\section{SUMALAR STATEMENT OF TIIEORY OF ORIGIN OF TIIE LAFE SUPERIOR IRON ORES.}

The Lake Superior iron ores include the genetic types lescribed in the following paragraphs.

1. Lake Superior sedimentary type: Iron brought to the surface by igneous rocks and contributed either directly by hot magmatic waters to the ocean or later brought by surface waters under weathering to the ocean or other body of water, or by both; from the ocean deposited as a chemical sediment in ordinary succession of selimentary rocks; later, under conditions of weathering, locally enriched to ore by pereolating surface waters. To this class belong most of the producing iron ores of the Lake Superior region, those of the Michipicoten district of Canada, and most of the nonproducing banded iron-bearing formation belts of Ontario and eastern Canada.

2. Magmatic segregntion type: Ores brouglit to the outer part of the earth in molten magmas but were retainel in then during crystallization, with the result that the ores form part of the rock itself, just as do the feldspar and other minerals. Such are the titaniferous magnetites, which contain refractory silicates and in places sulphur and phosphorus in deleterious quantities. Although these ores are known in enormous quantities in the Duluth gahbro of northern Minnesertan they are not mined.

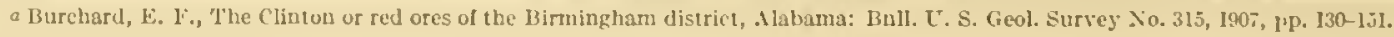


3. Pegmatite type: Ores which are carried to or near the surface in magmas and are extruded from them in the manner of pegmatite dikes, after the remainder of the magma las been partly cooled and crystallized. They are deposited from essentially aqueous solutions mixed in varying proportions with solutions of quartz and the silicates and have had no second concentration. 'To the pegmatite type are doubtfully assigned the ores of the Atikokan district of Ontario, and possibly also certain magnetites of the Vermilion district. (See p. 562.) No detailed study of the $\Lambda$ tikokan ores has been made. Ores of this type have been mined in small quantity in the Atikokan district.

4. Clinton sedimentary type: Sedimentary "flaxseed" ores deposited in shallow waters, presumably from weathering of the land arens in which the iron is either disseminated in igneous rocks or has undergone some of the concentrations outlined in the three preceding paragraphs. They have suffered no essential second alteration. These are the ores in the vicinity of Iron Ridge, Wis.

5. Brown or liydrated ores, associated with Paleozoic and Pleistocene deposits: Residual or bog deposits in limestone as at Spring Valley, Wisconsin, or in glacial drift. Also abundant in ores of the Lake Superior sedimentary type. The associated substance is largely clay and they are therefore not susceptible of second concentration.

Each of these classes of ores has counterparts in ores mined elsewhere in the country, except the Lake Superior sedimentary ores, the only ones which have undergone a second concentration. From this class hare been produced 99 per cent of the iron ores shipped from the Lake Superior region and annually $s 0$ per cent of the iron ores mined in the United States, a fact that indicates the great importance of a second concentration.

All the ores have been derived ultimately from the interior of the earth, whence they were delivered by igneous eruptions to points near or at the surface, there to undergo various distributions and concentrations under the influence of meteorie waters and gases. The rariations in composition, shape, and commercial arailability of an ore have been controlled by variations of conditions under which the ores have reached the surface and have been distributer. The titaniferous magnetites represent ores brought nearly to the surface but not allowerl to escape. The pegmatites represent ores which have been crystallized in the act of escape. The pre-Cambrian sedimentary formations of the Lake Superior region were derived largely from basic rocks of not dissimilar composition that reached the rock surface, though usually under water, in which case they erystallized as ellipsoidal basalts.

The eruptions to which is due primarily the introduction of most of the known ores have come up along the zone of the present Lake Superior basin. The copper ores of Keweenaw Point and the silver ores of Silver Islet have been brought up by similar igneous rocks at a little later date along the same zone. Along the strike of the Lake Superior zone during Keweenawan time igneous rocks also brought up the cobalt, nickel, and silver ores of Sulbury and Cobalt. The minerals and petrographic relations of the Keweenawan, cobalt, and nickel ores bear many similarities, suggesting possible differentiation from essentially the same magma. It is suggested that the entire Lake Superior and Lake Huron region is a great metallographic province from which the early extrusions brought up iron salts and the later extrusions were differentiated into the copper, silver, cobalt, and nickel ores.

\section{O'THER THEORIES OF THE ORIGIN OF THE LAKE SUPERIOR PRE-CAMBRIAN IRON ORES.}

Whitney, ${ }^{a}$ Wadsworth, ${ }^{b}$ Winchell, ${ }^{c}$ Hille, ${ }^{d}$ and others have held the Lake Superior preCambrian ores of the sedimentary type to be of igneous origin. Winchell's arguments are nearly all based on the similarity of the textures of the iron-benring formations to those of

a Foster, J. W., and Whitney, J. D., Report on the geology and topography of the Lake Superior land district, pt. 2, The iron region: Senate Iocs., $32 \mathrm{~d}$ Cong., special sess., 1851, vol. 3, No. 4, $406 \mathrm{pp}$.

$b$ Wadsworth, M. E., Proc. Boston Soc. Nat. Hist. rol. 20, 1851, pp. 470-179; Bull. Mrus, Comp, Zool., Geol, ser., vol. 1, 1880, p. 75.

cWinchell, N. Il., Structures of the Mesabi iron ore: Proc. Lake Superior Min. Inst., vol. 13, 1908, p. 203.

d Ilille, F., Genesis of the Animikie iron range, Ontario: Jour. Canadian Min. Inst., vol. 6, 1904, pp. 245-287. 
igneons rocks. For inslance, the concretions are compared with bombs, the spaces left by the leaching of silica are regarded as amygdaloidal cavities, the loreccias are regarded as volcanic breccias, the bedding is regarded as flow structure, the slump of the ores in contact with wall rocks is regarded as the result of flow of lava over the bluff represented by the wall rock.

In this view Winchel! practically reaches a conclusion similar to that of Wadsworth, who believed that theores and jaspers are chiefly eruptive and described the jasper and ore as intruded into the country rocks in wedge-shaped masses, sheets, and ilikes.

These resemblances between iron ores and igneous rocks are so superficial that they would searcely be taken serionsly by most observers, and conelusions as to igneous origin ignore so many fundanental facts of composition, texture, and structural relations described in these reports that it is not helievol necessary to attempt to refute them.

In earlier reports Winchell ${ }^{a}$ presents a different view of the origin of the ores, as follows:

$\Lambda$ chain of active volcanoes, having explosive emissions, extended arross northeaztern Minnesota about where the Mesabi iron range is found. This was near the shore line of the Taconic ocean, and was accompanjed by landlocked bays and perhaps by fresh-water lakes. Surh marginal volranoes had a chemical effect on the oceanic water, causing the precipitation of silica and probably of iron. Its basic lavas and obsidians were attacked by the hot waters and were converted by encroaching silica into jaspilite. Near the shore such glassy lavas were eroded by wave antion and distributed so as to form conglomerates and sandstones. Such action would have distributed lavas wholly silicified as well as those which were yet glassy, and the detritus of both would necessarily mingle with detritus from the Archean. Such lavas would exhibit great contortion and in places great brecciation, the same as later lavas, and these hreccias must have been mingled sometimes with the products of detrital action. After prolonged activity of the volcanoes most of the deposits and of the lavas which were submarine would be permeated by secondary silica, but carbonate of iron would permeate the mass where carbonic acid had freer access, as in the lagoons into which streams drained from the land surface to the north.

This view Winchell also applies to the Vermilion range. He argues that the iron of the iron-bearing formation was first deposited as a ferric oxide and that the ferruginons cherts making up the greater part of the formation to-day are origmal oceanic deposits laid down essentially in the present form.

In volume 6 of the "Geology of Minnesota" he arguer that the solutions formed from the igneous rocks accumulater in the rocks to the point of saturation and that precipitation came later as a result of cooling.

This discarded view of Winchell obviously has more points in common with the thenry of origin outlined in the present monograph than his more recent views, although important differences are still to be noted.

In a report on the Baraboo range Weidman ${ }^{b}$ reached the conclusion that the iron ores of that distriet were originally precipitated in bogs and shallow waters as limonite and hematite associated with slate, that they were then corered by the dolomite, tilted up, and eroderl, and that the deposits to-day are essentially the same in lithology as they were when deposited with the exception of certain minor vieissitudes in the way of dehyctration, recrystallization, etc. The deposits might under this theory extend to indefinite deptlis-indeed, as far as any of the sedimentary formations of the district-and in this way they would contrast with the distribution of the ores letermined primarily by a secondary concentration from the surface. In view of the evidence of secondary concentration found in other parts of the Lake Superior region the burden of proof must rest with one who attempts to exclude secondary concentration of the Baraboo ores. Deep drilling in the Barahoo district has seemed to show a diminution in thickness and grade of ore beds and a relative incrense of iron carbonate with increase in depth, pointing to secondury coneentration from the surfice as the agency which has been largely responsible in developing the ore bodies. The diflerence in opinion as to the origin of Baraboo ores here indicated is really one primarily of emphasis. Weidman emphasizes the primary deposition in rich beds; we believe that the primary deposition, while a large factur in localizing ores, has been supplemented by considerable secondary concentration to develop the commercial ore deposits. 


\section{GENFTIC CLASSIFICATION OF THE PRINCIPAI IRON ORES OF TIIE WORLD.}

Iron ores are known to have been developed by a great variety of ignenus and metamorphic processes. In almost any genetic classification of ore deposits iron ores will be represented in each of the divisions, contrasting thereby with the less abundant precious metals. Moreover, it is likely that certain iron-ore deposits would fall outside of any such classification and others would require assignment to two or more of the divisions. The following classification of the iron ores of the world has been constructerl with the idea of showing the correlatives of the Lake Superior pre-Cambrian ores and the wide range of conditions under which the larger and better-known deposits have developed.

1. Mafmatic segregations, usually in Basic rocks. Titaniferous and silicated magnetites, weathering to limonites, epidotic and chloritic magnetites. On disintegration yielding magnetir sands.

Titaniferous magnetites of northenstern Minnesuta and Arirondarks.

Magnetite of Vysokaya Gora and Goroblagadot of the I'ralo, Pussia.

Silicated magnetites and specular hematites of pre-Cambrian of Kiirunavaara, Gellirare, ete. Sweden.

Silicated magnetites of Kiirumavaara, Loussavaara, and Tuollavaara, Sweden.

Titaniferous magnetites in Taherg, Sweden.

2. Igneous after-effects, usually from Acidic rocks (pneumatolytic, pegmatitie, etc.), usually deposited within or near parent igneous mass.

Certain silicated magnetites of Vermilion and Atikokan distriets of Adirondacks and New Jersey, of Iron Mountain, Missouri, and of Iron Springs, Itah.

Contact-silicated magnetites of Christiania, suggested by Backstrom and DeLaunay to be aqueous sediments contributed by associated porphyries.

3. Residual limovites resulting Fron Weatherixg of igxeous rocks.

In this class are most of the laterite deposits resulting from the weathering of hasic igneous rocks in tropical regions. The limonites of northeastern Cuba, constituting the weathered mantle of serpentine rock, are in enormous tonnage.

4. SEHIMENTARY

A. Iron oxdes, mainly syngenetic.

Crystalline hematites of Minas Geraes, Brazil, the largest and richest known deposits of this type in the world.

Cambro-Silurian micaceous hematite and magnetite of Norway.

Oolitic limonites, containing subordinate quantities of iron-silicate granules of various descriptions and iron carbonates, in Silurian Clinton rocks of Wisconsin and Appalachians and Newfoundland; in Jurassic of Luxemburg, Lorraine, and elsewhere in Germany and in Cleveland district of England; in Tertiary of Louisiana, Texas, and Bavaria.

Bog and lake limonites, sometimes in granules. In glarial lakes and bogs of Lake Superior region. Small and nonproductive. Represented by Scandinavian lake ores, Finnish lake ores, lake and bog ores of eastern Canada, Massachusetts, and elsewhere.

A 1. Iron oxdes, developed manly by secondary surface alterations of sedigenetic carbonates and silicatrs.

Pre-Cambrian hematites and limonites of Lake Superior region.

Paleozoic limonites of Spring Valley, Wisconsin.

Brown ores of southern 1 ppiliachians, ete.

A 2. Iron orides. resulting from anamorphic alterations of sedimentary iron-bearing formations. Specular hematites and silicated magnetites derived from deep-seated anamorphism of uxiles, especially ni carlmates and silicates by deep burial, intrusion, or both.

Marquette specular hematites. Hard hilue hematites of Vermilion.

Silicaterl magnetites of Gunflint district of Minnesota, eastern Mesal)i, western Gogelic, western Marquette, etc.

- B. Iron carbonates. Usually assnciaterl with coal or carbonaceous slates. Also various intermixtures of calcium and magnesiun carbonates, with minor amounts of oxides and silicates.

Ifuronian original iron carlonates of Gogebic, Marquette, Menominee, and uther distriets of Lake Superior region, altering at surtace to limonites and hematites, and at depth or by igneous intrusion to silicated magnetites and hemetites.

Carboniferous black-l,and ores of Pennsylvania, Ohio, and Kentucky, altering at surface to brown ores or pot ores in clay. 
Tertiary black-band ores of Maryland.

C'arboniferous lblark-bant ores uf Ciermany.

Carbonilerous liack-thind ures of Wales and Scotland.

Permian lilack-bant ures of district of Erzherg, in the northern Alps.

C. Iron silicates. Greenalite, glauconite, chanusite, thuringite, ete, with minor mixtures of iron oxides and carlonates.

Huronian original greenalite rocks of Mesabi district of Minnesota, deriverl largely from direct igneous contributions, as indicated uncler 2. Altering 10 hematites and limonites at surface and th silinated magnetites at depth or at inneous contacts.

Lower Silurian chamosite ores of central bohemia and chamosite and thuringite ores of Thuringerwald and vicinity, in Germany.

D. Tarious combinations of alwove.

It will be noted that the Lake Superior ores are represented in most of the principal classes here given. They also constitute an important subclass, the greenalite ores, developed ly aqueo-igneous processes, not yet certainly identified elsewhere.

Much the largest part of the world's production of iron ore has come in recent years from the sedimentary ores. The largest reserves are in that elass. Also important for the future are the resilual weathering ores of the laterite type, such as are found in northeastern Cuha. The highest grades are reached in the sedimentary ores which, in addition to some purification by weathering in place in a parent rock, have leen sorted and segregated during transportation and deposition as sediments, and in the Lake Superior type, when aguin exposed to the surface, have undergone further purification through katamorphism. These successive concentrations have removed deleterious constituents, broken up complex silicates, and left the ores with a porous texture better adapted for furnace reduction than the ores of classes 1 and 2.

The iron ores therefore illustrate both a wide range of ore-depositing ageneies and the great increase of values effected by the reaction with meteoric waters and the atmosphere in the zone of katamorphism.

One of the most striking features of the ore deposits of the selimentary class is the prevalence in them of granular textures, both oolitic and amorphous. The prineipal types of granules are as follows:

Green ferrous silicates:

Greenalite, $\mathrm{Fe}(\mathrm{Mg}) \mathrm{SiO}_{2} \cdot \mathrm{nH}_{2} \mathrm{O}$, amorphous.

Glanconite, hydrous silicate or iron and potassium, amorphous, resembling earthy chlorite, in granules.

Thuringite, $8 \mathrm{FeO} .4(\mathrm{Al}, \mathrm{Fe})_{2} \mathrm{O}_{3} \cdot 6 \mathrm{SiO}_{2} .9 \mathrm{H}_{2} \mathrm{O}$, related to prochlorite, massive and fresh, oolitic when altererl.

Chamosite, $\mathrm{SiO}_{2} 29$ per cent, $\mathrm{Al}_{2} \mathrm{O}_{3} 13$ per cent, $\mathrm{Fe}_{2} \mathrm{O}_{3} 6$ per cent, FeO 42 per cent, $\mathrm{H}_{2} \mathrm{O} \mathrm{I} 0$ per cent. Related to prochlorite. Oolitic.

Oulites with concentric rings of quartz and some green silicate, of chloritic nature, undetermined. Found in clinton and other ores.

Hematile and limonite:

(bolites consisting of concentric rings of silica and iron oxide.

Amorphous granules representing oxiclation of some of the ferrous silicate granules mentioned above or replacing shells.

All the above granules lic in various cements of silica, iron oxide, and ealcium carbonate.

The corretation and origin of these various granular forms present an interesting field for monographic sturly. It is known that some are organic, as, for instance, the glauconite and certain of the amorphous iron-oxide granules replacing shells. It is known further that probaby the larger part are inorganic, including the oolites and amorphous greenalite and iron oxide. As shown in another place (p. 525), both the greenalite and iron-oxide granules form in ordinary ehemical precipitates, and it is further suggested that they are perhaps related to Lehmann's liquid crystals. It may be of interest to note that of the three common iron compounds, oxides, silieates, and carbonates, the two former appear in granules, while the last does not. The oxides and silicates have weak erystallizing power, which, accorling to I.chmann, is usually associated with the derelopment of granular or anorphous forms; the carbonates have strong cryst allizing power, tending to give the surface definite and angular out lines. 


\section{CHAPTER XVIII. THE COPPER ORES OF THE LAKE SUPERIOR REGION.}

By the authors, assisted by Edward Steidtuans.

\section{THE COPPER DEPOSITS OF KEWEENAW POINT.}

\section{GENERII, ICCOUNT.}

Although the authors have studiod the copper of the Kewecnawan series in many parts of the Lake Superior region and have visited the copper deposits frequently, they have made no systematic investigation of the ore deposits themselves. Since the publication of Irving's monograpl ${ }^{a}$ on the listrict by the United States Geological Survey, the detailed mapping done by the Survey in this region has been confined to the iron deposits. It is nevertheless thought desirable to include in this monograph a general account of the copper deposits in order to summarize, as fully as possible, the present state of knowledge of the geology of the Lake Superior region. The portion of this chapter dealing with the origin of the ores contains certain new features.

The following description of the ores is based partly on our own observations and largely on the published descriptions of Irving, ${ }^{a}$ Rickard, ${ }^{b}$ Lane, ${ }^{c}$ Graton, ${ }^{d}$ and others.

The copper-producing listrict of Keweenaw Point follows the axis of the point in a general northeasterly direction for 70 miles and has a width of 3 to 6 miles. The richest portion of the belt is the central portion, in Houghton County, arljacent to Portage Lake (see Pl. XLLX), in association with the upper lava flows.

The copper is metallic. With the exception of the comparatively small amount of coarse copper-"mass" and "barrel work"-sorted ont at the mines, all the ores are subjected to crushing by steam stamps, followed by concentration.

The principal gangne minerals of the copper of this district are calcite, quartz, prehnite, and lammontite, with smaller but still considerable quantities of analcite, apophyllite, natrolite and other zeolites, orthoclase, datolite, epidote, chlorite (delessite), and native copper. Rarer associates are, according to Prof. A. E. Seaman, of the Michigan College of Mines, ${ }^{e}$ adularia, agate, anhydrite, algodonite, azurite, aragonite, argentite, amethyst, ammabergite, amplibole, ankerite, barite, braunite, biotite, bornite, cerargyrite, chalcocite, chloanthite, chrysocolla, chalcopyrite, chlorastrolite, cuprite, covellite, clinochlore (?), dolomite, domeykite, fluorite, gypsum, hematite, iddingsite, jasper, kaolinite, keweenawite, limonite, magnetite, martite, mareasite, malnchite, melaconite, muscovite, mohawkite, niccolite, pyrite, pyrrhotite, phillipsite, powellite, saponite, selenite, stibiodomeykite, semiwhitneyite, serpentine, silver, siderite, tale, whitneyite, thomsonite, wad, and wollastonite. Thongh this gromp of minerals

a lrving, R. D., The copper-bearing rocks of Lake Superior: Mon. U. S. Geol. Survey, vol. 5, 1883.

$b$ Rickard, T. $\Lambda$., The copper mines of the Lake Superior region, New York, 1905.

c Lanae, 1. C., The geology of Keweenaw Point-a brief description: Proc. Lake Superior Min. Inst., vol. 12, 1907, pp. 81-104; The geology of copper deposition: Am. Geologist, vol. 34, 1904, pp. $29 \overrightarrow{6}-309$.

d Graton, L. C., Silver, copper, lead, and zine in the Western states: Mineral Resources U. S. for 1907, pt. 1, U. S. Geol. Sturver, 1908 (Michigan, pp. 49i-523; Copper, pp. 57 L-641).

e Personal communication, 1910. 
is characteristie of the deposits in general, they may vary in importance in the different types as woll as in the different parts of the district. Calcite is the most abunlant associated mineral in the transverse veins and conglomerates; epiclote is the most abundant in the dipping voins. 'The genetic sequence of these minerals is discussed uncer the origin of the ores.

The coprer "onstitutes (1) veins intersecting the northwestward dipping beds of the Keweenawan series described in Chapter XV and (2) bedded deposits formed by infiltration or replacement of both the conglomerate and anygdaloidal beds of the Keweenawan series, chicfly in the beds below the "Great" conglomerate, which is the diviling line between the lower part of the Keweenawan, where traps predominate, and the upper part, where sediments predominate. (See fig. 75.) Copper deposits lave not been found in folsitic beds and compact traps, except in minute quantities in the latter, where they are closely associated with amygdaloid beds. Rich cores of native copper are reported to have been drilled on the Indiana property, in Ontonagon County, from a very lense felsite, which appears to be intrusive. Development, howerer, has not reached the productive stage. Only one bed above the "Great" conglomerate contains copper, and this is the Nonesuch shale, which carries a little disseminated copper throughout its extent and has been worked in the Poreupine Mountain district.

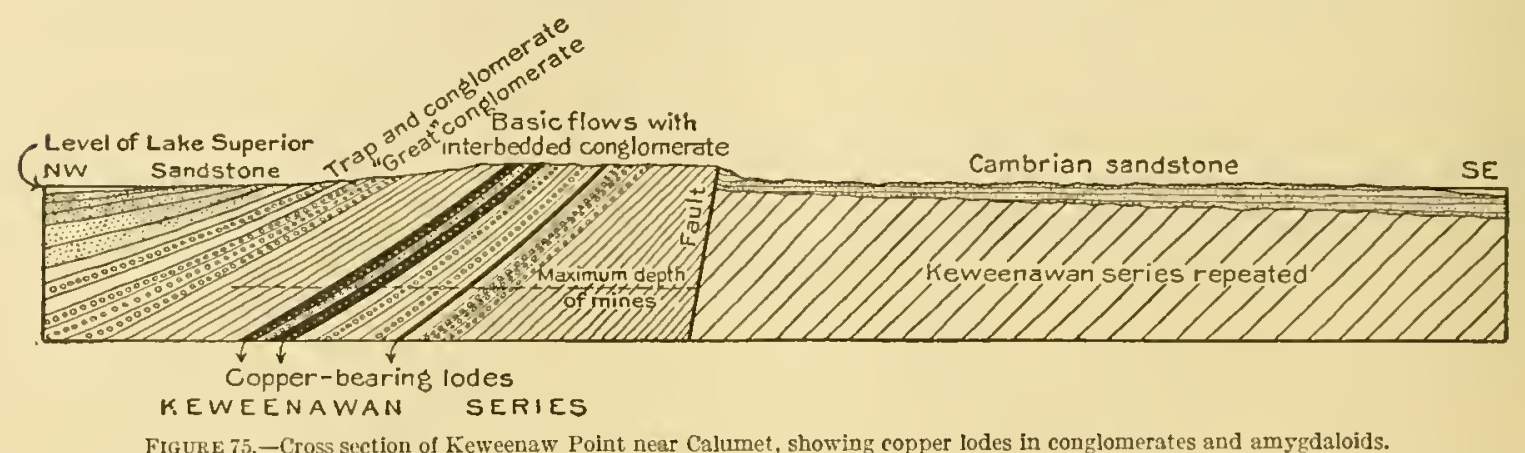

The deposits earliest exploited were the veins transverse to the strike of the beds in the Eagle River area at the northeastern extremity of the district; the next were the veins parallel to the strike, though not uniformly to the dip, in the Ontonagon area at the southwest end of the district. The vein deposits, especially those in the Ontonagon district, are characterized by masses of copper, being in this respect distinguished from the amygdaloidal and conglomerate copper deposits, in which the copper is, as a rule, much more minutely disseminated. The amygdatoidal deposits were the next to be opened, principally in the central portion of the district, but also in the Ontonagon area. The conglomerate cleposits occurring only in a small area in the vicinity of Calumet, in the central portion of the district, were the last to be opened. (For summary of history see pp. 35-37.) In 190773.1 per cent of the ore mined came from amygdaloidal lodes and 26.9 per cent from conglomerate lodes, the vein deposits at present being practically nonproducing, although of the total production from the district approximately 3 per cent is sorted out at the mines as coarser mass material.

The rrade of the ores is low and is becoming lower. In the early days of mining nuch ore above 3 per cent was mined. In 1906 the average grade for the district was 1.26 per cent, and in 1907 it dropped to 1.1 per cent, and to 1.05 per cent in 1908 . Only four mines in 1905 worked ore yiclding an average of 1 per cent or more in metallic copper. In 190s the richest 'lodes mined carried less than 2 per cent metallic copper, while the poorest rielderl but little wrer 0.5 per cent. 'The grades and amounts mined from the principal mines in 1907 are as follows: ${ }^{a}$ 
1. Lake lode (amygdaloid)

2. Nonesuch lode (conglomerate and sandstone)

3. Arnold lode (ash bed amygdaloid) (Equivalent to No.11?

5. Branch lode (amygdaloid)

6. Calico lode (amygdaloid)

7. Evergreen lode (amygdaloid

8. Butler lode (amygdaloid)

10. Winona lode (amygdaloid)

11. Atlantic lode (amygdaloid)

12. Pewabic lode (amygdaloid)

13. Allouez or Boston and Albany lode (conglomerato)

15. Osceola lode (amygdaloid)

16. Kearsarge lode (amygdaloid)

17. Isle Royale lode (amygdaloid)

18. Batic lode (amygdaloid)
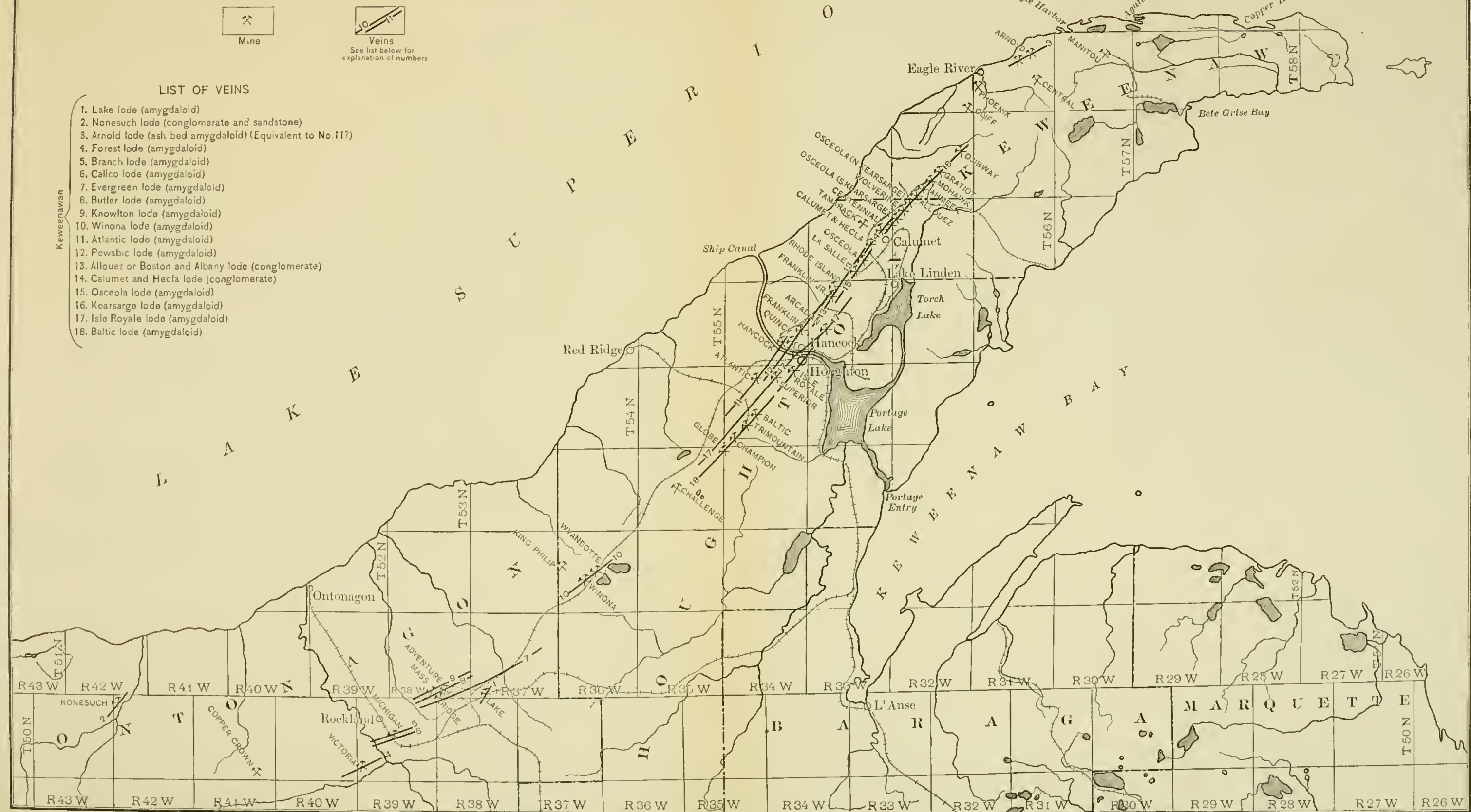

MAP SHOWING LOCATION OF COPPER-BEARING LODES AND MINES ON KEWEENAW POINT.

See page 573
F

(2) River, 

Ore output and grade of the principal Nichigan lodes in $190 \%$.

\begin{tabular}{|c|c|c|}
\hline Lode. & $\begin{array}{l}\text { Ore } \\
\text { (tons). }\end{array}$ & $\begin{array}{c}\text { Grade } \\
\text { (per cent). }\end{array}$ \\
\hline 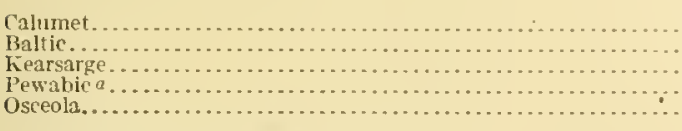 & $\begin{array}{l}\text { 2. } 400,0000 \\
1,900,0401 \\
2,350,000 \\
1.2201,0000 \\
750,000\end{array}$ & $\begin{array}{l}1.835 \\
1.06 \\
.87 \\
.79 \\
.895\end{array}$ \\
\hline 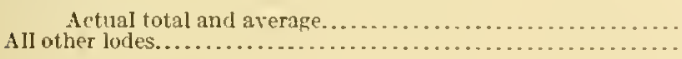 & $\begin{array}{l}8.141,361 \\
1,250,853\end{array}$ & $\begin{array}{r}1.67 \\
.62\end{array}$ \\
\hline
\end{tabular}

a Partly estimated.

A little native silver occurs with the copper in some lodes. Averaged on the total tomnage in 1908 , the silver yield was 0.023 ounce to the ton. Native silver is present in all the deposits, but is particularly characteristic in the veins of the Eagle River and Ontonagon areas, where also mass copper is abundant.

The amygdaloidal and conglomerate deposits have great extent along the strike, the Kearsarge locle, for example, being activcly mined almost without break for a distance of 12 miles and other lodes being mined for 2 miles along their strike. They have been followed down the dip to a maximum distance of more than $1 \frac{1}{2}$ miles and a vertical depth of about a mile, making these mines among the deepest in the world, and are still found to be productive, although of somewhat lower grade. The depth to which mining may be carried is not yet known. That it should be possible to mine at a profit ores as low as 0.5 per cent at a depth of a mile is due to the remarkable uniformity and continuity of the deposits along both strike and dip. Shoots of richer ore pitching paralled to the strike of the beds-as, for instance, the northward-pitching shoot of the Calumet and Hecla conglomerate-are known in a few places, but these are themselves so extensive that their existence and alternation with leaner portions of the beds have becn ascertained only after years of extensive mining.

\section{TRANSVERSE VEINS OF EAGLE RIVER DISTRICT.}

The veins of the Eagle River district, in the northern part of Keweenaw Peninsula, cut vertically across the strike of the beds of sediments, traps, and amygdaloids. The veins are not commonly formed by the filling of a simple fissure, but by a large number of subparallel, anastomosing fissures with blocks of small rock inclosed between, forming rather a fracture zone. The productive zone is in the amygdaloid beds immediately below the Allonez conglomerate and above the greenstone. The vcins vary from mere scams to those 20 or 30 feet wide, being widest where they eut across loose-textured amygdaloidal beds and not exceerling a width of 3 feet where they are in contact with compact traps. The greatest depth reached in the mining of transverse veins is 1,600 feet, in the Cliff mine. The texture of the rock traversed by the veins also controls the ore content, the veins being rich where they cut porous anygdaloidal layers and poor where they cut compact layers. Many of the amygdaloid beds themselves are rich cnough to be productive adjacent to transverse veins.

The gangue materials associated with the copper of the Eagle River veins are mainly calcite, quartz, prehnite, and laumontite, but analcite, apophyllite and other zcolites, orthoclase, datolite, epidote, natrolite, and other minerals are found. Native silver is present. Teins containing only calcite are generally bare of copper.

The copjer is scattered through the gangue in thin films penetrating other minerals or in coarser fragments filling interstices between other mincrals, or occurs in lenses, in this oceurrence usually with a crystalline form. Mass copper also is found here, the masses ranging up to many tons in weight and many of them containing fragments of wall rock.

Irving ${ }^{a}$ believes that these veins are replacements along fissured zones rather than fillings of open fissures. As evidence he cites the gradation between rein and wall rock, the replacement of wall rock by copper masses, the occurrence of fragments of wall rock in the vein and in the 
copper masses, and the greater width of the veins adjacent to amydgaloidal beds than of those in contact with dense traps. The origin of the copper ores is discussed on pages 580 et sey.

Transverse fissure veins are not restricted to the Eagle liver district, but are present in nearly every mine on Keweenaw Peninsula. In the southem districts, however, these veins, as a rule, contain no copper, or at least not enough to make them productive. Ilany of them are barren even where they cross productive beds of amygdaloids.

No mines are now operating in the Eagle River district. Explorntions have recently been conducted there with a view to further mining. The mines which have produced ore in this district are the Atna, Empire, Delaware, Amvgdaloid, Copper Falls, Central, Phoenix, and Cliff.

\section{DIPPING VEINS OF ONTONAGON DISTRICT.}

The dipping reins of the Ontonagon district are noted chiefly for the great amount of mass copper that has been removed from them. The principal "mass" deposits are in the group of amygdaloids, traps, and conglomerates corresponding roughly to the strata betwen Portage Lake and the area covered by the upper sediments. The veins are fillings of fractures following the strike of the beds. Many of those within weaker portions of the bed-for instance, along amygdaloidal layers-have a dip steeper than the bedding. Those that lie between two different beds are likely to dip at the same angle as the beds.

The veins vary in width from a few inches to many feet. The reins between different beds are more likely to be narrow; those cutting amygdaloidal beds may consist of a wide fracture zone, with fragments of rock interspersed with vein minerals. Slickensided walls locally bound the veins, but on the whole the contact is irregular. Irving ${ }^{a}$ believed these veins, as well as the transverse veins of the Eagle River district, to be largely replacements of wall rock.

Transverse reins (crossing the strike) are present also throughout the mines of the Ontonagon district, but they are unprorluctive except where they cross dipping reins.

The chief vein materials associated with the copper are epidote and calcite, but the other minerals above named as generally associated with copper are present. The copper occurs in irregular hackly masses, some of which are many tons in weight. One mass found in the Minnesota mine in 1857 weighed 420 tons. The large proportion of mass copper originally mined in this district gradually decreased and the production of amygdaloidal copper increased. In 1908 the production was derived wholly from amygilaloid lodes. The principal jroducing mines are the Adventure. Mass, Michigan, and Victoria. Receut explorations have shown additional copper deposits.

\section{AMYGDALOID DEPOSITS.}

The copper deprosits in amyglaloids are by far the most numerous and most productire in the Keweenaw Point region. The anygdaloids are the upper, and in some places the lower, vesicular portion's of the many lava flows, with here and there an interbedded detrital larer. The thickness of the productive portion of the amygdaloids varies from a few feet to 35 or 40 fect. The depth to which amygdaloid beds are productive has not been determined; the greatest depth yet reached is shown in the Quincy mine-5,2S0 feet along the incline, or 4,00 feet vertically.

The copper deposits in the amygdaloids, though lean in places, are much more continuous along the strike than those in the conglomerates, several mines miles apart working the same bet. There are very unusual variations in strike in the vicinity of the Baltic, Trimountain, and Champion mines.

The dip of the amygdaloids flattens out below and also to the northeast along the strike. The Quiney lode has a dip of 5. ${ }^{\circ}$ at the surface and $37^{\circ}$ at a depth of albout 5,000 fret along the incline. The Atlantic lorle dips $5 t^{\circ}$, the Wolverine $40^{\circ}$, and the "Baltic" $70^{\circ}$, the dip thus showing a considerable variation even in a small area, though in general being steeper in the southern purt of the region.

a lrving, 1R. D., Mfon. IT. S. Geol. Survey, vol. $5,1 \mathrm{N3}, \mathrm{pl}$. 4:2-426. 
In amygdaloidal beds the copper occurs in cavities in amygdules party filled by other minerals, along cleavage or fracture planes within these minerals or replacing them partly or completely. The minerals associated with the copper are prehnite, chlorite, calcite, and quartz. Accorling to Irving, ${ }^{a}$ eonsiderable portions of the beds have lost all semblance to their original amygdaloidal structure and now consist of chlorite, epielote, calcite, and quartz intimatcly associated or forming separate masses of the most indefinite shape merging into one another. In places portions of partlyaltered prehnite occur associated with copper, but as a rule prelonite has given way to its alteration products. In these highly altered masses (onper crystallized free wherc it harl a chance, but more commonly it replaced other minerals. In calcite bodies it formed those irregular, solid branching forms lically known as horn copper, some of them many luundred pounds in weight; in epoldote, quartz, and prehnite bodies it ocen's as thread and flakelike impregnations; in foliaceous, lenticular chloritic bodies it forms flakes between cleavage planes and oblique joints, or here and there-this is more particularly true of fissure veins it replaces the chlorit ic selvage-like substance till it forms literally pseudomorphs, some of which are several hundred tons in weight.

In the Baltic and adjacent mines are considerable quantities of black sulphides near the surface, but even here they are not in sufficient amount to have economic value. The amount of these sulphides decreases greatly with increasing depth.

The ampurdaloids are productive only where broken. Usually they have both strike and dip fractures in addition to very irregular fracturing. Commonly the strike fractures are not exactly parallet to the beds but cut across them at acute angles. Many of these fractures show slickensidling, proving considerable differential movements. At the Quincy and Baltic mines the amygdaloid is lean where there are cross fractures, but a little distance away from the cross fractures it is rich.

In some places the copper goes down into the compact rock beneath the amygdaloid, following zones of fissuring, alteration, and replacement.

In a number of places productive amygdaloid occurs below a heary trap bed, as at the Winona, Quincy, Atlantic, Wolverine, and Baltic mines.

The mines operating in the amygdaluidal deposits and producing 60 per cent of the total output of the Keweenaw Point district in 1908 were the Calumet and Iecla, Tamarack, Osceola, Quincy, Centennial, Wolverine, Tecunseh, Franklin, Isle Royale, Atlantic, Baltic, Trimountain, Champion, Winona, Allouez, Ahmeek, Mohawk, Adventure, Mass, Michigau, and Victoria. The distribution of these mines and the lodes upon which they are operating are shown on Plate XLIX (p. 574). The Calumet and Heda, Osceola, Ahmeek, Wolverine, and Mohawk are on the so-called Kearsarge lode, which has been developed for an extent of about 14 miles, the largest deposit in the district. The Wolverine has the richest deposit, runming about 1.35 per cent of refined copper. The ore runs as low as 0.7 per cent in other mines. Bolow 0.7 per cent it has not been found profitable to mine. South of Portage Lake the only locle which has a large production is the Baltic. Its surface extent is about 4 miles and the yiekl averages about 1.1 per cent.

\section{COPPER IN CONGLOMERATES.}

Only two workable beds of conglomerate have been found among thirty or more beds distributed through the Keweenawan series unierneath the "Great" conglomerate-the Allonez ("Boston and Albany") conglomerate and the Calumet and Hecla conglomerate-and eren these are workable only in a small area. A number of other conglomerate beds have been found to contain small impregnations of copper but not cnough to be productive. The Allouez conglomerate is being worked by the Franklin Junior mine and the Calumet and Hecla conglomerate by the Calumet and Hecla and Tamarack mines. (See Pl. XLIX.)

The Calumet and Incla conglomerate is the richest and largest copper lode in the district and ranks among the first two or three large copper deposits of the world. It is fumous as the principal source of copper of the Calumet and Hecla Companr, which has been the greatest. 
dividend payer in the history of mining. This conglomerate thins both to the north and soutli. It the North Hecta mine it is not more than 3 feet wide in one place. It thins so rapidly to the south that on the Oscoola property it has not been discovered. Thus the Calumet and Iecla conglomerate is essentially a lens.

The Calumet and Hecla complomerate bed is productive only in the 2 miles covered by the C'alumet and Jlecta and Tamarack properties. North of this area the bed was mined by the Centemial mine without success, and to the south it was mined by the owners of the Osceola belore they sunk down to the Osceola amyerdaloid.

The conglomerate dips $39^{\circ} \mathrm{W}$. at the surface, Hattening to $36^{\circ}$ with deptls. It is followed down the dip from the outcrop to a maximum depth of $S, 100$ feet by the Calumet and IIecla Company, representing a vertical depth of 4,748 leet. A vertical shalt belonging to the same company about a mile from the outcrop on the hanging-wall side passes through the lode at a depth of 3,287 feet and goes to a depth of 4,900 fect. One of the Tamarack shafts reaches a depth of 5,229 feet, being the deepest shaft in the world. The conglomerate lode has increased in thickness from 13 feet at the surface to 20 feet in the deepest workings. The upper half (stratigraphically) is richer than the lower half of the bet.

The copper content of the ('alumet and Hecla conglomerate was formerly about 4 per cent near the surface, and now a mile vertically below the surface is 1 to $1 \frac{1}{2}$ per cent and arerages for the mine slipment 1.83 per cent. The copper is of lower grade and less regularly distributed in the Tamarack part of the same bed. This decrease in grade of the ore worked with increase in depth is partly a real one and partly due to improvements and lower costs, enabling lower-grade ores to be worked. The richer ores of the Calumet and Hecla concromerate constitute a shoot pitching to the north and extending to the Centennial ground. The upper half of the conglomerate bed is finer grained than the lower lialf. It contains more interstratified sandstone layers, called sandstone bars, which are usually barren but in places are very rich. In some places they separate the conglomerate into two parts and in such places the values may be either above or below the sandstone. The conglomerate is well cemented to both foot and hanging walls.

Below the conglomerate are several amygdaloidal beds. Inmediately over the conglomerate is a trap, 300 or 400 feet thick, which separates it from the first amygdaloid. The crosssection maps of the formations, made from the drifts of the deep shafts intersecting the beds for thousands of feet above and below the conglomerate, divide the lavas into two classes, traps and amygdaloids. The traps form the creater part of the sections and many of them are hundreds of feet in thickness. The amygdaloids compose a much smaller portion of the sections and are usually thin. The copper values are very small in the trap and amygdaloids, both above and below the conglomerate.

The rich portions of the conglomerate are usually light colored; the poor portions are dark. This is a practical distinction by mining men, who speak of the lean conglomerate as "black" and mean by this that wherever it is in this condition the values are low or lacking. This difference in color is due to the fact that the alterations, a part of which resulted in the deposition of the copper, have bleached the conglomerate. In many places in the rich conglomerate aurcoles of lighter-colored material may be seen at the outer parts of pebbles and bowlders.

The Allouez conglomerate, worked by the Franklin Junior mine, varies between $S$ and 25 feet in thickness, with 3 to 4 feet of sandstone at the base. It is of lower grade than the Calumet and Hecta conglomerate, averaging about 0.5 per cent in copper.

The pebloses in the conglomerates are mainly porphyritic felsite with diabase and anygdaloids in subordinate amounts. Locally, as in the Cahumet and Hecla conglomerate. cramitic mol quartz porphyry pobbles are abundant. The original comenting materials were silicous and feldspathic particles, lout these have been replaced largely by secondary calcite and epidote, with chlorite, and where the conglomerates are productive the copper is an important or the chicf comenting material. Copper also replaces pebbles to varying degrees. In this process the pebble first becomes porous and discolored and is altered to a mass of ppidote nud chlorite with a spongelike skeleton of copper associated with calcite. As a rule epiclote and chlorite 
first replace the matrix and porpliyritic leldspars and later copper replaces them, but often copper replaces feldspar directly, penetrating in thin films along cleavare planes. Pebbles like these, some of them as large as a man's head, are found in both the Calumet and llecla and the Allouez conglomerates, being composed of copper in various degrees up to nearly solid bowlders of metal. In some peblles the copper has almost entirely replaced the original material as well as the epidote alteration, but more commonly the copper skeleton contains in its cavities unaltered crystals of orthoclase and quartz, surrounded by a crust of epidote and clilorite.

Few fractures are noted in the conglomerate, nor is there evidence of slipping or faults at contacts with walls. The hanging wall is not safe, tending to lall down. Whether this is due to the weakness of the rock when the stopes are taken out so that new fractures are formed, or whether incipient fractures were present, has not been determined. Certainly the distribution of values is not a function of exceptional shattering.

In the Nonesuch shale of the Porcupine Mountain district copper is found as a cementing material, as a replacement of cementing material, and as a replacement of rock particles. Many of the copper fragments in this bed are peculiar in having minute cores of magnetite.

\section{COMPOSITION OF COPPER-MINE WATERS.}

Lane has assembled a large number of analyses of copper-mine waters. He finds that in the upper levels of the mines, to depths varying from 500 to 1,000 feet, the waters are abundant and fresh, though on the whole somewhat softer than the river waters of the Mississippi Valley. Below these deptlis the waters are much less abundant and more highly concentrated and contain principally chlorides of soda and calcium. At the deepest levels the calcium and soda may be in about equal proportions, or the calcium may predominate orer the soda. At intermediate levels the soda predominates over the calcium. The contrast in composition of the upper and lower waters slightly resembles that of the waters of the upper and lower levels of the iron mines. Reference is made on pages 543-544 to possible causes of this difference im composition.

Of the several analyses arailable, three are selected as typical of the three classes of water.

Analyses of copper-mine iraters. ${ }^{a}$

[Parts per million.]

\begin{tabular}{|c|c|c|c|}
\hline & $\begin{array}{l}1 . \\
\text { reep } \\
\text { water. }\end{array}$ & $\begin{array}{l}2 . \\
\text { Inter- } \\
\text { inediate } \\
\text { water. }\end{array}$ & $\begin{array}{l}3 . \\
\text { Surface } \\
\text { water. }\end{array}$ \\
\hline 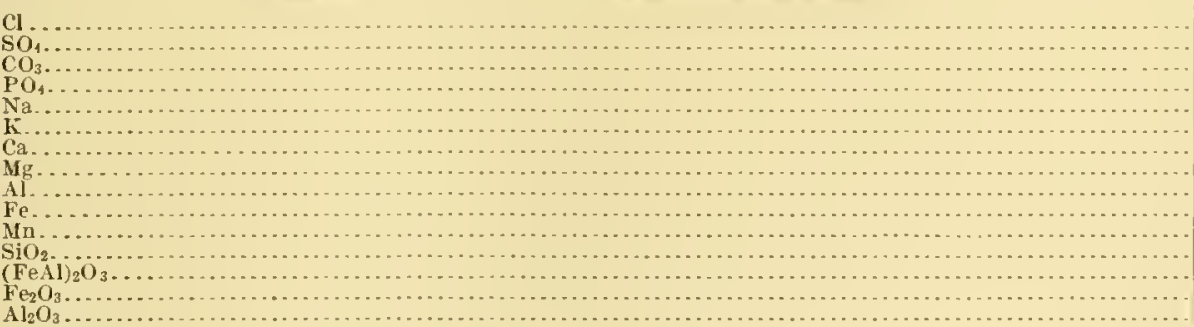 & $\begin{array}{r}134,916 \\
2,123 \\
2,123 \\
\text { None. } \\
11,592 \\
\text { None. } \\
65,341 \\
2,123 \\
\text { None. } \\
\text { None. } \\
\text { None. } \\
2,123 \\
\ldots . \ldots .\end{array}$ & 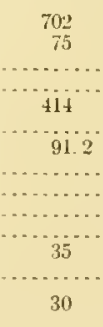 & $\begin{array}{c}b 3.5+ \\
6+ \\
40+ \\
62.3+ \\
19 \\
4 \\
\ldots \ldots . \\
10 . \\
1.5 \\
\ldots \ldots .\end{array}$ \\
\hline 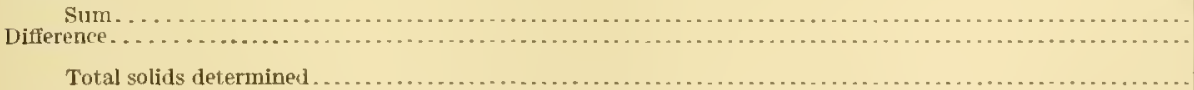 & 212,300 & $\frac{1,347.2}{2 . x}$ & $\begin{array}{r}86.3 \\
\ldots .6 .\end{array}$ \\
\hline
\end{tabular}

a Lane, A. C., Mine waters: Proc. Lake Superior Min. Inst., vol. 13, 1908, pp. 74-12t5.

$b$ If contaninated.

1. Water from one of the lower levels of the Quincy eopper mine, Hancock, Mich. Analysis by George Steiger. Cited in Bull. U. S. Geol. Survey No. 330, 1908, p. 114.

2. Water from South Kearsarge mine, Keweenaw Point, No. 1 shaft, ninth level, dripping collected by F. W. McNair and C. D. Hohl. Analysis given by Lane, A. C, Proc. Lake Superior M1in. Inst., vol. 13, 1908. p. 116.

3. Water from Tobacco River, Michigan. Analysis given by Lane, A. C., op. cit., p. 90. 


\section{COPPER IN KETERAITAN ROCLS IN PARTS OF TIIE LALE SUPERIOR REGIOA OTIER THAN KEWEENAW POINT.}

Copper is known in small quantities in the liewechawan traps and secliments in Douglas County, Wis., in adjarent parts of Ninnesota, on Isle Rovil, on Ifichipieoten Island, and elsewhere. These occurrences are not essentially diflerent from those of licweenaw Point in theil' mineralogical and goologic associations. The copper oceurs principally in fissure reins cutting the bedding of the traps and to a less extent in the amyerdaloidal openings and interbedded secliments. Exploration las been cartied on intermitently in all the areas namer. On Isle Roval al considerable amount of metalhe copper has been mined. (See pj). 37-38.) None of these districts an now prohucing copper.

\section{ORIGIN OF THE (OPPER ORES.}

\section{CONIION ORIGIN OF THE SEVERAL TYPES OF DEPOSITS.}

The ropper ores of the Lake Superior region are in part replacements of conglomerates and cementing material filling the original openings in the conglomerate, in part fillings of amygdaloidal openings and replacements in traps, to a slight extent fillings of reins and replacements of arjacent wall rock, and finally cement and replacements of a basic sandstone high in the series. The copper is an integral part of the cementing material of these rocks.

In a discussion of origin the three types of deposits must be considered ats essentially a unit. Irving ${ }^{a}$ sees in them-

simply the results of a rock alteration entirely analogous to that which has brought ahout the deposition of copper and its associated vein-stone minerals within the cupriferous amygdaloids. They are alteration zones which traverse, instead of following, the hedding, simply because the drainage of the altering waters has been given this directiun by the preexisting fissures. *** Thus the differences in origin of the several classes of copper depusils-conglomerate beds, cupriferous amygdaloids, epiclote veins parallel to the bedding, and "fissure" veins transverse to it-which at first sight seem to be great, on closer inspection for the most part disappear.

That much of the copper was introduced as filling and replacement of wall rocks admits of no doubt. Sereral hypotheses are still open as to the source of the copper and the manner in which it was transferred and redeposited.

\section{I'REVIOUS VIEWS OF NATURE OF COPPER-DEPOAITING SOLUTIONS AND} SOURCE OF COPIER.

Irving, ${ }^{b} \mathrm{~W}_{\text {indsworth }}{ }^{c}$ and nearly all other geologists who have studied the copper-hearing rocks believe that the source of the copper was in the basic igneous rocks, and that so fall as it was derived from the sediments, its ultimate source was still the basic igneous rocks, because the sediments came from those rocks. This belief is founded principally on the uniform and close association of copper witl the basic igneous rocks and the known existence of copper sulphides minutely disseminated through some of the coarser igneous rocks. The source of the copper was believed hy Pumpelly do be in the overlying sediments.

Smythe believed that the ores did not come from the adjacent wall rocks but from a deepseated source, the nature of which does not appear from his report.

The conditions and agents under which the copper has been supposed to bave been taken from the aljacent rocks and concentrated have been variously interpreterl. Irving, I'umpelly,

a Irving. R. 1). The copper-begring rocks of Lake Superior: Mon. [T. S. Feol. Survey, vol. 5, 1s-3, pp. 424-425.

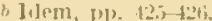

Wadsworlh, M. L.. The origin anel mode of oecurrence of the Lake Superior eopper deposits: Trans. Am. Inst. Min. Eng., vol. ri, 1san,

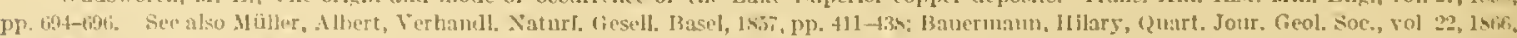

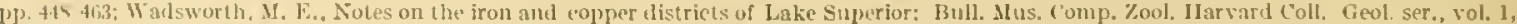
150), 1. 120.

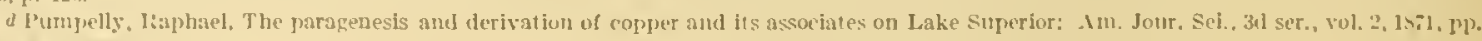

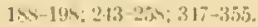

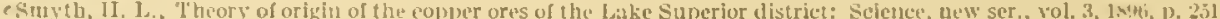

Irving. R. D., op. cit., pp. Hig-1206.

o l'umpelly, laphacl, op, cil.. pl]. 353-355. 
Wadsworth, ${ }^{a}$ Lane, ${ }^{b}$ and others have been inclinerl more or less strongly to the theory of concentration under the direct downward movement of meteoric waters. Pumpelly has also implied that concentration may have occurred when sediments were still below sea level. Lane ${ }^{c}$ has suggested that the waters were salt waters of the type now found in the rleep copper mines, and that they represent fossil sea waters or fossil desert waters, which in the tilting of the series have migrated downward. Van Hise ${ }^{d}$ has argued that while meteoric waters have done the work, it has been during their upward escape after a long underground course. Smythe assigned the first concentration of the ores to ascending solutions from a deep-seated source not specified.

\section{OUTLINE OF HYPOTHESIS OF ORIGIN OF COPPER ORES PRESENTED IN THE FOLLOWING PAGES.}

The copper ores are characteristically associated with basic igneous rocks. The source of the copper-bearing solutions lies in these igneous rocks. The original copper-bearing solutions were hot. These solutions may be partly direct contributions of juvenile water from the magma, partly the result of the action of meteoric waters on crystallized hot rocks.

\section{ASSOCIATION OF ORES AND IGNEOUS ROCKS.}

From 60 to 70 per cent of the copper produced in this region comes from the amygdaloids. The veins of mass copper also are all in igneous rocks and these veins are richest where they lie parallel to or intersect amygdaloilal beds. The ore-bearing rocks are characteristically near thick rather than thin flows. Barren conglomerates are interbedled with productive flows. The only productive conglomerates, the Calumet and Hecla and the Allouez, are associated with thick flows. Especially is the overlying flow thick.

Not only is the association of the ores and the imneous rocks conspicuous in the prorlucing district, but throughout the Kieweenawan area of Lake Superior traces of copper are widely distributed in the igneous rocks.

Copper is associated principally with basic igneous flows, but it is now reported in drilling in felsite, supposedly intrusive, at the Indiana mine. Copper sulphide is also reported by Wright $f$ in association with intrusive gabloros and ophites of Mount Bohemia.

\section{ORE DEPOSITION LIMITED MAINLI TO MIDDLE KEWEENAWAN TIME.}

It is believed that the original deposition of the copper was limited mainly to middle Keweenawan time, or, if not, at least to the cooling period of the igneous rocks of that time. As shown below, the wall-rock alterations associated with the ores seem to be characteristic of hot water. Some of the gangue minerals are hot-water deposits. Bowlders of some barren conglomerate beds show mineralization which was developed before they were broken from the parent underlying ledge. The reposition of the copper was an episode in the work of cementation of both sedimentary and igneous rocks, which certainly began as soon as the beds were deposited but which continued to the end of the voleanic period of the middle Keweenawan and even longer. Pumpelly's work, mentioned below, shows that the copper was relatirely late among the minerals introduced. The same thine is shown in some places by the absence of deformation effects upon the copper. The late introduction of the copper is argued by Sinyth $g$ from the contrast of minerals first cleposited in the copper-bearing series with those coming later and carrying the copper, the first, according to him, being developert under conditions of weathering before the series was folded, and the second being dereloped after the series was folded.

(1) Wadsworth, M. E., The origin and mode of orcurrence of the Lake Superior copper deposits: Trans. Am. Inst. Min. Eag., vol. 27, 1895, p. 695.

b Lane, A. C., The theory of copper deposition: Am. Geologist, rol. 34, 1904, pp. 297-309.

$c$ Lane, A. C., The ehemical evolution of the ocean: Jour. Geology, vol. 14, 1906, pp. 221-225.

dVan Hise, C. R., A treatise on metamorphism: Ifon. U. S. Feol. Survey, vol. 4i, 1904, p. 1136.

E Op. eit., p. 251 .

$f$ Wright, F. E., The intrusive rocks of Mlount Bohemia, Michigan: Ann. Rept. Michigan Geol. Surrey for 1908, 1909, pp). 361-397.

g Smyth, 11. L., Theory of the origin of the copper ores of the Lake Superior district: Science, new ser., vol. $3,189 t, p$. 251. 
Wadsworth a cites the extension of eopper in a continuous mass from one flow to another as evilence of introrluction "after the copper-bearing series was complete."

Wright ${ }^{b}$ finds veins of iron and copper sulphides dereloped in the intrusives of llomt Bohemia, but is uncertain whether they are elosely related in time with the consulidation of the intrusives.

It may well be that the introduction of the copper, begun relatively early in the mildle Keweenawan, was to a considerable extent the work of hot solutions after the entire midlle Keweenawan was pilcd up, when relatively quiescent conditions had been reached; for the lavas, the slowly coling, deep-seated intrusives, and the muderlying reservoir would be sourees of heat and hot solutions for a long time after actire rolcanism had censed.

On the whole, the evildence seems to indicate clearly that part of the copper was deposited soon after the extrusion of the associated igneous rocks, but late in the cycle of mineral deposition in which copper was formed, and that much of the deposition of the copper followed the folding and deformation of the Keweenawan rocks. As this deformation undoubtedly accompanied and immediatcly followed the deposition of the Keweenawan series, the fact that copper deposition followed deformation does not necessarily remove it much in time from the formation of the adjacent rocks. But, on the other hand, there is no evidence which fixes the close of this period of deprosition.

\section{DEPONITION OF TIE COPPER ACCOMPIASHED BY IIOT SOLUTIONS.}

That the copper was deposited by hot solutions seems to be established by the facts stated below.

\section{NATURE OF GANGUE MINERALS.}

Prehnite, epidote, chlorite, lammontite, and other gangue materials of the copper are aluminum silicates. Alumina is not ordinarily transported by cold plurial waters, and, specifically, it is not transported by the fresh mine waters near the surface at the present time in any but the most minute quantity. (See analyses, p. 579.) In the deeper, warmer, hearily concentrated chloride waters (see analyses) alumina and ferric oxide are in larger though still small amounts. The analyses report the alumina and ferric oxide together, and the proportion which is alumina is not known.

Other characteristic associates of the copper are datolite, containing boron, and apophyllite. a fluorine mineral-both substances which are not ordinarily ascribed to solution, transportation. and deposition by cold solutions. Mine waters working on the gangue materials, which may be said to contain a concentration of boron and fluorine, even now contain only traces of the boron and fluorine minerals, not enough to afford materials for their precipitation.

\section{NATURE OF WALL-ROCK ALTERATIONS.}

The wall rocks are obriously altered by the same solutions that have leposited the copper. The bleaching of the wall rock is so characteristic of copper veins that it is regarded as a favorable sign in exploration. This bleaching alteration, when measured quantitatively, is found to rary in several important respects from alterations which would be typical of surface waters carring the agencies of the atmosphere. Below is a table containing two pairs of analyses of the fresil and altered wall rocks, selected carefully to eliminate, so far as possible, rariations in original composition: a group of analyses made under the direction of Pumpelly, which inclieate the general trend of chemical change in the trappean beds: an analysis of an altered Calumet and Ifecla conglomerate bowkley described by Lane; a group of analyses by Lindgren illustrating the changes in ehemical compusition of basic igneous rocks altered by hot solutions: and two analyses of fresh and wathered basic igneous rocks given hy Merrill.

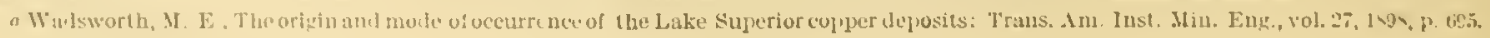
o Wrisht, F. F., op. cit., 1'.393. 
Analyses of fresh and altered wall rocks compared with other rock alterations.

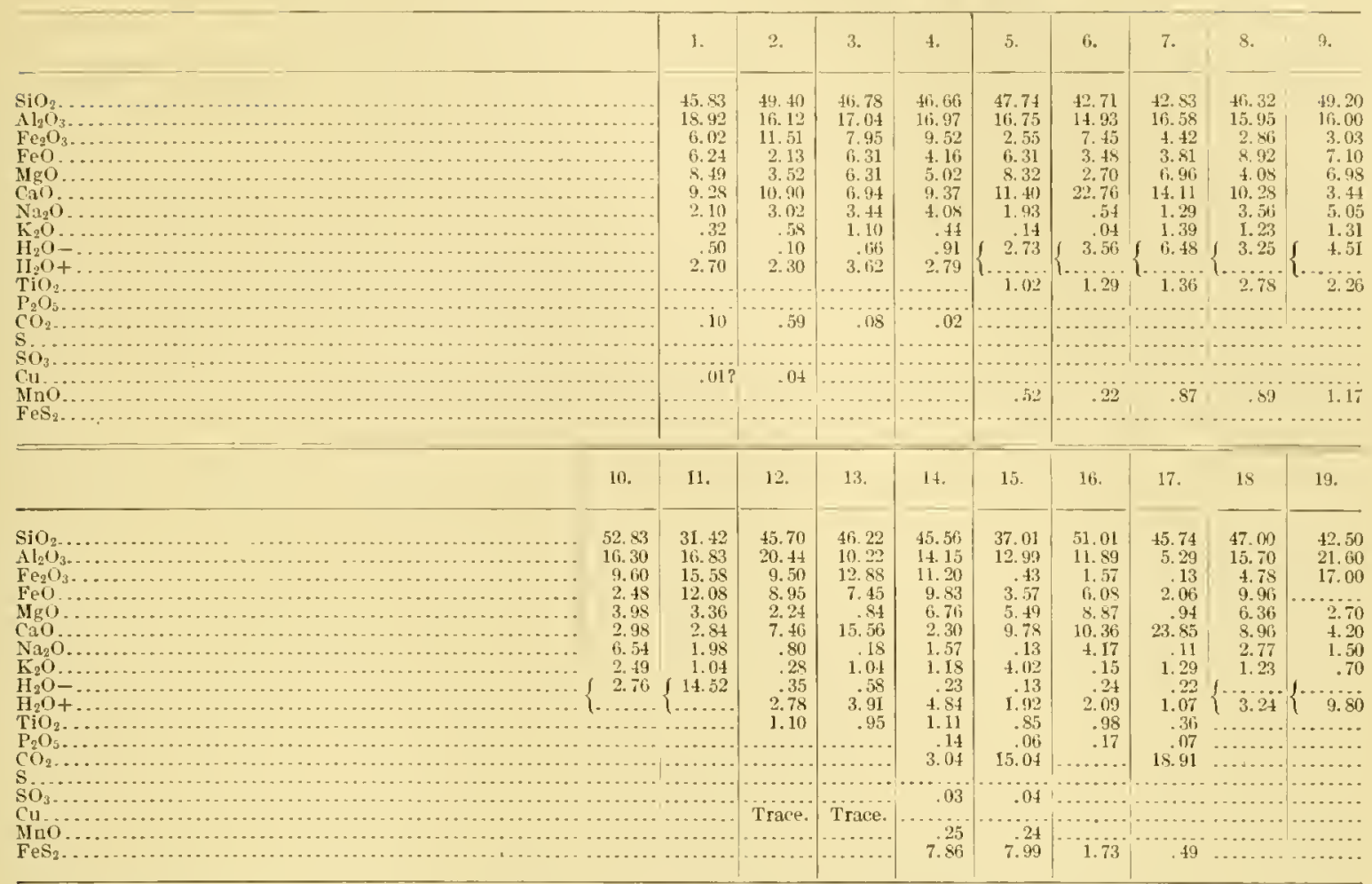

1. Specimen $47500 \mathrm{~B}$, country rock 70 feet from the lode, seventh level of Winona mine, Keweenaw Point, Mich. Inalssis by R. D. Hall, University of W isconsin, 1909.

2. Specimen 47499 , center of lorle, sane locality. Analysis by R. D. IIall, Unjversity of Wisconsin, 1909.

3. Specimen 47506, 12 feet from footwall of sixty-third level of Quincy mine, Keweenaw Point. Mich. Analysis by R. D. Hall, Unjyersity of 4. Specimen 47505 , lootwall near lode, same locality. Analysis by R. D. IIall, University of Wisconsin, 1909.

5. Melaphyre, lower zone of bed 64, Eagle River section, Mich- Pumpelly, Raphael, Metasomatic development of the copper-bearing rocks Lake Superior: Proe. Am. Acad. Arts and sei., vol. 13, 15is, p. 293.

7. Pseludo-amygdaloid, niddle zone of bed 64, same locality. Idem.

8. Bottom of bed 87 , same locality. Idem., p. 285.

(he original of the altered conglomerate. Lane, A. C., The decomposition of a bowlder in the umet and IIecla conglomerate: Econ. Geology, vol. 4,1909 , p. 161.

12. Fresh hasaltic rock from center of flow, 15 feet from lode, Dingle Creek mine, Douglas County, Wis. Aualysis by W. G. Wilcox, University of Wisconsin, 1910.

13. Superjacent amygdaloidal lode, same flow. Analysis by W. G. Wilcox, University of Wisconsin, 1910.
14. Amphibotite schist, Mina Rica vein, Ophir, Placer County, Cal. Fairly fresh, hut contains some calcite and pyrite. Lindgren, Waldemar, Metasomatic processes in fissure veins: Trans. Am. Inst. Min. Eng., vol. 30, 1901, p. (ifí.

15. Completely altered amphibolite schist. Conrad vein, Ophir, Placer County, Cal. Idem.

16. Fresh diabase, Grass Valley, Cal. Idem.

18 and 19. A verage of five fresh (16) and weathered (17) basic igneous rocks-diabase from Spanish Guiana, diabase from Medford, Mass., basalt from Bohemia, basalt from Cronzet, France, and diorile from llbemarle County, Va. Calenlated from analyses given hy G. P. Merrill in Rocks, rock weathering, and soils.

In the following table the first two pairs of analyses given above are calculated as closely as possible into the minerals actually observed in the rocks:

Mineral compositions of fresh and altered wall rocks calculated from first turo pairs of analyses given above.

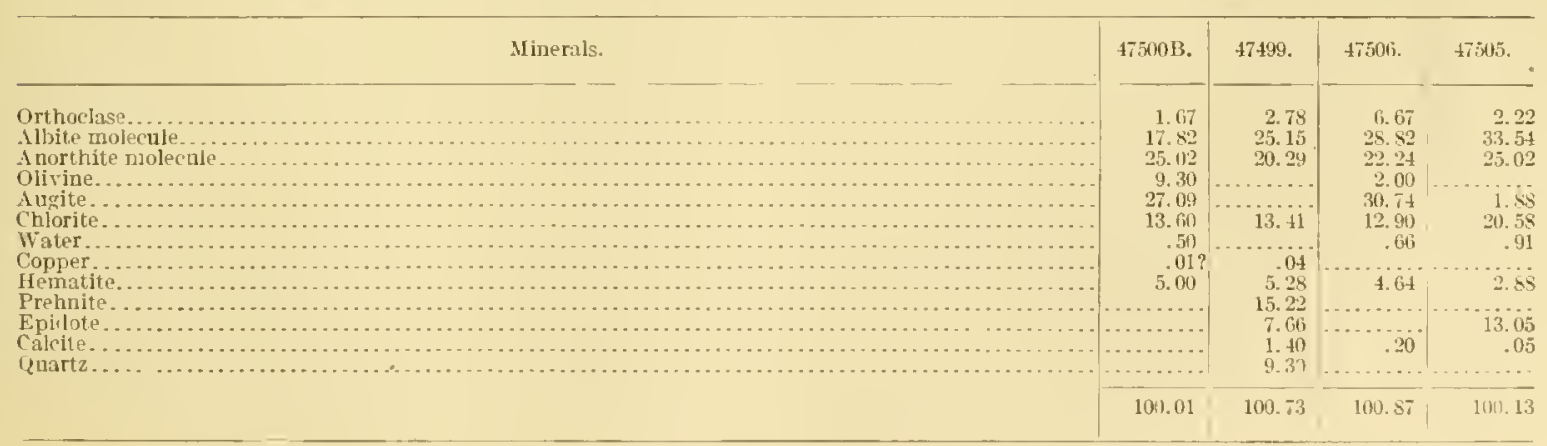


Analyses representing ordinary weatlering alterntions indionte a uniformity of results which may serve as a bacis for conparison with alteratons of unknown ease. Comparing the alterations of the wall rocks of the anpper deposits of unknown origin with the known results of weathering of similar types of bisic rocks and the results of the alteration of similar basic igneous rocks by thermal solutions, the following conclusions sem justified:

1. The changes in the eliemical composition of the Lake Supcrior copper rocks lack unilormity

The changes in the monposition of hasio igneous rocks by thermal solutions lack uniformity.

The weathering of basic igneous rocks, as well as the weathering of all other rocks, causes certain changes in the chemical composition, which are almost rigilly uniform.

2. The changes efferted in the silica content of the Lake Superior copper rocks anljurent to the deposits are not governed by silicate ratios in the original rock.

The changes effected in the silica content of basic igneous rocks elsewhere by theil alteration by thermal solutions are not controlled by silieate ratios in the original rocks.

The changes effected in the silica content of basic igneous rocks by weathering, as well as thuse effected by the weathering of all other silicate rocks, are gorerned by the silicate ratios in the original rocks.

3. The changes in the chemical composition of the Lake Superior copper rocks show local concentration of line or alkalies, depending on the stage of mineral paragencsis represented by the analysis. There has been an increase in the ferric iron and water content throughout; $\mathrm{FeO}$ appears to have been consistently removed or rather oxidized in place. There is evidence of both the removal and the introduction of $\mathrm{N}_{2} \mathrm{O}_{3}$.

The changes in the chemical composition of the rocks altered by thermal solutions elsewhere show a consistent increase in $\mathrm{K}_{2} \mathrm{O}$ and a consistent decrease in $\mathrm{Na}_{2} \mathrm{O}, \mathrm{Fe}_{2} \mathrm{O}_{3}$, and $\mathrm{IgO} . \quad \mathrm{Al}_{2} \mathrm{O}_{3}$ lias suffered considerable deerease in some rocks. In others the evidence for the decrease, inerease, or stability of $\mathrm{Al}_{2} \mathrm{O}_{3}$ is not very clear.

The changes in the chemical composition of basic rocks by weathering consist in a uniform decrease in $\mathrm{CilO}, \mathrm{MgO}, \mathrm{Na}_{2} \mathrm{O}, \mathrm{K}_{2} \mathrm{O}$, and $\mathrm{SiO}_{2} ; \mathrm{Al}_{2} \mathrm{O}_{3}$ remains nearly constant and water is introduced.

It follows from the facts presented that the ehanges in the ehemical composition of the Lake Superior copper rocks effected by their alteration aljacent to the copper deposits are fundamentally different from those which are known to have been caused by the action of weathering solutions. On the other hand, these changes present similarities to the changes effected by thermal solutions.

4. Coincident with the elnanges in the chemical composition of the Lake Superior copper rocks, the tendency of their mineralogical alteration is not in accord with the change produced by weathering, but it is in hamony with the mineralogical alterations effected hy thermal solutions.

The weathering of basic igneous rocks results in the devclopment of kaolin, quartz, ('arbonates, and other simple compounds and the decomposition of all minerals not in the list of secondary minerals. The development of kaolin in the absence of the derelopment of other secondinry silicates is one of the best-established criteria of the decomposition of rocks under the influence of meteric solutions.

The minetalogiral changes caused by the alteration of the Lake Superior copper rocks arljacent to the deposits can be generalized as a progressive development of chlorite. juchnite. epidote, quartz, and the alkaline silicates in succession, with more or less overlap, in place of the origunal mincral ronstituents of these rocks plagioclase foldspars, augite, some monghetite, olivine, and other acecessory minerals.

The mineralogrical changes of the basic igneous rocks altered elsewhere by hot solutions consist in the development of sericite and alcite from angite, homblende, epidote, biotite, and feldspars. The feromignesian mincrils alter also to chlorite, whidh in turn changes to nuscovite. Maguetito altors to siclerite, and ilmenite to rutile. The finil product is cescentially sericite, carbonates, quart\%, and sulphicles. 
The results of the alteration of the copper-bearing rocks by the solutions which deposited the copper and gangue minerals have been found to contrast with the effects of weathering in a manner similar to the results of the alteration of certain basic igneous rocks by thermal solutions elsewhere. A fuller diseussion of these contrasts will be found in a paper by Steiltmann. ${ }^{a}$

\section{PARAGENESIS OF COPPER AND GANGUE MINERALS.}

I study of the paragenesis of copper and gangue materials, accorling to Pumpelly, ${ }^{b}$ discloses the following order of deposition of the minerals: (1) Chlorite and some laumontite; (2) laumontite: (3) laumontite, prehnite, epidote; (4) quartz and a green earth mineral; (5) calcite; (6) ropper and calcite; (7) calcite, alkaline minerals, orthoclasc, analcite, apophyllite, datolite. The members of this order overlap one another. Copper was largely deposited after the development of ferrous iron-bearing minerals, chlorite, and epidote and is more intimately associated with these iron-bearing minerals than with non iron-bearing minerals, except prehnite.

The phenomenon of mineral paragenesis in deposits derived from solutions indieates that the parent solutions have experienced certain definite physical and chemical changes. Depositional cycles are as certainty related to changes in concentration of the solutions, changes in temperature or pressure, chinges in chemical composition, etc., as cycles of sedimentary deposition are related to certain definite changes in physiographic conditions. It is dillicult to see how present pluvial waters could develop such a depositional cyele.

Smyth ${ }^{c}$ argues that, of the above-named series of minerals, the first deposits, principally chlorite with other nonalkaline, hydrous silicates, were dereloped hy orlimary weathering immeliately after the igneous rocks were extruded at the surface; that the copper and later associated minerals were introduced later, after the folding of the lieweenawan series; that therefore the succession of minerals does not, as Pumpelly ${ }^{d}$ supposed, represent a continuous march of alteration. The minerals of the second period are sharply separated from the alteration products of the first period, which they often replace, by their richness of alkalies and by the presence of fluorine and boron. Smyth's ${ }^{e}$ argument is essentially that copper was introduced in solutions contrasting with ordinary meteoric solutions and of later origin. Still further, Smyth ${ }^{e}$ cites the occurrence of copper under impervious layers of greenstone as eridence of arrest of solutions coming from below.

\section{CONTRAST WITH PRESENT WORK OF METEORIC SOLUTIONS.}

In general, the kind of work done by the waters which deposited the copper contrasts with that being accomplishel to-day by meteoric waters. It is true that tho minute quantities of sulphicles in the basic igneous rocks are oxidized to the sulphates of copper, transported, and releposited by coming into contact with ferrous solutions in the presence of alkaline carbonates. Evidence of solution at the surface is to be seen at many places in the stains of carbonates of copper, and yet there is no evidence that gromel or surface waters are at present segregating copper deposits from the country rocks. Pluvial solutions now active in the coprer ores are not known to carry copper. The concentrated solutions of the deel mines, which can not, umder any hypothesis of deposition from meteoric solutions, be regarded ats the normal meteoric solutions from which the copper was derived, are known to deposit small amounts of copper on mine tools, but analyses of these waters show only a rery small percentage of copper. It seens evilent that if pluvial solutions are so inefficient in carrying copper from the concentrated materials at the present time, their inelliciency in leaching the sparsely disseninated primary

a Steidtmann, Edward, A graphic comparison of the alteration of rocks by weathering with their alteration by hot solntions: Econ. Geology, ธol. 3, 190s, pp. 3.5I-109.

o Pumpelly, Raphael, Paragenesis and derivation of copper and its associates on Lake Superior: Am. Jour. Sui., 3il ser., vol. 2, 1sil, p. 350.

e Smyth, H. L., Theory of origin of the eopper ores of the Lake Superior district: Science, new ser., vol. 3, 1×96, p. 251.

1 i'umpelly, Raphael, op. cit.

cop. cit., p. 251. 
copper of the igneous rocks of the series would be a thousundfold granter. Watcrs away from the mines, even where they are ruming through the basic igneous rocks. are foum to be nearty if not quite lacking in copjere.

\section{SOURCE OF THEIRMA, SOLUTIONS.} THREE HYPOTHESES.

Three hypotheses as to the source of the thermal solutions suggest themselves-that they were juvenite solutions, aqueous or gaseous, given ofl by the igneous rocks on cooling; that they were metcoric witers heated by contalct with igneous rocks; that they were some conbination of the two. That both juvenile and meteoric sourees contributed to the thormal solutions would be expected from the general conditions of sedimentation of the líweenawan series. Lava beds were piled one above another at comparatively short intervals, separated by the deposition of coarse fragmental sediments, probably developed subacrials: Simultaneously, or later, intrusives penetrated the interbedded igneous and sedimentary rocks, both parallel to and across the bedding. The waning of igneous activity allowed sediments to accumulate in thicker berls and finally, in the upper Keweenawan, without intermption. The igneous rocks may be supposed to have carried with them the usual complement of magmatic waters and vapors. They were fluid and became anygdaloidal. Such solutions would be speedily mixed with surface meteoric waters. The rapicl piling up of beds would imprison both juvenile and meteoric waters under conditions that wonld cause them to lose their heat only slowly. The maximum bleaching and cementation of both igneous rocks and sediments and the simultaneous deposition of copper may be supposed to have occurred at this time. Tilting of the beds, with accompanying fractures and faults, began early in Keweenawan tine and continued throughout the period. The tilting may be supposel to have slowly moved the contained solutions, and when erosion had beveled the beds, access for more meteoric waters was given. At this time, when the elevations were certainly mountainous and the openings in the rocks not cemented, as at present, meteoric solutions would have a rigorous and deep circulation. These general facts lay the burden of proof heavily on anyone attempting to show that the thermal solutions were jurenile or meteoric alone. They seem to show that the meteoric solutions were in the greater abundance. They do not show whether the distinctive work of copper deposition accomplished by these solutions was due to the jurenile or the meteoric contributions, or both.

This leads us to the question whether the copper was contributed directly in hot juvenile solutions escaping from the igneous rock, or whether it was leached from crystalline wall rocks by hot solutions of both juvenile and meteoric nature. In the nature of the ease, quantitative evidence with which to answer this question is rlifficult to obtain.

The riew that at least some of the ore-bearing solutions were magmatic is favored by the evidence cited on foregoing pages that the ores are associated in place and time with igneous extrusions, that the ore-depositing solutions were hot, that they carried fluorine and boron, and that the ores were deposited in mineral cycles showing rapilly changing conditions.

Of similar import is the apparent scarcity in the crystallized wall rocks of copper which could be leached and concentrated in suflicient amounts to explain the present deposits. Coppper has been found most sparingly as a primary constituent in the fresh ignoous rocks. It las not been reported from microscopic examination of the fine-grained surfate rocks, and in only a lew cases, in minute quantities, have suphicles of copper been found in the coarser igncous rocks. No evidence has been thus far adduced that such minutely disseminated cop)per is more abundant in the igneous rocks in the copper-bearing areas than in igneous rocks outside the copper-bearing areas. The few copper detemintions which have been made in the analyeses of fresth igneous rocks show either no copper or but little more than an trace. On the othere hand, analyses are fow, and the final word as fo the original eoplere content of the

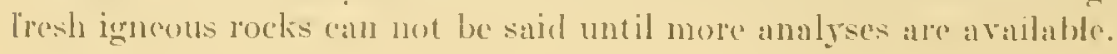


There is no reason to beheve from present known facts that the unleached wall rocks are any richer in copper in the vicinity of productive lodes than they are in other parts of the Kewernawan series throughout the Lake Superior region. In northern Ifinnesota and other known nomproluctive areas there seems to be fully as much copper in the igneous rocks as in those of Keweenaw Point. If it is assumed that the copper deposits have been concentrated entirely by the action of meteoric waters on the basic igneous rocks, it is difficult to account for the absence of depusits throughout much of the Keweenawan and also in certain potous strata within the producing district. The extreme localization of the deposits in time and place seems to be something more characteristic of highly concentrated magmatic solutions than of a universally acting agent like meterric waters working duwn from the surface.

But granting that the fresh igneous rocks eontain minute quantities of copper, which may have been picked up and concentrated by meteoric solutions later, is not their presence in these wall rocks evidence that during the cooling of these lavas concentrated copper-bearing solutions were present, some of which may have escaped from the parent rock during erystallization? The inherent probability of such an origin of the solutions is increased by consideration of the evidence derived from certain westem copper deposits, where a fairly good case has been made out for the direct contribution of copper salts in juvenile solutions, as, for instance, in the Clifton district of Arizona by Lindgren.

None of the evidence above cited for the direct contribution of copper salts in juvenile solutions entirely excludes the hypothesis that meteoric waters, ailled by the heat of the lavas, may have accomplished the result by leaching of wall rocks. From the known conditions of extrusion of the lavas and the association of the sediments it is practically certain that meteoric waters were present, that they were hot, and that therefore they were able to accomplish some alterations. To what extent they may have concentrated copper we have no apparent means of knowing. They were probably effective in rearranging the copper to give the present rariation in grade with depth. This change in depth is the one fact which seems to be more closely relaterl to the activity of meteoric solutions than to the deposition from juvenile solutions.

On the whole the evidence is taken to point to a probable original concentration of copper by hot solutions largely of juvenile contribution, but more or less mixed, necessarily, with meteoric waters and a later working over of the deposits by waters dominantly of neteoric source. In any case there is a high degree of probability that the associated basic igneous rocks are the source of the copper deposits. The doubt arises only as to the manner of their derivation from these wall rocks - whether they are due to the escape of solutions of a juvenile nature before or churing the crystallization of the laras, or whether on the breaking up of the erystallized rocks by katamorphic alterations the minute portions of copper they contained were concentrated in the deposits.

\section{WERE THE THERMAL SOLUTIONS DERIVED FROM EXTRUSIVE OR FROM INTRUSIVE ROCKS?}

The attempt to ascertain the particular igneous rocks from which the copper ores were contributed and the conditions favoring the release of the copper solutions leads first to a scruting of the conditions under which the igneous rocks associated with the copper ores cooled. Most of the igneous roeks containing the copper deposits or associated with them are clearly surface flows, with typical surface textures, interbedded with other flows and with sediments. So clear is this origin and so uniform the bedled suecession that it has been commonly assumed that most of the igneous rocks associated with the ores are flows, yet some undoubted intrusive rocks are known and some of the bedded traps lack specifie evidence of extrusive character and may possibly be sills or laccolithic intrusives, such as are known to be present in other parts of the keweenawan of the Lake Superior region. Certain irregularities in the strikes, dips, and thickness of the igneous beds mily bo thus explained.

Was the copper brought in by the extrusive rocks which are interbedied with the sediments, or was it subsequently introluced by intrusives? The evidence arailable is not conclusive. 
There are perhaps fewer parallels alsewhere of the eleposition of metallic ores in quantity from surface extrusive locks than from intrusives, though it has been shown definitely that some ores have been dorived from extmisives.

At the base of certain barren conglomerates oceur copper-bearing amygrdaloidal pebbles that are apparenty identical in character with an underlying amyglaloidal flow, from which they seem to have freen terived. In such eases mineralization has cridently taken place before the development of the conglomerate, which points to the offusive rock as the source of the copper-bearing solutions, for the conglomerates dosely followed the lavas in deposition.

(opper-bearing amygdaloidal traps have been found in Naska ${ }^{a}$ in which a similar line of evidence points to the trap as the direct soure of the copper.

\section{SIGNIFICANCE OF SULPHIDES OF COPPER IN THE INTRUSIVES AND LOWER EFFUSIVES.}

The intrusive rocks carrying sulphicles are possibly the deep-seated equivalents of the lavas whicl carry metallic copper. Wright so regards the intrusives of Mount Boheniin. The alsence or subordination of native copper in the intrusives may be lue to the temperature conditions of the rocks when copper deposition took place. If lot euprous sulphates were delivered from the intrusive rocks, they may have been deposited as sulphide in the highly heated intrusive, and party as native copper in the equivalent traps, where there was more rapid cooling and where a lower temperature prevaled. (See p. 589.) Another speculation is that the extraordinary differential concentration of native copper in the upper lavas may have been due to a process of magmatic differentiation. The intimate relation of the ores vith basic igneous rocks and their general alsence from the felsites is further suggestive of this.

\section{CONCLUSION AS TO SOURCE OF COPPER-BEARING SOLUTIONS.}

It is concluded, therefore, that the copper-hoaring solutions were hot, that they were both juvenile and meteoric, that the copper probably was in part contributed directly in jurenile waters and in part by leaching of wall rocks by the hot solutions, the evidenee developed being as yet insuflicient to enable cuantitative statements as to the relative importance of the two.

It is known that magmas expel on consolidating all constituents which can not assume stable mineral form under the existing chemical and physeal conditions. Water, copper, and numerous other substances belong to this class. Such a source for ore-bearing solutions has been repeatedly appealed to in the search for the origin of western copper and other ores. Positive evidence for such contribution is in the nature of the case extremely elusive. As a rule the best that ean be clone is to present evidenec ehminating the hypothesis that meteorie waters are accomplishing the work, and to show that direct igneous contribution is a possible alternative source. For the Lake Superior copper this explanation of source meets the objections which hare been cited against the deposition of the copper by meteoric solutions and best explains the transportation of abusclant aluminis silicates, fhorine, and boron, the remarkable concentration of copper as compared with other constituents, the cycles of mineral deposition, the peculine alterations of the wall rocks, the facts that the period of ore cleposition was largely limited to middle Ficweenawn time and that ore deposition at the present time is ahmost nil, and finally the extreme localization of the copper lodes, a localization which scens to be charareteristic of the assoeiation of ores of all kinds with igneous rocks. The conclusion that the ore-tepositing solutions have been contributed hot by the igneous rocks does not exclude the cooperation of hot and cold metcoric waters, either in the primary deposition of the ore or in further segregation and moditication of it.

It is suggested later that the present decp mine waters represent the residumm or brine of these solutions, possibly more or less mixed with phuvial waters. Wr are unable to follow Lame $b$ in his conchusion that the waters represent fosil or connate waters either of the liewernawan sean or of the arid conditions under which the lieweenawan may have been deposited.

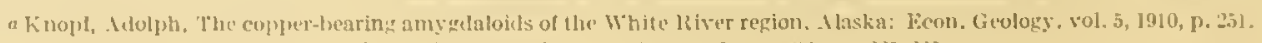

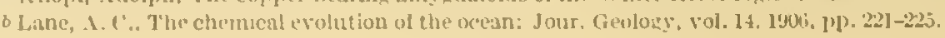




\section{CIIEMISTRY OF DEPOSITION OF COPPER ORES.}

The uncertainty of the conditions of deposition of the copper of course requires that any discussion of the chemistry of the deposition of these ores be tentative and that a wide range of processes lye taken into consideration. A lyppothesis of the eluemical processes of copper deposition may be based on the postulates that the hot solutions which deposited the copper derived part of their constituents, notably boron, fluorine, and perlaps copper, directly from the igneous rocks as magmatic emanations; that they may have partly derived the alkalies, alkaline earths, alumina, silica, and perlaps some eopper, from the decomposition of the wall rocks, affected by the thermal solutions, and that these solutions probably earried the copper as the chloride and possibly as the sulplate. The sparseness of sulplicles in the deposits seens to imply that the primary solutions were either lean in sulphates or else the conditions were unfarorable to the deposition of sulphides. The abundance of chlorides in deep-mine waters of possibly residual origin suggests that the eopper was earried as chloride.

The deposition of metallic eopper from such solutions has been accomplished experimentally in these ways and perlaps others. First, Fernekes succeeded in precipitating metallic copper from a eupric chloride solution with ferrous chlorile at a temperature of $200^{\circ} 10250^{\circ} \mathrm{C}$, in the presence of prehnite and other silicates, which neutralized the hychochloric acid resulting from the reaction. ${ }^{a}$ Second, Stokes obtained metallic copper by the cooling of a hot solution of cuprous and cupric sulphate; by the action of ferrous sulphate on cuprie sulphate at $200^{\circ} \mathrm{C}$; ; and by the action of hormblende and silerite on cuprie sulphate at $200^{\circ} \mathrm{C} .{ }^{b}$ Third, Billlle succeeded in throwing down copper from a solution of ferrous and cupric chlorides in the presence of an excess of alkaline carbonate at ordinary temperature. ${ }^{c}$ Fourth, Sullivan ${ }^{d}$ finds that various silicates-feldspar, biotite, shale, prehnite, augite, amphibole, ete.- will throw out copper from copper sulphate solutions by an act of double decomposition. The bases of the silicates pass into solution in very nearly the same proportion as copper is taken out. The mineral form of the copper deposited in this manner is unknown, but the process may bear some relation to the problem in liand.

Lane $e$ suggests that electrochemical action between the copper solutions and the wall rock may have caused the precipitation of copper. Pumpelly fegards the intimate association of copper with protoxide silieates, in which the replacement of alumina by forric oxide is especially favored, as indicative of a close genctie rolation between the ferric conclition of the iron oxicle in the associnted silicates and the metallic state of the copper, and believes that the higher oxidation of the iron was eflected through the reduction of the oxide of copper at the expense of the oxygen of the latter. Van Hise $g$ believes that the reducing agents which precipitated native copper were ferrous solutions derived from the iron-bearing silieates and ferrous compounds in the solid form, magnetite and silicate. This view is in accord with the findlings of Sullivan.

The geologic relations of the copper which are especially applicable to the problem are these: First, copper is intimately associated with and preceded by ferrous silicate minerals; second, it was deposited with calcite, it is known to replace quartz, and its deposition was usually followed by the development of alkaline silieates.

A tentative hypothesis of the chemistry of the deposition of the ore may be built on the preceding postulates as follows:

Hot solutions containing copper chlorides, looron, and fluorine compounds, $\mathrm{CO}_{2}$, and possibly otler magmatie cmanations entered the porous parts of the formations, where they began

a Econ. Geology, rol. 2, 1907, p. 580 .

b Stokes, Ir. N., Experiments on the solution, transportation, and deposition of copper, silver, and gold: Econ. Geology, vol. 1. 1906, ply. 6t1-650.

c Biddle, H. C., The deposition of copper by solntions of ferrous saIts: Jour. Geology, vol. 9. 1901, pp. 430-436.

d Sullivan, E. C. The interaction between minerals and water solutions: Bull. U. S. Geol. Survey No, 312, 1907, p, 64.

e Ann. Rept. Michipan Geol. Survey for 1903, 1905, p. 219: Econ. Geology, rol. 4, 1909, p. 170.

f Pumpelly, Raphael, The paragenesis and derivation of copper and its associates on Lake Superior: Am. Jour. Sci., 3d ser., vol. 2, 1871, pp. 353-354.

o Van Hise, C. R.. A treatise on metamorphism: Ilon. ‥ S. Ceol. Survey, vol. 4 t, 1904, p. 1136. 
the work of deposition and the solution and replacement of the wall rock. Ilot solutions. in gencral, remove lime and soda with great rapidity. P'ressure and $\mathrm{C}_{2}$ alone could cause the solution of alumina. ${ }^{a}$ In general, there would be a tendency for the decomposition of all minerals in the wall rocks, and a consequent enrichment of the solutions in the constitucnts taken out of the wall rocks. IInwever, as Janeb suggests, the calcium silicate and sodium silicate in the solution would tend to keep magnesium out of solution. These processes would tend to develop) chlorite by replacement and to keep magnesia permanently out of solution. In general, chlorite is the most stable mineral form which magnesia assumes in the presence of hot solutions. ${ }^{c}$ This lirst step in the eyele of deposition thus aceounted for left the solution rich in lime, iron, and aluminum silicates. ('hanging conditions, perliaps, of concentration, heat, and pressure brought about the saturation of these constituents, and a generation of laumontite, prohnite, and epilote followed the development of ehlorite. Silica became insoluble in this solution after the deposition of the lime-aluminum silicates, which resulted in the precipitation of quartz. The individualization of quartz was followed by the deposition of copper. It is suggesterl that the solutions were relatively rich in alkalies, probably the carbonates and chloride hoth, when the period of copper deposition began, for the deposition of copper accompanied the solution of yuartz and was followed by the deposition of alkaline silicates. Under these conditions copper-bearing solutions reacting with the ferrous silieates of the wall rock and perhaps with ferrous salts in solution in presence of alkaline carbonates caused the precipitation of copper. It is furthermore suggested that the deposition of calcite, coeval with the deposition of copper, was due to the interaction of alkaline earbonate and calcium chloride, As calcium cliloride is a solvent of copper, its precipitation as a carbonate would give additional impetus to the precipitation of copper.

It is quite possible that the progress of the cycle of deposition of the copper outlined on page 585 was accompanied by a gradual loss of hent and pressure and that this loss was greatest where the solutions were nearest the surface. Accorling to Soret's principle ${ }^{d}$ when two parts of a solution have different temperatures, there will be a concentration of the dissolved parts in the cooler portion. This concentration tends to bring about deposition of some of the dissolved parts. This is shown also hy the work of Stokes ${ }^{e}$ on the interaction of cuprous and cupric sulphates. Consequently, deposition of copper may have begun in the upper zones of the solution and gradually extended downward. Diffusion and conrection currents would tend to keep the composition of the solutions uniform. Howerer, when the deposition of copper began at the lower horizons the richness of the solutions was diminished. It is possible that such a process causer the gradual diminution of the richness of the ore deposits with increase in depth.

Throughout this process there was a continual concentration of the alkalies in the solutions. After the deposition of copper these alkalies beeame partly insoluble in the solution under the cxisting physifal and chemical conditions and were thrown out as analeite, orthoclase, fluorinebearing apoplyylite, and otlier alkaline zeolites. The horon silicate, datolite, was thrown out at the same time. It is also possible that the major precipitation of the datolite and apophyllite took place in the upper zones, as appears to have been the ease with copper, for hane and other olservers are inclined to believe that certain alkaline silicates are more abundant in the upper levels of the mines.

This closes the cycle of deposition of the copper and gangue minerals. The general results of the process sugrgest that the present deep mine waters represent the more or less modified resiluum or brine of the solutions that accomplished the deposition of the copper.

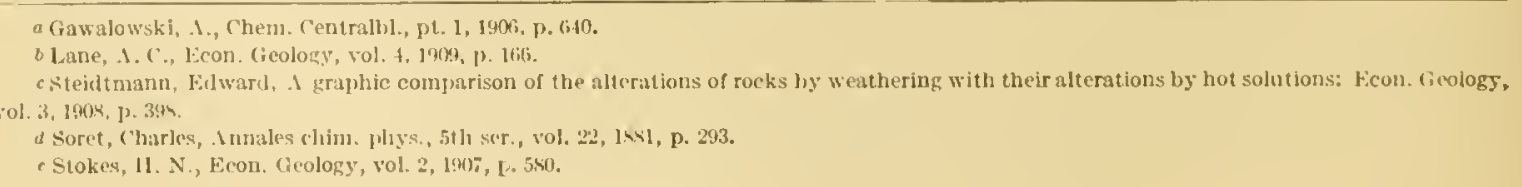




\section{CAUSE OF DIMINUTION OF RICHNESA WITH INCREASING DEPTH.}

There is little in the Lake Superior copper deposits in the nature of the oxide or weathered zone so characteristic of sulphide deposits. Possibly glaciation has removed marked evilences of surficial change. In a few places the upper few hundred feet of the lonles is less rivh than the parts below, suggesting a leaching from the upper part of the lode. Below this the ores very gradually and uniformly diminish in richness with increase in depth, a diminution which is caused mainly be slight changes in proportions of minerals rather than by differences in kinds of minerals in the ores.

The relation of the richer portions of the lode to the erosion surlace suggests at once a downwarl concentration by meteoric waters such as has been demonstraterl to explain this relation in so many mining districts. But this explanation presents many difficulties. The present underground waters near the surlace do uot carry copper in abundance, nor can we suggest any probable chemical reaction which woukl explain the solution of metallic copper. The ore diminishes in value far below the depth of the present meteoric circulation. There is no sharply discriminated oxirle zone. The kinds of minerals are essentially the same from the top down, and the changes in proportions and values are much more gradual than the ('hanges ordinarily ascribed to secontary concentration from the surface. The diminution of value with increase in depth has been demonstrated so generally to be the result of concentration from downward-moving meteoric waters that one hesitates to offer any other explanation except on most decisive proof. Such decisive proof is here lacking. But nevertheless another hypothesis seems to us reasonable-that the richness of the ore near the surface was due to a precipitation of copper from primary solutions near the surface, where they were cooled under less pressure and became mingled with oxidizing waters. It would be necessary to assune that convection and diffusion would tend to equalize the concentration of the copper solutions, thus causing some migration of copper salts toward the zone of precipitation and thus diminishing the amounts of salts precipitated from solutions lower down. The oxillation of cuprous salts in solution, effecter by the mingling of meteoric waters, would develop cupric salts which in moring down and by reacting with the cupric salts would deposit metallic copper, as noted on page 559.

This liypothesis avoils the difliculty of getting the copper into solution from the metallic form, which would have to be assumed on the hypothesis of a downward concentration by meteoric waters.

In this hypothesis of deposition of richer copper ores by primary solutions near the surface, there is no emphasis on the direction of movement of the solutions. It is conceivable that they may have been upwarl-moving waters, that at the time of deposition the waters may have been moving little or none at all, or possibly that the waters had begun to take a downward movement as a result of the cooling and contraction of the lavas. Lane ${ }^{a}$ has estimated such downward movement as amounting to possibly a mile down the dip in the vicinity of the present erosion surface. So far as the currents were downward moving, there may have been upward artesian flow through fissures in impervious beds overlying pervious beds. Wadsworth ${ }^{b}$ eites as evidence of downward-moving waters the occurrence of spikes of copper and calcite which extend from one bed down into others, with the small end downward, hike an icicle.

\section{RELATION OF COPPER ORES 'TO OTHER ORES OF THE KEWEENAWAN.}

It.is an interesting and significant fact that rocks of probable Keweenawan age are closely associated with a considerable variety of ores on the north and east sides of Lake Superior. On Silver Islet, on the nortluwest side of the lake, and thence westward on the main shore are igneous dikes of probable keweenawan age cutting the slates of the Animikie group and carrving native silver and other minerals. (See pp. 593-594.) On the north shore of Lake Huron basic igneons bosses and dikes of probable Kieweenawan age are associated with quartz veins carrying chal-

a Lane, A. C., Econ. Geology, vol. 4, 1909, p. 164.

$b$ Wadsworth, M. E., The origin and mode of occurrence ol the Lake Superior copper deposits: Trans. Am. Inst. Min. Eng. , rol. 27, 1s9s, p. 695. 
copyrite, which is the soure of the copper ores of the Bure mines and many small prosprects in this district. In the Sudbury district, to the northeast, basic inneous rocks of probable kewecnawan age are relusely associntod with the nickel deposits; and still farther to the nort least hasic igncous rocks, probably of kewernawan age, are associatcel with cobalt-silver deposits. The main structural lines in all these distriets trend nortl of east and suth of west, corresponeling to the axial line of the Lake Superior syncline. All these dist ricts lave certain ore-lenaring minerals in common. The difference is primarily a difference in proportion. For instance, the Lake Superior copper deposits are associated witl metallic silver and a mimite nmount of cobalt ambl nickel. The silver leposits of Silver Istet carry small amounts ol' eopper, cobult, and nickel. The Sudbury nickel deposits carry considerable coppere and a small amomnt of cobalt and native silver. In the cobalt district the native silver and cobalt ores carry consiclerable amounts of niekel and copper. In the discussion of general grology (('hapter XX) it will be shown that the general recion was probably a geosyncline of deposition during pre-Cambrian time, alfected by repeated follings along axes parallel to the shore, and a locus for igneous actirity. The distrilution and character of the ores through this general zone further suggest the generalization that here is a metallographic province along which igneous rocks have brought up quite different but still related ores, these ores taking a consicleralle variety of structural, mineralogical, and chemical characteristics, partly because of original differences in the composition of the ore-bearing solutions in these different districts and partly because of the different conditions under which they approached the surface, those in ('anada remaining as intrusive beneath the surface and those at Keweenaw Point coming largely to the surface.

Still further, in pre-Keweenawin time this same general region was a shore line of deposition with repeated outbursts of volcanism. The attempt has been made to connect the iron-ore deposits of the Lake Superior legion with this volcanism. Thus along this great geosyncline earlier voleanism was associated with extrusion of iron salts and later rolcanism with a variety of cobalt and silver, copper, and nickel salts. 


\title{
CHAPTER XIX. THE SILVER AND GOLD ORES OF THE LAKE SUPERIOR REGION.
}

\author{
SILVER ORES. \\ PIRODUCTION.
}

Mention has already been made of the mining of silver with the Keweenaw Point copper ores. The total value of silver thus mined from 1887 to the end of 1909 is $\$ 1,805,308.50$.

In addition to this, veins in the slates of the Animikie group on the northwest side of Lake Superior have rielded silver ores, principally from Silver Islet, as follows:

$$
\text { Silver produced from veins on northwest side of Lahe Superior. }{ }^{a}
$$

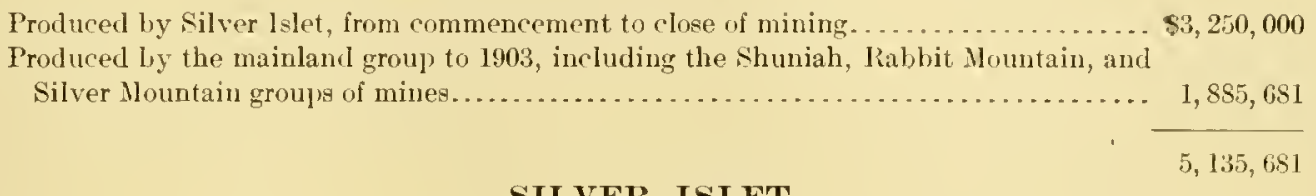

\section{SILVER ISLET.}

The following account of Silver Islet is largely quoted from Ingall. ${ }^{b}$ Silver Islet is a small island of nearly flat-lying Animikie slates about a mile out in I ake Superior of Tlunder Cape.

The silver-bearing vein cuts the Animikie slates and a diorite dike, but its prineipal value is found within the diorite dike. This dike dips from $60^{\circ}$ to $75^{\circ} \mathrm{SE}$. The dikes in the Animikie of this part of the Lake Superior region are connected with the Logan sills, of Kiewcenawan age. The vein strikes $\mathrm{N} .35^{\circ} \mathrm{W}$. and dips $70^{\circ}$ to $80^{\circ} \mathrm{SE}$.; its thickness averages about 8 to 10 feet, but in some places it has shown from 20 to 30 feet of solid vein stuff. Two bonanzas were found in the vein; the first, yielding over $\$ 2,000,000$, was shaped like an irregular pear with its large end down; the second bonanza, found considerably later, was shaped hike an inverted cone. The gangue of the vein consists of ealcite, quartz, and dolomite, the dolomite varying in color from cream to pink accorling to the varying amounts of manganese it carries. The relative quantity of calcareous and siliceous matter varies, however, in different parts of the vein, and in places streaks of quartz have preponderated to such an extent as to make some of the ore highly siliceous. The metallie minerals are native silver, argentite, galena, blende, copper, and iron pyrites, with marcasite. Macfarlane also mentions tetrahedrite, domeykite, niccolite, and cobalt bloom, the two latter probably oxidation produets of a peculiar mineral called macfarlanite, containing arsenic, cobalt, nickel, and silver. Two new minerals are also said to have been found in the ore by Wurtz, called by him huntelite and animikite. The three minerals last named, according to Lowe, "are now [October, 1881] the principal producing silver ores of the mine." Besides the aloove, Courtis found in the ore shipped to the Wyandotte smelting works rhodochrosite, annabergite, antimonial silver, and cerargyrite, the last "where the rock has been deeomposed." The native silver is gencrally disseminated through the ore in more or less dendritie masses, the points of native silver forming nuelei for the deposit of niecolite and sulphurets. Graphite also oceurs in considerable quantity and seems to be connected in some way with the occurrence of the silver. Silver loes not occur without graphite, but graphite may be present without silver. Out of the whole series of twenty-one

a Eighteenth Ann. Rept. Ontario Bur. Mines, pt. 1, 1909, p. 12.

$b$ Ingall, E. D., Report on mines and mining on Lake Superior: Ann. Rept. Geol. and Nat. Hist. Survey of Canada for 1 hiz-48, vul. 3 , new ser., pt. 2, 1585, pp. $27 \mathrm{H}-10 \mathrm{H}$. 
dikes cut by the rein the Silver lshet, arrying the ore, is the only one impregnated strongly with graphite and prorite.

A curious feature of the vein is the combustible gas which has been encountered in larere quantities in the workings. This gas is acempanied by water containing calcium chloride in solution. The gas and water are confined principally in large vugs or cavities in the rein, unler great pressure in the deejest workings. Above the eighth level all water infiltrating into the mine is pure lake water. In analysis of the water is as follows:

Analysis of water from Silver Islet mine."

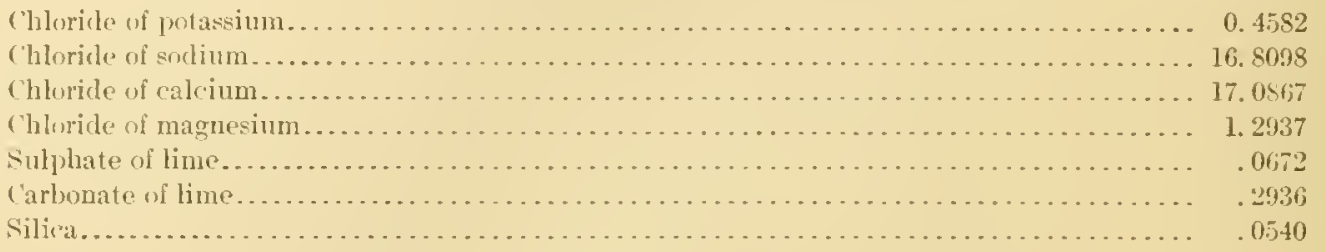

GENERIL ICCOUN'T OF NILVER IN TIE INIMIKIE GIOLP.

Passing orer lngall's detailed lescription of mines and prospects, his summary of the occurrence of silver in the Animikie group northwest of Lake Sujerior is partly as follows:

The reins, as regards their strike directions, resolve themselves into three series-a northwest series, a northeast series, and an east-west series. The northwest direction of strike characterizes the Const group of mines, of which the famous Silver Islet vein is the most striking example. The vein of the Beaver mine also has this trend.

All the reins of the Rabbit Mountain group of mines, with the exception of the Bearer, may be classed as northeast; the vein in the Thunder Bay mine also belongs to this series.

The veins of the third series do not run in general due east and west, but a little north of east and south of west. To this series belong nearly all the chief reins of the Port Arthur mines, with the exception of the Thunder Bay, just mentioned, and nearly all the Silver Hountain group of mines.

The vein-filling minerals consist in general of quartz, barite, calcite, and fluorite constituting the basis of the gangue, in which occur the clifferent metallie minerals-blente, galena, pyrites of screral species, and here and there some sulphurets of copper; the silver in the orey parts occurs as argentite and in the native state, the former being the more common. It some places the veins carry a clark-green, probably chloritic material which on some surfaces has a bright, waxy luster. Locally a soft, greasy talcose material, probably saponite, accompanies the ore, notably at the Beaver mine and to a lesser extent at one or two other places. Carbon in rarious forms has also been found here and there. In some of the rugs in the reins, which have been found near the surface, stiff clay and ocherous material have sometimes been obtained, along with nuggets of argentite, the formes, however, having erilently been winshed in from the surface and having thus embedderl the silver mincrals already existing in the rugs.

The Silver Islet vein was somewhat exerptional in carrying, besides the minerals abore noted, various arsenical and antimonial ores of silver, with compounds of nickel and cobalt and other metallic minerals which have, so far, not been found in the rest of the verins. Other salient features of this rein were the pink and cream-colored dolomite spar which formed a characteristic and prominent constituent of much of the gangue of the rich ore and the predominance of native silver in the rich parts, whereas in the rest of the reins, though native silver oceurs in considerable quantity at some places, yet argentite secms to be the form in which it is generally found.

It is interesting to note that both the mineral waters and the inflammable gas that were found in opening the Silver Islet nine have also been encountered at of her points in the district. Inllanmable gals comes up at sereral points in and around Thunder Bay, causing considerable elublition in the water and kecping it open all winter. At one of these points has loen 
placed a small tank connected with an inverted funnet anchored on the bottom, and it affords sufficient gas to keep a goosl-sized light burning. At the Rabbit Mountain mine, in one of thr lower levels, water running over the breast of the drift gave off a faint odor of sulphureted hydrogen and was depositing a white flocculent material, and both herr and at the Beaver mine it was reporter that small quantitics of inflammable gas harl been struck.

\section{ORIGIN OF SILVER ORES IN TIIE ANIMIKIE GIROUP.}

The origin of the silver ores in the Animikie group has not been studind by the writers. The ores have been regarded by some observers as brought up by thermal waters accompanying the trap intrusions. All the ore bodies found so far orenr near or within a moderate distance of trap in some form, either in dikes, as in the Coast group of mines, or in sleets, as in the other groups. Many similarities to the Sudbury and Cobalt ores further suggest this origin. Ingall argues, ${ }^{a}$ on the other hand, that as the fissures intersect and dislocate the trap sheets and dikes equally with the other rocks the traps must have been formed and soliclified long before the fissures. He suggests that the silver may be derived from the traps through decomposition of some of their mineral constituents carrying minute quantities of silver by waters infiltating downward through all their joints and pores, and that these waters, passing onward and soaking inte the permeable parts and minerals in the gangue of the veins, have there deposited their silver eontents, the rarious forms of carbon present in the sedimentary rocks having har some influence in effecting this precipitation. The presence of the soft talcose and the various chloritic materials in this comnection he regards as favorable to this assumption.

\section{GOLD ORES.}

Low-grade, free-milling gold-quartz ores have a widespread distribution in the Lake Superior region. The best known of them are the Rainy Lake deposits, the Ropes gold mine in the Marquette distriet of Michigan, and many gold prospects on the northeast shore of Lake Superior, including the Grace mine near Michipicoten. The gold-benring quartz veins of Ontario are principally in the Laurentian and to a less extent in the Keewatin series. Coleman ${ }^{b}$ classifies them as follows (his "Huronian" includes Keewatin):

1. True fissure veins.

a. In granite and gneiss.

$b$. In Huronian massive or schistose rocks.

2. Bedded, lenticular, or segregated veins.

a. In gneissoid rocks.

b. In Huronian schists.

3. Contact deposits between granite or gneiss and Huronian rocks.

4. Fahlbands iu II uronian schists.

5. Dikes of porphyry or felsite with associated quartz, mainly in IIuronian rocks.

6. Eruptive masses.

7. Placer deposits of Pleistocene age.

The Rainy Lake and Michipicoten gold ores are mainly in rocks of the Lanrentian scries. Though containing rich shoots, the ores are as a wholr of low grade, yielding less than $\$ 12$ a ton, and their mass is not large enough for profitable mining of ores of this grade. A large number of mines and plants have been equipped at much expense for the mining and extraction of these ores, but thus far none have apparently been put on a reasonably profitable basis. Mfining began in 1891 and reached its maximum in 1899, since which it has waned and is now almost abandoned.

Gold mining on the northeast side of Lake Superior is yet in the explorntory state, nocorsiderable shipments having been marle. 
The total production of goll in Ontario since 1891 has been $\$ 2,281,292 .^{a}$

like the wold ores of the north shore of Lake Superior, the ores at the Ropes mine consist of metallic gold in quartz veins in peridotite in the laurentiun rocks. Their grade is low and it is coublful whether there has been a profit on the ore taken out. Mining was conducted intermittently at the Ropes mine from 1882 to 1897 . During this period of activity the mine producerl rold (with some silver) to the value of about $\$ 6,50,000$. Since that time some gold has been taken out of the tailings.

$\Lambda$ small amount of gold has been taken out of similar quartz veins in the peridotites at the Michigan minc, about 3 miles west of the Ropes.

a Report on the mining and metallurgical industriles of Canada, 1907-8, Dept. of Mines, 1905, p. 307. 


\section{CHAPTER XX. GENERAL GEOLOGY.}

\section{INTRODUCTTON.}

In the early chapters of this volume the general geography and physiography of the Lake Superior region have been treated, and a history of the development of knowledge concerning the region, as well as the views of various authors, has been given. In the chapters on the individual districts have been considered the geologic succession, topography, deformation, and the lithology, metamorphism, relations, and thickness of each of the formations. Also the formations have been classified by groups and series, and the relations of these groups and series have been discussed. Finally, a résumé of the geologic history of each district lias bcen given. In short, each chapter treating of a district is substantially independent, giving briefly a complete discussion of the geology.

It therefore remains for this closing chapter to consider the broaler features of the Lake Superior geology, and especially the comparative features. The fumdamental thought of this chapter will be the comparison of the different districts with one another from several points of view. This comparison will be essentially confined to the principal ore-producing districts which have been studied in detail by the United States Geological Survey. Several outlying areas, including nortli-central Wisconsin and the Baraboo and Mimnesota River districts, are so isolated that attempts at correlation are largely speculative in the present state of knowledge. These districts, therefore, will be referred to only incidentally in the following discussion, and the reader is referred to Chapters IX and XIV for the available information concerning them.

In Bulletin 360 of the United States Geological Survey the reasons are fully given which lead to the major division of the pre-Cambrian rocks into Archean and Algonkian. The discussion leading to this conclusion will not be here repeated. Those who are interested in it may refer to that volume. ${ }^{a}$ The general succession of series of the Lake Superior region proposer by the Uniterl States geologists has been agreed to by an international committee of geologists. (See p. 84.) This suecession has been established in the Lake Superior region since 1904. It has now been found to apply to parts of Canada, and has been recently applied by Arlams ${ }^{b}$ to the entire Canadian shield. But Canadian geologists have not grouped the series into the major systems of Archean and Algonkian, as has been done for the Lake Superior region.

It remains to distribute the formations that occur in each of the districts of the Lake Superior region between the broader divisions of Archean and Algonkian, and to correlate the series and, so far as possible, the formations which occur in one district with those found in another. Our classification and correlation of the Lake Superior pre-Cambrian rocks are given in the accompanying table.

\section{PRINCIPLES OF CORRELATION.}

The lowest rocks foumd in the region are those of the Archean system or basement complex, consisting of the Keewatin and Lanrentian series, with their characteristic features and relations. This system gives us a horizon from which to work upward. At the top of the preCambrian is the Kewecnawan series, which occurs mainly in a great continuous area, and which gives us a horizon from which to work downward. Between the Arehean and the Keweenawan

a Van Hise, C. R., and Leith, C. K., The pre-Cambrian geology of North America: Bull. U. S. Geol. Survey No. 360,1909, pp. $19-25$.

b Adams, F. D., Jour. Geology, rol. 17. 1909, pp. 1-2. 
is the lluronian series. The Keweenawan and Iluronian series together make up the Algonkian system. In certain districts the lluronian is separable into three divisions, marked by nnconformities; in other clistricts it is sepanable into two divisions, and in still other districts it is not ret divisible. The most serious questions therefore arise in the correlation of the Huronian formations of the several tist ricts.

In correlating the Ifuronian rocks the following principles are used:

1. Relations to series or groups of known age; that is, to recognized horizons. In using this eriterion the relations of the Ihuronian to the Arehean and to the Kewernawan are especially lolpful, for these rocks are readily recognizable and afford datum planes from which to work up and lown. The upper Huronian (Animikie group) adjacent to Lake Suprrior, being continuous through so much of this region, is also very lielpful as a recognizable datum plane.

2. Ineonformities. The uneonformities between the divisions of the Iluronian are of great ansistance in correlation. Where all of the Iluronian is present, separated ly two unconformities, there is naturally no difficulty in separating it into lower, mickile, and upper. Where, however, the Juronian has only one unconformity or where in a disconnected district only one division of the Huronian is present, the unconformities fail to be a determining factor.

3. Lithologie likeness of the formations. This criterion is of assistance, but it clearly has serere limitations, because again and again the geologic conditions have been the same, producing like formations at different times. This is illustrated by the remarkable similarity of the iron-bearing formations of the upper Iuronian, midlle Huronian, and Archean. The natural belief that they were of the same age long acted as a bar to progress.

4. Like sequence of formations. Similar sets of formations in the same order are of much greater importance as a criterion for correlation than the likeness of single formations. But conditions producing similar sets of formations hare frequently recurred during geologic time. For instance, when a sea transgresses orer a land area, there are normally formed in order a psephite, a psammite, a pelite, and a nonclastic formation.

5. Subaerial or subaqueous origin. Closely connected with the thind and fourth criteria is the question whether the deposits were formed under air or uncer water. It is clear that the conditions of the formation of these two classes of deposits are so different, and therefore the nature of the formations which may be contemporaneous so variable, that there is difficulty in correlating the two. Also it is plain that the difficulties in correlating disconnected continental deposits are searcely less great. On the other hand, the correlating of subaqueous deposits with one another is relatively easy.

6. Relations with intrusive rocks. The older the series the more intricately it is likely to be cut by intrusive rocks, and this relation is of assistance in connection with the other criteria. However, as there have been igneous intrusives, both acilic and basie, in great quantitios up to middle Keweenawn time, this criterion has relatively small utility in the correlation of the Lake Supcrior Huronian.

7. Deformation. The amount and nature of deformation are of assistance in correlation. On the whole the okder the series the greater and more intricate the deformation. Thus in this respect the Archean rocks exceed all later series. The Keweenawan is much less deformed than the other pre-Cambrian series. But the differences in deformation of the Huronian divisions may not be so marked in a single district as to give important assistance in the discrimination of these divisions from one another. Also a particular division of the Huronian may be much deformed in one distriet and not in another.

$\therefore$. Degree of netamorphism. The degree of metamorphism is of some assistance in colrelation. On the whole the older rocks are more metamorphosert than the younger rocks, but this criterion has limitations, since within comparatively short distances the closeness of folding and the quantity of ignoous intrusions may greatly vary, and these are very important factors in producing metunorphism.

The eriterion relied on more than all others in the correlation of the cambrian and post('ambrian formations - that of fossits, showing similarity of the life on the earth at the tine the apuated formations were laid down- is not avainable for the pre-cambrian rocks of the 


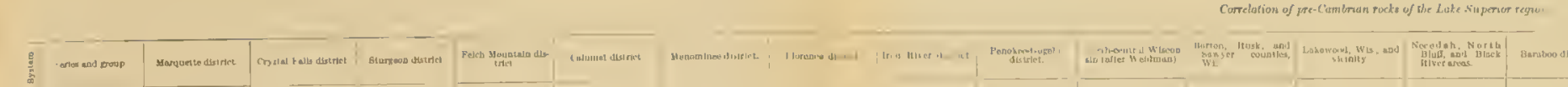

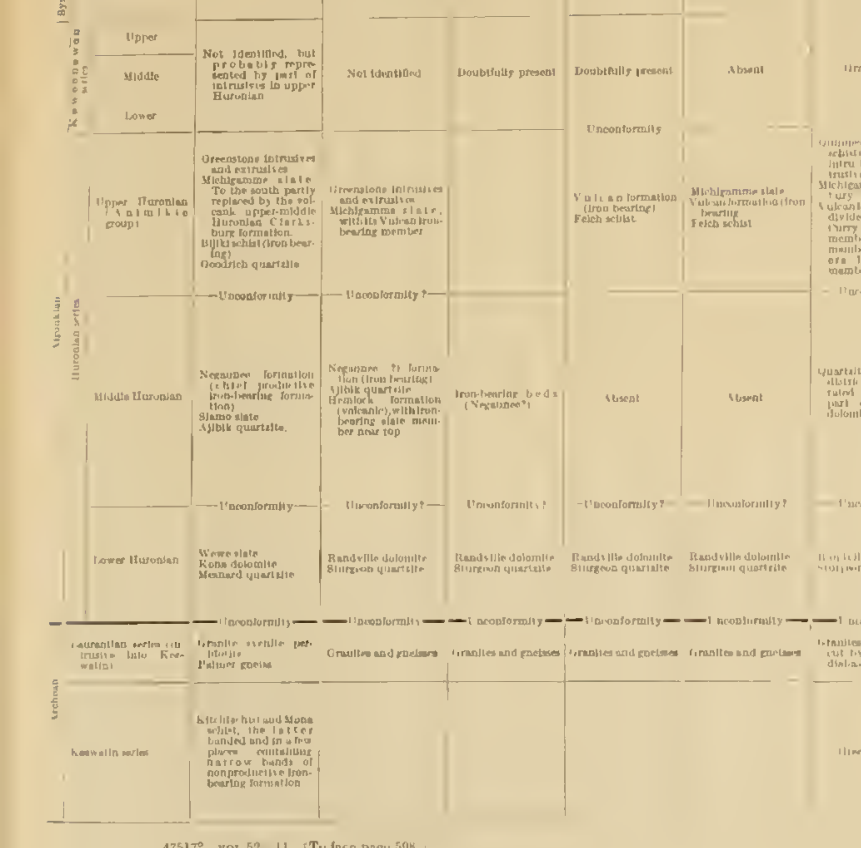

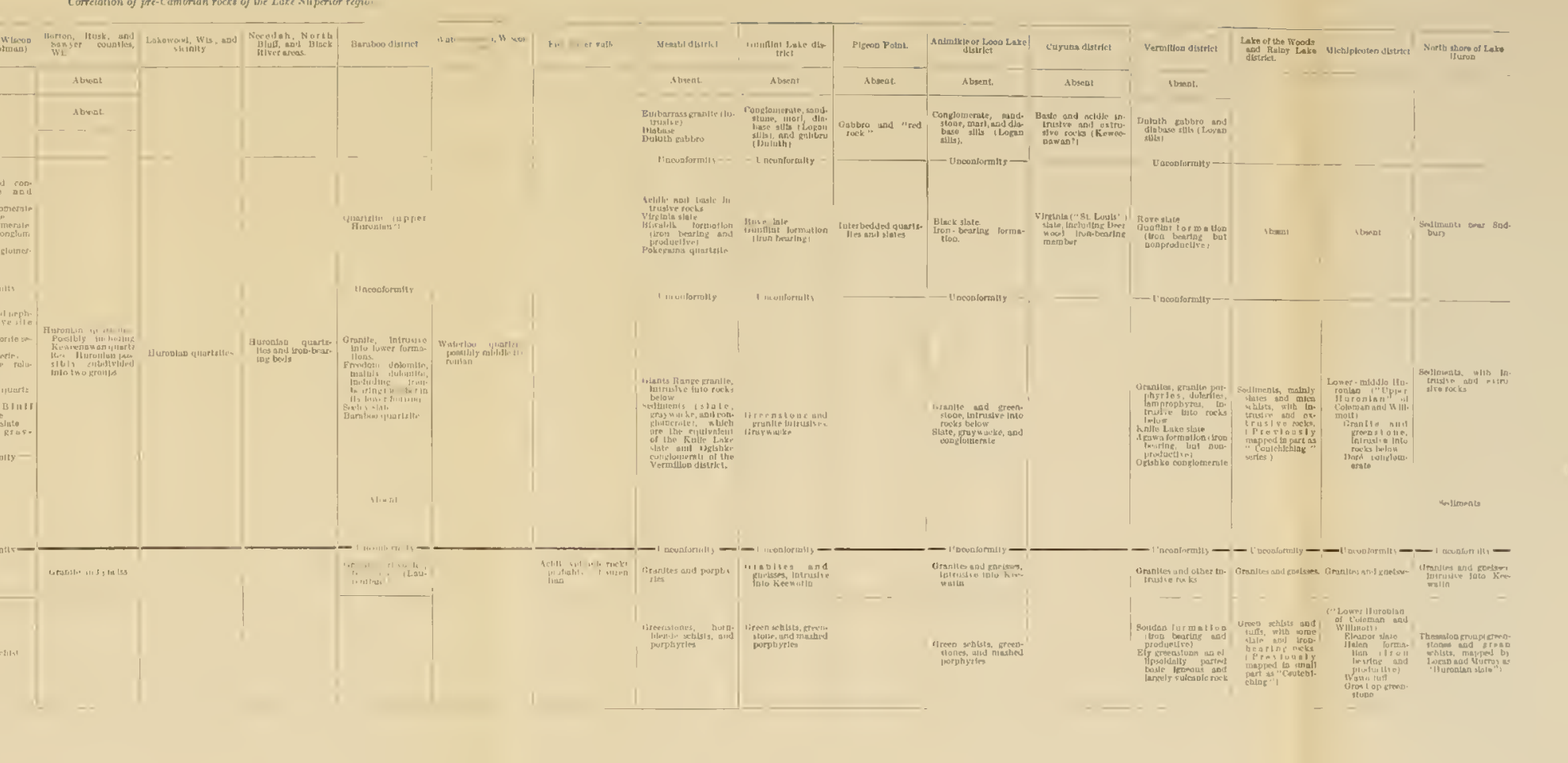



Lake Superior region. Recognizable fossils have not yet been discovered in these rorks, although the carbonaceous slates which extend back to the Archean seen to show that life existerl at the time of the earliest pre-Cambrian series.

The correlation of the pre-Cambrian rocks is not as definite as that for fussiliterous rocksa fact which makes it desirable to retain loeal names to an extent not warranted were fossil evidence arailable. The use of loeal names is desirable in this region also for the reason that the districts in which they are applied are separated hy consilerable areas that are much less known. The geologist or mining engineer is seldom interested in the general correlation of formations and fimls it convenient to have local terms which have areal as well as stratigraphic significance. Local terms have been used in the six preceding reports on this region by the United States Geologieal Survey, have become permanently entrenched in the literature, and are known and understood by the local mining men. To discart these terms in favor of more general terms would, it is believed, introtuce confusion and perhaps ragueness. At some future time, when explorations shall have marle the areal comection so definite that there can be no question about correlation, a sweeping change in nanes might he introducel to adrantage. At present, with so many unsolved problems and with possibilities for changes in views of correlation, there can be little advantage in substituting general names, even for formations whose correlation is regarded as reasonably well established.

\section{GENERAL CHARACTER AND CORREIATHON OF TIFE ARCHEAN.}

The Archean system comprises the Keewatin series and the Laurentian series.

\section{KEEWATIN SSERIES.}

The Keewatin series, wherever it is found in a relatively unchanged condition, is remarkably uniform in its general character, and even the portions that have been metamorphosed show features that are consistent with the theory that before metamorphism they had the same general character as the less altered portions. The Keewatin comprises two great formations, a dominant igneous formation and a suborlinate sedimentary formation. It is found in its most typieal facies in a comparatively malteres condition in the Vermilion and Lake of the Toods clistricts. The characterization of the Ely greenstone for the Vermilion district, given on pares 119-122, might be applied to each of the other districts without important changes. The Keewatin is a great volcanic series, composed dominantly of basalts and intermediate rocks. For all of these regions where the rock is lava and is least metamorphosed, a peculiar ellipsoilal or pillow structure is characteristic. It has been pointerl out (see pp. 510-512) that this strueture and the relations of the Keewatin to the iron-bearing rocks are evilences that the eruptions were at least in part subaqueous. Associated with the lavas are vast quantities of voleanic fragmental rocks. In some listricts - for instance, the Marquette and the Nlenomineethe tuffaceous variety of greenstone appears, but the ellipsoidal structure is not conmon. Ifowerer, in these districts the Reewatin is much metamorphosed by dynamic action and by later intrusions, so that the ellipsoidal structure would have been largely destroyed even if it once existed, as it has been where the Keewatin rocks lie close to similar large intrusive masses on the north shore. Barring the changes due to metamorphism, there is a very remarkal,le likeness of the dominating igneous portion of the Keewatin in the different parts of the Lake Superior region.

Associated with the igneous roeks of the Keewatin are suborlinate masses of serliments. These seliments eomprise slates, iron-bearing formation, and dolomite. The slates that have been metamorphosed are so similar to the schistose phases of the greenstone itself that they are in places difficult to recognize. They have been found in almost every district. The iron-bearing formation is the prominent sedimentary one in the Vermilion, Atikokan, Kaministikwia, and Michipicoten districts. It occurs vely subordinately in the Marquette district. In the Lake of the Woods district the iron-bearing formation has not been found, but small masses of dolonite occur. In all the districts the iron-bearing formation and the clolomite are 
associated with the slates. It is believed that in areas where these sedimentary formations are of consilerable extent and thickness they represent later liepwatin time. The chicf reason for this belief appears in the Vermilion district, where the iron-bearing formation is thick and large masses of it oc'ur aljacent to the Huronian, in both the Lake Vermilion and the Ely areas, showing that the main mass of this formation was at the top of the series at the beginning of Huronian sedimentation.

The kicewatin is the oldest series in the Lake Superior region. It is dominantly rolcanic. Moreover, the lavas were poured out mainly bolow the water. Thus for the carliest time of which we have record in this region the surface conditions were those of submarine, regional rolcanisu. Sedimentation was local and subordinate, and the sediments of the Feewatin are believed to have a close genetic connection with the associated voleanic rocks. (See pp. 126-127.)

The Keewatin locally is schistose and the original textures and structures are discernible with difficulty. Where not schistose the lieewatin may be separated into distinct lava flows and beds of pyroclastic rocks, with interlenved sedimentary beds for which strike and dip are determined. The folding is usually close and the beds stand at steep attitudes. Topographically the Keewatin, though rough in detail, has on the whole less bold relief than the Algonkinn sediments. The schistose phases are in general less resistant to wathering and stand fower than the massive phases. The lieewatin occupies a part of the great Archean peneplain.

\section{TAURENTIN SERIES.}

The Laurentian series is dominantly represented by great masses of granite, granitoid gneiss, and syenite-all acidic rocks. Intermediate and basic rocks are subordinate. The Laurentian intrudes the Keewatin series, the intrusive masses ranging from great batholiths many miles in diameter to dikes and minute injections, even to "lit par lit" intrusions. The great batholiths are perhaps best illustrated and have been most accurately described for the region north of Lake Superior, particularly near Lake of the Woods and Rainy Lake, by Lawson. ${ }^{a}$ These intrusive rocks, in connection with the concurrent dynamic action, have produced profound metamorphic effects in the older Keewatin rocks, which in consequence have been changed over extensive areas to hornblende schist and homblende gneiss. In many considerable areas the Keewatin and Laurentian are so intimately mixed that it would be difficult to give an estimate of the relative proportions of the two. In some places there is evidence that the Keewatin has actually been absorbed to some extent and thus modified the composition of the Laurentian intrusires. This, combined with the intricate relations along the contacts of the two formations, gives locally an appearance of gratation from the massive Laurentian granite through the gneiss containing various mixtures of intrusive and intruded rocks to the extremely metamorphosed rariety: These facts hare led Lawson ${ }^{b}$ to his theory of subcrustal fusion, according to which all the acidic material is but the fused lieewatin. From our point of view, bowever, the evidence for such a conclusion is inalequate, the most fundamental point against its correctness being the rery great difference in chemical composition of the Laurentian and Keewatin. Where not influenced br each other, the Laurentian has the chemical composition of ordinary acidic igneous rocks, whereas the Keewatin has the average composition of a basie rock of the basalt type. If, as Daly ${ }^{-c}$ suggests, the Lamrentian is supposed to have invaded the Keewatin by a process of overhead stoping and the stope blocks have sunk, the contrast in composition near contaets is explained. In the nature of the case, evidence for this kind of suberustal fusion is diffieult to obtain, and so far as the Lake Superior region is concerned this hypothesis may be noted merely as an interesting guess.

L Lawson, A. C. Report on the reology of the Lake of the Woods regton, with spectal reference to the Keerratin (lluronian) belt of the Archean rocks; Ann. Rept. Geol. and Nat. 11 ist. Survey Canad: for 1sm5, new ser., vol. 1, 1kst, pp. 5-151 cc, with geologlc ninp; Report on the

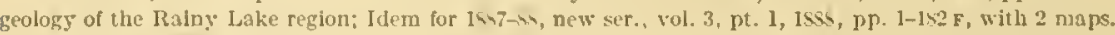

0 Op. dt., $1 \mathrm{~m}$, p. $131 \mathrm{~F}$

c Daly, R. A., The mechanics of igneous intrusion: Am. Jour. Sci., 4th ser., vol. 20,1905, p. 30. 
The Laurentian of the Lake Superior region as a whole is characterized by both massive and schistose phases. It is perhaps surprising that so large a proportion should be massive. It is topographically rough in detail, the massive parts usually standing somewhat higher than the schistose parts, but altogether it forms a part of the Archean peneplain.

\section{GENERAL STATEMENTS CONCERNING THE ARCIEAN SYSTEM.}

Both Lumrentian and Keewatin rocks appear in each of the important districts that have been considered in the detailed chapters. Minifestly the wide and irregular distribution of the Archean is a natural consequence of the fact that these rocks constitute the basement complex upon which later formations were laid down. Whether or not they are now at the surface at any particular locality depends on subsequent deposition, folding, and denudationthat is, it depends on whether geologie ageneies have brought them to the surface.

If, in the future, erosion should cut the Lake Superior region to a depth of several thousand feet below the present surface, it woukd probably be seen that much the larger part of the area would be occupied by the Archean, and it is believed that the Archean everywhere underlies all la ter rocks.

It appears from the foregoing characterization of the Feewatin and Laurentian that the Archean as a whole was a period of regional igneous activity. All succeeding series contain sedimentary rocks in large or dominant proportions; they are treated essentially as sedimentary series and the igneous rocks are considered with reference to the sediments. In the Archean, on the other hand, the igneous rocks, which make up more than 90 per cent and probably more than 95 per cent of the area, are primarily considered, and the subordinate masses of sedimentary rocks are discussed in reference to the igneous rocks.

The igneous activity of Archean time was both plutonic and volcanic on a tremendous scale. Probably at present the plutonic igneous rocks of the Archean oceupy a much larger area at the surface than the voleanic rocks, but this is doubtless due in large measure to the very profound erosion which has taken place since Archean time, and which has in considerable measure removed the voleanie rocks and exposed the plutonic rocks.

A very characteristic feature of the Archean of the Lake Superior region is its likeness from one district to another, and this is so whether the lithologic types of rocks or their relations are considered. The foregoing description of the intrusive relations between the Laurentian and Keewatin is applicable with searcely a change to each of the several districts. If a set of specimens from the Laurentian or Keewatin south of Lake Superior were unlabeled, they could not be discriminated from a set of specimens from the Arehean northwest or east of the lake. There are, of course, some exceptional types of rocks which oceur only locally, but these are extremely subordinate in their mass. This extraordinary parnllelism of phenomena of the Archean of one part of the Lake Superior region with that of another part-and, for that matter, with the Archean of other parts of the world-has led to the phrase that the Arehean is "homogeneous in its heterogeneity" - that is, while it is heterogeneous for any one district, it shows the same kind of heterogeneity in each of the other districts.

Topographically also the Arehean is a mit. Though rough in detail it is a great peneplain, the irregularities of which do not constitute regular lineaments, and it is thus in contrast to the Algonkian rocks, part of which usually stand above the peneplain surfaces with conspicuous linear features.

Whether or not it is generally accepted that the Archean, as the term is here used, can be safely correlated with similar rocks of other geologie provinces, it can hardly be doubted that the Archean rocks of the different districts of the Lake Superior region form parts of a single great system. This conchusion is supported by substantially all the criteria in reference to correlation given on pages 597-599. The system wherever it occurs is in a basal position. It rests unconformably below all the series with which it comcs into contact. The general lithologic likeness of the heterogeneous mass is remarkable. The Keewatin rocks are largely submarine. The complexity of intrusives is greater than that in any other series. The deformation is 
greater than in other pre-Cambrim series. The metamorphism is profound. Similarity of sepuence of formations in different ureas of the Keewatin is lacking, hut in place of this are the prevalent intusive relations which exist betwern the Keewatin and Laurentian.

It is of interest to note that the ohlest recognized Archean rocks are basalts, with textures indirating both sulnqueous and subactial extrusion. 'The bascment upon which they rest has not been identifiod. It is natural to tum to the Laturentian granites and gncisses, but whererer these are fouml in contact with the Keewatin they are intrusive into it. Whether some parts of the Laurentian represent the original basement or whether the lanrentian as a whole has formed the basement and has been subsequently fused, there is no cridence to show.

\section{GENERAL STATEMENTS CONCERNING THE ALGONKIAN SYSTEM.}

\section{CHARACTER AND SUBDIVISIONS.}

The Algonkian system on the whole contrasts with the Archean in being dominantly sedimentary rather than dominantly igneous, in being less metamorphosed, in having distinctlyrecognizable stratigraphic sequence, and in topography. The serliments are largely water assorted and deposited but in part are probably subaerial. The iron-bearing formations are regarded as having an exceptional character, being derived partly from submarine rolcanic rocks either in magmatic solutions or by the reaction of hot volcanic material with sea water. or both. (See p. 516.)

The Agonkian system comprises in its fullest development in the Lake Superior region four unconformable divisions-lower IHuronian, muldle Juronian, upper Huronian, and Keweenawn. The Keweenawan series is essentially a unit geographically and lithologically and is considered as such in the following discussion. The Huronian series, especially the lower and middle Huronian, presents such rariation in lithology and succession as to require its consideration under two main geographic subprovinces-(1) the northern subprorince, including the north shore of Lake Supcrior and westwarl extension into Minnesota, and (2) the southern subprorince, including the Gogèbic and Marquette districts of the south shore of Lake Superior and the continuation of this belt eastwarl to the north shore of Lake Huron, and the Mlenominee, Crystal Falls, and Iron River districts of Michigan.

\section{NORTHERN IURONIAN SUBPROVINCE.}

\section{LOWER-MIDDLE HURONIAN.}

LITHOLOGY ANI SCCCESSION.

The Huronian rocks unconformably above the Archean and unconformabiy below the upper Huronian (Animikie group) of the north shore of Lake Superior are cxtensive and thick. The unconformities above and below are great. At many places the comparatively flat-lying Animikie group may be seen resting upon the stceply inclined or rertical truncated edges of the mickle or lower Huronian. The latter rocks consist mainly of conglomerates, graywackes, slates, and mica schists. In some places it is possible to divide them into two formations, the lower consisting dominantly of conglomerates and the upper dominantly of grarwackes and slates and their metamorphosed equivalents.

The most characteristic and widespreat of these rocks are the conglomerates of the lower formation. Those which lie near the subjacent rocks from which they are derived are commonly coarse bowlder conglomerates. Their fragments rary in lithology, depending on the underlying formation. They may be lominantly from granite, from greenstone, or from gueiss. or mixtures of these three in rurious proportions and also with other materials. Many of the conglomerates at higher horizons have a fine-gramed matrix. Some of them have a slate matrix through which very numerous isolated pebbles and lowklers ane suattered in an irregular manner. 'These have heen called slate conglomerates. In certain localities the 
slate couglomerates are the only rocks found. Associated with the slate conclomerates in many places are heds of well-laminated slate and schist.

As has been intimated, the upper formation consists commonly of pelites. The most extensive areas of pelite are those of the Termilion, Rainy Lake, and IIunters Island listricts.

At the west end of the Vermilion district, between the conghmerate (there callect the Ogishke conglomerate) and the slate (known as the linife Lake slate) is a thin iron-bearing formation (called the Agawa formation) which appears to grade toward the southwest into a calcareous slate. The latter is the only known representative of a limestone in the lower or midlle IIuronian of the northern subprovince. At this particular loeality the succession is in rertain respects similar to that of the midlle Ituronian of the Marquette distriet, but by far the greater areas and masses of these rocks in the northern subprovince exhibit noclose analogy in succession or lithology with either the lower Iluronian or the mildle Huronian of the south shore.

IGNEOUS ROCKS.

During the time of the deposition of the rocks under discussion there were very great outbreaks of igneous rocks, basic and acidic, plutonic and volcanic. Contemporaneous volcanic detritus is mingled in varying proportions with ordinary sedimentary material, from a subordinate to a dominant amount, as at Kelkekabic Lake. The contributions of volcanic material were so great as to make them quantitatively very important. Some of the larger of the plutonic masses are the intrusive granites in the Mesabi and Vermilion districts. The slates that have been intruded by great masses of granites and have been deformed have become pelite sehists (mica schists). This phase is extensively illustrated in the Raing Lake and Namakan Lake areas. The conglomerates under similar circumstances are metamorphosed to psephite sehists or gneisses, as illustrated by the schistose conglomerates adjacent to the Snowbank granite in the Vermilion listriet.

\section{CONDITIONS OF DEPOSITION.}

Coleman ${ }^{a}$ holds that the lower Huronian slate conglomerate at one locality in the Cobalt distriet of Ontario is a glacial till. Ile points out the likeness of the great masses of the slate conglomerate to modern glacial till and to the Dwyka glacial deposits of South Africa, and concludes that they are all till. IIowever, even if the glacial origin of the conglomerate-bearing striated and grooved bowhlers at Cobalt is accepted-geologists are not all agreed as to thisit does not follow that the Ifuronian conglomerate of the northern subprovince as a whole is of this origin, because, among other reasons, the Cobalt area is a long way east of the Lake Superior region.

Whether or not Coleman's conclusion as to origin applies to the lower-middle IIuronian in this subprovince, it is regarded as likely that these rocks are essentially of terrestrial deposition because of their unassorted character, being made up principally of conghomerate and graywacke, lacking quartzite and limestone; because of the recurrence of eonglomerates at many horizons through several hundred feet; because the extensive conglomerate beds, like the Ogishke, have a thickness and extent which are more easily explained ly terrestrial than by subaqueous sedimentation, which, according to Barrell, ${ }^{b}$ is not likely to produce conglomerates over 109 feet thick; and finally because the part of the lower-middle Huronian nearest the granite or greenstone of the Archean is locally a recomposed rock, which has not beeu sorted

\section{CORRELATION。}

The criteria under which the formations under discussion are classed as middle or lower Huronian are the following: They rest upon the Archean and are below the Animikie group. or upper IIuronian; they are separated from these rocks by unconformities: they are exten. sicely cut by both basic and acidic igneous rocks; they are similar in their delormation and

a Coleman, A. P., The lower Huronian ice age: Jour. Geology, rol. 16, 190s, 1) 154.

$\checkmark$ Barrell, Joseph, Relative geological importance of continental, littoral, and marine sedimentation: Jour. Geology, rol. 14, 190is, pp. 433-446; also personal communication. 
degree of metamorphism. It thus appears that the assignment of the rocks under diseussion to the general place of lower Huronian and middle Huronian is unquestioned. But as large portions of these rocks may be land formations, they can not be exactly correlated with the aqueous deposits of the middle and lower IIuronian to the south. The deposition of land sediments may well have begun earlicr than that of the aqueous deposits or it may have continued later. On earlier maps published hy the United States Geological Survey the rocks lere named lower-midlle IJuronian appear as lower Iluronian. As earlier continental deposits are likely to be removed Iy later crosion, however, it is probable that part, probably the larger part, of these rocks are of middle-Huronian age. It has alrearly been noted that in northeastern Winnesota there is a similarity in succession to the middle Huronian of the Marquette district.

\section{UPPER HURONIAN (ANIMIKIE GROUP).}

\section{IITIOLOGY ANI SUCCESSION.}

The upper Huronian of the northern subprovince extends from a point some distance east of Nipigon Bay, on the north shore of Lake Superior, westward through Thunder Bay to the Mesabi district of Minnesota, thence southwest and sonth to the Cuyuna, Little Falls, Cartton, Cloquet, and St. Lonis River districts of Mimnesota. The belt extending from Nipigon Bay ro the Mesabi district consists from the base up of the following rorks:

1. Conglomerate, quartz slate, and quartzite. These reach a thickness of 200 feet on the Mesabi range. Farther east, in the vicinity of Gunflint Lake and Thunder Bay, the thickness becomes only a few inches or a few feet.

2. Iron-bearing formation, 700 to 1,000 feet thick in the Mesabi district and thimning somewhat toward the enst and west.

3. Slate, best exposed in the Thunder Bay district. Thickness unknown, but large.

Throughout the northern part of this belt the sediments are gently inclined to the south at angles ranging from $5^{\circ}$ to $20^{\circ}$ and locally even up to $45^{\circ}$, with pitches of gentle minor folds in the same direction. In general the upper Huronian is not schistose but has suffered contact metamorphism where it is in contact with the Keweenawan gabbro and granite and other large intrusive masses. It rests unconformably against the older rocks to the north, the unconformity being marked by areal relations, differences in steepness of dip, amount of schistosity, kinds of metamorphism, relations to intrusive rocks, basal conglomerates, and topography. The unconformity is one of the most conspicuous in the Lake Superior region. The line of contact is easily recognized by casual field observation. That the essential continuity of the upper. Iuronian is obvious is indicated by the early use of the term Animikie not only for the upper Huronian rocks on Thunder Bay, but for those in the Mesabi district.

In the area southwest of the Mesabi district, in the St. Louis River and Cuyuna districts and the country to the west, the upper Huronian consists principally of slate, carrying lenses of ironbearing formation, with many intrusive and possibly extrusive rocks and certain rare quartzites, the horizon of which is not satisfactorily determined but which are probably basal to the division. The upper IIuronian in this area contrasts narkedly with that along the Mesabi range and farther east in being closely folded, in the abundance of its intrusive rocks, and in possession of cloarage, as well as in the differences in lithologie churacter just noted. It is suggested (pp. 214, 528, 611) that the structural differences may be related in some way to proximity to the axis of the Lake. Suprerior syncline, or that the Mesali and eastward belt of the upler Huronian may represent a shore phase of deposition, while the upper Ifuronian of the Cuyuna area to the south may be an oflshore phase.

\section{IGNEOUS ROCKS}

Intrusive into the upper Huronian are the great Duhuth gabloro of northern Minnesota, the basic sills of the Gunflint and Animikie Bay distriets (Logan sills), a fow basic dikes and possibly sills in the Mesahi district, a granite mass on the east end of the Mesabi range, and 
more abundant basic and intrusive masses in the Cuyuna district. Jost of the intrusives are of Keweenawall age. Contemporaneous voleanie rocks have not been recognized.

Extrusive roeks rest on the Animikie in the Cuyuna district. It has been slown that many of the eapping diabases of the Nipigon area may be extrusive. These are doulstless middle Keweenawan, but some of them may be late Aninikie.

CONDITIONS OF DEPOSITION.

The upper Huronian is a unit for the region, hence the conditions of deposition are discussed on pages 612-614, after the southern subprovince has been treated.

CORRELATION.

The correlation of the upper Huronian of the northern subprovince with that of the southern subprovince is discussed on page 610 .

\section{SOUTIIERN IIURONIAN SUBPROVINCE.}

LOWER HURONIAN.

LITIOLOGY AND SUCCESSION.

The lower Huronian of the southern subprovince reaches its fullest development in the Marquette district, where it consists, from the base up, of the Mesnard quartzite, Kona dolonite, and Tewe slate. In the Gogebic district the lower Huronian includes similar quartzite and dolomite named respectively the Sunday quartzite and the Bad River limestone, but the slate overlying the limestone is absent.

Althongh the north shore of Lake Huron does not fall within the area covered by this report, it is desirable to consider the position of the series there because that is the district to which the term IIuronian was first applied. The lower Huronian of the north shore of Lake Huron includes a great clastic formation above which is a limestone. In most places the clastic formation comprises a conglomerate at the base, above this a quartzite, and above this a slate. In other places the conglomerate is almost immediately overlain by the limestone. The succession is very similar in its essential features to that of the lower Huronian of the Marquette distriet.

The lower Huronian is represented in the Menoninee, Iron River, and adjacent districts of Michigan and Wisconsin. It consists of a quartzite (the Sturgeon quartzite) followed by a dolomite (the Randville clolomite); but in the Iron River district the quartzite and dolomite are interbedded and for them the new name Saunclers formation has been introduced.

The lower Huronian partakes of the major structure described for each of the districts. As a whole the folding is not as intense as in the Archean. Cleavage is usually lacking, jointing is abundant, and bedding is easily discerned.

The quartzite of the lower Huronian of this subprovince represents a cleanly assorted sand, now strongly indurated, more or less iron stained, and locally showing fracturing and rock flowage, but retaining its original bedding structure as a conspicuous feature. It therefore contrasts in many respects with the lower Iuronian of the northern subprovince. The clolomite overlying the quartzite is very cherty and shows more evidence of deformation than the quartzite. The weathering of this dolomite emphasizes the folded and brecciated ehert layers and serves to make the formation easily irlentifialsle.

IGNEOUS IROCKS.

In the areas which are certainly known to be lower IIuronian, contemporaneous igneous activity was not important. This applies to all the distriets south of Lake Superior, as well as to the area north of Lake Huron. In this respect the lower Huronian contrasts with the miclle and upper Huronian and to a more narked degree with the Archean. The contrasts between 
the Arehean and the lower IJuronian in this respect are contributory eridence of the unconormity between the two. (See Pr. 617-(i18.) The volcanic activity of Archean time apparently had died out completely in this ITuronian subprovince before the deposition of the rocks uncuestionably belonging to the lower Ihuronian.

Later intrusive rocks cut the lower Huronian in small dikes. The post-Ihuronian or Feweenam granites of the Florence distriet of Wisconsin doubtless also cut the low rer Huronian, but expesed contacts are only those of the gramite and upper Hurmian.

\section{CONDITIONS OH DLPOSITION.}

It has appeared that the lower I Iuronian south of Lake Superior and on the uorth shore of Lake Iluron comprises first a great (dastic formation consisting from the base up of conglomerate, quartzite, and slate. Over this is a largely uondastic formation now represented by a dolomite, and localy above this in the Ifarquette district is another clastic slate formation.

The essential subaqueous origin of the lower Huronian is believel to be shown by the cleanly assorted nature of the sedinents, the ripple marks of a shore rather than a stream trpe, and extensive beds of limestone. It remains to be proved that such thick and continuous limestone formations may be produced as terrestrial formations. Finally the conglomerate at whe base of the group contrasts strongly with the arkose abd thick conglomerate masses at the base of the middle-lower Huronian of the north shore, and is believed to be more characteristic of aqueous sedimentation.

It therefore appears that at the beginning of lower Huronian time the conditions in the southern subproviuce had become those of normal sedimentation in which the material destroyed by the epigene agents was sorted and laid down in berls one upon another. the lithologic cliaracter varying from time to time. This is evidence that the erosive forces of air and water were working as at present. Moreover, as emphasized by Chamberlin and Salisbury, ${ }^{a}$ it is evidence that the weathering processes possessed their full efficiency, and this would faror abundant regretation. ${ }^{b}$ With the beginning of IIuronian time at the latest commences the part of the history of the world to which Lyell's principles of uniformity ${ }^{c}$ are applicable. These ancient Huronian rocks have no lithologic peculiarity which can discriminate them from the rocks of much later age: indeed, there is nothing to indicate that when they were laid down the conditions were in any respect diflerent from those which prerail to-day, with the sole negative point that fossils liave not been found.

\section{CORRELATION.}

The Gogebic, Marquette, and original Ifuronian districts are approximately in an east-west. line and the prevailing strikes of the lower Huronian in all but the Crystal Falls and Iron River districts are in the same general direction, favoring the correlation of the rocks of the dillerent distrie'ts.

In each district the lower IIuronian rests with profound unconformity upon the underlying Archean or basement complex, the unconformity being maked where exposed ly diflerences in lithology, by metamorphism, and by the presence of a hasal conglomerate, and being shown also by the areal relations and relations to intrusive rocks.

The fower IIurnian is orerlain unconformably by the upper Ituronian (Animikie group) in all the districts, and by the midlle and "Iper IIuronian in the Marquette, Crystal Falls, original Thuronian, and Menominee districts.

The lower Iluronian of the southern subprovince has no counterpart in the northern subprovince, though it oreupres the same general position in the succession as the lower-midele Turonian of the northern subprovinee.

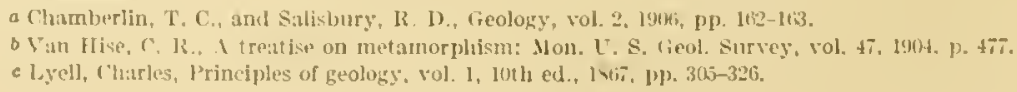


MIDDLE HURONIAN.

LITIIOLOGI AND SUCCESSION.

The middle IImonian is represented in the Marquette, original Huronian, Crystal Falls, and Ilenominee (listricts. In the Marquette district, where it was first discriminated and is best developed, it consists from the base up of the Ajibik quartzite, Siamo slate, and iron-Jearing Yegaune formation (nonclastic). On the nort th shore of Lake Huron the broader leatures of the middle Huronian are analogous with those of the Marquette district-that is to say, the rocks comprise a clastic fomation below, consisting of a conglomerate at the base and orel this a quartzite, both so thick and extensive that they have been mapped separately, and abore these clastic formations a cherty limestone.

In the Crystal Falls district the niddle Ituronian is represented principally by the rolcanic Ifemlock formation, contaning iron-bearing slate near the top. The iron-bearing Negaunee formation is doubtfully present; the Ajibik quartzite is present near the northeast eorner of the district, near the Mirquette district. Volcanism seems to have intervened leetween the deposition of the lower IJuronian and the npler Huronian, making lithologic correlation difficult. It is to be noted, however, that the Clarksburg volcanic rocks of the Marquette district began to be extruded in middle Huromian time, and these are therefore to be partly correlated with the Hemlock roleanic rocks of Crystal Falls.

In the Ilenominee district the middle IInonian is taken to be represented by rherty quartzite, heretofore not separated from the Randville dolomite of the lower IIuronian. There is evidence also in the jasper and iron pebhles in the conglomerate at the base of the mprer Huronian that an iron-bearing formation corresponding in position and character to the Neganne was present in the clistrict before upper IImonian time, but no remnants of this are now known.

IGNEOUS ROCKS.

In the Marquette distriet the midlle Ituronian is associated with part of the Clarksburg formation of basic intrusive and extrusive rocks. In the original Huronian district igneous rocks are lacking in the middle Huronian. The presence of igneous rocks in the middle Huronian of the Marquette district and their absence in the middle Huronian of the original Huronian district may perlaps be correlated with the presence in the former, and the absence in the latter, of an iron-bearing formation. (See pp. 506-507.)

Hemlock volcanic rocks form the principal part of the middle Huronian in the Crystal Falls district. In the Mlenominee district roleanic rocks are absent from the dirision. The Keweenawan (?) granites of Florence County doubtless also cut the middle Ifuronian, thongh they nowhere come into contact with it at the surface.

CONDITIONS OF DEPOSITION.

The extensive formations of elemly assorted, well-rounded, ripple-marked sands, now quartzites, of the miditle Huronian, both south of Lake Superior and north of Lake Ifuron, point towarl subaquenus deposition. The pure nonclastic iron-bearing formation south of Lake Superior and the cherty limestone formation north of Lake Superior point in the same direction. Still further is this shown ly the association of these rocks with partly subaqueous voleanic rocks of the Clarksburg formation. The iron-bearing formation and possibly some of the associated slates have a close genetie comection with some of the associated rolcanic rocks.

In the Crystal Falls district the middle Ifuronian was principally a time of extrusive rolcanism, partly subaqueous. The voleanic rocks are interbedsed with the slates and ironbearing rocks, subaqueously deposited. In the Henominee district the middle Huronian is represented only by shreds of quartzite and perhaps by the iron-bearing Negaunee formation. 
The quartzite is rery cherty, as if derived from decomposition of the Randrille dolomite, against which it rests. It is well bedded and well assorted. At one locality there secns to be a conglomerate with well-rounded bowlder's near its base.

On the whole the evilence favor's subaqueous deposition of the iniddle Huronian.

\section{COLIRELATION.}

The middle [Iuronian rocks in the Marquette and original Huronian districts are correlated on the basis of similar succession of clastic and nonclastic rocks, similar relations to the lower Ifuronian, similar east-west trend, similar netamorphism, and the fact that they are subaqueous in both districts. They differ in that the nonclastic formation of the Marquette distriet is an iron-bearing formation and that of the original Ifuronian district a limestone, that associated igneons rocks are present in the Marpuette district and not in the original IIuronian district, and that in the Harquette district the overlying rocks are upper Huronian and in the original Huronian district no upper Huronian is present, althongh to the northeast in the Sudbury basin rocks probably to be correlated with the middle Hurqnian are overlain unconformably by rocks with upper Iuronian characteristics.

The middle Iluronian of the Crystal Falls district, being largely volcanic, may be correlated lithologically with the lower part of the Clarksburg formation of the Marquette district. So far as the Ajibik and Negaunee formations are present in this district they are correlated directly with formations of the same names in the Marquette district. They occur, howerer, in the northeast corner of the Crystal Falls district, the area nearest to the Mlarquette district, and the correlation is of little aid in correlating the middle Huronian as a whole. The middle Huronian of the Crystal Falls district is principally a great assemblage of roleanic rocks lying between the lower Huronian and upper Huronian and differing from the dominantly sedimentary middle Huronian of other districts. Its correlation is therefore based principally on its position in the geologic column.

The midlle Huronian of the Menominee district is correlated with the middle Huronian of other areas almost entirely on the lasis of its stratigraphic position, unconformably above the lower Huronian and unconformably below the upper Huronian. As it consists only of a remnant of quartzite, lithologic comparison with the middle Huronian of other districts is of no villue.

The equivalents of the middle Huronian have not been identified in the other districts of the Lake Superior region, though it is possible that future work may result in its identification in the Florence and Iron River districts.

UPPER HURONIAN (ANIMIKIE GROUP).

LITIIOLOGY AND SUCCESSION.

The upper Huronian of the southern subprovince consist mainly of a thick slate fomation carrying two or more iron-bearing beds or lenses near its base and possibly others higher in the group.

In the Gogrebic district it consists from the base up of the Palms formation, the iron-bearing Ironwood formation, and the Tyler slate.

In the Marquette distriet it consists from the base up of the Goodrich quartzite, the ironbening Bijiki sehist, and the Michigamme slate.

In the Menominee district the lower iron-bearing part of the upper Huronian is called the Vulean formation and the upper slate the Michigamme ("Ianbury") slate. The Vulcan formation is sublivided, from the base up, into the Traders iron-bearing member, the Brier slate member, and the Curry iron-bearing member.

In the C'ystal Falls district a similar subdivision into Vulcan and Mlichigamme is made, but there not only are the members of the Tulcan formation not discriminated, but the formaltion is interbedeled near the base of the slate and is treated as a member of the Michigamme 
and not as a distinct formation, although it is mapped separately. On former maps of the Crystal Falls distriet ${ }^{a}$ the iron-bearing rocks were not given a separate name, but were mupped with the slite as upper Huronian. In this report they are correlated with the Vulcan formation and called the Vulcan iron-bearing member.

In the Calumet district the upper Huronian is divided into the Nichignmme slate, the Vulcan formation, and a thind formation at the base, the Felch schist. The Vulcan formation is subdivided into three iron-bearing beds and two slate beds.

In the lelch Mountain district the slate is absent except where the listrict opens ont to the west; the Vulcan formation is not subdivided and the lielch schist forms the base of the upper Huronian. The Vulcan and Felch formations of this district correspond respectively. with the "Groveland" and "Mansfield" formations of the earlier mapping of the district. The reasons for the change of names are given on pages 303-305.

In the Iron River district the upper Huronian is represented by the Nichigamme slate, interbedded near the base of which is an iron-bearing member that has been correlated with the Vulcan formation, although the evilence is not conclusive that certain iron-formation bands classed as Vulcan may not belong stratigraphieally higher than the Vulean formation as typieally developed in the Menominee dist rict. The same remarks may be made concerning the Florence district in Wisconsin.

Throughout the southern subprovince the Michigamme slate is closely folded and in much of the area, especially in the vicinity of the int rusive rocks it has a strongly developerl cleavage. Bedding is uswally to be observed except in places where there has been exceptionally good development of cleavage. The iron-bearing formations and quartzites also have been closely folded, but lack cleavage.

\section{IGNEOUS ROCKS.}

Basic intrusive and extrusive rocks in the upper IIuronian are represented in this subprovince by the Clarkshurg formation of the Marquette district; by the Presque Lale area of the Penokee-Gogebic district, where volcanic rocks, lavas, and tuffs were built up during the larger part of upper Huronian time, and by basaltic schists of the Ienominee, Crystal Falls, Iron River, and Florence districts. In individual occurrences it has not been found possible to determine whether these basic igneous rocks are intrusive or extrusive or even to exchude the possibility of the rocks being pre-Huronian. Some of the intrusive rocks are probably of Keweenawan age. Granites of probable Keweenawan age int rude the upper Huronian and associated basaltic extrusives in the Florence district.

\section{CONDITIONS OF DEPOSITION.}

The conditions of deposition of the upper Ituronian in this subprovince are discussed on pages $612-614$.

\section{CORRELATION.}

There can be little doubt about the correlation of the upper IIuronian in the several districts of the southern subprovince. The rocks as a whole are easily eroded and heavily drift covered and therefore have few outcrops, with the result that areal connections have not been everywhere traced, although they probably exist. The upper II ronian of the Marquette district opens on the west and southwest into a great slate area, which, so far as known, is the same shate area as that surrounding the Crystal Falls listrict, and thence extends south and southwest into the Menomince and Iron River districts. Throughout the subprovince the greater part of the upper Huronian is slate and the iron-bearing formation is characteristically neal the base of the group. In metamorphism, folding, amount of iutrusive rocks, and relations to intrusive rocks the upper IIuronian within the province is a unit. 
From a stuly of the structural fancts alone it may not be aflimed that the unconformity at the base of the upper lluronian of the southern subprovince represents a considerable time interval. Ilowever, when this unconformity is considered in connection with the decp erosion amblocal absence of the middle Ilurunian between two divisions, which are identified on satisfactory evidence, as upper Huronian and lower IIuronian, it is evident that the time break represented may be a large one. Great time intervals are known to be represented in other parts of the geologic column, as, for instance, between the Palcozoic and Mesozoic in parts of the West, where structural evidence is stight.

The correlation of the upper Huronian of the southern and northern subprorinces is scarcely less clear. In each subprovince the basal member is quartzite and state, followed by an ironbearing formation and then by thick slate. The differentinl motamorplism is similar in the two subprovinces. In both the upper Huronian rests with strong unconformity upon Arehean or miklle or lower IIuronian. In both it is unconformably beneath the Keweenawan. On the north shore it dips gently to the south under the Lake Superior syncline; in the northern part of the southem subprovince the upper Huronian of the Ciogebic district dips stecply to the north uncler the same syncline. The identity in the succession of formations in these two subprorinces, their position immediately below the Keweenawan, and their general structural alliances with that series give such strong evidence of equiratence that no one can seriously doubt that the upper Iluronian of the two regions is essentially contemporaneous.

If one saw the llat-lying, little-altered upper Huronian at one locality and the most folded and metamorphosed phases at another far distant and had not proved their continuity, he might think that the rocks of the different localities belonged to different divisions, but in many places the rarious metamorphosed aud ummetamorphosed phases hare been found to connect.

\section{GENERAL REMARKS CONCERNING TIIE UPPER HURONIAN (ANIMIKE GROUP) OF THE LAKE SUPERIOR REGION.}

CHARACTER.

The Animikie is the only group that is continuous throughout the Huronian subprovinces. It is the principal iron-bearing group. Although it has been described in comnection with each of the subprovinces, a further general description is here presented to emphasize its unity over the Lake Superior region.

The upper Huronian was deposited on a remarkably uniform peneplain. Rennants of this pencplain appear from beneath the upper IJuronian in the Nesabi, Animikie, and Gogebic distriets. The post-Animikie and post-Keweenawan folding have resulted in the tilting of this plain to various angles and it is truncated by later peneplains. In each of the districts in which a full succession is found there is a clastic formation at the bottom, a midelle iron-bearing formation, and an uppor slate formation. The bottom chastic formation consists of a conglomerate at the base, which in the northern subprovince and the northeru part of the southern subprovince passes up into a shate or slate and in most places finally into a quartzite. In the dilferent districts, and in the same distriet, the relative proportions of conglomerate, quartzite, and slate vary, as does also the particular phase which is adjacent to the iron-bearing formation. For instance, in the Marquette district conglomerate and quartyite are dominant in the Goohich quartzite and there is comparatively little slate. In the P'noke-Gogebic district conglomerate and state are clominant in the Palms formation and the quartzite is a thin formation at the top. In the Mesabi clistrict the Pokegama quartzite is somewhat similar. In the Inimikic, Nenomince, and Crystal Falls districts the clastic formation is very thin indeed.

Over the clastic formation is the iron-bearing formation, which in the Marquette district is known as the Bijki schist, in the Ilenominee distriet as the Vulean formation, in the Crystal Falls, Iron River, and likorence distriets as the Vulcan iron-bearing member, in the Gogrelic district as the Irouwool lomation, in the Mlesabi clistriet as the Biwabie formation, and in the Cuyuna district as the Decrwood iron-bearing member. 'This iron-bearing formation is by far 
the most persistent and important of those of the Lake Superior region. In it are probahly 95 per cent of the known ore reserves. It is not a pure nonclastie lormation, but has interstratified shaty layers of variable thickness. A number ol these layers have been recognized in the Mlesaloi and Gogebie districts. In the Menominee district one of then is of suflicient thickness to constitute a distinet member of the formation and is known as the Brier slate member; it separates the two ore-bearing members ol the Vulcan, the Curry and Traders. The maximum thickness of the iron-bearing formation forthe region is 1,000 leet.

In parts of the region the iron-bearing formation does not lie at a definite horizon between the coarse clastic sediments at the base and the shales above, but appears as more or less isolated and overlapping lenses entirely within the slate which lorms the upper prart of the upper Huronian. This is the characteristic occurrence of the iron-beaning lormation of the upper Iluronian in the great area extending south and west from the Mesabi and St. Lonis River districts, including the new Cuyuna range, and of the triangular area of Nichigan between the Marquette, Mlenomince, and Gogebie districts, including the Florence, Iron River, and Crystal Falls districts. The iron-bearing formation in this relation to the slate appears also in the western part of the Marquette district. Iron-bearing lenses of this lind seem on the whole to be more numerous near the base of the slate than elsewhere, but in many places it is not known what their stratigraphic position really is, the rocks both above and below them being slate. It will be noted that the sharply delinited, extensive iron-bearing formations, occurring at at definite horizon alove the lower clastic lormations of the upper Furonian, border the older formations on the northwest and southeast sides of the Lake Superior syncline, and that the discontinuous lens-shaped parts of the formations in the slate are located far from the contacts with the older formations. The suggestion is made that this diflerence may be due to original diflerence of conditions of deposition near the old slore against which the upper Huronian sea washed, as compared with the conditions off shore.

Above or associated with the iron-bearing formation is the upper slate formation known as the Michigamme slate in the Marquette, Crystal Falls, Calumet, Menominee, Iron River, and Florence districts, the Tyler slate in the Penokee-Gogebic district, the Virginia slate in the Mesabi, Cuyuna, and adjacent districts, and the Rove slate in the Vermilion district. It occupies a large area in Michigan south of Lake Superior, an immense area west of Lake Superior extending far into central Minnesota, and a very large area about Thunder Bay and vicinity. It probably extends westwarl beyond the western boundary of Minnesota and widens out in this direction. It is entirely possible that this formation will ultimately be found to connect beneath the later formations with the slates of the Black Hills of South Dakota and even with the Belt series of Montania. Indeed, the areal extent of this formation is far greater than that of all the other Huronian sediments of the Lake Superior region.

The formation being for the most part a slate and so soft as to be extensively corered by the drift, exposed sections in which to measure its thickness are rare. Also clearage in these sections has so obscured bedling that estimates are worth little. In the Penokee-Gogebic distriet, where such a section is exposed, the possible maximum thickness has becn estimated at about 12,000 feet, but this is probably too large. Seaman and Lane ${ }^{a}$ suggest 4,000 feet.

The rocks of this formation in the Mesabi and Animikie districts are principally shales. Elsewhere they are principally slates. At Carlon and Cloquet, on St. Louis River, the formation is much folded and has a slaty deavage, and farther to the southwest, where intruded by masses of granite and diorite, it locally becomes so metamorphosed as to pass into a sehist. $A$ like change is noted in the character of the upper lomation, the Tyler slate, at the west end of the Penokee district, where it is intruded by igneous rocks.

Conspicuous in the slate at many horizons are seams and lenses of pyritiferous and graphitic slates. These are so characteristically associated with some of the discontinuous ironbearing lenses, originally iron carbonate, as to serve as gruiles in exploration. 
The slate as a whole gives evidenee lyy its composition ol being less leached of its bases than arerage sates or resilual clays. The composition also slows that it must have been derived from rocks on an arerage more basie than granites. In figure 76 , prepared by $\mathrm{S}$. II. Davis, the mineralogieal composition of the upper Ituronian slates, calculated from chenical composition, is eompared graphically with that of a variety of otler clays and soils.

The upper Huronian slate and iron-bearing formations are interbeckled locally with abundant hasaltic extrusive rocks, partly subaqueous, and tuffs in the southern subprovince. In the northern sulprovince these are yet known definitely only in the cuyuna distriet of Minnesota.

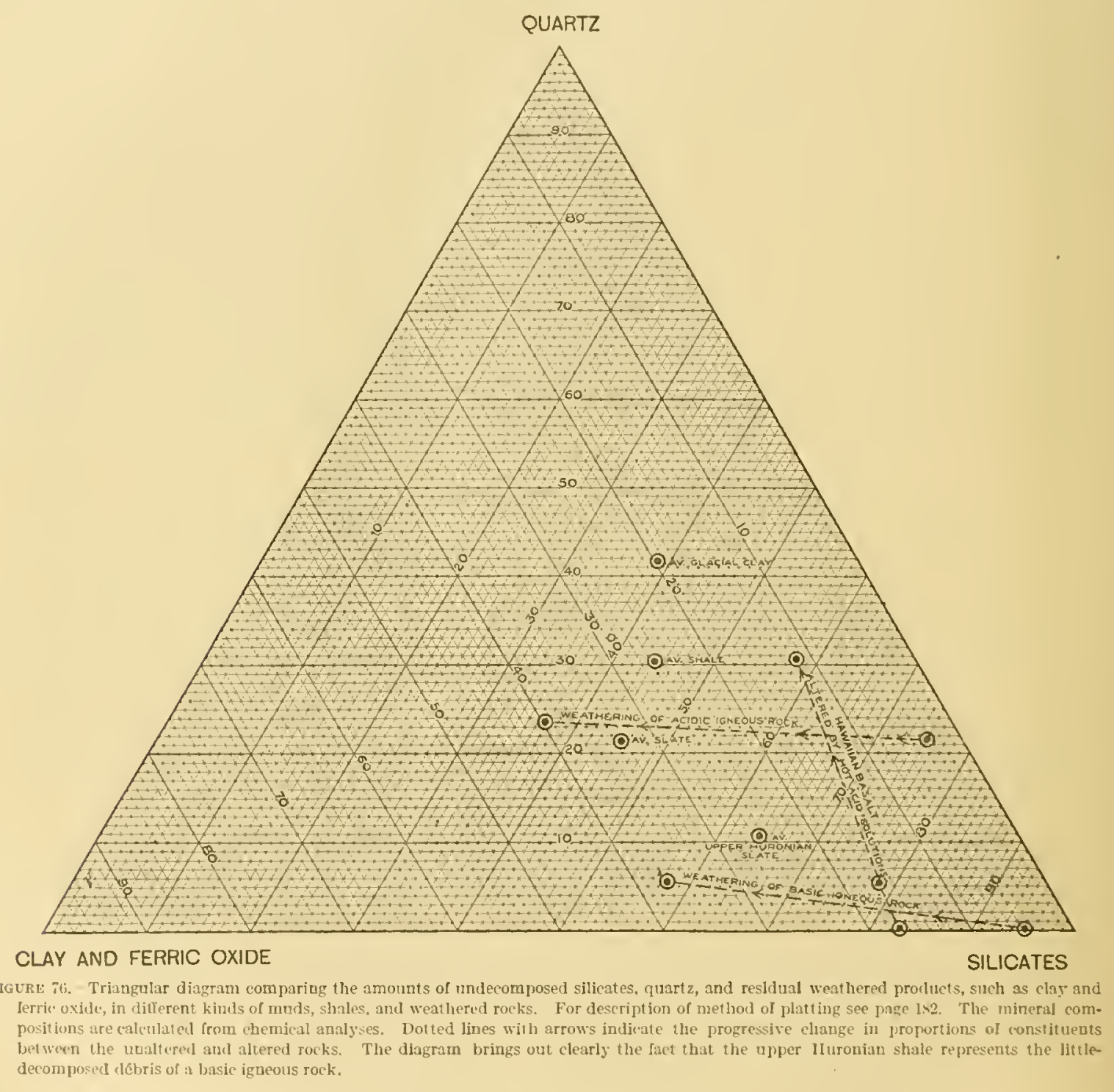

\section{CONDITIONS OF DEPOSITION OF THE UPPER HURONIAN (ANIMIKIE GROUP).}

Any hypothesis of the conditions of deposition of the upper lluronian must be built around the following salient facts:

The succession of a thin fragmental base, an iron-bearing formation, and a thick mud deposit, and the thinness, evenness, and wile extent of the basal conglomerate and quartzite.

The lact that the upper. Ifuronian rests upon a flat plane beveling alike hard and soft, resistant and nonresist ant rocks, without residual or terrestrial deposits at the batse. 
The association of discontinuous iron carbonate lenses with craphitic slates at different horizons, pointing strongly to bog or lagroon conditions.

The lack of sorting or decomposition in the slates as shown by analyses.

Contemporaneous voleanism, partly submarine, probahly related to the deposition of the ore, so associated with the upper Ifuronian as to indicate subaqueous origin for at least a part of it.

The hypothesis which seems to fit this group of facts better than others which have suggested themselves to us is this:

1. The first upper Huronian event was the advance of the upper Huronian sea to a shore line somewhere north of the present northern boundary of Lake Superior. In the area of Michigan and Wisconsin it passed over midclle and lower IIuronian rocks which were nearly flat-lying and perhaps not much eroded. On the north shore it passed over middle and lower Ituronian rocks which had been closely folded and deeply eroded. This arvance was perhaps accompanied by some planation or scouring of the land area, as suggested by the evenness of this plane and the manner in which it bevels alike soft and hard formations and by the absence of residual or terrestrial deposits beneath the cleanly assorted fragmental base of the upper Huronian. Had the land been base-leveled by terrestrial crosion prior to the advance of the sea, that advance would secm likely to have flooded the river mouths and required them to build up to grade, resulting in the development of terrestrial deposits, including much mud, in adrance of the encroaching sea, to be ultimately covered by it, and not removed. It is entirely conceivable that farther to the south the upper Huronian sea may actually have aulvanced over this zone of terrestrial deposition, but that in the Lake Superior region the sea had encroached upon the upper portions of the rivers and was eutting into the rock. There seems to be an absence of sea cliffs to the north of the present upper Huronian beds, but this may be explained by later erosion.

The advance of the sea over a gently sloping surface was accompanied by deposition of a thin conglomerate and sand formation spread evenly over a large area. Barrell ${ }^{a}$ has shown that with the low graclient characteristic of such advance the conglomerate at the base is likely to be very thin, if not altogether lacking, being worn out by littoral abrasion, and in modern instances being observed to disappear a short distance from the shore. Conglomerates of this sort may be thick and coarse only around monarlnocks standing above the plane of transgression. The deposit of the upper Iuronian sea seems to be similar to the thin fragmental base of the Cambrian, which was laid lown by the Paleozoic sea arlvancing also from the south over a flat surface. The absence of conglomerate in the Cambrian except around monadnocks is well known.

2. Then came the deposition of the iron-bearing material. This is a chemical precipitate requiring either quiet conditions of deposition or extreme rapiclity of deposition to account for the lack of interbeded coarse fragmental sediments. It has been argued in another place (pp. 506 et seq.) that the thick iron-bearing formations near the base of the upper Huronian, such as those of the Mesabi, Gogebic, and Menominee districts, find their essential explanation in their genetic relation with basic volcanism, which furnishes sonrces for unusually abundant deposition of iron salts. The abruptness of the change from quartz sand to iron-bearing formation and the usual lack of any fragmental material in the iron-formation layers seem to imply some unusual change of conditions, probably not related to topographic or climatic changes.

3. The advance of the upper IIuronian sea overlapped the Lake Superior region but may not have progressed much farther north. We find no record of it farther north, though allowance must be made for much erosion. The flatness of the plane would require that planation or scouring should be weakened during the northward transgression. The rivers would then be able to hold their own agrainst the sea, and deposition of river alluvium in the form of great deltas may he supposed to have preclominated over marine fragmental deposition. Then were

a Barrell, Joseph, Relutive geological importance of continental, littoral, and marine sedimentation: Jour. Geology, vol. 14, 1906, pp. 433-446; also personal communication. 
built up the thick masses of mud deposits characterized by diseontinuous, pyritiferous, graphitic seams, and iron-carlonate lenses at different horizons, which seem better explained by delta and lagoon conditions than by any other hypothesis that has been suggested. Association with subaqueous extrusions is thus explained. So far as deltas are terrestrial the upper Iluronian muds are terrestrial.

The lack of decomposition of the muds and the graplitic material associated with iron carbonate, indicating the probable existence of peaty material associated with hog deposits, faror the riew that the climate may have been eontinuously cool and wet, for nowhere are the conditions for lack of lecomposition, log formation, and absence of oxidation of carbon so well developed as in a district where a continuous covering of water prevents the access of oxygen. In warmer regions or in those in which a part of the year is hot and dry the organic material is likely to be oxidized, giving an abundance of carbon clioxide for attack of the rocks.

Contemporaneous lasic igneous extrusions, so abundant in the upper Ituronian, doubtless furnished an inusual source for mud, by their decomposition when hot, ${ }^{a}$ through the agencies of acid solutions, through the agencies of the atmosphere acting upon sulphides and therely freeing sulphuric acid for attack on the adjacent rock, and finally perhaps by reaction of the hot lavas with sea water. In figure $76(\mathrm{p} .612)$ is indicated the direction of alteration of basalt by hot sulphuric-acid solutions of the IIawaiian Islands. The most altered phase represents rock which has not been transported. It is to be noted that the direction of alteration is somewhat different from that of weathering. It is entirely possible, if not proballe, from the position of upper IIuronian slates in the diagram, that they have been derived from the katamorphism of basic igneous rocks, both by oddinary weathering and by the unusual alteration of hot acid solutions associated with the igneous rocks themselves.

The upper Ilumnian sediments are therefore regarded as the combined result of an adraneing sea scouring, perhaps cutting the old surface, of a source in which basic volcauic rocks form a distinctive part, and of the final deposition of a great mud delta.

The building up of the upper IIuronian, developing terrestrial conditions toward the close, furnishes an appropriate setting for the inauguration of the great Keweenawan period of terrestrial sedimentation which followed after an interval of erosion.

\section{IEEWEENAWAN SERIES.}

As the Kewcenawan is a unit to a greater extent than the Huronian or the Archean, being located along the border of Lake Superior with large inland extensions, and as the general outline of the history of the Keweenawan has been giren in Chapter XV, we give here only the briefest summary of the salient features of the series.

\section{LATHOLOGT AND SLCCESSION.}

It has been seen that the Keweenawan is separable into three divisions, a lower, middle. and upper. The lower Keweenawan was formed during a period of sedimentation and consists of conglomerates, sandstones, shales, and limestones. This division of the Kieweenawan is not very thick, hut is wilespread. The maximum measurement is 1,400 feet. The middle Kewcenawan represents a time of combined sedimentary and igneous action, containing many alternations of selimentary and ignenus deposits. In general the igneous activity greatly dominated in the early part of middle lieweenawan time, lut was less dominant in the later part. Upper Keweenawan time was again a period of normal sechmentation. At the base of tỉe upper lieweenawan are thick conghmerates, which are overlain by shales and these by a very thick sandstone formation.

As contrasted with the Huronian the Kerreenawan sediments are dominantly clastic. Nonclastic sediments are found only in one locality, in the Nipigon-Black Bay distriet. Moreover. the clastic formations are coarse, being dominantly either psephitic or psammitic. Only sub-

a Maxwell, Walter, Lavas and solls of the II awaían Islands: Buil. 1, Exper. Sta. IIuwalian Sugar 1'lanters Assoc., 1905, pp. S-22. 
ordinately are pelites present, the single important representative being the shale of the upper Keweenawan.

Another feature in which the Keweenawan sediments eontrast with the Ifuronian is that they are lirgely derived from the igneous rocks of the series itself.

IGNEOUS ROCKS.

The igneous rocks of the middle Keweenawan are both plutonic and voleanic. They include basic, aeidic, and intermediate varieties, the basie rocks being dominant. As the detritus of the middle and upper Keweenawan is deriverl largely from the inneous rocks of the period itself, in arriving at an estimate of the mass of igneous intrusions and extrusions of this time we must eonsider not only the original igneous roeks, but the sediments which are derived from them. The mass of the Keweenawn volcanie and plutonie fueies is enormous.

\section{CONIMTIONS OF IUEPOSITION.}

It is probable that the sedinents of the Keweenawan were largely land deposits. (See pp. 416-418.) The prineipal arguments for this conchusion are their prevailing red color, their hittle-assorted, feldspathic nature, and their rapid alternation with abundant extrusive rocks haring textures that are ordinarily associated with subaerial cooling, in contrast with the textures of subaqueous cooling so common in the roleanic rocks of the lower Huronian and the Keewatin. But it is also probable that a portion of them were deposited under water. In the discussion of orogeny (Pp. 622-623) it is shown that the Lake Superior basin was formed largely in Keweenawan time, and it is highly probable that this basin contained water.

\section{CORRELATION.}

The correlation of the different areas of the Kewcenawan is a simple problem. The great area of Keweenawan, extending from Keweenaw Point througl northern Mlichigan into Wisconsin and Minnesota and thence northeast ward to the Thunder Bay distriet and Lake Nipigon, is almost continuous. Therefore the only problem of eorrelation so far as the general series is concerned is that of the rocks of Isle Royal, Michipicoten, and the areas on the east coast of Lake Superior. The placing of these roeks in the Keweenawan is based on their position at the top of the pre-Cambrian, the unconformity at their base, and their remarkiable likeness in litholngy, succession, deformation, and metamorphism to the rocks of the main Kieweenanan area. Though all these points bear' on the question, it was the likeness of the lavas of these areas to those of the main area and their interstratifieation with red sandstones and conglomerates which led the earlier geologists who worked in the Lake Superior region to recognize the identity of the separated areas of Keweenawan rocks.

The problem of fixing the exact relations of the Keweenawan and Cambrian is not so simple The evidence as given in Chapter $X V$ is in favor of the Algonkinn age of the main part of the Kewcenawan.

\section{PALEOZOIC ROCKS.}

The Keweenawan is the latest period which this monograph treats in detail. On the general geologie map (Pl. I, in pocket) the Paleozoic and later rocks are shown as covering a large part of the area soutl of Lake Superior, but they are all represented by one color, for it is not our purpose to consider the post-Algonkian formations separately. The Paleozoic roclis are mentioned only in so far as they are related to the Proterozoic-that is, the Algonkian and Archean.

For the most part the formation which overlies the Proterozoic rocks is a sandstone, which is generally recognized as of Cambrian age. Its basal portion where in contact with iron-bearing formations consists of detrital ferruginous rocks. This formation is everywhere in a substantially horizontal attiturle, thus contrasting strongly with the Proterozoic roeks. In general the relations between this sandstone and the Proterozoic rocks are those of most profound uneon- 
formity, and this is true whichever of the more ancient series underlies the sandstone. The manner in which the Cambrian sandstone cuts unconformably acloss the several series of the pre-Cambrian is well illustrated on the ast side of the pre-Cambrian area of the Upper P'ninsula of Michigan and northern Wisconsin. Here the Cambrian is fossiliferous. The unconformable relation to the Ardean is splendilly illustrated along the Lake Supcrior shore north of Marpuette. The diseordant relations with the Ifuronian are shown at many localities in the Menominee distriet. At some lowalities in northorn Wisconsin the sandstone rests upon the Keweenawn. The discordant relation between the Cambrian sandstone and the Keweenawan is particularly well seen at Taylors Falls, on St. Croix River. Here the sandstone rests upon the tilted edges of the lower Koweenawan. At this locality the sandstone has been found to contain fossils which have been determined by Berkey a to combine "to a cortain clegree charncteristics of both the Viddle and Upper Cambrian," which "do not as a whole present a primitive faunal aspect." Apparently the earliest Paleozoic rocks here are eitlier those of the upper part of the Niildle Cambrim or the lower part of the Upper Cambrian, or both.

Adjacent to Lake Superior is an area of sandstone, about the acre and relations of which there is room for difference of opinion. This area of sundstone is south of the west end of Lake Superior, making the shore of Chequamagon Bay, the south shore of the west end of Lake Superior, and the Marlaline Islands (Lake Superior sandstone). In this area the Lake Superior sandstone does not carry fossils and is possibly Koweennwan, but it has been regarded by all as probably the equivalent of the fossiliferous Upper Cambrian to the south and is so treated in this monograph. That these sundstones have relations to the Archean and Huronian like those described for the more extensive areas of Cambrian sandstone to the south has been agreed to by all observers from early days. It is also agreed that these sandstones are certainly later than and have unconformable relations with the middle and lower keweenawan. Following Irving, we have inclined to the riew that the same relation exists between these sandstones and the upper division of the Keweenawan. Ilowerer, Lane and Seaman ${ }^{b}$ believe that the Upper Cambrian sandstone of Chequamagon Bay and the Madaline Islands grades down into upper Kewcenawan sundstone (which they call Freda). This has been confirmed by recent work of Thwaites, of the Wisconsin Geological Survey (unpublished). The significance of this relation in the correlation of the Keweenawan series is discussed in the chapter on the Keweenawan (pp. 415-416).

The Paleozoic rocks of this region, except in the area above noted, contain marine fossils at several horizons and are therefore in large part submarine deposits. They form a portion of the great series of Paleozoic rocks which has been traced in contimuous overlap over a large part of the North American continent. That any of them are of terrestrial origin is not proved, though it is not impossible that part of the sandstone bordering the southwest shore of Lake Superior may be terrestrial. The abundant partly decomposed feldspar in the Cambrian of the Lake Superior region is probably derived largely l'rom the Keweenawan below, which is believed to be in part a terrestrial deposit.

\section{CRETACEOUS ROCKS.}

In northern Michigan, Wisconsin, and eastern Minnesot a the Paleozoic are the fossiliferous formations that rest upon the pre-Cambrian, but in northern Nimnesota there are local pat lies of Mesozoic (Cretaceous) rocks which have this position. These show that in such areas cither Paleozoic rodks were never deposited over the pre-Cambrian, or else, and this is morc probable, they were deposited and removed by erosion before Cretaceous time. The Cretaceous carries mane lossils. Its basal portion rontains detrital ferruginons sediments.

a Berkey, C. P., (ieology of the St. Croix Dalles: Im. Cieologist, vol, 21, 1595, p. 2n2.

b Lane, 1. C., ani Senman, A. E., Notes on the geological section ol Michigan; pl. 1, The pre-Ordovician: Jour. Geology, rol. 15, 1907, pp. Cino-695. 


\section{PLEISTOCENE DEPOSITS.}

The Pleistocene deposits of the Lake Superior region are separately treated in Chapter XVI (pp. 427-459) and will not be summarized here.

\section{PRE-CANBRIAN TOLCANISII.}

It is by contrasting the voleanism of the different pre-Cambrian periols that we gain an ilea of their relative importance. The voleanism of the Archean is unique, both as to volume and as to extent. If we may presume that the Arehean which is burierl is of the sance charaeter as that which is now at the surface-and this has been shown in some places by drilling-it would follow that the Arehean rocks not only once covered the cntire Lake Superior region but extended to an indefinite distance in all directions. They are composed dominantly of igneous roeks, voleanic and plutonic. The mass of igneous rocks of this time is immeasurably greater than that of any sueceeding pre-Cambrian epoch; indeed, much greater than that of all of them put together. Evidence has also been given (pp. 510-512) in linvor of the idea that some of the basie voleanie rocks are submarine.

In the IIuronian also there are intrusive and extrusive, rocks of both basic and acidic character in rast rolume, but far less in amount than the enormous masses of the Arehean. The basie extrusive rueks are abundant in the middle and upper Huronian of the southern subprovinee and especially in the upper Huronian, lout their distribution is local. Like the extrusive rocks of the Kcewatin, those of the IIuronian are partly submarine. They are represented by the Clarksburg formation of the IIarquette district, the IIemlock formation of the Crystal Falls district, the voleanie rocks of Brule River in the Florence district, the roleanic rocks of Presque Isle in the Gogebic distriet, and many unnamed greenstones in the Crystal Falls and Iron River distriets. In the lower Huronian basic extrusive rocks are subordinate. Granites are extensively intruded into the Ituronian.

The Keweenawan was a tine of roleanism, plutonie and surface, which extended over the entire Lake Superior basin and to varying distances inland -indeed, a time of regional volcanism which ean be fairly compared with the outbreaks of Tertiary voleanoes in parts of the western United States. In northern Canada and in the southwestern Initer States are large areas showing many voleanic rocks which may belong to this same perior. The basic extrusive roeks of the Keweenawan eontrast with those dominant in the Huronian and Kecwatin in exhibiting textures peculiar to subacrial cooling instead of textures characteristic of subaqueous cooling.

\section{PRE-CAIBBIAN LIFE.}

No fossils definitely recognizable as such have yet been found in the pre-Cambrian of the Lake Superior region. The greenalite granules of the Mesabi district, first ealled glauconite and thought possibly to be of organie origin, are now known to be chemical precipitates. The carbon that is so abundant in the shales, a part of it in the form of hydrocarbon, is probably of organic origin. The limestones give no decisive proof one way or the other, but they are eviclence of extensive carbonation of the rocks, which is now largely aceomplished by the assistance of organisms. The probable existence of life is also inclieated by the well-assorted nature of the sediments of some of the series, implying the presence of vegetable life to assist in rock decay.

\section{UNCONFORMITIES.}

\section{UNCONFORMITY BETWEEN THE ARCHEAN AND LOWER HURONIAN.}

Unconformity may signify diseordance of structure and intervening erosion with or without great time lapse, or great time lapse with or without great discordance in structure or erosion, or both. The lapse of time may be measured by the extent of the intervening deformation and erosion or by the absence of beds known to have been deposited elsewhere during the interval, 
which may or may not have covered the area in question. "Great unconformity" as the term is ordinarily used means struetural discordanee, deep crosion, long time iuterval, and lack of deposition of sodinents known to be deposited clsewhere, or some combination of these conditions. Of these criteria, the first throe are the ones here cmphasized. The correlation of the pre-Cambrian between widely separated areas is still so uncertain in the lack of fossils that the last criterion can not be satisfactorily used.

Wherever the lower Huronian is distincty recounizel as such, there is an unconformity at its base. The rocks on the two sides of the unconformity contrast widely. Those on one side of it are dominantly ignenus rocks, partly plutonic; those on the other side are dominanty sedimentary. During the time represented hy this uneonfomity what seems, from present eridence, to have been a great world period of roleanism ceased and the conditions became such that normal sediment ary rocks were formed.

Contrast in the character of the rocks on the two sides of the unconformity is correlated with other evidence of the greatness of the break. Before the lowest Huronian was deposited, the Keewatin and in places the Laurentian rocks had taken on a sehistosity. The plutonie rocks of Archean time had been brought to the surface by erosion. The basal conglomerate beds of the lower IInomian rest upon the Feewatin schists at various angles. It is mot easy to conceive of a plysical break more indicative of lapse of time than that, for instance, which is shown with diagrammatical sharpmess at the east end of the Gogelic listrict between the lower Huronian Sunday quartzite and the Keewatin schists. Of course where the folding has been close and the shearing between the Inmonian and the Archean very great, the evildence of unconformity may have been partly obliterated and the two series appear to grade into each other-for instance, at certain places near Teal Lake, but eren here the unconformity may be recognized.

On the north shore of Lake Superior the umeonformity at the base of the fluronian is not conspicuous but is as certainly existent as that south of Lake Superior. In the Vermilion district the Huronian series is a definite succession beginning with conglomerates and passing up into slates. The discrimination between the basal complex and the Iuronian is an easy one. The break usually has the aspect of one of the first magnitude. In some Termilion localities, especially where only the conghomeratic and arkosic lacies of the IIuronian are found, and these are largely composed of the immediately undertying lock, the break could not he asserted to be of great nragnitude. If the suggestion is correct that in lower Fluronian time the region north of Lake Superior was in large measure a land rather than an aceanic area, this, combined with the fact that basaltie tuffs and conglomerates occur in the Archean, is sufficient to expinin the confusion and the apparent insignificance at some places of the unconformity at the base of the IIuronian. It is entirely possible that mistakes have been made in the placing of certain conglomerates in the IIuronian. If it is admitted that there may be localities in which the relation is confused, wherever the Iluronian is represented by a great series of sediments, as in the Vermilion district, the Michipicoten district, and the Cobalt district, there is no difficultr whatever in discriminating between the Archean and the Iluronian as a whole and in proving that a profound unconformity separates the two.

\section{UNCONHORMITY BETWEEN THE LOWER AND MIDDLE IIURONIAN.}

Eridence of the meonformicy between the lower Huronian and the middle Ituronian is plain in the Marquette district, where the basal conglomerntic formation of the midile Iluronian cuts diagonally acms all the formations of the lower Huronian and down to the Arehean. This means that after the horer Ituronian was deposited and before middle Huronim time the hwer Huronian was indurated and brought to the surfice, and diflerential erosion occurred sullieient to cut thromgh the rntire chivision into the Archean. The discordance of strike aud dip between the two divisions at any one loeality is slight. 
In the Crystal Falls distriet the midllle Luronian is composed mainly of volcanie rocks. So far as its structure can be worked out it is nearly accordant with the lower furonian, but in the nature of the case conformity or unconformity is diflicult to prove. In the Nenominee district the middle Ihuronian quart zite rests on the Randville dolonite of the lower Huronian with slight though distinet struetural discordance. Conglomerate is found at one locality in this district.

\section{UNCONFORMITY AT TIIE BASE OF THE UPPER HURONIAN (ANIMIKIE GROUP).}

The unconformity at the hase of the upper Huronian is easily reengnized as extending over the Lake Superior regiom. The upper Ifuronim rests at different localities on each of the more ancient divisions of middle Ituronian, lower Ifuronian, and Archean, truncating and deriving detritus from whichever of these divisions it overlies. The erosion precerling upper Huronian time apparently reduced the larger part of the Lake Superior region to a peneplain. The best illustration of this is fumished by the Penokee-Gogebic, Mesahi, and Animikie distriets, in each of which the quartzite at the bottom of the upjer Huronian does not vary more than 200 l'cet in thickness for a distance of more than 80 miles and is in contact here with the Keewatin, there with the Laurentian, ant in still other places with the lower Huronian. This shows that the maximum elevations of these heterogeneous rocks at the time of the encroachment of the upper. Ifuronian sea did not exceed a few humbed leet. Even after the deformation which the deposition plane has undergone, it is still to be recognized in the Mesabi and Gogebie districts as a remarkably cren surface.

In the Crystal Falls district the relations of the upper Huronian (Animikie group) to the underlying rocks are obscured by the fact that the immediately umderlying rocks are those of the rolcanic Ilemlock formation, and lack of exposures makes it extremely dillienlt to ascertain the relations, but there is some evidence of unconformity. (See p. 300.) The uneonformity between the upper Huronian and underlying rocks in the Menominee distriet is marked by discordance of structure, bisal conglomerates, and overhup.

On the south shore of Lake Superior the discordance in strike and lip between the upper Huronian and the middle and lower Huronian is not strong, but nevertheless is distinet. On the north shore of Lake Supcrior before upper Huronian time the earlier Huronian had been closely folded and a nearly rertical schistosity developed, so that at many places the upper Huronian (Animikie group) rests upon the edges of the metamorphosed Huronian below.

\section{UNCONFORMITY AT THE BASE OF THE FEWEENAWAN.}

The upper Huronian and Keweenawan have an appoximately similar strike and dip, and it was only slowly recoguized that the two series are discortant. The best eridence of this, so far as contacts are concerned, is found on tha north shore of lake Superior, in the Thunder Bay and Nipigon districts, where the basal lieweenawan contains abundant detritus derived from the upper Iluronian (Animikie group) and rests upon its croded edges, showing that the older series was deposited, indurated, and croded after having been formed before Keweenawan time. However, the depth of erosion between the two is best shown on the south shore of Lake Superior, where, in the Penokee-Gogebic district, the dilferential erosion of the upper Iluronian apparently amounts to several thousand feet within a few miles.

\section{UNCONFORNITY AT THE BASE OF THE CAMBRIAN.}

All the pre-Cambrian lormations are in a more or less tilted position, the dip varying from a few degrees in the newest parts of the Keweenawan to verticality in parts of the Huronian and Archean. The Cambrian, on the other hand, is horizontal or nearly so. Moreover, the Cimbrian is nowhere cut by igneous rocks. These relations give evidence that the orogenie movements and igneous intrusions so characteristic of the pre-Cambrian had ceased, 
and that the conditions had arrived which marked the great cambrin transgression. The Canbrian rests upon a rmarkably uniform pre-('ambrian peneplain, which is known to extend far to the north and sonth of the hake Superior region. The unconformity at the hase of the Cambrian is evidently one of the great breaks in the geologic eolumn.

I possible exception to the above general statements may axist in the relations of the Cambrim and upper sundstone beds of the Feweenawan. From the bottom to the top of the Keweenawn there is progressively less tilting. The structural discordance between the (ambrian and the midcte and lower lieweenawn is therefore much more conspicuons than that between the Cambrian and upser Keweenawn, which ate perhaps conformable. The significance of this loeal conformity is discussed on page's $415-416$.

\section{DEFORMATION A.D METAMORPIISA.}

\section{GENERAL CONDITIONS.}

From the preceding section on unconformities it is evident that during or after the formation of each of the pre-Cambrian series, or both, there was a time of orogenie movement which produced folding, faulting, and metumorphism. Of the several periods of deformation, three stand out conspicuously- that at the elose of the Arehean throughout the region, that at the close of the lower-middle Ifuronian, mainly on the north shore, and that at the close of the keweenawan on the south shore. As a result of these successive deformations the lake Superior region is essentially an asymmetric synclinorium with nearly east-west axis.

The amount of deformation in each series is partly" a function of the age of the series, as after its formation each series was subject ad to all the movements which followed. One would expect the complexity of structure to be the greatest in the Archean and least in the lieweenawan, and such are the facts. But it does not follow that ench series has a characteristic degree of deformation and metamorphism corresponding to its position in the geologic column. The difference in deformation of different parts of the Huronian series may be nearly as great as the difference between the deformation of the Archean and that of the Keweenawan.

The Lake Superior region exhibits every variety of folding, from the most intricate plication of the Archean and lower lluronian to the broadest open folding of the upper Keweenawn. The major structure of the region is unquestionably cont rolled by folding rat her than by fruet ure deformation, but the latter is not unimportant. Every district which has been considered in detail slows faults of greater or less magnitude and exhibits innumerable joint fractures. For the most part these faults are comparatively small and do not greatly modify the general distribution of the formations, althongh many produce considerable displacements which are important in the detailed geology of the distriets. Exceptions to the above statement are to be made in reference to the great fuults of the kieweenawan, of which one runs through the center of Keweenaw Point and another extends along the northern part of northern Wisconsin and is believed to be continuous between Isle Royal and the mainland of Minnesota. These faults result in the repetition of the Feweenawan rocks and give them a wider present distribution.

The competent strata controlling the deformation of the pre-Cambrian rocks of this region, whether by folding or by faulting, have been the quartzites and the plutonic rocks, especially the granites. These rocks show on the whole more simple folding and faulting than the softer beds associated with them. The slate formations especially have accommodat ad themselves to this control by close folding and development of elearage. For instance, in the Marquette district the Arehean and the overlying quartzites are folded into a broad composite syncline with consideruble faulting. The lintervening and overlying slates, on the other hamd, appear in elosc folds, characteristic of incompetent strata. Their deformation has been obviously controlled by the realjustments between them and the quartzites. It may be assumed that, so far as the competent quartzite is concerned, the development of the Marquette simeline has required movement of the upper beds upward and outwarl from the syncline as compared with the lower beds, as inclicated by arrows in figure 35 (p. 25.3). The major readjustment lits resulted in the overthrust or clrag folels in the slate. 'This is the essential explanation of the 
abnormal fan-shaped folding of the Marquette district. Similar drag folds in the soft layers between the competent strata may be found in almost any part of the Lake Superior region where competent and incompetent layers lave been folded together.

In connection with the folding, faulting, and int rusions there have developed slaty, schistose, and part of the gneissose structures. All these structures are common in the Arehean and are widespreal in the lower and middle Huronian. In the upper Iluronian slatiness ocenrs rat her extensively and schistosity is common where the rocks have been intruded by granite, as in northern Mimesota and Florence County, Wis. The Keweenawn loes not exhibit any of these secondary structures.

These structures are all characteristic of the zone of flowage, in which the alterations are anamorphic. During their formation all the phenomena of granulation and erystallization of the individual mineral constituents are exhibited in very diverse rocks and in widely varying degrees, from moderate changes to complete recrystallization. Where the rocks have been under deep-sented conditions and these secondary structures are not foum the changes may be moderate, lout on the other hand they mar be extreme.

In connection with the faults, joints, and other fractures all the alterations of the zone of katamorphism have taken place. These are perhaps best illustrated in the Keweenawan series.

In gencral in the zone of observation more or less extensive katamorphic changes are superimposed upon the anamorphic changes above mentioned, for the once deep-seated rocks, now near the surface, have long been in the zone of fracture, where the changes are katamorphic. It thus appears that varions combinations of the alterations of the zones of anamorphism and katamorphism are exhibited by the same rocks.

\section{PRINCIPAL ELEMENTS OF STRUCTURE.}

The major axes of the orogenic movements in this region have been in general parallel to Lake Superior, producing a synelinorium. But the eastem and western parts of Lake Superior show a difference in trend, the clividing north-south line being at about $s S^{\circ}$ longitude, which cuts Keweenaw Point a few miles west of its end. West of this line the trend of the axis of the lake is about $30^{\circ}$ north of east. East of it the trend of the axis is south of east. To these trends the strike of the rocks corresponds almost exactly for the west half of Lake Superior and approximately for the east half. The average strike for the region is nearly east and west. This prevailing structure is represented in the Lake Superior trough itself, in the Mesabi and Animikie nonocline, in the repeated folds of the Cuyuna, Iron River, Crystal Falls, and Florence districts, in the Gogebic monocline, and in the Marquette, Menominee, Felch Mountain, Cahmet, and Sturgeon synclinoria.

The strikes of the lake Superior rocks are in accord with those in the greater part of the pre-('ambrian shield to the northwest, north, and northeast, even as far north as the IIudson Bay region.

Locally the strikes vary greatly from the general clirections indicated, and they may be even north and south, as is conspicuously illustrated in the Republic trough and the Archean oral of the Fence River area in the Crystal Falls distriet. The local rariations in strike and dip, are partly explained by original configuration of the basement rocks. They are more largety explained by the cross fokling of the region. The axis of one great cross fold rums north and south through Keweenaw Point and the eastem part of the Crystal Falls district. Another crosses the Marquette district in a north-south direction in the vicinity of Ishpening. Others cross the Mesalji distriet from northeast to southwest.

The intrusive rocks are also inportant factors in producing the rariations of the strike of the lolds from the major Lake Superior structure. Very commonly the strikes of the strata about massive laccoliths, bosses, or batholiths are much influenced by the igneons rocks, there being a marked tendency for the strikes to be peripheral or tangential to the intrusives. This relation is illustrated in all the districts in which the intrusive rocks occur in large masses, but is best exemplified in the region northwest of Lake Superior. Here the intrusive masses are 
so large as to be the most important factor in the eontrol of the lecal strikes and dips, although even here there is an uncuestioned tendency for the general east-west strike of the region to mintain itsell.

The cress sections $1-1$ and B-B on the general map (Pl. I, in pocket) give the best conception of the dips of the fommations. It will be noted that the Archean, lower Ifuronian, and midlle Humian beds lave strep dips in northerly or sontherly directions, that the mpper II beds are as a whole less stereply inclined and have in part a definite relation to the synclinal structure of the Lake Superior region, and that the Kewenawn beds are still less steeply inclined and are entirely in accord with the synclinal strueture ol the basin. All this deformation was complete before cambrian tine exeept the faulting. There is no evidence that the faulting was not much later than the cambrian-possibly post-('retaceous.

\section{TIE LAKE STPEHIOJ BASIN.}

The strueture of the Lake Superior basin is well shown lyg the cross sertions on the reneral map (Pl. I, in pocket). The hasin is essentially an east-west asymmetrir synclinorium with stecper dips on the sonth than on the north side, shown principally in the lieweenawan and upper IJuronian rocks bordering the lake.

The upper IIuronian of the Penokee district dips north, toward Lake Superior, at a steep angle, varving considerably but for the most part heetween $55^{\circ}$ and $80^{\circ}$. The upper Huronian of the north shore in the Jesabi and the Animikic districts dips south, toward Lake Superior, at comparatively flat angles, ranging from substantial horizontality up to $45^{\circ}$, the more common dips being between $8^{\circ}$ and $20^{\circ}$.

The folding of the Keweenawan has a very close relation to the Lake Superior trough. On the south shore of Lake Superior the Keeweenawan rocks dip northwest, toward the lake, at angles rarying from as high as $80^{\circ}$ in the lower part of the series to extremely flat angles in the upper part of the series. On the north shore of Lake Superios and on Isle Royal they dip at moderate angles to the southeast, toward Lake Superior. Thus the Keweenawan at Keweenaw Point and its extension to the southwest and the Keweenawan of the north shore constitute a clearly marked synclinal trough which extends inland in Michigan, Wisconsin, and Minnesotn. The axis of this syncline lies about halfway between Isle Royal and Keweenaw Point. It does not run to the heal of the lake, but to the head of Chequanegon Bay and thence far inland to the southwest. Ifre it carries minor folds.

To the southeast of the smelinorium in Nichigan there is one great fault, and probably two. To the northwest of it in Wisconsin there is another great lault, and this fault, or another, is supposed to continue between Isle. Royal and Thunder Bay. The Keweenawan rocks nearest the axis of the syncline are on the upthrow sides, and the "eastem" and "western" sanditones sorutheast and northwest of the sychomium, respectively, are on the lownthrow sides of the faults. Consequently the Feweenawan of northerm Wisconsin and Isle Royal is probablyrepeated, at least in part, on the Mimnesota coast, and below the rocks thus repeated the Ninnesota Feweenawan extends down to the base of the series. Similarly a part of the fieweenawan roeks of Keweenaw Point are probably repeated in the "South Range."

It Vichipicoten the lips are to the south. On the east shore of Lake Superior the Keweenawan clips westward toward the lake. Some thrusting and buckling have accompaniod the faulting along the north side of the synelinorial axis in Wisconsin.

Wherever there is a thick sucession of Keweentwan rocks the dips aresteeper at the base and grow Hatter at the top. This is best illustrated ly Keweonaw Point, Iste Royal, and Michipicoten. Elsewhere the changes of dip are not so great. This general lessening of the dip of the Kewecuawn in pussing from lower to higher horizons is regarled as erilener that the folding of the series which caused the bake Superiol basin took place largely during Korwenawan time.

The development of the İake Superior hasin in Keweenawan time has tended to give parallehism of strike (1) all the rocks of the region hut is not regarded as sufficient to cxplain the remarkable parallelism actually wherved in older rocks. The trend of the axial lines of the 
Lake Superior syncline is in accord with that of the folds through a large part of the preCambrian shield of Canala. It is doubtful if the Kewconawan folding ever affected a large part of this shic]d. Inch of the folding is unquestionably earlier. Therefore it is reasonable to assume that the dominant trend in the Lake Superior folds, as well as in the pre-Cambrian of Canarla, was probahly established before Keweenawan time.

Borlering the main Lake Superior hasin are minor synclinal folds of the Marquette, Folch Mountain, Calumet, Menominee, and Mesabi-Cuyuna clistricts, with axes nearly parallel to the longer axis of the lake Superior basin. These districts present evidence that they were foldorl to their present attitude in consichable part at the same time as the main Lake Superior basin; that is, in Kewcenawan time. Another fact seems to relate them eren more closely to the latie Superior basin of Keweenawan age. The minor synelinoria are asymmetric and tend to have their steeper sides toward the lake. This may be abserved in the Harquette, Felch Mountain, and Calumet distriets, principally in the upper Ifuronian socks. The upper Juronian of the nortl shore has a gentle southwarh dip along the Mesabi, Gunflint, and Animikie ranges, which changes to steeper dips near the axis of the basin in the Cuyuna district. The Vernilion clistrict shows eridence of a similar strueture in the Keewatin schists. The nomal derelopment of a great syncline of the Lake Superior type woukd be accompanied ly a diflerent ial slipping between the competent layers, whereby the upper.layers would move up and awy from the syncline as compared with the lower layers, just as has been already described for the Marquette district. So far as there is failure of the beds taking part in this movement, it is likely to be influenced by this differential movement and to result in minor folds with steeper sides toward the axis. It is believed that the accordance of structure of the districts mentioned with the requirements of this general princip) is more likely to be a natural and necessary sequenee than a coincilence. It may be notel that the displacement of the beds in this type of folding las nearly the sane direction as the displacement along the main fanlt lines already mentioned.

The departures from this control of minor folds by the Keweenawan fold of the Lake Superinr basin are due to original configuration of basement, to plutonic intrusive rocks, or to cross folding.

The asymmetric character of the Lake Superior hasin itself may have interesting significance as to the gencral orogeny of the region. If, as suggested in the following pages, the Lake Superior basin has been essentially the locus of a shore zone against the continental area to the north, then the gentle southwarl slope of the north limb of the Lake Superior syncline is away from the old shore line and the steeper chip of the south limb of the syncline faces the shore, as if there had been a thrust from the south toward the continental area to the north.

The extrusions of the roleanie rocks along the borders of the lake on an extensive seale of themselves gave opportunity for subsidence elsewhere. It may be that the depression of the center of the Lake Superior basin was a correlative of the outflows of lava along the border, the two togetler and the inciting or attendant epeirogenic and orogenie movenents lowering the center of gravity of the Lake Superior masses. 'This movement of subildence for the basin would be assisted by the deposition of lava beds and of secliments within the basin, although these are regarded as aceessory rather than as prime factors in the development of the basin.

\section{RESLIE OF HISTORY.}

This monograph may close with a briof résumé of the great events of the pre-Cambrian period in the Lake superior region. Early in the history of the earth, when the Lake Superior region was at least in part below the sea, there were great outhreaks of volcanic rocks, which continued for an indefinite time and as a result of which the Kieewatin was mainly built up). Subordinate masses of sediment-conglonerate, slate, and iron-bearing rocks-were laid down, especially late in Archean time. The beginning of the Krewatin period we can not even climly see, for we do not recognize the basement on which the Keewatin rests. Later, or eontemporaneously at least with the later stages of the rast regional extrusions, which, as has been explained, were of a magnitude never subsectuently approached, was the intrusion of enomous masses of acilie rocks, including great batholiths, bosses, stocks, and likes. These rocks consti- 
tute the Laurentian series. For some unknown reason the extrusive rocks of the Keewatin were dominantly of the basic and intermediate types, and the Laurent ian intrusive roclis dominantly of the acilic ty]er, although all these types occur both as extrusives and int rusives.

In Archean time the Kieewatin meks were greatly deformed and extensirely motamorphosed, largely unler the influence of the laturentian intrusions. It is extremely probable that cluring Archean time at many places the land was raised alove the sea by the uphuilding of the lavas, the intrusion of the batholiths, and the folding. But the Keewatin rocks now observable are largely submarine, and contemporaneous sedinnents known to result from erosion are rare or lacking.

Finally there eame a time when a general epeirogenic movement, perhaps in ennection with the orogenic movements and intrusions, raised the entire Lake Superior region above the sea. This gave the comlitions for deep denudation which removed a great but unkmown thickness of the Archean rocks, exposing the schistose Keewatin rocks and the coarse, massive textures of the Laurentian batholiths.

The lower Huronian sea then advancel over the region from the south, extending at least as far north as the present south shore of Lake Superior. Under the water of the alvancing sea the lower II uronian sediments were laicl down. These are of a normal subaqueons type, consisting, first, of a pseplite, followerl by a psammite, next a pelite, in places carbonaceous, and finally a limestone. The character of these sediments proves beyond question that at the time of their deposition the conditions hat become similar to those which prevail to-tay, hoth as to the agents concerned in erosion and as to those concerned in deposition.

The deposition of the lower Huronian was followed by an uplilt and recession of the sea. The area of the southern IJuronian subprorince and perhaps also that of the northern subproyince were gently folderl. Erosion locally cut through the lower IItonian of the Marquette district, but in most of the southern subprovince it has not gone throngh the Ramlville dolomite. The next period of deposition was that of the middle Huronian, eridence of which is found only in the sonthern Huronian subprovince. The midlle Huronian here consisted of subaqueous sediments-psephites, psammites pelites, and a nonclastic iron-bearing formationindicating that the sea had again advanced.

It is believed that during lower and middle Huronian time the sea dicl not advance over the area nortl of the present Lake Superior, that this was a land area, and that the great rivers flowed to the south into the Huronian sea. On this northern hightand were deposited an extensive and peculiar slate conglomerate and little-assorted graywackes, slates, and conglomerate, which in their general characteristies and associations are taken to be subaerial and lelta deposits.

After mikllle Iuronian time the northern and southern IJuronian subprorinees were raised above the sea, folded, and eroled. The northern subprovince was much more affected at this time than the southern subprovince. The advance of the upper Huronian sea from the south across the area brought about the deposition of upper Huronian secliments upon a remarkablyplane surface, with elevated areas that were perhaps not covered in several places in northerm Wisconsin and south of the Marquette distriet of Michigan. To what extent this surface was one of previous base-leveling by subaerial erosion and to what extent by marine planation is not known. The fresh surface of contact, the manner in which the plane truncates hard and soft rocks, the lack of residual soils or serliments, and the thinness, evenness, and wide area of the fraguental hase of the upper Inronian seem to faror the view that the surface may have been finally chared by marine scouring, whatever the extent of earlier erosion. In the southern Huromian sufprovince the rocks had not been previously folded as much as in the northern sulprovince, in consequence of which erosion and plunation accomplished less conspicuons, or less casily identified results, though erosion seems to have remored nearly all of the mirlde Huronian in the Menomince district. The upper II uronian was thus laid down, with conspicuous unconformity in the northern part of the region, beeause of the folding of earlier rocks, and with far less discordance in the southern part of the southern lluroninn subprovince, where the earlier rocks had not been so much folded. 
The shore deposits of the alvancing upper Ifuronian sea were thin pseplites, which were followed by psammites or pelites, and these very extensively by an iron-bearing formation, locally alternating with pelites. This is the formation containing the great doposits of Lake Superior ores, in the Mesabi, Penokee, Menominee, Cuyuna, and other distriets. The deposition of the iron-hearing rocks to a thickness of nearly a thousand feet, with so little fragmental sediment, is not duplicated elsewhere in the geologic record and seems to require some unusual condition. The explanation is believed to lie in the great basic extrusions both preceding and accompanying the upper Iuronian deposition, furnishing an unusual source of materials for the iron-bearing formation. (See pp. 513 et seq.)

The alternations of iron-bearing formation and pelite were followed by a very thick pelite, the greatest of the Huronian formations. The conditions allowing this unusual accumulation of mud may have been those of delta deposition. The sea seems not to have advanced much farther north than the I ake Superior region, and it is conjectured that when the advance stopped, the rivers were able to make headway against the sea and build up' great delta and mud deposits over the previously deposited iron-formation sediments. The character of these deposits is perhaps related to volcanism. The existence of abundant discontinuous pyritiferous and graphitic lenses in the slate, associated with lenses of iron carbonate, seems to be evidence of lagoon conclitions accompanying delta deposition. $\Lambda$ s in most deltas, a considerable part of the deposits may be regarded as terrestrial.

At the close of upper IIuronian time the land was raised or built above the surface by delta deposition and the upper IIuronian beds were very gently folded and deeply eroded, the differential erosion amounting apparently to thousands of feet. Then followed the events of Keweenawan time, which were first those of terrestrial deposition, associated with enormous extrusions of igneous rock, merging later into conditions of subaqueous deposition in the I ake Superior syneline.

During the time the Keweenawan series was being built up the Lake Superior basin was formed, resulting in marked diminution of dip in passing from lower to upper Keweenawan. The folding of the lower Keweenawan and middle Keweenawan rocks which produced this basin cleformed also the arljacent rocks, especially the upper Huronian of the west half of the basin, so that they share in the synclinorial structure. The antecerlent movements were probably along axes parallel to that of the Lake Superior syncline, but the present marked parallelism of axes of folds in all of the pre-Cambrian is probably due largely to Kieweenawan folding.

At the end of the Keweenawan period the land was raised for the fourth time above the sea and the long-continued denulation preceding the Cambrian period took place, developing a peneplain that is even yet largely preserved. The Cambrian transgression began far to the south and finally overmole the entire Lake Superior region. The floor for the Cambrian deposition was composed of tilted rocks with the exception of the upper Keweenawan sandstone. The structural and lithologic accordance of the Cambrian with the upper Keweenawan bets raises the question whether the deposition of the upper Keweenawan sediments in the Lake Superior basin dit not continue until the Cambrian sea reached them and gradually merged into Cambrian deposition. The Cambrian was succeeded by the later Paleozoic deposits.

After Paleozoic time the regrion was again raised above the sea and eroded. Since then there have heen many episodes of uplift, subsidence, and warping. At one time the Cretaceous sea covered the western part of the region. Erosion has removed all but small patches of the Cambrian from the uplands, and reexhumed and molified the pre-Cambrian topography. Faults developed in post-Cambrian and perhaps in post-Cretaceous time.

It thus appears that in the Lake Superior region, from the carliest time to the Cambrim, there were five great periods of rock formation separated and followed by poriods of epeirogenic movement, orogenic movement, and erosion, each of these intervals heing marked by an unconformity. The first of these unenformities, that at the top of the Archean, is the most conspicuous, represents a strong lithologic contrast, and has been by all geologists taken as an

$$
47517^{\circ}-\text { rou } 52-11-40
$$


essential datum plane in mapping and working out the geologic history. The unconformities separatine the divisions of the IIuronian and the II uronian from the keweenawan are of lifleriug value, but all represent important struetural and time breaks. The unconformity at the base of the Cambrian is one of the first magnitude and is coextensive with the great unconformity at this horizon ontsile of the Lake Superior region.

Of the five periods of deformation, thee stand out conspicuously-that at the close of the Archean throughout the region, that at the close of the lower-middle Huronian principally on the north shore, and that at the close of the Keweenawan prineipally along the axis of the Lake Superior basin and on the south shore. These areas of folding had been shore zones of heary Huronian and Leweenawan deposition. As is common, the shore zone was a place of recurrent upheaval and subsidence, markel orogenic movement, igneous activity, and seclimentation. To these many causes combined is the the complexity of the greology of the region.

These shore conditions may bear some relation to the fact that part of the Lake Superior region south of the international boundary is one of the great iron-producing areas of the world. It has been a source of surprise to many that the adjacent Canadian region, in which the geology seems to be in a general way similar, has not been found to bear iron ore in anything like the abundance of the States to the south. But by far the larger part of the iron-ore deposits in the States occur in the middle Huronian and dominantly in the upper Huronian formations. The midclle Ifuronian is known in a general belt fringing the main pre-Cambrian area of Canacla along the north shore of Lake Superior and extending northeastward through Lake Timiskaming. It may exist also farther north in the interior of the Canadian pre-Cambrian, but, to judge principally from the facts observed on the north shore of I ake Superior, the interior pre-Cambrian region of Canada was probably above the sea cluring middle and upper lluronian and lieweenawan time and only continental deposits were formerl in it. The upper Huronian, the principal iron producer, is but seantily represented along the southern margin of the Canadian preCambrian. The only iron-bearing formation which has an extensive oceurrenee in the great pre-Cambrian shield of Canala is that of the Keewatin series. The Keewatin iron-hearing formation has not been largely productive. If the apparent scarcity of middle and upper Huronian rocks over this area is a real one, which is not yet finally proved, it can not be expected that in the central highlands of Canada will be found iron-bearing formations that are to be paralleled with those of the middle and upper Huronian south of Lake Superior.

But it may be that in Huronian time the central highland area had a shore zone to the north as well as to the south. The oceurrence of probable late Algonkian sediments on the east const of Hudson Bay and in the Copper Mine region, on the west sicle of the bay, give color to this suggestion. The IIudson Bay region seems, from arailable facts, to be another geosyncline of sedimentation and folding corresponding somewhat to that of the Lake Superior and Lake Huron regions. An iron-bearing formation, remarkahly similar to the Animikie, is here known. ${ }^{a}$ If this hypothesis proves to be true, this northern region warrants careful exploration for mineral wealth.

Attention has been ealled on pages 591-592 to the possible genetic association of the Lake Superior copper ores with the Georyian Bay copper ores, Silver Islet silver ores, Sulbury nickel ores, and Cobalt silver-cobalt ores. This suggests an hypothesis as a reasonable hasis for further ceologic work. Huronian and keweenawan rocks seem to be more abundantly present in the Lake Superior, Georgian Bay, and Timiskaming areas than farther to the north. They have been folled along parallel axes in all of these chistriets. Voleanism has been an important aceompaniment of this deformation. Eartier volennism has been associated with the deposition of unique iron-hearing formations owing their wide distribution to the ageney of sedimentation intervening between their contribution by igneous masses and their final deposition. Later volcanism developed copper, nickel, cobalt, and silver ores, showing some evidence of genetic relationship. The Lake Superior recrion, then, may be regarted broally as a part of a great metallographic province containing a variety of ores associated with vol'anism, which mel be related with folling along an old shore zone.

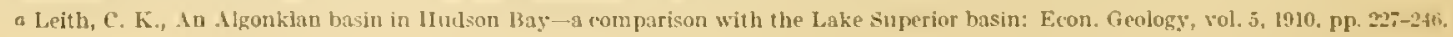




\section{INDEX.}

A.

Abbott, C. E., mine sections by ....................... 138
Ackuowledgments to those ajding. .................. $30,427,573$

Adams, Cnyler, discovers by ...................................... 44

Adams, F.S., on geology of Cilyuna range ............... 219

Agassiz, Lake, description of .......................... 442, 443

Agawa formation, correlation of ..................... 132, 598

distribution and character of ..................... 132, 603

topography of ...

Agarra Lake, geology near.

Ajibik llills, geology at.

Ajibik quartzite, correlation of . . . . . . . . . . . . . . 595, 607, 605 deposition of ........................................ 501 distribution and character of . ......... 252, 259-261, 287, 258, 299, (in)7 relations of . . . . . . . . . . . . . . . . . . . . . . . $200-261.204$ structure of . . . . . . . . . . . . . . . . . . . . . . . . . . . . $\quad 259$ topography of ................................... 105

Alden, W. C., on glaciation.

Algonkian rocks, correlation of ...................... $594-599,602-6115$ distribution and character of ................... $\$ 5,123-137$, 14i-150, 159, 161-178, 198-208, 212-215, 225-235, 251-252, $256-269,2 \$ 3-323,339-345,356-35 \bar{z}, 360-361,598,602-61] 5$ igneons rocks in..

iron borizons in .

$344-345$

Algonquin, Lake, description of . . . . . . . . . . . . . . . $446-447$

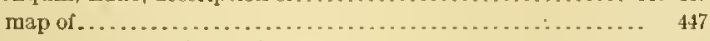

Allen, R. C., on Iron River district .................... 308-320

on Spring Valley ores ............................ $565-5 t i 6$

on Woman River district........................ 555

Alloa, geology at................................... 360

Allowez conglomerate, copper in ................. 575,577, 578 production from

Alteration. Sce Secondary concentration; Weathering, etc.

Amasa, geology near.

$293,298,299,323,507$

iron near.

Amicon River, geology on.

formation of..

sulphur in.

surface alteration of

Amygdaloid deposits, character of

copper in...

distribution and character of

Hate showing.

production from

Amygdules, filling of.

Anderson, T., on ellipsoidal structure

Angeline Lake, geology at

Animikie district, correlation of.

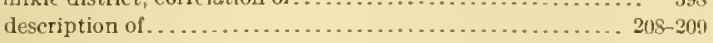

extension of...

geologr of

$205-208,611$

iron ores of .......................... $206-207,20 n-210$ analyses of.

concentration of

map of...

physiography of.

reserves of ..... . .

structure of

Animikie group, correlation of

deposition of.

distribution and character of

$159,16,3-177,196-201,204-209,212-214,225,234-234,251-250$

$265-268,283-290,294-299,306-307,309,311-323,410,608-614$

intrusions in

$197,208,215,290,318,370,372-375,420$

iron in.
. $42.46,206-207,460-161.507,515,610$
Animilic group, rmations of... 176, 202-203,234,318,370-371, 114,513 , silver i:1. . . . origin of.................................... 595

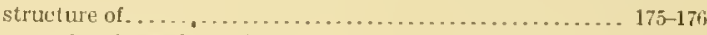

unconformity at base of ............................ 619 Sec also lluronian.

Antoine Lake, geology near. . . . . . . . . . . . . . . . . . . . 333, 336

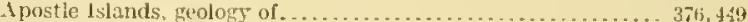

Aqueous sediments, character of . . ..................... 501-5012

Aragon mine, geology near ............................ 33, sections of figure showing ...................... 347,34s

Aragon region, cross sections in, plate showing .............. 346

Archean system, correlation of . . . . ................... $590-602$ deposition of . ..................................... $6123-124$ distribution and character of.................... 85, 118 $129,14 t-154,160-1(11,198,205,225-22-252-25,253,25 ;-258,291$ $293,300-302,306,309-310,329,331,351 j, 357,36,0,597,599,601-102$ igneous rocks of . . . . . . . . . . . . . . . . .

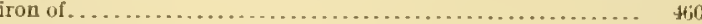

relations of . . . . . . . . . . . . . . .

structure of ................................... 161

unconformity at top of ......................... $617-615$

view showing rocks of ............................. 112

Archean time, volcanism in . . . . . . . . . . . . . . . . . . . . 617

Arpin quartzite, correlation of ........................... 598

distribution and eharacter of .................... 356, 357

tonography on . ................................... 108

Ishland, geology near..................... 376,379,415,421.452

Ishland mine, section of, figure showing................. 237

A tikokan district, treology of .......................... 149.599

iros ore of ............................ 149,:60,561,569

Itikokan mine, history of ................................

Atikokan River, iron on................................ 149

Atikokan series, distribution and character of ................ 195

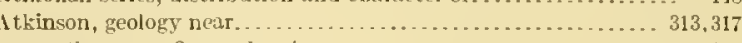

section near, figure showing....................... 318

A thantic mine, geology at .................................... 238,576

history of .................................... 36

iron ore of, analysis of ............................ 238

Aurora, geology neat ................................ 178,236

A ustin mine, geology at............................ 285

B.

Bad River, feology near.

Bad River limestone, correlation of ..................... . 598,605

distribution and character of ..................225.228.605

relatious of

Bad Vermilion Lake, geology at....................... 140

Balsam, geology near.............................. 299

Baltic anygdaloid, description of .................. $37,576,577$

Bandins, caltse of . . . . .

Baraboo district, correlation of . . . . . . . . . . . . . . . . . . . . . . 598

description of .................................... 359

geology of ......................................... 360-362

iron $\operatorname{ores}$ of . . . . . . . . . . . . . . . . . . . . . . . . . . 362-364.570-571 anal $y$ se of . . . . . . . . . . . . . . . . . . . . . . . $362,363,491$ protluction of ................................... 461

reserves.ol...................................... 492

secondary concentration of ........................ $363-364$ manganese in ................................... 488

map of ......................................... 359

mining in, history of .............................. 45

section ol, flgure showing........................... 360

Baraboo quartzite, correlation of ..................... 35ĩ ,598

distribution and character of . . . . . . . . . . . . . . . . 3t 30 3fit.36t

Bare lIill, geology at.............................. $382,385,410$ 
Barrell, Joseph, on dleposition.

Bas:it, decomposition of....

Basement Complex, definition ol . .

Basswood Lake, geology near.

granite of.

relations of topography of

Batchewanung liay, geologs at.

Baukltry Lake, geology near...

Bayley, W. S., on keweenawan series on Menomine district.

Bayles, W. S., and Van Hise, C. R., on Harquet tedistrict

Bayley, W. S., Clements, J. M., and smyth, II. L., on Crystal Falls district

Bearhes, old, elevation of . formation of.

Beaver 13ay, geology at laecolith 21 .

13eck, lichard, on limonite.

Becker, $\mathrm{G}, \mathrm{F}$. on iron ores.

13ell, J. 11., on region northeast of Lake Superior . . . . . . . 95, 155-156 Belted plain, origin of

Bertier, C. P. on Cambrian series. on glaciation

on Keweenawan series.

Bessemer, geology near.

Bessemer ore, definition of. exhaustion of

Bessie mine, geolagy at .

Bibliography of region.

Bidrle, H. $\dot{C}_{\text {. }}$, work of.

Bigsby, J.J., on glacial erratics.

Bij̄iki sebist, alteratıon of. correlation of

distribution and character of.

garnet in

iron ore in.

relations of

topography of

Bingoshick Lake, geology on

Birch Lake, geology near

Birch Lake arch, mIning in, history of

Bittern Lake, iron near.

Biwabik formation, circulation in, figure showing correlation of..

distribution and eharacter of

folding in, plate showing.

greenalite in...

intrusions in.

iron ore ol .

$$
\text { plates showing. }
$$

paint rock in.

phosphorus in.....?

relations of

section of, plate showing

Biwabik mine, geology near.

history of.

Black 13 is, geology at... section at.

Black River, correlation near geology near. section on.

Black Sturgeon River, geology at

I3ogs, iron in

Bohemia, geology near

13ohemia conglonerate, distribution ani character of.

Bone lake, geology neitr.

Bone Litke sehist, topography on. .

Bowen, N. I. , on igneous rocks.

Bowen, $C . F$, and Corey, $(i, W$, on Menominee district .... 410-4I

Boyer Lake, geology at .... 153,157-158

iron at...

mud and rork at, analyses of

2fic, $270,272,275,278,2 \times 3,286,460,503$

598, 608, $610-611$

616

437,439

377

475

475

279

$73-81$

32

270

, 283, 28.5, 0005

162, 164, 177

then, iron ores of.......

Breccia, distribution and eharacter of ...

Brise 1lill, geology at .

Brier slate nember, correlation of

distrihution and eharacter of

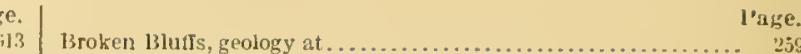

Brooks, A. II., on Harquette district.....

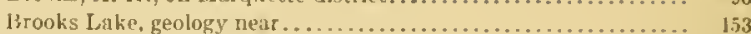

Brotherton minc, geology at . . . . . . . . . . . . . . . . . . . . . 235,238

l3rown iron ores, mining of, history of ......................

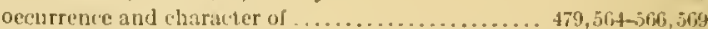

13 ruce mines, copper ores of .......................... 592 Brule liviver, geology near............ 310.313.317,319.321, 322-323, 617 Burchard, F. F., on production of manganilerous iron ores....... its Burntside Lake, geology near.......................... 129 Burt, W. A., discoveries of............................ 38 Burt mine, iron ore from, numlyses of ....................... 193 Burwash, E. N., on Michipicoten Island ............... 3n-391 By-products, recovery of ............................ is c.

Cacaquabic granite, distribution and eharacter of ............. 136 intrusions by.................................... topograply of

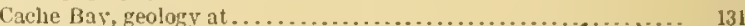

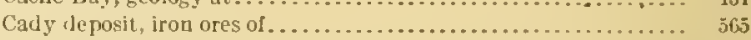
iron ores of, analysis of ............................ Calumet and Hecla conglomerate, Ilistribution and character of. . 342,575 copper in ................................. $577-578$ Calumet and Heela mine, production from............... 37 Calumet district, geology of . . . . . . iron ores of . analysis ol. . secondary eoncentration of . .

volumetric diagram of . . . ........... 353

copper ores in.................................. 574

correlation in ................................ 595,609

loeation and area of .............................. 32.306

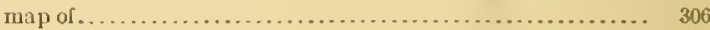

section of, figure showing......................... 37

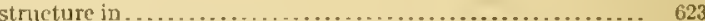

Cambrian systen, deposition of . . . . distribution and character of . . . . . . 225, 235, 251, 269, 243, 245, 291, $300.302,304,306,307,329-330,332,345-346,355,356,360,615-616$ iron ores at base of . . . 352-353 relations of ...................... $354.415-116,615-610,619-620$ unconformity at. ............................. $619-620$

Canadian shore, geologic work on, history of ................. 70

Cape choyye, geology at............................. 391,393

Carbonate ores, greenalite and, relations of ................. 525 nature of .................................. $520-521$ occurrence and character of ............................. 479 origin of................... $502,503,507,514,516,519-520,571$ secondary development of........................ 552 Carbon dioxide, source of............................ j27 Carlton district, geology of .................... 213,214,215,375 Carlton Peak, geology of .................................... 374

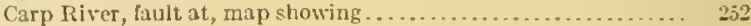
geology at. . . . . . . . . . . . . . . . . . . . . . . . . . 253.2039

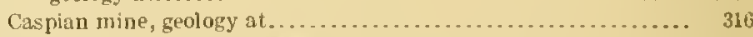
Chamberlin, T. C., on glaciation ....................... 439 on Wisconsin topogriphy.........................99.100 Chamberlin, T. C., and Irving, R. D., on physiography........ 115 Champion, geology near............................. 20.6 Champion location, discovery of......................... 37

Chandler mine, iron ores of ......................... $4 \$ 0.553$ section of, figure showing................................. 138

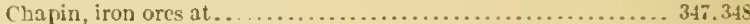

Chequamegon $\mathrm{Bay}$, geologs near........................... 3713

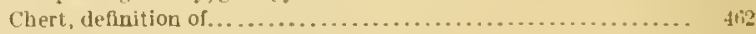
distrihution and character of..................... 462.529

Chert, am ulibolitic, photomicrogta phs of ................ 5is

Chert, ferruginous, composition of ..................... 528

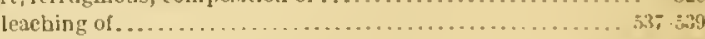
photomicrographs of ........................ 524, 234,34

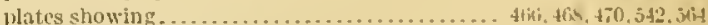
Chester, $\mathbf{A}$. 11., on Giunts Range ores.................. th Chicago Lake, formation of ............................. 416 map of ......................................... 440

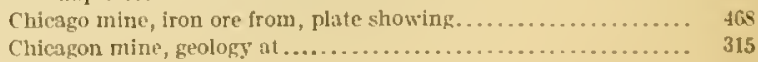

Chippewa River, deposition by.......................... +3s gcology on ....................... 357 
Chippewa- Kerreenaw lohe of Labrador glacier, extent of.... 427, 125, 441 Cincinnati mine, history of. .......................

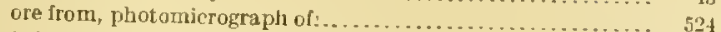

Clarksburg formation, correlation of . . . . . . . . . . . . $607,009,617$ distribution and character of................ $251,265,607,609$ iron ores in ..................................... ${ }_{507}$

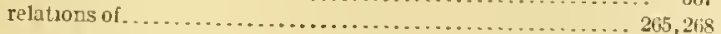

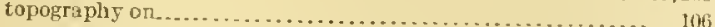

Clements, J. M., on Crystal Falls distriet. . . . . . . . . . 29. 294-295.510

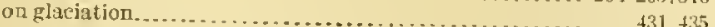
on pbysiography...................... 91, 92, 13-94,98, 102 on Termilion district.

Clements. J. M., and Smytl,

on ('rystal filis district. 39-40,107 I., and Bayley, Wr. F., on Crystal Falls district.

Cleveland mine, geology at . . . . . . . 271

Clift mine description of

history of ........................................... 575

Clinton iron ore, deposits of .............................. 36

distribution and character of .......................... $467-560$

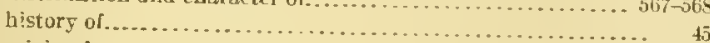

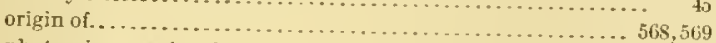

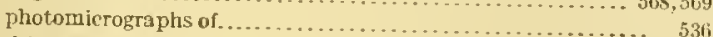
shipments of......................................... ${ }_{567}^{536}$

Clinton Point, geology near...

Cloquet district, geology of

213,214,215,375 603

ores of ....................................... 592.626

Coke, nse of. .

Colby mine, geology at

Cole, G A J. and Gregory, J. Wr on enipso

Coman, A. P., on gold ores. on lake basins. .

on northwestern ontario............................ $149-150,603$

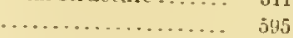

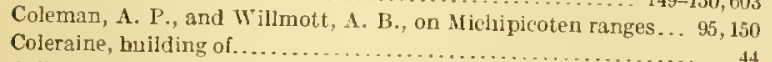

Collins, W. H., on region nortl of Lake Superior............... ${ }_{95}^{44}$

Commonwealth, geology near........................... ${ }_{95}^{95}$

Common wealth district. See Florence distriet.

Competition in mining, effects of.

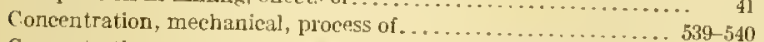

Conecntration, secondary. See Secondary concentration; Weathering.

Conglomerates, copper in

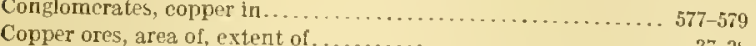

.......................... $37-38$

area of, map showing.

association of, with igneous rocks.......................... $58 \ldots \ldots$

chapter on ................................. $573-593$ Sce also hieweenaw Point, copper ores of.

cbaracter of.

deposition of, chemistry of

means of....

time of...

deposits of, types of.

depth and, relations of

extent of.

grade of...

mine twaters from

mineralogy of.

mining of, history of

occurrence of

modle of ...

origin of...

proiluetion of.

relations of, to other ores.

wall rocks of, alteration of

Copper Lake, iron at

Copper River, geology near.

$\begin{array}{r}378-379 \\ \hline\end{array}$

Cordierite bornstone, distribution and character of ......... 173-174, 200

Corey, G. W., and Bowen, C. F. on Menominee district...... 345

Correlation, cbart showing.

details of. See particular systems, etc.

principles of...

Courtis, W. H., on silver mincrals.

Coutchiching schists, correlation of.

occurrenee and character of...

Cox, G. H., on bydration of ores.

Creosote, recovery of

35

351
Cretaceous rocks, deposition of.... detrital ores in analysis o1..

distribution and charactir of iron of.

phosphorus in...

Crystal Falls, geology near.

Crystal Falls district, correlation in

explotation in

geology of.

$$
\text { map showing. }
$$

iron ores of, alteration of

character of.

composition of .

magnetic phases of.

plate showing.

proportion of.

relations of.

reserves of.

secondary concentration of.

volumetric diagram of.

location and area of. .

map of .

mining in, history of.

physiography of.

Cuba, iron ores of

Cuff mine, geology near

Current River, geology near.

Curry nember, correlation of .

distribution and character of.

iron ore of.

Curry mine, geology near.

Cuyuna district, eorrelation in

deseription of......

exploration in.

geology of...

iron ores of, alteration of

analyses of.

character of...

composition of.

figure showing

distribution of

magnetic phase of.

phosphorus in...

relations of

reserves of.

secondary concentration of

section of, figure show ing.

structure of. .

topography on

manganese in...

maps of.

mining in, history of

phosphorus in

physiography of.

rocks of, correlation of

I'age.

625

196-197

$159,174-179,211,215,(116$

$176-179,19 i-197,460,503$

.......... 194-195

295,323

$54 \mathrm{~N}$, di06, 610-6i1 1, 617

$41-300,441,407-609,419$

, 619

.... $\quad 292$

323,325

$324-325$

.... 486

... 472

$501,507,559$

.. 459

326,533

3.33

32,291

Pocket.

39-40

$96-97,107$

.... 495

205,206

598

$335-340,347$

346

339
$0-611$

$594,610-611$

32,211

$484-485$

$211-216,375.601-605$

546

219-220

$230-203$

221.222

216

$17-219,486$

220

501,507

489

$223-224,539$

216, 2183

476

488

212

41-45

224

structure of.

$(62$

I

Tuly, R. . 1., on intrusion.

on lavas. .

60

am Lake, geology near.

Dizlis, C. 1., on Marquet te district. ..................... 45

Davis, W. M., on physiography .......................... 96

Dead River area, description of .........................

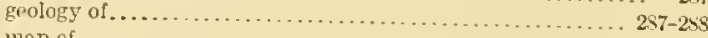

map of ..........................................

Deception Lake, geology near........................... 208, 370

iron near.................................... 207

Deerhunt mine, geology at. ......................... 301

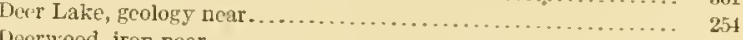

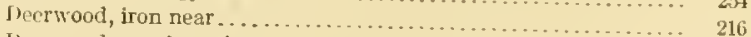

Deerwood member, altera tion of . ..................... 223-224

correlation of ............................ 59s, 6110-611

distribution and eharacter of . . . . . . . . . . . . . . . . . . . 212-215

iron in . .........................................

magnetic rocks in .................................. 216-219

structure of. . . . . . . . . . . . . . . . . . . . . . 
Deformation, changes due to...

description of.

Deltas, formation of

Deming, A C., ais! of

Density, relation of, to rnl is fert of ore, diagram showing.......

Dialıse', composition of

Diamonds, liscovery of in drift

Diemer, M. E., work of.

Dikes, distribution and chisticters of . .

Dip needle, use of, in prasperting. . .

Disappointment Lake, greology" at .

Disappointment Mountain, geology at...

Districls, ore-bearing, list of . . .

Ducks, ore, list of view of.

Dor liver, geology on

Doré conglomerate, correlation of. . distribution and chararter of pettrography of

Duundas County, Wris, copper of .

Drag folds, description of... figure showing.

Drainage, character of.. deseription of....

Prainage, ancient, character of... modification of.

$$
\text { figures showing. }
$$

Drift, ages of .

areas of . . .

deposition of.

distribution of.

drainage of areas of..

obsetration by

stratification of

topography of. modification of

See also Pleistocene; Glaciers; Moraines; Kames; Ontwash plains, ete.

Driftless Area. lakes in ........

location of.

map showing.

pluysiography" of.

view of ....

Drilling. exploration by

Drumlins, formation of

Dubois, $11, W_{.,}$and Mixer, C. T., analysis by ...............

Duluth, geology near.

physiography near.

Duluth, Lake, formation of. map of..

glaciation of. view of.

Duluth gabbro, correlation o distribution and character of ...

dikes of...

intrusion by ....

metamorphism by . plate showing.

relations of ...

segregations in

view of .........

Dumortierite, accurrence of.

$159,177,198,201-202,372-373,410,41+15$

$4-445$

445
-115

598 137 $5+1$

Eagle 1 arbor. geology near mining near.

Eagle River district, copper veins of . .

geology of

section in.

silver in.

Eanes, 11. II., on Mesali clistrict.

Eastern sandstune, relatious of

Fa.kel, F. C., on prodnetion of manganiferous iron ores

Ele:mur, lake, grology ne:r.

Elcanor slate, correls lion of .

distribution and character ol........
Elftinan, .1. II., on Minnesota geology . . . . . . . . . $371,375-37 f$

Ellipsoklal structure, occurrence and characker of . . . . . . 120, 14 151

origin of .......... $502,511-512$

plate showing ................................... 120

signifikance of in ore genesis....................... $510-512$

Ely, geology near ...................... 119, 122, 123, 124, 12k; iron ores ne:ar $\ldots \ldots \ldots \ldots \ldots \ldots \ldots \ldots \ldots \ldots \ldots \ldots \ldots . .13-138$

character of............................... 140

composition of ................................ 139, 1\%n

secondary concentration of .................... 1+2-1+3

changes in ............................... 142-143 figure showing. ......................... 143

Filv" greanstonn, acidic flows interbnded with . . . . . . . . . . . 121 age 0 l. . . . . . clastic rocks assoriated with . . . . . . . . . . . . . . . . . . 121 correlation of ...................................... j9s distribution and character of . intrusions in............................. 121-122, 124-129 mineral composition of .......................... 120-121

relation of, to Soudan formation.................... 12t-125

topoyraphy on ............................... 93,119

Ely Lake. geology near. . . . . . . . . . . . . . . . . . . . . . 122

Embarrass granite, correlation of.......................... 595 distribut ion and (haracter of . . . . . . . . . . . . . . . $154,17 \mathrm{~s}, 415$

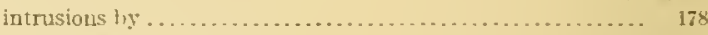

Embarrass Lake. geology near......................... 100,170

Emerald Lake, geolonx near....................... 1't2, 123, 126

England, iron ores of.............................. 495

English Bar, geology at.............................. 368

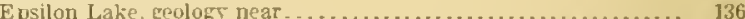

Erosion, amount of ......................... $89-90,109,555-559$ relation of, 10 iron-hearing serliments........... $503-504,556-559$ topography une to ............................ \$6, 9s-9n, 109

Eruptive rocks, iron in. . . . . . . . . . . . . . . . . . . . $512-513,569$ mineralization of ............................... 569 relations of, to iron ores......................... $506-516$ solutions from. Ste also Lavas; Igneous rocks.

Escarpments, age of ................................... 116

description of .............. 112-116

distribution and character of ..................... 110-111 origin of. ................................ 111-112. 117 structural relations of ............................ 116-117

Eskers, formation of ................................ 434

Exploration, cost of .................................. 47 methods of .................................... $451+46$

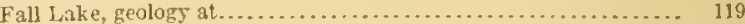

Faulting, description of . ........................... 620 evidence of ............................ $5,104,114,117$ influence of, on physiography........ $5 ., 94-99.101,104,112-115,117$ figure showing............................. 112 Fault scarns. See Escarpments.

Far Lake, geology near.............................. 131 Felch, iron ore near............................... 327 Felch.JJountain district, correlation in .................. 594, ing geology of .............................. 302-305, 3vi, 609

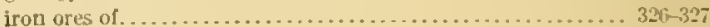

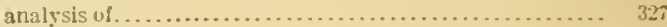
relations of ...................................... secondary concent ration of ..................... 323 volumetric diagram of . location and $a r e a$ of . . . . . . . . . . . . . . . . . . . . . . . . . 32,302 physiography of.................................. 10; struxture in ..................................

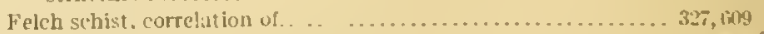
distribution and charaxter of . . . . . . . . . . . . 302.303.30i, 30\%, $600^{\circ}$ relations of

Felsite, copper in....................................

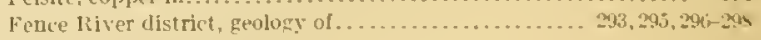
Fence River, plyysiography of ......................... 107

Fenner, $\mathbf{C} . \mathbf{X}$, on igneous rocks....................... 511

Fernekes, G., work of .............................. $5 \times 9$

Hidld work, correlatlon of laboratory experiments and........ $527-5: 9$

Fish Creek, geologr on ............................. 379,415

Flumbean kiver, kevlogy on ........................ 357 
Page.

Florence district, correlation in ................. $598,610-611,617$ exploration in................................. 484 geology of . . . . . . . . . . . . . . . . . 320-323, 376, 379-380, 1606 iron ores of, alteration of. . . . . . . . . . . . . . . . . . . 546 character of . . . . . . . . . . . . . . . . . . . . . . . . . . . 323325 composition of............................. $324-325$ production of ........... relations of. ................................ 501, 507 reserves of .................................. 492 secondary concentration of . . . . . . . . . . . . . . . . . ....... 326 structure of $\ldots \ldots \ldots \ldots . .475$ rolumetrie diagram of . . . . . . . . . . . . . . . . . . . 333 location and area of . . . . . . . . . . . . . . . . . . . . . . . . . 32.320 map of . l'orket.

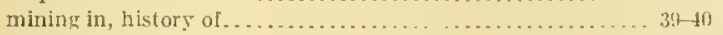

Flowage, rock, alteration by . . . . . . . . . . . . . . . . 554.55

Fluor lsland, geology on .................. 3tis

Folding, extent af............................ 123,1:30 622 , figure showing.

Fond du Lac, physiography near....... 452

Foster. J. IV, and Whitney, J D., on Mlarquedie disfrict . 96

Fourloot Falls, geology at ............................ 345

Fox River valley, correlation in

geology of.. map of ..........

Freda sandstone, deposition of distribntion and character of

Freedom dolomite, correlation of distribution and character of. iron in.... . .

Freight rates, relation of, to grade of ores

Fnel, nature of

Fumce, Lake, geology near

G.

Gabbro, metamorphism hy.

Gabbro platean, character of monadnocks on

Gahimichigami, Lake, geology near

Gary, E. II., on iron ore and freight rates.

Gate Harbor, geology near.

Geikie, 1. ., on igneons rocks. on iron ores.

Geography, maps showing. ontline of. .

Geologic history r résumé of.

Geologic map of Lake Snperior region

Geography, physical account of

Geologic knowledge, growth of...

Geologic work, history of.

Georgian Bay, copper ores at.

Geology, general .

Germany, iron ores of

Giants Range, definition of. description of. geology of..

iron of.

mining on, history of

physiography of. siructure of

Giants Kange granile, correlation of distribution and character of. intrusions of.

phosphorus in.

relations of.

topography on.

Gilbert, G. K., on glaciation.

Gilman deposits, iron ores of iron ores of, analysis of

Glacial deposits, distributinn and charaeter of

Sce also Pleistocene deposits; Irift: etc

$216,308-300,3535,509-500$

Ste also Pleistocene deposit
Glacial epoch, discription of Ste also l'leistucene.

Glacial lakes, beaches of deposits in. distribntion and character of. (ilacial lakes, formation of..... ... tilting of eticet of

Glaciation, effects of. ............... 33,91,92,98, 10f, 114-115, 427-453 crosion by ....................................... 427 period of . . . . . . . . . . . . . . . . . . . . . . . . . . . .

Glaciers, advance of . . . . . . . . . . . . . advance of, map showing.............................. 428

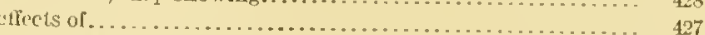

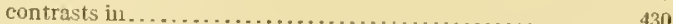
constructive work of . ......................... $433-441$ Sce also Moraines, rte.

erosion by................................... $430-432$

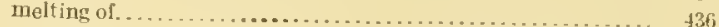

retreat of. . . . . . . . . . . . . . . . . . . . . . . . . . $429-135$

source of .......................................... 427

transportation by ........................... $432-133$

Sec also Drifts.

Clanconite, relation of, to iron....................... 503

Goetz Lake, geology near............................. 153

Gogebic district, correlation of... . . . . . . . . . . . . . geologs of . . . . ............................. 214, 380, 423,600 iron ores of, alleration of.......................... 546 analyses of . . . . . . . . . . . . . . . . . . . . . . . . . . . 491

magnetic phase of .......................... 486

production of .......................... $49-51,(19,461$

relations of ........................ 50.5017

reserves of.............................. $489-492$

secondary concentration in .................... 475,539

structure of...............................475. 486

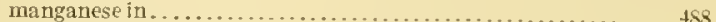

mine waters in, analysis of ....................... 543

mining in, history of . . . . . . . . . . . . . . . . . . . . . . .

Sce also Penokee-frogebic.

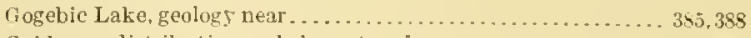

Gold ores, distribution and character of . . . . . . . . . . . . . $595-596$

Gold. mining of, history of ............................ 40

Gold hivait, J. WF, on glaciation..................... 451

Goodrich mine, geology near ........................ 265

Goodrich quartzite, correlation of..................... 59s, 608 distribution and character o[ ......... 251,265, 243, 285, 258, 249, 008 iron ores in......................................... $270-272$

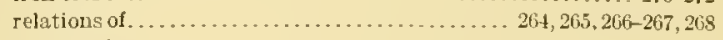
topography of ................................. 106

Coose Lake, geology near .......................... 258

Fordon,. . T., analysis by ......................... 179, 191, 193

Gordon, W. C., on Black River geology .................384-385.38s

Graben faulting, description of...................... 112 figure showing.............................. 112

Grace mine, gold in ................................... 595

Grand l'ortage Bas, geology at. . . . . . . . . . . . . . . . . 370

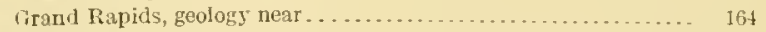

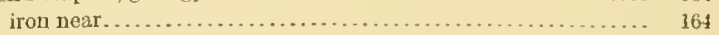

Grand Traverse, physiograjhy near..................... 433

Granite Bluff, geology at........................... 306

Granite Islaud, geology at. . . . ..................... 414

Grant, U. S., map by ................................ 355

on Gunflint Lake district........................ 201

on Keweenawan. ........................ 39x-399. $400-101$

on physiography.......................... 91, 92, 9s-99. 100

on Wisconsin geology .............................. $37 \mathrm{~s}$

Frantsburg, glaciation at.............................. 437

Cireat conglomerate, deposition of . . . . . . . . . . . . . . . 125 distribntion and character of $\ldots \ldots \ldots \ldots \ldots$ 3s $[-3,7,390,413,416,418$

relations of

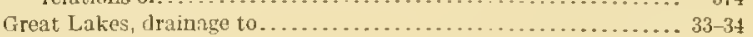
history of ...................................... $44-149,450-159$ maps showing......................... 457,458 structural relations of . .............................. 111 transportation on . . . . . . . . . . . . . . . . . . . . . . . . . . . .

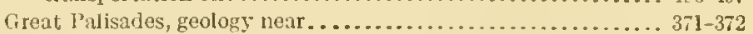
section at, figure showing. ........................ 371

Greenalite, alkaline solutions producing, source of................. 525 alteration of . . . . . . . . . . . . . . . . . . 187, 197, 210,530.537 chernistry of . . . . . . . . . . . . . . . . . . . . $55 n-551$

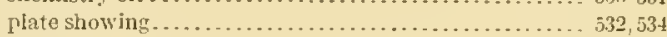

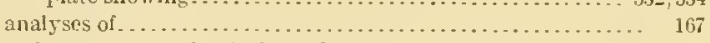
carlonate ores and, relations of . . . . . . . . . . . . . . . . . . 
Greenalite, earhon dioxide producing, saurce of ............. composition of - . . . deposition of. distribution and charactor of 503, 521-522 iron in. nature of. oxilution aud bydrat ion of. phosphorus in. photomirrouriphs of plates showine.

freen Bay lohe of Labrador glacier, extent of

Greens'one conclomerate correlation of

distribution and charneter of. jron in.

Creenumer Lakn, iron of

Gregory, J, II , and Cole, G. I. J., on ellipsoidal strueture........ 511 Gros Cap, geology at

Gros Cap greenstone, eorrelation of .

distribution and character of

intruslons of

petrography of

Grout, W. F on the Kewernawan.

Groveland, iron ores near.

Gioveland formation, distrilution and character of ........ 296, 304, 305 topography of

Gunflint formation, analysis of currelation of.

listrihution and charaeter of ...

iron ores in. .

magnetite in.

metamerphism of

Jhosphorus in...

relations of

section of, figure showing

structure of.

topography of

Gunflint Lake district, correlation in deseription of...

geologs of.

iron ore from photomicrograph of.

physiography of.

$151,152,153,154.393$

154

151

376

327

07

07 594

$95,199-200$ $200,203-204.460,486$

II.

Irall, C. W., on Cuynna district. on glaciation. .

on lieweenawan series.

Hall, R. D., analysis by

Jamburg slate, distribution and eharaeter of .................. topography of

IIanlury IIijl, geology at.

ITaniury slate, correlation of. . topostaphy of

$26 \bar{i}^{2}, 30-330.310$

Hancock mine, geology at

Hanking valless, sulmerged, oceurrener of
IIartford mine, ore from, washing tests un.

II whins mine, folding at, view of.

IIelen furmation, eorrelation of .

distrilution and character of.

intrusions in

iron in.

petrography of.

raliations of.

$130,172,177,198-203,209,604$

203-20.4

524

101,102

Iclen minu, description of . .

g('olegy near

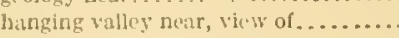

history of.

Ifmatitu, ileposition of

mining of , history of . .

oceurrence and character of

Ilematite Monntain, glaciat ion mar.

llematitic chert, jlate showing.

llenluck formation, correlation of.

distribution and chatucter of.

reliations of.

topograpliy of

II crmans ville limestona, dlistrilution and character of.

IIcron 13ay, topogriphy neik
HIbl,ing, Minn., geology near ....................... 105, 16

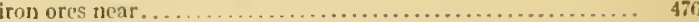

siction near, figure show ing........................ 180

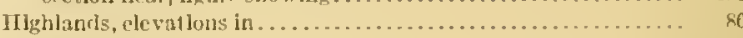

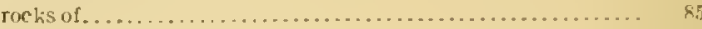

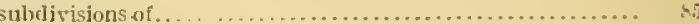

topographic development of....................... $45-40$

Sce also l'plands; M onaluocks; ]'rnoplain.

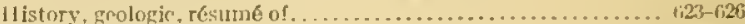

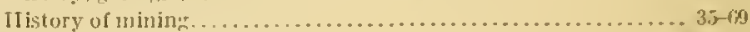

Holyoke minr, geology nma. ........................... 2.4. 28

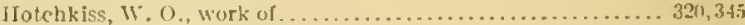

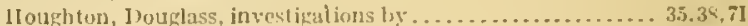

II ulubard. T. I., on kewenawan rocks................ 3६ -342, $345,394,4(0(2)-4) 1,404-40,3,118,421$

lludson Bay, drainage to ............................ 34

grology of . . . . . . . . . . . . . . . . .

glaciers from................................ 425,498

iron-hearing rocks in region of . . . . . . . . . . . . . .

If umbloldt, geology at............................... 20.5

It unt, T. s., on Xipigon Bay......................... 368

II unters Island, geology of . . . . . . ................ 122,12ti, 130

physiography of ............................... 9495

I Iunters Islant series, distribution and character of ........... 118

1 luron Creek, view of ............................. 434

Iluronian series, correlation of . . . . . . . . . . . . . 305. 5itu-599, $102-614$

deformation of ................................. $624-625$

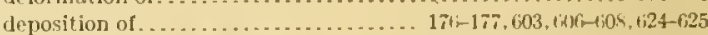
distribution and character of ................ 129-13 $\vec{i}, 145-15 n$,

159, 161-175, 198-201, 205-207, 212-214, 224-234, $251-269,243-323,329-344,35+5-357,394,602-614$ igneous rocks in . . ........................... 176 , $178,197,206,268-269,299,304,318,322-323$, ; i03, 609, 6114, 617 iron horizons in . . . . . . . . . . . . . . . . . . . . . . . iron ores of . . . . . . . . . . . . . . . . . . . . . . . . . $501,504,505,513$ relations of ....................... 17i, 230,300,31\$.372.617-619

map showing $\quad 292$ structure of ................................... $175-166,225,246$ unconformities at and in .......................... 617-619 topography of ............................ 92,94,94, 102-10s view of......................................... 112 Huronian, upper. Sce Animikie.

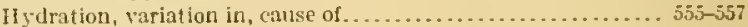

了.

Iee. Sce Glaciation: Glaciers; etc.

Jgneous rocks, alteration by intrusions of............... 545-554

association of, with copper ores. ...................... 581

with iron ores . . . . . . . . . . . . . . . . . . . . . . . . . $504-510$

malcium-magnesium content of .................... 500

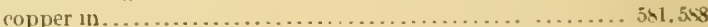

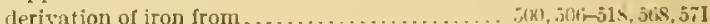

distribution of .............. . ...........5.50 50.5

erosion of................ . . . ........... 507

iron in ........................ $5,512-513,566$

metanorphism by .......... . . . . . . . . . 545-5.44,558

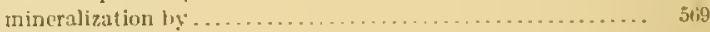

nomenclature of . . . . . . . . . . . . . . . . . . . . . . . . $395-407$

physiography of ............................... $10 \mathrm{~s}^{\circ}$

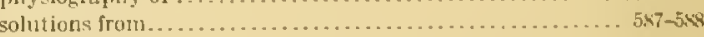

Sce also Solutions.

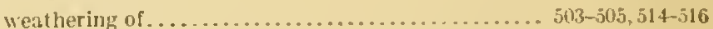

Scc ulso Eruptive rocks; InIrusive rocks: I Javas.

jllinois minc, section of, figure showing................. 3tot

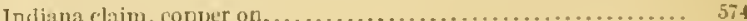

Indians, use of copper by.....................................

Industry, changes in, history of ...................... 47

intluence of physiogra phy on ...................... 49

Ingall, F. I) on silver ores....................... $593-595$

International ficological rommittee, ciled ............. 14j, 14i, 597

Intrusive rocks, distribution and character uf............. 13i-130. filt

ges 607 tel

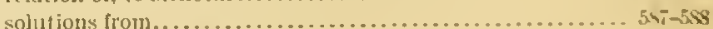

Site also ]gneolis rocks.

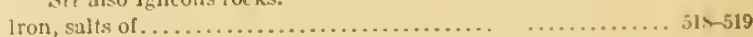

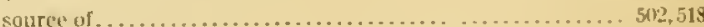

conclusions on.............................. 510

Iransportation of ................................. 539 
Page.

Iron-bearing formations, alteration of............. 500,529

alteration of, by jgneols rocks....................... 545-554 chemistry of................................ $550-551$ analyses of .

association gf, with igneous rocks.................. 502-518, 611 character of .......................... 461-462,549-550 composition of.

correlation of.

deformation of.

402,506

deposition of...

eharacter of.

(1)

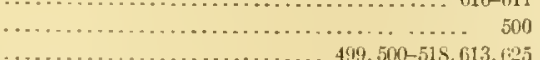

. . 500-506

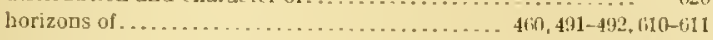

magnetism in.

ore in proportion of

antions

opography of

weatliering of

Sce also particular formation.

Iron Belt mine. geology at .

Iron carbonate. Sce Carhonate ores.

Iron Ilill geology near. map and cross section at

476,477

476

$502-505,516,532-540$

Iron ores, analyses of

bodies of. See Ore bodies

chapter on .

rharacter of .

chemical cormposition of

representation of figures showing.

chemieal origin of...

contents of.

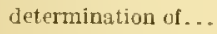
diagram for...

depasition of

chemistry of

order of ....

genetic classification of

grade of . .

figrure showing.

horizons of...

hydration of, variation in

localization of . .

magnetic phases of

magnetitic phases of

manganese in.

mechanimi concentration of

metanorphism of ...

mineralogy of .

mine waters of, composition of

mining of, history of.

methods of.

vecurrence of

in pitching troughs, figure showing.

$333,334-335,340,341,343$

Iron ores, foreign, consumption of. .

l'ilge.

ron ores, manganiferous, origin of................. 486,540

Iron River, geology near ...................... 313.315-316,507

ron River district, correlation in .............. 59s, $606,609-611,617$

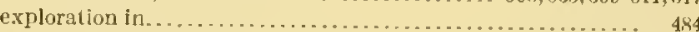

geology of.... . ....................... 309-320, 695.409

iron ores of, alteration of............................ character of . . . . . . . . . . . . . . . . . . . . . . . . . . . . composition of . . .......................

relations of . . . . . . . . . . . . . . . . . . . . . . 501, 507 sécondary concentration of ..................... 326 structure of ............................... 475

volumetric diagran of.......................... $35 \%$

location and area of ................................... $32,30 \mathrm{~s}$

map ol... . ..................................... Pocket.

mining in, history of . ........................... $39-20$

phystography of..... . ....................... 308-309

Iron sulphirie, deposition of. . . . . . . . . . . . . . . . . . . . . . 527

Ironwood, geology near. . . . . . . . . . . . . . . . . . . . . . . . 243, 394

ronwood formation, alteration of .................... 243-245

alteration of, figure showing........................ 245

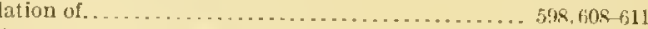

distribution and character of . ................... 225, 230-232

iron of ............................... 235-247, 250, 460

phosphorus in . . . . . . . . . . . . . . . . . . . . . . . 24i-249

figures showing............................ 24s, 249

relations of . . . . . . . . . . . . . . . . . . . . . . . . .

structure of. . . . . . . . . . . . . . . . . . . . . . . . 235-236, 250

Irving, R. D., on copper ores.................... . $575,57.580-58$

on glaciation..................... 439

on fieweenawan series..... 366, 372-3T-, 381.385-389, 394, 397, 409, 414

on Keweenaw district............................ 100

on Lake Superior hasin ............................ 421, 457

on phrsiography ....................... 97,9s, 102-103,104

work of . . . . . . . . $29.30,71$

Irving, $R$. $T$, and Chamberlin, $T, C_{-}$on Keweenaw Point... 115,354

Irving, R. D., and Van 1lise, C. R., on physiography ........... 103

Ishpeming, geology near.................263, 265, 267, 269, 270,271 jaspitite from, plate showing.................... 464

Ishpeming formation, topography of .................... 100

Isle Royal, copper ores of . . . . . . . . . . . . . . . . . . . . . ... 580

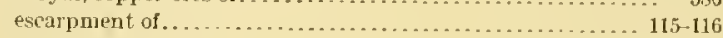

geology of ........................ 389-390, 405, 418, 421,425

correlation of................................ 615

mining on.......................................... 580

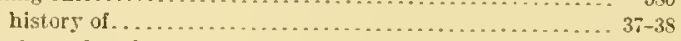

physiography of............................ 99, 116,457

ridge on, view of . ................................. 90

lsle Royal location, history of . . . . . . . . . . . . . . . . . . . . . . 36

Issati, Lake, formation of ............................ 443

4139

(5)

Jast one, distribution and character of . ........... 385

distrihution and character of $12+-125,+61-462$

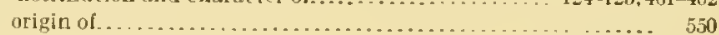

plates showing.......................... $464,466,472,564$

section of, figure showing . . . . . . . . . . . . . . . . . . . . 123

Jasper B hutf, jaspilite from, plate showing .................. 464

Jasper conglomerate, plate showing ....................... 542

Jasper Lake, geology at ............................. 126

Jasper Peak, description of . . . . . . . . . . . . . . . . . geology of .............................................. 122

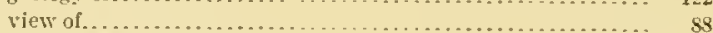

Jaspilite. Ser Jasper.

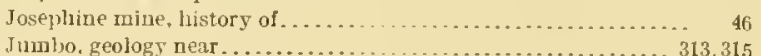

h.

secondary concentration of. Scc Secontary coacentration.

structure of. Scc particular districts.

texture of.

chart showing

transportation of, cost and methods of . . . . . . . . . . . . $495-497$

hy glaciers........................... 432.559-550

valne of

views of.

volume of, relation of to culbic feet of ore, chart showing...

Scc also Itenıtite: Limonite; Clinton ores; Brown ores, etc.; particular districts.

\section{1}

09

490
40

Keewatin series, age of ..........................................

forrelation of................................ 549-600

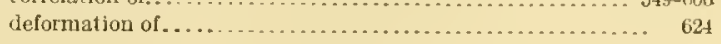


Keewatin series, distribution and character of $14+145,14 \times, 150154,160,144,205-2010,225,226,2=2$ $254-255,247,309-310,322,330-331,59(7,599-16(3)$ extertsion of

goll in

iron ores of alteration of.

production of.

relations of

relations of

Sce also particular formations.

Tekérabic Lake, geology near. . .

Lettle liver, geology near..

Ketlles, formition of.

Kewernawan series, age of.

area of

copper ores in.

correlution of

deposition of

distribution and charneter of

$46,140,460-41$

$5 !: 1$

$159,17 \mathrm{i}-1 \mathrm{i}, \mathrm{1}, \mathrm{k}, 201-209,212,215,221-226,244$ $235,250,251,300-305,346-424,597,1002$ 614-ilis

faulting of..

$420-121,620,622,425$

folding in....

grain of ... . .

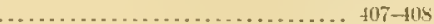

igneous rock

nomenclat ure of. source of

$42+-42 t ;, 615$

intrusions of . . . . 171-172, 197, 215, 278-279,377-378, $418,424,425-126$

iron horizons in ...

jointing io...

metamorphism of....

relations oí.

section of..

$23 t-235,33 s-379,3 s t-3 s 6,3 s s-3 s 9,41 t-4] 6.420,619$

figure show

sediments in...

structure of...

figure showing....

subdivisions of.

thickness of.

topography or.

unconformity at........

rolume of.

Sec also particular formations.

Keweenaw district, loeation aud area of ................ 31

mining io, history of...

physiography of..

production of..

topography of ............................ 91-92,94,100

Keweedaw escarpment, description of

Keweena w lobe of Labrador glacier, extent of............... 425

Keweenaw Point, copper ores of ...................... $573-593$

copper ores of, eharacter of .......................... $57 . \ldots$

extent of

grade of..

minerals of

occurrence

$573-574$

production of.

geology of and near

mitps of.

stetion of, figure showing...

silver at..

structure on

veins on....

Keyes Lake, geology near.

Kintball Lake, geology neitr.

King, F. 11., on glactation.

Kitclai schist, correlation of distribution and rlaracter of

liloos, J. Il, on Ki'ween:wan seris.

Knife Litke, feology near.

Knife labe sliste, correlation of

distribution and vharacter of

intrusion of.

lithology" of...

Inlumers eharacter of

$340-345,404,409,412-413,415,41 \uparrow, 425$

$3.81), 5.4$

99,574 nife Lake slate, relations of struseture of ....................

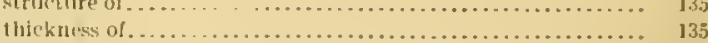
lopograthy of ................................. 94.119

ona dolonsite, correlation of . . . . . . . . . .

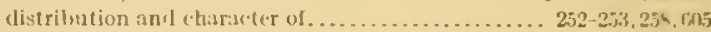
relations of . . . . . . . . . . . . . . . . . . . . . . . . . topogra phy of . ....................

Lahoratory synthesis, correlation of fiell work and......... $527-529$ Labrudor flacier, advance of ......................... $f_{2 y}$ Lac lis Belle conglomerate, distribution and character of ......... $3 \times 1$ Lake Angeline mine, whing tests on ores from.............. . al

Lake basins, formation of . . . . . . . . . . . . . . . . . . . . $4: 31-432$ section of, figure slowing........................... 432 Lake Jluron shore, correlat ion on ....................... 59.

Lake Michigan lobe, extent of......................... $\$$.

Lake of the Woorls, feolony at........................... 122

Lake of the IVoots district, correlation of................ 594.595 .100 description of ..................................... $1 \mathrm{t}$

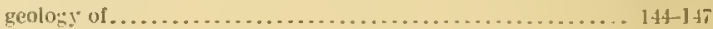
iron absent in .................................... $1+4$ physiography of................................... 94

Lakes, origin of . ............. 9]

Lakes, glacial. See Glacial lakes.

Lake Shore trap, distribution ant character of .......... 3\$1.3\$4 425 Lake Snperior, east coast of, geology of .................... 39. $39^{\prime}-392$ Lake Superior basin, character of............... 33,110-111,421 423 escarpments of.................................. 112-116 ape of ....................................... 116

relations of................................... 116-117

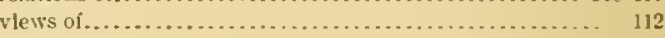
formaition $0[. . . \ldots \ldots \ldots \ldots \ldots \ldots \ldots \ldots \ldots \ldots \ldots \ldots$. ti22-4i23.625 map of -4.20 origin of... . . . . . . . . . . . . . . . plysiography of.............................. 100, $4 ;$.

Lake Superior lobe of Lahrador glacier, extent of. . . . . . . . . . . 424, 442 Lake Superior sandstone, distribution and character of ......... 109 ,

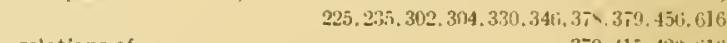

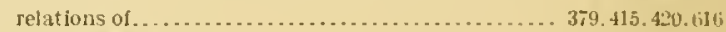

Lakewoor, geology of ............................... 355 geology of, map showing.......................... 358 Lane, $\Lambda$. C., on copper ores............................... . $541.544-590$ on glaciation ...................................... $43 ! 1-410$ on Isle Royal.................................. 34!-390 on Keweena wan series..... $3 \times 2,3 \times 3,3 \times 5,398,410-403,405,40 ; 414,42]$ on mine waters......................................

Lane, A. C., and Seaman, A. E., on Iake Superior sandstone.... 616 Larsen, E. S., and Wright, F. E., on quartz crrstallizasion...... 549 Laterite, associstion of, with irop ores................... 503

Laurentian highlands, location of ......................... 3.5

Laurentian peneplain, extent of ........................ ss

Laurentian series, batholiths of ....................... 145 cortelation of............................... 30t, th0 10101 deposition of . . . . . . . . . . . . . . . . . . . . . . . . . . ti23-1;24 distribution and character of ..................... 119 , 124-129, 145-150, 154-155, 16in, 194, 205, 2:5 220. 252, $25,251,253-293,300-302,304,330-331,3100,597,1000-6,02$

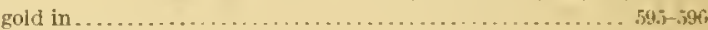

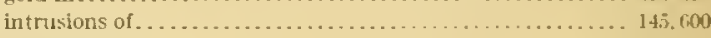
relations of .................................... 227,240

Lavas, extension of periods of........... variation in, relation of, to iron..................... sliting Sce also Eruptive rocks: Igneous rocks.

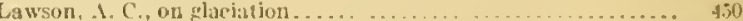

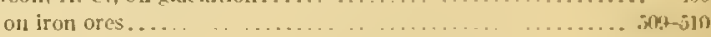
on Lake of the Hoods and Rainy Lake districts....... 144-14.3, 147 on Minnesota.... ......... . . . . . on 1 hysiography...................... $94,9,101,112,450$ on subcrustal fusion, theory of ................... $146^{\circ}$ Leaching, proeess of . . . . . . . . . . . . . . . . . . . . . . . $337-539$

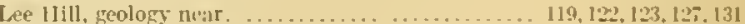

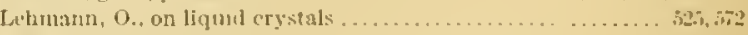

Leith, C. K.. on physiography................... 1113-104, 432

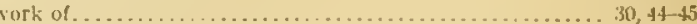

Lerch Brothers. analyses by ........................... 193, 235 
Page.

Life, pre-Cambrian, existenee of

Lighthouse l'vint, geology near.

Lime, relation of to phosphorus.

(96, 249,282, firmes showing.

$19 \%, 39,20$

Limonite, formation of $514-520,571$ nature of.

$520-521$

Lincar monaduocles. See Uomadnocks, linear.

Literature, list of ................................. $73-84$

Little Falls distriet, geology of . . . . . . . . . . . . . . . . . $213,214,375$

Little Presque Isle River, geology near................... 227

Loess, distribution and character of . ..................... 43.

Logan, W. E., on liewenawan series...................... 392, 393 on Michipicoten Island . . . . . . . . . . . . . . . . . . . . 391

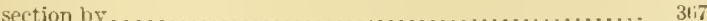

Logan sills, correlation of. distribution and charaeter of . . . . . . . . . . . . . $195,202,204,374,410$ intrusion of .

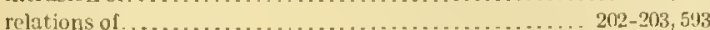
relations ol .......................................... 202-203, 593
silver in. topography on.

.. 10I, 102

Long Lake, geology near.

$119,132.153$

Loon Lake, Mich., geology near ......................... 201,370 iron at.... .

(3)

Sof a $/ s o$ inimikic flistrict.

Loret to mine, geology near........................... 332, 330

Low, A. P., on iron ores............................ 50.4

Lower Magnesian limestone, distribution and character of. . 3til, 361-3ti2 iron ores in.

Lowlands, description of.

$56+565$ geology of ................ .

$108-110$ M

Mic Farlane, Thomas, on Keweenawan series. on Mamainse Peninsula

on Nipigon Bay.

on silver.

MeInnes, William, on II unters Island and Thumder Bay region. 94-95, 101

Mcliass Mountain, geology of

Mc Kenzie, geology near

Magma, iron from solutions from. Scc solutions.

Magnetic phases of ore, occurrence of Sec also Amphiliole-magnetite rocks

Magnetic survey, prospecting ly

Iagnetite, deposition of occurrence and character of origin ol.

Magnetite, titaniferous, eharacter of origin of.

\$1 agpie Valley, geology near

Mahoning nime, concretions in concretions in, analyses of geology near. iron ore from, plate showing

Mamainse l'eninsula, geology of section on...

1anganiferous ores, occurrence and charaeter of . . . . . . . . . . 456,560

Mansfield, geology near

Mansfield slate, iron in occurrence of relations of. . tonography of

Jap of Lake Snperior region showing topographic de welopment showing topographic prorinces.

Maps, geologice, aceuracy of. of Lake Superior region

Map, index, of region

Marathon conglomerate, correlation of distribution ancl character of .

Mareniscan series, name of.

Marenisco, geo $\log y$ near.

Mariska, geology near

Marquette district, acknowledgments conceming.............. 251 correlation in . . . . . . . . . . . . . . . . 598, 599, (606,610-611,617 exploration in .................................. 4.45 geology or... $251-269,429,411,605-610,615,620-621$ $185,216-219$ $44.481-458$ $479,4 \times 0,480$

561,568

151
$192-193$ $513-514,564,571$

larquette district, iroun ores of,

ration of .........5 546,551,610-611 iron ores of, analyses of . . . . . . . . . . . . . . . . . . 273,491 charact

classification of ................................ $271-272$

composition of . ................................ 273-274

distribution of ............................. 270

magnetic phases of .......................... 486

occurrence of ................................. 270-271

figure showing .............................. 270

phosphorus in............................. $279-283$

conerntration of ........................... 2\$1, 253

figure's showing. . . . . . . . . . . . . . . . . . . . . . 280.282

plates showing.......................... $46,4,46,470$

production of . .............................. 461

proportions of ............................

relations of . . . . . . . . . . . . . . . . . . . . . . . . 507

reserves of . . . . . . . . . . . . . . . . . . . . . . . $\$ 59-492$

secondary coneentration of . . . . . . . . . . . . . 275-279, 539 conditions of............................. 275 sequence of............................. 27..279

location ancl area of ........................... 3l-32, 25l map of . . . . . . .

mining in, history of . ................................ 3\$-39

physiography of ......................... $96,105-100 i, 252$

prouluction from................................ $39 . .1-10,69$

structure of . . . . . . . . . . . . . .

figute showing.............................. 253

Marshatl II ill graywacke, correlation of................... 595 distribution and character of . . . . . . . . . . . . . . . . . 35ti, 357

tonography of ......................................... 108

Martin, L, on Keweenawan series.................... t20 421

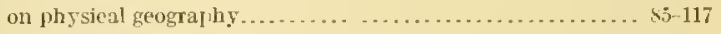

on 1'ieistocene................................... $427-459$

Mass nine, geology at............................. 271 history of .................................. 36

Mastodon mine, geology at ......................... 295

Matawin district, geology of............................ 119-150 iron of ......................................... 150

Mead, W. J., diagram method devised by . . . ............. 182-183 on iron ores................................ 137-143, $179-197,235-250,270-2 \times 3.2 \times 6,323-32 \times, 341-3.44 .362-305,460-571$ work of........................................ 518

feadow mine, phosphorus in......................... 194

Meetls, A. 1).. analysis by.............................. 191

Menominee distriet, correlation of . ................ $594,599,610-611$ cross sections in, plate showing...................... 346

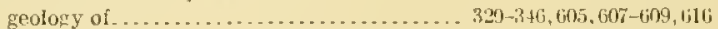
iron ores of, alteration of ........................... 540

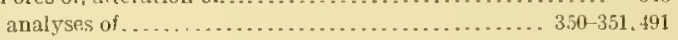
character of ............................... 352.503

composition of ............................... 350-352

magnetic hases of.......................... 486

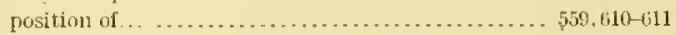
production of ............................... 461

proportion of ................................ 462 relations of . . . . . . . . . . . . . . . . . . . . . 501,507

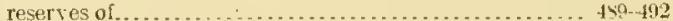
secondary concentration of . . . . . . . . structure of . . . . . . . . . . . . . . . . $34(-350.475-176,623$ figures showing........................ $346,347,348,349$ volimetric diagram of........................... 353

location and area of . . . . . . . . . . . . . . . . . . . . 32,320 map of ...................................... Pocket mining in, history of . . . . . . . . . . . . . . . . . . . . . . . . . physiography of........................ 94, 1n: 10t, 329,433 production of................................. 39.t1-ti5.199

Menominee River, geolo:y on................. 321.322.344-345

Lerriam, W. N.. map by.......................... 320

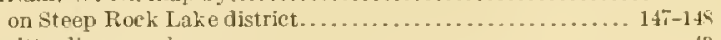
Ierritts, discovery hy................................ 43

aha, iron at and near.

meaning of name .................................. 159

lesahi district, correlation in..................... $598,610-611$ definition of . .................................... 41,159 
I'age.

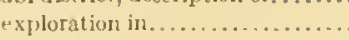
reology of

glaciation in, map showing. history of..

iron ores of, alteration of

altertintion of, plizte showing.

analyses of.

vhisarterist ics of

composition of . .

figure slowing.

distribution of.

magnet ic phanst's of . . .

phospliorus in

concentration of

figures showing.

plates showing. ...

production of .

proportion of.

relations of.

reserves of .

rocks associated with, alteration of - 191-192

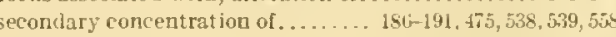
figureshowing.......................... 186

sequence of............................ 197

structure of . . . . . . . . . . . . . . . . . . 150, $475-476,450$

figure showing............................ 1s0

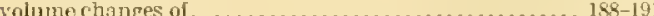

figures showing. . . ...................... 15s, 189, 190

location and area of...

Pocket

mining in, history of ............................. $42-4$

maguetic portion of, character of.

development of .

mine waters in, analysis of

mining in. .

siograply in ........................................ 105

plate showing................................ 532

production of ................................. tis-tis, 69

strueture in.

view of...

fesas, distribution ani character of ................... 100-102

structure of, figure showing...

Mesuard quartzite, analyses of

correlation of

distribution and chang

relations of.

topography of

Metamorphism, cause of.... .

cycle of .

effects of.

relation of to secondary concentration

temperature of.

Sre also Igneous rocks.

Mieliigmme Lake, geology near...........

Michiganume mine, geology at

history of.

Michigamme Mountain district, geology of physiography of.

Miclignmme River, geology on.

Mirhigammy slate, correlation of . distribution and chararter of .

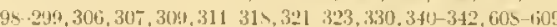
intrusions in . rolutions of. structure of. topogr:ipliy of

Michigan, bibliography for. ginology of

investigations in iron ores of

$$
\text { proulut tion of. }
$$

physiography of ..

Sec also parlicular distracts.

Michigan mine, gold of. Sec also Minmeta mine.

Miehipicolen alistrict, ("opper ores of

correlation in.

description of.

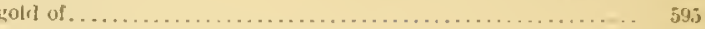

iron ore of, amalyses of . $15 \mathrm{H}^{\circ}$ distribution and character of ................... $15 \mathrm{f}-157$

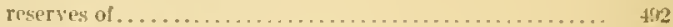

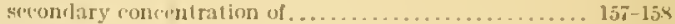

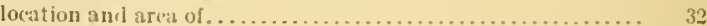

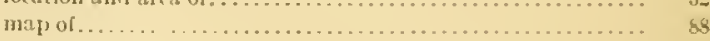
mining in, hist ory of ............................ t5 40 physiogrably of .... section in ................................... 391

Michipj roten IIarbor, geology near.................. 131,15t. 15j

Mirlule conflonerate, distribution and charactur of . . . . . . . . 341347

Middle River, geology on . . . . . . . . . . . . . . . . . . . . 379,415

Mikado mine, geology at........................... 231;, 239

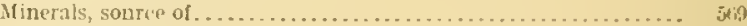

Nine waters. analyses of . . . . . . . . . . . . . . . . . . . . . 543,579 composition of ........................... 540. $348-544.579$

Minimg, history of .... Sec alsa Copper: Iron: Silver; fold

Minnesota, bibliography for .......................... $78-80$ copper ores of ..................................... 540 geology of .................................. 367-379, 425, 429 investigations in ................................ 72 iron ares of . . . . . . . . . . . .

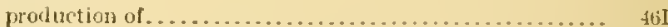

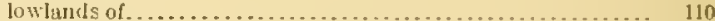
man of . . . . . . . . . physiography of.......................... 91-92.99,116-117 titaniferons ores of ............................... $56 \mathbf{I}$ Ste also particular districls.

Minnesota lobe of Labrador glacier. Sce Red River lobe.

Minnesota mine, history of ............................ 36 ores of ............................................. 36,5 Sce also Michigan inine.

Minnesota River valley. geology of ..................... 224

Hinnesota tax commission. aid of ............................. 30

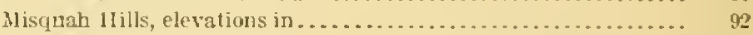

Mississippi River, drainage to ............................. 34 ponding of

Mixer, C. T., and Dubois, II. W., analysis by................ 281

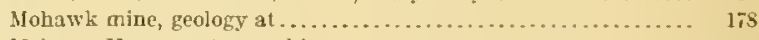
Moissan, II., on metamorphism...................... $549-50$

Moistnre, relation of to cubic contents of ore............... 4 43-4s4 relation of, to cubic contents of ore, figure showing......... 4 . Blokoman, Ont.. geology near.......................... 149

Monadnocks, character and cause of ............... 90

Monadnocks, linear, descriptions of ...................... 9s-10s structure of figure showing ......................... 101

Mona schist. rorrelation of............................ 598 distribution and character of . 25.2.25t-25.5.297

Monorlinal ridges, distribution and character of ......... 99-100, 102-108 structure of, figure showing........................ 101

Momopoly in mining, effects of........................ 41

Monroe mine, folding at, view of . . . . . . . . . . . . . .

Montreal River, gcology near........................... 413, 414

Hoose Lakin, geology near ........................ 119, 127, 129, 131

Moraine, gruund. formation of .......................... 433

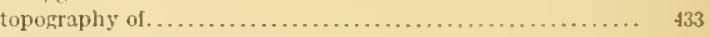
436

Aforaine, recessional and intorlohate, formation of ............. 435

loraines, terminal, formation of ........................ fist

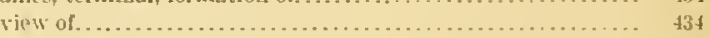

Jorrison Creek, geology on ...................... 313.316-317

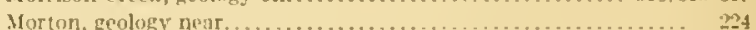

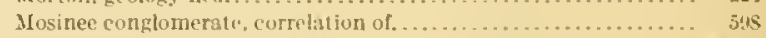
distrilution and rharzeter of ........................ 350, 3.5.

Hotley, geolury near a

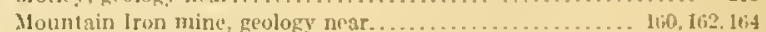

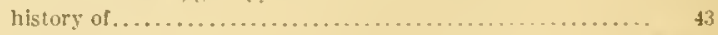
views in ................................... 140.432

Ilount lloughton, goology at ........................... 3\$2

Hount 1 foughton felsite, correlation of ..................... $3 \times 2$ distribution and character of ....................... 3s

Hud Lake, geology near ................................. 254. 257

Mussey, 11. R.. on Marguette district...... ....... 3s 
Page.

Namakon Lake, geologs at.

Nashwauk, geology near.

National mine, history of.

Necedah, correlation at. geology near. maps showing

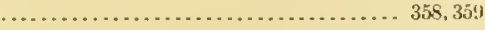
hematitic chert from, plate showing . ..................... 4466

Negaunee formation, alteration of ...................... 276-279 alteration of, figure showing ........................ 270 analy'sis of. composition of . . . . . . . . . . . . . . . . . . . . . . . . . . 273, 505 correlation of . .......................... 12t, 132, 59s, tio7, $60 \mathrm{~s}$ deposition of distribution and character of.................. 252, 262-2ti4, $270-272,257-289,291,296-295,300-301,607$ intrusions in

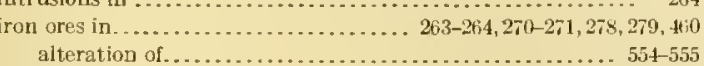
hosphorus in ..................................... 279 relations of . . . . . . . . . . . 262, 264, 265, 269, 296, 297, 305, 506-507 structure of ....................................... 262-26i3 topography on

105

Nemadji, Lake, formation of . . . . . . . . . . . . . . . . . . . 443-444 mare of

Newport, geology near.............................. $227,236,243$

New Ulm, geology near.

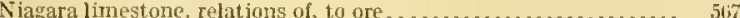
topography on.

Nicollet, J. N., map by

Nicollet Lake, formation of

Nipigon Lake, geology near. . .................... 3tis-370, 421,423 physiography near.

Nipigon Bay, geology near... 367-370, 393-394, 422 sections near.......... physiography near................................... 95

Nipigon series, name of map of .

Nonesuch shale, copper ores in. deposition of.

charer of . ...

Norrie mine, geology at.

iron ore of, analyses of. .

section at, figure showing.

North Blufi, correlation near geology near.

North Mlound quartzite, correlation of . distribution and character of topography of ..

Norway, cross sections near, plate showing geology near

Norwood, J. .1., on Mesabi district.

Nunataks, effects of.

o.

Ogish ke conglomerate, correlation of

distribution and character of. .

intrusions in

lithology of.

metamorphism of

relations of.

structure of

thickness of

topography on

Ogishke Lake, geology at

oliver mine, phosphorus in

Oliver Mining Co., aid of area controlled by

Ontario, bibliography for gold of....

pre-A nimikie districts of $382-3 \$ 4,3 \times 5,413-414,426$
236.238 236.238
238 357 108 ... 346 .... 42 436 tonagon district, copper ores of mining in, history of silver in. .

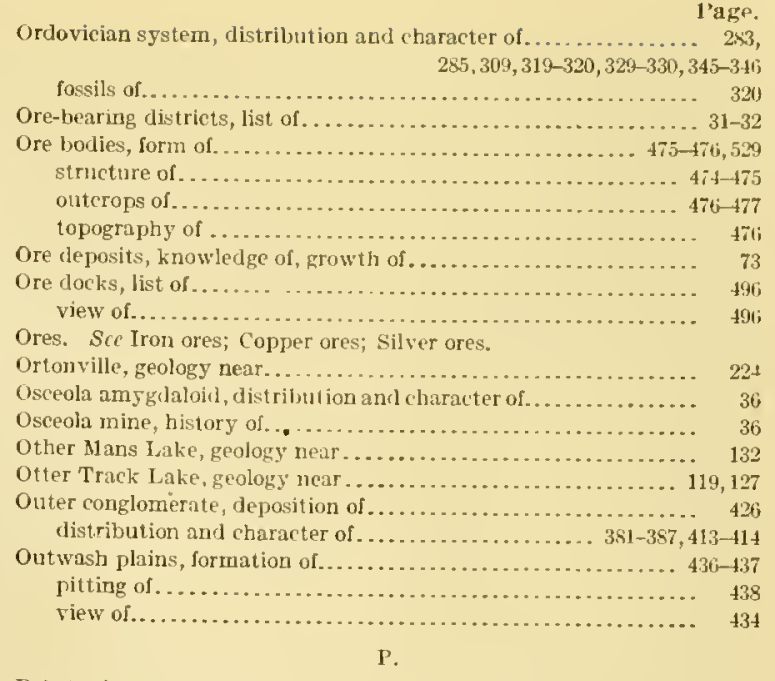

Pabst mine, geology of...

Paint River, geology near ............................... 236, 237

Paint rock, analyses of . . . . . . . . . . . . . . . . . . . . . . . . . . . distribution and character of ............................ 17 phosphorus in ..................................... 195

Paleozoic rocks, distribution and character of.......... 10;-116, 615-1i16 Palmer, relations at. . . . ............................ 265 Palmer gneiss, correlation of ............................ 598 distribution ant character of . . . . . . . . . . . . . . . . . 252, 255-256

Palms formation, correlation of . . . . . . . . . . . . . . . . . . 595,608 distribution and character of . . . . . . . . . . . . . . . . 225, 229-230,608 relations of . ....

Palms mine, geology at.............................. 229, 236

Paragenesis of copper ores, data on .......................... 585 of iron ores, data on ................. $570-572$

Paulson nine, geolog $y$ near. . . . . . . . . . . . . . . . . . . . . . 199, 200, 202 iron of . . . . . . . . . . . . . . . . . . . . . . . . . . . . . . . 204

Pegmatitic origin of ore, evidence of...................... nature of . ........

Pelites, deposition of ...................................... 625 oceurrence of ...................................... 603

Peneplain, age of . .......................... 85-\$9,116-117

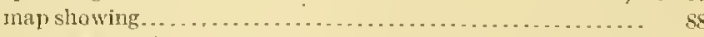
modification of . . . . . . . . . . . . origin of..................................... 85,90,559

relations of fignre showing........................ 116 Sce also Highlands.

Penohscot mine, iron ore of, plate showing................. 468

Penokee Gap, geology at..........................229, 231 slate from, photomierograph of ..................... 548

Penokee-Gogebic district, correlation of . ................... 598

deseription of .....................

geology of ............................. 225-235, 414415,611

iron ores of, analyses of. . ................ 238, 239, 240,241, 244

character of . . . . . . . . . . . . . . . . . . . . .

composition of ............................. 235-240, 244 figures showing........................... 239.240

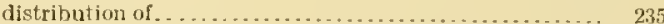

magnetitic phases of ........................... 241-242 analyses of ............................... 241

phosphorus in.............................. 24i 249 figure showing . . . . . . . . . . . . . . . . . . . . 248, 249

plate showing ................................. 472

production of . . . . . . . . . . . . . . . . . . . . . . . . . . .

proportion of.................................... $\$ 62$

reserves of ................................. 492

secondary concentration of . . . . . . . . . . . . . $242-250,475$ conditions of . .......................... 242-243

sequence of ................................ 2507

rocks associated with, alteration uf . . . . . . . . . . . . 245-247 analyses of .................................. 240

structure of .

figures showing........................ 236, 23 
l'enoken rogebic district, misp of physiography of.

section of figure showing.

Ser also Gogebio districl.

l'enokee Range, deseription of .

Perch Lake district, description of. gcology of...

$$
\text { map showing }
$$

inap of. . .

I'ewabic location, listory of

Phospliorus, conceut ration of distribution and character of... figures showing

Telation of lime and. figure showiog.... source of.

Physical geography, account of. ...

Physiography, influence of on develomment................ ts

Pie Island, geology of ................................ 209, 420

Pigeon l'oiat district, geology of ...................... 204-205

map of

pliysiography of.

Pine Creek, geology near.....

bioneer mine, pliosphorus io. section of, figure showing

Pitching trougbs. Sec lron ore; Drag folels

Pleistocene deposits, distribution and character of .... 179, 211,216, 269, $283,2 \times 5,287,264,290,323,35 \bar{i}, 360,362,42 \overline{7}-459,559-560,617$

map showiog..... diseussion of .

modification of .

provinces of $2 \geq 0,24,247.279-24]$ $192,1916,245,249,240$

$196,249,242$ 196.249 .2402$$
\text { tew's of }
$$

Sce also Glaciation; Glaeiers: Drift; ctc.

Pleistocene history, chapter on summary of

Plueking, explanation of....

Point anx Mines, geology at.

Pokegama Lake, iron near... .

Pokegana quartzite, correlation of dist ribution and character of

Porcupine Jountain district, copper in geology of. physiography of..

Porosity, relation of, to cubic contents of are. relation of, to cuhic contents of ore, figure showing.

Porphyry, age of. .

distribution and character of...

Portage Lake, copper near..... geology at. section at... view at .........

Port Arthur, geology near.... iron near

Potato River, geology at.

Potsuam sandstone, distribution and character of iron ores in...

Powers Bluft quartzite, eorrelation of . dist ribution and character of. topography of

Pre-Cambrian rocks, investigation of . .

I'resque Isle, geology near.

l'resque Isle River, geology near....

Princoton mine, geology at ...

P'rospecting, glacial drift in. . vethods of

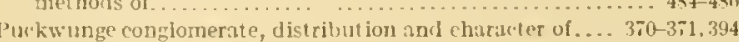
relations of.

I'ump.lly, $\mathrm{R}$, on copper ores. on Keweenawan series.

Quartz, erystallization o!

Ruincy amyedisloid, distribut ion and character of

Qulucy mine, bistory of ores in.

Qıinnesce, geology near $41-3450$ av

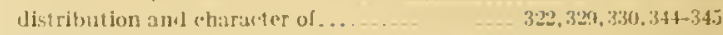

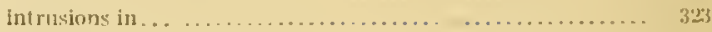
relations of . . . . . . . . . . . . . . . . . . . . . . . . 311,342

1R.

Rabbit Iake, reology near ..................... 213, 214 iron of .... . . . . . . . . . . composition of. figures showing .................221,222 Rabbis Mouminin, silver at ......................... $394-505$

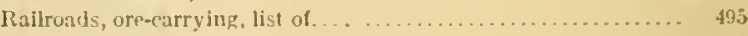

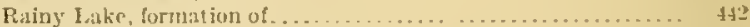

Rainy Lake district, correlation in . . . . . . . . . . . . . . . deseription of ....................................... 144 elevations in ..................................... 94 reology of . . . . . . . . . . . . . gold in . . . . . . . . . . . . . . . . . . . . . . . physiography of.............................. 94 Rainy Lake lole, extent of. .................. $427,42 x-129,441$ liandall, geology near............................ 21:;

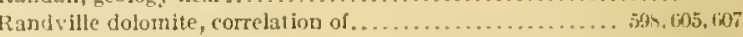
distribution and character of ...................... $293.3(k)-303,306,330,3333-334,342,10,3,607-108$ relations of......................... $305.333 .334,342.343$ topography on .............................. 107,329

Ransome, F. L., on ellipsoidal structure ................. ill on iron ares . . . . . . . . . . . . . . . . . . . . . . . . . . . 50.510 Rat l'ortage, grology near........................... 145 Red Cedar River, geology on .......................... 357 Red Lake, formation of ............................. $4 t_{2}$

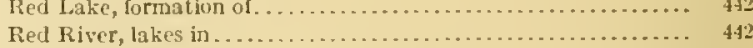
Red River lohe of Labrador glacier, extent of ........429,430,441-142 Red Rock mine, geology at . . . . . . . . . . . . . . . . . . . . . . . 29-,300 Redstone, geology near.............................. 224 Reid, Clement, on lavas............................. 511 Relief, character of ................................. 33,90-91 neasure of ....................................... $\$$

Republic tnine, geology at........................... 272 history of ....................................... iron ores of ................................. $440.352-2 i 33$ Republic, chert from, plate showing.................... tio Republic trough, physiography in ...................... $10 \mathrm{i}^{\mathrm{n}}$ Rib IIill, map of ....................................... Rib Hill guartzite, correlation of .......................... 5gs distribution and character of . ...................... 350 topograpby on .................................... 10,

Roberts, II. II., on prortuction of iron ore................ $490-191$

Rohinson Lake, geology of . . . . . . . . . . . . . . . . .

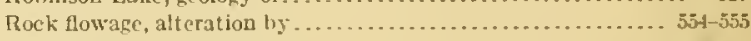

Rocks, depths of formation of . . ....................... $\$ 2,90$

Rominger, Carl, on Marquette district . . . . . . . . . . . . . . 96, 105 on Meoomince district ............................ $3 t i$

Ropes mine, gold of................................ 595.59t; production of ........................................ ti

Rove slatr, correlation of........................... 594, (il] distribution and character of ........................ 19x,200-201 metarnorphism of ............................... 201 topography on ................................. 102

Russell, 1. C., on ellipsoidal strueture ................... 511 on glaciution. ............................430,435,437,440 on physiography................................ 110

Salvawe Lake, iron near. Saganaga Iake, grology at . . . . . . . . . . . . . . . . . . . 119.130 Saganaga Lake granite. Sec Basswood Lake, granite of.

St. Ctoix River, geology near............. $376,375-379,4(9), 415,421$ section on, figure showing....................... 379 St. Ignace Islmul, geology on ........................... 3tis St. Lawrence River, drainage tributary to................. 34 St. Louis Lake, formation of .......................... 443

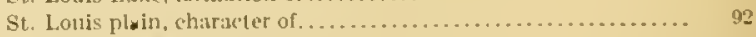
St. Louis River, chammel of, changes in........... 112-113,45i t5is ghimuet of, maps showing. ..................... 113,45.,454 geology near ............................. $371,372,379,41$. St. Louis slate. Ser Virginia slate

St. Marys River, descripliton of 
$\operatorname{Pagn}$

St. Peter sandstone, distribution and character of ........ 360,361-31;2

Salt waters, distribution and charactpr of.................. 54 .

Sault Ste. Marie, physiography north of . . . . . . . . . . . . . . $95-90$ j

Saunders, geology near ............................. 310

Saunders formation, correlation of. .................... 598, tin distribution and character of ........................... 309, 310-311, 105

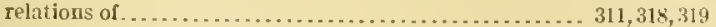

Savor mine, section of, figure showing.................... 138

Sawteeth Mountains, physiography of.......................

Sayers Lake, geology near............................ 152

Scotty Islands, geology on.

Seaman, . 1. E., on lron River district. $\quad 319$

on Keweenawan series............................ 389

on Marquette district . . . . . . . . . . . . . . . .

Seaman, A. E., and Lane, .1. C., on Lake Superior sandstone.... file

Sea water, reaction of, on hot igneous rocks . . . . . . . . . . . . 515-510

Sehenins, J. U., aid of............................... 15

Secondary concentration, alteration due to ............ 186-188,529 character of .................................... 529-539 alterations due to.................................. 18ti-18s condition of........

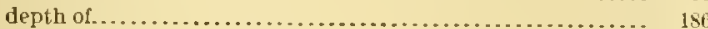

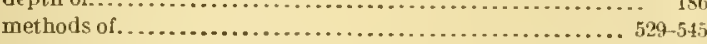

quantitative study of.............................

relations of contact alteration and................... $552-558$

sequence of.................................... $557-560$

volume changes due to ........................... 184-191

figure showing.................................. 189, 190

See also particulat districts.

Section 16 miine, section of, figure showing.................. 270

Section 30 mine, geolog: of

Seetions, geologic, of Lake Superior region, map showing..... Pocket.

Sedimentation, conditions of. ...................... 500-518

Seeley slate, correlation of.....

distrihution and character of ..................

Sellers mine, iron ore from, analyses of ........................ 193

Shehandowan River, iron on. . . . . . . . . . . . . . . . . . . . 150

Shenango mine, wiew in..............................

Sheridan Hill, geology of............................. 310,319

Siamo slate, correlation of . . . . . . . . . . . . . . . . . . . . . . 598,607

deposition of

distribution and character of . ........252, 261-262, 287, 288, 289, 607

relations of................................ 261,262,264

topography of

Sibley mine section of figure showing . .

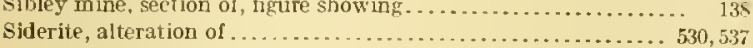

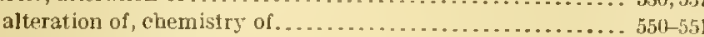
plates showing................................ 532, 53.

oxidation and brdration of . . ....................... 530,537

plates showing . . ................................. 472,524

Silica, deposition of.

leaching of....

transportation of

Silicate ores, distribution and character of ............... $571-572$

Silver 1slet, geology at

silver ores of......................46,591-592, 593-594, (j24) analysis of

Silver Lake, iron near

mining of... history of..................

origin of.

production of

source of.

Slate, composition of.

composition of, diagtam showing.

correlation of. .

iron associated with

$46,591-592,593-594,626 ;$

207

$-595$

575
46

595

54,9

Slate, ferruginous, distribution and character of .............. 462 plates showing.

Smelting, hy-products from

history of.

Smith, W. H. C., on Hunters Island

Smith mine, history of.

Smyth, H. L., on copper ores.
Smyth, II. L., on folding ................. I'age.

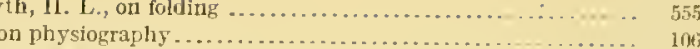

or Steep Roek Lake distriet

Smyth, 1I. L., and Clements, J. M., on frystal Falls jistrict.... $3 !-40,107$ Smyth, H. L., Bayley, W. S., and r"jements, J. M., on Crystal

Falls district ............................... $91 ;-97,107$

Snowlank granite, distribution and character of ............ 9 - 98,107 intrusions by ...................................... 131, 13t; topography of .

Snowhank Lake, geology near................119, 120,131,132-134, 136

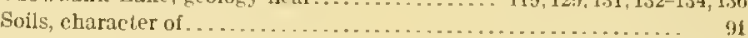

Solutions, hot, metasomatism by ................. $513-514,582-580,614$

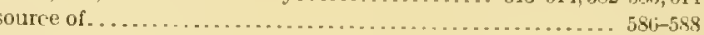

Soret, C. A., law of..................................... 590

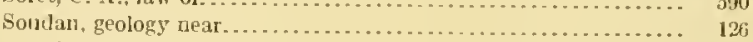

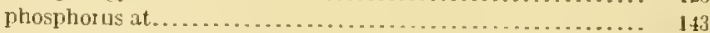

Sondan formation, age of............................. 127-12S analogy of, to Negaunee formation ..................... 126

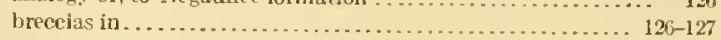
correlation of ...........................................

iron ores of, analyses of ........................ 139-140

character of . . .................................. $1140-141,460$

secondary concentration of . . . . . . . . . . . . . . . . . . . . . 141-142

structure of . . ........................ 137-139

jaspilite frons, plate showing......................... 466

origin of................................................ 126

relations of , to Ely greenstone. . . . . . . . . . . . . . . . . . 124-123

structure of . ................... 123-124

topography of ........................................ 93,119

See also Jasper.

Soudan Hill, geology near .................. 119,122,123, 127,137

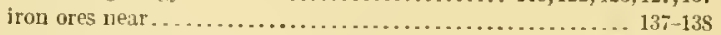

South Range, geology of . . . . . . . . . . . . . . . . . . . . . . $355-386,389$

Spain, iron ores of . . . . . . . . . . . . . . . . . . . . . . . . . .

Split Rock, geology at .............................. 374

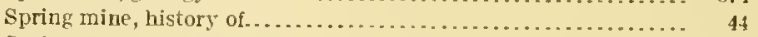

Spring Valley, iron ores at . . . . . . . . . . . . . . . . . . $460,564-566$

Spurr, J. E., on greenalite.......................... 167-168

Spurr mine, history of . . . . . . . . . . . . . . . . . . . . . . . . . . . 38

Stambaugh 11ill, geology at................................... $315,317-318$

Stannard Rock, geology of ............................. 425

Stanton, T. W., fossils determinel by . . . . . . . . . . . . . . . 179

Steep Rock Lake district, Ontario, geology of . . . . . . . . . . . . 147-149

iron of . . ............................. $46,148,149$

Steep Rock group, distrihution and character of ............ 148

Stegmiller mine, geology at . . . . . . . . . . . . . . . . . . . . . 2 2 3,285

Steidtmann, Edward, on copper ores. . . . . . . . . . . . . . . . .

Steiger, George, analyses $h y \ldots \ldots \ldots \ldots \ldots \ldots \ldots .166,173,191,40 j-406$

Stevens, I. I. on copper mining. ..................... $35-36$

Stevenson mine, excavation of, views of ...................... 496

ores from, analyses of . . . . . ....................... 188

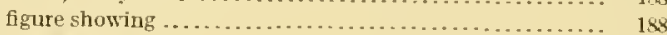

Stillwater, geology at . . . . . . . . . . . . . . . . . . . . . . . .

Stokes, 11. N., analyses by ......................... 191,589

Stoneville, geology near ................................ 268

Straw llat Lake, geology near......................... 118

iron near..................................... 149

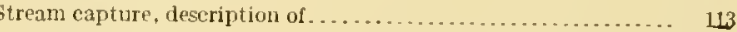

figure showing............................. 113

Stream systems, character of ............................ $\quad 91$

Stremme, U1, on hydration.......................... 557

Streng, ג, on Keweenawan series. . . . . . . . . . . . . . . . . . 397, 402

Strix, evidence of ................................. $\$ 30$

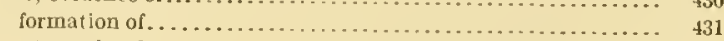

Structure, development of............................ 621

elemerts of .................................... $621-622$

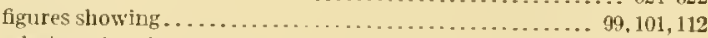

relation of, to iron ores............................ 544545

Stuntz Bay, geology near ......................... 128, 199,131

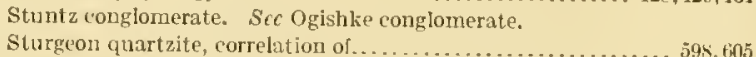

turgeon quartzite, correlation of ......................... 596.605
dist ribution and charaeter of ... 291,293,300-302, 306,330,332-333,605 
Sturgeon quartzite, int rusions in... relations of. tonography un.

Sturgeron River distriet, correlation of deseription of greology of.

Subcrustal fusion, theory of .

Sudbury district, copper and nickinl ores of.

Sulliwn, E. C., work of

Sulphur, metauorphism and... oceurrence of .

Surnlay lake, geology near . . Sumlay quartzite, ('orrclation of . distribution and character of. reliztions of.

Superior, geology near

Superior escarpment, deseription of . .

Surprise Lake, geology at...

Surveys, progress of

Swamp Lake, geology at. .

Swatlyy district,

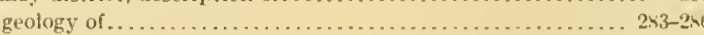
iron ores of .................................... 286

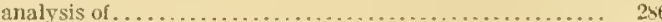

reserves of ................

secondary concentration of........................ 246

structure of . ................................. 47

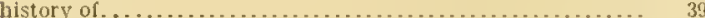

map of.

production of.

Swanzy mine reolory at . -

Sweden, iron ores of ...

Sweet, E. T., on glaciation

on Keweenawan series.

(4...................... $402,403,404$

Swineford, A. $P$. on Mcnominee district ..................... 39

Taconite, alteration of.

analyses of.

conposition of.

distribution and character of

utilization of .

See also Iron ore.

Talbott Lake, geology near

Tamarack mine, history of.

Taylor, F. B., on glaciation.

Taylors Falls, geology near. section at, figure showing. qeolugy at, map showing.

$379,409,425,6116$

Temperance River grousp, distribution and cheracter of $37 \mathrm{I}-372,375-376$

'Terrestrial sediments, rharacter of.....

That Ians Lake, geology near.

Thessilon group, correlation of .

This Maus Lake, geology near.

Thompson, Liske, description of

Thunle'r Bay, geology near.......

physiography near

silver at.

Sec also Inimikie rlistrict.

Thunder cape, geology" of.

Thwaites, F. T., on Wisconsin geology

Tijlen mine, geology at.

'li1:ulum, occurrence of . .

Topographic development, history of mup showing.

Topographie provinces, $t y^{*}$ pes of . mat shawing. siec n! Pleistocene, provinces of

Topography, char:keter of.... modificatlon of. relation of, to iron ores

Tower, grology near.

Tower llill, geology nur iron ores near.

Trualers member, correlation of distrlbution and character of . iron ore of relistion of.

501-502

$209,410,421$, tio-

$94,1010-101$

$20 ! 4,426$

374,379

236

$477,533,561$

$\rightarrow 5,90$
T'raders mine, geology near Transportation, methods and cost of . . . . . .

Trap Range, yeolos of . . .

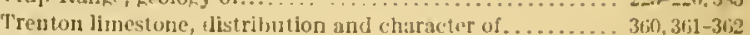

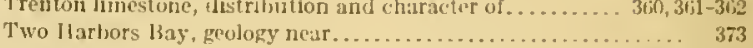

l'yler slate, correlation of.

distribution and character of . ............. 22,i-226, 225, 232-233, tos

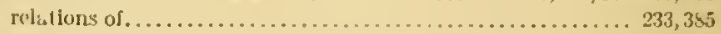

U.

Utrich, E. O., fossils determined by .................. 320 on Iron Mountain . . . . . . . . . . . . . . . . . . . . . .

[nconformities, description of................... 617 1;20,625-1;26

Tnited States, iron rescrves of ......................... 492

Cnitel States Geologieal Surrey, work of .................. 72 73

['pham, Lake, rescription of .......................... 443,453

I pham, W , on glaciation ....................... 440, 442

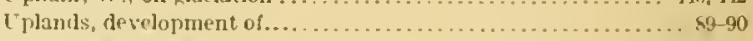
districts of description of $91-99$

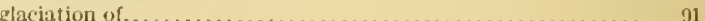
monadnocks on ....................................... 90

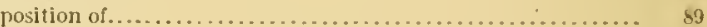

relief in .

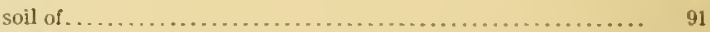

valieys in ................................... 90-91

Upson, geology near.................................. 230

r.

Valleys, character of ...............................90-91

Van Hise, C. R., on copper ores.......................... 551

on formation of limonite............................... 519

on keweenawan series. . . . . . . . . . . . . . . 402

on mctamorphism......... 551

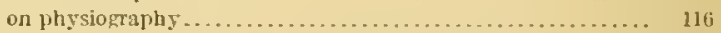

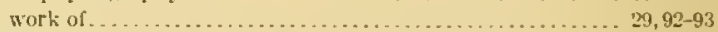

Van 11 ise, C. R., and Bar]ey, W. S. on Marquette district ... 9i, 10;-10i

Van Ilise, C. R., and lrving, R. I., on jhysiography......... 103

Veins, copper. Sec Eagle River; Ontonaron; Keweenaw Point.

Vermilion district, correlation in . . . . . . . . . . . . . . . 595, 599- $\{00,611$

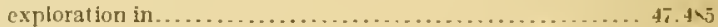
geology of ................................ 11 intrusive rocks of ............................. 135-136

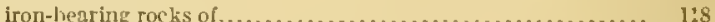

iron ores of .................................. 137-143, 4vi

alteration of ............................ 554-555

characteristics of . ................................. 140-141

composition of .............................. 13?-140

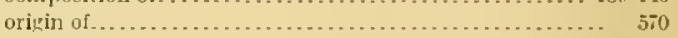

plates showing . . . . . . . . . . . . . . . . . . . . . . 4t66.5 bit

production of .................................. 4111

proportion of . . . . . . . . . . . . . . . . . . . .

relations of .............................. 504,507

reserves of ............................... 4 .

secondary concentration of ..................... 141-143

changes in .................................. 142-143 fignre showing .

structure of

topography of ................................ $4 \pi 6$

location and area of . . ............................. 32,115

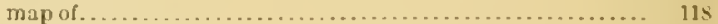

mines in, sections of, ligures showing................ 135

mining in, history of . . . . . . . . . . . . . . . . . . . .

phosphorus in.................................... 143

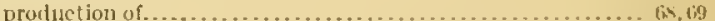

physiography of.............................. 29-94, 431

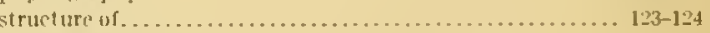

fipure show ing .............................. 123

topography of . ............................... 119

Vermilion Lakw, formation of......................... 442

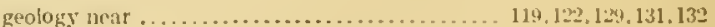
gold near.........................................

Vumilion range, nining on, history of . . . . . . . .

Virginia, grenalite frim wicinlty of, plate showing............ 4t.

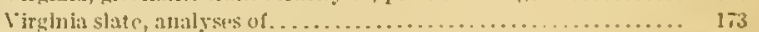

correlation of ................................... 594.611

distribut ion and churacter of . . . . . . . . . . 159.172-174.212-213

phesphorus in ................................. 194

relations of . . . . . . 
INDEX.

641

Volcanic vents, distribution and character of. Volcanism, occurrence of . .

Volume changes. Sic Secombary concentration. Volunteer nine, geology" it t. . .

Vulcan formation, alteration of correlation of.

distribution and character of iron ore in.

relations of

structure of.

topographic on.

Vulcan member, correlation t of distribution and clara ter of . iron ore in. magnetic phase of relations of. structure of

IV.

Wadsworth, M. E., on copper ores. on iron-bearing rocks. on iron ores.

on Keweenawan series.

Walcall, ('. I), on fossils of Lake superior sandstone.

Wall rock, alteration of.

alteration of, analyses showing.

: $\mathrm{Y}$ aping, effects of evidence of

Water, circulation of, in rock $\mathrm{k}$ circulation of, figure showing.

Waterloo district. correlation in. geology of.

maj of

Waterloo quartzite, correlation of distribution and character of.

Waucedah, geology near.

Wausau district, geology of.

IVausangray wacke, correlation of distribution and character of. topography on.

Waushara district, map of

Wa wa tuft, correlation of.

distribution and character of . petrography of

Waws. Lake, geology near.

Weathering, absence of .

effect of, on concentration. processes of.

relation of, to iron ores.

Weidman, $S_{\text {, }}$ on age of peneplain on drainage.
Page.

Weidman,, , on gl:Leiation. on iron ores. on physiography on Wisconsin geology. West lond, geology near. West sinful Lake, geology at. West Vulcan mine, section of, figure showing. Were slate, correlilition of. distribution and whacker of . relate ions of. topography un.

Weyerliuser, geology near white Iron Lake, geology near.

Whitney, J. D., and Foster, J. W., on Narquetre district Whittlesey, Charles, on dil'sabi district,

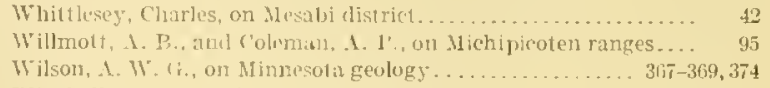
Winchell, .1. X., on limwenawan series. on nomenclature.

Winchell, N. 11 ., on glaciation. on iron ores. on lieweenawan series. on Mesa hi district. on Minnesota geology . on physiography. ... 1'a:2a. $437,+339$ $564,54 i f, 570-i 7 i]$ , $107-108,116$ $35.5-36,5,377$
$353,355,410$ ......... 131 31
349
605 innebngo, Lake, formation of Wisconsin, bibliography for correlation in. r linton ores of copper ores of geology of . hematite in. investigations in. iron ores of. production of physiography of. figure slowing. Sec also particular dismcts. Wisconsin stage, glaciers of. Wolverine mine, history of. ores of.

Woman River. geology neat Wood al oho, recovery of ... Woodward, R. W, analyses by Wright, F. E., on igneous roc ks................... $410-411,424,542$
Wright, F. F, and Larsen, E. \&., on quart a crystallization...... 549 Wort $2, H$, on silver minerals. ...................... 5459 z. Zenith mine, sections of, figures slowing. Zaplie, Carl, on Cuyuna district.

134

$47517^{\circ}-\operatorname{VOL} 52-11-11$ 

a 


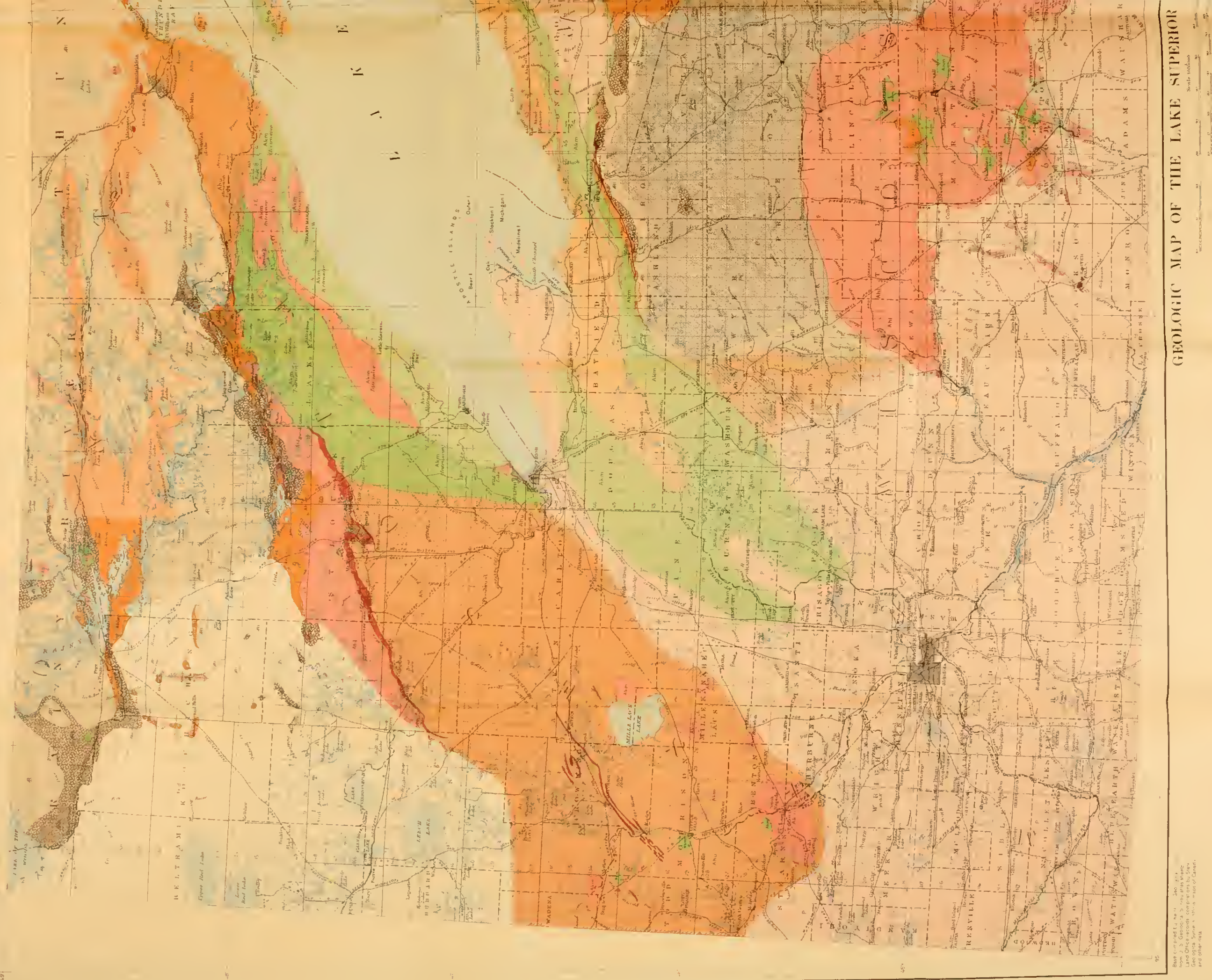




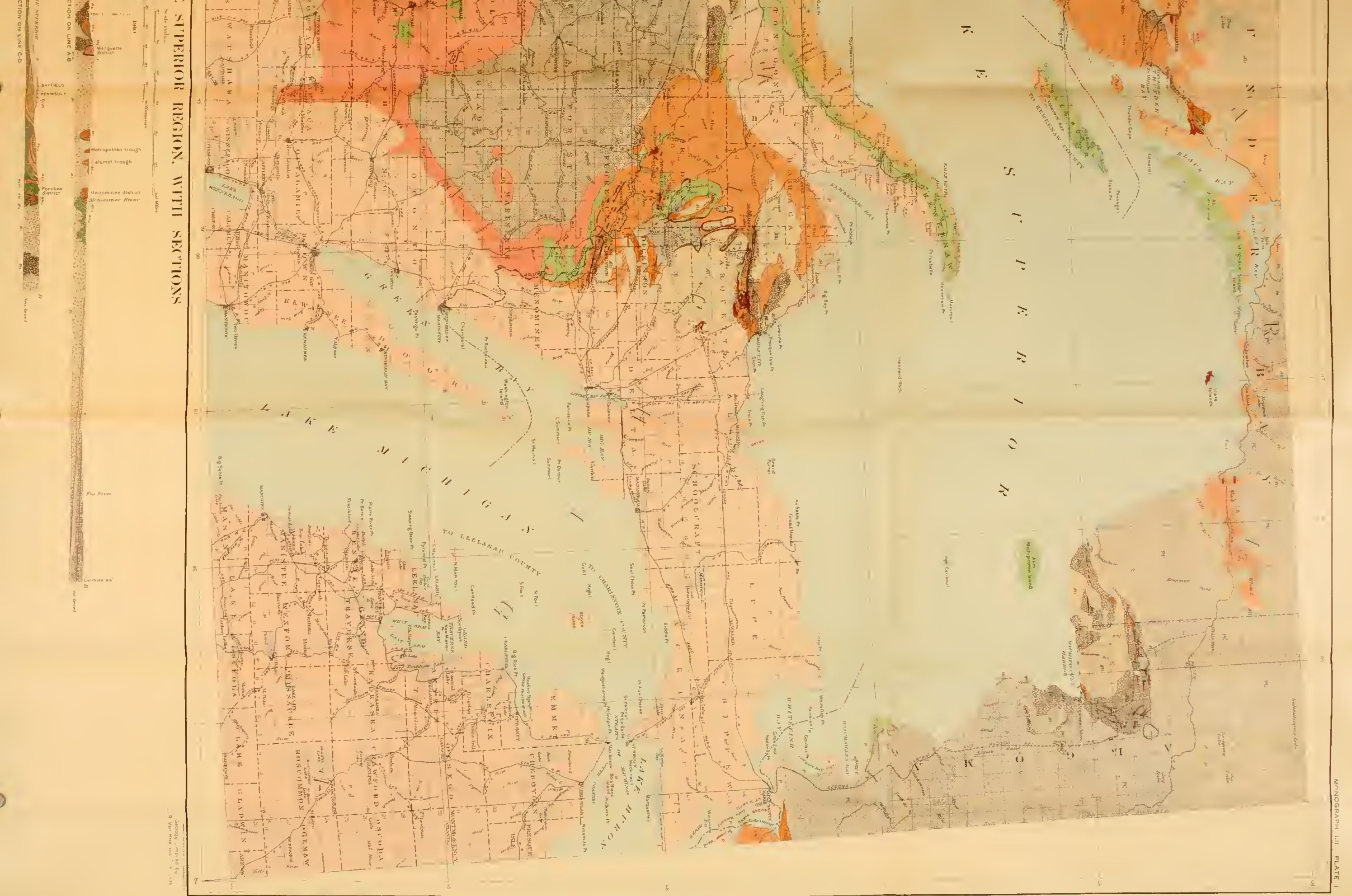




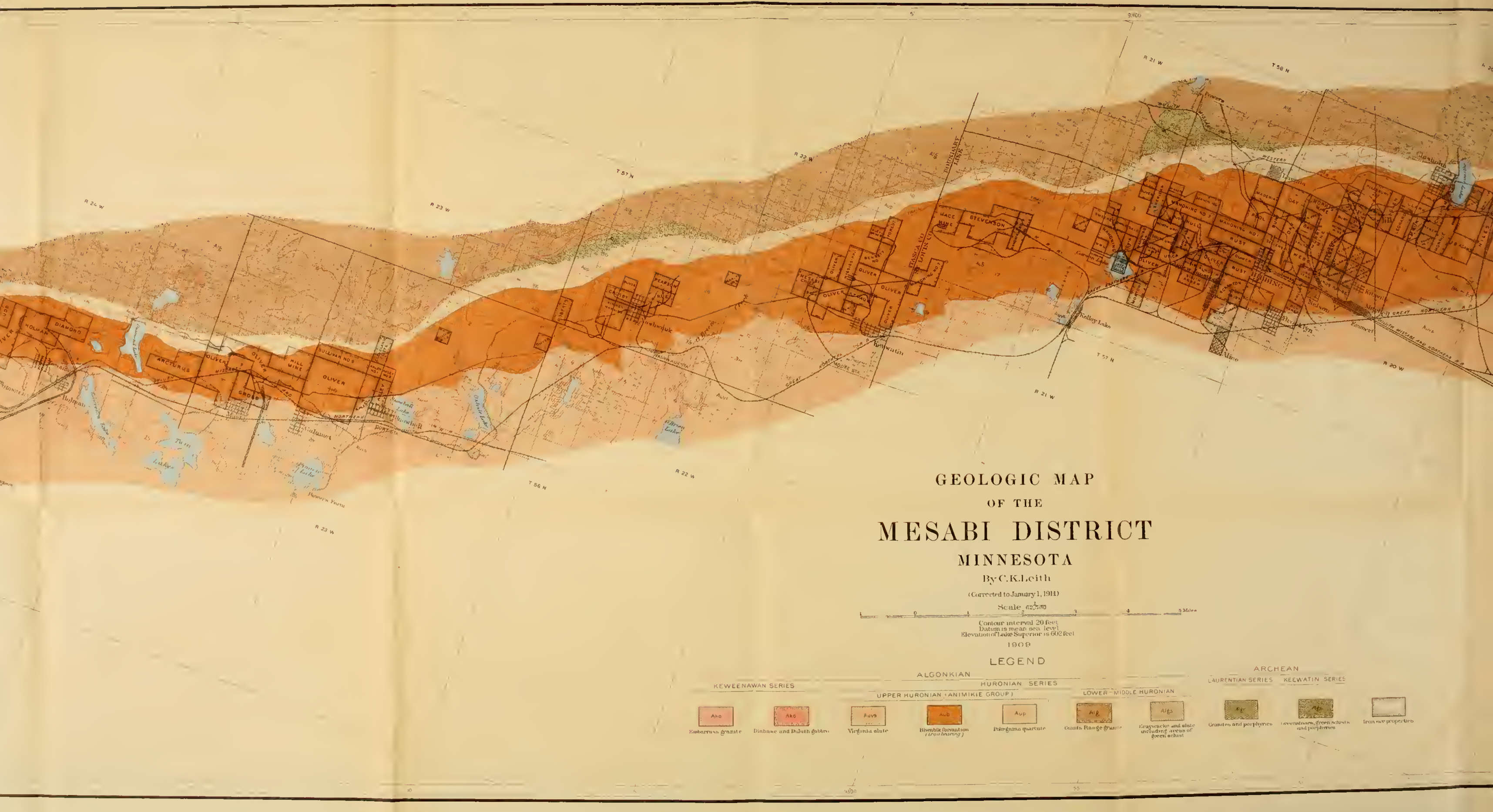




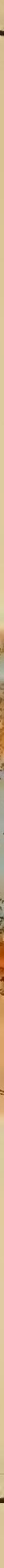




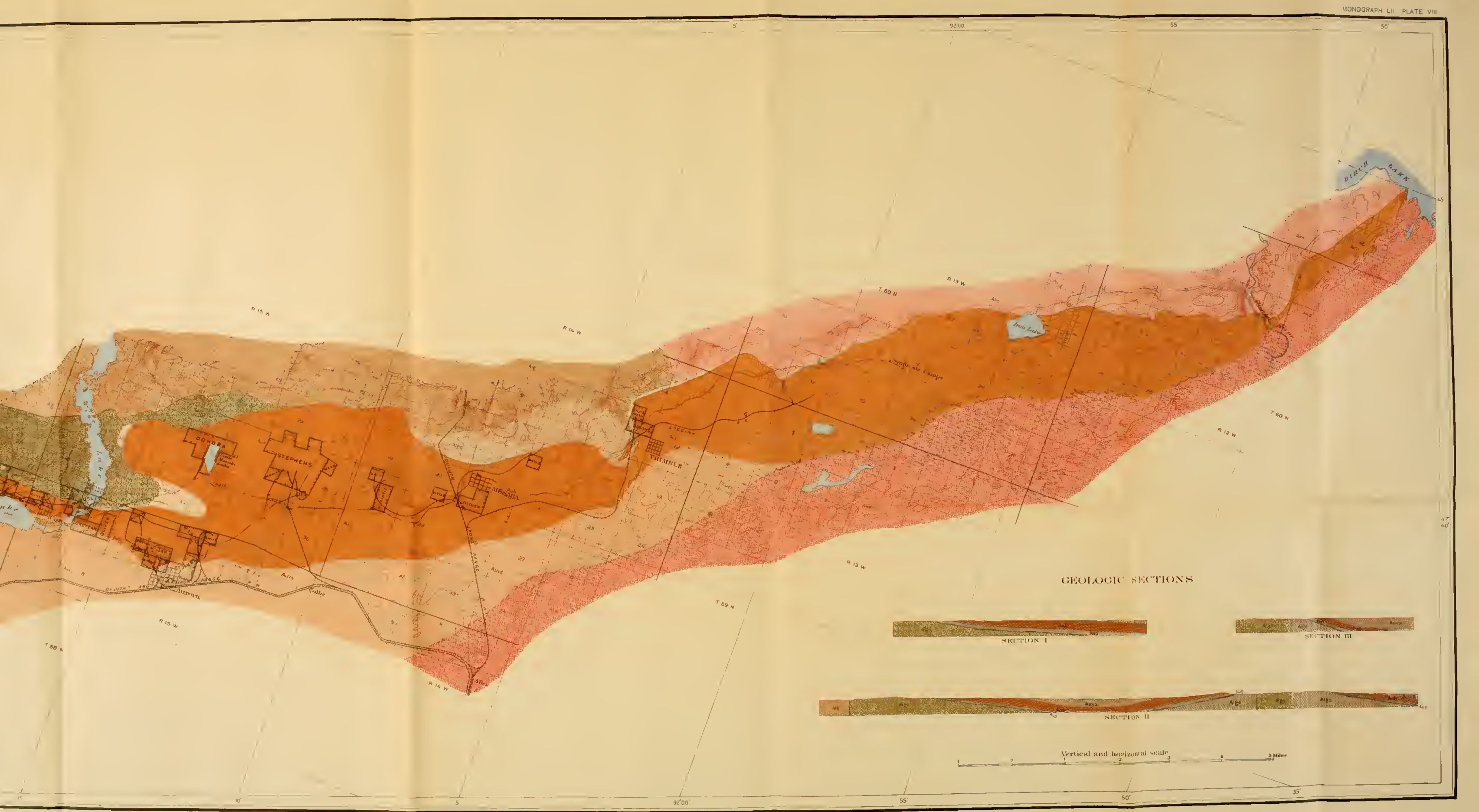




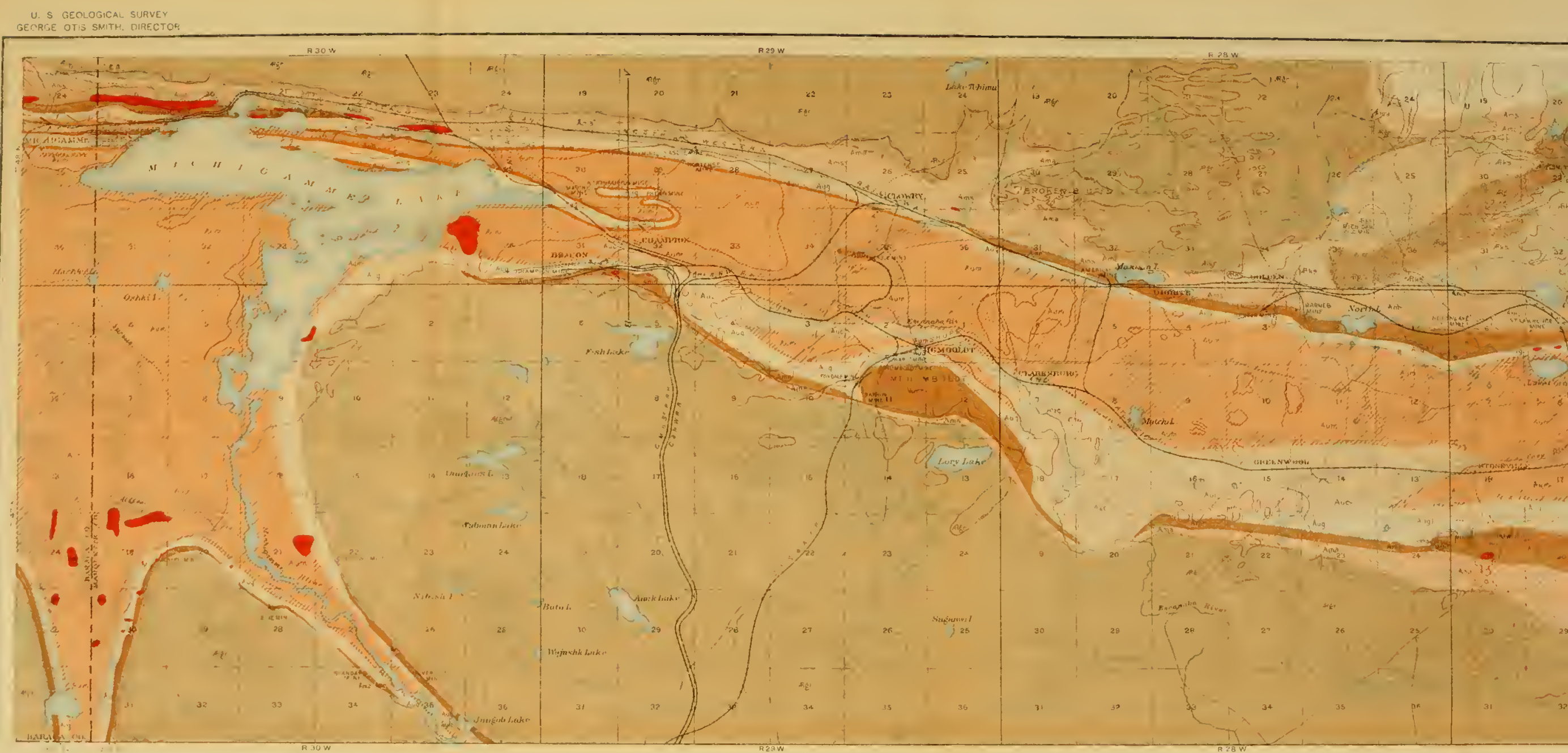

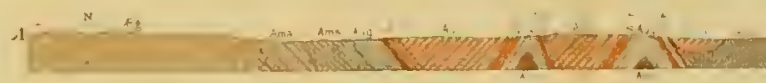

c

$\cos 1$

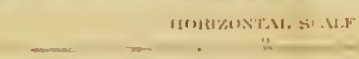

GEOLOGIC MAP' AND SECTIONS OF THE MARQTLTTE IRON-1

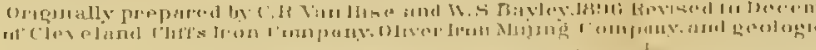

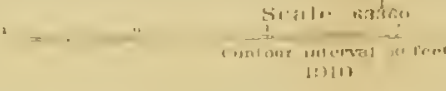

WUATERNARY LAMBRIAN

HLEISTOCENE

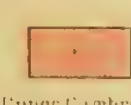

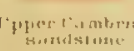

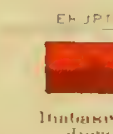

$\therefore$

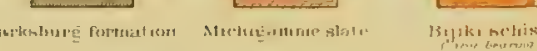

ALGONKIAN

LEGEND

\section{PPER HUROMIAN}




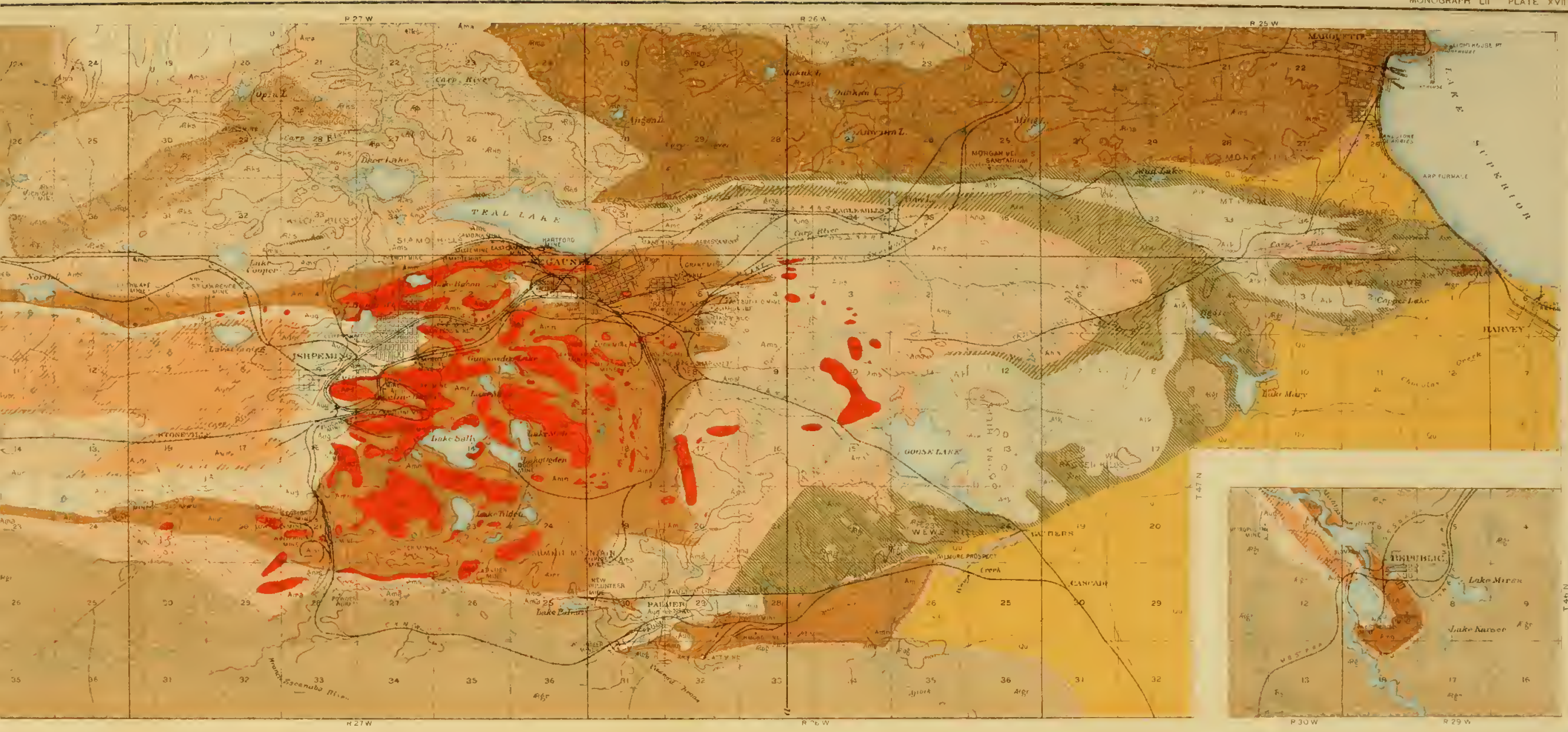

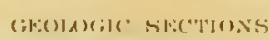

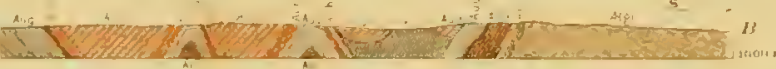

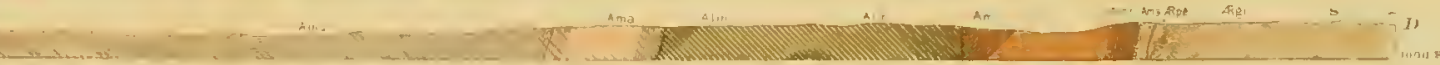

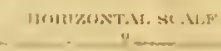

OF THE MAROUETTE IRON-BFARIN(; DOISTRICT, MICIIGAN

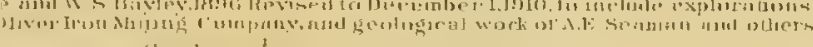

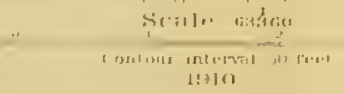

LEGEND

\section{Writerstate}




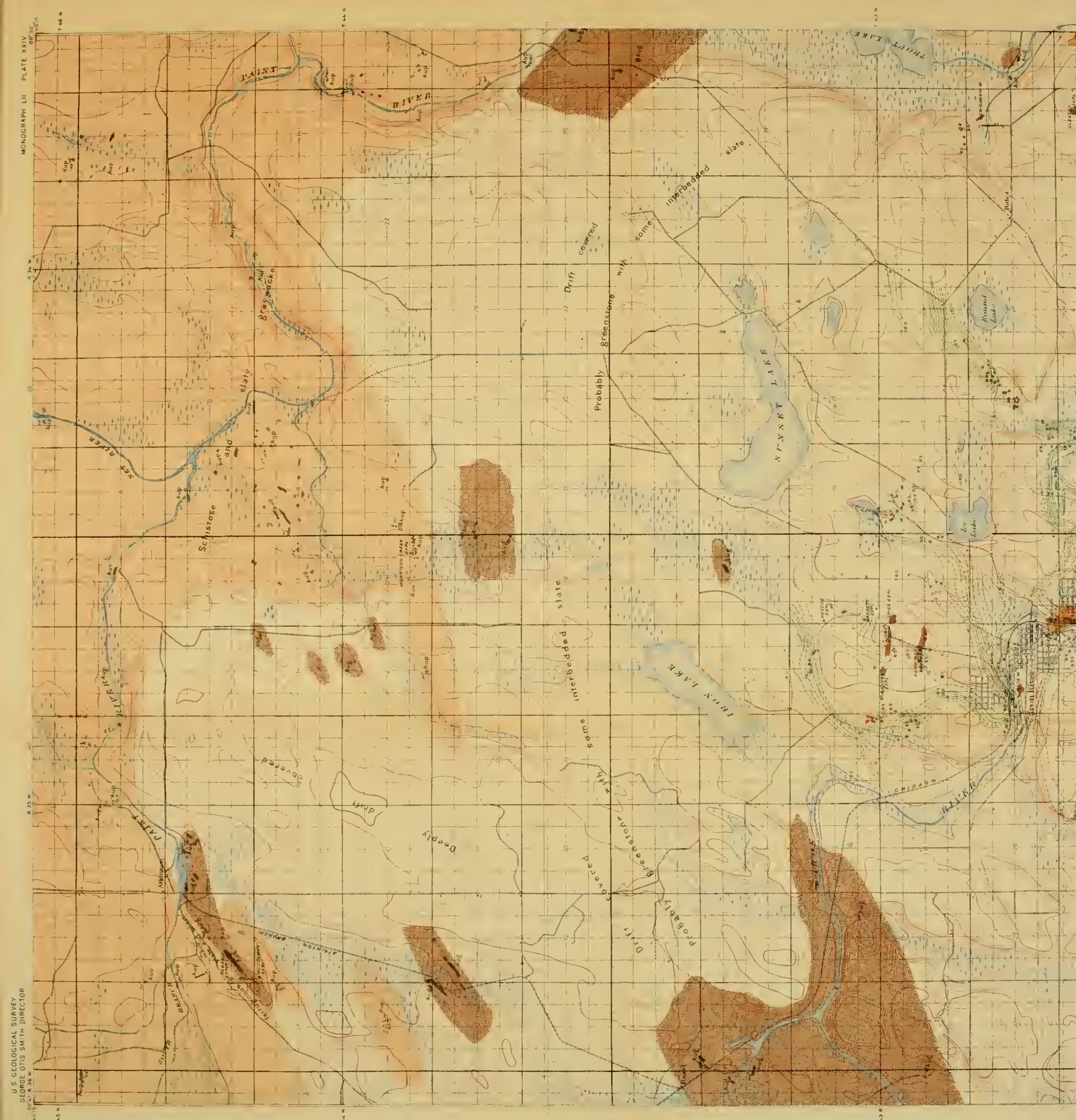




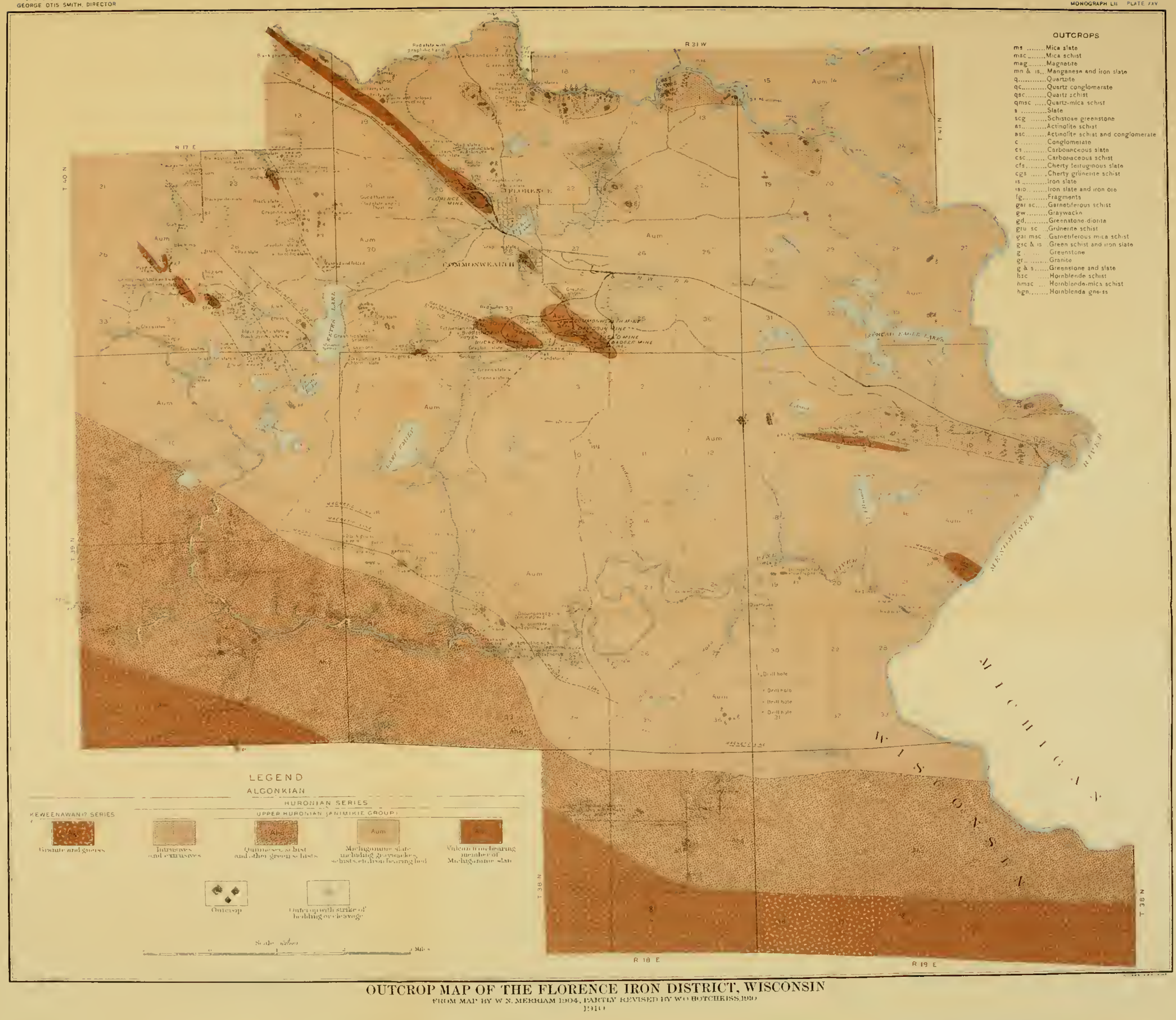


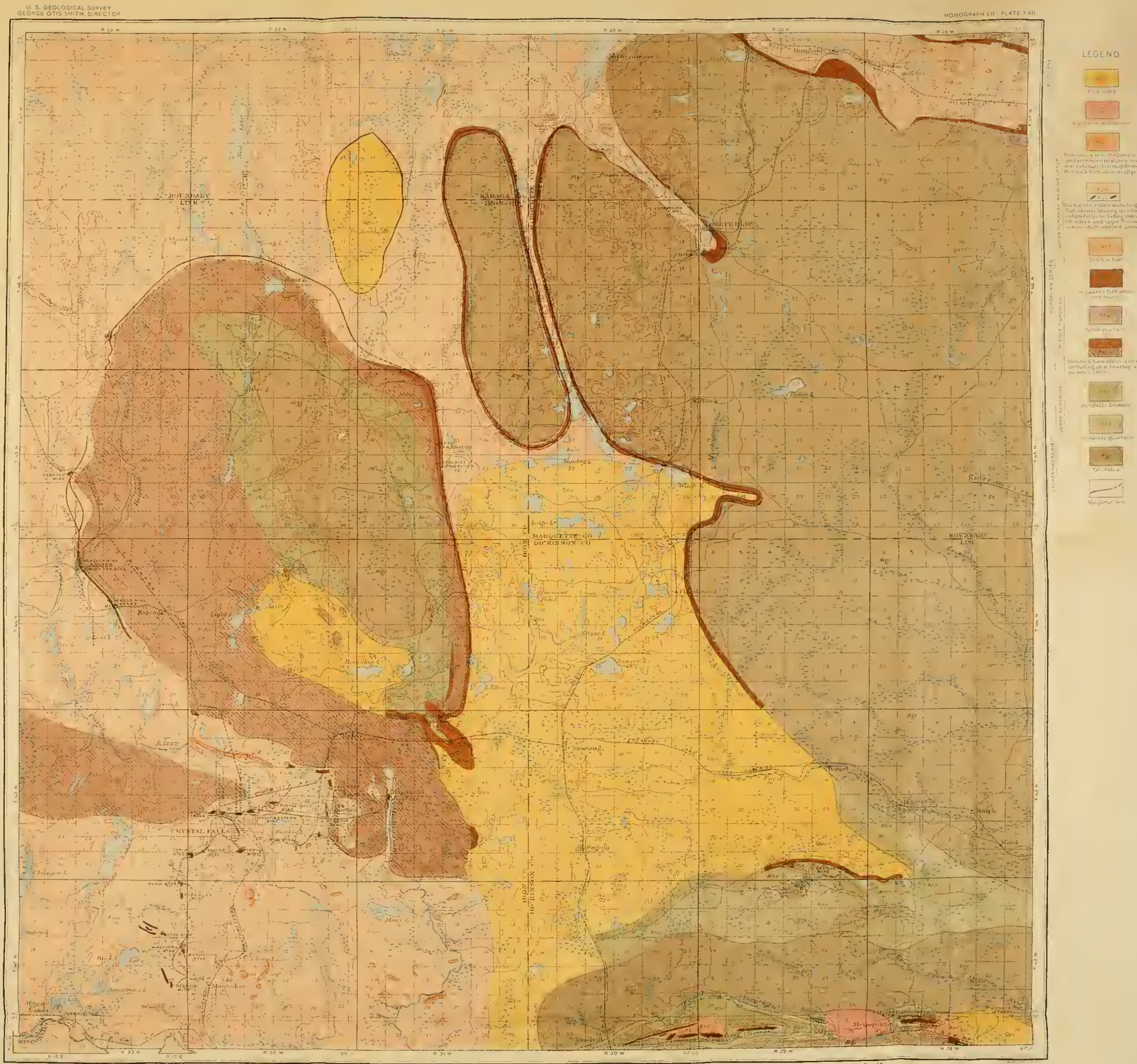



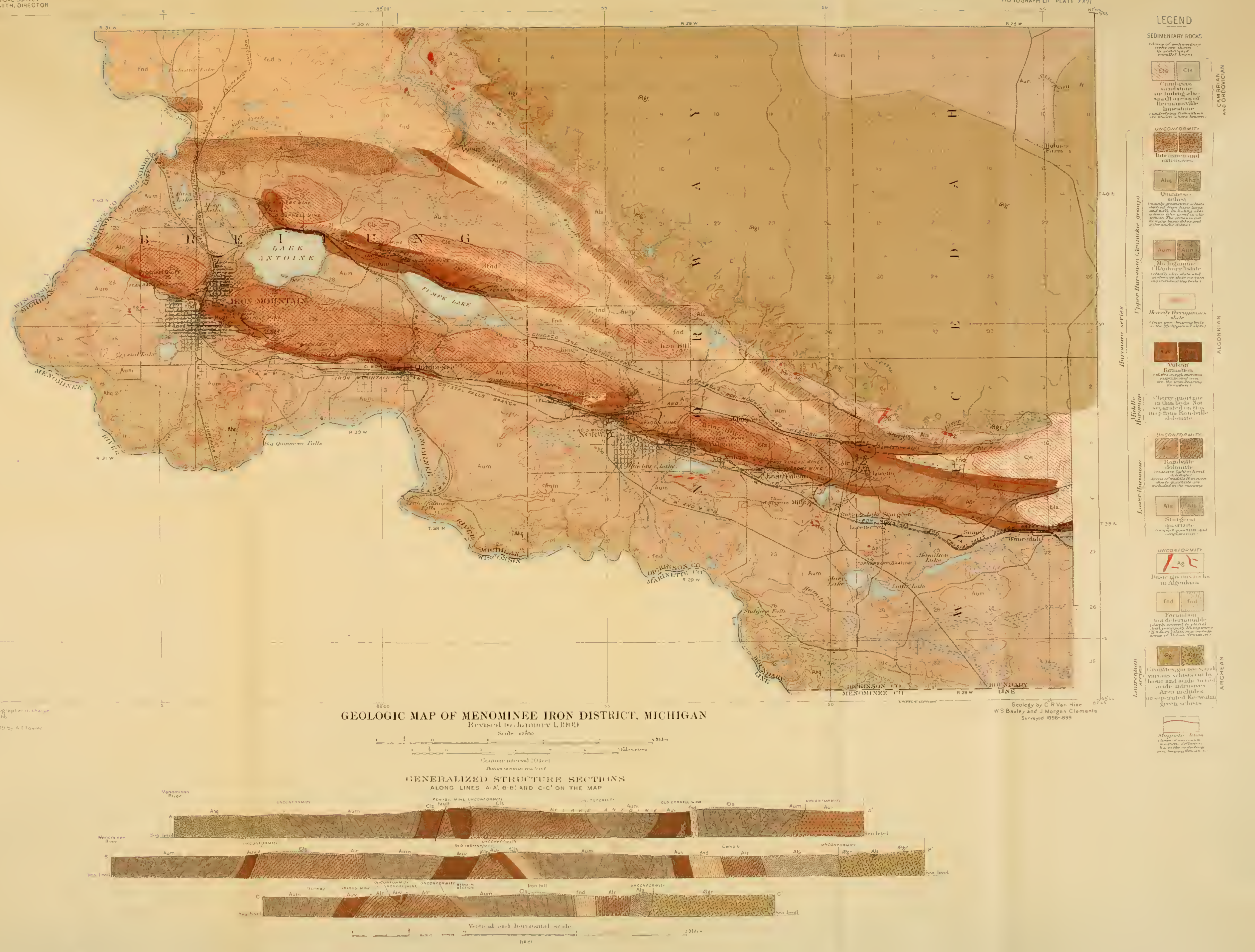





\section{(Shoodo \\ I.}

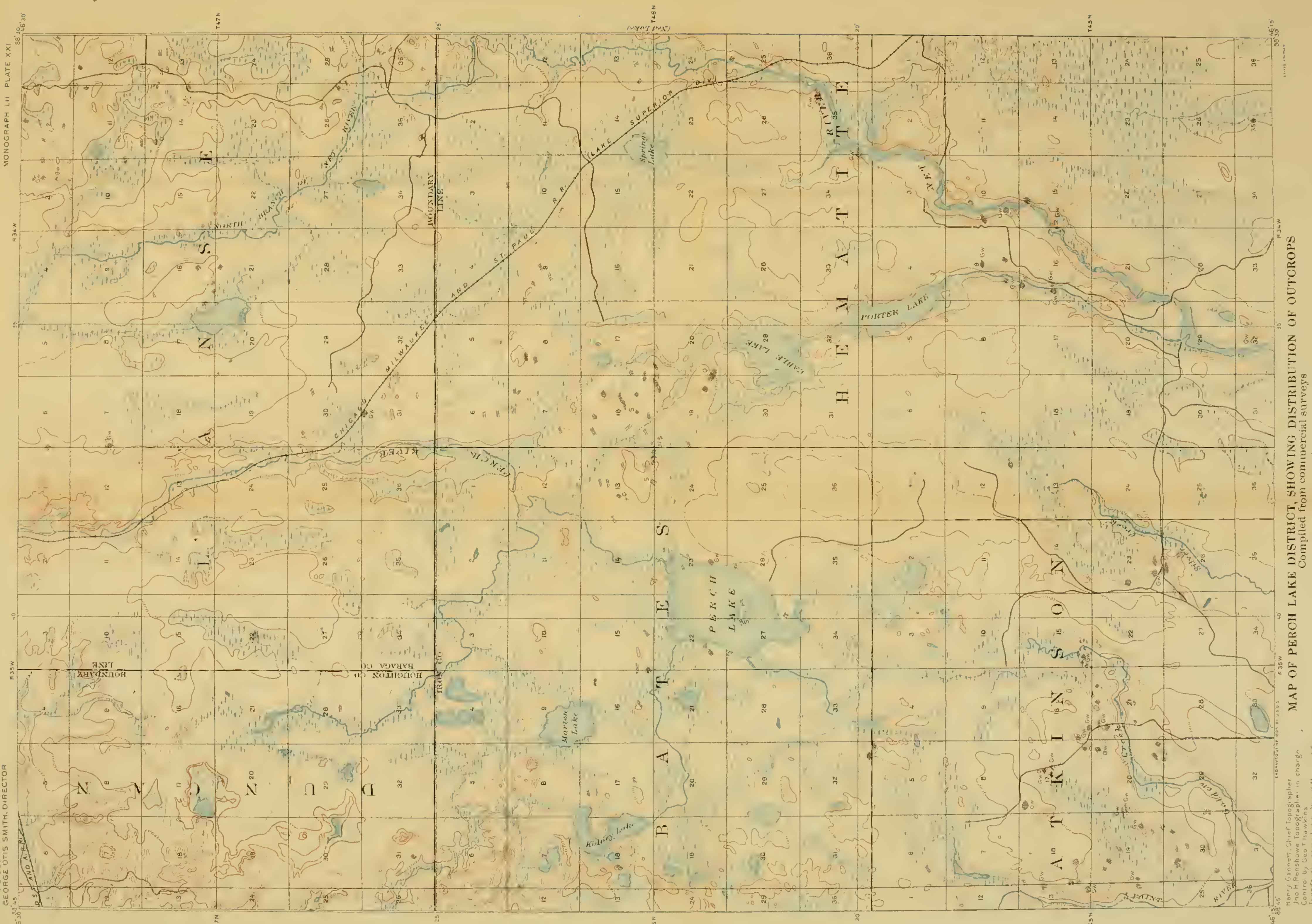


